If 10 . 13.

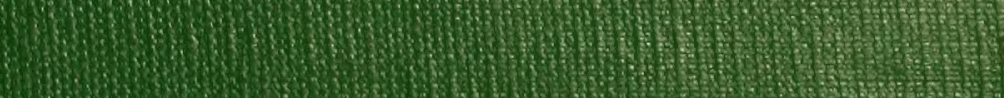

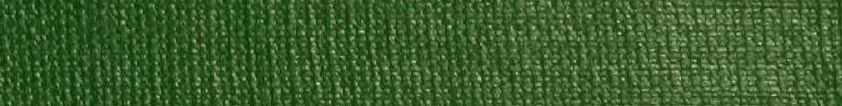

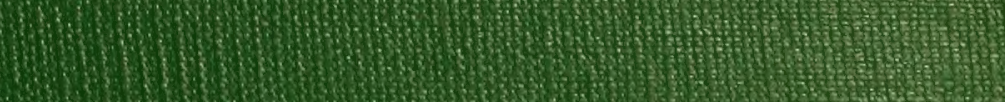
31
1

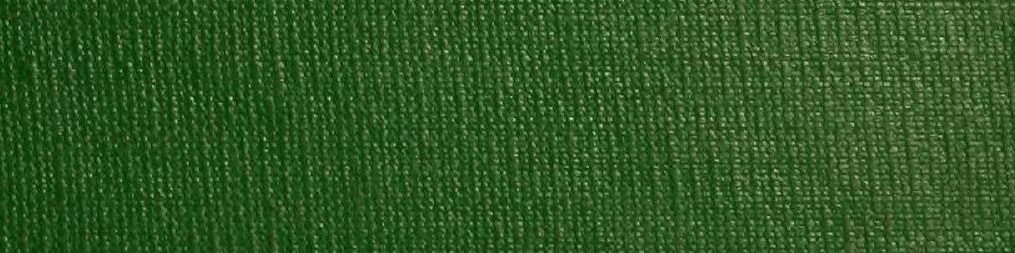
1. (5) His

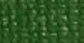
2.

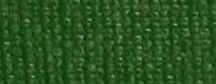


$C_{r}-B$

\section{HARVARD UNIVERSITY}

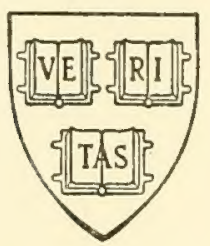

LIBRARY

OF THE

Museum of Comparative Zoology 






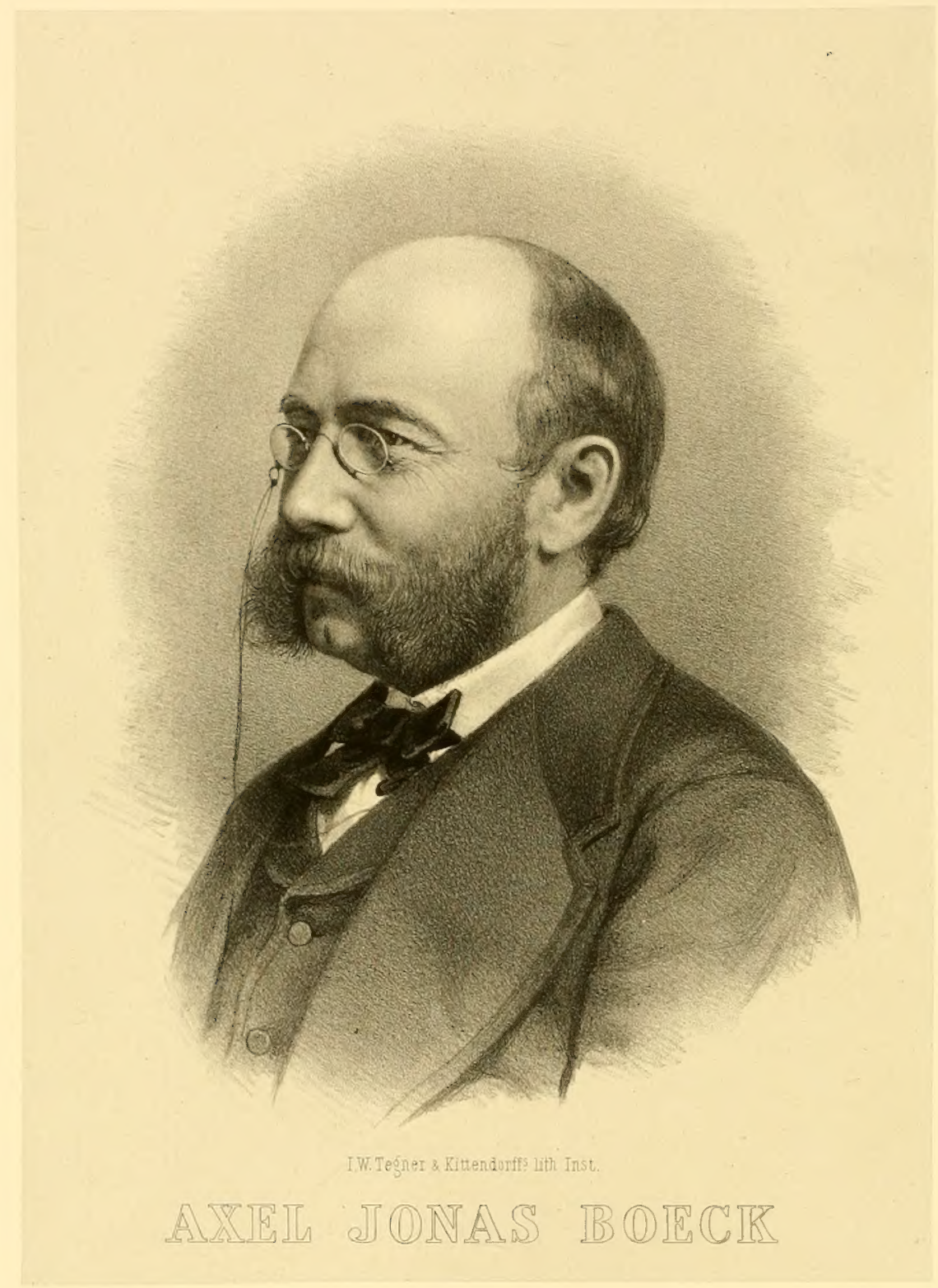

cand. med.og Stipendiat i Zoologi ved Universitetet i Christiania. 


\title{
DE SKANDINAVISKE OG ARKTISKE
}

\author{
A M P II I P 0 I) ER,
}

BESKREVNE

A $\mathrm{F}$

\section{Axel Boeck.}

Pörsle Helte.

(Med 7 kobberstukne Tavler.)

CHRISTIANIA.

Trykt hos A. W. Brogger.

Sm $18 \% 2$.

- 8 
$C r-B$

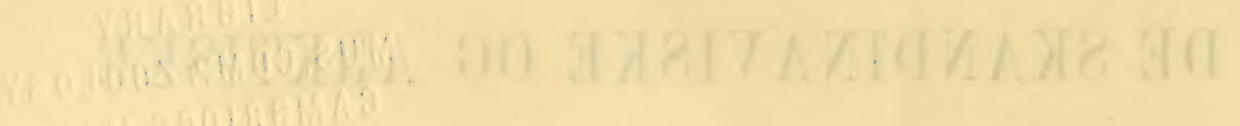

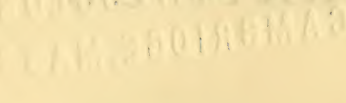

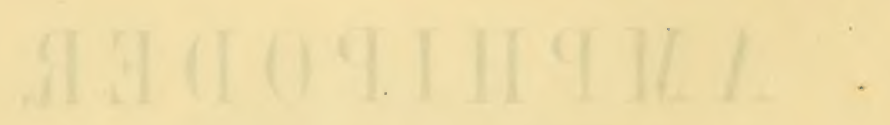

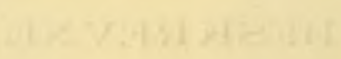

Hog08 loxA 


\section{Indledning.}

I 1859 blev der af Unirersitetet foreslaat folgende Opgare som Prisafhandling for de Studerende: „De norske Amphipoder og deres Naturhistorie“, hvilken Opgave bler af mig besvaret og tildelt Prisen samme Aar. Imidlertid udkom Bruzelius's Arbeide over Skandinaciens Amphipoda gammarina, trykt i Kongl. Vetenskaps-Akademiens Handlingar 1859, som forst udkom i det folgende Aar, hrilket i hoi Grad maatte modificere mit Arbeide, da Materialet væsentlig var kommet fra de samme Steder. Nresten det samme Antal Arter vare beskrerne $\mathrm{i}$ begge, idet Bruzelius havde optaget 77 Arter, og jeg 92, men hvorfra der gaar 7 , henhørende til Hyperidernes og Caprellidernes Familie, som laa udenfor hans Afhandlings Plan.

De Arter, som vare optagne i hans Arbeide, og som jeg ikke havde fundet, vare: Latmatophilus tuberculatus, Callisomả Kröyeri, Gammarus Lovèni, Gammarus lrevis, Paramphithö̈ tridentata, Eriopis elongatu, Lencothö̈ clypeata og norvegica, Pontoporeia affinis og furcigera.

Derimod havde jeg ogsaa et Antal Former, som han ikke kjendte, nemlig:

Trischizostoma Raschii, Anonyx serratus, pingvis, obtusefrons, Bruselii, Icnopus spinicornis, Urothoë norvegica, Pontoporeia armata, Oedicerus norvegicus, Aceros obtusus, Ampelisca spinipes, Stenothoë Danai, Eusirus longipes, Iduna fissicarnis, Dexamine Thea, Amphithopsis glaber, longicaudata, Acanthosoma parasitica, Podoceropsis Sophia, Amphilhoë grandimana, Hela monstrosa. Desuden optog jeg de bekjendte Caprellida og IIyperidce, soin han ikke havde medtaget.

Jeg forelagde derfor ved Naturforskermødet i Kjobenharn 1860 mit Arbeide, hroraf et Uddrag, vasentlig med korte Beskrivelser af de nye Former, bler optaget i Mødets trykte Forhandlinger. Da der ikke var Anledning for mig til at faa Afhand. lingen udgivet $\mathrm{i}$ sin Helhed, blev den indtil Videre henlagt. For 2 Aar siden bler der gjennem Hr. Overintendant, Kammerherre Holst givet mig af Hs. Maj. Kongen et Bidrag af 150 spd. til Stikning af nogle Plader, hvorhos Christiania Videnskabsselskab tilbod at lade Texten trykke. Jeg lod derfor strax stikke de 5 forste Plader og optog paany Bearbeidelsen af Texten. Imidlertid fandt jeg, at Arbeidet ikke nu langere kunde udkomme i den Form, som det for 9 Aar tilbage harde, i Særdeleshed da en 
stor Mrngde nyere Arbeider over denne Dyregruppe i det mellemliggende Tidsrum havde forandret meget Anskuelserne med Hensyn til dens systematiske Opstilling og de forskjellige Landes Fauna var betydelig foroget med et stort Antal Former. Jeg besluttede derfor at omarbeide fuldstændig det Hele, og gjennemgik derfor paany de Samlinger af denne Gruppe, som jeg kunde overkomme. Der havde ogsaa været Anledning for mig til at finde ved Kysten adskillige Former, som jeg maatte anse for $n y, o g$ ved at gjennemgaa de Samlinger, som bleve mig udlaante fra Museer og private Eiere, fandt jeg et ikke ringe Antal Arter, der dels vare aldeles nye for Videnskaben og dels for vor Fauna. Da vort Bibliothek i hoi Grad manglede den til Bearbeidelsen nodvendige Litteratur, maatte jeg sgge denne i Kjøbenhavn, hvor Bibliothekerne i denne Retning vare rigere udstyrede; her fik jeg paa samme Tid Leilighed til at undersoge Museernes rige Samlinger samt Kroyers Typer fra Gronland, Danmark og andre Steder. Jeg tog dexfor den Beslutning at optage i mit Arbeide ikke alene de norske, men ogsaa de arctiske Amphipoder.

Ved at studere dette store Antal Arter, over 260 nordiske og omtrent halvt saa mange fra Middelhavet, Vestindien, Sydafrika og Indien, kom jeg snart til den Overbevisning, at deres systematiske Opstilling maatte grundes paa ganske andre Karakterer, end dem, der hidtil vare benyttede, og især at en noiagtigere Undersogelse maatte gjore sig gjaldende. Resultatet heraf har jeg nedlagt i et Arbeide, optaget i Christiania Videnskabsselskabs Forhandlinger for 1870 under Navn af Crustacea amplipoda borealia et arctica. 


\section{Indledende Bemtiderkininger om Amphipodernes Horphologi.}

Det er ikke min Hensigt her at gaa ind paa en detailleret Beskrivelse af Am. phipoderues Anatomi, men kun at give de nodvendige Oplysninger om de Forhold, der komme i Betragtning ved deres systematiske Opstilling, og blot nøiere beskrive de Munddele og Lemmer, som benyttes i det folgende af mig udkastede System.

Amphipodernes Lemmer, hroriblandt Munddelene, udgaa, som hos alle Arthropoder fra Mellemrummet mellem Ryg-og Bugpladen, hvilket er dækket af en Sideplade, Epimera, hrortil de Muskler, der beræge Lemmet, fæste sig. Paa Hovedet ere disse Sideplader meget store, og Ryg-og Bugpladen træder der betydeligt tilbage, saa at den førstnærnte kun fremtræder som et dækkende Skjold foran Munddelene.

\section{Ep is to met.}

Epistomet ligger tildels under og mellem de nedre Følere og sender en smal Forlængelse mellem disse og de ovre Folere op til Hovedets Kant, som her gjerne er udtrukket til et længere eller kortere Pandehorn, rostrum. Nedad udvider Epistornet sig, er der forbundet med Overlæben og danner Skjoldet, Chypeus. Naar Hovedet er meget bredt, er Epistomet ogsaa tydeligt aforæendset fra Kindet, genæ, og vel udviklet, bredt; er Hovedet derimod meget smalt, sammentrykt fra Side til anden, trænges Epistomet frem og danner en mere eller mindre skarp Ryg. Den kan hos enkelte Former, henhorende til Lysianassidernes Familie, endog blive udtrukket i en lang Spids. Paa den indre Flade hefter sig Kindbakkens, Mandibelens, Boiemuskel.

\section{Folerne.}

Folerne, Antemce, ere to Par, hvoraf de orre ere fæstede i Enden af Hovedet, medens det andet Par findes under eller bagenfor de ovre. Begge dannes af et Skaft, pedunculus, og en Svobe, flagellum. De orres Skaft er altid treleddet, hroraf det forste Led er det længste, og det tredie det korteste; særdeles korte ere de to sidste Led hos Lysianassiderne, hror de derfor let kunne orersees; ogsaa hos Hyperiderne, Stego- 
cephaliderne og flere Andre ere disse Led korte, medens det forste Led er meget tykt. Hos Batyporeia bliver det forste Led udad strerkt fortykket, og det andet Led udspringer da ikke fra Enden af det foregaaende, men fra den nedre Flade, saa at Skaftet synes at være knæbøiet. Hos nogle Former er det tredie Led meget forlænget, som hos Podoceropsis, Podocerus og Janassa, samt hos mange Former af Caprellidce, hror det tredie Led endog kan være længere end det forste. Svoben bestaar som oftest af en stor Mrngde smaa med Børster besatte Led. Hos nogle Former ere ikke alle Led af den samme Bygning, men hvert andet eller hvert tredie kan være stærkere udridet mod Enden og bærer der de Leydigske kolbeformede Legemer, medens det ene eller de to mellemliggende Led ere smale. Hos nogle er Svoben meget faaleddet, hos Janassa bestaar den saaledes kun af et meget langt og to ydre, meget korte Led; hos Podocerus er den ogsaa faaleddet.

Foruden denne Hovedsrøbe findes der ogsaa udspringende paa den indre Side af Svoben fra Skaftets tredie Led en Bisvobe, flagellum appendiculare, der altid er kortere end Hovedsvøben; sjelden nærmer den sig denne $\mathrm{i}$ Længde, og da kun hos de Former, der have en kort, faaleddet Horedsvobe, som hos Slægten Phoxus. Hos Slægten Lilljeborgia er den mangeleddet, men dog kortere end Hovedsroben. Det er eiendommeligt hos nogle Former, at Hovedsvobens forste Led sammensmelter til et meget stort Led, der da paa sin indre Flade er forsynet med to Rader af Børstebundter; dette er næesten altid Tilfældet hos Slregterne henhorende til Underfamilien Lysianassince, men findes ogsaa hos Pardaliscina, samt hos Slagten Ilalicreion, der horer til Underfamilien Oedicerinc, dog her mere som en Undtagelse, idet Svobens Led som oftest ikke ere sammensmeltede, i hvilket Tilfælde Skaftets andet og tredie Led ere forlængede. Naar derimod Srobens forste Led ere sammenroxne, ere Skaftets andet og tredie Led stærkt forkortede.

De nedre Føleres Skaft dannes af fem Led, hvilket allerede Bruzelius har angivet. Det forste af disse er meget tykt, kort og som oftest sammensmeltet med Horedet; det andet Led er udad ogsaa kort, men indad meget bredere. I den nedre Ende forlænger dette andet Led sig i en lang, mod Enden tilspidset tornformig Deel. Dette er det af Spence Bate kaldte Olfactorspina, som han med Urette lader udgaa fra det forste Led. Den er i Enden aaben, dog saaledes, at den er drkket med en tynd Hinde, der udklæder ogsaa den indre Side. Den kan maske være et Lugteorgan. Det tredie Skafteled er i Almindelighed kort; hos Orchestide ere disse tre Led sammensmeltede med Hovedet og ere ikke frie. Ofte ere de to forste Led ogsaa dækkede af Hovedets Sideplader, saaledes som hos Underfamilien Lysianassina, undtagen hos Slægten Eurythenes. Hos Slægten Gammarus og mange andre sees de to forste Led at ligge i et Indsnit i Hovedets Sidedele. Det fjerde og femte Led ere som oftest forlrengede. Svoben kan ofte være meget forlænget, mangeleddet, og kan dette rære Tilfraldet hos Hanuer tilhorende enkelte Former, medens Hunnernes Svabe er meget kort, som hos Lysianassiderue og Phoxinerne. Naar Skaftet er meget stærkt og Sro- 
ben kun har faa Led, kalder man Folerne: næsten fodformede, subpediformes; ere de stærkere, benærnes de: fodformede, pediformes. Det sidste Svobeled er i disse Tilfælde forsynet med to Kloer. Hos Caprella er Svoben kun toleddet, og dens sidste Led er overmaade kort, hos Chelura danner Svoben et eneste, stort, ovalt Led, der benyttes til dermed at bortskaffe de Spaaner, der afgnaves af Kindbakkerne. Hos flere Former ere begge Følere hos Hannerne væbnede med Sugeskaale, der ere frestede paa Undersiden af de ovre og paa den ovre Side af de nedre, f. Ex. hos Lysianassina, hos Slægten Eusirus og hos flere Former horende til Familien Atylina.

\section{Overlæben.}

Overlaben, Labium superius, slutter sig med sin bredere fastheftede Deel til Epistomet, men er altid tydeligt adskilt fra dette ved en Fure; hror dette er udtrukket i en skarp Ryg, ex dette ligeledes Tilfældet med Overlæben, og disse trende Partiers Form slutter sig i det Hele meget til hinanden. Endskjønt Overlæben ikke er et parret Lem, ligesom de ovrige Munddele, men ligesom Underlæben kun er den yderste, udvidede og chitiniserede Deel af Mundrøret, er den dog berægelig, og man seer trende stærke Huskler at gaa fra Epistomet, en paa hver Side, og faste sig pan en tværsgaaende, opbøiet og noget bueformig Rand, der falder paa den indre Side af Overlæbens indre Flade. Disse Muskler tjene til at presse Overlæben, idet Kindbakkerne fra begge Sider boies mod hinanden, over Gribedelen af disse, saaledes at det tagne Bytte ikke kan glide ud fortil. Aabnes Kindbakkerne, viger Overlaben noget fra disse, og red Lukningen presses den mod dem. For hensigtsmæssig at opfylde den Bestemmelse, at beskytte Munden fortil og hjælpe Kindbakkerne, er Overlabens frie, buede Ende noget forskjellig bygget hos de forskjellige Former. Son oftest er den i Enden ikke ganske tynd, men noget bredere, og Spidsen er forsynet med talrige fine Borster, der fra begge Sider ere rettede ind mod Midlinien, som har en haardere, chitiniseret, neglformig Fremstaaenhed, hvilken dog ofte er saa liden, at den bliver skjult af de hinanden fra begge Sider mødende Borster. Ved at undersage Overlaben fra den indre Side, efterat Kindbakkerne ere fjernede, vil Neglen dog kunue sees.

Hos andre Former er Overliben i den nedre Kant ikke saa bred, men der. imod tilskjærpet samt ikke forsynet ned Børster; den el derimod indskanret i Midtlinien, og Fligerne kunne undertiden gabe meget.

Hos enkelte Former er det ogsaa karakteristisk, at Orerlæbens ene Flig er længere end den anden, hrorved den ikke bliver symmetrisk til Siderne. Naar Orerlæeben er bygget saaledes, er ogsaa Kindbakkerne ulige paa begge Sider, idet den, som svarer til den læugere Flig, mangler den bevægelige Bigren, der her pleier at være frestet under Gribedelen. Med den Bygning af Overlæben folger desuden nogle Forhold i de ovrige Munddeles Form, hvortil vi senere komme tilbage. 


\section{Kindbakkerne.}

Kindbakkerne, mandibulce, ere hos Amphipoderne de stærkeste af alle Mundlemmer og de, der egentlig benyttes til Fødens Sonderlemmelse. De frembyde ogsaa talrige Modifikationer, efter det Brug, der gjøres af dem. De frestes med sit ydre, bagre Hjørne i en egen Indskjæring i Mundrammen, og deres ydre, ovre Kant ligger indenfor og glider mod Mundrammen, naar de berreges. Men ikke alece paa dette Sted har Kindbakkerne sit Fæstepunkt; ved Undersøgelse af dem in situ, og naar man beræger dem mod hinanden, findes, at de ogsaa have et Hangsel i Form af en Tap, som er fæestet i en Fordybning i Epistomet, hvor dette er forenet med Underlæben. Dreiningen af hver Kindbakke foregaar saaledes ikke om en Axe, som man kan truke sig at være parallel med Mundrammen, men om en, som staar mellem det ydre, bagre Hjørne samt den omtalte Tap. Naar Kindbakkerne derfor ere meget forlængede, smale, som man ser er Tilfreldet hos flere Former af Lysianassidernes Familie, og Epistomet pan samme Tid er meget forlænget, danner denne Kindbakkens Berægelsesaxe ikke en ret, men en meget spids Vinkel med dens Længdeaxe, og begges Bevægelser blive ikke fuldstændig horizontale mod hinanden, men mere klippende.

Paa den indre Side af Kindbakkerne er der et bredt, trekantet, aabent Rum, hrorigjennem de stærke Bøiemuskler, som konme fra Epistomet, træde ind og freste sig paa den indre Side af Kindbakkens ydre Væg.

Den ydre Væg er buet, conrex, medens den indre Flade er concav, og Enden dannes af en mere eller mindre skarp og bred Skjærerand. Denne er som oftest indskaaret i talrige Tænder, hvilke nærmest Overlæben ere mindre, men blive storre mod den anden Kant, dog saaledes, at de sidste Trender igjen ere mindre. Naar begge Kindbakkers Gribedele boies sammen, glide de kun tildels over hinanden, og den nærmest Overlieben liggende Del drekkes af denne, som trykker sig mod den.

Hos andre Former er Gribedelen ikke indskaaret i Tænder, men mere but, og da foregaar Sonderlemmelsen af Føden red, at den mere knuses end skjæres. Dette finder Sted hos de Former, som væsentlig ernære sig af Aadsler i en mere eller mindre oplest Tilstand. Hos nogle har dog den ydre Ende af Gribedelen en skarp Tand, som saaledes forst gjennemstøder Byttet, forinden det sønderknuses af den øvrige Gribedel.

Hos nogle Former - Pardalisca og nerstaaende Former - er Kindbakkens Gribedel overordentlig ulig paa begge Sider, idet den ene er delt i talrige fine Trnder, medens den anden i 4 meget store ng grove.

Under denne Gribedel findes der en anden, som er forbundet med Kindbakkerne ved et Led, og som har en stærk Boiemuskel og en mindre stærk Strækkemuskel, der frster sig inde i Kindbakkerne. Endskjont denne Bigren er liden og drekes af Kindbakkens Gribedel, maa den dog betragtes som et andet Led ipaa denne, der saaledes bliver toleddet. 
Nærmere Roden, paa den indre Side af Kindbakken, finder man en stærk Fremragning, den saakaldte Tyggeknude, Tuberculum molare. Som oftest er denne stærk og mangler sjelden fuldstændig; undertiden er dens Bygning dog saaledes, at den ikke kan bruges til dermed at knuse Foden. Naar den er stærkest udviklet, er Enden bred, trart afskaaret og danner saaledes i Enden en rund, oval eller undertiden hesteskoformet Plade, der er omgivet af en Krands af Trender, og Fladen selv er enten forsynet med saadanne eller har et chagrinagtigt Udseende, ved at Fladen er drkket af haarde Korn. Denne Krands, der omgiver Endefladen, er ikke altid uafbrudt, men hos en stor Mrngde Former, Gammarina, Chorophince og Andre, er der i det ydre, nedre Hjorne frestet en lang, fjærformet Borste. Istedetfor at vare saaledes afskaaret og forsynet med Tæender i Enden er Tyggeknuden hos enkelte Former tynd og tilspidset mod Enden og forsynet med blode Borster.

Mellem denne Tyggeknude og den indre, berægelige Bigren strækker sig en Rrekke Torne eller Borster i en noget buet Retning. Hos Enkelte bestaar denne Rxkke af faa - 3-4 - blode, fjarformede Borster (Orchestida); hos Audre er denne Række næsten rudimentær (Lysianassince), hos atter Andre kan den bestan af tret til hverandre staaende starke Torne, der enten ere bueformige, i den convexe Rand saugtakkede, eller ogsaa bredere mod Enden og ere der indskaarne i Trender, eller endelig gaffeldannede eller have et andet Udseende.

Fra den Rand, som lregger sig op til Epistomet, udgaar der som oftest en Palpe, som i rolig Tilstand af Muuddelene slnar sig om Epistomet og lægges om Enden ind mellem dets Folere, i Furen mellem Epistomet og Kinden. Sjelden mangler en saadan Palpe (Orchestidce, Stenothoë, Caprella o. s. v.), og som oftest er den treleddet. Hos enkelte Former svinder dens yderste Led og bliver kun knudeformet (Metopa). Er Palpen vel udviklet, er dens tredie Led forsynet med en Rælkke Borster, der mod Enden blive længere, krumme sig og ere fjærformet dannede; mellem disse findes fine Porer, der syues at fore ind til nogle smaa Srkke.

\section{Det forste Kjæbepar.}

Det folgende Par Munddele, det saakaldte forste Kjæbepar, Maxillc primi paris, er i Almindelighed lidt mere udvidet end det andet. Grundleddet ligner det tilsvarende hos det foregaaende Par, men er strerkere; det andet Led, som her var meget lidet og vanskeligt at se, er hos dette storre, men ogsaa trekantet; det forlænger sig fortil i en smal baandformig Del, der gaar indad og udvider sig paa de forste Kjabers indre Rand til en med Borster besat Plade af forskjellig Storrelse.

Det folgende Led er temmelig stort og forlænger sig i Lighed med det foregaaende Kjæbepar indad til en bred Plade, deri den skraat afskaarne Ende er vabnet med strerke Gribetorne. I den ydre Kant af denne Plade, nær Roden, fæster sig Palpen, der som oftest paa dette forste Kjæbepar er toleddet, medens den hos 
det foregaaende var enleddet. Palpen har ogsaa som oftest i Spidsen Tænder eller Torne.

I Beskrivelsen kalder jeg den forste Plade den indre, den anden den ydre, og de vende sine med Torne og Borster besatte Render mod hinanden samt lagge sig, ligesom det foregaaende Kjæbepars Plader, buet ind i den Huling, som dannes af Underlæben. Palpen derimod dækker fra Siderne denne Del af Munden og hrælver sig over begge Kjæbeparrene samt Underlæben, idet dens ørre, med Tænder besatte, Rand moder den anden fra den modsatte Side. Denne Kjæbe kan ogsaa være af en noget afvigende Form. Naar Hovedet er meget smalt fra Siden eller de ydre Plader ere meget brede, bliver der kun lidet eller intet Rum mellem begge Kjæeber, og de indre Plader svinde derfor eller blive rudimentære, saaledes som hos Caprellida, hvor de aldeles ikke findes, eller hos Nicippe, hror de ere rudimentære; meget smaa ere de hos Corophida; hvorimod de ere store hos flere Andre, som Syrrhoince. Naar Munddelene blive meget forlængede, bliver det samme Tilfældet med den indre Plade, og hos Familien Lysianassina kan man hos de forskjellige Slægter se denne Overgang fra en meget liden til en meget stærkt forlænget Plade. Den kan derfor tjene til at give et godt Begreb om Mundens almindelige Bygning og er derfor af meget systematisk Vierd.

Palpen er som oftest meget stor, toleddet, da den indad skal dække Munddelene. Naar Munden er meget bred og Munddelene meget tynde, og Kindbakkerne tynde, pladeformige, ikke trekantede, hvorred Orerlaeben og Kjæbefodderne rykke nær til hinanden, behøves ikke dette Dække af Palpen udad, og denne bliver da kort, smal, enleddet, som hos Slegocephalus. Ere Kindbakkerne stæerkt forlængede, tynde, mere svage og ikke skulle tjene saa meget til at klippe Føden, som til at bore Huller, og naar det første Par Kjæber ogsaa forlænger sig, modificeres ogsa Palpens Form, saaledes som man ser det hos Familien Iphimedince; her er den temmelig stor, toleddet hos Slægten Iphimedia, medens den hos Slægten Verlumnus vel er toleddet, men neget kort og smal, hos Odius, hror Munddelene ere end langere, bliver den tynd og enleddet, hvorimod den hos den afvigende parasitiske Slægt Laphystius bliver rudimentær. Saaledes frembyder ogsaa denne rigtige Kjendetegn i systematisk Henseende.

\section{Underlæben.}

Mellem dette Kjæbepar og Kindbakkerne ligger Underlæben, Labium inferius. Denne henhører egentlig ikke til Mundens Lemmer, men er kun den bagre, chitiniserede Fremragning af Mundrøret. Den er bagtil frestet til Hypostomet, medens der paa hver Side strækker sig trende baandformige Forlængelser hen til Orerlæben og lægger sig hen til Mundrammen samt omslutter Mundaabningen. Trende tynde Muskler fra den frste sig til Hypostomet og tjene til dens Bevægelse. De ere i Midten spaltede mere eller mindre dybt, eftersom Munddelene ere kortere eller længere, og 
bestaa saaledes af trende Sidehalrdele, der red Roden ere forenede. Den dannes af to Par Plader; de ydre ere de storste, og i den orre Rand i Regelen forsynede med Børster; den ydre Rand er nærmest Euden smal, men bliver mod Roddelen bredere og gaar paa hver Side ud i en oval Lap. Denne Lap tjener til at fylde det ellers tomme Rum mellem Kindbakkerne og det første Kjæbepar, som ved Roden staa længere fra hinanden, men som nærme sig hinanden mod Spidsen. Derfor er denne meget bred hos de Former, hvis Kindbakker ere meget strerke, trekantede og meget buede mod Spidsen, medens den er meget tynd og smal hos dem, der have brede, flade Kindbakker. Enden af disse ydre Plader er afrundet, sjelden, som hos Slægten Vertummus, forsynet med en bevagelig Tand, eller dybt fliget, som hos Underfamilien Amplithoince.

De indre Plader ere som oftest smaa, rudimentære, og da tilroxet de $y$ dre; hos Lysianassince sees de derfor som trende smaa Flige paa den indre Rand af de ydre; hos Iphimedia ere de noget storre, hos Ampelisca, Dulichia, Syrrhoë, hvor Underlæben er meget kort, sees de derfor tydeligere; hos Alylus og de nærmest den staaende Slægter samt hos Underfamilien Dexamine sees de som tvende smaa Plader ved Spaltens Bund; hos Familien Corophida ere Pladerne meget store, og blive endog tykke hos Slægten Amphithoë. Denne forskjellige Udvikling af Pladerne afhænger for en stor Del af Kindbakkernes Bygning, idet, naar disse ere stærke, trekantede og have en stor Tyggeknude samt ere meget boiede i Spidsen, der opstaar mellem dem et tomt Rum, som skal udfyldes af Underlæben med dens Biflige, og derfor ere disse forskjelligt modificerede efter Kindbakkernes Bygning.

\section{Andet Kjæbepar.}

Det nreste Fodpar er det andet Kjrebepar. Dette ligger lige indenfor Kjabefødderne, meu berører disse kun med den ydre Kant, da Kjæbefødderne have en mere convex Orerflade, inedens hint er boiet i modsat Retning lig det forste Par Kjæber og Kindbakkerne. Derred vilde der opstaa et tomt Rum mellem Kjæbefødderne og det andet Par Kjæber, hris det ikke, som anfort, bler opfyldt af Kjæbefoddernes indre Plade. Det andet Kjæbepar bestaar forst af et Grundled, dernæst af et meget kort Led, som ofte meget vanskelig sees, og til dette slutter sig en temmelig las lig. gende Del; disse tvende svare fuldstæudig til det af Kjæbeføddernes Led, som bærer den indre Plade. Derpan følger et meget stort Led, som indad er forlænget til en stor, med Borster besat Plade, hrilket svarer til Kjæbefoddernes ydre Plade. Indled. det paa Grunddelen af dette Led finder man ogsaa en Plade, som aldeles er tilsva. rende til Kjrbefoddernes Palpe, hvilken saaledes her er enleddet, medens den er flerleddet paa Kjæbefodderne. Jeg kalder disse dog for Lethedens Skyld det andet Kjæbepars ydre og indre Plader. Mellem begge Kjæbepar ligger Hypostomet, hror flere af deres Muskler ere frestede. 


\section{Kjæbefodderne.}

Hos Amphipoderne slutter den forste Legensring sig noie til Hovedet, og dennes Fodpar optræeder i Mundens Tjeneste og danner tilsammen ligesom en Underliebe, der drekker de øvrige Mnnddele; de kaldes Kjæebefødderne, Maxillapedes.

Disse Kjæbefodder dannes hos alle Amphipoder, undtagen hos Hyperiderne, hvor de ere i en meget rudimentær Tilstand, af folgende Dele: Nederst findes et af tvende Sidedele sammensmeltet Led, som kan ansees at rære Grundleddet for begge Kjæbefødder og tilhorer egentlig ikke Legemsringen. Dette Led er indbugtet i Midten $0 \mathrm{~g}$ omfatter til begge Sider det folgende Led. I dette fæster sig paa hrer Side to stærke Muskler, der bevæge det følgende. Dette bestaar oprindelig af to Led, som hos de fleste Former ere sammensmeltede og kun sjelden sees tydelig adskilte. Dog kan man undertiden, hvor Adskillelsen mellem begge ikke sees, vide, at en saadan virkelig findes, idet man seer Muskler, der tjene til at boie begge Led mod hinanden. Det overste of disse Led fortsatter sig i den ovre, indre Vinkel pan hver Side i en bred, temmelig lang Plade, der i Enden er mere eller mindre tvært afskaaret og besat med Tander og Børster. Disse Plader ere fuldstændig adskilte i den storste Del af sin Liengde og hænge kun sammen ved sin Rod. De indre til hinanden stødende Rande ere forsynede med stærke, fjærformede Borster, og hver af dem boier sig i Randen ind mod det folgende Par Munddele for at opfylde et tomt, trekantet Hul mellem Kjabefodderne og det forste Par Kjæber.

Det folgende, tredie Led, er fuldkommen adskilt paa hver af Kjæbefodderne fra det andet $\mathrm{og}$ er i Almindelighed temmelig kort, men udvider sig til en i Regelen overmaade stor, bred, halvoral Plade, der paa den indre, almindeligvis ret afskaarne Rand, som lregger sig til den tilsvarende paa der anden Side, er væbnet med stærke Tænder eller Torne, sjelden kun med Borster.

De folgende Led ere tynde og udride sig i Regelen kun lidet. Jeg kalder dem Kjæbefoddernes Palpe, medens jeg benævner de store, pladeformige Udvidninger af de foregaaende Led Kjæbefoddernes indre og ydre Plader. Palpen dannes oprindelig af 丂 Led, hvoraf det første i Almindelighed er kort, det andet noget længere, det tredie atter noget kortere, og det fjerde og femte er som oftest sammensmeltet til et kloformigt Led; dog sees ofte det sidste Led lig en Klo at viere frstet til det foregaaende Leds mere butte Ende. Da dette dog er meget sjeldent og disse trende Led oftere ere sammensmeltede, kalder jeg dem tilsammen det fjerde Led.

Dette Kjæbefodpar kan dog ofte blive modificeret i sit Udseende. Undertiden mangler det sidste Palpeled fuldstændig, og Palpen er saaledes treleddet, som Tilfreldet er hos Dexamine og Iphimedia; sjeldnere er Palpen kun toleddet, som hos Laphystius. Hos Parlalisca og Andre er Kjæbefoddernes indre Plade rudimentær, medens den hos Leucothoë, Nicippe, Eusinus og Flere er meget liden. Den Jdre Plade kan ogsaa blive meget liden, som hos Nicippe, Paramphilhoë, Eusirus og Flere, næsten rudi- 
mentrer hos Leucothoë og Stenothoë. Fuldkommen mangler Palpen hos IIyperia og beslægtede Former, der ere Yderpladerne vel bevægelige mod hinanden, men de indre ere fuldstændig sammenvoxede og tjene kun til at fylde det ellers aabne trekantede Rum mellem Kjæbefodderne og de følgende Munddele, naar Munden er lukket.

\section{Truncus.}

Efter Hovedet følger 7 Led, som jeg tilsammen - i Lighed med Lilljeborg kalder Truncus, og ethvert af dem, fra 1ste-7de, Truncusled eller Legemsled, idet jeg antager, at kun de tvende forste i Orerensstemmelse med, hrad der findes hos Insecterne, maa regnes til Thorax, medens de 5 bagre maa henføres til Abdomen. Hvert af disse Led dannes af en Ryg- og en Bugdel samt trende mellem disse liggende Sidedele, som kaldes Epimererne.

Fra disse Sidedele udspringer i Almindelighed et Fodpar, som kun mangler hos enkelte Caprellider, hos hvilke i Regelen tredie og fjerde Led ere fodlose. Undertiden smelter det forste $\mathrm{g}$ andet Led sammen, som hos en Art Iyperia og Parathemisto, undertiden ogsaa de trende sidste, som hos Dulichia. Hvert af Fodparrene bestaar af 6 frie Led, hroraf det yderste i Almindelighed er kloformigt, og som derfor gjerne benævnes Kloen. Et syvende Led, som er det første, er ubevægeligt og sam. mensmeltet med Epimererne og bærer A a $\mathrm{de}$ - og Eggeplader, forsaavidt saadanne forekomme. Aandeplader findes aldrig paa det første Fodpar, men kan være tilstede paa alle de orrige, dog oftest mangle de ogsaa paa det syrende, og hos Slægten Caprella findes de kun paa tredie og fjerde Legemsring. Aandepladerne ere hos de yngste Individer sækformige, hvilken Form de ogsaa oftest har hos Slægten Caprella; hos andre blive de fladtrylzte, skiveformige, hvilken Form man fiuder i Regelen hos de ovrige Amphipoder. De bestan saaledes af 2 Plader, der ligge tret til hinanden, og mellem disse er der et tret Maskeværk, der forener dern, og mellem hvilket Blodet cirkulerer. Langs Randen er der en storre fri Gang mellem begge Plader, medens Maskerærket er tættest i Midten. Overst, ner deres Udspring, ser man mellem Pladerne en storre Aabning, hrorfra Blodet fra Legemet strømmer ud, og denne er fra Begyndelsen til den omtalte Gang i Randen. Blodet lober nu i større eller mindre Buer, dels i Randgangen og dels i Maskevreket, og strommer tilbage i Legemet gjennem en Aabning, som ligger noget bagenfor Indstrømningsaabningen.

Eggepladerne udspringe indenfor Aandepladerna, ogsaa paa det fastroxte Grundled, og findes ikke paa de trende forste, men paa de fem bagre Fodpar, dog undertiden blot paa det tredie og fjerde, som hos Slægten Caprella. I sin forste Udrikling vise de sig som smaa Blærer, der ofte kan sees, især meget tydelig hos Slægterne Caprella og Eyina, hvor de ikke skjules af Sidepladerne eller Fodparrene, der hos disse Slægter ikke ere udriklede paa disse Legemsled. De have her givet Anledning til, at nogle Forfattere have antaget dem for rudimentære Fodpar; saaledes er Egina 
Phasma ( $E$. longispina Kroyer) henregnet til Slægten Prolella, idet de ikke udviklede $\mathbb{E g}$ geplader have været anseede for at være rudimentære Fødder. Deres videre Udvikling foregaar saaledes, at de forlænge sig og deres forreste og bagre Væg lægge sig til hinanden, endelig voxe de videre frem, deres Kanter erholde lange Borster, og idet de krumme sig mod hinanden fra begge Sider, danne de en fast tilsluttet Rugepose. Disse Plader ere hos nogle Former meget brede, som hos Atylince, medens de hos Andre, Lysianassince, Corophince O. S. v. ere smale.

De tvende forste Eodpars første Led er i Almindelighed langt, det andet og tredie oftest kort, det fjerde er i Regelen strerkere udviklet, og naar det femte er uddannet til en Gribehaand, kaldes den Carpus. Bliver Carpus forkortet, forlanger dets bagre, nedre Hjorne sig i en storre eller mindre, i Enden som oftest afrundet Del, som jeg kalder Hælen, Calx. Det fente Led kan enten være lidet, smalt, eller ogsaa meget stort, bredt, opulæst, og Neglen kan da være udviklet til at slaa sig op mod den bagre eller nedre Rand af det femte Led, som da gjerne er tilskjærpet, væbnet med Trender eller Torne; Leddet kaldes da Haanden (manus), og den tilskjærpede Rand, hvorimod Neglen liegger sig, kalder jeg Griberanden, Acies. Undertiden forlænger det nedre, bagre Hjorne sig til en Tommel, hrorimod Kloen kan slaa sig ind, og Haanden kaldes da saxdannet, Chela. Naar Tommelen ikke er udviklet, siges Haanden at vare subchelat. Kloen mangler sjelden, saaledes som paa det andet Fodpar hos Batyporeia. Uudertiden er Neglen overmaade bred, og da ikke kloformig, som hos Pardalisca ruspidata; den er ogsaa undertiden iklke uddannet til at slaaes ind mod Haanden, og da er denne ikke gribende.

De trende folgende Fodpar have den samme Retning, som de foregaaende, medens de tre bagre vende den modsatte Vei af hine. Hos disse er i Regelen det forste strerkt pladeformigt udridet, og dette sker vaentlig $\mathrm{i}$ den Hensigt at dæklke Gjællerne, som findes paa den indre Side, og som her ikke dækkes af de smaa Sideplader. Dette kan indsees deraf, at hos de Former, hos hvilke den fjerde Sideplade udvider sig meget bagud, og drekker de forste Led af disse Fodpar, ere disse ikke meget udvidede, ja ofte fuldkommen linirere, som hos enkelte Arter af Slægten Metopa. Hos flere Former, som leve i Rør, og som ikke forlade dette, ere disse Fodpars forste Led, uagtet Sidepladerne ere saa smaa, dog ikke udvidet, da Dyret ikke behøver nogen Dækning af Aandepladerne pą Grund af sin beskjærmende Bolig, f. Ex. hos Ilela, medens hos Slægten Ampelisca, som ogsaa bor i Rur, men ofte forlader dette, ere de tre bagre Fodpars forste Led meget bredt. Hos Caprella, hvor ingen Aandeplader findes paa disse Fodpar, er ogsaa deres forste Led smalt. Deres andet Led er i Almindelighed kort, medens det tredie er meget længere, det fjerde atter kortere og det femte er noget længere end det fjerde. Dog findes heri forskjellige Afrigelser; sjelden er det femte Led uddannet til en Haand, idet dets nedre, forreste Kant er udriklet til en Griberand, hrormed Neglen kan slaaes op, f. Ex. hos Slægterne Icara, Sunamphithoë, og især hos Caprella. 


\section{Postabdomen.}

Legemets sidste Led kalder jeg tilsammen Postabdomen. Denne danues i Al. mindelighed af syv Led, hroraf dog det sidste ikke er fuldstændig udviklet, men er enten pladeformigt, helt eller klovet, eller ogsaa tykt. Tarmen aabner sig aldrig i dette Led, som vi kalde Halevedhænget, appendix caudale, men i Enden af det foregaaende. Hos nogle Former kunne femte og sjette Led være sammenvorede, f. Ex. hos Slægterne Atylus og Ampelisca, uden dog at mangle. Hos Slægten Dulichia svinder fuldstiendig et af Postabdomens Led, som saaledes kun bliver sexleddet, og hos Caprellide og Cyamide bliver Postabdomen i end hoiere Grad rudimentrer, idet den endog kun bliver enleddet. Naar Halen er vel udviklet, er den forsynet med sex Par Fodder, hvoraf de tre forste have een Form, medens de tre bagre ere af en anden. De tre forste kaldes Svommefodder og dannes af et Grundled og to mangeleddede, med lange fjærformede Borster besatte Grene. Disse Fodpar ere i en bestandig Beræelse og tjene Dyret ikke alene til at fore det frem, men ogsaa, naar det ligger roligt, til at drive en stadig Vandstrom ind paa Gjællerne mellem de forreste Fodpar. Naar Halen er meget smal, sammentrykt fra Side til anden, ere ogsaa de anforte Fodpars Grundled smale, og de ligge fra begge Sider nær ind paa hinanden samt ere forenede indbyrdes ved trende strerke kloformige Hager, der sidde paa Enden af den indre Rand. Naar Halen er meget bred, nedtrykt, udvider Grundleddet sig ogsaa meget indad for at kunne lægge sig til og hefte sig fast til det paa den anden Side. Sjel. den findes der mere end tvende af disse Hager; hos Slagten Photis er der dog munge. De tre bagre Fodpar rende bagud og dannes af et Grundled og to Endegrene. Hos Slægten Dulichia, hvor et Led mangler, findes ogsaa kun to af disse Fodpar; hos Caprellide og Cyamidce ere de meget rudimentrere; hos Paradulichia er det andet Par rudimentert, men dog tilstede; hos mange Former er det sidste Par kun engrenet. Den ydre Gren er paa dette Par oprindelig toleddet, men det andet Led er som oftest rudimentært, om endog synligt i Form af en stark Torn, som hos Sliegterne Stenothoë og Hetopa; sjelden ere begge Led vel udviklede, som. hos Batyporeia og Viphargus. 


\section{Alphabetisk Fortegnelse over de vigtigste Arbeider vedkommende Amphipoderne til Aaret 1870.}

1. Abildgaard, Peter Chris., Znologire Danicre seu animalium Daniae et Norregiae rarior, ac minus notorum, descriptiones et historia, auctore $\mathbf{O}$. F. Hïiller. vol. III. 1789.

2. Allman, George James, Biological Contributions. On Chelura terebrans, Philippi an Amphipodous Crustacean destructive to submarine tember-works. Ann. Nat. Hist. XIX, p. 361-370.

3. Andrzejowski, A. Catalogue des object qui se conservent dans le Cabinet zoologique de l'université de St. Vladimir a Kief (c. diagnos. spec. nouv.) 1ère Partie. Bull. Soc. Imp. Natur. Moscou 1839. I. p. 3-24.

4. Aristoteles, Naturgeschichte der Thiere, übersetzt und mit Anmerkungen begleitet von Dr. Friedrich Strack 1816.

5. Audouin, Jean Victor, Explication sommaire des planches de l'ourrage de la commis. sion d'Egypte. In fol. Paris 1825-1827, des Mollusques, des Annilides, des Crustacés, des Aracnides, des Insectes, des Echinodermes, des Ascidies de l'Egypte.

6. Baster, Job., Opuscula subsecira, observationes miscellaneas de animalculis et plantis qrisbusdam marinis, eorumqve orariis et seminibus continentia. II. Tom. Libr. Harlemi 1759-65.

7. Bate, C., Spence, Notes on the boring of marine animals. Brit. Assoc. Rep. 1849, p. $73-75$.

8. - - Notes on Crustacea. Ann. Nat. Hist. VI, 1850, p. 109-111. VII. 1851, p. $297-300$.

9. - - On some Crustacea dredged by Mr. Barlee in Shetland. Ann. Nat. Hist. X. 1852, p. 356-357.

10. - - On a new Amphipod. Dublin. Nat. Hist. Soc. Proc. II. 1856-1859, p. $58-59$.

11. - - On the British Edriophthalma. Anı. Nat. Hist. XX. 1857, p. 524-525.

12. - - On a new Amphipod, Iphimedia Eblanc. Nat. Hist. Review. IV, 1857, p. 229-230.

13. - - On sorne new genera and species of Crustacea Ainphipoda. Annals and Magz. of Nat. Hist. 3. ser. vol. I. (1858), p. 361-362. 
14. Bate, C., Spence, Characters of new species of Crustaceans, discovered by $\boldsymbol{I}$. $\boldsymbol{K}$. Lord on the coast of Vancouver Island. Proc. Zool. Soc. 1864, p. 661-668.

15. - - On the Morphology of some Amphipoda of the Division Hyperina. The Annals and Magaz. of Nat. Hist. 3. ser. vol. VIII. 1861, p. 1-15, pl. $1 \& 11$.

16. - - On the nidification of Crustacea. Ann. of Nat. Hist. 3. ser. vol. I. (1858), p. 161-169. 317. Ann. Sci. Nat. IX. (Zool.) 1858, p. 255-264.

17. - - A Synopsis of the British Edriophthalmous Crustacea. Part. I. Amphipoda. Ann. of Nat. Hist. 2. ser. vol. 19. 185\%, p. 135-152.

18. - - On a new Genus and sereral new species of British Crustacea. The Annals and Hagaz. of Nat. Hist. vol. VII. 1851, p. 318-321.

19. - - On the Genus Niphargus, Schiodle. Dublin, Zool. Bot. Assoc. Proced. I. 1859, p. $237-240$.

20. - - On the fossil Crustacean found in the magnesian limestone of Durham, and on a new species of Amphipod (1858). Geol. Soc. Journ. XV. 1859, p. 137-140. Nat. Hist. Review. VI. 1859. (Proc.), p. $163-166$.

21. - - Note on the supposed, "Discovery of an extremely minute Vertebrate Lower Jaw in mud dredged at St. Helena, by Dr. Wallich." Ann. Nat. Hist. X, 1862, p. 440-441.

22. - - Catalogue of Amphipodous Crustacea in the Brit. Museum's collect. London 1862 u. 58 plates.

23. Bate, C. Spence, \& Westwood, I. 0. History of the british sessile-eyed Crustacea. vol. I. 1861-63. vol. II. parts VIII. XIV. XV. 1866. London.

24. Bell, Thomas. Account of the Crustacea. Last of the arctic royage under the Command of Captain Sir Edward Belcher in scearch of Sir John Franklin during the years. 1852-53-54. vol. II. 1855 .

25. Beneden, P. I. van. Recherches sur les Crustacés du littoral de Belgique. Memoires a l'Academie royale des Sciences des lettres et des Beaux-arts de Belgique. Tom. XXX. 1861, p. 95.

26. Boeck, Axel. Crustacea amphipoda borealia et arctica. 1870. Særskilt Aftryk af Forhandlinger i Videnskabs-Selskabet i Christiania Aar 1870.

27. - - Bidrag til Californiens Amphipodefauna. Sarskilt Aftryk af Forhandlinger i Videnskabs-Selskabet i Christiania Aar 1871.

26. - - Bemærkninger anganende de ved de norske Kyster forekommende Amphipoder. Forhandlinger ved de Skandinaviske, Naturforskeres ottende Mode i Kjobenharn 8-14de Juli 1860, p. 631-67\%.

29. Bosc, Louis Augustin Guillaume. Histoire naturelle des Crustacés, contentut leurs description et leurs moeurs. 2 vol. aux. 1802. 
30. Bosc, Louis Augustin Guillaume. Histoire naturelle des Crustacés, comprenent leurs description et leurs moeurs. Edit. mise au niveau des connaissances actuelles, par A. G. Desmarest. 2 rol. orné de $18 \mathrm{pl}$. in. 18. Paris 1829.

31. Bouchard-Chantereaux. Animaux sans vertebres observés dans le Boulonnais. Extr. du précis de l'histoire physique, civile et politique de la ville du Boulogne sur mer par M. Bertrand. 1829.

32. Brady, G. S. On the Crustacean Fauna of the salt-marches of Northumberland and Durham. Nat. Hist. Transact. of Northumberland and Durham III. p. $120-136$, pl. $4 \& 5$.

33. Brady, G. S. \& Robertsen, David. Notes of a week's dredging in the west of Ireland. Ann. \& Mag. Nat. Hist. 4. ser. rol. III. p. 353-374, pl. $21,22$.

34. Brandt, I. F. Beiträge zur Kenntniss der Amphipoden. Bull. physs. math. Acad. St. Pétersb. Tom. 9. 1851. Erste Artikel 134-138. Zweiter Artikel 138-144. Dritter Artikel 310-313.

35. - - Ueber den gleichzeitig mit der Ausrottung der Pflegemutter bewerkstelligten geschichtlich nachweisbaren Untergang einer kleinen parasitischen Krebsart (Cyamus oder Sirenocyamus Rytinae). Bull. phys. math. Acad. St. Pétersb. Tom. V. 1847, p. 189-192.

36. - - Crustaceen, A. Th. - Middendorft"s Reise in den äussersten Norden u. Osten Sibiriens 1851.

37. Brébisson, E. Alphonse de, Catalogue des Crustacés, terrestres, fluriatiles et ma. rins, ricuellis dans le département du Calvados in 8. Falaise 1815.

38. Bruzelius, Ragnar Magnus. Bidrag till Künnedomen ou Skandinaviens Amphipoder. Lund 1859.

39. Burgersdijk, Leon Alex. Jean. Specimen academicum inaugurale, continens annotationes de qribusdam Crustaceis indigenis. Lugduni Batar. 1852.

40. Cajander, A. I. Bidrag till Kännedommen om sydresten Finlands Krustaceer. No. tiser ur Sällsk. pro Flora and Fauna fennica Förh. 1869, p. 373-376.

41. Caspary, Robert. Gammarus putaneus Koch. Rheinl. u. WVestphal. Verhand. 1849, p. 39 - 48.

42. Claus, C. Bemerkungen über Phronima sedentaria Forsk. und elongata. Zeitschr. f. wissensch. Zool. XII, p. 189-197, Tar. 19.

43. - - Ueber Phronima elongata Cls. Würzburger naturwissenschaftliche Zeitschrift. 3. Band. 1862, p. 247-251.

44. Cocco, Anast. Descrizione di alcuni Crostacei di Jessina, Giorn. di Scienz. Litt. ed Arti per la Sicilia. Tom. 44. 1833, p. 107-115.

45. - - Su di alcuni nuovi Crustaces de mari di Messina. Effemeridi scien. tifice \& litterarie per la Sicilia. rol. 6. 
46. Costa, A. Ricerche sui Crostacei amfipodi del Regno di Napoli. Rendiconto dell' Accad. de Sci. di Napoli. Tom. 3. 1853, p. 167-168.

47. - - Ricerche sui Crostacei amfipodi del Regno di Napoli. Mem. della R. Accad. de Sci. di Napoli. Vol. I. 1857, p. 165-235.

48. - - Osservazioni sulla Diphya qradrivalris e su' Crostacei che si sviluppano entro i bottoni delle appendici urticanti. Tom. 3. 1862, p. 90. Annuario del museo zoologico I. 1862, p. 90. T. 3, fig. 18.

49. - - Di alcuni Crostacei degli Acalefi e di un Distomidio parassitto. Rendiconto dell' Accademia delle scienze fisiche e matematiche III. Na. poli 1864, p. 86 ff.

50. - - Sopra una specie Mediterranea del genere Lestrigonus. Rendic. dell Accad, delle sc. fis. e matemat. Napoli 1865, p. 34.

51. - - Di due nuove specie di Crostacei amfipodi del Golfo di Napoli. Annuario del museo zoologico della R. Universita di Napoli 1864. II, p. $153-157$.

52. Dana, J. D. Synopsis of the genera of Gammaracea. American Journal of science. Sec. ser. Vol. VIII. Nor. 1849, p. 135-140.

53. - - Catalogue and description of Crustacea collected in California by Dr. John Le Conte. Proceed. Acad. Philad. VII. 1854, p. 175-177.

54. - - A new genus Orchestida (Talitronus). Silliman Americ. Journal of science and arts. 1850. IX, p. 295.

55. - - On the classification of the Crustacea Choristopoda or Tetradecapoda. The American Journal of science and arts. Sec. Series, T. XIV. 1852, p. $297-316$.

56. - - Conspectus crustaceorum in orbis terrarum circumnavigatione, Carolo Wilkes e classe Reipublicæ foederatæ Duce, collectorum. Amer. Acad. Proceed. I. Silliman Jour. IV. 1852-1853, p. 6-10, 16-28, $73-86$.

57. - - The Cruslacea: United States Exploring Expedition during the years 1839-42 under the command of Ch. Wilkes. Philadelphia 18521854. 96 plates 1855 .

58. Danielssen, D. C. Beretning om en zoologisk Reise, foretagen i Sommeren 1857. Nyt Magaz. for Naturvidensk. XI. 1861, p. 1-58.

59. Desmarest, An. Gaëtan. Cousidérntions géteérales sur la classe des Crustacés et description des espèces de ces animaux, qui vivent daus la mer, sur les côtes, ou dans les eaux douces de la France. Arec 5 tableaux et $56 \mathrm{pl}$. gravées. 1825 . $8 \mathrm{ro}$.

60. Dictionnaire nouveau d'histoire naturelle, appliquée aux arts, principalement à l'agriculture et à l'economie rurale et domestique. Par une Societé des naturalistes et d'agriculteurs. Avec de figures larcées des trois 
regnes de la nature. I. edit. Paris. 24 vol. in 8 . Crustacés par Bose et Latreille. 2. edit. ou 150 planches 36 vol, Paris. Crustacés par Latreille.

61. Dohrn, A. Zur Naturgeschichte der Caprella. 'Zeitschrift f.'wiss. Zool. XVII, p. $245-252$.

62. Edward, Th. Stray notes on some of the smaller crustaceans No. 1. On the Habits etc. of the Hyperidre No. 11. Journ. Linn. Soc. vol. IX, p. $143-166$.

63. Eichwald, Edwardus. Faunae Caspio-Cancasiae nonnullis observationibus novis illustravit. Nemoires de la Societé des Nouveaux des naturalistes de Moscou. T. VII. 1841.

64. Eschsholtz, Fr. Uebersicht der zoologische Ausbeute während der Reise vou Kronstadt bis St. Peter und Paul. (Mit Abbild.) Isis 1825, p. 733-747.

65. Fabricius, Joh. Christ. Reise nach Norwegen, mit Bemerkungen aus der Naturhistorie u. Oeconomie. Hamburg 1779.

66. - - Systema entomologiæ, sistens Insectorum classes, ordines, genera, species, adjectis synonymis, locis, descriptionibus, observationibus. Flensburgi 1775. 8 maj.

67. - - Mantissa Insectorum, sistens eorum species nuper detectas; adjectis characteribus genericis, differentiis specificis, emendationibus, observationibus. II. Tom. Hafnire 1787. 8 maj.

68. - - Entomologia systematica, emendata et aucta, secundum classes, ordines, genera, species; adjectis synonymis, locis, observationibus, descriptionibus. IV. Tom. Hafnia 1792-1794. 8 maj.

69. - - Supplementum. 8 maj. Hafnir 1798.

70. - - Genera Insectorum, eorumque characteres naturales, secundum nu. merum, figuram situm et proportionem omnium partium oris; ad. jecta mantissa specierum nuper detectorum. Kilonii 1777. 8 maj.

71. Fabricius, Otho. Fauna Groenlandiæ systematice sistens animalia Groenlandiæ occidentalis hactenus indagata, etc, maximaque parte secundum proprias observationes. Cum tab. aen. I. mai. Hafniæe et Lipsia 1780.

72. Fleming, John. Gleanings of natural history gathered on the coast of Scotland during a voyage in 1821. The Edinburgh philosophical Journal con. ducted by Dr. Brewster and Professor Jameson 1823, p. 294-303.

73. Forel. Introduction à l'étude de la faune profonde du lac Leman. Bulletin de la Soc. Vandoise de Sci. Nat. X. 1869, p. 220-224.

74. Forskål, Pet. Descriptiones animalium Avium, Anphibiorum, Piscium, Insectorum, Vermium, qvæ in itinere orientali observarit. Post mortem auctoris ed. Carst. Niebuhr. Adjecta est materia medica kahiriana atque tab. maris rubri geographica. Hafnix 1775. 
75. Frey u, Leuckart. Beiträge zur Kenntniss d, wirbellosen Thiere, 1847. 4.

76. Frisch, Joh. Leonh. Beschreibung rou allerley Insecten in Tentschland, nebst nutzlichen Anmerkgn. u. nöthigen Abbildgn. von diesen kriechenden $u$. fliegenden inländischen Gewürme, zur Bestätigung u. Fortsetz. der gründlichen Entdeckung, so einige von der Natur dieser Creaturen herausgeg. u. zur Ergänz. u. Verbesser. der audern. 13 Thle. 1730.

77. Geer, Charles baron de. Mémoires pour servir à l'histoire des Insectes. T. VII. Arec $238 \mathrm{pl}$. gr. in 4. Stockholm 1752-78.

78. Geoffroy, Etienne Louis. Histoire abrégée des Insectes, qui se trouvent aux environs de Paris, dans laquelle ces animaux sont rangés suivant un ordre méthodique. 2 Tom. Paris 1764.

79. Gerstfeldt, G. Ueber einige zum Theil neue Arten Platoden, Anneliden, Myriapoden und Crustaceen Sibirien's, vamentlich seines östlichen Theiles und des Amur-Gebietes. Mem. de l'acad. de St. Pétersbourg par divers sarants. VIII. 1859, p. 291-296.

80. Gervais, Paul. Notes sur deux espéçes de Crevettes (Gammarus), qui vivent aux envirous de Paris. Ann. Scienc. natur. 2 Ser. (Zool.) Tom. IV.1835, p. $127-128$.

81. Gesner, Conr. Medici Tigurini historiæ animalium. Liber IV. Qui est de Piscium et aqvatilium animantium natura. Cum icunibus singulorum ad vivum expressis fere omnibus 1712. Tiguri 1548.

82. Godiheu de Riville. Mémoire sur la mer lumineuse. Mémoires de Mathematique et de Physique présentés à l'Academie Royale des Sciençes par divers sarants. Tom. 3ine. Paris. 1760, p. 269-276.

83. Goës, A. Crustacea amphipoda maris Spitsbergiam alluentes cum speciebus aliis arcticis. 6 Tabb. aen. Öfvers. Vetensk. Akad. Förhandl. 1865, p. $517-536$.

84. Goodsir, Harry D. S. On a new genus, and six new species of Crustacea, with observations on the developement of the egg, etc. Edinb. New Phil. Journ. Vol. 33. 1842, p. 174-192. Ann. Sci. Nat. XVIII. (Zool.) 1843, p. $181-184$.

85. - - Descriptions of some new crustaceous animals found in the Frith of Forth. Edinu. New Phil. Journ. Vol. 33. 1842, p. 363-368.

86. - - Descriptions of some animals found amongst the Gulf-weed. Ann. nat. hist. XV. (1845), p. $73-76$.

87. Gosse, P. H. Notes on some new or little-known Marine-Animals. Ann. and Mag. of nat. hist. XVI. 1855 , p. 27-36 \& 305-313.

88. - - A Manuel of marine Zoology for the British Isles. 2 Pts. London 1855 .

89. - - A naturalist's rambles on the Deronshire coast. London 1853. 8. 
90. Gould, A. A. Report on the Invertebrate animals of Massachusetts. Cambridge 1841. 8 .

91. Gronovius, Laur. Theo. Zoophylacium Gronovianum, exhibens Qvadrupeda, Amphibia, Pisces, Insecta, Vermes, Molusca, Testacea et Zoophyta, qvæ in museo suo adservavit, examini subjecit, systematice disposuit atque descripsit etc. Additis rarissimorum objectorum iconibus, Lugduni - Batavorum 1781.

92. Grube, Ed. Beschreibungen einiger Amphipoden der Istrischen Fauna. Archiv f. Naturgesch. XXX. 1864, p. 195-213.

93. - - Mittheilungen über St. Vaast - la Hougue und seine Meeres, besonders seine Anneliden Fauna. Verhandl. der schlesischen Gesellschaft f. vaterländische Kultur 1869 , p. 38.

04. - - Beiträge zur näheren Kenntniss der Istrischen Amphipoden-Fauna. Archiv für Naturgesch. 1866, p. 377-417. Tab. IX und X.

95. - - Die Insel Lussin und ihre Meeresfauna. 1. Tom. Karte von Lussin. Breslau 1864. 8.

96. - - Ausfluge nach Triest und dem Qvarnero. Beiträge z. Kenntu. der Thierwelt dieses Gebietes. Berlin 1861.

97. Guérin-Méneville, Felix Edouard. Némoire sur le nouveau genre Themisto de la classe des Crustacés. Soc. Hist. Nat. Mém. IV. 1828, p. 378-386.

98. - - Description de quelques genres nouveaux de Crustacés appartenant ¿̀ la famille des Hypérines (Oxycephalus piscatorius, O. oceanicus). Mag. de Zool. VI. 1836. Cl. VII, pl. 17-18.

99. - - Description du genre Phlias et espèce P. serratus. Mag. de Zool. VI. 1836. Cl. VII, pl. 19.

100. - - Description d'un Crustacé amphipode formant un genre nouveau dans la famille des Hypérines. Rerue zool. (1842), p. 214-216.

101. - - Iconographie des Crustacés (fais. partie de l'Iconographie du règne animal de Curier). Paris 1829. 43. 8vo. avec 36 plehs.

102. Haan, W. de. Fauna Japonica auc. Ph. Fr. de Sieboldt. Crustacea elaborante W. de Haan. C. tab. lith. LXV. Lugd..Bat. 1850.

103. Hammer, Christopher. Forsøg til en norsk Naturhistorie. 1775.

104. Heller, C. Beiträge zur Crustaceen - Fauna des rothen Meeres. Sirzungsber. der mathem.-naturwiss. Classe der Acad. d. Wissensch. zu Wien. Bd. 43, p. 297-374 m. 4 Taf. und Bd. 44, p. 241-295 m. 3 Taf.

105. - - Kleine Beỉträge zur Kenntn. der Süsswasser-Amphipoden. Verh. zoolog.-bot. Gesellsch. XV. Wien 1865, p. 979-984. Tab, XVII.

106. Heller, C. Zur näheren Kenntı. der in den süssen Gewassern des südlichen Europa vorkommenden Meerescrustaceen. Zeitsch. f. wiss. Zool. XIX, p. 156-162. 
107. Heller, C. Beiträge zur naheren Kenntniss der Amphipoden des Adriatischen Neeres. Wien 1866 in 4 to. 62 p. u. $4 \mathrm{Kpfr}$. Denkschriften d. K. K. Acad. B. 26. 2 Abth. p. 1-62.

108. - - Reise der oesterreichischen Fregatte Novara um die Erde in den Jahren 1857-58_59 unter den Befehlen des Commandoers B. von Wiullerstorf-Urbair. Zonl. Theil. 2. Band, 3. Abth. Crustaceen. Vienna 1865. 4to. 25 Kpfrtaf.

109. Herbst, Joh. Friedr. Wilh. Versuch einer Naturgesch. der Kraben u. Krebse, nebst einer system. Beschreib. ihrer verschiedenen Arten, 3 Bde. in 18 Heften. Mit 62 illum. Kpfrtaf. gr. 4. Zürich, Berlin u. Stralsund 1782-1804.

110. Herklots. Symbolæ carcinologicæ. Etudes sur la classe des Crustacés. Leyden 1861.

111. Hesse, M. Observations sur des Crustacés rares nu nouveaux des côtes de France. Quinziéme article descript. d'un nouveau Crustacé appartenant au genre Limenoria. Ann. Sci. Nat. X, p. 101-120, pl. 1.

112. Hogan, A. R. On the habits and localities of Niphargus fontanus (n. S.), V. Kochiamus (n. s.) and Crangonyx subterraneus (n. g. et n. s.) Spence Bate. Proceed. Dubl. Univ. Zool. and Bot. Assoc. 1859, p. 241-244. Nat. Hist. Review. VI. 1859 (Proc.), p. 166-169.

113. Hope, Fr. Gugl. Cataloge del Crostacei Italiani e di molti altri del Mediterraneo. Napoli 1851. 48 Pag.

114. Hosius, Aug. De Gammari speciebus, qvæ nostris in aquis reperiuntur. Dess. zoologica. Bonnæ 1850. 8. \& 2 Tabb. aen.

115. - - Ueber die Gammarus-Arten der Gegend von Bonn. Archiv f. Naturgesch. 16. Jahrg. 1850. 1 B., p. 234-248.

116. Johnston, George. Contribution to the British Fauna. Zoological Journal vol. IV. 1829 , p. 52-57, 416-421.

117. - - Illustration in British Zoology (Caprella acuminifera, Nymphum coccineum). The Magazin of Natural History and Journal, conducted by Laudon. 1833, p. 40-43.

118. - - Illustration in British Zoology (British species of genus Caprella and Proto, Order L(emodipoda Latreille). Mag. nat. Hist. VIII. 1825, p. $668-675$.

119. Kay, James de. History Natural of New-York. Zoology Crustacea 1844. roy. 4. w. 23 col. plates.

120. Kinahan, John Rob. Repurt of the Committee appointed to dredge Dublin Bay. Report of the 30 meeting of the Brit. assoc. for the avanc. of science, held at Oxford, 1860, p. 27-30. 
121. Kinahan, John Rob. Note on the marine Fauna of the coast of Claire. Dublin qvart. Journ. of science. III. p. 7. eff:

122. Klein, Jac. Theod. Summa dubiorum circa classes Qradrupedum et Amphibiorum in celebris domine Carol. Linnaei systemate naturae: sive naturalis Qvadrupedum historiae promovendae prodromus cum praeludio de Crustatis. Gedani et Lipsiae. 1743.

123. - - Historiae naturalis Piscium promovendae. missus V. cum praefatione de Piscium anditu. Gedani 1740-1749.

124. Kock, C. L. Deutschlands Crustaceen, Myriapoden u. Arachniden. Ein Beitrag zur deutschen Fauna. Herausgeg. von Herrich-Schäffer. Regensburg 1835-1841. Heft. 36.

125. - - Zusammenstellung der in Kock's „Deutschlands Crustaceen, Myria. poden und Arachniden“, daneben so in "Deutschlands Insecten von Dr. Panzer und Herrich-Schäfter," vorkommenden Crustaceen. 1847.

126. Kröyer, Henrik. Grønlands Amphipoder beskrevne. Det Kongelige Danske Videnskabernes Selskabs naturvidenskabelige og mathematiske Afhandlinger. 7de Deel. 1838, p. 229-326.

127. - - Om Cyamus Ceti Linn. med et Par Bemærkninger, betræffende de paa Hvalerne levende Smaadyr's Anvendelse til Hvalarternes Adskillelse. Naturh. Tidsskr. B. 4. 1843, p. 474-489.

128. - - Beskrivelse af nogle nye Arter og Slagter af Caprellina, med indledende Bemrerkninger om Lamodipoda og deres Plads i Systemet. (3 Tarl.) Naturh. Tidsskr. B. 4. 1843, p. 490--518 og 585-616.

129. - - Nye nordiske Slægter og Arter af Amphipodernes Orden, henhorende til Familien Gammarina. Naturh. Tidsskr. Bd. 4. 1843, p. $141-166$.

130. - - Karcinologiske Bidrag. Naturh. Tidsskr. 2. R. 1. B. p. 113 og 2. R. 2. B.

131. - - Voyages de la commission scientifique du Nord; en Scandinavie, en Laponie, au Spitzberg et aux Ferö, pendant les années 1838-40, sur la corrette la Recherche, publiés par ordre du Roi sous la direction de M. Paul Gaimard. Crustacés.

132. Lamarck, Jean Bapist, chevalier de. Histoire uaturelle des animaux sans rerièbres. Tom. V. Paris 1818.

133. - - do. Edit. deuxième. Tom. V. 1838 par G. P. Deshayes et H. MilneEdwards.

134. Latreille, Pierre André. Cousidérations générales sur l'ordre naturel des animaux composant les classes des crustacés, des arachnides et des insectes, avec un tableau méthodique de leur genres, disposés par familles. Paris (1806) 1810. 8. 
135. Latreille, Pierre André. Genera Crustaceorum et Insectorum secundum ordinem naturalem in familias disposita, iconibus exemplisque plurimis explicata. 4. voll. cum tabb. aen. 16. 8. Parisiis et Argentorati. 1806, 1807, 1809.

136. - - Les crustacés, les arachnides et les insectes distribués en familles naturelles. 2 vol. Paris 1829.

137. - - Histoire naturelle, générale et particulière, des Crustacés et des Insectes. Ouvrage faisant suite aux oeurres de Leclere de Buffon et partie de cours complet d'hist. naturelle redigé par C. S. Sonini. 14 vol. avec $374 \mathrm{pl}$. Paris an $\mathrm{X}-\mathrm{XIII} .8$.

138. - - Encyclopédie méthodique. Planches de crustacés et des insectes avec leur explication. Paris 1818.

134. Leach, William Elfort. Crustaceology. Edinb. Encyclopedia. Tom. 6. 1813-1814.

140. - - A general arrangement of the classes Crustacea, Myriapoda and Arachnides, with descriptions of some new genera and species. The Traus. of the Linu. Society of London. Vol. XI.

141. - - A tabular view of the external characters of four classes of animals, which Linneus arranged under Insecta. The Trans, of the Linn. Society of London. Vol. XI. 1815, p. 306-400.

14:. - - A Voyage of Discovery etc. by John Ross. 1819. Appendix. A List of invertebrate animals discovered by His Majesty ship Isabella. 1819.

143. - - Zoological miscellany being description of new or interesting animals, illustrated with col. figures. 3 vol. London 1814-1817. 4.

144. Lepechin, Iwan. Tres oniscorum species descriptae. Acta academiae scientiarum imperialis Petropoliana pro anno MDCCLXXVIII. pars I. p. 247.

145. Liljeborg, W. Bidrag till den högnordiska hafsfaunan. Öfversigt af Kongl. Vetenskaps-Akademiens Förhandlingar. 1850, p. 82-88.

146. - - Bidrag till Norra Rysslands och Norriges Faunn, samlade under en vetenskaplig resa $\mathrm{i}$ dessa länder 1848. Kongl. Vetenskaps.Akademiens Förhandlingar。1850, p. 233-242. Naumannia 1852, p. 87-93.

147. - - Hafs-crustaceer vid Kullaberg. Öfvers. af Kongl. Vetenskaps-Akademiens Förhandl. 1852, p. 1-13. 1855, p. 117-138.

148. - - Zoologisk resa i Norra Ryssland och Finmarken. Öfrersigrt af Kongl. Vet.-Akad. Förhandl. 1849, p. 16-37.

149. - - Norges Crustaceer. Öfvers. af K. Vet.-Akad. Förhandl. Stockholm 1851 , p. $19-27$.

150. - - Örersigt af de inom Skandinavien hittills funna arterna af slägtet Gammarus Fabr. Kongl. Vetenskaps-Akademiens Förhandl. 1853, p. 444-460.

151. - - On the Lysianassa magellanica of Milne-Edwards, and on the Cru- 
stacea of the Suborder Amphipoda and the Subfamily Lysianassina found on the coast of Sweden and Norway. Nova acta regiae societatis scientiarum Upsaliensis. 3. Ser. 1865.

152. Lindström, G. Bidrag till käunedomen om Östersjüns invertebrat-fauna. Öfversigt af Kongl. Vetenskaps-Akaderniens Förhandl. 1855, p. 49-73.

153. Linné, Carl von. Ölandska och Gothlandska resa på riksens Högloflige Ständers befallning förrättad år 1741 med Anmerkninger uti Oeconomien, $\mathrm{Na}$ tural.Historien, Antiqviteter. Stockholm och Upsala 1745.

154. - - Skănska resa, på höga Öfverhetens befallning förrüttad år 1749. Stockholm 1751.

155. - - Fauna Suecica. I. edit. I. vol. Lugduni Batavorum 1746.

156. - - Systema naturæ. Ed. XII. Holmiæ 1766.

15\%. Lovén, S. Om năgra i Vettern och Venern funna Crustaceer. Öfvers. K. Vet.Akad. Förhandl. 1861, p. 285-314.

158. Lucas, H. Exploration scientifique de l'Algérie pendant les années 1840, 1841, 1842. Zoologi. Histoire naturelle des animaux articulés. Paris 1845.

159. - - Castelnau, Expedition dans les parties centrales de l'Amerique du Sud de Rio Janeiro au Lima et de Lima au Para 1857. Zoologi. Tom. III. Crustacea.

160. - - Essai sur les animaux articulés qui habitent l'îsle de Crête. Revue et Magas. de Zool. 2. sér. Tom. 5. 1853, p. 418-424.

161. Lütken, Chr. Bemarkninger om Cyamus. Forhandlinger paa Skandinav. Naturf. ottende Møde i Kjobenhavn 1860, p. 590-592.

162. Mandt, Mart. W. Observationes in historiam naturalem et anatomiam comparatam in itinere Groenlandicae factae. Berlin 1822. 8.

163. Marcusen, I. Zur Fauna der schwarzen Dleeres, Arch. f. Naturg. XXXIII. 1867, p. $357-363$.

164. Martens, Ed. von. Ueber einige ostasiatische Süsswasserthiere. II. Crustacea. Wiegm. Arch. XXXIV. 1868, p. 17-61.

165. Martens, Friderich. Spitzbergische oder grcenländische Reisebeschreibung gethan in Jahr 1671. Hamburg.

166. Metzger, A. Die wirbel!osen Thiere der oestfriesischen Küste u. 2 Beitrag. Hanover 1871.

167. Milne-Edwards, M. H. Extrait de recherches pour servir à l'histoire naturelle des Crustacés amphipodes. Annales des Sciences naturelles. Tom. XX. 1830, p. $353-399$.

168. - - Histoire naturelle des Crustacés. 3. vol. Paris 1834-1840. 8. avec Atlas de 44 pls.

169. - - Note sur une Anplipode crustacé, remarquable par sa grande taille. Ann. des Scienc. natur. 3. ser. Zool. Tom. 9. 1848, p. 398. 
170. Milne-Edwards, M. H. Note sur un Crustacé amphipode, remarquable par sa grande taille. Ann. des. science naturelle (Zool.). III. ser. Tom. IX. 1848 , p. 398.

171. - - , M. H., \& Lucas. d'Orbigny, Alcide, Voyage dans l'Amerique méridionale exécuté dans le cours des années 1826, 1827, 1828, 1829, 1830, 1831, 1832, 1833. Vol. VI. Animaux articulés. Crustacées par Milne-Edwards \& Lucas.

172. Milne-Edwards, Alph. Description de quelques Crustacés nouveaux provenant des rosages de M. Alfred Grandidier à Zanzibar et ̀̀ Madagascar. Nouvelles Archives du Muséum d'hist. nat. T. IV. p. 49-60, pl. $16-18$.

173. Mohr, Nic. Forsog til en islandsk Naturhistorie med adskillige oekonomiske samt andre Anmærkninger. Kjobenharn 1786.

174. Montagu, Georg. Description of several marine' animals found on the south coast of Devonshire. The Transact. of the Linnean Soc. of London. Vol. VII. (1804), p. 81-114.

175. - - Description of several new or rare animals, principally marine, discorered on the south coast of Devonshire. The Transact. of the Linn. Soc. of London. Vol. II. (1815), p. 1-26.

176. Moufet, Thom. Insectorum sive minimorum animalium theatrum, olim ab Ed. Wottono, Conr. Gesnero, Thomaque Pennio inchoatum, tandem a Th. Moufeto perfectum. London 1634. Fol.

17\%. Müller, Friedrich. Ueber Gammarus ambulans. Archiv f. Naturg. 12 Jalxrg. 1846, p. $296-300$.

178. - - Orchestia Euchore u. Gryphus, neue Arten aus der Ostsee beschrieben. Arch. f. Naturg. 14 Jahrg. 1848, p. 53-64, Tab. IV. fg. 1-28.

179. Müller, Fritz. Für Darwin. Leipzig 1864, 8. maj. m. 67 Holtzschn.

180. - - Description of a new genus of Amphipod Crustacea. Ann. \& Mag. of Nat. Hist. 1865, p. 276-27\%, pl. I.

181. Müller, Otto Fried. Zoologiae Danicae prodromus, seu animalium Daniae et Norvegiae indigenarum characteres, nomina et synonyma imprimis popularium. Hafniae 1776.

182. Münter, Jul., \& Buchholz, Reinh. Ueber Balanus improvisus (Darw.), var. gryphius (Münter). Beitrag zur carcinologischen Fauna Deutschland. Mit. theilungen d. naturwis. Vereins $v$. Neu-Vorpommern u. Rügen. I. 1866. p. $1-40$.

183. Natale, Guiseppe de. Descrizione zoologica d'una nuora specie di Plojaria e di alcuni Crostacei del porto di Messina con poche considerazioni generali sulla natura delle appendici aculeiformi delle piante e degli animali. Messina 1850, Tab. 2. 
184. Natale, Guiseppe de. Su Pochi Crostacei del porto di Messina. Lettera del Dottor Guiseppe de Natale al Sig. Achille Costa. Con una tarola. Napoli 1850.

185. Nicolet. Gay Claude, Historia fisica y politica de Chili segun documentos adquiridos en esta republica durante doze años de residentia en ella y publicada bojo los suspicios del supremo gobierno. Articulados, Crustacea. Paris 1843.

186. Norman, A. M. Report on Crustacea. Reports on Dredging Operations on the coast of Northumberland and Durham in Juli and August 1863. Edited by Brady. Trans. Tynes. Nat. Field. Club. 1864, 1865. Vol. IV.

187. - - Report on the Crustacea. Nat. Hist. Trans. Northumberland and Durham 1865. Vol. I. p. 12-29.

188. - - Report of the Committee appointed for the purpose of exploring the coast of the Hebrides by means of the dredge. Part. II. Crustacea. Report Brit. Assoc. 1867, p. 193.

18?. - - On Crustacen amphipoda new to science or to Britain. Ann. and Mag. of Nat. Hist. 1868, p. 411-421. Pl. XXI-XXIII.

190. - - Last Report on Dredging among the Shetland isles by Gwyn Jefireys, Ierle Norman, M'Intosch, Edward Waller. Report of the British Association for the Advancement of Science 1869, p. 273.

191. - - Shetland Final Dredgivg Report. Part. II. On the Crustacea. Report of the British Association for the Advancement of Science at Norwich. 1868, p. $247--336$.

192. Olafsen, Eggert, og Povelsen, Biarne. Reise gjennen Island, Tom. I og II. Soro 1772.

193. Olivi, Gius. Zoologia adriatica, ossia catalogo ragionato delgi animali del golfo e delle lagune di Venezia, proceduto da una dissertazione sulla storia fisicae storia naturale del golfo. Con tav, in rame IX. 4. Bassano 1792.

194. d'Orbigny, M. C. Notice sur le Corophium longicorne Lalr. Crustacé observé dans les Bouchotz à moules, de communes d'Esmeudes et Charon près La Rochelle. Journal de Physique et Chimie d'histoire naturelle et des Arts. 1821. Tom. 93, p. 194-200.

195. Owen, R. Appendix to the narrative of a second voyage in search of a Northwest Passage and residence in the arctic regions during the years, $1829,1830,1831,1832,1833$ of Sir John Ross. Account of the object in the several departments of natural history. Marine inrertebrate animals inhabiting parts of the Arctic Ocean. With 2 . plates. London 1834.

196. Packard, A. S. Observations on the glacial Phenomina of Labrador and Maine, with a view of the recent invertebrate fauna of Labrador. Memoirs 
of the Boston Society of Natural History. Vol, I. part. 2. 1867, p. $210-303$.

197. Pagenstecker, H. A. Phronima sedentaria. Archiv für Naturgeschichte. 27. Jahrg. 1. B. p. 15 .

198. Pallas, Pet. Sim. Spicilegia zoologica, qribus novae imprimis et obscurae animalium species, iconibus, descriptionibus atqve commentariis illustrantur. Cum 58 tabb. aen. Tom. I. Fasc. I-X cum 43 tabb. aen. Berolini $1767-74$.

199. - - Reisen durch verschiedene Provinzen des Russischen Reichs in den Jahren 1768-74. 3 Thl. Mit Kpf. 4. maj. Petersburg 1771-1776.

200. Pennant, Thom. Zoologia Britannica, tabulis aeueis 132 illustrata. London 1768.

201. Philippi, R. A. Einige Zoologische Notizen. Chelura teribrans, ein neues Amphipodegenus, Archiv f. Naturgeschichte. Vol. V. 1839, p. 113.

202. - - Reise durch die Wüste Atacama. p. 170.

203. Phipps, Constantine John. A voyage towards the northpole undertaken by his Majesty's command 1774. London 1774.

204. Plateau, F. Recherches sur les Crustacés d'eau douce de la Belgique. Mem. Ac. Belg. sar. étr. Vol. XXXV.

205. Poda, Nicol. Insecta musci graecensis, qvae in ordines, genera et species juxta systema naturae Carol. Linnaei digessit. Cum 2 tabb. aen. 8. Graecii 1761.

206. de Qvéronic. Description d'un Insect esingulier trouvé dans la rade de Lomariaker. Mem, de math. et de phys. pres, a l'Acad. de Science Paris. Tom. IX. 1780, p. 329-330.

207. Rafinesque-Schmaltz, C. S. Précis des décourertes somiologiques entre 1800 et 1801, ou choix des principales découvertes en zoologie, et en botanique. 8. Palerme. 1814.

208. Rathke, Heinrich. Beiträge zur Fauna Norwegens. Verhand. d. Kaiserl. Leopoldinisch - Carolinischen Academie der Naturforscher. B. XX. 1843, p. $1-264$.

209. - - Beitrag zur Fauna der Krym. Mémoires présentés à l'Académie Impériale des Sciences de St. Petersbourg par divers Savans. Tom. III. 1837 , p. 241- 454 .

210. Ray, Joa. Historia Insectorum. Opus posthumum, jussu regiæ societatis Londinensis editum. Londini MDCCX.

211. Reinhardt, J. Naturhistorisk Bidrag til en Beskrivelse af Gronland. Amphipoda. Gronland geographisk og statistisk beskrevet af $\mathrm{H}$. Rink.

212. Risso, A. Histoire naturelle des Crustacés des enrirons de Nice. Arec 3 pl. 8. Paris 1816.

213. - - Histoire naturelle des principales productions de l'Europe méridio- 
nale et principalément de celles des environs de Nice et des Alpes maritimes. Tom. V. 8. Paris 1826.

214. Risso, A. Mémoire sur quelques noureaux Crustacés observés dans la mer de Nice. Journal de Physique, de chimie et d'histoire naturelle. Tom. 95. 1822 , p. 241-248.

215̆. Römer, J. J. Genera Insectorum Linnaei et Fabricii, iconibus illustrata. Cum XXXVII tabb, aen. 4. maj. Vitoduri Helvet. 1787.

216. Roesel von Rosenhof, Aug. Joh. Monatlich herasgegebene Insektenbelustigungen. 4 Thl. Mit 356 illum. Kpfrn. 4. Nürmberg 1746-61.

217. Rondelet, Gulielm. Libri de piscibus marinis in quibus verae piscium effigies expressae sunt. Fol. Lngduni 1554.

218. Ross, James Clark. Appendix to the narrative of a second voyage in search of a North-West Passage. London 1835.

219. Roussel de Vauzéme, Augustus. Mémoire sur le Cyamus ceti Latr. de la classe des Crustacés. Ann. Scienc. natur. 2. Sér.(Zool.), Tom. I. 1834, p. 239-255, 256-265.

2:20. Sabine, Edw. A supplement to the appendix of Capten Parry's first voyage 1824. 4. London 1824.

221. Samouelle, Geo. A nomenclature of British entomology, or a catalogue of above 4000 species of the classes Crustacea Myriapoda, Spiders, Mites and Insects, intendet as labels for cabinets of insects etc. alphabetically arranged. London 1819. 8.

222. Sars, G. O. Om en i Sommeren 1862 foretagen zoologisk Reise i Christiania og Throndhjems Stift. Nyt Magaz. for Naturvidenskab. XII, p. 193-252.

223. - - Om en i Sommeren 1863 foretagen zoologisk Reise i Christiania Stift. Nyt Magaz. for Naturvidenskab. XIII. 1864, p. 226-260.

224. - - Histoire naturelle des crustacés, d'eau douce de Norvège. I. livr. Les Malacostracés. Christiania 1867, p. 146. 4.

225. Sars, Michael. Oversigt over de i den norsk-arktiske Region forekommende Krebs. dyr. Forhandl, i Videnskabsselskabet i Christiania 1858, p. 122-163.

226. Saussure, Henr. de. Mémoire sur divers crustacés nouveaux des Antilles et de la Mexique. Mém. Soc. de Phys. et d'Hist. nat. de Genère. Tom. XIV. P. 2. 1858 , p. 417-490.

227. Savigny, Jules Caesar. Description de l'Egypte, publiée par ordre du Gouvernement. Planches des crustacés. 1809-1813.

228. - - Description des arachnides de l'Égypte et de la Syrie. Déscrit par I. V. Audouin Extracte de la description de l'Égypte. Paris 1812. Fol.

229. - - Mémoires sur les animaux sans vertébres, en deux parties, avec 32 pl. I. partie. Paris 1816. 8.

230. Say, Thomas. On a new genus of the Crustacea, and the species on which it 
is etablished. Journ. of the Acad. of natur. Science of Philad. 181 ' I. Philadelphia, p. 49-52.8.

231. Say, Thomas. An account of the Crustacea of the United States. Read Juni 1818. Journ. of the Acad. of natur. Ścience. Vol. I. Philadelphia 1818.

232. Schiødte, J. C. Undersøgelser over Huledyrene i Krain og Istrien, Oversigt over det Kgl. danske Vidensk. Selskabs Forhandlinger for 1847, p. 75-81.

233. - - Bidrag til den underjordiske Fauna. Det Kgl, danske Videnskaber. nes Skrifter, 5. Række, 2. Bind, 1851, p. 1-40.

234. - - Om den i England opdagede Art af Hulekrebs af Slagten Niphargus. Overs. over d. Kgl. danske Vidensk.-Selskabs Forhandl. 1855, p. $349-51$.

2:35. Schousboe, P. K. A. Iagttagelser orer trende sjeldue og lidet bekjendte Krebs. arter. Skrifter af Naturhistorie-Selskabet i Kjobenhavn. 5. Bind, 2. H. 1797 , p. 1-18.

236. Schur. Systematisch Aufzïhlung der Crustaceen, Arachniden und Iyriapoden der Umgebung von Trier. Jahresbericht der Gesellschaft fur nütz. Forschungen zu Trier 1856.

237. Scopeli, Joh. Ant. Entomologia camiolica, exhibens Insecta carnolicae indigena et distributa in classes genera, species, varietates, method. Linnaeana, cum tabb. XLIII. Vindobonne 1763.

238. Scoresby, W. An account of the arctic Regions, with a history and description of the Northern Whale.fishery. 2 Vol. Edinburgh 1820.

230. Seba, Albert. Locupletissimi rerum naturalium thesauri accurata descriptio et iconibus artificiosissimis expressio, per universam physices historiam. Crustacis Tom. III. Amsterdami 1734--1765.

240. Slabber, Martinus. Natuurkundige verlustigingen, behelzende nuicroscopise, waarniemingen van in-en uitlands water-en land-dieren. 1-18. Stuk. Haarlem 1778, 4. 18 color. Kpfrt. p. 79.

241. Steenstrup, Japetus. Foreløbig Bemarkning om Forekomsten af en Otion og en Cyamus paa den faeroiske Grindehval (Delphinus globiceps auct.) Videnskabelige Meddelelser fra den naturhistoriske Forening i Kjobenhavn for Aarene 1849 og 1850 , p. $95-96$.

242. - - og Chr. Lütken. Mindre Meddelelser fra Kjobenhavns Unirersitets zoologiske Museum. Forelobig Notits om Danske Havkrebsdyr. Naturh. Forenings Vidensk. Meddelelser 1861, p. 278.

243. Stimpson, William. Synopsis of the marine Invertebrata of Grand Nanan. Smithsonian contributions to knowledge. Vol. VI. Washington 1854.

244. - - Synopsis of the marine Invertebrata, collected by the late aretic expedition. Proceed, acad, nat, science of Philadelphia 1863, p. $138-142$. 
245. Stimpson, William. Descriptions of new species of marine Invertebrata from Puget sound, collected by the naturalists of the Northwest boundary com. mission. Proc. acad. nat. science of Philad. 1864, p. 153-159.

246. - - On the Crustacea and Echinodermata of the Pacific shores of North. America. Journ. of the Boston Soc. of nat. hist. Vol. VI. 1857, p. 444-532, 6 plates.

247. - - Descriptions of some of the nerv marine Invertebrata from the Chinese and Japanese Seas. Proceed. acad, nat. sc. Philad. VII. 1854-1855, p. $373-384$.

248. Strauss-Durckheim, H. E. Mémoire sur les Hiella $n . g$. Crustacés arriphipodes. Mém. du Muséum. Parịs. Tom. XVIII. 1829, p. 51-62.

249. - - Mémoire sur les Hiella, noureau genre de Crustacés amphipodes, arec planche. Paris 1824.

250. Strom, Hans. Physisk og oeconomisk Beskrivelse orer Fogderiet Sondmor. I. Deel.1762.

251. - - Beskrivelse over 10 norske Insecter. Forste Prove. Skrifter, som udi det Kjøbenharuske Selskab af Lærdoms og Videnskabens Elskere ere fremlagte og oplæste fra Aarene 1761-1764. Kjøbenhavn 1765.

252. - - Beskrivelse orer Norske Insecter. Anden Prore. Sammesteds for Aarene 1765-1769. Tiende Deel.

253. Sulzer, Joh. Heinr. Die Kennzeichen del Insecten nach Anleit. K. Linnés; durch $24 \mathrm{Kpf}$. erläut. u. mit derselben natiurlichen Geschichte begleitet. Mit ein Vorrede des Hrn. Joh. Gessner. 4. Zürich 1761.

254. Tellkampf, Th. G. Beschreibung einiger nenen in der Mammuth.Höhle in Fentucky aufgefundenen Gattungen von Gliederthieren. Archiv f. Naturgesch. 1844. 10. Jahrg. I. B. p. 318-322.

255. - - Ueber den blinden Fisch der Mammuth-Höhle in Kentucky mit Bemerkungen über einigen andern in dieser Höhle lebende Thiere. Joh. Hüllers Archiv f. Anatomie u. Phys. 1844. S. 381-395.

256. Templeton, Rob. Descriptions of some undescribed exotic Crustacea. Transact. Entom. Soc. Vol. I. 1836, p. 185-197.

257. - - Catalogue of Irish Crustacea, Myriapoda and Arachnoidea, selected from the papers of the late John Templeton. The Magazin of natural History and Journal of Zoologie. Vol. IX. 1836, p. 9-14.

258. Thompson, William. Note un the Teredo nortegica, Nylophaga dorsalis, Limnoria terebrans and Chelura terebrans, combined in destroying the submerged woodwork at harbour of Androssan on the coast of Ayrshire. Ann. Nat. Hist. XX. 1847, p. 157-164.

259. Tilesius, W. Guil. De cancris Camtschaticis, Oniscis, Entomostracis et Cancellis marinis microscopicis noctilucentibus, auctore Tilesio. III. 1813. Hé. 
moires de l'Academie imperale des sciences de St. Petersbourg. Tom. V. 1815, p. 331-405.

260. Treviranus, G. R., und L. C. Vermischte Schriften anatomischen und physiologischen Inhalts. 2. B. 1. 2. mit 10 u. 7 Kpfrtaf. Göttingen 1816. 4. maj.

261. Valette, St. George, Adolph baron de. De gammaro putaneo. Diss. inaug. Accedunt II. tabb. aeri incisae. Berlin $185 \%$.

262. Viviani, Domin. Phosphorescentia maris, quatuordecim lucescentium animacnlorum novis speciebus illustrata. Genua 1805.

263. Westrood, I. O. Notice of the discovery in England of a new genus of Amphipodous crustacea, Niphargus stygins Schiodte. Ann. of nat. hist. II. ser. Vol. XII. 1853, p. 44.

264. White, Adam. Descriptions of new or little known Crustrcea in the collection of the British MIuseum. Proceedings of the Zoological society of London. Part. XV. 1847, S. 118.

265. - - List of the specimen of Crustacea in the collection of the British IIuseum 1847.

266. - - Catalogue of British Crustacea 1850.

265. - - A popular History of British crustacea, comprising a familiar account of there classification and habits. London 1867. 8, w. 20 color. plates.

268. - - Journal of a voyage in Baffins Bay and Barrow straits in the years 1850-1851, performed by H. M. Ships Lady Franklin and Sophia. By Peter C. Sutherland. Crustacea.

269. Zaddach, E. G. Synopseos Crustaceorum prussicorum prodromus 4. Regiomonti 1844. 4.

270. - - Ein Amphipode in Bernstein. Schriften der Königlichen physikalischökonomischen Gesellschaft. 5. Jahrg. Königsberg 1864. p. 1.

271. Zenker, Jonath. Carol. De Gammari Pulicis, Fabr., historia naturali atque sanguinis circuitu commentatio. 4. maj. Jenae 1832.

272. Ödman, Sam. Grundmärglan. Cancer pulex. Kgl. Vet. Acad. Nya Handl. B. 2. 1781, p. 163-168.

273. - - De cancro pulice et noxa, qvam retibus piscatorum infert. Nor. Act. Soc. Upsal. Tom. VI. 1799, p. 86-97. 


\section{Chronologisk Oversigt over Udviklingen af vor Kundskab til Amphipoderne, især de nordiske, indtil Aaret 1855. ${ }^{1}$ )}

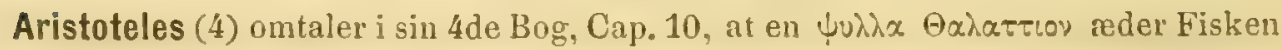
i Garnene, naar de staa en Nat over, og derefter kunne de optages i en Klase. Der kan ei rære Tvirl om, at denne $\bigcup u \lambda \lambda x$ maa vare en Amphipode, da disse i de nordlige Have ligeledes fortare de fangne Fiske og samles om dem i store Masser, saa at de kunne optages i store Klumper. - Rondelet (217) troer ogsaa, at denne $\psi \mathrm{u}_{\lambda \lambda x}$ er den samme som den af ham S. 575 i Cap. XXVII: ${ }_{n}$ De pulici marina beskrevne Amphipode, som synes at være en Art Gammarus. Conrad Gesner (81) gjentager S. 994 Rondelets Text uden videre ræsentligt Tillæg under Overskrift: De pulici marino Rondeletico, medens Moufet (176) i 1634, S. 322, Cap. XXXIX: De pulici sice asello, omtaler blandt andet, at den befrier sig ved hyppige og lange Spring, samt at den findes baade $\mathrm{i}$ det ferske og salte Vand. Han har saaledes sandsynligris hart for sig en Orchestia eller Thalitrus fra det salte og en Gammarus fra det ferske Vand; bag i Bogen copierer han Rondelets Tegning. I 1675 afbilder Friderich Martens (165), der i Aaret 1671 foretog en Reise til Spitsbergen, S. 85 , 3 kleinen Garnellen", som Fuglene spise; de findes mellem og under Stene i Vandet. Dette maa være Gammarus locusta, da denne Art forekommer paa saadanne Steder ved Spitsbergen. Tegningerne af den paa hans Tab. P ere overmaade lidet kjendelige; derimod er en Art Caprella, der er afbildet paa samme Tarle, Fig. I, ret kjendelig og kan kun rære Arten septentrionalis $(\mathrm{Kr}$. ), da denne alene forekommer red Spitsbergen. Afbildnin. gen af "die sogenandl Walfisches Laus", Tab. Q, Fig. a, er mindre heldig, men denne Afbildning er rigtignok ogsaa den forste af nogen Art af Sligten Cyamus. Ray (210) beskrirer S. 44 en Pulex fuviatilis, som er en kjendelig Amphipode, men han indbefatter under dette Navn 2 Arter, hvoraf en forekommer i det rindende ferske Vand og er derfor maaske de nyere Zoologers Gammans pulex, den anden, som forekommer i de varme Kilder ved Custoza i Italien, er vel Gammarus pungens. Ligeledes beskriver Ray S. 43 Pulex marinus; denne maa efter Beskrivelsen vrere Orchestia littoria Leach, da 2de Par Fodder ere rabnede med streke Hrnder. S. 44 beskriver han endridere Pulex marinus cormutus, hvilken utvivlsomt er Corophium grossipes Lin. Angaaende Amphipodernes Levemaade gjor han den Observation, at Moderen brerer Ungerne under Bugen. Frisch (76) giver i sit Værk, Tom. VII, S. 26, en kort Beskrivelse ,von Krebs-formigen

') Fra denne Tid ere Hjælpemidlerne til Kundskaben om Amphipoderne let tilgjængelige ved de $i$ de forskjellige Lande udgirne zoologiske Aarsberetninger. 
Wasser-Wurm" og tegner nogenlunde kjendelig paa Tab. XVIII, Fig. 1, 2, 3, en Amphi. pode, som ristuok maa henfores til Gammarus pulex.

I Aaret 1743 gav Klein (122) en meget tarvelig Afbildning af en Talitrus eller Orchestia $q$ og beskriver den S. 36 under Navn af Sqvilla saltatrix; den skal efter ham fortare Garnene og den fangue Fisk, naar de staa over om Natten.

I 1745 udkom Linnès Öländska ock Gothländska Resa (153), hrori han beskriver Cancer Pulex fluviatilis, som han fandt ved Stranden paa Oland. Hans Beskrivelse passer for Gammarider i Almindelighed, men han anforer dog tillige, at paa Siden af hrert Led paa den ydre Kant var der en aflang rød Plet, hvorfor jeg maa antage, at han har havt Gammarus marinus for sig. S. 96 girer han en mere ud. forlig Beskrivelse af denne. Endvidere beskriver han S. 260 en Cancer macrourus coeruleus thorace articulato fra Havstranden paa den sydlige Odde af Gottland; den man efter hans Beskrivelse være Gammarus locusta.

I den i de folgende Aar udkomne forste Udgave af Fauna Svecica opstiller Linné under Num. 1253 Cancer macrourus mfescens thorace articulato, den samme, som han fandt red Gottland. De Synonymer, som han anforer for denne, nemlig Ray's Cancer fluviatilis og Frisch's Vermis aqvaticus cancriformis, ere ei rigtige, da disse Navne tilhøre en Ferskvands Amphipode. Under Num. 1254 opstiller han den fra Gottland fundne Form under det samme Navn, nemlig Cancer macrourus coeruleus thorace articulato. Jeg kan ei finde, at disse 2 Linnés Arter ere forskjellige, og begge bør efter min Mening henfores til Arten Gammarus locusta.

I sin Skånska Resa 1749 -1751 (154) fortæller Linnẻ, at han ved Raflunda Kyrka fandt Pulex fluviatilis i mangfoldige Sandhuller i Stranden; ligeledes fandt han den under den opkastede Tang paa Stranden; den hoppede som en Græshoppe, hrorfor Indbyggerne kaldte den Sandharer. Denne Form er klarlig ei den samme som den østersøiske, men sikkert Orchestia littorea, som nu ogsaa forekommer paa det samme Sted under lignende Forholde.

Klein afbilder 1749 (123) Tab. IV, Fig. a, b, c, en Amphipode, som nærmest synes at ligne Gammorus locusta; dog undlader han at tegne den karakteristiske Bisvobe paa de orre Folere, og ligeledes tegner han Øinene runde, hvilket ei er. Til. fældet hos Gamm. locusta. Tegningen kunde maaske forestille Amphithoë podoceroides, men Halen stemmer ikke dermed.

Roesel (216) afbilder Tom. III, Tab. LII en Amphipode, som han kalder Astacus fluviatilis, hrilken er den, der efter ham er benæevnt Gammarus Roeselii.

Baster (6) beskriver og afbilder Tab. III, Fig. 7, 8, en Amphipode, som han S. 31 kalder Pulex marims, hvilken IJdelig er Orchestin littorea.

En Afbildning af en Caprella fra Ceylon giver Godeheu de Reville (82) i Aaret 1760, som maske er Arten Caprella ultima, Spence Bate.

Seba (239) beskriver. I Tom. III, S. 55 Sqvilla mantis Amboinensis og giver paa Tab. XXI, Fig. II en Afbildning af en Amphipode, som senere er kaldı Seba imominala. 
Den Amphipode, som han afbilder paa samme Plades Fig. 12, er mere trivlsom. Den synes at vare en Tegning af et defekt Exemplar. Paa Tab. XC, Fig. 5, afbilder han Pediculus ceti, der er en Art af Slægten Cyamus, men Arten kan ei nermere bestem. mes, da den Hvalart, hvorfra den er taget, ei er nævnt.

Poda (205) beskriver i 1761 kortelig en Podura maritima, som af Scopeli citeres under Cancer locusta og er utvirlsomt en Orchestia.

Geoffroy, Etienne, (78) afbilder meget smukt Roesels Astacus fluviatilis under Narn af Crevelte des ruisseaux, Tab. XXI, Fig. 6. Denne Afbildning er kopieret af Sulzer (253) Tab. XXIII, Fig. 152.

Linné gjentager i sin nye Udgave af Fauna Srecica 1771 de samme Arter, som i Udgaven 1746 (155), idet han under Num.2041 opstiller Cancer pulex macrourus articularis rostro acuto, manibus adactylis, cauda attenuata, spinis bifidis, og citerer der den forrige Udgaves Num. 1253. Af Synonymerne anforer han med Urette den af ham i hans Skanska Resa opstillede Amphipode samt de af Ray og Frisch anførte Arter.

Baster (6) aftilder i 1762 Tab. IV, Fig. 11 A, B, C, og beskriver S. 43 som Mirum animaculum in Corallinis en Caprella, der uden Tvivl er Hannen til Linnés Capr. linearis.

Scopeli (237) opstiller S. 411 under Num. 1136 en Cancer locusta (?), som efter Beskrivelsen maa være en Art af Slægten Orchestia, og som findes „abunde prope Tergestium". Under Nummer 1137 opstiller han en Cancer pulex, der forekommer i ferskt Vand og saaledes maaske ex Gammarus pulex. Han citerer med Urette Linnés Arter.

Strøm anforer i 1762 fra Sondmore (250) en Pulex cancriformis eller Cancer macrourus rufiscens, som findes under Stene ved Stranden og i Fiskenes Bug. Frerndeles giver han paa Tab. I, Fig. 12-13, en meget kjendelig Figur af Hyperia medusarum under Narn af Pulex cancriformis, antennis brevissimis, corpore latiore, og anforer, at den findes under de store Meduser.

Gronovius (91) afbilder i Aaret 1764 paa Tab. XVII, Fig. 7, den af ham kaldte Astacus muticus, som han beskriver S. 232 under Num. 989. Idet han antager, at de nedre Følere ere det forste Fodpar, afbilder og beskriver han meget tydelig Corophium grossipes, Lin. (C. longicorne, Fabr.); han siger, den findes ved Leyden. Paa Side 990 anforer han sammesteds en Sqvilla cauda subulata, bifida, pede utrinqve antico chelifero, tribus utrinqve ultimis natatorius, som maaske er Gammarus locusta eller Pulex.

Strom beskriver 1765 S. 588 (251) et "hummerlignende Insect med runde Laar paa Bag.Fodderne, Cancer macrourus articularis manibus adactylis, femoribus posticis orbicularibus, spinis caude bifidis". Hertil giver han en god Afbildning af Orchestia liltorea; i Beskrivelsen kalder han Kjæbefodderne Underlæben og angiver, at Farven er blaa eller rodagtig, samt at den hopper $1 / 2$ Alen. Endvidere siger han, at Pulex cancriformis kommer den nærmest $i$ Lighed. Af denne siger han, Linné gjor to Species, og skjont begge beskrives meget nøiagtigt $\mathrm{i}$ den Öländska 
Resa, S. 420 g S. 262, synes dog begge Beskrivelser at løbe ud paa det samme. Heri har Strøm fuldkommen Ret; i den nyere Tid ere begge slaaede sammen under Navn af Gammarus locusta.

Linné udgav 1766 den 12te Udgave af Systema naturce (156). Heri optager han under Insekternes 7de Orden Aptera følgende Amphipoder under Slægtsnavnet Cancer: I, Num. 80 C. grossipes, som han opstiller paa Gronovius's Astacus muticus, idet han som denne antager de nedre Følere for at være det forste Fodpar. II, Num. 81 C. pulex, som han angiver at forekomme baade i det ferske og salte Vand; denne Art indbefatter saaledes paa Grund af de Synonymer, han opfører under den, baade de nyere Zoologers Gammarus pulex, Roeselii og G. locusta. III, Num. 82 C. locusta. Denne maa ogsaa paa Grund af Synonymerne indbefatte de $2 \mathrm{i}$ det salte Vand forekommende Gammarus locusta og Orchestia littorea. IV, Num. 83, C. linearis; dette maa være en Caprella, og Arten er uden Trivl den samme som Caprella lobata, Müller, omendskjønt han citerer Martens, som har havt Caprella septentrionalis for sig. V, Num. 84, C. atomos, hvortil han citerer Basters Mirum animaculum in Corallinis. Denue har jeg allerede sagt at vrere Hannen af Caprella lobata, og den falder saaledes sammen med den foregaaende Art. VI, Num. 85, C. filiformis er ogsaa en Caprella og vistnok ei forskjellig fra den foregaaende. Endelig anforer Linné under Slægten Oniscus Arten O. Ceti, som er en Collectivart for de nordiske Cyamus-Arter.

Strøm giver 1770 den „Anden Prøve af Beskrivelse over de norske Insecter ${ }^{65}$ (252). S. 5 beskriver han „en Marflue eller liden Krabbe med Kjol-dannet og Sav-lignende Ryg, C. macrourus articularis dorso carinato, serrato, spinis caude bifidis." Paa Tab. II, Fig. 1, afbilder han meget godt Gammarus Sabinii, Leach. Han tror, at de 3 forste Par Halefodder benyttes til at spille mod Aggesækkene, saa at Ungerne en for en kunne komme ud. Paa Tegningen af Kindbakkerne giver han Palpen nogle flere Led, end den i Virkeligheden har.

Eggert Olafsen og Bjarne Povelsen (192) omtale i sin islandske Reise S. 609 en Marflue, Cancer pulex, som fordxrver Garnene, som man sætter for Foreller og Rodmaver, og som reder de Fiske, som komme deri. Kun naar de nederste Masker ere af Hestehaar, angribe de dem ikke. Dette maa altsaa væere Gammarus pulex fra det ferske Vand paa Island.

Pallas (198) opstillede de af ham observerede Amphipoder under Slægtsnavnet Oniscus og angriber Linné meget stærkt, især for hans anførte Synonymer. S. 52 opstiller han som en ny Art Oniscus cancellus og afbilder den paa Tab. III, Fig. 8. Denne er senere henfort til en egen Slægt: Pallasea. S. 55 beskriver han Oniscus locusta og aftilder paa Tab. IV, Fig. 7, meget kjendelig Orchestia littorea . . Den forekommer efter ham i det ferske Vand red Leyden. Oniscus gammarellus, hvortil han ci. terer Scopeli og Gronovius, og som han afbilder paa Tab. IV, Fig. 8, er vistnok kun Hannen til den foregaaende Art. Oniscus volutator er allerede af Linné opstillet under 
Navn af Cancer grossipes. S. 77 beskriver han Oniscus ceti og afbilder den paa Tab. IV, Fig. 14, A, B, C. - S. 80 beskriver han Oniscus scolopendroides, og under dette Narn sammenfatter han de 3 af Linné opstillede Arter: Cancer atomus, C.linearis og C. filiformis.

Phipps (203) anforer som ny fra det nordlige Polarhav Cancer boreas og C. ampulla samt beskriver dem S. 191. Denne sidste afbilder han paa Tab. XII, Fig. 2, og er nu Typus for Slægten Stegocephalus. Endelig beskriver han S. 192 C. nugax, som synes at være en Anonyx, sandsynligvis A. lagena, $\mathrm{Kr}$.

Joh. Chr. Fabricius opstiller i 1775 (66) Slegten Gammarus, der omfatter alle de nuværende Amphipoder. Denne Slægt, sammen med 4 andre Krebsdyrslægter samt Slagten Scorpio blandt Arachniderne, stiller han sammen under en fjerde Klasse af Insekterne, Agonata.

Hammer (103) opregner i sin norske Naturhistorie de fra den norske Kyst af Strom beskievne Arter.

Otto Fr. Müller (181) optager i Zoologiae Danicae prodromus under Slægtsnavnet Cancer folgende Amphipoder: Num. 2,355 C. medusarum, Num. 2,356 C.macrourus thorace antrorsum aculeata, pedum paribus $\mathbf{X}$, cauda foliacea, fra Island, Num. 2,357 den af Strom 1755 opstillede Art, der er Orchestia littorea, og under Num. 2,358 den af Strøm 1770 opstillede Art, som er Gam. Sabinii, Leach. Endelig opstiller han under Num. 2,359 og 2,360 Sqvilla lobata og Sq. ventricosa, hvilke begge ere 2 Arter af Caprellide, nemlig Caprella linearis, L。 og Proto pedata. Under Num. 2,366 opstiller han en Oniscus pulex, fra det ferske $0 g$ salte Vand, og det er saaledes en Gam. locusta; fremdeles under Num. 2,362 Oniscus volutator, som er den samme som Corophinm grossipes, L.

Joh. Fr. Fabricius anforel 1777 S. 142 (70) de Karakterer, hrorpaa han begrunder sin Slagt Gammarus, hvilke vaesentlig hentes fra Munddelene. S. 248 giver han Diagnoser for Gammarus (Corophinm) grossipes.

Pallas opstiller 1776 i sin russiske Reise (199), S. 70, Oniscus muricatus, som han meget kortelig beskriver, og angiver vasentlig kun, at Halens 3 første Led ere væbnede med en Tand.

Pennant (200) anforer for England i Vol. IV, S. 14, en Cancer, der synes at være Caprella linearis, da han citerer Basters Mirum animaculum in Corallinis. Cancer pulex angiver har at forekomme i Brkke, og den er saaledes vistnok Gam. pulex. Hans Astacus locusta er Orchestia litlorea. Endelig afbilder han meget kjendelig Corophium grossipes, L.

de Geer (77) beskriver i Tom. VII, 1778, Sqvilla (Pulex) aqvatica, corpore compresso, pedibus qvatuor anticis chelatis, cauda setis sex bifurcis terminata, og han afbilder den paa Tab. XXXIII, Fig. 1-2. Da den anfores at forekomme baade i det ferske og i det salte Vand, samt da han citerer Linnés Art Cancer, Num. 1253 i 1ste Udgave af Fauna Svecica, er dette baade Gam. pulex og G. locusta, der staa hinanden saa nær, at de selv nu vanskelig kunne adskilles. Hans Citater af Geoffroy og Klein ere natur- 
ligvis urigtige, da disse have havt andre Arter for sig. I samme Tome beskriver han Squilla de la baliene og afbilder den paa Tab. XLII, Fig. 6 og 7.

Joh. Chr. Fabricius forgger Antallet af Amphipoderne 1779 (65) med Gam. corniger, S. 383; dette er den samme som Epimeria tricristata, Costa, og Amphitoe parasitica, Sars. S. 258 anforer han Gam. locusta og Gam. longicomis, hvortil han citerer Linnés Cancer grossipes, og som saaledes er Corophium grossipes. S. 326 og S. 354 beskriver han Gammams medusarum, der er identisk med Hyperia galba.

Lepechin (144) foroger den arktiske Amphipode-Fauna med Oniscus aculealus, der senere af Krøyer er givet Navnet Amphithoë Edwardsii, og som nu maa kaldes Acanthonotus aculeatus. Denne afbilder han paa Tab. VIII, Fig. 1. Oniscus cuspidatus afbilder han paa Tab. VIII, Fig. 3; denne kan efter Tegningen neppe være nogen anden end Owens Acanthosoma hystrix. Derimod er hans Oniscus scorpioides ingen Amphipode, men en Cuma.

de Qvéronic (206) afbilder fra Bretagne en Caprella, der synes at være Humnen til C. linearis og en Varietet deraf, som er opstillet som en egen Art, C. acuminifera. Otho Fabricius (71) udgav 1780 sin Fauna Groenlandice, hvor han opforer af Amphipoder folgende allerede beskievne Arter: Sqvilla lobala, der maa være Caprella septentrionalis; Oniscus ceti, som, da den findes paa Balena boopis, maa være den af Lintken beskrevne Cyamus boopis; Oniscus pulex, der er den samme som Ganmarus locusta; Oniscus medusamum, der er Iyperia galba s. medusarum. Om Arterne Oniscus cicada, arenarius, Strömianus og abyssinus er det vanskeligt at afgjore, hvilke Arter han har havt for sig. Oniscus serratus er af Kroyer gjenkjendt og beskrevet under Navn af Amphithoè serra. Efter Kroyer kan Oniscus cicada vrere en Art Anonyx, og 0 . arenarius er maaske, da Fabricius citerer Act. Hafn. X, 5, Tab. II, Fig. 1-8, Gam. $S a-$ binii. O. Strömianus kan maaske være en Art Orchestia, skjont ingen saadan Art kjendes fra Gronland.

Ödman beskriver 1781 (272) Canc, pulex, om hvilken han fortæller, at den i store Masser stiger op i Skjærgaarden i December og nærmer sig Landet i Jan., Febr. eller Marts; især opspiser den i disse Maaneder Fiskegarnene. Om Sommeren formindskes den i Antal.

Mohr (173) omtaler i sin islandske Reise, 1786, S. 110, Canc. fliformis, der er den samme som Caprella septentrionalis, og S. 112 Monoculus pulex, hvis Levemaade han narmere omtaler.

Joh. Chr. Fabricius opregner 1787 i sin Mantissa insectorum (67), S. 334, under Slægtsnarnet Gammarus de Amphipoder, som ere kjendte af ham; disse ere: G. ampulla, F. nugax, G. cancellus, G. longicornis, G. locusta, G. pulex, G. corniger, G. linearis, G. salinus, G. stagnalis, G. gibbosus, G. esca og G. medusarum. Af disse ere G. salinus, stagnalis, gibbosus og esca ingen Amphipoder. Han optager saaledes ikke Kleins Sqvilla sallatrix, der er en Orchestia, heller ikke Martens's Pediculus ceti, der er en 
Cyamus, ligesaa lidt som Sebas, Geoffroys, Godeheu de Revilles, Slabbers, Forskåls, Otho Fabricius's, Lepechins og Andres Arter.

Roemer (215) afbilder paa Tab. XXXIII, Fig. 6, Gam. longicornis meget gadt og beskriver den S. 63.

Abildgaard (1) beskriver i Zoologia Danica, Vol. III, S. 59, Gam. podurus og afbilder den paa Tab. CXVI, Fig. 1-6; dette er uden Trivl en Gammarus, da Halens 3 sidste Led tydelig have Torne paa Rygsiden; men da de bagre Springfødder ere tabte, kan Arten ei med Sikkerhed angires. Da han ei har afbildet nogen Bisvobe paa de øvre Folere, er den af Milne-Edwards og Spence Bate stillet hen blandt andre Slægter. Fremdeles beskriver han $G$. mutilus, S. 60, og afbilder den paa samme Plade; denne, som skal forekonne ved Færøerne, ligner efter Tegningen meget $G$. locusta; dog er Bisvoben paa de øvre Følere mere forlanget, end den er hos G. locusta, og Grenene paa det sidste Par Halefodder ere lige lange; desuden passer Beskrivelsen : oculi punctiformes nigri aldeles ikke paa denne Art. Hans G. qvadrilobata, S. 58, Tab. CXIV, Fig. 11-12, er Caprella linearis, L., G. pedatus, S. 33, Tab. CI, Fig. 11-12, er Proto pedata, Leach. Gam. spinicarpus, S. 66, Tab. CXIX, Fig. 1-4, der er taget paa Østsiden af Sjælland, er senere beskrevet under Narnet Leucothö̈ articulosa, men maa naturligvis beholde Artsnarnet spinicarpus. Oniscus ceti, afbildet paa Tab. CXIX, Fig. 13-17, er taget af Monodon monoceros og er derfor den af Littken beskrerne Cyamus monodontis.

Herbst (109) sammenstiller 1792 de af ham af Literaturen kjendte Amphipoder i en 6te Afdeling af Krebsdyrene, som han kalder Onisci gamarelli. Han folger saaledes Pallas i hans Nomenclatur og optager ei Fabricius's Slægt Gammarus, der omfatter Amphipoderne. I denne Afdeling optager han foruden Amphipoderne ogsaa de langhalede Krebse og Mysider. Under Nr. 113 opstiller han Canc. homari, Fabr.; men dette er ingen Amphipode, og derfor citerer han med Urette hertil Stroms Canc. dorso carinato, serrato, som er en Amphipode og er Gam. Sabinii. Efter Phipps optager han Canc. ampulla og C.nugax; efter Abildgaard i Zoologia Danica C.podurus, C.mutilus, C. spinicarpus og C. ventricosus; efter Linné C. grossipes og C. linearis; efter Pallas C. cancellus og C. locusta, hvilken sidste han opfatter i. Pallas's Mening; fremdeles efter Pallas C.gammarellus; disse 2 sidste ere saaledes Orchestia littorea $q 0 \mathrm{~g} \sigma^{7}$. Efter Otho Fabricius optager han $C$. arenarius, C. Strömiunus, C. cicada, C. serratus, C. abyssimus; efter Forskal C. sedentarius; efter Jol. Chr. Fabricius C. corniger. De ovrige, som han opforer, ere ikke Amphipoder. Om disse af Herbst optagne Arter har jeg allerede $i$ det Foregaaende ytret mig. Herbst synes aldeles ikke at have kjendt Lepechin, Slabber, Seba 0. S. v.

Joh. Chr. Fabricius optager i den 2ten forogede Udgave af Entomologia systematica (68), B. II, S. 514, under Slægten Gammarus følgende Amphipoder: G. ampulla, G. nugax, G. carinatus, G. cancellus, G. longicomis, G. locusta, G. pulex, G. corniger, G. linearis, G. salimus, G. stagnalis, G. gibbosus, G. esca, G. medusarum; deraf er G. salimus, stagnalis 
og esca ingen Amphipode. Af de andre ere G. carinatus og G. gibbosus nye; den forste af disse to er Atylus carinatus, den anden er en Hyperide, nærmest henhørende til Amphipronoë eller en nærstaaende Slæegt. Senere opforer han Cyamus celi dels under Slægtsnavnet Cymothoë, S. 509, og Pygnogonum, S. 670.

Latreille opstiller paa Canc. sedentarius Slægten Phronima, og i 5te Bind (137), S. 294, optager han efter Bosc Slægten Talitrus og efter Lamarck Slægterne Caprella og Cyamus. Disse. Slægter danne den 2den Familie Crevettines, der henhorer til hans 2den Orden Branchiogastres af Malacostraces blandt Crustaceerne.

Schousboe (235) giver en særdeles god Afbildning og Beskrivelse af Canc. sedentarius, Forskil. Crustaceens Hus tror han at have sin Oprindelse fra et ubekjendt Bløddyr.

Viviani (262) udgav 1805 sin Phosphorescentia maris, hvori han kortelig beskriver og afuilder adskillige Amphipoder fra Middelhavet. Denne Bog synes lidet at vare paangtet, skjont Figurerne ei ere saa slette, at jo de fleste maatte kunne gjenkjendes. Hans Gam. caudisetus, Tab. I, Fig. 1-4, er uden Trivl en Hyperia, hos hvilken Halens Svømmefødder, idet den er tegnet, have ligget bagtil, saa at deres Børster ere komne frem bagenfor Halen. Hans Gam. longicornis, S. 8, Tab. II, Fig. 3-4, har lange Folere og en kjolet Ryg. G. truncatus, S. 8, Tab. II, Fig. 5-6, er en Allorchestes; hans G. circinatus, S. 9, Tab. II, Fig. 9-10, synes at vare en Art Amphithö, og hans $\boldsymbol{G}$. crassimams er maaske en Gammarus; derimod er hans $\boldsymbol{G}$. heterochilus en Tanais, og ingen Amphipode.

Dumerille stillede Amphipoderne til den 2den Orden af Crustaceerne, nemlig Astacoides, og til Familien Artocéphales ou Captes, hrortil foruden Phronima, Talitrus og Gammarus ogsaa Squilla og Mysis henhore. Derimod næerner han ei Caprella og Cyamus.

Montagu (174) afbilder og beskriver 1806 tre Amphipoder fra Kysten af Devonshire. Den forste af.disse er C. Phasma, der beskrives S. 66 og afbildes paa Tab. VI, Fig. 3; dette er Egina Phasma (longispina, Kr.). S. 69 beskriver han Canc. palmatus og afbilder den paa Tab. VI, Fig. 4. Hans Canc. articulosus, der er afbildet paa Tab. VI, Fig. 6, er derimod den af Abildgaard beskrevne $C$. spinicarpus, der nu henregnes til Slaggten Leucothoë.

Latreille forøger i $180 \%$ (135) Amphipodernes Slagter med Corophium.

Montagu (174) beskriver endvidere i 1808 nye Amphipoder fra Kysten ved Devonshire; disse ere Cancer Gammarus grossimanus, der afbildes paa Tab. VI, Fig. 5, og som nu henregnes til Slægten Hara; fremdeles Canc. Gamm. rubicalus, Tab. VI, Fig. 10, der nu henfores til Slageten Amphithoë; Canc. Gamm. falcalus, der er en Art Podocerus; endelig Oniscus Testudo, der er den af Spence Bate og Westwood opstillede Pereionolus Testudo. Desuden giver han Afbildning og Beskrivelse af de reldre bekjendte Canc. Gamm. locusta, C. G. pulex, C. G. saltator og C. G. littorus.

Rafinesque-Schmaltz (207) opstiller i 1812 en Slægt Pisithoë med Arterne P. spi- 
nosa og $P$. levifrons, men de ere saa slet beskrevne, at de ikke kunne identificeres med bekjendte Former; formodentlig er Slægten den samme som Phrosina Risso.

Leach henforer Amphipodearterne i Tom. VI af Edinburgh's Encyclopedia (139) til 3die Tribus af hans Malacostracea Gasteruri og til Familien Gammarini. Han forøger Slægterne med Orchestia, Dexamine, Leucothoë, Melita, Mcera, Amphithoë, Pherusa, men han tager Corophium bort, som med de nye Slægter Podocerus og Jassa danner en Familie Corophionii; han danner ogsaa af Caprella og Cyamus (Larunda s. Panope) og Proto Familien Caprellinii. Disse Familier samt Familien Gnathonii, der indbefatter Slægten Gnathia (= Anceus), danne en Tribus Gasterurii. I et Tillreg til dette Arbeide opstiller han en Tribus II. Gammarides med folgende 4 Familier: Fam. I. Orchestida med Slægterne: Talitrus og Orchestia. Fam. II. Dexaminida med Slægterne: Dexamine og Leucothoë. Fam. III. Gammaridce med Slægterne: Melifa, Mcera, Gammarus, Amphithoë og Pherusa. Fam. IV. Podoceridce med Slægterne Podocerus og Jassa. Af Slægten Phronima danner han en Tribus III. Phronimarides, og af sin tidligere Familie Caprellini gjor han en Tribus IV. Caprellides.

Leach forandrer i 1815 (140) igjen sit System paa folgende Maade: Legio II. Edriophthalma deler han i 3 Sektioner; den forste af disse indbefatter alene Slægten Phronima. Den anden Sektion deler han i 5 Divisioner; til den første Division hører Slægten Talitrus og den nye af ham opstillede Orchestia; den anden Division indbefatter Slægten Atylus, som han har opstillet paa Arten Gamm. carinatus, Fabr.; den tredie Division indbefatter Slægterne Dexamine, opstillet paa Cancer Gamm. spinosus, Mont,, og Slægten Leucothö̈, der opstilles paa Canc. articulosus, Mont., der er den samme som Canc. spinicarpus, Abildgaard. Den fjerde Division deler han i 2 Subdivisioner; den første indbefatter Slrgterne Melita, der ẹ opstillet paa Canc. Gammarus grossimamus, Mont,; den anden Subdivision indbefatter Slægterne Gammarus, Amphithoë, hvilken sidstes Typus er Cancer Gamm. rubicatus, og Slægten Pherusa, hris Typus er den af ham opstillede Art $\boldsymbol{P}$. fucicola. Den 5te Division indbefatter ogsaa 2 Subdivisioner. Til den forste hører de 2 nye Slægter Podocerus med Arten variegatus og Slægten Jassa med Arten pulchella, til den anden horer Slægten Corophium. Endelig kommer den 3die Sektion. Dens forste Division deles i 2 Subdivisioner; til den forste horer Slægten Proto, der opstilles paa Arten Gamm. pedatus, Abildg., og Slægten Caprella; til den anden Subdivision hører Larunda, der er den samme som den før opstillede Slægt Cyamus. Hans ørrige Afdelinger henhøre ei til Amphipoderne.

Tilesius (259) offentliggjor i 1815 „De cancris Camtschaticis" og antager her S. 374, at den af Pallas opstillede Oniscus scolopendroides neppe afviger fra Limnés Canc. linearis.

Latreille opstiller i 1816 Amphipoderne som en egen Orden, men han forener endnu 1817 Læmodipoderne under Narn af Cystebranches, hrorunder han ind. befatter de 4 Slægter Leptomera, Proto, Caprella og Cyamus, hroraf de 2 fors te imidlertid falde sammen, med Isopodernes Orden. I 1817 opstiller han i Regne animale 
under Amphipoderne Slagterne Phronima, Gammarus, under hvilken sidste han indbefatter Leach's Slægter Leucothoë, Dexamine, Melita, Mara, Pherusa ng Amphithoë, fremdeles Slægten Talitrus, hvorunder han stiller Slægterne Atylus, Talitrus og Orchestia, dernæst Slagten Corophinm; endelig stiller han Podoceros og Jassa udenfor de andre. Den af ham opstillede Leptomera falder sammen med den reldre Slægt Prolo, og Slægten Naupridia beror kun paa et defekt Exemplar af en Proto og falder derfor bort.

Savigny offentliggjorde 1816 (229) sine udmærkede Undersøgelser af Arthropodernes Munddele og beskriver S. 51, Tab. IV, Munddelene til Slægten Gammamus, og S. 109 beskriver han og afbilder paa Tab. IV, Fig. 2, Munddelene af Lycesta furina. Herved var Veien banet for noiagtigere Undersogelser af de Dele, hroraf man maa tage de vigtigste Karakterer for en systematisk Opstilling af Amphipoderne. Paa Tab. V, Fig. 1, afbilder han Cyamus ceti og foreslaar, at denne skal skilles fra Caprelliderne og stilles hen til Pycnogoniderne.

Treviranus (260) gav i Aaret 1817 en Anatomi af Cyamus, afbilder or og 우 dens Munddele og Intestina. Han tror, at Munddelene ligne Oniscus's, men ere simplere byggede. Paa det andet Kjæbepars Form rar han ei sikker, ligesom han heller ikke kunde finde, om Kindbakkerne havde en Palpe eller ikke. Maven angiver han at være ganske simpel, uden Spyt- eller Galdegange. Nervestrængen tillægger han 7 Knuder, og endelig beskriver han Hjertet som et fortil bredt, bagtil smalt Organ, samt de cylindriske Aandeblærer. Han antager, at denne Slægt maa staa i samme Familie som Oniscus, og at den ikke hører sammen med Sqvilla, som de Geer, eller med Canc. pulex, som Latreille antager.

Risso (212) forøgede Antallet af Middelhavets Amphipodeformer med de nye Slregter Typhis og Euphens, som han med de orrige af ham kjendte Amphipodeslrgter : Phronima, Talitrus, Gammarus, Caprella, Cyamus, sammenstiller til en 7de Familie Crevetines. Denne Familie sammen med den 6te Squillaires danner hans 3die Sektion, Sqvillines, blandt Crustaceerne. Han folger saaledes Latreille's System fra 1807, men forandrer Latreille's Navn Branchiogastres til Squillines. Af nye Arter opforer han Typhis ovoides, som han afbilder paa Tab. II, Fig. 9, og beskriver den S.122. Phronima custos beskriver han S. $121 \mathrm{og}$ afbilder den paa Tab. II, Fig. 3. Talitrus rubropunctatus omtaler han S. 127 og Caprella punctata S.130. Typhis maa erstattes af Tyropus, Dana, da Navnet allerede har været brugt før. Capr. munctata skal efter Spence Bate være den samme som Capr. linearis, Linné. Slægten Eupheus gaar ud.

Say beskrev 1817 (230) den nye Slrgt Cerapus fra de nordamerikanske Stater og grundede den paa Arten tubularis, som han beskrer S. 51 og afbildede paa Tab. IV, Fig. 7-11, samt Unciola, som han grundede paa Arten irrorata; feilagtig er som Synonym til denne Slægt og Art antaget Krøyers Glauconome leucopis. Aaret efter (231) optager lıan under Ordenen Aphipoda, Latreille, en ny Slregt, Lanceola, S. 374, der manske er synonym med Hyperia eller Vibilia; fremdeles Lepidactylis, S. 379, der ranskelig lader sig bestemme. Til Slregten Gammarus henforer han som nye Arter 
S. 374 G. fasciatus, der forekommer i Floderne, S. 376 G. mimus, ogsaa en FerskvandsAmphipode, S. 376 G. mucronatus fra Havet og S. 377 G. appendiculatus, ligesaa fra Saltrandet. Senere opstiller han S. 384 Talitrus longicornis, S. 383 Amphitoë dentata og A. punctata, ligesaa S. 382 A. serrata.

Lamarck antager i 2 den Udg. af Animaux sans vertebres (133), Tom. V, Latreilles systematiske Opstilling, idet han skiller Les Caprellines fra Isopoderne og lader dem danne en egen Sektion med Slægterne Leptomera (Proto), hvorunder han forener Latreilles Leplomeres og Protens sant Caprella og Cyamus. Til Leptomera stiller han 2 Arter: L. mubra og L. pedata, den forste er synonym med Sqvilla ventricosa, Abildg., og den anden med $G$. pedalus. Disse to falde altsaa sammen. Under Slregten Caprella optager han C. scolopendroides og phasma; den forste er synongm med Canc.linearis, I. Til Sektion III., Crustacés amphipodes, henforer han Slægterne Phronima, Gammarus, Talitrus og Corophium. Han opstiller Phronima med Arterne P. sedentaria og P. custos, Gammarus med Arterne G.pulex, G. spinosus, G. articulosus, G. grossimanus, G. palmatus og G. pherusa. Saaledes indbefatter denne Slægt Gammarus. Leach's Slregter, Dexamine, Leucolhoë, Melita, Mara, Amphithoë, Pherusa, Podoceros og Jassa; fremdeles under Slægten Talitrus opstiller han Arterne T. locusta, T. gammarellus og $T$. carinalus, og saaledes indbefattes under denne Slægt Leach's Orchestia og Atylus; endelig under Slægten Corophium Arten C. longicorne, der falder sammen med Cancer grossipes, L. Slægten Typhis, Risso (Tyropus, Dana), forener han med Anceus og Praniza blandt Isopoderne.

Leach forgger i 1819 (142) Slægten Gammanus med Arten Sabinii fra BaffinsBugten; denne havde allerede Strøm godt beskreret og tegnet i Aaret 1770.

Latreille (134) opstiller en Slrgt Hyperia paa Arten Lesueurii (Suerii), der dog blev mindre godt beskrevet.

d'Orbigny (194) giver i 1821 en nøiagtig Beskrivelse af Corophium longicorne (grossipes) og dens Levemaade, ligesaa en Beskrivelse af dens Munddele, og angirer, at den om Vinteren forlader Stranden og gaar til Dybet.

Scoresby (238) beskriver S. 341 Gamm. arcticus og afbilder den paa Tab. XVI, Fig. 14; dette er dog kun $G$. locusta. Han angiver ogsaa som forekommende i de arktiske Have Canc. pulex, C. ampulla og C. mugax. Han omtaler, at Cyamus ceti findes snyltende paa Gronlandshralen og en smalere Art paa Nordhralen.

Mandt (162) beskriver i 1822 Gammarus libellula S. 32; dette er en Themisto, som senere af Kroyer er opstillet under Navnet Th. arctica og Th. crassicornis; fremdeles S. 34 G. Gryllus, der senere er beskrevet under Navnet Lysimassa (Eurytenes) magellanica, Milne Edwards.

Risso opstiller i 1822 (214) Slægten Phrosina med Arterne Ph. seminulata og Ph. macrophthalma; den sidste er en meget tvirlsom Art.

Fleming (72) gjor i 1823 opmærksom paa den Misforstaaelse, som Latreille gjor sig skyldig i ved at optage baade Slegten Proto, som skal have 10 Fodder, og 
Leptomera, som skal have 14; thi begge falde sammen og hare begge 14 Fodder; ligeledes gjor han opmærksom paa, at Lamarck, der henforer dem begge under een Slægt Leptomera, heller skulde hare opfort dem under Slægtsnarnet Proto, som er et ældre Narn, samt at han ei skulde hare aufort i Slægtskarakteren, at de have fra 10 til 14 Fodder. Han tror, at Leach's Caprella Pennantii og C. acanthifera ere Synonymer med Cancer phasma; thi denne rarierer meget med Hensyn til Legemets Torne.

Strauss-Durckheim (248-49) beskriver meget noiagtig den af Latreille mindre heldig karakteriserede Hyperia under Narn af Iliella, og han begrunder denne Slrgt paa en Art fra den franske Vestkyst, hvilken han kalder Orbignii; han afbilder den paa Tab. IV. Denne afriger ei fra Stroms Cancer medusarum.

Sabine (220) beskriver i 1824 Gammarus boreus og G. pulex, der ikke afviger fra G. locusta og G. Sabinii, Leach. Som nye Arter opstiller han G. loricatus og Talitrus Edwardsii, hrilken sidste allerede er beskrevet af Lepechin under Navn af Oniscus aculeatus; endvidere Talitrus Cyanece, der af Otho Fabricius er opstillet under Navnet Cancer medusarum. Desuden nævner han som forekommende i Davisstrædet G. nugax og G. ampulla. Af disse afbilder han paa Tab. I G. loricatus, Talitrus Edwardsii og T. Cyanea.

Desmarest (59) udgav i 1825 et Hovedværk over Crustaceerne. Hrad Amphi. poderne angaar, slutter han sig aldeles til Leach's sidste System; kun opstiller han dem under en særegen Orden i Orerensstemmelse med Latreille. Han optager de senere efter Leach beskrerne Former og maa derfor udvide Systemet lidt. Som Karakterer for Amphipoderne antager lıan ogsaa efter Latreille, at Kindbakkerne ere uden Palpe. Hans forste Sektion stemmer averens med Leach's, kun er der kommen en ny Art til, Phronima custos, Risso. Derpaa indskyder han en ny Sektion for at optage Hyperia, Latr., og Phrosina, Risso; han angirer, at den forste af disse kun skal hare 10 Fodder. Leach's Sektion II bliver hos ham Sektion III, og den deles i sex Dirisioner; deraf er den 6te Division en ny, der optager Say's Slægt Cerapus. Leach's Sektion III ophoies af ham til en egen Orden, der indbefatter 2 Sektioner; den forste med Slægterne Leptomera, Proto og Caprella, den anden med Slægten Cyamus. Say's Slægter Lepidactylus og Lanceola, Rafinesque's Slægter Sperchus, Lepturus, Pisitoë, Leach's Slægt Aerope, Savigny's Slægter Cymadusa og Lyceste forbigaar han eller omtaler dem kun i Anmærkninger. I et Tillæg tilfoier hau enkelte af Risso's Arter fra Middelhavet.

E. A. de Brébisson (37) opregner i samme Aar de Amphipoder, som af ham ere fundne ved Calvados. Gammarus pulex og Cancer Gammarus, siger han, findes baade i salt og ferskt Vand. Hans Tulitrus locusta, som efter ham findes i fugtigt Sand, og hris Fødder ei hare nogen Gribehaand, maa være denne Art, medens hans Talitrus gamarellus er Orchestia littorea. Han optager ogsaa Slæglerne Melita og Corophium.

Risso beskriver i 1826 (213) Amphipoderne red Nizza. Han opforer her Phro- 
nima med de 2 Arter Phr. sedentaria og Phr. custos, fremdeles Phrosina med Arterne Phros. semilunata og Phros. macrophthalma, Typhis med Arten T. ovoides, Gammarus med Arterne G. pulex og den nye G. marinus, en ny Slægt Enone med Arten E. punclata, som er en meget tvivlsou Slægt; fremdeles Slæegten Talitrus med Arterne T. locusta oy T. Niccensis, Slægten Orchestia med Arten O. littorea, Slægten Atylus med Arten A. corallimus, endelig Slregten Eupheus med Arten Eu. legiodes. Denne sidste kan ligesaalidt som hans øvrige nye Arter henføres til nogle senere kjendte Former paa Grund af den ufuldstændige Beskrivelse. Til Lamodipodes henforer han Caprella, med Arterve C. linearis og C. punctata, og Pycnogonum ceti, der maa vare en Art Cyamus.

Guérin-Méneville opstiller i Aaret 1828 (97) Slægten Themisto paa Arten Th. Gaudichaudii fra Malouinerne og girer en god Tegning af dens Munddele og Fodder.

Johnston foroger det samme Aar (116) den britiske Amphipode-Fauna med en ny Art Gammarus spinipes og senere med $G$. carinatus samt aftegner paa Tab. XIV, Fig. 8-11, eu Art Stenothoë.

Latreille udgav i 1829 (136) en ny Udgave af Cuviers Règne animal, hvori han $\mathrm{i}$ Tom. VI behandler Amphipoderne. Han indforer under denne Orden 24 Slægter, hvoraf dog kun 19 kunne blive staaende, idet Slægterne Ione, Anceus, Praniza og Apseudes maa henfores til Isopoderne og Slregten Pterygocera maa gaa ud, da den kun er opstillet paa en ufuldstændig Tegning. De ovrige Slægter, som af ham optages, ere: Phronima, Hyperia, Dactylocera, Phrosina, Talitrus, Orchestia, Atylus, Dexamine, Leucothoë, Gammarus, Amphithoë, Typhis, Melita og Mara.

Milne-Edwards udgav i 1830 sit forste Amphipode-System (167). Han deler dem i Famille des Crevettines og des Hypérines, idet han anforer som Karakterer for dem, at Kjabetodderne danne hos begge en lorskjelligformet Underlabe. Famille des Crevetlines deler han igjen i Tribus des Sauteurs og Marcheurs; til de forste, som have en Springhale, henforer han Slægterne Talitrus, Orchestia, den nye Slægt Lysianassa, Amphithoë, Gammarus, Isca, Leucothoë.

Guérin-Méneville (97) udgav i 1832 sine Bearbeidelser af Crustaceerne, som vare samlede ved Expeditionen til Morea. S. 44 anfører han Talitrus saltator, Milne-Edw., Orcheslia Fischerii, Milne-Edw., Caprella lobata, og som nye fremstiller han Talitrus platycheles paa Tab. XXVII, hvilken han tror at burde danue en ny Slægt mellem Orchestia og Talitrus, fremdeles S. 45 Gammarus Peloponnesicus, der er ganske eiendommelig og afbildet paa Tab. XXVII, Fig. 5.

Johnston beskrivel og afbilder i det folgende Aar i Fortsættelsen af sin Illustration in British Zoology (117), S. 40, Caprella acuminifera, Leach.

Roussel de Vauzéme (219) foroger Slægten Cyamus med flere nye Arter og omhandler dem S. 234-255, idet han beskriver Cyamus erraticus, C. ovalis og C. gracilis; de vare alle tagne fra eet Hralindivid, men de adskilte sig indbyrdes ved Bygning, Opholdssted og Livsytringer. Om den sidste Arts Berettigelse rar der dog nogen 
Trivl. At derimod den ene af dem skulde være synonym med Linnés Oniscus (Cyamus) celi, som Forfatteren tror, er ei Tilfældet.

James Ross (218) opregner i 1835 de Amphipoder, som hans Fader, Sir John Ross, medbragte fra sine Nordpolarreiser 1829-1833. Themisto Gaudichaudii, som Guérin har beskrevet fra Sydhavet, tror han at gjenkjende i en Form fra Ishavet, men dette er en anden Art, som Mandt forst har beskreret og benærnt Gammarus libellula. Senere har Krøyer beskrevet den samme Themisto Gaudichaudii under Narn af $T h$. arctica og crassicomis. De fra de tidligere Reiser bekjendte Cancer maga og C. ampulla stiller han under Slægten Gammarus. Arterne Gamm. boreus ere G. locusta og G. loricatus, Lin., og G. Sabinii, Leach, gjenfinder han. Ligeledes opstiller han Talitms Edcardsii, Sab., under Slregten Amphithoë; men den er allerede af Lepechin givet Navnet Oniscus aculeatus. Owen opstiller Slægterne Acanthonotus paa Arten cristatus og Acanthosoma paa Arten hystrix. Af disse findes der meget gode Figurer, men korte Beskrivelser. Den sidste af disse Arter er dog allerede beskrevet og nogenlunde tegnet af Lepechin under Narn af Oniscus cuspidatus. Da begge disse Slægtsnarne allerede for ere benyttede for Insektslrgter, maa de ombyttes.

George Johnston giver i 1835 i Illustration in British Zoology (118) en Bearbeidelse af de engelske Læmodipoder eller Caprellider. Han afbilder Montagues Canc. phasma, der henhører til Kroyers Slægt Aegina, samt Caprella acanthifera, Leach, C. Pemantii (acutifrons, Latreille), C. linearis og endelig Proto pedata, hvilke alle han aftegner og giver deres Synonymik.

Gervais (80) skiller i 1835 Gamm. pulex fra det ferske Vand i 2 Arter, som have været sammenblandede under dette Navn, nemlig G. pulex, Fabr., og G. Roesellii, Gerv., hvilken sidste er den samme som Astacus fluviatilis, Roesell.

Guérin-Méneville forogede i 1836 (98) Hyperiderne med flere nye Slægter, nemlig Pronoë, som han opstiller paa Arten capito, samt Primno, der er opstillet paa Arten $P$. macropa. Hans Hieraconyx med Arten abbreviafa falder sammen med MilneEdwards Ancylomera. Til Slægten Oxycephalus (Milne-Edw.) tilføier han en ny Art fra Chili, nemlig oceanus; til Latreille's Slægt Phronima tilføier han en ny Art atlantica, der maaske ei er forskjellig fra $P$. sedentaria. Derimod er hans Slægt Phlias fra Malouinerne ingen $\mathrm{Hy}$ peride.

Robert Templeton opstiller i samme Aar (256) Slægten Anisopus med Arten dubius, sum dog falder sammen med Slaggten Amphithoë. Say's Slægt Cerapus foroger han med Arten abditus, paa hvilken Art Milne-Fdwards i 1840 grundede den nu af Systemet udskilte Slægt Cerapodina. Slægten Caprella foroger han med 2 nye Arter: C. nodosa og C. scaura, begge fra Mauritius, hvilke dog kun synes at være Han og Hun af samme Art.

Robert Templeton udgav ligeledes i samme Aar en Katalog over de irske Crustaceer (257). Af Amphipoder opforer han Talitrus locusta, Orchestia littorea, Gam. 
pulex, Linné, og Gam. aqvaticus, Leach, hvilken sidste, han siger, findes i Bække, samit Gam. locusta og Corophium grossipes, Lin., fra Havet.

H. Rathke foroger i Aaret 1837 (209) Amphipodeslrgterue med en ny Amalhia. der opstilles paa Arten A. carinata, og Slægten Hyale, som han opstiller paa Arten H. pontica. Den forste af disse er i den nyeste Tid igjen optaget, men da Narnet har været brugt for en Insektslægt, er det forandret til Amathilla. Slægten Hyale har man hidtil ikke opfattet rigtig, da den uden Trivl er den samme som Slægterne Allorchestes og Nicca, hvilke Narne saaledes maa falde bort, da de kun ere Synonyıner til hin Rathke's Slægt. Til bekjendte Slægter opforer han fra det sorte Har folgende Arter: Orchestia littorea, der efter Spence Bate er den samme som Orch. mediterranea, Gam. gracilis, der er den samme som Gam. marinus, Gam. pulex og Gam. locusta samt Amphithoë picta, n. S. Til disse Amphipoder leverer han Beskrivel. ser og meget gode Afbildninger.

Deshayes \& Milne-Edwards udgave i det folgende Aar en ny Udgare af Lamarcks Histoire naturelle des animaux sans vertèbres (132). Denne Udgave slutter sig, hrad Amphipoderne angaar, fuldstændig til den forste Udgave, men optager en Division les Caprellines, der stemmer overens med Læmodipodernes Orden, og denue Division dele de i 2 Futnilier: Caprelloidiens ou Lamipodes filiformes og Cyamoidiens ou Lamipodes ovalaires. Desuden tilfoies de Slægter og Arter, som efter den forste Udgave vare blerne bekjendte, nemlig: Hyperia, Pharcus, Lestrigonius, Daira, Themisto, Dactylocera, Hieraconyx, Primnoë, Oxycephalus, Vibilia, fremdeles tilføies Lysianassa, Phlias, Jassa, Podocerus, Cerapus og Erichthonius. Til disse og andre bekjendte Slæg. ter angives de da bekjendte Arter.

Krøyer beskriver i 1838 Grønlands Amphipoder (126). Han giver forst indledende Bemærkninger orer de seneste, for ham publicerede Arbeider, beskriver dernæst Lysianassa Vahlii, Lyss. lagena og appendiculosa, for hrilke 3 nye Arter han foreslaar Slægtsnarnet Anonyx; derpaa beskrirer han Gam. Sabinii, Leach. Gam. loricatus, Sab., Gam. pingvis, n. s., og Gam. locusta, Amphithoë carinata, A. hystrix (Acanthosoma), Owen, A. serra (Oniscus serratus, Fabr.), A. panopla, A. bicuspis, A. mermis, A. crevulata, A. lceviuscula; fremdeles beskriver han Ischyrocerus angvipes, n. g. og n. s., hvilken Slægt han karakteriserer nærmere; dernæst omtaler han Metoecuis medusarum (Oniscus medusarum, Fabr.) og karakteriserer denne Slrgt. Han opstiller Themisto arctica, der er den samme som Th. Gandichaudii, Ross, Themisto crassicornis, Lestrigonius exulans og Hyperia oblivia. Af disse ere Anonyx lagena og A. appendiculosa kun Han og Hun af samme Art; ligesaa forholder det sig med Amphithoè inermis og A. cremulata. Slæg. ten Ischyrocerus falder sammen med Podocerus, og Slagterne Lestrigonius og Hyperia falde sammen, da den forste Slægt er opstillet paa Hanner og den sidste paa Hunner af samme Arter, derfor falde Arterne Lestrigonius exulans og Hyperia oblivia sammen; ligeledes er Themisto arctica den samme som Th. crassicornis, hrorfor de af ham beskrevne Arter fra Gronland kun blire 17, hroraf 12 ere nye. 
Andrzejowski (3) adskiller i Bull. Mosk. 1839, S. 23, tha Gamm. pulex Gamm. stagnatis, som skal have meget storre eliptisk-nyreformige Dine og et Haleappendix, som ei er kortere, men læengere end det sidste Haleled.

Philippi opstiller i samme Aar i Archivf. Naturg. (201) den nye Slregt Chelura med Arten teribrans fra Middelhavet.

Milne-Edwards udgav 1840 III. Tom. af Hist. nat. d. Crustacés (168), hrori Am. phipoderne blive behandlede. I denne fastholder han sin tidligere Adskillelse mellem Amphipoder og Lxmodipoder som 2 adskilte Ordener og deler ligesom i 1830 Amphipoderne igjen i Famille des Crevettines og Famille des Hyperines paa Grund af Kjæbefoddernes forskjellige Udvikling, idet disse hos den sidste Fannilie ikke dakke den hele Mund med 4 store Plader og 2 lange palpiforme Svober, men kun Basis af Munddelene, idet de mangle Palper. Den forste Familie deler han i 2 Tribus: Creveltines sautenses og $\mathrm{Cr}$. marcheuses, eftersom Halen er mere eller mindre særeget udviklet. Til Tribus. I høre 2 forskjellige Grupper, hvoraf den forste kun indbefatter Slægterne Talitrus og Orchestia, som ei have Palper paa Kindbakkerne, den anden Slregterne Lysiantassa, Alibrotus, Plilias, Acanthonotus, Iscea, Anisopus, Amphitö, Gammarus, Ischylocertus og Leucothoë. Af Talitrus opforer han 5 Arter, hvoraf en ny; af Orchestia 8, hroraf 3 nye; af Lysianassa 5 Arter; under denne sidste Sliegt optages Kroyers AnomyxArter; Alibrotus ligesom Phlias, Iscea og Anisopus have hos ham kun een Art, Acanthonotus 2 Arter; Amphithoë har derimod 26, hroraf 3 nye. For Oversigtens Skyld afdeler han Arterne i forskjellige Grupper, eftersom de have Torne eller Trender paa Ryggen eller mangle disse, samt eftersom de ovre Folere ere længere eller kortere i Forhold til de nedre og efter Storrelsesforholdet af det andet Par Hænder. Slagten Gammarus indbefatter hos ham 23 sikre Arter, hroraf 3 ere nye, desuden nogle, som han kun med Forbehold opforer, f. Ex. Montague's G. palmatus, grossimamis, Müller's G. mulilus, Say's G. minus. Disse deler han ogsaa for Oversigtens Skyld i forskjellige Afdelinger efter Øinenes Form, eftersom de 3 sidste Postabdomenled have Trender i Midtlinien eller kun Torne, og efter Formen af det 2det Fodpar hos dem, der have runde Dine. De 2 sidste Slagter, Ischyrocerus og Leucothoë, have, den forste kun en, den anden to Arter. Tribus II, Crevettines marcheuses, indbefatter Slægterne Erichthonins og Cerapodina, hver med 1 Art, Cerapus, Podocerus og Corophium, hver med 2 Arter. Med mindre Sikkerhed opforer han Slægten Atylus og Unciola hver med 1 Art. Famille IIyperines deler han i 3 Tribus: Hyperines gammaroides, H. ordinaires og H. anomales. Til Tribus I hører kun Vibilia med en Art; til Tribus II hører Hyperia med 4 Arter, Metoecus, Phorcus, Tyro, n. g., Primnoë og Daira hver med 1 Art, Lestrigonius med 2 Arter, hrortil han dog med Trivl henforer L. exulans, $\mathbf{K r}$.; fremdeles Themisto med 3 Arter, Anchylomera med 2, hivortil han ogsaa regner Hieraconyx, Phrosina ligeledes med 2 Arter, hroraf den ene, Ph. semilunata, er usikker, Phronima med 3 Arter; endelig henregner han til Tribus III Slagterne Typhis med 3 Arter, Pronoü med 1 og Oxycephalus med 3 Arter. Lamodipodernes Orden deler han i 2 Familier: Fam. des Caprelliens, 
der indbefatter Slægterne Caprella med 9 Arter, Naupridia med 1 og Leptomera med 3 Arter, og Fam. des Cyamidiens med Slægten Cyamus, der har 3 Arter. Leach's Slægter Dexamine og Pherusa opforer han under Amphithö̈ ligesom Jassa under Cerapus, Melita under Gammarus. Mlora forbigaar han, ligesaa Rafinesque Sperchus og Lepturus; Say's Lanceola opfører han under Hyperia, og Cocco's Orione tror han bor henfores til Typhis. Latreille's Pterygocera, Say's Lepidactylus og Strauss's IIiella forbigaar han. Templetons Slagt Anisopus gaar ud, da den er synonym med Slægten Amphithoë, ligeledes Krøyers Slægt Ischyrocerus, da den er synonym med Podocems, fremdeles Milue-Edwards Sliegt Erichthonius og Cerapodina, der begge falde sammen med Say's Slægt Cerapus. Slægten Lestrigonius, Milne-Edw., falder sammen med Hyperia.

E. Eichwald (63) beskriver i 1841 Gammarus caspius, Pallas, samt den nye G. homobaphes, der synes at stemme meget overens med G. locusta.

Gould (90) opforer i samme Aar folgende Amphipoder fra Nordamerika: Orchestia longicornis, Say, Orch. gryllus, Bose, hvilken sidste han stiller synonym med Talitrus gamarellus, dernest Gammarus locusta og minus saint Hyperia galba; sammen med den sidste fandt han en lignende Form, men med en mangeleddet Srobe, som han tror bor regnes til den samme Slægt eller til Hieracomyx. Af Læmodipoder opforer han Cyamus ceti, som han siger varierer meget efter Alder, og 2 Arter af Slægten Caprella, hvoraf han antager, at den ene falder sammen med Capr. sanguinea, Say.

Guérin-Mẻneville opstiller i 1842 (100) Slægten Cystosoma med Arten Cyst. Neptuni fra det indiske Hav, hvilken udmærker sig ved sin Størrelse. Herred blive Hyperiderne forøgede med en ny Slægt.

Kroyer beskriver 1843 (128) flere nye Slægter og Arter af Amphipodernes Orden ræsentlig fra det grønlandske Har. Disse nye Slregter ere: Opis, Stegocephalus, Phoxus, Pontoporeia, Pardalisca, Protomedeia, Ampelisca, Photis, Oedicerus og Laphystius, med Arterne O. Eschrichtii, S. inflatus, Ph. Holbäli og plumosus, Pon. femorata, Par. cuspidata, Pro. fasciata, A. Eschrichtii, P. Reinhardi, Oe. saginatus og L. Sturionis. Af Arter, henhørende til bekjendte Slægter, henfører han til Leucothoë L. clypeata og L. glacialis, til Gammarus Arten dentatus, til Acanthonotus A. inflatus, til hans egen Slægt Ischyocerus Arterne angvipes og latipes, til Slægten Podoceros P. Leachii. Endelig omtaler han den tidligere opstillede Slægt Anomyx og viser, at de nedre Folere hos denne ligesom hos Slægterne Opis, Phoxus og Ampelisca blive hos ot meget forlængede og forsynede med Sugeskaale, medens de hos $q$ forblive korte; han sammenslaar derfor sine for opstillede Arter Amphithoë crenulata og inermis til een Art. Han viser red denne nye Forøgelse af Amphipoderne, at de nordiske Have maa vare disses rette Hjem.

Imidlertid ere ikke alle disse af ham opstillede Arter nye, og flere Former ere ogsaa i den sidste Tid blerne miskjendte. Stegocephalus inflatus falder sammen med Phipps's Cancer ampulla. Protomedeia med Arten fasciata er i den seneste Tid fuldstrendig miskjendt og antaget for at rære den samme Slægt som Zaddach's Leptocheirus, 
men ved Undersogelse af Originalexemplarerne har jeg fundet, at den er den samme Form som den af Lilljeborg beskrevne Gammarus macronyx. Slægten Ampelisca er senere af Costa bleven kaldet Araneops, af Stimpson Pseudophthalmus og af Spence Bate Tetromatus, Photis er af Spence Bate bleven kaldet Eiscladus, og Lafystius er kaldet Darwinia. De nye Arter, som Krøyer henforer til Leucothö̈, kan imidlertid ei blive straende der, men maa henføres til den af mig opstillede Slægt Metopa. Gamm. dentatus bor henregnes til Slægten Melita; hans Slægt Ischyrorerus bortfalder, da den er synonym med Podocerus, og den af ham opstillede Podocens Leachii er synonym med Cerapus difformis.

Harry Goodsir (84) giver i samme Aar i the Edinburgh new philosophical Journal p. 183 en Beskrivelse af Caprellidernes Anatomi og fortæller, at deres Tarmkanal pulserer uregelmæssig. Ovarierne angiver han at være fæstede til Maven og at ud. strække sig fra den bagere Del af Postoccipitalsegmentet ved forste Brystning, og at de afgive fra Midten af dette sidste Led en smal Oviduct, der fra begge Sider møde hinanden til fælles Aabuing i Ovariesækken; en anden Aabning har Oviducten i fjerde Segment. Hau observerer ligeledes et Karsystem af Arterier og Vener, de forste i den øvre Deel, de sidste $\mathrm{i}$ den nedre Deel af Følerne. Blodkuglerne finder han ikke at være kugleformige. De af ham optorte Caprelarter ere C.spinosa, der er synonym med Montagues Cancer phasma; C. Iuberculata, der er synonym med C. acanthifera, Leach, og maaske neppe forskjellig fra $C$. septentrionalis, Krøyer; $C$. lavis, der vel er den samme som C. linearis, Linné, og C.lobata, Müller, og er Hannen til den følgende Art, som han rigtig kalder $C$. linearis.

Krøyer (127) beskriver derpaa Cyamus ceti og erraticus og viser, at ingen af de af Roussel de Vauzéme's Arter falder sammen med Linné's $C$. ceti. Dernæest giver han et Par Bemærkninger angaaende den mulige Anvendelse af de paa Hvalerne levende Smaadyr ved Hvalarternes Adskillelse.

Krøyer (128) giver samme Aar en Fremstilling af Læmodipodernes Plads i Systemet, idet han forst kritisk behandler Savignys, Strauss-Durckheims, Latreille's og Burneisters systematiske Opstilling og de af dem for denne Familie girne Karakterer. Han viser, at de ikke kunne adskilies fra de andre Amphipoder, og at de Karakterer, hvorpaa mun har grundet denne Adskillelse, dels bero paa Misforstaaelse af de undersøgte Dele, dels ere altfor ubetydelige til at grunde derpaa en saadan Adskillelse. Han karakteriserer derpaa Læmodipoderne som en Familie under Amphipoderne, deler den i to Underfamilier, Caprellina og Cyamina, og endelig giver han Diagnose af Slregterue Leptomera, Caprella, Cercops og Aegina, livoraf de to sidstnærnte ere nye. Slægten Naupridia viser han er grundet paa et odelagt Exemplar af en Leptomera. Som nye Arter beskrives Caprella Jamuarii, Cercops Holbolli, Aegina longicornis, hroraf den forste er fra Brasilien og de to sidste fra Gronland.

James de Kay (119) beskriver i 1843 i Natural history of New.York. Zoology. p. 35 de Amphipoder, der forekomme red denne Stads Kyster. Af Slægten Orchestia opregner han 0 . longicornis, der er synonym med Talitrus longicornis, Say, samt 0 . 
gryllus, Bose. Til Talitrus, blandt hris Slægtskarakterer han anfører, at det 3die Led paa de nedre Folere er læengere end de 2 foregaaende tilsammen, samt at det 2det Fodpar ikke er bredere end det,1ste og mangler Klo, henforer han den nye Art T. quadrifidus, som han afbilder paa Pl. IX, Fig. 27. Til Gammarus henforer han Arterne G. minus, mucronatus, fasciatus, locusta og appendiculosus. Til Slægten Amphithoë henfører han Arterne A. serrala, punctata samt dentata fra det ferske Vand. Til Cerapus regner han Arten tubularis, til Lepidactylis Arten dyliscus, til Unciola Arten irrorata, til IIyperia Arten Latreillii, der er synonym med Lanceola pelagica, Say, til Podocerus P. cylindricus, Say; endvidere af Læmodipoda opfører han Cyamus med Arten ceti, som han afbilder paa Pl. VI, Fig. 14, samt Arten abbreviatus, Say, fremdeles Slægten Caprella med Arteme geometrica og eqvilibra, Say, samt sangvinea, Gould.

Heinrich Rathke (208) foroger i samme Aar den norske Fauna med flere Amphipoder. Disse er Gamm. anomalus, som han beskriver S. 63 og afbilder paa Pl. IV, Fig. 7. Han beskriver baade Han og Hun, men den forste er blot en gammel Hun uden Æggeplader, medens Bruzelius har oplyst om den virkelige Han. Dernæst beskrirer han S. 63 Gamm. Sundevalli, n. s., som han afbilder paa Pl. III, Fig. 2; denne er senere af Spence Bate beskrevet under Navn af Liljeborgia Shetlandica; fremdeles Gamm. locusta, som han finder ved Sammenligning med de Krimske Exemplarer kun lidet at afvige fra disse; fremdeles beskriver han Gamm. poecilurus, n. s., S. 68 og afbilder den Pl. IV, Fig. 2, og Gamm. Kroyeri, n. s., hvilke begge falde sammen ng ere maaske kun identiske med Gamm. murinus; dernæst Gamm. Sabini, hvilken han viser staar nær Anathia carinata fra det sorte Hav, hvilket Slægtsnavn han finder for at vare benyttet til en Decapodeslagt, og som derfor maa ombyttes, hvilket Spence Bate ogsaa har gjort. Gamm. angulosus, n.s., beskriver $0 \mathrm{~g}$ afbilder lan S: $72 \mathrm{og}$ Pl. III, Fig. 3. Gamm. Zebra, n. s., der beskrires og afbildes S. $730 \mathrm{~g}$ Pl. III, Fig. 4, er kun en Hun af Podocerus cylindricus. Amphithoë tenuicornis, n. s., (S. 77, Pl. IV, Fig. 3) er den samme som Dexamine spinicornis, Leach, og ikke, som Spence Bate antager, en ny Art; paa det af ham beskrevne Exemplar var Haleappendixet afbrudt, og derfor siger han: appendice caudali nulla. Amphithoë podoceroides, n. s., (S. 79, Pl. IV, Fig. 4) viser han dannede ved de nedre Foleres Bygning Overgangen til Sliegten Podocerus org falder sammen med Amphithoë albomaculata, Kroyer. Amphithoë Prevostii, Milne-Edwards?, (S. 81. Pl. IV, Fig. 5) forandrer han senere til Artsnavnet A. Nilssonii, da han finder, at den ei er den samme som A. Prevostii; den staar meget nær den af ham beskrevne IIyale pontica, hvilket viser, at Slægten Hyale er den samme soun Nicea $0 \mathrm{~g}$ Allorchestes, og disse maa sanledes stilles synonyme med den. Amphithoë Norvegica, n. S., (S. 83, Pl. IV, Fig. 6) horer til Slægten Calliopius. Iphimedia obesa, n.g. \& n. S., (S. 35, Pl. III, Fig. 3) er senere af Kroyer opstillet under Navnet: Microcheles armala. Podocerus calcaralus, n. s., (S. 89, Pl. IV, Fig. 8) synes han at ligne P. variegatus, Leach, men denne sidste har dog de ørre Folere kortere end de nedre og andet Fodpars Haand uden Tænder, dens tredie Fodpar er kortere end fjerde, det sidste Brystled og forste Postabdomenled ere ræbnede med en stærk Torn, livorfor laan antager den 
for en ny Art, hvilket dog ikke er Tilfreldet; Podocerus calcaralus, n. s., (S. 91, Pl. IV, Fig. $9)$ vil han skille fra $P$. cylindricus, Say, og P.variegatus og $P$. pulchellus, Leach: imidlertid er den synonym med P. falcatus, Montague. Melita palmata, Montag, er M. obtusata. Hans Caprella phasma, C. acuminifera og C. scolopendroides ere allesammen kun Capr. linearis, Linné. Endelig opforer han tilsidst Leptomera pelata.

E. G. Zaddach (269) omtaler i det folgende Aar de red Preussens Kyster forekommende Amphipoder. Til Slagten Talitrus henforer han T. saltator, Milne-Edwards. Han beskriver endvidere af Slægten Gammarns lorusta, G. fluviatilis og G. Dugesii;

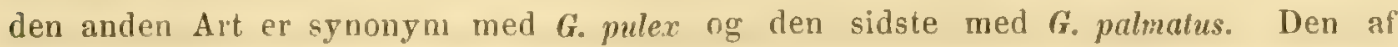
ham opforte $G$. locusta afviger fra Milne-Edwards's Beskrivelse af den samme derved, at de nedre Følere ere kortere end de orre, og at begge, især de nedre, ere forsynede med lange Borster; paa alle Postabdomenled findes der efter ham tre Knipper af Torne, medens Milne-Edwards anforer kun et Knippe; ligeleles er hos Zaddach den ydre Gren paa det sidste Par Springfødder lrengere og bredere, end den indre. medens begge efter Milne-Edwards skulle være lige lange. Dette grunder sig dogkun paa mindre noiagtige Observationer fra dennes Side. Amphithoë Fathkei, n. s., som han fuldstændig beskriver og viser, hrorledes den aldeles afviger fra Rathkes A. Norvegica, er synonym med Krøyers A. Iaviuscula. Hans nye Slægt Leptocheirus er ikke, som man senere har troet, identisk med Kroyers Protomedeia, men visselig en ny. Slægtsnavnet maa dog ombyttes med Stimpsons Ptilocheirus, da det allerede for har været benyttet som Slægtsnavn for et Insekt. Endelig anforer han ogsaa Corophium longicorne, Fabr., som forekommende ved hin Kyst.

Tellkampf (254) beskriver i Archiv f. Naturg. 1844, S. 321, en Crustacé fra Hulerne i Kentucky, hvilken han kalder Triura cavernicola. Denne synes, saa vidt man kan dømme af den meget uheldige Beskrivelse og Afbildning, at være en Amphipode og ra nærmest at henhore til Slægten Niphargus.

Kock (124) omtaler i 1844 i Deutschl. Crust. Myriapod. und Arach., H. XXXVI, Gammarus pulaneus, som nu henføres til Slægten Niphargus.

Krøyer (130) giver i sine „Karcinologiske Bidrag“ Diagnoser af en ny Slagt og Art blandt Caprellina, nemlig Podalirins typicus fra Nordsøen. Af Slægten Orchestia beskriver han 0 . grandicornis fra Valparaiso, $O$. nidrosiensis fra Trondhjem og $O$. platensis fra Laplatafloden, dernæst Talitrus tripudians fra Kattegattet, Gammarus anisochir fra Rio Janeiro, Aora typica, en ny Slægt og Art fra Valparaiso, samt Amphithoë femoratn fra det samme Sted. I Fortsættelsen af dette Arbeide nævner han Aegina longispina fra Drobak, Siphonoecetes typicus, Glauconome lencopis, Eurirus cuspidatus, Dulichin spinosissima, Stegocephalus inflatus og Pontoporeia femorata fra Grønland. Af Slægten Leucothnë beskriver han L. glacialis og L. clypeata; af Slagten Phoxus, P. Holbolli og P. plumosus, af Slrgten Anonyx A. Vahlii, A. gulosus, A. littoralis og A. plautus, alle fra Gronland.

Krøyer (130) beskriver i det samme Aar Anonyx Edwoardsii, A. IInlballi, A. Inmidus, 
A. minutus, dernest Opis typica, Ilicrocheles armata, Amphilhoë albomaculata og A. Eduardsii, hvilke vare fundne ved Grønlands Kyster. Disse af Kroyer beskrevne Slregter og Arter ere ikke alle nye, men Orchestia nidrosiensis er allerede beskrevet under Navn O. Nilssonii af Rathke og hører til Slægten Hyale, Rathke. Talitrus tripudians er kun en $q$ af Orchestia littorea, Aegina longispina er den af Montague beskrevne E. phasma, Leucothoë glacialis og L. clypeata henhøre ikke til denne Slægt, men til en ny, Metopa, Boeck, Phoxus plumosus til den nye Slægt Harpina, Boeck, Anonyx Vahlii til Socarnes, Boeck, A. littoralis, plautus og Edwardsii til Onisimus, Boeck, A. Holbolli til Hippomedon, Boeck, A. tumidus til Aristias, Boeck, A. minutus til Orchomene, Boeck, Microcheles armata er den af Rathke beskrerne Iphimedia obesa, og Amphithoë Edwardsii er den af Lepechin beskrevne Oniscus cuspidatus, der hører til Slagten Tritropis, Boeck.

Goodsir (86) opstiller i 1845 Amphithoë pelagica fra Sargassoharet, beskriver den i An. nat. hist. XVI, p. $73 \mathrm{og}$ afbilder den paa Pl. VII. Denne er efter Spence Bate den samme som Milne-Edwards's A. pelagica.

Fried. Müller (177) beskriver i 1846 i Archiv f. Naturg., S. 296, Gammarus ambulans fra Fæstningsgravene ved. Greifswald og afbilder den paa Pl. X, A, B, C. Dens sidste Par Springfodder ere kun engrenede, hrorfor denne Art vistnok horer til den af Spence Bate opstillede Slægt Crangonyx, men ex dog ikke optagen af ham. Den afviger imidlertid fra Slægten Crangonyx, saaledes som Spence Bate beskriver den, red at de tre Postabdomenled ere sammenvoxede, og ved at Haleappendix er dobbelt.

Krøyer (131) afbilder, antagelig i 1846, i Voyages de la commission scientifique du Nord en Scandinarie, en Laponie etc. følgende Arter: Acanthonolus tricuspus, Amphithoë carinala, A. panopla, A. Edwarlsii, A. pulchella, Ampelisca Gaimardii, Pontoporeia femorata, Stegocephalus influtus, Opis typica, Anonyx Vahlii, A. Ilolbolli, A. minutus, A. gulosus, A. namus, A. Edwardsii, A. tumidus, A. littoralis, A. ampulla, Glanconome leucopis, Amphithö̈ albomarulata, Siphonocceles typicus, Microcheles armata, Eusirus cuspidatus, Leucothoè clypiata, L. glacialis, Aegina longispina, Caprella hystrix, C. septentrionalis, C. lobata, Cercops Holbolli, Aegina longicornis og Podalirius typicus.

I. F. Brandt (35) praviser i 1847, at efter Stellers Beskrivelse faudtes der i Sprækker i Huden af Rytina Stellerii et parasitisk Insekt, som efter Brandts Mening maa være en Cyamus eller rigtigere en ny Slægt, som han kalder Sirenocyamus, og som Artsnarn tillægger han den Rytine. Denne er imidlertid udryddet tilligemed sin Pleiemoder.

Allman (2) giver i samme Aar i Biolog. contributions en udforlig Beskrivelse og en god Tegning af Chelura terebrans; han opstiller den tilsidst som en Typus paa en egen Familie Cheluride.

W. Thompson (258) omtaler i samme Aar den samme Chelura terebrans, som han fandt sammen med Teredo Norvegica, Xylophaga dorsalis og Limnoria terebrans i Træstykkei, der laa paa Havbunden i Ardrossans Havn paa Kysten af Irland.

Leuckart (75) opregner og tildels beskriver i 1847 de Amphipoder, som han 
sammen med Frey fandt ved Helgoland: Orchestia littorea, hvoraf han ogsaa fandt en Varietet, hvis fjerde Led paa det sidste Hodpar ikke var udvidet; men dette er dog kun en yngre Han; dernæst Gammarus Sabinii og $G$. angulosus, Melita palmata samt Podalirius typicus, desuden to, som han anser for nye, Gammarus elongalus, der synes at være en Art Mora, maaske Mcera longimana, Thompson, og Amphithoë. gibba, der dog kun er Calliopius lceviuscula. Han giver desuden sammen med Frey en Fremstilling af Caprellidernes Anatomi og af Blodomløbet hos Gammariderne.

Adam White (264) giver i samme Aar en Beskrivelse af en Amphipode, som han kalder Ephippiphorc, der staar nær Anomyx Vahlii. Han fandt den ved van Diemensland.

Kock (125) sammenstiller i 1847 i „Deutschlands Crustaceen, Myriapoden und Arachniden ${ }^{4}$ de der fundne Amphipoder, nemlig: Gammarus fossarum, G. pulex, G. puleanus og desuden de nye Arter $G$. medius og $G$. pilicornis, hvilke han afbilder paa Pl. VII, Fig. 92-93.

White (265) giver i samme Aar en Liste over de i det britiske Museum værende Amphipoder. Han ombytter Slagtsnavnene Acanthonotus med Vertummes og Chelura med Nemerles. Forovrigt er hans Gammarus glaber synonym med Lysiunassa Costa og hans Opis typica med Lysianassa atlantica.

Schiødte (232) giver i 1847 i „Oversigt over det Kgl. danske Videnskabs-Selskabs Forhandlinger", S. 81, en kort Diagnose af Gammarus stygicus, der senere er opstillet som Typus paa Slægten Niphargus.

Milne-Edwards (170) beskriver i Annales des seienses naturelles 1848, S. 398, Lysianassa magellanica, der af d'Orbigny blev fundet i Maven paa en Fisk ved Cap Horn.

Fried. Müller (178) opstiller i det folgende Aar to nyo Amphipodearter fra Østersoen, nemlig: Orchestia euchore og 0 . gryphus, hvoraf den forste ei kan skilles fra O. litlorea. Desuden gjor han Rede for Kjonsforskjellen indenfor Slæagterne Orchestia og Talitrus, livilket før ikke var videre paagtet. Han anfører ligeledes, at Zaddachs Slregt Leptocheirus besidder en Bisvobe paa de ovre Folere.

Lucas (158) opstiller 1849 i Exploration scientifique de l'Algérie. Crust., p. 53, Lysianassa longicomis, Orchestia Pereiri, Amphithö̈ Vaillantii, Vibitia Jeangerardii og C"aprella tabida.

Nicolet (185) beskriver i Gays Historia fisica etc. de Chili, Vol. 1II, 1849, folgende Amphipodearter: Talitrus chilensis, n. s., Orchestia Gayi, n. s.,derpaa opstiller han den nye Slægt Orchestoidea med Arten O. Iuberculata, hvilken Slægt Dana antager maa falde sammen med hans Talitronus; fremdeles opstiller han Amphithö̈ chilensis, u. s., og A. Gayi, n. s., samt den nye Slægt Nicaa, der dog falder sammen med Allorchestes, Dana, og den allerede i 1837 opstillede Slæegt Hyale, Rathke. Af Slægten Gammarus opstiller han en ny Art, G. chilensis; hans nye Slrgt Lalaria med Arten L. longitarsis er synonym med Krøyers Slægt Aora; af Slægten Caprella opstiller han 3 nye Arter: C. longicollis, C. brevicollis og C. spinifrons. 
Dana (52) udgav en Synopsis of the genera af Gammaracea i Americ. Journ. of science 1849, p. 39. Heri hæver han Milne-Edwards's Famille des Crevetines til en hoiere Gruppe, Subtribus, og deler den i sex Familier: Orchestidae, Gammaridae, Corophidae, Icelidae, Cheluridae, Dulichidae. Til Orchestidae henfører han en ny Slægt Allorchestes, der falder sammen med Hyale. Den anden Familie, Gammaridae, deler han igjen i tre Subfamilier: I. Lysianassinae med Slægterne Lysianassa, Phlias, Stegocephalus, Opis, Anonyx, Pontoporeia og to nye, Uristes og Stenia, hvilken sidste han dog senere forkaster; II. Gammarinae, hvortil han henfører Slægterne Alibrotus, Acanthonotus, Leptocheirus, Gammarus, med hvilken sidste han sammenslaar Slægterne Mara, Melita og Amathia, endvidere: Amphithoë, Photis, Oediceros, Leucothoë, Erichthonius, Pardalisca, Ischyrocerus, Lepidactylus, Protomedeia, Ampelisca, Aora og Phoxus, derimod optager han ikke Dexamine, Pherusa, Eusirus, Iphimedia og Acanthosoma; III. Iscinae med Slægterne Isca, Anisopus og Lafystius. Til den tredie Familie, Corophidae, henforer han Slagterne Cerapodina, Cerapus, Corophium, Podocerus og Unciola, til hvilken sidste henfores Glauconome, fremdeles: Atylus og den nye Slægt Clydonia. Til den fjerde Familie, Icelidae, henfører han Slægterne: Pterygocera og Icilius. Til den femte Familie, Cheluridae, horer efter ham Slægten Chelura, og til den sjette Familie, Dulichidae, Slægten Dulichia. Endridere giver Dana Diagnoser for de nye Slagter.

Dana (54) giver i 1850 en Beskrivelse af 92 nye af hain paa Jordomseiling fundne Arter, hvilke henhøre til de i det foregaaende Aar opstillede Familier og Slægter.

De Haan (102) beskrirer i Fauna Japonica, S. 228, Caprella Kroyeri og afbilder baade dens Han og Hun paa Pl. L, Fig. 8.

Hossius (115) giver i Archiv f. Naturgesch. 1850, S. 233, en Beskrivelse af de Gammarusarter, som forekomme i Omegnen af Bonn, nemlig: G. pulex, G. Roeselli og G. pulaneus; han afbilder dem paa Pl. III \& IV.

Guiseppe de Natali (183) beskriver i samme Aar nogle Amphipoder, tilhorende Hyperiderne, fra Middelhavet. Disse er den allerede af Cocco opstillede Cheiropristis messanensis, som han beskriver paa S. $8 \mathrm{og}$ afbilder paa Pl. I, Fig. 2; den synes at være en Han af en Anchylomera eller Phronima. Dernæst omtaler han S. 12 Orio Zancleus, Cocco, som maaske ogsaa er en Phronima, samt Ornithorampus Coccoi, Natali, der synes at vaere en Art af Oxycephalus.

Guiseppe de Natali (184) girer endvidere i samme Aar i et Brér til Achille Costa en Beskrivelse af to andre Hyperideformer; disse ere: Orctirino pulchella, Natali, som synes at rære en Vibilia, og Reptorramphus Costae, der ser ud som en Platycheles. Hans Beskrivelse af dem er meget kort, og Tegningerne ere mindre fuldkomne.

Liljeborg (145) giver i 1850 et Bidrag til den høinordiske Havfauna i Öfversigt af K. Vet.-Akad. Förhandl., S. 82. Han opregner de Amphipoder, som han har fundet i Finmarken; disse ere Gammarus locusta $\mathrm{og}$ en Varietet af denne, hos hrilken Følerne ere noget forskjellig byggede; endvidere Pardalisca cuspidata, Kr., Anonyx 
ampulla, Caprella lobata samt hans nye Art Leucothoë Norvegica, der isæer ved Formen af det andet Fodpars Haand afviger fra $L$. clypeata.

Liljeborg (149) opregner i 1851 de Amphipoder, som af v. Düben vare fundne i Nrerheden af Bergen, ialt 37 Arter, hroraf han anser Anonyx Norvegicus, Gammarus Dubenii og G. assimilis for nye. Imidlertid falder hans A. Norvegicus sammen med Kroyers Anonyx gulosus og G. Dubenii sammen med G. locusta, saa at kun den sidste hævder sin Plads som en ny Art. Han viser dernæst Kjonsforskjellen hos Orchestia littorea, hvis Hun ligner meget Talitrus tripudians, Kr. Han er uvis med Hensyn til Arterne Amphithö̈. Pausilipii og A. Prevostii samt en Leucothö̈, som han anser for en Unge af $L$. clypeata, Kr. Den af Rathke opstillede Podocerus calcaratus anser han kun for en Varietet af Ischyrocerus angripes, $\mathbf{K r}$. Ligeledes viser han, at Caprella lobata varierer meget.

Spence Bate (8) opstiller i samme Aar i Ann. mag. nat. hist. 1851, p. 318, de to Arter Bellia arenaria og Amphithoë Moggridgei. Den forste har han senere givet Slregtsnavnet Sulcator, og den anden afviger i Intet fra Gammarus Sabinii.

I. F. Brandt (34) giver i Bull. acad. imp. sciences de St. Petersb., S. 133 og S. 310, et Bidrag til Kundskaben om Amphipoderne. Forst giver lıan en historisk Oversigt og almindelige Bemarkninger over Familien Orchestidae og mere indgaaende over Slægterne Talitrus og Orchestia, karakteriserer dem og opregner de da bekjendte Arter. Han deler Slægten Talitrus i 6 Sektioner, hvilket allerede var foreslaaet af Guérin, eftersom det forste Fodpar er længere eller af samme Længde som det andet. Dem, hvis forste Fodpar er kortere, opstiller han i en Underslægt Talorchestia. Slægten Orchestia deler han ligeledes i to Sektioner, eftersom de ovrige Folere ere kortere eller længere end de nedre Føleres Skaft. Den første Sektion beholder Navnet Orchestia, den anden opstiller han som en Underslægt Allorchestina. S. 310 nærner han en ny Slægt Megalorchestia med Arten M. califormiana, hvortil han ogsaa henforer Talitrus longicornis, Say; men denne hans nye Slægt falder dog sammen med Nicolets Orchestoidea.

I. F. Brandt (36) bearbeider ligeledes i samme Aar de Amphipoder, som Middendorff' medbragte fra Siberien. Til Slagten Orchestia henforer han en ny Art $\boldsymbol{O}$. Ochotensis og anforer som fundne Anonyx ampulla, hvortil han henforer Mandts Gammarus gryllus og A. Edwardsii, Kr. Til Slægten Gammarus henforer han med Trivl G. locusta, der blev funden $\mathrm{i}$ en Flod, G. pulex og den nye Art G. Sitchensis, der visselig falder sammen med $G$. locusta. Disse Arter henfører han til en Afdeling, hvis sidste Par Springfodders indre Grene ere mere end halvt saa lange som de ydre. Til dem, som have den samme Gren meget kortere og næsten rudimentær, opfører han Gammarus Atchensis, G. locustoides. Dernast opforer han G. dentatus. Til Slagten Allorchestes, Dana, (Hyale, Rathke, henforer han en ny Art A. Ochotensis; det sidste Par Springfodder har hos denne Art to rhomboidale Plader. Til Caprella henforer han Arterne C. affinis og C. Nichlensis. 
Fr. G. Hope (113) giver i samme Aar en Katalog over de italienske Crustaceer. Af Amphipoder opstilles der S. 46 den nye Slægt Amphithonotus med Arten A. acanthophthalmus og Epimeria med Arten $E$. cristata. Den forste af disse falder vistnok sammen med Dexamine spinosa; disse Slægter samt de Amphipoder, som der opregnes, beskrives senere mere fuldstæudig af Achille Costa.

Dana (55) giver i 1852 en Classification af Amphipoderne. Disse regner han som en egen Tribus til Tetradecupoda. Amphipoderne deler han i tre Subtribus: Caprellidea, Gammaridea og Hyperidea. Den forste af disse har to Familier: Caprellidae og Cyamidae, den forste Familie indeholder Slagterne Proto, Protella, Caprella, Aegina, Cercops og Podalirins, den anden Familie kun Slægten Cyamus. Den anden Subtribus, Gammaridea, deler han ligesom i 1849, men udelader Icilidae som en egen Familie, idet han opstiller den som en Subfamilie under Corophidae ved Siden af Clydoninae og Corophinae. Familien Gammaridae deler han i tre Underfamilier: Stegocephalinae, Pontoporinae og Iccinae. Den tredie Subtribus i: Iyperidae, Phronimidae og Typhidae; den forste af disse har tre Subfamilier: Vibellinae, Hyperinae og Synopinae, den anden Familie har ligesaa tre Subfamilier: Phroniminae, Phrosininae og Phorcinae, den tredie Familie ogsaa tre Subfamilier: Typhinae, Pronoinae og Oxycephalinae.

White (268) beskriver i $1852 \mathrm{i}$ Southerl. Journal of a voyage in Baffins Bay etc., Vol. II, Append. p. CCVI, folgende Amphipoder: Gammarus nugax, Sab., Acanthonotus tricuspis, Kr., Amphithoë Edıcardsii, Sab., og Stegocephalus inflatus, Kr.; dernæst en ikke nøiere omtalt Anonyx samt endelig Caprella cercopoides, n. s., der falder sammen med Caprella septentrionalis, $\mathrm{Kr}$.

L. A. Burgersdijk (39) offentliggjor i eu Dissertation en Beskrivelse af de Amphipoder, som findes omkring Leyden, nemlig: Gammarus putaneus, G. Roeselii og G. locusta.

A. Costa (46) opregner i 1853 de af ham ved Neapel fundne Amphipoder. Disse beskriver han nøiere og forøger dem i 1856. De nye Slægter, som han opstiller i dette Arbeide, ere: Araneops, der falder sammen med Ampelisca, Kr., Ichnopus, Aegidia, der falder sammen med Dana's Urothoë, Nototropis, der er synonym med Alylus, og Dexamine, Leach; samt Probolium, der er identisk med Danas Stenothoi, endelig Ceradocus, der er synonym med Mara, Leach, og tilsidst Microdeutopus.

Stimpson (243) opregner i Synopsis of the Gammarine invertebrata of Grand Manan, 1853, p. 44, de af ham fundne Amphipoder. Disse ere: Caprella med fire Arter, hvoraf C. robusta og C. longimana ere nye, Aegina med Arten Ae. spinosissima, Unciola med Arten $U$. irrorata, Say, Podocerus nitidus, den nye Slagt Leptolkoé med Arten $\boldsymbol{L}$. Danae, hvilken Slægt falder sammen med Mara, Leach, fremdeles Cerapus med Arterne C. rubicornis, C. fusicola, hrilken sidste vel neppe adskiller sig fra Podocerus cylindricus, Say, og C. fasciatus, der neppe er en Cerapus; endvidere Orchestia gryllus, Gould, Allorchestes littoralis, Lysianassa spinifera, Anonyx nobilis, A. palidus og A. exiguns, Stenothoë clypeata, Leucothoë grandimana, Amphitonotus cataphractus, Amphithoë virescens, som Spence Bate sætter som Srynonym til A. maculata, Say, Iphimedia rulgaris, som Spence 
Bate henforer til Atylus, den nye Slagt Monoculodes med Arten M. demissus, Gammarus Sabinii og G. macrophthalmus, der efter Spence Bate henhorer til Gammaracanthus, G. pulex og G. purpuratus, hvilken sidste efter Spence Bate skal vare synonym med $\boldsymbol{G}$. dentatus, Kr. Hans nye Slægt Ptilocheirus stemmer aldeles overens med Leptocheirus, Zaddach, og ikke med Protomedeia, Kr., som almindelig er antaget. Da Zaddach's Navn er benyttet til et Insekt, maa Stimpson's Navn blive gjældende. Fremdeles opforer han den nye Slægt Pseudophthalmus synonym med Krøyer's Ampelisca, hrortil høre Arterne $\boldsymbol{P}$. pelagicus og $\boldsymbol{P}$. limicola, hvilken sidste neppe kan skilles fra $\boldsymbol{A} m-$ pelisca temicornis, endelig Phoxus med Arten $P$. fusiformis, der efter Spence Bate er synonym med $\boldsymbol{P}$. plumosus, $\mathbf{K}$., og Arten $\boldsymbol{P}$. Kroyeri, der staar meget nær $\boldsymbol{P}$. Ilolbolli.

Dana (57) beskriver i 1853 de Amphipoder, som af ham bleve fundne ved hans Verdensomseiling, og benytter den Classification, som han havde givet i 1852. I dette hans sidste System indordner han alle de af ham kjendte Amphipodeslægter. Under Caprellidae opforer han Slægterne: Proto, Leach, Protella, Dana, Caprella, Lam., Aegina, Kr., Cercops, Kr. Til Cyamidae henføres Slægten Cyamus; til den forste Subfamilie af Gammaridae, Stegocephalinae, henføres Stegocephalus, Kr., til den anden, Lysianassinae, henføres Lysianassa, Edw., Phlias, Guer., Opis, Kr., Uristes, Dana, Anonyx, Kr., Urothoë, Dana; til tredie, Leucothoinae, henfores Slægterne Stenothoe,, Dana, og Leucothoü, Leach; med Uvished stiller han ogsaa herhen Microcheles, Kr., og Amphithoë marionis, Edw., hvilken dog henfores til Slægten Dexamine. Til den fjerde, Gammarinae, henforer han Acanthonotus, Owen, Alibrolus, Edw., Leptocheirus, Zadd., Iphimedia, Rathke, Oediceros, Kr., Gammarus, Fabr., Photis, Kr., Melita, Leach, Mcera, Leach, Dercothoë, Dana, Ischyrocenus, Kr. Af disse ere Pyctilus og Dercothoë kun Han og Hun af den samme Form og synonym med Cerapus; ligesaa er Ischyrocerus identisk med Podocerus. Til den femte, Pontoporinae, horer efter ham Lepidactylis, Say, Pontoporeia, Kr., Ampelisca, Kr., Protomedeia, Kr., Aora, Kr., og Phoxus, Kr. Til den sjette Subfamilie Iscrinae horer Iscea, Edw., Anisopms, Templt, hrilken sidste dog er synonym med Amphithoë. Med Hensyn til Laphystius, Kr.; er han i Uvished oin, hrorhen han skal stille denne. Til den første Familie Iyperidae af den tredie Subtribus Hyperidea hen. fører han Slægten Vibilia, Edw., til dennes anden Subfamilie Vibilinae; til den tredie Subfamilie Hyperinue reguer han Slægterne Lestrigonius, Tyro og Hyperia, Latr.

Westvood (263) anforer i Proceeding of the Linnean Society of London 1853, p. 44, at Niphargus stygius (aqvilex, Schjodte) er fundet i England.

Spence Bate (8) forandrer samme Aar det af ham givne Slægtsnavn Bellia til Sulcator, da en Crustacé allerede forud havde faaet hint Navn.

Dana (53) opregner i 1854 i Proceed. Acad. Philad, VII, p. 177, nogle Cru. staceer, der vare fundne i Californien, og beskriver disse.

Liljeborg (147) beskriver 1855 Harcrustaceerne ved Kullaberg i Skine. Han opregner 13 Amphipoder og beskriver deraf folgende 4 som nye: Ampelisca lavigata, $A$. tenuicornis, Gammarus erythrophthalmus og G. macronyx. Af ældre bekjendte beskriver 
han Lencolhoë articulosa, Leach, Iscyrocerus minutus, Lilljb., Erichthonius difformis, Edw., Laphystius sturionis, Kr., og Gammarus angulosus, Rathke, og han opregner uden at beskrive dem Gammarus Sabini, G. poecilurus, Caprella lobata og Leptomera pedata. Endelig giver han nogle Rettelser til sine foregaaende Afhandlinger og viser, at Ampelisca Eschrichthii ikke er Krøyers Art, men er en ny Slagt og Art, som han opstiller under Navnet Haploops tubicola og tilføier en ny Art: H. carinata; disse to Arter beskriver han tilligemed Ampelisca macrocephala og Gammarus longipes. Endvidere viser han, at hans G. maculatus er synonym med G. obtusatus, Montag.

Lilljeborg (150) giver 1855 en Oversigt over de i Scandinavien fundne Arter af Slægten Gammarus. Han beskriver kortelig $G_{\text {. }}$ Sabini, G. angulosus, G. mutatus, G. locusta, G. pulex, G. poecilums, G. obtusatus, G. palmatus, G. Sundevallii, G. assimilis, G. erylhrophthalmus, $G$. anomalus, $G$. longipes og G. macronyx. Han foreslaar derpaa at adskille de Arter, hvis bagere Springfodder ere coniske, og at give dem Navnet Gammaropsis.

Gosse (87) beskriver i 1855 i Ann. and Mlag. of nat. hist. XVI, p. 30, en ny Art Cyamus, som han kalder Cyamus Thompsoni og anfører, at han har fundet Unciola irrorata, Say, ved Weymouth.

Lindström (152) beskriver i Öfversigt af Kgl. Vet.-Acad. Förhandl. 1855, p. 48, den nye Amphipodeslagt Bathyporeia med Arten B. pilosa fra Gottland.

Bell (24) opregner og beskriver i 1855 de Amphipoder, som bleve inedbragte fra Sir Edw. Belchers Reise i det arktiske Hav. Disse ere Gammarus Sabini, Leach, G. loricalus, Sab., G.boreus, Sab., hvilken er synonym med G.locusta, Lin., G.Kroyeri, Bell, hvilkeu han afbilder paa Pl. XXXIV, Fig. 4, og er synonym med G. dentalus, Kr., endvidere Lysianassa lagina, Kr., Amphithoë lceviuscula, Kr., A. Jurinii, som efter Spence Bate skal være den samme, som Pherusa fusicola, Leach, Stegocephalus ampulla, Phipps, hvilken han afbilder paa Pl. XXXV, Fig. 1, og endelig Caprella spinifera, som afbildes paa samme Plades Fig. 2. Da denne sidste har Palpe paa Kindbakkerne, maa den imidlertid henføres til Slægten Aegina.

Schjodte (234) omtaler i Overs. af det Kgl. Danske Vidensk. -Selsk. Forhaudl. 1855 den i England fundne Art af Niphargus og viser, at den er forskjellig fra den i Adelsbergerhulen forekommende Art, og kalder den $N$. aqvilex.

Stimpson (245) giver en Beskrivelse af nye Invertebrata fra det chinesiske og japanesiske Hav, deriblandt 20 nye Amphipoder, henhorende til Slægterne Phoxus, Leucolhoë, Ocdiceros, Iphemedia, Anonyx, Allorchestes, Orchestia, Amphithoë, Gammarus, Corophium, Caprella og Dercothoë.

Gosse (88) omtaler i A manuel of marine zoology for the British isles 1855, p. 138, de Amphipoder, som dengang vare kjendte fra de engelske Kyster. 


\section{Amphipodernes, især de nordiskes, geographiske Udbredning.}

Om end Amphipodefaunan med storre Nøiagtighed kun er undersøgt for Grønlands, Spitsbergens, Skandinaviens, Englands samt Adriaterhavets Vedkommende, me. dens vi fra de andre Have blot mindre fuldstændig kjende denue Fauna, i Særdeles. hed gjennem Dana's og Stimpson's Undersggelser af det stille og atlantiske Ocean $0 \mathrm{~g}$ disses Kyster samt gjennem Spence Bate's Bearbeidelse af det store Materiale, der findes i British Museum, kunde det dog vare af Interesse at faa en Oversigt over Udbredningen af de forskjellige Amphipoders Slagter og Arter under de meget afrigende Temperaturforhold paa de forskjellige Punkter i Verdenshavet.

Flere Forfattere have allerede givet en saadan Oversigt over Amphipoderues geographiske Udbredning efter den Kundskab, som de paa den Tid havde til denne Dyregruppe, men eftersom denue Kundskab er bleven udvidet og man har lært at kjende flere Slregter og Arter, ligesom de forskjellige Haves Fauna nøiere er undersøgt, ere ogsaa Anskuelserne om deres Udbredning blevne forandrede. Dette vil naturligvis ogsan fremdeles blive Tilfrldet, og jeg vil derfor kun give nogle Antydninger i denne Hensende, idet jeg forst kortelig vil omtale de Meninger, som andre Forskere have havt i denne Sag.

Kroyer har i 1842 i sin Afhandling om "Nye nordiske Slagter og Arter af Amphipodernes Orden" osv. fremhrevet, at de koldere Have kunne betragtes som Amphipodernes rette og egentlige $1 \mathrm{Hjem}$, idet han fandt, at alene de gronlandske Arter paa den Tid udgjorde en Fjerdedel af de omtrent 120 Arter, der vare kjendte fra hele Jordkloden. Ikke alene i Formernes Rigdom stod dengang det gronlandske Har foran alle andre, men ogsaa deri, at Formerne opnacede der sin storste Massendrikling. Han anforer derpaa flere Exempler, saaledes forekom Themisto arctica, Kr., i en saadan utrolig Mængde i "Godt-Haabs“-Bugten den 11te Juli 1841, at man ikke kunde se gjennem Vandet; ligeledes forekom nogle Arter af Anonyx i saa stor Mrengde i enkelte Fjorde, at disse smaa Dyr i en Nat kunde fortære den største Sælhund, saa at kun Skelettet blev tilbage. Capitain Holboll skriver ogsaa til Kroyer om disse Dyr og siger: "Jeg har ved paa 75 Favners Dybde at udlægge en Ravn og et Stylke af et Hahoved $\mathrm{i}$ en Kurv i to Timer erholdt over 6 Potter af disse smaa Dyr, uagtet Kurven var aaben og efterlod en bred Stribe af Dyr, lig en Bisværm, som forlod den under Ophalingen,"

Ogsaa i Arternes Størrelse synes det at vare en fremadskridende Udvikling mod Norden, idet den samme Art, som fandtes ved Spitsbergen, Gronland og den 
nor'ske Kyst var storst paa det forste Sted, mindre i det sydligste af det gronlandske Hav og aftog fremdeles i Storrelse paa den norske Kyst, alt eftersom man rykkede længere mod Syd, f. Ex. Gammarus locusta, der ved Spitsbergen var 18" lang, var red den norske og danske Kyst kun halvt saa lang.

Imidlertid steg Antallet af de bekjendte Former ved Dana's Beskrivelse af de paa en Jordomseiling af ham fundne Arter, hvilke ere offentliggjorte i United States Exploring Exped. Crust. Part II ; herved blev Forholdet mellem de bekjendte gronlandske og żndre Former meget forrykket.

Af de 1853 af ham bekjendte Amphipodearter fandtes der 83 i den kolde Zone, 157 i den tempererede og $82 \mathrm{i}$ den varme, idet Dana selv havde samlet ikke mindre end 110 Arter. Dana finder saaledes, efter de af ham anstillede Undersggelser, at Amphipodernes (og Isopodernes) geographiske Udhredelse staar i en fuldstændig Modsatning til Decapodernes, idet Arternes Antal tiltager mod Norden og udenfor Tropezonerne; og selv om de nordlige Have ere bedre undersogte, synes han dog, at Forholdet mellem den store Masse extratropiske og det ringe Antal tropiske Amphipoder er meget slaaende til at bevise den større Rigdom af Former i den koldere Zone. Mrrkelig er Fattigdommen paa eiendommelige Slrgter ved Troperne; af de ham bekjendte c. 50 Gammarideslægter findes 17 baade $\mathrm{i}$ og udenfor Troperne, medens kun 9 ere udelnkkende tropiske; de ovrige tilhøre alene de nordiske Have.

I Troperne tiltage Hyperiderne orermaade meget, og Orchestiderne synes ogsaa at viere mest udbredte i de sydlige Have.

Da Middelhavets Amphipode-Fauna blev mere bekjendt red Costa's, Luca's og Andres Arbeider, og endelig da Spence Bate i flere Afhandlinger bearbeidede den en. gelske Amphipode-Fauna samt Bruzelius, Lilljeborg og Kroyer den skandinaviske, sank det store Forholdstal mellem de bekjendte grønlandske og de ovrige Amphipoder meget stærkt, saa at den Antagelse af Krøyer, at egentlig det hoie Norden (Gronland) skulde vare Amphipodernes egentlige Hjem, ikke længere kunde holde Stik, da Formrigdommen i Gronland nu befandtes at vare meget mindre i Forhold til de bekjendte Former, end det af ham tidligere var antaget. Vel findes endnu ikke Amphipoder, i en saadan stor Masseudvikling noget Sted saaledes som ved Grønland og Spitsbergen, men derfor kan inan ikke sige, at dette Hav er Amphipodernes egentlige Hjem.

I den af Spence Bate udgivne "Catalogue of the specimens of Amphipodous crustacea in Brit. Museum", der synes at have til Hensigt ikke alene at beskrive de Amphipoder, der dengang fandtes i Museet, men ogsaa alle Arter, der da vare bekjendte, opregnes $5 \%$ Arter, delte i 118 Slagter. Der kommer dog hertil nogle, som af ham ikke vare medtagne, saaledes de af Viviani i 1805 beskrevne og afbildede כ Arter fra Middelhavet samt de af Achilles: Costa i $1850 \mathrm{og} 1856$ beskrevne Former, der ikke ere optagne $\mathrm{i}$ hans tidligere Arbeider, samt endelig de af mig i 1860 fra den norske Kyst beskrevne Former. Herved vil Antallet baade af Slagter og Arter foroges noget, hrorimod visselig en ikke ringe Del af de af Spence Bate opregnede Ar- 
ter og Slrgter maa udgaa, da de falde sammen med andre. Denne Forfatter synes heller ikke at have kjendt Bruzelius's og M. Sars's Arbeider, forinden haus Vark nxsten var afsluttet, og disse ere derfor kun tildels optagne i en Efterskrift, og man savner saaledes i det hele Vark Augivelsen om Arternes Udbredning ved den norske Kyst. Det es derfor meget vanskeligt gjennem hans Afhandling at kunne give noget nøiagtigt Udtryk for Kundskaben om de dengang kjendte Amphipoders Udbredning.

Man ser dog, at Englands Fauna, naar man ikke tager Hensyn til Hyperidernes Gruppe, indeholdt 142 bekjendte Arter, hvoraf dog nogle vare fra det ferske Vand. Den norske Fauna indeholdt kun noget over 80 Arter; fra Gronlands og de nordiske Have kjendte man ikke fuldt 50 Arter, medens der i Middelhavet fandtes 62 af Costa undersøgte Arter, hvortil endvidere komme de af Viviani, Milne-Edwards, Risso, Natali og Andre beskrevne foruden nogle Former fra det sorte Hav. Man kan antage, at omtrent 80 Arter paa den 'Tid vare kjendte fra Middelhavet. Om end de ovrige Verdenshave havde faaet nogen Forogelse i sit Artantal paa samme Tid, var dette dog ikke af rasentlig Betydning; man maa saaledes dengang antage, at Hovedpunktet for Amphipodernes geographiske Udbredning var Englands Kyster.

Efter 1862 har Englands Fauna foroget sig noget ved de fortsatte Undersogelser af Spence Bate, Westwood og Norman, dog ikke mod hvad der paa samme Tid er fundet af Amphipoder i Middelhavet af Grube og Heller, hvilken sidste alene for Adriaterhavets Vedkommende opteller 100 Arter, og heraf falde kun enkelte sainmen med de af Costa beskrevne. Over 160 Arter kjender man saaledes nu fra Middel. havet. Vi se saaledes, at dette Havs Fauna nu ikke staar tilbage for Englands. Goës opreguer i sit Arbeide fra Spitsbergen alene 70 Arter og desuden 9, som endnu ikke ere fundue der, men vel ved Gronland, Island og Finmarken; af disse 79 Former forekomme ved Grønland 59, og det kan saaledes nu ikke længere ansees at væere et saadant Centralpunkt for Amphipodernes Udbredning. Heller ikke er dette Tilfaldet lingere ved England, da $r i$ se, som allerede er nærnt, at Middelhavet har ligesaa mange Arter at oprise.

Ved mine seneste Undersogelser af Amphipodefaunan steg Antallet af de ved Norge fundne Arter tilligemed de, som vare kjendte fra Isharet, meget stærkt, dajeg i "Crustacea Amphipoda borealia et arctica" har beskrevet 270 Arter i 123 Slagter"; herfra gaar dog 9 Arter og 5 Slægter som henhørende til IIyperidea. Der var af disse fundet ved Norges Kyst 212 Arter foruden 4 Hyperider. Hvis man altsaa skulde kumne drage nogen Slutning fra dette Antal, der i saa høi Grad overstiger de fra England og Niddelhavet fundne og beskrevne Former, maatte man antage, at den norske Kyst var et Centralpunkt i denne Henseende. Da imidlertid den storste Del af de af mig som nye beskrevne forekommer paa de store Dyb, hvilke forhen kun lidet have været granskede, og da vort Museum i den lille Samling, som af M. Sars blev medbragt Ira Middelhavet, besidder ikke faa ubeskrevne Former, tvivler jeg ikke paa; at man ved fortsalte Undersogelser i dette Hav vil kunne fordoble Antallet af de 
kjendte Arter, og jeg tor saaledes ikke anse de nordiske Have for noget saadant Celltralpunkt. At de rarmere Have ikke ere saa fattige paa Gammarine Amphipoder, som man hidtil har troet, - thi man har længe antaget, at de Hyperine Amphipoder tiltage i Formrigdom i varmere Have, - kan blandt andet sees deraf, at Fritz Müller aleue ved Desterro har uden at gaa noget i Dybden fundet et stort Antal Arter. Ved at gjennemgaa de i Kjobenhavn opberarede Former fra Vestindien, Sydafrika og andre Steder fandt jeg ogsaa et ikke ringe Antal nye Former, saa jeg maa vare af den Formening, at fortsatte Undersogelser meget ville foroge Antallet ogsaa i de tropiske Have.

I 1871 gjorde jeg i et Bidrag til Kaliforniens Amphipodefauna opmærksom paa, at der fra Kalifornien, russisk Asien, Japan og China, fra hvilke Steder-Amphipoderne ere undersøgte af Dana, Brandt, De Haan, Stimpson samt mig, ikke rar fundet en eneste Slægt, af hvilke ikke Arter ere fundne ved Norges Kyster; jeg omtalte ligeledes, at Amphipoderne fra den sydlige Halvkugle, naar man undtager Iyperidea, der i de sydlige og varmere Have optræde i stor Rigdom og ofte i eventyrlige Former, meget lidet aĩvige fra de Former, vi kjende ved vore Kyster. Kun enkelte, som Dana's Slæegter' Clydonia og Icilius, have et fra vore afvigende-Præg. Heller ikke blandt de Amphipoder, som jeg har havt Anledning til at undersoge fra Vestindien og Sydafrika, findes der mange nye Slrgter, og disse bave ikke noget særegent Præg, men slutte sig nær til de hos os kjendte Former. Saaledes synes Amphipo: derne fra alle Jordens Have at have en støre Orerensstemmelse med hverandre, end hvad inan ved er Tilfeeldet med andre Ordener af Crustaceer, isar Decapoder, som, jo længere man kommer mod de varmere Zoner, optræde med en langt storre Rigdom af Former, end i de nordiske Have.

Naar vi næermere undersøge de nordiske Amphipoders geographiske Ud. bredning, finde vi, som jeg allerede har anfort, med Hensyn til Masseudvikling. af de enkelte Former, at de mest nordlige Kyster i denne Henseende staa høiest. Derimod er Formernes Mangfoldighed storre, jo længere man kommer mod Syd. Af Slægter, der forekomme udelukkende i det arktiske Hav, er der hidtil kun fundet een, nemlig Acanthostepheiu. Alle de ovrige gronlandske og spitsbergiske Slagter forekomme ogsaa ved Norges Kyster.

Ihvorvel vi gjennem mit sidste Arbeide over Crustacea Amphipoda borealia et arctica kjende et stort Antal Slægter, der ikke ere fundne ved Englands Kyster, maaske væsentlig paa Grund af Havets mindre Dybde paa disse Steder, forekomme dog der flere Slægter, som ikke ere fundne hos os, hvilke da nærmest synes at burde regnes til sydligere Former; saadanne ere Euonyx, Grayia, Westwoodilla, Phredra, Iscea, Pereionotus, Gammarella, Cyrtophium, Cratippus og Dryope, medens de, der ere fundne ved Shetlands Kyst, rimeligvis ogsaa kunne findes hos os. I Middelharet har man den eiendommelige Slrgt Icridium, Grube, men fororrigt er der her ikke fundet for dette Sted særegne Slægter af Gammarider. 
Af Orchestidae bliver Faunan rigere ved England og end mere i Middelhavet, paa hvilket sidste Sted Hyperidea optræde i langt storre Rigdom paa Former end ved Norges Kyst, hvor denne Familie kun er repræsenteret ved 5 Slæegter.

Sammenligne vi derpaa de Amphipoder, der forekomme ved Norges Kyster, der paa intet Sted omgives af et virkelig arktisk Hav, da Golfstrømmen overalt ved Kysten gjor sig gjæeldende, med dem, der forekomme ved Grønland og Spitsbergen, der omgives aldeles at' et arktisk Hav, er der desuagtet en mærkverdig Orerensstemmelse mellem de nævnte Kyster i denne Henseende.

Udelukkende for Gronland er kun een Art, samt een Slregt; udelukkende for Spitsbergen er ligeledes fem Arter og een Slagt, medens det storste Autal er identisk med det, der forekommer paa de norske Kyster. Dog er det en interessant Kjendsgjerning, at en Del af de gronlandske Former, som der forekomme paa en ringe Dybde, hos os kun tindes paa de større Dybder eller i de dybere Brkkener ved Kysteu, og jeg tvivler ikke paa, at disse Dybrandsamphipoder ere en fra de tidligere Tider efterladt Fauna, la ogsaa vor Kyst beskylledes af et arktisk Hav, hvis Levninger vi finde i alle store Skjælbanker. Disse Arter af de forskjellige Slægter, som Pardalisca, Stegocephalus o. s. v., er ikke alle identiske med de gronlandske Arter af de samme Slægter, men synes gjenuem Tidernes Løb at have varieret saa meget, at de nu maa ansees for nye Arter, medens de tidligere matte ansees at vare identiske med de gronlandske Arter. Professor Lovén har allerede paavist, at i Dybderne af Sveriges store Søer findes der en Krebsdyrfauna, der maa betragtes at være en tilbagebleven Del af en arktisk Havfauna, efterat Landet har hævet sig over. Harniveauet og Saltet $\mathrm{i}$ de forhenværende Havarme, der efterhaanden ere omdannede til Indsøer, er blevet udvasket $\circ \mathrm{g}$ Vandet deri omdannet til Ferskvand. 


\title{
Den specielle systematiske Del.
}

\author{
Systemets Udvikling.
}

Fra den 'lid af, at Latreille opstillede Ordenen Amplizpoda, Lvorfra Lamadipoda eller Caprellidac dengang af ham vare udskilte, har man forsggt at gruppere de Former, som henhore hertil, paa eu naturlig Maade. Jeg har allerede forhen med nogle Ord omtalt Desmarest's System fra 1825, hvilket i det Vrsentlige stemte overens med det af Leach opstillede og kun skilte sig fra dette ved, at han maatte optage nogle nye Forme1: Milne-Edwards fremkom i 1840*) med en ny Opstilling, som jeg i det Foregaaende har omtalt, ligesom jeg ogsaa har berørt Dana's Classification fra $18520 \mathrm{~g}$ 1853. Da denne danner et Grundlag for den nyere Anskuelse i denne Retning, vil jeg kortelig gjentage Hovedpunkterne af Dana's System, saaledes som han fremstillede det i 185.3. Det er for en stor Del grundet paa Iunddelenes Bygning, og han deler Amphipoclerne i tre Subtribus. De tvende forste ere Caprellidea or Gammaridea, hos hvillie begge Kjæbefodderne ere forlængede og forsynede med Palpe, men de adskilles indbyrdes ved Postabdomens Bygning, idet denne hos den forste er liden og rudimenticr, hos den sidste derimod vel udviklet og forsynet med sex Par Fodder. Den tredie Sultribus kalder han Hyperidea, hvilken afviger fra de foregaaende ved Bygningen af Kjæbefødierne, som ere korte og laagformede. Vi se saaledes, at han folger Krøyer i at indordne Lcemodiporda under Amphipoda. Den forste Subtribus, Caprellidea, deler ham atter, ligesom Kiroyer, i to Familier: Caprellidae og Cyamidae. Den anden. Gammaridea, deler han i fem Familier: Dulichidae, Cheluridae, Corophidae, Orchestidae og Gammaridae. Af disse er Cheluridae allerede opstillet af Allman, Corophidae svilrer omtrent til Tribu des Crecettines marcheuses; de to sidste Familier svare til de tvende Afdelinger hos Milne-Edwards af Tritn des Crevettines santenses. FamiIien Dulichidae er opstillet paa den af Krøyer beskrevne Slægt Dulichia. Den tredie Subtrihus, Hyperidae, inteholder los Lana tre Familier: Hyperidae, Phronimidae og Typhidae, af hvilke den sidste svarer til Milne-Edward's Hyperines anomales: de to forste ere spaltede af dennes Hyperines ordinaires og $H$. gammaroides.

Enkelte af disse Dana's Amphipode-Familier ere igjen delte i Underfamilier: saaledes Corophidae i tre, Gammaridae i sex, Hyperidae, Phrcnimidae og Typhidae hver i tre Underfamilier. I Corophidac benytter Dana især Postabdomens og Folernes

-) Histoire naturelle des crustacés. Tom. III, Paris 1840. 
livgning som Inddelingsgnund. medens han i Gammaridae tillige fremhaver Mumlelenes Form, isar Kindbakkernes og Kjæbefoldernes forskjellige Bygning.

Han har ved denne systematiske Opstilling lagt Grunden til Amphipodernes videnskabelige Systematik. Medens Caprellidae og Corophidac vise en gjennemgarende. Ensartethed i Munddelenes Bygning, saa at der fra disse intet kunde hentes til dermed at karakterisere de større Grupper, har han, som anført, netop benyttet Munddelene ved Inddelingen af Gammaridae, hos livilke de optrade i en storre Mangfoldighed af Former. Hos Hyperidae derimod har han ikke taget Hensyn til denne Inddelingsgrund skjont Munddelene ogsaa der kunde vare blevne benyttede. Baade Bruzelius og Lilljeborg bruge dette af Dana givne Inddelingspriacip, forsaavidt som det kan anvendes for de nordiske Eormers Verlkommende. Folgende Tabel vil tydeliggjore hans System.

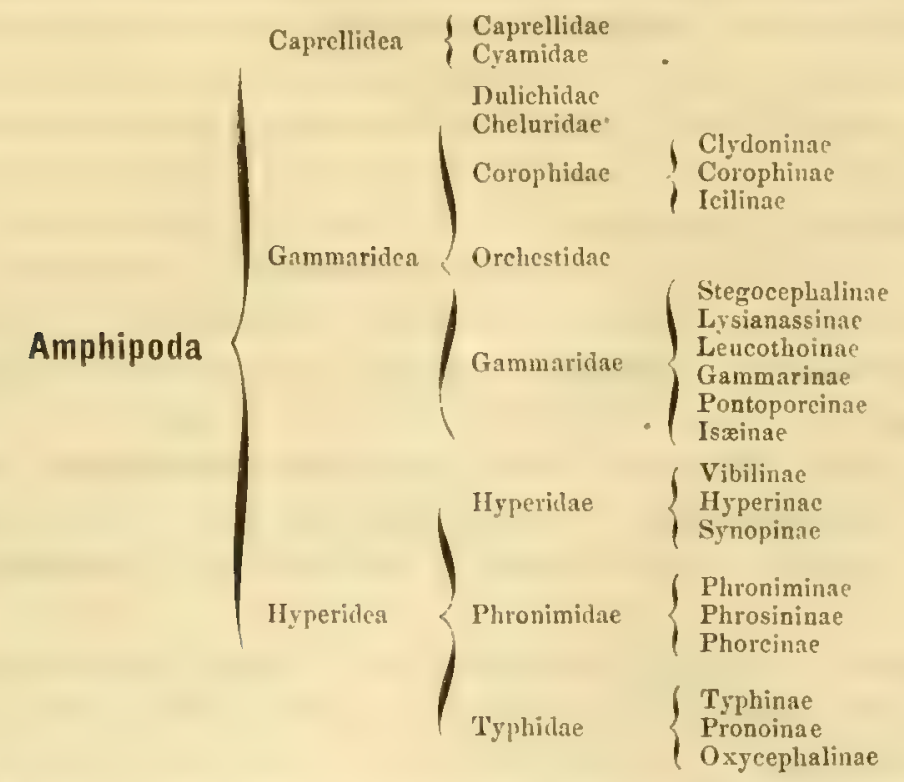

Spence Bate's Inddelingsprincip afviger meget fra Dana's, da han aldeles ikke lagger nogen Vregt paa Munddelenes Bygning, men derimod kun tager vresentligt Hensyn til den ydre Form. Han opstillede dette System i 1855 og udviklede det senere i 1862, da han fuldstandig gjengav det $i$ "Catalogue of Amphipodous Crustacea in British Museum". Han deler Amphipoderne forst i to Crupper: Normalia og Aberrantia; hvilke han adskiller paa folgende Maade: Sidepladerne (coxce) paa de fire forste Fodpar (pereiopoda) hos den første Gruppe, nomalia ere pladeformet udviklede, Postabromen (plcon) er normalt udvililet, de tre Svommefodder (pleoporla) bestaa af cilierede, dobbeltgrenede, mangeleddede, boielige Vedhæeng, de tre Springfodder, livoraf det sidste Par varierer mere eller mindre, ere i Almindelighed togrenede, og Haleverhanget (trlson) $\mathrm{el}^{\circ}$ dannet af en enkelt eller dobbelt storre eller mindre Plade, der undertiden er forsynet med Hager. Hos den anden Gruppe, Abcrantio, ere derimod Sidepladerne ilke plarleformet udviklede, og nogle eller alle ere optagne i Legemsleddene, Postabdomen 
mangler et eller Here Led; forovrigt ligner demne (irmple den foreganende. Man ser saaledes, at han ikke tager Hensyn til Munddelene, men liegger Tragten paa den ydre Form og især paa, at enkelte Led af Postabdomen mangle. 'Thi, hvad Sidepladerne angaar, ere disse hos Familien Dulichidae ligesaameget udviklede, som hos mange Slægter af Familien Corophidac. Det forekommer mig derfor meget tvungent at stille Dulirkidue ved Siden af Camellidae og Cyamidae.

Gruppen Normalia inddeler han igjen i to Divisioner: Gammarina og Hyperina. Disse skiller han fra hinanden ved, at hos den sidste skulle Foleme vare mere eller mindre abnorme, og desuden ved den af Milne-Edwards allerede angivne Karakter, at Kij:ebefødderne ere ufuldstændigt udviklede og dakke de øvige Munddele som et Laag hos den første Division, derimod ere Folerne og Mundfodderne vel udviklede. Denne indeholder to Subdivisioner, Vagantia og Domicola, hvoraf den forste udmarker sig. ved, at de nedre Folere ikkẻ ere "nwsten fodformede" samt forsynede paa Lnden med stærke, krumme Torne, ligesom det sidste Par Springfodder heller ikke har saadame. De herhenhorende Former, der ikle danne sig Boliger, svare til Vilne-Eilward's Tribus Smuteurs. Sublivisionen Domicola svarer til hans Mavcheurs. Den forste if disse spalter Spence Bate igjen i to Tribus, Saltatoria og Natatoria, medens $D_{0}$ micola ikke deles i Tribus, men kun i Familier. Til Saltatoria henfører han kun ilen enc Fumilie Orchestidae, og til Natatoria ligeledes kum (en Familie, Gammaridae. I)ivisionen Hyperina, som svarer til Milne-Elward's Familie Hypérinés og til Dana's Familie My,ntidr, deler han i fem Fimilier, Hyperidae, Phronimidae, Platyscelidae,

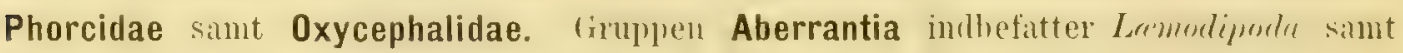
Dima's Familie Dulichidae. Denne (rruppe deles i Familierne Dulichidae, Caprellidae og Cyamidae.

Dette System benytter han fremieles i det af ham og Westwood ulgivne Arbeide "British sessile-eyed Crustacea." Den verffriede Tabel par naste Sille vil lette Oversigten af hans Opstilling.

Sammenligner man nu Spence Bate's System med Dana's, se vi, at der i det forste findes langt flere slagter, som ere opstillede, efterat Dana's Arbeide var udkommet. Tager man kun Hensyn til de Slægter, der forekomme los begge Forfattere, for ret at kumne bemarke forkjellen mellem deres Anordning af Amphipoderne i systemet, vil man se, at Familierne Cyamidae, Caprellidue, Dulichidae, Cheluridac og Orrhestidae indeholde de samme Slagter, hvorimod Familien Corophidac er anderledes upfiattet hos spence Bate, da han sløifer Dana's Underfamilier Icilinae og C'ydoninat, samt stiller Slagterne Icilius og Clydonia under sin Underfamilie Corophides, medens han forbigaar Slagten I'terygocera. Af' de til Underfamilien Corophinae stillede Slægter udgant Platophizm, Cratophium, Corapodina og Erichtonius, der kun ere synonyme med andre Slregter; de tilbageblevne ere af ham indordnerle $i$ hans to Underfamilier Podocerides, hos hvilken Slagterne Podocents, Siphonoeretes samt Cevopus, og Corophides, luvis slaghter Cyrtophium, Inciolu og Corophium ere stillede sammen med Jcithes og 


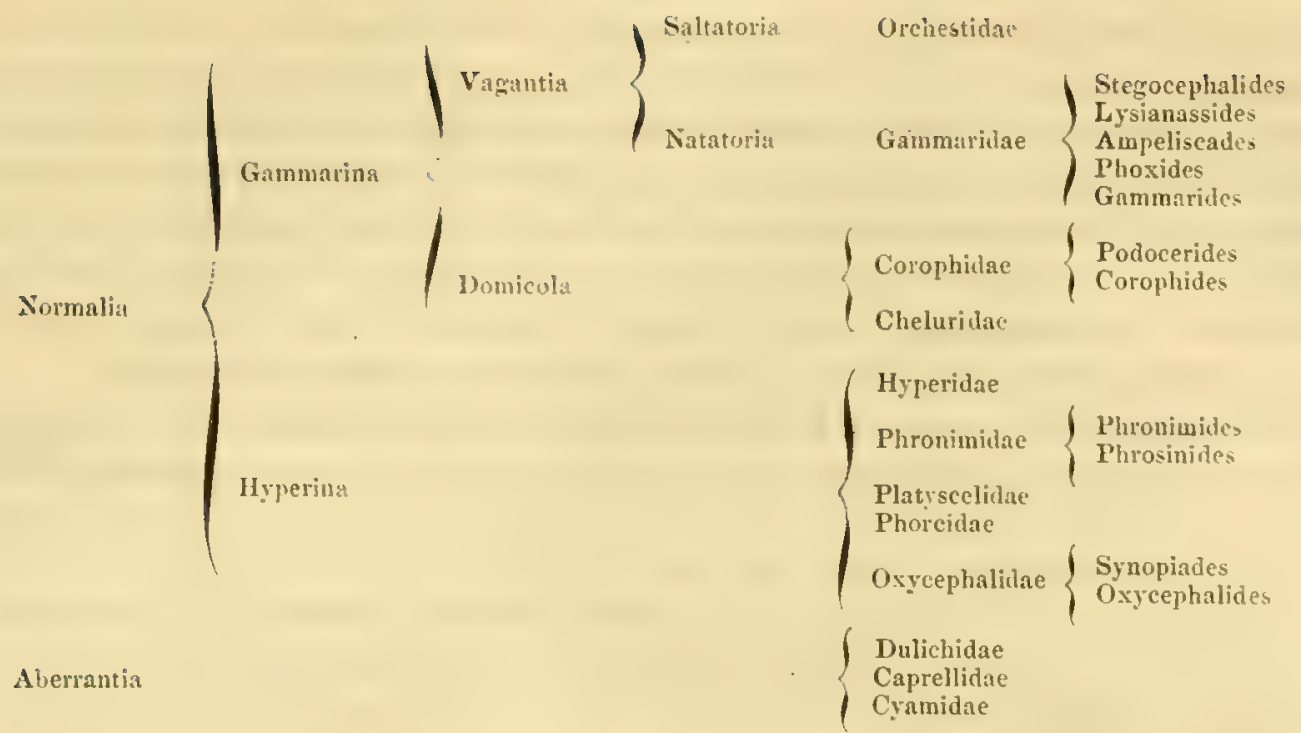

Clydonic. I disse to Underfamilier optager Spence Bate ogsaa Dercothoë og Amphithoë. Familien Gcommaridae deles hos Dana i sex, hos Spence Bate í fem Underfamilier, da demne sidste ikke optager Lencothoinac, af hvis Slrgter Stenothoï og Leucothou han henfører den første til sin Underfamilie Stegocephalides, og den sidste til Gammarides; han optager heller ilike Isceinue, af hvis Sligter han henfører Isca til Underfamilien Phoxides og stiller Anisopus synonym med Amphithoë og saaledes til Familien Corophidae. Han optager desuden ikke Underfamilien Pontoporinae, men indordner dens Slagter Phoxus under sin nye Underfamilie Phoxides og Pontoporeia under Lysiancassides. Protomedeic og Aora henforer han til Gammarides og Ampelisea til en ny Underfamilie Ampeliscudes. Dana's Underfamilie Stegocephatinae indbefatter kun den ene Slægt Stegocephalus; Spence Bate's Underfamilie Stegocephalides har desuden Dana's Slægt Stenothoë. I Underfamilien Lysianassinae, der hos Dana indbefattede Slagterne Lysianassa, Phlias. Opis. Uristes, Anomy og Urothoë, optager Spence Bate desuden Pontoporeia og Alibrotus samt nogle andre, som Dana ikke kjendte. Derimod henfører him Urothoë til Phoxides. Dana's Underfamilie Gammarinae svarer heller ikke til Spence Bate's Gammarides, idet den sidstnevnte Forfatter henfører Slægterne Phoxus, Acanthonotus, Oediceros, Iplemedin og Lepriductylus til Underfamilien Phoxides, Alibrotus og Pontoporeia til Lysianussides, Dercotheë til Podocerides og Ampelisca til Ampeliscades. Slægterne Gammarus, Melita, Maera, Pardalisca, Atyhs, Protomedeia og Aora henregne begge til den samme Underfamilie. De af Dana opførte Slægter Leptocheinus, Pyctilus og Ichyrocerus falde efter Spence Bate bort, da de ere synonyme med andre Sliggter. Lepidactylus forbigaar Spence Bate med T'aushed. Ogsaa ved Ordningen af Formerne indenfor den sidste Subtribus Hyperidea afviger Spence Bate fra Dana i Opfatningen af den nærmere Slægtskab. Dama deler den i tre Familier, Hyperidae, Phromimidae og 
Typhidae, medens Spence Bate har fem saadame, nemlig: Hyperidae, Phronimidae, P'letyscelidae, Phorcidae og Oxycephatidae. Han haver nemlig Dama's Underfamilie Phorcinae op til en Familie Phorcidae; ligeledes opstiller han Familien Oxycephalidae at Dana's to Underfamilier Symopinae og Oxycephatinae. Familien Hyperidae opfatter han heller ikke saaledes som Dana; han sloifer dennes Underfamilie Vibilinae og drager den anden, Synopinac, til Oxycephalidae. Dernæst opstiller lan F'amilien Phonimidae med Underfamilierne Phronimides, der svarer til Dana's Phromimae, sạt Plorosinides, der svarer til demes Phrosininae, hvis ene Slægt Themisto han stiller til Hyperidae.

Afvigende fra Spence Bate's System er det, som Lilljeborg i 1865 angav i sit Arleide "On the Lysianassa Magellanica“, og som oplyses i den efterfylgende Tabel.

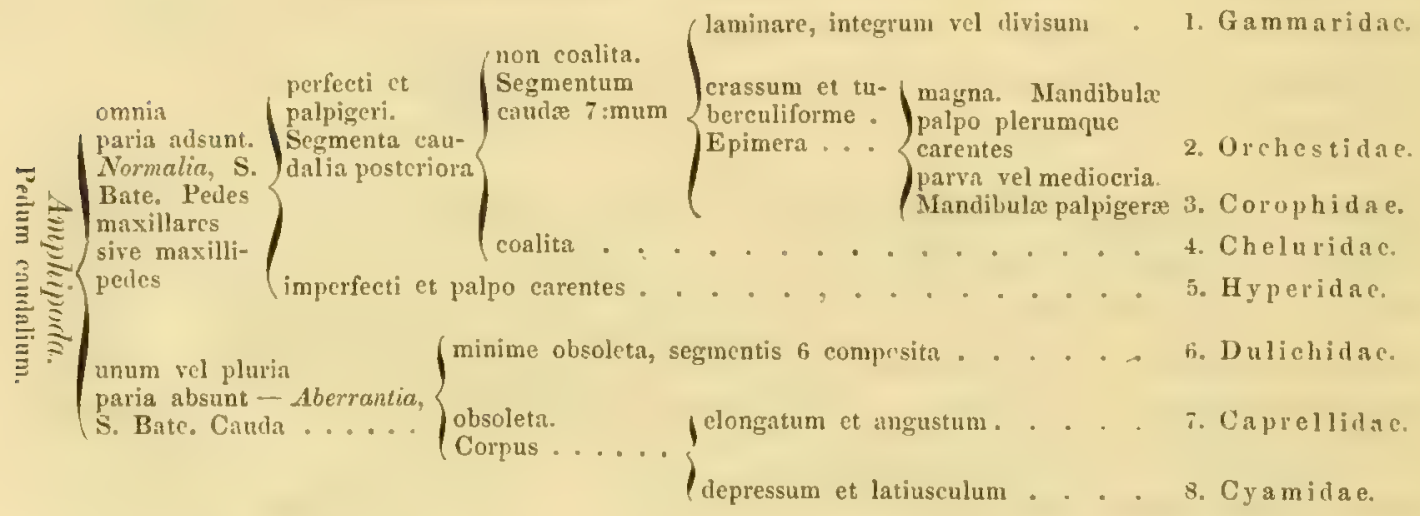

I en anten 'Tabel giver han en Oversigt over de ni Underfamilier og sex og tredive Slægter, hvori han deler den forste og største Familie Gammaridae. Disse UnIerfintilier ere: Lysianassina, Pontoporina, Gammarina, Phoxina, Trischizostomina, Oedicerina, Leucothoina, Atylina og Ampeliscina. Velfuiede Tillel paa neste vide viver hans Inddeling I Underfamiliel af Gammaridae.

Sammenligne vi Lilljeborg's systematiske Opstilling med den af Spence Bate, finde vi, at den slutter sig hertil, idet han nemlig skiller Amphipoda nomalia fra Anphipoda aberantia og deler ligeledes Normatia i to Afdelinger, der svare til Spence Bate's Gammarinae og Hyperinac. Derimod benytter han ikke demes Indleling i Vayantia og Domicola, men deler Grmmarinac, eftersom Halens bagre Led ere forenede eller adskilte, hyorved lam udsondrer Chcluridae fra de tre ovrige, Orchestidac, Gammaridac og Corophidae. If den Afdeling, ler svarer til Spence Bate's Hyperina, optager han kun Familien Hyperidac, da alene denne findes ved Skandinaviens Kyster. Han deler Gammaridae i ni Underfamilier, medens de deltes i fem af Spence Bate. Af Slægtel optager han kun dem, der forekomme ved Skandinavien. Folgende Sliegter, der ikke forhen vare kjendte, ere optagne af Lilljeborg: Eurytenes, Acidostoma, Tiron, Trischizostoma og Oediceropsis. Af hans ni Underfamilier stemmer Lysianassinae overens med den samme hos 


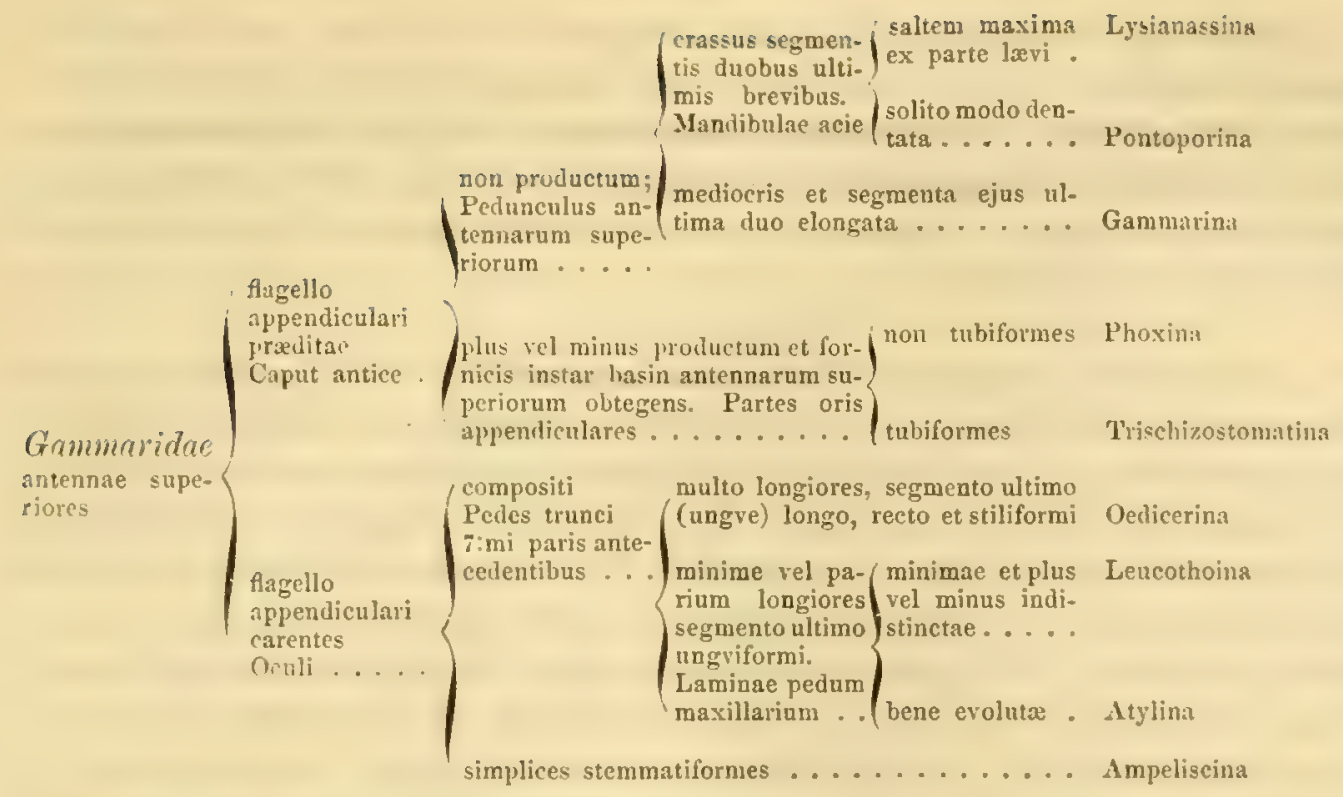

Spence Bate, med Undtagelse af at Pontoporeia el udelukket, og merl Dana's Lysianassince, frat hvilken dog Urothoë el udelukket. Til Underfamilien Pontoporinae henforer han Pontoporeia, Batyporeia og Stegocephalus, paa hvilken sidste Slagt Dana grunder sin Underfamilie Stegocephalinae, som ogsaa optages af Spence Bate, men som Lilljeborg slvifer. Af disse til deme Undertamilie henhørende Slagter henfører Spence Bate Pontoporcia til Lysinnassides og Bathypareic til Gammarides. Til Underfamilien Gammarina henreguer Lilljeborg Gammanus, Eusins, Pardalisca og Eriopis, hvilke ogsaa Spence Bate regner til Gammarides, og tillige Microplax (Lilljeborgia) og Nicine, der af Spence Bate blive henforte til Phoxides. Med Dana's Underfanilie Gammarime ere kun Slrgterne Gammarus og Pardalisea frlles for ham og Lilljeborg, da de wrige ikke vare kjendte af den Forste. Han optager Underfamilien Ploxinae efter Spence Bate og stiller, ligesom han, hertil Slrgterne Phoxus og Urothoë, hvorimod han ulsondrer Oedicerus Monoculodes og Kroyeria, af livilke Slagter han damer en ny Underfamilie Ocdicerina. Efter Dana optager han Underfamilien Leucothoina (Leucothoinae, Dana), hvortil han forulen de Slagter, som hin havde optaget deri, Lencothoë og Stenothoë, Montague, ogsaa henforer den senere tilkomne Slægt Pleustes. Disse Slægter vare af Spence Bate henforte til Underfamilien Stegocephalides. Af Slagterne Laphystius, Iphimedia, Odius (Otus) og Acanthonotus, hvilke Spence Bate henfører til Underfamilien Phoxides, af Dexamines Atylus samt af Calliopius (Calliope), som den silstnrevnte henforer til Gommarides, og af Bruzelius's Slagt Parcmphitoë damer han en ny Underfamilie Atylina. Den sidste Underfamilie Ampetiscina stemmer overens med Spence Bate's Ampeliscades. Han grunder disse Inderfamilier paa Folernes, Hinenes. Fuddernes og Mundredskabernes forskjellige Bygning og afviger saalerles $i$ sit system ikke lidet fra det af Spence Bate opstillede. 
Efterat jeg i 1860 i ,Bemrerkinger angarende de ved len norsle hyst forekommende Amphipoder"6 havde delt de af mig dengang kjendte Former i fire 'lribus: Hyperidae, Prostomatae, Gammaridae og Caprellidae, samt atter llelt Gammaridae i Familieme Orchestidae, Gammaridae og Corophidae, udgav jegr i 1870 . ('rustaceat amphipoda borealia et arctica", hvori jeg har grupperet de af mis der opforte norske og arktiske Former i et nyt System.

Jeg troede, at Amphipodernes systematiske Opstilling vasentlig maatte grundes paa Bygningen af Mundielene, da disse frembyde de vigtigste $0 g$ skarpeste harakterer for alle Artroporter og er den egentlige Provesten for deres næmere eller fjemere Slægtskab. Allerede Chr. Fabricius hentede fra disse Deles forskjellige form sine Karakterer for Crustaceemes Slagter, men Vanskeligheden i Undersøgelsen af dem har bragt de senere Forskere til at soge andre lettere Karakterer, hvis Undersogelse ogsaa mindre skadede Exemplareme. Den ydre Form varierer meget efter Dyrenes forshjellige opholdssted, der har ladet nærstaaende Former udvikle sig suart i en snart i en anden Retning, men som dog let kunne tilbagefores til en fielles Typus. Vil man derfor vasentlig hente sine Karakterer fra den ydre Form, vil man ogsaa let komme til at fore beslægtede Former hen til langt fra hinanden staaende Afdelinger, og derimod sammenstille dem, der naturlig ikke høre sammen. For at anfore et Exempel har jeg i min Underfamilie Phoxinue væsentlig hentet mine Karakterer fra Munddelenes og ikke fra Pandehornets form, som jeg antager er af liden Vigtighed, og som hos de forshjellige Slrgter, der af Spence Bate henføres til Underfamilien Phoxides, er af en meget forskjellig Form. Til demne Underfamilie har jeg henfort de fire ved Norges hyster forekommende Slrgter Phoxus, Harpina, Sulcator og Urothoë, der meget afvige i den yilre Form og Foddernes Dannelse, men destagtet umiskjendelig have ch vis overensistemmelse ogsaa heri. I Munddelenes Bygning stemme de derimod meget overens, men skille sig heri fra Oediccrus, Monoculodes, Amphilocus, Lafystius, Lilljeboryia og andre, der ere stillede sammen med dem. Hos Slagten L'hoxus og Harpina, der lever paa sandblandet Lerbund mellem storre og mindre Stene, er Legemet sammentrykt fra Side til anden, Hovelet giar frem i et langt Pandehorn, som benyttes sammen med Folerne til dermed at valte bort smaa Stene; de to forste Fodpar ere starke, og de tre sidste ere ikke meget brede. Hos Slagten Sulcutor, som graver i Sand, er derimorl Pandehornet megret kortere, Legemet meget sammentrykt, det forste og det andet Fodpar have kun en svag Haand, det tredie $\mathrm{og}$ det fjerde Fodpars fjerde $\mathrm{og}$ femte Led ere srerdeles brede 0 vabnede med stærke Kilor og ere saaledes uddannede til at grave med; de tre bagre Fodpars Led ere overordentlig brede, spadeformige og bruges til at haste den sand bagover, som opgraves med det tredie og fjerte Fodpar; endelig ere Postabdomens tre sidste Led bøiede under det tredie, meget forliengede Led, da disse Led sammen med forlparrene ikke eller kun lidet benyttes som Bevagelsesredskaber. Hos den fjerde Slayt af Phoxinue, Urothö, der lever par Dyndbund, er Legemet, isterletfor at viere sammen- 
trykt fra Silleme, netop neiltrykt, meget bredt, og Sideplademe staa ud til Silen; Pandehornet mangler nasten aldeles, da dette ei er nodvendigt paa den blole Bund; derfor ere de tre bagre Fodpar heller ikke saa stærkt udviderle som hos de to ovenfor omtalte Slagter; derimod er det sidste Par Springfodders Grene meget brede og forsynede i begge Rande med lange, fjorformede Borster. Undersoger man derimod Mundtelene, vise disse en meget stor indbyrdes Overensstemmelse og henvise til, at alle disse tre Slagter leve af sma Dyr, som det ikke er ganske let at sønderhide, om de end ikke kumne gjøre nogen videre Modstand, thi Kindbakkernes Form er stærk og kort, medens de øvige Mundele ere svage. Saaledes forholder det sig, forat benytte endnu et andet Exempel, ogsaa indenfor. Underfamilien Iphimedinae; de herhen horende Slagter Vortumnus, Iphimedia, Odius og Lafystius ere meget forskjelligt udviklede i den ydre Legemsform, isie den sidste Slagt par Grund af sin parasitiske Levemaade. Munddelene lıos dem alle vise $\log$ en typisk Overensstemmelse, men dog ere de af en lidt afvigende Bygning hos de forskjellige Slagter. Undersnger man Mundlelenes liygning hos en storre lixkke af Amphipoder, f. Ex. Los Divisioneme Hyperina og Gammarina, saa ville vî se, at de ere byggede efter en meget forskjellig Typus. I den første Division finter man saledes, at hos den typiske Slagt Hyporia ere Kindbakkerne forsynede men en meget brefl Gribedel og fremstarende Tyggeknude, medens de svrige Munddele ere svage, isar lijabetodderne; de ere ufuldkommen byggede uden Palpe og med sammenvoxede indre Plader. Hos en anden Slagt blive Kindbakkerne svagere, ja nasten rudimentære, nen den samme Hovedform, isar i lijwbefoddernes Dannelse, giver sig tilkjenile. Derimod ere Kjabefodderne hos Gammarida stærkt byggede, forsynede med Palper og dette er ogsar Tilfreldet med Caprellidae, som vel i den yolre Form synes at afvige fra Grommarida, men som dog slutter sig nær til Corophidae og Dulichidae, isar til den sirlste, som ogsata damer et tydeligt Overgangsled mellem begge.

Jeg opstillede derfor de nordiske Amphipoder i to Divisioner, Hyperida og Gammarida, hvis Munddele vare af en saa forskjellig typisk Form. Hyperida lelte jeg i to Familier, Hyperidae og Tryphanidae, lovoraf den sidste kun bestorl af een sliegr. dit jeg ikke kunde stille den til nogen af de for opstillede Familier, fordi Mundilelenes Bygning afveg fra den hos de bekjendte Former. Divisionen Gammarida delte jeg i fen Familier: I. Prostomatae, der damede en Overgang mellem Hyperidue og Orrestidue, men hvis Mundredskaber havile antaget en Form, som synes at tyile paa en parasitisk Levemaade, II. Orchestidae, der hos mig havde det simme Omfang som hos de senere Forfattere, ligesom III. Caprellidae, idet dog Dana's Familier Caprellidae og C'ymulue bleve opfattedesom Tnderfamilier under deme, og IV. Dulichidae. Hos disce to sidstnavite stemmede Mundredskabernes Form sarleles meget overens med dem hos Gammaridae, men Legemsringenes Antal reduceredes hos dem mere eller mindre, saaledes at der hos Dulichidae forsvinder een Postabdomening med sit Lemmepar og hos Caprellidu: Here. Familien Gammaridae, der indbefattede de fleste Former, blev atter spaltet i 2.2 Underfamilier, hvoraf Chelurinae og Coropkince af Dana, Spence Bate og Lilljeborg 
vare optagne som Familier. Jeg fandt nemlig, at disse heller burde stilles som Underfanilier sideordnet de andre under Familien Grommuridur, ta indenfor de Luderfamilier, der allerede fandtes, eller som jeg mante opstille, vare stgrre Variationer i Munddelenes Bygning end mellem Slægterne Gammams, Chelura og Corophim, der ere 'Typer for disse Familier, og at der i den ydre Form kunde findes talrige mere eller mindre tydelige Overgange mellem dem og de andre Typer for Underfamilier. Folgende Underfamilier vare i mit System opstillede som nye: Amphilochinae, Stenothoinae, Syrhoinae, Pardaliscinae, Iphimedinae, Epimerinae, Dexaminae, Leptocheirinae, Microdcutopinae, Amphithoinae og Podocerinae.

Falgende Tabel viser min systematiske Opstilling af Amphiporlerne i 1870.

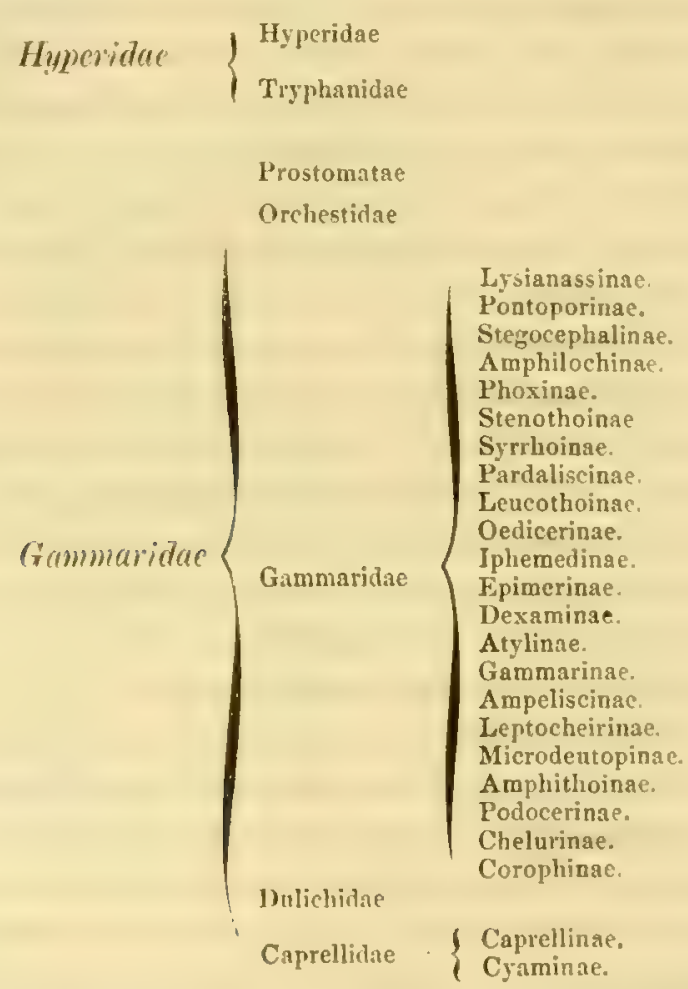

I dette mit nye Arbeirle afviger jer lidt fra den Anskuelse, som jeg havde i hint. Jeg var nemlig af den Formening, at Dana's Subtribus Camellidea ved Munddelenes Bygning stor saa nær hans anden Subtribus Gammaridca, men derimod skilte sig saa meget fra hans Iyperidea, at de to forste Subtribus ikke burde adskilles, men at Caprellidea kum burde opstilles som en Familie under Gammaridea. Imidlertid har jeg nu frafaldt denne Anskuelse og folger Dana $i$ at opstille Amphipodeme i tre Divisioner: Hyperina, Gammarina of Caprellina. Den furste Division. Hyperina, indloefattel hos os kun meget faa Former, hroraf de Heste henhore til Dana's Familie Hyperidae, og hvis Munddele ere rel udviklede. Den anden Division, Gammarina, indbefatter den 
største Del af de i de norliske Have forekommende Former. Denne Division inddelte jeg i 1870 i folgende Familier: I. Prostomatae, hvilken jeg allerede havle opstillet i 1860, men som Lilljeborg i 1865 havde gjort til en Underfamilie under Navn af Trischizostomutinu, II. Orchestidae, III. Gammaridae, IV. Dulichidae $0 \mathrm{~g}$ V. Caprellidae. I dette nye foreliggende Arbeide udskyder jeg, som anfort, Familien Camellidac og stiller den som en egen I livision, Caprellina, med to F'anilier: Caprellidae or Cyamidae, istedetfor to Underfamilier. I)ivisionen Gammarina deler jeg m igjen i folgende Familier: I. Gammaridae, der omfatter de af mig i det foregnaende Arbeide optagne Underfamilier Lysianassinae, Pontoporinae, Phoxinae, Oedicerinae, Elmorinae, Dexaminae, Atylinac, Ampeliscinae og Gammarinae; II. Fanilien Leucothoidae, der indbefatter Underfamilierne Stenothoinae, Stegocephatinae, Amphilochinae, Symhoinac, Pardatiscinae, Iphimedinae og Lencothuina:; III. Familien Ampeliscaidae; IV. Fimilien Photidae, der indhefatter I'nderfamili-

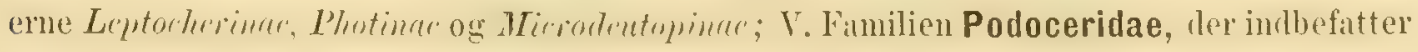
Underfamiliene Amphitönac og Podocrinae. Dernæst optager jeg Cheluridae som en egen Fimilie, istedetfor at den for lim dimnede en Tnderfamilie; ligesaa Corophidae, som jeg deler i to Underfamilier: Corophinae og IIclainae, hvilken sidste kun indbefatter den af mig i 1860 opstillede Slægt Hela. Endelig optager jeg Dana's Familie Dulichidae og de to af mig allerede for omtalte Familier Caprellidae og Cyamidae, saa at Familiernes Antal bliver 14, henhorende til de tre Hovedgrupper eller Divisioner Hyperina, Gammarina og Caprellina.

Tabellen paa næste Side vil vise denne nye Opstilling.

I Realiteten normer dette af mig opstillede System sig meget mere Dana's end nogen Andens, men jeg har kun optaget i dette System de nordiske Amphipoder, da for en stor Del Munddelenes Bygning er ubekjendt for en Mrngde udenfor Norden forekommende Former, og jeg vilde saaledes have megen Vanskelighed for at indordne disse sydligere Former i mit System.

Under disse Familier og Underfamilier ere 121 Slægter fordelte, hvilke alle ere funcine ved Norges Kyst og i de arktiske Have, medens i 1862 optoges af Spence Bate fra alle Jordens Have kun 118 Slrgter, hvoraf mange ere usikre, og som ville bortfalde. Trækker man fra dem, der høre til Divisionen Hyperina, nemlig 5 Slægter i mit Arbeile og de 24, der af Spence Bate i hans "Catalogue" regnes til den samme Afdeling, saa bliver Forskjellen mellem Antallet af Slagterne end betydeligere. Af disse 121 Slagter høre, som anfort, 5 til Divisionen Hyperina, nemlig 4 til Familien Hyperidac og 1 til Familien Trypleanidae. Til Divisionen Gammarina hore 108 Slegter, deraf 1 til Familien Prostomatidae, 3 til Orehestidae, 3 til Ampeliscaidae, 1 til Chchridae, 4 til Dutichidae. Til Gammaridac hore 57 Slægter, hvoraf jeg regner til dens Underfamilie Lysianassinac. 17, til Pontoporinae 4, til Amphilochinae 3, til Ploxinae 4, til Ocdicerinae 8, til Epimerinae 2, til Dexaminae 2, til Atylince 7, til Gammarinae 10 Slægter. Til Familien Lencothoinae høre 19 Slagter, deraf til Underfamilien Stegocephalinae 2, til Stenothoinae 3, til Syrrhoinae 3, til Pardaliscinae 3, til Lencothoinae 5, til In himedinae 3 Slrgter. 


\begin{tabular}{|c|c|c|}
\hline \multirow{3}{*}{$\begin{array}{l}\text { Divisioner. } \\
\text { Amplipoda } \\
\text { Hyperina }\end{array}$} & Familier. & \multirow[t]{3}{*}{ Underfamilier. } \\
\hline & Hyperidae & \\
\hline & Tryphanidac & \\
\hline \multirow{7}{*}{$\begin{array}{l}\text { Amplipoda } \\
\text { Gammarina }\end{array}$} & $\begin{array}{l}\text { Prostomatidae } \\
\text { Orchestidae }\end{array}$ & \\
\hline & Gammariclae & $\left\{\begin{array}{l}\text { Lysianassinac. } \\
\text { Pontoporinae. } \\
\text { Phoxinae. } \\
\text { Oedlicerinae. } \\
\text { Epimerinae. } \\
\text { Dexaminae. } \\
\text { Atylinae. } \\
\text { Gammarinae. }\end{array}\right.$ \\
\hline & $\begin{array}{l}\text { Lencothoidac } \\
\text { Ampeliscaidac }\end{array}$ & $\begin{array}{l}\text { Stegocephalinac. } \\
\text { Amphilochinac. } \\
\text { Stenothoinae. } \\
\text { Syrrhoinae. } \\
\text { Pardaliscinae. } \\
\text { Letrothoinae. } \\
\text { Iphemedinae. }\end{array}$ \\
\hline & Photidae & $\left\{\begin{array}{l}\text { Leptocheirinae. } \\
\text { Photinae. } \\
\text { Microdedopinae. }\end{array}\right.$ \\
\hline & Porloceridne & $\left\{\begin{array}{l}\text { Amphithoinae. } \\
\text { Podocerinae. }\end{array}\right.$ \\
\hline & Corophidre & ) Corouhinae. \\
\hline & $\begin{array}{l}\text { Cheluidac } \\
\text { Dulichidae }\end{array}$ & \\
\hline Ampleipoda & $\left\{\begin{array}{l}\text { Caprellidae } \\
\text { Cyanidae }\end{array}\right.$ & \\
\hline
\end{tabular}

Sammenligner man dette System med Lilljeborg's, som ogsaa liun omfatter de nordiske Amphipoder, saa afviger det særdeles meget: forst ved Opstillingen af de tre sideordnede Divisioner af Amphipoderne, Hyperina, Gammarina og Caprellina, medens Lilljeborg savel som Spence Bate deler dem i to, Normatia og Aberantia, idet Hyperina stilles til Gammarina trods den særdeles afvigende Dannelse af Mundredskaberne, og til Aberrantia regnes Cameltina sammen med en Familie af Gammarina Dulichidae, fordi et eller flere Led af Halen er bortfaldt hos disse. Dette Forhold tror jeg dog er af en mere underordnet Betydning end Mundredskabernes Form. Af mig er der optaget 14 Familier, medens Lilljeborg kum har 8. Af disse ere Hyperidae, Orchestidae, Cerophidae, Chchuridae, Dutichidae, Caprellidac og Cyamidae frlles. Podoceridae og Photidae ere nye, hans Underfamilie Ampcliscina er hrvet til en Familie, og den af mig for opstillede Tribus Prostomatae, der af ham var opstillet som en Underfamilie, er her optaget som en Familie. Desuden er tilkommet Familien Tryphthanidae, der er opstillet paa en ny Slegt. Hans Familie Gammaridae er hos mig delt i to: Gammaridae og Lencothoidae. Sammenlignes Grupperingen af Underfamilier og Slægter i hans Familie Gammaridae med den i mine Familier Gammaridae og Lencothoidae, hvilke tilsammen omtrent svare til hans, saa findes, at han har optaget deri 7 Underfamilier (idet Ampetiscina og Trischizostomatina ere af mig stillede som egne Familier), medens jeg har optaget 15. 
Hans Underfamilie Lysianassina svarer til min Lysianassinae, kun at jeg har flere Slægter, dels nye, dels saadanne, hrori jeg har spaltet to gamle. Af hans Pontoporina udtager jeg Stegocephalus, der tilligemed en ny Slagt damner Underfamilien Stegocephalinae. De to tilbageblevne Slagter tilligemed to nye dimne Underfanilien Pontoporinur. Min Amphilor hinat indeholder kun Slægter, som lian dengang ikke kjendte som skandinaviske og ere derfor ikke optagne i hans System. Hans Phoxina, der indbefatter Slrgterne Phoxus, Urotlioë og Tiron, afviger fra min Phoxinae, idet Tiron føres over til en ny Underfamilie Syrrhoinae. Hans Underfamilie Oedicerina stemmer fuldkommen overens med min Ordicerinae, kun at der er tilkommen det dobbelte Antal af Slægter. Underfamilien Lencothoinae afviger derimod noget fra min Lencothoinae, idet jeg optager deri Lilljeborgia, Euscrus og Tritropis (Amphithonotus), som af Lilljeborg ere stillede til Atylinae. I denne sidste Underfamilie er det kun Slægterne Atylus og Calliopins, som ere frelles for begge, idet Dexamine med en ny Slagt af mig er stillet til en ny Underfamilie Dexamininac og Acantionotus (Vertumnus) og Lafystius til den nye Iphimcdinae. Af Slægter, der af Lilljeborg ere henførte til hans Underfamilie Gammarina, er Gammans og Eriopis (Niphargus) frelles med dem, jeg stiller i min Underfamilie, derimod overforer jeg Eusenus og Microplax (Lilljeborgia) til Lencothoinae samt Nicimpe og Pardalisca til den nye Underfamilie Pardaliscinac. 


\section{Divisio.}

\section{Hyperina.}

Instrumenta cibaria plus minusve perfecta.

Pedes maxillares palpo carentes, laminis externis cetera instrumenta cibaria tegentibus; laminis internis coalitis.

Antennæ plerumqve imperfectæ, antennæ superiores aut inferiores sæpe absentes.

Pedes sæpe mire compositi.

Postabdomen plus minusve perfectum.

Milne Edwards opstillede i 1830 fomille des Hypérines, som han grundede paa de Slægter, hvis Kjæbefodder vare ufuldkomment byggede og dannede en Art Underlæbe. De Slægter, som han optog i denne, vare Hyperia, Phorcus, Vibilia, Lestrigonus, Daira, Anchylomere, Oxycephatus, Phronima, Typhis, Themisto. I 1840 beholdt han denne Familie, idet han karakteriserede den ved, at Mundføddeme bedække kun Grunddelen af de foreganende Munddele og dame en uparret Underlæbe, der er uden Palpe, eller har kun Spor deraf. Han deler igjen denne Familie i 3 Tribus: 1) Tribu des Hypérines gammaroides, hvortil han kun regner Vibilia, 2) Tribu des Hypérines ordinaires, hvortil-hører Slægterne Hiyperia, Aletoccus, Phorcus, Tyro, Primno, Lestrigonus, Daira, Themisto, Anchylomera, Phrosina og Phronima. 3) Tribu des Hypérines anomales, hvortil henfortes Slægterne Typhlis, Pronoe og Oxycephalus.

Dana ophøier den i 1863 til en Subtribus Hyperidea og karakteriserer den saaledes: Maxillipedes operculiformes breves. Caput grande, oculonm comeis plerumque tectum. Appendices abdominales seepius latiores. Han deler den i 3 Familier: Hyperidae, Phronimidae og Typhidae.

Spence Bate opfatter Dana's Sultribus, der er sideordnet med dennes ovrige Divisioner, som en Subdivision, sideordnet med Gammarina, under Divisionen Amphiporda normalia til Modsstning af Amphipoda aberantia, indenfor livilken sidste Caprelliderne har sin Plads. Saaledes tror han, at Hyperideme er nærmere beslægtet med Gammarideme end med Caprelliderne.

Lilljeborg opfattede i 1865 Hyperidae liun som en Familie ved Siden af Gammaridae, Orchestidae, Corophidac, Cheluridae, Dulichidae, Caprellidae og Cyamidae. I 1871 stillede jeg Hyperidae som en Division ligeoverfor en anden, Gammaridae, under 
hvilken jeg stillede Caprellidac som en Familie, da jeg fandt, at Hyperiderne i Munddelenes Form skille sig meget mere fra de ovrige Amphipoder, end Caprelliderne skille sig fra Gammarideme. I dette Arbeide følger jeg imidlertid Dana og stiller Hyperiderne som en Division, Hyperina, ved Siden af Divisioneme Gammarina og Camellina. Af denne Division have vi i de nordlige Have kun 5 Slagter, hvoraf de 4, nemlig $M c$ toccus, Hyperia, l'arathemisto og Themisto i det Hele staa hinanden meget nar og vise en stor Overensstemmelse i Munddelenes Bygning, hvorimod Slægten Tryphana afviger heri fra de foregaaende. Derfor har jeg delt deme Division i to Familier, Hyperidac og Tryphanidac.

Familia $I$.

H Y P E RID A E, Dana.

Syn.: 1853. IIy

14i2. Hyperidae, Spence Bate, Crust. Amphip. Brit. Mus. p. $28 \%$.

1870. Hyperidae, Boeck, Crust. Amphip. bor. et arct. p. 4.

Mandibulæ in apice latæ, valde dentatæ; mala interna lata; tuberculo molari permagno, palpo 3 articulato.

Antenne perfectre, superiores pedunculo perbrevi, 3articulato; llagello apud marem multiarticulato et longiore, apud feminam perbrevi, articulis carenti.

Pedes 3tii-7mi paris non prehensies.

Corpus inflatum, crassum, raro compressum.

Oculi capitis latera tegentes.

Pedes saltatorii biramei; ramis laminiformibus.

Appendix caudalis parva, non fissa.

Denne Familie er opstillet af Dana, som delte Milne Edwards' Hypérincs ortinaires i tvende Familier, Hyperidae og Phromimidac. Han beskrev den forste saaledes: Antenne secunde excerte. Abdomen in ventren se non flectens. Pedes 5ti, Gti, rmique forma longitudineque mediocres štis et Gtisve non pererassis nee prochensilibus. Han delte den i tre Underfamilier: Vibilinae, Hyperinac og Synopinac. Spence Bate henforte til sin Familie Hyperidae de samme Slagter, men udelod Synopria, som han stillede hen til sin femte Familie Oxycephatidae. Til Hyperidae hore af de hos os forekommende Amphipoder Slagterne Hyperia, Mctoccus, Parathemisto og Themisto.

I Munddelenes Bygning vise disse en meget stor Overensstemmelse derved, at Overlxben er stor, Kindbakkernes Gribedel meget bred og strerkt tandet par Enden. Tænderne ere fine, saugdannede, og kun de yderste ere større end de ovrige, ligesom der findes et støre Mellemrum mellem dem. Den indre Bigren er stor, dog mindre end Hovedgrenen og tandet ligesom denne. Mellem denne og Tyggekmuden findes der en Række fine, men ikke korte Børster, der strække sig i en skraa Rad noget opover og udad. Tyggekuuden er særdeles stor, omgiven med et Gjærde af saugdamnede Trn- 
der; Palpen er forlienget, meget smal, tynd; dens forste Led er forlænget, rlog meget kortere end det andet, og det tredie er noget krummet og tilspidset mod Enden. Underlabens Flige ere vidt adskilte, paa Enden afrundede og forsynede med Borster. Det forste Kjæbepars Plade har i Spidsen nogle stærke Torne og talrige, stærke Børster. Palpen er stor, enleddet, og den indre Plade mangler. Det andet Kjabepars indre Plade er bredere end den ydre. Kjæbefoddernes indre Plader ere sammenvoxede til en triangular, med Børster besat Lap, og de ydre Plader, der mod Enden ere tilspidsede, dække kum Grunddelen af de gvrige Munddele. Begge Foleres Svober ere korte hos Humnen, men forlængede og mangeleddede hos Hamnen.

Til demne Familie hore Slægterne Hyperia, Metoceus, Parathemisto og Themisto, sandsynligvis ogsaa Cyllopus og muligens tillige Vibilia, Dairinia, Tyro og Cystosoma.

Gen. I. HYPERIA, Latreille, 1818.

Deriv.: Hyperia, et mythologisk Navn.

Syn.: 1818. Hyperia, Latreille, Encyc. Méthod. Crust. IX. tab. 328.

1825. Hyperia, Desmarest, Consid. sur les Crust. p. 258.

1829. Hiella, Straus, Mem. du MIuséum. XVIII. p. 51.

1830. Hyperia, Hilne Edwards, Ann. des Sc. Nat. XX. p. $38 \%$.

1830. Lestrigonus, Milne Edwards, Ann. des Sc. Nat. XX. p. 392.

1840. Hyperia, Milne Edwards, Hist. des Crust. III. p. 84.

1840. Lestrigonus, Milne Edwards, Hist. des Crust. III. p. 81.

1853. Hyperia, Dana, The Crust. U. States Explor. Exped. p. 986.

1853. Lestrigonus, Dana, The Crust. U. States Explor. Exped. p. 981.

1862. Hyperia, Spence Bate, Cat. Amphip. Crust. Brit. Mus. p. 287.

1862. Lestrigonus, Spence Bate, Cat. Amphip. Crust. Brit. Hus. p. 2S7.

1870. Hyperia, Boeck, Crust. Amphip. bor. et arct. p. S.

Typus: Hyperia Suerii (Lesueurii), Latr.

Pedis Imi et 2di paris manu subcheliformi carentes; carpo in angulo inferiore posteriore in calcem brevem producto; manu apicem versus attenuata.

Pedes 3 tii et 4 ti paris articulo 4 to perbrevi, non dilatato.

Pedes trium parium ultimorum breves, invicem ferme eadem longitudine; articulo 1 mo subdilatato.

Denne slagt blev i 1^1s opstillet af Latreille; Milne Edwards dammede Slaggten Lestrigoms, som skulde afvige fra Hiperia ved, at Folemes Svober vare meget forliengede; senere har det vist sig, at dette er kun en Kjonsforskjel, og den sidstnavnte Slægt falder saaledes bort. Slægten Hiella, der var dannet af Straus, falder ogsaa fuldkommen sammen med denne Slingt; jeg kin derimod ikke med Spence Bate forene hermed Metocas, Kroyer, thi den synes mig ved de tvende forste Fodpars Form at vise en ge- 
nerisk Forskjel fra Hyperia, skjont Dana allerede har paavist, at $H$. trigona danner en Overgang mellem begge Slægter. Jeg vilde ogsaa have forenet begge, hvis der ikke fandtes saa mange Arter af Hyperia, $0 \mathrm{~g}$ hvis jeg ikke havde fundet en ny Art af $M c-$ toécus ved Norges Kyster. Det synes mig derfor bekvemt igjen at optage Kiroyers Slægt. Spence Bate anforer i sin "Catalogue" ni Arter henhørende hertil. Af lisse liører dog II. (Metoecus) medusamm, Kx. (non Fabr.), til Metoecus, ligesom H. (Tauria) macrocephala, Dana, Hyporia galba, $H$. cyancac og $H$. oblivia ere en og den samme Art samt synonyme med $H$. medusarm, Mïller. Der bliver kun salerles fire Arter staatenite igjen i denne Slægt, hvortil i 1871 af mig tilføiedes en femte.

\section{HYPERIA MEDUSARUM, O. F. Müller, 1776.}

C'ancer medusarum, MIüller, Zool. dan. prodromus, 2355. p. 148.

Gammarus medusarum, Fabricius. Reise nach Norwegen. 1729. p. 326 et p. 354.

- = Fabricius, Entomol. syst. 1743. II.

Cance gammasus yalba, Montagu, Linn. 'Trans. XI. 1815. p. 4. t. 2. f. 2.

Talitrus cyancae, Sabine, Suppl. to Parry's first Voyage. 1824. p. 238. pl. 1. fig. $12-18$.

Hiella Orbignii, Straus, Mem. du Muséum 1829. XVIII. pl. 4.

Hyperia Latreillii, Milne Edwards, Ann. des Sc. Nat. XX. 1830. p. 388. pl.11. fig. 1-7.

- =- Milne Edwards, Hist. des Crust. III. 1840. p. 76.

- - White, Hist. Brit. Crust. 1850. p. 206. pl. II. fig. 3.

- =- Gosse, Marine zool. 1855. p. 139. fig. 251.

--=- Danielsseu, Beretning om en zoologisk Reise 1858. p. 16.

Hyperia galba, White, Hist. Brit. Crust. 1850. p. 206.

- =- Spence Bate, Catal. Crust. Amphip. Brit. Mus. 1862. p. 292. pl. XLVIII. fig. 9.

- - - Spence Bate et Westwood, Brit. sessile-eyed Crust. II. p. 12.

- =- Boeck, Bemærkninger etc. i Naturforskermødets Forhandl. 1860. p. 636.

Hyperia cyanea, Milne Edwards, Ann. des Sc. Nat. XX. 1830, p. $38 \%$.

--.- Spence Bate. Cat. Crust. Amphip. Brit. Mus. p. 294.

Metoceus cyanca, Milne Edwards. Hist. des Crust. p. 78.

Lestrigonus exulans, Kroyer, Gronl. Amphip. p. 68. fig. 18.

- =- Spence Bate, Cat. Crust. Amphip. Brit. Mus. p. 287. pl. XLVIII. fig. 2.

Hyperia ollivia, Krøyer, Gronl. Amphip. p. 70. pl. 4. fig. 19.

- =- Spence Bate, Cat. Crust. Amphip. Brit. Mus. p. 298, pl. XLIX. fig. 5.

Lestrigonus Bocckii, Boeck, Bemærkninger etc. i Naturforskermodets Forhandl. 1860. p. 636.

Lestrigonus Kinahani, Spence Bate et Westwood, Brit. sessile-eyed Crust. p. 8.

Hyperia exulans, Goës, Crust. Amphip. Spetsb. 1865. p. 18.

Hyperia medusarum, Spence Bate, Catal. Crust. Amphip. Brit. Hus. p. 295. pl. XLIX. fig. 1 . 
Pedes 1mi paris manu non lata extrorsum gradatim angustiore, in margine posteriore serrata et spinis nonuullis armata; carpo extrorsum multo latiore; calce non ad median manum porrecta. Pedes 2di paris manu panlo angustiore; calce multo longiore, qvam $1 \mathrm{mi}$ paris. Pedes saltatorii ultimi paris pedunculo duplo longiore qram lato. Appendix caudalis parum longiore qvam ad basin lata, et ad medium pedunculum pedum saltatoriorum ultimi paris porrecta.

Dyrets Langde er omtrent $10-12 \mathrm{~mm}$.

Legemet er opblist, tykt, noget smalere bagud mod Halen end fortil mod Hovedet, der er meget bredt. Halens tre første Led ere meget bredere end de syv Led paa Kroppen, der dog efterhaanden blive noget bredere. Den nedre bagre Sidevinkel par de tre forste Haleled er noget tilspidset, især det tredie. Sidepladerne ere smaa; de fire forste ere kun ubetydelig høiere end de tre sidste, som ere noget bredere end hine; de forste ere noget tilspidsede mod Enden. Hovedet er, seet forfra, ovalt med to dybe Indsnit paa den forrere afrundede Flade, hvortil begge Folerne.fæstes. Vinkelen mellem disse Indsnit er ikke meget stor. Oinene indtage hele Siden af Hovedet og stode paa den ovre Side sammen, men adskilles dog ved en smal Rand.

Overlaben er bredere end hoi og har paa Enden et bredt, ikke meget dybt Indsnit.

Kindbakkerne ere i Enden brede, stærkt tandede. Den indre Bigren er ligeledes tandet. Palpen er forlænget, smal, dens tredie Led er bøiet og kun forsynet med faa Borster.

Det forste Par Kjaber ere brede, Hovedgrenen er især paa Enden og paa den indre Flade forsynet med talrige korte Borster, der skjule de tre strerke Trnder. Palpen rager kun lidt udenfor Hovedgrenen og er paa Enden svagt saugtakket med en stærkere Tand par den nedre Ende.

Det andet Par Kjabers indre Plade er meget kortere end deu ydre, men begge have næsten den samme Form, irlet de blive smalere mod Enden og ere der vabnede med ẹ stærk Tand; begge ere især mod Enden forsynede med talrige, smaa Borster.

Kjabefodderne ere langere end brede og blive smalere mod Enden; langs Widten af den ydre Flade strreklier sig en ophoiet Rand, besat med Borster, der ende i en mei stærlie korte Borster besat ovre Plade, der danues af de sammenvoxne indre I'Jadepar; de ydre ere smaa, smalere mod Enden og have i den indre rette Rand flere meget smaa Torne.

Det første Fodjars forste Led er meget brert, fladt, med en starkt boiet forreste Rand. Det andet $0 \mathrm{~g}$ tredie Led ere meget korte og have paa den bagre Del af den bagre Rand smale Torne. Det tredie Led bliver bredere udad og er i den nedre bagre Vinkel forsynet med en liden, i Enden afrundet Hrel; lets bagre og nedre Rand ere rabnede med Torne. Det femte Led er noget boiet, bliver smalere mod Enden og er paa den indre Rand besat med mange fine Torne og nogle storre paa den ydre Flade. 
Jet andet Fodpar ligner det firste, men Hrelen paa Carpus er her meget længere, og Haanden er tyndere sant dens Negl længere. Det tredie og fjerde Fodpars tredie Led er lidt bredere, men kortere end det fjerde, der igien er kortere end det femte Led.

De tre sidste Fodpar ere omtrent af den samme Form og Strrelse. Deres forste Led er ulvidet, omtrent eller noget mere end dobbelt saa langt som bredt, deres tredie Led er kum lidet ulvidet og ontrent saa langt som det fjerde Leil, der er kortere end det femte. Det forste Par Springfødder naar langere bagud end det andet. Grenene ere forlængede, lancetformede, og af disse er den ydre lidt kortere end den indre. Det andet Pars Grene ere kortere end dem paa det forste Par og i Forhold til Længden noget bredere. Det tredie Pars ydre Gren er lidt længere end den indre og kun ubetydelig kortere end Skaftet; den indre Gren er lancetformet, forsyuet paa begge Rande med smaa Torne. Halevedhænget er noget længere end bredt ved Roden, afrundet paa Enden og ubetydelig længere end Skaftet paa det sidste Par Springfodder.

Den findes i Ishavet, Atlanterhavet, Nordsøen, ver Grønlands, Islands, Norges og Englands Kyster.

\section{HYPERIA SPINIPES, A. Boeck, 1860.}

(P1. II. Fig, 2.)

Hyperia spinipes, A. Boeck, Forhandl. ved de Skand. Naturf. 8de Mqde 1860. p. 636. Hyperia medusarum, var., Goës, Crust. Amphip. Spetsb. 1866. p. 18. Hyperia spinipes, A. Boeck, Crust. Amphip. bor. et arct. 1870. p. 6.

Pedes $1 \mathrm{mi}$ paris manu ovali aut fere cylindrica, spinis longis multis armata: calce perbrevi. Pedes 2 di paris calce parum longiore qvam apud pedes 1 mi paris: manu spinis longis instructa. Appendix caudalis longiore qvam lata, ad pedunculi pedum saltatoriorum ultimi paris tertiam partem porrecta. Pedes saltatorii ultimi paris pedunculo duplo longiore gram lato.

Dy rets Længde er $10 \mathrm{~mm}$.

Legemet ligner meget det hos den foregaaende Art. Hovedet er, seet forfra, noget længere og smalere. Den Vinkel, det danner mellem de ove og nedre Folere, er forlænget, bred.

De to forste Fodpar ere stærkere byggede end hos den foregaande Art.

Det forste Fodpars fjerde Led er smalere, og den nedre bagre Vinkel er ikke meget udtrukket. Haanden er forlonget, oval; det fjerde Led, men især Haanden, er tæet besat med lange, rette og stærke Torne.

Det andet Fodpars fjerde Led er i den nedre bagre Vinkel noget mere udtrukket end paa det forste Fodpax, dog meget mindre end hos den foregaaende Art; ogsaa dette Fodpars fjerde Led og Haand ere besatte med lange, stirke Tome. 
Det sidste Par Springfollers Gundled er mere end dobbelt saa langt som breilt, og den indre Gren er ubetydelig langere end Grundleddets lalve Langde.

Halevedhanget er ved Roden lrengere end bredt, paa Enden afrundet.

Den forekommer parasitisk hos Cyanea capillata paa Vestkysten, ved Stavanger og Farsund samt i Christianiafjorden, hvor den blev taget af Professor C. Boeck.

\section{Gen. II. TAURIA, Dana, 1853.}

Deriv.: Tauria, et Egennavn.

Syn.: 1838. Hetoccus, Krøyer, Gronlands Amphipoder beskrevne. D. Vid.-Selsk. Afh. VII. p. 288. (Navnet brugt til et Insekt 1833).

1853. T'auria, Dana, U. S. Explor. Exped. p. 988.

18\%0. Metoecus, A. Boeck, Crust. Amphip. bor. et arct. p. 6.

Type: Metocus Medusarm (Fabricius), Krøyer.

Pedes $1 \mathrm{mi}$ et 2 di paris manu forficiformi, chelata; calce carpi in angulo inferiore postico ad aut ultra finem manus producta. Cateroqvin ferme ut apud genus IIyperia.

Krøyer opstillede Slagten Mctoccus i Aarét 1838 (Gronl. Amphipoder, D. Vid.Selsk. Afh. VII. p. 288), og han adskilte den fra Slægten Hyperia, paa Grund af at de to forste fodpar ere forsynede med en saxdannet Haand. Dana damede i 1853 (U. S. Explor: Exped. p. 988) Sliegten Tauria, der er fuldkommen synonym med denne, og det sidste Navn bør ogsaa beholdes, da Navnet Metoecus allerede i 1833 har været bortgivet til en Coleopterslægt. Spence Bate har (Catal. Amphip. Crust. Brit. Mus.) imidlertid sløifet denne Slægt og slaaet den sammen med Hyperia, ligesom Goès i 1865 . Jeg tror dog, da begge slægter tælle Here Arter, at burle optage den paany og i samme Betydning som Kroyer. Af denne Slægt har Goës fundet Hanner med mangeledlet Svolse paa Folerme. Den skiller sig saaledes fra Hypcria ved de tvende første Fodpars Hander, der ere saxdannede, idet Hælen paa Carpus forlænger sig til Enden af Haanden.

Foruden de nedenfor anforte Arter har Dana opdaget i de anarktiske Have en Art, H. (Tauria) macroceplata, og Spence Bate og Westwood H. tauriformis og prehensilis fra England.

TAURIA MLDUSARUM, O. Fabr., 1780, †

Oniscus Medusarum, 0. Fabricius, Fauna Grenlandica. 1780. p. 257.

Metoecus Medusarum, Krøyer, Grønlands Amphipoder. D. Vid.-Selsk. Afh. VII. 1838. p. 288. t. 3. fig. 15 .

Metoecus Medusarum, Milne Edwards, Hist. des Crust. III. p. 78.

Metoecus Meduserum, White, Cat. Crust. Brit. Mus. 184\%. p. 91.

Hyperia Medusarum, Spence Bate, Cat. Amph. Crust. Brit. Mus. 1862. pl. XLIX, fig. 1. 
Hyperia Medusarum, Goës, Crust. amphip. Spetsb. 1866. p. 18.

Metoecus MEedusarum, A. Bock, Crust. amphip. bor. et arct. 1870. p. 6.

Pedes $1 \mathrm{mi}$ paris articulo 3 tio in margine posteriore ad radicem calcis producto. Pedes 3 tii et 4 ti paris articulo 3 tio perbrevi, vix longiore quam lato: articulo 4to permagno, ovato, ferme duplo longiore qvam lato. Pedes trium parium ultimorum articulo 3tio perbrevi. Ito longitudinem duplam articuli 3tii superanti. Pedes saltatorii ultimi paris pedunculo prælongato, fere ter longiore qvam ramo exteriore.

Efter Krøyer's Beskrivelse er Hovedet hos denne Art stort, tykt, større i Høide end i Bresdle.

Det forste Fodpars tredie Led er temmelig stort og forlænger sig i det bagre nedre Hjorne til en spids Vinkel, der naar frem til Enden af det fjerde Led, der er meget kort, triangulæert; Hælen naar frem til Enden af Haanden, som er triangulær, omtrent dobbelt saa lang som bred ved Roden, og har paa den indre, rette Rand smaa Tænder.

Det tredie og fjerde Fodpars fjerle Ised er stort, ovalt, med Borster paa den bagre, convexe Rand.

Efter Kroyer forekommer den ved Gronland, og ifølge Goës el den temmelig hyppig taget ved Spitsbergen, snart parasitisk, snart fri. Desuden har Torell og Amondsen fumlet den ved Gronland og den nordlige Del af det atlantiske Ocean.

TAUIIA ABYSSORUM, A. Boeck, 1870.

(Pl. I. Fig. 2.)

Metoccus Abyssorum, A. Boeck, Crust. amphip. bor. et arct. 1870. p. 6.

Pedes $1 \mathrm{mi}$ paris articulo 3tio brevi, non ad basin calcis producto; manu ferme duplo longiore qvam ad basin lata in margine interiore serrata: calce carpi perlata, usqve ad finem manus porrecla, in margine interiore serrata; ungve parvo. non serrato. Pedes 2di paris ferme ut pedes $1 \mathrm{mi}$ paris; sed articnlo 3tio perbrevi: carpo angustiore: calce ad finem ungvis porrecta: ungve in margine posteriore spinis instructo. Pedes 3 tii et 4 ti paris articulo 3 tio longiore qvam apud speciem antecedentem: articulo 4 to longitudinem dimidiam articuli 3 tii reqvanti. non dilatato. angusto. quater longiore qvam lato. parum modo breviore qram articulo 5 to gracili. Pedes trium parium ultimorum ungre hreviore qvam apud speciem antecedentem. Pedes saltatorii ultimi paris pedunculo ter longiore qvam lato.

Dy ret er omtrent $5 \mathrm{~mm}$.

Is gemet er meget sammentrykt.

Det forste Fodpars forste Led er temmelig bredt fortil med en strerk convex Rand; det tredie Led udvider sig noget i den nedre forreste Viukel, der er forsynet 
med Børster, men naar ikke frem til Enden af Carpus. Denne er meget størie og bredere end det tredie Led og udvider sig i den nedre bagre Vinkel til en i Enden tilspidset og i den indre Rand saugtakket Hæl, som er kortere end Haanden. Denne sidste er omtrent saa lang eller noget kortere end Carpus, men betydelig smalere og saugtakket $\mathrm{i}$ den indre Rand samt naa frem omtrent til Enden af Hælen paa Carpus.

Det andet Fodpar ligner det forste, men dets tredie Led er kortere, og Hælen paa Carpus er meget længere, saa at den naar frem næsten til Spiclsen af den udstrakte Kklo og er saaledes meget langere end til Enden af Haanden.

De tvende folgende Fodpars tredie Led er omtrent saa langt som Halvdelen af det fjerde, der er liniært og lidt kortere, men bredere end det femte.

De tre følgende Fodpar ere af samme Bygning; deres første Led er ikke udvidet; det tredie Led er omtrent saa langt eller noget langere end Halvdelen af det fjerde, der paa det fente Fodpar er saugtakket paa den forreste Rand og lidt udtrukket i det forreste nedre Hjorne; ogsaa det femte Led, der kun er lidt lingere end det fjerde, er paa det femte lodpar saugtakket paa den forreste Rand.

Det sidste Par Springfodders ydre Gren er ubetydelig længere, men smalere end den indre, der er saugtakket paa begge Rande og omtrent halvt saa lang som Skaftet, ler igjen er tre Gange saa langt som bredt.

Haleved liænget er triangulært, længere end brest ved lioden og ulgjor kun en Trediedel af Skaftets Langde paa det sidste Par Springfodder.

Den er fundet paa 2-300 Favnes Dybde i den indre Del af Hardangerfjorden af $G$. $O$. Sars og $\mathrm{i}$ den ydre ved Lyngholmen af mig omtrent paa den samme Dybde.

Gen. III. PARATHEMISTO, A. Boeck, 1870.

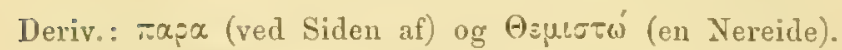

Syı.: 1870. Parathemisto, A. Boeck, Crust. amphip. bor. et aret. p. 7.

Type: Parathemisto abyssorm, A. Boeck.

Corpus sat compressum; dorso carinato.

Mandibulx in apice perlatie, serratie, xeqve ut mala interna; tuberculo molari latissimo, in margine crenato; palpo longissimo.

Maxilla $1 \mathrm{mi}$ paris dentibus qvatuor perlongis et firmis armale.

Pedes 2di paris (non pedes 1 mi paris) carpo in angulo inferiore posteriore valde producto; manu cheliformi.

Pedes 3tii 4tiqve paris articulo 4 to subdilatato.

Pedes trium parium ultimorum subrevales.

Denne Slagt danner en Overgang mellem Hyperia og Themisto, men staar narmest ilen sidste, hvorfia den dog vasentlig afviger ved, at de tre sidste Fodpar ere af samme Form og Strmelse, medens hos Themisto det femte Fodpar er uligt de andre og 
særileles forlænget. Herhen maa ogsaa den af Spence Bate og Wostwood (brit. sessile-eyed Crust. II. p. 16) benævnede Hyperia oblivia hore, skjønt de beskrive og tegne begge de forste Fodpar, som om de ere af den samme Bygning og ikke udrustede med en saxdannet Haand paa anden Fod, og heller ikke nævne, at Ryggen er kjølet eller vinklet; thi i alle ovrige Forhold ligner den de efterfolgende Arter. H.trigona, Dana, hører vistnok ogsaa hicl. Dens Arter ere saaledes udbredte over en meget stor Strakning af Havet.

\section{PARATHEMISTO ABYSSORUM, A. Boeck, $18 \% 0$.}

(Pl. III. Fig. 1.)

Prorathemisto Abyssorum, A. Boeck, Crust. amphip. bor. et arct. 1870. p. 7.

Carina spinas retroversas non formans. Pedes 3tii et 4 ti paris articulo 4 to subangusto. Pedes 5ti paris articulo 3tio parum modo breviore qvam 4 to.

Dyrets Langile el omtrent $5 \mathrm{~mm}$.

Le gem et el temmelig sammentrykt, især mod Ryggen, hvor Leddene clame en Kijsl langs Midtlinien. Sidepladerne ere smaa, alle næsten af den samme Storrelse. Hovedet ovalt og sammentrykt fra Side til anden. Øinene indtage næsten hele Hovedets Overflade. Det forste og det andet Legemsled ere oftest sammensmeltede, ligesom deres Sideplader. Den nedre bagre Vinkel par det tredie Haleled danner en masten ret, i Enden afrumdet Vinkel.

De øvre Folere ere omtrent saa lange, som Hoveclet er hoit; hos Hannen er Svoben mangeleddet, hos Humen ikke ledtet.

Kindbakkerne ere i Spidsen meget brede, delte i talrige 'Tander; den indre Flig er ligeledes bred; Tyggeknuden er meget stor, omgivet af et Gjorle at smaa Tænder; Palpen er forlænget og det andet Led nasten dobbelt sai langt som det buerle i Enden spirlse tredie Led.

Det forste Kjabepars yolre Plade er i Spidsen væbnet med fire starke 'T'ender; Pálpen er enledilet; det indre Hjome er uitrukket i en 'Tand, og den ydre Kant er paa Enden indskaaret i Saugtænder.

Det andet Kjabepars indre Plade er meget bredere end de ydre og ha stacke Borster i Kanten og paa den indre Flade.

Kjabefoddernes Grumlled er forlanget, de sammenvoxne indre Plarler ere besatte med Børster og indskame i Spidsen; de ydre Plader ere lidt krumme og blive smalere mod Enden; den indre concave Rand har nogle Børster og i Enden smaa Tander.

Det forste Fodpars Carpus er bred, forsynet i den bagre Rand med strerke Borster og er ikke udtrukket til nogen Hæl; Handen er omtrent saa lang som Carpus og bliver smalere mod Enden; den indre, næsten rette Rand er saugtakket og har faa, men stxrke Torne, medens den ydre convexe Rand kun har Børster. Kloen er lidt kirummet, noget kortere end Haanden.

Det andet Fodpars tredie Led er ultrukket i sit nedre bagre Hjorne og har nogle Borster; det fjerle Led eller Carpus er længere og stærkt udtrukket i det nedre 
bagre Hjøme til en meget tynd Hrl, som i Enden og paa den indre Rand har mresten tornformede Børster. Haanden er ountrent saa lang som Carpus, triangulær, paa den indre Rand saugtakket og med nogle faa stærke Børster; den ydre Rand har kun Børster; den ydre Gren er meget kortere end den indre, der er forlænget, smal.

Paa det sidste Par er den ydre Gren kortere $0 \mathrm{~g}$ smalere end den indre, der er omtrent halv saa lang som Skaftet.

Hal eved ha nget er meget lidet, triangulirt.

Den er fundet i Christiania- og Hardangerfjorden paa 2-300 Favne.

\section{PARATHEMISTO COMPRESSA, Goës, 1865. †}

Themisto compressa, Goës, Crust. Amp̣h. mar. Spetsb. p. 17. fig. 34.

Parathemisto compressa, A. Boeck, Crust. Amphip. bor. et arct. 1870. p. 7.

Segmentum trunci ultimum et segmenta postabdominis duo anteriora carina spinas retroversas formanti. Pedes 3 tii et 4 ti paris articulo 4 to magno. elongato ovali. Pedes 5 ti paris articulo 4 to duplo longiore qvam articulo 3 tio.

Denne Art, som jeg selv aldrig har seet, er efter Goës's Tegning $10 \mathrm{~mm}$ lang.

Den ligner meget den foregaaende Art, men Legemet er mere sammentrykt, især $\mathrm{i}$ den bagre Del af det sjette $0 \mathrm{~g}$ syvende Legemsled samt af det første Haleled, $0 \mathrm{~g}$ gaar i Midten af den bagre Rand ud i starke Tænder. Den nedre bagre Vinkel paa det forste Haleled er tilrundet.

Det tredie og fjerde Fodpars fjerde Led er mere end dobbelt saa langt som det tredie og har paa den bagre convexe Rand en tret Rad Torne.

Springfødderne synes ogsaa efter Goës's Tegning at være meget længere og smalere end hos den foregaaende Art; den indre Gren par det sidste Par synes at vare nasten dobbelt saa lang som den ydre og at vare af samme Liengde som Skaftet.

Den findes efter Goës ved østre Grønlands Kyst og i Davis-Street, hvorfra den er medbragt af Professor Torell; endelig er den taget af Amondsen i den nordre Del af det atlantiske Hav ved den 58de Læengdegrad.

\section{Gen. IV. THEMISTO, Guérin, 1828.}

Deriv. As'sıró (en Nereide).

Syn.: 1828. Them isto, Guérin-Meneville, Mem. de la Soc. d'Hist. Nat. de Paris. IV. 1828.

1830. - Milue Edwards, Am. des Sc. Nat. XV. p. 393.

1840. - - Hist. des Crust. III. p. 84.

1853. - Dana, The Crust. U. St. Explor. Exped. p. 836.

1862. - Spence Bate, Cat. Amphip. Crust. Brit. Mus. p. 311.

1870. - A. Boeck, Crust. Amphip. bor. et arct. p. 7.

Type: Themisto Gaudichaudii, Guérin-Meneville. 
Instrumenta cibaria et pedes Imi et 2di paris arve ut apud genus antecedens.

Pedes 3 tii et 4 ti paris articulo 3tio brevissimo; articulo 4 to perdilatato, in margine posteriore spinoso et manum yyodammodo formanti; articulo 5to et fito junctis ungvem longum 2articulatum efficientibus.

Pedes 5 ti paris pedibus 6ti et $7 \mathrm{mi}$ paris multo longiores; articulo 1 mo dilatato, 3 tio brevi, 4 to el 5 to prilongato.

Guérin-Meneville opstillede demne Slregt i 1828 paa Arten Gaudischauli fra Maluinerne. Ross troede at have gjenkjendt denne Art i det arktiske Hav, men lans Art falder sammen med Grammurus libellulı, Mandt, og er salalerles en anden. Dana or Spence Bate har foroget deme Sliegt med tvende nye Arter fra Sydhavet og det sydlige Atlanterhav, og hertil hommer en ny fra Norden, saaledes at Slagten synes at være spredt over ret liele Jordbælte.

Gjennem den foregaaende Slagt forbindes denne med Hyperia og Tauria, hvilke den i mange vasentlige Punkter ligner; saledes have Mundelene den samme Bygning, og $\mathrm{i}$ de to forste Fodpars Form stemmer den ogsaa overens med hine Slogter. Derimod vise det tredie og fjerde Fodpar en eiendommelig Bygning, derved at deres tredie Led bliver meget kort, bredt og optager i sin indskaarne indre Rand ilet store ovale fjerde Led. Dette er i den bagre Kant besat med fine Torne og danner en Haand, mod hvilken lagger sig det tynde, men lange, noget buede fjerde Led og den korte Kilo. Dette er, om end i mindre Grat, ogsaa Tilfaldet hos Slagten Parathemisto, men fra deme slægt skiller den sig verl, at det femte Forlpar forlanger sig stærkt i Forhold til de to sidste; det fjerde og femte Led forlænger sig og faar en egen Besætning af 'Torne, medens det tredie Led er forkortet.

THEMIISTO BISPINOSA, A. Boeck, $18 \% 0$.

(Pl. I. Fig. 4.)

Themisto bispinosa, A. Boeck, Crust. amphip. bor. et arct. 1870. p. 8.

Corpus compressum. Segmentum trunci 6tum et 7 mum in medio margine posteriore in spinas productum. Pedes 3tii et thi paris articulo tho oblongo. Pedes trium parium ultimorum articulo 1 mo perangusto, non dilatato; articulo itio magnis elongato qvam apud speciem antecedenlem.

D yrets Langde er $25^{\mathrm{mm}}$.

L egem et er noget mere sammentrykt end hos den foregaaende Art; dets sjette og syvende Led gaa i Midten af den bagre Rand ud i skarpe, bagudrettede Tome. Hoverlet er ovalt.

De ovre Føleres sammenvoxne Svobeled ere saugtakkede i den underste liand.

Det forste Fodpars Haand er kortere end Carpus og bliver meget smalere mod Enden samt har paa den bagre Rand fine Torne. 
Det andet Fodpars Carpus forlanger sig paa Enden af den bagre Rand til en Hæl, der næsten naar frem til Enden af Haanden $0 \mathrm{~g}$ er paa den indre Rand forsynet merl Børster.

Det tredie og fjerde Fodpars første Led bliver noget bredere nedad; det tredie Led er triangulært; det fjerde er ovalt, mere end dobbelt saa langt som breit og væbnet paa den bagre Rand med fem til sex stærke Torne; det femte Led er meget længere, smalt, lidt krummet og med fine Torne og lange Børster paa den bagre Rand. Kloen er omtrent halv saa lang som det sidste Led.

Det femte Fodpar er lidt liengere end de følgende; dets forste Led er kun svagt udvidet med en convex forreste og en ret bagre Rand; dets tredie Led er meget kort; ilet fjerde er smalt, neppe mere end fire Gange saa langt som bredt, og forsynet med Torne i den forreste Rand; det femte er meget liengere og fint sangtakket i den forreste Rand.

De to folgende Fodpar ere kortere; deres tredie Led er smalere og noget liengere; det fjerde og femte ere kortere og smalere end de tilsvarende Led paa det femte Forlpar.

I Halens og Springfoddernes Form ligner denne Art meget den foregaaende. I Kjobenhavns Museum fandtes Here Exemplarer af denne Art fra Gronland.

'THEMISTO LIBELLULA, Mandt, 1822.

(Pl. I. Fig. 5.)

Gammarus Libcllula, Mandt, Observ. in hist. nat. in iten. gronlandico factae 1822. Diss. p. 32 .

Themisto aretica, Kroyer, Gronl. Amph. D. Vid.-Selsk. Afh. VII. p. 291. t. 4. fig. 16.

- - Spence Bate, Cat. Amph. Crust. Brit. Mus. 1872. p. 315. pl. L. fig. 11.

-_ crassicornis, Krøyer, Gronl. Amph. D. Vid.-Selsk. Afh. VII. p. 295. t. 4. fig. 17.

- - Spence Bate, Cat. Amph. Crust. Brit. Mus. 1862. p. 315. pl. L. fig. 12.

- Lilicllula, Goës, Crust. amphip. Spetsb. 1860. p. $1 \%$

- $\quad$ A. Boeck, Crust. amphip. bor. et arct. 18\%0. p. 8.

Corpus subcompressum; dorso spinis destituto. Pedes 2di paris manu ferme duplo longiore qvam ad basin lata. Pedes 3tii et 4 ti paris articulo 4 to lato, ovato. parum modo longiore quam lato. Pedes 5 ti paris articulo 1 mo perlato et in margine anteriore spinis validis instructo. Pedes saltatorii ultimi paris ramo interiore parum modo breviore qvam pedunculo, plus duplo longiore qram lato. Appendix caudalis longior rvam ad basin lata.

Dyrets Liengde er $40^{\mathrm{mm}}$ fra Hovedets Ende til Halevedhrenget.

Legemet er ikke meget sammentrykt; Ryggen er rund, uden Kjol eller 'Torne. Hovedet er tykt, opsvulmet og langere end det forste Legemsled; det danner en stump Vinkel mellem de ovre Følere. De to forste Sideplader ere meget smaa, medens de 
folgende ere storre; den fjerde el noget bredere end hoi og svagt udskaret i den bagre Kant for den femte, der er meget bredere, men ikke saa hwi; de folgende to Sideplader ere næsten af samme Størrelse, og deres bagre Vinkel udvirler sig og bliver tilrundet. Den nedre bagre Vinkel paa de to forste Haleled danner en liden Tom, men paa det tredie er den tilrundet.

Dé øvre Foleres forste Skaftled er ontrent dobbelt saa langt som de tvende folgende tilsammen; Svoben er enten lang, uleddet, eller ogsaa ledilet i den ydre Ende.

De nedre Foleres to forste Led ere sammensmeltede og stærkt opsvulmede nedad; det tredie Led er meget kort, knap saa langt som tykt; det fjerde Led er omtrent dobbelt saa langt som tylit; det femte er en 'Trediedel langere, men smalere end lette. Svøben er enten uleddet og da noget langere end Skaftet, eller ogsaa leddet.

Overlaben er meget stor, blod og tyk, næsten firkantet, samt indskaaret i Midten af den indre Kint; dens Sidevinkler ere noget forlangede nedarl.

Kindbakkerne ere meget tykke, men blode, kun i Spidsen mere haarle. Deres Eg danner en Bue, som er væbnet merl tvende strok og tolv mindre T'render. Paa den indre Side findes en Bundt af Tome.

Underlæben mangler aldeles de indre Plader; de ydre ere tykke og have i Spidsen og paa den indre Kant mange fine Borster; de ydre Flige cre brede.

Det forste Kjabepar har i Spidsen tvende længere og tvende mindre Kilor; Palpen er bred, i Spidsen vabnet merl en Tand og i Kanterne med fine Torne.

Det andet Kjabepars indre Plade er vabnet med een og den ydre med to Klgr.

Kjabefoddernes ydre Plade er forlanget, krummet, noget bretere paa Midten end mod Enderne og har paa den ydre Ende smaa Tæunder, og paa den ydre Rand findes fem storre Borster: de sammenvoxede indre Plader have i Spidsen to Trender.

Det forste Fodpar er paa den indre Side fladt, men convex paa den ydre og der forsynet med talrige Børster. Haanden er omtrent saa lang som rlet fjerde Led og buet, samt bliver smalere mod Spidsen. Kloen er liden.

Det andet Fodpar er meget laugere; dets tredie Led forlanger sig nedar i et lancetformet, med talrige Børster besat Fremspring, der omtrent er saa langt som det folgende Led; det fjerte forlanger ligeledes sin bagre nedre Vinkel ud i et langt, stort, cylinderformet Fremspring, der er saa langt som det femte Led, der er bredt ved Roden, men bliver smalere udad. Kloen er meget liden.

De to folgende Fodpar ere af den samme Form, men det femte er noget langere end det fjerde; det forste Led bliver meget bredt mod den nedre Ende; det andet Led er kort, det tredie er skjævt, triangulært, idet dets forste Vinkel er mere forlanget end den bagre; det fjerde Led er udvidet; dets forreste Rand er svagt krummet, medens den bagre er starkere $0 \mathrm{~g}$ i Randen forsynet med talrige Torne; det femte Led er smalt, krummet, saa langt som det foregaaende, og lregger sig til dettes bagre Rand: Kloen er liden. 
Det femte Fodpar er sarleles forlanget; dets forste Led er udvidet, ret i llen bagre Rand, men convex i den forreste; begge de nedre Vinkler ere noget udvidede nedad og afrunderle; det tredie Led er kort, men bredt, triangulart, og dets bagre Vinkel er udvidet nedad; det fjerde er omtrent saa langt som de tre forste Led tilsammen, bliver smalere nelad og har smaa Torne i den forreste Rand; det femte Led er meget langere, men smalere, $0 \mathrm{~g}$ i den forreste Rand forsynet med en tat Rakke af fine Torne samt med talrige, noget større, tornformige Børster i bestente Afstande mellem hine. Kloen er liden.

De to folgende Par ere af den samme størrelse og Form, samt meget kortere end det foreganende Par; deres forste Led er forlienget, ikke meget breit; det andet er kort, det tredic er mere end dobbelt saa laugt som bredt, det fjerde er nasten dobbelt saa langt som dette, og det femte er længere, men smalere end det fjerde. Kloen er liden.

Det forste Par Springfødders Grundled er smalt, noget længere end den ydre Giren, der er en Trediedel langere end den indre; begge Grene ere smale.

Det andet Par naar ikke saa langt bagud som det forste, men er meget brelere; Grundleddet er ontrent saa langt som den brede, lancetformige, indre Flig; den ydre er smalere og kortere.

Det tredie Par nar langst bagud; Grundledlet er meget bredt, knapt (lobbelt saa langt som den brede, lancetformige, yure Gren, der er noget langere eid den smalere indre. Deres Rande ere uden 'Truder.

Haleved hanget er lancetformigt, dobbelt saa langt som bredt.

Efter Goës skal der ogsaa i Fimmarken forekomme en anten Form eller Varietet. Den adskiller sig fir den almindelige Form ved, at det fjerle Led paa det tre die og fjerde Fodpar er smalere og det femte Led langere, samt verl at det femte og syvende forlpar ere temmelig lige i Laengle.

\section{Familia II.}

I'RYPHANIUAE，A. Boeck, 1870.

Syn.: 1870. T'yphanirlae, A. Boeck, Crust. amphip. bor. et arct. p. \&.

Instrumenta cibaria non perfecta.

Mandibulae palpo deslitutix.

Maxillae obsoletre.

Pedes maxillares laminis interioribus coalitis, perlatis exterioribus hrevibus.

Antenna superiores ex articulis tribus compositre.

Antenne inferiores parvula.

Pedes non subcheliformes.

Pedes saltatorii biramei: ramis laminiformibus. 
Den Sliegt, der' er 'Typus for denne Fanilie, viser' ved Undersngelse af Munddelene en saa betydelig Afvigelse fra de foregaaende Slagter, som vi have regnet til Inyperidur, at den ikke kan henfores til denne Familie. Hverken Dana eller Spence Bate beskriver imillertid Mumdelene hos de svrige Familier, og man skulde derfor tro. at disse ere dannede efter den samme Typus som hos Hyperidae. Jeg har imidlertid ikke havt Anledning til nøiere at studere fremmede Slregter af denne Tribus, hvorfor jeg har maattet opstille Slægten Tryphana i en egen Familie Tryphanidae, hvis vasentlige Karakter saaledes ligger i Munddelenes Bygning. Hvis man vil stille den ind efter

Dana's System, maa den høre til hans anden Familie, Phronomictae, som han karakteriserer saaledes: Antennce ade exserte. Abdomen in ventrem se non flextens. Pedes äti btiqe sive crassi sive clongati, scemins prehensiles. Af de tre Underfamilier, hvori Dana deler denne Familie, maatte den enten hore til den anden, Phrosinac, som han karakteriserer saaledes: Abdomen versus basis sat crassum. Pedes 5ti prehensiles, monodaltyli, quoque 3tii stique prehensiles; til denne Underfamilie hore Slagterne Anchylomera, Phrosina og Themisto, men da den sidste har vel uddannede Munddele, som vel ogsaa de andre Slagter have, kan den ikke regnes did; eller til den tredie Underfamilie, Phorcince, som han tillægger følgende Karakter: Pedes 5ti Gtique valde clongati, et crassi, sed mam non confecti, men derhen kan den heller ikke høre, da den meget afviger fra dlens.eneste Slægt, Phorsus.

Gen. I. 'TRYPHANA, A. Boeck, 1860.

Deriv.: Tpuparva (et græsk Kvindenavn).

Syn.: 1870. Iryphana, A. Boeck, Crust. Amphip. hor. et aret. 1) 9.

Typ.: Tryphana Malmii, Boeck, 1870.

Truncus segmentis septem perangustis.

Postabdomen segmentis tribus anterioribus perlatis.

Caput permagnum antice obtusum.

Pedes $1 \mathrm{mi}$ 2diqve paris sat parvi; articulo 5 to non subcheliformi.

Pedes 3tii et 4 ti paris magnitudine et forma rqvales.

Pedes trium parium ultimorum gradatim magnitudine valde decrescentes: pedes 5 ti paris pedibus $7 \mathrm{mi}$ paris plus duplo majores.

Denne Slagt, som ikke falder sammen med nogen forhen opstillet blandt Hypevidae, og hvis markvardige Bygning er antydet ved Diagnosen af Familien og Slagten, el ikke funden parasitisk, men af mig taget op fra Bunden med Skraben. Mundens Bygning tyder dog par, at den ikke kan leve, som mange andre Amphipoder; af Rov, men maske af blode, forrashede Substantser paa Bunden af Havet. 
(PI. 1. Fig. 3.)

Tryllhana Malmii, A. Boeck, Crust. Amphip. bor. et aret. 1870. p.9.

Pedes Imi paris articulo 3tio minimo; carpo apicen versus dilatalo, lere eadem longitudine ac latitudine; articulo 5 to ferme longiludinem carpi reqvanti, apicem versus angustiore; ungve parvo in extremo articulo 5to affixo. Pedes 2di paris longiores et angustiores articulo 4 to et 5 to angustis; ungve in margine utroqve setoso. Pedes 3tii 4tiqve paris validi et lati; articulo 5 to ex angulo posteriorc inferiore spinam emiltenti. Pedes sti paris arliculo Imo ovato et duplo ferme longiore qvam lato; articulo 5 to in fine marginis anterioris in spinam producto. Segmentum postablominis 3timm angulo inferiore posteriore fere recto. Pedes saltatorii ultimi paris ramis ferme argalibus. latis, lancenlatis of Iongitudinem pedunculi ferme rervantibus.

Dyret el omtrent $5^{\mathrm{mm}}$ langt.

Legemet er noget, men ikke starlit sammentrykt fra Siderne. Hovedet er meget stort, ovalt, noget sammentrykt; đinene indtage hele Hovedets Sider. De syv Legemsled ere meget smale, tilsammen neppe langere end Hovedet. Sidepladerne ere smaa, alle lige høie, men den femte er den bredeste. Halens tre første Led ere meget brede, næsten lige store, og hvert af dem er sat bredt som fire til fem Legemsled tilsammen; den nedre bagre Vinkel par det tredie Led or næsten ret, noget afrundet i spidsen.

Folerne sidde $i$ en Fordybning paa Hoverlets forreste Flade.

De "ivre Folere synes kun at være treleddede; deres forste Led er ovalt, temmelig stort; det andet er meget kort; det tredie er omtrent saa langt som det forste, firkantet, med el: skraa afskaaret, med faa (fem), men stærke Børster forsynet Enderand.

De nedre Foleres forste Led er ovalt; det andet er forlenget, smalt, og det tredie er end smalere og længere end det foregaaende.

Kindbakkerne ere forlængede, smale, lidt boiede mod Spidsen; ingen Palpe forefiniles.

Kjabefaddernes Grundled er ulad bredere og forlanger sig pai Midten til en afrundet Lap; de sammenvoxede indre Plader ere meget brede og tilsyneladende uden Børster; de ydre ere brede veil Roden, smalere mod Spidsen og der boiede; deres indvendige, S-formig boiede Rand har tine T'snder.

Det forste lodpar er meget kort; llets furste Led er ovalt; det andet er lidet $0 \mathrm{~g}$ det tredie end mindre; det fjerde er langere end de tvende foregaaende tilsammen og udviler sig starkt mod Enden, især i den bagre Rand; det femte Led er af samme Langde, men meget smalere og har paa Milten af den ydre og den indre

*) Arten er opkaldt efter Intenlant A. Malm i Gotheborg. 
Rand en stark Torn; paa Spidsen er cler en Indskjæring, i hvis Ende ller sidder en liden Negl; de tre sidste Led ere paa Enden af den forreste Rand viebnede med 'Torne.

Det andet Fodpar er noget lengere end let forste, og dets silste Led er smalere; det forste Led er temmelig brealt, ovalt; det tredie Led er lidt liengere enl det andet og har nogle Torne paa dlen forreste Rand; det fjerle $0 \mathrm{~g}$ femte Lerl ere omtrent lige lange, i den forreste og bagre Rand forsynede med fine Borster; Neglen er noget kortere og meget smalere end det sidste Led og har ligeledes paa begge Rande tatte Børster.

Det andet og tredie Fodpar have samme Form; det tredie Led bliver indad bredere; det fjerde er kortere og smalere end dette og ovalt; det femte Led er smalt, lidt krummet med parallele Ranle; den nedre bagre Vinkel er forlanget i en stump land; Neglen kan slaaes mod deme, saa at derved dames en Gribehaand.

Det femte Fodpar er overordentlig stort, meget store end de foregaaende. De trende folgende Fod par aftage efterhanden strokt i Strirelse.

Det femte Pars forste Led er ovalt, omtrent saa langt som le tre følgende Led tilsammen; dets tredie Led bliver lidt bredere nedad, og den nedre bagre Vinkel er noget forlwnget og tilspidset; det fjerde er meget kortere, og kortere end femte Led, livis forreste Rand er noget saugtakket, og hvis nedre, forreste Vinkel forlinger sig, som paa de foregaaende Fodpar, til en stump Tand.

Det sjette Fodpars første Led er lidt kortere og smalere end paa ret femte Fodpar, hvorimod de folgende Led ere meget kortere end le tilsvarenle paa det femte, men af samme lorm.

Det syvende Fodpar er bygget paa samme Maade som det femte, men er sarleles lidet.

Det forste Par Springfodder nar længere bagud end let andet; len ydre Gren, som er lidt saugtakket i Randen, er kortere og smalere end den indre.

Iet andet $\mathrm{P}$ ar ligner dette, men er mindre.

Det tredie Par's Grundled er næsten saa langt som Grenene, hvoraf then inche er ubetydelig kortere end den ydre og saugtakket i Randen.

Haleved hxnget er triangulært, lidt længere end bredt verl Roden; let er ikke fuldt saa langt som Grundleddet paa det sidste Par Springfoulder.

Den er funden af mig i Hardangerfjordens ydre Del ved Lyngholmen pai 100 Favne. 


\section{Divisio.}

\section{Ga m m a rin a.}

Instrumenta cibaria perfecta.

Pedes maxillares laminis non coalitis: palpo articulato instructi.

Postabdomen perfectum, raro uno articulo destitutum et qvinqve modo paribus pedum instructum.

Epimera plerumqve magna.

Denne svarer til Milne Edward's "Famille des Crerettines", til Dana's Amphipoda yammaridea, til Spence Bate's Amphipoda gammarina, naar der kun undtages, at Ien af den sidste udelukkede Familie Dulichidac er optaget i denne Division. Den adskiller sig saaledes, som allerede Dana har angivet, fra Hyprevider ved hijobefoddernes Bygning, men ligner i Munddelene særdeles meget Caprellidea, hvorfra den dog skilles verl, at Halen hos den sidste er rudimentær. Denne Gruppe omfatter Here Familier: Chehridae er opstillet af Alman, Dulichidae, Corophidae, Orchestidae og Gammaridae af Dana, jeg har i 1870 opstillet Familien Prostomatidae, og endelig kommer hertil Podoceridae, Amphithoidae, Photidae og Leucothoidae som nye Familier.

Inddelingsgrunden for denne Tribus i de anforte Familier er Munddelenes og Halens Bygning. De førstnæunte ere enten af en ganslie eiendommelig Bygning, idet lle ere omdammede til en Art Sugeredskab, som hos Prostomatidae, eller de ere mere normalt udviklede, som hos Orchestidae, medens de dog hos denne frembyde særegne Eiendommeligheder; hos Lencothoidte ere Kindbakkeme betydelig forskjelligt dannede pas hegge Sider, medens hos de ovrige Fanilier Munddelene have omtrent den nomale Typus, kun med ringe Modifikationer; her viser dog Halens form en hos dem indbyrdes afvigende Bygning. Hos Prostomatidae er Halens Bygning omtrent som hos Slagten Hyperic, hos Orchesticlue er den meget kort, ligesom Springfødderne ere korte, Halevedhnnget tykt, og tilsammen damner den et kraftigt Hopperedskab, hvilket ikke er Tilfreldet hos de følgende Familier. Hos Leucothoidae og Gammaridae er Halen af rlen typiske Form; hos Photidac er deu lig den hos hine Familier, men her er Halevedhrenget meget tykt; dette er ogsa Tilfaldet hos de to folgende Familier, Amplithoidue og Podocridae, men her ere tillige det sidste Par Springfodders Grene overmaade korte, besatte med Hager: hos Corouhidae er derimod Halevedhænget atter pladeformigt, men alle Springfodder ere sarieles korte, isar det sidste Par; hos Dutichindur mangler et af Halens 
sidste Lerl med tilhwrencle Fodpar, saaledes at der her kun findes to Par springforlder. Gjennem denne sidste Familie damnes Overgangen til den 3die Division, Canrellidae.

Familia I.

PROSTOMA'TAE, A. Boeck, 1860.

Syn.: 1860. J'rostomatae, A. Boeck, Forhand. ved de Skand. Naturf. Side Mssde 18150. p. 637 .

1865. Trischizostomatinat, Lilljeborg, On the Lysianassa magellanica. p. 17.

1870. Prostomatae, A. Boeck, Crust. amphip. bor. et aret. p. 10.

Instrumenta cibaria valde prominentia et conjuncta processum 3 lissum. tubilormem formantia.

Labium superius pralongatum, angustum.

Jlandibula styliformes, acula, palpis longis triarticulatis inslructie.

Maxillæ angustæ, elongatæ, in apice acuminatæ.

Pedes maxillares laminis interioribus angustis, exterioribus brevibus ef latioribus; articulo palpi 4to longo, non ungviformi.

Corpus compressum, latum; epimeris latis.

Antenna superiores breves, flagellis accessoriis instructa.

Pedes $1 \mathrm{mi}$ paris mann pervalida subcheliformi.

Pedes 2di paris elongati, angusti; manu subcheliformi, parva.

Pedes saltatorii biramei: l'amis lalis.

Appendix caudalis parvula.

I 1860 dannede jeg (Forhandl. verl de skand. Naturf. sie Mode, p. 647) demne Familie, da jeg fandt, at den eneste Slagt, Trischizostoma, afviger verl sine Munddeles Bygning saa meget og saa karakteristisk fra alle andre Slægter, at den ikke kan liomme ind i nogen af de hidtil opstillede Familier, og dog paa samme Tid viser Overensstemmelse med Hyprridae, Orchestidae og Lysianassinae. Lilljeborg optog den som en Underfanilie Trischizostomatina og satte den efter Phoxina, hvorfra den skulde skille sig verl sin rorformede Mund; jeg tror dog fremdeles, at den ikke bør staa indenfor Familien Gammaridae, men danne en egen Familie, sideordnet med denne. Det, som i Srordeleshed er karakteristisk ved Munddelene, er den meget forlængede Overlæbe, der danner ligesom Halvdelen af et Rør, hvortil Kjobeføddeme slutte sig, idet de ere forlængede og deres indre Plader ere ligesaa lange, som de ydre. Herved damnes et fremstatende, tilsynelarlende treklappet Ror, indenfor hvilket Kindbakker og Kjaher ligge skjulte. Mod Roden gabe dog Sidesprakkeme saa meget, at Kindbakkemes stærke Palpe kommer frem. Denne sidste tilligemed Kjabeføddernes Palpe omgiver saaledes paa begge Sider det i Midten liggende Mundror. Ver Bygningen af disse Mumdele 
synes Iyret at henvises til en parasitisk Levemaade, og de afvige saa meget fra dem hos de ovrige Gammarider, at det ikke kan staa i nogen anden Familie, men maa danne en egen. Ved de store Øine, der dxkke hele Hovedets Sider, og ved den brede Hale med dens brede Springfodiler faar Dyret et Udseende, der giver det Lighed med $\mathrm{Hy}$ periderne; jeg har derfor stillet denne Familie som den forste i Riekken af Gammarina, narmest Hyperina.

Gen. 1. 'TRISCHIZOSTOMA, Esmark \& Boeck, I860.

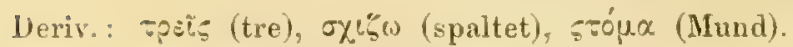

Syn.:"1860. Trischizostoma. A. Boeck, Forl. ved de Skand. Naturf. Sde Møde 1860. p. $63 \%$.

1870. Trischisostoma, A. Boeck, Crust. amphip. bor. et arct. p. 10.

Typ.: Trischizostoma Raschii (Esmark), Boeck.

Capul antice in rostrum frontale crassum, latum, in apice rotundalum, productum.

Antennse inleriores articulo 4 to longitudinem 5 ti superanti.

Pedes $1 \mathrm{mi}$ paris manu permagna, inflata, ovata; ungve non in angulo inleriore anteriore, ut solito, sed in angulo inferiore posteriore inarticulato. antice verso.

Pedes 4li paris arliculo 3 tio valde dilatalo et latiore qvam pedum 3tii paris.

Epinerum 1 mum parvum.

Epimerum 2dum deorsum valde dilatatum, 1 mum partim tegens.

Oculi permagni.

Appendix caudalis lata.

Den eneste Slægt, som tilhører denne Familie, afviger meget ved det forste biekast fra alle de ovrige Former. Mundrøret er nemlig saa eiendommeligt fremstaaende og henviser tydelig til, at Dyret maa nyde sin Fode paa en ganske anden Maade end andre Amphipodeformer. Efter Professor Rasch, hvem de tre Exemplarer i Universitetets Samling shyldes, fangedes de ved, at man i Skraben nedsankede para store Dybder ell nylig skudt og thatet Fugl, paa hvis Legeme de holdt sig fast og sugede Blod. Senere har jeg faget den fra Throndhjemsfjorden, hvor den var taget parasitisk paa en Hai.

Jeg har allerede under Familiens Karakter narmere omtalt Munddelenes eiendommelige Bygning og fremhævet, hvorledes den med sine store Øine, der drkke den hele Sirleflade af Hovedet, og ved sin brede Hale med de brede og korte Springfødder far Lighed med Hyperiderne. Fra disse skiller deme Slægt sig log ved, at Hovedet fortil gaar frem i et stort, bredt Pandehorn, der oventil dakker de grre Folere. Disse, saavelsom de nedre, ere vel udviklede og ligne dem hos Lysianassiderne derverl, at Skaftet paa de ovre Folere el meget tykt og deres Svohes forste Led ere sammenvoxede til et meget langt Led, samt ver at de have en Bisvabe. Som hos Slangten Opis, Nor- 
mania og nogle andre blandt Lysianassiderne er det forste Fodpars Haand meget kraftig udvililet; det andet Fodpar er derimod forlanget, tyndt, lig det tilsvarende hos alle Lysianassider. De tvende folgende Fodpar, som hos de fleste Amplipoder have ens Bygning, ere her noget forskjellige derved, at det tredie Led paa det fjerde Forlpar er meget stærkt udviklet og meget bredere end paa det tredie Fodpar.

TRISCHIZOSTONA RASCHII, Esmark \& Boeck, 1860.

(Pl. II. Fig. 1.)

Trischizostoma Raschii (Esmark), A. Boeck, Forh. ved det Skand. Naturf. Sde Móde 1860. p. 637.

Trischizostoma Raschii, A. Boeck, Crust. amplip. bor. et arct. 1870. p. 11.

Antennæ superiores articulo 1 mo brevi, sed multo longiore qvam articulis duobus seqventibus conjunctis: articulo flagelli 1 mo longitudinem articulorum $\mathbf{6}-\mathbf{z}$ seqventium conjunctorum aqvanti: arliculo flagelli accessorii Imo multis partibus longiore qvam articulis duobus seqventibus junclis. Pedes 1 mi paris manu perinflata, in acie serie spinarum, deorsnm in spinam majorem desinenti, instrucla. Pedes 2di paris articulo 2do ferme longiludinem articuli 4 ti mqvanti. Pedes 4ti paris articulo 3tio dilatato, parum modo longiore qvam lato. Pedes trium parium ultimorum articulo Imo deorsum et postice producto et rotundato. Pedes saltatorii ultimi paris ramis in marginibus non setosis, longitudinem duplam pedunculi arvantibus. Appendix caudalis longior qvam lata, in apice rolundata.

De største Exemplarer ere $25-30^{\mathrm{mm}}$ lange fra Pandehomet til Halevedhanget.

Lege met er ikke strerkt sammentrykt, og Ryggen er rund nden nogenstels at danne en Kjol. Det fjerde Haleled har en liden Indtrykning paa Ryggen nar Leddets Begyndelse. Det forste Legemslerl er det bredeste, og det sjette og syrende de smaleste. De tre forste Haleled ere bredere end de sirlste Brystled.

De fleste Sidepladel ere store, men den første er næsten ludimentær of skjult under den store anden, der er særdeles bred, triangulier, med Basis indar, og drekker med sit forreste Hjørne den første Sideplade.

Den tredie og fjerde Sideplade ere næsten lige store, og den sidste noget indskaret bagtil for den femte, som er bredere end høi. Hovedet forlænger sig fortil i et kort, men særleles bredt, fortil afrundet Pandehorn, der dæklier Udspringet for de ovre Folere. Øinene indtage hele Siden af Hovedet og stode nasten Sammen oventil.

De ovre Folere ere noget lrengere end Hovedet. Skaftet er sardeles tylit, og dets forste Led er det storste, neppe saa langt som tykt; de to folgende aftage $i$ Stgrrelse. Svoben er længere end Skaftet og damnes hos Humen af $10 \mathrm{Led}$, lroraf det forste er saa langt som de folgende syv til otte Led tilsammen. Bisvoben dames af et sar- 
deles stort, bredt Led, der er saa langt som Svobens forste Led og de ovrige smaa Led tilsammen.

De nedre Følere ere forlængede. Skaftets forste Led er meget stærkt og bliver nerlad udvidet; det andet er meget lidet ligesom det tredie, der er meget kortere end bredt; det fjerde er noget længere og meget bredere end det femte Led. Svøben ilames omtrent af 30 meret korte Led.

Overlæben er særdeles forlænget, nedad spids og danner med Kjæbefoddernes tvende Plader et treklappet, fremstaaende, tilspidset Rør, der nær Basis i Sideranden lader Kindbakkernes Palper faa en Gjennemgang.

Kindbakkerne ere sinaa, men forlængede, smale, spidse i Enden, uden nogen Tyggeknude, medens Palpen er særdeles stor, treleddet, af den sædvanlige For'm; det tredie Led er næsten saa langt som det andet, bliver smalere mod Enden og er paa len indre Rand forsynet med mange Borster.

Det forste Kjæbepar synes kun at dame en enkelt forlænget Plade med nogle smaa T'orne i Spidsen.

Det andet $\mathrm{K} j$ abepar er forlanget, smalt.

Kjabefoddernes Grundled er forlænget, og de folgende to Led, der bare den indre og ydre Plade, synes at være sammensmeltede. De ydre Plader ere brede, afrundede mod Enden, og lagge sig saa næer til hinanden, at de skjule de forlængede, smale, indre Plader. Palpen er, som sædvanlig, fireleddet; let forste Led er kort, det andet meget længere end det treilie, og det fjerde er forlienget, ikke kloformigt.

Det forste Fodpar er sarleles stort; det forste Led ex forlænget, men stærkt; det andet er lidet, ligesom det tredie og det fjerde I.ed, der lægge sig paa den indre Side af det særdeles store, agformige femte Led, hvis nedre Kant er tilskjærpet og bevabnet med en Rad bagudrettede Torne, der fortil ende $\mathrm{i}$ fire storre, to paa hver Side, mellem hvilke Kloen lregger sig. Denne, ler ikke, som sædvanlig, udspringer fra det forreste nedre, men fra det bagre nedre Hjorne, er temmelig lang, noget krummet og uden Tænder.

Det andet Fodpar er forlænget, af samme Byguing som hos Slægten Anonyx. Det andet Led er meget langere end det fjerde, og det femte er temmelig breit, besat med starke Buske af smaa Børster, der nasten skjule den lille Negl.

Det tredie Fodpar er af den sadvanlige Bygning; det tredie Led er ikke meget udvidet, men lrengere end det fjerde.

Det fjerde Fodpar afviger fra det tredie Par ved, at det tredie Led er særdeles udvidet og langt, ovalt, og det fjerde Led er kort.

De tre folgende Fodpar tiltage ubetydelig i Langde. Det forste Lerl er paa rlet femte Par ultrukket i den nerlre bagre Vinkel. Kloen er meget liden.

springfodderne ere pladeformige, og det sidste Par naar langst tilbage. Dens Grene ere lige lange og af en bred lancetagtig Form. Den ydre Gren par det sidste Par er i Spidsen vabnet med en Torn, og Skaftet er kort. 
Halevedhænget er lidet og bredt, spaltet i Spidsen.

Denne Art blev først fundet paa Havbroen af Professor lasch. senere af Conservator Storm i Throndhjemsfjorden, hvor den blev taget snyltende paa en Hai. En liden Unge har jeg fundet i Christianiafjorden med Skraben paa 60 Favnes Dyb.

Familia II.

ORCHES'IIDAE, Dana, 1849.

Syn.: 1849. Orchestidae, Dana, Synop. of the Genera of Gam. Amer. Journ. of Science. VII. p. 307.

1856. Talitrini, Costa, Su' crost. amfip. del regno di Napoli. Mem. Accad. d. sei. di Napoli 1856. p. 173.

1862. Orchestidac, Spence Bate, Cat. Amphip. Crust. Brit. Mus. p. 4.

1865. - Lilljeborg, On Lysianassa magellanica. p. 17. (Tabel).

1866. - Grube, Beitr. z. Kenntn. Istr. Amphip. Fauna. Arch. f. Naturg. 1866. p. 378 .

1870. - Boeck, Crust. Amphip. bor. et arct. p. 11.

Labium superius validum, in apice rotundalum.

Mandibulæ pervalidx, seriem spinarum plumosarum gerentes, curvata, in apice perdentatie: mala interna valde dentata; tuberculo molari valde prominenti: palpo absenti.

Maxillæ $1 \mathrm{mi}$ paris dentihus firmis pectiniformibus armatæ; lamina interiore elongata, angusta, in apice setis duohus phmosis instructa: palpo parvo aut absenti. Maxille 2di paris laminis latiș.

Pedes maxillares lamina exteriore parva, lati, ovata, in margine spinis gracilibus vel setis instructa; lamina interiore elongata, lata, in apice truncata. dentibus tribus firmis armata; palpo valido latoqve: articulo palpi ultimo interdum absenti.

Corpus compressum; dorso rotundalo; epimeris majoribus.

Antennæ superiores inferioribus plus minusve breviores, llagello appendiculari destitutre.

Antennæ inferiores articulis duobus anterioribus perbrevibus sed sat latis.

Pedes saltatorii breves et validi; iisdem $1 \mathrm{mi}$ et 2 di paris biramei, ultimi paris simplices.

Appendix caudalis brevis et crassa.

Dana opstillede denne Familie i 1849 og henforte lertil Slregterne Talitrus, Orchestic og Allorchestes. Spence Bate beholdt den som en Familie under hans forste Tribus Saltatoria og tilfnier Slagten Galanthis, som han dog senere har opgivet. Achilles Costa opfører i 1856 Slægterne Talitrus og Orchestia i en Underfamilie Talitrini under 
Familien Gammaridei. I Lighed med Dana beholdt jeg i 1860 Familien Orchestidae, og baalde Spence Bate og Lilljehorg har fulgt deme ()pfitning. I ..Catal. of Crust. amphip. Brit. Mus." henforer Spence Bate sex Slagter til deme Familie, hvoraf dog de to, Allorchestes og Nicea, falde sammen.

Denne Familie omfatter saaledes de Former, som Milne Edwards henforte til Tribu des Crécetines surteuses, Invis ove Folere vare meget korte, og som manglede Palpe paa Kindbakkeme. Efterat Dana havde opstillet Familien i "Synopsis of the genera of Gammaracea“, tilfoiede Brandt i „Beiträge zur Kenntniss der Amphipoden“" (Bull. physico-mathématique de l'académie de St. Petersbourg) en Del Bemarkninger dertil samt gav en kritisk Opstilling af Arterne. Karakteristisk for denne Familie er Munddelenes Form. Kindbakkerue mangle hos alle Former Palpe; heri ligne de visselig flere andre Amphipoder, som Slrgten Dexamine og andre; men fra disse adskiller den sig fra de faa, store, men blode, fjærlannede Børster, rler findes mellem den stærke Gribedel $\mathrm{og}$ den store, i Spidsen brede Tyggeknude paa Kindbakkerne. Det første Kjæbepar er $\circ$ gsaa eiendommelig bygget; T'wnlerne, hvormed dens Spids er forsynet, ere særleles grove i Forhold til Pladen, hvorpaa de sidde, mere end der sxdvanlig finder Sted, og Kjabens Palpe mangler som oftest; den findes kun hos Slagten Hyale, men er dog her meget kort. Kjabefoddemes ydre Plade er hos denne Familie liden, bred, oval og har ikke Tander paa den indre Rand, men kun Børster; derimod ere de indre Plader meget storre, end det sadvanlig er 'Tilfældet, og har tre meget stærke Tænder, der dog tildels ere skjulte af den stærke Harbesxtning, som sces paa den ovre Rand. Kjæbefoddernes Palpe er kort, men meget bred; de forste Led ere nemlig som oftest bredere end lange og udvide sig indad, lıvilket især er Tilfældet med det andet Led; dens fjerde Led mangler i liegelen, men hos Slægten Hyale er det tilstede i Form af en lang, krum Klo. De ovre Folere ere som oftest meget kortere, end de nedre, og endog kortere end de nedres Skaft; kun hos Slægten Hyale ere de længere end dette. De syv Fodpar ere strerke, Sideplarlerne ere store. Halens Folder ere korte, men meget starke; Springfodlernes Grene ere ogsaa korte, og let sidste Par af disse har kun cen Gren. Halevelhanget er kort og tykt.

Gen. I. ORCHESTI, Leach, 1814.

Deriv. : óp

Syn.: 1813. Archestia, Leach, Crustaceology, Edinburgh Encyclopealia. t. XI. p. 3 э6.

1814. - Leach, Trans. Linn. Soc. t. XI. p. 356.

1825. - Desmarest, Consid. sur Crust. p. 261.

1530. - Milne Edwards, Ann. des Sc. nat.

1840. - Milne Edwards, Hist. des Crust.

1849. - Dana, Syn. of the gen. of Gam. Amer. Journ. of Sc. VIII. p. $13 \%$.

1851. - Brandt, Bull. sc. de la classe physico-mathém. t. IX. p. $133 \mathrm{ff}$. 
1853. Orchestia, Dana, the Crust. U. States Explor. Exped. p. 851.

1859. - Bruzelius, Bidrag t. Skand. Amphip. gamm. p. 33.

1862. - Spence Bate, Catal. crust. amplip. Brit. IIus. p. 17.

1866. - Grube, Beitr. z. Kenntn. Amphip. Archiv f. Naturg. 1866. p. 378.

1867. - Heller, Denkschr. d. K. K. Acad. II. Abth. p. 2.

1870. - Boeck, Crust. amph. bor. et arct. p. 12.

Typ.: Oniscus gammarcllus, Pallas (Cancer gammarus littoreus Montagu).

Maxillæ $1 \mathrm{mi}$ paris palpo destitutæ.

Pedes maxillares palpis perbrevibus, latis; articulo palpi 2 do sursum dilatato, 4 to absenti.

Antennæ superiores minime, pedunculo inferiorum breviores.

Pedes 1 mi paris sexus utriusque manu plus minusve lata, subcheliformi.

Pedes 2di paris articulo 5to sive manu maris permagna, subcheliformi, feminæ parva, chelam debilem formanti.

Leach spaltede Slrgten Talitrus i to Slægter, livoraf den ene beholdt Latreille's Benævnelse Talitus; denne udmarkede sig ved: "Pedes quatuor antici in utroqve sexu subcevales monodactyli," medens den anden, Orchestia, karakteriseredes ved: "Peclum paria quatuor antica monodactyla, pari sccunda manu compressa magna, focminae pari antica moriodactyla secundo didactylo." Senere beholdtes begge disse Slægter, men man var ikke opmærksom paa den af Leach opgivne Kjønsforskjel og henforte Humnerne, horende til Slrgeten Orchestia, til Talitrus. F. R. Müller i 1848 og Lilljeborg i 1851 parviste, at Humerne af Slxgten Orchestia lignede Talitws. I 1849 var Dana ilke fuldstrndig paa det Rene med denne Kjønsforskjel, men i 1853 stillede han Slægterne Talitrus og Orchestia samt en ny, Talorchestia, som Underslagter under en Hovedsliggt Orchestia. Brandt fandt ved Undersøgelse af flere Arter ligesom Krøyer, at det femte Led paa det andet Fodpar hos Humnerne af Slagten Tatitrus var forsynet med en ufuldkommen Haand med en rudimentrer Endeklo. Forskjellen mellem begge Slægter ligger efter ham ikke i Bygningen af det andet, men af det forste Fodpar, idet Haanden hos Humerne af Talitrus er kugleformig $0 g$ bevæbnet med en lang, kun lidt ombøiet Endeklo, medens den hos Hunnen til Orchestia er i. Enden udvidet og forsynet med en krum Klo, der kan slaaes ned mod Griberanden. Til (lenne Slagt hører et betydeligt Antal Arter, saaledes opregier Spence Bate i 1862 (Catal. amphip. crust. p. 17) ikke mindre end 30 Arter, hvoraf de tvende nordiske, 0 . Tittorea og $O$. euchore, falde sammen. Senere er der beskrevet ikke fa nye Arter fra de varmere Have, saa at man kan se, at Antallet af Arter aftager meget hurtigt mod Nord; medens der saaledes i Norge liun er fundet een Art, er der fra Englands Kyster beskrevet fire og fra Middelhavet syv eller otte Arter. 
ORCHESTIA GAMMARELLUS, Pallas, $1 \% \%$.

Oniscus gammarellus, Pallas, Spicil. zool. Fasc. IX, 1772. tab. IV. fig. 8.

Cancer gammarell us, Herbst, Versuch einer Naturgesch. der Krabben u. Krebsen. 1782-1804.

Cancer (gammarus) littoreus, Montagu, Linn. Trans. IX. p. 96. t. 4. fig. 4.

Orchestia littorea, Leach, Edinb. Encyc. VII. p. 402.

- Desmarest, Concid. sul les Crust. p. 261. pl.75. 13.

- Milne Edwards, Hist. des Crust. III. p. 16.

- Frey et Leuckart, Beitr. z. Kenntn. d. wirbellos. Thiere. 1847. p. 160.

- Lilljeborg, Norges Crust. Öfvers. K. Vet. Akad. Forh. 1851. p. 13.

- Gosse, Marine Zool. 1855. p. 142.

- Costa, Su' crost. Amfip. del regno di Napoli. Mem. d. R. Accad. de Sc. di Napoli 1856. p. 181.

- $\quad$ Spence Bate; The Aunals and Magaz. Nat. Hist. 1857. ser. 2. p. 136.

- White, Hist. Brit. Crust. 185\% p. 162.

- Bruzelins, Skand. Amphip. Gam. p. 33.

- Spence Bate, Cat. Amphip. Crust. Brit. Mus. 1862. p. 27. pl. IV. fig. 8.

- Spence Bate et Westwood, Brit. sessile-eyed Crust. p. $2 \%$

- Heller, Denkschr. d. K. K. Akad. d. Wissensch. 1867. 2 Abth. p. 2.

- Boeck, Crust. Amphip. bor, et arct. 1870. p. 12.

Orchestia Euchore, F. Müller, Archiv f. Naturgesch. XIV. p. 53. pl. 4.

Talitrus tripudians, Kroyer, Nat. Tidsskr. 2. R. 1. p. 311. tab. III. fig. 2, a-e.

II as. Antenne superiores ferme ad articulum pedunculi ultimum antennarum inferiorum porrecte. Antenna inferiores tertiam partem longitudinis animalis agvanles. Pedes $1 \mathrm{mi}$ puris carpo triangulari; manu breviore et minore qvam carpo. Pedes 2di paris manu magnn, ovali, in acie percurvata. Pedes 5ti et 6ti paris articulo 1 mo fere eadem longitudine ac latitudine: articulo 3tio parum modo dilatato el ferme longitudinem 4 ti rqvanti, breviore qvam 5to. Pedes 7 mi paris articulo 3 tio deorsum valde dilatato et in angulo inferiore posteriore producto; articulo 4to perlato, 5to angusto. Femina. Pedes $1 \mathrm{mi}$ paris carpo Iriangulari, latiore qvam manu qvadrangulari, apicem versus angustiore. Pedes 2di paris articulo 1 mo perlato, carpo paulo longiore qvam manu et deorsum multo latiore; manu obovata. in margine anteriore incisa; ungve parvo in incisura manus affixo.

Langden er $12-15^{\mathrm{mm}}$.

Le gemet er sammentrykt fira Sideme, men Ryggen er bred og ruml, Hovedet er omtrent saa langt som forste Legemsled, Øinene ere store, lidt orale.

De ovre Folere ere saa lange som eller noget kortere end Hovedet; de naa ikke fuldt frem til de nedre Foleres sidste Skaftled; Svoben dames af 8 smaa med Borster 
besatte Led; de nedre Folere ere omtrent en Trediedel af Legemets Langle. Skaftets forste Led er meget bredt og ligger i Hovedets Plan, det andet er meget kort; det tredie er omtrent tre Gange saa langt som tykt; det fjerde og femte ere omtrent lige lange og meget længere ent det tredie. Svoben damnes af 20 korte Led.

K in dbakkerne ere meget stærke, paa Enten krummede; deres Griberand er væbnet med indtil sex Tænder og den indre Bigren med fire til fem saadamne. Tyggekuuden er trekantet, stærlit fremstanende.

Det forste Kjabepar har i Spidsen stærke og paa den indre Rand kamformet indskaarne Trender; den indre Plade er meget lang, smal, i Spidsen forsynet med to strerke, cilierede Børster; Palpen mangler.

Det andet Kjæbepars Plader ere meget brede; den indre har en Mrngie kortere Borster, samt to til tre lingere.

Kjabefodlderne ere meget brede og starke; den indre Plade er lang og bred, dens imlre Rand har en Rrkke Borster samt paa Enden tre stærke T'ænder; den ydre Plade er meget liden, næsten oval, og har paa den indre Rand samt paa Enden tynde, næsten borsteformede Torne; Palpens tre Led ere særrleles brede, dens andet Led forlrenger sig i det indre forreste Hjørne til en afrundet, med Borster besat Lap; det sidste Led el forlænget, ovalt.

Det forste Fodpar er meget mindre end det andet, hos Hamnen er dets fjerle Led triangulært, nedad bredere samt i den bagre og nedre Del forsynet med en opsvulmet, myg Kant, der er besat med T'orne; Haanden er kortere end det fjerde Led, triangulær med en paa Enden afskaaren Griberand; Neglen er liden og har et Par Borster. Hos Humnen er det fjerde Led triangulært, lidt langere end Haanden, som har parallele, lidt krummele ydre og indre Rande og en paa Enden ret afskaren Griberand; Kloen ex strexk, bred ved Basis og har paa Midten af den bagre Rand flere korte Torne.

Det andet Fodpar er hos Hannen meget strerkt; dets andet, tredie og fjerle Led cre meget korte; Haanden er meget stor, oval, ikke fuldt dobbelt saa lang som bred, par Enden skraat afskaaren med en krummet og med Torne besat Griberand; Kloen er særdeles stor, stærkt bøiet, paa Lnden spids, og uden Tænder paa den indre Rand; hos Humnen er det første Led meget bredt, især i den ovre Del, samt med bueformet forreste og ret bagre Rand; det fjerde Led er langere end det femte, bliver nedad bredere, og dets bagre Rand er opsvulmet; det femte Led er forlænget, omvendt regrundt, og har paa den nedre Ende en Indskjæring, hvori Kloen sidder, medens den hagre Kant er opsvulmet.

Det tredie og fjerde Fodpar ere temmelig stærke; deres tredie Led er kun lidt udvidet nedad.

De tre bagre Fodpars forste Led er meget bredt, kun lidt hoiere end brest, merl stark bueformet og saugtakket bagre Rand.

Det femte og sjette Pars tredie Led er kun lidt udvidet, neppe saa langt som det fjerde, der er kortere end det femte; begge disse sidste Led have pail den 
forreste Rand stærke Torne; det tredie Led paa det syvende Fodpar er hos Hannen meget bredt, triangulært med en starkt uddragen nedre bagre Vinkel, det fjerde Led er liengere end det tredie, der er særdeles bredt, medens det femte er langt og smalt; hos Hunnen derimod ere det tredie og fjerde Led smale ligesom par de tvende foregazende Fodpar.

Det forste Par Springfodder naar langere tilbage end det andet, dets Grene ere nasten lige lange, cylindriske og have Torne paa den ovre Kant.

Det andet Par har samme. Bygning, men er kortere.

Det sidste Par har kun een Gren, der er kort, mod Enden smalere og med nogle Borster i Spidsen.

Halevedhrenget er kort, tylit, bliver meget smalere i Enden, hvor det er indbugtet; i Kanterne har det Torne.

Den. forekommer fra Throndhjemsfjorden rundt Kysten lige ned i Ostersøen, især paa Sandstrande, og gjemmer sig under opkastet Tang og Stene. Ved Englands og Irlands Kyster er den fundet paa mange Steder. Van Beneden har paavist den ved Belgiens Kyst, Milne Edwards ved Irankriges. I Middelhavet $0 \mathrm{~g}$ det adriatiske Hav er denne Art fundet af Savigny, Costa, Lucas og Heller, i det sorte Hav af Czemiarskyi

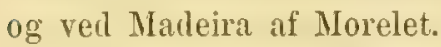

Det af Pallas angivne Artsnavn 0 . gammarcllus bor benyttes, da det er det ældste binære Navn, efterat Linné's tolvte Udgave af "Systema naturæ" var udkommen. Limué, der fandt den paa sin skaanske Reise, har henfort den til Gammanes (Cancer) locusta og ikke opfattet den som en egen Form.

Gen. II. TALITRUS, Latreille, 1802.

Deriv.: Talitrus, et mythologisk Navn.

Syn.: 1802. Talitrus, Latreille, Histoire naturelle gẻnérale et particulière des Crustacés et des Insectes. V. p. 294.

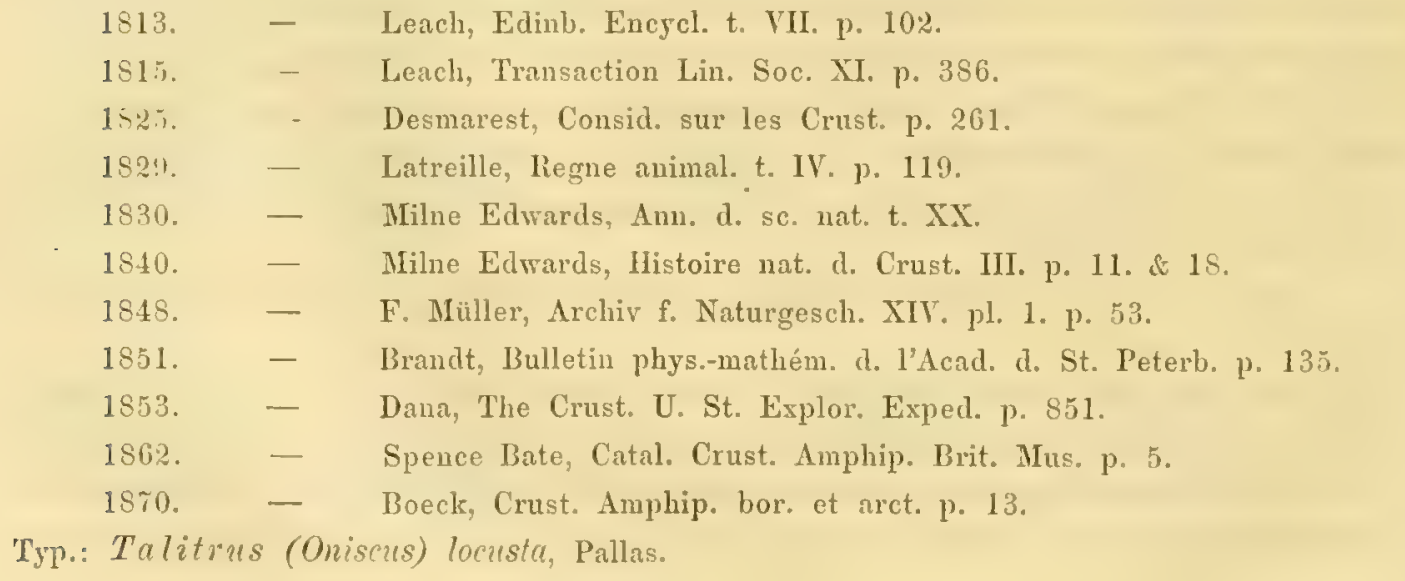


Instrumenta cibaria, antenne et postabdomen reqve ut apud genus Orehestia. Pedes 1 mi paris non subcheliformes.

Pedes 2di paris articulo 5to utrinsqve sexus debili; ungve obsoleto.

Latreille opstillede denne Slagt i 1802 for at optage de Arter af Fabricius's Slægt Gummans, hvis ovre Folere vare meget korte. Disse Arter havde han i 1796 benævnet under Slægtsnavnet Gammarus og adskilte dem fra de andre Arter, som han stillede under Slagtsnavnet Carcimes. Talitmes blev ogsaa optaget af Bosc i andet Volumen af "Hist. nat. des Crustacés“. Fra denne Slægt ere efterhaanden mange Former udskilte, hvorved den nu har en anden Begrendsuing end forhen. Da man ikke noiagtig kjendte Kjonsforskjellen, har man lige til den senere Tid henfort til denne foruden dens egne Arter ogsaa alle Hunner, der hore til Slægten Orchestia, medens Hannerne stode igjen. Derfor har Slægtskarakteren ogsaa til de forskjellige Tider veret afvigende. Leach skilte (Edinb. Encyl, t. VI, pag. 402, og Transact. of the Limean society, vol. XI, 1815, pag. 376) fra denne Slægt Orchestia og angav som Karakter for Talitrus: "Pedes quatuor antici in utroque sexu subcruales monodactyli" medens han for Orchestia angav Kaxakteren at være: "Pectum paria quatuor antica maris monodactyla, pari secundo manu compressa magna femince pari antica monodactyla secunda didactyla". Saaledes havde allerede Leach varet opmarksom paa deme Kjønsforskjel, som senere Forskere have overseet, og hvorved begge Slægter ere blevne sammenblandede, som jeg forhen har anfort. F. Müller i 1848 (Archiv f. Naturgesch. B. XIV, Side $53)$ paaviste forst paany denne Forsliel. hrorom ogsa Lilljeborg og Brandt have oplyst. Af denne Slagt findes der kun faa Arter, Spence Bate opfører i "Cat. Crust. Brit. Mus. 1862" kun tre sikre Arter, nemlig foruden den typiske $T$. locusta, T. Wrericomis, Milne Edwards, fra New-Zealand og T. platycheles, Guérin, fra Morea.

\section{TAlitrus LOCUSTA, Pallas.}

Oniscus locusta, Pallas, Spicil. Zool. fasc. 9. tab. 4. fig. 7.

Astacus locusta, Pennant, Brit. Zool. IV. p. 21.

Talitrus locusta, Latreille, Hist. nat. des Crust. et Ins. t. 0. p. 229.

- Leach, Edin. Encycl: Crustaceology. vol. VII. p. 332.

- Desmarest, Consid. sur des Crust. p. 260. t. 45. f. 2.

- White, Popular Hist. Brit. Crust. p. 160.

- Spence Bate, Ann. Nat. Hist. 2nd. ser. vol. XIX. p. 155.

- Spence Bate, Cat. Crust. Amphip. Brit. Mus. p. 5. pl. 1. fig. 1.

- Boeck, Crust. Amphip. bor. et arct. p. 13.

Cancer (Gammarus) saltator, Montagu, Lin. Trans. IX. p. 94. t. 4. f. 3.

Talitrus saltator, Milne Edwards, Ann. des Sc. nat. t. 20. p. 364.

- Milne Edwards, Hist. nat. des Crust. III. p. 13.

- Brandt, Bull. physs--mathém. de l'Académie de St. Pétersb. 1851. p. 13\%. 
Talitrus saltator, Zaddach, Syn. Crust. Pruss. prod. p. 4.

- Costa, Memorie d. r. Accad. d. Scienze 1856, p. 184.

- Czerniavskyi, Mat. zoograph. pont. comp. p. 104. pl. VII. fig. 42-44.

Antenne superiores articulo pedunculi 2 do et 3 tio ferme aqvalibus. Anlemme inferiores articulo pedunculi 4 to dimidiam longitudinem 5li arvanti. Pedes $1 \mathrm{mi}$ paris articulo 4 to longiore [vam 5to; hoc apicem versus angustiore, ferme ter longiore qvam lato. Pedes 2di paris articulo 5to elongato, ovali. Pedes 3tii et 4 ti paris articulo 3tio longiore qvam 4 to et 5̆to, sed breviore qvam his articulis junctis. Pedes 5 ti paris articulo 1 mo fere eadem latitudine ac longitudine.

Det største af mig fundne Exemplar er $18^{\mathrm{mm}}$ langt.

Legemet er ikke meget høit, med en bred, afrundet Ryg. Hovedet er meget langere end det første Legemsled og danner fortil intet Pandehorn mellem de ovre Folere; ligeledes er dets Sidevinkler afrundede. Øinene ere smaa, svagt ovale eller runde. De fire forste Sideplader tiltage efterhaanden lidt i Størelse og ere lidt hoiere end brede; den fjerde er i det overste bagre Hjorne svagt indskaaret for den femte, der er meget længere, men ikke saa høi som denne, og nedad tolappet. Den nedre bagre Vinkel paa de to forste Haleled el tilmudet, paa det tredie Led er den ret; den bagre Rand paa disse tre Led er forsynet med Here Torne.

De grre Folere ere meget korte og naa kum næsten til Enden af de nedre Foleres fjerde Skaftled; det forste Skaftled er tykkere, men kortere end det tredie, og meget kortere end det andet; Swoben er lidt længere end det sidste Skaftled og dannes af 8 korte Led.

De nedre figleres forste Led er meget kort, men breder sig ud paa hver Side af Midten af Hovedets Forside og er besat med smaa Torne; deres andet Led er ligeledes meget kort og danner nedad og fortil et liort med Tome besat Fremspring, det tredie Led er ligeledes kort, nen forlænger sig langs det følgende Leds indre Rand, livilket omtrent er fire Gange saa langt som tykt; det femte Led er meget længere end det fjerde; Svoben dannes af 32 Led og er længere end Skaftets sidste Led.

Det forste-Fodpar er meget stærkt, dets første Led er lidt krummet og bliver bredere nedad, de to folgende Led ere korte, det fjerde er forlsenget og ikke meget bredt; det femte er meget kortere end det fjerde og bliver smalere mod Enden, der indtages af den korte Klo.

Det andet Fodpars forste Led er paa Midten bredt, $0 \mathrm{~g}$ den forreste $0 \mathrm{~g}$ bagerste Rand ere buede; det fjerde Led er spolformet; det femte er ovalt med en liden Indskjæring paa Enden af den ydre Rand, hvori den lille Klo er frestet.

Det tredie og fjerde Fodpar ere starke, deres tredie Led er kort, kun lidt udvidet og ubetydelig længere end det fjerde, der er bredere, men lidt kortere end det femte Ised.

Det femte Fodpars første Led el neppe hoiere end bredt, dets tredie Led 
er bredere, men næsten af samme Længde som det fjerde, der igjen er bredere, men ubetydelig kortere end det femte.

De tvende følgende Fodpar tiltage efterhaanden i Langde, og deres fjerde Led er omtrent saa langt som det femte.

Kløerne paa de fem sidste Fodpar ere korte, og alle Leds forreste Rand er væbnet med Tornebundter.

Det første Par Springfødder's Grundled er lidt langere end Grenene, der have 'Torne paa den øvre Rand.

Det andet $\mathrm{Par}$ er kortere.

Det tredie Pars Gren er lidt længere, men meget tyndere end Gundleddet og har nogle Børster paa Spidsen.

Gen. III. HYALE, H. Rathke, 1837.

Deriv. : ว́ $\alpha>0$ (klar).

Syn.: 1837. Hyale, Rathke, Lur Fauna der Krym. Mém. Acad. Imp. St. Pétersbourg. III. 1837. p. 378 .

1849. Allorchestes, Dana, Amer. Jouru. Sc. (2). VIII. p. 136.

1849. Nicea, Nicolet, i Gay, Hist. fis. de Chili. III. p. $23 \%$.

1851. Allorchestes, Brandt, Crustaceen i Middendorff's Reise. p. 142.

1855. Galanthis, Spence Bate, Brit. Assoc. Rep. 1855. p. 57.

1857. Galanthis, Spence Bate, Ann. Nat. Hist. (1857). p. 176. 3

1859. Alloreliestes, Bruzelius, Skand. Amphip. gammar. p. 34.

1862. Allorchestes, Spence Bate, Catal. Amphip. Crust. Brit. Mus. p. 34.

1862. Nieea, do. p. 38.

1862. Hyale, do. p. 87.

1863. Allorchestes, Spence Bate and Westwood, Brit. sessile-eyed Crust. p. 38.

1863. Nicea, do. p. 45.

1866. Allorchéstes, Grube, Beiträge z. näh. Kennt. Istrichen Amphipoden-Fauna.

Arch. f. Natur. (1866). p. 382.

1866. Nicea, do.'p. 387.

1866. Nicea, Heller, Beitr. zonäh. Kennt. d. Amphip. adriatischen Meeres. Denkschr.

d. K. K. Acad. Wien 1866. p. 4.

1868. Cacrniavsliyi, Mat. zoograph. pont. comp. p. 98.

1870. Hyale, Boeck, Crust. amphip. bor et arct. p. 13.

Typ.: Hyale pontica, Rathke.

Iaxilla $1 \mathrm{mi}$ paris palpo perbrevi, angusto, 1articulato.

Pedes maxillares palpo perlato: articulo palpi fto ungvem longum. curvum formanti.

Antennæ superiores pedunculo inferiorum longiores. 
Pedes Imi 2diqve paris subcheliformes. Pedes "2di par'is manu validiore qvam Imi paris et apud marem multo validiore qvam apud feminam.

Appendix caudalis brevis, crassa et fissa.

Rathke opstillede denne Slagt i 1837 (Z. Fauna der Krym, p. 377). I Karakteren siger han: "Antenne inferiores superioribus aliquntulum longiores abdominis appondicula terminalis simplex erecta vernciformis." Senere, i 1842 (Acta acad. Leopold. t. XX. p. 81) siger han om Amphitö̈ Prcvosti (A. Nilsoni), at denne ligner hans Typus for Hyale, nemlig $H$. pantica, men at den adskiller sig derfra ved Mangel paa Halevedhæng. Dette er dog ikke Tilfaldet; Halevedhrenget er som hos $H$. pontica ikke let at se paa Grund af sin Korthed $\mathrm{og}$ er derfor saavel af ham som af Andre mindre rigtigt angivet. Dana opstillede Slagten Allorchestes i 1849 med følgende Karakter: "pedes primi secundiqve plus minus subcheliformes. Antenne superiores breviores, basi inferiontm longiores. Maxillipedes apicom ungviculati," og i 1853 karakteriserer han den nærmere. Han fremhever vasentlig, at de ovre Folere ere langere end de nedres Skaft, $0 \mathrm{~g}$ at det sidste Led paa Kjobefoddernes Palpe er kloformet. Samme Aar opstillede Nicolet Slægten Nicca paa Arten $N$. Lucasii fra Chili, ved hvilken han dog vasentlig liun fremhæver, at Kindbakkerne mangle Palpe: "Antenne superiores ceteris brevioribus, camut crassum. - Oculi ovati, obliqve positi. Pedes breves, primi ct secundi paris subcheliformes, manibus lrevissimis. Mandibulce brevissimce, bilobate, multidenticulate non palpegere. Labium stemale maximum." Spence Bate optager som Slagter baade Allorchestes og Nicea, lvilken sidste han i 1855 kalder Galanthis, og skiller dem fra hinanden ved, at Halevedhænget hos den sidste er klovet, medens det skal være helt hos Allorchestes. Dette finder dog ikke Sted. Spence Bate fandt selv, ved at gjemnemgaa det typiske Exemplar af Milne Edwards's A. Precosti, at denne er synonym merl A. Nitsoni, men lıan kunde ikke se Halevedhrenget, som imidlertid af Milne Edwards er beskrevet at bestaa af tvende smaa Styli; dette er ogsaa Tilfældet med A. Nilsoni, skjønt Rathke har overseet dette; baade Bruzelius (Scand. Amphip. Gammar. p. 35) og Brandt angive, at Haleverhanget er klovet hos Allorchestcs. Saaledes har netop en af de Arter, som Spence Bate henfører til Slægten Allorchestes, kløvet Halevedliæng, og den stemmer saaledes fuldkommen overens med Nicea, og hans $N$. Lublockiana er kun en Hun af hans Allorchestes Nilsomi. Grube kaller Slagten Nicea, fordi Halevedhrenget er lybt klovet, og for Allorchestes angiver han, at Halevedhænget er enten helt eller kløvet. Heller sammenstiller begge Slagter, Allorchestes og Nicea, under Navnet Nicea. Heri har han vistnok ogsaa Ret, men han har dog ikke ogsaa henfort dem til Rathke's Slægt Hyale. Czerniavskyi opfører Grube's Art Amphithoë istrica under Slægtsnavnet Nicea og anforer i Karakteren for deme Slægt: "Telson bipartitum". Blandt Synonymerne hertil opforer han ogsia Rathlies slapgtonaru Hyale. Denne Slargt Hyale er af Spence Bate gjenoptaget (Catal. Amphip. Crust. Brit. Mus. p. 87) og stillet mellem Allibrotus og Phlias i Underfamilien Lysiannssides, hvilket ogsaa er gjort af Dana. Han tror dog, at 
$1(1 !)$

;

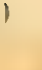

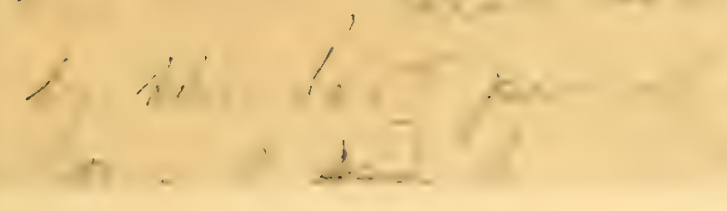

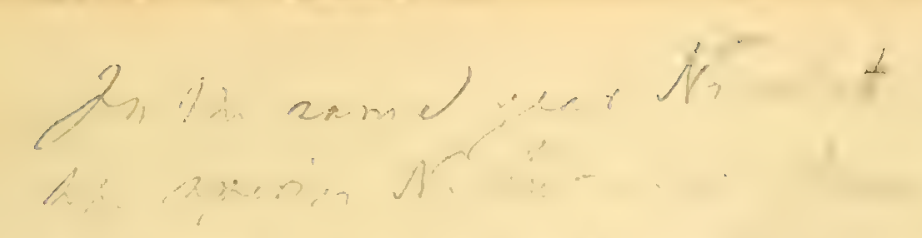


Pedes Imi 2olliqve paris subcheliformes. Pedes 2di paris manu validiore quam Imi paris et apud marem multo validiore "fvam apud feminam.

Appendix caudalis brevis, crassa et lissa.

Rathke opstillede denne Slægt i 1837 (Z. Fauna der Krym, p. 377). I Karakgienoptaget (Catal. Amphip. Crust. Brit. Mus., p. 87) og stillet mellem Allibrotus og Phlias i Underfamilien Lysianassides, livilket ogsaa er gjort af Dana. Han tror dog, at 


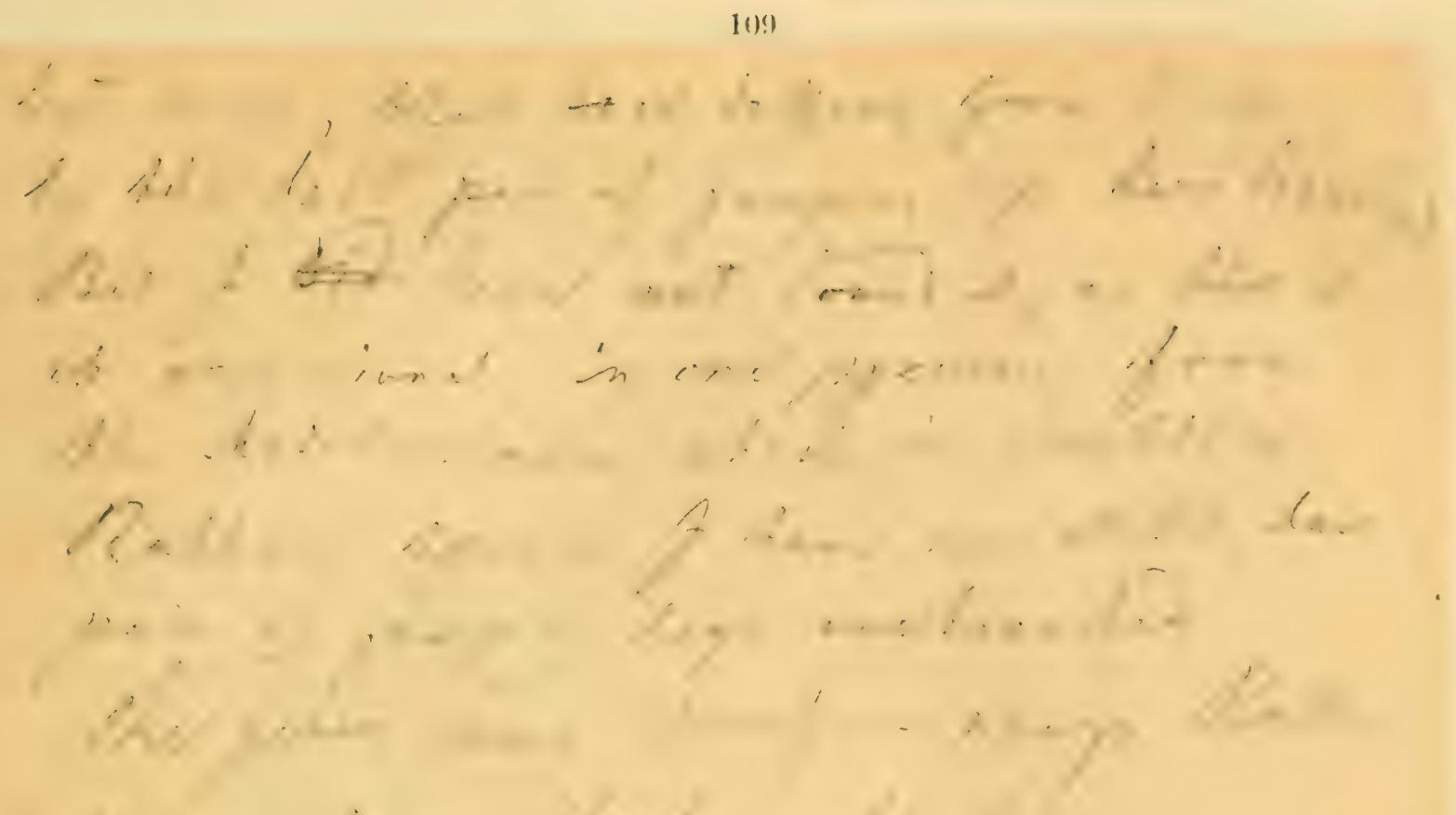


Pedes Imi

qvam Imi paris e

Appendix

Rathke op:

teren siger han:,$A$

dicula terminalis.

XX. F

for $H$

hæng.

se pac

angive

primi

arreme.

nærme

og at

Nicole

fremha

cretssum

manibu

Labium

Nicea,

Halever

Dette $t$

Exempl

han kul

bestaa :

har ove

give, al

som Sp

mer saa

af hans

dybt kila

Heller s

har laan

Hyale.

og anføre

opforer 1

gjenopta

Phlias i Underfami. 
den bor staa mar Niced, men siger, at den afviger fra denne ved, at det bagre Par Springfodder er togrenet. Jeg har dog ikke fundet, at dette er Tilfreldet; paa et Exemplar fra Middelhavet, hvilket ulen Tvivl er den af Rathke beskrevne Art, har jeg seet, at det silste Par Springfødder er eengrenet. Slagten maa derfor beholik Rathke's Slægtsnavn Hyale som ilet rldste.

HYALE NILSONI, Rathke, 1843.

(Pl. III. Fig. 3.)

Amplithoë Prevosti, Tathke, Acta acad. Leopold. t. XX. p. 81. tab. 4. fig. 5.

- Lilljeborg, Öfvers. af Kgl. Vetensk.-Acad. Förhandl. 1851. p. 22.

Amphithoü Nilsoni, Rathke, Acta Acad. Leopold. t. XX. p. 264.

Alborchestes Nilsoni, Bruzelius, Bidrag till Känn. Skand. Amphip. Gam. p. 35.

- Spence Bate, Cat. Amphip. Brit. Mus. p. 38. pl. VI. fig. 4.

- Spence Bate and Westwood, Brit. sessile-eyed Crust. p. 40.

Allorchestes Danai, Spence Bate, Rep. Brit. Assoc. 1855. p. $5 \%$.

- Spence Bate, Ann. Nat. Hist. Febr. 1857.

- White, Hist. Brit. Crust. 1858. p. 163.

Galanthis Lubbockiana, Spence Bate, Brit. Assoc. Report. 1855. p. $5 \%$

- Spence Bate, Ann. Nat. Hist. $185 \%$

- White, Popul. Hist. Brit. Crust. p. 164.

Nicea Lubbocliana, Spence Bate, Cat. Crust. Amphip. Brit. Mus. p. э1. pl. VIII. fig. 3.

- Spence Bate and Westwnod. Brit. sessile-eyed Crust. p. 47.

Orchestia nidrosiensis, Kroyer, Nat. Tidskr. 2. B. 1. p. 299.

Nicea Nilsoni, Heller, Beitr. z. näh. Kennt. d. Amphip. adriat. Meeres. p. 4.

Hyale Nilsoni, Boeck, Crust. amphip. bor. et arct. 1870. p. 14.

Antenna superiores ultra pedunculum inferiorum porrecte: flagello longitudinem pedunculi ferme aeqvanti. Antenna inferiores articulo pedunculi to et 5 to æqvalibus. Mas. Pedes $1 \mathrm{mi}$ paris carpo fere quadrangulari et calce parvo instructo: manu majore, rectangulari. Pedes 2di paris articulo 3tio trimgulari, in angulo inferiore posteriore acuto; manu ovata, in acie obliqve truncata. Femina. Pedes 2di paris rectangularis, pedibus $1 \mathrm{mi}$ paris paulo majores. Pedes saltatorii ultimi paris ramo breviore qvam pedunculo brevi. Ad oras occidentales Nidrosia usque ad Bohuslieni.

Legemet er $\left(i^{1} / 2-10^{\mathrm{mm}}\right.$ langt, sammentryt fia Siderne, men dog med en bred Ryg, der er uden Kjøl eller Tome. Sidepladerne ere store, længere end brede, med afrundede nedre Ender. Hovedet er langere end det første Legemsled. Panden gaar fortil ikke ul i noget Horn. Øinene ere smaa, ovale, sorte.

Folerue ere korte, tykke. De ovre ere omtrent saa lange som Hovedet eller 
noget langere: Skaftets forste Led er det lingste, ikke fuldt lobbelt saa langt som bredt; det andet er omtrent halvt saa langt og meget smalere end dette; det tredie er kun noget længere og tykkere end Svobens ti til tolv Led.

De nedre Følere ere meget læugere end den ovre. Skaftets tvende første Led ere sammensmeltede, dets tredie I.ed er kortere end tykt, de sidste ere indbyrdes omtrent lige lange, og hvert af dem er omtrent dobbelt saa langt som tykt; Svoben er meget langere end Skaftet og bestaar af 12 Lied.

Overlaben er i Spidsen afrundet.

Kindbakkerne ere meget stærke, triangulære, bøiede og tilskjerpede paa Enden samt delte i sex til syv Tæender; den indre Bigren er ligeledes stark og delt i fem til sex Tæuder; Tyggeknuden, der næsten er hesteskoformet, er omgivet af en Rad starke Trnder; Borsteraden bestan af fat, men tykke, i Spidsen blorle og i beggre Rande cilierede Børster; Palpen mangler, men paa den ydre Side, hvor den pleier at sidde, fincles en Dusk med Børster.

Underlæbens Flige ere i Enden stærlt afrundede og forsynede med Borster.

Det første Kjæbepar er forlænget; den ydre Plade har paa Enden faa, men stærke, paa den indre Rand grovt sangtakkede 'Tænder; den indre Plade er meget lang og smal, vabnet med tvende lange, stærke, cilierede Børster paa Enden; Palpen er eenledilet, smal og naar kun frem til Enden af den indre Plade til Roden af dens Tandbesætning.

Det andet Kjæbepars Plader ere smale, noget bøiede, omtrent lige lange og have i Spidsen og paa den indre Rand større og mindre, tildels cilierede Børster.

Kjæbefod derne ere stærke; deres indre Plade er bred, særdeles lang og naar frem til Enden af den ydre; i Spidsen har den fire stærke Tænder og nogle Børster, den yolre Plade er kort, bred og oval, og har kun Borster. Palpen er meget bred; dens tredie Led er ubetydelig langere, men smalere end det andet; det sidste Led danner en lang, tynd, lidt krummet Kilo.

Det forste Fodpar er kraftig bygget; dets fjerde Led er næsten saa bredt som langt og i den nedre bagre Vinkel udtrukket i en kort, smal Hal; Haanden er næsten firkantet, noget langere end bred, med en paa Enden afskaaret Griberand.

Det andet Fodpar er hos Humnen kun lidt større end det forste Par, men nasten af den samme Form; hos Hannen derimod er dette Fodpar kraftig udviklet; dets første Led er bredt, med en meget convex forreste Rand; det tredie Leds nedre bagre Vinkel er tilspidset; det fjerde er meget kort; Haanden er swrdeles stor, af en nasten xgrund Form, men har en paa Enden skraa afskaaret, med fine Tronder besat Griberand; Neglen er kort, men stærk.

De trende følgende Fodpar ere meget starke; deres tredie Led er kun lidet udvidet; det fjerde Led er knapt halvt saa langt som det femte, der paa den bagre Rand, især mod Enden, har grove Tome.

De tre følgende Fodpar have omtrent samme bygning, men deres forste 
Led bliver paa det syvende Par bredere og mere tilundet enl paa det femte; paa Enden af den forreste Rand el det femte Led vabnet med en grov Toru, som Kloen slaar op imorl.

Det første Par Springfødder naar længst bagud; Grenene ere næsten lige lange og have Torne paa den øve Rand og i Spidsen.

Det sidste Par er kun eengrenet; Grenen er kortere og smalere end Grundleddet og har nogle Torne.

Halevedhænget dannes af to tykke, næsten pyramidale Grene.

Efter Spence Bate og Westrood er den iagttaget paa Here Steder ved Englands Kyst, efter Heller findes den i det adriatiske Hav, ved Skandinaviens Kyster findes den fra Bohuslen (Bruzelius) langs hele Kysten til Altenfjord, hvor den er taget af R. Collett. Ved Mandal er den fundet af mig, ligesom ved Stavanger, Haugesuml og Bergen, verl Christianssand af Rathke, i Foldenfjord af Collett.

\section{Familia III.}

GAMMARID A E, Dana, 1853.

1853. G G mmaridac, Dana, U. States Explor. Exped. Crust. p. 902 (pars).

\begin{tabular}{|c|c|c|}
\hline 1862. & 一 & Spence Bate, Cat. Amphip. Crust. Brit. Mus. 1862. p. 53 (pars). \\
\hline 1865. & - & Lilljeborg, On the Lysianassa magellanica. p. 18. Tabel. (pars). \\
\hline 666. & & $\begin{array}{l}\text { Grube, Beitr. z. Kenntu. der Istr. Amphipodefauna. Archiv f. Na- } \\
\text { turgesch. } 32 . \text { Jahrg. p. } 389 \text {. (pars). }\end{array}$ \\
\hline & & Boeck, Crust. amphip. bor. et aret. p. 14. (pars). \\
\hline
\end{tabular}

Labium superius latum in apice rolundatum.

Mandibulæ plus minusve elongatæ, fere æqvales, palpo 3articulato, raro absenti.

Maxilla Imi paris palpo plerumqve 2articulato, raro Iarticulato aut absenti.

Pedes maxillares palpis plus minusve elongatis.

Corpus plus minusve compressum; epimeris plerumqve mediocribus, interdum maximis, raro parvis, oculi compositi.

Postabdomen 6 paribus pedum biramosum instruclum.

Appendix caudalis laminaris integrum vel divisum.

Denne Familie svarer, saaledes som jeg nu begræulser den, ikke til Dana's Gammaridac, der indeshttede ogsaa Underfamilierne Stegocephalinae og Lacothoiniac, som jeg nu henforer til en anden Familie Leucothoidae. Heller ikke svarer den til

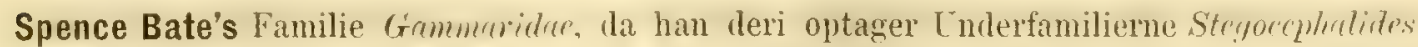
og Ampelisrades. I) omfatter ligeledes et langt ringere Antal af L'nderfamilier end Lilljeborg's Gammaridae og min egen Familie Gammaridae fra Aaret 1870, da jeg 11 har spaltet 
den i to Familier, nemlig Gammaridae og Lacothoidac. Det forekommer mig nemlig, at Kindbakkernes Form hos den sidstnævnte Familie er eiendommelig derved, at de ikke ere lige paa begge Sider, men at de begge ere særegent udviklede. Derfor bor man skille disse tvende fra hinanden. Hos Gammuridur ere Kindbakkerne fuldkommen lige paa begge Sider, som det kan være Tilfxldet, naar deres Tænder skulle gribe ind i hverandre fra begge Sider. Overlæben er ogsaa uden Indsnit i Enden, som hos hin anden Familie. Halen er hos dem alle vel udviklet, og alle Springfodder ere, paa en eneste Lndtagelse nar, togrenede; Halevedhanget er altid pladedannet og enten helt eller mere eller mindre delt. Til denne regner jeg Underfamilierne: Lysianassinae, Pontoporinae, Phoxinae, Oedicerinae, Epimerinae, Dexamininae, Atylinae og Gammarinae.

\section{Subfamilia I.}

\section{Y S I A N A S SI N AE.}

Syn.: 1849. Lysianassinae, Dana, Sillim. Amer. Journ. vol. VIII. p. 136.

1853. Lysianassinae, Dana. Crust. U. St. Explor. Exped. II. p. 908.

1856. Lisianassini, Costa, Recerches sur Cost. Amfip. del regno di Napoli. Mem. d. reale Accad. d. sc. vol. I. 1856. p. 165.

1862. Lysianassides, Spence Bate, Catal. Crust. Amphip. Brit. Mus. p. 64. 1865. Lysianassina, Lilljeborg, On the Lysianassa magellanica. p. 18. (Tabel). 1870. Lysianassinae, Boeck, Crust. amphip. bor. et arct. p. 15.

Labium superius et epistomum plus minusve prominens.

Mandibula elongatæ; mala lata, edentata aut modo in margine interiore dentibus perpaucis instructa; mala interiore in sinistra mandibula sita; tuberculo molari parvo, plus minusve prominenti; serie spinarum dentibus paucis obtusis et sape minimis instructa; palpo elongato, 3articulato.

Labium inferius elongatum; laminis internis parvulis prope apicem.

Maxilla $1 \mathrm{mi}$ paris palpo 2articulato; raro palpo carentes.

Maxillæ 2di paris plus minusve elongatæ.

Pedes maxillares robusti; laminis plus minusve elongatis: articulo ultimo palpi ungviformi, raro tuberculoformi vel obsoleto.

Corpus altum; dorso crasso, plerumqve rotundato; rarissimo carinato.

Epimera alta, angusta.

Antenna superiores pedunculo perbrevi, crasso; articulo 2 do et 3 tio perparvo: llagello plus minusve elongato: articulo 1 mo plus minusve elongato. semper longiori qvam articulis religvis. et in latere interiore duabus seriebus scoparum instructo. 
Antenne inferiores llagello apud marem elongalo. apud leminam hreviore.

Pedes 1 mi paris plus minusve elongali, plerumqve manu parva subcheliformi instructi; raro manu magua aut non subcheliformi.

Pedes 2di paris pralongali. filiformes. manu parva instructi: raro ungve destituti.

Pedes trium parium ultimorum paulatim longitudine crescentes; arliculo Imo postice laminari, dilatato.

Denne Underfamilie blev opstillet af Dana i 1849 og i 1853. Han henforer til denne Slagterne Lysianassa, Phlius, Opis, Uristes, Anonyx og Urothoë, men allerede i 1846 havile Kroyer anmærket, at Anonyx og Opis burde dame en egen Underafdeling af Familien Gammaridac. Costa optager den ogsaa som en Underfamilie i 1856 og kalder den Lisianassini, samt henforer hertil Lysianassa, Callisoma, Ichnomis, Alibrotus og Phlias. Spence Bate deler sin Underfamilie Lysianassides i to Afdelinger, af hvilke det andet kodpar hos den forste er tyndt og ufuldkommen saxformet. Hertil henfores Slagterne Lysianassa, Anonyx, Pontoporcia, Opis og Ichnopus. Til den anden Afolong, hos hvilken det andet Fodpar er stierlit og mere eller mindre saxformet, og hvis forste Fodpar er mindre kraftigt udviklet, henhøre Slægteme Callisoma, Phlias og Uristes.

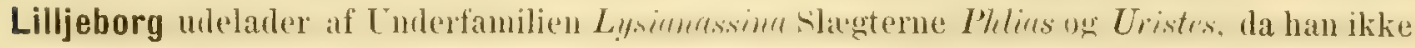
kjendte dem, og endelig Pontoporcia, som han henforer til en egen Underfamilie Pontoporina, og som i Kindbakkemes Bygning adskiller sig fra Lysianassa. Han optager saaledes kum Slægteme Lysianassa, Anonyx, Callisoma og Opis, medens han sammenslaar Slrgten Ichnopus med Lysimassa. I 1871 optog jeg denne Familie med den samme Begrendsning som den, lex er givet den af Lilljeborg, og forogede Slagterne med et betydeligt Antal. Dana gav i 1853. folgende Karakterer for denne Familie: "Antemuce breves, superiores basi crassue. Mandibula apice parce dentatae ct cuspidatae, acie vin instructae palpo 2-3articulato. Maxillipedes lamellis internis yrandibus. Epimerae permagnac." Han fremhaver saaledes Kindbakkernes eiendommelige Bygning, men indeslutter Familien desuagtet i Slægten Urothoë, hos hvilke Kindbakkerne ere anderledes byggede, fordi de ovre Foleres Gruntdel er nneget kort. Costa's tredie Underfamilie Lisianassini inleslutter Slregterne Lysianassa, Callisoma, Ichnopus, Alibratus, Phlias og Acanthonotus; han nevner forovrigt kun ydre Karakterer i sin "Prospetto" ved Opstillingen af denne Underfamilie. Spence Bate optager i sin Underfamilie Slagterne Lysianassa, Anonyx, P'ontoporina, Opis, Ichnomes, Callisoma, Alibrotus, Hyale, Phlias os Uristes, samt deler den i to Afdelinger, eftersom det andet Fodpar er ufuldkommen saxdannet og let forste Fodpar er starkt, eller det omvendte er Tilfoldet. Til den friste Afdeling hemregner han de fem forste Slægter, til den anden Afdeling de orrige. Lilljoborg fremhavede i 1865 (On the Lysianassa magellanica etc. S. 15) starkt Kindbakkernes eiendommelige bygning hos denne nye Familie og sagde, at de have en mere eller 
mindre skarp Eg med faa eller ingen Tæuder, og at den indre Bigren er liden eller mangler. Derved skiller den sig fra Pontoporidae og Phoxidae, hos hvilke Familier Kindbakkernes Eg er indskaaret i talrige 'Tænder og den indre Bigren er stærk, derfor udskyder han Slægten Urothoë. I 1870 omtalte jeg ogsaa Kindbakkernes og de "vige Munddeles Bygning hos I,ysianassiderne og nevite, at Overlaben er meget strerkt fremragende, derved at Kindbakkerne forlænge sig, samt at Mundlæben ligeledes forlanger sig, og at de indre Plader sees som smaa Lapper paa Enden af de ydre Pladers indre Side. De ovrige Karakterer stemme væsentlig overens med dem, som Dana allerede har anført. Han udelod derfor Pontoporcia og optog i Familien tvencle nye Slagter. Kroyer gjorde i 1842 (Nat. Tidsskr., Side 164) opmærksom paa, at Følerne hos Slægterne Anonyx og Opis blive hos Hannen mere udviklede, end hos Hunnen, idet de, foruden at de antage en betydelig Langdeudvikling, hvilket isar gjoller de nedre Folere, desuden ere forsynede med en Mængde smaa Hudvedhæng, der synes at tjene som Sucreskate. hvorved formortentlig Hanneme under Paringen fastholde Humnerne. Ffter at han var kommen paa det Rene hermed, sammenslog han flere af sine tidligere opstillede Arter, da de af ham forhen anforte Karakterer ved de fornyede Undersøgelser viste sig kun at bero paa en Kjonsforskjel. Senere har man ikke været nok opmærksom lerpaa, og Flere, f. Ex. Spence Bate, benytte Folernes Længdeforskjel som Artsmarker. Holbøll, der har undersøgt flere Formers Levemade, fortaller, at de fleste Arter grave sig ned i Sandet og anvende dertil de øvre Følere; desuden benyttes disse som Gang- eller Kryberedskab. I dette Tilfælde blive de nedre Føleres Svøber, naar de ere korte, boiede opad og tilbage; hvis de ere lange, lagges de ind langs Bugen, enten indenfor eller udenfor Sideplademe. Naar Dyret graver i Sandet, bruges de gvre Folere til derved at udbore Hullet, medens det første Fodpar skraber Sanclet bort; benyttes de under Gangen, stotter Dyret sig paa dem, medens det Hytter det tredie $0 \mathrm{~g}$ fjerde Fodpar og undertiden de tre bagre frem foran disse Folere. Det kan anmærkes som eiendommeligt for denne Familie, at tvende Slægter, som henføres til den, nemlig Uristes, Dana, og Lepidepicrinm, Spence Bate \& Westwood, skulle paa de øvre Følere mangle Bisvober, som de svrige herhen horende Slægter besidde.

Gen. I. LYSIANASSA, Milne Edwards, 1830.

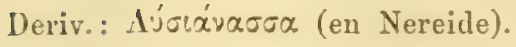

Syn.: 1830. Lysianassa, Milne Edwards, Am. des Sc. nat. t. XX. p.

1840. - Milne Edwards, Hist. des Crust. t. III. p. 20.

1853. - Dana, U. St. Explor. Exped. p. 908.

1863. - Spence Bate, Cat. Amphip. Crust. I3rit. Mus. p. 64.

1863. - Spence Bate and Westwood, Brit. sessile-eyed Crust. p. 72.

1865. - Lilljeborg, On the Lysianassa magellanica. p. 20. 
1866. Lysianassa, Grube, Archiv f. Naturgesch. 32. Jahrg. p. 389.

1866 . Costa, Su' Crost. Amfip. Mem. d. real Accad. d. Scienze, vol. 1. u. 173. Mus. p. 64.

1870. - A. Boeck, Crust. amphip. bor. et arct. p. 15.

Typ.: Lysianassa Coste, Milne Edwards.

Mandibulæ mala in margine interiore dente parvo, sed longo, tenui instructa: palpo elongato, in eadem altitudine ac tuberculo molari minuto affixo.

Maxillæ $1 \mathrm{mi}$ paris lamina interna permagna, in apice setam parvam aut obsoletam gerenti.

Maxilla 2di paris lamina interiore lata, exteriore angusta.

Pedes maxillares lamina exteriore ovata vixqve in margine interiore noduJosa, non ad finem articuli 2 di palpi elongati angustiqve porrecta: Lamina interiore elongata.

Antenne superiores articulo pedunculi 2 do et 3 tio paulo elongalis.

Pedes 1 mi paris manu non subcheliformi; articulo 5 to elongato, apicem versus altenuato; ungve parvo.

Pedes saltalorii clongati; ramis paris ultimi brevioribus qvam pedunculo, selosis.

Appendix caudalis parva, integrá, postice rotundata.

Milne Edwards grundede denne Slrgt i 1830 (Ann. des Sc. Nat., Tome XX) paa tvende meget forskjellige Arter. Krøyer henfører hertil i 1838 (Grønl. Amphipoder) adskillige nye Arter, som han $\log$ fandt at adskille sig saa meget fra de af Milne Edwards opforte, at de lumle danne en egen Slregt, Anomy.e. Milne Edwards skiller inirllertid i 1840 (Hist. de Crustacés, Tome III) sin ene Art fra Slægten under Navn af Alihotus og forenede alle Kroyers Anonyxarter med den anden under Lysirmus.s. Kroyer tror dog, i 1842 (Nat. Tidsski., S. 166), at Lysianassa og Anonyx kunne bestaa ved Siden af hinanden, da det andet Fodpars Form er forskjellig hos begge. Dana optager Slæogten Lysianassa og adskiller den fra Anonyx ved det forste Fodpars Form. De senere Forfattere have fulgt denne Anskuelse, undtagen Goës i 1865, som sammenfatter alle de nordiske Arter, der henhøre til Underfamilien Lysianassinac, under Slægten Lysianassa; Lilljeborg tror, at han har gjenfundet den typiske Art ved Norges Kyst; skjønt jeg ikke er aldeles sikker paa Identiteten, folger jeg ham dog i hans Mening, men finder ikke nogen Grund til at hemregne Ichnopus spinicomis, Boeck, og Anonyx Vahti til Lysianassa, ¿a jeg anser begge som Typer paa gode Slagter; jeg henregner til denne Slagt L. Costre, Milne Edwards, og L. plumosa, Boeck. De Karakterer, hvorved denne Slagt skiller sig fra de nærstaaende $0 \mathrm{~g}$ da vasentlig fra Slægten Socames, ere: Overlæbens Form, der hos hin er ganske simpel, merlens den hos den sidstnavite er meget forlanget, fremstatande og skarp samt forener sig med Lpistomet i en skarp Spids; desuden ere Kindbakkerne 
korte, hvorved Palpen ikke er firstet saa ilybt nede som ellers. Med Hensyn til det Ydre er det meget karakteristisk fol demne Slagt, at Halevedhanget er helt, hvorved den skiller sig let fra de ovrige Slagter af denne Familie, med hvilke den har Lighed deri, at det forste Fodpars Haand ikke er gribende. Til denne Slægt hører, foruden de tvende nedenfor beskrevne, manske de af Costa beskrevne Arter $L_{0}$ spinicornis og L. loricata, hos livilke Halevedhænget ogsaa er helt. Muligens horer hertil ogsaa L. Tongiconis, Lucas.

LYSIANASSA PLUMOSA, A. Boeck, 1870.

(PI. III. Fig. 5.)

Lysianassa plumosa, A. Boeck, Crust. amphip. bor. et aret. 1870. p. 16.

Angulus lateralis anticus capitis produclus, acutus. Oculi reniformes, nigri. Angulus lateralis posticus segmenti poshabdominis 3 tii sursum produchus et acutus. Intenna superiores articulo pedunculi $2 d o$ eadem longitudine ac crassitudine; articulo Imo flagelli longitudine reliqvis tribns junctis aqvali. Antenna inferiores articulo pedunculi to paulo longiore qvam crasso: articulo 5 to duplo ferme longiore: llagello praelongato. Pedes $1 \mathrm{mi}$ paris articulo 5 to tribus articulis antecedentibus junctis longitudine aqvali, s-formi. Pedes 2di paris articulo 2do paulo longiore qvan carpo. Pedes 5ti paris articulo 1 mo, eadem latitudine ac altitudine. Pedes saltatorii 3tii paris ramis brevioribus q vam pedunculo, setis plumosis longis instructis. Appendix caudalis postice truncata.

Dyret er $9^{\mathrm{mm}}$ langt.

Legemet er temmelig sammentrykt, Ryggen er rund, Sidepladerne ere middelmaadig store, og den fjerde er bagtil dybt indsliaret for den femte, der er ubetydelig bredere end hoi. Det tredie Haleleds nedre bagre Vinkel danner en opadboiet Hage. Hovedet er af middelmaarig Storrelse, og dets Sidevinkler ere meget ultrukne og tilspidsede, ligesom Spidsen er noget indalboriet. Øinene ere store, nyreformede.

De ovre Føleres Skaft er forlænget; det forste Led er tykt, bredt, med nogle fjordannede Borster paa den ledre Rand; det andet er ontrent saa langt som bredit, det tredie er kort. Svgben er liengere end Skaftet $0 \mathrm{~g}$ bestaar af $10 \mathrm{Led}$, hvoraf det forste er rlet tykkeste og saa langt, som de tre folgende tilsammen. Bisvoben er smal og hestaar af 4 forlengede Led.

De nedre Fuleres tredie Led er kort, det fjerle er langere end bredt $0 \mathrm{~g}$ paa den ovre Rand forsynet med Here Borsteknipper, det femte er nasten dobbelt saa langt og ligeledes paa den ovre Rand besat med Borsteknipper. Svoben er sxrdeles lang og bestaar omtrent af hs forlangede Led, hvoraf de overste have Sugeskale. Kindbakkerne ere forlangede; under Spidsen, der ikke er meget bred, er fiestet tre sma Torne. Palpens forste I,ed er temmelig langt, llet tredie el meget kortere end let andet. 
Det furste Kjabepar er kraftig udviklet og i Spidsen vahnet merl starke med Bitronder forsynede Trender. Palpen er bred, med nogle Trender i spirtsen. Den indre Plade el forlænget, noget tilspidset paa Enden og uden Borster.

Det andet Kjabepars ydre Plade er meget smalere end den indre og har mange Borster i Spidsen.

Kjabefoddernes ydre Plade el bred, oval, med meget svage Knuder par den indre Rand. Den indre Plade er ogsaa bred og tret besat med smaa Burster paa Spilsen og paa den indre Rand. Palpen er smal; dens andet Led er temmelig langt. og Kloen er staerk.

Det forste Fodpar er lidet; dets forste Led er omtrent saa langt, som de folgende tilsammen; det andet, tredie og fjerde Led ere korte; ilet femte er meget smalt, forlæuget, lidt s-formet krummet, Kloen er liden.

Det andet Fodpars andet Led er sarleles langt og smalt, det fjerde el noget kortere end dette, men bredere, det femte er ovalt, tat besat med Borster.

De trende folgende Fodpar have eens Bygning; deres tredie Led er lidt udvidet nedad, det fjerde er kortere og smalere, og det femte er noget langere, men smalere end dette; de tre sidste Led have paa den bagre Kant lange fjærformede Borsțer og paa den forreste lignende, men smaa. Kloen er lang, smal, dog meget kortere end det femte Led.

De tre folgende Eodpar tiltage efterhanden i Længde; det forste Led er pala det femte Par næsten ligesaa bredt som hoit, paa det syvende er det meget langere end bredt, svagt saugtakket paa den bagre Rand og forsynet med smaa Børster, det fjerde Led er kortere og det femte læugere end det tredie. Kloen er swrdeles lang; masten saa lang som det femte Led.

De tre Springfodder ere forlangerle og naa nasten lige langt bagud. Grenene ere paa de tvende forste omtrent lige lange, besatte med Burster paa Randen; det tredie Pars Grene ere kortere end Skaftet, og den indre er noget kortere end den ydre; begge have lange, fjarformede Børster paa den indre Rand.

Halevedhænget er helt, forlanget, skraat afskaaret paa llen bagre Rand.

Denne Art liguer meget $L$. longicornis, Lucas, men den afviger fra denne derved, at de ovre Folere mangle den lange Torn paa Skaftets forste Led, der findes hos hin Art. Hovedets Sillevinkel er ogsaa mere tilspidset. Ogsaa ligner den L. Iongicomis, Spence Bate \& Westwood (British sessile-eyed Crust. p. 85), da denne mangler Torne paa de ovre Folere, skjont den skal vare identisk med den af Lucas opforte Art: disse Forfattere tegne dog den nedre bagre Vinkel paa det tredie Haleled tilrundet. hvilket ikke er 'Tilfoldet med denne Art. Et eneste Exemplar blev taget ver Haugesund paa 50 Eavmes Iybde i 1868. 
LYSIANASSA (?) CYMBA, Goës. †

Lysianassa (?) Cymba, Goës, Crustacea amphipoda. p. 5. fig. \%

Alta ac lata, dorsum carina acuta, media, a segmento primo ad decimum continuata, hic in spinula angulari postica desinente; segmentum undecimum dorso excavato, Iamina sursum curvata, apice acuto, terminatum; frons rostro compresso. perpendiculari, valido, marginem inferum epimeri tertii aqqvante vel superante: pedes primi gracillimi, filiformes, arliculo qvarto longissimo. Epimera primum et secundum rudimentaria. qvartum permagnum securiforme; appendix cauda late ovalis apice integro. Mediam tenet inter Lysianassas et Stegocephalos. (Goës).

Dyrets Længde er efter Goës $10^{\mathrm{mm}}$. Hvorvidt denne Form hører til Lysianassa eller er en Mellemform mellem denne og Stcgocephahus, kan jeg ikke afgjøre, da jeg ikke har seet Dyret. Blandt Lysianassideme have vi en Form, paa hvilken Ryggen er kjølet, nemlig Orchomene umbo, medens jeg ikke kjender nogen med kjølet Ryg horende til Underfamilien Stegocepphatinae. Det andet Fodpars Haand henviser ogsaa denne Form til Lysianassiderne, men det saa stærkt forlængede forste Fodpars Haand viser, at den ikke kan henhøre til Slægten Orchomene, hvilken den dog forøvrigt ligner meget ved sine hoie Sideplader. Den kommer vistnok efter fornyet Undersogelse til at damne en ny Slrggt blandt Lysianassiderne.

Denne blev tagen ved Spitsbergen i Storfjord af Malmgren paa 5 Favnes Dybde. LYSIANASSA COST E, Milne Edwarls, 1830.

(Pl. IV. Fig. 1.)

Ly sianassa Coste, Milne Edwards, Anm. des Sc. Nat. t. XX. 1830. p. 365. pl. 10. fig. 17.

- Costa, Su' Crost. Amfip. Mem. d. Accad. d. Sc. d. Napoli. Vol. I. 1856. p. $18 \%$.

- Spence Bate, Synopsis Brit. Amphip. Ann. Nat. Hist. 1857.

- Spence Bate, Cat. Amphip. Crust. Brit. Mus. 1862. p. 69. pl. X. fig. 11.

- Spence Bate and Westwood, Brit. sessile-eyed Crust. t. I. 1863. p. 74.

- Lilljeborg, On the Lysianassa magellanica 1865. p. 21.

- Heller, Beitr. z. näh. Kenntn. Amphip. adriat. Meeres. p. 18.

- Boeck, Crust. amphip. bor. et arct. p. 16.

Gammarus glaber (Spinola), White, Cat. Brit. Mus. (Crustacea). 184\%. p. 89.

Angulus lateralis posticus segmenti 3 tii postabdominis sursum productus. acufus. Angulus lateralis anticus capitis productus, acutus. Oculi magri, reniformes, nigri. Antenne superiores articulo pedunculi 2do longiusculo, apicem versus attenuato; articulo 3tio breviore et angustiore qvam 2 do, duplo ferme longiore qvam crassiore; articulo flagelli 1 mo non multo longiore qram articulis cxteris; Hagello accessorio biarticulato; articulo ultimo minimo. Intenne inferiores articulo tho et 5 to eadem longitudine. Pedes $1 \mathrm{mi}$ paris articulo 5 to apicem versus attenuato, vix longiore 
qvam 4to. Pedes 2di paris articulo 2do et to ferme eadem longitudine. Pedes 5 ti paris articulo 1 mo ferme latitudine eadem ac altitudine. Pedes saltatorii ultimi paris ramis setis paucis instructis. Appendix caudalis paulo longior quam ad basin lata, postice rotundata.

Dyret er $\mathrm{s}-10^{\mathrm{mm}}$ langt.

L e g emet er forlænget, smalt, temmelig sammentrykt. Den nedre bagre Vinkel paa det tredie Haleled er opadbøiet i en stærk Hage. Hovedet. er længere end det første Legemsled, og dets Sidevinkel er ultrukket i et langt, tilspidset Fremspring; Øinene ere store, nyrefornede.

Sidepladerne ere hoie; de fire forrste damne tilsammen nedad en smal Bue; den fjerde Sideplade er dybt indskaaret bagtil for den femte, der knapt er saa hoi som brerl.

De orre Føleres forste Led er tykt, opsvulmet, med fjærformede Børster i den nedre Rand; de tvende folgende, der aftage stærkt i Tykkelse, ere tilsammen knapt saa lange som det forste Led. Svoben daunes af 12 Led, hvoraf det første ikke er meget længere end de folgende; nogle af disse have par Enden af den undre Rand lange, tykke Børster. Bisvøben er toleddet og dens sidste Led meget lidet.

De nedre Følere ere hos Hunnen ubetydelig længere end de øvre, deres tredie Led er forlænget, næsten tre Gange san langt som tykt; det fjerde Led er længere end dette og saa langt, men tykkere end det femte; Svgben er hos Hunnen saa - lang som Skaftet og damnes af 8 Led.

Kindbakkerne ere forlængede, smale; Griberlelen er afrundet $0 \mathrm{~g}$ har kun en liden Tand paa den ydre Rand; Tyggeknuden er meget liden, og den indre Bigren er lang og tynd. Palpen er ogsaa forlænget; dens tredie Led er tyndt og har kun lidt mere end Halvdelen af det andet Leds Længde.

Underlæbens Flige ere temmelig smale.

Det $\mathrm{f} ø \mathrm{r}$ ste Kjæbepars ydre Plade er paa Enden skraa afskaaret og har stærke, paa den indre Rand saugtakkede Trender; den indre Plade er forlænget, mod Enden smalere og har kun faa Børster. Palpen er toleddet, paa Enden sangtakket og paa den ydre Rand vabnet med en bevægelig Torn.

Det andet Kjæbepars ydre Plade er Here Gange saa smal som den indre, der er af en forlænget oval Form.

Kj $æ$ b ef $ø$ dd ernes indre Plade er temmelig stor, med fjærdannede Børster og tre smaa Tænder paa Enden; den ydre Plade er oval, i Spidsen afrundet, uden Knnuder paa den indre Rand; den naar ikke frem til Enden af Palpens andet Led.

Det forste Fodpars forste Led er temmelig bredt, med lange Børster paa den forreste Rand; det andet og tredie Led ere korte; det fjerde Led bliver bredere udad og er omtrent saa langt som det femte, ler bliver tilspidset mod Enden, hvor den lille, spirlse Klo er frstet. 
Det andet l'ody ar er meget forlanget, smalt; dets andet Led er laengere end det tredie $0 \mathrm{~g}$ omtrent saa langt som det fjerde, der paa begge Rande har Bundter af Børster; Haanden er kortere end det fjerde Leds halve Længde, bliver udad bredere og har en paa Enden skraa afskaret Griberand.

De folgende tvende Fodpar ere meget tynde, især deres fjerde og femte Led.

Det femte lodpars forste Led er neppe hoiere end bredt; len bagre liand er halvcirkelformet $0 \mathrm{~g}$ fint tandet.

De folgende tvende Fodpar tiltage lidt i Langde, ligesom ileres furste Led er langere end bredt.

Springfodderne ere lange og smale; deres ydre Gren er kortere end den indre, som paa det sidste Par er meget kortere end Grundleddet.

Halevedhanget ex ovalt, smalere i den ydre Del end ved Roden, med en svag. bueformet bagre Rand.

Denne Art stemmer saa neget overens med den af Spence Bate it Westwood tegnede $0 \mathrm{~g}$ beskrevne $L$. Costac, saa at jeg ikke tvivler paa, at begge ere den samme Art. Da disse Forfattere have sammenlignet sin Art med Milne Edwards's Originalexemplar og fundet, at den er den af ham beskrevne Form, tvivler jeg heller ikke paa Identiteten med Milne Edwards's Art L. Costac, skjont den afviger meget fra hans 'Tegning. Efter Heller skal ogsaa $L$. lumilis, Costa, hore hid.

Denne Art er saaledes udbredt fra Middelhavet og Adriaterhavet til Linglands Kyster, hvor den gaar lige op til Shetland. Ved Norges Kyst er den fundet af Lilljeborg ved Christianssund, af G. O. Sars ved Mosterhavn paa 100-150 Favnes Dybde og af mig par 60 Favnes Dybde ved Haugesund.

Gien. II. AMBASIA, A. Boeck, 1870.

Deriv: Ambasia (Namet par en Flod).

Syn.: 1870. Ambasia, A. Boeck, Crust. amphip. bor. et arct. p. 17.

Typ.: Ambasia Daniclsscnii, Boeck.

Epistomum valde gibbosum, prominens.

Mandibula palpo elongato et tenui, profundius quam tuberculo molari parvo affixo.

Maxilla $1 \mathrm{mi}$ paris lamina interiore minima, ovata.

Haxilla 2di paris breves, non latre.

Pedes maxillares laminis exterioribus permagnis, ovatis, vix in margine interiore nodulosis; palpo brevi; arliculo 4 to tuberculiformi.

Antemne inferiores articulo 3tio prelongato.

Pedes Imi paris graciles, manu subcheliformi destituti. 
Pedes saltatorii ultimi paris breves; ramo interiore multo breviore qram exteriore.

Appendix caudalis brevis, fissa.

Denne Slægt skiller sig vasentlig fra Lysianassa med Hensyn til Munddelenes Bygning, medens den ligner den 1 let forste Fodpars Form. Kindbakkerne ere her, ligesom hos Lysianassa, korte, men dog er Palpen fæstet noget under Tyggeknuden. Den indre Plade paa det forste Kjæbepar er meget liden, oval, og saaledes meget mindre end hos den foregaaende Slagt, ligesom Tandbesætningen paa den ydre Plade er meget svagere. Mest eiendommelig er dog Kj̉zelbefoddernes Bygning; deres Palpe er nemlig meget forkortet, og dens fjerde Led, som ellers i denne Familie or klodannet, er her meget liden, næsten rudimentær og knudeformet. Den ydre Plade er derimod særdeles stor, hvorved Palpen kun rager lidt udenfor dens Ende. Ved det forlængede tredie Led paa de neilre Foleres Grunddel ligner den Slægten Orchomene, med hvem den ogsaa lar Lighed deri, at Epistomet og Overlæben ere stærkt udbugtede, hjelmdannede, men dette er dog mere Tilfreldet hos denne Slægt, end hos Orchomene. Heraf har jeg kun fundet den typiske Art, men maaske hører hid Anonyx Smardae, Heller, (Beitr. z. näh. Kennt. Amphip. Adriat. Meeres, p. 21. t. II. fig. 29-32), hvis forste Fodpars Haand bliver tilspidset mod Enden, og hvis Halevedhreng el dybt kløvet, samt A. filicomis, Heller, (do. p. 23. t. III. fig. 13-16i). Derimod kam L. attantica ikke hore herhen, da Halevedhrenget hos denne er udelt.

AMBASIA DANIELSSENII. A. Boeck. $187 \%$.

(Pl. III. Fig. 6.)

Ambasia Danielssenii, A. Boeck, Crust. amphip. bor. et arct. 1870. p. 1\%.

Oculi magni, lageniformes, rubri. Epimera qvatuor anteriora peralta: epimerum 5tum eadem longitudine ac latitudine. Angulus posticus lateralis segmenti postabdominis 3tii paulo sursum productus el aculus. Segmentum postahdominis 4lum in margine medio posteriore pergiblosum. Antenne superiores articulo flagelli Lmo eadem longitudine ac reliqvis 6 junctis. Antenne inferiores articulo pedunculi 5 to multo breviore qvam 4to. Pedes 1 mi paris manu longitudine articulo 4 to aeqvali et vero apicem versus attenuata. P'edes 2 di paris manu ovala, dimidiam 4ti longitudinem reqvanti. Pedes pariua trium ultimorum articulo 3tio parum dilatato. multo breviore qvam articulo 5to. Appendix caudalis multo longior qvam lata. ad basin fere fissa; laciniis in apice singula spina instructis.

Dyret er 8-10mm langt fra Spidsen af Hovedet til Halevedhxnget.

Legemet er noget sammentrykt fra Siderne, men Ryggen er rund, uden Kjøl. Det tredie Haleleds nedre bagre Vinkel er tilrundet, dog med en liden, svagt udtrukket 
Hage. Det fjerte Haleled har en starkt fremstaaende, noget tilspidset Pukkel. Sidepladerne ere store, den forste lirkies for en Del af den anden; den er meget høiere end bred. Hovedet har et ganske lidet Pandehorn mellem de wre Finlere; Hovedets Sidevinkler ere stærkt forlængerle, tilspidsede mod Enden.

De ovre Foleres forste Led, der er meget stort og tykt, er opad noget udvidet over det andet, der ligesom det tredie er meget kort. Svobens forste Led er meget langt, bliver smalere mod Enden og er par den indre side forsynet med mange dobbelte Tværrader af Borster. Svobens folgende fem Lell ere tilsammen omtrent saa lange som dest forste Led.

De nedre Føleres tredie Led er forlanget; det fjerde er end langere, men det femte noget kortere end fjerde. Svoben bestaar hos Hannen af fem cilierede Led. Overlaben er bredere end his.

Kindbakkerne ere starke. Deres Spids er meget bred, og under denne findes der to smaa Torne. l'alpens andet Led er meget langt, og det tredie er kort, forsynet med en Rad af korte, tylke Borster.

Det første $\mathrm{Kj}$ be par er starkt $0 \mathrm{~g}$ har i Spidsen lange smale, i Kanten saugtakkede Torne. Palpen har i Spidsen en Torn og nogle smaa Trender. Den indre Plade er meget liden.

Det andet Kjæbepar's ydre Plade er bredere end den indre.

K jæb efod d ernes ydre Plade er særdeles stor, oval, ikke væbnet med Tæuder eller Knuder; den indre er ogsaa sardeles forlænget, bliver bredere mod Enden og har ler nogle Borster, men ikke Tauder. Palpen er særdeles kort, den naar kun ubetydeligt frem over den ydre Plade, dens Klo er rudimentar, knudeformig.

Det første Fodpars første Led er stærkt; de følgende meget smalere; det fjerde Led er forlænget, og det femte, der er meget lingere, men smalere, dammer ingen Haand. Kloen, hvis Basis indtager hele Spidsen af det sidste Led, er kort og noget krummet.

Det andet Fodpar er forlanget; det forste Led er næsten saa langt som de folgende tilsammen; det andet Led er ubetydeligt kortere end det fjerde; det femte er forlanget og danuer en saxdannet Haand, der drkkes af mange Børster.

Det femte Fodpars forste Led er meget bredt og bliver smalere nedad; det tredie Led er kum noget langere end bredt; det fjerde er langere og smalere, og det femte er meget Iængere end dette.

Det syvende Fodpars forste Led er middelmadig stort, forlanget, firkantet, med afrumdede Hjorner. Leddene ere noget kortere end paa det femte Par.

Springfodderue ere korte, og Grenene paa dem alle naa lige langt bagud; den indre Gren er paa de tvende forste ubetydeligt kortere end den ydre, men paa det sirlste Par er den meget kortere og tykkere.

Halevedhæn get er noget langere end bredt, klovet nasten til Roden og paa spilsen rabnet med tvende 'Torne. 
Denne Art er taget af G. O. Sars ved Mosterhavn par 40 Favnes Dyb og af mig udenfor Skudesnas paa 100 Favnes Dyb.

Gen. III. ICHNOPUS, Costa, 1853.

Deriv.: ixvos (tynd), rovs (Fod).

Syn.: 1853. Ichnopus, Costa, Recherche Crost, amfip. IRendicont. dell. Accad. di Sci. Napoli. 1853. p. 172.

1856. - Costa, Su' Crost. amfip. d. reg. Nap. Mem. d. Accad. d. scien. d. Napoli. 1856. p. 176 et 188 .

1860. - Boeck, Bemærkninger ang. Amphipoder. Forh. ved de Skaud. Naturf. 8de Møde 1860. p. 644.

1862. - Spence Bate, Cat. Amphip. Brit. Mus. p. 84.

1866. - Heller, Beiträge z. näh. Kenntn. Amphip. adriat. Meeres. p. 18.

1870. - A. Boeck, Crust, amphip. bor. et aret. p. 18.

Typ.: Ichnopues taurus, Costa.

Nandibulae breves: mala truncata, in margine sinuata; palpo in eadem altitudine ac tuberculo parvo molari affixo; articulo palpi 3 tio tenui, curvalo.

Maxilla $1 \mathrm{mi}$ paris laminis interioribus parvulis.

Maxillre 2di paris laminis gracilibus.

Pedes maxillares laminis cxterioribus perlongis et perlatis, in margine nodulosis: articulo palpi 2 do brevi; 3 tio elongato.

Antennæ flagellis prælongatis, multiarticulatis.

Pedes $1 \mathrm{mi}$ paris manı gracili, apicem versus attenuata, haud subcheliformi.

Pedes saltatorii paris 2 di ramo interiore diverso ab exteriore, in margine medio interiore gibboso; in gibbere illo seta valida affixa.

Pedes saltatorii paris ultimi ramis elongatis.

Appendix caudalis longa, fere ad basin fissa.

Vesicula branchiales pectinatim plicatr; plicaturis ab rachi media exeuntibus.

Costa opstillede denne Slrgt i 1853 og i 1856. I det sidste Aar giver han følgende Diagnose af Slægten: "Antennae longae, graciles, superiores bisctae. Pentes quatuor anteriores longi, graciles, filiformes, haud prehensiles, primi ungviculo mimuto infra peetinato terminati; secundi membranacei, mam apice longe fimbriata, ungviculo vix conspicue." Derpaa viser han, at den skiller sig fra Slagterne Callisoma og Alibrotus, og omtaler Gjallernes særegne Form. Den blev optaget af mig i 1860, og jeg henforte hertil den nye Art I. spinicomis (Forhandl. ved de skand. Naturf. 8de Mode. p. 645). Spence Bate (Cat. Crust. Amphip. Brit. Mus. p. 84) optager ligeledes denne Slrgt, som han forøvrigt ikke kjender. Lilljeborg slog den i 1865 sammen med Lysianassa, medens 
Heller (Beitrigge 0. s. v. p. 18) optog den paany, ligesom jeg i 1870 (Crust. amphip. bor. et arct.) Costa fremhaver isæer, at Folemè tre lange, tynde, og at det forste Fodpar er forsynet med en licken kamdannet Klo. Dernæst omtaler han, at Gjællerne ere eiendommelig byggede derved, at de som et Blad have en Midtribbe og derfra udgaande Sideribbe, hvilke alle fremstaa ved Folder i Gjællebladet. Denne Bygning har jeg, foruden hos deme, kun fundet hos een anden Slrgt, nemlig Atylus. Heller angiver kun som Forskjel mellem denne Slagt og Anomyx, at det forste Fodpar er tyndt og slankt. og at den indre Side af Kloleddet er besat med 'Torne. Derimod omtaler han ikke de ovrige, ganske karakteristiske Mærker, hvorver den skiller sig fra alle de nærstaaende Former. Hos denne Slægt ere Munddelene ikke forlangede, men derimod meget korte; Overlaben er łerfor bred, ikke udstaaeude, simpel; Kindbakkernes Palpe er frstet ovenfor Tyggekmuden; Underlabens Flige ere brede, men korte, og Kjæbefoddernes Plader ere brede. En anden Eiendommelighed, som jeg har fundet hos een drt af denne Slagt, er, at det andet Par Springfodders indre Gren er paa det indre Parti fortykket, medens Endedelen er meget smal, tynd. Derved opstaar der midt paa denne Gren en Pukkel, hvorfra en Børste udspringer. I det Ydre er denne Slagt meget iøinefaldende veil de meget forlangede ovre Følere, hvilket ikke er sadvanligt i deme Familie og gjentindes kun hos Anomyx littoralis. Sliegten indeholder fire Arter, hvoraf den typiske I. taums er opstillet af Costa, I. affinis af Heller og $I$. spinionin (I. calceolatus, Heller) samt I. mimutus af mig.

ICHNOPUS SIINICORNIS, A. Boeck, 1860.

(Pl. H. Fig. 3.)

Ichnopus spinicornis, Boeck, Forhandl. ved de Skand. Naturf. Sde Mode i Kjobenhavn 1860. p. 645 .

-1- Boeck, Crust. amphip. bor. et arct. 1870. p. 18.

Lysianctsa spinicornis, Lilljeborg, On the Lysianassa magellanica. 1865. p. 20.

Ichnopus calceolatus, Heller, Denkschr. k. Akad. d. Wiss. B. 26. 1867. p. 20. t. II. fig. $26-28$.

Oculi magni, fere reniformes, nigri. Angulus lateralis anticus capitis elongatus, rotundalus. Ingulus lateralis posticus segmenti postabdominis 3tii paulo sursum produclus et acutus. Antenna elongata; superiores articulo pedunculi tmo in exIremo margine inferiore aculeo instructo: articulo 2do item infra armato; flagello apud feminam circiler $60-66$ articulato: apud marem $55-100$; flagello appendiculari 10articulato. Pedes $1 \mathrm{mi}$ paris arliculo 5to eadem longitudine, angustiore vero qvam carpo, duplo longiore qvam lato; articulo '2do elongato, curvato et paulo breviore qvam carpo, ungve magno et intus serie aculeorum armato. Pedes 2di paris mamu parva, lata, ovata, ferme tertiam articuli 4ti longitudinis partem reqvanti: 
articulo 4 to apicem versus clavalo, dilatato. Pedes trium ultimorum parium articulo Imo lato: eodem articulo 5 ti el 6li paris parum producto, in postico inferiore margine rolundato. Pedes óti paris articulo 5 to ferme earlem longitudine ac duobus articulis antecedentibus junctis. Pedes 6ti et $7 \mathrm{mi}$ paris articulo 5to breviore. Appendix caudalis plus duplo longior qvam ad basin lata et ultra medium fissa.

Dyret er i Almindelighed $18^{\mathrm{mm}}$ langt fra Hovedet til Halevedhenget, men et Exemplar naaede $30^{\mathrm{mm}}$ Langde.

Legemet er temmelig forlonget, sammentrykt, med rund Ryg. Det femte Haleled er meget kort, og det sjette er paa Ryggen fladt og begrændses til Sideme af to lave Kjøle. Sidepladerne ere af middelmaadig Størrelse, og den fjerde er ilke meget dybt indskaaret for den femte, der er lengere end høi. Den indre bagre Vinkel paa det brede Haleled er afruntet, men der damnes ved et Indsnit i den bagre Rand en liden opadboiet Hage. Hovedet er meget kort, og der dames intet Pandelıom mellem de ovre Folere. Hovedets Sidevinkler ere noget udtukne $0 \mathrm{~g}$ afrundede. Oinene ere meget store, noget nyreformede.

De $\emptyset \mathrm{vre}$ Folere ere forlangede og ere omtrent saa lange som Hovedet og de tre eller fire forste Legemsled tilsammen. Deres Skaft er ikke meget forlanget; det første Led er langere end tykt og ulsender en kort Torn paa Undersiden af dets Ende; de to folgende Led ere meget korte og tilsammen ikke fuldt saa lange som det forste Led. Svoben er meget forlanget og bestaar af henved 70 med Sugeskale forsynede Led, der ere meget korte. Bisvgben er meget lang og tynd og danues af ni forlængede, men tynde Led.

De nedre fulere ere longere end de ovre; de tvende forste Led ere utylelig adskilte; det tredie er omtrent saa langt som bredt, skraat afskarret paa den forreste Ende; det fjerde er omtrent dobbelt saa langt som bredt, og det femte er noget kortere og tyndere og som det foregaaende noget udvidet udad; begge have paa den nerlre Kant korte fjactamede Borster. Svoben dannes hos Hannen af 46 merl Sugeskale forsynede Led.

Kindbakkerne ere i Spidsen brede og med en fremstaaende smal'Tyggeknude; Palpen er forlænget; dens andet Led er det lengste, og det tredie er stærkt bøiet, smalt og forsynet med smaa Børster paa den concave Rand.

Det første Kjabepar er paa Enden stærkt tilspidset $0 \mathrm{~g}$ forsynet med faa, men starke, noget krumme Trender og cilierede Børster langs den indre Rand. Palpen bliver bred mod Enden og er der nasten tvart afskaaret og forsynet med smaa Tander.

Det andet $\mathrm{Kj}$ a $\mathrm{b}$ epar er forlænget, lidet; den ydre Plade er den langste.

Kj a b e foddernes ydre Plade er særleles bred, skraat afskanen opad, og har paa Randen smaa Knuder. Palpen er kort, hvilket især skyldes det korte, men brede andet lied.

Det forste Fodpars forste Led er meget starkt; det andet er mere end dob- 
belt saa lingt som bredt. og de folgende blive efterhatuden smalere. saa at Foden bliver tilspidset mod Enden; det femte er noget langere, men smalere end det fjerde.

Paa det andet Fodpar er det andet Led forlænget, medens det fjerde knapt er længere, men lidt tykkere end dette $\mathrm{g}$ har paa Enden en stærk Dusk af lange Børster; det femte Led er kort, — omtrent Halvdelen af det foregaaende Leds Langde, men godt dækket af Børster, der ere længere paa den forreste end paa den bagre Rand.

De tvende følgende Fodpar ere starke; deres tredie Led er ikke meget udvidet, men langere end det smalere fjerde Led; det femte er langere end det fjerde, og Kloen er temmelig lang, krum.

De tre sidste Fodpar tiltage efterhaanden i Langde; deres første Led er -bredt og paa den bagre Rand saugtakket; det er paa det forste Par kortest, men tiltager i Langde par de følgende Par; deres tredie Led er sardeles kort, men bredt og har fjærdannede Borster; det fjerde er omtrent ligesaa langt, men smalere, og det sidste er længere og smalere sant vabnet med tætte, mien korte Torne paa den forreste Rand.

Det forste og tredie Par Springfodder naa omtrent lige langt bagud, medens det andet Par er noget kortere. Det forste Pars Grene ere lange og krumme samt forsynede med mange smaa Torne. Den indre Gren paa det andet Par er kortere end den ydre, men meget bredere paa det inderste Parti og bliver ved Midten pludselig smalere; til den derved fremstaaede indre Fremragning er en Børste frestet.

De sidste Par Springfodders Grene ere forlsengede, lancetformede, fint cilierede paa begge Kanter; den indre er ubetydeligt kortere end den ydre.

Halevedhænget er forlænget, smalt, spaltet næsten til Roden.

Deme Art skiller sig fra $I$. taums, Costa, ved at de ovre Foleres forste Skaftled er væbnet med en Tand, ved at de to forste Fodpar ere meget kortere og tykkere, ved at det femte Led paa femte til syvende Fodpar er kun lidet eller neppe langere end fjerde Led, medens det hos $I$. taurus er mere end dobbelt saa langt, og endelig ven at den nedre bagre Vinkel paa det tredie Haleled er damet til en liden Hage.

Yed Norges Kyst er den fundet af M. Sars i Manger paa 40-50 Favnes Dyb, ved Beian er den fundet af C. Boeck, i Stavangerfjorden af G. O. Sars paa $30-40$ Fames Dyb og sammesteds nær Skudesnæs af mig paa 50 Favnes Dyb. I Adriaterhavet er den fundet af Heller ved Ragusa.

ICHNOPUS MINUTUS, A. Boeck, 1870.

$$
\text { (Pl. III. Fig, i.) }
$$

Ichnopus minutus, A. Boeck, Crust. amphip. bor. et arct. 1870. p. 19.

Oculi reniformes. Angulus lateralis anticus capitis parum productus, rotundatus. Angulus lateralis posticus segmenti postabdominis 3tii paululum sursum productus, acutus. Antemix superiores pedunculo spinis carcnti: articulis brevibus: llagello brevi. Antenna inferiores articulo pedunculi tho el jto inter se eadem longitudine. 
Pedes Imi paris manu longitudine carpum superanti: loc longitudinem arliculi $2 \mathrm{di}$ aeqvanti. Pedes 2di paris manu elongati, ovata, longiore qvam dimidia carpi parte; carpo longitudine arliculum 2dum ferme xefvanti. Pedes trium parium nltimorum articulo Imo postice valde dilatato, infra vero non producto. Appendix caudalis ferme ter longior quam lata, in tertia exteriore parte fissa.

Dyrets Langde er $4^{\mathrm{mm}}$.

Legemet er temmelig sammentrykt, men Ryggen er urlen Kjøl. Sidepladerne ere af middelmaadig Storrelse; den fjerde er ikke meget indskaaret hagtil; den femte, der er længere end høi, er indskaaret paa den nedre Rand, hvori det femte Fodpar er frstet. Paa let andet Haleled er den nedre bagre Vinkel noget tilspidset; det tredie Leds Vinkel er opadboiet til en liden Hage. Hovedet er længere end det forste Legemsled, og dets Sidevinkler ere ikke meget forlængede, men afrundede.

Folerne ere forlangede, temmelig tykke.

De øve Folere ere langere og tykkere end de nedre og strække sig, nar de bries tilbage, til det fjerde Legemsled; Skaftets første Led er omtrent saa langt som Hovedet og liengere end de tvende folgende tilsammen; Svgben er længere end Skaftet og bestaar af tolv grove Led, som hos Hannen ere forsynede med Sugeskaaler.

De nedre Føleres fjerde og femte Led ere kun noget længere end brede, indbyrdes omtrent lige lange; Svgben dannes af tolv tykke Led, hvis ovre Side hos Hannen har Sugeskaaler.

De trende forste Fodpar ere temmelig smale og korte; det forste Pars andet Led er omtrent af samme. Længde eller noget længere end det fjerde Led; det femte er længere end de foregaaende Led, tykt ved Roden samt bliver tilspidset mod Enden, hvor den lille krunme Klo er fxstet.

Det andet Fodpars andet Led er noget kortere end det fjerde, der er tykt mod knden; det femte Lerl er meget kortere end dette, ovalt forlæuget og forsynet med en Dusk Borster paa Enden.

Det tredie og fjerde Fodpar ere stærke; det tredie Led er temmelig, bredt, og det femte Led er en Trediedel lingere end det foregaaende og forsynet med en stærk, noget krummet Ǩlo.

Det femte liodpars forste Led er meget bredt, ovalt; det tredie Led er ogsaa meget bredt, men kort; det fjerde er noget længere, og det femte er meget langere og smalere.

Det forste og tredie Par Springfødder naa omtrent lige langt bagud, medens det andet er kortere. Grenene paa det sidste Par ere lancetformig forlængede; den ydre Gren er noget læugere end den indre.

Halevedhænget er kløvet.

Denne blev af mig fundet i et eneste Exemplar i Christianiafjorden nær Moss. 
Hvis den ikke havde havt Sugeskaaler paa Folerne, hvilke kun findes hos de voxne Hanner, vilde jeg have anseet den for en Unge af den foregaaende Art.

Gen. IV'. SOCARNES, A. Boeck, 1870.

Deriv. :

-Syn.: 1870. Socarnes, Boeck, Crust. amphip. bor. et aret. p. 19.

? 1848. Ephippiphora, White, Ann. and Magaz. of Natural History. Ser. 2. 1. p. 226. Typ.: Lysianassa (Anonyx) Vahli (Reinharit), Kroyer.

Labium superius prolongatum, prominens, acerrimum, cum apice epistomi acuto conjunctum.

Mandibulae mediocriter elongate: palpo multo profundius yram tuberculo molari prominenti affixo.

Maxilla lmi paris dentibus perlatis; lamina interiore prolongata. angusta et in apice duobus setis plumosis instructa.

Ilaxillæ 2di paris laminis angustis, elongatis.

Pedes maxillares laminis exterioribus ovatis, in margine interno nodulos parvulos gerentibus: lamina interiore prelongata: arliculo palpi 2do elongato: articulo 4to ungviformi.

Antennæ breves.

Pedes $1 \mathrm{mi}$ paris breves; manu apicem versus allenuata el haud subcheliformi.

Appendix caudalis longitudine mediocris, usqve ad medium fissa.

Denne Slægt stemmer i enkelte Dele overens med Lysianassa, især med Hensyn til det forste Fodpars Bygning, idet Haanden ei er indrettet til at gribe med, men bliver smalere mod Enden. Derimod afvige de fra hinanden i Munddelene, især ved den saerdeles store Overbhe og det fremstanende Epistomum, hvilke ere forbundine med hinanden og danne en fremstaaende skarp Forlængelse foran Munden. Kjæbefoddernes Plader ere hos Socarnes meget storre end hos Lysianassa: ligeledes vise Kindbakkerne og det andet Kjabepar Uoverensstemmelse. I det Ydre afvige de mest fra hinanden ved Halens Form, idet det sidste Par Springfodders Grunddel er kort og Halevedhanget er forlænget, dybt indskaaret paa Enden.

Den eneste Art af deme Slrgt i Norden er S. Vahli, der af Spence Bate og Lilljeborg er henfort til Slægten Lysianassa. Hvorvidt forovrigt Slægten Socarnes afriger fra White's Ephippiphora, kan jeg ikke afgjore; men den af Spence Bate givne Tegning af White's typiske Art $E$. Kröyeri fra Van-Diemensland synes at stemme overens med s. Tuhli: dog har han tegnet Haleverlhanget aldeles klovet, hvilket ikke er Tilfaldet hos Socarnes. Det er muligt, at herhen hører Heller's Lysiannssa filicomis, da Overlæben efter Tegningen viser en Overensstemmelse med den hos denne Slæegt, men Haleved- 
hrenget er dog tegnet helt, hvori den saaledes afviger. fra Socarnies. Anomyx nardonis synes ogsaa at ligne denne i flere Henseender og at høre herhen. En ny Art, der af M. Sars er taget ved Neapel, horer til denne slægt, saa at den omfatter mindst tvende, maaske fire Arter. Den af Heller opstillede $A$. fiticornis synes ogsaa at hore til denne Slagt, og Halevedhænget er her dybt spaltet.

\section{SOCARNES VAHLI, Krøyer, 1838.}

(P1. V1. Fig. 8.)

Grammarus nugax, Owen, Append. to J. Ross' second Voyage. 1834. p. 87.

- Spence Bate, Cat. Crust. Amphip. Brit. Mus. 1862. p. 65. pl. X. fig. 3.

Anonyx (Lysianassa) Vahli, Kroyer, Gromlands Amphipoder. 1838. p. 万.

- Kroyer, Naturhist. Tidsskrift. 2. Række. B. I. 1844. p. 599.

- Krøyer, Voyages en Scand. etc. t. 14. fig. 1. (1848?).

- Bruzelius, Skand. Amphip. Gammar. 1859. p. 43.

Lysianassa Vahli, Milne Edwards, Hist. Nat. des Crust. III. 1840. p. 21.

- Spence Bate, Cat. Crust. Amphip. Brit. Mus. 1862. p. 68. pl. X. fig. 5.

- Lilljeborg, On the Lysianassa magellanica ete. 1865. p. 21.

- Goës, Crust. amphip. Spetsb. 1866. p.2.

Socarnes Vahli, Boeck, Crust. amphip. bor. et arct. 1870. p. 20.

Oculi magni, reniformes, nigri. Angulus capitis anticus lateralis productus. rolundatus. Angulus inferior posticus segmenti postabdominis 3tii valde rotundatus. Antenne superiores arliculo pedunculi 2do el 3tio parvulis: flagello appendiculari elongato et 5-6articulato. Antenne inferiores articulo 4 to apud feminam cylindrico. multo longiore qvam articulo 5io: apud marem perbrevi et in margine inferiore producto. Pedes $1 \mathrm{mi}$ paris carpo apicem versus valde dilatato: manu parum longiore et apicem versus angustiore. Pedes 6ti et $7 \mathrm{mi}$ paris articulo 3 tio breviore qvam 4 to et parum dilatato; articulo 5 to parum longiore qvam 4to. Pedes saltatorii ultimi paris ramo interiore parmm breviore qvam exteriore, eadem longitudine ac pedunculo: ramo utroqve in margine nonnullis selis instructis. Appendix caudalis ferme duplo longior qram ad basin lata, ultra medium fissa et hians.

Dyret er i udstrakt 'Tilstand $10 \mathrm{~mm}$ langt.

Legemet er kort og sammentrylit fra Silerne, men Ryggen er dog afrundet $0 \mathrm{~g}$ bred. De fire første Sideplader ere meget høie $\mathrm{g}$ smale; den fjerde er bagtil dybt indskaaret for den femte, der er noget bredere end høi. Det tredie Haleleds nedre bagre Vinkel er stærkt tilrundet. Hovedet er kortere end det første Legemsled og danner mellem de øre Følere en meget stump Vinkel. Øinene ere nyreformede.

De ovre Folere ere omtrent saa lange som Hovedet og Legemets trende forste 
Led. Skaftets forste Led er ikke meget tykt og ikke fuldt dobbelt saa langt som de tvende folgende tilsammen. Svoben dannes af 12 Led; det første er ikke meget langere end bredt og neppe dobbelt saa langt som det folgende. Bisvoben er saa lang som Svøbens syv forste Led og danues af 6 smale Led.

De nedre Følere ere hos Humnen noget lengere end de øvre; Skaftets tredie Led er meget kort, knapt saa langt som bredt; det fjerde er hos Hunnen forlænget, smalt, meget langere end det femte, der naar frem til Enden af de øve Føleres Skaft. Hos Hannen bliver det fjerde Led meget bredt udad og forlænger meget sin øvre ydre Vinkel; det femte Led er ligesaa langt, meget sinalere og noget krummet. Svoben dannes af 9 Led hos Hunnen, men af 56 Led hos Hamnen.

Overlæben er forlænget, tilskjærpet paa den undre Kant, og fortil mellem de wve Folere gaar den ud i en kort Hage; dens Sidelapper ere stærkt behaarede.

Kindbakkerne ere kraftige, brede i Spidsen, uden Bitand; der findes en tydelig forlæuget Tyggeknude. Palpen er frestet meget nær Roden af Kindbakkerne.

Underlaben er meget stor og starkt behaaret paa Enden af de ydre og indre Flige.

Det forste Kjabepar er væbnet med stærke 'Tsender, der have Bitæuder paa den indre Kant; Palpen er tandet oventil. Kjæbeføddernes Palper ere meget smale, og deres andet Led er forlænget; den ydre Plade er forsynet med særdeles smaa Knuder paa den indre Rand; den indre Plade er stærkt forlænget med tre Tænder i Spidsen og nogle fjærdannede Børster paa den indre Rand.

Det forste Fodpar er af den samme Bygning hos begge Kjøn, dets femte Led er omtrent saa langt som det fjerde og tilspidser sig mod Enden, der optages af den korte Klo, som ikke kan bøie sig ind mod Haanden.

Det andet Fodpars fjerde Led bliver meget tykkere mod Enden; det femte Led er kort, og Griberanden er ret.

Det sjette Fodpar er noget langere end det femte og det syvende; deres forste Led er bagtil maadelig udvidet 0 g har en saugtakket Rand; deres tredie Led er meget kort og lidet udvidet; det fjercle er noget længere end det tredie og saa langt som det femte.

Det forste l'ar Springfodder naar langst bagud.

Det tredie Pars indre Gren er lidt kortere end den ydre, der omtrent er saa. lang som Grundleddet.

Halevedhinget er af middelmaadig Størelse og kløvet til lidt over Midten.

F arven paa et Exemplar fra Nordkap var gulhvid, marmoreret med brunrødt paa de tre forste samt det sjette og syvende Legemsled med tilsvarende Sideplader, ligesom der fandtes tvende brunsorte Pletter paa de tvende første Haleleds Rygdel. Ffter Krøyer ere de gronlandske Exemplarer rent hvide med smuk karmosinrod Marmorering paa Ryggen og Midten af Siderne; Øinene ere sorte. 
Dens Udbredning er fra Grønland og Spitsbergen, hvorfra Krøyer og Goës har faret den, lige til Haugesund, hvor jeg har fundet den paa 60 Favnes Dybde. Ved Island er den taget af 'Torell, ved Bergens Kyst er den fundet af M. Sars, Lilljeborg og Danielssen, i Nordland er den taget af G. O. Sars ved Skraaven og Brettesnæs paa 10-40 Favnes Dybde, ved Langenas af mig, ved Nordkap af Collett.

Goës angiver, at der ogsaa findes en Varietet, der i Formen lidt afviger fra de typiske Exemplarer og er mindre: "Var. segmenti abdominalis tertii angulo postico rotundato, neqve truncato nec emarginato, statura minori."

Denne Art er først beskreven af $O$ wen under Navnet Gammarus nugax, men da Cancer nugax, Phipps, ikke er denne Art, men den af Krøyer i 1838 under Navn af Lysianassa (Anomyx) lagena beskrevne Form, maa Arten beholde Kroyers Navn.

\section{Gen. V. CALlisOMA, Costa, 1851.}

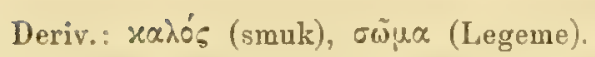

Syn.: 1851. Callisoma, Costa, Cat. Crust. Ital. hy the Rev. Mr. Hope. 1851.

1855. Scopelocheirus, Spence Bate, Brit. Assoc. Report 1855. p. 58.

1856. Callisoma, Costa, Su' crost. amfip. d. reg. Napoli. Mem. d. Accad. d. sci. di Napoli 1856. p. 174.

1857. Scopelocheirus, Spence Bate, Synopsis etc. Ann. Nat. Hist. XIX. p. 138.

1862. Callisoma, Spence Bate, Cat. Crust. Amphip. Brit. Mus. p. 84.

1863. - Spence Bate and Westwood, Brit. sessile-eyed Crust. p. 119.

1865. - Lilljeborg, On the Lysianassa magellanica etc. p. 33.

1866. - Heller, Beitr. z. näh. Kenntn. d. Amphip. adriat. Meeres. p. 26.

1870. - A. Boeck, Crust. amphip. bor. et aret. p. 21.

Typ.: Callisoma Hopei, Costa.

Mandibula elongatæ: palpo infra profunde aflixo, sed in eadem altitudine ac tuberculo molari.

Maxilla $1 \mathrm{mi}$ paris lamina interiore elongata, in margine interno selis multis instructa; palpo in apice lato, dentibus multis latis, in apice furcatis, armato.

Maxillæ 2di paris laminis perbrevibus, sed latis.

Pedes maxillares palpis elongatis, angustis; lamina exteriore in margine interno spinis robustis armata; lamina interiore lata.

Pedes $1 \mathrm{mi}$ paris graciles, sat elongati, imprimis articulus 4 tus et 5tus; hic ungve parvulo instructus.

Appendix caudalis longa, profunde fissa. 
Costa opstillede denne Slrgt i 1851 paa Arten U. Hopei fra Neapel. Spence Bate, som ikke kjendte Costa's Arbeide, opstillede en anden Art, C. crenata, under Navnet Scopelocheirus. Bruzelius henførte en Art, der af ham var fundet ved Norges Kyst, C. Kröyeri, til Slægten Anonyx. I 1856 havde imidlertid Costa tilføiet en uy Art, ('. pumetutum, som ikke er optaget i Spence Bate's Catal. of Crust. Amphip. Brit. Mus. Arternes Antal af denne Sliegt el saaledes fire. Lilljeborg og Heller optage ogsai slagten. Som Karakter fremhavede Costa Formen af det forste Fodpar, der er langt, tyndt, traaldannet, hworved den skilte sig fra den nerstanende slægt Lysiunnssa; Spence Bate fremhaver ogsaa den samme Karakter, men siger, at det første Fodpar ikke har en klodannet Finger; desuden anforer han, at det andet Par Spriugfidder ere eengrenede, lıvilket dog ikke er Tilfællet, heller ikke er Halevedhrenget dobbelt, men kun dybt kløvet. Lilljeborg omtaler, at det første Fodpar har en rudimentær Klo eller mangler denne, og at det ikke er tykkere og undertiden tyndere end det andet Par. Desuden henter han adskillige Karakterer fra Munddelene, idet han anforer: at den indre Plade paa det forste Kjæbepar er forsynet med talrige Borster; og at dets Palpe er i Spidsen væbnet med gaflede Tænder. Kjæbeføddernes ylre Plade har endelig Torne i den indre Rand. Heller tager derimod som Slægtskarakter kun Hensyn til det forste Fodpars Form og siger, at dette mangler Endeklo. Kindbakkerne mangle efter ham Tyggeknude, der dog findes paa begge de norske Arter. C. Hopei skal efter ham være fundet i Middelhavet levende paa Spatanger og mellem Alger.

\section{CALLISOMA CRENATA, Spence Bate, 1855.}

(Pl. VII. Fig. 1.)

Seopelocheirus crenatus, Spence Bate, Brit. Assoc. Report. 1855.

- Spence Bate, Synopsis. Ann. Nat. Hist. Feb. 1857. p. 138.

Callisoma crenata, Spence Bate, Cat. Amphip. Brit. Mus. p. 85. pl. XIV. fig. 5.

Spence Bate and Westwood, Brit. sessile-eyed Crust. p. 120.

A. Boeck, Crust. amphip. bor: et arct. p. 21.

Angulus lateralis posticus segmenti postabdominis 3 tii rectus; margine postico crenulato. Segmentum postabdominis 4tum incisura selliformi transversa. Antenna superiores articulo 1 mo multo longiore qvam crasso; articulo flagelli 1 mo elongato. longitudinem trium articulorum seqventium junctorum xqvanti. Pedes $1 \mathrm{mi}$ paris prælongati; carpo elongato, qvadrangulari, paulo breviore qvam articulo 5to; hoc qvater aut qvingivies longiore qvam lato et parum curvato; ungve parvo. Pedes 2di paris ferme eadem crassitudine ac $1 \mathrm{mi}$ paris: articulo 3 tio in margine antico dente uno obtuso armato; articulo 4 to multo longiore qvam 3tio et fere duplo longiore qvan 5to; hoc duplo longiore qvam crasso. Appendix caudalis ferme ter longior quam lata et fere ad basin lissa. 
Dyrets L $\mathfrak{i n g}$ ge er $8-10^{\mathrm{mm}}$.

Legemet er fortil meget tykt, ligesom opblast; med rund liyg, medens Halen bliver mere sammentrykt fra Sideme. lira det sidste Rygled begynder en Kjøl, der bagud tiltager i Høide og faar et dybt Indsnit tvært over den øvre Del af det fjerde Haleled. Sidepladerne ere store; den fjerde er bagtil dybt indskiaret for den femte, der er longere end høi. Den nedre bagre Vinkel paa Halens tvende første Led er afrundet; det tredie Led er retvinklet, afskaaret og den bagre Rand er svagt rundtakket. Hovedet er meget lidet og gaar mellem de avre Folere ud i et meget lidet Pandehorn. Hovedets Silevinkler ere afrundede og ikke meget fremstaaende.

De gvre Foleres Skaft er meget tykt; det forste I ed er stort; de tvende folgende sman. Svohens furste Led er af middelmaadig Liengde, noget langere end de tre følgende tilsammen. Bisvgben bestaar af tre Led, hvoraf det forste er meget langt.

De nedre Føleres første Led er meget tykt, opblast; det andet er kort, men danner paa den nedre Rand en lang stærk Torn; det tredie I.ed er kortere end tykt; det fjerde er forlænget, omtrent tre Gange saa langt som tykt; det femte er lidt kortere og smalere; Svoben er lang; hos Hunnen dannes den af 22 Led.

Kindbakkerne ere i Spidsen brede, og Tyggeknuden er utydelig:

Det første Kjabepars Palpe har i Spidsen stærke Tænder, der nær deres Ende ere forsynede med en liden Bitand. Den indre Plade er forlænget, med en Rxkke fjerdannede Borster langs den indre Rand.

Kjæbef $ø$ d dernes ydre Plade er forlænget, smal, med en Række Tænder paa den indre Kant og Spids; Palpen er forlenget, smal.

Det første Fodpar er meget forlænget; det første Led er stærkt, de øvrige meget smalere; det andet Led er flere Gange saa langt som tykt, og det fjerde er forlænget, men noget kortere end det femte, der bliver smalere mod Enden; denne er tvært afskaaren og forsynet med tæette, noget krummede Børsterader.

Det andet Fodpars femte Led er forlænget, men dog kortere end det fjerde.

De trende folgende Fodpar have den sædvanlige Form; det fjerle Led er meget kortere end det tredie $0 \mathrm{~g}$ femte, som indbyrdes nasten ere af den samme I.ængde, men det femte er meget smalere.

De tre bagre Fodpar tiltage efterhaanden. i Længde.

Det femte Fodpal's forste Led er særdeles udvidet bagtil, saa at det er bredere end høit, og saugtakket; det tredie Led er ligeledes udvidet og udtrukket i Spidsen; det fjerde bliver bredere nedad; det femte er meget længere, men smalere.

Det syvende Fodpars forste Led er høiere end bredt, næsten firkantet, med afrundede Hjørner; det fjerde Led er længere end det tredie, der ikke er meget udvidet; det femte er igjen langere end dette; disse tre Led have Tome paa den forreste Rand.

De tvende første Par springføider naa omtrent lige: langt bagud. 
Det tredie Pars ydre Gren er noget langere end den indre, der paa den indre Kant har enkelte Borster; begge er hetydeligt langere end det korte Grundled.

Halevedh nget er forlænget, lancetdannet og kløvet nasten til Roden.

Spence Bate angiver, at det sidste Par Springfødder kun er eengrenet, hvilket sandsynlig maa bero paa en mindre nøiagtig Observation. Han angiver, at Farven er lys orangefarvet, og at hvert Legemsled er kantet med hvid Farve, samt at Dyret er oversaaet med en Mrngde smaa sorte Pletter. Det kan være Tvivl underkastet, om denne Art afviger fra $C$. Hopei fra Middelhavet. I England er denne Art almindelig par forskjellige Lokaliteter og er ogsaa fundet af Norman ved Shetland. Danielssen har taget den ved Christianssund, G. O. Sars ved Aalesund paa 60-100 Favnes Dybde og i Hardangerfjorden pa 40-50 Favne. Af C. Boeck er den fundet ved Sondfjord og af mig ud for Haugesund paa 70 Favnes Dybde.

\section{CALLISOMA KRÖYERI, Bruzelius, 1859. †}

Anonyx Kröyeri, Bruzelius, Skand. Amphip. Gam. 1859. p. 45. t. II. fig. 7.

Callisoma Kröyeri, Spence Bate, Cat. Amph. Crust. Brit. Mus. 1862. p. 371.

- $\quad$ - Lilljeborg, On the Lysianassa magellanica. 1865. p. 33.

A. Boeck. Crust. amphip. bor. et arct. 1870, p. 22.

Oculi magni. ovati. nigri. Angulus lateralis posticus segmenti postabdominis 3tii perrotundatus. Segmentum postabdominis ttum supra non impressum. Antenna superiores articulo pedunculi 1 mo perbrevi. Pedes Imi paris carpo multo breviore qvam manu, triangulari: manu ter longiore quam lata. Pedes 2di paris breviores et latiores quam apud speciem pracedentem: articulo 3tio spina obtusa carenti: carpo ovato. crasso, paulo longiore qvam manu ovata: hac duplo longiore quam lata. Appendix caudalis duplo longior qvam lata, profunde fissa.

Dyret er omtrent $7_{\mathrm{mm}}$ langt.

L e gemet er tykt, høit, med afrundet Ryg; det fjerile Haleled er uden nogen paatvrers gaaende sadelfornig Indtrykning paa dets Midte: den nedre bagre Vinkel paa det tredie Haleled er stærkt tilrundet. Hovedet er lidt læengere end den forste Legemsring. Øinene ere store, ovale.

De grre Følere ere kortere end de nedre; det første Skaftled er meget tykt, stort, opsvulmet; de tvende folgende ere swrdeles korte: Svobens forste Led er omtrent saa langt som de folgende tre til fire tilsammen og har paa den indre Side lange Børster; de øvrige Led blive tyndere mod Enden; Bisvoben dannes af tre til fire Led, af hvilke det første er smalt og meget længere end de øvrige tilsammen.

De nedre Føleres fjerde og femte Led ere omtrent lige lange; Svaben bestaar af fire til fem Led hos Hannen og to hos Hunnen.

I Mundelene er denne Art lig den foregaaende. 
Det forste Fodpar er meget langt og smalt; dets forste Led er ret, bliver nedad betydeligt bredere, det andet Led er ikke fuldt sait langt som det foregaaende, men længere end det tredie; det fjerde er næsten af en triangulær Form med buet forreste Rand, det femte Led eller Haanden er saa langt som de tvende foregaaende Led tilsammen, af en smal rectangulær Form, paa Enden lidt skraat afskaaret og der forsynet med en Mængde krumme Børster; paa Enden af den bagre liand findes en fin tandet Indskjæring, hvori Kloen sidder næsten skjult af Børsteme. Denne er forsynet paa den concave land med nogle Tæuder.

Det andet F odpar er lidt kortere end det forste; dets andet Led er kortere end Halvdelen af det forste, det fjerde bliver meget bredere udad og er onvendt aegrundt; det femte Led er kortere end dette, ovalt, og dets nedre bagre Vinkel lidt udtrukket; Kloen er meget lort og stærk.

Det tredie og fjerde lodpar ere strerke.

Det femte til syvende Fodpar tiltage efterhanden bagud i Langde, deres forste Led er meget bredt, i den bagre Rand fin saugtakket; det tredie Led er ikke langere end det fjerde og kortere end det femte.

Det første og andet P’ar Springfødder naa lige langt bagul; Grenene ere af samme Langde.

Det sidste P'ars Grene ere smalt lancetformede, den indre er noget kortere end den ydre, og begge have $\mathrm{i}$ den ydre Rand nogle Tome.

Halevedhrnget er omtrent dobbelt saa langt som breit og erkløvet nasten til Roden; Fligene ere i Spidsen forsynede med en 'Torn.

Venne Art synes saaledes at skille sig fra den foregaaende, vasentlig ved at den nedre hagre Vinkel paa det tredie Haleled er stiekt tilrundet, medens den hos den foregatende Art danner en nasten ret Vinkel, or ved at det fjerde Haleled mangler det dybe sadelformige Indsnit tværs over dets Rygdel. Det andet Fodpars Carpus er ogsaa forholdsvis meget kortere, ligesom det hele Fodpar er kortere og tykkere end hos C. crenata.

Jeg har selv ikke seet denne Art, som efter Bruzelius er fundet fra Fimnarken til Bohuslen.

Gen. VI. HIPPOMEDON, A. Boeck, $18 \%$.

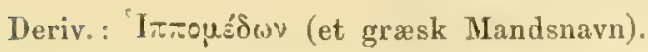

Syı.: 1870 Hippomedon, A. Boeck, Crust. amphip. bon. et arct. p. 22.

Typ.: Anonyx Holbölli, Krøyer.

Iandibulæ breves: mala exteriore angusta, in sinistra parte dente parvulo accessorio instructa: palpo in eadem altitudine ac taberculo molari permagno affixo.

Iaxilla $1 \mathrm{mi}$ paris palpo in apice dentibus multis. brevibus, lalis, parum serratis instructo: lamina interiore sat brevi, in apice duabus setis plumosis instructa. Maxillæ 2di paris laminis brevibus. 
Pedes maxillares breves. lati: lamina exteriore ultra articulum palpi 2dum porrecta, in margine interno dentibus crebris, validis armata; lamina interiore brevi. Antenne elongate: antennæ inferiores articulo 5 to multo longiore qvam 4 tu.

Pedes $1 \mathrm{mi}$ paris sat elongati; imprimis articulus 4tus; manu invalida, subcheliformii.

Appendix caudalis elongata. mofunde fissa, ultra pedunculum pedium saltatoriorum paris ultimi porrecta.

Lilljeborg fandt i 1865 (On the Lysianassa magellanica etc. S. 31), at Anonyx Holbölli afveg meget fra de andre under Ammy.x hurenile Arter ved Bevæbning af den ydre Plade paa Kjabefodderne og ved det forste Fodpars Form, saa at den burde damne Typus for en ny Slægt, uden at han dog opstillede en saadan. Goës forggede samme Aar Lysianassa-Arterne med en ny, L. abyssii fra Grønland, der viser et særdeles nært Slægtskab til A. Holbölli, og begge bør saaledes stilles sammen til en ny Slægt, som af mig i $18 \% 0$ blev givet Navnet Hippomedon.

Denne afviger fra de øvrige vasentlig ved le tvende af Lilljeborg allerede anforte Karakterer, desuden kommer hertil flere, der kumne hentes fra de ovrige Munddele, det sidste Par Springfonder og Formen verl Halevedhanget. Kindbakkerne ere saaledes meget korte og stærke, næsten mere end hos nogen anden Slægt i denne Familie, hvorfor ogsaa den tynde Palpe er frstet høit oppe, langt ovenfor Tyggeknuden. Af samme (rund ere ogsaa Underlabens Flige meget korte, og de indre Bitlige ere hnapt antydede. Kjæberne ere tillige korte, men brede, af hvilken Grund det første Kjæbepars Palpe, der til Silleme drekker Mellemrummet mellem Kindbakkeme og Kjabefoiderne, opad bliver meget bred. Paa Enden af denne sees en Bessetning af meget kraftige Tænder. Halevedhænget er ogsaa meget forlænget og rager frem bagenfor det sidste Par Springfodders Grunddel; Halevedhanget er spaltet mere eller mindre dybt.

Af denne Slrgt kjendes kun to Arter, nemlig den typiske H. Holbölli og den af Goës beskrevne Lysianassa abyssi fra Grønland.

\section{HIPPOMEDON HOLBÖLLI, Kroyer, 1846.}

(Pl. V. Fig. 6. Pl. VI. Fig. 7).

Anonyx Holbölli, Krøyer, Naturhist. Tidsskr. 2. R. 2. B. (1846) p. 8.

Krøyer, Voyage en Scand. etc. Crustacés. P1. 15. f. 1.

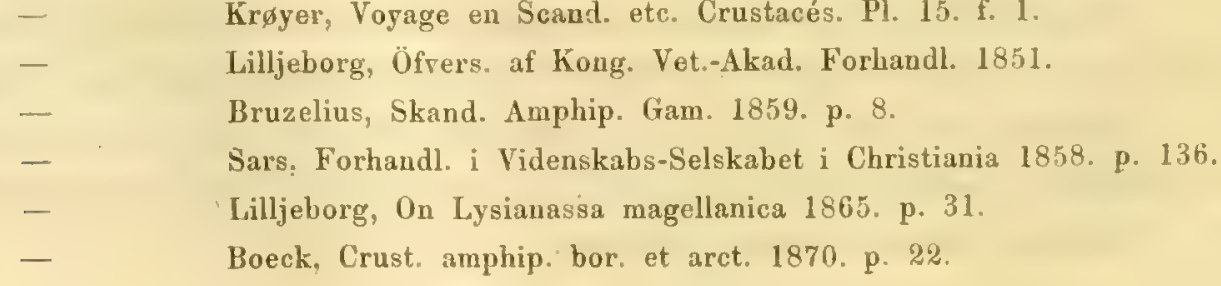


Anonyx denticulatus, Spence Bate, Cat. Amphip. Crust. Brit. Mus. 1862. p. 75.

Spence Bate and Westwood, Brit. sessile-eyed Crust. t. 1. 1863. p. 101 .

Lysianassa Holbölli, Goës, Crust. amphip. Spetsb. 1866. p. 4.

Oculi magni, reniformes, rubri. Angulas lateralis posticus segmenti postalıdominis 3tii sursum productus et acutus. Antennæ superiores articulo pedunculi 2 do et 3tio brevissimis et in extremo margine superiore productis; articulo flagelli 1 mo longituline $8-10$ articulos scyventes junctos aptrvanti: articulo llaggelli accessorii 1 mo longiore qvam seqventibus duobus. Pedes 1 mi paris manu elongata, ovata, duplo vel ter longiore qvam lata et in acie obliqve truncata, parum modo longiore quan dimidia carpi longitudine; carpo angusto. Pedes 2di paris manu ovata; articulo 2 do paulo breviore qvam carpo. Pedes parium trium ultimorum articulo 1 mo haud valde dilatato: articulis reliqvis angustis: arliculo 3tio subdilatato; articulo 4to parum longiore; ungve longo et subcurvato. Pedes saltatorii ultimi paris ramis multo longioribus yvam arliculo basali. Appendix caudalis duplo longior qvam ad basin lata, ultra medium fissa.

Legemet er $10-14^{\mathrm{mm}}$ langt fra Hovedets Spids til Halevedhænget. Ryggen er rund, uden Spor af lijol; Sideplaterne ere middelmathig lange: den fjerde, der er hredere end de foregarende, er paa den bagre Rand særdeles dybt indskaaret for Optagelsen af den femte Sideplade, der er længere end høi. Hovedet er ikke fuldt saa langt som de tvente forste Legemsled: Sidevinklerne ere sardeles lange og strerkt afrundede i Spidsen. Oinene ere lange, men smale og blive bredere nedad.

De øvre Følere ere korte, Skaftet er særdeles tykt; dets første Led er næsten saa tykt som langt, de tvende andre ere meget korte. Svoben er langere end Skaftet og dannes af 10 Led, hvoraf det forste er omtrent Halvdelen af Skaftets Længde og omtrent saa langt som de folgende tre tilsammen.

De nedre Folere ere længere end de øvre; Skaftets fjerde Led er det længste og mere end dobbelt saa langt som tylit samt forsynet med fem Børster paa den indre Side; det femte Led er kortere $0 g$ meget smalere. Svoben bestaar af 17 forlængede Led.

Kindbakkerne ere meget brede og uden Tænder i Spidsen, men tre smaa saadanne sees paa den ydre Rand noget indenfor Spidsen.

Kjabefoddernes ydre Plade er i Randen fint knudret og paa Enden forsynet med tvende suaa krumme Torne. Den indre Plade er i Spidsen væbnet med en stærk stump Tand $0 \mathrm{~g}$ forovrigt med fjærdannede Borster.

Det forste Fodpar er forlænget; det andet Led er meget langt, omtrent tre Gange saa langt som bredt. Det femte Led eller Haanden er forlænget, smal og længere end det foregaaende Led. Kloen er liden, med en Tom paa den concave Side. 
Det andet frodpars fjerle Led er noget længere end det andet; Haanden er oval.

De tvende følgende Fodpars tredie Led er langt og bredt.

De tre bagre Fodpar tiltage indbyrdes efter hinanden $i$ Læengde 0 g ere forlængede; det fjerde Led er længere end det tredie, og det femte er længere end det fjerde. Det bagre Hjorne af det tredie Haleled er starkt udtrukket i en ikke meget lang, lidt opadbøiet Hage.

Det tredie Par Springfodder strskker sig ligesaa langt bagud som det første, medens det andet Par er kortere. Den ydre Gren paa det tredie Par er noget langere end den indre, og begge ere smale.

Halevedhænget er meget forlænget og klovet nasten til Roden.

Demne Art er fundet ved Gronland, hvor den dog efter Krøyer ikke er hyppig; fra Spitsbergen er den medbragt af den svenske Expedition. Ved Norges Kyst er den fundet af M. Sars fra Bergen til Vadso, og sammesteds ogsaa af Danielssen. Verl Aalesund er den taget af G. O. Sars paa 60-100 Favnes Dybde, og efter Bruzelius er den fanget ved Bohuslen.

Jeg har taget den ud for Haugesund paa 60 Favnes Vand og inde i Bukkenfjorlen paa 150 Favne, i Stavangerfjorden er den ogsaa taget af G. O. Sars paa 40-60 Favne. Udenfor Norge findes den efter Spence Bate ved England, Syd til Plymouth.

Farven var paa de Exemplarer, jeg tog ved Haugesund, lys, brunlig gul paa Ryggen, medens den nedad paa Kroppen var hvid. Oiet var smukt rosenrodt. Hele Legemet var forovrigt plettet med rosenrode Flekker, der især vare stærkest paa de tvende forste Sideplader, paa alle Halens Led og Springfoddernes Grundled. Efter Krøyer er Farven paa de grønlandske Exemplarer lys, ansigtsrod med morkere liyg eller smuk rodgul med xblerød Ryg.

HIPPOMEDON ABYSSI, GoëS, 1865.

Lysiancessa abyssi, Goës, Crust. amphip. maris Spetsb. p. 3. f. う̆.

Hippomedon abyssi, A. Boeck, Crust. amphip. bor. et arct. 1870. p. 23.

Angulus posticus lateralis segmenti postabdominis 3tii acutus, sursum valde productus et curvatus. Oculi ovati, rubri. Antennæ articulo pedunculi 1 mo præIongato; articulo flagelli Imo brevi, longitudine articulos tres seqventes junctos æqvanti. Pedes 1 mi paris manu parum breviore qvam carpo, fere qvadrangulari. Pedes 2di paris articulo 2do plus duplo longiore qvam brevi. Pedes parium trium ultimorum articulo 1 mo paulo breviore qvam apud speciem pracedentem; articulis reliqvis item multo brevioribus et Iatioribus; articulo 3tio vix longiore quam lato. Appendix caudalis paulo longior qvam ad basin lati, in summo dimidio fissa: laciuis in apice truncatis, spinis qvinis instructis. 
Dyrets Langde er $13-14 \mathrm{~mm}$.

Legemet er temmelig sammentrykt med rund Ryg. Sidepladerne ere af middelmaadig Høide; den fjerde er dybt indskaaret for den femte, der er noget bredere end høi og er midt paa den nedre Rand indskaaret for Befæstelsen af det femte Fodpar. Det tredie Haleleds nedre bagre Vinkel damer en lang opad briet Hage; det fjerde Led har ingen saddelformig Indtrykning ovenpaa. Hovedet er nasten saa langt som de tvende forste Legemsled tilsammen, og dets nedre forreste Vinkel gaar ud i en Spids.

De $ø$ vre Fole re ere omtrent saa lange som Hovedet og Legemets tre forste Led tilsammen; Skaftets forste Led er forlænget, cylindrisk. De tvende folgende ere meget korte. Svoben dannes af 10 til 12 Led, hvoraf det forste kun er saa langt som de folgende 2 til 3 Led tilsammen, Bisvoben dannes af 3 forlængede Led, der alle have næsten den samme Læugde.

De nedre Foleres tredie Led er kort, det fjerde og femte ere omtrent lige lange, men det fjerde er tykkere; Swoben dannes af 22 Led.

Mund delene stemme aldeles overens med dem hos H. Holbölli.

Det forste Fodpar er meget kortere end det andet, men af samme Form som hos $H$. Holbölli; Haanden er kortere end det fjerde Led, og dens forreste og bagre Rande ere nasten parallele; i den nedre Ramd er den meret skiat afskaret og forsynet med Børster samt en 'Torn paa Enden.

Det andet Fodpars fjerde Led er længere end det andet og bliver meget bredere nedad.

De tvende folgende Fodpars tredie Led er kun lidet udvidet, og dets Rande ere parallele; det femte Lerl er langere, men smalere end det fjerde. Paa den forreste Rand ere de to eller tre sidste Led besatte med tornformede Borster.

Det sjette Fodpar er langere end det foregaaende og efterfolgende, og alle have paa den forreste Rand lange tornformede Børster. Deres forste Led er meget bredt og sangtakket paa den bagre Rand; deres tredie Led er udvidet paa det femte og sjette Fodpar, men smalt paa ret syvende; deres femte Led er noget kortere end det fjerde; Kloen er tynd $\mathrm{og}$ lidt boiet.

Alle Springfod der naa næsten lige langt bagud.

De to forreste Pars ydre Gren er kun ubetydeligt kortere end den indre, $0 \mathrm{~g}$ begge ere besatte med tynde forlængede Torne.

Det tredie Pars indre Gren er bredere og kortere eud den ydre Gren, der paa den ydre Rand og Spids har mange forlængede tynde Torne. Den indre Gren er kortere og smalere $0 \mathrm{~g}$ er ligeledes forsynet i Spidsen med nogle saadame Torne.

Halevedhæuget er klovet omtrent til Midten; Fligene ere vidt adskilte, i Spidsen afstumperle og der besatte med flere tynde Torne.

Denne Art er fundet af Torell ved Gronland i stor Mrngde paa 250-280 Favnes Dyb. I Kjobenhavns Museum saa jeg et Exemplax, der ligeledes var taget ved Gronland, i Baffinsbugten, paa 300 Favne. 
Gen. VII. Cyphocaris, Lütken.

Deriv.: xij фos (Pnkkel), xápx (Hoved).

Syn. : 1870. Cyphocaris, A. Boeck, Crust. amphip. bor. et arct. p. 23.

Typ.: Cyphocaris anomyx, Liitken.

Mandibulie brevissimæ; palpo longo et latissimo, in eadem altitudine ac tuberculo molari robusto affixo.

Maxilla $1 \mathrm{mi}$ paris palpo apicem versus dentibus paucis sed validis et una seta pralongata plumosa armato; lamina interiore elongata el in margine interno setis multis plumosis instructa.

Pedes maxillares lamina exteriore brevissima, in margine interno dentibus pancis sed validis armata: palpo prielongato; articulo tto cylindrico, non ungviformi, seta una robusta plumosa instructo.

Antenna inferiores articulo 1 mo ab integumentis capitis non tecto, sed extus visibili, in incisura eorundem sito.

Pedes 1 mi paris manu apicem versus acuta, vix subcheliformi.

Pedes 2di paris elongati, ungve destituti.

Appendix caudalis profunde fissa, longe ultra articulum basalem pedium sallatoriorum ultimi paris porrecta.

Segmentum trunci Imum valde gibbosum; caput sub segmento eodem silum, ex parte tectum; epimerum Imum nullum, 2dum parvulum; 3tium et 4tum coalita, magna.

Blandt de Amphipoder, som fandtes i Kjobenhavns Museum fra Gronland, var ogsaa denne eiendommelige Form, som af Lütkcn var erkjendt som en ny Slagt og var opstillet under ovenstaaende Navn. Allerede i det Ydre skiller den sig meget fra de øvige Former, især ved. det forste Legemsleds eiendommelige Bygning; det er nemlig starkt puklet fremstarende, medens Hovedet ligger skjult under det. Man kunde derfor let tro, at det var Hovedet, som havde demne Form. Nedad bliver dette Led meget smalt og dækkes tildels af det andet, hyorfor ogsa dets Sideplade svinder aldeles, medens den anden Sideplade er meget liden. Bagenfor denne sidste findes desuden kun een særdeles stor, som jeg ma antage at vare dannet af den sammensmeltede tredie og fjerde Sideplade, da den synes at være fæstet til begge Led. I Munddelenes Bygning viser denne Slagt en fra de andre afvigende Bygning. Kindbakkerne ere saaledes meget korte, hvorved den slutter sig nær til den foregaaende Slæigt, dog er Palpen fæstet noget længere nede, omtrent i samme Hoide, som Tyggeknuden, medens den hos den foregaaende er fastet nærmere Spillsen. Denne er hos denne Slægt meget bred, medens den hos Himpomedon er tynd. Da Munddelene i det Hele ere noget længere, bliver ogsaa det forreste Kjæbepars indre Plade noget forlænget og ex paa den afskaane Ende, der er temmelig bred, besat med mange fjærdannede Børster. Derimod 
er den ydre Plade paa Kjæbefudderne meget kort, hvorfor Tændeme i Randen ere faa, men dog stærke, ligesom hos Hippomedon; deres Palpe er forlænget, og det sidste Led er ikke klodannet, men stumıt paa Enden og har der nogle stærke, fjærdannede Børster. Hvad der ogsaa i Særdeleshed el eiendommeligt for deme Slægt, er, at de nedre Føleres Grundled til Siderne ikke er dxkket af Hovedets Sideplade, hvilket sadvanlig er Tilfæeldet, men ligger aabent i en Indskjæring af denne. Dette Forhold finder Sted ogsar hos en anden Slægt indenfor denne Familie, nemlig Eurytenes, Lilljeborg.

CYPHOCARIS ANONYX, Lütken.

(Pl. VI. Fig. 1.)

Cyphocaris anonyx, A. Boeck, Crust. amphip. bor. et arct. 1870, p. 21.

Gibber segmenti trunci 1 mi tegit summum caput, qvod propterea minimum videtur. Epimera duo coalita, postice lationa et in margine postreno pro 5to, latiore qvam alto, incisa. Angulus posticus lateralis segmenti postabdominis 3tii rectus. Antenne superiores usqve ad articulum postabdominis 1 mum porrecte: perluneulo brevi: arliculo flagelli luo longitudinem articulorum octo seqventium junctorum seyvanti: llagello accessorio longo, gracili. 5articulato, eadem longitudine ac articulo flagelli Imo. Antenne inferiores iisdem superioribus paulo longiores; articulo pedunculi 3 tio brevi; articulo 5 to breviore et angustiore qvam 4to. Pedes $1 \mathrm{mi}$ paris manu el carpo eadem longitudine. manu apicen versus allenuata; carpo extrorsum latiore. Pedes 2di paris articulo 2do et to eadem lerme longitudine: articulo 5to multo breviore. Pedes trium parium ultimorum articulo Imo in margine postremo et infimo profunde serrato. Pedes 5 ti paris angulo inferiore postico acuto, producto, eodem parium duorum sepventium rolundato. Pedes saltatorii paris ultimi ramis invicem cadem longitudine. lanceolatis, in margine interno selis crebris plumosis instructis. Appendix caudalis apicem versus acuta, fere ad basin fissa.

Dyrets L w $_{\mathrm{gde}}$ er fra Pukkelens Ende til Halevedhænget $14^{\mathrm{mm}}$.

Legemet er noget sammentrykt med afrundet Ryg. Det forste Legemsled er meget støre end de nærmest folgende og skyder fortil ud i en stærk, noget opad og fremarrettet Pukkel samt drkker med sin forreste Rand den største Del af Hoverlet. Den forste Sideplade er liden; de to folgende ere sammenvoxede til et enkelt Stykke, som bagud bliver bredere og er paa den bagre Rand indskaaret for den femte, der er meget bredere end liøi; de tvende sidste aftage efter hinanden i Størrelse. Den nedre bagre Vinkel paa de tvende forste Haleled er afrundet; paa det tredie danner den en ret Vinkel.

Hovedet er lidet og med sin overste Del skjult under llet store forste Legemsled, der hvalver sig udover det. Øinene sees ikke. 
De øvre Følere strække sig, naar de bøies bagover, næsten til Halens forste Led. Deres Skaft er meget kort og tykt; det forste Led er meget større end rle tvende følgende tilsammen. Svoben dannes omtrent af 30 Led; dens første Led er meget langt, omtrent saa langt som. Skaftet, men meget smalere ved Roden og aftager i Tykkelse udad. Den indre Side er forsynet med dobbelte Tvarrader af lange Borster. Svobens folgende Led ere korte, saa at de $7-9$ første tilsammen ere saa lange som det første Led. Bisvoben er omtrent saa lang som Svøbens forste Led og er meget tynd; den dannes af 6 Led, hvoraf det forste er det længste.

De nedre Følere ere meget længere end de ovre. Skaftets tvende forste Led ere sammensmeltede, og Lugteknuden er liden; det tredie Led er sardeles kort; det fjerde er nasten tre Gange saa langt som tylit; det femte er kortere og smalere og naar noget foran let forste Led af Svoben paa de ovre Folere. Svoben er mere end tre Gange saa lang som Skaftet $\mathrm{gg}$ dannes af 50-60 forlangede Lerl.

Overlaben er kort.

Kindbakkerne ere i Spidsen brede, med fremstaaende Hjørner; under Spidsen findes en indre Tand. Torneraden dannes af faa, korte Torme, og Tyggekmuden er oval. Palpen er særdeles stor; det andet Leds øvre Rand er noget vinklet; det tredie Led er kortere end det andet $\mathrm{g}$ forsynet med en Rad af stive Børster, af hvilke de yderste ere de længste og fjærdannede.

Underlæben er bred, med en svag Antydning til Bilæbe.

Det forste Kjæbepars ydre Plade er væbnet med stærke kamdannede Torne i tvende Rader; den indre Plade er forlænget, med mange fjærdannede Børster paa den indre Rand, hvilke blive længere mod Spidsen. Palpens andet Led er temmelig bredt, i Spidsen tvært afskaaret, væbnet med Here Tænder og en længere, meget stark og fjærdannet Børste.

Det andet $\mathrm{Kj}$ bepars indre Plade er bredere end den ydre, og begge have fjærformede Borster.

Kjæbefoddernes indre Plade er lang, mea tre Trnder i Spidsen og med mange fjerformede Børster paa den indre Rand. Den ydre Plade er liden og har paa den indre Rand faa (5), men stærke Tænder, og paa Enden enkelte fjærformcde Borster. Palpen er forlænget; det forste Led er særdeles langt og naar næsten til Enden af den ydre Plade; de tvende folgende Led aftage i Læengde og ere paa deres indre Rand forsynede med talrige fjærformede Borster; det fjerde Led er ikke kloformet, men tykt, stumpt i Spidsen, til hvilken er fæstet en lang, fjærfornet Børste.

Det forste Fodpar er meget kort; Haanden og Carpus ere omtrent lige lange, begge have mange Børster paa deres bagre Rand. Haanden bliver smalere mod Spidsen, hvori den korte, lidet krumme Negl er fæstet.

Det andet Fodpar er meget forlanget; dets andet og fjerde Led ere omtrent lige lange, og det femte er meget kortere end hine; begge de sidste have talrige Børstebundter paa den bagre Rand. Koen synes at mangle. 
De tvende folgende Fodpar ere lange og tynde; det fjerde Led er noget kortere, men det femte er læugere end det tredie, der nedad kun ulvider sig lidet; det femte Led bliver noget tykkere mod Enden og er paa den indre Rand vabnet med nogle smaa Torne.

De tre følgende Fodpar tiltage efterhaanden stærkt i Længde; deres forste Led er dybt saugtakiet paa den bagre og nedre Rand.

Paa det femte Fodpar er den indre, bagre Vinkel meget udtrukket. Paa de derpar folgende trende er den derimod tilrundet.

Det femte Fodpars fjerde Led er kortere end det tredie; paa det sjette er det omtrent af samme Længde, og paa det syvende er det længere. Det femte Led er langere end det fjerde, undtagen paa det syvende Par, hvor de omtrent ere af samme Liengde.

Det sidste Par Springfodder naar langst bagul. Dets Grene ere omtrent lige lange, af en meget forlænget, lancetformet Dannelse og med Børster paa den incle Raul.

Halevedluxuget er forlanget, lancetformet og spidst i Enden; det er paa hver Sile forsynet med en Tom og kløvet næsten til Roden.

Et Exemplar af denne mærkelige Form tindes i Kjobenhavns Museum fra Gronland.

Gen. VIII. EURYTENES, Lilljeborg, 1865.

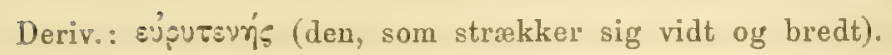

Syn.: 1865. Eurytenes, Lilljeborg, On the Lysianassa magellanica. 1865. p. 12.

1870. - A. Boeck, Crust. amphip. bor. et arct. p. 25.

Typ.: Gammarus gryllus, Mandt.

Mandibulæ breves; palpo profundius qvam tuberculo molari magno prominenti affixo.

Maxilla $1 \mathrm{mi}$ paris palpo angusto, in apice nonnullas setas gerenti; lamina interiore ovata. setis multis ciliatis instructa.

Maxillæ 2di paris laminis latis; exteriore multo longiore qvam interiore.

Pedes maxillares Iamina exteriore magna, in margine interiore nodulis multis sed parvis instructa: lamina interiore clongata; palpo longitudine mediocri; articulo ultimo ungviformi.

Antenne inferiores articulo pedunculi lmo magno et inflato, ab integumentis capitis non tecto, extus visibili; articulo 5to pedunculi longiore qvam 4 to.

Pedes $1 \mathrm{mi}$ paris breves, robustissimi, manu subcheliformi instructi.

Pedes 2di paris elongati.

Pedes saltatorii paris ultimi ramis brevibus et latis.

Appendix caudalis profunde fissa. 
Par den af Milne Edwards i 1818 opstillede Art Lysiancssa magellanica blev deme Slagt grundet af Lilljeborg i 1865, som troede at have gienfundet Arten i Finmaken. Han omtaler, at den afviger fra de ovrige Slægter i Særdeleshed ved, at de nedre Foleres Grundled er meget stort, opsvulmet og bedækkes ikke af Hovedets Sideplader. Halevedhænget er dybt kløvet og har ikke nogen bevægelig Torn paa Lappenes Ender. Den eneste Art, som man forhen kjendte, var af d'Orbigny fundet i Magellansstrædet og antaget at være den samme som den, der senere er funden ved Grønland, Spitsbergen og Finmarken. Dette giver Lilljeborg Anledning til at fremheve, at deme Form er en af dem, der er frelles for det nordlige og sydlige Ishav og er bleven paa den Tid, Glacialtiden traalte tilbage, drevet af sit falles Udgangspunkt ved Eqvator dels mod Nord og dels mod Syd, eftersom Havet tiltog i Varme. Imidlertid kan det maaske vare tvivlsomt, om denne Art er den samme paa begge Steder, thi den af Lucas i 1858 afbildede Form, der var fundet i Maven paa en Fisk fra Cap Horn, stemmer ikke fuldkommen overens med vor Form, især viser det femte, sjette og syvende Fodpar en tydelig afvigende Bygning derved, at det tredie Led er meget kortere end hos E. gryllus, saa at jeg maa tro, at der findes tvende Arter, en fra det nordlige og en fra det sydlige Polarhav. Kindbakkerne ere hos denne mere forlængede end hos den foregaaende Slægt, hvorved Palpen er frstet nærmere Roddelen end Tyggeknuden. Kjæberne ere brede, som hos den foregaaende Slægt, men dog noget længere, saa at den indre Plade er mere oval. Kjæbeføddernes ydre Plade er derimod stor og har ikke Tander, men kun Kunder i Randen. Det sidste Springfodders Grene ere sardeles brede, den ydre er lidt længere end den indre, og begge have paa den indre Rand talrige Borster.

\section{EURYTENES GRYLLUS, Mandt, 1822.}

Lysianassa gryllus, Mandt, Observationes in histor. natur. in itinere Grœnland. factae 1822. Dissert. p. 34.

- $\quad$ - Goës, Crust. amphip. Spetsb. 1866. p. 1.

Lysianassa magellanica, Milne Edwards, Ann. des Sciences naturelles, 3me série. Zoologie. IX. 1848, p. 398.

Spence Bate, Catal. Amphip. Crust. Brit. Mus. 1862. p. 66. pl. X. fig. 5 .

Eurytenes magellanicus, Lilljeborg, On the Lysianassa magellanica etc. p. II. Acta Ups. 3. sér. 1865. t. I. II. III. fig. 1-22.

Eurytenes gryllus, A. Boeck, Crust. amphip. bor. et arct. 1870. p. 25.

Angulus lateralis capitis productus, in apice rotundatus. Angulus inferior posticus lateralis segmenti postahdominis $1 \mathrm{mi}$ et 3 tii rotundatus, 2 di vero acutus. Antenna superiores arliculis pedunculi brevissimis; articulo flagelli 1 mo elongato. longiudinem 6 seqventium junctorum arvanti. Antenna inferiores articulo 1 mo valde inflato et articulum 2dum tegenti: 110 parum modo longiore qvam lato, multo bre- 
viore el latiore quam articulo b̃o. l'edes 1 mi paris carpo brevi, triangulari. manu plus duplo longiore qvam lata, apicem versus angusliore ot parum curvata. Pedes 2di paris articulo 2 do multo breviore qvam carpo; manu elongata, angusta. in angulo inferiore postico producta et rotundata. Pedes trum parium ultimorum articulo 1 mo brevi sed latissimo: articulo Btio deorsum valde produclo; articulo fto pedum sti paris brevissimo: 5to elongato. Iongiludinem ferme articulorum dnorum pracedentium jumclormm ayvanti. Pedes saltatorii parris ultimi ramo exteriore fermu duplo longiore gram pedunculo. in apice spina una valida instructo: ramo interiore paulo breviore el angustiore qvam exteriore: ramo utroqve in margine interno valde setosis. Appendix caudalis apicem versus angustior, ultra medium fissa: laciniis postice aculis.

Dyrets Langde el $70-8(1 \mathrm{~mm}$.

L e gemet er meget tykt, robust; Ryggen er mud. men det sidste Legemsled og de fem forste Haleled have langs Mirtlinien en smal Kjol. medens det sjette Led har tvende saadame, en paa hver Side af Midtlinien. Den nedre bagre Vinkel paa det firste Haleled er afrundet, par det andet er den uitrukket i en skarp Spids, og par det tredie afskaret. tilrundet. Sidepladerne ere brede, men ikke meget høie; den fjerde er paa den bagre Rand dybt indskaaret for den femte, der er dobbelt saa lang som hoi. Hovedet er omtrent saa langt som ret forste Legemsled, dets Sidevinkler ere lidt udtrukne, men afrundede, og moler disse findes en dyb Indshixing for de nedre Frleres strerkt opsvulmerle andet Skaftled.

De svre Foleres forste Skaftled er kort, dog liengere end de tvende folgende Led tilsammen. og ikke meget opsvulmet. Svgben dannes af ontrent 30 Led, hvoraf let forste er saa langt som de sex folgende tilsammen; Bisvoben dames af ? Led, livoraf det forste er saa langt som de tire til fem folgende tilsammen.

De nedre Foleres andet Skaftled er tykt, opsvulmet; det tredie er kun lidt lwngere end breit; det fjerde Led er kortere, men bredere end det fente: Svoben danues af henimod do Led og har i den indre liand meget lange burster.

Overlaben er par Enden hijelmformig boiet og dxkker Spirken af Kindbakkerne, ller ere forliengedle, men meget.stærke: Gribedelen er skarp, med et svagt tandformet Fremspring paa hver Side: den nedre Bitand er liden. Tyggelinuden er meget stor. bred, med talrige fine Borster. Palpens andet Led er langere og tykkere end det tredie, der pas sin indre Rand har en Rad Borster.

Underlaben er meget forlanget; dens indre P'lade sees par Énden af den indre land af den yilre Plalle, sai at den far i Spidsen et dobbelthiget. Udseende.

Det forste Kjabepars ydre l'lade er meget kraftig vabnet i Spidsen 0 gar par len indre Rand med stierke, pai den concave Side saugtakkede Trender; Palpen er frnd, para Linden afrundet og hatr her far, tymle 'orne; den indre Plade er oval, med mange fjachannede Burster. 
Det andet Kjabepars indre Plade er meget kortere og smalere end den ydre, og begge have fjerdannede Børster paa den indre Rand og i Spidsen.

Kjabeføddernes indre Plade er forlænget, og den ydre naar frem til Enden af Palpens andet Led sant har paa den indre Rand talrige smaa Kmuder. P'alpens forste Led forlænger sig meget paa den ydre Rand; det fjerde Led er stærkt kloformet.

Det forste Fodpar er kraftigt; det fjerle Led er kort, triangulart; Haanden er meget længere, bliver lidt smalere mod Enden og er lidt krummet; Griberanden er svagt skraat afskaaren.

Det andet F o dpar er meget smalere, men længere end det første; dets andet Led er kortere end det fjerde, der er lidt længere end det smale, lidt krumme, med talrige Borster forsynede femte Led; Kloen er meget liden og fastet i en Indskjæring paa Finden af den forreste Rand.

Det tredie og fjerde Fodpar ere meget starke, dleres fjerde Led har omtrent ren halve Størrelse af det femte.

Det femte til syvende Fodpar tiltage efter hinanden lidt i Langde; deres forste Led er meget bredt, med saugtakket bagre Rand; (let tredie Led er bagtil meget uividet; det femte Led er næsten tre Gange saa langt som det fjerde.

De trende første Par Springfodders indre Gren er lidt kortere end den ylre.

Det tredie Pars Grene ere meget brede, mel talrige Borster paa den indre Rand; den ydre Gren er lidt længere og bredere end den indre; begge have paa Enden af den ydre Rand en Torn.

Haleve dhanget er omtrent dobbelt saa langt som bredt ved Rorlen og kløvet til over Midten. Fligene blive meget tilspirlsede paa Enden.

Goës har undersogt det typiske Exemplar paa denne Art. der opbevares i Berlins Museum, og fundet, at den stemmer overens med $E$. magellanica, Lilljeborg. Af Mandt blev den fundet i 1822 af rlet Opkastede af Proccllaria glacialis, af Fries er den taget ved Beeren-Eiland i Maven paa en Hai, og under lignende Omstandigheder er den fundet ved Finmarkens Kyster og indsendt til vort Museum. I Kjøbenhavns Museum opbevares talrige Exemplarer fra Grønland, som ogsaa vare tagne i Fiskemaver.

\section{Gen. IX. ARISTIAS, A. Boeck, $18 \% 0$.}

Deriv.: 'Apírią (en græsk Digter).

Syn.: 1870. Aristias, A. Boeck, Crust. amphip. bor. et arct. p. 26.

Typ.: Anonyx tumidus, Kroyer.

Mandibulæ elongate, angustæ, in apice vero late, sine dente accessorio; tuherculo molari prominenti, acuto; palpo in eadem altitudine infixo.

Maxilla $1 \mathrm{mi}$ paris perlatæ; in margine crebras setas plumosas gerentes; 
lamina interiore etiam brevi, ovata, in apice crebris setis plumosis instrucla; palpo angusto, in apice paucis spinis ornato.

Maxillæ 2di paris laminis latissimis, in margine setis multis instruclis; lamina exteriore angustiore qvam interiore.

Pedes maxillares lamina exteriore permagna, in margine setis pancis modo armata et ferme ad finem articuli palpi 3tii porrecta; articulo palpi 3tio brevi el gracili; 4to ungviformi; lamina interiore brevissima, triangulari, ad basin lata, et in apice dente uno et setis pluribus plumosis armata.

Antenna superiores pedunculo elongato, angusto.

Pedes 1 mi paris manu apicem versus angustiore.

Pedes 2di paris elongati; manu sat angusta.

Pedes saltatorii ultimi paris ramo interiore paulo breviore qvam exteriore: ramo interiore in margine externo et interno, exteriore in margine interno modo serrulatis.

Appendix caudalis hrevissima, non ad finem pedunculi pedum saltatoriorum ultimi paris porrecta, usqve ad basin fissa.

Lilljeborg troede i 1865 (On the Lysianassa magellanica p. 32), at Grammans tumidus, Kroyer, burde blive Typus for en ny Slægt paa Grund af Munddelenes eiendommelige form. Det forste Fodpai ligner ogsan det hos Lysianassa og afviger fra det tilsvarende hos Anonyx. Det sidste Par Springfodder finder han at ligne det hos Slagten Hyperia, idet Grenene ere fint saugtakkede, den ydre alene par den indre Rand, den indre Gren derimod i begge Rande. Slægten synes at have en vis Overensstemmelse med Callisoma i Kjabefoddernes Bygning derved, at den ydre Plade er vabnet med Torne og det forste Kjabepars indre Plade er meget stor og har mange fjærdannede Borster langs den indre Rand, men hos Aristias ere Munddelene i det Hele meget bredere og kortere, ligesom let forste Fodpar har en meget forskjellig Form fra det tilsvarende hos Callisoma. Kindbakkerne blive hos deme Slægt meget forlængede, men Palpen er $\log$ frestet i samme Hoide som Tyggeknuden. Det forste Kijabepar er meget breit, dets indre Plade er ogsaa bred, oval, og lar i Spidsen talrige, fjærdannede Børster; dets Palpe er derimod smal, da Kindbakkerne ere saa lange, og Kjabeføddernes Plader ere meget store, saa at det Rum, de skulle udfylde, er meget lidet. I Spidsen er den derfor ogsaa kun vabnet med faa Torne. Det andet Kjobepars Plader ere sardeles brede og have paa Randen mange Børster. Uagtet Kjabefoddernes ydre Plader ere meget store, findes der kun paa deres indre Rand nogle faa Børster; Palpen er tynd, og dens sidste Led er klodamnet. De indre Plader ere i Forhold til de ydre smaa $0 \mathrm{~g}$ af en triangulæi Form, paa Enden tilspidsede, og have der kun en eneste Tand, men derimod mange Borster. Til denne Slagt horer, foruden A.tumidus i de nordlige Have, 
der tillige findes i Middelhavet, ogsaa Lysianaswa ciliatn fra Istrien og maaske ogsai L. humilis, Costa. da den synes at stemme overens med denne slagt i Folernes form oc den smale fjerde Sideplade.

ARISTIAS TUMHUUS, Kroyer, 1846.

(P'I. III. Fig. 4.)

A nony.x tumidus, Kroyer, Naturhist. Tidsskr. 2 I. 2 B. 1846. p. 16.

-- - Kroyer, Voy. en Scand. etc. 1848. pl. 16. fig. 1.

- _ Lilljeborg, Öfvers. af Kgl. Vetensk-Akad. Förhaudl. 18.31.

- - Bruzelius, Skand. Amphip. gam. 1859. 1. 4.

- - Spence Bate, Catal. Crust. Amphip. Brit. MIus, p. 13.

- $\quad$ - Lilljeborg, On the Lysianassa magellanica etc. p. 32. fig. 51.

- - Ieller, Beitr. z. uäh. Kenutn. d. Amphip. adriat. Meeres. p. "25. t. III. fig. $6-12$.

Lysianassa tqumila, Goës, Crust. amphip. mais Spetsb. 1866. p. '2.

Lysianassa Audoniniana, Spence Bate, Brit. Assoc. Rep. 185 ว̃.

- - Spence Bate, Catal. Crust. Amphip. Brit. Mus. p. 69. XI. fig. 1. spence Bate and Westwood, Brit. sessile-eyed Crust. 1). 79. Aristicts tumidus, A. Boeck, Crust. amphip. bor. et arct. 1870. p. 27.

Oculi magni, reniformes, nigri. Epimera parva; 4tum parum modo altius IVam latum. postice subincisum. Angulus inferior posticus lateralis segmenti poslabdominis 3tii rectangularis. Antenna superiores articulo pedunculi 2do et 3tio prælongatis. Pedes $1 \mathrm{mi}$ paris carpo brevi et lato; manu apicem versus angustiore et in margine posteriore crebras spinas breves gerenti; ungve in margine interiore spinis nommullis armato. Pedes 2di paris manu breviore yvam carpo, sed quater longiore fram lata, in angulo inferiore postico producta. Pedes 3tii et 4ti paris articulo ultimo in angulo inferiore posteriore ad spinam producto. Pedes trium parium ultimorun articulo Imo non valde dilatato: 5lo in angulo anteriore inferiore spina armato. Pedes saltatorii $1 \mathrm{mi}$ paris ad finem 3 tii paris porrecti; pedes saltatorii 2di paris breviores; ramo interiore $1 \mathrm{mi} 2$ dirfue paris et ramo exteriore paris ultimi in margine interno spinis multis gracilibus, brevibus et nonnullis longis instructo: ramo interiore ultimi paris breviore, lanceolato et in margine utroqve spinas tenues gerenti.

Dyrets I, a $n$ gile er $6^{\mathrm{mm}}$.

Le gemet er meget tykt, med en temmelig bred, afiumlet Ryg. Hovedet er meget kort, omtrent saa langt som det forste Legemsled; dets Sidevinkler ere ikke ultrukne, men ligesom ret afskane, og ler er et bredt skillerum mellem de ave og 
nerlre Fglere. Ginene ere af en forlanget oval eller agrund Form. Den forste Sideplade er meget liden og tildels drkket af den anden; den fjerde er kun lidt hoiere cnd bred og bagtil kun svagt indskaaret for den femte Sideplade, hvilken sidste er bredere end høi. Det tredie Haleleds nedre, bagre Vinkel er ret.

De ore Fglere ere omtrent en Fjerdedel af det hele Legemes laungde $0 \mathrm{~g}$ naa, naar de boies bagover, til det tredie I,egemsled. Skaftet er forlænget, ikke tykt; dets forste Led el omtrent dobbelt saa langt som tykt; det andet er noget kortere end Halvdelen af det forste; let tredie Led er kort; Svgben er noget langere end Skaftet og dannes af s-10 Led, hvoraf det første er saa langt som de tre følgende tilsammen; Bisvoben dannes af $5-6$ Led, hvoraf det forste er saa langt som de tre folgende Led tilsammen.

De nedre Foleres tredie Led er omtrent saa langt som tykt, eller noget kortere, og bliver noget bredere udad, det fjerde og femte Led ere nasten lige lange; livert af dem er dobbelt saa langt som det tredie Jed, men det femte er noget smalere end ret jierile.

Kindbakkerne ere korte, i spidsen brede og tilskjærpede; en Tyggeknude sees lige over for Palpens Tilheftelsessted, hvilket sidste ikke er langt fra Kinrlbakkernes liodilel.

Det forste Kjabepal' el meget brert, i Spidsen besat med talrige smaa, med Bitander forsynede l'orne: Den inlre Plade er oval, bred, med far $(\gamma-8)$, men staerke fjærformede Børster pai den indre Rand og i Spidsen; Palpen er smal, med nogle 'Torne i spidsen.

Det andet Kjabepars indre Plade er meget bred, med tahige, fint fiarformede Børster paa Enden; den ydre Plade er smalere.

Kjabefoddernes ydre Plade er bred, oval, besat paa Randen med fine Torne og i Spidsen med krumme Børster; den indre Plade er meget kort, tilspidser sig mod Fnden $0 g$ er forsynet med fjorformede Børster. Palpens tre første Led ere nasten af samme Langde, men aftage i 'Tykkelse. Kloen el forlænget, næsten ret.

Det forste Fodpar er stærkt; dets fjerde Led er breit og har samme Laengile som det fente; dette sidste, hvis forreste Rand er convex, bliver smalere mor Enden, og paa den bagre, lige land findes tatstaaende fine Torne, imellem hvilke der findes nogle starkere og langere. Kloen er kun lidt krummet og omtrent af det femte I eds halve Latngde, med tvende fine Torne paa den concave Rand.

Det andet Fodpar er meget forlanget; dets fjerde Led er meget langere end det andet og med talrige Borster paa begge liande; Haanden er meget forlsenget, smal, meget kortere end det foregaaende Led; dens nedre bagre Vinkel er noget forlanget for at mode den lille Klo.

Det tredie og fjerde lodpars tredie leel er kun lidet udvidet; let fjerde er kun lidt mere end halvt saa langt, medens det femte, lıvis nedre bagre Vinkel er noget udtrukket, er af samme Langde. Kloen er kort. 
De tre folgende Fodpar tiltage efterhanden ubetydeligt i Langde; deres forste Led er langere, ikke bredt, $0 \mathrm{~g}$ det femte Led, der er noget liengere, end det tredie, er ligeledes ultrukket, men i det nedre forreste Hjorne.

Det forste og det sidste Par Springfodder na begge lige langt bagud, medens det andet Par er noget kortere; den indre Gren par de tvende første og den ydre paa det tredie Par have paa den indre Rand talrige fine Torne, mellem hvilke der findes lignende langere; den indre kortere Gren paa det tredie Par, livilken har en lancetlignende Form, har fine 'lorne paa begge Rande.

Halevedhanget er kort, bredt og klovet til loden; liver af Fligene er val)net med en liden 'Tand.

Dyrets larve er livil, ofte med et svagt rodligt Skjær. Denne Art er af Kroyer og Goës angivet at forekomme ved Grønland, og efter den sidstnæevnte findes den hyppig paa 15-40 lavne ved Spitsbergen. Ved Norges Kist er den overalt temmelig hyppig $0 \mathrm{~g}$ er fundet lige fra Finmarken sydover og lige til Kullen, som oftest i Ascidicmaver. Paa strirre Dybder er llen af $G$. O. Sars fundet ved Utne par 40-100 Favne og ved Aalesund paa 100 Favme, ligesom af mig ved Aabningen af Harlangerfjorden par nær 150 Favne. Efter Heller findes den paa Here Steder i Arriaterhavet.

\section{(ielı. ANONYX, Kirłyer, 1838.}

Deriv, : a, uden, övง⿳亠 (en Negel).

Syn.: 1838. Anonyx, Kroyer, Gronlands Amphipoder beskrevne. Kjobenham 1838. p. 14.

1844. - Kroyer, Naturh. Tidsskr. Bd. 4. p. 64.

1853. - Dana, Crust. U. States Explor. Exped. II. p. 908.

1859. - Bruzelius, Skand. Amphip. Gan. p. 39.

1860. - A. Boeck, Skand. Naturf. Selsk. 8de Mode Kjobenhavn 1860. p. 041.

1862. - Spence Bate, Cat. Crust. Amphip. Brit. Mus. p. 72.

1863. - Spence Bate and Westwood, Brit. sessile-eyed Crust. 1.90.

1870. - A. Boeck, Crust. amphip. bor. et arct. p. 20.

Typ.: Anonyx (Lysianussa) lagena, (Reinhardt) Kroyer, (Caucer nugax, Phipps).

Epistomum cassiforme.

Iandibule palpo propius apicem qvam tuberculo molari valde prominenti affixo.

Maxilla Imi paris lamina interiore ovata, parva, in apice duabus setis plumosis instructa.

Maxilla 2di paris laminis latis brevibusqve: Iamina interna multo breviore y vam externa.

Pedes maxillares lamina exteriore parva, non ad finem articuli palpi 2di porrecta et in margine interno nodulosa; palpo robusto; articulo ultimo ungviformi. 
Pedes Ini paris plus minusve elongati, robusti; manu qvadrangulari, in acie obliqve truncata.

Appendix caudalis pedunculo pedum saltatoriorum ultimi paris longior.

Pedes saltatorii ultimi paris ramis longioribus fvam pedunculo, setosis.

Corpus non altum. Epimera haud alta; 4tum nec valde incisum nec latius qvam altum.

Angulus inferior posticus segmenti postabdominis 3tii productus et sursum aculus.

Kroyer fandt i 1838 (Gronlands Amphipoder beskrevne), at de af ham fra (ironland beskrevne Arter skilte sig fra den af Milne Edwards opstillede Sliegt Ly/siancusar ved de trende forste Fodpars Form, og foreslog for sine Arter Sligtsnavnet Anonyx. I 1840 delte Milne Edwards Slægten Lysianassa i tvende Slagter, idet han opstillede en ny Slagt Alibrotus paa den ene Art og henforte Krøyers Anonyxarter til den gamle Slagt Lysianassa. Kroyer troede rlesuagtet i 1844, at begge Slægtel liunde bestaa ved Sillen af hinanden, og de senere forskere have ogsia optaget Slrgten Anomyx, undtagen

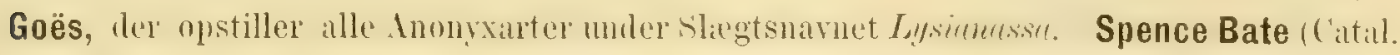
Curst. Amphip. Brit. Mus. 1) 72) finder, at det første Forlpars Form er det eneste Marke. hvorved Anomyx skiller sig fra Lysianassa, og at det maske er muligt, at en fremtidig Undersogelse vil afgjøre, om ikke deme Karakter hos nogle Species alene er en Kjønsforskjel. Krøyer har log allerede forlungst pavist, ved hvilke Karakterer Kjomnene skille sig fra hinanden, og disse ligge ikke i loddernes, men i Folemes Bygning. Fa demne Slagt har jeg allerede i det loregaaende ulsondret Here Slægter; hvis Arter ikke stemme overens med den typiske Art (C. mugax, Phipps), A. layena, Kroyer, og en stor Mrngile af de til denne Slagt henforte Arter maa udsondres fra den. Mundilene los denne Slagt vise en vis Overensstemmelse med dem hos nogle af de folgende Slagter, især hos Orchomene, Tryphana og Tryphosa; Overlaben er nemlig hos alle disse hjehnformig og dwkker med sin fortykkerle Ende Kindbakkernes Spidser. Disse Slæchter afvige dog igjen fra liverandre ved de ovrige Mundleles Form samt ved Folernes, de tvende forste Fodpars og Halens forskjellige Bygning. Kindbakkeme ere saaledes hos Slegten Anony.x. meget stærke, men ikke synderlig forlæugerle, de lave en lang, men smal Tyggeknude, og lleres Palpe er frstet nærmere Enden end Tyggeknuden. Det furste Kjabepar er ogsaa meget bredt, men dets indre Plade er meget kort, kun lidt lengere end bred ow hir paa Enden tvende stærke, fjorlannede Børster. Det andet Kjæbepars Plader ere ogsa korte, men brede, Kjæbefoldernes ydre Plader ere meget store, og de have paa lianden en trt Rickke af smaa Knuder. De neilre Fisleres tredie Led er kort, og det forste Fodpar er mere eller mindre forlænget. Halevedhruget er ogsaa forlænget, længere end Grundleddet paa det sidste Fodpar, og dybt kløvet. Legemet er ogsaa i det Hele temmelig langstrakt, hvorfor den femte Sideplade er længere end høi. 
ANONYX (LYSIANASSA) LAGHAN (Reinhard), Kiøyer, 1838.

Lyysunassu (Anony.r) layena, Kroyer, Gronl. Amphip. Danske Vidensk. Afh. VIl. 1838. 237. t. 1. f. 1. (q).

- Milne Edwards, Hist. des Crust. t. III. 1840. p. 21.
- Bell Belchers, Last of the irctic Voy. Append. 185.
- Goës, Crust. Amphip. Spetsb. 1866. p.
- Spence Bate, Cat. Crust. Amphip. Brit. Mus. 186\%. p. 7\%.pl. XII. f. 7.

Lyysinnassa (Amomyc) appendienlosa, Kroyer. Gronl. Amphip. 1838. p. 240. tah. I. pl. 告 $\left(\sigma^{x}\right)$.

- Milne Edwards, Hist. nat. des Crust. 1840. t. HI. J. 01.

- Spence Bate, Cat. Crust. Amphip. Brit. Mus. 1\$69. p. 6\%. pl. X. f. 8. Anonyx amp ulla, Kirøyer, Nat. Tidsskr. 2. I. I. 1844, p. этя.

- Ḱnoyer, Nat. Tidsskr. 2. K. B. II. 1846. p. 43.

- Brandt, Middendortt's lieise. Crust. 1851. p 131.

- Bruzelius, Skand. Amphip. Gammar. 1859. p. 34.

- Lilljeborg, Ont the Lysianassa magellanica. 1865. p. 93. fig. 52.

Anony.x layena, A. Boeck, Crust. amphip. bor. et arct. 1870. p. 28.

Angulus lateralis capitis rotundalus. Angulus inferior posticus segmenti postahdominis 3tii valde productus et sursum acutus. Oculi magni, ampullacei, nigri. Anteme superiores articnlo pedunculi 1 mo pluribus partibus longiore qvan duobus cateris junctis; articulo flagelli Imo brevi, longitudinem 2-3 articulorum seqvenlium junctorum aqvanti; articulo llagelli accessorii lmo 10-12articulato, longitudinem articuli llagelli 1 mi a paulo breviore qvam 4to, et haud duplo longiore qvam lato. Pedes Imi paris articulo 2do brevi: carpo brevi, triangulari: manu apicem versus angustiore et longitudine carpum superanti. Pedes 2di paris articulo 2 do et carpo longitudine ferme apqualibus. Pedes trium parium? 6ti paris dilatato, 7mi paris non dilatato. Pedes saltatorii ultimi paris ramis elongatis, lanceolatis, in margine interiore setis multis plumosis instructis. Appendix caudalis duplo longior yvam ad basin lata.

Dyret er $18^{\mathrm{mm}}$ lat $\mathrm{gt}$ fra Spidsen af Hovedet til Halevedhenget.

Legemet er noget sammentrykt fra Siderne, men liyggen er bred og rund. Det fjerde Haleled viser paa liyggen en ilke meget dyb saddelformig Indtrykning uden nogen fremtrædende Ophøining fortil, men med en Pukkel bagenfor ileme. Det femte Led er sierileles kort. De fire forste Sideplader ere ikke sardeles hoie; den femte er bredere end høi. Det tredie Haleleds nedre bagre Vinkel danner en opadboiet Hage, Hovedets Sidevinkler 
ere kun noget udtrukne og tilrundede. Oinene ere thaskeformede, idet de bugformet udvile sig nedad, dog mest fortil par Hovedets Sidevinkel.

De øvre Folere ere omtrent saa lange som Hovedet og Legemets fire forste Led. skaftets andet og tredie Led. der ere meget korte, gaa paa den indre Side ud i en Tand. Svobens forste Led er kort og omtrent saa langt som de fire til fem folgende Led tilsammen $0 \mathrm{~g}$ er paa den indre Side forsynet med Borster i tolv Tværrader. Bisvoben dannes af 9 Led, hvoraf det forste er nresten saa langt som, men meget tyndere end Hovedsvgbens forste Led og saa langt som de fire følgende Led tilsammen.

De nedre Foleres tredie Led er kort, kun lidt længere end bredt; det fjerde er neppe dobbelt saa langt som tykt, det femte er lidt langere og smalere. Svoben dannes af 30 Led. Epistomet er langs Midtlinien kjolformigt og ender i en Pukkel, hvorfor den korte Overlabe lægger sig over Kindbakkernes Spids.

Kindbakkerne ere korte, strerke, paa Enden meget brede og paa den femte Rant forsynede med en stump Tyggeknude, der paa den indre Side har tvende strerke Torne. Tornerækken dannes af mange flade Torne. Tyggeknuden er starkt fremstaaende, men i Enden smal, og en Ophoining strxkker sig fra den opad mod Knuden over Palpen. Palpens andet Led er det langste.

Underlahens begge Sidedele ere meget smale og vidt shilte fin hinanden.

Det forste Kjabepars indre Plade er meget kort, oval, med to fjærdannede Brrster i Spidsen. Tyggepladen er meget bred, med talrige Børster og lange T'zender, forsynede med Bitrender. Palpens Ende har sex til syr store Tander, hvis Rodilel er fortykket.

Det andet hijobepar er ikke meget forkenget.

Kjabefoddernes Palpe er forlænget og stærk. Den ydre Hade er meget bred og naar ikke fuldt frem til Enden af Palpens andet Led; den er forsynet med Knuder langs hele den indre Rand. Den indre Plade er ikke meget lang og barer adskillige Borster i Spidsen.

Det forste Fodpar er hort, men strerkt; det fjerde Led er triangulaert. forlanget, men meget kortere end det femte, som er noget smalere mor Enden end ved Rorlen. Griberanden er lidt skrat afskaren og vabnet med en stark 'Torn der, hvor rlen moder Kloens Spids.

Det andet Fodpar er forlanget, smalt; dets fjerde Led er noget liengere end let andet og smalt, det femte er dakket med stierke Borster, og det bagre nerlre Hjørne er kun lirlet udvidet.

Det tredie og fjerde fodpar ere af den sadvanlige form.

De tre sidste Fodpar tiltage efterhaanden lidt i Lxngde, og deres forste lad ur satugtakket i den bagre Rand; det tredie Led er kort, bredest paa det femte Fodpar og meget smalt, paa de tvende ovrige; det fjerde Led er liengere end dette, og det femte er endnu langere. 
Springfuddernes (irene ere niesten lige lange og ere starkt forsyuede merd 'Torne.

Det sidste Par naar langt bagud; dets Grene ere afplattede paa den ydre Rand og vabnede med talrige Torne, medens der paa den nedre findes mindre Torne og talrige fjardannede Borster.

Halevedhanget er forlanget, klovet til Roden.

Firven er ifolge Kroyer lys, rosenrod paa liyggen, og sideme ere lyse, nasten hvide. Paa Exemplarer fra Haugesund var Ryggen derimod lys gulbrun og Siderne hvide. Et Exemplar fra Langenas i Nordland var ensfarvet lysegult, Oiet er sort. En Varietet, eller maske en ny Art, havile et rosenrodt Øie, men var forovigt saa lidet afvigende fra andre Exemplarer af deme Art, at jeg initil Videre ikke lar vovet at opstille den som ny.

Denne Art forekommer ved Gronland, let nordlige Amerika, Spitsbergen, Island og gaar efter Brandt ligetil det okhotske Hav, saa at den er en circumpolær Form. Den findes langs den hele norske Kyst, ved Vadsø, hvor den er taget af Damielssen paa 40-80 Favne, ved Nordkap, hvor ien er fundet af R. Collett, M. Sars og Lilljeborg. I linmarken og i Nordland paa there Steller er len taget af $\mathbf{t}_{0} 0$. Sars og mig, ved Christianssund paa 50-100 Favne af G. O. Sars, ved Christianssund og Molde af Danielssen paa 30-60 Eavne, ved Bergen. af Danielssen og Kroyer, i Hardangerfjorden paa 300 Favne af $G$. O. Sars, sammesteds paa to Favne af mig, ved Haugesund og Hvidingsg af $G$. O. Sars og mig paa 20 - 40 Favne, og paa samme Dybde ved Flekkefjord. Den tiudes ogsaa efter Bruzelius ved Bohuslen.

ATONYX I.HLJEBORGI, A. Boeck. 1870**)

(PI. IV. Fig. 3.)

Anony.x Lilljeborgi, 1. Boeck, Crust. amphip. bor. et aret. 1870. p. 29.

Oculi magni, rubri. Angulus capitis lateralis rolundatus. Segmentum postabdominis tlum transverso profunde depressum. Antemm superiores articulo pedunculi Imo fere eadem longitudine ac crassiludine; articulo flagelli 1 mo brevissimo, Inngiludinem articulorum duorum sepventinm junctormm iegvanti: flagello accessorio ex arliculis tribus elongatis composito. Pedes 1 mi paris carpo et manu fere eadem longitudine. Pedes 2di paris carpo Inngiore qvam articulo '2do et parum modo longiore quam manu angusta. Appendix caudalis ter longior qvam lata, profunde fissa. Pedes saltatorii ultimi paris ramis multo angustioribus qvam apud speciem pracedenten, in margine interiore setis et aculeis instructis.

Dyrets L $\mathrm{L} n \mathrm{gde}$ er $8-9^{\mathrm{mm}}$.

L e gemet er forlanget, dog baade temmelig hoit og med en rund Ryg, der

*) Denne Art er opkaldt efter Yrofessor Lilljcborg i U1,sals. 
kun paa det fjerde Haleled danner en langsgaaende, skarp. tuberkelformet Kjøl. De fire forste Sideplader ere hwie og tiltage efterhanden i Længde; den fjerde er paa den bagre Rand meget indskaaret for den femte, der er lidt hoiere end bred. Den nedre hagre Vinkel paa det tredie Haleled er tilıundet uden at damne nogen fremstaaende Rand.

Hovedet er noget kortere end Legemets forste Led og danner et meget lidet Horn mellem de ovre Folere. Dets Sidevinkel er meget stor. fortil tilrundet. Oinene ere rode, ovale, mere end dobbelt saa lange som brede.

De ovre Falere ere korte; Skaftets forste Led er meget tykt, de tvende folgende ere meget korte: det forste Led paa Svoben, der dannes af 12 Led, er saa langt som de fire folgende tilsammen og er paa den indre Side forsynet med mange dobbelte Tvarrader of Birster.

De nedre Foleres tredie Led er omtrent dobbelt saa langt som tykt; det fjerde er meget længere og noget tykkere; let femte er smalere end det fjerde og meget kortere, kun dobbelt saa langt som tykt; Svaben dannes af 16 Led.

Overlæben er sammentrykt fra Silerne, med en skarp Rand og ved et tydeligt Indsnit adskilt fra Epistomet. Bagtil springer den noget frem over Kindbakkerne og har tvende med Borster forsynede Sideplader.

Kindbakkerne ere meget starke. brede; de ere ikke meget forlangede og have ikke Tiender paa Euden. men en liden indre Gren, der ligner en Taud. 'Tomeriden dannes af korte Torne; Tyggeknuden er meget fremstaaende; Palpen er frestet omtrent i samme Hoide som 'Tyggeknuden under den svre Ledknude, der er lang, isar dens andet Led, og vabnet paa den concave Rand af let tredie Led med en Rad starke Borster.

Det forste Kjabepar har i Spidsen sterke, kamdannede 'Trender. den indre Plade er forlæuget, med tvende fjærdannede Børster i spidsen, hvoraf den ene er længere end den anden; Palpen har i Spidsen smaa, men mange og tætstillede Tænder.

Det andet Kjabepars ydre Plade er meget læugere end den indre.

Kjabefødilernes ydre Plade er paa Randen vabnet med smaa, trtstillede Trender samt med en langere Tand i den grre Del af den ydre Rand; den indre Plude er forlanget, udtrukket paa Enden af den indre Rand og der besat med trende smaa 'Tander og desuden med nogle krumme Borster. Palpen er kort, saa at den ydre Plade. naar frem nsesten til Halvilelen af det tredie Led, det fjerde damer en spids Klo.

Det forste Fodpar er forlanget; dets tredie Led er kort; det fjerde er mere end dobbelt saa langt som tykt, og det femte har omtrent den samme Laengile som let foregaaende; Kloen har en stark Tand ner Spidsen af den concave liand.

Det andet fodpars fierde Led er ontrent saa langt som det andet: det femte er kortere, og dets nedre bagre Vinkel er udtrukket.

Det tredie og fjerde Fodpars tredie Led er ikke meget udvidet, men langt; rlet fjerde Led er meget kortere, og det femte er omtrent af samme Langde, men smalere end dette. 
Det femte Fodpars firste Led er meget udvidet, nasten lige saa bredt som hoit, med en svagt, sangtakket Rand; dets tredie Led er kort; det fjerde er af samme Langde, men smalere; det femte Led er omtrent saa langt, som de tvende foregarende tilsammen.

Det sjette Fodpar er meget langt.

Det syvende Fodpars forste Led er meget storre end hrerit, bagtil fint saugtakket; let tredie Led er kum lidt tykkere og neppe længere end det fjerie, inedens det femte er langere.

Det forste Par springfodder naar langt bagud, og dets Grene ere lidt kortere end Skaftet; det tredie Pars ydre Grene ere longere end Skaftet og den indre Gren.

Halevedhrnget er omtrent dobbelt saa langt som bredt og spaltet nasten til Roden, samt forsynet med en Tand $i$ hver af Fligenes afrundede Ende.

Denne Art er fundet af G. O. Sars ved Utne i Hardangerfjorden paa 40-200 Favne samt ved Brettesnzes i Nordland paa 40 Farne og ved Hvidingsa, ved Haugesund og Skudesnos af mig par $60-70$ Favne.

\section{ANONYX MARTENSI. GOës, 1865. †}

Lysirnassu Martensi, Goës, Crust. Amphip. maris Spetsb. 1865. p. 3. fig. 2. Anony. Martensi, A. Boeck, Crust. amphip. bor. et arct. 1870. p. 29.

Angulus lateralis capitis non longe productus, rotundatus. Antemna superiores articulo pedunculi 1 mo endem longitudine ac crassitudine; articulo flagelli Imo haud longiore qvam articulis seqventibus duobus junctis. Antemne inferiores articulo 4to duplo ferme longiore qvam lato. Pedes Imi paris manu brevissima. haud duplo longiore qvam lata. Pedes 2di paris breves; articulo 2 do et carpo radem ferme longitudine; carpo non duplo longiore qvam manu ovata. Pedes sallatorii ultimi paris ramis angustis, land magnopere selosis. Appendix caudalis duplo ferme longior qvam ad basin lata; laciniis in apice subserratis.

Efter (ioës's Tegning $0 \mathrm{~g}$ Beshrivelse er Dyrets $\mathrm{L} \rightsquigarrow \mathrm{ngde} 4^{1 / 1} \mathrm{~m}^{\mathrm{mm}}$.

Legemet el tykt med rund Ryg; den nedre bagre Vinkel paa det tredie Haleled er opadhøiet til en strerk Hage; den fjerde Sideplade er mere bred end høi.

Hovedet er lidt langere end det forste Legemsled; iets Sidevinkel er kun lidt udrukket, tillundet.

De $\emptyset$ vre Folere ere meget korte; det forste Skaftled er kun lidt langere end tykt; de tvende folgende ere meget korte; Svoben har 8 Led, hvoraf det forste er omtrent saa langt som de tvende folgende tilsammen. Bisvoben er treleddet, og dens laed aftage efterhanden i Langde og Tykkelse. 
De nedre Foleres fierde Led er omtrent dobbelt saa langt som tylit; det femte er smalere og ubetydeligt kortere; Sroben damnes af 9 korte Leil.

Det forste Fodpar er meget kort og stærkt; det fjerde Led er longere end Haandel, der bliver lidt smalere mod Enden, med en skraat afskaaren (iriherand.

Det andet Fodpar er ogsaa kort; det andet Led er omtrent saa langt som det fjerle, der er triangulært og noget langere end den ovale Haand.

De tre bagre Fodpars forste Led er kun svagt saugtakket pata den bagre Rand; deres tredie Led er nasten ikke udvidet, og lleres fjerde og femte Ised ere nasteu lige lange.

Det sidste Par Springfodder nar langst bagud; Grenene ere forlangede. smale, den indre kortere end den ydre, forsynede i den indre Rand med faa Borster.

Halevedhænget er omtrent dobbelt saa langt som hreit ved Roclen, spaltet i den ydre 'lotrediedel.

Den er fundet ved Spitsbergen. dog ikke meget hyppig, paa 20) Favnes Dybile.

ANONYX (aULOSUS, Kroyer, 1845.

(1). V. Fig. 4.)

Anony. !nulosus, Krgyel, Naturh. Tidsslir. 2. R. 1. B. 1844. p. 611.

- - Krøyer, Voyage en Scand. 1848. pl. 14. fig. 2.

- - Bruzelius, Scand. Amphip. gamm. 1859. p. 44.

- - Spence Bate, Catal. Amphip. Crust. Brit. Mus. 1862. p. 3 \%o.

- - Tilljeborg, Ou the I.ysianassa magell. 1865. p. 24.

- - Heller, Beitr. z. näh. Kenutn. der Amphip. adriat. Meeres. 186\% p. 24.

- $\quad$ A. Boeck, Crust. amphip. bor. et arct. 1870. p. 30.

Anonyx Vorvegicus, Lilljeborg, Öfvers. af Kgl. Vetensk. Akadem. FörL. 1851. p. 22.

- - Spence Bate, Catal. Amphip. Crust. Brit. Mus. 1862. p. 81.

AnonyxHolballi, Spence Bate, Catal. Amphip. Crust. Brit. Mus. 1862. p. 75. pl. XII. fig. 4.

- - Spence Bate \& Westwood, Brit. sessile-eyed Crust. 1863. p. 104.

Lysianassa gulosa, Goës, Crust. amphip. maris Spetsb. 1866. p. 4.

Angulus capitis lateralis rotundatus. Angulus lateralis posticus segmenti postahdominis 3tii acutus. Oculi ovati, rubri. Antenne superiores arliculo pedunculi Imo brevi. crasso; articulo llagelli Imo perbrevi; flagello appendiculari gracillimo. 3--tarticulato. Intenne inferiores articulo 5 to ferme duplo longiore qvam lato. Pedes Imi paris multo magis elongati qvam apud speciem procedentem: arliculo 2do longitudinem carpi l'erme apvanti: manu rectangulari. elongata, paulo longiore fvam carpo: ungve in apice uno denticulo instructo. Pedes saltatorii ultimi paris ramis angustis et in margine interiore setosis. Appendix caudalis ter ferme longior yvam 
ad basin lata. Fere nsquve ad basin lissa: lacinis in margine exteriore dentibus duobus. in apice dente uno armalis.

Dyrets $\mathrm{L}_{\mathrm{a}} \mathrm{ngde}$ er $10^{\mathrm{mm}}$.

Legemet er nogenlunde sammentrykt fra Siderne. liyggen er rund. uden nogen Kjøl paa Legemets eller Halens Led. Sidepladerne ere haie; de tre forste ere meget smale; den fjerde har et meget dybt Indsnit paa den bagre Rand for den femte, der er noget bredere end hoi og har et lidet Indsnit langt forn Midten af den indre Rand. Det nedre bagre Hjorne af det forste Haleled er tilrundet, og pai det tilsvarende Sted af det tredie Haleled boier det sig til en bagud rettet 'l'and. Hovedet er noget langere end Het forste Legemsled, og den forreste nedre Vinkel er ikke meget forlanget $0 \mathrm{~g}$ tilrundet.

De grle Følere ere meget korte; Skaftets forste Led er kun lidt langere end tykt, og dets tvende folgende Led ere srerdeles korte; Svoben er kun noget langere end skaftet og bestaar af 8-10 Led, hvoraf det forste er omtrent saa langt som de folgende tre tilsammen, og er paa sin indre Side forsynet med strorke Borsteknipper; Bisvoben dannes af 3 grove Led, hvoraf det forste er det langste.

De nedre Folere ere noget langere end de ovre: Skaftets forste Led er meget tykt, det andet er sæerdeles kort, det tredie sender en kort, bred'Torn udover den ovre Flade af det følgende lange og tykke Led; det femte Led er smalere, men omtrent af samme Længde eller noget kortere end det fjerde Led. Swoben bestaar af 14-18 Led.

Kindbakkerne ere ligesom svulstformig udvidede i Spidsen, urlen l'sender indad, men en saadan er frestet paa den ydre Ende af deme Svulst: 'Tornene ere faa og korte. Tyggeknuden er fremstaaende, forlænget, men smal.

Det forste Kjabepars Ende er skraat afskaren og vabnet med mange stærke, saugtakkede Tænder; Palpens Ende har omtrent 8 korte Tænder, der aftage istorrelse indover mod Roden, og har en forlænget, bevægelig Tand paa den ydre Rand.

Det andet Kjabepars Plader ere forlangede, laadne, og paa Enden af dem sees fjirformede Børster.

Kjabefodderne ere starke; den ydre Pade er i Randen besat med hunder og nogle Torne paa den nedre afrundede Rand; den indre Plade er paa Enden af den indre Kant vabnet med en stærk, men stump Tand og forovrigt med fjarformede Borster.

Det forste Fodpar er forlanget; det andet Led er omtrent halvt saa langt $\therefore:$ forste, men smalere; det fente Led eller Haanden er liengere end dette og meget liengere end Carpus.

bet andet Fodpars fjerde Led ex det lengste, med Cindtagelse af det forste, og er betyleligt laengere end Haanden.

Det tredie og fjerde forlpar ere lange og sticre.

De derpa folgende tre Fodpars forste Led er temmelig bredt, det tredie Led er kort, og det femte I.ed er langere end det fjerte. 
Det andet Par Springfodiler naar ikke saa langt frem som det furste og det tredie Par, hvis Grene ere lancetformig forlangede.

Halevell anget er forlanget, spaltet niesten til Rorlen.

Harven er efter Kroyer gul med rod Ryg.

Efter Lilljeborg er hos unge Individer det tredie Led paa det forste fodpar kortere end Halvielen af det andet, og den ligner heri $T$. nanoides, men alskiller sig dog fra deme Art derved, at det forste liodpar er lengere og smalere, samt ved at Haandens forreste og bagerste Kant ikke convergere, som hos $T$. nanoides.

Denne Art er fundet verl Gronland af Torell og Holboll, ved Spitsbergen af Malmgreen, verl Island af Torell; ved Norges Kyster er den taget ved Varlso af M. Sars og Danielssen paa 40-60 Favnes Dybde, i Nordland ved Slotholmen af Danielssen, ved Skraaven af (r. 0. Sars. verl Bergen af M. Sars og Koren, ved Haugesund af mig, ved Stavanger af G. O. Sars paa 40-60 favnes Dybde og ved Mamulal og i Christianiafjorden at mig; den tindes ogsaa efter Bruzelius ved Bohuslen. Heller angiver. at den er funter ver l,essina i Arriaterhavet.

ANONYX PUMILUS, Lilljeborg, 1865.

I'I. V. Fig. ; og PI. VI. Fig. 6.)

Anonyr pumilus, Lilljeborg. On the Lysianassa magellanica etc. 186\%. p. 26. t. IV. fig. $35-41$.

Lysianassa producta, Goës, Crustacea Amphipoda maris Spetsb. alluentis. Irofi. p. 3. pl. XXXVII. fig. 1 .

Anonyx: pumilus, A. Boeck, Crust. amphip. bor. et aret. 1870. p. 30.

Ingulus lateralis capitis anticus longe productus, acutus. Angulus latralis posticus segmenti postabdominis :3tii sursum curvatus, acutus. Segmentum postabdominis 5lum in medio margine posteriore dente uno acuto instructum. Epimerum 5tum paulo altius qvam latum. Antenne superiores articulo pedunculi 2 do et 3tio brevissimis: arliculo flagelli lmo brevi, longitudinem articulorum duorum seqventium junctorum fere advanti: Alagello appendiculari parvo. Barticulato: articulo rjusdem Imo breviore qvam duobus cateris junctis. Pedes $1 \mathrm{mi}$ paris breves, rohusti; carpo triangulari: manu longitudintm rarpi ferme arvanti, apicem versus allenuata. Podes qvinqve parium posteriorum ungvibus longis et fere rectis. Pedes saltatorii ultimi paris ramis subulatis, non selosis. Appendix caudalis duplo ferme longior qvam ad basin lata, fere usque ad radicem lissa.

Dyret er omtrent $4^{1 / 2}-5^{\mathrm{mm}}$ langt.

l, egemet er tykt, hoit og kort, sammentrykt. sidepladerne ere meget hoie og smale; den fjerde af disse er ikke meget indskaret i den bagre Rand, den femte 
er hoiere end bred, og Indsnittet for det her befrestede fodpar findes midt par den mdre kand. Det tredie Haleleds nedre bagre Tinkel lober ud i en skarp, lidt opadboiet Spids, og Rygsiden er hvælvet i Midtlinien. Det folgende Haleled er nedtrykt paa Midten og har en liden Pukkel paa Enden. Det femte Led er i Enden af Midtlinien vabnet med en Tand. Hovedets Sidevinkler lobe ud i skarpe Spidser og ere noget nedadboiede.

De ovre Folere ere korte, Skaftets forste Led er meget forlænget, cylindrisk, medens de tvende folgende ere meget korte. Svobens forste Led er noget liengere end bredt. Bisvoben er toleddet eller treleddet.

De nedre roleres temte Led er ubetydeligt kortere og smalere end rlet fijerde; Svoben dames af 9 til 10 Led.

Kindbakkernes Gribedel er forsynet med en indre smal Bigren; Palpens tredie I,erl har paa Enden nogle fau Borster.

Det andet $\mathrm{Kj}$ abepars Plader ere smale, ten ydre er lidt langere end den indre.

Kjabefodderne ere korte; den indre Plade naar frem foran Palpens forste Led, er smal samt har paa Enden tre smaa 'l'sender: den ydre P'lade er liden og naar ikke frem til Enden af Palpens andet Led; den har paa den indre Rand enkelte Ínuder og nogle smaa Torne. Palpens forste Led er meget bredt, det andet er kort og bredt, det tredie er ikke meget kortere end dette.

Det forste Fodpars fjerde Led er triangulart: Handen er omtrent af samme Lengde, bliver smalere mod Spidsen og har midt paa den bagre Rand en staerk Torn. Kloen er kort, forsynet med nogle fine lorne paa den concave Rand.

Det andet Fodpar er tenmelig kort; dets fjerde Led er meget langere end det andet og bliver ikke meget fortykket udad. Haanden er oval; ilen nedre bagre Vinkel er ikke nutrukket.

Det tredie og fjerde Fodpars fjerde Led er smalt, det fente er meget lingere, $0 \mathrm{~g}$ Kloen er tynd, lidt krummet og ikke meget kortere end det sidste Led.

Det femte Fodpars forste Led er noget udvidet bagtil, saugtakket paa den bagre Rand $0 \mathrm{~g}$ besat med Torne paa den forreste; dets tredie Led er kort, ikke meget længere end det fjerde; det femte er langere og smalere end det fjerde Led. Kiloen er nesten ret, smal og noget kortere end det femte Led.

De trende folgende Fodpar have omtrent den samme Form, men tiltage efter himanden i Liengde.

Det forste Par Springfodders Grene ere vabuede med fa 'orne pata den ovre Rand.

'Det andet I'ars Grene ere lidt langere end Grundleddet.

Det tredie Pars indre Gren er langere end Grundleddet; den er mod Enden meget tynd og kortere end den ydre, hvis sidste Trediedel damnes af en stark Torn, der ved Roden har nogle Bitome.

Halevedhenget er ikke fuldt dobbelt sat langt som bredt red hoden og 


\section{Explicatio tabularum.}

a. De orre Folere. (Antema superiores).

b. De nedre Folere. (Antenna inferiores).

c. Overlæben. (Labium superius).

d. Kindbakkerne. (Mandibula).

e. Underlaben. (Labium inferius).

f. Det forste Kjabepar. (Maxilla primi paris).

g. Det andet Kjebepar. (Maxilla secundi paris).

1. Kjobefoddeme. (Maxillipedes).

i. Det forste Fodpar. (Perles primi paris).

k. Det andet Fodpar. (Pedes secundi paris).

I. Det tredie og fjerde Fodpar. (Pedes tertii et quarti paris).

m. Det femte Fodpar. (Pedes quinti paris).

m. Det sjette Fodpar. (Pedes sexti paris).

n. Det syvende Fodpar. (Pedes septimi paris).

p. Det forste Par Springfodter. (Pedes saltatorii primi paris).

p. Det andet Par Springfødder. (Pedes saltatorii secundi paris).

q. I) sidste Par Springfodder. (Pedes saltatorii tertii paris).

r. Halevedhænget. (Appendix caudalis).

s. Den nedre, bagre Vinkel paa det tredie Haleled. (Angulus inferior posticus lateralis segmenti postablominis tertii).

t. Det fjerde Haleled. (Segmentum postabdominis quartum).

x. Landehornet. (Rostrum frontale).

z. Forste Sideplade. (Epimerum primum).

0. Amdepladerne. (Vesiculiu branchiales). 



\section{DE SKANDINAVISKE OG ARKTISKE}

\section{A IV P II I P O D E R,}

BESKREVNE

AF

A xel B o eck.

Andet llefle.

(Med 25 kobberstukne Tarler.)

EFTER FORFATTERENS DOD UDGINET VED

HAKON BOECK.

CHRISTIANIA.

Trykt hos A. W. Brggger.

1876. 



\section{Préface de la deuxième Livraison.}

L'impression de cet ouvrage, dont le texte est édité aux frais de la Société des Sciences de Christiania - Sa Majesté Charles XV contribuant pour la somme de spd. 150 à l'exécution des planches sur cuivre - fut interrompue après la publication de la première livraison par la mort de l'auteur Mai 1873.

Puisque l'auteur a laissé son manuscrit à peu près complet, sans que cependant la désignation des figures déjà gravées y fût ajouteé partout, il ne lui aurait pas été difficile d'y mettre une dernière main; mais cet arrangement pour tout autre, ne devait pas être chose facile, et je ne m'en serais pas chargé si je n'avais pas eu l'occasion d'être parfaitement au courant du plan de l'auteur et si je n'avais pas suivi avec intérêt la mise en oenvre de ce groupe d'animaux. De plus, j'écrivis une grande partie des diagnostics sous la dictée de l'auteur qui, souffrant d'une affection nerveuse était souvent empêché d'écrire lui-même.

J'espère qu'on fera un bon accueil à cet ouvrage dont la publication est, selon moi, d'un grand intérêt principalement pour les naturalistes scandinaves, qui se sont occupés de ces formes animales dont ils ont: ou enrichi les musées d'exemplaires, ou la littérature zoologique par des contingents plus ou moins importants, en faveur de l'histoire naturelle de ces animaux.

Quant aux synonymes, j'ai été ohligé de m’appuyer, en partie, sur les données de Spence Bate et Westwood, parceque la bibliothèque de l'université de Christiania n'a pas des ouvrages traitant suffisamment des Amphipodes, ce qui m’a empêché de les étudier à fond, tandis que l'auteur a fait ses études à l'université de Copenhague, où il avait une Eource plus riche, puisque, par la bonté de la Direction, le musée des Amphipodes était à son service.

I'ai ajouté les noms aux fignres, qui n'étaient pas notés, après une longue et mûre comparaison des différentes formes. Dans deux ou trois cas j'ai été obligé de renoncer à en trouver la désignation, car elles n'ont pas de marques assez convaincantes pour la classification de l'espèce

La difficulté de désigner les noms manquants provient en partie de ce que l'auteur a rassemblé bien des formes différentes sur la même planche, car il avait pour but d'en faciliter l'apercu en montrant plus exactement la ressemblance ou la différence entre plusieurs espèces, tant pour ce qui est de la forme exté:ieure que pour la construction de la bouche.

L'auteur s'est plaint, au sujet de sa première livraison, de ce que pendant son absence causée par son voyage de recherches sur la pêche du hareng, il n'a pas éu l'occasion de faire relire par un zoologiste les épreuves où se sont glissées plusieurs fautes d'impri- 
merie surtout dans les mots latins de l'introduction, ainsi que quelques petites inexactitudes, et sur les planches, qui toutes devaient être imprimées à Copenhague quelques erreurs de lettres. Quelques fautes ou inexactitudes semblables se sont aussi glissées dans cette livraison, mais se font facilement reconnaitre par la lecture ou par la confrointation des figures:

Je dois aussi m'excuser de ce que la Sousfanille Iphimedinæ n'est pas à la place, qui est indiquée dans l'aperçu systématique, une fausse disposition du manuscrit en est la cause.

Quant à l'arrangement systématique des Amphipodes, et au plan suivi dans le livre, l'auteur dit dans son introduction, qu'il croit que c'est principalement la construction des parties de la bouche qui en est le fond, car elles présentent le caractère principal et le plus distinct de tous les Arthropodes et c'est la vraie pierre de touche pour en reconnaître la parenté plus ou moins éloignée.

La forme extérieure varie beaucoup suivant les différents endroits où ces animaux séjournent, ce qui fait développer en eux des formes ressemblantes tantôt d'une part, tantôt d'une autre, mais qui peuvent facilement se ramener à un seul type.

Si on veut chercher spécialement les caractères de la forme extérieure on arrivera facilement à ramener des formes parentes dans des divisions biens éloignées les unes des autres, et d'un autre côté, de rassembler celles qui, de nature, ne sont pas conformes.

Christiania, Avril 1876.

Hakon Boeck. 
spaltet i den ydre 'Totredierlel. Fligene ere indskantne i Spidsen, og i hver Indskjaring findes en Torn.

Farven er hvid, med et rotligt Anstrog paa Enden af hvert Legemsled samt paa begge Folere og Fodparrene. Den var paa et Exemplar fra Haugesund lyserod, ligesom paa det, der var taget af Lilljeborg, der heller ikke paa sit Exemplar fandt Øine.

Efter Goës findes den temmelig sjelden ved Spitsbergen paa 2-25 Harnes Dybde; Lilljeborg fandt et Exemplar ved Molde pai 40-50 Favnes Dybde, og jeg har fundet et ved Skudesnas paa 30 Favnes Dỵde. Af Lovén er den ogsa taget ved Vảderaeme i Bohuslen.

Gen. XI. ONESIMUS, A. Boeck. 1870.

Deriv.: 'Ovńounos (et græsk Mandsnavn).

Syn.: 1840. "'A librotus, Milne Edwards, Hist. des Crust. III. p. 23.

1862. Alibrotus, Spence Bate, Catal. Amphip. Crust. Brit. Mus. 1862. p. 86.

1870. Onesimus, A. Boeck, Crust. amphip. bor. et arct. p. 31 .

Typ.: Anonyx litoralis, Kroyer.

Epistomum prominens.

Mandibula in apice dente firmo et dente accessorio angusto instructa: palpo in eadem altitudine ac tuberculo molari mediocri aftixo.

Iabium inferius lacinis in apice spina uno armatis.

Maxilla $1 \mathrm{mi}$ paris lamina interiore parva. ovata, in apice selas duas plumosas gerenti; palpo in apice $5-6$ spinis instructo.

Naxillæ 2di paris laminis brevissimis; exteriore duplo fere longiore qvam interiore.

Pedes maxillares laminis exterioribus parvis, non ad finem articuli palpi 2di porrectis; in margine interno nodis pancis et in apice dente uno instructis.

Epimera qvatuor anteriora angusta; epimerum 4tum subcurvatum.

Angulus inferior posticus segmenti postabdominis 3tii aculus.

Antennæ plus minusve prælongatre.

Antennæ inferiores articulo 5 to breviore qvam 4 to.

Pedes 1 mi paris brevissimi. rohusti: manu quadrangulari, in acie obliqve truncala.

Pedes saltatorii ultimi paris ramis brevibus.

Appendix caudalis sat brevis, non ad finem pedunculi pedum saltaloriorum ultimi paris porrecta. 
Hvorvidt deme slagt falder sammen med den af Milne Edwards i 1840 opstillerle slught Alibrotus, tor jeg ikke med Sikkerhed afgjore. Han udsondrede nemlig i let anforte Aar Lysianassa Chousica fra den anden Art L. Coste under Navn af Alibrotus, hvilken Slægt skulde ardskille sig fra Lysianassu verl Længden og den tynde form af de "wre Folere, samt ved at det andet Fodpar er stærkere. Dette passer kun for en Del para de Arter, der henhore til den af mig opstillede Slaggt Onesimus, og da Milne Edwards's Beskrivelse er saa ufuldkommen, kan Intet afgjores med Hensyn til de øvrige Karakterer, lwvorved jeg skiller deme Slægt fra de øvrige, hørende til Underfamilien Lysianassinac. Spence Bate henfører min typiske O. litoralis, Kroyer, til Slægten Alihrotus. men det er tvivlsomt, om han heri har Ret. De ovre Folere ere kun tildels af en meget forlwnget Form, thi hos en af Arterne ere de ikke mere forlængede end hos Anonyxarteme. Dana (U. S. Explor. Experl. 1. 909) henforer Slægten Alibrotus til Gammarmae og stiller den nær Acanthonotus; derimod stiller Spence Bate den nær til Callisoma og henforer til den, foruden den typiske Art Chansica, ogsaa Anonyx litoralis, Kroyer. Han kjender inidlertid ikke selv nogen af Arterne, men beskriver dem efter Milne Liwards og Kroyer. Havde Originalexemplaret varet opbevaret i Paris, maatte Spence Bate sandsynligvis have undersggt dette. Formen af Overlaben er den samme som hos Slagten dnomy; Kundbakkernes Tyggeknude er derimod langt mindre fremtrædende. I det forste Kjæbepars Form ligner den Anomyx, men Palpens 'Tandbesntning er mindre stærk. Det andet Kjabepars indre Plade er meget kort. I det Ydre afvige disse tvende Slagter i Sxrdeleshed verl Halens Form, irlet Halevedhanget hos denne er meget kort og kun lict indskaaret i den bagre Rand. Den fjerde Sideplade er ogsaa smal og bagtil kun svagt indskaret for den femte, livorved Slægten er let kjendelig.

(ONESIMUS LITURALIS, Kroyer; 1844.

(HI. V. Fig. 7.)

Anony.r litoralis, Kroyer, Naturh. Tidsskr. 2. R. 1. 13. 1S44. p. 621.

- - Kroyer, Voyage en Scand. etc. 1848. pl. 23. fig. 1.

- - Bruzelius, Skand. Amplip. gamm. 1859. p. 46.

- _ Lilljeborg, On the Lysianassa magellanica. 1865. p. 30.

Alibrotus litoralis, Spence Bate, Catal. Amphip. Brit. Mus. 1862. p. S6. pl. XIV. fig. 7. Lysianassa litoralis, Goës, Crust. amphip. maris Spetsb. 1860. p. 5.

Onesimns litoralis, A. Boeck, Crust. amphip. bor. et arct. 1870. p. 32.

Oculi parvi, reniformes, rubri. Antenna prælongate; superiores tertiam Iongitudinis animalis partem reqvantes: articulo pedunculi 2 do et 3tio angustis; articulo flagelli Lmo brevi, longitudine modo seqventibus $3-4$ junctis reqvali. Anlennæ inferiores articulo 5 to breviore et angustiore qvan 4to. Pedes $1 \mathrm{mi}$ paris manu rectangulari, paulo longiore qvam lata et parum longiore qvam carpo trian- 
gulari. Pedes triun parium ultimorum articulo 1 mo in margine posteriore valde serrato; articulo 3 tio brevi. in angulo inferiore postico subdilatato et subproducto: articulo 4 to paulo longiore el angustiore; articulo bto longitudine ferme arliculis duobus pracedentibus junctis acqvali. Pedes 7 mi paris articulis posterioribus yvatuor junctis longioribus gram articulo Imo. Pedes saltatorii ultimi paris ramis longiludinem pedunculi vix superantibus. in margine interiore setosis. Appendix caudalis longior qvam lata. in margine posteriore subinsinuata et spinis duabus instrucla. Angulus inferior posticus lateralis segmenti postabdominis 3tii acutus.

Det af mig undersøgte storste Exemplar var $18 \mathrm{~mm}$ langt fra Pandespidsen til Halevedhrenget.

Legemet er forlanget, men meget tylit, med en bred Ryg. Overgangen mellem det tredie og fjerde Haleled er pukkelformig. Sideplademe ere meget høiere end brede; den forste er bredere end de tvende folgende; den fjerde er iklie meget bred og bagtil swagt indskaaret for den femte, der er omtrent sai høi som bred. Det tredie Haleleds nedre bagre Vinkel er noget udtrukket og tilspidset.

Hovedet er kort, omtrent saa langt som Legemets forste Led; dets forreste, nelre Vinkel er udtrukket og i Spidsen tilrundet. છinene ere smaa. rode, ovale eller svagt nyreformede og sidde langt nede paa Hovedets Sider.

Folerne ere forlengede: le ovre naa, naar de boies bagud, omtrent til det fjerde Legemsled; Skaftets forste Led er tykt, omtrent af Hovedets Langde, og dobbelt saa langt som de tvende folgende tilsammen; Svoben er mere end dobbelt saa lang som Skaftet og dannes af 16 Led, hvoraf det første er saa langt som de tre folgende Led tilsammen; Bisvoben er tynd og saa lang som Hovedsvobens tvende forste Lerl tilsammen; den dannes af $4 \mathrm{Led}$, hvoraf det forste er dobbelt saa langt som de folgende tilsammen.

De nedre Følere ere længere end de ovre; Skaftets tvende forste Led ere sammensmeltede; det tredie er omtrent saa langt som bredt; det fjerde er omtrent tre Gange saa langt som bredt, og ret femte er meget kortere og smalere end lette; de tvencle sidste Led ere paa den ovre Side forsynede med korte og paa de undre med langere Borster; Svoben er dobbelt saa lang som Skaftet og damnes af 40 korte Led.

Overlaben er kort, afiundet i Spidsen og besat med Børster.

Kindbakkerne ere forlængede, i Spidsen ubevabnede, men med en Hage paa hver Side; Tyggeknuden er liden, bredere nedad og spids opad; Palpens andet Lerl er noget langere end det tredie, der er krummet og har Borster paa den convexe Side.

Det forste Kjabepars ydre Plate er forlinget, tilspidser sig mod Enden og har paa den indre Side txtte Børster og sex kamdamede, stærke 'T'mder; Palpen er i Spidsen forsynet med faa Trender og med nogle Borster mellem disse; den indre Plade ex middelmaadig, med tvende fjaerdamede Borster paa Enden. 
Vet andet Kjabepal's ydre l'lade er meget lixgere end den indre, og begge ere besatte med tomdannede Børster.

Kjabef $y$ didernes ydre P'lade har en stark, convex ydre og en mere ret indre Rand; denne er forsynet med nogle faa Knuder, og den ydre Rand har i Spidsen en 'Tand; den indre Plade er forlænget, firkantet $0 \mathrm{~g}$ har fjærdannede Børster paa den indre Rand og i Spidsen. Palpen er forlæuget, stærk; dens tredie Led er saa langt som eller lingere end det andet.

Det første Fodpar er starkt; dets tjerde Led er kort, triangulært; Haanden er nasten rhomboidalsk, ikke ganske dobbelt saa lang som bred, med en skraat afskaaren Griberand; Kloen er forsynet paa den concave Rand med trette, korte 'orne samt med en lignende, men længere nærmere spidsen.

Det andet Fodpars fjerde Led er liengere end det andet og det femte, der er omtrent dobbelt saa langt som bredt, med en ret afskaaren Ende, og som er strerkt forsynet med Børster; Kloen er liden, krum.

Det tredie og fjerde Fodpar er strerkt; deres tredie Led or nedad udvidet og saa langt eller noget kortere end det meget smalere femte Lerl.

Det sjette Fodpar er noget langere end det femte og det syvende; dets forste Led er meget udvidet og har par den bagre Rand faa, men grove, sangformede 'Tænder; det fjerde Led er længere end let korte, men nedad meget brede tredie Led, undtagen paa det sidste Fodpar, livor det er kortere; let femte Led er paa lem alle meget længere, men smålere end det fjerde.

springfødderne ere korte, og det sidste Par naar langt bagul; deres Grene ere nasten lige lange; det tredie Pars ydre Gren er omtrent saa lang som Skaftet; den indre er ubetydeligt kortere; begge ere uden Børster.

Halevedhanget er noget longere end bredt ved Roden, bliver smalere udad og har en svag Indbugtning og to smaa Torne paa den bagre Rand.

l' arven er hvid eller hvidgul.

Kroyer angiver $\mathrm{L} x \mathrm{ngden}$ til $\mathrm{y}_{\mathrm{mm}}$, Lilljeborg til $14-15^{\mathrm{mm}}$.

Den findes ved Grønland, Spitsbergen og Finmarken, hvor den el taget af Friis i Varangerfjord.

ONESINUS PLAU'TUS, Krøyer, 1845.

(P1. IV. Fig. 2.)

Anonyx plautus, Kroyer, Naturh. Tidsskr. 2. R. 1. 13. 1844. p. 629.

- Krøyer, Voyage en Scand. etc. 1848. t. 15. fig. 2.

- - - Spence Bate, Catal. Amphip. Crust. Brit. Mus. 1862. p. 78. pl. Xill. fig. 1.

- - Spence Bate and Westwood, Brit. sessile-eyed Crust. 1863. p. 111.

Lysianassa plauta, Goës, Crust. Amphip. maris Spetsb. 1866. p. 5.

Onesimus plautus, A. Boeck, Crust. amphip. bor. et arct. 1870. p. 32.

Angulus capitis lateralis subacutus. Oculi rubri, magni, ovales. Antennæ

breves: superiores articulo pedunculi Imo elongato, cæeris duobus sat brevibus; 
articulo flagelli I mo el codem flagelli accessorii praxlongatis. Iongitudinc articulis seqventibus +1-5 junctis fere apvali. Pedes Imi paris manu vix longiore qvan carpo. Pedes Irium parium ultimorum articulo 3tio latissimo, in angulo inferiore postico producto: arliculo 4 to angustiore, fere eadem longitudine ac 3tio. Pedes $7 \mathrm{mi}$ paris articulo Imo longiore aut parum breviore fvam seqventibus qvatuor junclis. Pedes saltatorii ultimi paris ramis in margine haud setosis. Appendix candalis longior "yam lata, in margine posteriore parum incisa. Angulus inferior posticus segmenti postabdominis 3 tii sursum productus, aculus.

Dyrets Langde er $8-10^{\mathrm{mm}}$.

I, egemet er ikke meget hoit, dog tykt, med afrumlet liyg.

Hovedet er omtrent saa langt som det forste Legemsled; Sidevinklernc ere ultrukne, men ikke meget tilspidsede, Ginene blive smalere opad; Sideplaterne ere smale, de fire forste tiltage efterhanden i Laengde og Bredde, og den fjerde er kun svagt indskaret paa den bagre Rand for den femte, der kun er ubetydeligt hoiere end hred. Den nedre bagre Vinkel paa det tredie Haleled er udtrukket i en opalbsiet Hage; det fjerde Haleled har tvart over Ryggen en sadelformet Indbugtning.

De avre Folere ere ikke meget forlængede; Skaftets forste Led er meget tykt og mere end dobbelt saa langt som de tvende folgende tilsammen. Svobeus forste Led er hos de seldre Exemplarer meget langt, saa langt som de fire til fem folgende Led tilsaminen, medens det hos de yngre er meget kortere og kum saa langt som de folgende to til tre Led. Dens Led er hos Hannen 10-12, hos Hunnen 8-10 i Antal. Bisvoben er meget kortere og smalere end Hovedsvoben og dannes hos Hannen af $\%$ hos Humen af 5 Led; dens forste Led er forlanget, hos store Exemplarer saa lang som de fire til fem folgende Led tilsammen, hos de smaa som de folgende to til tre Lerl.

De nedre Foleres femte Leil er meget kortere end det fjerde, men hos unge Exemplarer kan det være lige langt.

Kindbakkerne ere temmelig brede paa Enden, og 'Tyggeranden har en T'and paa hver Side. Den indre Bigren damnes af en tynd Tand, og indenfor denne findes tre tornformede Børster. Tyggeknuden er fremstaaende, oval, og Palpen udspringer i samme Hoide eller lidt ovenfor denne; ren sidstnæuntes tredie Led er meget kortere end det andet, tilspidset mod Enden og buet, og har paa den concave Rand en lang Rakke torndamede Borster.

Underlaben el forlanget; Hligenes afrundede Ender have talrige Borster og en skarp 'Tand.

Det forste Kjabepar er temmelig bredt; den ydre Plade har tvende Rader af stærke, brede, lidt krumme, paa den concave Rand saugtakkede Tænder; den indre Plade er oval, neppe tre Gange saa lang som bred, og forsynet paa Enden med tvende 
fjardannede borster; hroraf den ene er nasten dobbelt saa lang som den anden. I'alpens andet Led blivel bredere mod Enden $0 \mathrm{~g}$ ei der afrundet samt besat med sex strerke Trender og en lang bevægelig Borste.

Det andet Kjabepars ydre Plade er meget længere end den indre, og begge have lange, strerke, fjærdannede Børster, tildels i lobbelte Rader paa den indre Rand.

Kjæbefodderne ere forlængede; deres ydre Plade er temmelig lang og smal, med ti til toly Knuder paa den indre Rand, og indenfor disse i deres Mellemrum sees ligesaa mange fine Truder; der findes en stierk, krum 'Tand nær Enden af den ydre convexe Rand. Den indre Plade er temmelig kort, forsynet paa den indre Rand med stærke, fjardannede Børster og med tre Trender par Enden. Palpen er forlænget; dens forste Led er paa den ydre Rand nesten ligesaa langt som det andet, medens dets indre Rand er meget kort; det andet Led naar kun lidt fremmenfor den ydre Plades Ende, dens fijerde Led danner en stærk, mod Spidsen tydelig leddet Klo.

Det forste Fodpar el kort, men kraftig udviklet: Carpus er triangular, idet den bliver bredere udad. Haandens forreste $\mathrm{og}$ bagere Rand ere begge krumme, den ene convex, ten anden concar. Griberanden er skraat afskaaren og har fine Tænder. Kloen er ikke meget lang, paa den bagere Rand forsynet med fine Tæender samt med en strerkere Tand nae Spidsen.

Det andet Fodpar er forlænget, tyndt; Carpus er kun lidt længere end det andet Led; Haanden er neget kortere end Carpus, og dens nedre bagre Vinkel er kun lidt udtrukket.

Det tredie og fjerde Fodpars tredie Led er temmelig langt, medens det fjerde er meget kort.

Det femte fodpars forste Led forlanger sig nedad i en bred, afrundet Lap, det tredie er sardeles bredt og meget bredere end hoit, samt er udtrukket $\mathrm{i}$ den nedre bagre Ende: det fjerde Led bliver ogsaa meget bredere nedad, men er dog lidt hriere end bredt.

Det sjette Fodpars forste Led er langere end paa det foreganende Par: det. tredie og fjerde ere lidt smalere.

Det syvende Fodpars forste Led er sxrdeles forlænget, omtrent saa langt som de folgende fire Led tilsammen; det fjerde Led er ubetydeligt langere end det femte.

Det sidste Par Springfodders ydre Gren er lidt længere end den indre $0 \mathrm{~g}$ er omtrent saa lang som Grundledilet.

Halevedhrnget er noget langere end bredt ved Roden, svagt indskaaret paa len bagre Rand, og liver af ilets Lapper er besat med en liden T'and.

F arven er efter Kroyer smuk rodgul med morkere Ryg. Han angiver, at den forekommer verl Gronlands sydlige Kyst. Efter Goës er den ikke meget almindelig ved Spitsbergen, af (x. 0. Sars er den taget ved Skraaven paa 5-20 Favines Dybde og af mig ved Haugesund paa 60 Favnes Dybde. Spence Bate har efter Norman med T'vivl henfort hertil en Art fra Laminariezonen fra Out-Skerries Harbour. 
ONESIMUS EIDWARDSI, Kroyer, 1846.

(Pl VI. Fig. 4.)

Anonyx Eidwardsii, Kroyer, Naturh. Tidsskr. 2. R. 2. B. 1846. p. 1.

- Kroyer, Voyage en Scand. etc. pl. 16. f. 1.

- $\quad$ - Bruzelius, Amphip. Gammar. 1859. p. 46.

Lilljeborg, On the Lysianassa magellanica. 1865. p. 30.

Lysianassa Liłwardsii, Goës, Crust, amphip. maris Spetsb. 1866. p. 4.

Onesimus Edwardsii, A. Boeck, Crust. amphip, bor. et arct. 1870. p. 33.

.Non.: Anonyx Edwardsii, Spence Bate, Catal. Amphip. Brit. Mus. p. 33.

Oculi magni, rubri. Antemnæ breves; pedunculo crasso: arliculo llagelli I mo Inngitudine modo serventibus duobus aut tribus junctis aqvali. at articulo eodem llagelli accessorii longiore. Pedes $1 \mathrm{mi}$ paris mann magis elongata qvam apud speciem praecedenterm. curvata, multo longiore qvam articulo flo triangulari. Pedes trium parium ultimorum articulo :3tio parum dilatalo; articulo 5to breviore qvam duobus pracedentilus junctis. Pedes rmi paris articulo Imo non longiore qvam cateris junctis. Pedes saltatorii paris ultimi ramis brevissimis. Appendix caudalis eadem ferme latitudine ac longiludine, in margine posteriore sinuati. Ingulus inferior posticus lateralis segmenti postabdominis 3 tii sursum non productus.

Dyret er smn langt, udstrakt fra Panden til Halevedhanget; de gronlandske Exemplarer ere betydeligt store.

Legemet er meget tykt og ligesom opblist, med en rund Ryg. De fire forste Legemsled tiltage bagud i Bredde; det fjerde Haleled har en liden sadelformet Indsynkning over Ryggen lige ved Leddets Begyndelse, det femte er sardeles lidet. Sidepladerne ere høie, men smale; den forste er noget bredere end de tvenile følgende, og den fjerde er dybt indskaaret for den femte, der er noget høiere end bred. Det tredie Haleleds nedre bagre Vinkel danner en stark Hage. Hovedet er omtrent saa langt som det firste Legemsled og danner mellem de ovre Følere et kort Pandehorn; dets Sidevinkler ere udtrukne, men afrundede. Ginene ere temmelig store, blive spidsere opar, men ere nedart afrundede $0 \mathrm{~g}$ bredere.

De øvre Følere ere korte. Skaftets forste Led er tykt og stort; de tvenite folgende ere sarleles smaa. Svoben bestar af 6 Led hos Hunnen og af 10 hos Hannen, og dens forste Led er saa langt som de folgende to til tre Led tilsammen. Bisvoben har 3-4 Led, hvoraf ret forste er liengere end de tvende folgende tilsammen.

De nedre Foleres tredie Led er omtrent saa langt, som bredt; det fjerde er mere end dobbelt saa langt som bredt, og det femte er kortere og smalere. Svoben damnes af 8-12 I.ed hos Humnen og af 2 ! hos Hannen, hvilke silste have Sugeskaale. 
Kindbakherne ere store, ikhe meget udvidede i Spidsen, og under denne Udvidning findes en Torn. Tyggeknuden er lidet fremstaaende; Palpen er frestet i Høide med denne.

Det forste Kjabepars Palpe har i Spidsen fern Trnder; ren indre Plade er forlænget, oval, med tvende fjærdannede Borster.

Det andet Kjabepars indre Plade er meget kortere end det ydre.

Kjobefordernes ydre Plade er af middelmadig Størrelse og vabnet med tvende Torne paa den bagre Rand og med smaa Knuder paa den indre Rand. Den indre Plade er lang og har i Spidsen tre smaa T'render og paa den indre Rand lingere, fjærdannede Børster, samt nar neppe frem til Enden af Palpens andet Led. Palpen er forlanget, $o g$ dens tredie Led er kun lidt kortere end det andet.

Det forste Fodpar er kraftigt; dets fjerde Led er kort, triangulart; det femte er forlænget og bliver smalere mod Spidsen, hvor den stærke, men korte Klo er fæstet; denne har en 'I'and nwr Spidsen.

Det and et Fodpar er forlanget; dets fjerde Led er forlænget, ikke meget bredt og meget langere end det andet; det femte er omtrent halvt saa langt, som let andet, tret forsynet med Børster og lidt udtukket paa den nedre bagre Rand.

Det tredie og fjerde Fodpar ere temmelig brede og korte. Det femte Pars forste Led forlænger sin bagre nedre Vinkel til midt paa det tredie Led, er sangtakket paa den bagre og har strerke Torne paa den forreste Rand; det tredie og fjerile Led ere meget korte og brede, medens det femte er smalere. Kloen er liden.

Det sjette Fodpar er lidt langere end det femte; llets fjerde Led er kun lidet udvidet og omtrent saa langt som det forste Led.

Det syvende ligner det foregaaende, men er noget kortere; dets forste Led er ligeledes lidt bredere, og det tredie er ikke saa ulvidet; det andet til femte Led ere tilsammen længere end det første Led.

Halens Springfodder naa alle nasten lige langt bagud; det sidste Par er lidet, tykt; den ydre Gren er omtrent saa lang som Grundleddet, og den indre er noget kortere; de ere ikke forsynede med Børster. Halevedhænget er noget langere end bredt og spaltet lidt paa Fnden samt vabnet med tvende smaa 'Tome.

Fra den af Kroyer beskreme Form, der findes ved Gronland, afviger den i nogle enkelte Punkter. Efter hans 'Tegning er Legemet hos de gronlandske Exemplarer ikke saa høit, som paa vor Form, og den femte Sideplarle synes derfor at være bredere end høi. Den nedre bagre Vinkel paa det tredie Haleled tegner han afrundet og ikke optrukket i en Hage; Svobens femte Led paa de ovre Folere er ogsaa paa hans Tegning kortere, end Tilfieldet er paa vor Form.

Farven er ifølge Kroyer rolgul med morkere rod liyg. Den for'kommer efter ham sjelden ved ret sydlige Grmland samt ved Spitsbergen. Ved den norke Kyst har jeg fundet den meget sjelden verl Lyngholmen i Hardangerfjorden. Efter Bruzelius skal den forekomme almindelig langs hele Skandinaviens vestre Kyst ned til Kattegat; hans Beskrivelse afviger dog noget fra vor Form, og let er muligens 0 . plartus, som 
han der beshriver. Ifolge Brandt (Middendorffs Heise) tindes den red det nordlige Asien og Amerika: den er saaledes en circumpoler Form.

Gen. XII. MkNIGRA'lES. A. Boeck, $18 \% 0$

Deriv.: Meverpxiาre (et graesk Mandsnavn).

Syn.: 1870. MLniyrutes, A. Boeck, Crust. amphip. bor. et arct. 1, 33.

Typ.: Anonyx obtusifrons, A. Boeck.

Mandibula brevissime: palpo brevi, prolundius fram tuberculo molari robusto affixo.

Maxilla Imi paris lamina interiore ovata, in appice selis duabus plumosis instructa; palpo in apice pancas spinas gerenti.

Maxilla 2di paris laminis mediocriter elongatis.

Pedes maxillares latissimi, hreves; lamina exteriore ultra finem articuli palpi 2di porrecta, paucis spinis gracilibus nodisqve et in apice spina una valida armata: articulis palpi brevissimis el latis: articulo 410 processum brevem, obtusum. tuberculiformem formanti.

Corpus peraltum et crassum.

Antenna sat breves.

Pedes Imi paris robustissimi; manu vis subcheliformi.

Pedes saltatorii brevissimi et crassi.

Denue Slægt ligner meget Orchomenc i det Ydre ved Legemets høie, dog tykke og undersatte Bygning og ved de korte Springfodder. Halevedhanget er dog hos ML' nigrates kløvet, meilens det hos Orchomenc er helt. I Munddelene afvige de fra hinanden i flere Punkter, idet disse hos den forste ere meget kortere end hos den sidste: lerved bliver Overlæben ikke fremstaaende; det forste Kiæbepars indre Plade er hos Mrmigrates meget kort: Kjabefordernes Palper ere korte og brede; det sidste kloformede Led er paa Enden kort og stumpt. Derimod ligne de hinanden i Munddelene derved, at Kindhakkernes Palpe er frstet under Tyggekmulen.

\section{MENIGRA'TES OHTUSIFRONS. A. Boech. 1860. \\ (PI. VI. Fise. 2)}

Anouyx obtusifions, A. Boeck, Forhandl. ved de Skand. Naturf. sde Møde. 1860. 1. 1it3. Anonyx brachycerens, Lillib., On the Lysianassa magellanica etc. 1865. p. 32. f. 42-49. Menigrates obtusifrons, A. Boeck, Crust. amphip. bor. et arct. 1870. p. 34.

Antenne superiores articulo pedunculi 1 mo ferme eadem longitudine ac crassitndine: articulo flagelli lmo longitudine ferme seqventihus duolus jumctio erquali: 
articulo llagelli accessorii I mo longiore qvam articulo llagelli primarii eodem. Antenna inferiores articulo 5 to paulo longiore qvam lato, breviore qvam 4to. Pedes $1 \mathrm{mi}$ paris manu apicem versus angustiore et multo longiore qvam carpo triangulari. Pedes 2di paris articulo 2do breviore qram carpo. Pedes parium trium ultimorum hrevissimi et sat lati; articulo 3tio et 4 to majore latitudine qvam altitudine; hoc hreviore qvam illo. Pedes saltatorii ultimi paris ramo exteriore parum longiore qvam pedunculo, interiore breviore. Appendix candalis paulo longior quam lata, in exteriore tertia parte fissa. Angulus inferior posticus lateralis segmenti postahdominis 3 tii sursum curvatus et acutus.

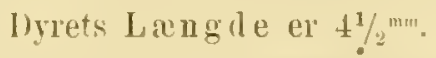

Legemet er meget tykt, bredt. Sidepladerne tre hoie; den femte er meget hoicre end bred; den nedre bagre Vinkel paa det tredie Haleled er bsiet op i en spids Hage. Hovedets Sidevinkler ere tilrundede. Øinene ere store og agformige, idet de blive smalere opad. Folerne ere meget korte og tykie.

De ovre Foleres forste Skaftled er lidt langere end tykt; de tvende folyenle ere meget korte. Svoben dammes af 5 Led, hroraf det forste er kun lidt liengere end det folgende. Bisvobens forste Led er Here Gange sa langt som de trende meget smaa frigende Led.

De nedre Folere ere saa lange som, men tyndere end de svre; deres tredie Skaftled er omtrent saa langt som tykt; det fjerde er meget langere og brerlere end det femte. Svoben er meget kortere end Skaftet og danmes af 4 Led.

Kindbakkerne ere meget forlengede; Griberanden har paa begge Ender en liden 'T'and, og den indre Bigren dannes af en tynd l'and. Tyggeknuden er ikke meget fremstaaende, men tydelig. Palpen er fæstet under'Tyggeknuden og er temmelig kort; dens tredie Led er kortere end det andet og har paa Euden en Del Burster.

Det forste Kjæbepars ydre Plade har sterke, paa den concave Rand fint saugtakkede Tænder. Palpens andet Led har faa, men stærke T'ænder; den indre Plade er liden, smal, med trende fjærdamnede Børster paa Enden.

Det andet Kjaluepars Plader ere meget smale; den indre er meget kortere end den ydre.

Kjæbefodderne ere temmelig brede og korte; den indre Plade er meget forlixnget, med tre smaa Tæroder og nogle Borster paa Enden; den ydre Plade er ikke meget stor, men rager dog langt frem for Enden af Palpens andet Let; den er paa den indre Rand forsynet med faa Knuder og nogle Trender samt med en skarp Torn nær Enden af den ydre Rand. Palpens forste Led er meget kort, det andet er knapt saa langt, men er bredere end det tredie; Kloen er meget kort.

Det forste liodpar er meget kort, men starkt; Carpus er triangulier, meget 
kortere end Haanden, der bliver smalere mod Finden: K'loen er kort, forsynet med et P'ar. 'Tome paa den bagre liand.

Det andet Fodpar er ikke meget smalt; dets andet Led er kortere end det fjerde: Haanden er kortere end dette, og dens nedre bagre Vinkel er ikke forlanget. Det tredie og fjerde Fodpar ere korte, men strerke.

De tre sidste Fodpars forste Led el meget udvidet bagtil og nedad, ligesom leres tredie Led er bredere end høit; dette er ogsaa Tilfreldet med det fjerde, der dog er meget kortere og smalere end det tredie; det femte Led er smalt.

Springfadderne ere korte og tykke.

De trende første Pars Grene have i Randen nogle 'l'ome.

Det sidste Pars ydre Gren er længere end den indre og vabnet med en stark l'and paa Enden. Skaftet er tykt, omtrent saa langt som den ydre Gren.

H alevedhænget er længere end bredt ved Roden og spaltet nasten til Midten. Ginene ere ifølge Lilljeborg rode. Han fandt et Exemplar ved (xuib udenfor Christianssund paa 20-30 Favne, og jeg har fundet et ved Udo ved Mandal.

lien. XII. Olichodienf, A. Boeck. 18\%o.

Deriv.: 'Opyousesoñ (en By).

Syn.: 1870. Orchomene, A. Boeck, Crust. amphip. bor. et arcet. p. 35.

Typ: Orchomene servatus. A. Boeck. Is60.

Epistomum proninens, cassitorme.

Mandibulae longr, anguste; palpo profundius quam tuberculo molari prominenti affixo.

Naxilla $1 \mathrm{mi}$ paris lamina interiore prelongata, angusla, infra in apice setas duas plumosas gerenti; palpo in apice dentibus multis, minutis instructo.

Naxilla 2di paris laminis perlongis et perangustis: exteriore paulo longiore et angustiore qvam interiore.

Pedes maxillares lamina exteriore ultra linem articuli palpi 2di porrecta: articulo palpi lino magno.

Corpus sat altum. Epimerum 5tum altius qvam latius. Angulus inferior posticus lateralis segmenti postahdominis ätii non sursum productus et curvatus.

Antenne inferiores articulo pedunculi 3tio prælongato, angusto.

Pedes 1 mi paris brevissimi, robusti: manu qvadrangulari, longitudinem carpi triangularis superanti.

Pedes 2di paris manu in angulo inferiore postico producta.

Appendix candalis brevissima, in apice parum lissa, non ad finem pedunculi pedum saltalorium ultimorum porrecta. 
Deme Slagt, hvis Arter stai hverandre meget nur, skiller sig fia de foregataende verl, at Mumdelene blive sai starkt forlangede. Springfodleme ere ogsaa sardeles korte ligesom Halevedhienget, hvilket sidste derfor ikke naar frem til Enden af det sitste Par Spriugfodders Skaft. Ved Overlabens Form staar den derimod ner de foregaaende Slægter, men afviger heri fra Socancs. Den er hos denne Slægt hjelmformig ligesom hos Anonyx, Onesimus, Tryphosu og Here. Kindbakkerne ere meget forlangede, og Palpen er fæstet nærmere Roddelen end Tyggeknuden, derved afviger den fra de ovrige af de navnte slagter, og ligeledes ver at det forste og andet Kjæbepar blive stærkt forlængede. Herved forlænges ogsaa meget det forste Pars indre Plade: medens denme hos de nævite Slagter kun er lidt længere end bred. Kjæabefnddernes Palpe er temmelig kort og bred, hvorfor den ikke rager meget udenfor ile ydre Pla(ler, hvilke paa laanden kun ere svagt besatte med Knuder. De nedre Foleres tredie Led er meget forlænget, hvorved den slagt let skiller sig i det Ydre fra le ovrige slagter. Det forste Lodpar er kort, idet Carpus er kortere end den tirkantede Haand. Denne er paa det andet Lodpar udtrukket i sin nedre Vinkel. Legremet er kort, men boiet, og den fente Sideplade er paa Grund heraf hosiere end bred: den fjerde er bagtil indskaret for at optage denne. Halen er meget kort, ligesom hos Oncrimus, saa at Halevelhrenget ikke naar saa langt bagud som til Enden af Grundledklet paa det sidste Par Springfodder. Onesimus plautus damner en Overgang til denne i rlet Yrdre, men skiller sig fra den verl Kindlakkernes Fom og ved, at den nedre bagre Vinkel pai rlet tredie Haleled er tilspirlset.

()RCHOMLNE SERLATL'S, A. Boeck, Is60.

$$
\text { (1\%, V. Fïg. 2). }
$$

Anonyx scrvatus, A. Boeck, Forhandl. ved de Skaud. Naturf. Sde Mgde. 1860. p. 641.

Lilljb., On the Lysianassa magellanica etc. 1865. p. 29. fig. 8.

Anony.e Edwardsii, Spence Bate, Catal. Amphip. Crust. Brit. Mus. p. 73. pl. XI. fig. o.

- $\quad$ - Spence Bate and Westwood, Brit. sessile-eyed Crust. p.97.

Lysianass a crispata, Goës, Crust. Amphip. maris Spetsb. 1865. p. 3. fig. 3.

O)rhomene serratus, A. Boeck, Crust. amphip. ho1. et arct. 1870. p. 35.

Angulus capitis anticus lateralis valde productus, rotundatus, Oculi ovati, nigri. Segmentum postabdominis :3timm in margine posteriore serratum. Epimerum 5́tum latius qvam altum. Antennæ superiores articulo 1 mo pedunculi sat elongato; articulis duobus seqventibus brevissimis; articulo flagelli 1 mo longitudine sequentes 2-3 junctos aqvanti. Pedes 1 mi et 2 di paris reque ut apud speciem pracedentem. Appendix caudalis brevissima, lata, postice incisa.

Det største Individ, som jeg har fumlet, var $11^{\text {mm }}$ langt mellem Pamden og Halevedhanget. 
Legem et er temmelig hoit, sammentrykt fra Siderne, men log med bred liyg. Det fjerde Haleled er nedtrykt i den forreste Del. sideplademe ere hoie: den fjerde er temmelig dybt indskaaret for den femte, som er noget længere end høi; ilet tredie Leds nedre bagre "Vinkel er ret, og len bagre Rand er saugtakket. Hovedet er' kort og damer fortil mellem de gvre Folere et meget lidet Pandehorn; dets Sirlevinkler ere ilke ubetydeligt ultrukne, on Enden er afrumlet. Yinene ere forlangerle, noget hredere nedad end oparl.

De "vre Folere ere korte, men Skaftets forste Lerl er forlanget, cylindrisk: de tre folgende Led ere korte. Svoben er omtrent saa lang som Skaftet og bestaar af 8 Led, livoraf det første el sal langt, som de tre til fixe folgende tilsammentagne. Bisvohen er temmelig lang; lens forste Led er omtrent saa langt som ile tire ovrige tilsammen.

De nedre Folere ere langere end de ovre og tynde; skaftets tredic Len er dobhelt saa langt som bredt; det fjerde er en Trediedel langere og er paa rets avre Rand besat med trette Borsteknipper; det femte Led er kortere og smalere; Svoben dames af 9 Led $0 \mathrm{~g}$ er kortere end Skaftet.

Kindbakkerne ere forlwngede, smale, spidse nedad og lidt midvide mort Eurien. Svoben er fiestet temmelig langt fra Spidsen; dens andet l.erl el meget langere end det trerlie.

Det forste Kjabepar er ogsa forlanget og i Spidsen vabnet med grove Trender, livoraf hver er forsynet med to sma Bitender; Palpen har sex Tronder og en Borste.

Det andet $\mathrm{K}$ jabepar er smalt og langt.

Kjabefoldernes Plader ere store og forlangede; den ydre, der strakker si omtrent til Enden af Palpens andet Lerl, har nogle, ikke meget tydelige Ḱnuder paa Ianden $0 \mathrm{~g}$ indenfor disse, paa den indre Side, en Række smaa Tome; den indre Plarle er vabnet med tre Truder i Spidsen og med nogle korte Børster par den indre Rand, samt strakker sig frem til den ydre Plades Midte; Palpen er forlæuget, smal.

Det første Fodpar er stærkt; dets femte Led eller Haanden er forlænget, firkantet, noget boiet og meget længere end det foregaaende I.ed, der morl Enden er næsten triangulart, paa Enden mere afrundet og der forsynet med snaa Tauder. Kloen er kuu lidt langere end Griberanden og har en lille Torn nar Spidsen.

Det andet Fodpars fjerle Led er noget langere end det andet; let fente er ikke meget forlænget, men tret drkket af Borster, der skjule Kloen, og denne misder den udtrukne nedre bagre Vinkel.

Det tredie og fjerde Fodpar ere forlnengede; leres tredie Led el nerlad noget udvidet $0 \mathrm{~g}$ noget længere end det femte, medens det er meget liengere end det fjerde Led. kloen er liden.

De tre sidste Fodpax tiltage noget i Langde; det femte Pars forste Iad 
er breit, saugtakket paa Randen: det tredie er temmelig udvidet bagtil og er langere end det fierde, men meget kortere end det smale femte Led.

Alle Led paa de folgende fodpar ere længere og smalere.

Det sidste Par Springfødder naar langt bagud; "den ydre (iren er noget langere end den indre og ontrent saa lang som Skaftet, samt uden Borster.

Halevedhanget er bredt, med en dyb Indskjaring, der dog ikke watr frem til Vidten. Fligene staa ud fra hinanden.

- Harven er melkehvid, Oinene role. Et Exemplar havde et purpurfaryet Anstrog paa den ovre Del af Ryggen. *) Denne Art forekommer ved Spitsbergen og nordenfor, paa den 80 Breddegrad, hvor et Exemplar i 1861 blev taget paa 60 Favnes Dybde. Ved Norge er den fundet af G. O. Sars ved Skraven paa 300 Favne, af Lilljeborg ved Grib i Narheden af Christianssund og i Hardangerfjorden paa $\overline{00}$ Favne af (x. (). Sars, af mig ved Lyngholmen paa 150 Favne $0 g$ ved Skudesnas paa 40 Favne, af 6 . 0 . Sars i Christianiafjorden paa $150 \mathrm{og} 300$ Favnes Dybde. Af Lovén er den taget i Bohuslen, ligesom den er fundet paa Here Steder ved Englands liyst.

ORCHOMENE MINUTUS, Linger, IN46.

(1'. V. Fig. 3)

Anony, minutus, Kroyer, Naturh. 'lidsskr. 2. R. 2. I3. p. 23.

- Kroyer, Voyage en Scand. etc. 1848. pl. 18. f. :

- Spence Bate, Catal. Amphip. Crust. Brit. Mus. 1862, p. Fi. pl. XII. f. li.

- Spence Bate and Westwood, Brit. sessile-eyed Crust. p. 108.

- Heller, Heit. \%. näh. Kenntn. d. Amphip. adriat. Meer. p. 24.

OHehomene mimutus, A. Boeck, Crust. amphip. bor. et arct. 1870. p. 36.

Oculi magni, ovati, rubri. Angulus capitis lateralis productus et rotundatus. Epimerum 5 tum altus qvam latum. Angulus inferior posticus lateralis segmenti postabdominis 3 tii fere rectus. Antenne superiores articulo pedunculi Imo brevi et crasso: articulo llagelli lmo longitudine ferme seqventibus tribus junctis angrali: articulo flagelli accessorii 1 mo breviore qvam articulo flagelli 1 mo et multo breviore qvam articulis cateris. Pedes 1 mi paris manu Jongitudinem carpi lerme seqvanti. Pedes trium parium ultimorum multo breviores qvam apud species duas præcedentes. Appendix caudalis profunde fissa: rima valde lianti.

Dyret er $6^{\mathrm{mm}}$ langt fra Panden til Halevedhanget.

Legemet er temmelig sammentrykt, men Ryggen er rund, uden hjol. l)et tredie Haleled viser tviert over Ryggen en dyb Indsankning og bagenfor demne en linude. Sidepladerne ere store; den forste er tildels skjult af den anden, og den fjerde er dybt

*) Spence Bate angiver dens Farve at vere transparent bleggul til lysebrun, Oinene anfures at vare rade hos de unge, meil sorte hos de ramle Fixemplarer. 
indskaret for den femte, iler er ontrent saa brer som hoi. Det tredic Haleleds nedre bagre Vinkel er uden nogen Hage, men afrumlet. Hovedet er lidet, og dets sidevinkler ere ikke udvidede, men afrundede. Øinene ere store og blive smalere opad.

De ovre Foleres Skaft er kort; dets forste Led er stort, opblast; de avrige ere korte. Svgben bestaar af 8 lued hos Hunnen og af 6 hos Hamnen; det forste led er saa langt som de folgende fire til fem led tilsammen. Bisvghen damnes af is lange, men smale Led.

De nedre F́nlere ere forliengede; Skaftets tredie Led er mere end dobbelt saa langt som bredt; det fjerde er end langere, men let femte er meget kortere. Svohen hestaar af 16 Led hos Humnen og af 32 hos Hannen.

Kindbakkerne ere i spidsen meget hrede og udvidede, og under ilem findes nogle smaa Tome.

Det forste Kjabepar har en enkelt Ral starke saugtakkede l'ender. Palpen er i Spidsen vabnet med Here sma 'Tander; den indre Plade er forlanget og forsymet med tvende Børster.

Kjabefoddernes ydre Plade har smat Knuler par den indre Rand og en Torn paa den ydre nær Spidsen. Den indre l'lade bliver tilspidset mod buden og er paa den indre Rand forsynet med Børster.

Det forste Fo il ar er forlanget; det andet og tredie Led er kort; det fierie og femte ere forlangede, smale og nasten lige lange. Kloen er liden.

Det andet Fodpars andet Led er forlanget; det fjerde er ubetyrleligt langere samt udvidet fortil; det femte er forlanget, ovalt, vel besat med Børster.

Det tredie og fjerde Fodpar ere af den sadvanlige Bygning; deres tredie Led er lidet uividet; det fjerde er meget kortere, $o g$ det femte har omtrent den samme I.

De tre sidste Fodpar tiltage efterhanden i hangde; deres forste Led er saugtakket bagtil; det tredie er langere end det fjerde, men meget kortere end det femte, der dog er meget smalere. Kloen er liden.

De tre Par Springfodder naa alle næsten lige langt bagud; let silste P'ar's indre Gren el noget kortere end den ydre, som er vabnet med tvende Tander nar Spidselı.

Halevedhanget el nasten dobbelt saa langt som breilt og kinvet nasten til Riolen.

Farven er efter Kroyer hvidgul med kamosinn Ryg; Ginene ere rollbrume. Jeg har fundet ganske hvide Exemplarer mell rosenrode oine.

Denne Art findes hyppig ved Gronland paa 60 Favnes Dybile, ved Spitsbergen ere Here Exemplarer tagne paa 2-10 Favnes Dybde, i Finmarken er den fundet af Lovén og Malmgren, i Nordland af G. O. Sars paa 60-100 Favnes Dybde, ved Lyngholnen af mig paa 1j0 Favnes Dybde, ver Christianssund af Ianielssen. Den, som Spence liate 
afbilder fra Englands hyst. stenmex ikke fuldstrudig overens med vor Art, og den, som Metzger har fundet ved deu ostfrisiske hyst. skal efter ham heller ikke stemme overens med Krovers Beskrivelse. Heller har fundet den ved Lessina i det adriatiske Hav.

ORCHOMENL: PINGVIS, A. Boeck, 1860.

(P1. V. Fig. 1.)

Anonyx lingvis, A. Boeck, Forhandl. red de Skand. Naturf. 8de Møde. 1860. p. 642.

- - Lilljeborg, On the Lysianassa magellanica etc. 1865. S. 29.

Orchomene pingvis, A. Boeck, Crust. amphip. bor, et arct. 1870. p. 35.

Oculi magni, reniformes, rubri. Angulus posticus lateralis capitis rotundalus. Epionerum 5tum eadem altitudine ac latitudine. Angulus inferior posticus lateralis segmenti postabdominis 3tii valde rotundatus. Segmentum postabdominis 4 tum transverso impressum et in marginc posteriore gibbosum. Antenna superiores articulo pedunculi Imo crassissimo: articulo flagelli 1 mo longitudine articulos segventes $5-6$ junctos aeqvanti. Pedes $1 \mathrm{mi}$ paris carpo brevissimo: manu duplo longiore qvam lata. Pedes 5̆ti paris articulo 1 mo postice valde dilatato et latiore qvam alto. Pedes saltatorii ultimi paris ramis setosis. Appendix caudalis duplo longior qvam ad basin lata. et in exteriore tertia parte lissa.

Dyrets Langile er $y^{\mathrm{mm}}$.

Le gemet er meget tykt og ligesom opbliest. Sideplademe ere temmelig hrie; den fjerde er dybt indshaaret bagtil for den femte, der er hoiere end bred. Hovedets Sidevinkler ere afrumledle.

De orre Foleres Skaft er tykt: Svobens forste Led er ligesaa langt som de følgende 8-10 Led tilsammen: Bisvoben er fireleddet, og dens forste Led er lrengere end ret tredie.

De nedre Foleres fjerde Led er kun dobhelt saa langt som bredt, ng det femte er ovalt: Svoben bestaar af $y_{0}$ Led.

K indbakerne ere $\mathrm{i}$ Spidsen brede. og under deme sees Spor af tre sma 'Trender: 'Tyggeknuden er liden.

Det forste Kjabepar er i Spidsen bredere, vabnet med særdeles brede, paa Randen saugtakkede Tander; Palpens Spids har smaa Trender, der indad aftage i Storrelse.

Kjabeforddernes indre Plade har paa Spidsen tre Tsender: iten ydre er bred og har paa Randen Knuder samt paa Spidsen tvende Trender.

Det forste Fodpar er strert: dets femte Led er rectangulært, meget liengere end rlet fjerde.

Det andet Fodpars fjerde Led bliver mod Fnden meget bredt og er besat 
med mange Hade, brede Borster; det sidste Led er convext par den forreste og concavt paa den bagre Rand og udtrukket i Spidsen.

Det femte Fodpars første Led er meget bredt, saugtakket, med korte Børster paa den bagre Rand mellem Saugtakkerne; de tre følgende Led ere korte, det tredie er meget udvidet samt besat med 'Torne paa den forreste og med Borster par den bagre Rand; de tvende folgende Led tiltage efter hinanden lidt i Langde og ere meget mindre brede.

Det sidste I'ar Springfodder er forlænget, smalt, deres ydre Gren er længere end den indre.

Halevedhanget er forlanget og kløvet omtrent til Midten. Det tredie Haleleds nedre bagre Vinkel er tilrundet; det fjerdle Led har paa Vidten en sadelformet Fordybning.

Denne blev fundet i eet Exemplar ver Mandal, $0 g$ G. O. Sars liar fundet et ved Skraaven paa 2-300 Favnes Dybde.

\section{ORCHOMENE GOËSII, A. Boeck, 1870**)}

(Pl. IV. Fig. 5.)

Orchomene Gö̈sii, A. Boeck, Crust. amphip. bor. et arct. 1870. p. 36.

Oculi magni, ovati, nigri. Angulus capitis lateralis valde rolundatus. Epimerum 5tum altius qvam latum. Angulus inferior posticus lateralis segmenti postabdominis 3tii rotundatus. Segmentum postabdominis 4tum transverso profunde impressum et postice pergibbosum. Antenna superiores brevissima; articulo pedunculi Imo paulo longiore qvam lato: articulo flagelli 1 mo longitudine articulos duos sequentes junctos xqvanti. Pedes 1 mi paris manu ovata, haud duplo longiore qvam lata, longitudinem carpi triangularis superanti. Pedes trium parium ultimorum et pedes saltatorii brevissimi. Pedes saltatorii 3 tii paris pedunculo apicem versus valde dilatato; ramis parvulis. Appendix caudalis apicem versus parum incisa.

Dyrets L $\mathfrak{L} \mathrm{ngde}$ er omtrent $5-6 \mathrm{~mm}$.

Le gemet er hoit, dog ikle sardeles sammentrykt, med rund liyg. Det fjerde Haleled har tvæert over Leddets Milte en strerk Indtrykning, og bag denne findes en høi, spids Knnude. Den nedre bagre Vinkel paa det tredie Haleled er nasten ret, paa Enden afrundet. Sidepladerne ere meget høie; den femte er høiere end bred. Hovedet er næsten saa langt som det forste Legemsled; begge Sidevinkler ere strerkt afrundede. Øinene ere næsten nyreformede.

De øvre Folere ere korte; det forste Skaftled er meget tykt; de tvende følgende Led ere korte; ligesaa Svobens forste Led, der ikke er dobbelt saa langt som

*) Denne Art er opkaldt efter Dr. Goès i Stockholm. 
tykt verl Roden og neppe saa langt som de tvende folgende Led tilsammen. Bisvoben hestaar af tre lied, livoraf det forste er meget langere end de tvende følgende tilsammell.

De nedre Foleres tredie Led er forlanget, bliver bredere mod Enden og er omtrent af samme Tykkelse som det fjerde, der dog er lidt langere; det femte er kortere og smalere end det fjerde samt kortere end Svoben, der dannes af $5-6$ Led.

lijabefoddernes indre Plade er meget smal og forlwnger sig outrent til Enden af Palpens andet Led; den ydre Plade er meget stor, naar frem til Midten af Palpens tredie Led og er i Midten af den indre laand vabnet med en Tom.

Det forste Fodpar er meget kort og tykt; dets tredie Led er paa den bagre Rand forsynet med lange Børsteknipper; Carpus er kort, bred og har i den bagre nedre, afrundede Vinkel en lang Børstebundt; Haanden er omtrent saa lang som Carpus, nasten xgformet; Kloen har nær Enden af den bagre Rand en liden Torn.

Det andet Fodpars andet Led er kortere end det fjerde, der paa Enden af den bagre Rand er butet og forsynet med talrige brede Borster; Haandens nedre forreste Vinkel er" ultukket.

Det tredie og fjerde Fodpar ere korte og brede; deres fjerde Led er omtrent lobbelt saa langt som bredt.

De tre sidste Fodpar ere ligeledes korte og brede, deres forste Led er bagtil stærkt udvidet; det tredie Ler er ogsaa meget bredt; det fjerde er lidt langere end liredt.

springfouderne ere meget korte.

Det tredie Par Springfodders Grundled bliver ndad meget bredere og er par knden forsynet med nogle Torne. Grenene ere meget smale og korte; den indre meget smalere og kortere end den ydre.

Halevedhænget er kort og tykt, lidt indskaret paa Enden.

F'arven er hvid og klar. Den svre Del af Hoverlet samt Folernes Skaft er morkt, pomerantsgult. Paa Ryggen af de fem forste Legemsled fincles nar den bagre Rand en pomerantsgul Flek, der paa det sjette Led er overmaade stor, medens den paa de tre bagre er liden. Sidepladerne, de tre bagre Forlpar, Halen og Springfodderne cre svagt gule.

Den findes ver Haugesmo i Tangen.

ORCHOMENE UMBO, Goës, 1865.

Lysianassa umbo, Goës, Crust. amphip. maris Spetsb. 1865. p. 4. fig. 6. Orehomene umbo, A. Boeck, Crust. amphip. bor. et arct. 18\%0. p. 3\%.

Corpus peraltum, compressum; dorso valde carinato; carina segmenti postabdominis 1 mi et 2 di in denticulum, eadem 3 tii et 4 ti in dentem sursum produclum desinenti. Angulus capitis anticus lateralis productus. Epimerum 5tum in medio 
gibbera magum emillens. Antenne superiores arliculo pedunculi 1 mo crassissimo carinato; carina in apice in dentem obtusum desinenti: articulis duobus seqventilus longitudinem articuli lmi arvantibus: articulo flagelli lmo fere eadem longitudine ac seqventibus duobus junctis. Pedes 1 mi paris manu elongata, parum longiore qvam carpo angusto. Pedes 2di paris carpo apicem versus postice produclo. Pedes trium parium ultimorum hreves: articulis qvatuor ultimis angustis. Appendix caudalis profunde fissa.

Dyrets Langde er $6{ }^{m m}$.

Legemet er sammentrykt fra Side til anden, og Iyggen danner en skarp Kjol. som begynder med Hovedet og indtager alle Ryggens Led. Denne Kjøl springer paa det tredie Haleled ud i en stump Tand, og paa det fjerde damner den en opadboiet Hage. Sidepladerne ere særdeles høie og smale, og den fjerde er bagtil dybt indskaret for den femte, der er høiere end bred samt springer frem i en stor Pukkel. Det tredie Haleleds nedre bagre Vinkel er ret. Hovedet er noget længere end det forste Legemsled og damer mellem de ovre Folere et kort Horn. Hovedets Sidevinkler ere urltrukne.

De øvre liglere ere korte. Skaftets forste Led el sardeles stort og damner en Pukkel paa Enden af den gvre Side; det andet og tredie Led ere korte; Svobens første Led er kun noget længere end breit; de folgende aftage meget i Tykkelse. Bisvoben er liden, toleddet.

De nedre Foleres tredie Led er forlænget, dobbelt saa langt som tykt; det fjerde er meget liengere og liengere end det femte Led. Svoben er kort og damnes af 6 Led.

Overlæben er fremstaaende.

Kindbakkerne ere forlængede, smale; Gribedelen synes ikke at være forsynet med Tænder; Tyggekuuden er tydelig; Palpen er frstet langt nedenfor denne, og dens tredie Led er meget kortere end det andet.

Det første Kjæbepars indre Plade er ikke meget forlænget, bliver smalere mod Enden og er der forsynet med tvende smaa, fjærformede Børster; Palpen har paa Enden 9 tretstanende smaa T'ruder.

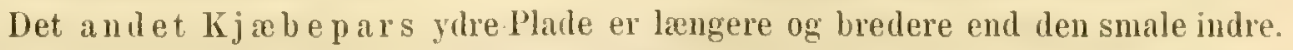

Det forste Fodpar er forlanget, smalt, dets andet og tredie Led ere korte, det fjerde er tre Gange saa langt som bredt, det femte er noget langere, med parallele Rande, paa Enden næsten ret afskaaret samt forsynet med tvende strerke Torne paa Enden af den bagre Rand. Kloen er kort.

Det andet Fodpars fjerde Led bliver fortil meget tykt og er der forsynet med fine Børster; dets femte Led er ikke meget langt, men med en strerkt udtrukket, nedre bagre Vinkel, mod hvilken lægger sig en lilen Ḱlo. 
Det tredic og fjerde Forlpar ere meget forlangede; rleres tredie Led er kort, ikke meget udvidet; det fjerde er næsten af samme Læugde, medens det femte er meget længere end dette. Kloen er omtrent Halvdelen af det femte Leds Lxngde, er smal og svagt krummet.

Det femte Fodpar er kort, dets forste Led er stærkt udvidet bagud, saa at Leddet kun er noget hoiere end bredt; det tredie Led er udvidet, og den nedre bagre Vinkel er udtrukket; det fjerde er af samme Langde, men meget smalere, det femte er længere end tredie. Kloen er omtrent Halvdelen af det femte Leds Langde og noget krummet.

De trende folgende Fodpar tiltage ubetydeligt i Langde; alle Led have omtrent den samme Bygning som paa femte Fodpar. Disse Fodpars forste Led er ikke saugtakket paa den bagre Rand.

springfodderne ere korte.

Halevedhanget er forlenget, mere end lobbelt saa langt som bredt ved Koden og næsten fuldstændig klovet.

Denne Art er fundet temmelig sjelden ved Spitsbergen paa 20 Favnes Dybde, vel Brettesuæs par $40 \mathrm{og}$ vel Skraven paa $50-100$ Favne af G. O. Sars.

Gen. XIV. TRYPHOSA, A. Boech, 1870.

Deriv.: 'Ipup̧üa (et grask Kvindenavn).

Syn.: 1870. Tryphosa, A. Boeck, Crust. amphip. bor", et arct. p. 37.

Typ.: Anonyx nanus, Kroyer.

Epistomum plus minusve prominens.

Mandibula palpo gracili fere in eadem altitudine ac tuberculo molariafixo; articulo palpi 3tio brevi.

Maxilla Imi paris lamina interiore ovata, in apice setas duas plumosas gerenti; palpo in apice dentibus nonnullis obtusis instructo.

Maxilla 2di paris laminis haud valde prælongatis.

Pedes maxillares lamina exteriore lata, ovata, in margine interiore nodis multis, in apice spinis duabus armata, ultra tinem articuli palpi 2di porrecta.

Pedes Imi paris elongati.

Appendix caudalis pralongata, ultra finem arliculi ultimi pedum saltatoriorum porrecta.

Deme nye Slægt indbefatter fire Arter, hvoraf $T$. longipes, Spence Bate, maaske senere vil blive udskilt, da Overlaben i sin Form meget afviger fra den hos de gvrige hidhørende Artex. L. uordonis, Heller, fra Adriaterhavet maa efter hans Beskrivelse og 'Tegning henfores hertil. I Overlebens Form stemmer denne overens med Slxgten Orchomene, og ligesom hos denne er det første Kjabepars indre Plade noget for- 
længet, men dog ikke saa strekt, som hos hin Slægt. Derimorl ere Kindbakkerne meget kortere, af hvilken Grund Palpen er fastet i samme Hoide eller endog nærmere deres Ende end Tyggeknulen. Det tredie Led paa ile neire Folere er temmelig forlanget, dog mindre end hos Slagten Orchomene; ligesom hos denne er den femte Sideplade høiere end bred, men Halevedhænget afviger meget fra det hos hin Slrext, idet det nar" meget længere bagud end det sidste Par Springfodders Grundled.

TRYPHOSA NANUS, Kryyer, $18 \pm 6$.

Auonyx nunus, Kroyer, Naturin. Tidsskr. 2. R. 2. B. 1846. p. 30.

- Kroyer, Voyage in Scand. etc. pl. 1\%. f. 2.

- Spence Bate, Catal. Amphip. Crust. Brit. Mus. 1862. 1. is. pl. XII. f. 9.

- Lilljeborg, On the IJysianassa magellanica etc. 1868. p. 28.

- Heller, Beitr. z. näh. lienntr. adriat. Meer. 1867. p. 24.

Typhosa nauns, A. Boeck, Crust. amphip. bor. et arct. 1870. p. 3\%.

Oculi ovati, rubri. Angulus inferior posticus lateralis segmenti postabdominis 3tii nerve acutus neqve productus. Antennæ superiores articulo pedunculi 2do et 3tio elongatis, junctis paulo hrevioribus yvam articulo 1mo; articulo flagelli Imo elongato. longitudine :3-4 articulos seqventes junctos æeqvanli; llagello appendiculari ad finem articuli 3tii flagelli porrecto: articulo Imo flagelli appendicularis eadem longitudine ac articulo flagelli $1 \mathrm{mo}$ et pluribus partibus Iongiore qvam sergventibus duobus junclis. Pedes Imi paris manu longiludinem carpi aeqvanti, duplo longiore qvam lato. Appendix caudalis duplo longior yvam ad basin lata, ultra medium fissa. Pedes saltatorii ultimi paris ramo exteriore in margine interiore setas plumosas gerenti.

Dyrets Lan gde er $5^{\mathrm{mm}}$.

Legemet er starkt sammentrykt og høit, men Ryggen er rund. Hovedet er ontrent saa langt som det første Legemsled, og dets nedre Sidevinkel er ikke meget ultrukket. Sidepladerne ere høie; den fjerde er dybt indskaaret bagtil for den femte, der er saa høi som bred, næsten firkantet med afrundede Hjømer. Det tredie Haleleds nedre bagre Vinkel er buet og danner ingen Hage.

De øvre Følere ere omtrent en Femtedel af Legemets Totallængde. Skaftets andet $\mathrm{og}$ tredie Led ere noget længere end sedvanlig; Svoben er længere end Skaftet; dens første Led er forlænget, omtrent saa langt som de grrige Led tilsammen. Bisvøben naar til Enden af Hovedsvobens tredie Led og er treleddet; det forste Ler er tlere Gange saa langt som de tvende gvrige tilsammen.

De nedre Foleres femte Led er meget kortere end det fjerde. Svoben, der dannes af 9 Led, er omtrent saa lang som Skaftet. 
Kjabefolderues ydre Plade, dér nar frem til noget foran Palpens andet Led, er forlenget og paa den indre Rand vabnet med 14-15 Knuder og i Spidsen forsynet med en Tand. Den indre Plade har tre Tiender og nogle Børster.

Det første Fodpar er strerkt, dets andet Led er kort; det femte eller Haanden er forlanget, rectangulært, noget boiet og omtrent af samme Liengde som rlet fierle Led. Kloen er liden, væbnet paa den bagre Rand med en stærk Torn.

Det andet Fodpars fjerde Led er ubetydeligt liengere end det andet, og Haanden er omtrent af det foregaaende Leds halve Langde samt i det bagre Hjorne noget ultrukket forat morle Kloen.

Det tredie og fjerde Fodpar ere af den samme Form; deres tredie Led er omtrent lige saa langt, medens det fjerde er kortere end det femte Led.

De trende folgende Fodpar tiltage efterhanden noget i Lrengde; deres fjerde Lerl er paa det femte Par noget kortere end det tredie, men paa de ovige er det derimod langere.

Halens Springfodder naa alle nasten lige langt bagud.

Det tredie Pars ydre Gren er paa den indre Rand forsynet med mange fjordannede Borster og merl en stærk 'Tom paa Enden; den indre er noget kortere.

Halevedhanget er forlanget, mindst dobhelt saa langt som bredt og spaltet til over Midten; dets Flige er aabne.

Farven er gulhvid, Øinene rode.

Denne Art er fundet ved Molde og Chistianssund af Uanielssen paa $30-50$, af G. O. Sars paa 50-100 Favnes Dybde. Ved Haugesum har jeg fundet et Exemplar paa 50 Favne. Kroyer har taget den i Kattegat paa 11 Favne, Lindstrom ved Farsund og Bruzelius i Bohuslen. Af Norman er den fundet ved Shetlandsøerne. Efter Heller findes den ogsaa i Adriaterhavet.

TRYPHOSA HÖRINGII, A. Boeck, 1870。*)

Tryphosa Höringli, A. Boeck, Crust. amphip. bor. et arct. 1870. S. 38.

Antenna superiores articulo pedunculi 2 do et 3tio brevissimis; articnlo thagelli 1 mo brevi, longitudine seqventibus $2-3$ junctis aqvali. Pedes 1 mi paris multo longiores et angustiores qvam apud speciem præcedentem; manu et carpo eadem longitudine. Appendix caudalis fere usque ad basin fissa. Pedes saltatorii ultimi paris ramo exteriore hand setoso. Angulus inferior posticus lateralis segmenti postabdominis 3tii fere rectus.

Dyret er $6^{\text {mom }}$ langt.

Legenet er temmelig hoit. Hovedet er kun lidt lingere end det forste Legemsled, og dets Sidevinkler ere niesten rette med noget buede Rande. Oinene ere temmelig store, ovale. De fire forste Sideplater tiltage efterhaanden i Hoide, og den

*) Arten er opkaldi efter Dr. Hüring i Kjobenharn, der har sanlet Amphipoder fra Danmarks líster. 
sidste er meget dybt indskatret paa den bagre Rand for len femte, hvilken er ontrent saa hoi som bred ved den nedre Ende. Det tredie Haleleds nedre bagre Vinkel er nasten ret, men med buede Rande. Det fjerde Haleled har tvart over Ryggen en saddelformet Fordybning.

De $ø$ vre Foleres forste Led er nasten saa langt som Hovedets wvre Rand og Here Gange saa langt som de tvende folgende korte Led tilsammen. Svobens forste Led er temmelig kort, saa langt som de 2-3 folgende tilsammen, og har paa den indre Side tvende Rader Børstebundter. Bisvoben dannes af 4 Led, livoraf det første er det langste, ikke fuld saa langt som Hovedsvoben, og kortere end de trende folgende Led tilsammen. Svoben dannes hos Hunnen af $10-12$, Bisvoben af 5 Led.

De nedre F'glexes tredie Led er temmelig langt, omtrent saa langt som det femte, der er meget kortere end det fjerde. Svoben dannes hos Humen af $14-15$ Led. Epistomet er meget fremragende, og mellem dette og den pukkelformet fremstaaende Overlabe findes en dyb Indsynkning.

Kindbakkerne ere meget kraftige, korte; Griberanden er forsynet med en Tand paa den ene Side. Tyggeknuden er ikke meget fremstarende, og mellem denne og Griberanden sees 5 smaa Torne i en Rakke. Derimod synes den indre tandformede Bigren at mangle. Underlæbens Flige ere temmelig brede, og Bifligene ere ikke synlige.

Det forste Kjæbepar er temmelig strerkt. Den ydre Plade er paa Enden viebnet med streke, niesten kamformede Truder; den indre Plade er ikke meget forlanget og har i Enden tvende fjærdannede Børster, hvoraf den ydre er den lingste. Palpen bliver mod Enden temmelig bred og har mange (9-10) smaa 'Tander.

Det andet Kjæbepars Plader ere smale; den indre er smalere og kortere end den ydre, begge have paa den skraat afskame Rand mange fjærdannede Børster.

Kjæbefødderne ere temmelig store; den ydre Plarle er stor og bred og naar frem foran Palpens andet Led. Dens indre Rand har mange smaa Kuuder, og mod Enden af den ydre findes en lang Tand. Den indre Plade er kort, paa den skraat afskaarme Ende vabnet med tre smaa Tænder og nogle fjærdannerle Borster.

Det forste Fodpar er forlænget, smalt; det fjerde Led eller Carpus er ogsai forlænget, lidt længere end Haanden, der er næsten tre Gange saa lang som bred. Griberanden er pa Enden skraat afskaaren, og Neglen har en Tand nar Enden af den bagre Rand.

Det andet Fodpar er ike meget forlanget; det fjerde Led bliver bredere mod Enden $\mathrm{og}$ er kun lidt langere end det andet; Haanden er ikke dobbelt saa lang som bred, og dens nedre bagre Vinkel er kun lidt udtrukket.

Det tredie og fjerde Fodpars tredie Led er langere end det fjerde og nasten saa langt som det femte.

Det femte Fodpars forste Led er bagtil meget udvidet, saa at det neppe er høiere end bredt; det tredie Led bliver morl Enden advidet og el udtrukket i den nedre bagre Vinkel. 
Det sjette og syvende Fodpars forste Led er hiere end bredt; deres tredie Led $\mathrm{er}^{\circ}$ kun lidet udvidet og saa langt som eller kortere end det fjerde, der er kortere end det femte.

Det første Par Springfodder nar langst bagud, dets Grene ere nresten lige lange.

Det tredie Pars indre Gren er meget kortere og smalere end den ydre og omtrent saa lang som Grundleddet.

Halevedhænget er mere end dobbelt saa langt som bredt ved lioden og nasten spaltet; hver af Fligene har en Torn paa Enden.

Farven er hvidgul, strøet med lyserøde Pletter; Øinene ere rosenrøde.

Den. blev fundet $i$ et enkelt Exemplar ved Haugesund. Af Packard el den fundet ved Labrador.

Den afviger saaledes fra $T$. nam ved de ovre Foleres forskjellige Bygning, ved den langere og smalere Haand paa det forste Fodpar og ved, at det tredie Led paa det tredie og fjerde Fodpar er langere end hos hin Art.

TRYPHOSA LONGIPES, Spence Bate, 1863.

(Pl. VI. Fig. 5. Pl. V. Fig. 8).

Anonyx longipes, Spence Bate, Cat. Amphip. Crust. Brit. Mus. p. 79. pl. XIII. fig. 4. . Spence Bate and Westwood, Brit. sessile-eyed Crust. 1863. t. I. p. 113. ㅇ.

- - Spence Bate and Westwood, Brit. sessile-eyed Crust. 1863. p. 116. of.

- _ _ Lilljeborg, On the Lysianassa magellanica etc. 1865. S. 23. fig. 23-31.

Anonyx ampulla, Spence Bate, Cat. Crust. Amphip. Brit. IIus. 1862. p. 79. pl. XIII. fig. 4. ㅇ.

- _ Spence Bate and Westwood, Brit. sessile-eyed Crust. 1863. p. 116.

Typhosa longipes, A. Boeck, Crust. amphip. bor. et arct. 1870. p. 38.

Oculi ovati, rubri. Angulus lateralis capitis productus et acutus. Antemme superiores elongate: pedunculo angusto, attenuato; articulo flagelli 1 mo longitudine seqventibus 1 junctis aqvali. Angulus inferior posticus lateralis segmenti postabdominis 3 tii valde sursum productus et acutus. Epistomum antice in longum acumen curvatum produchum. Pedes 1 mi paris elongati, tenues; manu flongata, rectangulari: carpo ferme eadem longitudine; ungve parvo, dente uno prope apicem armato. Pedes trium parium ultimorum longissimi et angustissimi; articulo 1 mo postice dilatato: ungve longo recto. Pedes saltatorii ultimi paris ramis lanceolatis; ramo utroqve longitudine aqvalibus, in margine interiore setosis. Appendix caudalis plus duplo longior qram ad basin lata. in duabus teriis partibus fissa: utraqve lacinia supra spinas $1-3$ gerenti. 
Det storste af mig fundne Exemplar var omtrent $10^{\mathrm{mm}}$ langt, men Arten kan blive $12-13^{\mathrm{mm}}$.

Legemet er temmelig forlanget og sammentrykt, uden at der findes nogen Kjøl langs Legemets Ryg. Sidepladerne ere høie; den fjerde er dybt indskaret for den femte, der er bredere end høi. Det tredie Haleleds nedre bagre Vinkel danner en meget stor, spids, opad- og bagudrettet Hage. Hovedet er temmelig forlanget, men danner intet Horn mellem de øve Falere. Dets Sidevinkler ere udtrukne, men i Spidsen ere de afrundede.

De ovre Folere ere forlangede. Skaftet er tyndt; det forste Led er forlanget, det andet og tredie ere korte. Svøbens første Led er forlænget, saa langt som de $3-4$ folgende Led tilsammen. Bisvoben er lang, smal og dannes af 6 Led, hvoraf det forste er meget længere end de tvende følgende tilsammen.

De nedre Foleres tredie Led er omtrent saa langt som bredt, det fjerde el længere og tykkere end det femte. Svoben er meget længere end Skaftet og bestaar af 9-14 Led, hos Hannen af 38 Ised.

Overlieben er særdeles stor, kraftig, gaar fortil ud i en skarp Spids og bærer tvende Bilapper paa sin nedre Del.

K indbakkerne ere meget store; Spidsen er ikke meget bred, men dog ulvidet. Tyggeknuden er liden, smal. Palpen er smal, forlænget, dens andet Led er sardeles langt, og det tredie er hort med Børster langs den ovre Rand.

Det forste Kjabepar har i Spidsen grove, saugtakkede Trnder. Palpen er rundtakket paa knden, og dens indre Plade er liden.

Kjabefoddernes ydre Plade er stor, oval, med Knuder paa Randen og med tvende korte Trender i Spidsen; den indre Plade er forlænget, tilspidset paa Enden. Palpen er meget kort, hvilket væsentlig skyldes det korte andet Led.

Det f $ø$ rste Fodpar er forlænget, smalt, dets fjerde Led er noget længere end det femte.

Det andet Fodpars andet og fjerde Led ere nasten lige lange, og Haanden er forlæenget, smal.

Det tredie og fjerde Fodpar ere forlangede, men af den sædvanlige Form.

De folgende tre Fodpar tiltage i Lengde; det femte Pars forste Led er meget udvidet, tykt, næsten saa bredt som hoit og af en rhomboidalsk Form med afrundede Hjorner; det fjerde Led er noget lengere end. det tredie, og det femte er endnu liengere end dette.

Det sjette og syvende Fodpars forste Led, men især det fjerde og femte, blive langere end paa det femte Fodpar.

Alle Springfodder naa nzesten lige langt bagud. Jet sidste P'ars Grene ere forlangede, lancetformede; den ydre er noget langere end den indre, som er forsynet med nogle Børster paa den indre Rand.

Halevedhrnget er forlanget og klovet i de yderste Totrediedele. 
Farven er efter Lilljeborg lividgul, Øinene rale.

Den er fundet ved Molde og Christianssund af Danielssen, vel Aalesund paa 60-100 Favnes Dybde af (x. 0. Sars, af mig ved Lyngholmen i Hardangerfjorden $0 \mathrm{~g}$ af G. O. Sars ved Hvidingsøeme. Udenfor Norge er den af Norman taget ved Shetlandsqerne.

TRYPHOSA NANOHDES, Lilijeborg, 1865.

Anony $x$ nanoides, Lilljeborg, On the Lysianassa magellanica etc. 1865. p. 25. fig. 32-34. Anonyx nanus, Bruzelius, Skand. Amphip. Gammar. 1859. p. 42.

Tryphosa nanoides, A. Boeck, Crust. amphip. hor. et arct. 1870. p. 38.

Angulus inferior posticus lateralis segmenti postabdominis 3tii productus sed in apice obtusus. Antennæ superiores articulo pedunculi 2 do et 3 tio brevissimis; articulo flagelli Imo tertiam longitudinis flagelli partem aeqvanti; flagello appendiculari 6articulato, ad articulum flagelli 5tum porrecto. Pedes $1 \mathrm{mi}$ paris manı et carpo eadem longitudine. P'edes saltatorii ultimi paris spinis, non setis armati.

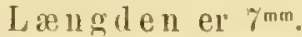

L e gemet er nogenlunde sammentrylit, dog temmelig tykt paa Midten. Det fjerde Haleled viser en svag Indsynlkning paa Ryggen nar det foregaaende Led. Sideplademe ere store; den fjerde er bagtil dybt indskaaret for den femte, der er længere end høi. Den nedre bagre Sidevinkel paa det tredie Haleled boier sig meget opad og damer en stor Hage. Øinene ere ovale. Pandehornet er meget lidet. Hovedets Sidevinkler ere ikke meget stærkt udtrukne, men tilrundede.

De øvre Foleres Skaft er kraftigt og tykt, dets andet og tredie Led ere smaa. Svobens forste Led er neppe dobbelt saa langt som tykt; de 12 øvrige Led ere korte og hlive smalere ulad mor Svøbens Spids. Bisvoben dannes af 6 I،ed, hvoraf det forste er temmelig langt og tykt, men dog ikke saa langt som de ovrige Led tilsammen.

De nedre Foleres tredie Led er omtrent saa langt som bredt; det fjerde er dobbelt saa langt som breit og tret besat merl Borster paa Kanterne. Svøben dames af 20 Led hos Humnen og af 35 hos Hannen. Kindbakkerne ere korte, men starke. Enden er meget brerl og er paa den forreste Rand under Spirlsen vabnet med en rlobhelt Tand.

Det forste lijæbepars Palpe, ler ex-meget bred, har i Spidsen 6 kraftige Trnder og en Torn. Kjaben barer nedenfor Tandbesætningen en stark Dusk med Burster:

Kjobefoddernes ydre Plade har paa den indre Kant smaa, adskilte Knuder og par den indre Side findes tilsvarende smata Torne, livorimod der ikke sees Torne eller Tænder paa Enden. Den indre Plade er af middelmaadig Storrelse og kun hesat med smaa Knuder og nogle fjærformede Burster. 
Det forste F odpar er stierkt; det fjerde og det femte Led eller Haanden ere omtrent lige lange, det sidste mere end dobbelt saa langt som bredt, skraat afskaaret paa Enden. Neglen er kun saa lang som Enderanden.

Det andet Fodpars andet $0 \mathrm{~g}$ fjerde Led ere omtrent lige lange; Haanden er forlænget $0 \mathrm{~g}$ besat med tætte Børster.

Det tredie og fjexde Fodpar ere kraftigt udviklede.

Det syvende Fodpars forste Led er forlenget, firkantet, med afrundede Hjorner og saugtakket paa den bagre Rand; det tredie Led er kun lidt udvilet nedad og ikke længere end det fjerde, hvorimod det femte er meget længere, men smalere.

Springfodderne ere forlangede; ret andet Par naar ikke saa langt tilbage som de tvende ovrige.

Det sidste Pars Grene ere læugere end Skaftet, forlængede, lancetformede; den indre er noget kortere end den ydre og vabnet paa Kanterne med Torne og Børster.

$\mathrm{H}$ al evedhænget er forlrenget, mere end dobbelt saa langt som bredt, smalere mod Enden og kløvet i den yderste Totrediedel; begge Lapper have en Torn i Spidsen.

Farven er hid, Øinene role.

Den er fundet af G. 0. Sars ved Skraaven par.2-300 Favnes Dybde, af mig ved Langenres i Vesteraalen, af Lilljeborg ved Molde, af mig ved Haugesund, og efter Bruzelius findes den ved Bohuslen. Norman hax ogsaa fundet den i 1868 ved Storbritamiens Kyster.

Gen. XV. NORMANIA, A. Boeck, 1870.

Deriv.: Normania (opkaldt efter den engelske Zoolog Rev. A. M. Norman).

Syn.: 1868. Opis, Spence Bate and Westwood, Brit, sessile-eyed Crust. II. p. no3.

1870. Normania, A. Boeck, Crust. amphip. bor. et aret. p. 39.

Type: Opis quadrimana, Spence Bate and Westwoorl.

Mandibula palpo gracillimo, elongato.

Maxilla $1 \mathrm{mi}$ paris palpo latissimo, ovato; lamina interiore angusta, non vero pralongata, setas duas plumosas gerenti.

Naxilla 2di paris laminis angustis, non vero longis.

Pedes maxillares lamina exteriore latissima, in margine spinis paucis gracilibus instructa; lamina interiore prixlongata. angusta: palpo multo breviore qvam lamina exteriore, 3articulato; articulo palpi 4to absenti.

Antenne superiores breves, non crassi.

Antenna inferiores breves: segmento pedunculi 1 mo inflato et extus visibili.

Pedes 1 mi paris manu magnopere inflata. Iata. valde subcheliformi.

Pedes 2di paris elongati.

Pedes saltatorii elongati.

Appendix caudalis perbrevis, lata, non fissa. 
Spence Bate og Westwood (Brit. sessile-eyed Crust. 1868. p. 503) henforte til Slagten Opis en ny Art O. quadrimana fra Bamffshire. Denne stemmer dog ikke overens med Opis, hverken med Hensyn til Munddelene eller Danmelsen af det forste Fodpars Haand, og maa derfor generisk udskilles herfra. I Lighed med Slægten Eurytenes er ogsaa hos denne Slagt de første Led af de nedre Fyleres Skaft meget store og opsvulmede samt ere ikke dækkede af Hovedets Sideplader, men derimod synlige i et Indsnit i disse. Kindbakkerne ere mod Spidsen meget stærkt forlæugede, smale. Det forste Kjæbepars indre Plade er forlænget, smal. Den er meget afvigende fra de øvrige Slægter med Hensyn til Kjæbefoddernes Form; Palpen er nemlig særdeles kort, treleddet og naar ikke frem til Enden af de ydre, store Plader. Den indre Plade er ogsaa forlænget,. smal. Det første Fodpars Haand er meget stærkt opsvulmet, og det andet Fodpars Haand bliver saxdannet, ved at den nedre bagre Vinkel forlanger sig til Enden af den korte Klo. Springfødderne ere forlængede, medens Halevedhænget er meget kort.

NORMANIA QVADRLLANA, Spence Bate \& Westwood, 1868.

(Pl. VI. Fig. 3.)

Opis quadrimana, Spence Bate and Westwood, Brit. sessile-eyed Crust. vol. II. p. 503. Normania quadrimana, A. Boeck, Crust. amphip. bor. et arct. 1870. p. 40.

Oculi permagni, ovati. Antennæ superiores articulo 1 mo elongato, angusto; articulo flagelli 1 mo longitudine seqventibus duobus junctis æqvali. Antennæ inferiores articulo pedunculi 5to breviore qvam 4to; articulo 1 mo non valde inflato. Pedes 1 mi paris manu magna, fere rhomboidali, in acie truncala, postice spina valida armata. Pedes 2 di paris manu angusta, in angulo inferiore postico laterali producla, longitudine carpum dimidium ferme aqvanti. Pedes trium parium ultimorum articulis postice non valde dilatatis; articulo 3 tio brevi, multo breviore qvam 4to. Pedes 5́ti paris articulo tto multo longiore qvam 3tio, longitudine ferme 5to aqvali; ungve longitudinem articuli ultimi fere aqvanti. Pedes saltatorii ultimi paris pedunculo breviores. Appendix caudalis latior qvam longa, in margine interiore parum insinuata.

Dyret er $4^{\mathrm{mm}}$ langt.

I e gemet er sammentrykt fra silerne. Hovedet er læugere end de tvende første Legemsled tilsammen; Øinene ere meget store, slirae, ovale, mørke. Hovedets Sidevinkel er ikke udtrukket, men afrundet. De fre forste Sideplader ere ikke meget hvie; den fjerde er kun lidt indskaaret paa sin bagre Rand for den femte, der er meget liden; den nedre bagre Vinkel paa det tredie Haleled er tilrundet.

De ovre Føleres Skaft er ikke meget tykt; det første Led er omtrent tre 
Gange saa langt som de tvende ovrige tilsammen; Svøben har / Led, hvoraf det forste er ikke fuldt saa langt som de tvende ivrige tilsammen; Bisvoben bestaar af 3 Led.

De nedre Folere ere tyndere og kortere end de ovre; deres andet Skaftled er opsvulmet og ligger i en Indskjæring i Hovedets nedre Kant; det tredie Led er meget kort; det fjerde er lidt langere og tykkere end det femte; Svoben er omtrent saa lang som skaftet og damnes af $\check{~ L e d . ~}$

Kindbakkerne er forlængede; Griberanden er temmelig but, uden nogen Indskjæring; ingen Tyggeknude sees; Palpen er meget forlænget, tynd; dens tredic Led er ubetydeligt kortere end det andet, lidt bøiet og har paa Enden nogle Børster.

Det forste $\mathrm{Kj}$ æbepars ydre Plade er meget bred, væbnet paa Enden med faa, men strerke 'Tænder og paa den indre Rand med nogle Borster; den indre Plade er kort, smal, med tvende fjærformede Borster paa Enden; Palpen er meget bred; dens andet Led er ovalt og har i Spidsen nogle smaa saugformede Tronder og tre strerkere Torne.

Kjabefoddernes indre Plade er meget forlanget, smal og forsynet med nogle Borster i den indre Rand; den ydre I'lade er oval, uden Spor af T'sender eller Knuder paa den indre Rand; Palpen er sardeles kort, kortere end den ydre Plade, og dannes af tre nasten lige lange Led, hvoraf det sidste har paa Enden nogle Borster:

Det fjerde Fodpar er meget strerkt; dets fjerde Led eller Carpus er kort, triangulart; Haanden er temmelig stor, bred, med en i Enden ret afskaaren Griberand, der er vabnet i Enden med en stærk Klo; denne er stærkt saugtakket i len concave Rand.

Det and et Fodpar er forlanget, tyndt; dets andet Led er kortere end Carpus. Haanden er lidt mere end Halvdelen saa lang som denne, og den indre bagre Vinkel forlænger sig noget, saa at Haanden bliver saxdannet.

Det tredie og fjerde Fodpar ere meget tynde; deres tredie Led er kun lidt længere og bredere end det fjerde, men kortere end det femte; Kloen er liden.

De tre bagre Fodpars forste Led or neppe saugtakket i den bagre Rand; deres tredie Led er meget kort, og paa det syvende Fodpar er det meget kortere end det fjerde Led, der er omtrent saa langt, men tykkere end det femte; Kloen er nrsten ret, kun lidt kortere end det femte Led.

Springfodderne ere temmelig lange og tynde; de tvende forste Pars ydre Gren er kun lidt kortere end den indre; begge ere tynde og uden Torne i Randen; det sidste Pars Grene ere omtrent lige lange, meget kortere end Skaftet.

Halevedhænget er meget kort, bredere end langt og lidt indskaret paa den bagre Rand.

Den er fundet ved Haugesund af mig i eet Exemplar paa 30-40 lavmes Dybre, desuden af Norman ved Englands Kyst. 
Gen. XVI. OPISA, n. g.

Deriv: ' $\Omega$-:

Syn.: 1842. Opis, Kroyer, Naturh. Tidsskr. 1. R. 4. B. 1842. p. 149. (Navnet er benyttet af Defrance i 1821-24.)

1853. - Dana, U. States Expl. Exped. Crust. p. 908.

1862. - Spence Bate, Cat. Amphip. Crust. Brit. Mus. p. 83.

1870. - A. Boeck, Crust. amphip. bor. et arct. p. 40.

Typ.: Opis typica, hrøyer.

Mandibulae palpo profundius qvam tuberculo molari affixo.

Maxilla Imi paris lamina interiore angusta, non longa, in apice setas duas plumosas gerenti.

Maxillæ 2di paris laminis angustis, non vero longis.

Pedes maxillares lamina exteriore elongata, angusta, in margine interiore denticulis instructa. fere ad finem articuli palpi brevis 3tii porrecta: articulo palpi 4 to ungviformi.

Pedes $1 \mathrm{mi}$ paris manu permagna, inflata. in angulo inferiore antico producta et acuta.

Appendix caudalis prelongata, profunde fissa.

Kroyer opstillede denne Slægt i 1842 og adskilte den fra Slrgten Anomyx verl, at iet forste Fodpar har overordentlig store saxdannede Hænder. Spence Bate og Westwood har henfort hertil trende nye Arter, hvoraf den forste, O. quadriman. af mig allerede er optagen som Typus paa en ny Slægt, Normania; den anden, O. Teptocheta, horer heller ikke til denne Slægt, da det forste Fodpar har en meget forlanget Carpus og en forlanget saxdannet Haand, hvorved den ligner Slægten Kröycria, der hører til Underfamilien Ocdicerinac. Den bor derfor ogsaa blive Typus for en ny Slagt, der kunde kaldes Leptochcla. I Munddelenes Bygning afviger den ikke saa meget fra Sliegten Anomyx, men dog især derved, at Kjæebeføddernes ydre Plader ere temmelig smale og vabnede med smaa Trender istedetfor Linuder paa den indre Rand. Springfodderne ere forlængede, og Halevedhænget er sardeles langt, dybt kløvet. Da Kroyer's Slægtsnavn allerede var benyttet, har jeg sat et a i Enden af hans Navn.

\section{OPISA ESCHRICH'TI, Krover; 184\%.}

Opis Eschrichti, Kroyer, Naturh. Tidsskr. 1 R. 4 B. 1842. p. 14!.

- Spence Bate, Catal. Amphip. Crust. Brit. Mus. 1862. p. 83. pl. XIV. fig. 4.

Opis typica, Krøyer, Naturh. Tidsskr. 2 R. 2. B. p. 46.

- Voyage en Scaud. 1848. pl. XVII. fig. 1.

- Spence Bate, Catal. Amphip. Crust. Brit. Mus. 1862. p. 83, pl. XIV. fig. 3. 
Opis typica, Goës, Crust. Amphip. maris Spetsb. 1866. p. 1.

A. Boeck, Crust. amphip. bor. et aret. 18\% p. 40.

Oculi oblongi, reniformes, nigri. Angulus inferior posticus lateralis segmenti postabdominis 3tii rolundatus. Epimerum 5tum latius qvam altum. Antenne superiores pedunculo brevi: articulo pedunculi Imo duplo longiore quam duobus seqventibus junciis; articulo flagelli lmo longitudine seqventibus 45 junctis reqvali. Antennæe inferiores articulo 5 to breviore quam 4to. Pedes 1 mi paris manu latiore qvam longa, in angulo inferiore postico laterali valde producta et acuta. Pedes 2di paris manu ovata. breviore qvam carpo; carpo longitudine articulo 2do ferme anvali. Pedes saltatorii ultimi paris ranis longioribus qvan pedunculo, angustis, in margine interiore setas longas plumosas gerentibus. Ippendix candalis ler longior qvam ad basin lata et fere usque ad basin fissa.

Dyrets Længde er $9^{\mathrm{mm}}$.

Legemet er temmelig tylit og his. Sidepladerne ere store; den fjerde er paa den bagre Rand dybt indskaaret for den femte, der ikke er saa hoi som bred. Det tredie Haleleds nedre bagre Vinkel er tilrundet. Hovedet er noget kortere end let forste Legemsled, og dets nedre Sidevinkel er ikke meget udtrukket, men kort og tilrundet. Øinene ere store, nyreformede og stode ovenfor Panden næsten til hinanden.

De øvre Føleres Længde er omtrent en Femtedel eller noget mere af Legemets 'Totallwugde. Skaftets andet og tredie Led ere korte. Svøben er omtrent saa lang som skaftet og dannes af 9 Led; det forste Led er forlanget $0 g$ saa langt som de fire folgende tilsammen. Bisvoben er noget liengere end Svobens Halvilel og damnes af 6 Led, hvoraf det forste er noget langere end det andet og de folgende aftage efterlaanden i Langhe.

De nedre Foleres femte Led er kortere end det fjerde. Svoben dames hos Humen af $8 \mathrm{Led}$, hos Hannen af mere end $20 \mathrm{Led}$, hvoraf nogle ere saa lange som det hele Legemes.

Kjabefoddernes ydre Plader, der ere store og tilspidsede mod Enden, ere fat den indre Rand vobnede med $6-\gamma$ Touder; de indre ere forlongede paa Enden og have tvende stærke Tæniler og nogle Borster. Palpen er scerdeles kort og nar knapt med sit tredie Led til Enden af de ydre Plader. Kloen er spids.

Det forste Fodpars andet, tredie og fjerde Led ere korte; det femte Led eller Haanden er megret strerkt opsvulmet, og dets nedre bagre Hjørne er udtruklet til en lang Hage, medens den meget kitumme Klo, ler bxrer en liden Biklo nær Spidsen, faster sig i det andet Hjorne.

Det andet Fodpars andet og fjerde Led ere omtrent lige lange; det fente er ovalt, tret dækket af Børster. K'loen er liden.

Det tredie og fjerde Fodpars tredie og femte Led ere lige lange, mertens det fjerde er noget kortere. 
De tre følgende Par tiltage efter hverandre i Langle; det femte Pars første Led er ikke høiere end bredt, og det tredie samt det femte ere omtrent lige lange, medens det fjerde er kortere.

Halens Springfodder ere tynde; det tredie Pars Grene ere forlangede, meget smale, den indre er noget kortere end den ydre og begge paa den indre land forsynede med fjarformede Borster.

Halevedhæuget er meget forlænget, smalt og spaltet næsten til Roden.

Farven er efter Kroyer smuk ansigtsrod, med en mork ablerød Ryg, Øinene ere sorte.

Efter Krøyer og 'Torell er den fundet paa Here Steder ved Gronland. Ved Islands Kyster er den fundet af Torell, og ved Grotsund i Finmarken paa ro Fames Dybde af Goës og Malmgreen.

Da Kroyer forst har kaldt denne Art Opis Eschrichti og forst senere har uden Grund forandret Navnet til Opis typica, tror jeg, at det aldste Navn bor foretrakkes.

Gen. XVII. ACIDOSTOMA, Lilljeborg, 1865.

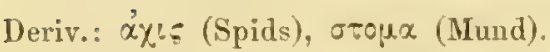

Syn.: 1865. Acidostoma, Lilljeborg, On the Lysianassa magellanica etc. 1865. p. 34.

1870. - A. Boeck, Crust. amphip. bor. et arct. p. 41.

Type: Anonyx obesus, Spence Bate.

Mandibula dente parvo accessorio et tuberculo molari carentes; palpo perlongo et tenui, profunde infra affixo.

Maxillæ $1 \mathrm{mi}$ paris palpo destituta: lamina interiore elongata. in apice setas paucas gerenti.

Maxillæ 2di paris laminis perangustis, longis.

Pedes maxillares lamina exteriore magna in margine interiore nodulis paucis instructa: lamina interiore elongata, ad apicem setis paucis instructa: palpo pergracili, et parum modo ultra fuem lamina exterioris porrecto: articulo ultimo noduliformi.

Pedes 1 mi paris breves, robusti; manu subcheliformi.

Pedes 2di paris graciles, ungve carentes.

Peles saltatorii breves.

Appendix caudalis brevis, lata, profunde fissa.

Paa den af Spence Bate (Catal. Crust. Amphip. Brit. Mus. p. 74) beskrevne Art Anomyx obesus har Lilljeborg i 1865 (On the Lysianassa magell. etc. p. 34) opstillet Slagten Acidostoma, da Munddelenes Bygning vasentlig afviger fra Slægten Anonyx. Den adskiller sig fra alle de øvrige Slagter i Sichleleshed ved, at det første Kj: bepar 
aldeles mangler Palpe. Mundulene cre formrigt meget forlangede, Kindbakkerne ere uden Tyggeknude og mangle den indre Bigren, medens Palpen er forlanget, tynd. I Kjabeføddernes Form ligner den noget Slægten Ambasia, idet Palpens sidste Led er knudeformet og Pladerne ere store, saaledes at Palpen kun nar lidt udenfor dem. Hos denne Slægt ere Palpens Led tyude, medens de hos Ambasia ere brede. Fodparrene og Springfodderne ere korte.

\section{ACIDOSTOMA OBESUM, Spence Bate, 1862.}

Anonyx obesus, Spence Bate, Catal. Amphip. Crust. 1862. p. 74. pl. XII. fig. 1.

- - Spence Bate and Westwood, Brit. sessile-eyed Crust. 1863. p. 28. Acidostoma obesum, Lilljeborg, On the Lysianassa magellanica etc. 1865 . p. 34. pl. Y. fig. $53-65$.

- - A. Boeck, Crust. amphip. bor. et arct. 1870. p. 41.

Corpus obesum; dorso rotundato. Oculi parvuli, rotundi, nigri. Epimerum 5tum latius qvam altum. Angulus inferior posticus lateralis segmenti postabdominis 3tii fere rectus. Antennæ superiores pedunculo brevi; articulo flagelli $1 \mathrm{mo}$ vix longiore qvam articulo segventi; liagello accessorio elongato, angusto. flagello fere reqvali. Pedes $1 \mathrm{mi}$ paris carpo triangulari; manu apicem versus attenuata. Pedes 2di paris manu elongata, aqvilata, multo breviore qvam carpo. Pedes 3tii el 4 ti paris ungve paulo breviore qvam articulo 5to. Pedes trium parium ultimorum arliculo 1 mo postice valde dilatato, in margine posteriore serrato. longitudine articulis reliqvis junctis fere rqvali: arliculo 3tio et 4 to latissimis et brevissimis: ungre fere recto. Pedes saltatorii paris ultimi ranis longioribus quam pednnculo, in margine non setosis. Appendix caudalis eadem ferme longitudine ac latitudine, profunde fissa.

Dyrets Længde er omtrent $5 \mathrm{~mm}$.

Legemet er hoit, dog meget tykt, med rund Ryg. Sideplademe ere høie; den fjerde er paa den bagre Rand dybt indskaaret for den femte, der er noget bredere end høi. Den nedre bagre Vinkel paa det tredie Haleled er næsten ret, lidt tilrundet. Hovedet er omtrent saa langt som det forste Legemsled; dets Sidevinkel er ikke udtrukket, men tilrundet. Oinene ere runde.

De ovre Foleres Skaft er tykt; det andet og tredie Led ere korte, dog lidt langere end sædvanligt; Palpen dannes af 8 Led, hroraf det forste ikke afviger meget i Langde fra det folgende. Bisvoben er kun lidt kortere og tyndere end Hovedsvoben og dannes af 6 forlængerle Leil.

De nedre Folere ere lidt længere end de ovre, men meget tyndere. Skaftets fjerde Led er længere end det femte; Svoben dannes af 7 Led og er noget kortere end Skaftet. 
Overlæben er skarp, kjolet, paa Enden tilspidset og der forsynet med Borster.

Kindbakkerne ere meget forlængede. Griberanden har en liden Tand; den indre Bigren og Tyugelinuden mangle; Palpen er meget forlanget og tymi; dens andet Led er kun lidt længere end det tredie, der paa Randen og i Spidsen har nogle Børster.

Det første Kjæbepars ydre Flade er smal med strerke Trnder i Spidsen; den indre Plade er ogsan. smal, kun væbnet med nogle smaa Børster paa Enden; Palpen mangler.

Det andet $\mathrm{Kj}$ æbepars Plader ere smale; den ydre er langere end den indre.

Kj xbeføddernes indre Plader ere smale, med nogle Borster i Spidsen; de ydre er store og paa den indre Rand forsynede med nogle faa smaa Knuder. Palpen er meget tynd; dens forste Led er længere end det andet og kun lidt kortere end det tredie Led; det fjerde er kun som en liden Knude.

Det forste Fodpar er kraftigt udviklet. Carpus er triangulær, kun lidt kortere end Handen, der mod Enden bliver meget smal og har paa den indre Rand fine Borster; Kloen er tynd, lidt krummet.

Det andet Fodpar er smalt, dets fjerde Led er meget læengere end let andet og længere end den smale, med talrige Borster besatte Haand, der mangler Klo.

Det tredie og fjerde Fodpar ere stærke; deres Kloer ere kun lidt kortere end det femte Led, buede og tilspidsede.

De tre sidste Fodpar ere meget korte og brede; dets forste Led er bredt, grovt saugtakket paa den bagre Rand, men ikke meget udvidet nedad; de folgende tre Led ere brede, medens det femte er smalt $\mathrm{og}$ lidt længere end den næsten rette Klo.

Springfodderne ere korte; det sidste Pars ydre Gren er læengere end den indre, der atter er. længere end Grundleddet.

Haleved hanget er omtrent saa langt som bredt ved Roden og dybt klovet.

Farven er rod, ginene sorte.

Denne Art er fundet forst ved Shetlands Kyst af Norman, ved Molde paa $30-40$ Favnes Dyb af Lilljeborg, ved Haugesund af mig og ved Farsund af Lindstrom. Den skal ogsaa forekomme verl Bohuslen.

Subfamilia II.

PONTOPORINAE. Dana, 1853.

Syn.: 1853. Pontoporeinae, Dana, U. States Explor. Exped. Crust. p. 912.

1865. - Lilljeborg, On the Lysianassa magellanica etc. p. 18.

1870. - A. Boeck, Crust. amphip. bor. et arct. p. 42.

Labium superius latum, in apice rotundatum.

Nandibula in apice alte el valde dentata, ramo accessorio instructe; tuberculo molari prævalido; palpo 3arliculato. 
Maxilla Imi paris palpo biarticulato, in apice dentibus validis armato: lamina interiore plerumqve magna, in margine interiore setosa.

Maxillæ 2di paris laminis latissimis.

Pedes maxillares palpis brevibus et validis; lamina exteriore dentibus asperrimis instructa.

Corpus altum, compressum; dorso lato.

Epimera magna, in marginibus inferioribus plumosa.

Antenne superiores breves, validæ, flagello appendiculari instructæ.

Pedes 2di paris graciles, interdum manu subcheliformi instructi.

Pedes trium parium ultimorum apud genera forma diversa, maxime pedes 5 li paris; pedes $7 \mathrm{mi}$ paris paulo breviores qvam 6 ti paris; articulo 1 mo valde dilatato; pedes 6 ti paris ut plurimum longiores qvam iidem 5 ti paris.

Pedes saltatorii biramosi; iidem ultimi paris ramo interiore plerumqve multo breviore quam exteriore.

Appendix caudalis lata, brevis, plus minusve tissa.

Dana dannede denne Underfamilie i 1852 og indesluttede deri Slægterne Lepidactylus, Ampelisca, Protomedeia, dora og Phoxus. Han karakteriserede den ved, at det tredie og fjerde Fodpar ere mere eller mindre indrettede til at gribe med, medens dette ikke er Tilfreldet med de tre sidste Par. Jeg paaviste i 1860, at Slæaten Pontoporeia afviger fra de fleste af de af Dana til denne Underfamilie henregnede Slagter, $o g$ at den stemmer meget overens med Bathyporeia sant nærmer sig til Anomyx, ligesom at det tredie og fjerde Fodpar ikke ele nere væbnede med Gribehrender, end Tilfreldet er hos Anonyx og Bathyporeia. Spence Bate optog ikke denne Underfamilie, da han fandt, at det tredie og fjerde Fodpar ikke vare indrettede som Gribeorgan, men stillede den typiske Slægt nær til Anonyx. Lilljeborg adskilte i 1865 igjen Pontoporcia fra Underfamilien Lysianassina og optog Dana's Underfamilie Pontoporcinae, hvortil han henforte Slrgterne Pontoporeia, Stegocephalus og Bathyporeia. Denne Underfamilie skilte han fra Lysianassina ved, at Kindbakkernes Gribedel er tandet, medens den for den største Del er glat hos disse. Af Lilljeborgs Slagter udskjod jeg i 1870 Stegocephalus, som maa henfores til den af Dana opstillede Familie Stegocephatinae, og som afviger meget fra den her omhandlede Underfamilie ved, at Kindbakkerne paa begge Sider ere ulige, idet den ene mangler, medens den anden har en indre Biflig. Jeg tilfoiede derimod tvende nye Slægter, Priscilla og Argissa. Min Underfamilie Pontoporinae er saaledes anderledes begrændset, end det er skeet af Dana og Lilljeborg, idet de Slægter, der ere optagne $\mathrm{i}$ denne, ere andre end hos hine Forfattere. Men ligesom Lilljeborg adskiller jeg den fra Lysianassinae ved Kindbakkernes forskjellige Form; de ere nemlig hos Pontoporinae meget stærke og i Spidsen indskaarne i talrige Tænder, ligesom der her findes en kraf- 
tigt udviklet tandet Bigren, hvilket ikke er Tilfældet hos Lysianassinae. Underlæbens indre Flige ere vel udviklede; det første Kjæbepars indre Plade er meget bredere end hos Lysianassinae, og Kjabefoddernes ydre Plade er væbnet med meget stærke Tænder. Forovigt have disse tvende Underfamilier en vis Overensstemmelse ved, at Legemet hos begge er høit og tykt, samt ved, at de ovre Folere ere korte og forsynede med Bigren. De Slægter, som henhøre til denne Underfamilie, afvige fra hverandre især med Hensyn til Fodparrenes og Sidepladernes forskjellige Form, idet de ere udviklede ifølge deres forskjellige Opholdssted; saaledes lever Bathyporeia paa en mere dyndet Bund end de ovrige, medens Priscilla lever paa Sandbund.

Gen. I. PONTOPORELA, Kroyer, 1872.

Deriv.: rovтoropssx (Navnet paa en Nereide hos Hesiodot).

Syn.: 1842. Pontoporeia, Kroyer, Nye nordiske Slagter og Arter af Amphipodernes Orden. Naturh. Tidsskr. 1. R. 4. B. p. 152.

\begin{tabular}{|c|c|c|}
\hline 353. & 一 & Dana, U. States Explor. Exped. Crust. p. 912. \\
\hline 1859. & - & Bruzelius, Bidrng til Känn. Amphip. Gammar. p. $4 \%$ \\
\hline 862 & - & Spence Bate, Catal. Amphip. Crust. Brit. Mus. p. 82. \\
\hline & - & Lilljeborg, On the Lysianassa magellanica etc. p. 18. (Tabel). \\
\hline & - & A. Boeck, Crust. amphip. bor. et arct. p. 43 . \\
\hline
\end{tabular}

Typ.: Pontoporeia feniorata, Kroyer.

Epimera anteriora qvatuor lata, longitudine gradatim crescentia, in margine inferiore fere truncata.

Pedes $1 \mathrm{mi}$ paris breves, lati, robusti; manu subcheliformi.

Pedes 2di paris manu angusliore; ungve parvulo.

Pedes 3 tii et 4 ti paris robusti.

Pedes 5 ti et 6 ti paris arliculo 1 mo postice paulo dilatato; ungve parvo.

Pedes $7 \mathrm{mi}$ paris arliculo $1 \mathrm{mo}$ postice magnopere dilatato, clipeoformi; ungve parvo.

Pedes 6ti paris longiores quam idem 5 li et $7 \mathrm{mi}$ paris.

Pedes saltatorii ultimi paris ramis universis longitudine fere agvalibus.

Appendix caudalis fere ad basin fissa.

Krøyer opstillede denne Slægt i 1842 og angiver blandt Karaktereme: "Pedes tertii qvartiqve paris longiores, validi, subcheliformes, articulo qvarto dilatato palmam efficiente ungve armati conico“. Dette er dog en mindre rigtig Opfatning. Det fjerde Led er kun kort og bredt, og det femte kan boie sig mod dette, ligesom det er Tilfældet hos mange andre Slægter, hvilke Krøyer ogsaa har tildelt den samme Karakter. 
I 1845 siger han, at den nærmer sig Slægten Anonyx paa Grund af sine korte øvre Folere, der ere forsynede med en Bisvøbe, og ved det høie Legeme.*)

Spence Bate oversætter kun Krøyers Slægtskarakter, da han ikke kjender nogen Art, og stiller Slægten nær Anonyx. Lilljeborg paaviste forst med Skarphed, at den væsentlig skiller sig fra alle Slægter, der henhøre til Underfamilien Lysianassina, verl at Kindbakkerne ere stirkt tandede paa Enden. Han optager derfor Dana's Lnderfamilie Pontoporeinae, dog anderledes begrændset og med andre Karakterer. I 1870 matte jeg med andre Karakterer, enil de af Kroyer, Bruzelius og Lilljeborg anfurte. skille den fra de øvrige Slægter, som jeg stillede i Underfamilien Pontoporinac, da tvende af disse, Priscilla og Argissa, ere nye Slægter. Sidepladerne hos denne Slægt ere temmelig store, og de fire forste tiltage efterhanden lidt i Størrelse, medens den femte, som ellers er meget kortere end den fjerde, hos denne er usædvanlig stor, ligesom ogsaa den forreste Del af den indre Rand ex mere forlænget end den bagre. Derved er det femte Fodpar ikke rettet lige nedad, men meget mere bagover, end sædvanligt el Tilfaldet. Dyret benytter nemlig dette og tildels det følgende Forlpar til dermed hurtig at skyde sig udaf den Hule, som den har dannet sig mellem de smaa Stene, blandt hvilke den har sit Opholdssted. Det første Fodpar er af en temmelig kraftig Bygning og forsynet med en Gribetaud, derimod er det andet Par meget forlænget, smalt, og dets Haand har kun en liden Klo, hvorved dette Fodpar ligner meget det tilsvarende hos Slægten Anomyx og andre Slægter i Lysianassidemes Familie. Medens det femte og sjette Fodpars første Led er kun lidet udvidet, er dette desto mere Tilfaldet med det syvende Par; dette Led er her nemlig stort, skjoldformigt og besat med mange lange Borster paa den bagre Rand. Dette Fodpar er ogsaa kortere end det foregaaende, hvilket beror paa, at det andet 0 g fjerde Led ere saa korte i Forhold til de tilsvarende paa det sjette Par.

Af denne Slagt kjende vi for Oieblikket kun tre Arter, der alle findes i Skandinavien eller i det arktiske Hav, og kun en af den er fundet ved Skotland, hvorimod ingen af dem er fundet ved Englands Kyster eller i Middelhavet. De maa saaledes betragtes som nordlige Former. Den ene af Arterne, $P$. affinis, fiudes kun i Østersøen og

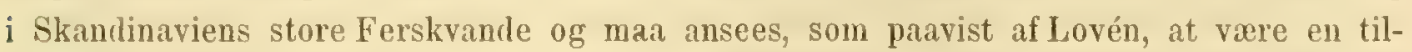
bagebleven arktisk form.

PONTOPOREIA FEMORATA, Krøyer, 1844.

Pontoporeia femorata, Krøyer, Naturh. Tidsskr. I. R. 4. B. 1844. p. 153 .

$\begin{array}{lll}- & \text { Krøyer, Voyages en Scand. etc. pl. 23. fig. 2. } \\ \text { - } & \text { - M. Sars, Forhandl. i Vid.-Selsk. i Christiania 1858. p. } 130 . \\ \text { - } & \text { - Krøyel, Naturh. Tidsskr. 2. R. 1. B. p. } 530 .\end{array}$

*) Bruzelius anforer heller Intet i sin Slxgtskarakter om, at det tredie og fjerde Fodpar ere dannedc som Griberedskaber, og stiller Slægten lige efter Anonyx. 
Pontoporeia femorata, Spence Bate, Catal. Amphip. Crust. Brit. Mus. 1862. p. 82. pl. XIV. fig. 1 .

- $\quad$ - Goës, Crust. Amphip. maris Spetsb. 1866. p. 1.

A. Boeck, Crust. amphip. bor. et arct. 1870. p. 43.

Antennæ superiores flagello appendiculari biarliculato; articulo 2 do minimo. Segmentum postabdominis 4 tum prıcessum parvum, in apice fissum, emittens. Pedes $1 \mathrm{mi}$ paris manu triangulari, parum longiore qvam lata. Pedes 2di paris clongati; manu multo breviore qvam carpo, circiter tel longiore qvam crassa. Pedes $7 \mathrm{mi}$ paris articulo 3tio longiore qvan 4 lo; hoc longiore qvam 5́to.

Det største undersøgte Exemplar var $15 \mathrm{~mm}$ I ang tra Panden til Halevedhænget.

Legemet er forlænget, men meget tykt, opsvulmet, med rund Ryg uden Kjøl. Paa Midten af det fjerde Haleled findes en i Spidsen spaltet Torn. De fire forste Sideplader have paa den nedre Rand fjærdannede Børster og ere høiere end brede samt tiltage bagtil i Bredde; den fjerde, som er den bredeste, er ikke indskaret paa den bagre Rand for den femte; denne sidstnævnte er ligesaa hoi som den foregaaende, men meget bredere $0 \mathrm{~g}$ indskaret paa den bagre Del af den indre Rand for det femte Fodpar. De tvende folgende Sideplader ere meget mindre. Det tredie Haleleds nedre bagre Vinkel er næsten ret og noget tilrundet. Hovedet er næsten saa langt som de tvende forste Legemsled tilsammen og gaar fortil ul i en meget stump Vinkel mellem de ovre Folere. Hovedets Sidevinkel er ultrukken og noget tilrundet.

De ovre Følere strække sig, naar de boies bagover, til det tredie Legemsled; Skaftets første Led er kortere end Hovedet; det andet er mere end halrt saa langt og meget tyndere; det treslie er kortere og tyudere. Svoben er noget kortere end Skaftet og dannes af 10 forlangede Led. Biswoben er meget kort, enleddet og saa lang som Hoverlsvobens forste Lerl.

De nedre Folere ere noget langere end de øvre; Skaftets tvende første Led ere sammensmeltede, og Lugteknuden er sardeles liden; det tredie Led er noget langere end tylit; det fjerle er noget lingere, men meget smalere, og det femte er lige saa langt, men smalere end let foregatende. Paa den nedre Ende af hrert af de tre sidste Led findes en Dusk af lange fjordannede Borster; de to sidste Pars ovre ydre Rand danner en med Børster besat stump Knude. Svoben er meget kortere end Skaftet og dannes los Hannen af 9, hos Hunnen af 65 Led, hvoraf det forste er det længste.

K indbakkerue ere strerke og i Spidsen tvedelte; hver Gren er forsynet med Trender; Torneraden dannes af omtrent 8 smale Torne. Tyggeknuden er stor, oval. Palpens andet Led er det liengste; det tredie er paa den skraat afskaarne Ende forsynet med talrige Borster

Det første Kjæbepars yire Plade har mange, men ikke stærke T'ænder, og 
Palpen, hvis andet Led er temmelig bredt i Spidsen, er væbnet med 8 smale Tænder og nogle Børster. Den indre Plade er temmelig stor og har paa den skraat afskarne Ende tvende fjærdannede Børster.

Det andet $\mathrm{Kj}$ æbepars ydre Plade er meget bredere end den indre.

Kjæb efodderne ere meget korte og brede; den ydre Plade har paa den indre Rand tætstaaende Tænder, der mod Spidsen blive længere og gaa paa den øvre ydre Rand over til indadbøiede stærke Borster; den indre Plade er af middelmaadig Størrelse. Palpen er meget bred; det forste Led er triangulart, med en lang, udtrukkeu ydre, øvre Vinkel; det andet er særdeles bredt, og den indre Rand er forsynet med tæette, korte Børster; det tredie er lidet og bøier sig indad over det andet Led; det fjerde er meget kort, ikke kloformet.

Det forste Fodpar er meget kort og kraftig udviklet; dets forste Led er næsten saa langt som de følgende tilsammen, noget krummet og paa den forreste Rand forsynet med talrige fjærdannede Borster; det fjerde er meget stærkt, udvidet bagtil til en bred Flig, og har ligesom det foregaaende Led trette Borster i Randen. Haanden er nesten triangulær med afstumpet forreste Vinkel.

Det andet Fodpar er forlanget, smalt; ilet femte Led eller Haanden er meget forlænget, smalt, med talrige Børsteknipper paa begge Rande. Kloen er meget liden.

Det tredie og fjerde Fodpar ere stærke og have ens Bygning; begge Rande have talrige Knipper af tildels fjærdannede Borster; det fjerde Led har omtrent Halvdelen af det tredie Leds Langde; det femte er noget langere end det foregaaende.

De derpaa folgende tvende Fodpar have den samme Bygning, men det sjette Par er liengere og stærkere. Alle Led have paa begge Rande fjardannede Borster; deres første Led er kun lidt udvidet, tre Gange saa langt som bredt; det fjerde er langere, men smalere end det lidt udvidede tredie Led; det femte er meget kortere. Kloen er liden.

Det syvende Fodpar er kortere end det foregaaende, men dets forste Led er meget udvidet bagtil og paa begge Rande besat ined fjærdannede Børster; de følgende Led ere tilsammen omtrent saa lange som det forste Led; dets tredie er baade længere $n g$ tykkere end det fjerde, der er omtrent af samme Længde, men tykkere end det femte. Kloen er liden.

Detvende forste Par Springfødder naa omtrent lige langt bagud, og deres ydre Grene ere ubetydeligt længere end de indre; begge ere besatte med tildels fjærdannede Børster.

Det tredie Par Springfodders Grene ere meget langere end deres Grundled; den ydre er lidt længere end den indre.

Halevedhænget er ikke fuldt dobbelt saa langt som bredt og spaltet næsten til Roden.

Den forekommer ved Grønland paa lige indtil 250 Favnes Dybde; ved Spitsbergen 
er den fundet paa 6-20 Favne, af Lilljeborg er den taget i Finmarken og skal efter M. Sars gaa sydlig til Christianssund. Af Packard anfores den at forekomme verl Labrator.

PONTOPOREIA FURCIGERA, Bruzelius, 1859.

Pontoporeia furcigera, Bruzelius, Scand. Amphip. Gamm. 1859. p. 44.

Spence Bate, Catal. Amphip. Crust. Brit. Mus. 1862. p. 370.

A. Boeck, Crust. amphip. bor. et arct. 1870. p. 43 .

Antennæ superiores flagello accessorio 3articulato. Segmentum postabdominis 4tum processu magno, in apice furcalo, instructum. Pedes 2di paris breves et crassiores qvan apud speciem pracedentem; manu duplo longiore qvam lata. Appendix caudalis parum longior quam ad basin lata.

Dyrets Læugde er 7mm $^{\mathrm{mm}}$.

Denne Art ligner den foregaaende, men det gaffelformige Fremspring paa det fjerde Haleled er meget større og i Spidsen delt i tvende lange Flige. Sideplademe ere høiere og nedad mere tilrundede.

De $ø$ vre Følere naa neppe til det fjerde Legemsled; Skaftets første Led er særdeles tykt; det andet er kun lidt storre end det tredie; begge have paa den nedre Rand fjærformede Børster. Svøben er kortere end Skaftet og bestaar af 7 Led; Bisvoben dannes af 3 Led, af hvilke det forste er tykkere samt lidt langere end de tvende øvrige tilsammen.

De nedre Følere ere lidt læugere end de gre; deres Svobe bestaar af 9 Led.

Det første Fodpars fjerde Led er meget stærkt og saa langt som det femte, der har en triangulær Form.

Det andet Fodpar er kortere og stærkere end hos den foregaaende Art; dets fjerde Led er forlænget og forsynet med talrige Børster paa den nedre Rand. Haanden er oval, dobbelt saa lang som bred, lidt ndtrukket i den nedre bagre Vinkel; den har Børster paa den bagre og nedre Rand.

Det tredie og fjerde Fodpars tredie Led er kun lidt kortere end let fjerde og femte tilsammen.

Det syvende Fodpars første Led er ikke saa bredt som langt.

Halevedhænget er lidt længere end bredt ved Roden og dybt spaltet.

Jeg har været meget uvis, om den ikke heller burde regnes til en Varietet af $P$. femorata, men da jeg kun Hygtig fik undersøgt nogle Exemplarer i Kjøbenhavns Museum fra Sundet, livilke syntes at være temmelig ulige de gronlandske, saa har jeg optaget den som Art; Beskrivelsen og Diagnosen er vasentlig efter Bruzelius.

Den er fundet i Bohuslen af Bruzelius, og i Kjobenhavns Museum fandtes ikke faa Exemplarer fra Sundet. 
PONTOPOREIA AFFINIS, Lindstrōm, 1855.

Pontoporeia affinis, Lindström, öfvers. af Ǩgl. Vetensk. Akad. Förhandl. 1855. p. 63. Spence Bate, Cat. Amphip. Crust. Brit. Mus. 1862. p. 83. pl. XIV. fig. 2.

- - Bruzelius, Skand. Amphip. gamm. 1859. p. 48.

A. Boeck, Crust. amphip. bor. et arct. 1870, p. 4.4 .

Antennæ superiores flagello accessorio 3articulato; articulo 1 mo fere duplo longiore ac articulis reliqvis junctis. Segmentum poslabdominis 4tum leve. Pedes 1 mi paris magis elongati qvam apud species antecedentes. Pedes 7 mi paris articulo 3tio breviore qvam 4to; hoc longitudinem 5ti ferme aqvanti. Appendix caudalis brevior qram ad basin lata et ultra dimidium fissa.

Længden er $8-9$ mm.

Legemet er kort; Ryggen bred. Det fjerde Haleled er uden noget Fremspring. Den nedre bagre Vinkel paa det tredie Haleled er ret. Hovedets Sidevinkler ere afrundede; Øinene ere ovale eller svagt nyreformede.

De ovre Følere ere korte; Skaftets forste Led er meget kortere end Hovedet; de tvende folgende aftage $\mathrm{i}$ Langde og Tykkelse; Svøben dannes af $10-12$ og Bisvoben af 3 Led, hvoraf det første er saa langt som de tvende folgende tilsammen.

De nedre Foleres forste Led er meget opsvulmet; det tredie er ikke fuldt dobbelt saa langt som tykt; det fjerde er meget lrengere, og det femte er lidt kortere og meget smalere end det fjerle.

De nedre Foleres Srobe bestaar hos Hunnen af 8, hos Hamen af noget over 25 Led.

Det forste Fodpar er meget kraftigt udviklet; det fjerde Led er triangulart og læengere end det agformede femte Led eller Haanden, der paa den bagre Rand har lange Borster; Kloen har paa den bagre Rand fine Tænder.

Det andet Fod par er langere og tyndere end det første; det forste Led er krummet og forsynet med lange, fjardamnede Borster paa den forreste Rand; det fjerde er forlænget, triangulært 0 g længere end det femte Led, der er noget briet, paa Enden ret afskaaret, og hvis indre Tinkel er noget uddraget. Kloen er meget stærk. De tvende sidste Led ere paa den bagre Rand vabnede med Bundter af tandede Borster.

Det tredie og fjerde Fodpar ere meget stærke; det tredie Led er bredt, men tiltager ikke noget særdeles i Bredde udad; det har paa begge Rande fjardammede Borster samt er noget kortere end de trende folgende Led tilsammen, hroraf det femte er meget længere og smalere end det fjerde. Kloen er liden og bred.

Det femte og sjette Fod par ere af samme Bygning, men det sjette Par er storre end det femte; deres forste Led er ikke meget breit og bliver smalere mod Lnden samt er paa begge Rande forsynet med fjærdannerle Børster; deres tredie Led 
er kortere, men tykkere end det fjerde, der er omtrent saa langt som det femte; Kloen er liden.

Det syvende Fodpar er kortere end det sjette; det forste Led er særdeles bredt og har lange Børster i den bagre halvcirkelformede Rand; det tredie Led er kortere end det fjerde, og begge have fjærdannede Børster.

Det andet Par Springfodder er meget kortere end det forste Par; Grenene paa begge ere forsynede med Torne.

Det sidste Par Springfodders Grene ere omtrent lige lange og dobbelt saa lange som Grundleddet.

Halevedhanget er ikke længere end bredt ved Roden, dybt klovet, og dets Flige ere afrundede.

Denne Form er fundet af Lindström i Østersøen; Lovén og G. O. Sars have fundet den i Skandinaviens dybere og store Ferskvandssøer, saasom i Vettern og Mjøsen.

Den er efter den af Lovén først fremstillede Mening en tilbagebleven Rest af deu Fauna, der fandtes i saadanne Søer, da de, for Skandinavien hævede sig saa høit op, vare Havbugter. Senere, da de bleve skilte fra Havet og Saltet efterhaanden udvaskedes, bleve kun nogle enkelte Former tilbage, hvoriblandt denne.

\section{Gen. II. PRISCLLA, A. Boeck, $18 \%$.}

Deriv. : $\pi p \iota s x \iota \lambda \lambda \alpha$ (et græsk Krvindenavn).

Syn.: 1870. Priscilla, A. Boeck, Crust. amphip. bor. et arct. p. 44.

Typ.: Pontoporeia armata, A. Boeck.

Epimera anteriora qvatuor rigida, longa, attenuata, in apice setis longis plumosis instructr.

Pedes $1 \mathrm{mi}$ et 2di paris inter se eadem fere forma, manu parva, subcheliformi instructi.

Pedes 3 tii et 4 li paris robusti; articulo ultimo serie setarum validarum instructo.

Pedes 5 ti et 6 ti paris articulo 1 mo perrigido, parum dilatato, in angulo superiore producto.

Pedes 7 mi paris articulo 1 mo valido, clipeoformi, dilatato; articulo 5 to in apice spinis multis, rigidis armato.

Pedes saltatorii ultimi paris ramo interiore parvulo.

Appendix caudalis latissima, insinuata modo, non fissa.

11860 beskrev jeg en ny Amphiporle, som jeg henforte til Slagten Pontoporeia og kaldte $P$. ammata, idet jeg dog anforte, at den i flere Heuseender afveg fra de ovrige Airter. I 1870 satte jeg den som Typus for den nye Slægt Priscilla, da den ikke 
lod sig stille sammen med de tre til Pontoporcia henhorende Arter, uden at Slægtskarakteren blev for omfattende. Med Hensyn til Munddelene viser denne Slægt stor Overensstemmelse med P'ontoporcia, men afviger dog i enkelte Henseender fra denne. Ligeledes ere Folerne næsten af den samme Bygning som hos hin. Slægt; derimod afviger den fra den i forskjellige andre Deles Bygning. De fire forste Sideplader ere saaledes meget stive og tilspidsede mor Enden, merlens den femte, som hos Pontoporeia er meget stor, hos denne Slægt er meget liden, og Indskjæringen paa den undre Rand for Befæstelse af det femte Fodpar lader dette blive rettet nedad og ikke bagover, som hos den foregaaende Slægt. Det forste og andet Fodpar have hos denne Slægt den samme Bygning, medens det andet Par betydelig afviger fra det forste hos Pontoporeia. De tre sidste Fodpar have en vis Overensstemmelse med de tilsvarende hos den foregaaende Slægt; det første Led paa det fente og sjette Par er nemlig lidet udvidet, medens det i hoi Grad er Tilfældet paa det syvende Par. Dette sidstnæunte er ligesom hos hin Slægt noget kortere end det sjette. Bygningen af det sidste Par Springfødder viser ogsaa en afvigende Bygning fra Pontoporcia, idet den ydre Gren er meget bred pladeformet, medens den indre er næsten rudimentær. Af denne Slægt findes kum een Art.

PRISCILLA ARMATA, A. Boeck, 1860.

(Pl. II. Fig. 4.)

Pontoporeia armata, A. Boeck, Forhandl. ved de Skand. Naturforskeres 8de Møde. 1860. p. 648.

Priscilla armata, A. Boeck, Crust. amphip. bor. et aret. 1870. p. 44.

Antenne setas longas plumosas gerentes. Antenna superiores articulo 2 do in apice marginis superioris nodo instructo. Antennæe inferiores articulo 4to multo latiore qvam 5to. Pedes 5 ti paris articulo 1 mo in angulo superiore postico sursum producto et acuto. Pedes 6ti paris articulo 1 mo longiore qvam eodem 5 ti paris et in angulo superiore postico spina una valida armato. Segmentum postabdominis 2dum el 3tum spinis singulis obtusis armata. Pedes saltatorii nltimi paris ramo exteriore lanceolato, in margine exteriore setoso, circiter ter longiore qvam ramo interiore, brevi, ovato. Appendix caudalis parum longior qvam lata, in margine interiore paululum incisa.

Længden paa de forefundne Exemplarer er af forskjellig Størelse, fra S-12"mm.

Legemet er meget tylit og høit. Ryggen er bred, uden Kjol. Panden gar fortil ud $i$ et liort Horn. Det tredie og fjerde Haleled have paa den bagre Rand en liden Kjol, der springer noget frem par Enden af det tredie Led og noget bagenfor Midten af det fjerde. Hovedet ex lidet, men bredt. Øınenes Form kan ikke iagttages. Folerne ere korte. 
De øvre Folere ere de ministé og frestede foran de nedre. Skaftet er længere end Svoben; lets forste Led er det liengste og tykkeste; det andet er noget mere end Halvdelen af det forste baade med Hensyn til Længde og Tykkelse; det tredie er omtrent halvt saa langt som det andet; alle Led ere forsynede med Knipper af lange fjordamede Borster, især mod Enden af hvert Led. Svoben bestaar af 9 med Børster besatte Led. Bisvgben er kortere og tyndere end Hoverlsvoben og har lange, men tynde Led.

De nerlye Folere ere liengere end de ovre; Skaftets tvende forste Led ere korte, og det forste springer indal og nedad ud i en stwrk Lugteknude; det tredie Led er neppe saa langt som tykt; det fjerle er omtrent tre Gange saa langt og meget tykkere, med lange fjærdamede Børster par begge Rande og med en Rxkke Torne par den ydre Side; det følgende Led er kortere og meget tyndere end det foregaaende og forsynet par sin øvre og nedre Rand med flere Bundter af lange fjærdamede Børster. Svoben har omtrent samme Langde som Skaftets fjerde Led og bestaar af 8 med korte Torne besatte Lerl. Overlæhen er rund.

Kindbakkerne ere i Spidsen tvedelte med tandede Grene. Tornerækken bestaar af 10, i Spidsen gaffelformet delte Torne. Tyggekuuden er kraftig, paa Enden besat med mange Tvarrader af smaa Trnder. Palpen er meget stor; det forste Led er meget kort; det andet $0 \mathrm{~g}$ tredie ere lige lange, og det sidstnævnte er forsynet paa sin ovre Rand med fem Trærrokker af lange, i Spidsen boiede Børster; de korteste af dem ere langs Randen forsynede med en Rakke spitse Truder.

Det forste Kjæbepar er af den sædvanlige Form. Den ydre Plade har paa Enden liraftige Tiender. Palpen er toleddet; det forste Led er kort, det andet har i Spidsen en dobbelt Rakke spidse Trnder. Den indre Plade er oval, lancetformet, med boiet Spids og forsynet paa sin indre Rand med 18 fjærdannede Børster.

Kjabefodderne ere meget store. Den ydre Plade er temmelig stor og har paa den indre Rand en Rakke Tænder, der mod Enden tiltage i Langde. Den indre Plade er bred, firkantet, i Spidsen besat med tvende Trender og har paa den indre Rand en Rokke (8) fjordannede Borster.

Det forste Fodpar er af den siervanlige Form; Haanden er saa lang eller lidt liortere end Carpus. De tre sirlste Led ere stirkt besatte med lange, tildels tanlede Borster.

Det andet Fodpar er ligt det forste, men er lidt liengere. Kloen er overmaale liden, næsten skjult af de mange i Tvicrader staaende Haarbuniter. Haanden er forlanget, oval, meget kortere end det foregaaende Led.

Det tredie og fjerde Fodpar ere af samme Storrelse og Form; det tredie Led har samme Lengle som det forste, er noget brẻdere mod Enden og forsynet med Here Borsteknipper; det fjerie Led er meget kortere og tyndere end det foregaaende; ilet sidste er længere, men tyndere end det fjerde, og har paa sin indre Rand en langsgaaende Rakke af Borster, der mod Enden af Randen gaar over til at danne stærke Torne. 
De tre sidste Fodpar ere ofte af en indbyrdes meget forskjellig Dannelse.

Det femte Fodpar er det korteste. Det forste Led er firkantet, med afrundede Sider; det bagre ovre Hjorne garr u i en opadhoiet lang Hage; den forreste Side er forsynet med 8 Bundter af fjærdannede Børster og den ydre Flade med 4 Tværrækker af Tome. Det andet Led er kort og bærer en Rad af Tome. Det folgende Led er længere og har tvende lignende 'Tornerækker, hvoraf den ene findes paa den nedre Rand. Det fjerde Led er længere, men smalere end det foregaaende, og er forsynet med tre Rader af Torne. Det sidste Led er ligesaa langt, men meget smalere, og er besat med Here Grupper af stærke Torne, livoriblandt den paa Enden er den strerkeste. Den bagre Rand paa alle disse Led er forsynet med Torne og lange, fjardannede Borster.

Det sjette Fodpar ligner det foregaaende i Form, men ikke i Langde, idet det forste Led er mere forlænget, end det tilsvarende paa hint, og lober ligesom dette i det ovre bagre Hjørne ud $\mathrm{i}$ en mindre Hage; den forreste og bagre Rand ere begge besatte med en Rxkke af lange, fjærdannerle Borster. Sidefladen har ogsaa en saadan Rakke af stærke Børster. De følgende Led ligne i Form de hos det femte Forlpar, men ere smalere og forsynede med Bundter af stærke Torne.

Det sidste Fodpar er det korteste. Det første Led er meget stort, skjoldformet; den forreste Rand er lidt convex, den bagre er næsten cirkelformet, 0 g begge ere besatte med lange, fjærdamede Borster. Det fjerde Led er lidt længere end det tredie; det femte er ovalt, besat med Knipper af Torne, og paa Enden sees $4 \mathbf{4} \mathbf{5} \cdot \mathrm{meget}$ lange Torne.

Det sidste Par Springfødders Grene ere ulige store, den inclre er ganske liden, oval, den ydre er lancetformet.

Haleved hanget er bredt, ovalt, indskaret i Spidsen.

Denne Art fandtes i Universitetets Samlinger, lıvor den antoges at være tagen paa Bergens Kyster, formodentlig i Sondfjord, af Professor Rasch.

Gen. III. ARGISSA, A. Boeck, 1870.

Deriv.: Approsx (en Stad i Thessalien).

Syn.: Argissa, A. Boeck, Crust. Amphip. bor. et arct. 1870. p. 45.

Typ.: Argissa typica, A. Boeck.

Antennæ superiores iisdem inferioribus multo breviores.

Epimerum 1mum magnum, in margine inferiore rotundatum. Epinera cetera magniludine valde decrescentia; epimerum 3tium parvulum, sed flum pergrande, clipeoforme.

Pedes $1 \mathrm{mi}$ el 2 di paris inter se eadem forma, infirmi; manu subcheliformi.

Pedes 3tii et 4 ti paris ungve minimo. 
Pedes 5 ti et 6 ti paris articulo 1 mo postice sat dilatato; ungvibus parvulis.

Pedes $7 \mathrm{mi}$ paris articulo 1 mo pergrandi, clipeoformi; ungve parvo.

Pedes saltatorii ultimi paris ramis universis inter se fere eadem longitudine. Appendix caudalis elongata, usqve ad basin fissa.

Denne Slxgt, som jeg opstillede i 1870 paa Arten $A$. typica, afviger end mere fra Pontoporeia end Priscilla. Sidepladernes Form er eiendommelig, idet den første er særdeles stor og de tvende følgende aftage meget i Størrelse, medens den fjerde atter bliver overmande stor, oval, skjoldformet. Dette finder ikke Sted med nogen anden Amphipodeslægt og giver Dyret et ganske egent Udseende. I Munddelene afviger den mere fra Slægten Pontoporeia end fra Priscilla; Kindbakkernes Tornerække er nemlig temmelig stor, og hver Torn har en eiendommelig pladeformet Udvidning mod Enden. Kjæbeføddernes ydre Plade har ikke en saadan Række stærke Tænder paa den undre Rand som hos de tvende foregarende Slægter, men kun tre lange, krumme Tænder, lworaf den sidste er den længste. De tvende første Fodpar have hos denne Slægt ens Bygning, og Haanden er kun svagt udviklet, hvorimod Kloen er lang. Det femte og sjette Fodpar, hvis første Led hos de tvende foregaaende Slægter er smalt, have hos denne et meget udvidet første Led, der dog ikke er saa stort som paa det syvende Forlpar. Det sidstnæunte er dog lige, som hos de tvende foregaaende Slægter, og kortere end det sjette.

ARGISSA TYPICA, A. Boeck. 1870.

(P1. VII. Fig. 2.)

Argissa typica, A. Boeck, Crust. amphip. bor. et arct. 1870. p. 45.

Antennæ superiores pedunculo inferiorum minores. Antennæ inferiores articulo pedunculi 3tio longissimo; 4to paulo longiore qvam 5to. Pedes 1 mi et 2di paris manu elongata, ovata, multo breviore et angustiore qvam carpo. Pedes 3tii et 4 ti paris articulo 3 tio breviore qvam 4to; 5 to perhrevi, augusto: ungve minimo, curvato. Pedes $7 \mathrm{mi}$ paris articulo $1 \mathrm{mo}$ latissimo, in margine inferiore rotundato et fere ad finem articuli 3tii producto; articulo 3tio longiore et latiore qvam 4to; 5to brevi angustoqve; ungve parvo, recto. Pedes saltatorii ultimi paris ramis eadem fere longitudine, elongatis, lanceolatis et in margine interiore setosis. Appendix caudalis fere duplo longior qvam ad basin !ata, profunde fissa.

Dyret er $6^{\mathrm{mnn}}$ langt.

Legemet er temmelig sammentrykt fra Siderne; Ryggen er. rund, ulen Kịøl eller Tome. Sidepladerne ere eiendommeligt dannede; den første er temmelig stor, oval, afrundet nedad; den anden og tredie aftage betydeligt baade i Høide og Bredie, saa at den sidstnævnte kun har Halvdelen af den førstes Høide og omtrent en Trediedel 
af dens Bredde. Derimod er den fjerde overordentlig stor, skjoldformet, oval, med en liden Indskjaring paa den bagre Rand for den femte Sideplade. De tre folgende ere smaa, noget bredere end hoie. Hovedet er næsten saa langt som de tre forste Legemsled tilsammen og viser ikke noget tydeligt Spor til Øine. Det bagre nedre Hjøme paa Halens tre forste Led er uden nogen Hage eller Torn, men tilrundet.

De øre Følere ere saa lange som Hovedet og de to eller tre første Legemsled tilsammen. Skaftets forste Led er kortere end Hovedet; de folgende aftage saavel i Længde som i Tykkelse. Sroben er kortere end Skaftet og dannes af 8 Led; en liden Bisvobe. der er een- eller toleddet, er frestet til Skaftets Ende.

De nedre Fglere ere meget længere end de orre; Skaftets tredie Led er nere end dobbelt saa langt som bredt; det fjerde Led er smalere, men meget lingere end det tredie, og det femte er meget kortere og smalere end det fjerde, men noget langere og smalere end det tredie; Swoben, der er saa lang som Skaftets trende sidste Led tilsammen. bestaar af $5-9$ Led.

Kindbakkernes Gribedel, der er forsynet med en stark indre Bigren, har ligesom denne talrige Tænder; Tyggeknuden er meget fremstaaende, næsten rund, og i Omkredsen besat med lange Tænder; Tornerakken dannes af talrige, i Spidsen gaffelformede Torne; Palpen synes at mangle.

Det forste Kjæbepars Palpe har i Spidsen stærke Tænder; den indre Plade er oval og har paa den indre og ovre Rand mange fjærdannede Borster.

Det andet $\mathrm{Kj}$ abepars Plader ere brede.

Kjabefodderne ere korte, men kraftige; den ydre Plade er paa Enden af den indre Rand væbnet med fem grove og krumme Tænder, der efterhaanden blive længere og smalere mod Spidsen; den indre Plade er ikke meget lang og er forsynet med fire grove, fjrerdannede Børster og med een Tand. Palpen er grov og kort.

De tvende forste Fodpar ere af eens Bygning, men det andet Par er noget storre end ilet forste; det andet og tredie Led ere meget korte, men det fjerde er meget langt og bredt samt forsynet med Børsteknipper paa den bagre Rand; det femte Led er forlæuget, ovalt. Kloen er lang og meget krum.

Det tredie og fjerde Forlpar ere korte; det forste Led er det lixngste; det tredie er meget kort og lidet udvidet; det fjerde er meget længere, medens det femte er kortere end det tredie og vabnet med en liden Klo.

De tre folgende Fodpars forste Led er særdeles stort, skjoldformet udvidet, og har en dyb Indskjæring paa den forreste og nedre Vinkel til Befæstelse for det andet Led.

Det femte og sjette Fodpars fjerde Led er langere end det tredie, medens det paa det syvende Par er kortere og har mange fjærdannede Borster; det femte Led er paa dem alle kortere end det fjerde og forsynet med en kort Klo.

Alle de bagre Springfodder ere togrenede; det tredie Pars Grene naa liengst bagud. 
H alevedhænget er forlænget, delt.

Blandt de af mig fra Christianiafjorden i 1861 medbragte Sødyr; hvilke vare overgivne til den zoologiske Samling, fandt jeg i 1869 et Exemplar af denne lille Art, uden at jeg $d o g$ med Bestemthed tor pastaa, at den er funden af mig i Christianiafjorden, da baade den og Flasken, hvorpaa den var, forekom mig fremmed.

Gen. IV. BATHYPOREIA, Lindström, 1855.

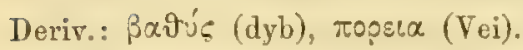

Syn.: 1855. Bathyporeia, Lindström, Öfvers. af Kgl. Vetensk. Akad. Förhandl, 1855. p. 59.

1855. Thersites, Spence Bate, Brit. Assoc. Report. 1855. p. 59.

1857 - Spence Bate, Synops ${ }_{i}^{\text {s }}$ etc. Ann. Nat. Hist. Feb. 1857.

1859. Bathyp oreia, Bruzelius, Skand. Amphip. Gammar. 1859. p. 90.

1860. - - A. Boeck, Forhandl. ved de Skand. Naturf. 8de Møde. p. 647.

1862: - Spence Bate, Cat. Amphip. Brit. Mus. p. 172.

1863. - Spence Bate and Westwood, Brit. sessile-eyed Crust. p. 302.

1870. - A. Boeck, Crust. amphip. bor. et arct. p. 46.

Typ.: Bathyporeia pilosa, Lindström.

Antennæ superiores articulo pedunculi 1 mo clavato, apicem versus inflato; articulis duobus seqventibus in extremo margine inferiore silis.

Pedes 1 mi paris parvi, vix manu subcheliformi instrucli.

Pedes 2di paris elongati, setis longis plumosis instructi; manu spatuliformi; ungve absenti.

Pedes 3 tii et 4 ti paris robusti.

Pedes 5 ti paris articulo 1 mo et 3 tio latissimis; hoc maxime setis longis plumosis instructo; articulis duobus ultimis tenuibus; ungve absenti.

Pedes $7 \mathrm{mi}$ paris articulo $1 \mathrm{mo}$ laminiformi, dilatato, sat brevi; articulis reliqvis elongatis; articulo ultimo in apice spinis validis pluribus armato.

Pedes saltatorii ultimi paris ramo exteriore elongato, 2articulato, setoso; lamina interiore parvula.

Appendix caudalis profunde fissa.

Deme Slægt, som af Lindström var stillet nær til Lysianassa, bler af Spence Bate fort hen til Gammaridernes Underfamilie og blev af ham forst kaldet Thersites, da han ikke kjendte Lindström's Arbeide. I Catal. Crust. Amphip. Brit. Mus., Pag. 172, stiller han den mellem Leptocheirus og Niphargus, hvor dens Plads dog neppe bor være. Bruzelius forer den hen mellem Haploops og Oediceros og finder, at den i mange Henseender skiller sig fra de ovrige Amphipodeslrgter. Lilljeborg har, som jeg tror med Rette, stillet den i Underfamilien Pontoporcina, og jeg har fulgt lam i denne hans An- 
skuelse. Den afviger ogsa meget fra Slagten Pontoporcia, men disse Afvigelser kunne uden Trang ansees begrundede i dens Levemaade paa en dyndet Bund. Derfor er vistnok ogsaa Kjæbefødderne saa eiendommelig byggede, idet Palpens andet Led bliver saa stort og er forsynet med saa talrige Borster paa den indre Rand, nemlig for at dxkke for de ovrige Munddele og tillukke Munden for Indtrængelse af fremmede Dele. Kindbakkerne afvige noget fra de hos Pontoporcia; de ere nemlig i Spidsen i mindre Grad delte i Tænder, og Tornerækken dannes af meget faa, men stærke Torne. Kjæberne ere forovrigt af samme Bygning hos begge Slægter. Det forste Fodpar el hos denne Slægt særdeles svagt, med en liden Haand, og er derfor undertiden overseet; det andet Fodpar er derimod meget stort $\mathrm{og}$ mere indrettet som en Slags Aare, derved at de tvende sidste Led blive særdeles store og ere paa den bagre Rand besatte med lange, fjærdannede Børster. Kloen mangler. Medens hos de foregaaende Slægter det femte og sjette Fodpar ere af eensartet Bygning, er det femte hos denne Slægt ganske særegent bygget derved, at foruden det forste Led er ogsaa det tredie meget udvidet og har paa den forreste Rand en tret Række af lange, fjærdannede Borster. De tvende sidste Led ere derimod mege: tynde og smale. Det syvende Fodpar er, ligesom hos de tre foregaaende Slagter, kortere end det sjette, men dets forste Led er ikke saaledes udvidet. Ligesom hos Priscilla er den indre Gren paa det tredie Par Springfodder liden, men den ydre voxer her end mere i Længde og viser sig tydelig toleddet.

Af denne Slrgt findes der et Par Arter ved de skandinaviske og engelske Kyster.

BATHYPOREIA PLLOSA, Lindström, 1855.

(PI. VII. Fig. 3.)

Bathyporeia pilosa, Lindström, Öfvers. af Kgl. Vetensk. Akad. Förhandl. 1855. p. 59.

- Bruzelius, Bidrag till Känn. om Skand. Amphip. Gam. Kgl. Vetensk. Akad. Handlingal. Ny följd. Bd. 3. p. 90.

- $\quad$ Spence Bate, Catal. Amphip. Crust. Brit. Mus. 1862. p. 172. pl. XXXI. fig. 4.

- $\quad$ - Spence Bate and Westwood, Brit. sessile-eyed Crust. 1863. p. 304. - - A. Boeck, Crust. amphip. bor. et arct. 1870. p. 46.

Thersites Guilliamsonia, Spence Bate, Rep. Brit. Assoc. 1855. p. 59.

Spence Bate, Anm. Nat. Hist. 2. ser. XIX. 1857. p. 146.

Thersites pelagica, Spence Bate, Rep. Brit. Assoc. 1855. p. วั9.

Spence Bate, Ann. Nat. Hist. 2. ser. XIX. 185\% p. 146.

Bathyporeia p clagica, Spence Bate, Cat. Amphip. Brit. Mus. 1862. p. 174. pl. XXXI. f. 6. Spence Bate and Westwood, Brit. sessile-eyed Crust. 1863. p. 309.

Segmentum postabdominis 4tum carinatum; carina paucis spinis brevibus et selis instructa. Pedes 1 mi paris manu elongata, ovata, multo breviore qvam carpo. Pedes 5ti paris articulo 1 mo multo longiose qvam lato, deorsum rotundato; articulo 
3tio magno, lalo, ovato, in margine inferiore paulo sinuato; Ito lineaformi, in angulo inferiore postico producto, longitudine articulo 5to acquali. Appendix caudalis laciniis in margine exteriore insinuatis.

Dyrets $L x n g d e$ er $6^{\mathrm{mm}}$.

Legemet er temmelig tykt, ikke meget høit; Ryggen er uden Kjøl, men paa det fjerde Haleled sees paa den bagre Rand en Knude, hvorpaa der sidder tvende Børster. Sidepladerne ere meget store; de fire første tiltage efterhaanden i Lrengde og Bredde og have lange Borster paa den indre Rand; de tre sidste ere smaa, den femte er dog større end de følgende. Hovedet er langere end det første Legemsled; Øinene ere temmelig store, ovale eller nasten nyreformede.

De ovre Folere have en eiendommelig Bygning; Skaftets forste Led er særdeles stort, bliver bredere mod Enden, hvor det paa den undre Side er skraat afskaaret, og her er frstet det andet Led. Dette er ligesom det tredie meget kort, neppe længere end bredt. Svoben dannes hos Humnen af $6-8$, hos Hannen af 10-12 korte Led. Bisvoben bestaar af 2 Led, hvoraf det sidste er det korteste.

De nedre Fglere ere meget langere; Skaftets andet Led gaar paa den undre Rand frem i en vel udviklet Lugteknude; det tredie er neppe længere end bredt; det fjerde er derimod meget stort, paa begge Rande forsynet med lange Borster; det femte er meget kortere og smalere end det foreganende. Svoben dannes hos Humnen af 8-10 Led, hvoraf det forste er det lrongste; hos Hannen er den derimod overmaade forlæenget $0 \mathrm{~g}$ dannes af $50-55$ korte Led. Overlaben er temmelig bred, afrundet paa Enden og har mange smaa Borster.

Kindbakkerne ere særdeles kraftige, tilspidsede paa Enden og kun svagt indskaarne i Trender. Tornerækken dammes kun af 3 stærke Tænder. Tyggeknuden er stor, skraa og oval og er drkket af butte Truder. Palpen er forlænget, smal; dens tredie Led er kortere end det andet, besat paa Enden med nogle Børster.

Det forste Kjæbepar er meget bredt; den ydre Plade har i Spidsen grove Tænder, der langs den indre Rand ere saugtakkede. Den indre Plade er særdeles bred, paa Enden skraat afskaaren og forsynet med talrige fjærdannede Borster. Palpens andet Led er afrundet paa Enden og har mange Borster.

Det andet $\mathrm{Kj}$ æbe pars Plader ere korte og brede; begge have paa den skrat afskaarne Ende tvende Rader af fjærlannede Børster.

Kjabefoddernes ydre Plade har paa den indre Rand fem til sex stærke Tænder; den indre Plade er bred, temmelig lang, afrundet paa Enden og der besat med Børster. Palpens andet Led er sadeles stort $\mathrm{g} g$ bredt, bliver bredere mod Enden, hvor det forlanger sig til en stor, oval Lap; langs hele dets indre Rand sees en tret Rrkke af lange, boiede Borster. Det tredie Led er temmelig langt, men smalt, og bøier sig over det andet Leds afrundede Lap. Det fjerde Led er kloformet med tydelig afsat Endedel. 
Det første Fodpar er meget lidet; det andet og tredie Led ere meget sman; derimod er det fjerde Led eller Carpus meget forlænget og smalt, medens Haanden er liden og oval.

Det andet Fodpar er meget forlanget, vel udviklet; det forste Led har paa begge Rande talrige Børster; det andet er kort; det tredie er triangulært og lagger sig til den bagre convexe Rand af det fjerde Led, medens dets forreste Rand er ret; det femte Led er lidt kortere end det fjerde, og ligeledes med convex bagre og ret forreste Rand. Disse tre sidste Led have paa den bagre Rand en tret Række af meget lange Børster.

Det tredie og fjerde Fodpar ere af ens Bygning og temmelig stærke; deres tredie Led udvider sig mod Enden og forlænger sig $\mathrm{i}$ det forreste og nedre Hjørne; det fjerde er ovalt, medens det femte er længere end dette $0 \mathrm{~g}$ meget smalt; begge disse sidstnæevnte Led have paa den bagre Rand mange fjærdannede Børster.

Det femte Fo dpar har en eiendommelig Bygning; det forste Led er meget bredt, dog længere end bredt, og er lidt indbuet paa den bagre Rand, medens den undre er tilrundet; pan den forreste Rand sees flere Trærrader af korte Børster, og lignende findes langs den bagre Rand; det tredie Led er ligeledes udvidet, dets forreste starkt buede Rand er, ligesom paa det andet Led, besat med meget lange, fjærdannede Borster, paa dets bagre Rand er det indbugtet, og $i$ begge de afrunderle Hjorner findes lange Borster; det fjerde Led, der er meget smalt, lidt buet, med forlanget nedre bagre Vinkel, er frstet til den nedre forreste Vinkel af det foregaaende Led; det femte Iued er omtrent ligesaa langt og bredt som det foregaaende og mangler Kilo.

Det sjette Fodpar er længere end det femte, men det første Led er dog ikke fuldt saa stort som paa det foregarende Fodpar; det tredie Led er ikke meget udvidet, og det fjerde er lidt kortere og smalere end dette; det femte Led er lige saa langt, men smalere end let fjerde, og Kloen er ikke fuldt saa lang som det femte Led.

Det syvende Fodpar er ikke kortere end det sjette, og dets første Led er kun lidt længere end bredt; dets tredie og fjerde Led ere omtrent lige lange, kun noget længere end brede, medens det femte er liengere og smalere end disse.

Det forste Par Springfodders ydre Gren er noget lrengere end den indre; begge ere besatte med Torne paa den ovre Rand og paa Enden.

Det andet Par Springfodder ligner det foregaaende, men er kortere.

Det tredie Par Springfodder er meget forlænget. Skaftet er meget kortere end den ydre Plade, der bliver smalere mod Endmu, hvor der er fastet et vel udviklet andet Led, og som paa begge Rande er forsynet med talrige Børster. Den indre Plade er meget liden, oval.

Halevedhanget er lidet, klovet til Roden; Fligene have nogle Borster i Spidsen samt en meget stærk Borste i et Indsnit paa den ydre Rand.

Denne Art er taget af Lovén ved Finmarken, verl Farsund og Mandal af mig, og findes efter Bruzelius ved Bohuslen $0 \mathrm{~g}$ i Sundet samt lige op i Østersøen, hvor den $2 \% *$ 
forst var beskrevet fra Gottland af Lindström. Af Norman er den fundet ved Shetlandsoerne; efter Spence Bate og Westwood er den taget ved Weymouth og Tenby og andre Steder ved den engelske Kyst; efter Metzger er den funden ved den ostfrisiske Kyst.

Subfamilia III.

PHOXINAE, Spence Bate, $185 \%$

Syn.: 1857. Phoxides, Spence Bate, Synopsis Brit. Amph. Aun. Nat. Hist. 185\%. vol. XX. 1862. - Spence Bate, Cat. Amphip. Crust. Brit. Mus. p. 97.

1865. Phoxina, Lilljeborg, On Lysianassa magellanica. 1865. p. 18.

1870. Phoxinae, A. Boeck; Crust. amplip. bor. et arct. p. 53.

Labium superius breve, in apice rotundatum.

Nandibulx breves sed robustie, in utroqve latere eadem forma, in apice dentatæ: tuberculo molari valido el serie spinarum firmarum instructo; palpo elongato, 3articulato; articulo palpi 3 tio prælongato.

Maxille $1 \mathrm{mi}$ paris parve; palpo 1 aut 2articulato; lamina interiore parva.

Maxille 2di paris parvie.

Pedes maxillares palpo elongato; laminis parvis.

Antenne superiores breves, flagello appendiculari instructr.

Antenne inferiores flagello apud marem sat elongato, apud feminam brevi.

Pedes $1 \mathrm{mi}$ et 2 di paris subcheliformes.

Pedes 3tii et 4 ti paris robusti et validi.

Pedes 5 ti paris plus minusve dilatati.

Pedes 6ti paris pedibus 5 ti et $7 \mathrm{mi}$ paris longiores, interdum valde dilatati.

Pedes $7 \mathrm{mi}$ paris articulo $1 \mathrm{mo}$ perdilatato.

Pedes saltatorii biramei.

Appendix caudalis duplex.

Corpus valde compressum ant paulum depressum; epimeris qvatuor anterioribus plerumqve magnis, in marginibus inferioribus plumosis.

Spence Bate opstillede denne Underfamilie i 1857 under Navnet Phoxides og beholdt den i 1862 samt henforte hertil Slagteme Phoxus, Grayia, Westroodilla, Oedicoros, MLonoculodes, Kröyeria, Amphilochus, Daminia (Lafystius), Guevinia, Lepidactylis, Sulcator, Wrothoë, Lilljoborgia, Phentra, Prosoponiscus, Iscea, Iphimedia, Otus og Acanthonotus. Han fremhever som Karakterer væsentlig, at Hovedet er mere eller mindre udtrukket $\mathrm{i}$ et Pandehorn, og at de ove Folere ere frestede langt foran de nedre. Dette passer imidlertid paa en Mrngde andre Amphipoder, som han ikke regner herhen, og 
flere af dem, som laan stiller til denne Underfamilie, have intet saadant langt l'andehorn, der er mere udviklet end sxdvanlig. Lilljeborg anfører i sin Karakter for denne Underfamilie, som han kalder Phoxina, at de ovre Folere have en Bisvobe, og at Hoverlet fortil er mere eller mindre udtrukket, saa at det dakker Grunddelen af de øvre Følere. Derfor udsondrer han en stor Del af Spence Bate's Slagter og beholder kun Slægterne Phoxus og Urothoe.. Jeg optog i 1870 kun Slægteme Phoxus, Sulcator og Urothoe af de xldre bekjendte og tilfoiede en ny, Harpina. Maske vil Lepidactylis høre herhen, men jeg kan ikke afgjore noget desangaaende, da Formen er mig ubekjendt. De ovrige Slægter maa udelades, da de paa Grund af sine Munddeles Bygning ikke kunne staa i samme Underfamilie som Phoxus. De. Slægter, som jeg har henfort hertil, vise en forskjellig Bygning med Hensyn til Kroppens Ydre, eftersom de - ligesom Phoxus - ere bestemte til at rode i sandblandet Leer, eller - som Sulcator - til at grave i Sand, eller - som Urothoë — til at rode i Dynd. Fodderne og Legemet faa saaledes en forskjellig Form, men den fxlles Typus er dog umiskjendelig udpræget.

Gen. I. PHOXUS, Krøyer, 1842.

Deriv.: Mo

Syı.: 1842. Phoxus, Krøyer, Naturh. Tidsskr. 1. R. IV. 1842. p. 150.

1853. Urothoü (pars), Dana, U. S. Explor. Exped. Crust. p. 913.

1860. Phoxus, A. Boeck, Forhandl. ved de Skand. Naturforskeres Sde Mode. 1860. p. 449 .

1862. - Spence Bate, Catal. Amphip. Crust. Brit. Mus. p. 97.

1863. - Spence Bate and Westwood, Brit. sessileeyed Crust. I. p. 139.

1870. - $\quad$ A. Boeck, Crust. amphip. bor. et arct. p. 54.

Typ.: Phoxus Holbölli, Kroyer.

Maxilla L mi paris palpo Iarliculato.

Pedes maxillares palpo angusto, laminis parvis.

Pedes 5 ti paris articulo 1 mo postice dilatato.

Corpus compressum, altum; capite in rostrum latum, apicem versus acuminatum nut curvalum, producto.

Pedes saltatorii ultimi paris ramo interiore apud marem longitudinem exterioris aqvanti, apud feminam multo breviore.

Kroyer opstillede denne Slregt i 1842 og fremhævede især som Karakter, at Hovedet er saa forlænget, at begge Folernes Skafter ere tykke, at de ovre Folere ere forsynerle med en særdeles lang Bisvobe, og at Halevedhænget er dobbelt. Han anfører endvidere, at det tredie og fjerde Fodpar skulle være næsten gribende, idet det tredie Led er uddannet til en Haand, men dette er ikke mere Tilfridet hos denne end hos andre Amphipodeslægter.' Krøyer fremhæver endvidere i 1859 den Eiendommelig- 
hed, at det forste Kjæbepars Palpe er eenleddet hos den ene Art, medens det er toleddet hos den anden. og tror, at de bør blive Typus paa tvende sliegter. Spence Bate forogede Antallet med en Art, $P$. simplex, som ogsaa findes hos 0 s, 0 g jeg har fundet nok en ny Art. Ved at undersøge Munddelene hos disse fire Arter fandtes, at paa tvende af dem er det første Kjæbepars Palpe enleddet, og at paa de samme er- det første Led paa det femte Fodpar meget bredt, medens det forste Kjæbepars Palpe hos de tvende andre er toleddet, og det første Led paa det femte Fodpar er ikke udvidet. Da der til den første Afdeling hører Krøyer's typiske Art $P$. Holbölli, beholdt jeg for de herhen hørende tvende Arter Navnet Phoxus, medens af de tvende andre dannedes en ny Slagt. Til Phoxus hører ogsaa Dana's Urothoë rostratus fra Zoolosøen. Om Simpson's Arter $P$. geniculatus, $P$. obtusus og $P$. Kröyeri kan Intet afgjøres, da Beskrivelsen er mindre fuldstændig. Øinene sees hos denne Slægt ikke paa Spiritusexemplarer, men sidde efter Holbgll paa Paudehornet lige over for Enden af Skaftets første Led paa de øvre Følere; de ere smaa, runde og voxgule. De nedre Følere forlange sig meget starkt hos Hannen, medens de hos Hunnen ere korte; derfor er det ikke rigtigt. at Spence Bate siger i sin Slagtsdiagnose. at de nedre Fulere ere saa lange som de øvre.

PHOXUS HOLBÖLLI, Krøyer, 1842.

(PI. VII. Fig. 2.)

Phoxus Holbölli, Krgyer, Naturh. Tidsskr. 1. R. IV. 1842. p. 151.

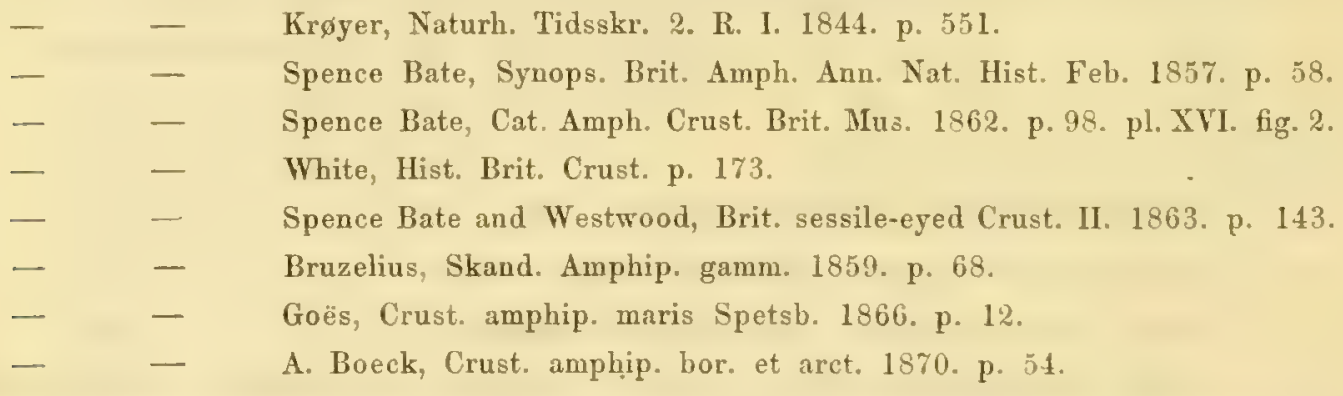

Rostrum rectum, in apice acuminatum. Setæ non plumosæ. Antennæ superiores articulo pedunculi $1 \mathrm{mo}$ in extremo margine superiore nodulo instructo. Antennæ inferiores articulo 3 tio et 4 to serie spinarum armatis. Pedes 3tii et 4 ti paris articulo $1 \mathrm{mo}$ non perlato, in angulo inferiore postico non producto. Pedes 7ıni paris articulo $1 \mathrm{mo}$ in margine inferiore truncato, ad finem articuli 3 tii porrecto; articulo 3tio, 4to et 5to ferme eadem longitudine; 5to multo angustiore. 3tio et flo parmm modo longiore qram lato. Angulus inferior posticus lateralis segmenti postabdominis 3 tii non aculus sed paulum rolundatus. 
Det største af de undersøgte Exemplarer var $5^{m m}$ langt fra Hovedets Spids til Halevedhængets Ende.

Legemet er høit, noget sammentrykt, men dog med en afrundet, temmelig bred Ryg, der bliver smalere mod Halens Ende. De fire forste Sideplader ere meget hrie og tiltage bagud i Langde: den fjerde silleplades bagre Rand er skraat afskiaren, og dens ovre De! er dybt indbugtet for den fente; disse Sidepladers nedre Rand er forsynet med mange simple, ikke fjærlannede Børster. Hovedet er meget forlænget og udgjør omtrent en Femtedel af hele Legemets Længde; dets ydre Del dannes af det rette, i Enden tilspidsede eller meget afrundede Pandehorn. Det tredie Haleleds nedre bagre Vinkel er lidt mindre end ret og meget afrundet.

De øvre Folere ere korte; Skaftets Ende naar kun til Pandehornets Spids; dets forste Led er meget tykt og paa Enden af den øvre Rand forsynet med en Knule, livorpaa nogle korte Børster ere fostede; hos Hannen er den nedre Rand forsynet med mange fine Børster, som mangle hos Humnen; de tvende følgende Led aftage efterhaanden betydelig baade i Langde og'Tykkelse, saa at det andet kun er halvt saa langt som det første; det tredie er endnu meget kortere. Svøben er omtrent saa lang som Skaftet og dames af $7-9$ smale Led. Bisvøben er omtrent to Trediedele af Hovedsvobens Længde og dannes af $4-6$ smale Led.

De nedre Folere ere hos Hunnen korte, kun noget langere end de ovre; hos Hannen ere de meget lange, ofte saa lange som hele Legemet. Skaftets tvende første Led ere sammensmeltede; det tredie er kortere end bredt samt hos Hannen forsynet mel en Dusk fine Børster; det fjerde er meget læugere og vabnet paa den ydre Flade med tre Tomerækker, hvoraf hver tæller en til tre stærke Torne; det femte er kortere og smalere samt bevæbnet med to Rækker, hver bestaaende af tvende Torne. Hos Hannen er begge disse Leds øvre Flade forsynet med talrige fine Borster. Svgben er hos Hunnen kortere end Skaftet og damnes af 8-9 Led; hos Hannen er den, fuldt udviklet, nasten af Legemets Langde og dannes af 40 smale Led, hvoraf hvert andet er forsynet med Sugeskaale.

Kindbakkerne ere stærke samt i Spidsen delte i Tæuder, med en ligeledes tandet Bisvabe, den indre Del synes at være den stærkeste. Tornerækken dannes af tre simple 'Tome samt af fine Børster. Tyggeknuden er ikke meget fremtrædende. Palpens tredie Led er saa langt eller maaske noget langere eller kortere end det andet samt bliver noget bredere mod den skraat afskaame Ende, hvor det er forsynet med talrige Borster.

Det forste Kjæbepars ydre Plade har i Spidsen sex Tænder, hver forsynet med en enkelt Bitand; den indre P'lade er temmelig stor. Palpen er liden, enleddet, i Spidsen tilrundet og forsynet med faa Børster.

Det andet $\mathrm{Kj}$ æbepar er lidet; den indre Plade er den største.

Kjæbefodderne ere forlangede. Den indre Plade har tre Børster paa Enlen og een paa den indre Rand. Den ydre, som kun ex noget storre, er paa den indre Rand og i Spidsen forsynet med syv grove, i Spidsen krummede Borster eller tynde 
'Tæender, der mod Enden efterhaanden tiltage i Lingde. Palpen er forlænget; det andet Led er det liengste; det tredie er forlænget, ovalt, med Børsteknipper par den indre Rand. Kloen er nesten saa lang som det sidste Led.

De trende forste Fodpar have samme Form og Storrelse og ere ens hos begge Kjøn. Deres tredie og fjerde Led ere korte; det femte er ovalt, næsten dobbelt saa langt som bredt, med en krum, svagt skraat afskaaren Griberand, der ender i en fremragende Torn, som møder Spidsen af den ikke meget krummede Klo.

Det tredie og fjerde Fodpar have ens Bygning og Storrelse; deres tredie Led er temmelig bredt og udvider sig mod Enden, hvor der paa den bagre Rand er en Dusk med Borster; hele den forreste Rand er forsynet med Borsteknipper; det folgende Led er forlænget, ovalt og har Børster paa sin forreste Rand, hvoraf en, den inderste, bliver særdeles tyk, næsten tornformig, og er næsten saa lang som det folgende meget laugere og smalere Led; dette sidstnævnte er paa den forreste Rand vabnet med Torne. Kloen er kort.

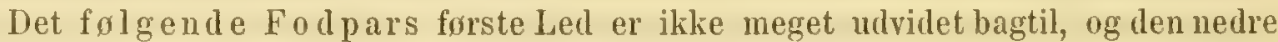
Vinkel er ikke meget udtrukket, men tilrundet; det tredie Led er meget kort og bredt, $o g$ de følgende aftage efterhaanden noget i Tykkelse, men tiltage i Længde og ere paa sin forreste Rand forsynede med Børster og stærke Torne.

Det sjette Fodpar er meget langere; dets første Led er udvidet og paa den forreste Rand forsynet med Knipper af lange Børster; det tredie er ikke meget udvidet nedad; det fjerde er noget kortere, men det femte er omtrent af samme Liengde som det tredie. Alle Led ere paa den forreste Rand vabnede med Torne.

Det syvende Fodpar er atter meget kort; det første Led er særdeles udvidet, saugtakket paa den bagre Rand og meget udtrukket paa den nedre, saa at denne Rand næsten nar til Enden af det tredie Led; dette sidste er kort, men bredt; det fjerde er omtrent af samme Længde eller noget længere; det femte er af samme Langde som det fjerde, men smalere. Kloen er kort. De fire sidste Led ere paa den forreste Rand forsynede med Torne og Borster. Svommefødderne ere korte og brede.

Det forste Par Springfodder naar lidt liengere bagud med Enden af sine Grene end det andet, og dette er længere og smalere hos Hamnen end hos Hunnen.

Det andet Par Springfodder er hos Hunuen kort; den ydre Gren er omtrent en halv Gang lrengere end Grundleddet, og den indre er betydeligt kortere; hos Hannen ere de meget forlængede, næsten dobbelt saa lange som Grundleddet, den indre er kun lidt kortere.

Halevedh rnget dames af 2 lancetformede Plarler. 


\section{PHOXUS SIMPLEX, Spence Bate, 1855.}

(Pl. VIII. Fig. 3).

Phoxus Kroyeri, Spence Bate, Brit. Assoc. Report. 1855. p. 58.

- - Spence Bate, Synopsis Brit. Amphip. Aun. Nat. Hist. 185\% p. 152.

- $\quad$ - White, Hist. of Brit. Crust. p. 173.

Phoxus simplex, Spence Bate, Ann. of Nat. Hist. Vol. XX. 1857. p. 525.

- - Spence Bate, Cat. Amphip. Crust. Brit. Mus. 1862. p. 97. pl. XVI. f. 1.

- $\quad$ - Spence Bate and Westwood, Brit. sessile-eyed Crust. p. 140.

- - Boeck, Crust. amphip. bor. et arct. 1870. p. 55.

Rostrum elongatum, hamiforme, deorsum curvatum. Antenna inferiores articulis pedunculi duobus ultimis sine spinis et modo setosis. Pedes 3 tii et 4 ti paris articulo 1 mo multo latiore quam apud speciem pracedentem et in angulo inferiore postico producto rolundatoqve. Pedes $7 \mathrm{mi}$ paris articulo 1 mo latissimo, in margine inferiore solum ad medium marginem posteriorem articuli 3tii porrecto; articulo 3tio longiore qvam 4to: omnibus multo longioribus qvam latis. Angulus inferior posticus lateralis segmenti postabdominis 3 tii valde rolundatus.

Længden er $4^{\mathrm{mm}}$.

Legemet er forlænget, sammentrykt fra Side til anden, men det er dog ikke meget høit. Hovedet er temmelig forlænget; det gaar fortil ud i et særleles bredt Horn, der fortil er afrundet og boier sig ned over de ovre Folere, som det for den største Del dækker, saa at kun Svøben rækker udenfor.

De øvre Følere ere meget korte; Skaftet er kun lidt længere end tykt, men dog næsten saa langi som den ovrige Del tilsammen; de tvende følgende Led ere kortere end tykke. Svoben bestarar af $6-7$ og Bisvoben af 3 Led.

De nedre Folere ere hos Hunnen korte, men hos Hamen meget forlangerle. Skaftets tvende forste Led ere sammenvoxede; det tredie er kort, hvorimod det fjerile er meget stort, tykt, noget længere end tykt og forsynet med et Knippe af tildels fjærdannede Borster eller Torne paa den bagre Rand; det femte Led er noget kortere end det foregaaende $\mathrm{og}$ er bevabnet par den forreste Rand med to Knipper Torne og pai den bagre med mange, tildels fjærdannede Børster og Torne. Svoben har hos Hunnen $5-6$, og hos Hannen 30-40 Led.

Kindbakkernes Palpes andet Led er meget bredt paa Midten og smalere i begge Ender; det tredie er saa langt som det foreganende og bliver noget bredere mod Enden, hvor det er forsynet med store Børster.

Kjæb eføddernes Palpe er forlænget, især det tredie Led, der er meget længere end det andet, noget krummet og bliver smalere mod Fnden, hvor der er befæstet tvende lange fjærdannede Borster: det fjerde Led udspringer fra det foregaaende Leds Midte; det er smalt, men ikke kloformet, og er paa Enden vabnet med en liden Torn 28 
De tvende forste Fodpar ere af ens Bygning, men det andet Par er noget strerkere og længere; deres tredie Led er lidt forlænget i den nedre bagre Vinkel, og til dens forreste Flade er befastet det smale, korte, noget buede fjerde Led; Haanden er oval med skrat afskaaren Rand; en Torn er fæstet i Vinkelen, hvor Kloens Spids moder. Kloen er tynd, noget krummet.

Det tredie og fjerde Fodpars forste Led er noget udvidet bagtil, og dets nedre bagre Hjøme er forlænget til en afrundet Lap; det tredie Led er meget forlænget, medens det fjerde knapt er Halvdelen af dettes Lrengde; det femte Led er smalt, noget bøiet, længere end det foregaaende og bærer i Spidsen den lange, næsten rette Klo. I den bagre Vinkel ere disse Led væbnede med Børsteknipper, hvilket især er Tilfældet med det fjerde Led.

Det femte Fodpar er kort; det forste Led er kort, bredt; det tredie er kun noget længere end bredt; det fjerde er kortere, medens det femte er ligesaa langt, men smalere end det tredie.

Det sjette Fodpar er derimor forlænget; det forste Led har en meget convex med Borsteknipper besat forreste Rand; let tredie Led er omtrent tre Gange saa langt som bredt; det fjerde er noget kortere end dette, og det femte har samme Længde, men er smalere. Kloen er noget kortere end det femte Led, smal og ret.

Det syvende Fodpar har et bagtil særdeles udvidet forste Led, der næsten er bredere end hoit; det tredie Led er omtrent dobbelt saa langt som bredt; det fjerde er meget kortere end dette; det femte er længere, men smalere end det foregaaende.

Det første Par af de tre bagre Springfodder har lige lange Grene.

Det andet Par har samme Bygning som det forste, men rækker ikke saa langt bagud.

Det tredie Pars Grundled er noget langere end bredt; den ydre Gren er mere end dobbelt saa lang som Grundleddet.

Halevedh ngets Grene ere forlængede, ovale, med nogle Børster i Spidsen.

Denne Art er af G. 0. Sars taget i eet Exemplar i Nordland. Ved Haugesund er den ikke ualmindelig paa 15-20 Favnes Dybde, ligeledes i Christianiafjorden, hvor den er fundet af mig ulenfor Moss. Ved Englands liyst er den fundet i Plymouth Sound.

Gen. II. HARPINIA, A. Boeck, $18 \% 0$.

Derivo: 'Aprivex (et græsk Kivindenavn).

Syn.: 1870. Harpina, A. Boeck, Crust. amphip. bor. et arct. 1870. p. 55.

(Da Navnet Harpina allerede for er brugt til en Coleopterslægt, er det ombyttet med dette nye.)

Typ.: Phoxus plumosus, Krøyer, 1842.

Maxillæ $1 \mathrm{mi}$ paris palpo 2articulato.

Pedes 5 ti paris articulo 1 mo non dilatato.

Cateroqvin ferme ut apud genus Phoxus. 
Denne Slægt adskiller sig fra Phoxus ved, at det forste Kjæbepars Palpe er toleddet, og at det femte Fodpars første Led ikke er udvidet. Forøvrigt stemmer den i sin Bygning saa meget overens med den foregaaende, at de ikke kunne skilles fra hinanden. Krøyer fremhæver, at hos $P$. plumosus ere Kindbakkeme lange og smale, og han tror, at denne og $P$. Holböllii bør opstilles i tvende forskjellige Slægter. Til Harpinia høre kun de to Arter $H$. plumosa og $H$. crenulata.

HARPINIA PLUNOSA, Krøyer, 1842.

(Pl. VIII. Fig. 5 et Fig. 1.)

Phoxus plumosus, Krøyer, Nat. Tidsskr. 1. R. IV. 1842. p. 152.

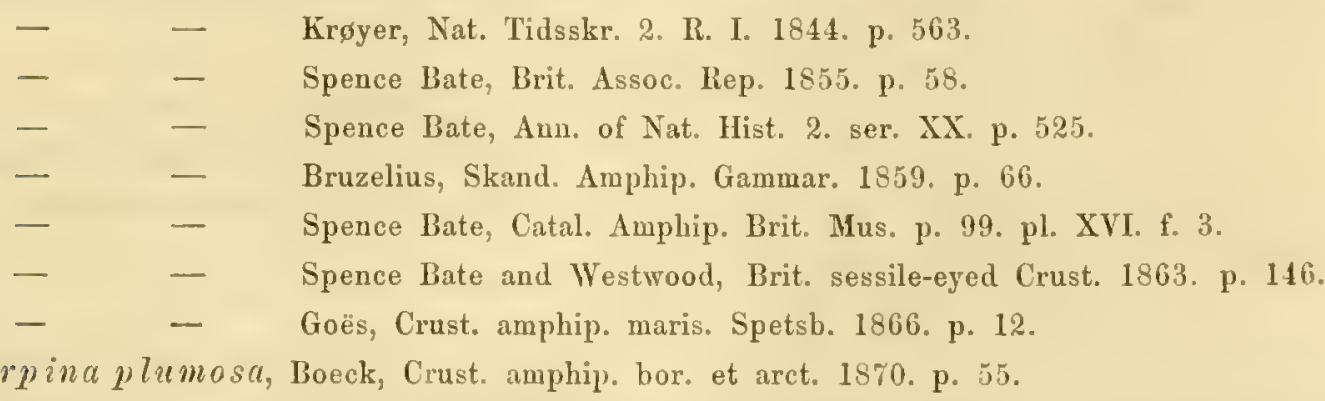

Antennæ inferiores articulo pedunculi tho sericbus duabus spinarum robustarum armato. Angulus inferior posticus lateralis segmenti postabdominis 3tii sursum acutus el valde productus. Pedes $1 \mathrm{mi}$ et 2 di paris manu perlata el apicem versus latiore. in acie obliqve truncata. Pedes 5ti paris articulo 3tio longiore et latiore qvam 4to. Pedes $7 \mathrm{mi}$ paris articulo $1 \mathrm{mo}$ perlato, in margine inferiore postico fere ad extremum articulum 3tium producto et in margine postico valde serrato, dentibus 2-3 robustis instructo.

Dyrets Længde er $5^{\mathrm{mm}}$.

Legemets Form er temmelig høi og sammentrykt fra Side til anden, med rund Ryg, uden Kjøl. Hovedet er forlænget og gaar umiddelbart over i det lange, ved Roden brede, men mod Enden tilspidsede Pandehorn, hvorved det i Langde overgaar de fire til fem forste Legemsled. De fire forste Sideplader ere hoiere end brede og tiltage efterhaanden i Storrelse, simt ere paa deres nedre Rand forsynede med mange fjardamede Børster. Den nedre bagre Vinkel paa det tredie Haleled danner en meget lang, opadbøiet, mod Enden spids Hage.

De ovre Følere ere korte og rage ikke fuldt frem foran Pandehornet med sin ydre Halvdel. Skaftet er længere end Svøben; dets første Led er meget stort, tykt og paa Enden af den nedre Rand besat med tre til fire kostdannede Børster; det andet Led er meget kortere og smalere, men bliver meget bredere mod Enden, hvor det har fire længere og tre kortere fjærdannede Børster; det tredie Led er kun noget læn- 
gere end tykt. Svøben dannes af 5-6 Led, hvoraf det første er det lingste. Bisvøben er kun noget kortere og dannes af 5 Led, der ere kortere end Hovedsvobens Led.

De nedre Følere ere noget langere end de øvre. Deres Skaft er meget tylit og stærkt; dets tvende første Led synes at væire sammenvoxede til eet Led; det tredie er kortere end bredt og paa den nedre Rand forsynet med to til tre fjardannede Børster; det fjerde er meget stort, bliver meget bredere nedad og er paa den ydre Flade væbnet med en øvre og en nedre Rad af stærke Torne, samt har paa den nedre Rand lange, fjordannede Børster; det femte Led er meget smalere og noget kortere samt er forsynet paa den nedre Rands Ende med fem fjardannede Borster og en krum Torn. Svoben er omtrent saa lang som Skaftet og dannes af $7-8$ Led, hvoraf det forste er noget kortere end de folgende tilsammen.

Overiæben er kort, i Spidsen tilrundet.

Kindbakkerne ere stærke, i Spidsen delte; Grenene er besatte, den ydre med sex, den indre med fire smaa Tander. Tyggeknuden er fremstaaende. Palpens tredie Led er lidt længere, men meget smalere end det andet, paa Enden skraat afskaaret og der forsynet med mange Borster.

Underlæbens Flige ere vilt adskilte.

Det forste Kjæbepars Palpe er paa Enden væbnet med syv forlæugede Torne; den indre Plade er liden og har en fjærdannet Børste.

Det andet $\mathrm{Kj}$ ibepar er lidet.

Kjæbefødderne ere smaa; den ydre Plade, der naar kun lidt langere frem end det forste Led, er paa den indre Rand og Spids væbnet med Tome. Palpen er forlanget; det fjerde Led er kloformet.

De trende forste Fodpar ere af ens Bygning og næsten af den samme Størrelse; det første Led er paa den bagre Rand besat med lange, tildels fjærdannede Børster; det tredie Led er meget ultrukket i det bagre Hjorne, der er tilrundet; det fjerde Led er kortere. Haanden bliver noget bredere fortil og har en skraat afskaaren Griberand, der er forsynet med Torne, hvoraf to, som sidde, hvor Kloens Spids møder, ere meget stærke.

Det tredie og fjerde Fodpars forste Led er paa den bagre Rand forsynet med lange fjærdannede Børster; det tredie er noget udvidet nedad og ligeledes besat med fjærdannede Børster, der dog ere kortere; det fjerde Led er ovalt, Børsterne paa lets bagre Rand blive mod Enden stærkere og ligne meget tykke Torne; den sidste af disse er næsten saa lang som det folgende Led; lette er længere end det foregaaende, men meget smalere. Kloen el stærk, men kortere end det foregaaende Led.

Det femte Fodpars forste Led er ikke udvidet; dets tredie Led er noget langere end det ovale fjerde, som er meget bredere end det femte. Alle disse ere paa begge Rande forsynede med mange Bundter af fjærdannede Børster. Kloen er kortere end det sidste Led og ret.

Det folgende Fodpar el det længste; dets tredie, fjerde og femte Led ere 
omtrent lige lange, men aftage efterhaanden meget stærkt $\mathrm{i}$ Tykkelse $0 \mathrm{~g}$ ere $\mathrm{i}$ den forreste Rand forsynede med Torne. Kloen er meget lang og ret.

Det syvende Fodpar er meget kortere; det første Led er meget bredt, men kort, og udtrukket nedad og bagtil samt indskaaret paa den bagre Rand med faa, men grove Saugtakker. De følgende Led tilsammen ere noget længere end det forste, og det tredie Led er det længste.

Alle Springfoddernes Grene rage næsten lige langt bagud, dog er det andet Par noget kortere end de tvende øvrige, og dets Grene er lige lange.

Det tredie Pars ydre Gren er paa den ydre og tildels paa den indre Rand forsynet med lange tynde Torne eller Børster.

Hal evedhæng ets Lappe ere lancetformede. En Varietet, hos hvilken den bagre rinkel paa det tredie Haleled er uitrukket i en liden Hage, og hvis syvende Forlpars forste Led bagtil kun har smaa Tiender, findes i det sydlige Norge, medens Former, der ligne de gronlandske Exemplarer, findes ved Nordlands Kyster.

Den forekommer ikke meget almindelig ved Grønland; ved Spitsbergen er den fundet paa flere Steder paa 20-30 Favnes Dybde. Ved. Island er den ogsaa funlet. Af G. 0. Sars er den taget ved Risvær i Nordland paa 180-200 Favne, ved Throndhjemsfjordens Udlıh) af C. Boeck, ved Christianssund og Molde paa 30-50 Favne af Danielssen, ved Haugesund og Lyngholmen fandt jeg den ikke ualmindelig par 30100 Favne. Den er af Norman fundet ved Shetlandsøerne og i Plymouth Sound af Spence Bate.

\section{HARPINIA CRENULATA, A. Boeck, $18 \% 0$.}

(P1. VIII. Fig. 2).

Harpina erenulata, A. Boeck, Crust. amphip. bor. et aret. 1870. p. 56.

Antennæ inferiores articulo 4 to et 5 to non spinis sed modo in margine inferiore postico scopis et paucis selis armatis. Angulus inferior posticus lateralis segmenti postabdominis 3 tii parum modo productus et acutus. Pedes 1 mi et 2di paris manu angusla, elongata, ovata. Pedes 5 ti paris articulo 3 tio vix longiore qvam 4to. Pedes $7 \mathrm{mi}$ paris articulo $1 \mathrm{mo}$ multo angustiore qvam apud speciem præcedentem, in margine postico serralo.

Dyrets Længde er omtrent $4^{\mathrm{mm}}$.

L egemet er forlænget og sammentrykt med middelmaadig store Sideplader. Den nedre bagre Vinkel paa let tredie Haleled er ikke udtrukket i en Hage, men Vinkelen er tilrundet $\mathrm{og}$ indskaaret $\mathrm{i}$ fire til fem Saugtænder.

De nvre Folere stemme fuldkommen overens med de samme hos $H$. plumosa, men Skaftets tvende første Led ere mindre forsynede med fjærdannede Børster end hos hin Art. 
De nedre Føleres fjerde Led mangle alle de stærke Torne i den bagre udbugede Rand, hvilke findes hos $H$. plumosa, og det femte Led er spolformet samt bliver ikke bredere nedad som hos hin Art.

De tvende forste Fodpars Form er lig den samme hos $H$. plumosa, men Haanden er mere oval, og Griberanden er laugere samt mere skraat afskaaren, hvorved den skilles let fra hin Art.

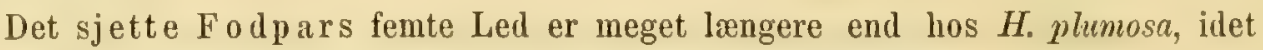
det er meget længere end det fjerde og meget længere end Kloen.

Det syvende Fodpars første Led er ligesom hos $H$. plumosa stærkt udtrukket $\mathrm{i}$ den nedre bagre Vinkel, men er hos denne Art indskaaret i talrige Tænder, medens der hos hin Art kun findes tre til fire, der hurtig tiltage i Størrelse. Disse Saugtænder ere heller ikke af den almindelige Form, men hver Tand har en lille Bitand paa hver Side, og mellem dem findes smaa Børster.

Det sidste Par Springfødders indre Gren er kun ubetydeligt længere end Grundleddet $0 \mathrm{~g}$ meget kortere end den ydre Gren, der i Spidsen er vabnet med en lang Torn og nogle Børster.

Denne Art har jeg fundet i Christianiafjorden udenfor Moss paa 60 Favnes Dybde, og et Exemplar har jeg taget ved Haugesund blandt Exemplarer af $I$. plumosa.

Gen. III. SULCATOR, Spence Bate, 1854.

Deriv.: Sulcator (en, som drager Furer efter sig.)

Syn.: 1851. Bellia, Spence Bate, Ann. Nat. Hist. Vol. VII. p. 318.

1854. Sulcator, Spence Bate, Ann. Nat. Hist. Vol. XII. p. 504.

1862. - Spence Bate, Catal. Amphip. Crust. Brit. Mus. p. 112.

1870. - A. Boeck, Crust. amphip. bor. et aret. p. 56.

Typ.: Oniseus arenatius, Slabber.

Maxillæ Imi paris palpo 1 articulato.

Pedes maxillares articulo palpi 2do sat lato.

Pedes $1 \mathrm{mi}$ et 2 di paris vix subcheliformes.

Pedes trium parium ultimorum articulis perlatis et ad fodiendum constructi.

Corpus non valde compressum; capite in rostrum mediocriter longum elongalo; epimeris permagnis.

Segmentum postabdominis 3tium valde elongatum, latum, semicylindricum: segmenta postabdominis tria posteriora sub 3tium curvata.

Appendix caudalis lata, fissa.

Denne Slagt opstillede Spence Bate i 1851 med Navnet Bellia, men kaldte den i 1854 Sulcator: Han henfører den til Phoxides, men stiller den dog langt fra Phoxus. Et Rudiment af den typiske Art $S$. arenarius, der neppe afviger fra den af 
Slabber beskrevne Onisens arcuatius, fandt jeg blandt nogle torrede Conchylier, som jeg havde medbragt fra Karmøen; jeg kunde saaledes ikke underkaste den nogen egentlig Undersøgelse, men blot constatere, at den var den samme, som den af Spence Bate opstillede Art. Slagtsdiagnosen er derfor kun hentet fra hans Tegning, som synes at være nøiagtig. Den stemmer overens mer Slægten Phoxus i de øvre Føleres Bygning, ligeledes synes Kindbakkerne at have den samme Form, som hos hin, derimod er det forste Kjæbepars Palpe, der hos Ploxus og Harpinia er meget smal, hos denne særdeles bred, toleddet $0 \mathrm{~g}$ besat paa Enden af den ydre Rand med talrige fjardannede Børster. Den indre Plade er ogsaa liden, men har derimod ikke faa fjærdannede Børster. Kjahefoddernes Plader ere efter hans Tegning meget storre end hos de trende foregaaende Slægter, især den ydre, som ogsaa er væbnet med lange, smale, tornformede Tænder. Palpens andet Led er særdeles bredt og ligner saaledes meget det hos Slægten $B a$ thyporcia, og ligesom hos denne boier det tredie Led sig over det udvidede andet Led. Herved ville Kijobefodderne kumne fuldstandig lukke for Iunddelene, saa at iklie fremmede Substantser mod Dyrets Villie kan trænge ind. De tvende forste Fodpar have, som hos de tvende foregaaende Slægter, ens Bygning, men Haanden er hos denne Slægt meget liden, især Kloen, hvilket viser, at den maa leve af meget svage Dyr. Det tredie og fjerde Fodpar ere særdeles brede, hvilket især er Tilfældet med deres fjerde og femte Led, som ere skovlformet udvidede og besatte paa Randen og den ydre Flade med Rxkker af Torne og have ikke, som sædvanlig, nogen Klo paa Enden. Dette viser, at de ere byggede til at grave med og ikke, som hos de tvende foregaaende Sliegter, til at fastholde Byttet. De tre sidste Fodpar blive ogsaa overordentlig brede, og Leddene faa et eiendommeligt, skovlformet Udseende samt ere paa den forreste Rand og paa den ydre Side besatte med stærke Rader af Torne og tildels fjærdannede Børster. Disse synes bestemte til at bortskaffe og kaste bagud den Sand, som opgraves med det tredie og fjerde Fodpar. Paa Grund af denne med Gravning forbundne Levemaade kan heller ikke Halen have den sadvanlige Stilling, da den i dette Tilfælde vilde hindre Dyret fra hurtig at grave sig ned. Dens tre sidste Led ere derfor slaaede ind under det tredie Led, og Springfoddernes Grene ere frestede i en Vinkel til Grundleddet; derved ville de sammen med Halen kunne benyttes til at stemme Legemet mod Sandet og trykke let fremad under Gravningen.

\section{SULCATOR ARENATIUS, Slabber, 1775. †}

Oniscus arenatius, Slabber, Natuurkundige verlustigingen etc. 1775. p. 92. pl.11. f. 4-3. Bellia arenaria, Spence Bate, Ann. of Nat. Hist. Vol. VII. 1851. p. 318.

Suleator arenarius, Spence Bate, Ann. of Nat. Hist. Vol. XIII. 1854. p. 504.

$-\quad$ Spence Bate, Rep. Brit. Assoc. 1855. p. 58.
- $\quad$ Spence Bate, Trans. Tyneside Nat. Field. Club. vol. IV. 1858. p.
15. pl. 11. fig. 2.


Sulcator arenarius, Spence Bate, Catal. Amphip. Brit. Mus. 1862. p. 112. pl. XVIII. - $\quad$ - Spence Bate and Westwood, Brit. sessile-eyed Crust. 1863. p. 189. - - A. Boeck, Crust. amphip. bor. et arct. 1870. p. $5 \%$

Oculi parvi, rotundi, rubri. Antennæ superiores fasciculis selarum plumosarum instructa. Antennæe inferiores articulo pedunculi 4 to perdilatato, multo longiore et latiore qvam 5to; utroqve in margine inferiore setis plumosis instructo. Pedes $1 \mathrm{mi} 2$ diqve paris manu breviore et angustiore qvam carpo; ungve parvo. Pedes 3tii et 4 ti paris articulo 4 to brevi, sed postice perdilatato et seriebus pluribus spinarum validarum instructo; articulo 5to ovato, in margine inferiore spinis firmis armato. Pedes 5 ti paris articulo 3 tio deorsum perdilatato; 4 to duplo latiore qvam alto; 5 to angusto, in margine anteriore et in apice spinis validis armato. Pedes 6 ti paris articulo 3 tio deorsum perdilatato, 4 to lato, ovato, 5 to angusto. Pedes 7 mi paris articulo 5to ovali, in margine utroqve spinis validis armato. Appendix caudalis laciniis latis, ovatis, in margine exteriore et in apice spinis firmis armatis.

Denne Art, som jeg selv kun har seet i et torret Rudiment, synes saa meget at stemme overens med Slabbers Oniscus arenatius, at jeg ikke tvivler om Identiteten. Da jeg ikke har havt Anledning til at undersoge den nxemere, lian jeg ikke beskrive den $0 \mathrm{~g}$ vil kun henvise til Spence Bate's Beskrivelse.

\section{Gen. IV. UROTHOË, Dana, 1852.}

Syn.: 1852. Urotho ë, Dana, The american Journ. of Science and Arts. 1852. p. 307.

1853. - Dana, U. States Explor. Exped. p. 920.

1853. Egidia, Costa, Ricerche sui Crost. amfip. d. r. d. Napoli.-Mem. d. r. Aucad. d. scienze di Napoli 1853. p. 165.

1856. - Costa, sui Crost. amfip. d. regno di Napoli.-Mem. d. r. Accad. d. sc. di Napoli 1856 . p. 174.

1860. Urothoe, A. Boeck, Skand. Naturf. 8 de Møde 1860, p. 646.

1863. - Spence Bate, Catal. Amphip. Crust. Brit. Mus. p. 114.

1870. - A. Boeck, Crust. amphip. bor. et arct. 1870. p. 57.

Typ.: Urothoë irrostratus, Dana.

Mandibula in apice parum modo dentata.

Maxillæ $1 \mathrm{mi}$ paris palpo 2 arliculato: articulo utroqve eadem ferme longitudine.

Pedes maxillares articulo palpi 2 do introrsum valde dilatato.

Pedes $1 \mathrm{mi}$ et 2 di paris manu parva, subcheliformi instructi.

Pedes 5ti paris articulis perlatis. 
Pedes saltatorii ultimi paris ramo exteriore paululum Inngioge qvam interiore. Appendix caudalis usqve ad basin fissa.

Corpus valde depressum, latum; capite antice parum modo producto et rotundato; epimeris angustis.

Dana opstillede denne Slægt i 1852 med trende Arter fra Zoolosøen, livoraf dog, som anført, den ene Art $U$. rostratus maa henfores til Slægten Phoxus, medens $U$. irrostratus maa blive Typus for Slægten. Dana fremhever i Slægtskarakteren, at de gve Folere ere kortere end de nedre, hvilket ogsaa altid er Tilfaldet hos Hanner, men ikke bestandig hos Hunner. Han teguer ogsaa det forste Kjæbepars Palpe enleddet og uden indre Plade, medens den hos vor Art er toleddet og forsynet med en indre Plade; hint kan dog bero paa en mindre nøiagtig Observation.*)

Spence Bate henforte i 1862 til denne Slagt tvende Arter, som vasentlig adskilte sig fra hinanden ved Længden af de nedre Folere, men dette er kun et Kjønsmarke og ikke nogen Artskarakter. Aaret efter, at Dana havde opstillet denne Slægt, grundede Costa Slægten Ergidia frit Neapel. Deme falder fuldkommen sammen med. Dana's SIrgt, hvilket bedre kan sees af Costa's Tegning af E. pulchella, end af hans Beskrivelse. I 1860 tilfoiede jeg en ny Art: U. norvegica, som jeg parviste at afvige fra U.clegans, Spence Bate, og med den falder sammen $U$. Bairdii, Spence Bate (1862). Slagten tæller saaledes i det Hoieste fire Arter. Fra Phoxus skiller den sig ved, at de øvre Føleres Skaftled er meget tyndere. Det første Kjæbepars Palpe er ogsaa meget bredere, og dens Led ere lige lange. Heri ligner den mere Slagten Sulrutor, og dette er end mere Tilficldet med Kjxhefuddernes Bygning. hvis I'laler ere meget storre end hos Slægten Phoxus; Palpens andet Led bliver nedad særdeles bredt og forsynet med lange Borster. Derimod afviger den fra Slægten Sulcator ved, at Palpens fjerde Led er vel udviklet. Ved de tvende første Fodpars Bygning dannes der et Mellemled mellem begge hine Slægter, idet de ikke ere saa strerke som hos Slægten Phoxis, og ikke saa svage som hos Urothoë. De tvende folgende Fodpars fjerde og femte Led ere meget mere udvidede, end 'l'ilfaldet er hos Slagten Phoxus, men heller ikke saa skovlformet udvidede som hos Sulcator. Det femte Fodpars tredie og fjerde Led ere temmelig udvidede og paa begge Rande besatte med Ḱnipper af Torne; men dette er langtfra Tilfreldet i saa høi Grad som hos Sulcator. De trende følgende Fodpars fire sidste Led ere ogsaa kun lidet udvidede. I Halens Bygning stemmer den overens med Slægten Phoxus, men afviger deri fra Sulcator. Den danner saaledes et Overgangsled mellem begge disse tvende tilsyneladende sia adshilte Slægter.

\footnotetext{
*) Den af lam anforte Karakter: -Maxillipedes longi et angusti lamellis internis perparvis" passe1 hellerikke paa Slxgten, men beror paa hans Undersagelse af $U$. rostratus, som er en Phoxus, og maa derfor nigaa. Han tror paa Grund af denne Bygning af Kjæbefodderne, at denne Slægt nærmer sig til Slægten Leucothoë, medens Kindbakkerne ere af Lysianassidernes Typus. Desuden finder han, at den ligner Ünderfamilien Pontoporeince.
} 
UROTHOË NOIVEGICA, A. Boeck, 1860.

(Pl. VI. Hig. 9. Pl. VII. Fig. 4).

Urothoë novveyica, A. Boeck, Forhandl. ved de Skaud. Naturf. 8de Iøde 1860. p. 647. Urotho ë Bairdii, Spence Bate, Catal. of Amphip. in Brit. MIus. p. 114 pl. XIX. f. 1. 1862.

- - Spence Bate and Westwood, Brit: sessile-eyed Crust 1863. p. 193.

Urothoü norvegica, A. Boeck, Crust. amphip. bor. et arct. 1870. p. 58.

Antenna inferiores articulo 4 to longiore qvam 5to; utrorve seriebus pluribus spinarum gracilium instructo. Pedes $1 \mathrm{mi}$ el 2di paris manu parva, triangulari, dimidiam longitudinem articuli fli setosi vix superanti. Pedes jli paris articulis perlatis, spinis validis armalis; articulo 3 tio et 4 to eadem ferme longitudine. Appendix canlalis laciniis in apice spina singula armatis." Pedes saltatorii ultimi paris multis setis plumosis armati. Angulus inferior posticus lateralis segmenti postahdominis 3 tii sursum productus.

Dyret er $5-6^{\mathrm{mm}}$ langt fra Hovelets Spids til Halevedhæuget.

Legemet er meget nedtrykt ovenfra nedad paa den forreste Del, saa at Hovelet og Ryggen ere meget brede, og Sidepladerne staa noget ud til Siderne. Hovedet er meget Hadtrylit, og de sman, runde Oine ligge paa Hovedets overste Flade. De syv forste Legemsled ere meget smale, Sidepladerne ere smaa og smale samt høiere end brede. Halens tredie Led garr bagtil ud i en spids.

De $\emptyset \mathrm{vre}$ Folere ere omtrent saa lange som Hovedet og de tvende forste Legemsled tilsammen; Skaftet er forlanget; dets forste Led er det længste og tykkeste, de folgende aftage efterhaanden noget baade i Længde og Tykkelse. Svøben er hos Humen noget langere end Skaftets sidste Led $0 \mathrm{~g}$ bestar af 6 Led. Bisvoben er meget kortere og damnes af 3 Led.

De nedre Folere ere omtrent af samme Lrengde som de ovre; Skaftets fjerde Led er noget langere og tykkere end det femte; begge ere besatte paa den øve Flade og Rand med starke, lange og rette Torne og paa den nedre med lange Borster. svoben er meget kort og bestaar af 4 med lange Borster forsynede Led. Overlaben er meget bred, ikke: spaltet, men tilrundet i Spidsen.

Kindbakkerne ere særdeles tykke $0 \mathrm{~g}$ stærke; Spidsen er tilrundet, uden 'Trender, men der findes et lidet Fremspring paa den indre Side, der dog kun vanskelig kan sees. Palpén er lang, tynd, treleddet; dens andet Led er det liongste.

Det første Kjabepar er i Spidsen vabnet med lange, starke, med smaa Bitænder forsynede Torne i tvende Rarler. Den indre Plade er forlænget, smal, med nogle Borster i Spidsen. l'alpen er toleddet; begge Led ere nosten lige lange.

Det andet $\mathrm{Kj}$ abepar er af den sædvanlige Form.

Kjabefodderne ere store; den ydre Plade er bred, lang og har paa den indre Rand starke Tander og Brrster; den indre er forlanget, firkantet, vabnet i 
Spidsen med nogle Tænder og Borster. Palpen er sardeles stor og bred; dens andet. Led bliver indad meget udvidet og er der forsynet med talrige krumme Borster i trette Rader; det tredie Led er bredest opad, det fjerde eller Kloen er. konisk samt har Børster i Spidsen.

De trende forste Fodpar have mesten samme Storrelse og Bygning; deres første Led er forlænget $0 \mathrm{~g}$ har lange Børster paạ den bagre Rand; det andet og tredie ere korte; det fjerde er forlænget $\mathrm{og}$ udvidet bagtil samt er der forsynet med mange Børster. Haanden er forlænget, oval, mere convex paa den bagre end paa den forreste Rand og forsynet med lange Borster. Kloen er strerk, meget krummet.

De tvende folgende Fodpars treclie Led er meget forlænget, par den bagre Rand besat med tvende Bundter af lange Borster; det fjerde er noget mere end Halvdelen af det foregaaende Leds Længde og vabnet par den bagre Rand med flere stærke, rette Torne og flere Børster; det femte Led er noget kortere og smalere, forsynet med tvende Rader starke, rette 'Torme. Kloen er ret.

Det femte Fodpars forste Led er ikke meget udvidet; det andet er kort, det tredie er lrengere og omtrent saa langt som brelt eller noget langere; det femte er langere end det fjerde, men meget smalere; alle Led ere i begge Rande vabnede med Knipper af stærke Torne. Ḱloen er lang og ret.

Det sjette Fodpar er liengere end det foregaaende; dets forste Led er udvidet; det tredie Led langere; det fjerde og femte ere indbyrles nasten lige lange, men kortere end det tredie: Leddene ere lige i den forreste Rand, vabnede med Knipper af Torme.

Det syvende Fodpars forste Leil er sterkt udvidet og med en kredsformig bagre Rand; det tredie Led er kortere end det fjerde, som er længere og tykkere end det forste.

Det andet Par Springfodder. er kortere end det forste; dets Grene ere cylindriske samt omtrent lige lange.

Det tredie Pars Grene ere pladedannede og langere end det korte Grundled; den ydre Gren er i Spidsen forsynet med en kort Torn; begge have Borster i Randen.

Halevedhruget er dobbelt; Plademe ere forlangèle og i Spirlsen briede ned i en Torn.

Denne Art er af G. O. Sars fundet red Risvar i Nordland paa 150-200 Favne; af mig er den fundet i Christianiafjorden og ved Haugesund paa 60-100 Favne.

Subfamilia IV.

EPIMERINAE。 A. Boeck, 1870.

Syn.: Epimerinae, A. Boeck, Crust. amphip. bor. et aret. 18\%0. p. 103.

Labium superius perlatum, in apice parum insinaatum.

Mandibulae validissima, in apice late el dentata: processu accessorio ro29 * 
busto et dentato; serie setarum ex setis multis, latis, lanceolatis et in margine convexo serratis, constanti.

Iaxillæ $1 \mathrm{mi}$ paris validæ; palpo 2articulato; articulo palpi ultimo in apice dentibus paucis armato; lamina interiore in margine interiore setis multis instructa. Maxillre 2di paris latæ.

Pedes maxillares laminis exterioribus latis et dentatis; palpo elongato, robusto; articulo palpi ultimo ungviformi.

Corpus crassissimum, robustum, carinatum et spinis armatum. Epimera magna, rigida. Oculi prominentes.

Antenna flagella longa gerentes; superiores flagello accessorio destituta.

Pedes 1 mi et 2 di paris graciles; pedes cateri validi.

Pedes saltatorii biramei; pedes 2 di paris breviores qvam iidem 1 mi paris, ramo interiore paulo longiore qvam exteriore; pedes 3 tii paris ramis invicem eadem longiludine.

Appendix caudalis rigida, magnitudinis mediocris, in apice parum incisa.

Denne Underfamilie indbefatter Slagterne Epimeria, Costa, og Acanthozone, (Acanthosoma, Owen), A. Boeck. Disse kume nemlig iklie henfores til samme Underfamilie som de foregarende; thi de afvige meget ved Munddelenes brede, liorte Form, medens disse hos den foregaaende Underfamilie ere ultrukne i Langden; de udvise saaledes fra dem en stor typisk Forskjel. Derimod stemme disse tvende Slagter mere overens med folgende Underfamiliers Slxgter, men kumne dog ikke godt forenes med lem. I det Ydre vise de dog en større Overensstemmelse med den foregaaende end med de efterfolgende Underfamiliers Slægter paa Grund af sit hoie Legeme med stive Sideplatder og sin kjølede Ryg; her bliver dog Legemet end mere tornet og lappet end hos den foregaaende Underfanilie. Øinene har den samme halvkugleformede, fremstaaende form som hos hin. Foleme ere ogsaa lidt mere forlangede end hos den foreganende Underfamilie, hvis Sliegt V'ertumms dog viser en Overgang mellem begge i denue Henseende. De tvende første Fodpars Haand er ogsaa lang, og saavel heri som i Halens Bygning stemmer den meget overens med den foregaaende Underfamilie. Men istedenfor at hos hin Overlaben er meget forlanget, er den derimod bred hos denne; ligeledes ere Kindbalkerne korte $0 \mathrm{~g}$ brede, hvilket ogsaa er'Tilfældet med Gribedelen, som er indskaret i talrige og strerke Trender, medens den hos hin Underfamilie er tynd, smal og har faa Tronder. Medens det forste Kjobepars Palpe hos Iphemedince er meget kort og undertiden manglende, er den her meget stor og har i Spidsen starke Tænder; og medens Kjabefoddernes Plader der ere smaa og svagt væbnede, ere de her temmelig store og starkt vabnede; altid er her Palpens fjerde Led kloformigt. 
Gen. I. ACANTHOZONE, A. Boeck, $18 \% 0$.

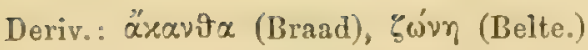

Syn.: 1835. Acanthozoma, Owen, Appendix to the second voyage of Capt. Ross. 1835. p. 461.

1860.

A. Boeck, Forhandl. ved de Skand. Naturf. 8de Møde, 1860. p. 665 .

1859. Paramphithoé, Bruzelius, Bidrag till Kän. om Skand. Amphip. Gam. Kongl. Vetensk.-Akad.'s Haudlingar. Ny följd. Bd. 3. 1859. p. 69. (pars).

1862. - Spence Bate, Catal. Amphip. Crust. Brit. Mus. 1863. p. 146.

1870. Acanthozone, A. Boeck, Crust. amphip. bor. et arct. 1870. p. 104.

Typ.: Oniscus cuspidatus, Lepechin.

Segmenta trunci et postabdominis seriebus pluribus dentium armata.

Epimera qvatuor anteriora non permagna sed rigida, in apice acuminata.

Pedes trium parium ultimorum articulo 1 mo valde dilatato et spinis armato.

Pedes saltatorii ultimi paris ramis lanceolatis.

Owen opstillede denne Slægt i 1835 med folgende Diagnose: Antemm inxqvales, superiores dimidio breviores; articulo ultimo e plurimis segmentis formato; articulis 3 tiis et 2dis superiorum aqvalibus. Pedes qvatuor antici monodactyli filiformes, articulo ultimo $1 \mathrm{mi}$ paris ungviculato. Rostrum productum, acutum, undulatum. Oculi parvi. Krøyer viser i 1838, at disse Karakterer ikke ere tilstrækkelige til derpan at begrunde nogen egen Slrgt, da de fleste af dem ere fielles for alle Amphipoder; han henfører den derfor til Slægten Amphithoë. Denne Mening følger Milne-Edwards i 1840. Bruzelius henforer den i 1859 til Slægten Paramphithoë. Jeg troede i 1860 at burde gienoptage slargten, idet jeg paaviste, at Bruzelius havde i sin slingt Paramphithö̈ foiet

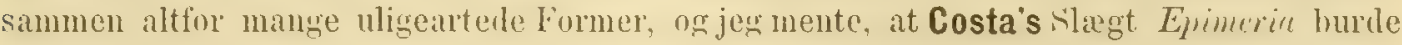
falde sammen med den. Spence Bate fulgte Bruzelius i $1862 \mathrm{og}$ stillede den til Paranphithoë, hvilket ogsaa I,illjeborg har gjort. I 1870 opstillede jeg den under den nye Underfamilie Epimerince som 'Typus paa en egen Slægt. Da imidlertid Owens Slægtsnavn allerede var benyttet til et Insekt, kaldte jeg den Acanthozone. Den adskiller sig især fra den efterfolgende Slægt ved den eiendommelige Bevæbning paa alle Legemets Led, ligesom de tre bagre Fodpars første Led er vel udviklet, medens det hos Epimeria er smalt. Slagten indeholder kun en eneste Art, som er en arktisk Form.

ACANTHOZONE CUSPIDATA, Lepechin, 1778.

Oniscus cuspidatus, Lepechin, Acta Petropolit. 1778. p. 247. tab. V1II. f. 3. Acanthosoma hystrix, Owen, Append. to the second voyage of Capt. Ross. 1835. p. 91. tab. B. f. $4-7$. 
Amphithoe hystrix, Lirgyer, Gronlands Amphipoder beskrevie. K. Danske Vidensk.Selsk. Afh. VIII. 1838, p. 231. tab. 2. fig. $\%$

- $\quad$ - Milne-Edwards, Histoire des Crust. III. 1840. p. 70.

Paramphithö̈hystrix, Bruzelius, Bidrag till Kän. om Skand. Amphip. Gam. Kigl. Ve. tensk. Akad. Handlingar. Ny føljd. B. 3. 1859. p. 71.

Spence Bate, Catal. Amphip. Crust. Brit. Mus. 1862. p. $14 \%$ tab. XXVIII. fig. 1.

Acantho:one cuspidata, Boeck, Crust. amphip. bor. et arct. 1870. p. 104.

Frons rostro parvo et acuto instructa. Oculi rotundi. Segmenta trunci qvinis aculeis armata: segmentum 1 mum insuper in margine anteriore aculeis tribus, medio maximo et antice curvato, instructum. Segmentum postabdominis $1 \mathrm{mum}$ et 2 dum aculeis novenis, 3tium qvingve. 4tum tribus, 5 tum et 6 tum binis armata. Antenna superiores duas terlias longiludinis inferiorum aqvantes: articulo pedunculi 1 mo ex extremo margine superiore aculeum. fere longitudinem articuli 2di rervantem, enitlenti. Pedes trium pariuni posteriorum articulo 1 mo postice insinuato, serrato. in angulo superiore et inferiore acuminato. Appendix caudalis parva, postice insinuala.

Dyrets 'Lang il e er $7^{\mathrm{mm}}$.

Legemet er noget høit, tykt, opsvulmet fortil, medens Halen er mere sammentrykket. De syv, Legemsled ere drkkede af fem Rxkker af Pigge, der ere rettede udad og bagtil, hvoraf den hoieste Rad gaar langs Ryggens Midte og tvende andre, en paa hver Side, indtage Midten af Leddene, medens de sidste ere frestede til Leddenes bagre Siderande. Alle disse tiltage bagur i Storrelse. Det forste Legemsled har desuden endnu tre Pigge, af hvilke den forreste i Midtlinien er den længste og ligger horizontalt fremad som et Horn over Hovedet. Par hvert af Bagkroppens tvende forste Lerl sees ni Pigge, af hvilke de tvende nederste ere de mindste; det tredie Led har fem, det fjerde har tre, og det femte sant sjette kun to. De Pigge, der skulde findes par Midtlinien af disse Led, mangle. Det syvende Led har ingen Pig. Sidepladerne ere ikke meget hoie, stive og rettede noget udad; den forste er forlænget i den forreste nedre Vinkel til en Spirls; de tvende folgende ere mere trekantede og ere spidse nedad; den fjerde er meget bredere $0 \mathrm{~g}$ længere end de foregaaende $\mathrm{og}$ er nedad i begge Vinkler udtrukket og tilspidset; den femte er ikke saa høi, men meget bredere, med et dybt Indsnit paa den nedre Rand; dens nedre bagre Vinkel er tilspidset, medens den forreste er rund. Hovedet er stort og danner fortil et Horn mellem de ovre Folere; en skarp Tand sees under de neilre Følere paa Hovedets Sider. Oinene er store, runcle. De ovre Folere ere noget mere end halvt saa lange som de nedre; deres første Skaftled er omtrent saa langt som Hovedet $\mathrm{g}$ er paa den ovre Sides Ende vabnet med en lang smal Tand; de tvende folgende aftage $\mathrm{i}$ Langde og Tykkelse. Svoben er mere end dobbelt saa lang som Skaftet og dannes af 80 korte Led, paa hvis indre Rand er fastet Borsteknipper. 
De nedre Foleres andet Skaftled udsender nedad et stwrkt Fremspring, og det tredie, der er noget læugere end bredt, udsender fra den ydre Side et lignende; det fjerde $0 g$ femte Led ere ontrent lige lange. Svoben er omtrent tre Gange saa lang som Skaftet og damues af henved 100 Led. Overlæben er meget bred med en lille Indbugtning i den gvre Ende.

Kindbakkerne ere meget starke, i Spidsen kløvede, og Grenene ere vabnede, den ovre med syv, den nedre med fem T'nder. Tyggeknuden er meget fremtræertende. Palpen er forlænget, smal, treledilet; det andet Led er det længste.

Det første Kjæbepar er meget bredt; den ydre Plade er vobnet med starke, saugtakkerle, krumme Torne. Den indre Plade er oval, mere tilspidset paa knden og har i den indre Rand ontrent ti fjardannede Børster, hvoraf de overste ere rle langste og starkeste. Palpen er meget strerk og har paa Enden nogle faa Torne.

Det andet Kijabepars Plader ere meget brede; den ylre er nogt langere end den indre, begge forsynede paa den indre Rand og paa Enden med lange fjardannede Borster.

Kjabefod derne ere meget stærke; den indre Plade naar frem til Encien af Palpens andet Led og er $\mathrm{i}$ den indre Rand forsynet med mange fjardannede Børster og i Spidsen med nogle faa Tæender; den ydre Plade er meget bred og naar frem til over Midten af Palpens andet Led; den er i den indre Rand vrebnet med en Rakke T'orne, der mod Spidsen forlænge sig og gaa paa Endefladen over i krumme, fjærdamede Børster. Palpen el forlænget, stark; det sidste Led er kloformet.

De trende forste Fodpar have næsten samme Størrelse og Form og ere svagt byggede; det femte Led eller Haanden er smalt, forlanget, nedad noget bredere og i Griberanden fint tandet; Kloen er strerk og krummet.

Det tredie og fjerde Fodpars tredie Led er langere end det fjerde.

De tre bagre Fodpars forste Led er bredt, i den forreste Rand forsynet med nogle tynde Torne; den bagre Rand er bueformet indskaaret og begrandset opad af en spids Vinkel; den nedre bagre Vinkel er tilspidset. Indskjæringen er saugtakket. Deres tredie Led er kun lidet udvidet nedad og bagtil og er længere end ilet fjerde samt saa langt eller noget kortere end det femte Led.

Det forste Par Springfolders Grene ere lange og smale, forsynede med Trender i Randen; den ydre Gren er ubetydeligt kortere end den indre.

Det andet $\mathrm{Par}$ er meget kortere end det forste; den ydre Gren er meget kortere end den indre.

Det sidste Par nar længst bagud; Grenene ere lige lange, afplattede og tilspidsede, i Randen tandede og forsynede med smaa Borster.

Halevedhænget er lidet, stivt, indhulet i den øvre Flade, paa Enden tilspidset, men har dog i Spidsen en liden triangulær Indskjæring.

Farven er efter M. Sars gulbrun. Fodderne og Sidepladerne ere farvede med rosemrode Ringe; ofte ere ogsaa Legemets L'irge rosenrole i Spidsen; oinene ere brunsorte. 
Den forekommer ved det arkiske Amerika ved Igloit, hvor den er fundet af Ross, ved Grønland paa flere Steder, ved Spitsbergen, lwor den findes mellem Alger og Bryozoer paa 7-60 Favne. Af Danielssen og M. Sars er den taget i Komagfjord, red Hammerfest $0 \mathrm{~g}$ Vadsø; af I,epechin i det hvide Hav. Den er forøvrigt fundet i Finmarken af Lovén.

Gen. II. EPIMERIA, Costa, 1851.

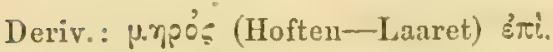

Syn.: 1851. Epimeria, Costa, in Cat. de' Crost. Ital. del Rev. Fr. Hope. 1851. p. 46.

1856. - Costa, Ricerche sui Crost. amfip. del regno d. Napoli. Mem. d. r. Accad. d. scien. vol. 1. 1856 . p. 197.

1862. - Spence Bate, Catal. Amphip. Crust. Brit. Mus. 1862. p. 153.

1870. - A. Boeck, Crust. amphip. bor. et arct. 1870. p. 105.

Typ.: Epimeria tricristata, Costr.

Segmenta trunci carinata.

Epimera qvatuor anteriora longissima, angusta, apicem versus acuminata, rigida; epimerum 4tum et 5 tum prominentia.

Rostrum frontale permagnum et inter antennas curvatum.

Pedes trium parium ultimorum articulo 1 mo parum modo dilatato, maxime eodem 5 ti et 6 ti paris.

Pedes saltatorii ultimi paris ramis perangustis.

Costa opstillede denne Slægt i 1851. I 1856 giver han den følgende Karakter: Antennæ superiores unisetx. Pedes qvatuor anteriores prehensiles, filiformes, subæqvales. Corpus dorso in postica thoracis parte ac in abdomine carinatum et spinosum. Epimera qvarti et qvinti articuli thoracis maxima, simul clypeum semilunare formantia. Abdomen lamina horizontali terminatum. Dette vir som Slagtskarakter meget utilstrakkeligt. Den typiske Art E. tricristata blev funden ved Englands Kyst og som en ny Art henfort til Slregten Acanthonotus. Ligeledes blev den af Sars fundet ved Norges Kyst og af ham henfort til Slrgten Amphithoë under Navn af A. parasitica. I 1860 troede jeg, at denne sidstnæunte Art burde skilles fra Amphithoë og henføres til Acanthosoma. Spence Bate optager Slagten Epimeria i 1862 med de af Costa i 1857 givne Karakterer, uden at han ser, at Acanthonotus Oxenii er den samme Art. I 1870 optog jeg den igjen med ovenstaaende Diagnose, idet jeg for den typiske Art antog Fabricius's Artsnavn comiycra. I Munddelenes Form viser den en stor Overensstemmelse med den foregatende Sliegt; dog ere Kindbakkerne her ikke saa strent udviklede son hos hin; de ere nemlig hos denne Slægt temmelig tynde. Kjæbeføddernes ydre Plade er ogsaa mindre, hvorfor den heller ikke er saa stærkt væbnet, og istedetfor en hel Rickke har den kun een Tand i den indre Rand. Palpens forste Led er ogsa laugere 
end hos hin Slægt. I det Ydre er der en meget karakteristisk Forskjel mellem begge disse Slagter derved, at Legemsleddene hos denne ikke ere saa udtrukne i Torne som hos hin, medens paa den anden sille den fjerde og femte Sideplade ere ganshe anderledes kraftige. Halevedhrenget er her som hos den foregaaende kun noget indskaaret paa den bagre Rand og ikke dybt kløvet, som anfort af Spence Bate og Westwood.

EPIMERIA CORNIGERA, Fabricius, 1779.

Gammarus corniger, Fabricius, Reise nach Norwegen 1779. p. 383.

- Fabricius, Entomol. Syst. emend. et auct. 1792-1794. tom. 11 p. 514 .

Cancer corniger, Herbst, Versuch einer Naturgesch. Krabben u. Krebsen. 1792.

Epimeria tricristata, A. Costa, Catal. di Crost. Ital. del Rev. Hope. 1851. p. 46.

Costa, Ricerche sui Crostacei amfip. del regno d. Napoli. Mem.

d. r. Accad. d. sci. 1856, p. 19\%, tab. 11. f. 2.

- - Spence Bate, Amphip. Crust. Brit. Mus. 1862. p. 154.

Vertumnus Cranchii, White, List Crust. Brit. Mus. 1847. p. 89.

Acanthonotus Cranchii, White, Cat. Crust. Brit. Mus. 1847. p. 57.

Acanthonotus testudo, White, Cat. Brit. Crust. 1850. p. 51.

- - White, Popul. Brit. Crust. 185\% p. 177.

- Spence Bate, Cat. Amphip. Crust. Brit. Mus. 1862. p. 12\%. pl. XXIIr. fig 3.

Acanthonotus Owenii, Spence Bate, Rep. Brit. Assoc. 1855. p. 58.

- $\quad$ - Spence Bate, Ann. Nat. Hist. 2. ser. vol. XIX. 185\%. p. 141.

- $\quad$ - Spence Bate and Westwood, Brit. sessile-eyed Crust. B. 1. p. 232.

Amp hithoë parasitica, Sars, Overs. over norsk-arct. Krebsdyr. Forhandl. i VidenskabsSelsk. i Christiania 1858. p. 131.

Epimeria cornigera, A. Boeck, Crust. amphip. bor. et arct. 1870. p. 10 .

Rostrum frontale longum, curvatum. Dorsum latum, carinatum; carina in segmento trmei 5to oriunda et in segmentis trunci seqventibus et postabdominis qqvatuor anterioribus in dentes retroversos desinenti. Segmenta poslabdominis duo posteriora edentata. Segmenta postabdominis duo anteriora in utroqve latere carinæ carina accessoria, postice in dentes desinenti, instructa et in medio margine posteriore et in angulo inferiore laterali acuminata. Epimerum Atum et 5tum permagna, exstantia; 4 tum in angulo inferiore antico in spinam validam, conicam, acuminatam et parum curvatam productum; epimerum 5 tum in angulo inferiore postico valde productum et acuminatum. Pedes 5ti paris articulo 1 mo parum modo dilatato, fere lineari. Pedes 6 ti paris articulo 1 mo plus qvam duplo longiore qvam lato. Pedes 7 mi paris articulo 1 mo magis dilatato qram eodem 6ti paris et in angulo inferiore postico paulo producto. Appendix caudalis in apice paululum incisa. 
Det største af mig undersøgte Exemplar var fra Pandehornet til Enden af den udstrakte Hale $14^{\mathrm{mm}}$ langt.

Legemet er meget tykt, ligesom opsvulmet. liyggen paa den forreste Del af Legemet er rund; men en Kjøl, som bagtil gaar ud i en bagud rettet Tand, begynder at danne sig paa Legemets tvende bagre Led og fortsatter sig paa alle Halens Led, undtagen paa de tvende sidste, og gaar bagtil på̉ hvert Led ud i et stærkt Fremspring, der voxer efterhaanden $0 \mathrm{~g}$ er storst paa de tre bagre Led. Paa hver Side af dette findes paa Halens tre forste Led et meget lidet Fremspring, der ligeledes i Enden af hvert Led damner en liden Torn. Halens tre forreste Led ere desuden i den bagerste Rand væbnede med tvende Fremspring under disse, hvoraf det nederste danner Leddets nedre bagre Hjørne. Sidepladerne ere meget store, forlængede, smale og tilspidsede i Enden; den fjerde er den lrengste og danner en bagudboiet Klo samt er par den gvre bagre Del indskaaret for den femte, hvis nedre bagre Hjorne danner en stærk Torn. De tvende følgende aftage i Størrelse. Hovedet er kort, men gaar fortil frem i et meget langt, strerkt Pandehorn, der er tilspidset i Enden. Øinene ere runde, fremstaaende og beliggende bagenfor de nedre Folere.

De øvre Følere ere saa lange som Hovedet 0 g Kroppens $4-5$ første Led. Skaftet er kort; dets første Led er noget længere end tykt; de tvende folgende aftage efterhaanden baade i Tykkelse og Længde. Svoben er meget længere end Skaftet og bestaar af 24 Led, hvoraf det forste er lingere end de folgende.

De nedre Følere ere længere end de ovre; Skaftets forste Led danner et kort Fremspring paa den ovre Side, medens det andet danner et lignende paa den nedre Side; det tredie Led er særdeles kort; det fjerde er noget mere end dobbelt saa langt som tykt; det femte er kortere. Svøben er meget langere end Skaftet og dannes af 36 Led. Overlæben er særdeles bred nedentil, paa Enden besat med Borster.

Kindbakkerne ere starke, i Spidsen delte; Fligene ere meget tandede. Tyggeknuden er særdeles fremstanende; Torneraden dannes af lange, rette Torne. Palpen er tynd; dens andet Led er det longste.

Det forste $\mathrm{Kj}$ b epar har i Spidsen mange brede, med Bitorne forsynede Torne; den indre Plade er stærk, i den indre Rand forsynet med fjærdannede Borster. Palpen er lang, men smal, i Spidsen tandet.

Kjæbefoddernes ydre Plade er særdeles bred; i den indre Rand findes en tynd, skiærende, tandet Plade, og nærmere Spidsen sees nogle Tæuler, der blive tyndere 0 g buede mod Spidsen. Palpen er forlænget; dens tredie Led er kun lidt kortere, men tyndere end det andet; Kloen er liden, tandet paa den indre Rand.

Det første Fodpar er svagt.

Det andet Fodpar er noget langere end let forste; Haanden er forlænget, firkantet, omtrent af det foregaaende Leds Langile; Kloen er i den bagre Rand saugtakket.

Det tredie og fjerde Fodpar ere meget smale; deres tredie Led er langere 
end det fjerde, men ikke udvidet; det femte er ubetydeligt langere end det foregaaende; begge disse ere stærkt væbnede med Tome paa den forreste Rand.

Det femte Fodpars forste Led er aldeles ikke udvidet.

Det sjette Fodpars første Led er noget, det syvende Pars første Led mere udvidet, og dets nedre bagre Hjørne er tilspidset; forøvrigt have alle tre den samme Bygning med Undtagelse af, at det sidste Par er noget kortere end det foreganende.

Springfødderne ere lange; det sidste Pars. Grene ere forlængede, lancetformede; den indre er ubetydeligt længere end den ydre.

Halevedhænget er bredt, indskaaret bagtil.

Spence Bate anfører, at Halevedhænget er langt og dybt kløvet, 'hvilket dog ikke er Tilfællet med de norske Exemplarer. Ligeledes skulle Ungerne vare forsynede med en eenleddet Bisvobe paa de øvre Folere, hvilket maa ansees for at være en Mærkvardighed, hvis dette bekræfter sig.

Farven er efter M. Sars's Iagttagelse blorlrod og mere intensiv rod paa den bagre Rand af hyert Led; Øinene ere brunsorte. Jeg lar dog fundet, at de yngre Exemplarer ere noget lysere.

Af G. O. Sars er den fundet ved Christianssund og Aalesund paa 50-100 Favne, ved Manger og Florøen af M. Sars omtrent paa den samme Dybde, fastet til Huden af Holothuria tremula. Under samme Forhold har jeg fundet den ved Farsund; sammesteds er den fundet af Fabricius. Af (i. O. Sars er den fremdeles talrig taget ved Hvitingsøerne paa 80-150 Fames Dybde. Ved Shetland er den fundet af Norman og paa flere Steder ved England, Skotland og Irland; den gaar efter Costa ned til Neapel.

Subfamilia V.

IPH I M E D I A E, A. Boeck, 1870.

Syn.: Iphimedina, A. Boeck, Crust. amphip. bor. et arct. 1870. p. 98.

Labium superius elongatum, in apice valde insinuatum.

Mandibulie elongatæ, sxpe validx, in apice productæ, parum aut non dentatæ; rumo accessorio item producto angustoqve; tuberculo molari parvulo, sæpe obsoleto; palpo elongato, robusto, Barticulato.

Labium inferius lamina interna parva, prope apicen sita.

Maxillæ $1 \mathrm{mi}$ paris plus minusve elongatæ; palpo nunc longo, 2articulato, nunc fere obsoleto, uniarticulato.

Pedes maxillares launinis interioribus elongatis, angustis, selis modo instructis; laminis exterioribus sat magnis aut magnitudinis mediocris et parum setosis: palpo parum elongato: articulo palpi ultimo non ungviformi; articulis duobus ultimis palpi interdum absentibus. 
Corpus aut compressum, crassum et epimeris magnis instructum, aut non depressum et epimeris minoribus instructum.

Antennæ superiores flagello accessorio destituta.

Pedes $1 \mathrm{mi}$ et 2 di paris nunc graciles et non subcheliformes, nunc robusti et subcheliformes.

Pedes 3 tii et 4 ti paris validi.

Pedes trium parium ultimorum longiludine gradatim crescentes.

Pedes saltalorii biramei.

Appendix candalis parva, interdum in apice incisa.

Denne Underfamilie opstillede jeg i 1870 og optog deri Slægterne: Vertumns (Acanthonotus), Iphimedia, Odius (Otus) og Laphystius (Darvinia). Disse Slægter staa i Here Henseender hverandre nær og afvige meget fra de til de nærstaaende Underfamilier henhorende ved de forlingede, tilspidsede Munddele, der ere af en eiendommelig Form og vise, at de maa opsøge og nyde sin Fode paa en ganske anden Maade end andre Slægter, som ere stillede sammen med dem. Slægten Laphystius lever ogsaa parasitisk paa forskjellige Fiskenter og er derfor i sin Form noget mere modificeret end de øvrige, der sandsynligvis leve af at suge af friske Aadsler; jeg har nemlig fanget enkelte Arter af dem paa nedsunkne Fugleaalsler. Slagten Laphystius viser paa Grund af denne parasitislie Levemaade selv i Munddelene en fra de andre Slægter saa afvigende Bygning, at den maaske bor ansees for Typus paa en ny Underfamilie. Overlæben er hos alle de herhen horende Slægter forlænget; Kindbakkerne ere ogsaa lange, smale, i Spidsen udtrukne og kun ubetydeligt delte i Tænder. Tyggeknuden findes hos Slagterne Iplimedia og Odius, men mangler fuldstandig hos Laphystius; Palpen er lang. Paa Grund af le forlængede Kindbakker og Overlæbe maa ogsaa Underlæben forlænge sig, og de ydre Flige ere derfor ultrukue, par Enden tilrundede, og nær Enden af den indre Rand sees de smaa Bitlige. Det første Kjæbepars indre Plader maa ogsaa blive store og brede, men dets Palpe bliver derved formindsket. Hos Vertumms er denne Palpe kortere end den ydre Plade; hos Iphimedia er den toleddet, kort, hos Otus er den meget tynd, enleddet, og hos Laphystins er den rudimentrer, knudeformet. Det andet Kjobepars indre Plade er altid kortere end den ydre hos denne Underfamilie; hos Slægten Vertumnus ere de brede, hos Odius og Laphystius smale. Kjæbeføddernes ydre Plade er temmelig liden hos nogle Slagter, medens den hos Vertumms er meget stor. Palpens tre forste Led ere forlangede hos Vertumnus og Odius, medens det fjerde er knudeformet; hos Iphimedia mangler det sidste Led, og hos Laphystius er Palpen kort, kun toleddet. Man ser saaledes, at der stadig findes Forandringer i Kjæbeføddernes Bygning los Slægterue i denne Underfamilie. I det Ydre afviger Laphystius noget fra de ovrige Slagter, idet dens Legeme er nedtrykket og Sidepladerne smaa, medens det hos de ovrige er sammentrykket og Sidepladerne ere store. Denne Forskjel grunder sig paa Dyrets parasitiske Levemaade, hvorefter Legemet er afpasset. De øvre 
Folere mangle hos alle disse Slagter en Bisvobe, men le ere mere eller mindre forlangede og blive hos Laphystius meget mere fortykkede end de nedre. De trende første Fodpar antage hos de forskjellige slagter en forskjellig Form; de ere kraftigt udviklede, saaledes som det første Fodpar hos Odius, snart svage, som hos de øvrige Slægter. Det tredie og fjerde Fodpar blive hos Laphystius særegent udviklede paa Grund af dens parasitiske Levemaade.

Gen. I. ACAN'HONOTOZOMA, A. Boeck.

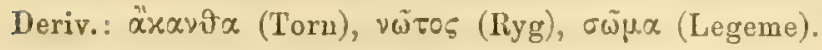

Syn.: 1833. Acanthonotus, Owen, Append. to the second voyage of Capt. Ross. p. 90.

(Navnet er brugt til en Fisk i Aaret 1801).

1840. - Milne-Edwards, Hist. nat. des Crust. 1840. p. 24.

1847. Vertumu s, White, Catal. of Crust. Brit. Mus. 1847. p. 89.

(Navnet er brugt til en Turbellarie i 1821 af Otto).

1853. Acanthonotus, Dana, U. States Explor. Exped. Crust. 1853. p. 909.

1857. - White, Popular Hist. Brit. Crust. 185\% p. 177.

1859. - Bruzelius, Bidrag till Kän. om Skand. Amphip. Gamm. Kgl. Vetensk. Akad.'s Handlingar. Ny följd. B. 3. p. 77.

1860. - A. Boeck, Forhandl. ved de Skand. Naturf.'s 8de Møde. 1860. p. 663.

1862. - Spence Bate, Catal. Crust. Amphip. Brit. Mus. p. 126.

1863. - - Spence Bate and Westwood, Brit. sessile-eyed Crust. p. 231.

1865. - Lilljeborg, On the Lysianasaa magellanica ete. p. 18. (Tabel).

1865. Vertumnus, Goës, Crust. Amphip. maris Spetsb. 1865. p. 6.

1870. - A. Boeck, Crust. amphip. bor. et arct. p. 99.

Typ.: Acanthonotus cristatus, Owen.

Labium superius pralongatum.

Maxillæ $1 \mathrm{mi}$ paris palpo 2articulato; articulo $1 \mathrm{mo}$ longo; lamina interiore permagna, triangulari, multis selis plumosis instructa.

Pedes maxillares palpo robusto; articulo palpi ultimo parvo.

Pedes $1 \mathrm{mi}$ et 2 di paris graciles, manu subcheliformi destituti; articulo 5to Imi paris prælongato, gracili; ungve in margine postico perserrato.

Corpus compressum; epimeris magnis, rigidis.

Owen opstillede i 1834 Slxgten Acanthonotus paa Arten A. cristatus fra Nordishavet. De Karakterer, som Owen giver denne Slægt, ere følgende: "Antennæ subæqvales, qvadri articulata, articulo altimo e plurimis segmentis formato, tertio superiorum brevissimo. Pedes qvatuor antice monodactyli, filiformes, articulo ultimo primi paris serrato. Rostrum productum, incurvatum, oculi parvi“. Diagnosen var saaledes ikke meget betegnende, hvorfor ogsaa Kroyer i $183 \triangleleft$ ikke troede at burde optage denne Slaght, men 
henfurte Oniscuss scrratus, Fabricius, til Slægten Amphithoë. Milne-Edwards optog Slagten i 1840 og skilte den fra Slægten Amphithoë, fordi de tvende første Fodpar ikke ere forsynede med en Gribehaand. Krøyer vil i 1854 helst lade Slægten Acanthonotus gaa ind, da han finder det vanskeligt at drage Grondsen mellem Acanthonotus og Amphithö̈. Da Slrgten Amphithoë efter Milne-Edwards indeholdt saa mange Arter, troede han dog at burde beholde den af praktiske Grunde og stiller derfor hen til denne Arterne $A$. serratus (serra) og A. inflatus, medens han dog tror, at Milne-Edwards' A. Nordmanii bor udelades. White forandrer Slagtsnavnet til Tertumus, da hint Navn allerede før var benyttet til en Fiskeslagt. Navnet Vertumms er dog ogsaa af 0 tto i 1821 benyttet til en Turbellarie. Af Spence Bate bliver Vertumms stillet sammen med Otus og Iphimedia til Underfamilien Phoxides, medens Lilljeborg i 1866 stiller den til Underfamilien Atyline.

Det første Kjæbepars Palpe er toleddet, og dennes første Led er langt; desuagtet naar ikke Palpen frem til Enden af den ydre Plade; den indre Plade er stor, triangulær: den indre er forsynet med talrige Børster. Det andet Kjæbepars Plader ere meget brede; den indre er bredere end den ydre. Kjæbeføddernes ydre Plade er temmelig liden; deres Palpe er længere og bredere end det andet Led, der igjen er længere og bredere end det tredie; det sidste Led er rudimentært, kuudeformet. Kloen par det forste Fodpars Haand kan ikke slaaes ind; det andet Fodpars Haand er forlænget, smalt, og dets Klo er grovt saugtakket paa den bagre Rand.

\section{ACANTHONOTOZOMA CRISTATUM, Owen, 1834.}

Acanthonotus eristatus, Owen, Appendix to the second voyage of Capt. Ross. 1834. p. 90. tab. 13. fig. $8-12$.

- $\quad$ - Milne-Edwards, Hist. des Crust. UI. 1840. p. 24.

Amphithoë cristata, Sars, Oversigt over norsk-arct. Krebsdyr. Forhandl. i Vidensk.-Selsk. i Christiania 1858. p. 131.

Vertumu us cristatus, Goës, Crust. Amphip. maris Spetsb. 1865. p. 6.

A. Boeck, Crust. amphip. bor. et arct. 1870. p. 99.

Rostrum frontale valde prominens, acutum. Dorsum trunci et segmenta qvinqve anteriora postabdominis carinata; carina in segmentis trunci 4 to - 7mo et in segmentis postabdominis qvatuor anterioribus dentem magnum, retroversum formanti. Anguli inferiores postici segmentorum poslabdominis trium anteriorum producti et acuti, maxime angulus segmenti 3tii. Pedes trium parium ultimorum articulo Imo latissimo, rectangulari, postice serrato, in angulo inferiore postico producto et acuto.

Dyret er $6-15^{\mathrm{mm}}$ langt.

Legemet er høit, men ikke meget sammentrykket, temmelig tykt paa Midten 
ved den fjerde Sideplade; det bliver tyndere fortil og isar bagtil, saa at Halen bliver temmelig sammentrykket fra Sideme. Ryggen er stierkt kjolet, og det tredie og fjerde Legemsled danne i Enden af den bagre Rand en Tand, som er meget stærk paa de tre følgende Legemsled og bliver. end stærkere udviklet paa de tre forreste Haleled, medens den igjen er mindre paa det fjerde og mangler paa de tre sidste, hvor ogsaa Kjølen er rudimentar. De tre sidste Legemsled og de tre forste Haleleds bagre Vinkel ere udtrukne til en skarp Tand, hvoraf den paa det sidste Led er den langste. Hovedet har ogsaa en Kjol, der gaar fortil ud i et langt, trekantet, spidst Horn. Dets nedre Sidevinkel ex ogsaa tilspidset. Øinene ere svagt ovale, fremstaaende. De tre forste Sideplader tiltage efter hinanden i Langde, ere smale og tilspidsede nedad; den fjerde er meget bredere og længere, tilspidset i sit forreste nedre Hjørne; det bagre nedre Hjøme er ligeledes udtrukket, men i Enden tvært afskaaret. De tre følgende Sidepladers bagre nedre Hjorne er ligeledes tilspidset.

De øvre Følere ere næsten lige lange og naa, naar de bøies bagud, til Endèn af det femte Legemsled. Skaftets forreste Led er meget tykt, langere end Pandehornet, og ender oventil og nedentil i en konisk Torn; det andet Led er meget kortere og tyndere og har ligeledes i Enden af den gvre og nedre Rand en konisk Torn; det tredie er omtrent halvt saa langt som det andet 0 g meget tyndere. Svoben dannes af 20 korte Led.

De nedre Føleres andet Led er paa Enden vabnet med tvende smaa Torne; det fjerde er dobbelt saa langt som det tredie og saa langt som det femte. Disse Led ere meget smalere end dem paa de ovre Føleres Skaft. Svøben er outrent saa lang som de tvende sidste Skaftled og dannes af 10 korte Led.

Kindbakkerne ere meget forlangede, smale, mod Enden tilspidsede og delte i tre til fire smaa'Tænder. Den nedre Bigren er ligeledes liden og svagt tandet. Palpen er stærk; dens tredie Led er næsten saa langt som det andet, buet, tilspidset paa Enden og har paa den indre Rand en tæt Rad fjærdamnede Børster. Underlæben er meget forlænget, smal; Bittigene ikke tydelige.

Det første Kjæbepar er ogsaa forlænget; den ydre Plade er væbnet i Spidsen med stærke, saugtakkede Tander; den indre er stor, trekantet, i Enden tilspidset og paa den indre Rand forsynet med talrige fjærdannede Børster, der mod Spidsen efterhaanden blive læugere. Palpen naar ikke frem til Enden af den ydre Plade; paa den indre Rand samt i Spidsen er den forsynet med korte Børster.

Det andet Kjæbepars ydre Plade er bredere og længere end den indre; begge have talrige fjærdannede Borster.

Kjabeføddernes ydre Plade er liden, væbnet med korte, tynde Torne; den indre Plade er meget forlønget, smal og naar ikke frem til Enden af Palpens forste Led. Denne er forlænget, smal; det første Led er ligesaa langt eller noget længere end det andet, der er udtrukket i Enden af den indre Rand; det tredie er kortere og meget smalere end det andet; det fjerde er rudimentært, knudeformigt.

Det forste Fodpar er meget lidet, tyodt. Carpus og Haanden ere omtrent 
lige lange, smale og forsynerle med Burster; Kloen er liden, men spirls og har paa den indre Rand Bitænder.

Det andet Fodpar er længere og smalere; baade Carpus og Haanden ere cylindriske; Kloen har paa den indre Rand henimod otte triangulære, boiede Tænder samt en med Børster forsynet Biflig.

De tvende folgende Fodpar ere kraftigt udviklede.

De tre sidste Fodpar tiltage efterhaanden ubetydeligt i Langde; det første Led er meget bredt, paa den bagre Rand saugtakket; den nedre bagre Vinkel er udtrukket, tilspidset; den indre Rand er indskaaret og fortil begrændset af en tilspidset Vinkel. Det tredie Led er nedad udtrukket, tilspidset, meget længere end det fjerde, men neppe saa langt som det femte; Kloen er stirk, lidt krummet, paa Enden tilspidset.

Det forste Par Springfodders Grene ere næsten lige lange, eller den ydre lidt langere end den indre; begge Grene samt Grundleddet har Torme paa den svre Rand.

Det andet Par er meget kortere, men af samme Bygning.

Det tredie Pars ydre Gren er kortere end den indre, men mere end dobbelt saa lang som Grundleddet.

Halevedhanget er oventil indhulet, bliver smalere mod Enden og indskaaret paa den bagre Rand.

Farven er rødlig hvid; Øinene ere høirøde.

Den er fundet ved Felix Harbour ved det arktiske Amerika og af M. Sars i et Exemplar ved Komagfjord i Finmarken paa 70-80 Favnes Dybde, desuden af Malmgren ved Spitsbergen i faa Exemplarer.

ACANTHONOTOZOMA SERRATUM, Fabr., 1780.

Oniscus serratus, Otto Fabricius, Fauna Groenlandix 1780. p. 262.

Amphithoë serra, Kroyer, Grønlands Amphipoder. 1838. p. 266. tab. 2. fig. S.

- - Krøyer, Nat. Tidsskr. 1. R. 2. B. p. 260.

Acunthonotus serra, Milne-Edwards, Hist. des Crust. III. 1840. p. 28.

- $\quad$ - Bruzelias, Skand. Amphip. Gammar. 1859. p. 78.

A canthonotus serratus, Stimpson, Marine Inverteb. of Grand Manan. 1853. p. 52.

Vertumus servatus, Goës, Crust. Amphip. maris Spetsb. 1865. p. 6.

- - A. Boeck, Crust. amphip. bor. et arct. 1870. p. 100.

Rostrum frontale valde prominens. Carina dorsi in segmentis trunci tribus ultimis et in segmentis postabdominis duobus anterioribus dentes minores, retroversos formans. Segmentum postabdominis 1 mum et 2 dum in margine posterioredenticulis armata. Segmenlum postablominis 3tium in margine postico in sinus profundos duos incisum, inter quos processus in apice dentibus duobus instructus. Sinus inferior infra a processu robusto, in margine utroqve serrato, terminatus. Pedes trium parium ultimorum arliculo 1 mo lato, rectangulari, angulo inferiore postico producto et acuto, in margine inferiore et posteriore serrato. 
Dyrets L 2 ngde er" $6^{\mathrm{minn}}$.

L e ge mets forreste Del er meget tyk, medens Halen bliver stærkt sammentrykket fra Siderne. Ryggen er ikke rund, men danner en Kjøl, der er mindre fremtrædende paa Ryggens forste Led, men tiltager bagud i storrelse; pata den bagerste Rand af Ryggens to-fire sidste og Halens tre forste Led springer den frem i starke, bagur rettede Torne; Kloen mangler paa Halens tre sidste Led. De tre forste Sideplader ere meget smale, store, tilspidsede paa Enden; den fjerde er meget bredere og noget langere; den overste Del af dens bagerste Rand er dybtindskaaret for den femte Sideplade, og den nedre Del, der lober skraat fortil, er noget udvidet, saa at det nedre bagre Hjorne danner en svag, noget bagud rettet Hage; den femte Sideplade er meget bredere end høi og i den nedre Rand stærkt indskaaret, saa at der dannes en mindre høi forreste $\mathrm{og}$ en større bagerste Lap; de tvende folgende aftage baade i Længde og Høide. Den nedre, bagerste Vinkel paa Halens tvende forste Led er tilspidset. Den bagerste Rand paa det tredie Led er dobbelt halvmaaneformet indskaret, saa at der dannes en øvre, i Spidsen opadrettet, Hage og en nedre, hvis øvre Rand og Spids er forsynet med starke Trender. Hovedet er kortere end det forste Legemsled, men fortsatter sig i det meget langere Pandehorn; dette er spidst, og dets yderste Ende er noget nedkrummet. Paa Hovedets forreste Rand, der er noget udbugtet, sidde de skraa, ovale Oine.

De øvre Følere ere saa lange, at de ved at bøies tilbage naa til det sjette Legemsled. Skaftets forste Led naar ikke fuldt frem til Pandehornets Spids. Det andet er kortere og smalere; det tredie er kun noget mere end dobbelt saa langt som tykt. Svoben er kortere end Skaftet og dannes af 9 Led, der ere længere end brede.

De nedre Følere ere omtrent saa lange som de ovre. Skaftets forste og andet Led ere korte; det tredie er knapt saa langt som tykt; det fjerde er forlænget og naar frem til midt paa det tredie Led af de ovre Foleres Skaft; det femte er iklie fuldt saa langt som det fjerde Led. Svoben er langere end det sidste Led og dames af 8 Led, hvoraf det forste er det liengste. Overlaben er meget stor, forlænget og indskaaret i sin Ende.

Kindbakkerne ere forlængede, smale, ilspidsede mod Enden, som er indskaaret med svage. 'Tænder; de have en tynd indre Gren med tre Tænder. Palpens andet Led er længere end det tredie, der paa den ovre liand er forsynet med nogle tildels fjardannede stærke Børster.

Det frrste Kjabepars ylre Plade er forlinget, mod Enden tilspidset og væbnet med stærke, med Bitænder forsynede Tænder, der staa i tvende Rader langs den indre Rand. Palpen naar nosten frem til Enden af den ydre Plade; dens forste Led er kun noget kortere end det andet, der i Spidsen er vabnet med nogle borster.

Underlæb en or dybt spaltet. Fligene ere forlængede og paa den indre land og i Spidsen forsynede med Borster; af de indre Plader fundes der kun Spor.

Det andet Kjabepars indre Plade har paa den indre Rand mange fjardannede Børster; den ydre er forlinget, i Enden skraat afskaaret og der besat med fjærdannede Børster. 
Kjabefodderne ere stærke; den indre Plade er forlænget, smal, med nogle lange, fjordaunede Børster i Enden; den ydre er stor, bred og paa den indre Side langs den ovre Rand væbnet med krumme, stærke Torne. Palpens forste Led er forlænget; det andet Leds indre Rand forlænger sig i Spidsen til en afrundet Lap, der er forsynet med Børster; det tredie er kort, med Børster i Spidsen.

Det forste Fodpar er forlanget, smalt; det fjerde Led er noget kortere og meget smalere end det forste; det femte er af samme Lingde som det fjerde, men er end smalere og aftager i Tykkelse udad. Kloen er ret, indskaaret paa den bagre Rand til 6 hrumme Tænder og har paa den nedre Side en meget bred fjrerdannet Børste.

Det andet Fodpar er stærkere, men kortere; det fjerde Led er noget længere end det femte; begge have paa den bagre Rand Torncknipper. Kloen er kort, i den bagre Rand besat med fine Torne.

De tveude folgende Fodpar ere af indbyrdes samme Bygning; deres tredie Led er meget kort og lidet udvidet; det følgende Led er næsten lige saa langt og det femite meget længere. Kloen er strerk.

De tre sidste Fodpar tiltage efterhaanden kun lidt i Langde. Det femte Pars forste Led er meget udvidet bagtil, saugtakket paa den bagre og nedre Rand, samt har en spids, ndtrukket, nedre bagre Vinkel; det fjerde Led er næsten lige saa langt som det noget udvidede tredie Led; det femte er nasten saa langt som disse tvende tilsammen; de folgende blive noget smalere.

Halens Spring fødder ere strerkt forsynede med Torne baade pan deres Grunddel og paa Grenene, hroraf den ydre paa dem alie er noget kortere end den indre.

Halevedhænget er meget stivt, bredt, wgformigt og noget indskaaret paa den bagre Rant.

Den findes ved Grønland, Island, Spitsbergen. Ved Tromsø og Vadsø er den fundet paa 30-50 Favnes Dybde af Danielssen og M. Sars, ved Brettesnæs og ved Reine i Lofoten er den fundet af G. O. Sars. Ved Haugesund har jeg fundet den meget sjelden, og Lovén har taget den ved Bohuslän.

\section{ACANTHONOTOZOMA INFLATUM, Krøyer, 1842.}

Acanthonotus inflatus, Kroyer, Nat. Tidsskr. 1. B. IV. 1842. p. 161.

Vertumnus inflatus, Goës, Crust. Amphip. maris Spetsb. 1865. p. 7. fig. 11.

A. Boeck, Crust. amphip. bor. et aret. 1870, p. 100.

Dorsum carinatum. Carina ex medio segmento trunci 6 to oriunda, in segmentis postabdominis tribus anterioribus altissima, in margine postico dentes non formans. Segmenta postabdominis duo anteriora in extremo margine postico serrata. Segmentum postabdominis 3tinm in margine postico parum insinuatum; in margine posteriore et inferiore serratum. Pedes trium parium ultimornm articulo 1 mo lato, 
rotundato, postice serrato. Appendix caudalis parum magis elongata qvam apud species præcedentes.

Dyrets Længde er, naar det er udstrakt, $6 \frac{1}{2} \mathrm{~mm}$.

Legemet er meget tykt, ligesom opblæst, med rund Ryg. Sideplademe ere meget smale og høie; de fire første tiltage meget i Længde og noget i Bredde, især det fjerde, som nedad er næsten tre Gange saa bredt som det tredie og bagtil dybt indskaaret for det femte, hvis bagre Lap gaar temmelig dybt ned i en Spids. Den nedre bagre Vinkel paa de tvende forste Haleled er afrundet, og den bagre Rand paa store Exemplarer er tildels saugtakket. Den hagre Rand paa dot tredie Haleled har tvende dybe Indbugtninger. hvorved der dannes to bagudrettede Torne, og Indbugtningerne mellem disse ere saugtakkede ligesom Leddets nedre Rand. Hovedet er kortere end det første Legemsled og gaar fortil frem i et meget langt, triangulært, mod Enden tilspidset Pandehorn. Hovedets forreste Rand er dybt indbugtet, hvor de øvre Folere frste sig, men springer frem i en fortil afrundet Lap nedenfor disse, hvor de ovale Øine have sin Plads.

De $g \mathrm{vr}$ e Folere ere korte, neppe langere end Hoverlet og de tre til fire første Legemsled tilsammen. Skaftets forste Led rager kun ubetydeligt længere frem end Pandehornets Spids; de tvende folgende Led aftage efterhaanden baade i Længde og Tykkelse. Svgben, der dannes af 10 Led, er omtrent saa lang som Skaftet.

De nedre Foleres Lugtekmude er temmelig lang; det tredie Led er omtrent saa laugt som tykt; det fjerde og femte ere lige lange, og Svoben, der dannes af 10 Led, er omtrent saa lang som Skaftets tvende sidste Led tilsammen. Overlæben er meget stor, spaltet i Spidsen.

Kindbakkerne ere forlængede, med Bigrene paa begge Sider. Palpen er fastet dybt nede paa Kindbakkeme; dens tredie Led, der er kortere end det andet, har paa den concave Rand 10 brede, noget saugtakkede Torne og nogle Børster. Underlæben er meget forlænget, smal, uden Spor af indre Plade.

Det forste Kjæbepar er forlrenget; Palpens første Led er mere end halvt saa langt som det andet, der i Spidsen er vabnet med 5.Torne. Den indre Plade er stor og forsynet med 12 stærke, fjærdamnede Børster.

Kjæbefoudernes indre Plade er i Spidsen forsynet med nogle korte, men stærke, fjærdannede Børster og med tre lignende, men længere og lirumme; den ydre, der nar frem til over Halvilelen af Palpens andet Led, er vabnet med sex forlangerle knivdannede 'Tænder samt med svage Børster. Palpens forste Led er af samme Længde, men bredere end det andet, der er tykkere end det tredie og ikke udvidet indaul. Kloen er kort.

Det forste Fodpar er kort og temmelig svagt; det første Led, der er krummet, er næsten saa langt som de følgende tilsammen. Haanden er smal, kortere end Carpus, og Kloen indtager hele dens nedre Rand. 
Det andet Fodpar er forlanget og aftager efterhaanden mod Enden i Tykkelse; det fjerle Led er kortere eud det femte, der er linixrt, smalt; Kloen, der er 'ret, har paa den bagre Rand fem korte, krumme Tænder foruden en med Borster besat Lap.

De tvende følgende Fodpars tredie Led er meget kort, kun lidet udvidet.

De tre bagre Fodpars forste Led er bagtil udvidet og nedad afrundet, ikke udtrukket i nogen Spids, men fint saugtakket. Fodderne tiltage kun lidt i Langde.

Det sidste Par Springfodder naar langt bagud; den indre Gren er noget længere og tykkere end den yire, som er længere end Grunddelen.

Halevedhrnget er i Spidsen tilrundet og noget indskaret.

Denne-Art er fundet ved Grønland og Spitsbergen paa 5-30 Fames Dybde.

Gen. II. IPHLLELA, Rathke, 1843.

Deriv.: Iphimedia (et mythologisk Navn, Neptuns Elskede.)

Syn.: 1843. Iphimedia, Rathke, Beitr. Fauna der Norwegens Acta Leopold. Tom. XX. p. 85.

1846. Mierocheles, Kroyer, Naturh. Tidsskr. 2. R. 2. B. p. 66.

1853. Ip himedia, (pars) Dana, U. States Explor. Exped. Crust. p. 926.

1859. - Bruzelius, Bidrag till Kän. om Skand. Amphip. Gam. Kgl. Vetensk.-

Akad.'s Handlingar. Ny följd. B. 3. p. 80.

1860. - A. Boeck, Forhandl. ved de Skand. Naturf.'s Sde Mode 1860. p. 654 .

1862. - Spence Bate, Catal. Crust. Amphip. Brit. Mus. 1862. p. 123.

1863. - Spence Bate and Westwood, Brit. sessile-eyed Crust. p. $21 \%$

1865. - Lilljeborg, On the Lysianassa Magellanica etc. p. 18. (Tabel).

1866. - Grube, Beschreib, einiger Amphip. der Istr. Fauna. Archiv f. Naturgesch. 1866. p. 202.

1570. - A. Boeck, Crust. amphip. bor. et arct. p. 101.

Typ.: Iphimedin obesa, Ratlse.

Labium superius haud valde elongatum, latum, in apice insinuatum.

Mandibulæ paulo breviores et latiores qvam apud genus Vertumnus.

Maxilla Imi paris palpo 2articulato; articulo 1 mo brevi; lamina interiore minore qvam apud genus præcedens.

Pedes maxillares articulo palpi nltimo absenti.

Pedes Imi et 2di paris graciles, sed inanu perangusta, cheliformi instructi.

Corpus crassum, attamen altum; epimeris magnis, rigidis.

Rathke opstillede denne Slogt i 1843, og lan fandt, at den matte staa Lercothoe tenmelig nær, fordi det forste Fodpars Haand er saxdamet. Krøyer opstillede den typiske Art. I. obesa under Navn af Microcheles armata, men Lilljeborg paaviste i 1852 , at de begge, baalle som slagt og Art, maatte falde sammen. Dana vilde i 1853 
mlelade af Rathke's. Slagtskarakter det, som er fielles for alle Amphipoiler, men urlelod desuden i Beskrivelsen den karakteristiske Haand paa det forste Fodpar. Han anfører saaledes kun: "styli caudales postici biramei, ramis oblongis, consimilibus, apice setigris et non uncinatis". Derved fik Slaxten en ganske anden Karakter end den, som Rathke havde givet, og blandt de Arter, han stiller under Slagten Iphimedia, findes der lim en, som hører til Rathke's Slægt, nemlig I. norlosa. I 1860 gav jeg en ny Slægtskarakter $0 \mathrm{~g}$ viste, at den maatte staa nær Acanthonotus. Spence Bate tilfoier en ny Art, I. Elance, $0 \mathrm{~g}$ Grube i $1864 \mathrm{en,} \mathrm{som} \mathrm{han} \mathrm{kalder} \mathrm{I.} \mathrm{multispina,} \mathrm{der} \mathrm{maske} \mathrm{falder} \mathrm{sammen}$ med Spence Bate's Art. I sin Karakter for Slagten siger Grube: "pedes maxillares haud ungviculati", hvilket i saa Henseende ikke er ganske rigtigt, da det sidste kloformede Led fuldstandig mangler. Heller beslkriver i 1868 en ny Art, $I$. carinata, saa at Slogten indeholder mindst fire Arter.

Kindbakkerne ere hos deme Slægt meget kortere og bredere end hos Slægten Vertumus, men dog karakteritiskt af den samme Form. Det forste Kjæbepars indre Plade er ogsaa meget mindre end hos hin, og Kjæbeføddernes Palpe mangler det sidste Led. Ved den saxdannede Haand paa det forste Fodpar skiller den sig ogsaa fra de wvrige Slægter:

\section{IPHIMEDIA OBESA, Rathke, 1843.}

In himedia obesa, Rathke, Acta Acad. Leopold. t. XX. 1843. t. XX. p. S5. pl. 1. f. 1.

- - Spence Bate, Ann. and Magaz. Nat. Hist. 2. ser. XIX. 185\%. p. 141.

- - White, Pop. Hist. Brit. Crust. p. 176. pl. X. f. 6.

- - Bruzelius, Bidrag till Kän. om Skand. Amphip. Gammar. 1859. p. 80.

- - Spence Bate, Catal. Brit. Amphip. Crust. 1862. p. 123. pl. XXII. f. 2.

- - Spence Bate and Westwood, Brit. sessile-eyed Crust. 1863. p. 219.

- - A. Boeck, Crust. amphip. bor. et arct. 1870. p. 101.

Microcheles armata, Kroyer, Nat. Tidsskr. 2. R. 2. B. 1846. p. 66.

Krøyer, Voyages in Scandinavie etc. pI. II. fig. 6.

Rostrum frontale elongatum, depressum, acutum. Oculi magni, fere reniformes. Margo posterior segmenti $\mathrm{mi}$ trunci et trium anteriorum postabdominis postice in medio dentibus binis armatus. Angulus inferior posticus segmenti postabdominis 3 tii dentibus duobus armatus; dente inferiore in margine inferiore serrato. Antennæ superiores arliculo pedunculi 1 mo in extremo margine inferiore in spinam producto; articulis duobus seqventibus perbrevibus, non dentibus armatis. Pedes 5 ti et 6ti paris articulo lmo fere reclangulari, sed in margine anteriore el posteriore curvato; angulo inferiore postico rotundato. Pedes $7 \mathrm{mi}$ paris articulo 1 mo in angulo inferiore posteriore in dentem producto. 
Dyret er $\gamma \rightarrow 8^{\mathrm{mm}}$ laugt.

Legemet er meget tykt og høit. Ryggen rund, uden Kjøl. Hovedets forreste Rand udsender et stort, nedadkrummet Pandehorn mellem de øvre Følere, der næsten naar til Enden af deres andet Skaftled. Øinene ere store, noget nyredannede, men deres forreste Rand er uæsten ret. Det syvende Legemsled og Halens tre første Led ere væbnede paa den bagre Rands Midte med tvende stærke Tænder, der ere noget længere paa de bagre Led. Den nedre bagre Vinkel paa det tredie Haleled er vabnet med tvende Tænder. Sidepladerne ere meget høie; de tre forste ere paa Enden tilspidsede, noget bøiede; den fjerde er bagtil meget bredere og indskaaret $\mathrm{i}$ den bagre Rand for den femte, der er temmelig stor. Folerne ere ikke meget forlængede, lige lange og naa omtrent til det sjette Legemsled.

De vre Føleres forste Skaftled er omtrent dobbelt saa langt som de trende folgente tilsammen og har paa Enden af den nedre Rand en Torn, som nasten naar til Enden af det andet Led. Svoben er omtrent dobbelt saa lang som Skaftet og damnes af 20-22 Led, der ere forsynede med Børster.

De nedre Foleres femte Skaftled er længere end det fjerde; Sroben dannes af $18-20$ Led.

Overlaben er i Spidsen indbugtet.

Kindbakkerne ere meget forlangede, i Spidsen lidt boiede og ikke væbnede med T'ænder; den indre Biflig, som er kraftig udviklet, er derimod indskaaret i Trnder: Tyggeknuden er liden, næsten rudimentær; Palpen ex forlænget, stærk; dens tredie Led er kortere end det andet, boiet og forsynet med Børster mod Spidsen.

Underlabens Flige ere paa Enden tilspidsede og have Borster; de indre Flige ere meget tydelige nær Enden af den indre Rand.

Det forste Kjabepar er bredt, par Enden tilspidset, og den indre land er væbnet med stærke, saugtakkede Torne. Den indre Plade er forlænget, oval, og dens indre Rand har mange $-8-10$ - fjærdannede Borster.

Det andet Kjæbepars Plader ere korte og ikke meget brede, i Spidsen vab- . nede med fjærdamede Borster.

Kjæbefødderne ere stærke; den ydre P'lade er stor og nar til Enden af Palpens andet Led; $i$ den indre Rand er den forsynet med tynde Torne og Bøster; den indre Plade er meget forlanget, smal; Palpens forste Led er sardeles forlænget, saa langt som de tvende folgende Led tilsammen; det andet Led bliver bredere nedad, er noget udtrukiet samt tilrundet i Enden; det tredie er meget smalere, og af det fjerde Led er der kun et svagt Spor.

Det forste Fodpar er forlenget, smalt; dets forste Led er noget krummet og kortere end de folgende Led tilsammen; det andet er lidt lengere end det tredie og noget kortere end det fjerde; det femte Led, eller Haanden, er omtrent saa langt som det foregaaende Led, paa Enden tilspidset til en Finger, der saxfornig moder Ḱloen.

Det andet Fodpar er noget langere og lidt tykkere end det forste og nasten 
af den samme Form, men det for'ste Led er kortere, og Haanden er stærkere samt bredere mod Enden.

De tvende folgende Fodpar ere kortere og starkere; deres tredie Led er meget kort, lidet udvidet og kun lidt langere end det fjerde, som er meget kortere end det femte; Kloen er stærk, krum.

Det femte og sjette Folpars første Led er bredt, langstrakt, firkantet, med afrundede Hjørner, medens det samme Led par det syvende Fodpar er udtrukket i den nedre bagre Vinkel til en stærk Torn og er concav og saugtakket i den indre Rand; deres tredie Led er langere end det fjerde.

Det forste Par Springfodder naar ligesaa langt bagud som det sidste Par; dets Grene ere saa lange som Grundleddet, lige lange, besatte med Torne og tilspidsede mod Enden.

Det audet Pars ydre Gren er kortere end den indre.

Det tredie Pars ydre Gren er kortere end den indre og neget lwngere end Grundledilet.

Halevedhænget er langt, smalt og vinkelformig indskaaret i den bagre Rand.

Legemet har efter Rathke en hvid Grundfarve med et svagt straagult Anstrog. Paa den ovre Side sees Tværband, bestanende af sorte Punkter, og derimellem liggende okergule eller rodgule, smale striber. Efter Kroyer har den vexelvise smale Striber af rodbrum og gul Farve. Oinene ere purpurfarvede. Exemplarer, som jeg tog vel Haugesund, havde en hvid Grundfarve; Folerne vare rodbrunt spraglede. Hovedet var rodbrunt langs Rygsiden og paa alle lande, men ogsaa de purpurrøde Øine omgaves af et lividt Felt. Legemets fire forste Led vare paa Midten tegnede med et rodbrunt Baand, der var indfattet af Gult; de tre følgende samt Halens fire første Led vare prydede med to saadanne Baand, der stode liengere fra hinanden, jo bredere Leddene vare. Mellemrummet mellem disse Baand havde en guldgul Farve, lignende Baand strakte sig langs hver af de fire forste Sideplader, og paa de tre bagre Fodpars forste Led saaes tvende saalanme. Paa Siderne antoge de brune Baand en rosenrød Farve. Ryggen havde hos enkelte Exemplarer et stærkere gult Anstrøg end hos andre. Nordligst er den taget af R. Collett i Folden-Fjord. Ved Christiansund og Molde er den fanget af liathke og Danielssen, af G. O. Sars ved Aalesund paa 50-100 Favmes Lybde, ved Haugesund fundt jeg den overmilule almindelig pai enkelte steder. Efter Bruzelius findes den ogsaa ved Bohuslïn og i Kattegattet efter Kroyer. Baade ved Shetland $0 \mathrm{~g}$ ved Englands Kyster findes den paa flere Steder og gaar efter Heller lige ned til Adriaterhavet.

Gen. III. ODIUS, Lilljeborg, 1865.

Deriv.: Forandring af Otus.

Syn.: 1862. Otus, Spence Bate; Catal. Amphip. Brit. Mus. 1862. p. 128.

(Navnet er brugt til en Fugl). 
1863. Otus, Spence Bate and Westwood, Brit. sessile-eyed Crust. I. p. 223.

1865. Odius, Lilljeborg, On the Lysianassa Magellanica etc. p. 19.

1870. - A. Boeck, Crust. amphip. bor. et aret. 1870. p. 10\%

Typ.: Otus carinatus, Spence Bate.

Labium superius et mandibulæ sat elongata.

Maxilla Imi paris palpo uniarticulato, gracili; lamina interiore minima. angusla. in apice parum setosa.

Pedes maxillares palpis gracilibus; articulo ultimo perparvo.

Corpus peraltum, compressum et carinatum.

Pedes Imi paris manu robustissima, subcheliformi.

Pedes 2di paris prælongati; manu parva, angusta et cheliformi.

Spence Bate opstillede i 1862 Slægten Otus, som han henregnede til Underfamilien Phoxides. De væsentlige Karakterer for den vare, at det første Fodpars Haand var saxdannet, $0 \mathrm{~g}$ at det andet Pars Haand var meget stark $0 \mathrm{~g}$ af den sædvanlige Form. Den indholdt een Art, Otus carinatus. Han skiller den fra den nærstaaende Slægt Iplimedia paa Grund af Kjæbeføddernes og de tvende forste Fodpars Form. Lilljeborg forandrede Slægtens Navn til Odius, da Otus allerede var benyttet, og hau adskilte den fra Ipkimedia, fordi Kjæbefoddernes Palpe hos den forste er treleddet, hos den anden firleddet. Han stillede begge i Underfamilien Atylince. I 1870 forandrede jeg Slrgtskarakteren og fremhævede foruden Kjæbefoddernes ogsaa det forste Kjæbepars eiendommelige Bygning ved, at Palpen er særdeles kort, enleddet, og ved, at Kindbakkerne samt Overlaben ere stærkt forlængede.

ODIUS CARINATUS, Spence Bate, 1862.

(PI. XIX. Fig. 5.)

Otus carinatus, Spence Bate, Catal. of Amphip. in Brit. Mus. 1862. p. 126. pl. XXIII. f. 2. Spence Bate and Westwood, Brit. sessile-eyed Crust. p. 224.

Odins carinatus, A. Boeck, Crust. amphip. bor, et arct. 1870. p. 102.

Dorsum valde carinatum. Carina edentata. Segnentum postabdominis 3tium in medio gibbere obtuso instructum; in margine laterali posteriore dente, sursum producto et acuto, armatum. Pedes $1 \mathrm{mi}$ paris manu magna, apicem versus latiore. in acie truncata el serrata. Pedes 2di paris manu angusta, multo breviore qvam carpo. Pedes trium parium ultimorum articulo 1 mo in margine posteriore obtuso. angulato, in angulo inferiore postico paulum producto et rotundato; articulo 3lio in angulo inferiore postico valde producto et acuto. Appendix caudalis in margine posteriore acula. 
Dyrets L $\mathrm{L}$ g g de er $7 \mathrm{~mm}$.

Legemet er høit, sammentrykket og forsynet med en Kjøl, der strækker sig fra Panden til det bagerste Legemsled, hvor den dog bliver svag. Hovedet ender fortil $\mathrm{i}$ et stort sammentrykket Pandehorm, der adskiller de øvre Følere. Hovedet er kort, stærkt indskaaret, hvor de øvre Følere faste sig. Øiet er ovalt. De fire første Sideplader ere smale og høie samt tiltage i Bredde fra den forste til den fjerde, som i den bagre Rands øvre Del har en stor Indbugtning for den femte og nedad ender i en spids Vinkel; den femte Sideplade er mindre, fortil tilrundet og nedad forsynet med et Indsnit for den fjerde Sideplades Vinkel. De tvende folgende aftage i Størrelse. Det andet Haleleds bagre Rand er nedad indskaaret, og det følgende danner paa Rygsiden en spids Pukkel, medens dets nedre bagre Hjørne gaar opad ud i en liden Torn. Følerne ere lige lange; de ere meget korte og naa neppe til Legemets tredie Led.

De $₫$ vre Foleres forste Led er stærkt; de tvende folgende aftage saavel i Længde som i Tykkelse. Svaben dannes af 6 Led, der efterhaanden aftage i L og Tykkelse, saa at de tvende sidste ere neppe synlige; de fire første Led ere $\mathrm{i}$ deres indre Rand forsynede med lange Knipper af Børster.

De nedre Føleres tvende første Led ere korte; det tredie neppe langere end det fjerde, der er noget længere og tykkere end det femte. Svøben er særdeles kort, kortere end Skaftets sidste Led. Dets forste Led er længere end de tre følgende tilsammen.

Kindbakkerne gaa ud i en Spids og ere paa den indre Side forsynede med en Række fine Tænder. Tyggeknuden er liden. Palpen er smal, forlænget, treleddet; dens andet Led er det langste; let tredie er bøiet og har paa sin ovre Rand fine Børster.

Det første Kjæbepars ydre Plade har i Spidsen længere Børster, og langs den hele indre Rand findes Torne og fine Børster; den indre Plade er liden, smal, med tvende Børster i Spidsen. Palpen er meget liden, enleddet.

Det andet $\mathrm{Kj}$ xbe par er meget forlænget.

Kjæbefoddernes indre Plade er meget forlæuget, smalt, væbnet med Børster; den ydre er bred, oval; den indre Rand er ret; den ydre er meget udbuget, uden Torne eller Børster. Palpen naar ikke langt foran den ydre Plade og er ikke meget bred; de tvende første Led tiltage efterhaanden i Langde, saa at det første ikke er længere end bredt, medens det andet er længere end bredt; det fjerde Led danner en lille Klo.

Det første Fodpar er stærkt; det tredie Led er triangulært, og dets nedre bagre Vinkel forlænger sig til et smalt Fremspring. Haanden er stor, triangulær, Griberanden er ret afskaaret og forsynet med smaa Torne.

Det andet Fodpar er forlænget, tyndt; det første Led er det længste og tykkeste; det fjerde er ikke fuldt saa langt og meget tyndere. Haanden er forlænget 
og krummet; dens nédre bagre Vinkel forlanger sig til en Tommel, der møder Kloen og er i Spidsen forsynet med Børster.

De tvende følgende Fodpar ere af indbyrdes samme Form; det første Led er kort, bredere nedad og med forlænget nedre bagre Vinkel; paa det tredie Led er derimod den nedre forreste Vinkel meget udtrukken; det fjerle Led er kort, og det femte er næsten saa langt som de tvende foregaaende Led tilsammen.

De tre bagre Fodpar have omtrent den samme Langde; deres forste Led er bredt, bagtil ligesom dobbelt indskaaret, saa at der dannes tre Flige paa den bagre Rand, der adskilles af en øvre og en nedre Indbugtning; det andet Led er fæstet $\mathrm{i}$ en dyb Indskjæring i den nedre Rand; det tredie Leds bagre nedre Vinkel er meget forlænget, saa at den naar længere ned end det folgende Led; det femte Led er langt og stærkt samt paa den forreste Rand forsynet med .Torne. Kløerne ere stærke.

Svommefodderne ere lange og tynde; Grenenes forste Led er usædvanlig forlænget.

Det forste Par Springfødder er det langste; dets Grene ere næsten lige lange.

Det andet Par er meget kortere; lets indre Gren er lidt kortere end den' ydre.

Det tredie Pars indre Gren er omtrent dobbelt saa lang som den ydre. Alle Grene have Torne paa den øvre ydre Rand samt paa Enden.

Halevedhænget er helt og i Enden tilspidset.

Farven er efter et Exemplar, som jeg har taget ved Haugesund, aldeles hvid, med gulagtige Indvolde og rode Øine.

Efter Goës findes den ved Spitsbergen lige op til $80^{\circ} \mathrm{n}$. Br. paa 20 Favnes Dybde; af Torell er den taget i Dawis Strait, af R. Collett er en Unge fundet ved Nordkap, af $G$. O. Sars er et Exemplar taget ved Haugesund og af mig et sammesteds. Ved Shetland er den fundet af Barlee og af Norman.

Gen. IV. LAPHYSTIUS, Kroyer, 184\%.

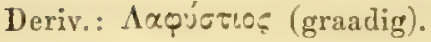

Syn.: 1842. Laphystius, Krøyer, Nat. Hist. Tidsskr. 1. R. B. IV. 1842. p. 156.

1855. - Lilljeborg, Öfvers. af Kgl. Vetensk.-Akad.'s Förhandl. 1855. p. 132.

1855. Darwinia, Spence Bate, Brit. Assoc. Rep. 1855. p. 58.

1857. - Spence Bate, Ann. Nat. Hist. 2. ser. XIX. 1857. p. 171.

1859. Laphystius, Bruzelius, Bidrag till Känn. om Skand. Amphip. Gam. Kgl. Vetensk.-Akad.'s Handlingar. Ny följd. B. 3. p. 98.

1862. Darwinia, Spence Bate, Catal. Amphip. Crust. Brit. Mus. 1862. p. 108.

1863. - Spence Bate and Westwood, Brit. sessile-eyed Crust. I. 1863. p. 182. 
1865. Laphystius, Lilljeborg, On the Lysianassa Magellanica etc. 1865. p. 18. (Tabel.)

1870. - A. Boeck, Crust. amphip. bor. et arct. 102.

Maxillæ $1 \mathrm{mi}$ paris palpo nodiformi; lamina interiore parva.

Pedes maxillares palpo 2arliculato.

Corpus suhdepressum, latum.

Antennx superiores inferioribus longiores.

Pedes Imi paris graciles, manu subcheliformi destituti.

Pedes 2di paris manu parva; ungve lato, laminiformi.

Pedes 3 tii et 4 ti paris robustissimi; articulo 2 do, 3tio et 4 to brevissimis; ungve pervalido, curvo.

Krøyer opstillede denne Slægt i 1842. Han skiller den fra de øvrige Slægter, foruden ved Legemets nedtrykte og ved Følernes korte og stærke Form, ved det tynde forste og det stærke andet Fodpar, hvis Haand er forsynet med en bred Klo, tillige ved de folgende Fodpars starke Bygning og ved Munddelenes eiendommelige Form. Denne slæagt blev af Spence Bate kaldet Durrinir, da han troede, at den afviger fra Krøyers Slagt Laphystius ved, at Kloen ikke er pladeformig og forsynet med Borster paa Enden. Dette er dog ikke ganske rigtigt; thi sees Kloen fra Siden, er den tynd og smal, men sees den forfra, er den bred. Han har desuden ikke undersøgt Munddelene, som fremhyde de karakteristiske Kjendemerker. Han finder ogsaa, at den nærmer sig Oxycephalus blandt Hyperiderne, ved at det tredie Haleled ikke er saa bredt som det foregaaende. Den henføres af ham til'Underfamilien Phoxides, medens den af Lilljeborg 1865 henfores til Atyline. Denne sidste fremhæver ogsaa, at Hannen er meget mindre end Hunnen, og at det andet Fodpars Haand er hos Hannen tykkere og kortere end hos Hunnen. Ved hele sin Form afviger denne Slægt meget fra de foregaaende, da Legemet er overensstemmende med dens parasitiske Levemade. Det er her nedtrykket, medens det hos de foregaaende Slægter er sammentrykket. Sidepladerne ere ogsaa meget mindre end hos de foregaaende, hos hvilke de ere meget store. Paa Grund af denne Legemets nedtrykte Form er Hovedet bredt, og Oinene komme derved til at ligge paa den ovre Side af Hovedet. Pandehornet faar ogsaa en usædvanlig bred Form, medens det hos de foregaaende Slægter er sammentrykket. Følerne ere korte; de grres Grundled bliver ualmindeligmeget fortykket i Forhold til de nedres, ligesom de ere længere end disse. Det forste Fodpar er meget tyndt, og dets femte Led ikke uddannet til en Gribehaand. Paa det andet Fodpar, som er noget tykkere, er derimod det femte Led uddannet til en Gribehaand, og dets Klo er bred. De tvende folgende Fodpar ere ganske eiendommeligt byggede og udviklede til, at Dyret dermed kan fastholde sig paa den Vært, hvorpaa den lever; de forreste Led ere meget korte, brede, stærke, medens det femte er forlænget, krummet, og paa dets Ende er fæstet den særdeles store, krumme, paa Enden spidse Klo. Munddelene frembyde ogsaa flere Eiendommeligheder. Kindbakkerne ere saaledes meget 32 * 
forlnngede, i spidsen delte i faa Trender; den indre Bigren er tyltelig, men liden; Palpen er lang, med et forlænget forste Led. Det forste Kjæbepars indre Plade er ikke meget bred $0 \mathrm{~g}$ har kun en enkelt Børste pá Spidsen; Palpen er rudimentær, knudeformet. Kjæbefødderne blive her mere reducerede end hos nogen af de øvrige Slægter; Palpen er nemlig kun toleddet. Af denne Slægt kjender man kun een Art, der lever parasitisk paa forskjellige Fiske.

LAPHYS'TIUS STURIONIS, Krøyer, 1842.

(Pl. XIX. Fig. 6.)

Laphystius Sturionis, Kroyer, Naturhist. Tidsskr. 1. R. B. IV. 1842. p. $15 \%$

Lilljeborg, Öfvers. af Kgl. Vetensk.-Akad.'s Förhandl. 1855. p. 132. Bruzelius, Bidrag till Känu. om Skand. Amphip. Gammar. Kgl. Vetensk.-Akad.'s Handlingar. Ny füljd. B. 3. p. 98.

- $\quad$ Spence Bate, Catal. Amphip. Brit. Mus. 1862. p. 40.

- - A. Boeck, Crust. amphip. bor. et arct. 1870. p. 103.

Darwinia compressa, Spence Bate, Brit. Assoc. Report. 1855. p. 58.

\begin{tabular}{|c|c|c|}
\hline- & 一 & Spence Bate, Brit. Nat. Hist. 1. ser. XIX. 185\% p. 141. \\
\hline - & - & White, Popul. Hist. Brit. Crust. p. 176. \\
\hline & - & $\begin{array}{l}\text { Spence Bate, Catal. Amphip. Crust. Brit. MLus. p. 108. pl. XVII. } \\
\text { fig. } 7 .\end{array}$ \\
\hline & & ssile-eyed Crust. 1863. p. 184. \\
\hline
\end{tabular}

Caput in rostrum frontale latum, in apice rotundatum, productum. Oculi parvi, rotundi, in lobulis latis et rotundatis siti. Antenna superiores breves et crassa, vix ad segmentum trunci 4 tum porrectæ, attamen inferioribus longiores et crassiores. Pedes $1 \mathrm{mi}$ paris iisdem 2di paris minores; articulo 5 to angusto et longiore qvam carpo. Pedes 2di paris manu non duplo longiore qvam lata, paulum curvata, in angulo inferiore postico parum producta; ungve lato, in margine anteriore parum setoso. Pedes 3 tii et 4 ti paris articulo 5 to longitudinem articulorum trium præcedentium junctorum xqvanti; ungve percurvato. Pedes trium parium ultimorum articnlo 1 mo lato, postice rotundato. Appendix caudalis parva, ovata.

Dyrets Langde er $7-8^{\mathrm{mm}}$.

Legemet er kort, stærkt nedtrykket. Ryggen er afrundet, uden Kjøl eller Tagger. Hovedet er særleles bredt, plat og gaar fortil ud i et stort, bredt, i Enden afrundet Pandehorn. Hovedets Sidevinkler ere afrundede. Øinene smaa, runde; de sidde paa Hovedets Sidelapper.

De ovre Følere ere korte og tykke; deres forste Led er kun lidt længere end tykt; de trende følgende Led aftage meget i Tykkelse, men kun lidt i Længde. Svoben dannes af 7-9 Led og er omtrent saa lang eller noget kortere end Skaftet. 
De nedre Folere ere meget tyndere og kortere end de ovre; deres tredie Led er forlænget; det fjerde ur ubetydeligt liengere end det femte. Svoben dannes af 7 Led og er længere end Skaftets sidste Led. Overlæben er særdeles forlænget, afrundet.

Kindbakkerne ere stærkt forlængede, udtrukne; Griberanden er delt i fire til fem skarpe Tænder og den indre Bigren i tvende saadanne. Tyggeknuden er overmaade liden. Palpen er forlænget; dens tredie Led er lidt længere end det andet og forsynet i den øvre Rand med en Rakke længere og kortere Børster.

Det første Kjæbepars ydre Plade er i Spidsen væbnet med stærke krumme, fint saugtaggede Torne; den indre Plade er tilspidset i Enden og kun forsynet med en enkelt Børste. Palpen er overordentlig liden, enleddet, med nogle Børster i Spidsen.

Det andet $\mathrm{Kj}$ æbepars Plader ere meget lange og smale.

Kjæbefodderues indre Plader ere smale og meget korte samt naa neppe frem til Palpens første Led; de ydre Plader ere store, skraat afskaarne i Lnden af den indre Rand og her saugtaggede sant forsynede med nogle Borster. Palpen er meget kort og naar kun lidt frem foran de ydre Pladers Ender; den er kun toleddet, og dens andet Led er omtrent saa langt som det forste: det bliver meget smalt mod Enden og er forsynet med nogle Borster.

Det forste Fodpars Haand er smal, noget bøiet, længere end den triangulære Carpus. Kloen er kun svagt krummet, i Enden tilspidset.

Det andet Fodpar er storre end det forste. Carpus er meget kort. Haanden er langere, ikke fuldt dobbelt saa lang som bred, med en krummet forreste og bagerste Rand. Kloen er bred, bøiet, med korte, stærke Torne i Spidsen, og i den forreste Rand forsynet med nogle Børster.

Det tredie og fjerde Fodpar ere meget stærke og indbyrdes af samme Form og Størrelse; deres forste Led bliver nedad bredere; det tredie er lidt bredere end langt; det fjerde er kortere end det tredie, medens det femte er saa langt som de tre foregaaende Led tilsammen og noget krummet. Kloen er særdeles stærk, krummet og i Enden tilspidset.

De tre sidste Fodpar ere næsten af samme Størrelse; deres første Led er bredt og krummet i den bagerste Rand; det tredie Led er længere og bredere end det fjerde, som er kortere end det femite. Kløerne ere stærke.

Det sidste Par Springfødders Grene ere forlængede og smale; den ydre Gren er lidt kortere end den indre, der er noget længere end Grundleddet.

F arven er efter Krøyer hvid, efter andre brun.

Den er fundet ved Danmark, Bohuslen, ved det sydlige Norge og Englands Kyster, levende parasitisk paa forskjellige Fiske, som Stør, Haier og Torsk. 
Subfamilia VI.

OEDICER INAE, Lilljeborg, 1865.

Syn.: 1865. Oedicerin ${ }^{2}$, Lilljeborg, On the Lysianassa Magellanica.

1870. - A. Boeck, Crust. amphip. bor. et aret. p. 80 .

Labium superius in apice insinuatum.

Mandibula robustissime, in apice late, plus minusve dentate; processu accessorio item plus minusve dentato; serie spinarum spinis simplicibus sed robustis instructa; tuherculo molari non permagno; palpo longo, 3articulato.

Labium inferius latum; lamina interiore magna.

Maxilla $1 \mathrm{mi}$ paris lamina interiore sat magna, in apice duabus setis, partim plumosis, instructa; palpo 2articulato, in apice spinas angustas gerenti.

Haxilla 2di paris laninis perbrevibus et latis, interiore latiore qvam exteriore.

Pedes maxillares lamina interinre parva: eadem exteriore partim longiore partim breviore. nunqvam permagna. in margine interiore spinis validis, apicem versus crescentibus, armata; palpo lato et robusto: articulo palpi ultimo valido, ungviformi.

Corpus parum compressum. Dorsum rolundum, raro carinatum et dentibus armatum. Epimera magnitudinis mediocris, in margine inferiore setosa. Epimerum 1 mum apicem versus dilatatum. Caput in fronte plerumqve in rostrum latum. in quo oculi siti, productum. Rostrum raro nullum et oculi in latere capitis siti.

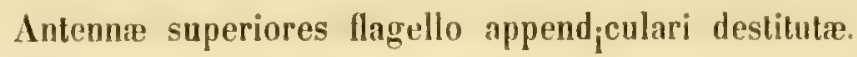

Pedes $1 \mathrm{mi}$ et 2di paris manu plus minusve valida, aut subcheliformi aut cheliformi; pedes 2di paris raro sine manu subcheliformi; carpo plerumqve in angulo inferiore postico paris utriusqve in calcem valde producto.

Pedes 5 ti et 6ti paris magnitudine et forma ferme aqvales.

Pedes $7 \mathrm{mi}$ paris pralongati, iisdem 5ti et 6ti paris sapissime duplo longiores.

Pedes saltatorii elongati, hiramei; iisdem ultimi paris ramis anguslis; pedunculo raro pralongato.

Appendix caudalis brevis, inlegra.

Denne Underfamilie er opstillet af Lilljeborg i $1865 \mathrm{og}$ er af ham givet folgende Karakterer: De øvre Følere mangle Bisvøbe. Øinene ere sammensatte. Det syvende Fodpar er meget længere end de tvende foregaaende Par; dets sidste Led er ret, styliformet. Til denne Underfamilie henregner han Slægten Oediceropsis, Ocdiceros, Monoculodes og Kröyeria. Jeg optog denne Underfamilie i 1870 og tilføiede nogle nye Slagter, blandt hvilke ved en Feiltagelse ogsaa Paramphithoë (Bruz.) kom ind. Spence Bate henførte Slægterne Oediceros, Monoculodes, Westwoodilla og Kröyeria til sin 
Underfamilie Phoxides paa Grund af, at Pandehornet hos nogle af disse er meget langt og dxkker Grunddelen af de øvre Folere. Men netop i denne Underfamilie kan man se, hvor lidet Værd dette Mærke har til derpaa at opstille nogen Underfamilie. Pandehornet er nemlig hos nogle overmaade forlænget, som hos enkelte Arter af Oediceros og Monoculodes, medens det hos andre bliver meget kort, som hos Arter af Slægten Halimedon; og endelig er det reduceret til en Ubetydelighed hos Aceros. Den vasentlige Grund til, at jeg i $18 \% 0$ optog og nu fremdeles beholder denne Underfamilie, er den karakteristiske Overensstemmelse i det Ydre mellem alle herhen horende slagter, idet det meget forlængede syvende Fodpar strax falder i Øinene hos dem alle, skjønt dette i mindre Grad er fremtræedende hos Slægterne Halicreion og Ocdiceropsis. De øvre Folere ere ogsaa hos næsten alle Slægter kortere end de nedre hos begge Kjøn, og dette er i Særdeleshed Tilfældet hos Oediceropsis; men heri afviger netop Hunnen hos Aceros, og hos Halicreion er der kun liden Forskjel mellem Følennes Længde. Legemet har i Almindelighed en rund liyg uden Kjol; men herfra gjør Slægten Acanthostepheia en Undtagelse derved, at Ryggen ikke alene har en Kjol, men denne gaar endog ud i Tænder og Tagger, hvorved den faar et fra de gvrige Slægter afvigende Udseende; den viser $d o g$, at den tilhører denne Underfamilie ved det lange syvende Fodpar. Jeg har allerede forhen omtalt, at Pandehornet hos de fleste Slægter er kraftigt udviklet, og at Øinene rykke op paa dette, ja endog hos enkelte Slægter og Arter rykker det lige ud paa dets Spids, som derfor er buet. Pandehornet maa saaledes mere betragtes som en Forlængelse af det egentlige Hoved end svarende til det egentlige Pandehorn, saaledes som det optræder hos andre Underfamilier. Hos Aceros mangler, som allerede anfort, denne Forlængelse, og hos denne Slægt have Øinene sin sædvanlige Plads. Halevedhenget er altid kort og udelt. Springfodderne ere i Almindelighed lange. Hos nogle sliegter forlenger det sidste Par Springfodder sig mere end sudvanlig, saaledes hos Halimedon Saussurei, dette er end mere Tilfældet hos Slægten Halicreion. I Munddelenes Bygning vise alle Slægter en meget stor Overensstemmelse. Kjæbefoddernes Palper ere altid forlængede, og Pladerne ere smaa; sjælden blive de sidstnævnte af middelmaadig Størrelse $0 \mathrm{~g}$ ere altid besatte med tynde Torne og ikke med Tænder paa den indre Rand. Kindbakkerne ere altid stierke, af den samme Bygning paa begge Sider; herved skille de sig vasentlig fra Underfamilien Leucothoine, som den forøvrigt ligner i flere Henseender. Overlaben er ogsaa i Spidsen afrundet og ikke spaltet som hos hin Underfamilie.

Til denne Underfamilie regner jeg otte Slægter, medens Lilljeborg kun opførte fire.

Gen. I. OEDICEROS, Krøyer, 1842.

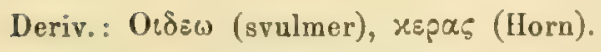

Syn.: 1842. Oediceros, Krøyer, Naturh. Tidsskr. 1. R. B. IV. 1842. p. 155.

1853. - Dana, U. States Explor. Exped. Crust. p. 933.

1850. - - Bruzelius, Bidrag till Känn. om Skand. Amphip. Gammar. Kgl. Vetensk.-Akad.'s Handlingar. Ny följd. B. 3. p. 92. 
1860. Oediceros, A. Boeck, Forhandl. ved de Skand. Naturf.'s 8de Møde. 1860. p. 656.

1862. - Spence Bate, Catal. Amphip. Brit. Mus. p. 103.

1863. - Spence Bate and Westwood, Brit. sessile-eyed Crust. 1863. p. 160.

1865. - Lilljeborg, On the Lysianassa Magellanica etc. p. 18. (Tabel.)

1870. - A. Boeck, Crust. amphip. hor. et arct. p. 81.

Typ.: Oediceros saginatus, Krøyer.

Pedes maxillares lamina exteriore ultra dimidium articulum palpi 2dum porrecta.

Caput antice in rostrum latum, crassum, apicem versus angustius, productum. Oculi in rostro, nunc prope basin nunc in apice, siti.

Antenna superiores iisdem inferioribus breviores, sed pedunculo inferiorum longiores.

Pedes $1 \mathrm{mi}$ et 2 di paris manu permagna subcheliformi instrucli; carpo sal

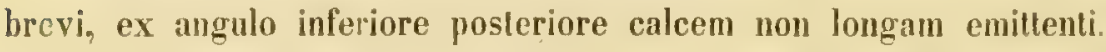

Pedes 5 ti et 6 ti paris magnitudine et forma intuse ferme æqvales.

Pedes 7 mi paris iisdem 5ti et 6ti paris fere duplo longiores.

Pedes saltatorii ultimi paris non ultra pedes saltatorios $1 \mathrm{mi}$ et 2 di paris porrecti.

Krøyer opstillede denne Slægt (Naturh. Tidsskr. B. IV. 1842, S. 155) paa Arten Oe. saginatus fra Grønland; denne er altsaa Slægtens typiske Art. Han fremhæver, at Panden er udtrukket i et større eller mindre, spidst eller stumpt Horn, der bestandig er forsynet med en gjennemsigtig, oval, rød eller gul Knude. Øinene kunde han ikke finde, ligesom ogsia Lilljeborg (Öfvers. af Vetensk.-Akad.'s Förhandl. 1852) fremhrver, at den mangler Øine. M. Sars har imidlertid vist, at denne Knude er Dyrets Øine.

Denne Slægt er af Dana i 1853 henfort til Underfamilien Gammarine. Han opforer herunder el ny Art Oe. Nove-Zealandic; men denne hører, som jeg paaviste i 1860 , ikke herhen, men til Slagten Aceros. I 1862 stillede Spence Bate denne Slagt til Underfamilien Phoxides, og da han dengang ikke kjendte nogen Art af samme, oversatte han Krgyers Slagtskarakter; han henfører hertil Oe. saginatus og Oe. Novce-Zealandix. I 186,3 tilfoie Spence Bate og Westwood en ny Art, Or. pumimamus, som imidlertid ikke synes at henhøre hertil, da baade det andet Fodpar er storre end det første og disse have ikke den karakteristiske Form, som er særegen for denne Slægt. I 1870 adskilte jeg denne Slægt fra de øvrige i denne Underfamilie. Munddelene stemme hos alle Slagter af Fami: en tenmelig overens, hvorfor det eneste Marke, der kunde hentes fra disse, er, at Kjabefoditernes ydre Plarle er temmelig liden hos demne Sliegt, sia at den ikke naar længere frem end til Midten af Palpens andet Led; de indre Plader ere derhos sardeles smaa. I det ydre frembyde de tvende første Fodpar et sardeles karakıeristiskt Mærke til at adskille den fra de ørrige Slægter. Haanden er nemlig sæerdeles stor, og Carpus er derimod forkortet, rlog i Almindelighed forsynet med en Hæl. De ovre Folere ere korte, dog længere end de nedre Føleres Skaft. Pandehornet er stort. Herved 
skilles den let fra de øvrige Slagter. Den forste Sideplade bliver bredere nedad og er derfor tillige bredere end den anden. Dette er ogsaa Tilfaldet med Here andre Slægter, men neppe i saa høi Grad som hos denne.

\section{OEDICEROS SAGINATUS, Krøyer, 1842.}

(PI. XIII. Fig. 3.)

Oediceros saginatus, Kroyer, Naturh. Tidsskr. 1. R. B. IV. 1842. p. 156.

- Bruzelius, Bidrag till Känu. om Skand. Amphip. Gammar. Vetensk,-
Akad.'s Handlingar. Ny följd. B. 3. p. 94.
- A. Boeck, Forhandl. ved de Skand. Naturf.'s 8de Møde. 1860.
p. 652.
- $\quad$ Spence Bate, Catal. Amphip. Brit. Mrus. 1862. p. 103.
- $\quad$ Goës, Crust. Amplip. maris Spetsb. 1865. p. 526. fig. 18.
-

Oculi ad basin rostri sili. Rostrum antice acutum et uspre ad finem articuli pedunculi Imi antennarum superiorum porrectum. Antenna inferiores articulo pedunculi 4 to multo breviore sed crassiore qvam articulo 5to. Pedes 1 mi et 2di paris forma reqvales; carpo minuto el ex angulo inferiore postico calcem non longam. sed setosam, emittenti; manu permagna, ovata. Pedes 3 tii et 4 ti paris ungve perlato, apicem versus motundato. Pedes 5 ti et 6ti paris articulo 4 to et 5to longitudine ferme acqualibus; ungve lato, lanceolato. Appendix caudalis ovato.

Dyrets L $\mathfrak{L}$ gde er $20^{\mathrm{mm}}$ fra Pandehornets Spids til Halevedhænget.

Legemet er temmelig tykt, opsvulmet, med rund Ryg. Halens fire første Led have en Kjøl langs Midten, der dog ikke bagud springer ud i Torne. Sidepladerne ere høiere end brede, dog ikke store, og forsynede med mange Borster paa den indre Rand; den forste er ikke meget storre end den anden, og meget bredere nedad end opad; den femte er kun lidt lavere, men meget bredere end den fjerle og i den indre Rand dybt indskaaret for det femte. Fodpar. De nedre bagre Hjorner af Halens Led ere meget tilrundede og besatte med Børster. Hovedet er temmelig stort, bredt bagtil, men bliver meget smalere fortil, hvor det danner et langt, strerkt, i Enden spidst Horn, der i en næsten ret Vinkel forbinder sig med Hovedet. Paa denne Vinkels Toppunkt ere Øinene beliggende tæt ved hinanden og kun adskilte ved en smal Rand; de danne tilsammien en Halvkugle. Hovedets Sidevinkler ere tilrundede.

De øvre Følere naa; naar de bøies bagud, omtrent til det tredie Legemsled. Skaftets første Led er det længste og tykkeste samt naar frem til Enden af Pandehornet; det andet Led er noget kortere og smalere, og det tredie er lidet. Svoben er omtrent saa lang som Skaftet og dannes af $16-20$ Lerl.

De nedre Folere ere meget langere end de gvre. De trende første Led ere 
meget korte og tykke; det andet udsender en kort Lugteknude; det tredie er omtrent lige saa langt som tykt; det fjerde er næsten dobbelt saa langt og bedreket med Borster paa den indre og ydre Side; det femte Led er en Trediedel længere og smalere. Svoben, der omtrent er saa lang som Skaftet, dannes af 50 Led. Overlaben er stor, nedad tilrundet og forsynet med Borster.

K indbakkerne ere stærke, i Spidsen delte; den ydre storre Gren har tre store og fem meget mindre Truder; den indre mindre Gren har fem saadanne, hvoraf den ene er meget stor. Tornerækken er uden Bitænder. Palpens andet og tredie Led ere omtrent lige lange.

Det forste Kjæbepar er væbnet paa Enden af den ydre Plade med 5-6 tynde, krumme Tæader, hvoraf kun de tre inderste have en enkelt Bitand paa den concave Rand. Palpens andet Led bliver smalere mod Spidsen og har der nogle børstelignende Torne. Den indre Plade er meget bred og forsynet med tvende fjærlannede Borster. Underlæben er meget bred; den ydre Flig er bred, -tilrundet i Enden og der forsynet merl fem Borster; den indre Flig mangler aldeles.

Det andet $\mathrm{K}$ jahepars Plader ere omtrent lige lange, men den indre er bredere end den ydre.

Kjabefoddernes indre Plade er kort, i spidsen forsynet med nogle borstelignende Tome; den ydre er kort, smal og paa den indre Rand væbnet med talrige borstelignende Torne. Palpen er meget forlænget; dens forste Led er meget kort, medens ilet andet er forlanget og paa den indre Rand forsynet med talrige stærke Borster; det tredie Led er neppe halvt saa langt som det andet, noget boiet, bliver bredere mod Spidsen. Kloen er noget langere end dette Led, krummet og spids.

De tvende forste Forlpar ere af indbyrdes samme Bygning, men det andet P'ar er storre end det forste; deres fjerde Led er meget kort, men udsender fra sit nedre bagre Hjorne et strerkt Hremspring; der er meget kortere end Halvdelen af Haanden og større paa det andet end paa det forste Par; Haanden er meget stor, oval, forlænget, næsten lige buet paa begge Rande og paa den indre forsynet med fine, i Enden krogdannede Børster, samt med en stærk Torn paa Enden, hvor den lange krumme Klo moder med sin Spids.

De tvende folgende F o dpar ere af indbyrdes lige Bygning; deres tredie Led udvider sig mod Enden og er i den bagre Rand sant i det forreste nedre Hjørne forsynet med lange Børster; det folgende Led er noget længere end bredt og ligeledes paa den bagre Rand besat med mange fjærdannede Børster; det femte Led er længere, men smalere end det foregaaende, krummet og har i den forreste Rand mange Bundter af lange Birster. Kloen er kortere end det foregaaende Led og meget bred, mod Enden afrundet. Det femte og sjette Fodpar have ligeledes indbyrdes samme Bygning; deres forste Led er ikke meget udvidet, ovalt, med fjærdamnede Børster paa begge Rande; de folgende Led ligne de tilsvarende paa de tvende foregaaende Par, men det tredie Led har mange fjærdannede Børster paa begge Rande. 
Det syvende $\mathrm{F}$ odpars første Led er meget udvidet, noget langere end bredt og smalere paa den nedre Ende, hvor det er tvært afskaaret og har fjærdannede Børster paa den bagre Rand; det tredie Led er ubetydeligt udvidet; det fjerde er noget længere end dette, men smalere, og de tvende folgende aftage efter hinanden noget i Længde og Tykkelse. Paa den forreste Rand ere alle forsynede med Knipper af korte Torne, og paa den bagre Rand have de stærke Børster.

De tre Par Springfoddèr naa alle omtrent lige langt bagud. Hvert Pars Grene ere lige lange og have paa den ydre Rand enkelte Torne.

Det sidste Pars Grene ere noget længere end deres Skaft.

Halevedhænget er ovalt, afstumpet paa begge Ender.

Farven er efter Krøyer hvid, marmoreret med sort og brunt.

Denne Art forekommer efter Kroyer ved Grønland; ved Spitsbergen, hvor den er taget af Lovén, skal den være meget sjelden. Torell har fundet den hyppig ved Island paa 25 Favnes Dybde; af Lovén er den fanget ved Finmarken, af Danielssen ved Tromsq, af v. Düben ved Christianssund.

OEDICHROS LYNCEUS, M. Sars, 1858.

(Pl. XIII. Fig. 4.)

Oediceros lyuceus, M. Sars, Oversigt over norsk-arct. Krebsdyr. Forhandl. i Vidensk-Selsk. i Christiania 1858, p. 143.

- $\quad$ A. Boeck, Forhandl. ved de Skand. Naturf.'s 8de Møde. 1860. p. 652 .

- $\quad$ Spence Bate, Catal. Amphip. Crust. Brit. Mus, 1862. p. 372.

- $\quad$ A. Boeck, Crust. amphip. bor. et arct. 1870. p. 82.

Oediceros arcticus, Danielssen, Beretning om en zoologisk Reise. Nyt Mag. for Naturv. 185\%. p. 7.

Oediceros propinqvus, Goës, Crust. Amphip. maris Spetsb. p. 10. fig. 19.

Rostrum productum, rectum el obtusum, articulo pedunculi 1 mo antennarum superiorum longius. Oculi prope ad apicem rostri siti. Antenna inferiores articulo pedunculi 4 to parum modo longiore et latiore quam 5to. Pedes $1 \mathrm{mi}$ paris carpo sat brevi et calce destituto. Pedes 2di paris carpo calcem non longam emiltenti: manu latiore qvam apud pedes 1 mi paris, clongata, ovata. Pedes 3tii et 4ti paris articulo 4to et 5 to elongatis; ungve longo, angusto, acuminato, acuto, longitudinem articuli 5 ti ferme aqvanti. Pedes 5 ti et 6 ti paris articulo 4 to et 5 to elongatis ef longiludine fere aqvalibus; ungve fere eadem longitudine ac articulo ultimo. Appendix caudalis elongata, apicem versus angustior et infra truncata.

Det storste af mig fundne Exemplar er $18^{\mathrm{mm}}$ langt.

Legemet er meget tykt, opblast, med rund Ryg; paa Halens Led findes 
Spor af en lille Kjøl. Paa livert Legemsled findes en paatvers gaaende Indtrykning lamgs den bagre Rand. Sideplaterne ere af en middelmaadig storrelse med fjardannede Borster langs deres indre Rand. Den forste Sideplade er større end den anden, skraat afskaaret fortil; den fjerde er kun svagt indskaaret bagtil for den femte, der er dobbelt saa bred som høi og indskaret midt paa den nedre Rand. Haleleddenes nedre bagre Vinkler ere afrundede. Hovedet er ikke meget langt. Pandehornet er forlænget, ret, kjølet, opsvulmet, tykt mod Spidsen, hvor Øinene have sin Plads.

De øvre Følere naa kun til Enden af de nedre Føleres Skaft eller ere noget længere. Skaftets Led aftage efterhaanden i Langde og.Tykkelse. Svoben er kortere end Skaftet og dannes af 11 Led.

De nedre Foleres tvende forste Led ere utydeligt adskilte; det tredie er ubetydeligt langere end bredt; det fjerde er næsten dobbelt saa langt og har paa begge Rande talrige Børster; det femte er noget kortere, men meget smalere. Svøben er noget længere end Skaftet og dannes af talrige korte Led.

Kindbakkernes ydre Flig er væbnet med 7 Tænder, den indre med $4-5$. Tornerækken er besat med fjærdannede Børster. Palpen er forlanget; dens tredie Led er omtrent saa langt som det andet og paa den nedre Rand vabnet med talrige Børster.

Det forste Kjabepar er bredt; i Spidsen sees en Rad gaffeldannede og en Rad saugtakkede Torne. Den indre Plade er sardeles bred og barer i Spidsen tvende fjordannede Børster. Palpen er kort, paa den nedre Rand og i Spidsen forsynet med Borstel:

Det andet Kjæbepars Plader ere brede.

Kjabefoddernes ydre Plade er liden og paa den indre Rand vabnet med mange, lange, tynde Torne; den indre bærer tjærdannede Børster og tynde 'Torne i Spidsen. Palpen er forlænget; det andet Led er indad meget udvidet; det tredie har talrige Borster paa den indre Rand og Flade. Kloen er forlanget, spids i Enden.

Det forste Fodpar er meget stort; dets forste Led er stærkt; de tre folgende ere smaa; det sidste af disse, eller Carpus, udsender ikke nogen Forlangelse langs den indre Side af det femte Led eller Haanden. Denne er meget forlænget, oval og midt paa den indre Side vabnet med en Tand og fra denne mod Spidsen med talrige fine Torne; Kloen er temmelig lang, noget krummet.

Det andet Fodpars fjerle Led udsender nedad et smalt Fremspring, der ikke er saa langt som Halvdelen af det femte Led eller Haanden; deme er noget bredere end paa det forste Par.

De trende folgende Fodpar ere meget stærke; deres tredie Led er ikke meget udvidet, men længere end det fjerde, som igjen er læugere end de folgende Led, der ere forsynede med talrige Borsteknipper paa den forreste Rand. Kloen er stark, men kortere end det femte Led.

Det fem te og sje tte Fo dp ar have indbyrdes nasten samme Størrelse og Bygning; det forste Led er lidet udvidet $0 \mathrm{~g}$ er paa begge Rande, især paa den bagre, forsynet med 
Iange fjardannede Børster; det tredie Led er noget udvidet nedad og i begge Rande besat med talrige Borsteknipper; det fjerde er kortere end det tredie og femte. Kloen er bred, i Enden spids og er omtrent saa langt som det sidste Led.

Det sidste Fodpar er forlænget; det forste Led er bredt, ovalt, med fjærdammede Børster i Randene; det tredie, fjerde, femte og sjette Led eller Kloen ere alle omtrent lige lange, men aftage efterhaanden i Tykkelse.

Alle Springfodder naa næsten lige langt bagud. Det silste Pars Grene ere lige lange, tilspidsede mod Enden og noget længere end Skaftet.

Halevedh nget er ægformet, næsten tvært afskaaret bagtil.

II. Sars angiver Farven at være lys rustbrun paa Ryggen, medens Bugsiden og alle Vedhæng ere grahuide; Øinene ere gulhvide. Et Exemplar, som jeg tog verl Langenæs i Vesteraalen, havde en gulbrun Grundfarve, marmoreret med brunt, livilket var stærkest langs de bagre Rande af livert Legemsled og de forreste Sideplarler. Paa Bagsiden val den derimod gulhvid.

Ved Spitsbergen er den meget hyppig mellem Alger paa 2-30 Fames Dybde og forekommer efter Goẻs ogsaa ved Grønland og Island. M. Sars tog to Exemplarer ved Vads paa 70 Favne. Danielssen fandt sammesteds nogle paa 40-60 Favne. Jeg har fundet et Exemplar ved Langenæs paa 30-40 Favne.

OEDICEROS BOREALIS, A. Boeck, 1870.

(P1. XIV. Fig. 1.)

Oediceros borealis, A. Boeck, Crust. amphip. bor. et arct. 18\%0. p. 82.

Rostrum obtusum, articulo pedunculi Imo antennarum superiorum multo brevius. Antennæ inferiores articulo pedunculi 4 to crassissimo et parum modo heviore qVam 5to. Pedes Imi paris carpo in calcem perlongam et angustam, longitudine ferme dimidia manu elongata, oviformi reqvalem, producto. Pedes 2di paris calce multo breviore quam apud pedes $1 \mathrm{mi}$ paris; manu magna, ovala. Pedes 3tii et 4 ti paris ungve brevi, non perlato. Pedes 5li et 6ti paris articulo 4 to et 5to non prrelongatis, junctis vix longioribus qvam articulo 3tio; ungve parum longiore yvam articulo 5to. Pedes $7 \mathrm{mi}$ paris articulis multo brevioribus et latioribus qvam apud species pracedentes. Pedes saltatorii non elongati; isdem ultimi paris ramis longitudinem pedunculi superantibus. Appendix caudalis infra rotundata.

Dyret èr i udstrakt Stilling omtrent ymm langt.

Legemet er tykt med rund Ryg. Sidepladerne ere høie, forsynede med talrige Borster paa den indre Rand. Haleus Led have fjærdannede Borster; deres nedre bagre Hjorner exe afrundede. Hovedet er langere end det forste Legemsled og gaar fortil ud i et kort, bredt, nedad bøiet Pandehorn. 
De ovre Folere ere omtrent saa lange som Hovedet og Legemets tvende forste Led tilsammen: Skaftets forste Led naar længere frem end Pandehornet; det andet Led er noget kortere og smalere; det tredie er baade meget kortere og smalere end det andet. Svøben, der bestaar af 8 Led, er kortere end Skaftet.

De nedre Følere ere længere end de ørre; Skaftets tredie Led er meget tykt; det fjerde er noget længere og smalere, hvilket ogsaa er Tilfældet med det femte Led. Svoben, der bestaar af 9 Led, er meget kortere end Skaftet.

Kindbakkernes andet og tredie Palpeled ere omtrent lige lange.

Det forste Kjæbepars Palpe er meget smal.

Det første Fodpar er kort, men strekt; det fjerde Led er megetkort, og dets nedre bagre Hjome forlenger sig til et smalt Fremspring, der ikke naar saa langt frem som der, hvor Kloens Spids møder; det femte Led er ovalt.

Det andet Fodpar er større end det første; det fjerde Leds nedre bagre Vinkel forlanger sig til over Halvdelen af det femte Leds nedre Rand eller til det Sted. hvor Kloens Spids moder: det femte Led er forlænget, agformigt og tilspidser sig strerkt mod Enden; Kloen er nesten ret og meget kortere end Haanden.

De tvende følgende Fodpar ere meget brede og paa den bagre Rand forsynede med lange Børsteknipper; det femte Led er lrengere end det fjerde; Kloen er bred og noget kortere end det sidste Led.

Det femte og sjette Fodpar, som ogsaa ere meget brede, have en strerk Klo, der er lige saa lang som det femte Led.

Det syvende Fodpars forste Led er omtrent saa bredt som langt; det tredie Led er læugere end det første; det fjerde og femte ere lige saa lange, men smalere end det tredie. Kloen er meget tyk, kortere end det femte Led og forsynet med Torne.

Det forste Par Springfodder naar langt tilbage. Grenene paa det tredie Par, der indbyrdes ere lige lange, ere længere end deres Skaft.

Halevedhanget er næsten firkantet, noget længere end bredt og med enkelte Torne i den bagre Rand.

Af denne Art fandtes enkelte Exemplarer fra Grønland i Kjøbenhavus Museum, og et fandtes blandt de Samlinger, som C. Boeck medbragte enten fra Finmarken eller fra Spitsbergen, formodentlig fra det forstnævite Sted.

Gen. II. ACANTHOSTEPHEIA, A. Boeck, 1870.

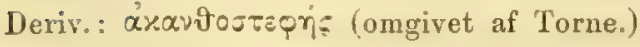

Syn.: 1870. Acanthostepheia, A. Boeck, Crust. amphip. bor. et arct. p. 83.

Typ.: Amphithonotus Malmgreni, Goës.

Pedes maxillares lamina externa parvula, non ad medium articulum palpi 2dum porrecla; lamina interna etiam parvula.

Antennæ prelongatæ, tenues; superiores inferioribus paulo breviores. 
Corpus valde carinatum; segmentis trunci posterioribus et segmentis postabdominis postice in processus longos et dentiformes exemntibus: epimeris posterioribus valde acuminatis; capite antice in rostrum longissimum producto.

Cateroqvin ferme ut apud genus Vediceros.

Goës afbilder og beskriver Amphithonotus Malmgreni fra Spitsbergen. Denne er dog en fra Amphithonotus meget afvigende Amphipodeform og viser ilerimod stort Slægtskab med Oediceros, hvorfor jeg har henfort den til Underfamilien Ocdicerince, hvor den maa blive Typus for en ny Slagt, som jeg har kaldet Acanthostepheia. I Munddelene stemmer den ganske overens med slagten Ocdireros, kun er Kjalrefodilernes ydre Plade end mindre end hos denne Slægt. I den ydre Form ligner den Ocdiceros deri, at Hovedet forlænger sig fortil i et langt, tykt Horn, at det sidste Folpar er dobbelt saa langt som de tvende foregaaende Par, og endelig stemme Springfodderne og Halevedhanget fuldstandig overens med hin slagt, ligesom ogsia den forste villeplade bliver bredere nedad og saaledes bredere end den anden. Derimod afviger den fra Oediccros og de ovrige nærstaaende Slægter ved sit kantede, kjolede og tornede Legeme, hvorved den faar et fremmed Udseende. Dette foroges ogsaa noget ved, at hegge Folere, især de øvre, ere forlængede; dog ere de ovre selv hos Hunnen kortere end de nedre, men længere eud deres Skaft. Den eneste Art, som kan henregnes til denne Slægt, er den af Goës opstillede Amphithoms Malmgreni, der findes verl spitsbergen.

ACANTHOSTEPHELA MALMGRENI, Goës, 1865.

Amph ithonotus Malmgreni, Goës, Crust. Amphip. maris Spetsb. p. 10. fig. 17. A canthostepheia Malmgreni, A. Boeck, Crust. amphip. bor. et arct. 1870. p. 83.

Corpus crassum et validum. Segmenta trunci duo posteriora et postabdominis qvatuor anteriora carinata et in medio margine posteriore in spinam firmam desinentia. Segmentum trunci ultimum el segmenta postabdominis qvaluor anteriora insuper ante spinas spinis singulis minoribus instructa: angulo inferiore posteriore acuto. Epimera tria posteriora angulo inferiore posteriore acuto. Caput antice in rostrum longum et rectum, in apice aculum, productum. Rostrum longiludinem capitis superans, ad extremum elongatum et anguslum articulum pedunculi 1 mum antennarum superiorum porreclum. Antenna inferiores articulo pedunculi 4 to et 5to longitudine reqvalibus. P'edes 1 mi paris manu ovata; carpo brevi; calce parva. Pedes 2di paris eadem forma ac iisdem 1 mi paris sed majores: manu paulo longiore. Pedes 3 tii el 4 ti paris elongati. Pedes $7 \mathrm{mi}$ paris articulo 4 to fere duplo longiore quam 3tio et longiore qvam 5to. Pedes saltatorii ultimi paris ramo interiore paulo hreviore qvan pedunculo. Appendix caudalis paulo longior qvam lata. 
L $x$ giden er omtrent $30^{\mathrm{mm}}$.

L egemet er meget tykt, stærkt, ikke meget sammentrykt. Legemets første Led ere forsynede med langsgaaende Furer og mellem disse med tallose Ophwininger. En Kjol strxkker sig langs Ryggens Midtlinie fra det femte Legemsled til det fjerde Haleled og gaar i Midten af den bagre Rand ud i strerke, bagudrettede Torne; desuden findes en mindre, forreste Tand paa det sidste Legemsled og de fire Haleled. Den nedre bagre Vinkel paa de tre sidste Legemsled og tre forste Haleled er udtrukket, tilspidset og staar ud fra Legemet. Den forste Sideplade bliver bredere nedad; de tre bagre Sidepladers nedre bagre Vinkel er tilspidset. Hovedet er lidt længere end det forste Legemsled og gaar fortil ud i et overmaade langt triangulært, stærkt Pandehorn, der paa den ovre og nedre Flade har en Kjol; den ovre Kjol fortsxtter sig bagover paa Hovedet og adskiller Øinene.

De øvre Folere ere forlængede og naa, naar de bøies bagover, omtrent til Halen; deres forste Skafted er særdeles forlænget og naar omtrent frem til Enden af Pandehornet; det andet er meget kortere og smalere, og det tredie kan ikke skilles fra Svobens Led. Denne sidste er omtrent saa lang som Skaftet $0 \mathrm{~g}$ dannes af henved 40 Led.

De nedre Følere ere længere end de ovre; deres tredie Skaftled er kort; det fjerde og femte Led ere omtrent lige lange.

Kindbakkerne ere strerke; Tyggeknuden er fremstaaende; Palpens tredie Led er lidt kortere end ilet andet.

Det forste Kjæbepars indre Plade er oval, forsynet med tvende Børster i den inctre Rand.

Kjabeføddernes indre Plader ere meget smaa; de ydre ere smale og naa neppe frem til Palpens andet Led; de ere paa den indre Rand væbnede med tynde Torne. Palpens andet Led er forlænget; det tredie er meget kort.

Det første og andet Fodpar ere næsten af indbyrdes samme Form, men det sidstnævnte er noget længere; Carpus er i den nedre bagre Vinkel forlænget til en kort HæI; Haanden er bredere udad med skraat afskaaret Griberand.

Det tredie og fjerde Fodpar ere korte og smale.

Det femte og sjette Fodpar lave samme Form og Storrelse; deres forste Led har en forlænget, oval Form; Kloen er nasten saa lang som det femte Led.

Det syvende Fodpar er omtrent dobbelt saa langt som de tvende foregaaende; det fjerde Led er meget længere end det tredie $0 \mathrm{~g}$ lidt liengere end det femte, som igjen kun er ubetydeligt længere end den rette Klo.

Det sidste Par Springfodders ydre Gren er lidt kortere end den indre, som er omtrent saa lang som Grundleddet.

Halevedh nget er lidt længere end bredt, bliver smalere mod Enden; den bagre Rand er lidt indbugtet.

Denue Art er fundet af Malmgren paa 5-20 Favnes Dybde i Storfjord samt i Belsund ved Spitsbergen i faa Exemplarer. 
Gen. III. MONOCULODES, Stimpson, 1853.

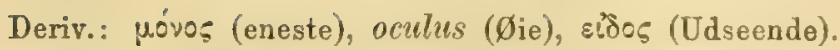

Syn.: 1853. Monoculodes, Stimpson, Marine Invert. of Grand Manan. 1853. p. 54.

1855. - (pars) Spence Bate, Brit. Assoc. Report. 1855. p. 13.

1857. Kröyeria, Spence Bate, Synopsis etc. Ann. Nat. 2. ser. XIX. I857. p. 140.

1862. Monoculodes, Spence Bate, Catal. Amphip. Crust. Brit. Mus. 1862. p. 104.

1863. - - Spence Bate and Westwood, Brit. sessile-eyed Crust. 1863. p. 163 .

1870. - A. Boeck, Crust. amphip. bor. et arct. 1870. p. 84.

Typ.: Monoculodes demissus, Stimpson.

Antennæ elongatæ; superiores inferioribus paulo breviores.

Pedes tmi paris carpo in angulo inferiore posteriore in calcem brevem producto; manu subcheliformi, non magna.

Pedes 2di paris manu prælongata, in acie obliqve truncata; calce carpi producta.

Reliqva cum genere Oediceros ferme conveniunt.

Denne Slægt blev opstillet af Stimpson i, 1853 paạ Arten M. demissus fra Grand Manan. En Art, der henhorer til denne Slagt, havde Spence Bate først optaget i Slægten Westuoodia og senere i Slægten Kröyeria. Den skiller sig kun lidet frạ Oedicoros og rasentlig kun med Hensyn til de tvende forste Forlpars Form. Spence Bate frembæver i 1862, at Øinene ere forenede til eet ovenpaa Hovedet; dette er dog ikke Tilfældet, da man kan se en tydelig Grændse mellem dem, skjønt de ere pressede tæt til hinanden. Pandehornet varierer hos denne Slægt meget betydelig; det er meget langt hos $\boldsymbol{M}$. longirostris, $\boldsymbol{M}$. affinis, $\boldsymbol{M}$. Packardii osv., men er meget lidet hos $\boldsymbol{M}$. Grubei, hoist ubetydeligt hos B1. Tonvicomis. Det, som i Særdeleshed skiller denne Slægt fra den foregaaende, er Formen af det andet Fodpar, hvis Haand er udtrukket, forlænget, men smal; Kloen er liden, merlens Hrlen paa Carpus forlænger sig overmaade meget. Der er en Overgang til Slægten Ocdiceros derveil, at Liengden af det andet Fodpars Haaud varierer, saaledes at den hos $\boldsymbol{M}$. longirostris er meget kort, medens den hos $\boldsymbol{M}$. affinis og andre er sxrdeles forlanget. Af Bekvemmeligheds-Hensyn bør Slægten beholdes, skjont det maaske var rigtigere at slaa den sammen med Oedireros.

Alene fra Norges Kyster og det arktiske Hav kjendes 11 Arter.

MONOCULODES AFFINIS, Bruzelius, 1859.

(PI. XIV. Fig. 6.)

Oediceros affinis, Bruzelius, Bidrag till Känn om Skand. Amphip. Ganmar. Kgl. Vetensk.-

Akad.'s Handlingar. Ny följd. B. 3. 1859. p. 43.

Westwoodia carinata, Spence Bate, Brit. Assoc. Rep. 1855. p. 58. 
Kröycria carinata, Spence Bate, Synop. Ann. Nat. Hist. 2. ser. XIX. 185\%. p. 140. Monnculodes rarinatus, Spence Bate, Cat. Brit. Mus. 1863. p. 104. pl. XVII. fig. 2. Spence Bate and Westrood, Brit. sessile-eyed Crust. 1863. p. 165.

Monoculodes affinis, A. Boeck, Crust. amphip. bor. et arct. 1870. p. 84.

Rostrum frontale parvum, percurvatum, articulo pedunculi fmo antennarum superiorum paulo brevius. 'Oculi magni, prope ad apicem rostri siti. Anteunæ superiores ferme ad fincm pedunculi inferiorum porrecta. Antenne inferiores articulo pedunculi 4 to multo breviore qvam 5to; utroqve brevibus. Pedes $1 \mathrm{mi}$ paris manu ovata; carpo brevi. Pedes 2 di paris manu fere quater longiore qvam lata, in acie obliqve truncata; calce carpi prelongata, ad finem marginis posterioris manus porrecta. Pedes 3 tii et 4 ti paris articulo 4 to postice non valde dilatato; ungve parvulo, vix conspicuo. Pedes 5 ti et 6 ti paris ungve parvo instructi.

Hovedet er temmelig stort; Pandehornet kort, men meget tykt, bredt og i Spidsen lidt afrundet; Øinene dxkke den hele ovre Flade, undtagen den yderste Ende.

De ovre Folere ere korte; Skaftets forste Led strækker sig lidt længere frem end Pandehornet og er lidt mere end dobbelt saa langt som tykt; det andet Led er kortere og tyndere; det tredie er ubetydeligt længere end Svobens Led; denne dannes hos Hunnen af 6 , hos Hannen af 10 Led.

De nedre Frgleres fjerde Skaftled er kortere, men bredere end det femte, hvis Svgbe hos Hunnen har 20 og hos Hannen 50 Led.

Kindbakkerne ere i Spidsen brede og indskaame i 5 brede Tænder; den indre Bigren er delt i $4-5$ Tænder; Tyggehnuden er meget stærk; Palpens tredie Led er krummet, omtrent af samme Liengde som det andet Led,-men smalere.

Det første Kjæbepars indre Plade er temmelig stor, i Spidsen afrundet og forsynet med en lang, fjærdannet Børste.

Kjabefoddernes andet Palpeled er meget bredt, bølgeformet indskaaret og forsynet med talrige Børster.

Det forste Fodpars tredie Led er lidt udtrukket i den nedre bagre Vinkel; Carpus er triangulær; Hælen er lidt længere end Leddet, paa Enden afrundet og forsynet med Børster. Haanden er næsten dobbelt saa lang som hred, af en uregelmæssig, oval Form; Griberanden er buet og har tynde Torne.

Det andet Fodpars forste Led er langt og har paa den forreste Rand lange Børster; det andet og tredie Led ere meget korte; Carpus er liden, triangulær og udsender fra sin nedre bagre Vinkel en smal, paa den bagre Rand med Burster forsynet Hæl, der er lidt længere end Haandens bagre Rand. Haanden er omtrent fire Gange saa lang som bred, med skraat afskaaren, bueformet Griberand.

De tvende folgende Fodpar ere indbyrdes af samme Form; deres tredie 
Led bliver temmelig bredt udad og har paa den bagre og forreste Rand lange Børstebundter; det fjerde Led er ogsaa udvidet bagtil og har der talrige Tvarrader af lange Børster; det femte Led er smalere, væbnet med Torne paa den bagre, convexe Rand og har lange Børster i Enden, der skjule den meget lille Klo.

Det femteog sjette Fodpar have indbyrdes den samme Form; det forste Led er forlænget, smalt; det tredie bliver udvidet mod Enden $0 \mathrm{~g}$ har paa den forreste $0 \mathrm{~g}$ bagre Rand lange Børster; det fjerde og fente Led ere omtrent lige lange, og begge, isar det sidste, have paa den bagre, convexe Rand lange Børstebundter.

Det syvende Fodpar er meget langt; det første Led er longere end bredt; det tredie er næsten saa langt. men bredere, end det fjerde, der omtrent er af samme Langde som det forste. Kloen er næesten saa lang som det femte Led, ret, i Enden tilspidset.

De trende forste Par Springfodders ydre Gren er kortere end den indre.

Det tredie Pars Grene ere lige lange, omtrent af samme Langde som

$\rightarrow$ Grundleddet.

Hal evedhxnget er ikke fuldt dobbelt saa langt som bredt ved Roden, paa Enden afrundet.

Af denne Art har jeg fundet nogle Exemplarer, hos hvilke der ogsaa saaes en svag Kjøl paa Halens Led, hvorfor jeg ikke vilde være i Tvivl om, at den af Spence Bate opstillede $\boldsymbol{M}$. carinatus er den samme som denne, dersom ikke den af ham givne Tegning viste enkelte Uoverensstemmelser fra $\boldsymbol{M}$. affinis, hvorfor jeg ikke har vovet at optage Artsnavnet carinatus, som er det aliste, hvis de ere Synonymer.

Et Exemplar fra Haugesund var bredt; de bagerste Legemsled vare paa Ryggen stærkt punkterede med brunt; Øiet var lyserodt. Paa et andet Exemplar yar den brune Punktering stærkere udbredt over det hele Legeme.

Farven paa Arten carmatus skal være hvid, med purpurrøde Øine. Hos en Varietet eller maaske en Abnormitet var det andet og tredie Skaftled paa de øvre Følere meget forkortede, medens det forste Svobeled var meget forlænget.

Den er fundet af Danielssen ved Ona ved Christianssund, af G. O. Sars ved Aalesund paa 60 Favne, af mig ikke sjelden ved Haugesund paa 50 Favne; efter Bruzelius findes den ved Bohuslän.

MONOCULODES NORVEGICUS, A. Boeck, 1860.

(Pl. XVI. Fig. 5.)

Oediceros affinis, Goës, Crust. Amphip. maris Spetsb. p. 11. fig. 21.

(Non Bruzelius.)

Monoculodes norvegicus, A. Boeck, Crust. amphip. bor. et arct. 1870. p. 84.

Rostrum frontale curvatum, articulo pedunculi 1 mo antennarum superiorum longius, in apice acuminatum. Antenne inferiores articulo pedunculi 4 to et 5 to longitudine 
fere aqualibus, altamen tlo paulo longiore. Pedes 3 tii et 4 ti paris articulo 4 to postice sat dilatato: ungve longitudine articulum ultimum fere reqvanti. Pedes 5ti et 6ti paris multo angustiores et longiores qvam apud speciem pracedentem; ungve longo, parum modo breviore qvan articulo ultimo. Pedes saltatorii ultimi paris ramis longitudinem pedunculi ferme æqvantibus. Cæteroqvin ferme ut apud M. affinis.

Dyrets $L \rightsquigarrow \mathrm{ngde}$ er $6^{\mathrm{mm}}$.

L e g e met er noget sammentrykket, men Ryggen er rund, uden Kjøl. Hovedet er meget stort, of Pandehornet er langt, spidst i Enden samt meget boiet. Sidepladerne ere af middelmaadig Størrelse, og deres nedre Rand er besat med fine Børster; den første Sideplade er større end den.anden og bliver bredere nedad; den fjerde er meget indskaaret bagtil; den femte er noget bredere end høi, samt meget svagt indskaaret paa den nedre Rand.

De gvre Følere ere temmelig lange og naa, naar de boies tilbage, til det syvenile Legemsleds Brystring. Skaftets forste Led er noget liengere, men meget tykkere end det andet; det tredie er meget kort; Svoben er noget længere end Skaftet og bestaar af 9 Led.

De nedre Følere ere noget langere end de øvre; Skaftets fjerde og femte Led ere næsten lige lange, men det fjerde er det tykkeste. Svoben er kortere end Skaftet $0 \mathrm{~g}$ bestaar af 9 Led. Munddelene stemme fuldkommen overens med dem hos den foregaaende Art.

Det første Fodpars forste Led er temmelig langt og smalt; det femte Led, eller Haanden, er mere end dobbelt saa langt som bredt, noget krummet og skraat afskaaret i Enden; forovrigt er den lig den tilsvarende hos den foregaaende Art.

Det andet Fodpar er forholdsvis langt læugere og smalere end hos den foregarende Art, men forøvrigt af samme Bygning.

De tvende følgende Fodpars tredie Led er ikke meget bredt. Kloen er lang, omtrent to Trediedele eller mere af det sidste Leds Længde.

Det femte og sjette Fodpar ere meget forlængede, især deres sidste Led, som er meget langere end det fjerde; Kloen er meget lang, smal og tilspidset, men noget kortere end det femte Led.

Det syvende Fodpar er meget forlanget; det forste Led er ved Roden meget bredt, dog ikke saa bredt som langt, og den bagerste Rand er besat med fjærdannede Børster; det tredie Led er længere end det første; det fjerde er længere, men smalere end det tredie, og det femte er af samme Længde, men meget smalere; Kloen er næsten ret og meget kortere end det silste Led.

Halens fjerde Led er puklet, det femte er lidet.

Halevedh n get er noget længere end bredt og indskaaret paa den bagerste Rand.

Efter Goës er den af Torell medbragt fra Grønland og forekommer nu og da ved Spitsbergen paa 20-30 Favnes Dybde. Af Lovén er den taget ved Finmarken, 
af G. O. Sars ved Skraaven paa $250-300$ Favne og ved Brettesnæs paa 40 Favne, af Danielssen ved Aalesund $\mathrm{g} g$ af mig $\mathrm{i}$ faa Exemplarer ved Karmøen.

\section{MONOCULODES GRUBEI, A. Boeck, 1870.}

(Pl. XVI. Fig. 1).

Monoculores Grubei, A. Boeck, Crust. amphip. bor. et arct. 1870. p. 85.

Rostrum frontale brevissimum. Antennæ superiores articulo pedunculi 1 mo paulo longiore qvam apud speciem precedentem; articulo 3tio pralongato, longitudine ferme 1 mum et 2 dum rqvanti. Antennæ inferiores articulo pedunculi 4to et 5to longitudine ferme aqpalibus. Ho crassiore. Pedes $1 \mathrm{mi}$ paris manu duplo ferme longiore qvam lata et apicem versus angustiore: calce carpi longitudine manum ferme xqvanti, acuta. Pedes 2di paris manu fere qvater longiore qvam lata; calce carpi longiore qvam manu et in apice acuta. Pedes 3 tii et 4 tì paris elongati; articulo 4to et 5to eadem ferme longitudine; 4to in angulo inferiore anteriore subelongalo et setis multis curvatis instructo; ungve angusto. acuminato, breviore qvam articulo 5to. Pedes 5ti et 6ti paris elongati: ungve paulo breviore qvam articulo 5to. Pedes $7 \mathrm{mi}$ paris articulo 4 to longiore qvam 3tio. Pedes saltatorii ultimi paris ramo exteriore parum hreviore qvam interiore: hoc parum breviore qvam pedunculo. Appendix caudalis paulo longior qvam lata. infra Iruncata.

Dyret er $4-5^{\mathrm{mm}}$ langt.

Legenet er ikke meget høit. Sidepladerne ere smaa; den første er næsten firkantet, noget høiere end bred, og besat med fjærdannede Børster paa den indre Rand. Den nedre bagre Vinkel paa Halens tre første Led er afrundet. Hovedet er omtrent saa langt, som Legemets tvende forste Led tilsammen, og gaar fortil ud i et kort, bredt, udadbøiet Pandehorn. Hovedets Sidevinkler ere afrundede. Begge Følere ere hos Hunnen intbyrles omtrent lige lange, eller de gvre ere noget længere, og saa lange som Hovedet og de fem forste Legemsled.

De øvre Føleres første Led er meget kortere end Hovedet; det andet er ubetydeligt kortere og tyndere, medens det tredie er lige saa langt som dette, men noget smalere. Svøben, der er saa lang som Skaftets tvende sidste Led, bestaar af 6-7 forlængelle Led. Hos Hanuen blive Svobens Led kortere og aftage efterhaanden i Liengde, saa at det tredie kun er debbelt saa langt som bredt. Undertiden sammensmelte de første Led til et stort spolformet, med talrige Børster besat Redskab.

De nedre Foleres tvende forste Led ere sammensmeltede; det tredie er omtrent saa langt som bredt; det fjerde er meget længere og tyndere, og det femte er af dettes Længde. Svøben, der er længere end Skaftet, bestaar af 14 Led hos Hunnen;

1 Opkaldt efter Zoologen Professor Dr. Grube i Breslau. 
hos Hannen er den forlænget og dannes af 28-30 Led. Følernes Skaft er bevæbnet med Knipper af tynde Torne.

Kindbakkernes Gribedel er meget bred og bestaar af 6 Dobbelttæender; deres tredie Palpeled er meget kort.

Det forste Fodpars første Led er meget langt; det fjerde forlænger sig i den nedre bagre Vinkel til et tilspidset Fremspring, der er saa langt som hele det femte Led og gaar derfor meget langere ned end til det Sted, hvor Kloens Spids støder an, naar den slaaes ind mod Haanden.

Det andet Fodpars første Led er længere end det tilsvarende paa det første Par; det fjerde Leds forlangede nedre bagre Vinkel er ligeledes tilspidset, tornformig og læengere end det femte Led.

De tvende følgende Fodpars fjerde og femte Led ere omtrent lige lange; det sjette Led er i Enden skraat afskaaret, saa at det nedre bagre Hjørne staar noget frem over Befæstelsen for Ḱloen, der næsten er af samme Længde som det femte Led; de tre sidste Led ere forsynede med mange Knipper af lange Børster.

Det femte og sjette Fodpars første Led er kun lidet bredt, men har i begge Rande lange fjærdannede Borster; det fjerde og femte Led ere forlangede, smale, indbyrdes lige lange, samt kortere end det tredie Led. Kloen er næsten saa lang som det sidste Led og temmelig bred.

Det syvende Fodpars første Led er temmelig bredt, dog ikke fuldt saa bredt som langt; det fjerde er læengere end det tredie, og det femte er omtrent saa langt som det fjerde, men meget smalere. Kloen er tynd, ret og lidt længere end det sidste Led.

De tre bagre Par Springfødder naa omtrent lige langt bagud; deres ydre Gren er noget kortere end den indre. Det sidste Pars indre Gren er omtrent saa lang som Rodleddet.

H a l evedhænget er næsten firkantet, men længere end bredt.

Den af Spence Bate og Westwood beskrevne $\boldsymbol{M}$. longimanus ligner denne Art i enkelte Punkter, men de tegne det forste Fodpar meget længere, end det er Tilfældet hos denne Art, og de anføre, at Ryggen har en Kjøl, hvilket heller ikke er Tilfaldet hos vor Art.

Af denne har jeg ogsaa fundet en Varietet eller Monstrositet, hos hvilken de ørre Føleres tredie Skaftled er meget forkortet, medens Svøbens forreste Led sammensmeltes til et langt, der paa den indre Side er besat med Rader af Børstebundter.

Den er fundet i Christianiafjorden af G. O. Sars og sammesteds af mig baade i Nærheden af Christiania og ved Moss.

MONOCULODES LONGIROSTRIS, Goës, 1865.

Oediceros longirostris, Goës, Crust. Amphip. maris Spetsb. 1865. p. 11. f. 20.

Rostrum frontale elongatum, rectum, in apice truncatum, articulo pedunculi 1 mo antennarum superiorum longius. Oculi prope ad apicem rostri siti. An- 
tenna superiores arliculo pedunculi I mo longiludinem 2di aqvanti sed crassiore quam eodem. Pedes $1 \mathrm{mi}$ paris manu ferme duplo, eadem 2di paris ferme ter longiore qvam lata; calce carpi 1 mi paris breviore, eadum 2di paris longiore quam dimidio margine posteriore manus. Pedes 3 tii et 4 ti paris elongati; arliculo 4 to ovali, 5 to curvato, in margine anteriore seloso; ungve longo, accuninato, longitudinem arliculi sti fere aqvanti. Appendix caudalis longior qvam, lata, infra truncata.

Dyrets L $\mathrm{L}$ ngde er $12^{\mathrm{mm}}$.

Legemet er ikke meget sammentrykket; Ryggen er rund, uden Kjøl. Den forste Sideplade er nedad lidt udvidet og tilrundet. Hovedet er temmelig langt og gaar fortil ud i et langt, ret, i Enden buet Pandehorn. Øinene sidde paa dets Rygsirle nær Spidsen.

De øvre Følere ere korte; Skaftets første Led naar ikke frem til Enden af Pandehornet; det andet Led er lidt kortere og meget smalere end det forste; det tredie er meget kort.

De nedre Foleres tredie Skaftled er neppe saa langt som tykt; det fjerde er nxsten tre Gange saa langt, og det femte er af samme Langde; Svoben er hos Hunnen kortere, hos Hannen meget forlænget og dannes af 60-70 Led.

Det første Fodpar er kortere end det andet; dets Carpus udsender nedad og bagtil en Hæl, der ikke naar frem til Midten af Haandens bagerste Rand. Den bagre Rand paa Carpus og paa det tredie Led er besat. med Knipper af Børster. Haanden er dobbelt eller noget mere end dobbelt saa lang som bred; dens Griberand er buet. Kloen er ikke meget lang, men krum.

Det andet Fodpar har samme Form som det forste, men Carpus er her noget kortere og Halen længere, men smalere end paa det første Par, og naar læengere frem end til Halvdelen af Haandens bagre Rand. Haanden er omtrent tre Gange saa lang som bred ved Roden og er lidt krummet.

De tvende folgende Fodpars tredie Led bliver nedad udvidet; det fjerde er ovalt; det femte er krummet, med en stark convex forreste Rand, der er besat med talrige lange Børsteknipper. Kloen er saa lang som det sidste Led, stærk og lidt krummet.

Halevedhanget er lidt længere end bredt ved Roden, i Enden tvært afskaaret.

Efter Goës variere de ovre Følere meget; han aftegner ogsaa en Form, hos hvilke de nedre Føleres femte Skaftled er kortere end det fjerde.

Den er fundet af Malmgren ved Spitsbergen paa 5-20 Favne; af Esmark er den fundet i et Exemplar ved Finmarken. 
(PI. XV. Fig. 6).

Monoculodes $\boldsymbol{K r o ̈ y e r i , ~ A . ~ B o e c k , ~ C r u s t . ~ a m p h i p . ~ b o r . ~ e t ~ a r e t . ~ 1 8 7 0 . ~ p . ~} 86$.

Rostrum frontale longitudine ferme dimidium articulum pedunculi $1 \mathrm{mum}$ antennarum superiorum aqvans. Oculi prope ad apicem rostri acuti siti. Antennæ superiores articulo pedunculi 1 mo et 2 do longitudine ferme a eqvalibus; 3tio perbrevi. Antenna inferiores articulo pedunculi 4 to parum breviore sed latiore qvam 5to. Pedes $1 \mathrm{mi}$ paris manu ovali; carpo paulo breviore qvam manu, calcem brevem, latam et setosam emittenti. Pedes 2di paris manu ferme ter longiore qvam lata; calce carpi angusta. non ad finem marginis posterioris manus porrecta. Pedes 3 tii el 4 ti paris brevissimi et latissimi; articulo 4 to vix longiore qvam lato; 5 to apicem versus latiore, in margine antico persetoso: ungve perlato, crasso, longiore qvam dimidio articulo 5to. Pedes 5 ti et 6 ti paris articulo 5 to ferme eadem longitudine ac ungve lato crassoqve. Appendix caudalis longior quam lata. infra truncata.

Dyrets Læugde er $17 \mathrm{~mm}$.

L e gemets Form stemmer meget overens med det hos Oediceros lynceus, Sars, idet det er tykt med rund Ryg, men det viser Spor af Kjøl paa de fire første Haleled; det fjerde har ogsaa en saddelformig Indbugtning af Ryggen. Hovedet. der er ontrent saa langt som de tvende første Legemsled, gaar fortil ud i et ret. i Enden spidst Pandehorn. Øinene have sin Plads paa dettes ydre Ende som en opsvulmet Knude.

De øvre Følere naa, naar de bøies bagover, det fjerde Legemsled. Skaftets forste Led er tykkest og naar frem et Stykke foran Pandehornets Spids; det andet er omtrent af samme Læengde, men tyndere; det tredie er meget kort. Svoben, der er meget kortere end Skaftet, dannes af 15 Led.

De nedre Følere ere meget længere end de ovre; Skaftets tredie Led er omtrent saa langt som tykt; det fjerde og femte ere lige lange, men det forste er tykkere; begge have fine, fjærdannede Borster, især paa den nederste og inderste Side. Svoben er omtrent saa lang som Skaftet $0 \mathrm{~g}$ dannes af 50-60 Led, uvoraf de forste ere meget korte. Munddelene ere aldeles som hos Oe. lyncens, Sars.

Det forste Fodpar er lidet; det forste Led er bagtil forsynet med lange Borster; det tredies nederste bagerste Hjorne gaar ud i et spidst Fremspring; det fjerde er tungeformigt. Haanden er ikke fuldt dobbelt saa lang som bred, noget bredere mod Enden $0 \mathrm{~g}$ med skraat afskaaren Griberand.

Det andet Fodpar er noget længere; dets fjerde Leds nederste bagerste Forlæugelse er omtrent Totrediedele sala lang som Haanden. Denne er næsten fire Gange

- Opkaldt efter den afdade Zoolog Professor Kroyer i Kjobenhava. 
saa lang som bred. med næsten parallele Rande. Griberanden er noget skraa og forsynet med talrige Børster.

Det tredie og fjerde Fodpar ere meget stærke; deres forste Led er kort, men særdeles bredt; det tredie udvider sig mod Enden og er ikke fuldt saa langt som de tvende folgende tilsammen; det fjerde er noget længere end det tredie, og begge ere forsynede med talrige Borsteknipper i den bagre Rand; det femte Led udvider sig udad og er paa Enden af den forreste Rand forsynet med lignende Børsteknipper. Kloen er meget.bred og kortere end det foregaaende lied.

De tvende folgende Fodpar ere indbyrdes næsten af samme Bygning; det forste Led er lidt udvidet og har i begge Rande Børster, hvoraf de i den bagre ere meget lange og fjardannede; det samme er Tilfældet med det tredie Leds bagre Rand; det fjerde er noget kortere end det femte, is ar paa det sjette Fodpar; den brede Klo er omtrent saa lang som det femte Led.

Det syvende Fodpars forste I,ed er neppe længere end bredt og har fjærdannede Børster i begge Rande; det fjerde er længère, men smalere end det tredie Led, og de tvende folgende aftage i Størrelse.

Alle Springfodder naa nxsten lige langt bagud, og deres Grene ere lige lange; det tredie Pars Grene ere omtrent saa lange som Skaftet og forsynede med nogle Torne, ligesom Grenene paa de to første Par.

Halevedhæinget er noget længere end bredt, ret afskaaret i Enden, hvor det er smalere end ved Roden.

F arve n er hvidgul, spettet med brunt; Oiet gulrødt.

Nogle faa Exemplarer af denne Art har jeg taget paa 60 Favnes Dybde ved Haugesund.

\section{MONOCULODES LONGICORNIS, A. Boeck, 1870.}

Monoculodes longicornis, A. Boeck, Crust. amphip. bor. et arct. 1870. p. 85.

Rostrum frontale perhreve. Antenna superiores articulo pedunculi 2do longiore et angustiore qvam lmo: 3tio breviore. Antenna inferiores articulo pedunculi d to paulo breviore qvam 5to. Pedes 1 mi paris manu fere qvadrangulari, duplo longiore qvam lata; calce carpi ad finem marginis posterioris manus porrecta. Pedes 2di paris manu circiter qvater longiore qvam lata el apicem versus angustiore; calce carpi paulo breviore qvam manu et infra rolundata. Pedes 3 lii el 4 ti paris robusti; ungve brevi, ferme tertian partem longitudinis articuli 5ti reqvanti. Pedes 5ti et 6ti paris ungve longiore qvam dimidio articulo ultimo. Pedes saltatorii ultimi paris ramis breviorihus qvam pedunculo. Appendix caudalis parum longior qvam lata. 
Dyrets L $x$ ngde er, naar det er udstrakt, $7 \mathrm{~mm}$.

Le gemet er meget tykt, opblæst, med rund Ryg. Sidepladerne ere middelmaadige, forsynede i deres nedre Rand med korté, noget spredte Haar. Hovedet, der er lidt længere end de tvende første Legemsled tilsammen, gaar fortil ud i et meget kort, bøiet, ikke meget bredt Pandehorn.

De svre Følere ere forlængede; deres første Led er kortere end Hovedet, det andet omtrent saa langt som dette; det tredie er omtrent af det første Leds Laengde; Svoben, der bestaar af 7 Led, er omtrent saa lang som Skaftets sidste Led.

De nedre Foleres femte Led er lidt længere, men smalere end det fjerde og naar ikke længere frem end til det andet Leds Ende paa de øvre Følere.

Det forste Fodpars fjerde Led danner et langt, temmelig tykt Fremspring, der gaar længere ned end til det Sted paa det femte Led, hvor Koons Spids møder; det femte Led, eller Haanden, er forlænget, firkantet, mere end dobbelt saa langt som bredt, noget bøiet og med en skraat afskaaren Ende.

Det and et Fodpar har et forlænget Fremspring, der er omtrent saa langt som hele det femte Led, hvilket er tykkere ved Roden end mod Spidsen.

De tvende følgende Fodpar ere meget stærke; deres tredie Led bliver meget bredt mod Enden; det fjerde er kun lidt kortere end hint og paa den bagre Rand forsynet med totte Knipper af lange Børster; det femte Led er noget kortere; Kloen er kort, men stærk.

Det femte og sjette Fodpars første Led er kun lidet udvidet; det tredie bliver meget tykt mod Enden, og det femte er længere end det fjerde; Kloen, der er meget bred, er noget mere end Halvdelen saa lang som det sidste Led.

Det syvende Fodpars forste Led er næsten saa bredt som langt; det tredie, fjerde $0 g^{\sharp}$ femte ere indbyrdes næsten af samme Længde.

Den forste af Halens tre bagre Springfodder naar langt bagud, og det tredie Pars Grene, hvoraf den ydre er ubetydeligt længere end den indre, ere omtrent saa lange som Skaftet.

Hal evedhænget er omtrent saa langt som bredt, paa Enden tvært afskaaret.

Et eneste Exemplar af denne Art blev af mig fundet ved Haugesund paa 6-20 Favnes Dybde.

MONOCULODES PACKARDI, A. Boeck, 1870. ${ }^{1}$

Monoculodes Packardi, A. Boeck, Crust. amphip. bor. et arct. 1870. p. 86.

Rostrum frontale longitudine fere articulum pedunculi 1 mum antennarum superiorum xqvans, apicem versus valde acuminatum, subcurvalum. Oculi in parte basali rostri siti. Antennæ elongatæ; superiores articulo pedunculi 2 do perlongo. tenui, parum longiore qvam 1mo; 3tio brevi. Antennæ inferiores articulo pedunculi 4 to et 5 to perangustis; 4 to paulo longiore et crassiore qvam 5 to. Pedes 1 mi paris

Opkaldt efter Zoologen Professor Packard i Nordamerika. 
manu brevi, apicem versus latiore; calce carpi brevi, in apice rotundata. Pedes 2 di paris manu paulo longiore, ferme duplo longiore qvam lata et apicem versus latiore; calce carpi angusta, ad linem marginis posterioris manus porrecta. Pedes 3 tii et 4 ti paris ungve sat lato et eadem longitudine ac articulo 5to. Pedes 5ti et 6 ti paris articulo 4 to angusto: 5 to multo longiore qvam 4to: ungve pralongato, acuto, ferme eadem longitudine ant longiore quam articulo 5to. Pedes 7 mi paris articulo 4to breviore qvam :3tio, longiore apud marem qvam apud feminam. Pedes saltatorii ultini paris ramis paulo brevioribus qvam pedunculo. Appendix cuudalis paulo longior qvam lata; infra truncata.

Dyrets Langde er $12 \mathrm{~mm}$.

Legemet er temmelig tykt, ikke meget høit. Hovedet gaar fortil ud i et meget langt, temmelig smalt, kun lidet krummet og fortil tilspidset Pandehorn, der er ikke fuldt saa langt som de øvre Føleres første Led. Øinene ere smaa og beliggende ved Hornets Rod, lige overfor Udspringet af de gvre Følere; disse ere forlangede.

De øvre Følere ere noget kortere end de nerle og rage langt udover de nedres Skaft; det andet Led er omtrent saa langt eller noget læingere end det første, men meget smalere; det tredie er kort, omtrent en Trediedel af det foregaaendes Længde og naar ikke ganske frem til Enden af de nedre Føleres Skaft.

De nedre Foleres tredie Led er langere end bredt; det fjerde er noget længere og tykkere end det andet Led paa de ovre Føleres Skaft; det femte er kortere og smalere. Svoben, der dannes af omtrent 18-20 Led, er kortere end Skaftet.

Det forste Fodpar er mindre end det andet; det tredie Led er triangulært og udsender nedad fra dets bagre Side et kort, men bredt Fremspring, besat paa den bagre Rand med en Rakke af knippevis ordnede Borster; det femte Led, eller Haanden, er omtrent dobbelt saa langt som bredt og bliver bredere udad; det er svagt krummet og besat med Borster paa den nederste Del af den bagerste Rand, der er tilrundet.

Det andet Fodpars fjerde Led udsender et længere og smalere Fremspring end paa det første Par; Haanden er meget lingere, men omtrent af samme Form.

De tvende folgende Fodpars tredie Led er lidet udvidet nedad og ueppe længere end det fjerde, der i den forreste Rand er besat med Børsteknipper; det femte er ubetydeligt kortere og svagt krummet; Kloen er saa lang som det sidste Led.

Det femte Fodpars forste Led er kun lidet udvidet, bliver smalere nedad og er i begge Rande, dog mest i den bagre, besat med fjærdanmede Børster; det tredie Led, der er længere end det fjerde, er lidet udvidet nedad; det femte er længere end det fjerde, og Kloen, der er bred, er længere end sidste Led.

Det sjette og syvende Fodpars første Led er pæreformigt, men udvidet opad i den bagre Rand, smalere og indskaaret nedad; det fjerde er omtrent saa langt som det tredie, og det femte er længere og smalere. 
Det femte og sjette Haleled ere meget smale.

Alle Springfodder naa omtrent lige langt bagud; det sidste Pars Grene ere kortere end deres Skaft.

Halevedhænget er ovalt, noget smalere bagud og her tvært afskaaret.

Et Exemplar af denne Art blev af mig taget ved Haugesund. Af.G. O. Sars ere nogle Exemplarer fundne i Christianiafjorden.

MONOCULODES TENUIROSTRATUS, A. Boeck, 1870.

(Pl. XIV. Fig. 4.)

Monoculodes tenuirostratus, A. Boeck, Crust. amphip. bor. et arct. 1870. p. 87.

Rostrum frontale prelongatum, parum modo curvatum, ultra finem articuli 1 mi antennarum superiorum productum. Oculi parvi, ad basin rostri frontalis siti. Antenna superiores articulo pedunculi 1 mo pralongato; 2do parum modo breviore et angustiore qvam lmo. Pedes Imi paris manu lata. fusiformi. longiore qvam carpo; calce carpi breviore qvam dimidia manus longitudine. Pedes 2di paris manu paulo Iongiore qvam eadem $1 \mathrm{mi}$ paris. Pedes 3 tii et 4 ti paris articulo 5 to et ungve longitudine ferme æqualibus. Pedes 5 ti el 6 ti paris praclongati, graciles; articulo 3 tio et 5to longitudine fere rqvalibus; ungve angusto. subicurvato, longitudinem articuli ultimi aqvanti vel parum superanti. Pedes saltatorii elongati; iidem ultimi paris ramo multo breviore qvam pedunculo.

Længden er $12 \mathrm{~mm}$.

Pandehornet er meget forlænget, smalt, svagt krummet og strækker sig frem foran de uvre Foleres forste Skaftled; †inene ere smaa og sidde over Roden af Pandehornet.

De øvre Følere ere lidt langere end de nedres Skaft; deres første Skaftled er tyndt, dog lidt langere og tykkere end det andet.

De nedre Føleres fjerde Skaftled er lidt tykkere, men af samme Langde som det femte; Svgben er næsten saa lang som Skaftet og dannes af omtrent 20 Led.

Det første Fodpars Haand er næsten rhomboidalsk; Griberanden er besat med smaa, hageformede Børster og nogle langere rette.

Det andet Fodpars Haand er ikke meget forlanget, kun lidt mere end dobbelt saa lang som bred; Carpus er ogsaa kort.

De tvende følgende Fodpar ere meget forlængede; det fjerde Led er omtrent saa langt som det femte; Kloen er ubetydeligt lengere, lidt krummet, svagt tilspidset.

Det femte og sjette Fodpars forste Led er ikke meget bredt, bliver smalere nedad $0 \mathrm{~g}$ er forsynet med lange, fjærdannede Borster; det tredie Led er længere end det fjerde og omtrent saa langt, men bredere end det femte; Kloen er særdeles forlænget, længere end det femte Led og lidt krummet. 
Det syvende Fodpars første Led er meget længere end bredt og bliver smalere nedad.

Springføddernes Skaftled ere meget forlængede; Grenene paa det sidste Par ere blot 'Totrediedele af Skaftets Langde.

Denne Art er kun fundet i faa Exemplarer af mig paa et eneste Sted i Christianiafjorlen nær Christiania.

\section{MONOCULODES TUBERCULATUS, A. Boeck, $18 \%$.}

(Pl. XV. Kig. 2.)

Monoculodes tubcreulatus, A. Boeck, Crust. amphip. bor. et arct. 1870. p. 8\%.

Rostrum frontale subcurvatum. in apice acuminatum, non perlongum, attamen ultra medium articulum pedunculi 2dum antennarum superiorum productum. Oculi prope ad basin rostri siti. Antenna superiores articulo pedunculi 2do longitudine $1 \mathrm{mum}$ fere æqvanti et in extremo margine superiore nodo magno, setoso instructo; articulo 3 tio non longiore qvam articulis llagelli setosis. Antenne inferiores articulo pedunculi 4 to et 5 to eadem fere longitudine. Pedes 2di paris manu ferme ter longiore qvam lata, in acie obliqve truncata; calce carpi angusta, ad finem marginis posterioris manus porrecta. Pedes 3 tii et 4 ti paris articulo 3 tio perbrevi et apicem versus latiore; 5 lo longiore et angustiore: ungve parum longiore qvam dimidio articulo 5to. Pedes 5ti paris articulo 4 to angusto, fere dimidiam longitudinem articuli 5ti reqvanti; ungve longiore qvam dimidio articulo 5to. Pedes 6ti paris iisdem 5li paris longiores. Pedes 7 mi paris articulo 3tio breviore qvam 4to; articulo 4 to item breviore qvam 5to. Pedes saltatorii ultimi paris ramis longioribus qvam pedunculo. Appendix caudalis brevis.

Længden er $6^{\mathrm{mm}}$.

Legemet gaar fortil ud i et bredt, lidt krummet Pandehorn, som naar frem til Midten af de ovre Føleres andet Skaftled. Øinene sidde over Udspringet af de øvre Folere paa Pandehornets Rod.

De øvre Følere er korte; det første Led er næsten tre Gange saa langt som tykt; det andet. er noget kortere, og dets øve Rand ender i en stærk, med Børster besat Tuberkel; det tredie Led er kort og kan ikke skilles fra Svobens Led, som ere 8 i Antal.

De nedre Føleres fjerde Led er længere end det femte. Svoben har 16 tynde Led.

Det forste Fodpar er ligt det hos den foregaaende Art.

Det and et Fodpars Haand er omtrent tre Gange saa lang som bred, med en paa Enden skraat afskaaren Griberand, der har enkelte Torne; dets tredie Led saavelsom Hælen paa det fjerde har i den bagre Rand mange Børster. 
De trende følgende Fodpar ere stærke; det tredie Led er kun lidet udvidet; det fjerde er meget kortere end dette og bliver stærkt udvidet mod Enden, saa at det nesten er triangulart; det femte er omtrent saa langt som det fjerde, men smalere, og er paa den bagre Rand væbnet med Torne; Kloen er Totrediedele af det foregaaende Leds Længde, smal, lidt krummet og i Enden spids.

Det femte Fodpars første Led er kun lidet udvidet; den forreste, stærkt krummede Rand er forsynet med Burstebundter; det fjerde er meget kortere og tyndere end det tredie, der har Børstebundter i begge Rande; det femte Led er omtrent saa langt, men meget tyndere end det tredie: Kloen er Totrediedele af det foregaaende Leds Læengde, tynd, spids.

Det følgende Fodpar er meget lingere; det fjerde Ised er kun lidt kortere end det femte.

Det syvende $\mathrm{F}$ odpars forste Led er bredt; det tredie er kortere, men bredere end det fjerde, der igjen er kortere erd det femte; disse Led have i begge Rande en Rad Torneknipper.

Det sidste Par Springfødders Grene ere lange, cylindriske, meget længere end Grundleddet.

Halevedhænget er kort.

Et eneste Exemplar af denne Form har jeg fundet ved Haugesund.

\section{MONOCULODES BOREALIS, A. Boeck, 1870.}

(Pl. XV. Fig. 4.)

Oediceros affinis, Goës, Crust. Amphip. maris Spetsb. p. 11. fig. 21.

(Non Bruzelius.)

Monoculades borealis, A. Boeck, Crust. amphip. bor. et arct. 1870. p. 88.

Rostrum frontale longum, geniculatum, in apice acuminatum. Oculi in genu rostri siti. Antennæ breves. Antennæ superiores articulo pedunculi 1 mo circiter ad extremum rostri apicem porrecto: articulo 2 do multo breviore. Antennæ inferiores articulo pedunculi 4to parum longiore qvam 5to. Pedes 2di paris manu plus qvam duplo longiore ac lata, in acie obliqve truncata; calce carpi ad finem marginis posterioris manus porrecta. Pedes 3 tii et 4 ti paris articulo 4 to et 5 to brevibus, setosis; ungve lato, paulo longiore qram dimidio articulo 5to. Pedes 5 ti et 6ti paris articulo 4to longiore qvam lato; 5to longiore qram 4to; ungve lato, paulo breviore qvam articulo 5to. Pedes $7 \mathrm{mi}$ paris articulo 3 tio et 4 to ferme eadem longitudine. Pedes saltatorii ultimi paris ramis parum brevioribus qvam pedunculo. Appendix caudalis brevis et lata.

L. ængden er $10-12^{\mathrm{mm}}$.

Den ligner meget den foregaaende Art; Pandehornet er i Enden næsten knæformigt 
boiet; Oinene ere ikke store og sidde paa Spidsen af dette Kñ, omtrent lige langt fra Pandehornets Rod og Spids.

De ovre Følere naa lidt langere frem end de nedres Skaft; det første Led naar næsten frem til Pandehornets Spids; det andet er meget kortere; Svoben dannes af $8-10$ Led.

De nedre Føleres fjerde Led er omtrent saa langt som det femte; Svgben har $12-14$ Led.

Det fgrste Fodpars Haand er omtrent dobbelt saa lang som bred.

Det andet Fodpars Haand er tre Gange saa lang som bred, med meget skraat afskaaren Griberand.

Det tredie og fjerde Fodpars fjerde Led er lidt kortere end det femte, som i den forreste, convexe Rand er forsynet med lange Børstebundter: Kloen er stærk, litt langere end det femte Leds halve Længde.

De tvende folgende Fodpars fjerde Led er kortere end det femte, der kun er lidt liengere end den stærke Klo.

Det syvende Fodpars tredie Led er omtrent saa langt, men bredere end det fjerde og femte; Kloen er omtrent saa lang som det sidste Led og ret.

Springfødderne ere korte; det sidste Pars Grene ere ubetydeligt kortere end Skaftet.

Halevedhænget er omtrent saa langt som bredt, i Enden afskaret.

Efter Goës forekommer denne Form ved Spitsbergen. Af G. O. Sars er den taget ved Skraaven paa 5-20 Favne. Iblandt hans Exemplarer fandtes ogsaa et, hvis Hiender paa de tvende forste Fodpar vare liengere og smalere end de avrige, men forovrigt viste det ikke nogen afvigende Bygning.

\section{MONOCULODES LATIMANUS, Goës, 1865.}

Oediceros latimanus, Goès, Crust. Amphip. maris Spetsb. 1865. p. 11. fig. 23.

Honoculodes latimanus, A. Boeck, Crust. amphip. bor. et arct. 1870. p. 88.

Rostrum frontale breve, attamen longitudine arliculo pedunculi 1 mo antennarum superiorum aqvale. Intennæ superiores articulo pedunculi 2do parum breviore et angustiore yvam 1mo; 3tio longiludine et crassitudine parum decrescenti. Antennx inferiores articulo pedunculi 4 to paulo breviore et crassiore qvam 5to. Pedes $1 \mathrm{mi}$ paris manu apicem versus latiore, in acie obliqve truncata; calce carpi perbrevi. Pedes 2 di paris eadem forma ac iidem 1 mi paris, sed paulo majores; calce carpi dimidiam longitudinem marginis posterioris manus aqvanti. Pedes 3 tii et 4 ti paris articulo 4 to et 5to elongatis; 5 to parum modo longiore qvam 4 to et in margine antico curvato et setoso; ungve tenui et multo breviore qvam articulo 5to. Pedes 5ti et 6 ti paris ungve ferme dimidiam longitudinem articuli 5 ti reqvanti. Pedes $7 \mathrm{mi}$ 
paris articulo 4 to breviore qvam 3tio. Appendix caudalis paulo longior qvam lata, infra truncata.

Længden er $7 \mathrm{~mm}$.

Legemet er temmelig sammentrykket, med rund Ryg. Sidepladerne ere store, med fjærdannede Børster i den indre Rand; den første er bredere nedad; den nedre bagre Vinkel paa Hælens Led er afrundet. Hovedet er temmelig stort; Pandehornet er kort, men bredt, noget bøiet.

De øvre Følere ere korte; Skaftets første Led er omtrent dobbelt saa langt som tykt; de tvende folgende aftage baade i Langrle og Tykkelse, men det tredie Led er længere end Totrediedele af det foregaaende; Svøben er noget kortere end Skaftet og dannes af 10 Led.

De nedre Følere ere noget længere end de ovie; Skaftets tredie Led er kort; det fjerde er omtrent dobbelt saa langt som tykt, og det femte er af samme Lrngde, men smalere; Svoben er kortere end Skaftet og bestaar af 14 Led.

Det forste Fodpar er kort, men stærkt; det tredie Leds nedre bagre Vinkel danner en lille Torn; det fjerde Led udsender et meget kort, men bredt, med Børstebundter besat Fremspring; Haanden er meget bred og bliver noget bredere udad.

Det andet Fodpar er længere og smalere; det fjerde Led er kort og smalt; det femte er nasten dobbelt saa langt som bredt, med en Torn midt paa den iudre Rand.

De tvende følgende Fodpar ere ikke meget brede; deres tredie Led udvider sig ubetydeligt; det femte er længere end det fjerde, og Kloen er kort, spids.

Det femte og sjette Fodpar ere ogsaa smale; det tredie Led udvider sig ubetydeligt; det fjerde er meget kortere og smalere, og det femte er langere og smalere end dette.

Det syvende Fodpar er forlænget smalt.

Halevedhænget er bredt, afstumpet paa Enden og forsynet med fire smaa Torne.

Paa de af G. O. Sars ved Brettesnæs og af mig ved Langenæs fundne Exemplarer var Pandehornet kortere, end det er angivet af Goës. Derimod stemte det Exemplar, som af R. Collett blev medbragt fra Finmarken, mere overens med Goës’s Tegning. Af Torell er denne Form medbragt fra Gronland og Spitsbergen. af $\mathrm{R}$. Collett er den fundet i Finmarken, af G. O. Sars og mig i Nordland. En Tegning, som jeg medbragte fra Haugesund, stemmer overens med denne Art, med Undtagelse af at de øvre Føleres andet Skaftled er forkortet, medens det tredie er forlænget; da jeg ikke længere har noget Exemplar, hvorefter min Tegning er gjort, kan jeg ikke afgjore, om den er identisk med denne Art. Dens Legeme var hvidt, Indvoldene gule og Øiet rødt. 
Gen. IV. HALIMEDON, A. Boeck, 1870.

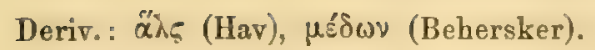

Syn.: 1870. Halimedon, A. Boeck, Crust. amphip. bor. et arct. p. 89.

Typ.: Halimedon Miilleri, A. Boeck.

Mandibulæ in apice parum modo dentatæ et crassa; palpo prælongato et angusto.

Pedes $1 \mathrm{mi}$ paris carpo tam longo aut multo longiore qvam manu ovata et in angulo inferiore postico parum dilatato.

Pedes 2di paris carpo prxlongato, angusto, calce parvula prædito aut destituto; manu tam longa aut breviore qvam carpo.

Denne Slægt, der indbefatter fire Arter, skiller sig ved sine tykke, korte Kindbakker, hvis Gribedele kun ere lidt indskaarne i Tander, og hvis Palper ere længere og tyndere end hos de tvende foregaaende Slagter, fra de ovrige til denne Underfamilie henhørende Slægter. Ved sine tvende første Fodpars Form, hvis fjerde Led eller Carpus er særdeles forlænget, skiller den sig ogsaa i det Ydre fra de nærstaaende Slægter, skjønt der heri maaske kan findes Overgange. Pandehornets Langde varierer ogsaa indenfor denne Sliggt; det er saaledes meget langt hos den typiske Art, medens det hos $H$. longimanus er meget kort. Arterne skilles let fra hverandre baade ved Pandehornets og de tvende forste Fodpars Form, som altid vise karakteristiske Kjendemærker. De øvrige Fodpar ere hos alle Arter temmelig forlængede; dette er mindre Tilfældet med Springfodderne; der dog hos $H$. Saussurei ere forlængede, især det sidste Par.

\section{HALIMEDON MÜLLERI, A. Boeck, 1870. ${ }^{1}$}

(Pl. XIII. Fig. 5.)

Halimedon Mülleri, A. Boeck, Crust. amphip. bor. et arct. 1870. p. 89.

Rostrum frontale longum, tumidum, in apice rotundatum, fere ad finem articuli $1 \mathrm{mi}$ pedunculi antennarum superiorum porrectum. Oculi magni, fere in toto latere rostri positi. Antenne superiores elongatæ; articulo pedunculi 2do parum longiore quam 1mo. Antenna inferiores articulo pedunculi 4 to parum breviore et latiore qvam 5to. Pedes $1 \mathrm{mi}$ paris articulo 3 tio in angulo inferiore postico producto. acuto; carpo apicem versus laliore, cordiformi: manu ovali. Pedes 2di paris articulo 3 tio item in angulo inferiore postico acuminato: carpo multo longiore et angustiore qvam 1 mi paris; manu obovata, breviore qvam carpo. Pedes 3tii et 4 ti paris elongati, angusti; ungve et articulo 5to ferme eadem longitudine; articulo 5to in margine antico setis longis instructo. Pedes 5 ti et 6 ti paris articulo 5to perangusto, longo, paulo longiore quam ungve longissimo, angusto et acuto. Pedes $7 \mathrm{mi}$ paris

\footnotetext{
1 Denne Art er opkaldt efter Zoologen Dr. Müller i Kjobenhava.
} 
articulo 4to fere cadem longitudine ac 3tio; 5to parum longiore. Pedes saltatorii ultimi paris ramis longitudine pedunculo ferme aqvalibus. Appendix caudalis paulo longior quam lata, infra truncata.

Dyrets Læing de er $6 \frac{1}{2}{ }^{\mathrm{mm}}$.

L egemet er fortil tykt, ligesom opblæst, og Ryggen er fortil bred, men bliver smalere bagtil, saa at Halen er tynd. Langs Ryggen findes der ingen Kjøl, medens Ledcnes bagre Del hæver signoget i Midten, saa at Ryggen seet fra Siden synes noget saugtakket. Hovedet er meget stort, og Pandehornet er forlænget, krummet og bærer de store Øine paa den øverste Side nær Spidsen, der dog er fri.

De øvre Følere ere noget længere end de nedres Skaft $\mathrm{og}$ ere temmelig smale. Skaftets forste Led er fire til sex Gange saa langt som tykt og naar frem til Pandehornets Ende; det andet Led er noget kortere, men smalere end det forste; det tredie er omtrent Halvdelen af det foregaaende Leds Længde. Svøben er længere end Skaftet og dannes af 12-16 Led, der paa den indvendige Side ere bedækkede med fine Børster.

De nedre Føleres fjerde og femte Skaftled ere næsten lige lange; men det femte er noget tyndere; begge er forsynede med fine Børster, der staa i Tværrader. Svgben er meget kortere end Skaftet og dannes af 15 Led hos Hunnen, medens den hos Hannen er meget længere $0 \mathrm{~g}$ bestaar af 55-60 Led.

Det forste Fodpar er kortere end det andet; dets fjerde Led er udvidet i den bagre Rand, men danner nedad ingen Hrl, idet Randen der er afrundet og forsynet med Børster. Haanden er ægformig, næsten dobbelt saa lang som bred; Hælen er noget mere end Haandens halve Længde.

Det andet Fodpar er længere og meget smalere end det første; dets første Led er længere end de tre folgende Led tilsammen og er i begge Rande forsynet med lange Børster; det tredie Led er meget kort og gaar i Enden af den bagre Rand ud i en liden Spids; det fjerde er forlanget, bagtil udvidet, og danner der et kort, tildels med knæformigt boierle Borster besat Fremspring; Haanden er forlænget, agdannet, smalere og længere end den paa første Fodpar og er i den bagre Rand forsynet med mange tynde Torne. Kloen er svagt bøiet og længere end Halvdelen af Haanden.

Det tredie og fjerde Fodpar ere forlwngede, smale; deres tredie Led er lidet udvidet; det fjerde er noget kortere og i den bagre Rand forsynet med mange Knipper af Børster; det femte er saa langt som det fjerde og $\mathrm{i}$ den forreste Rand besat med Knipper og Børster.

De tvende følgende Fodpars første Led er lidet udvidet; dette, saavel som det tredie Led, der er meget kortere og lidt udvidet nedad, have i begge Rande fjærdannede Børster; det fjerde Led er noget kortere end det tredie; det femte er langere og smalere. Kloen er saa lang eller noget kortere end det foregaaende Led. Det sidste Fodpar er særdeles forlanget, men dets første Led er dog bredt, 
uregelmæssig firkantet, med stærkt afrundede Hjorner og buet bagre Rand; dets tredie og fjerde Led ere næsten af samme Langile, medens femte Led er langere end disse.

Alle Springfødder naa næsten lige langt bagud.

Det sidste Pars Grene, der ere forsynede med fine Torne, ere lige lange og omtrent saa lange eller lidt kortere end Skaftet.

Halevedhænget er længere end bredt og bliver smalere mod Enden, hvor det er tvært afskaaret eller noget tilrundet.

Denne Art ligner meget $H$. brevicalcar, men skilles letteligen ved det længere Pandehorn og ved, at Carpus paa de to første Fodpar ikke er saa udtrukket som paa hin. De nedre Føleres Led ere ligeledes mere forlængede, og de bagre Springfødders Grene ere lige lange, medens den ydre er kortere hos Hunnen.

Den er fundet af G. O. Sars ved Risnæs paa 180-200 Favne, ved Christiansund paa 50-100 og ved Aalesund paa 60-100 Favne. Ved Haugesund er den fundet af mig paa 60 Favne, ligeledes ved Farsund $0 \mathrm{~g}$ i Christianiafjorlen udenfor Moss paa henved 100 Favnes Dybde.

HALIMEDON SAUSSUREI, A. Boeck, $18700^{1}$

(Pl. XV, Fig. 1.)

Il alimedon Sussurei, A. Boeck, Crust. amphip. bor. et arct. 1870. p. 90.

Rostrum frontale perbreve, vix ultra dimidium articulum pedunculi 1 mum antennarum superiorum porrectum. Antennie superiores articulo pedunculi 2 do parum breviore quam Imo. Antenna inferiores articulo pedunculi 4to ferme eadem longitudine sed crassiore qvam 5to. Pedes 1 mi paris carpo elongato, apicen versus dilatato, calce perbrevi et rotundala instructo; manu breviore qvam carpo, ovata. Pedes 2di paris carpo et manu longitudine requalibus et sat clongatis, perangustis: carpo in angulo inferiore postico non dilatato. Pedes 3tii et 4 ti paris prælongati; articulo 5to parum longiore qvam 4 to et longitudine ungvem longum et angustum rqvanti. Pedes 5ti et 6 ti paris articulo 5to parum longiore quam 4to, multo longiore qvam ungve angusto et in apice acuto. Pedes $7 \mathrm{mi}$ paris articulo 4 to multo longiore qvam 3 tio et 5to. Pedes saltatorii prælongati; ramis ultimi paris parum longioribus qvam dimidio pedunculo. Appendix caudalis brevissima.

Dyrets L $æ \mathrm{ngde}$ er $12 \mathrm{~mm}$.

L e g e met er ikke meget sammentrykket, og Sidepladerne ere ikke meget høie, men forsynede med smaa Børster i den nedre Rand. Hovedet er omtrent saa langt som de tre forste Legemsled tilsammen og gaar fortil ud i et meget kort, men bredt, i Spidsen nedarbøiet Pandehorn. Sidelapperne springe temmelig langt frem og danne med Pandehornet et dybt Indsnit for Befostelsen af de øvre Folere.

De øvre Føleres første Led er meget kortere og noget mindre end Hovedet;

1 Arten er opkaldt efter Zoologen H. de Saussure i Genf. 
det andet er længere, men tyndere end det første, og det tredie er neppe mere end halvt saa langt som det andet. Svoben er kortere end Skaftet $\mathrm{og}$ bestaar hos Hamnen af 15 horte, med fjardannede Borster besatte Led, og hos Hunnen af færre (8), men længere.

De nedre Følere ere meget længere end de ørre; det fjerde Led er lidt længere og tykkere end det femte. Svøben dannes hos Hunnen af 8 Led.

Det første Fodpars fjerde Led er omtrent Halvdelen af det første Leds Længde, bliver meget bredt mod Enden, idet den bagre Rand bliver bredere nedad og er afrundet i Enden og forsynet med en Rokke spidse Torne. Haanden er omtrent saa lang som det fjerde Led, oval, med et langt Fremspring i den bagre Rand, hvor Kloens Spids møder.

Det andet Fodpar er meget langere og smalere; dets fjerde Led er omtrent saa langt som Totrediedelen af det første Led; dets bagre Rand er kun lidet udvidet og forsynet med en Række Torne, der blive længere nedad. Haanden er meget kortere end det foregaaende Led, forlænget, oval.

De tvende folgende Fodpars fjerde Led er meget kortere end det tredie, meget bredere paa Midten end paa Enden og har en Række Borsteknipper i den bagre Rand; det femte Led er længere end det fjerde, noget bøiet $0 \mathrm{~g}$ har i den forreste Rands nedre Del en Række Børsteknipper. Kloen er noget kortere end det sidste Led, smal og lidt bøiet.

Det femte og sjette Fodpars forste Led er kun lidet udvidet og bliver smalere nedad samt har i sine Rande Torne og lange fjærdannede Børster; det fjerde Led er meget kortere end det tredie, og det femte er saa langt som eller ubetydelig kortere end det tredie, men meget smalere. Kloen har kun en Totrediedel af det femte Leds Længde og er smal.

Det sidste Fodpars forste Led er forlænget, dobbelt saa langt som bredt samt bliver smalere nedad; det femte Led er længere, men meget smalere end det tredie, der er længere og bredere end det fjerde. Kloen er lang, dog meget kortere end det sidste Lerl.

Alle de bagre Springfodder naa omtrent lige langt tilbage. Grenene paa det sidste Par ere kun lidt længere end Skaftet.

Halevedhænget er noget længere end bredt, i Enden tvært afskaaret, forsynet med tvende Børster.

Den er fundet af G. 0. Sars i Christiansund paa 50-100 Favne og af mig i Christianiafjorden paa samme Dybde.

HALINIEDON LONGIMANUS, A. Boeck, $18 \%$.

(Pl. XIII. Fig. 6.)

Halimedon longimanus, A. Boeck, Crust. amphip. bor. et arct. 1870. p. 90.

Rostrum frontale perbreve, vix ad dimidium articulum pedunculi 1 mum antennarum superiorum porrectum. Pedes 1 mi paris carpo antice dilatato, claviformi: 
manu ovata. parum breviore qvam carpo. Pedes 2di paris carpo magis elongato qvam apud pedes $1 \mathrm{mi}$ paris, apicem versus parum dilatato et in margine posteriore spinis gracilibus instructo; manu elongata, ovata, paulo longiore qvam dimidio carpo. Pedes 3tii-6ti paris ungve breviore qvam articulo 5to. Pedes $7 \mathrm{mi}$ paris articulo 4 to breviore quam 3tio. Pedes saltatorii breves; ramis ultimi paris tam longis aut parum longioribus quam pedunculo. Appendix caudalis vix longior quam lata.

Dyrets L ængde er $9^{\mathrm{mm}}$.

Legemet el temmelig tykt, og Ryggen bred. Hovedet gaar fortil frem i et lidet Pandehorn, der neppe er Halvdelen, ofte kun en Totrediedel af de ovre Foleres forste Skaftled. Hovedets Sidevinkler ere afskaarne i Spidsen og brede.

De øvre Føleres første Skaftled er meget kortere end Hovedet; det andet er længere, men smalere; det tredie er kun en Trediedel eller en Fjerdedel af det andet Leds Længde. Svøben er hos Hunnen noget kortere end Skaftet og bestaar af 15 Led; hos Hannen er den mere forlænget og bestaar af 20-25 Led.

De nedre Følere ere meget langere end de øvre; Skaftets tredie Led er kort; det fjerde er saa langt som, eller lidt kortere, men meget tykkere end det femte. Svøben dannes af $20-40$ ied.

Kindbakkernes Gribedel er i Spidsen indskaaret i grove Tænder; den indre Bigren er stærk. Palpens tredie Led er meget smalt og kortere end det andet. Underlæbens indre Flige ere meget store og brede.

Det forste Kjæbepars Palpe er i Spidsen væbnet med faa Torne; den indre Plade er meget stor, bred, i Enden afrundet og har tvende Torne.

Kjæbefoddernes ydre Plade er temmelig smal og væbnet $\mathrm{i}$ den indre Rand med 10-12 Tænder, der mod Enden voxe i Længde.

Det første Fodpar er forlænget. Carpus bliver bredere mod Enden, med afrundet bagre Rand, der er besat med to til tre Rader stærke Torne; Haanden er oval, lidt kortere end Carpus; Griberanden er temmelig lang.

Det andet Fodpar er meget længere end det første. Carpus er ikke meget kortere end det forste Led, bliver lidt bredere mod Enden, fordi den bagre Rand bugter sig udad, og paa denne Udbugtning findes der en tæt Rad af temmelig lange, tynde, i Enden boiede Torne. Haanden er længere og smalere end paa det forste Par og kun lidt længere end Halvdelen af Carpus.

Det tredie og fjerde Fodpar ere forlængede; det fjerde Led er omtrent dobbelt saa langt som bredt og $\mathrm{i}$ den bagre convexe Rand besat med en Rad af lange Borsteknipper; det femte er længere end det fjerde; Kloen er ikke fuldt saa lang som det femte Led, kraftig og lidt krummet.

Det femte Fodpars første Led er ikke meget udvidet og har i den forreste Rand lange, fjardannede Borster; det fjerte og femte Led ere narsten lige lange: Kloen er lidt kortere end det sidstnævnte Led. 
Det sjette Fodpars første Led er smalere end det samme paa det foregaaende Fodpar; det femte Led er lidt langere end det fjerde.

Det syvende Fodpars fjerde Led er meget kortere end det tredie, der næsten er saa langt som det femte.

Det tredie Par Springfødders Grene ere lidt længere end deres Skaftled, og den ydre Gren er i den øvre Rand forsynet med tre Torne.

Halevedhænget er ubetydelig længere end bredt og bliver lidt smalere mod Enden.

Den er fundet af G. O. Sars ved Skraaven paa 200-300 Favne. Af mig er den fundet i Christianiafjorden udenfor Moss paa 100 Favne.

\section{HALIMEDON BREVICALCAR, Goës, 1865. †}

(PI. XV. Fig. 3.)

Oediceros brevicalcar, Goës, Crust. Amphip. maris Spetsb. p. 11. fig. 22. Halimedon brevicalcar, A. Boeck, Crust. amphip. bor. et arct. 1870. p. 91.

Rostrum frontale breve, longitudine dimidium articulum pedunculi 1 mum antennarum superiorum aqvans. Pedes $1 \mathrm{mi}$ paris carpo brevi, calce perbrevi instructo; manu ovata, tam longa qvam carpo. Pedes 2 di paris forma pedibus 1 mi paris similes, sed longiores. Pedes $4 \mathrm{ti}$-6ti paris ungve longo, tenui, acuto, parum breviore qvam articulo 5to. Pedes saltatorii ultimi paris ramo interiore multo longiore qvam pedunculus et longiore qvam exterior. Appendix caudalis ferme tam longa quam ad basin lata.

Dyrets Langde er $9^{\mathrm{mm}}$.

Legemet er sammentrykkot. Hovedet er meget kort, kun lidt længere end det forste Legemsled, og gaar fortil frem i et triangulært eller koniskt Pandehorn.

De ovre Foleres første Skaftled er neppe dobbelt saa langt som bredt, men naar dog langt foran Enden af Pandehornet; det andet Led er omtrent saa langt som, men smalere end det forste Led.

De nedre Følere ere noget længere end de øvre; det tredie Skaftled er omtrent saa langt som tykt; det fjerde er saa langt, men lidt tykkere end det femte Led. Svøben er lidt længere end de tvende sidste Skaftled tilsammen.

Det forste og andet Fodpar ere omtrent af indbyrdes samme Bygning, men det andet Par er længere end det første. Carpus er triangulær og udsender fra sin nedre bagre Vinkel en kort, i Spidsen afrundet, med Børster besat Hrel. Haanden er ægformig. Kloen er lidt krummet, smal.

Det tredie og fjerde Fodpars tredie Led er omtrent saa langt som det femte $0 \mathrm{~g}$ meget længere end det fjerde. Kloen er meget lang, spirs og noget liortere end det femte Led.

De tre bagre Fodpar tiltage efterhanden stærkt i Længde; det første Led er 
forlænget xgformigt og forsynet med lange, krumme, fjærdannede Borster i den forreste Rand; det tredic Led er forlænget, smalt, omtrent saa langt som det meget smalere femte Led. Kloen er særdeles lang, tynd, noget kortere end det femte Led.

Det sidste Par Springfodders ydre Gren er omtrent saa lang som Skaftet og meget kortere end den indre.

Halevedhænget er neppe længere end bredt, afrundet i Enden og forsynet merl tvende korte Torne.

Den findes kun sjelden ved Spitsbergen, men oftere ved Island, Norges Kyst og Bohuslän paa 60 Favnes Dybde. Af G. O. Sars er den taget ved Skraaven.

Gen. V. PONTOCRA'TES, A. Boeck, $18 \% 0$.

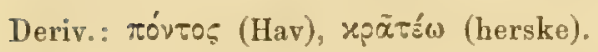

Syn.: 1862. Kröyeria, Spence Bate, Cat. Amphip. Brit. Mus. p. 106.

1863. - Spence Bate and Westwood, Brit. sessile-eyed Crust. p. 171.

1870. Pontocrates, A. Boeck, Crust. amphip. bor. et arct. p. 91.

Typ.: Oediceros norvegicus, A. Boeck.

Pedes $1 \mathrm{mi}$ paris pervalidi; manu magna, lata; calce carpi eadem longitudine ac margine manus posteriore.

Pedes 2di paris manu prælongata, cheliformi; calce carpi prælongata aut absenti.

\section{Cæteroqvin ferme ut apud Oediceros.}

Spence Bate opstillede denne Slægt i 1855, idet han væsentlig skilte den fra Westwoodilla, Oediceros og Monoculodes derved, at Øinene ikke ere sammensmeltede, at det andet Fodpar er saxdannet med en meget forlænget Haand, og ved at Carpus er forlænget i den nedre bagre Vinkel til en Hæl, som naar frem til Enden af Haanden. Denne sidste Karakter passer imidlertid ikke paa Kröyeria haplocheles, Grube, ( $K r$. brenicarpa, Spence Bate \& Westwood), hos hvilken Carpus aldeles ikke er forlauget til nogen Hil. Jeg har ogsaa paavist, at den heller ikke ved Øinenes Form skiller sig fra ITonoculodes, saa at kun den ene Karakter, at det andet Fodpar er saxdannet med en meget forlænget Haand, bliver tilbage. Hertil føiede jeg i 1870, at det forste Fodpars Haand er meget stærk, og saaledes er hos denne Slægt dette Fodpar stærkere end det andet, medens det som oftest er svagere end dette. De øvre Følere ere hos denne Slægt ikke meget kortere end de nedre, og de kumne ogsaa blive næsten lige lange. Den forste Sideplade er ikke meget bredere nedad, saa at den altid synes smalere end den anden.

Da Navnet Kröyeria allerede tidligere var benyttet af van Beneden til Betegnelsen af en Snyltekrebs, har jeg givet denne Slægt et nyt Navn. 
PONTOCRATES NORVEGICUS, A. Boeck, 1860.

(Pl. XVI. Fig. 4).

Oediceros norvegicus, A. Boeck, Forhandl. ved de Skand. Naturf.'s 8 de Møde, 1860. p. 650 .

Kröyeria arenaria, Spence Bate, Tyneside Nat. Field. Club. Vol. IV. pt. 1. p. 15. pl. 2. fig. 1. 1863.

- - Spence Bate, Catal. Amphip. Brit. Mus. 1862. p. 106. pl. XVII. f.4.

- $\quad$ Spence Bate and Westwood, Brit. sessile-eyed Crust. 1860. p. 173.

Pontocrates norvegicus, A. Boeck, Crust. amphip. bor. et arct. 1870. p. 91.

Rostrum frontale breve, in apice obtusum, deorsum non valde curvatum. Antennæ superiores brevissimæ et crassissimæ; articulo pedunculi 1 mo circiter eadem longitudine ac articulis seqventibus junctis aut parum breviore. Antennæ inferiores arliculo pedunculi 4 to et 5 to ferme eadem longitudine. Pedes $1 \mathrm{mi}$ paris manu triangulari non duplo longiore qvam lata, in acie curvata; calce carpi parum modo breviore qram manu. Pedes 2di paris carpo in calcem perlongam, angustam, ultra apicem manus porrectam et infra selosam, produclo. Pedes 3 tii et 4 ti paris breves; articulo 3tio valde dilatato; ungve minimo, vix conspicuo. Pedes saltatorii ultimi paris breves; ramis parum longioribus qvam pedunculo.

Dyrets Længde er $3^{\mathrm{mm}}$.

Legemet er sammentrykket fra Siderne. Hovedet er temmelig stort, medens Pandehornet er temmelig kort og stærkt nedadbøiet.

De $\emptyset$ vre Følere ere noget længere end Hovedet; Skaftets første Led aftage efterhaanden baade i Laugde og Tykkelse; Svoben er omtrent af Skaftets Langde og bestaar af 7 Led.

De nedre Følere ere noget længere end de øvre; det tredie I‘ed er.temmelig tykt; det fjerde $0 \mathrm{~g}$ femte ere næsten af indbyrdes samme Længde; Svoben bestaar af 8-10 Led.

Kindbakkerne ere korte og stærke, i Spidsen kløvede. Fligene ere brede og tandede. Palpen er lang og tynd; det andet Led er meget længere end det tredie Led.

Det første Kjæbepar er i Spidsen stærkt tandet; Palpen er toleddet, og den indre Plade er temmelig stor.

Det andet $\mathrm{Kj}$ æbepars Plader ere korte, men meget brede.

Kjæbeføddernes ydre Plade er liden, forsynet med faa, men lange Tænder; den indre Plade er liden, nxsten firkantet. Palpen er særdeles kraftig; det andet Leds indre Rand er meget udbugtet og har mange Børster.

Det første Fodpar er kort og stærkt; det fjerde Led udsender fra sin nedre bagre Vinkel et langt, smalt Fremspring, der naar til Enden af Haandens bagre Side. Denne er stor, trekantet, med tilrundet forreste Side og noget længere end bred. Kloen er krum, stærk. 
Det andet Fodpar er forlænget og smalt; det forste Led er omtrent saa langt som de følgende Led tilsammen; det andet, tredie og fjerde Led ere korte, det sidste udsender fra sin nedre bagre Vinkel en sxrdeles lang, tynd Forlængelse, der naar til Fnden af det femte Leds forlængede Hjørne eller noget længere; det femte Led er særdeles forlænget og smalt. Det nedre bagre Hjørne forlænger sig i en Tommel, der møder den bevægelige Klo, saa at der dames en Haand. Deme Forlangelse eller Tommel er omtrent saa lang eller noget kortere end Halvdelen af den øvie Haand.

De trende folgende Fodpar ere korte, stærke, med brede Led, hvoraf især de sidste ere besatte med rette, stive Børster; det femte Led, der er forlænget, ovalt, er længere end det fjerde Led. Kloen synes at være rudimentær.

Det femte og sjette Fodpar, der ere strot besatte med rette Torne, tiltage efterhaanden i Længde; ogsaa par disse synes Kloen at mangle.

Det syvende Fodpar er meget forlænget.

Springfoddernes Grene ere cylindrislie; den ydre er noget kortere end den indre.

Det andet $\mathrm{P}$ ar rakker langt tilbage.

Halevedhænget er helt, noget smalere mod Enden end ved Roden.

Denne Art synes at afvige fra den engelske Art arenaria og at adskille sig fra den ved det forste Fodpars Form og ved at det tredie og fjerde Par ere meget stærkere byggede og mangle Klo. Desuden er Følernes Skaft meget kortere end hos hin Art.

Jeg har fundet denne Art ved Haugesund og i Christianiafjorden paa omtrent 30 Favne.

PONTOCRATES HAPLOCHELES, Grube, 1864.

(PI. XVI: Fig. 3).

Kröyeria haplocheles, Grube, Die Insel Lussin etc. 1864. p. 72.

Kröyeria brevicarpa, Spence Bate and Westwood, Brit. sessile-eyed Crust. Vol. II. 1869. p. 508.

Pontocrates haplocheles, A. Boeck, Crust. amphip. bor. et arct. 1870. p. 92.

Rostrum frontale elongatum, deorsum curvatum. Antennæ superiores elongate, angustæ; articulo pedunculi 1 mo et 3tio longitudine fere rovalibus, sed 1 mo crassissimo; 2do parum longiore. Pedes 1 mi paris manu elongata, duplo longiore qvam lata, in acie dentibus obtusis aut nodis instructa; calce carpi longitudine manum dimidiam æqvanti. Pedes 2di paris manu longiore et angustiore qvan apud speciem pracedentem; carpo calce deslituto. Pedes 3tii et 4 ti paris angustiores; ungve minuto sed conspicuo. Pedes saltatorii longiores et angustiores; ramis ultimi paris ferme eadem longitudine ac pedunculo.

Dyret er $5 \frac{1}{2} 2^{\text {mm langt. }}$

Le ge met er forlænget, ikke meget sammentrykket, med bréd Ryg. Sidepladerne 
ere hoie og have Borster paa den nedre frie Rand; den forste er bredere end den anden. Hovedet, der er længere end de tvende første Legemsled, gaar fortil ud i et middelmaadig langt, bøiet Pandehorn; dets Sidevinkler ere brede, ret afskaarne fortil. Føleme ere hos Humen indbyrdes lige lange og saa lange som Hovedet og de tre forste Legemsled tilsammen.

De øvre Foleres første Led er kort, men meget tykt, og det andet er ubetydeligt langere, men meget smalere; det tredie er igjen noget kortere og smalere end dette; Svgben, der omtrent er saa lang som Skaftet, bestaar af 7 forlængede Led.

De nedre Føleres tvende første Led ere sammensmeltede; det tredie er kort; det fjerde er saa langt som de øvre Foleres andet Led; det femte Led er noget kortere end dette. Svgben, der bestaar af 5 forlængede Led, er kortere end Skaftet. Begge Føleres Skaft er forsynet med spredte Knipper af Torne.

Kindbakkerne ere stærke; deres Tyggeflig er meget bred, tolappet, med utydelige Tander. Tormerækken er kort og dannes af $4-5$ rette Torne. Palpen er kort; dens tredie Led er særdeles langt, men kun dobbelt saa langt som bredt.

Det forste Kjæbepar er strerkt, lidet; Palpen er tynd.

Det andet Kjæbepar er særdeles bredt, i Enden forsynet med Torne.

Kjæbefoddernes ydre Plade er i Spirsen væbnet med tvende og i den indre Rand med tre lange, stærke, krumme Torne; den indre Plade er bred og har i Spidsen fire Torne. Palpen er særdeles bred, især dens andet Led; Kloen er lang og stærk. .

Det første Fodpar er meget stærkt; dets fjerde Led er særdeles kort, men den nedre bagre Vinkel forlænger sig til Halvdelen af det femte Leds Langde. Dette er ovalt, mindre buget paa den forreste end paa den bagerste Rand og har der 8-10 Tænder, mellem hvilke der findes nogle fine.Borster. Kloen er lang og krum.

Det andet Fodpar er særdeles forlænget; det forste Led er liniert og krummet; det andet $0 \mathrm{~g}$ tredie ere særdeles korte; det fjerde, der er længere end det første Led, er noget tykkere ved Roden, men bliver lidt efter lidt. tyndere mod Spidsen og danner der en kort, tyud Tommel, der møder det tynde, smale femte Led; langs Midten af Tommelen sees en Fure.

De tvende folgende Fodpars forste Led er noget krummet, midt paa den bagre Rand er der fastet en Dusk Børster; det tredie Led bliver bredere udad og er paa den forreste Rand forsynet med Borsterreker; det fjerde og femte Led ere omtrent lige lange $0 \mathrm{~g}$ væbnede med Børsterækker. Kloen er usynlig.

Det femte og sjette Fodpars forste Led er ikke meget udvidet og har i begge sine Rande smaa Torne og lange fjærdannede Haar; det femte Led er noget kortere og smalere end det fjerde; Kloen er stærk, men kortere end det femte Led. Haleleddenes nedre bagre Vinkler ere afrundede.

De bagre Springfodders forste Par naar længst tilbage; de tvende følgende aftage i Længde og Tykkelse. 
Det tredie Pars Grene, hvoraf den indre er noget kortere end den ydre, ere kortere end Skaftet.

Hal evedhænget er bredt, noget indbugtet i den bagerste Rand.

Hos Hannen naar det første Led paa de øvre Føleres Skaft frem til Enden af Pandehornet; det andet Led er omtrent saa langt som det første, medens det tredie er meget kort, neppe dobbelt saa langt som tykt. Svøbens første Led er længere end de tvende følgende Led tilsammen. De nedre Føleres Svøbe er særdeles forlænget, smalt $0 \mathrm{~g}$ dannes af $40-50$ Led.

Jeg har fundet denne Art ved Haugesund paa 20 Favnes Dybde og i Christianiafjorden.

Gen. VI. ACEROS, A. Boeck, 1860.

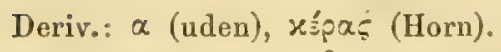

Syn.: 1860. A cero:, A. Boeck, Forhandl. ved det Skand. Naturf, 8 de Møde. 1860. p. 651.

1870. - A. Boeck, Crust. amphip. bor. et arct. p. 92.

Typ.: Lencothö̈ phyllonyx, Sars.

Maxillæ $1 \mathrm{mi}$ paris lamina interna elongata, angusta.

Caput rostro frontali magno destitutum; oculi non coaliti, in lateribus capitis siti; epimera minora qvam apud genus Oediceros.

Antennæ superiores pedunculo prelongato; flagello brevi.

Pedes $1 \mathrm{mi}$ et 2 di paris subcheliformes, non pervalidi; carpo calcem brevem enittenti.

Pedes $7 \mathrm{mi}$ paris pedibus 5 ti el 6ti paris fere duplo'longiores.

Cæteroqvin ferme ut apud genus Oediceros.

Dana opstillede i 1853 en Oediceres Novre-Zealandice, hvilken han henforte til Krøyers Slægi Oediceros, fordi det sidste Fodpar var saa betydeligt længere end de tvende foregaaende Par, hvilket ikke var Tilfaldet med Slagten Iphimedia, men derimod med Oediceros. M. Sars (Overs. over Norsk-Arct. Krebsd. Forhandl. i Vidensk.-Selsk. i Christiania 1858, S. 29) opstillede i 185 s en Amphipodeart, som han kaldte Leucothoë phyllonyx. Derne kunde imidlertid ikke hemregnes til Leucothoë, fra hvilken den skiller sig meget, idet den kun har en svag Lighed med den i de tvende første Fodpars Form. Bruzelius beskrev Aaret efter en lignende Form, som han henførte til Slægten Oediceros. Jeg paaviste i 1860, at disse tre Former i mange Henseender stemme overens med Slægten Oediceros, men at de dog ved det forlangede Skaft paa de øvre Følere og ved at Hovedet ikke danner noget stærkt Horn, hvorpaa Øinene skulde have sin Plads, afvige saa vasentlig fra den typiske Art Oed. saginatus, at disse Arter ikke kunne stilles sammen med den, men maa danne en egen Slægt. I det Ydre stemme de overens med Oediceros derved, at den forste Sideplade bliver meget bredere nedad og seer saaledes 
meget bredere ud end den anden; men de tvende forste Fodpars Hander ere her smaa, og deres Carpus er forlænget, medens det omvendte er Tilfældet hos Slægten Oediceros. Heri ligner den Halimedon, men fra begge adskiller den sig ved, at Pandehornet er aldeles borte, og Øinene sidde saaledes paa Hovedets Sider og ikke paa nogen Forlængelse af dette. Vi have vistnok seet, at dette, om end i noget mindre Grad, er Tilfalitet med flere Arter indenfor slagterne Nonoculodes og Hatimedon, om dog aldrig i saa høi Grad som hos denne Slægt. Hvad der her er paafaldende ved det første Øiekast er, at de øve, Folere blive længere end de nedre; dette beror paa, at Skaftets Led opnaa en usædvanlig Længde; dog forekommer der en Varietet eller maaske rettere en Abnormitet af den typiske Art, hos hvilken de ovre Foleres Skaftled blive meget korte, og en saadan findes aftegnet hos Goës. I Munddelene skiller denne Slagt sig fra de foregaaende ved, at Kjæbefoddernes ydre Plade her er større end hos de ovrige og faar istedetfor de tynde Torne lignende stærkere $\mathrm{i}$ en tat Rad. Det første Kjæbepars indre Plade er her ogsaa mere forlænget.

\section{ACEROS PHYLLONYX, Sars, 1858.}

$$
\text { (PI. XIV. Fig. 7.) }
$$

Lencothö̈ phyllonyx, Sars, Oversigt over Norsk-Arct. Krebsdyr. Forhandl. i Vidensk.Selsk. i Christiauia 1858, p. 148.

Oediceros obtusus, Bruz., Amphip. Gammar, K. Vet.-Akad. Handl. Ny Följd. III. p. 92.1859 .

Aceros obtusus, A. Boeck, Forhandl. veil de Skand. Naturf. 8de Móde. 1860. p. 651. Montagua phyllonyx, Spence Bate, Catal. of Amphip. Brit. Mus. p. 369. A ceros phyllonyx, A. Boeck, Crust. amphip. bor. et arct. 1870. p. 92.

Epimerum 1 mum antice in lobum rolundatum productum. Antenne superiores elongatx, ad segnentum postabdominis 1 mum porrecta; articulo pedunculi 2 do multo longiore quam Imo; 3tio brevissimo. Antemne inferiores articulo pedunculi 4 to et 5to longitudine xqualibus. Pedes $1 \mathrm{mi}$ et 2 di paris eadem forma, sed 2di paris paulo longiores et validiores: calce carpi breviore qvam dimidia manu; hac ovata, parum breviore qvam carpo. Pedes 3 tii et 4 ti paris robusti; articulo 4 to et 5 to ferme eadem longitudine ac ungve perlato, oblongo et eliptico. Pedes saltalorii elongati; iidem ultimi paris ramo interiore paulo longiore qvam exteriore.

- Dyrets L xngde 16 - 20 mim.

Legemet er forlænget, ikke meget sammentrykket, med bred, rund Ryg. Legemets forste Led have callose Rande, og deres Bredde tiltager efterhaanden. Hovedet er ikke fuldt saa langt som Legemets tre første Led tilsammen, og Panden er ikke forsynet med noget Pandehorn; Hovedets Sidevinkler ere heller ikke udtrukne, og dets Sider dække Udspringet for de nedre Fulere. Den forste Sideplade er fortil uddraget 
i en lang, fortil afrundet og med Borster forsynet Lap; den anden er meget smal, og de folgende tiltage efterhandeu i Bredde, dog saa at den fjerde er lidt storre end den femte; den nedre bagre Vinkel paa Halens tre forste Led er stærkt tilrundet.

De gvre Folere ere hos Hunnen noget forlængede og naa omtrent til Halens første eller andet Led; det første Skaftled er omtrent saa langt som Hovedet; det andet er omtrent en Totrediedel længere, men smalere, og det tredie er omtrent en Trediedel af andet Leds Liengde; det forste $0 \mathrm{~g}$ andet Skaftled ere i den ovre Rand forsynede med fjærdannede Borster. Svøben er noget kortere end Skaftet og dannes af $12-20$ Led.

De nedre Følere ere kortere end de øvre; deres tredie Skaftled er kort; det fjerde og femte ere omtrent lige lange; Svøben, der danner 20-30 Led, er længere end Skaftets nederste Led. Hos en Han var begge Følernes Skaft meget forkortet og Svøben forlænget. Overlæben er meget bred, i Spidsen afrundet.

Kindbakkerne ere stærke; Gribedelen er ikke tandet, derimod er den indre Bigren delt i tvende Tænder. Tyggeknuden er meget stor og stærk. Palpen er lang; dens tredie Led er noget kortere og meget smalere end det krummede andet Led.

Det forste $\mathrm{Kj} \rightsquigarrow \mathrm{bepar}$ er kraftigt, i Spidsen rabnet med stærke Torne, der i den indre Rand ere forsynede med faa Bitænder; Palpens andet Led er i Spidsen afrundet og har talrige fine Borster; den indre Plade er agrund og har i Spidsen nogle fjærdaunede Børster.

Det andet Kjabepars Plader ere korte og brede, den ydre lidt længere end den indre.

Kjæbefodderne ere kraftigt udviklede; de indre Plader ere korte, men brede; de ydre ere store, men naa ikke fuldt frem til Enden af Palpens andet Led og ere i den indre Rand væbnede med talrige stærke Torne. Palpen er forlænget; dens andet Led er meget bredt, og dets fjerde er kloformet.

Det forste Fodpars fjerde Led eller Carpus er forlænget, triangulært og gaar i den nedre bagre Vinkel ud i en kort, tilrundet, med Børster forsynet Hæl. Haanden er kortere end Carpus, oval, med mere convex bagerste end forreste Rand.

Det andet Fodpar ligner det forste, men er noget mere forlanget.

Det tredie og fjerde Fodpar ere lange og smale; deres tredie Led er forlanget, ikke meget bredt og omtrent saa langt som de tvende folgende Led tilsammen; disse ere omtrent lige lange og blive bredere udad samt ere forsynede med Børster i Randene; Kloen er omtrent saa lang som det sidste Led og er lancetformet.

Det fèmte og sjette Fodpar ere af indbyrles samme Form og Størrelse; deres første Led bliver smalere nedad og er $\mathrm{i}$ begge Rande forsynet med fjærdannede Børster; det tredie er neppe fuldt saa langt som det fjerde og femte Led tilsammen, der indbyrdes ere lige lange; Kloen er lancetformet.

Det syvende Fodpar er omtrent dobbelt saa langt som de tvende foregaaende Fodpar; dets første Led er meget længere end bredt og bliver smalere nedad; det 
tredie bliver nedad kun lidt udvidet og er omtrent saa langt som det følgende Led, der dog er smalere; det femte er omtrent saa langt som det foregaaende; Kloen er længere end det sidste Led og ret, nedad tilspidset.

Det første Par Springfødders Grene ere smale, meget kortere end Skaftet og vabnede med Torne paa den øvre Rand.

Det andet $\mathrm{Par}$ er kortere, men af den samme Form.

Det tredie Par er af samme Længde, meget smalt og forsynet med Børster, især paa den indre Rand, og er næsten dobbelt saa langt som Skaftet.

Halevedhænget er bredere end langt, svagt indbugtet i den bagre Rand.

F arven er brunlig. Goës har fundet en Varietet, hos hvilken de øvre Føleres Skaftled er meget forkortet, hvor det tredie og fjerde Fodpars fjerde Led er meget udvidet, og hvor Kloen paa tredie, fjerde og femte Fodpar er bladdannet, stump og forlænget.

Efter Goës findes den hist $0 \mathrm{~g}$ her ved Spitsbergen. Af M. Sars og Danielssen er den fundet ikke sjelden ved Vadso paa 30 - 50 Favnes Dybde; af R. Collett i Folden Fjord; af G. 0. Sars ved Skraaven par 300 Favne og ved Aalesund paa 60-100 Favne; af Danielssen i Hardangerfjorden; ved Haugesund har jeg fundet den ikke ualmindelig paa 100 Favne, og efter Bruzelius findes den ved Bohuslän.

Gen. VII. HALICREION, A. Boeck, 1870.

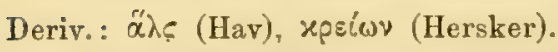

Syn.: 1870. Halicreion, A. Boeck, Crust. amphip. bor. et arct. p. 93.

Typ.: Halicreion longicaudatus, A. Boeck.

Pedes maxillares lamina utraqve minima; palpo prelongato.

Antennæe elongatæ; superiores articulis pedunculi longitudine parum modo decrescentibus et apud marem minimis; articulis flagelli anterioribus maris coalitis.

Pedes $7 \mathrm{mi}$ paris pedibus 5 ti et 6 ti paris paulo, non multo longiores.

Pedes saltatorii $1 \mathrm{mi}$ et 2 di paris postice ad apicem pedunculi ultimi paris porrecti.

Pedes saltatorii ultimi paris pralongati.

Cæteroqvin ferme ut apud genus Oediceros.

Denne Slægt afviger fra de foregaaende til denne Underfamilie henhørende Slægter, ved at det sidste Fodpar ikke er betydeligt forlænget i Forhold til de tvende foregaaende; fremdeles er let sidste Par Springfodder sxrdeles forlængede, hvilket er eiendommeligt for denne Slægt alene. Hos Slægten Oediceropsis er ogsaa det syvende Fodpar mindre forlanget end de foregaaende, men det er dog mindre Tilfældet end hos denne Slægt. Halimedon Saussurei har ogsaa ligesom denne Slægt forlængede bagre Springfodder, men her naar det næstsidste Par ikke længere frem end til Euden af Grunddelen paa det sidste Par. Ved de tvende første Fodpars Form stemmer den 
overens med Slægten Monoculodes: men det er i Sxrdeleshed eiendommeligt ved Halicreion, at hos Hannen blive de ovre Føleres Skaftled forkortede, medens de ere forlængede hos Hunnen; svobens forste Led ere sammensmeltede og have, ligesom hos Anonyx, tvende Rader af Børstebundter langs den indre Side.

\section{HALICREION LONGICAUDATUS, A. Boeck, 1870.}

(PI. XXI. Fig. 3.)

Halicreion longicandatus, A. Boeck, Crust. amphip. bor. et arct. 1870. p. 93.

Rostrum frontale longitudine articulum pedunculi $1 \mathrm{mum}$ antemnarum superiorum aqvans. Pedes $1 \mathrm{mi}$ paris carpo perbrevi et perlato; calce brevi, lata, rotundata; manu ovata, longiore qvam carpo. Pedes 2di paris pedibus 1 mi paris similes, sed longiores et angustiores; manu duplo longiore qvam lata. Pedes 3 tii--6ti paris ungve perlongo, angusto, eadem longitudine ac articulo 5to. Pedes saltatorii ramo exteriore breviore quam interiore; ramo exteriore 3 tii paris longitudine pedunculum ferme aqvanti.

Dyrets $L \Re n g d e$ er $7 \mathrm{~mm}$.

Liegemet er ikke meget sammentrykket fra Siderne, og Ryggen er rund, uden Kiøl eller Torme. De fire første Sideplader ere kun smaa og tiltage efterhaanden ubetydeligt i Storrelse. Hovedet er ontrent saa langt som de tvende Legemsled tilsammen og gaar fortil ud i et langt bøiet Pandehorn, der er længere end de øvre Føleres første Skaftled. Hovedets Sidevinkler ere afrundede.

De øvre Følere ere ikke meget lange; Skaftets første Led er omtrent tre Gange saa langt som tykt, og de tvende folgende Led aftage ubetydeligt i Langde og Tykkelse, saa at det tredie Led er omtrent Totrediedele af det forste Leds Længde eller noget mere. Svoben er kortere end Skaftet og dannes af $5-6$ forlængede Led. Hos en Han var det første Led meget tykt mod Enden, det andet og tredie Led meget korte, dog tykke. Svobens forste Led er meget forlænget $0 \mathrm{~g}$ besat med en dobbelt Tvrerrad af Borster; den lignede saaledes med Hensyn til de ovre Folere Slagten Anomyx.

De nedre Folere ere længere end de ovre. Skaftets tredie Led er ikke dobbelt saa langt-som tykt; det fjerde er næsten fire Gange saa langt og meget langere end det femte. Svoben er lidt langere end Skaftets sidste Led og dannes af 4-5 forlængede Led.

Kindbakkerne ere nneget stærke; Gribedelen er forsynet med fire til sex Tænder, og den indre Bigribedel med fire til fem lignende. Palpen er forlænget; dens tredie Led er langere end det andet,- noget krummet samt forsynet i den indre Rand og paa Enden med Børster; Tyggekuuden er stærkt fremstaaende.

Det forste F o d pars Carpus er i den nedre bagre Vinkel forlænget til en bred, men kort, paa Enden afrundet Hæl; Haanden er omtrent dobbelt saa lang som bred, 
lidt hrummet: Griberanden er skraat afskaren og lidt bøiet samt forsynet merl smaa Torne; Kloen er ikke meget stærk, lidt buet.

Det andet Fodpar er grovere end det føiste; dets Carpus forlanger sig til en Hæl, der er lidt længere og smalere end paa det første Fodpar; Haanden er større, men næsten af den samme Form.

Det tredie og fjerde Fodpars tredie Led er nedad ikke meget udvidet, længere end det fjerde Led, men af samme Længde eller lidt kortere end det femte. Kloen er omtrent saa lang som det femte Led, lidt krummet og paa Enden tilspidset.

De tre sidste Fodpar ere af indbyrdes samme Bygning, men forlæenge sig efterhaanden meget stærkt; deres første Led er ikke meget bredt, bliver smalere nedad $0 \mathrm{~g}$ er forsynet med nogle lange fjærdannede Børster paa Midten af den indre Flade samt med nogle mindre i den bagre Rand; det tredie Led er noget længere end det fjerde og ubelydeligt langere end det femte. Kloen er kun lidt krummet, paa Enden tilspidset og omtrent saa lang som det sidste Led.

De trende forste Par Springfødders ydre Gren er lidt kortere end den indre smale og væbnet med faa Torne i den gvre Rand.

Det tredie Pars Skaft naar nasten til Enden af det andet Par Springfødders ydre Gren, er i den øvre Rand vabnet med nogle Torne; den ydre Gren er lidt kortere end den indre og omtrent saa lang som Skaftet.

Hal eved hanget er lidet, i Enden afrundet eller svagt indbugtet.

Af denne Art har jeg fundel et enkelt Exemplar paa 30 Favnes Dybde i Christianiafjorden og i samme Dybde ved Haugesund.

Gen. VIII. OEDICEROPSIS, Lilljeborg, 1865.

Deriv: Oediceros og ö४เ६ (Udseende).

Syn.: 1865. Oedicerapsis, Lilljeborg, On the Lysianassa magellanica etc. 1865. p. 19.

1870. - A. Boeck, Crust. amphip. bor. et arct. p. 94.

Typ.: Oediceropsis brevicornis, Lilljeborg.

Maxilla 2di paris lamina exteriore multo angustiore qvam interiore.

Caput rostro frontali destitutum. Oculi in lateribus capitis siti.

Antennæ superiores perbreves, inferioribus multo breviores.

Antennæ inferiores articulo 4 to prælongato.

Pedes ultimi paris iisdem pracedentibus non duplo longiores.

Reliqva cum genere Oediceros ferme conveniunt.

Slægten blev af Lilljeborg 1865 opstillet paa Arten Oed. brericomis. Han fremhæver, at den i Legemsform meget ligner Slægten Oediceros, men afviger, ved at Hovedet mangler Horn og ved at det syvende Fodpar, der har en lang ret Klo, er noget, dog ikke dobbelt saa lang, som de tvende foregaaende Fodpar. Desuden ere 
de ovre Folere kortere end de nedre Foleres Skaft. De nedre Folere ere forløugede, næsten foddannede; Skaftets næstsidste Led er længere end det sidste samt er i Spidsen forsynet med en lang gror Borste. Hos denne bliver ogsa den forste Sideplade bredere nedad, og de fire forste ere i det Hele større end hos de foregaaende Slægter. Hovedet er ogsaa mere forlanget, skjont det mangler Pandehorn. De tvende forste Fodpars Form stemmer overens med de tilsvareude hos Slægten Oediccros; de fire folgende Fodpar ere mere forlængede, end det sædvanligt er Tilfældet hos de ovrige Slægter, undtagen hos Halicreion, og derfor er det syvende Fodpar heller ikke dobbelt saa langt som de tvende foregaaende. Det forste Kjæbepars indre Plade er temmelig forlænget, men især eiendommeligt er det andet Kjæbepars indre Plade, der er meget bredere end den ydre.

OEDICEROPSIS BREVICORNIS, Lilljeborg, 1865.

(P1. XIII. Fig. 2.)

Oediceropsis brevicornis, Lilljeborg, On the Lysianassa Magellanica etc. 1865. p. 19.

A. Boeck, Crust. amphip, bor. et arct. 1870. p. 94.

Antennæ superiores non ad finem articuli pedunculi fti antenmarum inferiorum porrectæ; articulis pedunculi gradatim magnitudine decrescenlibus. Antemme inferiores articulo pedunculi 3 tio perbrevi; 4 to fere duplo longiore qvam 5to, et in margine inferiore seta una perlonga et crassa instructo. Pedes $1 \mathrm{mi}$ et 2 di paris ferme eadem forma, sed pedes 2 di paris parum majores qvam iidem Imi paris; carpo brevi : calce item brevi et infra rotundata; manu permagna, ovata. Pedes 3tii et 4 ti paris prelongati, angusti; ungve paulo breviore qvam articulo jo. Pedes saltatorii 1 mi el 2 di paris ramo exteriore parum breviore qvam interiore; iidem ultimi paris ramo exteriore ferme endem longitudine aut parum longiore ac articulo pedunculi.

Dyret er $10^{\mathrm{mm}}$ langt fra Hovedets Ende til Halevedhænget.

Legemet er temmeligt tykt, ligesom opblast fortil, men bliver mere sammentrykket bagtil paa Halen. Ryggen er rund, uden Kjøl eller Torne. Sidepladerne ere høie, besatte med Børster paa den nedre Rand; den første af disse er temmelig bred; de tvende folgende ere smale, og den fjerde er dybt indskaaret bagtil for den femte, der er noget bredere end høi. Hovedet er forlinget, ikke fuld saa langt som Legemets tre forste Led tilsammen, og gaar fortil ud i et særdeles lidet Pandehorn mellem de ovre Folere. Øinene ere adskilte $0 \mathrm{~g}$ findes paa Siden af Hovedet bagenfor de ovre Følere; de ere af en oval Form.

De øvre Følere ere kortere end Hovedet og naa ikke frem til Enden af det fjerde Led paa de nedres Skaft. Skaftets første Led er omtrent tre Gange saa langt som tykt, og de trende folgende aftage efter himanden i Længde og Tylikelse. Svoben, der er kortere end Skaftet, dannes af 7 med Børster besatte Led. 
De nedre Foleres første og andet Skaftled ere meget korte, og det andet gaar nedad ud i en kort stump Knude; det tredie Led er kortere end bredt; det fjerde er særdeles stort, tykt og omtrent saa langt som de -øve Følere; paa Enden af den nedre Rand er der fæstet en lang, stærk Borste; det femte Led er meget kortere og smalere, i den ovre Rand vabnet med tre stærke Børster og i Enden af den nedre Rand med et Knippe lignende. Svoben er noget kortere end Skaftet og dannes af 30 meget korte Led.

Overlæben er meget bredere end høi, uden Indsnit i Spidsen.

Kindbakkerne ere meget stærke, i Spidsen kløvede; begge Grene ere væbnede med mange Tæuder. Tyggeknuden er stærkt fremstaaende og har mange fine Tænder. Palpen er forlænget; dens andet Led er længere end det tredie.

Det $\mathrm{f} ø \mathrm{rste} \mathrm{Kj}$ æb e $\mathrm{p}$ ar er lidet; den ydre Plade er paa Enden besat med nogle faa kamformede Tænder. Palpens forste Led er udad noget udvidet, medens det andet er forlænget. Den indre Plade er liden.

Det andet $\mathrm{Kj}$ æ be $\mathrm{p}$ ar er lidet; den indre Plade er meget bredere end den ydre.

K jæbef $ø$ dderne ere forlængede; Palpens andet Led er forlænget, i den indre Rand udvidet og forsynet med mange Borster; dens tredie Led er kort.

De tvende forste Fodpar ere af indbyrdes samme Bygning og af næsten samme Størrelse; deres fjerde Led er meget lort og gaar bagtil ud i et kort, stumpt, med Børster besat Fremspring. Haanden er meget stor, forlænget, oval og $\mathrm{i}$ den bagre Rand vabnet med smaa fine Torne. Kloen er lang, svagt krummet og uden Tænder.

Det tredie og fjerde Fodpar ere forlængede og smale; deres tredie Led er lidet urvidet; det fjerde er meget kortere, og det femte er næsten af samme Lrengde, men meget smalere. Kiloen er noget kortere end det femte Led, næsten knivformet.

De trende folgende. Fodpars forste Led er lidet udvidet bagtil; det tredie er omtrent af samme Længde som det forste. Alle Led ere i Randene forsynede med fine Borster.

Det syvende Fodpar er meget længere end de tvende foregarende; det forste Led er bagtil udvidet, men dog hoiere end bredt; det tredie er meget længere end det forste og langere end hvert af de folgende. Kloen er omtrent af den samme Længde, smal og tilspidset. Alle Led ere i Randene, især i den forreste, forsynede med Knipper af Torne.

Alle Springfodder naa næsten lige langt bagud; deres Grene ere lige lange og have paa den gvre Rand smaa Torne.

Det sidste Pars Grene ere kun lidet kortere end Grundleddet.

Halevedhæuget er lidet, næsten firkantet, med tvært afskaaren Ende.

F arven er gul, øinene røde.

Af Lilljeborg er den fundet i et enkelt Exemplar ved Molde paa 40-50 Favnes Dybde, af G. O. Sars ved Risvær paa 50-100. 
Gen. IX. PLEUS'TES, Spence Bate, 1858.

Deriv.: (?)

Syn.: 1858. Pleustes, Spence Bate, Ann. Nat. Hist. ser. 3. vol. 1. p. 362.

1859. Paramphithö̈, Bruzelius, Skand. Amphip. Gammar. Kgl. Vet. Akad. Handlingar. Ny följd. III. p. 68.

1860. - A. Boeck, Forhandl. ved de. Skand. Naturf.'s 8de Møde. p. 662 .

1862. Pleustes, Spence Bate, Catal. Amphip. Crust. Brit. 'Mus. p. 61.

1870. Paramphithoë, A. Boeck, Crust. amphip. bor. et aret.p. 94.

Typ.: Amphithoё panopla, Kroyer, ( $P$. tuberculatus, Spence Bate).

Labium superius profunde fissum.

Mandibulæ dissimiles; altera ramo accessorio instructs, altera hoc distituta; articulo palpi 3tio Jongitudinem 2di ferme xeqvanti.

Maxillæ Imi paris lamina externa ungvibus gracilibus instrucla; his partim in margine interiore serralis, partim in apice furcatis; palpo in apice spinis instructo; lamina interua parva, selis paucis armata.

Pedes maxillares lamina interna brevi sed lata; externa parva, in margine interiore spinis gracilibus instructa; palpo elongato et articnlo ejusdem ultimo ungvem longum, in margine interiore serratum, formanti.

Antennæ superiores inferioribus longiores.

Epimera qvatuor anteriora magna aut longitudinis mediocris et magnitudine gradatim crescentia.

Caput in rostrum frontale, plerumgrve validum, productum.

Pedes $1 \mathrm{mi}$ et 2 di paris plus minusve robusti, invicem. fere eadem forma; carpo brevi, ex angulo posteriore inferiore calcem parvam emittenti.

Pedes saltatorii ramo exteriore breviore qvam interiore.

Appendix caudalis parva, integra.

[Genus Pleustes ad subfumiliam Oedicerina vix referendum est].

Spence Bate opstillede denne Slægt paa Arten Pleustes tuberculatus, der er synonym med Amphithoë panopla, Kr., og som altsaa er Typus paa denne Slægt. Han fremhæver vasentlig de smaa Plader paa Kjæbefoddeme. I 1859 opstillede Bruzelius en Slrgt Paramphithoè, hvilken han gar folgende Diagnose: Corpus compressum, epimeris mediocribus aut magnis. Oculi duo compositi. Antennæ superiores graciles, articulo tertio pedunculi articulis Hagelli crassiore, sed flagello appendiculari carentes. Mandibula palpo triarticulato. Palpus maxillæe primi paris biarticulatus, pe- 
dum maxillarium e qvatuor articulis compositus. Pedes primi secundiqve paris manu subcheliformi instructi. Pedes septimi paris reliqvis pedibus non duplo longiores. Pedes abdominis ultimi paris biramei, ramis elongatis.

Til denne Sliggt henførte han Arterne $P$. panopla, $P$. pulchella, $P$. hystrix, $P$. compressa, $P$. bicuspis, $P$. clegans, $P$. lavinscula, $P$. Norvegica og desuden Acanthosonia hystrix. Arten $P$. hystrix var imidlertid før af Owen stillet som Typus paa en egen Slrgt Acanthosoma. Arten $P$. compressa henhorer til den af Leach opstillede Slægt Atylus. I 1860 paaviste jeg, at indenfor den af Bruzelius opstillede Slægt Paramplithoë fandtes mange Arter, som generisk ikke kunde hore sammen, og jeg optog dette Bruzelius's Slægtsnavn for Arterne $P$. panopla og $P$. pulchella, medens en af de ovrige blev opstillet under den ny Slagt Epidesura (Atylus) og Arterne $P$. elegans, $P$. laviuscula, $P$. bicuspis og $P$. tridentata under Slægtsnavnet Amphithopsis, hvortil jeg foiede tvende nye, $A$. glaber $0 \mathrm{~g}$ A. longicaudata. Den saaledes begrandsede Silggt Paramphithö hlev herved synonym med den Aaret iforveien opstillede Slægt Pleustes, ${ }^{1}$ Derimod anvender Spence Bate Slægtsnavnet Paramphithoë istedetfor. Acanthosoma, Owen, hvilket Navn forhen var benyttet. I 1870 anvendte jeg Slægtsnavnet Paramphithoë for Arterne A. pulchella, Kr., og A. panopla, Kr., samt for P. media, Goës, P. bicuspis, Kir., P. parva, A. Boeck, og P. glabra, A. Boeck, da jeg troede, at Slægtsnavnet Paramphithoë var aldre end Pleustes.

\section{PLEUSTES GLABER, A. Boeck, 1860.}

\section{(Pl. XXI, Fig. 1.)}

Amp thithopsis glaber, A. Boeck, Forhandl. ved de Skand. Naturf.'s 8de Møde. 1860. p. 662 .

Paramphithoё exigua, Goës, Crust. Amplip. maris Spetsb. 1865. p. fig. 12.

Paramphithoё glabra, A. Boeck, Crust. amphip. bor. et arct. 1870. p. 95.

Corpus non valde compressum, non peraltum vixque carinatum. Frons in rostrum breve, acutum producta. Oculi ovales, fere reniformes. Epimera tria anteriora in angulo inferiore postico hamulis singulis armata. Segmentum postabdominis 3tium angulo inferiore postico recto aut parum producto et acuto. Antenne superiores articulo pedunculi Imo Iongitudinem articulorum duorum seqventiun junclorum anquanti et in extremo margine inferiore in spinam longam producto. Pedes $1 \mathrm{mi}$ et 2 di paris manu clongata, ovata, multo longiore qvam carpo. Pedes 2di paris carpo in angulo inferiore postico parum producto. Pedes trium parium ultimorum articulo 1 mo postice dilatato et serrato. Appendix caudalis apicem versus angustior.

1 Denne Slrgt blev af Lilljeborg i 1865 stillet i hans Underfamilie Lencothoinae sammen med Leucothoë, Montagua og Stenothoë par. Grund af, at Kjæbefoddernes Plader ere meget smaa. 
Dyret er $7 \mathrm{~mm}$ langt.

L e g e m et er ikke sammentrykt, men Ryggen er rund, uden Kjøl. Sidepladerne ere høie; den første er smalere end de følgende og næsten skjult; de tre første Sidepladers nedre bagre Vinkel danner en fremadrettet Klo; den fjerde er noget bredere end de foregaaende og er bagtil svagt indskaaret. Hovedet er næsten saa langt som de tvende første Legemsled og gaar fortil mellem de øvre Følere ud i et langt Pandehorn; dets Sidevinkler ere spidse.

De $\emptyset$ v r e F $ø$ l eres første Skaftled er omtrent saa langt som Hovedet 0 g gaar nedad ud i et langt spidst Fremspring, der ikke naar fuldt til Enden af det andet Led; dette sidste er ikke halvt saa langt som det forste; det tredie er meget kort. Svoben, der hos Hunnen bestaar af 38-40 Led, er mere end dobbelt saa lang som Skaftet.

De nedre Folere ere meget kortere end de ovre. Skaftets andet Led udsender et langt, spidst Fremspring; det tredie er omtrent saa langt som tykt; det fjerde er omtrent tre Gange saa langt, og det femte har samme Længde som dette. Svoben er smal, længere end Skaftet og bestaar hos Hunnen af 24 Led.

Kjæbefoddernes ydre Plade er liden og smal; Palpen er forlænget, smal og vibnet med en stærk Klo.

De tvende forste Fodpar ere nosten af indbyrdes samme Form og Størrelse, men paa det andet Par udsender det fjerde Leds nedre bagre Vinkel et stumpt, med Børsteknipper besat Fremspring, luvilket mangler hos det forste Par. Haanden er forlænget, oval og vabnet i sin bagre Rand, hvor Kloens Spids møder, med tvende Par Torne, der staa noget over hinauden.

Det tredie og fjerde Fodpar ere stærke og besatte med Torneknipper $\mathrm{i}$ den bagre Rand; deres femte Led er længere end det tredie og meget langere end det fjerde.

De tre folgende Fodpars femte Led er ligeledes længere end det tredie.

De tre bagre Springfødders forste Par naar længst bagud, og dets ydre Gren er kun lidt kortere end den indre; derimod er den meget kortere paa de tvende folgende Par, og især paa det sidste, hvor den kun er lidt læugere end Halvdelen af den indre Gren.

H aleved honget er forlænget, xgformigt, afrundet paa Enden.

F arven er straagul, overstrøet overalt med talrige brune Pletter, der ere txttest paa Ryggen og miudre trtte paa Sidepladerne; paa Bagsiden er den gulhvid.

Den forekommer efter Goës ved Spitsbergen lige op til. $80^{\circ}$. Ved Grønland er den fanget af Torell i Dawis-Strædet, ligesom ogsaa ved Island. Ved Finmarken er den taget af Lovén, af $R$. Collett ved Nordkap paa 30-60 Favnes Dybde. Ved Haugesund er den meget sjelden, derimod ikke ualmindelig i Christianiafjorden, hvor jeg ogsaa har fundet en Varietet med et kortere Led paa de ovre Foleres Skaft. 
PLEUSTES MEDIUS, Goës, 1865. -

Paramphithoë media, Goës, Crust. Amphip. maris Spetsb. 1865. p. \%. fig. 13.

A. Boeck, Crust. amphip. bor. et arct. 1870. p. 96.

Corpus sat crassum. Dorsum vix carinatum. Caput in margine anteriore in rostrum frontale perlongum productum. Epimera qvatuor anteriora hamulis destitula. Oculi parvi, rolundi, oblongi, nigri. Antennæ superiores articulo pedunculi 1 mo breviore qvam apud speciem præcedentem, non spinoso. Pedes 1 mi et 2 di paris ferme ut apud $P$. glaber. Appendix caudalis lata, in apice rotundata.

Længden er omtrent $8^{\mathrm{mm}}$.

Legemet er temmelig høit, sammentrykket; Ryggen er bred, rund; de tre forste Sideplader ere meget høie; den fjerde er næsten saa bred som høi og dybt indskaaret i den ørre Del af den bagre Rand for den femte; den nedre bagre Vinkel paa det tredie Haleled er udtrukket, tilspidset; Hovedet er omtrent saa langt som de trende forste Legemsled og gaar fortil ud i et meget langt, bredt Pandehorn. Øinene ere smaa, næsten nyreformede.

De øvre Foleres forste Skaftled naar ikke saa langt frem som til Spidsen af Pandehornet.

De nedre Føleres fjerde og femte Skaftled ere meget korte.

Det forste Fodpars Carpus er triangulær; Haanden er oval, med stærkere convex bagerste end forreste Rand.

Det andet Fodpar er af samme Form, men lidt længere.

De tre sidste Fodpar ere længere og smalere end de foregaaende; deres første Led er ovalt; den bagerste Rand er saugtakket; den forreste har faa, men grove Torne.

Halevedhænget bliver ikke smalere udad, men er afrundet.

Denne Art er alene fundet ved Spitsbergen af Torell paa forskjellige Steder, men ikke hyppig, paa 20 Favnes Dybde.

\section{PLEUSTES PANOPLUS, Krøyer, 1838.}

(P1. XXI. Fig. 2.)

Amphithoё panopla, Kroyer, Grønlands Amphipoder. Kgl. Danske Vid.-Selsk. Afhandl. 1838. p. 270. tab. 2. fig. 9 .

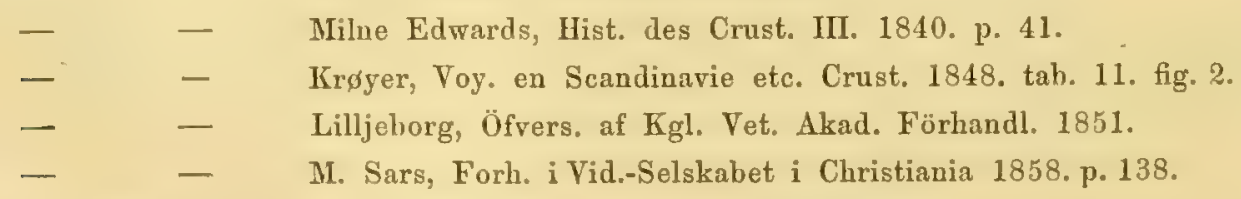

Pleustes panoplus, Spence Bate, Ann. Magaz. Nat. Hist. ser. 3. vol. 1. 1858. p. 362. Spence Bate, Catal. Amphip. Crust. Brit. Mus. 1862. p. 63. pl. IX. f. 8. 
Pleustes tuberculata, Spence Bate, Ann.\& Mag. Nat. Hist. 1868. ser. 3. vol. 1. p. 362. Pleustes tuberculatus, Spence Bate, Catal. Amphip. Crust. Brit. Mus. 1862. p. 62. pl. IX. fig. 8.

Paramphithö̈ panopla, Bruzelius, Skand. Amphip. Gamm., Kgl. Vetensk. Akad.'s Handlingar. Ny följd. 1859. B. 3. p. 69.

- - Goës, Crust. Amphip. maris Spetsb. 1865. p. \%.

- - A. Boeck, Crust. amphip. bor. et arct. 18\%0. p. 96.

Corpus crassissimum. Caput in margine anteriore in rostrum frontale robustum, triangulare sed in apice obtusum, productum. Dorsum angulatum vel carinatum. Carina segmentorum trunci duorum posteriorum et postabdominis trium anteriorum validissima. Carina in utroqve latere carina accessoria instructa; hac in segmentis postabdominis qvinque anterioribus in nodos desinenti. Pedes $1 \mathrm{mi}$ et 2di paris manu ovata, permagna; carpo in angulo inferiore postico in calcem brevem producto. Pedes saltatorii ramo exteriore multo longiore qvam pedunculo. Appendix candalis ferme eadem longitudine ac latitudine, in margine posteriore truncata.

L angden er $10^{\mathrm{mm}}$.

Legemet er tykt med bred Ryg. Legemsbelækningen er meget tyk og ru samt med ophøiede Punkter. Hovedet er saa langt som de tvende første Legemsled tilsammen og gaar fortil ud i et bredt, paa den ovre Side udhulet, i Enden tvært afskaaret Pandehorn, der naar til Enden af de øvre Føleres første Skaftled. Øinene ere store, runde, halvkugleformig fremstaaende. En Kjol strækker sig langs Midtlinien af den brede Ryg fra Hovedet til Halens sidste Led, men er dog utydelig par de sidste. Legemsleddenes nedre Rand er fortykket, og de tre sidste I.eds nedre, bagre Vinkel danner bagudrettede Fremspring. Halens første Led danner paa hver.Side af Ryggens Kjøl, nær den bagre Rand, en bag- og opadrettet Knule, der paa det følgende. Led bliver meget lang, men er atter mindre paa det tredie Led, hvor der ogsaa foran Randen sees en Kjøl, der mod Enden danner en liden Knude. Paa de folgende Led er Formen ligedan, men begge Knuder ere her lige store. Nedenfor disse Sidetorne danner den bagre Rand paa de tvende forste Led en skarp Vinkel. Sidepladerne ere megethoie og smale; den fjerde er den storste og bagtil meget udskaaret for den femte, der er firkantet med en Kjol, der naar det bagre Hjorne og danner der en Torn; de tvende folgende ere dannede paa samme Maade, men ere mindre.

De øvre Følere ere længere end de nedre. Skaftet er kort, og dets første Led naar saa langt frem som til Pandehornets Ende. De tvende folgende Led aftage baade i Langde og Bredde. Svoben er omtrent dobbelt saa lang som Skaftet og dannes af 30 korte Led.

De nedre Føleres tredie Skaftled er kort og gaar paa den ovre Rand ud $\mathrm{i}$ en Spids; det fjerde og femte Led ere omtrent lige lange. Svøben er omtrent saa lang som Skaftet og dannes af 20-22 Led. 
Kindbakkerne ere kraftig udviklede. Spidsen er meget bred, og begge Grene have mange Tænder. Palpens tredie Led er noget længere end det andet.

Det første Kjæbepars Palpe er smal; det andet Led er ikke meget stort og uden Børster.

Kjabefoddernes Palpe er bred og stærk; den indre Plade er bred og forsynet paa Randen med korte Fremspring; den ydre er forlænget.

Det forste Fodpar er meget mindre end det andet; dets tredie Led gaar bagtil ud i en liort Spids, og det fjerde forlænger sig i en ikle meget lang og smal Spore. Haanden er forlænget, oval og nær Midten af den bagre Rand væbnet med tvende Torne i et Indsnit, hvor den smale, krumme Klo møder; Randen, hvor denne lagger sig imod, er væbnet med korte Borster.

Det andet Fodpar er af samme Bygning som det foregaaende, men er stærkere; det tredie Leds Fremspring er ogsaa stærkere, og Sporen paa det fjerde er længere.

Det tredie og fjerde Fodpar ere lange og smale.

De tre folgende Fodpar tiltage meget i Langde; deres forste Led er forlænget, ovalt: det tredie er smalt, omtrent saa langt som det forste; det fjerde Led er liun noget mere end halvt saa langt og meget smalere; det femte er noget liengere end det fjerde.

Det forste Par Springfodder naar længst bagud; dets Grene ere indbyxdes lige lange, meget længere end Grundleddet, og forsynede med mange Torne.

Paa det andet Par er-den ydre Gren noget kortere end den indre og paa det sidste Par meget kortere end den indre, som nasten er fire Gange saa lang som Grundleddet.

M. Sars fremhever i 1858, at Halen paa den norske Form er mere knudret end efter Iirnyer's Beskivelse, og han foreslaar, at denne norske Form kaldes $P$. panoploides. Den stemmer imidlertid deri fuldstandig orerens med de gronlandslie Exemplarer, og Kroyer Iar kun overseet dette.

Efter M. Sars er Farven paa de Exemplarer, som han fandt ved Vadsø, rustbrun, marmoreret med hvidt, eller mørkebrun, med talrige hvide Prikker eller store uregelmæssige Pletter. De cirkelrunde, halvkugleformig fremragende Øine ere lyserode. De af mig iagttagne Exemplarer havde en gulbrun eller gulbrid Farve med lys-sotbrune Baand over det fjerde og femte samt syvende og ottende Legemsled. Iignende Baand strakte sig over de tre forste Sideplader og den forreste Rand af den fjerde samt over det forste Led af de bagre Fodpar. Paa Halen saaes lys-sotbrune Pletter.

Den er fundet ved Gronland, Spitsbergen, hvor den er meget hyppig paa 3-30 Favnes Dybde; af Danielssen og M. Sars er den fundet ved Vadsø, af R. Collett ved Nordkap, forøvrigt i Finmarken af Lovén og Malmgren, ved Groto af M. Sars ; den skal gaa lige ned til Bergen. 
PLEUSTES PARVUS, A. Boeck, $18 \%$.

(PI. XXIII Fig. 5.)

Paramphithoë parva, A. Boeck, Crust. amphip. bor. et arct. 1870. p. 97.

Corpus peraltum. Epimera item peralta et angusta. Dorsum non carinatum. Rostrum frontale non perlongum, perlatum, in apice rolundatum. Oculi parvuli, rotundi. Antennze sat breves. Pedes $1 \mathrm{mi}$ et 2di paris manu ovata. Pedes trium parium ultimorum articulo 1 mo parum dilatato, duplo longiore qvam lato. Pedes saltatorii ultimi paris ramo interiore brevissimo, parum modo longiore qvam pedunculo: ramo exteriore longiore. Appendix candalis circiter eadem longitudine ac latitudine, in apice Iruncata.

Langden er $7^{\mathrm{mm}}$.

Legemet er temmelig sammentrylket og høit, dog er Ryggen bred og rund, uden Kjol og Fremspring. Den nedre bagre Vinkel par det tredie Haleled er lidt tilspidset. Sidepladerne ere meget høie, firkantede; den fjerde el to til tre Gange høiere end bred og paa den bagre Rand ikke meget indskaret for den femte. Hovedet er ikke fuldt saa langt som de tvende forste Legemsled; det gaar fortil frem i et sardeles bredt, temmelig langt, fortil stærkt afrundet Pandehorn. Øinene ere meget smaa, runde.

De ovre Føleres forste Skaftled naar ikke frem til Pandehornets Spids; det andet $0 \mathrm{~g}$ tredie aftage i Langde og i Bredde. Svoben er noget langere end Skaftet og dannes af 2 Led.

De nedre Folere naa lidt længere frem end de ovre; deres tredie Led er kun lidt længere end bredt; det fjerde og femte ere omtrent lige lange. Svoben dannes af $6 \mathrm{I}$ serd.

Det forste og andet Fodpars fjerde Led er meget kort; den nedre bagre Vinkel paa det tredie Led er tilspidset; paa det fjerde gaar den ud i en kort og smal Hæl. Haanden er ægformet; dens Griberand er besat med fine 'lorne og tvende meget stærke lignende paa det Sted, hvor Kloens Spids møder. Kloen er lang og krummet, i Linden spids.

Det tredie og fjerde Fodpar ere forlængede.

De tre følgende Fodpar ere indbyrdes næsten af samme Form og tiltage ubetydelig i Langde; deres forste Led er nasten firkantet, med afrundet nedre bagre Vinkel og noget mere end dobbelt saa langt som bredt; deres tredie Led er ikke meget udvidet, kortere, eller saa langt som det fjerde, der er kortere end det femte. Kloen er stærk, lang og lidt krummet.

Det sidste Par Springfodders Grundled er kort og naar kun lidt længere frem end Halevedhænget, der omtrent er saa langt som bredt. Den ydre Gren er meget liengere end den indre, der er omtrent saa lang som Halevedhænget; begge ere smale.

Den er fundet af mig ved Haugesund paa 20 Favnes Dybde i eet Exemplar. 
Amphithoë pulchella, Kroyer, Voy. en Scandinavie etc. 1848. pl. 10. f. 2.

Paramphithoë pulchella, Bruzelius, Skand. Amphip. Gamm. Kgl. Vet. Akad. Handl.

Ny följd. III. 1859. p. 70.

Pherusa pulchella, Spence Bate, Catal. Amphip. Crust. Brit. Mus. 1862. p. 143. pl. XXVII. fig. 5 .

Paramphithö̈ pulchella, Goës, Crust. Amphip. maris Spetsb. 1865. p. 9.

A. Boeck, Crust. amphip. bor. et arct. 1870. p. 97.

Corpus altum. Epimera non tam magna qvam apud species præcedentes. Caput rostro frontali perbrevi sed perlato instructum. Angulus capitis lateralis rotundatus. Dorsum carinatum; carina postice magnitudine crescenti, in margine posteriore segmentorum trunci trium posteriorum et postabdominis duorum anteriorum in dentes validos producta. Segmentum postabdominis 3tium gibbere alto, acuto instructum. Epimerum $1 \mathrm{mum}$ in apice paululum acuminatum, triangulare. Epimera tria anteriora in margine posteriore serrata. Segmenta postabdominis tria anteriora in angulo posteriore inferiore acuminata. Antenne superiores inferioribus duplo longiores et longitudinem corporis superantes; articulo pedunculi 1 mo ter fere longiore fqum crasso. Pedes $1 \mathrm{mi}$ et 2 di paris graciles, longitudine fere ærqvales; manu oblonga, ovali, parum modo longiore qvam carpo. Appendix caudalis in apice rotundata.

Længden er $11^{\mathrm{mm}}$ fra Pandehornet til Halevedhængets Ende.

L e ge met er temmelig tykt, med meget stive Bedækninger. En Kjøl strækker sig fra det andet Legemsled til det tredie Haleled; den er kun svag paa de første Led, men danner paa det fjerde $0 \mathrm{~g}$ folgende Legemsled samt paa Halens tvende forste Led stærke, bagudrettede Tænder, der efterhaanden blive storre. Paa det tredie Haleled danner den en stump Forhoining eller undertiden en Tand. De fire forste Sideplader ere meget høiere end brede $0 \mathrm{~g}$ tiltage efterhaanden i Længde; den fjerde er den høieste og bredeste $\mathrm{g} g$ er $\mathrm{i}$ den ovre Del af den bagre Rand dybt indskaaret for den femte, der fortil er afrundet $0 \mathrm{~g}$ bagtil vinkelformig dannet samt med et dybt Indsnit paa den undre Rand for det femte Fodpar; de tvende folgende Sideplader aftage i Størrelse. De tre forste Haleleds nedre bagre Vinkel er meget udtrukket og tilspidset, især den tredie, der danner en lidt opadboiet Hage. Hovedet er længere end det første Legemsled og gaar fortil ud $i$ et bredt Pandehorn, der har en Kjøl i Midtlinien paa den ørre Side. Hovedets Sidevinkler mellem de øvre og nedre Folere danne en tilrundet liden Lap. Oinene ere kugleformet fremstaaende.

De gvre Folere ere noget kortere end Legemet; Skaftets forste Led er 
omtrent saa langt som Hovedet; det andet er meget kortere og smalere; det tredie er knapt dobbelt saa langt som tykt. Svøben dannes af omtrent 90 korte Led.

De nedre Følere ere meget kortere og smalere end de ovre; Skaftets forste Led er meget tykt; det andet udsender en lang Lugteknude; det tredie er noget længere end bredt; det fjerde er omtrent dobbelt saa langt og naar frem til Enden af de ovre Føleres første Led; det femte Led er omtrent saa langt som det fjerde og det andet Led paa de ovre Folere. Svgben dannes af omtrent 40 korte Led.

Kindbakkerne ere kraftig udviklede og af den sædvanlige Form.

Det forste Kjæbepar er meget bredt; den ydre Plades Ende har lange Torne uden Bitænder; den indre Plade er meget bred oval og har fjærdannede Børster i Spidsen. Palpen er bred, med fire Torne og mange Borster i Spidsen.

Kjabefoddernes indre Plade er kort, bred og forsynet med tvende smaa Tænder og flere Børster i Spidsen; den ydre er kort, naar kun frem til lidt over Enden af Palpens forste Led og er paa den indre Rand forsynet med svage Torne. Palpen er særdeles forlænget, kraftig; det andet Led er længere end det forste, og det tredie er omtrent af samme Langde, men smalere end det andet; alle Led ere paa den indre Rand væbnede med stærke Børster. Kloen er lang, smal og ret.

De trende forste Fodpar ere indbyrdes af samme Bygning, men det andet Par er noget storre; deres Haand, der er forlænget og bliver bredere mod Enden samt har en meget skraa afskaaret Griberand, er longere end det fjerde Led. Det forste Led er $\mathrm{i}$ den forreste Rand forsynet med lange Borster; det tredie og fjerde Led samt Haanden ere i den bagre væbnede med stærke Torne.

Det tredie og fjerde Fodpars tredie Led er meget smalt; det folgende er meget kortere, og det femte noget længere end det fjerde; alle ere forsynede i den bagre Rand med Knipper af Torne.

De tre følgende Fodpar ere nasten lige lange og af indbyrdes samme Form. Deres forste Led er bredt, saugtakket $\mathrm{i}$ den bagre Rand $\mathrm{og} \mathrm{i}$ den forreste forsynet med Knipper af Torne; det tredie Led er noget udvidet bagtil, og dets nedre bagre Vinkel er meget udtrukket; det fjerde er kortere; og det femte er længere end det tredie; alle tre lave paa den forreste Rand Knipper af starke Torne.

Det første Par Springfodder naar længst bagud; dets ydre Gren er noget kortere end den indre; paa det andet $0 \mathrm{~g}$ tredie Par, som er det korteste, er dette end mere Tilfoldet. Alle Grene ere cylindriske og forsynede med talrige Torne.

Halevedhænget er lidet, noget længere end bredt, udelt.

Den er fundet ved Grouland og Spitsbergen paa flere Steder, ligeledes ved Island; ved Norges Vestkyst er den fundet lige ned til Bohuslen, deriblandt af G. O. Sars ved Hvidingsø paa 150 Favne; i Nordland er den talrig paa de store Koralstilke, saaledes ved Melø. 
PLEUSTES BICUSPIS, Ḱrøyer, 1838.

Amphithö̈ bicuspis, Kroyer, Gronlands Amphip. Danske Vid.-Selsk. Afhandl. VII. 1838. p. 273. tab. 2. fig. 10 .

- Milne Edwards, Hist. des Crust. III. 1840. p. 28.

Paramphithoё bieuspis, Bruzelius, Skand. Amphip. Gamm. 1859. p. 73.

A. Boeck, Crust. amphip. bor. et arct. 1870. p. 98.

Amphithopsis bicuspis, A. Boeck, Forhandl. ved de Skand. Naturf.'s 8de Møde 1860. p. 662.

Pherusa cirrus, Spence Bate, Catal. Amphip. Crust. Brit. Mus. 1862. p. 143. pl. XXVII. f. 6. Pherusa bicuspis, Spence Bate, Catal. Amphip. Crust. Brit. Mus. 1862. p. 144. pl. XXVII. f. $\%$.

- - Spence Bate and Westwood, Brit. sessile-eyed Crust. 1863. p. 253.

Caput rostro frontali perparvo instructum. Corpus elongatum; epimeris multo minoribus qram apud species antecedentes; dorso rolundato. Segmentum postabdominis $1 \mathrm{mum}$ et $2 \mathrm{dum}$ in medio margine posteriore spinis singulis armalum. Angulus inferior posticus segmenti postablominis 3tii sursum subcurvatus et aculus. Antennx elongatre. Pedes $1 \mathrm{mi}$ et 2di paris manu magna et ovala, in acie spinis tenuibus armata. Pedes saltatorii ultimi paris ramo interiore plus qvam duplo longiore qvam pedunculo. Appendix caudalis elongata, ovata.

Langden er omtrent $6 \% 10 \mathrm{~mm}$.

Lege met er temmelig tykt, af middelmaadig Hoide og med rund Ryg; dennes Midtlinie danner ingen Kjol, men en saadan gaar paa det forste og andet Haleled ud i korte Torne. Foreningen mellem det tredie og fjerde Haleled danner en ikke meget stærk Pukkel. Hovedet er kun noget længere end det første Legemsled og gaar fortil ud $\mathrm{i}$ et kort, bredt Pandehorn mellem de ovre Følere; dets Sidevinkler ere afrundede. Øinene ere temmelig store, ovale eller svagt nyreformige. De fire forste Sideplader ere hoiere end brede og tiltage efter hverandre i Storrelse. Den nedre bagre Vinkel paa det tredie Haleled danner en liden opadbøiet Hage.

De $\emptyset$ vre Følere ere længere end Legemet; Skaftets forste Led er saa langt som eller noget kortere end Hovedet, og de tvende folgende aftage i Langde og Tykkelse. Svoben dannes hos Hannen af 90 Led og er fem Gange saa lang som Skaftet.

De nedre Folere ere meget kortere end de øvre; Skaftets tredie Led er omtrent saa langt som tykt sant naar frem til Enden af de gvre Foleres første Skaftled; det fjerde, der er noget længere, naar frem til det andet Leds Ende; det femte Led er ubetydeligt længere, men smalere end det fjerde og paa den indre Side forsynet med Knipper af korte, stærke Børster. Svoben, der omtrent er dobbelt saa lang som Skaftet, dannes af henved 60 Led. 
Kindbakkerne ere ulige paa begge Sider; den hoire har otte Trender, hvoraf den tredie indenfra er den storste, og en stærk indre Bigren, der dannes af syv Tæuder, der udad aftage lidt efter lidt i Størrelse. Tornerækken damnes af tolv til fjorten med fine Saugtakker forsynede Børster. Tyggeknuden er fremstanende. Palpens andet Led er det længste og krummet; det tredie er noget kortere og krummet, bliver smalere mod begge Ender og er. i den convexe Rand forsynet med mange korte fjærdannede Borster, der paa Enden blive længere.

Det første Kjabepars ydre Plade er kort, men bred og har lange, smale, tildels fint saugtakkede Tænder; den indre Plade er ikke meget stor, oval, og har tre fjærdannede Borster. Palpen er væbnet med fire stærke, korte Torne samt med en længere $0 \mathrm{~g}$ tyndere.

Kjæbefoddernes indre Plade er kun noget længere end bred og i Spidsen væbnet med fire Tænder, hvoraf to $\mathrm{og}$ to ere stillede hinanden nærmere, og desuden med nogle længere krummede tornformede Borster; den ydre Plade naar kun frem noget foran for Palpens forste Led og har i den indre Rand og i Spidsen et Antal tynde Torne. Palpens andet Led er noget længere end det første; det tredie er omtrent af samme Længde, men smalere og ovalt; det fjerde danner en lang, noget krummet, stærk Klo, der paa den indre Rand har smaa, fine Borster.

De trende forste Fodpar ere næsten af indbyrdes samme Form og Storrelse. Haanden er forlænget oval, med en laug Griberand, der indtager den største Del af den bagre Rand og er forsynet med fine Torne samt med flere længere Torne eller Tornerader. Kloen er lang og noget krummet. Haanden er noget mere forlænget paa det andet Par end paa det forste. Carpus er paa det andet Par mere udtrukket i den nedre bagre Vinkel end paa det første Par, inen los begge forsynet med Bundter af Borster.

Det tredie og fjerde Fodpar ere forlængede, smale.

De tre folgende Fodpar ere af indbyrdes samme Form og tiltage ubetydeligt efter hverandre i Langde; deres forste Led er ovalt, paa den bagre Rand fint saugtakket og paa den forreste vabnet med Torne; det tredie Led er noget krummet, ikke meget udvidet eller udtrukket i den nedre bagre Vinkel, men i begge Rande besat med flere Knipper af Torne.

Det første Par Springfødders Grene ere næsten lige lange.

Det andet Pars ydre Gren er noget kortere end den indre.

Det sidste Pars ydre Gren har kun Totrediedelen af den indres Langde, men er meget længere end det korte, tykke Grundled. Dette samt begge Grene paa alle Par have stærke Torne paa begge Rande.

Halevedhænget er omtrent dobbelt saa langt som bredt, ovalt og udelt.

Ved Grønland forekommer den paa flere Steder og ligeledes ved Spitsbergen paa 3-20 Favne lige op til $80^{\circ} \mathrm{n}$. Bredde.

Af Lovén er den taget paa Norges Vestkyst og lige ned til Bohuslen; 
Danielssen har fundet den ved Christianssund, hvor den er sjelden paa 10-30 Favne. Ved England og Irland forekommer den ogsaa efter Spence Bate og Norman.

\section{Subfamilia VI.}

DEXAMINAF, A. Boeck, 1870.

Syn.: 1870. Dexaminae, A. Boeck, Crust. amphip. bor. et aret. p. 106.

Mandibula pervalidx, in apice dilatata et dentatx; ramo interiore accessorio item dentato; tuberculo molari valde prominenti et lato; serie spinarum ex spinis paucis, sed latis, in margine convexo serratis, composita; palpo absenti.

Labium inferius latum; lamina interiore minima.

Maxillæ $1 \mathrm{mi}$ paris palpo 1articulatn, in apice maxillæ sinistræ dentibus, in apice dextræ spinis armato; lamina interiore parvula.

Maxillæ 2di paris angustæ.

Pedes maxillares lamina exteriore magna; spinis angustis armata; lamina interiore non permagna, in apice setis instructa: palpo angustissimo, tenui, articulo ultimo ungviformi destituto. Corpus compressum. Dorsum latum. Segmentum postabdominis 5tum et $6 \mathrm{tum}$ coalita. Segmenta postabdominis anteriora carinata; carina dentes retroversos formanti. Epimera vel magna vel parva.

Antennæ elongatæ; superiores flagello appendiculari carentes.

Pedes $1 \mathrm{mi}$ et 2 di paris ferme eadem forma.

Pedes 3 tii - 7 mi paris omnes plus minusve subcheliformes.

Pedes saltatorii biramei; 2 di paris brevissimi, et ramo exteriore breviore qvam interiore; 3tii paris ramis laminiformibus.

Appendix caudalis longa et fissa.

Denne Underfamilie indbefatter liun tvende Slægter og slutter sig i flere Henseender til den følgende Underfamilie Atylince, men afviger fra denne især derved, at Kindbaklierne mangle Palpe, at det furste Kjabepars Palpe er enleddet, og at Kjobefoddernes Palpe mangler det sidste kloformede Led. I Legemets ydre Bygning derimod vise de stor Overensstemmelse, saaledes at Arter snart have været henførte til Slægten Dexamine og snart til Slagten Atylus. Fra Underfamilien Oedicerince adskiller den sig derimod meget $\mathrm{i}$ den ydre Form derved, at Sidepladerne vel ere store, men opnaa her ikke den Stivhed som hos hin Underfamilie, og ved at Halevedhænget her er meget forlænget og dybt kløvet. Med Iphimedinae viser den i det Ydre en større Overensstemmelse, men den adskiller sig karakteristisk og let fra begge Underfamilier ved at Halens femte og sjette Led ere sammenvoxne hos denne, medens de ere skilte hos hine. Munddelenes Form er saa karakteristisk, at trods den store Lig- 
hed i den ydre Form med den folgende Underfamilie maa den skilles fra denne, hvortil jeg forst var tilbøielig til at henregne den. De tvende herhen hørende Slægter vise en noget fra hinanden afvigende Bygning i det Yolre derved, at Sidepladerne ere temmelig store hos Dexamine, men derimod meget smaa og stive hos Tritaeta. De stemme overens deri, at Halens femte $\mathrm{og}$ sjette Led hos begge ere fuldstæulig sammenvoxne. Munddelene vise ogsaa en stor Overensstemmelse mellem begge, med Lunltagelse af at Kjæbeføddernes ydre Plader hos den sidste Slægt ere længere end de korte Palper, men temmelig smale og krummede samt kun paa Enden besatte med faa Torne, medens de hos den første ere meget brede og store, dog kortere end de mere forlængede Palper, og paa sin indre Rand besatte med tynde Torne. I de fem bagre Fodpars Form skilles ogsaa begge Slagter let i det Ydre, ved at hos Dexamine er det tredie Led temmelig kort, og det fjerde og femte temmelig langt, medens det Omvendte er Tilfældet hos Tritaeta.

Gen. I. DEXAMINE, Leach, 1813.

Deriv.: $\delta \varepsilon \xi x \mu \varepsilon v \dot{~(e n ~ N e r e i d e) . ~}$

Syn.: 1813. Dexamine, Leach, Edinb. Encyc, vol. VII. p. 433.

1814. - Leach, Zoological Misc. vol. II. p. 23.

1825. - Desmarest, Consid. sur les Crust." p. 263.

1859. - - Bruzelius, Skand. Amphip. Gamm. p. 37.

1860. - A. Boeck, Forhandl. ved de Skand. Naturf.'s 8de Møde. p. 658.

1862. - Spence Bate, Catal. Amphip. Crust. Brit. Mus. p. 130.

1863. - Spence Bate and Westwood, Brit. sessile-eyed Crust. p. 236.

1864. - Grube, Beschreib. einiger Amphip. der Istrisch. Fauna. Archiv f. Naturgesch. p. 195.

1867. - Heller, Z. näh. Kennt. d. Amphip. des Adriat. Meeres. p. 30.

1870. - A. Boeck, Crust. amphip. bor. et arct. p. 106.

Typ.: Cancer (Gammarus) spinosa, Montagu.

Pedes maxillares lamina exteriore in margine interiore spinis armata; lamina interiore in apice paucas setas tenues gerenti.

Epimera magna, in margine inferiore rotundata; qvatuor anteriora epimero 5 to multo altiora.

Antennæ superiores inferioribus longiores.

Pedes qvinqve ultimorum parium articulo 4 to et 5 to elongatis; ungvibus longis, subcurvatis.

Denne Slægt blev opstillet af Leach i 1813 og optaget af Desmarest i 1825, men ikke af Milne Edwards i 1840 i hans Hist. des Crust. Tom. III. Dana optager den heller ikke i „United States explor. exped." 1853. Spence Bate optager atter 
Slægten ligesom Bruzelius og jeg i $1859 \mathrm{og}$-1860. 'Typus for denne er den af Montagu beskrevne Gammans spinosus. Leach beskriver ikke Nunddelene, men adskiller den kun fra de uærstaaende Slægter ved Folernes Bygning, hvilket ogsaa Desmarest i 1825 gjentager. Først Spence Bate anfører i 1857 den eiendommelige Karakter, at Kindbakkerne mangle Palpe. Bruzelius fremhaver i 1859 endvidere som Karakter det forste Kjobepars og Kjxbefoddernes eiendommelige Bygning. Costa adskiller fra Mine Ldwards Slægt Amphithoë, hvorunder ogsaa den typiske Art Dexamine spinosa horer, (Amphithoë Marionis, Milne Edwards), de Former, der have et kjølet, tandet eller tornet Legeme, under Navn af Amphithonotus. Herunder kommer da en stor Mangde Amphipodearter at natte henfores, der for vare henregnede til forshjellige Slagter, deriblandt A. acanthophthatmus, der udentvivl er synonym med Dexamine spinosa og A. spiniventris, der visselig ogsaa er en Art Dexamine, saa at denne Slægt Amplithonotus maa stilles synonym med Dexamine foruden med Here andre. Costas Slagtsnavn er optaget senere som Navn for en anden Slagt af Stimpson, medens Costas Navn er synonymt med Dexamine. Paa Grund af de ovre Foleres tredie korte Skaftled anser Spence Bate og Grube dette Led̀ at tilhore Svoben og opfører saaledes som Slagtskarakter, at Skaftet er toleddet, hvilket ikke er Tilfældet.

\section{DEXAMINE SPLNOSA, Montagu, 1818.}

(P1. XI. Fig, 5).

Cancer (Gammarus) spinosus, Montagu, Transact. of the Linn. Soc. 1818. vol. XI. p. 3. tab. II. fig. 1 .

Dexamine spinosa, Leach, Edinb. Encyc. vol. VII. p. 433. Transact. of the Linn. Soc. XI. p. 358 .
- - Desmarest, Consid. sur les Crust. 1825. p. 263. pl. XLV. fig. 6. - - White, Popular Hist. Brit. Crust. 1837. p. 178. pl. X. fig. 7.
- - Spence Bate, Catal. Amphip. Crust. Brit. Mus. 1862. p. 130. pl. XXIV. fig. 1.
- $\quad$ - Spence Bate and Westwood, Brit. sessile-eyed Crust. 1863. B. 1. p. 237.
- _ A. Boeck, Crust. amphip. bor. et arct. 1870. p. $10 \%$

Amphithoё Marionis, Milne Edwards, Ann. des Sci. Nat. XX. 1830. p. 375. Hist. des Crust. t. III. 1840. p. 40.

Amphitoë tenuicornis, Rathke, Fauna d. Norwegens, Acta Leopold. 1843. t. XX. p. 77. tab. 4. fig. 3.

Amphitoë spinosa, Gosse, Mar. Zool. 1855. p. 144.

Amphitonotus Marionis, Costa, R. sui crost. amfip. d. regno d. Napoli, Mem. d. real. accad. d. sci. di Napoli 185\%. p. 195.

Dexamine tenuicornis, Bruzelius, Skand. Amphip. Gamm. 1859. p. 79. 
Oculi magni, reniformes. Antennæ superiores articulo pedunculi 1 mo in angulo inferiore in spinam obtusam producto. Pedes $1 \mathrm{mi}$ paris manu ovata, in margine posteriore spinis duabus gracilibus, validissimis, armata. Pedes 2di paris manu parum breviore qvam carpo, elongata, ovata. Pedes 7mi paris articulo 1 mo dilatato; articulo 3tio longitudine Itum superanti. Segmenta postabdominis qvaluor arteriora carinata; carinis dentes formantibus.

L $æ n g d$ en er $14^{\mathrm{mm}}$.

Legemet er høit, men dog ikke meget sammentrykt; Ryggen er rund paa det forreste Parti, men har en Kjol paa de fire forste Haleled og gaar her, paa Enden af den bagre Rand, ud i en skarp, bagud rettet Tand. De tyende første Haleleds nedre, bagre Vinkel er tilspidset, og paa det tredie er den udtrukket til en opadbøiet Tand. De fire første Sideplader tiltage efter hverandre i Storrelse. Hovedet danner fortil et kort Pandehorn, og dets Sidevinkler ere tilspidsede. Øinene ere store, nyreformede.

De øvre F glere ere lidt længere end de nedre; det forste Led er meget kortere end Hovedet og er forlænget paa Enden af den nedre Rand til en Tand; det andet er meget lingere, men tyndere, og det tredie Led er kort. Svoben er længere end Skaftet $\mathrm{og}$ dannes af $35-45$ korte Led.

De nedre Føleres tredie Led er meget kort; det fjerde og femte ere nasten lige lange. Svoben er kortere end Skaftet og dannet af omtrent 30 Led.

Kindbakkerne ere særdeles stærke. Den wvre Gren er bred, delt i 4--6 Tænder; den indre Bigren er meget stor paa den ene, men liden paa den anden Side; Tornerækken dannes af tre lange Borster; Tyggeknuden er strer, indskaaret bueformet paa den undre Rand, der er væbnet i Midten med tvende stærke, og paa hver Side med tre korte Tænder og tvende lange Børster. Palpen mangler.

Underlabens ydre Plader ere meget brede, medens de indre ere smale on sidde ved Roden af de ydre.

Det forste Kjæbepars ydre Plade har lange, men stærke, paa den concave Rand saugtakkede Tænder; den indre Plade er liden, ægformet, med en Børste paa Enden. Palpeı er lang, krum, eenleddet, i Spidsen forsynet med Trender paa den ene Side og kun med Børster paa den anden.

Det andet Kjæbepar er lidet; begge Plader ere lige brede, men den ydre naar lidt længere frem end den indre.

Kjæbefoddernes ydre Plade er særdeles stor, med en næsten ret indre og en buet ydre Rand; den første er fint saugtakket og har desuden stærke Torne, der mod Spidsen forlænge sig og gaa mod den ydre Rand over til krumme Børster, hvilke ere fæstede ikke fuldkommen i Randen, men lidt paa den indre Side. Den indre Plade er meget liden, med nogle Børster paa Enden. Palpen naar kun lidt langere frem end den ydre Plade; dens tredie Led er meget kortere end det andet; det fjerde mangler. 
Det forste Fodpars første Led har paa begge Rande lange Børster; det fjerde er triangulært og kortere end Haanden, der er ægformet, og hvis Griberand har paa Enden tvende stærke Tænder samt langs Randen fine Torne. Kloen er meget stærk, spids, saugtakket.

Det andet Fodpar er længere og smalere; det fjerde Led er længere end Haanden, der er nasten dobbelt saa lang som bred, men forøvrigt er lig den paa det forste Fodpar.

Det tredie og fjerde Fodpars tredie Led er lidet udvidet, kun lidt længere end det fjerde og kortere end det femte Led, livilket paa den bagre Rand har 3-4 grove Torne. Kloen er-stserk, spids, lidt kortere end det sidste Led.

De tre følgende Fodpars første Led er ikke meget udvidet bagtil, deres forreste Rand er besat med stærke Torne; det tredie Led er længere end det fjerde og saa langt som det femte Led, hvilket er forsynet med grove Torne.

Det første Par Springfødders Grene ere lange, smale og lige store samt har fine Torne paa den ovre Rand.

Det a ndet Par er kortere end det forste, og dets ydre Gren er lidt kortere end den indre.

Det sidste Pars Grene ere lige lange, meget længere end Grundleddet, smale, lancetformede, og have fine Torne paa begge Kanter.

Halevedhrnget er meget forlænget, smalere bagtil, og er kløvet til Midten, Fligernes ydre Rand er besat med Torne.

Farven er efter Bruzelius hvidagtig, med søgrønt Anstrøg paa Sidepladerne. Ledilene, især Halens, ere bestroede med stjerneformede lyserode eller bleggule Pletter; tvers over den bagre Del af Halens Led gaa grønne og rode Baand. Folerne og Springfodderne ere undertiden blodrode, Winene ere hvidagtige. Jeg har fundet nogle Exemplarer, der ere næsten hvide med spredte, røde Flekker, der paa Legemets forreste $0 \mathrm{~g}$ Halens Led dame afbrudte Baand; nogle Exemplarer have været gulhvide med lignende Pletter.

Nordligst er den fundet af Danielssen ved Vadsø i eet Exemplar paa Lerbund, paa 20-30 Favne, og ved Christiansund paa 40 Favne; af G. O. Sars ved Skraaven par 6-20 Favne og ved Hvidingsøerne; af $R$. Collett i Foldenfjord; af Rathke i Throndhjemsfjorden. Ved Haugesund har jeg fundet den temmelig hyppig paa flere Steder, ligesom i Christianiafjorden udenfor Moss paa 20 Favnes Dybde. Efter Bruzelius gaar den lige ned til Kullen. Ved Skotland er den taget af Norman, og forøvrigt paa mange Steder ved Englands, Skotlands og Irlands Kyster, ved Shetland af Norman, ved Bretagne af Milne Edwards. Den findes if havet; Costa har taget den ved Neapel. 
DEXAMINE THEA. A. Boeck 1860.

(PI. XII. fig. 1.)

Dexamine Thea. A. Boeck, Forh. ved de skand. Naturf. 8 de Mosde 1860, p. 658 . Crust. amphip. bor. et arct. 1870, p. 107.

Oculi parvi, ovales. Antennx superiores articulo pedunculi 1 mo non armato; articulo 2do fere duplo longiore qvam 1mo. Pedes 1 mi paris manu apicem versus latiore, in acie obliqve truncata. Pedes 2 di paris manu longiore qvam carpo. Pedes $7 \mathrm{mi}$ paris articulo $1 \mathrm{mo}$ non dilatato sed anguslo; articulo 3 tio, 4 to et 5 to longitudine fere æqvalibus. Corpus ferme ut apud speciem præcedentem, sed altius.

Langden er omtrent $6^{\mathrm{mm}}$.

Legemet er temmelig sammentrykt, men ligner forøvigt det hos den foregaaende Art. Ligesom hos denne er den forreste Del af Ryggen uden Kjøl, men en saadan begynder allerede paa det syvende Legemsled $\mathrm{og}$ fortsætter sig paa alle Halens Led. Det sidste Legemsled gaar paa Midten af den bagre Rand ud i en, liden bagudrettet Tand, som paa Halens fire forste Led bliver meget stor; det fjerde Haleled har foran denne en dyb Nedsynkning; det tredies nedre, bagre Vinkel forlanger sig uden dog at dame nogen Hage. Hovellet er liengere end de tvende forste Legemsled tilsammen og gaar fortil, mellem de gvre Følere, ud i et kort, spidst Pandehorn; dets Sidevinkler ere ogsaa forlangede i en Spids. Øinene ere meget mindre end hos den foregaaende Art, skraa ovale.

De øvre Følere naa, naar de bøies bagud, omtrent til Halens andet Led. Skaftets forste Led er kortere end Hovedet og er ikke vabnet med nogen Tand paa Enden; det andet er ikke fuldt dobbelt saa langt, men meget smalere; det tredie er kort og kun noget længere end Svøbens Led, hvorfra det kun lidet adskiller sig. Svøben, der dannes af 18 meget forlængede Led, er længere end Skaftet.

De nedre Folere ere kortere og tyndere end de gvre. Skaftets tredie Led er særdeles kort; det fjerde og femte ere omtrent lige lange, eller det sidste er noget længere. Svøben er længere end Skaftet og dannet af 14 eller 16 forlængede Led.

Kindbakkernes ovre Gren bestaar af fire, og den indre Bigren af tre Tænder; Tyggeknuden er særdeles stor og tværstribet.

Det forste Kjæbepar er forlænget; den ydre Plade har paa Enden mange, stærkt saugtakkede Torne; den indre Plade er liden, oval. Palpen er eenleddet og væbnet paa Enden med Tæuder.og Borster.

Kjæbefoddernes ydre Plade er forlænget oval, med en ret indre Rand, paa hvilken sees Torne, der mod Pladens afrundede Ende blive lingere og mere krumme; den indre Plade er sardeles bred, paa Enden skraa afskaaret og forsynet med mange 
lange Børster. Palpen er særdeles tynd og naar kun lidt frem for Enden af den ydrePlade; dens andet Led er det længste. K̉loen mangler.

Det forste Fodpar er kort; det fjerde Led er triangulært, kort; det femte er meget langere og bredere. Griberanden er skraa afskaret samt har fime Tænder og Torne, af hvilke den, der er fæstet paa det Sted, hvor Kloens Spids lægger sig til, er sardeles stor.

Det andet Fodpar er meget længere og noget smalere; det fjerde Led er omtrent dobbelt saa langt som bredt; Haanden er forlanget og bliver bredere mod Enden, der er skraa afskaaret.

Det tredie og fjerde Fodpars tredie Led er meget kortere end det forste og kun lidet udvidet; det fjerde er kortere end det foregaaende Led, og det femte er af samme Længde, men smalere, samt har stærke Torne par den bagre Rand. Kloen er lidt kortere end det sidste Led og noget krummet.

Det femte Fodpars forste Led er lidt udvidet paa den bagre Rand og har en noget udtrukket nedre, bagre Vinkel; det fjerde Led er noget kortere end det foregaaende, og det femte er lidt længere end det fjerde Led. Det Gjælleblad, der hører til dette Fodpar, er fjærformet foldet.

Det sjette Fodpar har et meget udvidet forste Led.

Det syvende Fodpars første Led er ikke udvidet, men lige saa smalt som det følgende Led; det fjerde er længere end det tredie; det femte Led er kort og smalt.

Det forste og sidste Par Springfødder naa omtrent lige langt bagud; let andet er meget kortere.

Halevedhæn get er kløvet indtil Roden, og dets Rande ere væbnede med Torne.

Farven er hvidgul; de gulbrune Indvolde skinne gjennem paa Siderne af Legemet. Øinene er hvide, med mange røde Lindser.

Den er fundet af mig i Christianiafjorden $0 \mathrm{~g}$ ved Farsund paa $30-60$ Favnes Dybde, af G. O. Sars ved Brettesnæs paa 20-40 Favne.

\section{DEXAMINE HEIBERGI. A. Boeck 1870.}

(Pl. XII. fig. 3.)

Dexamine Heibergi. A. Boeck, Crust. amphip. bor. et arct. 1870, p. 107.

Oculi parvi, ovales. Antennæ superiores articulo pedunculi 1 mo non spinoso; articulo 1 mo et 2do longitudine fere æqvalibus. Antennæ multo breviores qvam apud species præcedentes. Pedes $7 \mathrm{mi}$ parıs articulo 1 mo non dilatato. Corpus ferme ut apud speciem præcedentem sed multo humilius.

L $₫$ ng den er $6^{\mathrm{mm}}$.

Denne Art ligner meget den foregaaende i Legemets Form og Bevæbnnig, 
men den er ikke saa høi, og Ryggen er meget bredere. Sideplademe ere heller ikke saa høie; den fjerde er kun svagt indskaaret for den femte, som neppe er høiere end bred. Hovedet er længere end de tvende første Legemsled tilsammen.

De øvre Følere ere korte og naa, naar de bøies bagud, omtrent til det femte Legemsled; Skaftets forste Led er kortere end Hovedet; det andet er omtrent saa langt som det foregaaende, men smalere; det tredie er meget, kort og kan ikke skilles fra Svobens Led, som er 14 i Antal.

De nedre Følere ere meget kortere end de øvre; Skaftets tredie Led er neppe saa langt som tykt; det fjerde er saa langt som det femte, men tykkere end dette. Svoben er kortere end Skaftet og dannet af 5 -6 Led.

Det første Fodpars Haand er meget bredere mod den ydre Ende, med en meget skraa afskaaret Griberand, der er forsynet med stærke Torne.

Det tredie og fjerde Fodpars tredie Led er meget lidet udvidet nedad, længere end det fjerde, men omtrent saa langt som det femte Led, der dog er smalere. Dette sidste har paa den bagre Rand fem kraftige 'Torne.

Det femte Fodpars forste Led har en meget convex forreste, men ret bagre Rand, hvis nedre, bagre Vinkel er afrundet; det tredie Led er længere end det fjerde.

Det sjette Fodpars første Led er paa den bagre Rand meget convex og saugtakket; det tredie Led er kun ubetydelig langere end det fjerde, hvilket er omtrent sala langt som det femte I.ed.

Det syvende Fodpars forste Led er ikke udvidet, men smalt; det tredie, fjerde $0 \mathrm{~g}$ femte Led have næsten den samme Længde.

Det sidste Par Springfødders Grene ere forsynede med faa, men stærke Torne paa Randene og ere længere end Grundleddet.

Halevedhænget er omtrent tre Gange saa langt som bredt og klovet næsten til Roden; Fligeme ere paa Enden tilspidsede, og hver bærer en Torn nær Enden af den ydre Rand.

Denne Art er funden i et eneste Exemplar ved Haugesund.

Gen. II. TRITAETA. n. g.

Deriv.: Tplraix, et Egennavn.

Syn.: 1870. Lampra. A. Boeck, Crust. amphip. bor. et arct. p. 108.

Type: Atylus gibbosus. Spence Bate.

Pedes maxillares laminis exterioribus angustioribus, valde curvatis et modo in summo dimidio spinis paucis sed validis armatis; laminis interioribus latioribus et longioribus yvam apud genus Dexamine, spinis multis curvatis et gracilibus armatis. 
Epimera minima; epimera quatuor anteriora 5 to non altiora, in margine inferiore armata.

Pedes qvinqve parium ultimorum articulo 4 to et 5 to perbrevibus; ungve parvo.

Denne nye Slægt skiller sig fra Dexamine ved, at Kjabeføddernes ydre Plader ere smalere og væbnede paa Enden med tynde, krumme Torne. Sidepladerne ere ogsaa særdeles smaa, og de fire første ere ikke høiere end den femte. Ved de fem sidste Fodpars Form er denne Slagt meget let kjendelig derved, at deres tredie Led er saa forlænget, medens de tvende sidste ere meget forkortede; det sidste Led er meget svagt bygget.

Typus for denne Slægt er den af Spence Bate (Catal. Amphip. Crust. Brit. Mus. 1862, p. 137) opstillede Atylus gibbosus, som af ham er henfort til Slrgten Atylus, da han ikke har undersogt Munddelene. Hertil hører ogsaa den af Grube opstillede Dexamine brevitarsus fra det adriatiske Hav.

Da Navnet Lampra sees at være (1816) brugt til en Lepidopter, el det forandret til Tritacta.

TRITAETA GIBBOSA, Spence Bate, 1872.

(Pl. XII, fig. 2).

Atylus giblosus, Spence Bate, Catal. Amphip. Crust. Brit. MIus. 1862, p. 137. pl. XXVI, fig. 3.

Spence Bate and Westwood, Brit. sessile-eyed Crust. 1863, rol. I, p. 248 .

- - Norman, Rep. on the Shetland Crust. 1868, p. 280.

Lampra gibbosa, A. Boeck, Crust. amphip. bor. et arct. 1870. p. 108.

Oculi ovales. Epimerum 3tium et 4 tum in angulo inferiore antico in dentem acutum producta; 4tum etiam in angulo inferiore postico productum. Segmenta postabdominis tria anteriora in angulo inferiore posteriore acuta; 2dum et 3tium in margine posteriore crenulata; segmentum 3tium in medio margine posteriore dente retroverso, triangulari instructum: segmentum 4tum carinatum. Pedes $1 \mathrm{mi}$ paris manu longiore qvam carpo, ovata. Pedes 2di paris pedibus $1 \mathrm{mi}$ paris longiores: manu paulo breviore qvam carpo. Pedes qvinqve parium ultimorum articulo 3tio multo longiore qvam articulis duobus seqventibus junctis; articulis valde spinosis. Pedes trium parium ultimorum articulo 1 mo postice parum modo dilatato. 
Langden er $8^{\mathrm{mm}}$.

Legemet er forlænget; Ryggen er rund, undtagen paa det fjerde Haleled, hvor den har en Kjøl, som gaar bagtil ud i en stærk Tand. Sidepladerne ere meget smaa; de tvende forste ere trekantede, have en fremadrettet Spids og nogle Borster paa den nedre, bagre Rand; den fjerde er den største og har fortil og bagtil en Spids. Den nedre, bagre Vinkel par Halens tre forste Led er udtrukket i en skarp Spids, og ovenfor denne er den bagre Rand noget saugtakket. Hovedet er meget længere end det forste Legemsled og gaar fortil mellem de øvre Følere ud i et lidet Pandehorn; dets Sidevinkler ere afrundede, men dog undertiden forsynede med en liden Tand. Oinene ere noget ovale.

De øvre Følere naa omtrent til Halens første Led, eller noget længere; Skaftets første Led er meget kortere end Hovedet; det andet er langere og smalere; det tredie Led er ubetydeligt længere end Svøbens første Led. Svøben er ikke fuldt dobbelt saa lang som Skaftet og danues af $18-20$ Led, der ere forsynede med hrandse af smaa Børster, hvoraf de paa hvert andet Led ere de største.

De nedre Følere ere omtrent af den samme Lengde som de ovie; det andet Led udsender en kort Torm; det tredie er omtrent saa langt som bredt; det fjerde er kortere end de øvre Føleres andet Led; det femte er kortere og meget smalere end det foregaaende Led, samt rager kun ubetydeligt frem for de øvre Føleres Skaft. Svøben er længere end skaftet og dannet af omtrent 24 Led.

Kindbakkerne ere meget tykke, stærke, delte i Spidsen; Grenene ere forsynerle med flere Tænder; under Spidsen sees tre brede, med Bitænder forsynede Torne; Tyggeknuden er meget stor og tværstribet.

Det forste Kjæbepars ydre Plade har paa Enden stærke Borster; den indre Plade er liden, oval. Palpen er ikke meget bred, afrundet paa Enden og forsynet med lange Børster.

Det andet $\mathbf{K j} \mathfrak{\mathrm { j }} \mathrm{b}$ epars Plader ere temmelig brede, med lange, krumme Borster paa Enden.

Kjæbef $ø$ d dernes Plader ere meget store; den ydre er noget lirummet mod Fnden og besat med krumme Tander, der blive noget længere mod Pladens Ende; den indre Plade bliver bredere udad, og paa den brede, afstumpede Ende findes lange Borster. Palpen er meget tynd og kort; dens andet Led er det længste.

Det første Fodpar er temmelig kort; det fjerde Led er triangulært; det femte temmelig bredt, Griberanden er skraa afskaaret og tandet, paa Randen samt paa den indre Flade sees en Rrkke korte Børster.

Det andet Fodpar er meget længere; det fjerde Led er forlænget smalt og paa den bagre Rand forsynet med Borsteknipper; Haanden er meget kortere og bredere, triangulær.

Det tredie og fjerde Fodpar ere forlængede, men stærke; det tredie Led er længere, men smalere end det første og $\mathrm{i}$ den bagre Rand væbnet med Here Torne- 
knipper; det fjerde Led er kun lidt længere end bredt $0 \mathrm{~g}$ har tre stærke Torne paa Enden af den bagre Rand; det femte Led er lidt længere, men smalere; Kloen er kort lidt krummet.

De trende følgende Fodpars forste Led er kun lidet udvidet bagtil, af en forlænget oval- Form; det tredie er meget langere end det forste Led og er ikke udvidet, med Torneknipper paa begge Rande; det fjerde er omtrent saa langt som bredt det femte Led er af den samme Længde, men smalere.

Det syvende Fodpars første Led er ikke udvidet bagtil undtagen noget paa det øverste Parti, forøvrigt har det samme Bygning som det foregaaende Forlpar; det txedie Led er dog kortere.

Det første Par Springfødd'er naar ikke fuldt saa langt bagud som det sidste Par; Grenene ere meget liengere end Grundleddet og forsynede med mange Torne.

Det andet Par er meget kort og naar neppe længere tilbage end til Enden af det sidste Pars Grundled; den ydre Gren er kortere end den indre, og begge have mange Torne.

Det sidste Pars Grene ere meget langere end Grundleddet og indbyrdes lige lange; den ydre har Torne paa begge Rande, paa den indre sees tillige Børster.

Halevedhænget er forlænget, næsten lancetformet, og i begge Rande væbnet med Torne samt er spaltet næsten til Roden.

Farven er hvirgul; Øimene ere rode.

Jeg har fundet denne Art kun i faa Exemplarer ved Haugesund; ved Skotland er den hyppig ifolge Norman.

Spence Bate og Westwoods Tegning og Beskrivelse af $A$. gibbosa afviger fra den af mig ovenfor angivne især med Hensyn til Sidepladernes Form, idet disse paa deres Tegning ere hoie og afrunderle paa den nedre Rand; de have ligeledes fundet, at det andet Fodpars Haand er bredere end den paa det første Fodpar. De tegne det femte Led paa de nedre Foleres Skaft langere end det fjerde, medens det hos vor Form er meget smalere og kortere. Jeg var derfor først tilbøielig til at anse den af mig beskrevne Form for en ny Art, men da jeg tror, at deres Afvigelser kunne bero paa en mindre nøiagtig Observation, har jeg henført den norske Form til den af dem beskievne Art.

Subfamilia VII.

ATYLINE. Lilljeborg 1865.

Syn.: 1865. Atylinœ, Lilljeborg.

1870. - A. Boeck, Crust. amphip. bor. et arct. p. 108.

Labium superius latum, in apice rotundatum.

Mandibulæ validæ, in apice dentatæ; ramo accessorio item dentato: seric spinarum ex paucis spinis, in margine convexo serratis, constanti; tuberculo molari 
prominenti et serie denlium inferiore in setam longam el phumosam desinenti: palpo plus minusve robusto, 3articulato.

Labium inferius latum.

Maxillæ $1 \mathrm{mi}$ paris dentibus firmis, pectiniformibus armatæ: palpo 2articulato. in apice maxilla sinistræ dentibus, in apice maxilla dextra spinis armato; lamina interiore mediocri aut parva, selas plumosas multas vel paucas gerenti.

Maxillæ 2di paris lamina exteriore paulum ultra interiorem porrecta.

Pedes maxillares lamina exteriore magnitudinis mediocris, raro permagna, in margine dentibus vel spinis armata; palpo plus minusve elongato; articulo ultimo in apice spinoso, perangusto et parum ungviformi.

Antenne longa: etiam inferiores flagellum elongatum, multiarticulalum gerentes.

Pedes trium parium ultimorum longitudine gradatim crescentes; articulo 1 mo postice dilatato.

Pedes saltatorii hiramei.

Appendix caudalis major vel minor, integra vel tissa.

Lilljeborg opstillede i 1865 (on the Lysianassa Magellanica) denne som den ottende Underfamilic af Familien Gammaride. Han karakteriserer den pat folgende Maate: De ovre Folere mangle Bisvobe; Øinene ere sammensatte; det syvende Fodpar er kun lidt længere end det sjette, og dets sidste Led er kloformet; Kjæbefoddernes Plader ere vel udviklede.

Paa Grund af den rummelige Diagnose indeslutter han i denne Underfamilie Slægteme Odius, Iphimedia, Lafystius, Calliopius, Paramphithoë, Atylus, Dexamine og Acanthonotus. Af disse udskilte jeg igjen de fleste i 1870, men tilføiede en Del nye Slægter, hvorved denne Underfamilie har faaet en ny, mere indskrænket Karakter.

Underfamilien Atyline viser Overensstemmelse med Gammarine og Dexamina ved, at Kindbakkeme ere nosten af samme Bygning paa begge Sider. Derimod har det forste Kjæbepars Palpe en forskjellig Bevæbning, idet den paa den ene Side har Tænder og paa den anden Borster. Fra Gammarince skiller den sig vasentlig kun ved, at de ovre Folere mangle Bisvobe, inedens den skiller sig fra Dexamince ved flere karakteristiske Forhold i Munddelene. Maaske bor denne Underfamilie sammen med Gammarince undergaa en Forandring i systematisk Henseende, da Karakteren, der er hentet fra Bisvoben, ikke kan have nogen saa"stor Betydning, at derved tvende Underfamilier kunne adskilles. Derimod er der flere andre Forhold, som ere fælles for Slægter indenfor begge Underfamilier, der burde kræve, at disse bleve stillede sammen ligeover for andre Slægtsgrupper.

Til denne Underfamilie har jeg henført Slægterne Atylus, Pontogeneia, Halirages, Calliopius, Amphithopsis, Clëppides og Laothoës. Af disse viser Atylus en sar- 
deles stor Overensstemmelse med Slægten Dexamine, men skiller sig fra denne vasentlig lerved, at Kindbakkeme have Palpe, medens Dexamine mangler en saadan. Pontogeneia er meget lig Slægten MLera. Enkelte Arter af Slægten Amphithopsis ligne Arter af Slagten Amathilla under Gammarince. Vi se saledes, at der er en Overensstemmelse mellem forskjellige Slagter af disse tvende Underfamilier.

Gen. I. ATYLUS, Leach 1817.

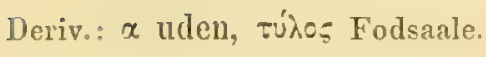

Syn.: 181\%. Atylus, Leach, Zool. Miscell. II. pl. 69.

1825. - Desmarest, Consid. sur les Crust. p. 262.

1830. - Milne Edwards, Ann. des Sci. nat. t. 20. p. 383; Hist. des Crust. 1840. III. p. 67.

1853. Notrotopis, Costa, Rend. della Reale Accad. delle Sci. di Napoli p. 170. t. 1. f. 7 og 8; Rich. sui Crost. amfip. d. Regno di Napoli, Mem. della Reale Accad. delle Sci. di Napoli. 1857. p. 193.

1560. Epidesura, A. Boeck, Forh. ved de skand. Naturf. 8de Møde. p. 659.

1862. Atylus, Spence Bate, Catal. Amphip. Crust. Brit. Mus. p. 133.

1863. - Spence Bate and Westwood, Brit. sessile-eyed crust. p. 244.

1865. - Lilljeborg, on the Lysianassa Magellanica. p. 18. (Tabel).

18\%0. - A. Boeck, Crust. amphip. bor. et arct. p. 109.

Type: Gammarus carinatus, Fabricius.

Mandibulæe palpo infirmo et gracili; articulo palpi 2do longitudinem 3tii superanti.

Maxillæ $1 \mathrm{mi}$ paris lamina interiore longitudinis mediocris, setis 7 -8 plumosis instrucla.

Maxillæ 2di paris elongatæ, angustæ.

Pedes maxillares lamina exteriore in margine interno dentibus validis mullis, apicem versus elongatis, curvatis et in setas desinentibus, armata; lamina interiore elongata, valida: palpo brevi et angusto; lamina exteriore ultra articulum palpi 2dum porrecta.

Corpus compressum; dorso carinato; carina in segmentis pluribus dentes retroversos formanti; capite rostro frontali longo curvato, compresso aut subdepresso, instructo; epimeris non peraltis, partim rigidis, in margine inferiore plumosis; articulis postabdominis duobus ultimis coalitis.

Antenna inferiores superioribus longiores. 
Pedes 1 mi 2diqve paris manu parva.

Pedes saltatorii 2di paris hreviores qvam 3tii paris.

Pedes saltatorii ultimi paris pedunculo hreviore qram appendice candali: ramis longitudine requalibus.

Appendix caudalis fissa.

Demne Slægt blev opstillet af Leach paa den af Fabricius beskrevne Gammarus carinatus, og lan fremhrvede som dens Karaktermærke, at de ovre Folere neppe ere kortere end de nedre, og at de dannes af fire Led, hvoraf det sidste igjen bestaar af en stor Mængde smaa Led. Desmarest gjentager i 1825 denue Karakter og tilføier nogle Here, der dog ere mindre heldige. Milne Edwards optager slesten Atylus i sin Hist. d. Crust. 1840. T. III., og han trol, at den staar nær Slægten Corophium, hvorfra den dog skiller sig ved sine store Sideplader. Dana optager den ogsaa, i U. S. Expl. Exper. 1852, og stiller den nær Ischyrocens, men finder dog, at den har noget tilfælles med Iphimedia. Spence Bate opforer den ligeledes i. 1855, efterat have undersøgt Leachs typiske Exemplar, og han adsliller den fra Dexamine vasentlig ved, at Kindbakkerne have en treleddet Palpe, som Dexamine mangler, og desuden ved at det tredie Skaftled paa de ørre Følere er adskilt fra Svobens Led. Som synonym med Atylus stiller Spence Bate Iphimedia, Dana, hvillien dog ikke hører herhen. Derimorl maa Costas Slagt Kotrotopis (1853) henregnes til vor slangt. Lilljeborg adkliller i 185. Sliggten Atylus fra Paramphithoë alene af den Grund, at de forreste Sideplader ere tilspidsede hos den sidste, medens de ere stumpe og afrundede hos Atylus. Som synonym med denne Slægt maa endvidere stilles den af mig i 1860 opstillede nye Slagt Epidesura, som jeg dengang troede skilte sig fra Atylus, især ved at de tvende sidste Haleled ere sammensmeltede, men ved senere at undersøge den typiske Art $A$. carinatus fandt jeg, at det samme er Tilfældet med denne. Den af Spence Bate opforte slægt Grayia staar ogsaa nær denne Slægt, skjønt han henregner den til Phoxidernes Underfamilie, medens han henforer Atylus til Gammariderne. Det, som i det Yure især karakteriserer denne heromhandlede Slægt, er, at Halens femte og sjette Led ere sammensmeltede, paa hvilket allerede Heller har været opmærksom. Legemet har forovrigt en Kjol, og paa flere af Legemsleddene og Halens Led gaar denne ud i bagudrettede Tome. Fortil gaar Hovedet ud i et langt, krummet Pandehorn. Sidepladerne ere ikke meget høie, men temmelig stive. Fra Slagten Dexamine, som den saaledes ligner meget i det Ydre, skiller den sig ved, at Kindbakkerwe have en Palpe. Det første Kjæbepars Palpe er lidt forskjellig bygget paa begge Sider, den er nemlig væbnet paa den ene Side med Tænder, paa den anden kun med Børster. Kjæbeføddernes ydre Plade er ikke meget stor, men har overmaade stærke Tæuder langs den indre Rand, hvilke mod Pladens Ende efterhaanden blive længere og gaa over til lange krumme Børster; den indre Plade er temmelig stor og har paa Enden tre stærke Tænder foruden adskillige fjærdannede Børster. Det er særdeles karakteristisk for flere Arter af deme Slrgt, at. 
Aandepladerne ere byggede pai samme Maade, som jeg har vist at være Tilfaldet hos Ichnopus: de have nemlig en ophøiet Ribbe langs Midten, hvorfra der udgaar talrige Folder som Sideribberne i et Blad.

ATYLUS CARINA'TUS, Fabricius 1793.

Gammarus carinatus, Fabricius, Ent. syst. 1793. t. II. p. 515.

Atylus carinatus, Leach, Trans. of the Linn. Soc. 1815. XI. p. 357; Zool. Miscell. II. p. 21. pl. 69.

- - Desmarest, Consid. sur les Crust. 1825. p. 262. pl. 45. fig. 4.

- - Guerin, Icon. crust. 1829. pl. 26. fig. 6. (efter Leach).

- - Milne Edwards, Hist. des Crust. 1840. III. p. 68.

- - Spence Bate, Catal. Amphip. Crust. Brit. Mus. 1862. p. 134. pl. XXV. fig. 1. 2. 3.

- $\quad$ A. Boeck, Crust. amphip. bor. et arct. 1870. p. 11.

Amphithoё carinata, Kroyer, Gronlands Amphip., det Kgl. Danske Vid.-Selsk. Afhl.

1838. VII. p. 256. t. 2. fig. 6; Nat. Tidsskr. 1 R. II. p. 259;

Voy, en Scand. t. 11. fig. 1.

- $\quad$ - Milne Edwards, Hist. des Crust. 1840. III. p. 41.

Paramphithö̈ carinata, Goës, Crust. Amphip. maris Spetsb. 1865 . p. 7.

Frons in rostrum longum et subdepressum, inter antennas superiores curvatum, producta. Oculi parvi, rotundi. Dorsum carinatum; carina ab rostro frontali usque ad segmentum postabdominis ŏtum porrecta et in margine posteriore segmentorum trunci trium ultimorum et postabdominis qvatuor anteriorum in dentem longum, acutum et validum, desinenti. Segmentum postabdominis 3tium margine posteriore serrato. Antenna vix longitudinem animalis dimidiam superantes. Antennæe inferiores articulo pedunculi 4 to et 5to longitudine aqvalibus. Pedes $1 \mathrm{mi}$ paris manu longitudinem carpi aeqvanti. lata, triangulari. Pedes 2di paris manu circiter duplo longiore qvam lata, apicem versus latiore. Pedes 3 tii et 4 ti paris articulo 4 to multo breviore qvam 5to; articulo utroqve conjunctis multo longioribus qvam 3tio. Pedes trium parium ultimorum articulo 5to Iongiore qvam 4to. Pedes 5ti paris articulo 1 mo parum dilatato, in angulo inferiore postico non producto. Pedes $7 \mathrm{mi}$ paris articulo $1 \mathrm{mo}$ perdilatato, in margine inferiore rolundato. Angulus inferior posticus segmenti postabdominis 3tii acutus. Appendix caudalis panlo longior quam ad basin lata, apicen versus angustior, in exterioribus duabus tertiis fissa. 
Langden er $32^{\mathrm{mm}}$.

Legemet er forlænget, dog temmelig tykt, med tilskjærpet Ryg, der er forsynet med en Kjøl. Denne strækker sig lige fra Hovedet til det femte Haleled og danner paa den bagre Rand af de tvende sidste Legemsled og de fire forste Haleled kraftige, bagudrettede Tænder. Hovedet har ogsaa en Kjol, der gaar fortil ud i et stærkt, liclt krummet Pandehorn, der naar frem til Midten af de ovre Føleres forste Skaftled; Sidevinklerne ere afrundede. Øinene ere runde, halvkugleformet fremstaaende.

De $\emptyset$ vre Folere ere korte og naa, naar de bøies bagud, neppe til det sjette eller syvende Legemsled. Skaftets forste Led er omtrent af samme Længde som det andet, men tykkere end dette; det tredie er længere end det foregaaende Leds halve Lingde. Svoben er lidt længere end Skaftet 0 g dannes af 25 Led.

De nedre Følere ere lidt længere end de ovre. Skaftets tredie Led er neppe liengere end bredt; det fjerde er omtrent saa langt som det femte, men tykkere end dette. Svoben er længere end Skaftets sidste Led $0 \mathrm{~g}$ dannes af omtrent 20 korte Led. Begge Foleres Skaft er paa den indre Rand forsynet med talrige Børstebundter.

Overlæben er paa Enden afrundet 0 g har der talrige smaa Borster.

Kindbakkernes Gribedel har fire til fem T'xnder, og den indre Bigren el forsynet med fire lignende; Tornerækken dannes af tolv brede, paa den convexe Rand saugtakkede Børster; Tyggeknuden el fremstaaende.

Det forste Kjobepars indre Plade er af middelmaadig Størrelse, besat med talrige fjærdannede Børster. Palpens andet Led er paa Enden vabnet med fem til sex 'Trender eller med forlængede T'orne.

Det andet $\mathrm{Kj} \rightsquigarrow \mathrm{b}$ epars ydre Plade er bredere og lidt længere end den indre; begge have paa Enden talrige Børster.

Kjæbefoddernes ydre Plade er bred og har paa den indre, rette Rand en Rad stærke Trender, der mod Pladens Ende blive længere og smalere samt gaa paa den ydre Rand over til krumme Børster, der tilsidst blive fjærdannede; den indre Plarle er ikke meget forlænget og har paa Enden tre stærke Tæender foruden nogle Børster. Palpen er meget stærk; det tredie Led er forlænget, ovalt; det fjerde bliver kloformet, ved at det i Spidsen er væbnet ned en stærk, kort Tand.

De tvende forste.Fodpar ere omtrent af eens Bygning; det fjerde Led er kort, triangulært; Haanden er ubetydelig kortere, ligeledes triangulær og forsynet med Børster paa den forreste og bagre Rand. Kloen har i Spidsen-en Torn.

Det tredie og fjerde Fodpar ere korte og stærke.

De tre folgende Fodpar ere ligeledes korte. Det femte og sjette Pars forste Led er kun lidet udvidet og bliver smalere nedad; det tredie Led er meget længere end det fjerde. Det syvende Pars første Led er meget stærkt udvidet bagtil.

Det andet Par Springfodders indre Gren er lidt kortere end den ydre, der er omtrent sata lang som Grundleddet. 
Det sidste Pars Grundled er særdeles kort; Grenene ere lige lange, forlængede, lancetformede og have Børster paa begge Rande.

Halevedhæuget er længere end bredt ver Roden, triangulært og spaltet i den ydre Totrediedel.

Milne Edwards siger, at dens Findested er ubekjendt, men Fabricius, som havde undersøgt Leachs Exemplar og lialdt Arten Gammarus carinatus, anfører, at den er fra det arctiske Hav; det samme har Spence Bate fundet ved en Prategning ved let typiske Exemplar i det Hunterske Museum. Han beskriver ogsaa Ungeme og har fundet, at de paa de gvre Folere have en liden, eenleddet Bisvobe. Kroyer har beskrevet og aftegnet denne Art efter grønlandske Exemplarer, men han optager ikke Slagten og henforer den til Slægten Amphithoè.

Den findes ved Spitsbergen og ved Grønland paa 2-30 Favnes Dybde. Af Lilljeborg er den fundet ved Molde paa 40-50 Favne.

\section{A'TYLUS SMITTI, Goës 1865.}

Paramphithö̈ Smitti, Goës, Crust. Amphip. maris Spetsb. 1865. p. S. fig. 14. Atylus Smitti, A. Boeck, Crust. amphip. bor. et arct. 1870. p. 110.

Oculi parvi, eliptici. Carina dorsi in segmentis trunci ultimis et in postabdominis quatuor anterioribus dentes retroversos, in segmento postabdominis 4to dentes duos, anteriorem minorem qvam posteriorem, formans. Rostrum frontale elongatum, fere ad extremum articulum pedunculi 1 mum antennarum superiorum porrectum. Anteme superiores longitudinem dimidiam animalis valde superantes: articulo pedunculi 1 mo non dentalo, longitudinem articuli 2di ferme apvanti. Antenne inferiores arliculo pedunculi 4 to et 5 to longitudine ferme requalibus. Pedes $1 \mathrm{mi}$ et 2 di paris manu gracillima, breviore qvam carpo. Pedes 5 ti paris articulo 1 mo angusto, in angulo inferiore posteriore rotundato, non producto. Pedes 7 mi paris articulo 1 mo multo latiore el in angulo inferiore posteriore subproducto. Pedes trium parium ultimorum articulo 4 to multo longiore qvam articulo 3 tio et 5to. Angulus inferior posticus segmenti postabdominis 3tii rotundalus. Appendix caudalis duplo longior qvam ad basin lata, in exterioribus duabus tertiis lissa.

Længden er $22^{\mathrm{mm}}$ fra Pandehornet til Halevedhænget.

L egemet er meget sammentrykt. Legemsleddenes Overflade er ru og ligesom sculpteret. Langs Ryggens Midtparti strækker sig fra Pandehornet en Kjol, der dog ikke findes paa de tvende sidste Haleled; paa Enden af det sidste Legemsled og Halens fire forste Led damner den stærke, bagudrettede Tænder. Desuden damnes paa 
det fjerde Haleled ved en paatvers gaaende skarp Indsynkning og den navnte Kjol endnu en Tand, der ligger foran den anden, men er meget mindre end denne. Sidepladerne ere smaa, smale, stive og forsynede med en efter Længden gaaende Kjøl. Den forste, der er meget smalere end de folgende, er krumnet forover under Hovedet og har, ligesom ogsaa len anden, paa den nedre Rand mange Borster, der udga fra sauglignende Indsnit. De tre folgende tiltage efter hverandre i Bredde. Den sidste af disse er bagtil kun svagt indskaret for den femte Sideplade, der er bredere end høi, og hvis forreste Del har nedadrettede Torne. De tre første Haleleds nedre, bagre Vinkel har ikke Torne eller Hager. Hovedet ex næsten saa langt som de tvende forste Legemsled tilsammen; Pandehornet er langt, meget sammentrykt fra Sideme. Øinene ere smaa, runde, halvkugleformet fremstaaende $0 \mathrm{~g}$ ere stillede noget nedenfor de øvre Føleres Udspring.

De gvre Følere naa, nar de boies bagud, noget langere tilbage end til det andet Haleled. Skaftets første Led er omtrent saa langt som Hovedet; det andet er omtrent af den samme Længde, men smalere; det tredie er meget kort. Svoben, der er læengere end Skaftet, dannes af ontrent 45 Led.

De nedre Fglere ere af den samme Langde som de ovre, eller lidt langere. Skaftets forste Led er meget tykt, opsvulmet; det andet er forsynet med en kun kort Lugteknude; det tredie er meget længere end bredt; det fjerde naar ikke ganske frem til Enden af det andet Led paa de øvre Føleres Skaft; det femte er næsten saa langt som det foregaaende Led, men tyndere end dette. Svøben, der dannes af ointrent 50 korte Led, er saa lang som Skaftets tvende sidste Led tilsammen.

Overlæben er bred, afrundet paa Enden.

Kindbakkerne ere starke; Tyggekmuden er kraftig udviklet. Palpen er meget smal og tynd; dens tredie Led er noget kortere end det andet, og forsynet med faa Bundter af Børster.

Underlæben er meget bred og tyk; den ydre Plade er væbnet med tynde 'Trender; den indre er bred, men kort.

Det føxste Kjæbepars ydre Plade har stærke l'orne, forsynede med ikke mange, men kraftige Bitænder; den indre Plade har syv fjærdannede Borster, der tiltage i Langde mod dens Ende. Palpen har i Spidsen paa den ene Side Torne, paa den anden 'Trender.

Kjæbeføddernes ydre Plade har langs den indre Rand et Antal af 10-11 stærke 'Tænder, der mod dens Ende forlænge sig og gaa over til krumme Børster og Torne; den indre Plade har foruden Børster ogsaa tre Tænder, hvoraf de tvende indre staa hinanden meget nær. Palpen er smal, med et særdeles kort første og et meget langt andet Led. Kloen er tydelig tvedelt.

Det forste Fodpar er ikke meget stærkt. Haanden er meget kortere end det foregaaende Led, af en forlænget oval Form, og besat med talrige Borsteknipper i begge Rande og paa den indre Side; Griberanden er skraa afskaret og forsynet med 
fine Torne samt med tvende stærkere saadanne, livor Ǩloens Spids lægger sig til. Kloen Iar en kraftig Bitorn og en Borste nær Spidsen.

Det andet Fodpar er langere og smalere; Haanden er kortere end det foregaaende Led, og begge dens Rande ere parallele; Griberanden er skira afskaaret. Kiloen har en Tand paa den bagre Rand nær Spidsen.

Det tredie og fjerde Fodpar ere af eens Bygning; det tredie Led er kum lidet ndvidet nedad og har kraftige Torne paa begge Rande; det femte er længere end det fjerle, og begge tilsammen ere noget længere end det tredie Led.

De tvende folgende Fodpar ere af eens Bygning, men det femte er kortere end let sjette Par; ilet første Led er meget lidet udvidet og bliver smalere nedad; det tredie er smalt og saa langt, som det følgende, eller ubetydelig kortere end dette, livilket er meget længere end det femte Led. De tre sidste Led have strerke Torne paa den forreste Rand.

Det syvende Fodpar ex noget kortere end det sjette; det første Led er temmelig udvidet bagtil i den ovre Del, men bliver meget indknebet i den nedre; det tredie er meget kortere end det fjerde og ubetydelig længere end det femte I.ed. Disse Led ere paa den forreste Rand besatte med stærke Torne.

Det forste og det sidste Par Springfodder naa omtrent lige langt bagud, medens det andet Par er kortere; den ydre Gren er paa dem alle ubetydelig kortere end den indre. Det sidste Pars Grene ere flere Gange saa lange som Grundleddet og have Torne paa begge Rande.

Halevedhænget er ikke dobbelt saa langt som bredt, spaltet til Midten eller noget over denne.

Den forekommer ved Grønland efter Torell og Amondsen. Ved Spitsbergen er den ifølge Goës fundet paa flere Steder paa 6-15 Favnes Dybde, af Esmark ved SydVaranger paa 180 Favne. Jeg har ogsaa nogle Exemplarer, tagne ved Finmarken, dog uvist fra livilket Sted og af hvem de ere fundne.

ATYLUS SCHIVAMMERDAMII, Milne Edwards 1830.

(Pl. TXI. fig. 5. PI. XXII. fig. 1.)

Amptithoü Schwammerdanii, Milne Edwards, Ann. d. Sci. Nat. 1830. XX. p. 378; Hist. des Crust. 1840. III. p. 35.

Amphithoë compressa, Lilljeborg, Öfv. af Kongl. Vet.-Akad. Forhandl. 1852. p. S. Dexamine Gordoniana, Spence Bate, Ann. and Mag. of Nat. Hist. 1857. 2. ser. XIX. p. 142 .

- - White, Pop. Iist. Brit. Crust. 185\%. p. 178.

Paramphithoё compressa, Bruzelius, Skand. Amphip. Gamm. 1859. p. 72.

Epidesura compressa, A. Boeck, Forl. v. det Skand. Naturf. 8de Møde 1860. p. 659. 
Dexamine Loughrini, Spence Bate, Catal. Amphip. Crust. Brit. Mus. 1862. p. 132. pl. XXIV. fig. 3.

Atylus Schwammerdamii, Spence Bate, Catal. Amphip. Crust. Brit. Mus. 1862. p. 136. pl. XXVI. fig. 2.

- Spence Bate and Westwood, Brit. sessile-eyed Crust. 1863.
p. 246.

- $\quad$ Norman, Rep. on the Shetland Crust. 1868. F. 280.

- - A. Boeck, Crust. amphip. bor, et aret. 1870. p. 111.

Atylus compressus, Spence Bate, Catal. Amphip. Crust. Brit.'Mus. 1862. p. 142.

Oculi ovales. Carina dorsi in segmento postabdominis to dentes duos, anleriorem minorem qvam posteriorem, formans. Rostrum frontale parvum. Antennie longitudine fere regvales, et longitudinem dimidiam animalis paulo superantes. Antennæ superiores articulo pedunculi 1 เno longitudinem 2di superanti, non spinoso. Antennæ inferiores articulo pedunculi 5to multo longiore quam 4to. Pedes $1 \mathrm{mi}$ 2diqve paris manu ferme eadem longitudine ac carpo. Pedes 3 tii et 4 ti paris articulo 4to multo breviore qvam 5to; articulo utroqve conjunctis longioribus qvam 3tio. Pedes 5ti paris articulo 1 mo non lato in angulo inferiore posteriore subproducto. Pedes $7 \mathrm{mi}$ paris articulo 1 mo dilatato. in margine inferiore producto. Angulus inferior posticus segmenti postabdominis 3 tii aculus. Appendix caudalis duplo longior quam ad basin lata, usque ad radicem fissa; lacinia utraqve in apice spinis singulis armata.

L ang gen er. $8 \mathrm{~mm}$.

Legemet er sammentrykt; en Kjøl strækker sig fra Pandehornet til Halevedhænget og gaar paa det fjerde Haleled bagtil ud $\mathrm{i}$ en Tand; foran denne sees en dyb Indskjæring, hvorved dannes endnu en Tand, der dækkes af det foregaaende Led, naar Halen holdes udstrakt. De tvende sidste Haleled ere sammenvoxne. Den nedre, bagre Vinkel paa de tre forste Haleled har en liden Tand. Sidepladerne ere af en middelmaadig Størrelse og meget høiere end brede, afrundede paa den nedre Ende og der forsynede med Børster. Øinene ere store, svagt nyreformede.

De øvre Folere naa, naar de bøies bagud, omtrent til det forste Haleled; Skaftets første Led er noget kortere end Hovedet; det andet er lidt kortere og smalere end det foregaaende; det tredie el kun dobbelt saa langt som tykt. Svøben dannes af 22 korte Led.

De nedre Føleres andet Skaftled udsender en spids Lugteknude; det tredie er knap saa langt som tykt; det fjerde er omtrent saa langt som det andet Led paa de øvre Foleres Skaft; det femte Led er længere end dette. Svøben dannes af 18 korte Led. 
Kindbakkerne ere af den almindelige Form; Tornerækken er forsynet med Bitolne, og Tyggeknuden er besat med fine Tænder. Palpen er svag, dens tvende sidste Led ere lige lange.

Det forste Kjæbepars ydre Plade er paa Enden vabnet med kamdannede Torne; den indre Plade er oval og har paa den indre Rand fjærdannede Borster. Palpen er i Spidsen bred og har nogle Tænder.

Kjæbefoldernes ydre Plade har paa den indre Rand tolv grove Tænder, der mod dens Ende blive stærkere og gaa tilsidst over til krumme Torne; den indre Plade er paa Enden vabnet med tre Tænder og nogle Borster.

Det forste Fodpar er ilke meget kraftig udviklet; det femte Led, eller Haanden, er saa langt som det fjerde og af en forlænget, oval Form.

Det andet Fodpar har den samme Form som det forste, men er noget længere end dette, Haanden er mere forlænget, smalere mod den ydre Ende.

Det tredie og fjerde Fodpar ere stærke og paa den bagre Rand besatte med mange Torne; det tredie Led er kun lidet udvidet nedad; det fjerde er meget kort, medens det femte er længere. Kløerne ere stærlie og lirumme.

Halevedhænget er omtrent dobbelt saa langt som bredt, spaltet til Roden, med en Torn og en liden Borste paa hver Fligs ydre Ende.

Denne Art er ifolge Bruzelius sjelden ved Finmarken. Verl Skraaven er den taget af G. O. Sars paa 10--20 Favne. Den er temmelig hyppig ved Haugesund, hvorfra jeg har medbragt mange Exemplarer. Bruzelius har fundet den ved Bohuslen. Paa Englands Kyster er den taget pai flere Steder og ved Shetland af Norman; af MilneEdwards ved Kirsten af Morbihan. Efter Metzger forekommer den ved len ostfrisiske Kyst.

ATYLUS VEDLOMENSIS, Spence Bate and Westwood, 1863.

(Pl. IX. fig. 9, Pl, XI. fig. 6).

Dexamine Vedlomensis, Spence Bate and Westwood, Brit. sessile-eyed Crust. 1863.

I. p. 242 .

Spence Bate, Catal. Amphip. Crust. Brit. Mus. 1862. p. 376.

- $\quad$ - $\quad$ Spence Bate, Catal. Amphip. Crust. Brit. Mus. 1862.

Atylus Veallomensis, A. Boeck, Crust. amphip. bor. et arct. 1870. p. 112.

Truncus et postabdomen carinatum. Carina segmenti trunci ultimi et segmentorum postabdominis qvatuor anteriorum postice in dentem validum desinens, in segmento postabdominis 4 to dentes duos anteriorum minorem qvam posteriorem, formans. Oculi ovales. Rostrum frontale curvatum, longitudinem dimidiam articuli pedunculi Imi antennarum superiorum aqvans. Antenne superiores articulo pedunculi $f$ mo in extremo margine inferiore spina valida armato; arliculo pedunculi 2 do 
longiore, angustiore vero qvam $1 \mathrm{mo}$. Antennæ inferiores articulo pedunculi 5to parum longiore qvam 4to. Perles 3tii 4tiqve paris articulo fto breviore gram 5 to: utroqve conjuncto longitudinem articuli 3tii vix aqvanti. Pedes 5ti paris articulo 1 mo in extremo margine posteriore in spinam longam curvatam producto. Pedes 6 ti et $7 \mathrm{mi}$ paris subproducti. Pedes trium parium ultimorum articulo 4 to parum longiore qvam 3tio, sed multo longiore qvam 5to. Angulus inferior posticus segmenti postabdominis 3 tii rotundatus. Appendix caudalis fere uspre ad basin fissa: lacinia utraqve in apice spinis singulis armata.

L angden er $S^{m m}$.

Legemet er sammentrykt fra Siderne, og Ryggen har en Kjøl. Det sidste Legemsled og Halens fire første Led gaa paa den bagre Ende af Ryggens Midtlinie ud $\mathrm{i}$ en Tand; det fjerde Haleled er foran denne Tand dybt indskaaret, hvorved fremkommer en anden kort, tandlignende Fremstaaenhed. De tre forste Haleleds nedre, bagre Vinkel er afrundet $\mathrm{og}$ har fjærdannede Børster. Sidepladerne ere meget smaa; de fire forste ere noget hoiere end brede og have fjærdannede Borster paa den nedre Rand. Hovedet er saa langt som de tvende forste Legemsled tilsammen; den navnte Kjol fortsætter sig langs dets Midtlinie og ender i det meget sammentrykte, lidt bøiede Pandehorn; Sidevinklerne ere tilspidsede; Øinene ere næsten nyreformede.

De $ø$ vre Føleres forste Skaftled er omtrent saa langt som Hovedet og gar paa Enden af den nedre Rand ud i en stærk Torn; det andet er lidt længere og meget tyndere; det tredie er kort. Svøben er noget lingere end Skaftet og dannes af $12-14$ smale Led.

De nedre Folere ere længere end de ovre; Skaftets tredie Led er kort; det fjerde er noget kortere og tykkere end det lange femte Led. Svoben er længere end Skaftet $0 \mathrm{~g}$ dannes af 25 smale Led.

Det forste Fodpars Haand er forlænget oval og omtrent saa lang som det foreganende Led.

Det andet Fodpar er langere og smalere, men forqvrint af den samme Form.

Det tredie og fjerde Fodpars tredie Led er meget forlænget, ubetydelig bredere nedad og er besat med fjordannede Børster paa begge Rande; det fjerde har næsten kun en Fjerdedel af det foregaaende Leds Længde og har fjærdannede Borster paa den forreste Rand; det femte er lidt læugere end det fjerde Led. Ǩloen er kort, men strerk.

Det femte Fodpars forste Led er paa sin nedre, bagre Vinkel forlænget til en fortil krummet Hage; det tredie er temmelig kort; det fjerde er langere og smalere end dette, og det femte Led er noget kortere.

Det sjette Fodpars forste Led er kun noget udtrukket og tilspidset i den nedre, bagre Vinkel, og det fjerde Led er lidt kortere end dette. 
Det syvende Fodpar ligner, det foregaaende, men det forste Led er end bredere samt saugtakket paa den buede nedre Del af den bagre Rand, den nedre, bagre Vinkel er noget udtrukket, tilspidset; det femte Led er noget længere end paa det foregazende Fodpar.

Det forste og sidste Par Springfodder naa næsten lige langt bagud, medens det andet Par er kortere. Det silste Pars Grene ere længere end Grundleddet; den indre Gren er noget kortere end den ydre og besat med Børster paa den indre Rand, medens den ydre tillige har Torne paa Randen. Grenene ere skraat afskaarne paa Enden og have her en hort Torn.

Halevedhænget er spaltet næsten til Roden; de skraa afskarne Flige ere paa Enden besatte med enkelte Torne.

Jeg tvivler ikke paa, at den ovenfor beskrevne Form er den samme som den, der er beskrevet af Spence Bate og Westwood under Navnet Dexamine Vedlomensis, ihvorvel den i flere Henseender afviger temmelig betydelig fra disses Tegning. Det tredie og fjerde Fodpars fjerde Led er hos dem tegnet længere end det tredie, medens dette hos min Form er endog længere end de tvende sidste Led tilsammen. Det femte Pars forste Led mangler paa deres Tegning, ogsaa den karakteristiske krumme Hage paa den nedre, bagre Vinkel. Desuden findes der flere andre, mindre Afvigelser.

Jeg har fundet den i et enkelt Exemplar baade ved Haugesund og Farsund. G. O. Sars har taget den ved Christiansund paa 50-100 Farnes Dybde. Norman har fundet den ved Shetland.

ATYLUS NORDLANDICUS, A. Boeck, 1870.

(P1. XXIII. fig. 2)

Atylus Norllandieus, A. Boeck, Crust. amphip. bor. et aret. 1870. p. 113.

Carina segmentorum trunci duorum posteriorum et postabdominis quatuor anteriorum dentes retroversos, in segmento postabdominis 4 to dentes duos, anteriorem minorem qvam posteriorem, formans. Oculi rotmoli. Roslrum frontale rectum, articulo pedunculi 1 mo antennarum superiorum brevius. Antenna superiores articulo pedunculi 1 mo in margine superiore et inferiore spina brevissima instructo; articulo 2do longitudinem Imi fere xrganti, sed angustiore. Antenna inferiores articulo pedunculi 5̆to parum longiore qram 4to. Pedes Imi paris carpo et mann longitudine ferme xqvalibus; manu ovata. Pedes 2di paris multo longiores et angustiores qvam 1 mi paris; manu angusta et breviore qvam carpo, in acie obliqve truncata. Pedes 3 tii et 4 ti paris articulo 3 tio longitudinem articulorum duorum segventium conjunctorum apqvanti. Pedes 5 ti paris articulo 1 mo in angulo inferiore posteriore in dentem la- 
lun sed brevem producto. Pedes $7 \mathrm{mi}$ paris articulo 1 mo dilatato, in marginc posteriore arcuato, in margine inferiore in spinam validam desinenti. Pedes trium parium ultimorum articulo 4to longitudinem 3tii et 5ti ferme reqvanti. Appendix caudalis duplo longior qvam ad basin lata, in partibus duabus tertiis exterioribus tissa.

Langden el $7-8^{m m}$.

Legemet er temmelig sammentrykt fra Siderne. Ryggen har en Kjøl, der paa den bagre Rand af de tvende sidste Legemsled og de fire forste Haleler danner bagudrettede Tænder, der efter hverandre tiltage i Længde; på det fjerde Haleled sees desuden en liden Tand foran den anden, storre; den nedre, bagre Vinkel paa de tre forste Haleled er tilspidset, og disse Leds nedre Rand er forsynet med Torne. De fire forste Sideplader ere smaa, næsten dobbelt saa hoie som brede, indskaarue i den nedre Rand, hvor de have smaa Børster. Hovedet er meget længere end de tvende forste Legemsled tilsammen $\mathrm{g}$ gaar fortil ud i et ret Pandehorn, der ikke naar fuldt frem til Midten af de ovre Foleres forste Skaftled; Sidevinklerne ere smaa, lidt tilspidsede. Øinene ere næsten runde.

De orre Følere naa, nar de boies bagud, omtrent til Halens andet Led; Skaftets forste Led er kortere end Hovedet og er paa den ydre Ende af den ovre og undre Rand udtrukket til en lille Spids; det andet er længere og smalere. Svoben er længere end Skaftet og dannes af omtrent 16 Led.

De nedre Folere ere længere end de ovre; Skaftets tredie Led er kort; det fjerde er ikke fuldt saa langt som de tvende forste Led tilsammen paa de ovre Følere; det femte er længere og smalere end det fjerle Led. Svoben er kortere end Skaftet og damnes af 16-18 tynde Led.

Det forste Fodpar er lidet; det fjerde Led er triangulært, lidt liortere end den forlængede, æogdamnede Haand, der paa den forreste Rand har fire Rader Borster og paa den bagre nogle stærkere Torne. Kloen har paa Enden af den indre Rand en liden Torn.

Det andet Fodpar er længere og smalere; det fjerde Led er ikke meget udvidet og har Borstebuniter paa den bagre Rand; Haanden er kortere end det foregaaende Led, med en nasten parallel forreste og bagre Rand, Griberanden er skraa afskaaren og har fine Torne samt tvende stærkere, hvor Kloens Spids lregger sig imod. Kloen har en Torn nær Spirlsen paa den indre Rand.

Det tredie og fjerde Fodpar ere stærke; det femte Led er længere end det fjerde Led, og disse ere tilsammen neppe liengere end det tredie, som kun er lidet udvidet.

Det femte Fodpars forste Led er $\mathrm{i}$ den nedre, bagre Vinkel forlienget til en stærk Tand; det tredie er kortere end det fjerde, der er omtrent saa langt som det femte Led. 
Det syvende Fodpars forste Led er meget bredere end det tilsvarende paa det foregaaende Fodpar, dets bagre Rand er noget S-formet krummet, og den nedre, bagre Vinkel forlænger sig til en bred, lang Tand; det tredie Led er omtrent saa langt som det fjerde, men bredere end dette og længere end det femte Led.

Det sidste Par Springfodders ydre Gren er længere end den indre, og begge ere paa Randene besatte med Torne.

Halevedhanget er omtrent dobbelt saa langt som bredt ved Roden og spaltet i de ydre Totrediedele; hver af Fligene har i Spidsen en liden Torn.

Den er fundet af G. O. Sars ved Skraaven paa 80-100 Favne og af mig omtrent paa den samme Dybde ved Hvidingsøerne.

Gen. II. PONTOGENEIA, A. Boeck, 1870.

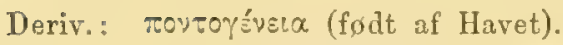

Syn.: 1870. Pontogeneia, A. Boeck, Crust. amphip. bor. et arct. p. 113.

Type: Amphithoё inermis, Kroyer.

Mandibula palpo valido; articulo 3 tio multo breviore qvam 2 do.

Maxilla $1 \mathrm{mi}$ paris lamina interna paucis $(3-6)$ setis plumosis instructa.

Pedes maxillares lamina externa et interna spinis (non dentibus) elongatis instructis; palpo brevi; articulo ejusdem 3 tio in fine marginis exterioris producto.

Antennæ superiores inferioribus paulo longiores.

Pedes saltatorii $1 \mathrm{mi}$ et 2 di paris ramis exterioribus brevioribus qvam interioribus.

Pedes saltatorii 3tii paris pedunculo perlorevi, breviore qram appendice caudali. Appendix caudalis duplex.

Corpus leve, non carinatum; epimeris parvis; epimero 4 to altiore qvam 5 to.

Da Milne-Edwards Slægt Amphithoë efterhaanden blev spaltet i mange Slægter, og Leachs Slagter Atylus og Pherusa atter bleve optagne, matte den af Kroyer opstillede Amphithoë inermis, der af Spence Bate var stillet til Slægten Atylus, danne Typus for en ny Slrgt, da den afviger meget fra Atylus ved de strerke Kindbakker $0 \mathrm{~g}$ ved at Kjæbefoddernes ydre Plader ere væbnede med Torne og ikke med Tænder. I det Ydre adskiller den sig ogsaa derfra, ved at Ryggen ikke har en Kjøl eller Tænder, og ved at de trende sidste Ha.eled ere frie og ikke sammenvoxne, som hos Slægten Atylus. Folerne ere hos Hannen, ligesom Tilfoldet er hos mange andre Amphipoder, forlængede $0 \mathrm{~g}$ forsynede med Sugeskaale, medens disse mangle hos Hunnen. Kroyer havde oprindelig af den typiske Art gjort tvende, $A$. inermis, der er Hun, og $A$. cremulata, der er Han. I 1842 (Nat. Tidsskr. p. 165) parviste han imidlertid, at begge ere 
den samme Form; dette har dog Spence Bate overseet, da han i 1862 opstillede begge Kjøn som forskjellige Arter.

\author{
PONTOGENEIA INERMIS, Kroyer, 1838. \\ (PI. XXI. fig. 4).
}

? Oniscus Cicadre, Otho Fabricius, Fauna Groenlandix. 1780. p. 233.

Amphithö̈ inermis, Kroyer, Gronlands Amph., Dauske Vid. Selsk. Afl. 1838. VII. p. 275. tab. 3. fig. 11 .

- - Milne-Edwards, Hist. des Crust. 1840. III. p. 34.

Amphithoë crenulata (Reiuhardt), Krøyer, Gronlands Amph., Danske Vid. Selsk. Afh. 1838. VII. p. 278. tab. 3. fig. 12.

- $\quad$ - Milne-Edwards, Hist. des Crust. 1840. III. p. 33.

- $\quad$ - Lilljeborg, Öfv. af Kgl. Vet.Akad. Förhandl. 1851. p. 22.

Atylus inermis, Spence Bate, Catal. Amphip. Brit. IIus. 1862. p. 138. pl. XXV. fig. 5. Atylus crenulatus, Spence Bate, Catal. Amphip. Brit. Mus. 1862. p. 139. pl. XXVI. fig. 6. Paramphitoë inermis, Goës, Crust. amph. mar. Spetsb. 1865. p. 8.

Pontogeneia inermis, A. Boeck, Crust. amphip. bor. et arct. 18\%0. p. 114.

Corpus non carinatum, leve. Frons rostro parvo instructa. Angulus inferior posticus segmenti postabdominis 3 tii truncatus, rotundatus. Oculi magni, reniformes. Angulus lateralis capitis truncatus. Antennx longitudine tola animalis paulo breviores. Antennæ inferiores articulo pedunculi 4 to in margine superiore in spinam producto. Pedes $1 \mathrm{mi}$ et 2 di paris elongati; manu breviore qvam carpo; eadem $1 \mathrm{mi}$ paris ovata, 2di paris rectangulari et apicem versus latiore. Pedes 5ti paris articulo 1 mo dilatato. Appendix caudalis usqve ad basin fissa.

Liengden er omtrent $12 \mathrm{~mm}$.

Legemet er noget sammentrykt fra Siderne. Ryggen er glat, uden Kjøl eller Torne. Sidepladerne ere smaa, den fjerde er den storste. Hovedet. gaar fortil ud i et ubetydelig fremtrædende Pandehorn; dets Sidevinkler ere tilspidsede. Øinene ere store, svagt nyreformede.

De orre Følere ere noget kortere end Legemets Længde. Skaftets første Led er omtrent saa langt som Hovedet; ret andet er tyndere, men næsten lige saa langt; det tredie er end tyndere og har noget mere end det foregaaende Leds halve Længde. Svoben dannes hos Hannen af $60 \mathrm{og}$ hos Hunnen af 34 Led.

De nedre Folere ere ubetydelig langere end de ovre; de tvende forste Led ere sammensmeltede, og Lugteknuden er ikke meget fremstaaende; det tredie er omtrent saa langt som tykt; det fjerde og femte Led ere næsten af eens Længde, men det sidste af disse er det tyndeste, og begge have paa den ovre Sides ydre Ende et kort, 
stumpt Fremspring, der dog ikke findes hos Humnen. Svoben dames af omtrent 68 korte Led hos Hannen $\mathrm{g}$ af 58 hos Hunnen. Den nedre Side af de ovre og den øvre Side af de nedre Føleres Skaft er hos Hanmen forsynet med Sugeskaale.

Overlæben er temmelig tyk, i Spidsen afrundet og der besat med Børster.

Kindbakkernes Spidser ere meget tandede. Palpens andet Led er længere end det tredie.

Underlæben er dybt kløvet, temmelig høi, med kun ringe Spor af et indre Pladepar.

Det forste Kjæbepars indre Plade er liden og har fem Borster, der mod dens Ende blive længere og tykkere samt fjærdannede. Palpen har paa Enden korte Torne.

Det andet Kjabepars indre Plade er smalere end den ydre og har paa Enden Borster, der staa i tvende Rader, samt paa den indre Rand Here længere, fjærdannede Børster.

Kjabefoddernes Plader ere korte, men brede; den ydre har paa den indre Rand flade Torne, der mod dens Ende gaa over til krumme Børster.

De trende forste Fodpar ere af eens Bygning, men det andet Par er noget længere end det forste; det fjerde Led er længere end Haanden, som er forlænget, med skraa afskaaret Griberand. De tvende sidste Leds bagre Rand er forsynet med Knipper af Børster.

Det tredie og fjerde Fodpars tredie Led er ikke meget udvidet, det fjerde er næsten lige saa langt, medens det fernte er længere. Begge disse Led have paa.den bagre Rand tildels fjærdannede Børster.

De tre folgende Fodpar tiltage efter hverandre i Længde; det forste Led er bagtil stærkt udvidet og saugtakket; de folgende have paa begge Rande Bundter af korte, men kraftige Torne.

De trende forste Par Springfodder naa omtrent lige langt bagud; af deres Grene, der ere stærkt forsynede med Torne, er den ydre noget kortere end den indre.

Det sidste Pars Grene ere pladeformede; den indre er lancetformet, noget længere og bredere end den ydre, og begge ere i Randene besatte med smaa Torne og Børster.

Halevedhæuget er delt næsten til Roden.

Kroyer har, som ovenfor anfort, forst opstillet tvende Arter, A. inemis og A. cremulata, hvilke han senere fandt at være Han og Hun af den samme Art. Foleme hos $A$. cremlata, Hannen, ere længere end hos $A$. inermis, Hunnen, og forsynede med Sugeskaale. Spence Bate henforte den senere til tvende Arter, da Lan ei var opmærksom paa Kjonsforskjellen.

Denne Art findes ved Grønland, ifølge Holböll og Torell, paa 30 Favnes Dybde. Efter Spence Bate er den fundet af Milne-Edwards ved Banff samt af Barrett i det nordlige atlantiske Ocean. 
Gen. III. HALIRAGES, A. Boeck, 1870.

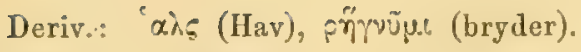

Syn.: 1870. Halirages, A. Boeck, Crust. amphip. bor. et arct. p. 114.

Type: Amphithoë fulvocincta, M. Sars.

Mandibulæ palpo elongato; articulo 3 tio breviore qvam 2 do.

Maxillæ $1 \mathrm{mi}$ paris lamina interiore ovata, in margine interiore setis paucis plumosis $(3-6)$ instructa.

Pedes maxillares lamina exteriore magnitudinis mediocris, non ad finem articuli palpi 2di porrecta et in margine interiore spinis tenuibus armata.

Corpus non valde compressum; dorso rotundato, non carinato; segmentis trunci ultimis et postabdominis anterioribus plerungve in medio margine posteriore in dentes retroversos desinentibus; epimeris magnitudinis mediocris vel parvis.

Antennx pedunculis brevibus sed flagellis pralongatis, multiarticulatis; superiores inferioribus breviores.

Pedes $1 \mathrm{mi}$ et 2di paris elongati, angusti; manibus parvis.

Pedes saltatorii $1 \mathrm{mi}$ 2diqve paris ramis exterioribus brevioribus qvam interioribus: pedes saltatorii ultimi paris pedunculo longiore qvam appendice caudali.

Appendix caudalis parva et integra.

Denne Slægt ligner meget den foregaaende i det Ydre derved, at Ryggen er rund, uden Kjøl; derimod ere enkelte af Legemsleddene og Halens Led væbnede med Tænder i Midten af den bagre Rand. De ovre Følere, som hos den foregaaende Slægt ere læugere, end de nedre, ere her kortere. Halevedhænget er ikke spaltet. I Munddelene afviger den fra Pontogeneia ved den tynde Palpe paa Kindbakkerne, medens den stemmer overens med den deri, at Kjæbefoddernes ydre Plader have Torne og ikke Tænder. Leachs Slægt Pherusa, hvis Typus er $P$. fucicola, og som ifølge Spence Bate adskiller sig fra Slægten Atylus alene ved, at Halevedhænget ikke er kløvet, og fra Slægten Calliopius (Calliope) ved Formen og Størrelsen af de tvende forste Fodpar, antog jeg forst at være overensstemmende med slægten Halirages, men jeg har fraveget denne Mening ved at finde, at de ovre Folere hos $P$. fucicola ere længere end de nedre, medens det Omvendte er Tilfældet hos Halirages. Atylus bispinosus horer hertil og ikke til Slægten Atylus, hvortil den er stillet af Spence Bate, da Halevedhænget ikke er kløvet. Amphithoë costata, Milne-Edwards, maa vistnok ogsaa henføres hertil. Halevedhænget er i Almindelighed saa kort, at det ikke naar frem til Enden af det sidste Par Springfodders Grundled, undtagen hos $H$. triclentatus, hvor det er noget længere. 
HALIRAGES BISPINOSUS, Spence Bate, $185 \%$.

(PI. XXIII. fig. 9).

Dexamine bispinosa, Spence Bate, Ann. Nat. Hist. 1857. 2. ser. XIX. p. 142.

- - - White, Pop. Hist. Brit. Crust. 185\%. p. 178.

Amphithoë macrocephala, M. Sars, Overs. over norsk-arct. Krebsdyr, Forh. i Vid.

Selsk. i Christiania. 1858. p. 142.

Spence Bate, Catal. Amphip. Crust. Brit. Mus. 1862. p. 381.

Paramphithoë elegans, Bruzelius, Skand. Amphip. Gamm. 1859. p. 75. fig. 14.

Ampleithopsis elegans, A. Boeck, Forh. ved de skand. Naturf. 8de Møde. 1860. p. 662. Pherusa eleyans, Spence Bate, Catal. Amphip. Crust. Brit. Mus. 1862. p. $37 \%$.

Atylus bispinosus, Spence Bate, Catal. Amphip. Crust. Brit. Mus. 1862. p. 140. pl. XXVII. fig. 1.

- $\quad$ - Spence Bate and Westwood, Brit. sessile-eyed Crust. 1863. p. 250.

- - Norman, Rep. on the Shetland Crust. 1868. p. 280.

Halirages bispinosus, A. Boeck, Crust. amphip. bor. et arct. 1870. p. 115.

Caput rostro parvo, acuto. Oculi permagni, ovati. Segmenta postabdominis duo anteriora in medio margine posteriore dentibus singulis acutis armata. Segmentum postablominis 1 mum angulo inferiore postico rotundato; 2dum angulo in spinam excunti; 3tim in dimidio inferiore marginis posterioris curvatum et valde serratum. Antemme superiores inferioribus longissimis multo breviores, ad segmentum trunci 5́tum porrectre; articulo pedunculi 1 mo longitudinem articulorum duorum sequentium junctorum reqvanti. fere duplo longiore quam crasso. Pedes saltatorii ultimi paris pedunculo longitudinem rami exterioris ferme reganti. Appendix caudalis ovata.

Lingden er $5-6^{\mathrm{nm}}$.

Legemet er forlænget, ikke meget høit eller sammentrykt; Ryggen er uden Kjol, men de tvende forste Haleled gaa i Midten af den bagre Rand ud i en skarp Tand; deres nedre Rand er forsynet med Torne; det andet Leds nedre, bagre Vinkel er udtrukket i en liden, spids, opadbøiet Hage; det tredie Leds bagre Rand er bueformet $0 \mathrm{~g}$ indskaaret i fem grove Saugtakker, der opad tiltage i Storrelse. Sidepladerne ere smaa, kun lidt hoiere end brede. Hovedet er omtrent saa langt, som de trende forste Legemsled tilsammen, og Panden gar mellem de ovre Folere frem i et spidst Horn. Ginene ere store, af en noget forskjellig Form hos de forskjellige Individer.

De ovre Følere eré omtrent saa lange som Hoveriet og de fire forste Legemsled tilsammen. Skaftets forste Led er henved tre Gange saa langt som tykt; de tvende folgende aftage i Længrle og Tykkelse. Svoben er noget længere end Skaftet og dannes af henved 20 Led. 
De nedre Folere ere meget længere end de øvre, og hos Hanmen næsten længere end Legemet. Skaftets tredie Led er neppe saa langt som tykt; det fjerde og femte ere korte og indbyrdes lige lange. Svoben dannes af 60 - 70 Led og er flere Gange saa lang som Skaftet.

Kindbakkerne ere forlængede; 'Gribedelen har fem til sex Tænder, og den indre Bigren er væbnet med fire saadanne; Tyggeknuden er meget fremstaaende, tandet og omgivet af et Tandgjerde, der $i$ den undre Vinkel afbrydes af en fjordannet Børste. Palpen er kraftig udviklet, dens tredie Led er ikke fuldt saa langt som det andet $0 \mathrm{~g}$ krummet.

Det første $\mathrm{Kj}$ jepars ydre Plade har stærke, kamformede Tænder; den indre Plade er oval og har tre til fire fjærdannede Børster. Palpen har paa Enden fire til fem korte Torne.

Det andet Kjabepars Plader ere korte.

Kj $x$ befoddernes ydre Plade er oval, buet paa den indre Raud og vabnet der med en Række forlængede Dóbbelttorne, der mod Pladens Ende blive end længere og gaa paa den ydre Rand over til krumme Borster; den indre Plade naar lidt frem for Fnden af Palpens forste Led og har tre Tænder sant fjærdannede Børster. Palpens andet Led er ikke meget langere end det tredie.

Det forste Fodpar er meget lidet; det fjerde Led er triangulært; Haanden er forlænget oval, med sliraa afsliaret Griberand.

Det andet Fodpar er næsten af den samme Form og Storrelse.

Det tredie og fjerde Fodpars tredie Led er meget kort, neppe saa langt som det fjerde, det er kortere end det femte Lud.

Det forste Par Springfodders ydre Gren er kortere end den indre, der paa Randene og i Spidsen er besat med stærke Torne.

Det sidste Par naar længst bagud; Grundleddet er omtrent saa langt som Grenene, der have en meget smal Lancetform, ere lige lange og have Torne paa den indre Rand og i Spidsen.

Hal eved hænget er meget kort, xgformet.

Hos denne Art skal efter Spence Bate og Westwood Halevedhænget være agformet, "with a slit down the middle", hvilket ikke er Tilfreldet hos den her beskrevne Form. Hvis dette skulde constatere sig, maa der handles om tvende forskjellige Arter, hvorved M. Sars's Benzevnelse $H$. macrocephala matte beholdes for denne. En Varietet ulmarker sig ved sit eiendommelige store Hoved og ligeledes ved sine store Øine. Efter et saadant Exemplar, som M. Sars fandt ved Tromsø, har han opstillet sin Art Amphithoë macrocephala; iovrigt adskiller hans Exemplar, om hvilket han siger: "Capite maximo, fere segmenta tria prima thoracis aqvanti; oculis maximis, ovalibus, nigris", sig ikke fra andre, der ere tagne ved vor Kiyst.

Farven var paa et Exemplar, fundet af mig ved Haugesund, lysegron med livide Fodder og Følere. Hovedet og de ovre Føleres første Skaftled vare drkkede med 
tætte, sorte Punkter. Langs Ryggen, paa hver Side af Midtlinien, saaes tvende langsgaaende, sorte Baand, der bagtil endte i de paa det femte og sjette Legemsled værende Torne. Paa Sidepladerne og paa Halens Led var Farven guul, punkteret med Grøngraat. Et andet Exemplar var lysebrunt, med mørkerød farvet Ryg. Øinene vare hvide, med smaa, rode Lindser. Følerne havde gulbrune Ringe, og over Halen var strøet stjerneformede, sorte Spidser. Efter Bruzelius er Farven mørkerød, med graaagtige Flekker paa Ryggen. Efter Norman er den hvid, med sorte Pletter.

Ved Tromsø er den taget af M. Sars paa 20-30 Favne; i Nordland af G. 0 . Sars ved Skraaven paa 10 - 20 Favne; af mig ved Langenæs paa 20 Favne. Ved Christiansund er den fundet af G. O. Sars paa.50-100 Favne; ved Haugesund af mig paa 20-30 Favne. Bruzelius har fundet den i Mængde ved Gullmarefjorden i Bohuslen paa ikle synderlig Dybde. Den er ligeledes fundet paa mange Steder ved den engelske Kyst.

\section{HALIRAGES BOREALIS, A. Boeck, 1870.}

(PI. Xxilı. fig. 6).

Halivages borcalis, A Boeck, Crust. amphip. bor. et arct, 1870. p. 116.

Oculi parvi, rotundati. Segmentum postabdominis 1 mum et 2 dum in medio margine posieriore spinis singulis armata. Segmenta postabdominis tria anteriora in angulo inferiore posteriore rotundata. Antenne superiores longitudinem dimidiam animalis ferme rqvantes. Antennæ inferiores articulo pedunculi 5́to parum longiore qvam 4to. Pedes $1 \mathrm{mi}$ et 2di paris manu qvadrangulari, parva, in acie obliqve truncata.

Denne Art ligner meget den foregaaende, inen den nedre, bagre Vinkel paa det andet Haleled er ikke udtrukket i nogen opadbøiet Hage, og det tredie Leds bagre Rand er uden Tænder; Panden gaar frem i et ganske lidet Horn; Øinene ere smaa, runde.

De nedre Føleres fjerde Led er meget kortere og bredere end det femte Led.

De trende forste Fodpars Haand er mere firkantet end hos den foregarende Art.

De tre bagre Fodpars første Led er kun lidt høiere end bredt, og den bagre Rand er næsten cirkelformet; det femte Led er næsten saa langt som de tvende foregaaende Led tilsammen.

Halevedhænget naar frem nesten til det sidste Par Springfødders Grundled.

Af denne Art har jeg kun faaet eet Exemplar fra Nordland, uden at jeg kan angive, af hvem det er fundet eller Findestedet. 
HALIRAGES TRIDENTATUS, Bruzelius, 1859.

Paramphithoë tridentata, Bruzelius, Skand. Amphip. Gamm. 1859. p. 74. fig. 13.

Amphithopsistridentata, A. Boeck, Forh. ved de skand. Naturf. 8de Møde. 1860.p. 662. Dexamine tridentata, Spence Bate, Catal. Amphip. Crust. Brit. Mus. 1862. p. 376. Halirages tridentatus, A. Boeck, Crust. amphip. bor. et arct. 1870. p. 116.

Caput rostro minimo, acuto. Oculi permagni, ovales aut fere reniformes. Dorsum rotundatum. Segmentum 7 mum trunci et postabdominis 1 mum et 2 dum in medio margine posteriore dentibus singulis aculis, retroversis instrucla. Segmenta postabdominis tria anteriora in margine posteriore serrata, imprimis segmentum 2 dum et 3tium. Antennæ sat elongatr: superiores ad segmentum postabdominis 2dum vel 3tium porrecta: inferiores superiorihus multo longiores, longitudinem animalis superantes. Pedes saltatorii ultimi paris ramis longioribus qvam pedunculo. Appendix caudalis apicem versus angustior, in margine posteriore truncala, denticulata et in medio parum incisa.

Lxigd en er $14^{\mathrm{mm}}$,

Legemet er ikke meget sammentrykt; Ryggen er afrundet, uden Kjøl, men den bagre Rand af det sidste Legemsled og af Halens tvende forste Led gaar $\mathrm{i}$ Midten ud i en bagudrettet Tand. De tvende første Haleleds bagre Rand er saugtakket; det tredie Leds bagre Rand er meget afrundet $0 \mathrm{~g}$ saugtakket Hovedet er omtrent saa langt som de tvende forste Legemsled tilsammen; den forreste Rand gaar i Midten, mellem de øvre Folere, ud ì et lidet, spidst Pandehoru. Øinene ere næsten nyreformede.

De øvre Følere naa, naar de boies bagud, omtrent til det tredie Haleled. Skaftets forste Led er kortere end Hovedet og omtrent saa langt som de tvende følgende Led tilsammen, der efter hinanden aftage meget i Langde og Tykkelse. Svøben er flere Gange saa lang som Skaftet og dannes af 40 Led.

De nedre Folere ere meget længere end de ovre og længere end Legemet. Skaftets tredie Led er liort, neppe længere end tykt; det fjerde er meget længere og af den samme Læengde som det femte Led, men tykkere end dette. Svoben dannes af omtrent 80 korte Leti.

Kindbakkerne ere kraftigt udviklede; Gribedelen er skarp, indskaaret i sex til syv Tænder; den indre Bigren har fem lignende. Palpen er stærk; dens andet Led er længere end det tredie, og begge ere forsynede med Barster.

Det første Kjæbepars indre Plade er oval, med fem til sex fjærdannede Børster paa den indre Rand. Palpen er væbnet med fire til fem Tænder eller grove Børster paa Enden.

Det andet $\mathrm{Kj} \rightsquigarrow \mathrm{bepars}$ Plader ere næsten lige lange. 
Kjabefoddernes ydre Plade er stor og har grove Borster paa den indre Rand; den indre Plade naar frem til Enden af Palpens forste Led og har i Spidsen tre Tænder og nogle fjærdannede Børster.

Det forste og andet Fodpar ere næsten af eens Bygning og Storrelse; det fjerde Led er forlænget, bredt, triangulært; Haanden er omtrent saa lang som det foregaaende Led og bliver lidt bredere mod Enden, med skraa afskaaret Griberand. Kloen er stærk, saugtakket paa den bagre Rand.

Det tredie og fjerde Fodpar ere meget stærke.

De tre følgende Fodpar tiltage efter hverandre i Længde; det første Led er bredt og bliver smalere nedad; den bagre Rand, der er meget mere krummet end den forreste, er fint tandet; det tredie er lidt længere end det fjerde Led.

Det forste Par Springfodder naar ei saa langt bagud som det sidste Par; dets ydre Gren er lidt kortere end den indre, og begge have Torne paa den øvre Rand samt i Spidsen.

Det sidste Pars Grene ere lige lange, længere end Grundleddet, smale, paa Enden tilspidsede og med Torne sant Børster paa begge Rande.

Halevedhænget er meget langere end bredt ved Roden, bliver smalere mod Enden, hvor det er afskaaret og fint tandet.

Denne Art skal ifølge Bruzelius forekomme lige fra Finmarken til Bohuslen. Jeg har kun seet eet Exemplar, som er taget af G. O. Sars ved Skraaven paa 5-20 Favnes Dybde.

\section{HALIRAGES FULVOCINCTUS, M. Sars, 1858.}

(Pl. XXIIr. fig, 11).

Amphithoё fulvocincta, M. Sars, Overs. over norsk-arctiske Krebsdyr. 1858. p. 22. Spence Bate, Catal. Amphip. Crust. Brit. Hus. 1862. p. 381.

Pherusa tricuspis, Stimpson, Proceed. acad. nat. sc. of Philadelphia. 1863. p. 138. fig. 15. Panamphithoë fulvocincta, Goës, Crust. amphip. maris Spetsb. 1865. p. 9. fig. 18. Halirages fulvocinctus, A. Boeck, Crust. amphip. bor. et arct. 1870. p. 116.

Oculi magni, ovati, fere reniformes. Segmentum trunci $7 \mathrm{mum}$ et postabdominis 1 mum et 2dum in medio margine posteriore dentibus singulis acutis armata. Segmentum postabdominis $1 \mathrm{mum}$ in angulo inferiore postico rotundatum, 2dum acuminatum. 3tium truncatum et serratum. Antenne prielongata; superiores tres qvartas longitudinis inferiorum partes ferme aqvantes et ad segmentum postabdominis 3 tium vel 4 tum porrectx. Pedes saltatorii ultimi paris ramis multo Iongioribus qvam pedunculo. Appendix caudalis elongala, in apice truncala et parum dentata. 
Langden er omtrent $16^{\mathrm{mm}}$.

Legemet er meget langstrakt, ikke stærkt sammentrykt. Ryggen er rund, uden Kjol, men det sidste Legemsled 0 g rle tvende første Haleled ere paa Midten af den bagre Rand vabnede med en spids, bagudrettet Torn. Halens forste Led er afrundet paa den nerre, bagre Vinkel; det andet har her en liden Torn, medens det tredie paa det nederste Parti af den bagre Rand har en Række smaa Saugtakker. Nogle lignende sees ogsaa langs Befæstelsesstedet for Springfodderne. Sidepladerne ere smaa; de fire første ere kun ubetydelig høiere end brede. Hovedet er næsten saa langt som de tvende forste Legemsled tilsammen, og Panden gaar mellem de øvre Følere ud i et lidet Horn; Sidevinklerne ere meget afrundede; Øinene ere store, ovale.

De øvre Følere ere noget kortere end Legemet; Skaftets første Led er kortere end Hovedet og neppe mere end dobbelt saa langt som tykt; de tvende folgende aftage efter hinanden i Længde og Tykkelse. Svoben er 4-5 Gange saa lang som Skaftet og dannes af en usædvanlig Mængde meget korte Led.

De nedre Fulere ere længere end de ovre og hos Hamen læugere end det hele Legeme. Skaftets tredie Lel er neppe saa langt som tykt; det fjerde er omtrent saa langt som det femte. Svoben er mange Gange saa lang som Skaftet og dannes ligeledes af en Mængde korte, tynde Led. Overlæben er i Spidsen afrundet og besat med stærke Børster.

Kindbakkerne ere stærke; Gribedelen er bred, indskaaret i 5-6 Tæuder, og den indre Bigren i 4-5; Tornerrkken dannes af $7-8$ i den convexe Rand saugtakkede Torne. Tyggelinuden er fremstaaende, den indre Tandrad afbrydes i den nedre Vinkel af en lang, fjærdannet Borste. Palpens tredie Led er lidt læengere end det andet, krummet og forsynet med talrige Børster.

Underlæbens indre Plader ere smaa og sees nær Bunden af Spalten.

Det forste Kjabepars ydre Plade har 10 stærke Torne, hvoraf den ene Halvdel er kamdamnet, den anden er saugtakket; den indre Plade er oval og har sex fjærdannede Borster. Palpen er paa Enden bred og har paa den ene Side en Række Tænder og paa den anden en Række Børster.

Det andet Kjæbepars yilre Plade er lidt langere og bredere end den indre.

Kjabefoddernes ydre Plade er ikke lang, men bred, vabnet med Torme paa den indre Rand, og som paa Enden af den ydre Rand gaa over til krumme Borster; den indre Plade har paa Enden tre Tæander og fjærdannede Børster. Palpens Led ere brede; det tredie bliver udad bredere og forlænget samt afrundet $\dot{i}$ det ovre, ydre Hjorne; det sidste Led er kloformet, merl en kort Torn paa Enden.

Det forste og andet Fodpar ere næsten af eens Bygning; det fjerde Led er forlænget og bliver iklie meget bredere mod den ydre Ende; Haanden er næsten af den samme Størrelse og ubetydelig bredere mod den ydre Ende, med skraa afskaaret Griberand. De tre sidste Led have stærke Borstebundter paa den bagre Rand. Kloen er saugtakket paa den bagre Rand. 
Det tredie og fjerde Fodpar ere forlængede, smale; det tredie Led er lidet udvidet nedad samt kortere end det femte Led.

De tre følgende Fodpar tiltage efter hverandre meget i Iıængde; det første Led er ovalt, saugtakket paa den bagre Rand, det tredie er kun lidet udvidet, lidt længere end det fjerde, men kortere end det femte Led. De tre sidste Led ere paa den forreste og bagre Rand forsynede med Torne.

De tvende forste Par Springfødders indre Gren er lidt kortere end Grundleddet, men længere end den ydre Gren.

Det sidste Pars Grene ere omtrent lige lange og læengere end Grundleddet. Alle Pars Grene have Torne paa den øvre Rand og i Spidsen.

Halevedhænget bliver smalere udad og saugtakket paa den tvært afskaarne Ende.

Farven er efter M. Sars gulhvid, gjennemsigtig; Legemsleddenes bagre Rand er gulrød, og lignende farvede Ringe sees paa Følerne. Øinene ere livlig cochenillerøde.

Af M. Sars og Danielssen er denne Art fundet i stor Mrengde ved Tromsø i Laminariabeltet, paa 1-10 Favnes Dybde, og ved Slotholmen i Lofoten. Af G. O. Sars er den taget ved Brettesnæs paa 40 Favne, ved Skraaven paa 250 og ved Aalesund paa 50-100 Favne. Af C. Boeck er den medbragt fra Christiansund. Den er taget af Torell ved Spitsbergen paa 2-20 Favne og er ligeledes fundet ved Grønland af Torell og Malmgren og ved Nordamerikas Kyst.

Det er formodentlig denne Art, som af Packard er opfort under Navnet $A$. inermis fra Labrador.

Gen. IV. CALLIOPIUS, Lilljeborg, 1865.

Deriv.: Calliope (Navnet paa en Nymphe).

Syn.: 1855. Calliope (Leach), Spence Bate, Brit. Assoc. Rep. Ann. Nat. Hist. 1857.

1857. - White, Hist. Brit. Crust. p. 179.

1862. - Spence Bate, Catal. Amphip. Crust. Brit. Mus. p. 148.

1863. - Spence Bate and Westwood, Brit. sessile-ejed Crust. p. 258.

1865. Calliopius, Lilljeborg, On the Lysianassa Magellanica, p. 19.

1870. - A. Boeck, Crust, amphip. bor, et arct. p. $11 \%$

Type: Amplithoülaviuscula, Kroyer.

Dorsum dentibus destitutum.

Pedes $1 \mathrm{mi}$ et 2 di paris manu valida, longitudinem carpi superanti.

Pedes saltatorii ultimi paris pedunculo non prælongato, breviore vel eadem longitudine ac appendice caudali magna.

Cateroqvin ferme ut apud genus Halirages. 
Spence Bate opstillede Slagten Calliope i 1855, hvortil han benyttede et ikke publiceret Navn af Leach og begrundede den i 185\% Den typiske Art var C. Leachii, som han senere stillede synonym med $C$. lavinscula. Hvad der efter lam egentlig larakteriserer Slægten er, at de tvende forste eller blot det andet Fodpar have en vel udviklet Haand, at det fjerde Led er udtrukket i den nedre, bagre Vinkel, samt at Halevedhænget ikke er spaltet. Han tror $\log$ i 1862, at denne Slægts Arter vise en gradvis Overgang til Arterne af Slægten Atylus og Acanthosoma. Lilljeborg forandrer i 1865 Slægtsnavnet til Calliopius, da det af Spence Bate givne Navn allerede var benyttet til en Drøvtygger. Han fremhever som Karakter for Slægten, at det andet Fodpars Haand er meget storre end den paa det forste Fodpar. I 1870 optog jeg andre Karakterer for denne Slægt, idet jeg væsentlig skilte den fra Slægten Halirages ved det sidste Par Springfødders Form, og ved at de tvende forste Fodpars Hænder ere meget stærke.

CALLIOPIUS LæEIUSCULUS, Krøyer, 1835.

Amphithoë laviuscula, Kírøyer, Gronlands Amphip., Danske Vid. Selsk. Afh. 1838. VII. p. 253. tab. 3. fig. 13.

- $\quad$ - Milne-Edwards, Hist. des Crust. 1540. tab. III. p. 30.

- $\quad$ - Bell, App. Belchers 1ast. arct. voy. 1855. p. 405.

Amphithoё Rathlei, Zaddach, Syn. Crust. Pruss. prodr. 1844. p. 6.

- - Spence Báte, Catal. Amphip. Crust. Brit. Mus. 1862. p. 243.

Calliope Leachii, Spence Bate, Rep. Brit. Assoc. 1855. p. 58; Ann. Nat. Hist. 1857.

2. ser. XIX. p. 142 .

White, Pop. Hist: Brit. Crust. 1857. p. 179.

Amphithoё serraticornis, M. Sars, Forh. i Vid. Selsk. i Christiania. 1858. 1. 140.

Spence Bate, Catal. Amphip. Crust. Brit. Mus. 1862. p. 381.

Paramphithoë leviuscula, Bruzelius, Skand. Amphip. Gamm. 1859. p. 76.

- - - Goës, Crust. Amphip. maris Spetsb. 1865. p. S.

Amphithopsis leviuscula, A. Boeck, Forh. yed de Skand. Naturf. 8de Møde. 1S60. p. 662.

Calliope laviuscula, Spence Bate, Catal. Amphip. Crust. Brit. Mus. 1S62. p. 148. pl. XXVIII. fig. 2.

- $\quad$ - Spence Bate and Westwood, Brit. sessile-eyed Crust. 1863. p. 259.

Calliope grandoculis, Spence Bate, Catal. Amphip. Crust. Brit. Mus. 1862. p. 149. pl. XXVIII. fig. 4.

Spence Bate and Westwood, Brit. sessile-eyed Crust. 1863. p. 265.

Calliopius laviusculus, A. Boeck, Crust. amphip. bor. et arct. 1870. p. 11 .

Oculi magni, reniformes. Antennæ superiores articulo pedunculi 3 tio in extremo margine inferiore in spinam validam, brevem desinenti. Pedes Imi ef 2 di 
paris manu permagna, ovala; carpo perbrevi et ex angulo inferiore posteriore calcem emittenli. Segmentum postabdominis 2dum et 3tium in angulo inferiore posteriore in spinusculas singulas producta, in margine posteriore rotundata. Appendix candalis in apice lata et rotnndata.

Lxngden er 7 - $11^{\mathrm{mm}}$.

Legemet er tykt, ikke meget sammentrykt, af en undersætsig Form. Ryggen har ikke Kjøl eller Tænder; dog sees paa de tre første Haleleds Midte en svag Kjøl, som hiever sig noget i den bagre Rand. Det første Haleleds nedre, bagre Vinkel er afrundet, paa de tvende folgende Led er den uddragen til en liden Spids. Sidepladerne ere smaa; de fire forste ere forneden afrundede, den første er noget høiere end bred, de følgende tiltage lidt i Langde. Hovedet er ikke saa langt som de tre forste Legemsled tilsammen; Panden gar frem i et lidet Horn; Sidevinklerne ere afrundede. Øinene ere sardeles store, nyreformede.

De ovre Folere naa, naar de bøies bagud, omtrent til det femte eller sjette Legemsled; Skaftets forste Led er kortere end Hovedet; de tvende følgende aftage efter hinanden $\mathrm{i}$ Længde og Tykkelse, og det sidste af disse forlænger sig i den nedre, forreste Vinkel til en stærk, men stump Tand. Svoben er meget længere end Skaftet og dannes hos Humnen af 22 , hos Hannen af $46 \mathrm{Led}$, som udvide sig i den nedre, forreste Vinkel, hvorved Svoben synes at viere saugtakket.

De nedre Folere ere ubetydelig langere end de ovre; Skaftets tredie Led er kun lidt længere end tykt; det fjerde er lidt længere og tykkere end det femte Led. Svoben er meget langere end Skaftet og damnes hos Hunnen af 28, hos Hannen af 53 Led.

Overlæben er paa Enden afrundet og forsynet med Borster.

Kindbakkerne ere meget stærke, triangulære; Gribedelen er bred, væbnet med syv Tander, den indre Bigren har 5-6; Tyggelinuden er meget fremstaaende. Palpens tredie Led er næsten saa langt som det andet og besat paa Randen ined talrige Børster.

Det forste $\mathrm{Kj}$ ¡ bepars indre Plade er oval, med fire stærke, saugtakkede Borster paa Enden. Palpen har Tænder paa Enden.

Det andet $\mathrm{Kj}$ bepars ydre Plade er større og bredere end den indre, som, foruden de kortere Børster paa Enden, har flere meget stærke fjærdannede Borster paa den indre Flade.

Kjæbefodderne ere meget kraftige; den ydre Plade er ikke meget stor, væbnet $\mathrm{i}$ den indre, rette Rand med tynde Torne, som forlænge sig mod Enden og gaa paa den ydre Rand over til krumme Borster; den indre Plade naar ikke frem til Euden af Palpens forste Led. Palpens andet I.ed er meget bredt; det fjerde er kloformet og besat med en Række fine Torne paa den indre Rand.

De tvende forste Fodpar ere af eens Storrelse og Bygning; det fjerde Led 
er temmelig kort, triangulært $0 \mathrm{~g}$ udsender en kort, smal Hæl fra den nedre, bagre Vinkel. Haanden er særdeles stor, ægformet; Griberanden, der indtager den storste Del af den bagre Rand, har fine Torne samt nogle meget stærkere paa Enden, hvor Kloens Spids lægger sig til.

Det tredie og fjerde Fodpar ere forlængede; det tredie Led er kun lidt længere end det fjerde, men kortere end det femte Led.

De tre folgende Fodpar tiltage lidt i Længde; det første Led er næsten ovalt; det tredie er udvidet nedad og udtrukket, tilspirset i den nedre, bagre Rand, paa det syvende Fodpar er dette Led kortere end det fjerde, der igjen er kortere, end det femte Led.

De tvende første Par Springfodders ydre Gren er kortere end den indre og begge have stærke Torne i den ovre Rand og i Spidsen.

Det sidste Pars Grene ere lancetformede, næsten lige lange; den ydre Gren er paa begge Rande væbnet med Torne, den indre har ogsaa Torne paa den ydre, men kun Børster paa den indre Rand.

Halevedhænget er meget stort, ovalt, meget Iængere end det sidste Par Springfødders Grundled.

Paa enkelte Steder i Christianiafjorden og især ved de danske Øer forekommer en Varietet med større Hoved og med større Øine, der nærme sig hinanden paa $\mathrm{H}_{0}$ vedets øvre Flade. Denne er af Spence Bate opstillet som en egen Art, C. grandocutis, men jeg har fundet alle Overgange fra denne til den almindelige Form, saa at jeg ei kan optage den som en Art. Den forholder sig til C. loviusculus paa samme Maade, som $A$. macrocephala til $H$. bispinosus.

Farven er almindeligvis gul, med svage, brune og ablerode Pletter over Halens tre forste Led og over den bagre Rand af de tre sidste Haleled og den bagre Rand af de tre sidste Fodpars første Led. M. Sars fandt Farven gjennemsigtig grønlig og Øinene morkbrune.

Ved Gronland er den fundet af Torell paa flere Steder og ligeledes ved Spitsbergen af Malmgren. Ved Nordkap er den fundet af R. Collett; ved Groto er den efter M. Sars sjelden paa 20-30 Favne, ligeledes ved Manger. Ved Haugesund og i Christianiafjorden fandt jeg den meget hyppig paa enkelte Steder, og den synes ogsaa . at være almindelig ved Bohuslen og omkring de danske Øer samt ved Gottland og i Østersøen ifølge Lindström, Smitt og Bruzelius. Den er fundet paa forskjellige Steder ved England og af Metzger ved den ostfrisiske Kyst, hvor den dog er sjelden, mellem -Tang og Sertullarier. Efter Packard findes den ogsaa verl Labrador. 


\title{
CALLIOPIUS NORVEGICUS, Rathke, 1843.
}

\author{
(P1. XXII. fig. 6).
}

Amplithoё Norvegica, Rathke, Beitr. z. Fauna Norwegens, Act. Acad. Leop. 1843. tab. XX. p. 83. tab. 4. fig. 6 .

Paramphithoё Norvegica, Bruzelius, Skand. Amphip, Gamm. 1859. p. 7\%.

Calliope Norvegica, Spence Bate, Catal. Amphip. Crust. Brit. Mus. 1862. p. 150.

Calliopius Norvegicus, A. Boeck, Crust. amphip. bor. et arct. 1870. p. 118.

Oculi multo minores quam apud speciem pracedentem, subreniformes. Antenme superiores articulo pedunculi 3tio nodulo instructo. Pedes $1 \mathrm{mi}$ et 2di paris manu apicem versus latiore in acie obliqve truncata; carpo paulo breviore qvam manu, calce destituto. Segurentum postabdominis 3tium in angulo inferiore postico in dentem productum et in margine posteriore perangulatum; angulo sape sursum acuto et producto. Appendix caudalis ovata et angusta.

Liengden er $8-10^{\mathrm{mm}}$.

Legemet er ikke meget sammentrykt; Ryggen er rund, uden Kjøl. Det tredie Haleleds nedre, bagre Vinkel gaar ud i en Tand, den bagre Rand har en storre Indbugtning, der nelad ender $\mathrm{i}$ et spidst, noget opadbøiet Fremspring, og mellem dette $\mathrm{og}$ den nedre Vinkel er Randen ogsaa indskaaret. Sidepladerne ere smaa, lige saa høie som brede eller kun lidt høiere. Hovedet er længere end det første Legemsled og danner mellem de ovie Folere et lidet Pandehorn. Øinene ere bagtil afrundede og have en svag Indbugtning.

De $\emptyset$ vre Følere ere kortere end de nedre; Skaftets forste Led er omtrent dobbelt saa langt som tykt, de tvende folgende aftage efter hinanden i Længde og Tykkelse, og det sidste af disse er paa Enden af den nedre Rand væbnet med en stump Tand. Svoben er Here Gange saa lang som Skaftet og dannes af 27 Led, hvoraf hvert andet Led er bredere paa den ydre Ende og har der en Dusk Børster.

De nedre Foleres tredie Led er omtrent saa langt som tykt; det fjerde og femte Led ere omtrent lige lange. Svoben dannes af omtrent 50 Led.

K indbakkerne ere meget kraftige, og Tyggeknuden er meget fremstaaende.

Det forste $\mathrm{K}$ jabepars indre Plade er oval og forsynet med fem strerke, $\mathrm{i}$ Spidsen bøierle, fjærdannede Børster.

Kjæbefoddernes indre Plade er forlænget firkantet; den ydre Kant naar kun frem til den ydre halve Del af Palpens andet Led.

Det forste og andet Fod par ere af eens Bygning og Storrelse; det fjerde Led er triangulært; Haanden er stor, omtrent dobbelt saa lang som bred, med en noget skraa afskaaret Griberand, der er forsynet med korte, fine Børster; den bagre Rand er besat med Torne, hvoraf et Par paa den ydre Ende ere meget stærke.

Det tredie og fjerde Fodpar ere meget stærke; det tredie Led er meget 
kort og kun lidet udvidet; det fjerde er næsten af den samme Læugde, men smalere, medens det femte Led er meget længere. Kloen er stærk, lidt krummet.

De tre folgende Fodpar ere af eens Bygning; det forste Led er bredt, ægformet, smalere mod den ydre Ende og saugtakket paa den bagre Rand; det tredie er længere end det fjerde, men kortere end det femte Led og ikke meget stærkt udvidet.

Det forste Par Springfodders ydre Gren er ubetydelig kortere end den indre.

Det andet $\mathrm{Par}$ er kraftigere og forkortet.

Det sidste $\mathrm{Par}$ naar omtrent saa langt bagud som det forste; Grenene ere kortere, lige lange, lancetdannede, med Torne paa begge Rande.

Halevedhænget er stort, af en ægrund Form, længere end bredt ved Roden, udelt.

Farven er bleg, gulagtig, med brunrode Pletter paa Ryggen og Legemsleddene.

Den er fundet ved Christiansund af Rathke, ved Haugesund af mig paa 1-3

Favnes Dybde, og er ifølge Bruzelius fundet af v. Düben ved den norske Kyst.

\section{Gen. V. AMPHITHOPSIS, A. Boeck, 1860.}

Deriv.: Amphithoë og öưs Udseende.

Syn.: 1860. Amphithopsis, A. Boeck, Forhandl. ved de Skand. Naturf. Sde IIøde. p. 661.

1870. - A. Boeck, Crust. amphip. bor. et arct. p. 118.

Type: Amphithopsis longicaudata, A. Boeck.

Mandibulæe articulo palpi 3tio valido.

Maxilla $1 \mathrm{mi}$ paris lamina interiore lata, ovata, in margine interiore setis paucis plumosis instructa.

Pedes maxillares lamina exteriore parva, in margine interiore spinis tenuibus instructa.

Corpus compressum, nec carinatum nec spinosum.

Antenne superiores elongate inferioribus longiores; articulis pedunculi brevibus; flagellis prælongatis.

Pedes $1 \mathrm{mi}$ et 2 di paris vel angusti vel robusti; manu 2 di paris validiore qvam $1 \mathrm{mi}$ paris.

Pedes saltatorii ramo interiore longitudinem exterioris superanti; pedes saltatorii ultimi paris pedunculo perbrevi.

Appendix caudalis parva, integra.

Bruzelius gav i 1859 Slægtsnavnet Paramphithoë til en stor Mængde Arter, hvoraf flere allerede forhen vare henforte til andre Slrgter. I 1860 fandt jeg imidlertid, at denne Slagt indeholdt saa mange differente Typer, at jeg troede at maatte ud- 
skille en Del Arter under Navnet Amphithopsis. I 1870 indskrankede jeg denne Slægt til de Arter, som staa nærmest Amphithopsis longicaudata, Boeck, 1860, og sammenstillede under denne de Former, der have et sammentrykt Legeme, uden Kjol eller Torne, samt hvis øvre Følere ere længere end de nedre, og som væsentlig skille sig fra de øvrige Arter ved Kindbakkernes stærke tredie Palpeled, ligesom ved, at Kjæbefødderne ere forsynede med kun smaa ydre Plader, der i den indre Rand ere vabnede med Torne. Herved skiller denne Slagt sig karakteristisk baade fra Calliopius og fra Halirages, der begge, ligesom denne, har et udelt Halevedhæng. Fra Slægten Phemsa, hvis ovre Følere ogsaa ere længere, end de nedre, og hvis Halevedhæng ligeledes er helt, skiller den sig i det Ydre let, ved at Springføddernes ydre Gren er kortere end den indre, medens de hos Typen for hin Slægt, $P$. fucicola, ere lige lange. Desuden er Legemet her uden Kjøl eller Torne. Sandsynligvis vil man ogsaa kunne finde en Uoverensstemmelse i Munddelenes Bygning, naar de blive kjendte hos hin typiske Art.

AMPHTHOPSIS MALMGRENI, A. Boeck, $18 \% 0$.

(PI. XXIII. fig. 7)

Amphithopsis Ilalmgreni, A. Boeck, Crust. amphip. bor. et arct. 1870. p. 119.

Oculi magni, reniformes. Segmentum postabdominis 3tium in angulo inferiore postico acuminatum, non vero produclum. Antennæ superiores apud marem non ferme longitudinem corporis agvantes; apud feminam breviores; articulo 1 mo pedunculi duplo modo longiore qram crasso et longiore qvam articulis duobus seqvenlibus junctis. Pedes 1 mi paris manu ovata et ferme eadem longitudine ac carpo non dilatatn. Pedes 2 di paris manu fere rectangulari, in acie obliqve truncata. longitudinem carpi superanti. Pedes trium parium ultimorum articulo 1 mo in margine posteriore non serrato. Pedes saltatorii ultimi paris pedunculo dimidiam longitudinem rani exterioris ferme aqvanti. Appendix candalis parvula, in apice acuminata.

Læn g den er $8-10^{\mathrm{mm}}$.

Legemet er ikke meget sammentrykt; Ryggen er rund, uden Kjøl eller Torne; det tredie Haleleds nedre, bagre Vinkel er tilspidset. Hovedet gaar fortil ud i et lidet Pandehorn. Øinene ere meget store, nyreformede.

De $ø$ vre Følere ere omtrent saa lange som Legemet; Skaftets første Led er meget kortere end Hovedet, neppe mere end dobbelt saa langt som tykt og omtrent saa langt som begge de folgende Led tilsammen, der efterhinanden aftage meget saavel i Længde som Tykikelse. Svoben ei meget forlænget, tynd og dannes hos Hannen af 50 Led.

De nedre Folere ere meget kortere end de ovre; Skaftets tredie Led er 
omtrent saa langt som tykt; det fjerde og femte ere omtrent lige lange. Śvoben, der er lidt længere end Skaftet, dannes af 24 Led.

Kindbakkernes Palpes tredie Led er længere end det andet.

$\mathrm{Kj} \mathfrak{j}$ bef $\emptyset$ d dernes ydre Plade er liden og væbnet med $3-4$ forlængede Torne; den indre Plade er ogsaa meget kort og liden, med tre særdeles smaa Tsender paa Enden. Palpens Led ere korte; det tredie er forlænget i sin øvre, ydre Vinkel. Kloen er lang og tynd.

Det forste Fodpar er mindre end det andet og forsynet med talrige Børster i den bagre Rand; Haanden er oval, omtrent saa lang som det foregaaende Led.

Det andet Fodpars Haand er af en noget firkantet Form og henimod tre Gange saa lang som bred, meget læugere end det triangulære fjerde Led, med skraa afskaaren Griberand. Kloen er liden, saugtakket paa den bagre Rand.

Det tredie og fjerde Fodpar ere meget forlængede.

De tre folgende Fodpar tiltage efter hverandre i Langde; det første Led er ovalt, neppe saugtakket i den bagre Rand; det tredie er ikke meget bredt, men udtrukket i den nedre, bagre Vinkel og er længere end det fjerde Led, men af den samme Længde som det femte eller noget kortere end dette Led.

Det forste Par Springfodder naar længst bagud; den ydre Gren er kortere end den indre og omtrent saa lang som Grundleddet; begge Grene have Torne paa den overste Rand.

Det andet Par har den samme Form, men er kortere.

Det sidste Pars ydre Gren er dobbelt saa lang som Grundleddet og meget kortere end den indre.

Halevedhænget er meget lidet, tilspidset paa Enden.

Af G. 0. Sars er den fundet ved Skraaven paa 150 Favnes Dybde og af mig ved Haugesund og i Christianiafjorden paa 50-80 Favne.

\section{AMPHITHOPSIS LONGICAUDATA, A. Boeck, 1860.}

(Pl XXII. fig. 3).

Amphithopsis longicaudata, A. Boeck, Forhandl. ved de Skand. Naturf. 8de Møde. 1860. p. 663:

A. Boeck, Crust. amphip. bor. et arct. 1870. p. 119.

Oculi ovales. Segmentum postabdominis 3tium angulo inferiore postico acuto. Antennæ superiores longitudinem animalis aqvantes; articulo pedunculi 1 mo elongato, angusto, circiter ter longiore qvam crasso, in apice spinoso et longiore qvam articulis duobus seqventibus junclis. Pedes $1 \mathrm{mi}$ paris manu ovata, parum longiore quam carpo; hoc apicem versus dilatato. Pedes 2di paris manu elongata, 
angusta, apicem versus parum latiore, longitudinem carpi angusti et elongati non aut fere reqvanti. Pedes trium parium ultimorum articulo 1 mo in margine posteriore parum serrato. Pedes saltatorii ultimi paris ramo exteriore tertiam modo partem longitudinis rami interioris aqvanti et paulo longiore qvam pedunculo perbrevi. Appendix caudalis ovata.

Læ $n g d$ en er 8 mm.

L e gemet er sammentrykt; Ryggen er rund, uden Kjol eller Torne; det tredie Haleleds nedre, bagre Vinkel danner en liden Hage. Sidepladerne ere sture, længere end brede, afrundede nedad; den fjerde er ikke meget indskaaret bagtil. Hovedet er omtrent saa langt som de tvende første Legemsled tilsammen og gaar fortil, uden at danne noget egentlig Pandehorn, over i en stump Vinkel mellem de ovre Folere. Øinene ere store, tilspidsede bagtil, ret afskaarne fortil.

De ovre Folere ere næsten saa lange som Legemet. Skaftet er kort; det forste Led er kortere end Hovedet, men noget længere end de tvende folgende Led tilsammen $0 \mathrm{~g}$ er indskaaret $\mathrm{i}$ den ydre Ende, hrorved dannes Tænder, af hvilke en paa den nedre Side er storre end de ovrige; det tredie Led er særdeles hort. Svoben er 3-4 Gange saa lang som Skaftet, med meget korte Led.

De nedre Følere ere kortere end de ovre; de tvende første Led ere korte, Lugteknuden er lang; det tredie er kort; det fjerde er omtrent dobbelt saa langt, men naar-ikke frem til Enden af de ovre Foleres Skaft; det femte er omtrent saa langt som det fjerde Led.

Kindbakkerne ere meget kraftige og stærkt tandede i den delte Spids; Tornerækken bestaar af otte grove Torne; Tyggeknuden er besat med mange fine Trender, der sidde i concentriske Ringe. Palpens tredie Led, der er meget langt, er paa Enden bredere og skraa afskaaret.

Det forste Kjabepars ydre Plade har paa Enden grove, med Torne forsynede Tænder; den indre Plade' er stor, oval, med fem fjærdannede Børster.

Det andet Kjæbepars Plader ere brede.

Kjæbefodderne ere særdeles kraftige $\mathrm{og}$ brede; den ydre Plade er bred, oval og besat paa den indre Rand med lange, krumme, men tynde Torne. Palpens Led ere særdeles brede.

De tvende forste Fodpar ere tynde, lange, subcheliforme; Haanden er liden. Det første Par, der er mindre, end det andet, har en forlænget oval Haand, der er lidt langere end det foregaaende Led. Det andet Pars Haand er ogsaa lislt oval samt noget mere end dobbelt saa lang som bred og noget længere end det foregaaende Led, paả Enden skraa afskaaret. Kkloen er liden, krum.

Det tredie og fjerde Fodpar ere lange, smale, men dog kraftige; det tredie Led er lidet udvidet mod Enden, men er forlænget i den nedre, bagre Vinkel; det fjerde 
er kortere; det femte Led er noget længere og i sin bagre Rand besat med stærke Torne. Kloen er kraftig, lang og kun ubetydelig krummet.

De tre folgende Fodpar tiltage efter liverandre i Langde; det første Led er pladeformet ovalt, saugtakket paa den bagre, udvidede Rand; det tredie er kun lidet udvidet og kortere end det femte Led, der er besat med stærke Torne.

Halens Svommefodder ere forlængede.

Springfødderne ere særdeles lange; Grundleddet er meget tornet; Grenene ere lange, cylindriske, besatte med fine Torne; den ydre er kortere end den indre. Paa de tvende forste Par er den ydre Gren kun en Trediedel kortere, men par det sidste Par har den neppe Halvdelen af den indre Grens Længde.

Halevedhæn get er udelt, ovalt, noget tilspidset mod Ender.

Denne Art er fundet af mig i tvende Exemplarer ved Haugesund.

AMPHITHOPSIS LONGIMANA, A. Boeck, 1870.

(Pl. XXII. fig. 2).

Amphithopsis longimana, A. Boeck, Crust. amphip. bor. et arct. 1870. p. 120.

Caput crassum, inflatum. Angulus capitis lateralis rotundatus. Segmentum postabdominis 3tium angulo inferiore posteriore parum rotundato. Antemm superiores ad segmentum postabdominis 3tium porrecta. Antemna inferiores articulo pedunculi 3tio tam lato qvam longo. Pedes $1 \mathrm{mi}$ paris manu longitudinem carpi aqvanti, 3-4 longiore qram lato, qvadrangulari. in acie obliqve truncala. Pedes 2di paris prælongati; manu paulo longiore qram carpo angusto. 5-6 longiore qvam lata. Pedes trium parium ultimorum articulo 1 mo non perdilatato, in margine posteriore serrato: articulo 3tio ferme eadem longitudine ac 410 et 5 to. Appendix caudalis longior qram ad basin lata, in apice truncata, parum incisa.

L ængden er $10-15^{\mathrm{mm}}$.

L e gemet er langt, kun lidet sammentrykt; Ryggen er rund, uden Kjol eller Twender. De tre forste Haleleds nedre, bagre Vinkel er svagt afrundet. Sidepladerne ere af middelmaadig Storrelse eller smaa; den fjerde er den storste, og den femte er meget bred. Hovedet er temmelig tykt, opsvulmet og danner fortil, mellem de ove Folere, et lidet Pandehorn.

De orre Folere naa, naar de boies bagud, til det tredie Haleled; Skaftets forste Led er meget kortere end Hovedet, det andet er end kortere og smalere; det tredie er lidet. Svoben er lang. 
De nedre Følere ere hortere end de ovre; Skaftets tredie Lerl er omtrent saa langt som brerlt; det fjerde naar længere frem end de ovre Føleres Skaft.

Overlaben er temmelig bred, afrundet paa Enden og udelt.

Paa Kindbakkernes Spids ere Grenene forsynede med mange Tænder; Tornerækken dannes af stærke, med Bitænder forsynede Torne; Tyggeknuden er forlænget, med Tværrader af fine Tænder. Palpens tredie Led er meget kort.

Det forste Kjæbepars ydre Plade har paa Enden Torne, besatte med Bitænder paa den concave Rand; den indre Plade er særdeles stor, triangulær, med en Række fjærdannede Borster paa den indre Rand. Palpen er paa den øvre Ende væbnet med Rader af Tænder, der ere længst paa Spidsen.

Underlæben er meget stor og har, fæstet paa den bagre Flade, trende tykke, indad afrundede Lapper.

Det andet $\mathrm{K} j a b$ epars indre Plade er temmelig bred.

K jabefodderne ere korte, brede; den ydre Plades hele indre Rand er væbnet med tætstaaende, men korte Tænder, der paa Pladens Ende gaa over til krumme Børster; den indre Plade har par Enden tre Tænder. Palpens andet Led er meget breit, Kloen er kort.

Det forste Fodpar er temmelig langt og smalt; det andet og tredie Led ere korte, medens det fjerde og femte, der ere omtrent af eens Langde, ere henimod fre Gange saa lauge som brede, samt paa den bagre Rand vabnede med korte Børbredt, steknipper.

Det andet Fodpar er overmaade forlænget, lyorved det faar en lineær Form; det andet og tredie Led ere ogsaa her meget korte, medens det fjerde, der er noget kortere end det femte Led, er mindst sex Gange saa langt som bredt. Begge de sidste Led ere paa den bagre Rand vabnede med Borsteknipper. Kloen er meget liden.

Det tredie og fjerde Fodpar ere forlængede; det tredie Led er lidet udvidet; det fjerde er kortere, men det femte er længere end dette Led.

De tre følgende Fodpars forste Led er forlenget i den-nedre, bagre Vinkel, den bagre, udvidede Rand er saugtakket; det femte er langere end det tredie Led.

Springfodderne naa omtrent lige langt bagud, eller det sidste Par er noget længere; de tvende forste Pars ydre Gren er ubetydelig kortere end den indre. Det sidste Pars ydre Gren har kun noget mere end Halvdelen af den indres Længde, der er næsten dobbelt saa stor som Grundleddets.

Halevedhinget er forlanget, ovalt afrundet paa den ydre Ende og her svagt indboiet.

I Kjobenhavns Museum fandtes nogle Exemplarer fra Grønland, der vare uden Følere, og i det Hele mindre godt conserverede. Af G. O. Sars er den taget i enkelte Exemplarer ved Christiansund paa 50-100 Favnes Dybde. 
AMPHITHOPSIS LATIPES, M. Sars, 1858.

Amphithoё latipes, M. Sars, Overs. over norsk-arctiske Krebsdyr, Forh. i Vid.-Selsk i Christiania. 1858. p. 139.

- $\quad$ - Spence Bate, Catal. Amphip. Crust. Brit. IIus. 1862. App. p. 380. Calliope Ossiani, Spence Bate, Catal. Amphip. Crust. Brit. Mus. 1862.p. 149. pl. XXVIII. fig.3. - - - Spence Bate and Wéstwood, Brit. sessile-eyed Crust. 1863. p. 263.

Calliope Fingalli, Spence Bate and Westwood, Brit. sessile-eyed Crust. 1863. p. 263. Calliopius Fingalli, Norman, Rep. on the Shetland Crust. 1868. F. 280.

Calliop ïus Ossiani, Norman, Rep. on the Shetland Crust. 1868. p. 281.

Amphithopsis latipes, A. Boeck, Crust. amphip. bor. et arct. 1870. p. 120.

Segmenta trunci levia. Segmenta postabdominis duo anteriora et segmentum trunci ultimum carina obtusa, in margine posteriore in dentem triangularem, obtusum desinenti. Segmentum postabdominis 3tium in medio gibbosum. Angulus inferior posterior segmenti postalodominis 3 tii subproductus et acutus. Frons in rostrum acutum producta. Oculi magni, fere reniformes. Antennæ superiores dimidiam longitudinem animalis superantes: articulo pedunculi lmo elongato, angusto, in margine superiore ef inferiore producto. Antennæ inferiores articulo pedunculi 4 to et 5to longitudine xqvalibus. Pedes 1 mi paris manu triangulari, multo breviore qvam carpo. Pedes 2di paris manu permagna, apicem versus latiore, in acie oblipve truncata et dentibus validis armala; carpo brevi. Pedes trium parium ultimorum latissimi: articulo $1 \mathrm{mo}$ in margine posteriore non serrato: articulo 3tio postice valde dilatato et in angulo inferiore postico producto; articulo 4to apicem versus latiore: articulo 5to lato: ungve robusto. subcurvato. Pedes saltatorii ultimi paris ramo exteriore duas tertias partes longitudinis rami interioris repvanti: ramo interiore vix duplo longiore qvam pedunculo. Appendix caudalis parvula, ovata.

Længden er i Almindelighed $9^{\text {nm }}$, men ifølge M. Sars skal denne Art længere mod Nord, i Finmarken, kunne opnar en Storrelse af indtil $13 \mathrm{~mm}$.

Le gemet er ikke meget sammentrykt; Ryggen er rund, men Halens Led faa en svag Kjol langs Midtlinien, og dens tvende forste Led gaa paa den bagre Rand ud i en trekantet, stump Taud, som ogsaa findes paa det sidste Legemsled. Det tredie Haleled har paa Ryggen et pukkellignende Udseende nær den bagre Ende, hvorved det fjerde Led danner en stump Vinkel med det foregaaende. De tre forste Haleleds nedre, bagre Vinkel er forlanget og gaar ud i en Spids. Sidepladerne ere af middelmaadig Storrelse, og de fire forste tiltage efter hverandre i Længle; den fjerde er indskaaret i den ovre, bagre hand for den femte, der er meget bredere end hoi. Hovedet er noget kortere end de tvende første Legemsled tilsammen og gaar fortil ud i et lidet, stumpt Pandehorn. Øinene ere nyredannede, af en mirdelmaadig Storrelse. 
De orre Folere ere Trefjerdedel af Legemets Længde; Skaftets forste Led er noget kortere end Hovedet, og den ovre og nedre Del af den ydre Ende udvider sig noget over det andet Led, der er knap saa langt som Halvdelen af det første; det tredie Led er særdeles kort. Svøben er meget lang og dannes af 37 Led, hroraf det forste er meget langt, medens de ovrige ere korte.

De nedre Følere ere meget kortere end de ovre; Skaftets tredie Led er meget kort; det fjerde er noget mere end dobbelt saa langt som tykt; det femte Led er næsten af den samme Lingde og naar frem omtrent til Enden af de ovre Føleres Skaft. Svobens forste Led er det laengste.

Kindbakkernes Spids er meget bred, væbnet med mange smaa og tre større Tænder, den indre Bigren synes at mangle; Tyggeknuden er liden, rund, besat med Torne; mellem Spidsen og Tyggeknuden sees tvende Torne og mange smaa Børster.

Det forste Kjæbepars ydre Plades Torne ere i Randen fint saugtakkede; den indre Plade er sierdeles stor, tvært afskaaren paa Enden og er der besat med tvende fjærdannede Børster. Palpens Ende er tvært afskaaren og har der fem Tænder og nogle Torne.

Det andet $\mathrm{Kj}$ æbepars Plader ere forlængede.

Kjæbefødderne ere korte, brede; den ydre Plade er ikke meget stor og har spredte Torne paa den indre Rand; den indre Plade er stor og har en stump Tand paa Enden af den indre Rand. Palpen er temmelig bred; det tredie Led er noget kortere end det andet $0 g^{\circ}$ er forlænget i det nedre, ydre Hjørne over' Udspringet af den strerke Klo.

Det forste Fodpar er forlænget; det fjerde Led er omtrent dobbelt saa langt som bredt, meget længere end Haanden; denne er meget brederé mod den ydre Ende, der er skraa afskaaret.

Det andet Fodpar er særdeles kraftigt; det fjerde Led er meget kort, dets nedre, bagre Vinkel er forlænget og forsynet med Borsteknipper; Haanden er særdeles stor, bliver bredere udad, mer en noget skraa afskaaret Griberand, der er væbnet med flere Tænder. Kloen er meget kraftig, med fine, korte Børster paa den concave Rand.

Det tredie og fjerde Fodpar ere forlængede, men stærke, med Torneknipper paa Leddenes bagre Rand; det tredie Led er udvidet nedad, og dets nedre, forreste Vinkel er udtrukket; det femte er ineget længere end det fjerde Led. Kloen er kort og stærk.

De tre folgende Forlpar ere særdeles brede; det forste Led er meget bredt ovalt, samt forlænger sig meget nedad og bagtil; det tredie er meget bredt, med en udtrukket nedre, bagre Vinkel; det fjerde er paa det nederste Parti næsten saa bredt som langt, medens det femte Led er forlænget. De tre sidste Led have stærke Torne paa den forreste Rand.

Springfodderne naa næsten lige langt bagud. Grenene ere cylindriske, uden 
Torne; den ydre er noget kortere end den indre, hvilket især er Tilfældet med det sidste Par, hvis indre Gren ogsaa er mere end dobbelt saa lang som Grundleddet.

Halevedhænget er meget lidet, ovalt.

Farven er hvid, punkteret med fine, brune Pletter paa Sidepladerne, Følerne, Hovedet, Halen samt paa Fodparrene. Øinene ere store, rosenrøde. Efter M. Sars er Farven lys, med minierøde Pletter paa Ryggen og med røde Ringe paa Fødderne.

Denne Art er fundet af M. Sars ved Hammerfest og Tromso i Corallinemes Balte mellem forskjellige Hydroider, pa 30-60 Favnes Dybile, sjeldnere ved Bergenskysten; af mig er den fundet fra Karmøen til Farsund og ind Christianiafjorden. Den synes ikke at vare ved Bohuslen, da den ikke omtales af nogen svensk Forsker. Ved England og Shetlandsøerne er den fundet af Norman.

Gen. VI. CLEÏPPIDES, A. Boeck, 1870.

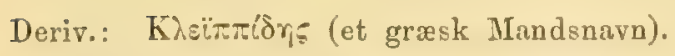

Syn.: 1870. Cleïppides, A. Boeck, Crust. amphip. bor. et arct. p. 121.

Type: Acanthonotus tricuspis, Kroyer.

Mandibulæ articulo palpi 3 tio perlato et brevi.

Maxilla $1 \mathrm{mi}$ paris lamina interiore elongata, in margine interiore setis multis plumosis instructa.

Pedes maxillares lamina exteriore spinis elongatis plumosis armata; palpis brevibus, latis.

Epimera qvatuor anteriora parva.

Antemne flagellis elongatis, multiarticulatis; superiores inferioribus longiores.

Pedes Imi et 2di paris manu parva.

Pedes trium parium ultimorum articulo 1 mo non multo dilatato.

Pedes saltalorii ultimi paris pedunculo elongato.

Appendix caudalis integra.

Denne Slægt, som jeg opstillede i 1870 og grundede paa Acanthonotus tricuspis, Kroyer, har ligesom nogle af de foregaaende et uspaltet Halevedhæng. De øvre Folere ere længere end de nedre. De fire forste Sideplader ere smaa. De tvende første Fodpars Hæuder ere mindre stærke, og de tre bagre Fodpars første Led er ikke saa udvidet som hos de foregaaende Slægter. Det, som i Særdeleshed adskiller den fra de ovrige, er Bygningen af Kjæbefodderne, hvis Palper ere korte og brede, medens de ydre Plader ere overmaade store og væbnede med tynde, tildels fjærdannede Torne $\mathrm{i}$ den indre Rand. Spence Bate regner ikke Typen for denne Slægt, Acanthonotus tricuspis, Kroyer, til Leachs Slægt Pherusa, lvilket vistnok vilde vare skeet, hvis denne havde varet overensstemmende med Pherusa fucicola, og jeg har derfor heller ikke villet stille den 
herhen, saa meget mindre, som den synes at afvige fra den ved sine smaa Sideplader og ved det lidet udvidede første Led paa de tre bagre Fodpar.

\section{CLEIPPIDES TRICUSPIS, Kroyer, 1846.}

Acanthonotus tricuspis, Krøyer, Nat. Tidsskr. 1846. 5. R. II. p. 115. pl. 18. fig. 1 a. - _ White, Sutherlands Journal of Voy. in Baffins Bay. 1852.

Dexamine tricuspis, Spence Bate, Catal. Amphip. Crust. Brit. Mus. 1862. p. 133. pl. XXIV. fig. 5 .

Paramphithoë tricuspis, Goës, Crust. amphip. maris Spetsb. 1865. p. 9.

Clëppides tricuspis, A. Boeck, Crust. amphip. bor. et arct. 1870. p. 121.

Corpus carina destitutum. Segmentum trunci ultimum et segmenta postabdominis duo anteriora in medio margine posteriore in dentes retroversos desinentia. Segmentum postabdominis 3tium in angulo inferiore postico in dentem longissinum, paulum curvatum, productum et in margine posteriore etiam denle. sed minore, armatum. Oculi magnitudinis mediocris, ovali. Antenux superiores articulo pedunculi Imo elongato, angusto, longitudinem articulorum duorum seqventium junctorum ferme æqvanti. Pedes $1 \mathrm{mi}$ paris manu ovata, breviore qvam carpo. Pedes 2di paris manu paulo longiore, qvadrangulari, longitudinem carpi ferme xqvanti. Pedes trium parium ultimorum articulo 1 mo angusto, ultimi paris latiore gvam 5 li paris. in margine posteriore crenulato et in angulo inferiore postico acuminato. Pedes saltatorii ultimi paris ramis paulo longioribus qvam pedunculo. Appendix caudalis ovata.

Længden er $6-8^{\mathrm{mm}}$.

Legemet er forlanget, smalt. Legemsleddene ere uden Kjol, men fra Midten af det syvende Leds bagre Rand udgaar der en flad Torn, og paa samme Maade ere de tvende første Haleled bevæbnede; det tredie Haleleds nedre, bagre Vinkel er udtrukket til en Tand, og ovenfor denne, paa den bagre Rand, sees en anden, adskilt fra den foregaaende ved en Indbugtning. Silepladerne ere smaa; de fire forste ere lidt høiere end brede, og den sidste af disse er bagtil svagt udbugtet. Hovedet er temmelig stort og tykt; den forreste Rand danner en Vinkel, uden at der dog dimnes noget egentligt Pandehorn. Øinene ere lange, smale, nyreformede.

De $\sigma \mathrm{vre}$ Folere ere meget kortere end Legemet $0 \mathrm{~g}$ meget tynde; Sliaftets første Led er det længste; de tvende følgende aftage efter hinanden i Langde. Svoben er omtrent tre Gange saa lang som Skaftet og dannes af 50-60 Led.

De nedre Følere ere kun lidt længere end Halvdelen af de ovre; Skaftets fjerde Led er noget længere end det femte. Svoben dannes af 40 Led. 
Overlæben er bred, afrundet paa Enden.

Kindbakkerne ere stærke. Gribedelen er ikke tandet, og den indre Bigren er utydelig forsynet med Tænder; Tornerækken dannes af 3-4 Borster; Tyggeknuden er stor. Palpen er kort og stærk; dens tredie Led er meget kortere end det andet og meget bredt, med talrige Saugborster.

Underlæbens indre Plader ere store.

Det første Kjæbepars indre Plade er meget bred, oval, med talrige fjærdannede Borster. Palpen har tynde Torne paa Enden.

Det andet Kjæbepars Plader ere meget brede.

Kjæbefodderne ere korte, brede; den ydre Plade har mange saugdannede Torne paa den indre Rand og i Spidsen; den indre Plade har tre Tænder paa Enden. Palpen er bred; de tre forste Led ere næsten lige lange, det fjerde er kloformet.

Det forste Fodpar er temmelig kort; Haanden el liden, oval, noget mere end halvt san lang som det fjerde Led. Kloen er meget kort og væbnet paa Enden af den indre Rand med en liden Torn.

Det andet Fodpar er lidt lrengere end det forste; Haanden er firkantet, omtrent saa lang som det fjerde Led.

Det tredie og fjerde Fodpar ere forlængede; det tredie Led er ikke meget udvidet $\mathrm{og}$ af den samme Længde som det femte, men længere end det fjerde Led.

Det femte Fodpars forste Led er meget lidet udvidet bagtil, dobbelt saa langt som bredt og ligesom crenuleret paa den bagre Rand; det tredie er længere end det fjerde, men meget kortere end det femte Led.

Det sjette Fodpars første Led el noget bredere.

Det syvende Fodpar er meget langere end det foregaaende Par; det forste Led er bredere, crenuleret paa den bagre Rand og med udtrukket nedre, bagre Vinkel; det tredie er længere end det fjerde, men lisortere end det femte Led.

Det forste Par Springfødder er smalt; den indre Gren er ubetydelig længere end den ydre og lidt kortere end Grundleddet.

Det anilet Par er lidt kortere.

Det sidste Pars Grene ere meget flade, med enkelte Torne i Randen, lige lange og lidt Iængere end Grundleddet.

Halevedhrnget er lidet, ovalt, bagtil svagt tilspidset.

Spence Bate har henført denne Art til Dexamine, uagtet han i Diagnosen for denne Slægt har fremhævet, at Kindbakkerne mangle Palpe. I Krøyers Tegning sees en Palpe paa Kindbakkerne; det havde maaske af ham været rigtigst at henfore Arten til Pherusa.

Farven er kastaniebrun, Øinene ere sorte.

Den er ifolge Kroyer kun fundet ved Grønlands sydlige Kyst. 
Gen. VII. LAOTHOËS, A. Boeck, $18 \% 0$.

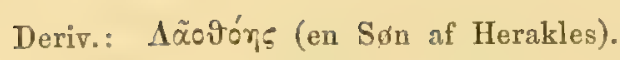

Syn.: 1870. Laothoïs, A. Boeck, Crust. amphip. bor. et arct. p. 122.

Type: Laothoës Meinerti, A. Boeck.

Mandibulæ articulo palpi 3tio perlato, dimidiam longitudinem articuli 2di ferme aqvanti.

Maxillæ 1mi paris Iamina interna parva, ovali, in margine setis plumosis paucis instructa; palpo uniarticulato, parvo.

Ilaxillæ 2di paris laminis angustis.

Pedes maxillares lamina interna longitudinis mediocris, in apice dentibus tribus armata; lamina externa permagna, in margine interiore dentibus multis, parvis sed firnis, apicem versus paulo majoribus, armata; palpo parvo, parum modo longiore qvam lamina externa; articulo palpi ultimo ungviformi.

Corpus elongatum, angustum, non carinatum; capite inflato; epimeris parvis: epimero 4to altiore sed breviore qvam 5 to.

Antennæ pedunculis brevibus; flagellis prælongatis, multiarticulatis; superiores inferioribus longiores.

Pedes 1mi 2diqve paris graciles, longitudine et forma fere æqvales.

Appendix caudalis integra.

Slægten Laothoës afviger laraliteristisk fra alle de ovrige, der hore herhen, ved at Kjæbefoddernes ydre Plader ere særdeles store og vabnede paa den indre Rand med en tæt Række af'Tænder. Palpen er derimod særdeles kort og naar ikke længere frem end den ydre Plade, men bestan dog af de typiske fire Led, hvoraf det sidste er kloformet. Kindbakkerne ere særdeles stærke, medens Palpen er kort, især dens tredie Led. Det forste Kjæbepars indre Plade er oval, med nogle fjærdannede Børster paa den indre Rand; dets Palpe er liden, rudimentær, eenleddet. I det Ydre er den eiendommelig ved sit meget store, ligesom opblaste Hoved og ved sine smaa Sideplader, hvoraf den femte er lidt kortere, men meget bredere end den fjerde. Halevedhænget er ogsaa hos lenne Slægt udelt.

Navnet Laothoës er i 1808 af Fabricius benyttet til en Lepidopter og bor derfor ombyttes med et andet. 


\section{LAOTHOËS MEINERTI, A. Boeck, 1870.}

Laothoës Meinerti, A. Boeck, Crust. amphip. bor. et arct. 1870. p. 122.

Oculi ovales. Antenna superiores articulo pedunculi 1 mo longiore qvam articulis duobus seqventibus conjunctis, in fine marginis inferioris in spinam parvam producto. Antennæ inferiores articulo pedunculi 3tio perbrevi, 4to longiore qvam 5to. Pedes $1 \mathrm{mi}$ paris manu elongata, qvadrangulari, longitudinem carpi ferme xquanti. Pedes 2di paris ejusdem forma ac pedes $1 \mathrm{mi}$ paris, sed paulo longiores et angustiores. Pedes 3 tii et 4 ti paris articulo 3 tio panlo longiore qvam 4to, breviore quam 5to. Appendix candalis ovala, in apice incisa et subserrata.

L $x$ ngden er $9^{\mathrm{mm}}$ fra Hoverlet til Halevedhænget.

Legemet er forlænget, smalt, lidet høit; Ryggen er bred, rund, uden Kjøl eller Torue; Legemsleddene tiltage efter hverandre i Langde; det tredie Haleleds nedre, bagre Vinkel er afrundet. De fire første Sideplader ere smaa; de tre forste ere lidt høiere end brede og tiltage efter hverandre i Storrelse; den fjerde er meget storre end de foregaaende, meget bred og er temmelig indskaaret $i$ den bagre Rand for at optage den lille femte Sideplade. Hovedet er ikke meget langt, men tykt, opsvulmet; dets forreste Rand danner mellem de ovre Folere kun en Vinkel, men intet fremtrædende Pandehorn. Vinkelen mellem de ovre og nedre Folere er ret afskaret og afstumpet. Et Øie sees midt paa den gvre Del af Hovedet nær Pandevinkelen, samt et paa hver Side, bag de ovre Folere; alle dannes af talrige, men smaa Lindser.

De ovre Følere ere meget langere end de nedre; Skaftets forste Led, der er saa langt som de tvende folgende tilsammen $\mathrm{og}$ er meget tylkere end det andet, er paa Enden af den nedre Rand forlænget til en Knude, forsynet med tvende Torne; det andet Led er næsten dobbeit saa langt som det tredie, der ikke er langere end tykt. Svobens Led ere korte.

De nedre Fgleres tredie Skaftled er neppe saa langt som tykt; det fjerde er noget længere og tykkere end det femte Led. Svobens Led ere korte.

Overlæben er stor, afrundet paa Endeu.

Kindbakkerne ere meget kraftige, brede i Spidsen og der indskaarne i 7 - 8 stærke Tænder; den indre, stærke Bigren har sex Tænder; Tornerækken dannes af syv tandede, meget kraftige Torne; Tyggeknuden er fremstaaende, med fjærdannede Børster paa den nedre Rand. Palpens tredie Led er meget kort, men bredt.

Underlabens Plader ere smale, uden Spor af Bifliger.

Det forste Kjæbepar er meget godt udviklet; den ydre Plade er væbnet med talrige, stærke, paa den indre Rand med Bitænder besatte Tænder; den indre Plade er oval, med faa, fem, men kraftige fjærdannede Borster. Palpens andet Led mangler, hvorved den bliver særdeles liden.

Det andet Kjæbepars Plader ere smale, med stærke fjærtannede Børster paa Enden. 
Kjæbefødderne ere meget brede; de ydre Plader, der ere overordentlig store 0 g naa næsten frem til Enden af Palpens tredie Led, ere tillige særdeles brede og forsynede paa den indre Rand med talrige, tæatstaaende Torne; de indre Plader ere meget lange, med tvende Tænder og mange fjærdannede Børster paa Enden og paa den indre Rand. Palpens andet Led er langt og temmelig bredt, medens det tredie er meget kort, ovalt. Kloen har nogle Torne paa Enden.

Det forste Fodpar er smalt, tyndt; det fjerde Led er forlænget, og Haanden er lige saa lang som dette, med en meget kort, næsten ret afskaaret Griberand. Kloen er liden.

Det andet Fodpar er af den samme Bygning som det forste, men de treude sidste Led ere noget smalere og meget længere.

Det tredie og fjerde Fodpars tredie Led er ubetydelig udvidet og længere end det fjerde, men kortere end det femte Led. Kloen er meget stærk, næsten ret.

De tre følgende Fodpars første Ised er afrundet paa den bagre Rand, ikke saugtakket, og bliver efter hverandre bredere; de folgende Led ere besatte med Torne paa begge Rande; det tredie Led er lidet udvidet, langere end det fjerde, og omtrent af den samme Længde som det femte Led.

Det første Par Springfødders Grene ere omtrent lige lange, smale, med Torne paa den ovre Rand og paa Enden.

Det andet $\mathrm{Par}$ naar ikke saa langt bagud; den ydre Gren er noget kortere end den indre.

Det tredie Par manglede paa det beskrevne Exemplar.

$\mathrm{H}$ a levedhanget er helt, noget langere end bredt; den ydre Ende er indbugtet, svagt saugtakket; den ovre Flade er skeformet indhulet.

Den er fundet af G. O. Sars ved Utne paa 300-500 Favnes Dybde.

\section{Subfamilia VIII.}

GAMMARINE. Dana, 1849.

Syn: 1852. Gammarine. Dana, U. S. explor. exped. p. 909.

185\%. Gammarini, Costa, R. sui Crost. amfip. del regno di Napoli.

1862. Gammarides, Spence Bate, Catal. Amphip. Crust. Brit. Mus. p. 129.

1863. - Spence Bate and Westwood, Brit. sessile-ejed Crust. p. 235.

1865. Gammarina, Lilljeborg, On the Lysianassa Magellanica.

1870. Gammarine, A. Boeck, Crust. amphip. bor. et arct. p. 123.

Mandibulæ utrobiqve similes, robusta, in apice dentale; processu accessorio ilem dentato; tuberculo molari valde prominenti; palpo elongato, 3articulato.

Labium inferius laminis perlalis; laminis internis magnis.

Haxillæ lui paris spinis validis, parlim furcatis parlim serratis, armata; 
palpo magno, 2articulato: palpo maxillæ sinistræ in apice sp̧inis, maxillæ dextræ in apice dentibus armato; lamina interiore plus minusve valida.

Pedes maxillares lamina exteriore majore aut minore, nunqvam vero permagna, in margine dentibus (raro spinis) et in apice setis curvis armata; lamina interiore elongata, dentibus tribus et setis multis instructa: palpo elongato; articulo ultimo apicem versus perangusto, ungviformi.

Corpus plus minusve compressum.

Epimera anteriora qvatuor vulgo magnitudinis mediocris, raro parva.

Antennæ elongatæ: superiores flagello multiarticulato et flagello appendiculari, inferiores flagello modo brevi instructæ.

Pedes $1 \mathrm{mi}$ et 2di paris manu subcheliformi.

Pedes trium parium ultimorum longitudine paulatim crescentes.

Pedes saltatorii 2ramosi; rarissime pedes ultimi paris simplices.

Appendix caudalis laminiformis, fissa aut non fissa.

Dana, som opstillede denne Underfamilie i 1849, henstillede lertil i $1852 \mathrm{f}$ flgende Slægter: Acanthonotus, Alibrotus, Leptocheims, Iphimedia, Oedicems, Amphithoë, Gammarus, Photis, Metita, Mcera, Dercothoë, Pyctilus, Pardalisca, Atylus og Ischyrocerus. Han karakteriserer den paa følgende Maade: Antennæ primæ basi graciles. Maxillipedes sat lati, lamellis internis sat elongatis. Mandibulx acie denticulata instructæe et altera accessoria qroqve processu molari et palpo 3articulato. Pedes 10 postici non subprehensiles.

Achilles Costa optog i 1857 denne Underfamilie og henførte dertil Slægterne Eggidia, Melita, Amphithoë, Amphithonotus, Nototropis, Epimeria, Probotium, Gammans, Ceradocus, Elasmopus. Spence Bate henforte i 1862 til Gammarides: Brandtia, Dexamine, Atylus, Phernsa, Paramphithoë, Calliope, Amphithonotus, Epimeria, Eusinus, Leucothoè, Pardalisca, Seba, Gossea, Aora, Stimpsonia, Bricrodeutopus, Protomedeia, Bathyporeia, Niphargus, Eriopis, Crangonyx, Gammarella, Melita, Hara, Eurystheus, Amathia, Pallasea, Gammaracanthus, Gammans, Megamara. Han giver den folgende Karakter: Legemet er i Almindelighed sammentrykket fra Siderne; Øinene ere to, sammensatte, siddende paa en Forhøining mellem de øvre og nedre Følere. Folerne ere stillede den ene over den anden. De ovre Folere ere lange, tynde, traadformede. De nedre Folere ere næsten lig de ovre. Det første Fodpar er mere eller mindre uddannet til at gribe med. Det andet Par ligner det forste og er i Alnindelighed vel udviklet. Det sidste Par Springfodder er aldrig væbnet med Hager. Halevedhænget er enten pladeformet eller rørformet. Lilljeborg henfører i 1865 til denne Underfamilie Slagterne Gammanus, Eriopis, Ensirus, Microplax, Nicippe og Pardalisca.

Man ser saaledes, hyor ulige Anskuelserne ere angaaende denne Underfamilies $46^{*}$ 
Begrændsning, og hvor forskjellige de Former ere, der ere optagne i den. Ligesaa ser man, hvor utilstrækkelige de Karakterer ere, som man har givet den. Jeg troede i 1870, at den burde indskrænkes til de Slægter, der nærmest sluttede sig til den typiske Slægt Gammarus, nemlig Pallasea, Mcra, Melita, Elasmopus, Cheirocratus, Gammaracanthus, Niphargus, Amathilla og den nye Slægt Melphidippa. Jeg optog saaledes kun de Sliggter, hvis øve Følere ere forsynede med en Bisvøbe. Jeg har allerede forhen omtalt, at endskjønt jeg ikke anser dette Mærke for noget saa væsentligt til dermed at adskille Underfamilier, har jeg - dog indtil Videre af Bekvemmelighedshensyn gjort dette, da vi her have en Karakter, der let kan bemærkes. Jeg tror, at flere Slægter af Atylince slutte sig nærmere til Slægter indenfor denne Underfamilie, end mange indenfor denne slutte sig til hverandre indbyrdes. Naar man senere lærer flere fremmede Former noiere at kjende, ville vistnok Slægterne indenfor begge disse Underfamilier blive grupperede anderledes, end her er skeet.

Gen. I. GAMMARUS, Fabricius, 1776.

Deriv: Gammarus, et Egennawn.

Syn: 1776. Gammarus, Fabricius, Genera insect. p. 142. Ent. Syst. II. p. 514.

1815. - Latreille, Hist. nat. d. Crust. VI. p. 315. Gen. Ins. I. p. 58.

- - Leach, Edinb. Encyc. art. Crust. VII. p. 404; Linn. Trans. XI. p. 359.

1818. - Lamarck, Hist. J. anim. sans vertebr. V. p. 179.

1825. - Desmarest, Consid. sur les Crust. p. 265.

1829. - Guerin, Icon. Crust. pl. XXVI. p. 6.

1830. -.. Milne-Edwards, Ann, d. sci, nat. XX. p. 366. Hist. d. Crust. 1840. III. p. 42 .

183\%. - Rathke, Fauna d. Krym. p. 372. Verh. d. k. k. Leop.-Carol. Acad. d. Naturf. 1843.

1838. - Krøyer, Grǿnlands Amphipoder. p. 27.

1849. - Dana, Synops. of the gen. of gamm. U. S. explor. exped. 1852. p. 910 .

1853. - Lilljeborg, Öfv. af Kgl. Vet.-Akad. Förhandl. p. 446.

1855. - Gosse, Mar. Zool. I. p. 141.

1857. - White, Hist. Brit. Crust. p. 182.

Spence Bate, Synopsis etc. Ann. Nat. Hist. Febr. Catal. Amphip.

Crust. Brit. Mus. 1862. p. 204.

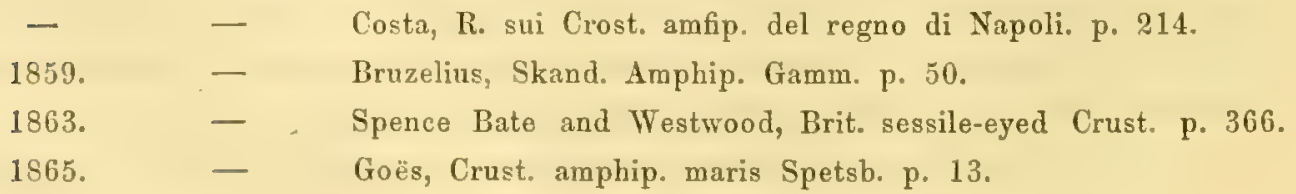


1866. Gammarus, Heller, Beitr. z. näh. Kenntu. d. Istr. Amphip.-Fauna.

1870. - $\quad$ A. Boeck, Crust. amphip. bor. et arct. p. 123.

Type: Gammarus locusta, Linné.

Mandibulæ articulo palpi 3tio elongato, angusto.

Maxillæ $1 \mathrm{mi}$ paris lamina interiore lata, longa, in margine interiore setis permultis, plumosis instructa.

Corpus non carinatum. Segmenta postabdominis tria posteriora in medio fasciculis spinarum instructa. Epimera anteriora mediocris magnitudinis.

Antenne superiores inferioribus longiores; pedunculo mediocriter elongato.

Antennæ inferiores flagello brevi instructæ.

Pedes $1 \mathrm{mi}$ et 2 di paris manu parva; pedes 2 di paris iisdem Imi paris majores.

Pedes saltatorii ultimi paris ramis longis, in margine spinis et setis plumosis instructis, ultra ramos duorum parium anteriorum porreclis; ramo interiore plus minusve breviore quam exteriore.

Appendix caudalis longa, usqve ad basin fissa.

Fabricius opstillerle denne Slægt i 1776, idet han under den optog alle de typiske Amphipoder, og ved Spaltning af denne Slægt er senere en stor Mængde nye Slægter opforte. Den typiske Art er Gammarus locusta, Linné, d. v. s. den Art, som han under dette Navn har beskrevet i sin Gothlandske Reise, da han selv senere sammenblandede den med andre Amphipoder. Under dette Slagtsnavn blev senere opstillet alle de typiske Gammarider, som have en Bisvobe paa de øvre Folere. Milne-Edwards optager saaledes over 23 sikre Arter, som nu ere opstillede under forskjellige Slægtsnavne. Han adsliller Gammarus fra Ischyrocerus, hvis gvre Folere ogsaa have en Bisvøbe, men hos den sidste Slægt udspringe disse fra en forlænget Pande, der løber frem over de nedre Folere. Saaledes sløifer Milne-Edwards flere af de af Leach opstillede Slægter. Dana optager Slægten Gammarus i en ikke saa omfattende Betydning og karakteriserer den saaledes: De øvre Følere ere forsynede med en Bisvøbe, de ere oftest længere end de nedre. Sidepladerne ere enten middelmaadig store eller korte. Det sidste Par Springfødder lignerikke det andet Par, og Grenene ere ofte lange, forsynede paa Enden med Børster eller sjelden med Torne, men ikke med Kløer. Lilljeborg viste, at Slægten Gammanus, saaledes som den var opfattet af Milne-Edwards, maatte opløses, og han udskilte under Navnet Gammaropsis de Gammarusarter, der havde et smalere Legeme, mindre Sileplader, og hvis sidste Par Springfolder er conisk og ikke pladedannet. Rathke havde allerede i 1837 opstillet Slægten Amathia paa en Form, der ligner Gammarus, men hvis Halevedhæng er helt; denne Slægt optog Dana igjen under Slægten Gammarus. Spence Bate henfører i 1862 til Slægten Gammanus ikke mindre end 42 Arter, hvoraf dog mange maa fjernes. Han diagnosticerer den skar- 
pere end Dana og fremhaver, at hvert af de tre bagre Haleled er forsynet med trende eller Hlere Bundter af korte Torne, og at Halevedhenget er dobbelt. Herved kunde han udskille flere Former, der forhen vare henreguede til denne Slægt. Grube giver i 1866 en Diagnose, der er meget overensstemmende med den af Spence Bate, medens Goës i det foregaaende Aar henforer hertil Arter, som bor' stilles til Slægterne Lilljchorgia, Mrera, Melita, Gammaracanthus, etc. I 1870 har jeg fulgt Spence Bate og Grube i deres Begrændsning af Slægten Grammarus og henført til denne kun fire Arter. Jeg optager kun dem, der paa den øvre Del af Halens tre sidste Led ere forsynede med Tornebundter, hvis Halevedhæng er spaltet, og hvis øvre Følere ere længere end de nedre. Af disse Karakterer vil man let i det Ydre kunne udskille de Arter, der høre til denne Slægt. Ogsaa IInddelene frembyde enkelte, om ikke saa skarpe Karakterer til at udskille denne Sliggt fra de øvrige.

GAMMARUS LOCUSTA, Linné, 1767.

Cancer loeusta, Linné, Syst. Nat. Ed. XII. 1767 p. 1055. Fauna Suecia. Edit. 2:da.

- pulex, Linné, Syst. Nat. Ed. XII. 1767.

- macrourus, thorace articulat o, coeruleus, Linné, Gothl. Resan. 1745.p. 260.

- (Gammarus) locusta, Montagu, Linn. Trans. 1804. IX. p. 92. t. 4. fig. 1.

Gammarus locusta, Fabricius, Syst. entom. 1775. Entom. syst. 1793. II. p. 516.

- - Leach, Edinb. Encyc. art. Crust. VII. p. 403. Linn. Trans. 1815. XI. p. 359 .

- - Desmarest, Consid. sur les Crust. 1825. p. 267.

- - Milne-Edwards, Ann. d. Sci. Nat. 1830. p. 369. Hist. d. Crust. 1840. III. p. 44 .

- - Owen, App. to Sir J. Ross sec. voy. 1837.

- - Templeton, The Mag. of Nat. Hist. and Journ. of Zool. 1836. IX. p. 12.

- - Rathke, Beitr. z. Fauna d. Krym. 1837. p. 372. pl: 5. fig. 11. Act. Acad. Leop. 1843. XX. p. 67.

- - Krøyer, Grønlands Amphip., Danske Vid. Selsk. Afh. 1838. VII. p. 255. Nat. Tidsskr. 1. R. II. p. 258.

- - Gould. Rep. on the Invert. anim. of Massach. 1841.

- - Zaddach, Synops. Crust. Pruss. Prodr. 1844. p. 4.

- - White, Hist. Brit. Crust. p. 182. Cat. Crust. Brit. Mus. 1850. p. 51.

- - Lilljeborg, Öfv, af Kgl. Vet.Akad. Förh. 1850. p. 82. 1852. p. 9. Kgl. Vet.-Akad. Handl. 1853. p. 448.

- $\quad$ Gosse, Mar. Zool. 1855. I. p. 141. fig. 257.

- $\quad$ Costa, R. sui Crost. amfip. del regno di Napoli. 1856. p. 214. 
Gammarus locusta, Spence Bate, Ann. and Mag. of Nat. Hist. 185\%. 2. ser. XIX. p. 141.

Catal. Amphip. Crust. Brit. Mus. 1862. p. 206. pl. XXXVI. fig. 6.

- - M. Sars, Forh. i Vid.-Selsk. i Christiania. 1858. p. 145.

- -. Bruzelius, Skand. Amphip. Gamm. 1859. p. 52.

- $\quad$ - Spence Bate and Westwood, Brit. sessile-eyed Crust. 1863. p. 379.

- - Goës, Crust. amphip. maris Spetsb. 1865. p. 14.

- - A. Boeck, Crust. amphip. bor. et arct. 1870. p. 124.

Oniscus pulex, Fabricius, Fauna Grønl. 1780. p. 254.

Gammarus arcticus, Scoresby, An Account of the Arct. Reg. 1820. I. p. 541. II. tab. 16. fig. 14.

- boreus, Sabine, Suppl. to the App. of Parrys first voy. 1824. p. 229.

- - Owen, App. to Sir John Ross sec. voy. 1834. p. 88.

- $\quad$ - Ross, App. to Parrys third voy. p. 119. Polar Voy. p. 204.

- Duebeni, Lilljeborg. Öfv. af Kgl. Vet.Akad. Förh. 1851. p. 22.

- mutatus, Lilljeborg, Kgl. Vet.-Akad. Handl. 1853. p. 447.

- Sitchensis, Brandt, Middendorffs Siber. Reise. 1851. II. part. I. p. 133.

Oculi magni reniformes. Angulus inferior posticus segmenti postabdominis 2 di et 3 tii in spinam productus. Dorsum segmenti postabdominis 4 ti-6ti tribus processibus instructum; processu 4 ti medio spinis duabus crassis armato; processibus Jateralibus spinis qvaternis armatis; processu medio segmenti 5li et 6ti spinis binis el setis monullis instructo; processibus lateralibus segmenti 5ti spinas qvinas, segmenti 6 ti binas gerentibus. Flagellum appendiculare 5-9arliculatum Pedes saltatorii ultimi paris aut ramis longitudine subæqvalibus aut ramo interiore quarta parte breviore quam exteriore.

L $x \mathrm{ngden}$ er $20-35^{\mathrm{mm}}$.

Legemet er høit, temmelig sammentrylit; Ryggen er dog bred, afrundet. Det forste Haleleds nedre, bagre Vinkel er afrundet; paa de tvende følgende er den udtrukket $\mathrm{i}$ en Spids, og disse Leds nedre Rand er væbnet med Torne. Halens fjerde, femte $0 \mathrm{~g}$ sjette Led have hver, nær den bagre Rand, tre Forhøininger, en i Midten og tvende paa Siderne. Den midtre Forhøining paa det fjerde Led har tvende storre og nogle sma Torne samt nogle Borster; Sideforhoiningerne have fire stærke Torne og mange Børster. Det femte Leds midtre Forhøining har tvende Torne og nogle Børster, og de paa siderne have fem Torne og mange Borster. Det sjette Leds midtre Forhoining har tvende, og Sideforhøiningerne 2-3 Torne og flere Børster. Sidepladerne ere hoie; den anden og tredie ere smalere end den forste; den fjerde er meget storre og er dybt indskaaret $\mathrm{i}$ den bagre Rand for den femte Sideplade, der paa den undre Rand er delt i en mindre forreste og en større bagre Lap. Panden lober ud i et lidet; meget bredt Horn. yinene ere store, nyreformede, sorte, og ligge i en skraa Retning paa Siderne af Hovedet. 
De ovre Folere ere forlængede og naa, naar de boies bagud, til det forste Haleled. Skaftets forste Led er kortere end Hovedet, men længere og tykkere end det andet; det tredie Led er kort. Svøben dannes af 20-40, og Bisvøben af $5-10$ Led.

De nedre Følere ere kortere end de øvre; det tredie Led er noget længere end bredt; det fjerde $0 g$ femte have omtrent den samme Længde. Svøben dannes af 12-16 med Børster forsynede Led.

Overlæben er paa Enden afrundet og har fine Børster.

Kindbakkerne ere særdeles stærke; Gribedelen er meget bred og delt i sex stærke Tænder, den indre Bigren er ligeledes bred og har fem Tænder; Tyggeknuden er meget høi, omgivet af et Gjærde af smaa, men stærke Tænder, der ende i en lang, fjærdannet Børste. Palpens tredie Led er kortere end det andet, temmelig smalt, og er i den øvre Rand besat med en Række Børster samt paa Enden med nogle længere fjærdannede Borster:

Underlaben er meget bred; den ydre Plade er afrundet paa Enden og har fine Børster og Torne.

Det forste Kjæbepar er kraftig udviklet; den ydre Plade er meget bred og har ti stærke, i den concave Rand kamdannede Tænder; den indre Plade er forlænget xgdannet og har paa den indre Rand omtrent tyve fjærdannede Borster. Palpen er forlænget smal; den høire er væbnet med fem Tænder, og den venstre med lige saa mange stærke Torne.

Det andet $\mathrm{K} j \rightsquigarrow b$ be ars Plader ere brede; den ydre er lidt længere end den indre, begge have i Spidsen talrige Borster, og den indre har ligeledes paa den indre Rand grove, fjærdannede Børster.

Kjæbef $\emptyset$ d derne ere stærke, brede; den ydre Plade er ikke meget lang, men bred, og naar til Midten af Palpens andet Led; den har paa den indre Rand forlængede Torne, der blive end langere mod Spidsen og gaa paa Enden af den ydre Rand over til krumme Børster; den indre Plade er smal, forlænget, naar frem næsten til Enden af Palpens forste Led og har krumme Torne og tre stærke Tænder paa Enden. Palpens tredie Led er noget kortere end det andet, krummet, bredere mod Enden og forsynet med talrige, stærke, lidt saugtakkede Børster.

De trende forste Fodpar ere næsten af eens Form, men det andet Par er det langste; det fjerde Led er kortere end Haanden og triangulært; Haanden bliver bredere udad og har en skraa afskaaret Griberand, der paa Enden har nogle stærke Tænder. Begge disse sidste Led have paa den bagre Rand tætte Tværrader af Børster.

Det tredie og fjexde Fodpar ere forlængede; det tredie Led er nedad ikke meget stærkt udvidet og er længere end det fjerde, som er kortere end det femte Led. Alle Leds bagre Rand har korte Torne og Børster. Kloen er strerk, lidt boiet.

De tre folgende Fodpar tiltage efter luverandre i Længden, men ere næsten af den samme Form; det forste Led er smalere nedad og. fint tandet paa den 
bagre Rand; det fjerde Led tiltager paa disse Fodpar i Længde, saaledes at det paa det syvende Par er saa langt som det femte Led.

Springfodderne ere forlangede; de tvende forste Pars Grene ere, næsten lige lange og have grove Turne $\mathrm{i}$ den ovre Randog i Spidsen. Det sidste Pars Grene ere forlænget lancetdannede; den ydre Gren er længere og bredere end den indre, begge have Torne $\mathrm{i}$ den ydre Rand og Børster i den indre; den ydre har desuden en grov Torn i Spidsen.

Halevedhænget er klovet til Roden; Fligerne ere ovale og have Kunipper af Torne paa den ydre Rand og i Spidsen.

Hunnerne have kortere Følere, og de tvende forste Fodpar ere i Forhold mindre samt mindre brede udad end hos Hannerne.

Bruzelius har paavist, at denue Art maa være Linnés Gammarus locusta, da den er den eneste Ganmarusart, der forekommer ved Gottland, hvor Limné forst observerede denne Form.

Den forekommer ved Gronland, Spitsbergen, langs alle Skandinaviens Kyster, rundt England og i Middelhavet; den er efter Heller ikke sjelden i Adriaterhavet og findes i det sorte Hav. Efter Packard forekommer den ogsaa ved Labrador.

GAMMARUS MARINUS, Leach, 1815

Gammarus.marinus, Leach, Linu. Trans. 1815. XI. p. 359.

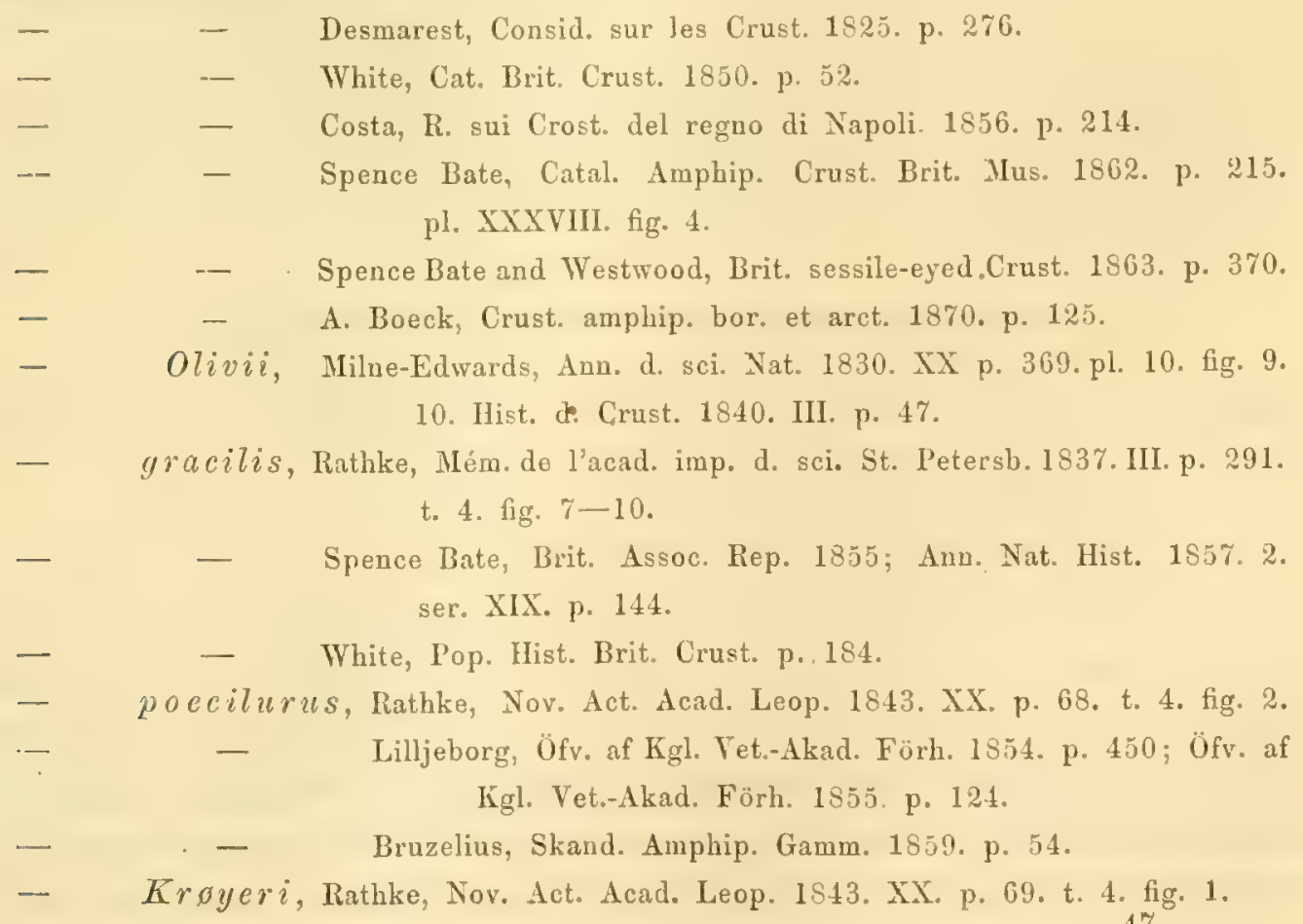


Oculi reniformes, angusti. Segmenta postabdominis tria posteriora spinis paucis, mullo minoribus qvam apud speciem præcedentem, instructa. Flagellum accessorium 4-6articulatum. Pedes $1 \mathrm{mi}$ et 2 di paris longitudine circiter rqvales; manibus fere ovalibus. Pedes saltatorii ultimi paris ramo interiore aut tertiam partem exterioris fere aqvanti et parum modo ultra finem appendicis appendicularis porrecto, aut brevissimo. Reliqva cum specie præcedenti ferme conveniunt.

L æ ngden er omtrent $15^{\mathrm{mm}}$.

Den ligner meget den foregaaende Art, men er mindre end denne. De tre sidste Haleled have færre Torne. Øinene ere nyredannede, men smalere.

De øvre Føleres Svøbe dannes af $20-30$ Led, Bisvøben af $4-6$ Led.

De nedre Folere ere kortere end de gvre. Svgben dannes hos Hunnen af 13, hos Hannen af 20 Led.

Det andet Fodpar er lidt større end det forste; Haanden er længere og Griberanden mere afskaaret end hos den foregaaende Art.

Det forste Par Spring fodder naar længere bagud end det andet, samt det sidste Pars Grundled.

Det sidste Pars indre Gren er kun en Trediedel saa lang som den ydre og naar kun ubetydelig længere tilbage end Halevedhænget.

Farven er efter Rathke brungul af forskjellig Styrke; paa hvert af Halens Led findes paa hver Side nær Bugen en stor, uregelmæssig, minnierød Flek. Paa hvert af Legemets Led sees paa den bagre Rand et let Anstrog af den samme Farve.

Denne Art er taget af $R$. Collett ved Thjottø i Nordland og forekommer fordvrigt langs hele Kysten indtil Kullen. Efter Metzger er den almindelig i Brakvandet ved den frisiske Kyst. Efter Heller findes den i Adriaterhavet.

GAMMARUS NEGLECTUS, (Lilljeborg), G. 0. Sars, 1867.

Gammarus neglectus, (Lilljeborg), G. O. Sars, Hist. nat. d. Crust. d'eau douce de Norvège. 1867 . p. 46 .

- pulex, G. 0. Sars, Reiseberetning 1862. p. 78.

- lacustris, G. 0. Sars, Reiseberetning 1863. p. 7.

Oculi parvi, fere reniformes. Angulus inferior posticus segmentorum postabdominis trium anteriorum acutus. Segmentum postabdominis 4 tum et 5tum in medio spinis hinis et in utroqve latere spinis singulis instrucla; segnentum 6tum ut plurimum in medio spinis destitutum. Antenne superiores flagello appendiculari longiludinem articuli pedunculi 3 tii xquanti, ex articulis tribus composito. Pedes 1 mi paris manu ovata; manı 2di paris ferme duplo longiore quam lata, in acie 
obliqve truncata. Pedes saltatorii ultimi paris ramo exteriore terlia parte longiore qvam interiore; ramo utroqve in margine setis plumosis instructo.

L. ængden er indtil 14-15 $\mathrm{mm}$ hos Hannen, indtil $10^{\mathrm{mm}}$ hos Hunnen. ${ }^{*}$ )

Le gemets Form er i det Hele lig den hos Gammarus locusta og mere kort samt tyk hos Hunnen, end hos Hannen. Legemsleddene tiltage efter hverandre i Længde, saa at det sidste er næsten dobbelt saa langt som det forste Led. De tre forste Haleleds nedre, bagre Vinkel danner en noget opadbøiet Hage, det fjerde og femte Haleled have paa Midten af den bagre Rand tvende Torne og paa den ydre Side af disse en liden Børste; paa Siderne af disse Led sees en enkelt Torn; det sjette Haleled har paa Midten kun tvende fine Borster og en Torn paa hver af Siderne. De fire forste Sideplader ere hoiere end brede, med en afrundet nedre Rand, der er forsynet med smaa, fine Borster; den fjerde er den storste og er noget indskaaret i den bagre Rand for den femte Sideplade; denne sidstes nedre Rand er indskaaret, hvorved dannes en forreste storre og en mindre bagre Lap; de folgende Sideplader ere meget smaa. Hovedet er næsten saa langt som de tvende forste Legemsled tilsammen og gaa fortil ud i et kort, næsten rudimentært Fremspring; Sidevinklerne ere afrundede. Øinene ere smaa, næsten nyreformede.

De ovre Folere naa omtrent til det femte Legemsled. Skaftets forste Led er næsten saa langt som de tvende paafolgende tilsammen; det tredie er kortere end det andet. Svøben, der i Regelen er langst hos Hannen, dannes af 18-24 Led. Bisvoben har 3 Led.

De nedre Følere ere kortere end de øve; Skaftets andet Led er meget kort og kun ufuldkomment adskilt fra det forste, samt udsender en lang Lugteknude; det tredie er lidt længere end tykt; de tvende sidste Led ere forlængede, men det femte er lidt kortere end det foregaaende Led; begge have Børstebundter, især paa den undre Rand. Svoben er neppe dobbelt saa lang, som Skaftets sidste Led, og dannes af 8-10 korte, med Borster, især paa den undre Rand, besatte Led.

Kindbakkerne ere meget korte og tylke, begge Grene ere i Spidsen indskaarne i Tænder; Tornerækken dannes af lange, med fine Borster besatte Torne samt af fjærdannede Borster; Tyggeknuden er transverselt afskaaret med Indskjæringer paa den venstre, men meget skraa afskaaret paa den høire Kindbakke.**) Palpens tredie Led er lidt kortere end det andet og har, foruden fine Børster langs Randen, nogle langere i Spidsen.

*) Beskrivelsen er væseatlig hentet fra G. O. Sars's Aflandling over denne Form.

* Den Del af hver af Kindbakkernes Tyyreknude, der vender mod den anden, danner et stort Antal transverselle Ophwiainger, der ere noget krumme og omgivne, især paa Tyggreknudens bagre Ende, med temmelig fremtrædende Tænder. Fru Tyggeknudens bagre Ende adgat en lang tynd Borste, besnt med fine, korte Bitorne. 
Det forste $\mathrm{Kj}$ æbepars ydre Plade har paa den næsten tvært afskaarne Ende en Række stærke, mod den ydre Ende bredere Torne, besatte med Bitænder; den indre Plade el bred, triangulær, med mange fjærdannede Børster paa Enden. Palpens forlængede, ovale andet Led er paa Enden besat paa det venstre Kjæbepar med tynde Torne og Børster og paa det høire med korte tykke Tænder.

Det andet Kjæbepars ydre Plade er noget længere og bredere end den indre, hvis indre Rand er besat med en dobbelt Række fine Børster, begge Plader have paa Enden længere og tykkere Borster.

Kjabefoddernes ydre Plade naar frem til Midten af Palpens andet Led og har paa den indre Rand nogle Borster samt korte Torne, der mod Enden gaar over til fjærdannede Børster; den indre Plade har paa den tvært afskaarne Ende tre Tænder og mange Borster. Palpen er forlænget; det andet Led er noget bredere mod den ydre Ende og har Borstelinipper langs den indre Rand og paa den ydre Rands Ende; det tredie er krummet indad, bredere mod den ydre Ende, der er besat med lange Børster; det fjerde Led er kloformet med en Torn og et Par Børster paa Spidsen.

Det forste Fodpars fjerde Led er triangulert, med en afrundet og med Borster besat nedre, bagre Vinkel. Haanden er mere fortykket, længere end det foregaaende Led, agformet, noget tilspidset morl den ydre Ende; hos Hannen sees langs den bagre stærkt buede Rands ydre Ende nogle stærkere Torne foruden Børster, hos Hunnen findes her nogle Borster og en Torn, hvor den krumme Kloes Spids lægger sig til.

Det andet Forlpar er af den samme Form, som det forste, men mere forlænget, især hos Hunnen, hos hvilken det i det hele er svagere. Hos denne er Haanden nasten dobbelt saa lang som bred, af en forlænget firkantet Form, Griberanden er næsten tvært afskaaret, med otte fine Borstebundter og nogle Torne, hvor Kloens Spids lægger sig til. Hos Hannen er Haanden noget bredere udad og Griberanden mere skraa afskaaret.

Det tredie og fjerde Fodpars tredie Led har 8-10 Borsteknipper paa den bagre Rand; de tvende folgende Led ere næsten lige lange, tilsammen lidt længere end det tredie Led, med nogle Børsteknipper paa den bagre Rand. Kloen er kort, ubetydelig krummet.

De tre folgende Fodpar tiltage efter hverandre i Længde og Tykkelse, især det forste Led, hvis bagre, buede Rand er svagt crenuleret og besat med smaa Borster; paa det syvende Fodpar er dette Led næsten dobbelt saa langt som bredt, smalere mod den ydre Ende, med en ret forreste og buet bagre Rand; det tredie Led er lidt kortere end det femte, men meget kortere end det fjerde Led. Alle Led have Borsteknipper paa begge, især den forreste Rand. Kloen er kort, nasten ret, og ligesom paa de foregaaende Fodpar utydelig toleddet.

Det forste Par Springfodders Grene ere meget kortere end Grundleddet; den ydre er lidt kortere end den indre. 
Det andet Par er kortere end det forste, og den ydre Gren mere kort end den indre.

Det sidste Pars Grundled er meget kort; Grenene ere flade, lancetdannede, den ydre er noget langere end den indre, og det yderste Parti er adskilt fra Grenens øvrige Del ved en tydelig Tværstribe. Grenene ere paa begge Rande besatte med lange Børster, og den ydre tillige med faa T'orne paa den ydre Rand.

Halevedhænget er kløvet til Roden og har paa den spidsere Ende en Torn og tre fine Børster.

Farven er hos Hunnen af en jævn mork, gron-sort Farve, hos Hannen er den mere lys, undertiden næsten gulagtig.

Denne Art er af G. O. Sars fundet $i$ vore Indsøer, saavel i de hoiere som lavere beliggende, i stor Mrngde, og tjene efter Prof. Nilsson (Skandinavisk Fauna, G. O. Sars 1. c. pag. 46) til Ernæring for Ørreten (var. Salmo punctatus), der derved erholder sin store Fedme. Sars har aldrig truffet denne Art i rindende Vand, der er Opholdstedet for G. pulex.

GAMMARUS PULEX, Pennant, $177 \%$.

(Pl. XXIV. fig. 7).

Sqville Puce, De Geer, Mém. pour servir à l'hist. d. Insectes. 1752. T. VII. p. 525. pl. 33. Cancer pulex, Pennant, Brit. Zool. 177\%. Vol. IV. p. 17.

Gammarus pulex, Desmarest, Consid. sur les Crust. 1825. p. 266. t. 45: fig. 8.

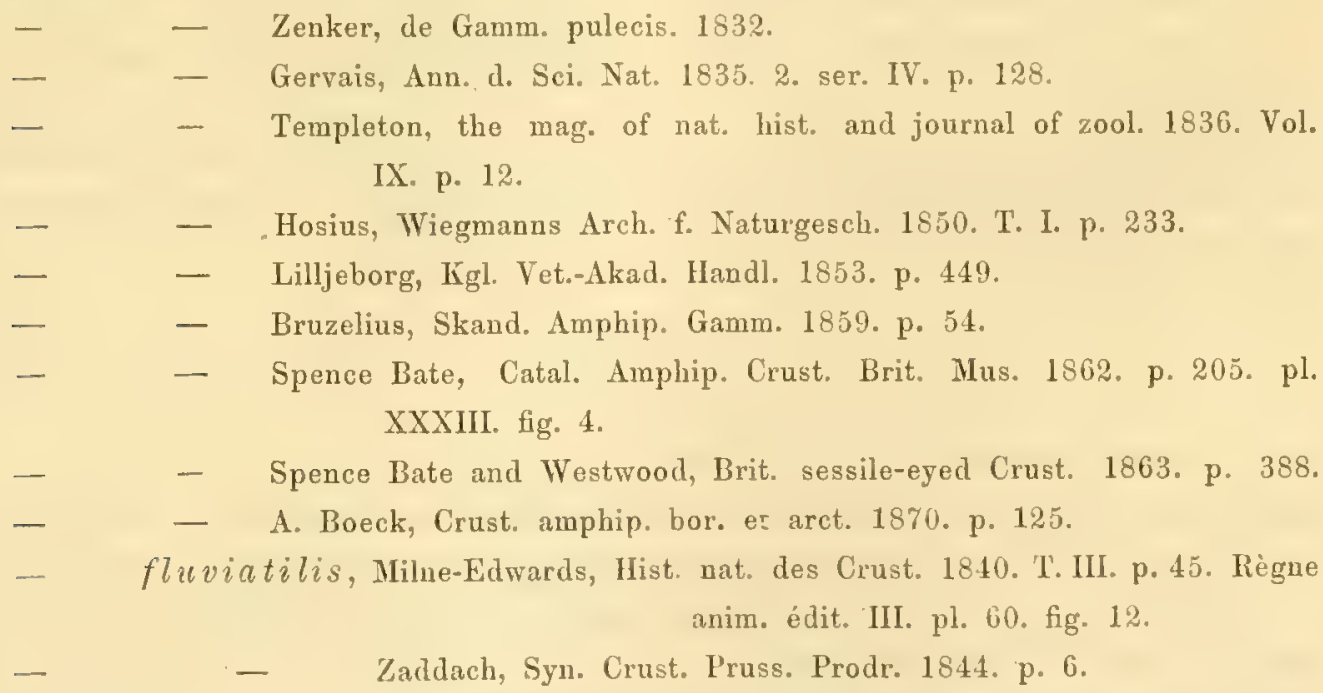

Oculi parvi, ovales. Angulus inferior posticus segmenti postabdominis $1 \mathrm{mi}$ rotundalus, 2di et 3 tii aculus. Segmentum postahdominis 4 tum processu destitutum sed in utroqve latere medii dorsi spinis duabus instructum; segmentum 5 tum in 
medio dente et in utroqve latere una spina armatum; segmentum ultimum spinas duas gerens. Antenna superiores flagello appendiculari perbrevi. Pedes saltatorii ultimi paris ramis elongatis, angustis; ramo exteriore tertia parte longiore qram interiore et in margine setis multis, plumosis instructo.

I. $æ n g d e n$ er $10-15^{\mathrm{mm}}$.

Denne Art ligner meget Gammarus locusta og adsliller sig lidet fra denne.

Legemet er høit og sammentrykt; det andet og tredie Haleleds nedre, bagre Vinkel er tilspidset; det fjerde er i den bagre Rand paa hver Side af Midtlinien vabnet med tvende smaa Torne; det femte har en stærk Torn paa Midten og en længere Børste paa hver Side; det sidste Haleled er lige over for Udspringet af Halevedhænget paa hver Side af Midtlinien vabnet med en Torn. Hovedets Sidevinkler ere meget afrundede. Øinene ere smaa, ovale.

De øvre Føleres Svøbe dannes af $25-30$ Led og Bisvøen af $3-4$ Led.

De nedre Foleres Svøbe dannes af 12-15 Led og er lidt længere end Skaftets sidste Led.

Det første Fodpar er kortere og stærkere end det andet; det fjerde Led er triangulært; Haanden er ubetydelig længere, af næsten ægdannet Form.

De tvende første Par Springfødders ydre Gren er lidt kortere end den indre; begge Grene have paa Enden tre Torne og nogle faa lignende i den ovre Rand.

Det sidste Pars ydre Gren er længere og bredere end den indre; begge have $\mathrm{i}$ Randene lange, fjærdannede Borster, den ydre har desuden i den ydre Rand nogle Torne og lignende stærke i Spidsen.

Halevedhængets Fliger have i Spidsen tre Torne, hvoraf den midtre er den stærkeste.

Den findes hyppig omkring Christiania i Bække og Elve. Efter Bruzelius er den ligeledes hyppig i Sverige, og efter Zaddach almindelig i Preussen. Norman har fundet den ved Shetland.

Gen. II. PALLASEA, Spence Bate, 1862.

Deriv.: Opkaldt til Ere for Zoologen Pallas.

Syn.: 1862. Pallasea, Spence Bate, Catal. Amphip. Crust. Brit. Mus. p. 200.

1867. - G. O. Sars, Hist. nat. d. Crust. d'eau douce de Norvège.

1870. - A. Boeck, Crust. amphip. bor. et aret. p. 126.

Type: Oniscus cancellus, Pallas.

Mandibulæ articulo palpi 3tio elongato, angusto.

Maxilla 1 mi paris lamina interna lata, non longa, in margine interiore setis multis, plumosis instructa. 
Oculi prominentes.

Antennæ non prælongatæ; superiores inferioribus longiores.

Segmenta trunci anteriora nodulis aut dentibus instructa.

Epimera parvula.

Segmenta postabdominis tria posteriora fasciculis spinarum destituta.

Pedes saltatorii 2di paris sat breves.

Pedes saltatorii ultimi paris prælongati; ramo interiore breviore qvam exteriore; ramo utroqve in margine setis plumosis instructo.

Appendix caudalis brevis, lata, in margine posteriore subinsinuata.

Til denne af Spence Bate opstillede Slægt, hvis Typus er den af Pallas (Spicil. Zool. fasc. 9, p. 52, pl. 3, f. 18) beskrevne Oniscus cancellus, horer en i Norges og Sveriges storre Indsøer hyppig. forekommende Art $P$. quadrispinosa. G. O. Sars har ligeledes optaget denne Slægt og givet den en noget nøiagtigere Diagnose. I 1870 har jeg stillet den ved Siden af Gammanus. Fra denne adskiller den sig vasentlig ved, at Halevedhænget er helt og kun indskaaret lidt i den bagre Rand. Det andet Par Springfodder er meget kortere end det første. Øinene ere halvkugleformet fremstaaende. Sidepladerne ere smaa. Kindbakkernes Palpe er hos denne Slígt smalere end hos den foregaaende, hvilket især er Tilfældet med det tredie Led, der er næsten linieformet. Navnet Pallasea er forhen (1830) benyttet til en Dipter.

PALLASEA QVADRISPINOSA, (Esmark), G. O. Sars, $186 \%$.

Pallasea cancelloides, var. quadrispinosa, (Esmark), G. 0. Sars. Hist. nat. des Crust. d'eau douce de Norvège. 186\%. p. 68.

- A. Boeck, Crust. amphip. bor. et arct. 1870. p. $12 \%$

(cancellus), Spence Bate Catal. Amphip. Crust. Brit. Mus. App. 1862. p. 380 .

Gammarus cancelloides, Gerstfeldt, Mém. d. l'acad. imp. de St. Petersb. T. VIII. p. 287. T. IX. tab. 9. fig: 8 .

$\begin{array}{ll}- & \text { - } \quad \text { Lovén, Öfv, af Kgl. Vet.-Akad. Förh. 1861. p. } 287 .\end{array}$

Oculi magni, fere ovales. Segmenta trunci qvinqve anteriora in margine inferiore processu prædita, segmenta duo ultima eodem fere destituta. Segmenta postabdominis duo anteriora in utroqve latere medii dorsi spinis singulis validis armata. Flagellum accessorium parvum, 2articulatum. Pedes 1 mi paris manu permagna ovata. Pedes 2 di paris manu apicem versus latiore, fere triangulari. Pedes ultimi paris articulo 1 mo elongato, fere qvadrangulari, in margine posteriore valde 
setoso; articulo 4to longiore quam 3tio et 5̆to. Pedes saltatorii ultimi paris ramo interiore dimidiam longitudinem. rami exterioris non aqvanti.

Længden er $20^{\mathrm{mm}}$ fra Pandehornet til Halevedhænget.

Leg emet er ilke meget sammentrykt; Ryggen er afrundet; de fem forste.Legemsled ere fortykkede i den nedre Rand, især mod den bagre Ende; de tvende forste Haleled ere paa hver Side henimod den bagre Rand vabnede med en bagudrettet stærk Tand; det tredie Leds nedre, bagre Vinkel er meget afrundet. De fire første Sideplader ere af middelmaadig Størrelse, dog meget hoiere end brede. Hovedets Sidevinkler ere afrundede. Øinene ere fremstaaende, næsten runde.

De orre Følere naa, naar de bøies bagud, næsten til det første Haleled; Skaftets første Led er lidt langere end Hovedet; de tvende folgende aftage efter hinanden i Lxngde og Bredde. Svoben er næsten saa lang som Skaftet og dannes af omtrent 20 Led; Bisvgben er liden, toleddet.

De nedre Folere ere meget kortere end de ovre; Skaftets forste Led er meget opsvulmet; det andet er kort og udsender en stærk Lugteknude; det tredie er neppe længere end tykt; det fjerde er længere end det femte Led. Svoben dannes af 7 Led.

Kindbakkerne ere meget triangulære; Palpens tredie Led er kortere end det andet og har talrige Børster $\mathrm{i}$ den gverste Rand.

Det første Kjæbepars indre Plade er meget stor, bred, med talrige fjærdannede Borster paa den indre Rand. Palpen er paa den ene side vabnet med 5-7 Tænder og paa den anden med lige saa mange Torne.

Kjæbefoddernes ydre Plade er kort, men bred, og har paa den indre Rand Tænder, der mod Enden blive tyndere og i den ydre Rand gaa over til forlæugede, krumme Børster; den indre Plade er ligeledes kort. Palpen er forlænget bred; dens sidste Led er kloformet og har en paa Enden frstet kraftig Torn.

Det forste Fodpars fjerde Led er kort, triangulært; Haanden er ægdannet og har paa Griberanden Torne eller stærke Tænder.

Det andet Fodpars Haand er bredere udad; Griberanden ermeget skraa afskaaren og har fire sticke Tæuder.

Det tredie og fjerde Fodpar ere tynde; det tredie Led er meget lidet udvidet, kun lidt læengere end det fjerde, og omtrent saa langt som det femte Led, alle Led have Børster især paa den bagre Rand.

De tre folgende Fodpar tiltage efter hverandre i Størrelse, især det forste Led, der bliver længere og bredere; det tredie er neppe udvidet og lidt kortere end det fjerde, der er længere end det femte Led. Alle Led have Børsteknipper paa begge Rande.

Det forste Par Springfodders ydre Gren er ubetydelig længere end den indre; begge ere uden Torne. 
Det andet $\mathrm{Par}$ er meget kortere og er kun lidt lengere end det forste Pars Grundled.

Det sidste Pars Grene ere pladeformede; den indre er kun lidt mere end en Trediedel af den ydre $\mathrm{i}$ Længde og har Borster paa den indre Rand; den anden har lange Borster paa begge Rande.

Halevedhrnget er omtrent saa langt som bredt ved Roden, noget indbøiet i den ydre Ende, paa Enden af hver Flige og paa den ydre Rand sees nogle Torne.

Farven synes at være gulhvid med stærkere brungule Anstrøg paa Hovedet og Halen, og med en lignende farvet Rand langs Enden af Legemsleddene; der sees ligeledes et rodgult Anstrog paa Folerne og Fodparrene, is ber paa de tre sidste Par. Efter Sars findes der ogsaa hos de fleste Individer en liden purpurrod Flek paa Siderne af Brystleddene og de tre forste Haleled, og som især er tydelig paa disse sidstnævnte Led. Øinene ere morkebrune eller næsten sorte, uden det ydre, hvide pigmentære Austrøg, som man finder los Slægten Gammanus.

Ifolge Lovén findes den i Wenern og Wettern. I Mjøsen er den forst fundet af Esmark, senere af G. O. Sars, der ogsaa har taget den $i$ Here andre af de store Ferskvand. Malmgren har taget den i Ladoga.

Gen. III. MERA, Leach, 1813.

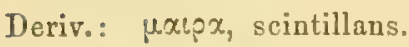

Syn.: 1813. MLera, Leach, Edinb. Encyc. VII. p. 403. Linn. Trans. Soc. XI. p. 359.

1825. - Desmarest, Consid. sur les Crust. p. 246.

1855. Leptothoë, Stimpson, Syn. of the Mar. Invert. of Grand Manan. p. 46.

1862. Magamara, Spence Bate, Catal. Amphip. Crust. Brit. Mus. p. 224.

- Mera, Spence Bate, Catal. Amphip. Crust. Brit. Mus. p. $18 \%$

1863. - Spence Bate and Westwood, Brit. sessile-eyed Crust. p. 348.

1866. - Heller, Beitr. z. näh. Kenntn. d. Amphip. d. Adriat. Meeres. p. 35.

1870. - A. Boeck, Crust. amphip. bor. et arct. p. $12 \%$

Type: Cancer (Gammarus) grossimanus, Montagu.

Mandibulæ articulo palpi 3tio angusto, non prælongato.

Maxillæ $1 \mathrm{mi}$ paris lamina interiore angusta et in apice setis paucis, plumosis instructa.

Corpus elongatum, anguslum.

Epimera parvula; epimerum 4 tum 5to vix majus.

Antenna superiores inferioribus multo longiores; pedunculo pralongato.

Pedes graciles, elongati; pedes 2 di paris manu multo majore qvam apud pedes 1mi paris; pedes trimm parium ultimorum arliculo lmo plus minusve dilatato. 
Pedes saltatorii ultimi paris ultra pedes $1 \mathrm{mi}$ et 2 di paris porrecti; ramis elongalis, anguslis, in margine admodum setosis; ramo interiore parum modo breviore quam exleriore.

Appendix caudalis non prelongata, profunde fissa.

Leach opstillede denne Slægt i 1813 paa den af Montagu beskrevne Cancer grossimanus. Desmarest optog den, medens Milne-Edwards stillede dens Arter under Slægten Gammarus. Dana optog vel Slægtsnavnet, men anvendte det paa Arter af Slægten IIclita. Spence Bate har atter restaureret denne Slægt efter at have undersogt Leachs typiske Art, og han henfører som synonym til denne den af Stimpson i 1855 opstillede Slægt Leptothoë. Fra Slægten Mcera adskiller han MIegamera paa Grund af, at denne sidstnæuntes Arter skulle have et kortere og stærkere Legeme, noget hoiere Sideplader og et noget stærkere andet Fodpar. Heller har dog allerede vist, at dette er en utilstrækkelig Karakter til derpaa at begrunde en særskilt Slægt, hvorfor han forener begge, hvilket vistnok er rigtigt.

Fra de tvende foregaaende Slægter adskiller den sig ved sit forlængede, smale Legeme og ved at de gvre Foleres Skaft er saa stærkt forlænget. Det sidste Par Springfodder er ogsaa meget mere forlænget, end det er Tilfældet hos de foregaaende Slægter; Halevedhænget er dybt kløvet, og dets Fliger staa ud fra hinanden. Ligesom hos Pallasea ere Kindbakkernes Palper tynde, men fra begge de foregaaende Slægter skiller den sig ved, at det forste IKjæbepars indre Plade er smal og har paa Enden kun nogle faa fjærdannede Børster.

MERA LOVÉNI, Bruzelius, 1859.

Gummarus Lovéni, Bruzelius, Skand. Amphip. Gamm. 1859. p. 59. fig. 9.

- - Goës, Crust. amphip. maris Spetsb. 1865. p. 14.

Mcera Lovéni, Spence Bate, Catal. Amphip. Crust. Brit. Mus. 1862.p. 193. pl. XXXV. fig. 1.

- - Norman, Ann. and Mag. of Nat. Hist. 1868. p. 416. pl. XXI. fig. 11-12.

- - A. Boeck, Crust. amphip. bor. et arct. 1870. p. 128.

Oculi parvi, ovales. Epimera deorsum rotundata; epimerum 1mum in angulo antcriore inferiore acuminatum. Segmentum postabdominis 3tium angulo inferiore postico parum producto et sursum acuto. Dorsum leve, non spinosum. Antemme superiores inferiorihus tertia parte longiores: articulo pedunculi 2 do parum longiore IV:m 1mo; hoc longitudinem capitis superanti. Antenne inferiores longitudinem pedunculi antennarum superiorum circiter æryvantes. Pedes longissimi et gracillimi. Pedes $1 \mathrm{mi}$ paris manu elongata, triangulari, breviore quam carpo. Pe- 
des 2di paris manu longiludinem carpi parun superanti, apicem versus paulo latiore, in acie obliqve truncata et dentibus minutis instructa. Pedes trium parium ultimorum articulo 1 mo perangusto sed latitudine gradatim crescenti: articulo 1 mo $7 \mathrm{mi}$ paris ferme ter longiore qvam lato. Pedes saltatorii ultimi paris ramis elongatis, lanceolatis; ramo interiore paulo breviore qvam exteriore. Appendix caudalis usqve ad basin issa.

L ængden er omtrent $20 \mathrm{~mm}$.

Legemet er forlænget smalt; Ryggen er uden Kjol og Torne; det tredie Haleleds nedre, bagre Vinkel er udtrukket til en liden, opadbøiet Hage. Den forste Sideplade er lidt høiere end bred, og dens forreste, nedre Vinkel er udtrukket, noget tilspidset, Hovedet er kortere end de tvende forste Legemsled tilsammen og gaar fortil neppe ud i et kort Pandehorn; Sidevinklerne ere noget afrundede. Oinene ere smaa, ovale.

De ovre Folere naa, naar de boies bagud, omtrent til det tredie Haleled; Skaftets forste I ed er længere end Hovedet og lidt kortere end det andet; det tredie lar neppe en Trediedel af det andet Leds Langde. Svoben er kortere end Skaftet og dannes af 24-30 Led; Bisvoben har 6-8 Led.

De nedre Følere ere meget kortere end de ovre; Lugteknuden par Skaftets andet Led er meget lang; det tredie Led er omtrent tre Gange saa langt som tykt, det fjerde er længere end det femte Led, der naar ikke ganske frem til Begyndelsen af det sidste Led paa de ovre Foleres Skaft. Svoben er kortere end Skaftets sidste Led $0 \mathrm{~g}$ dannes af $10-12$ Led.

Overlæben er afrundet i Spidsen og har sma Borster.

Kindbakkerne ere kraftige, triangulere; Gribedelen har 4-5 Tænder, og det samme Antal sees paa den indre Bigren; Torneræklien dannes af talrige, lange, med fine Borster besatte Torne; Tyggeknuden er meget hoi og meget tandet. Palpen er forlænget, meget smal; det tredie Led er ikke ubetydelig kortere end det andet og er sparsomt besat med Borster.

Underlæben er meget bred; Bifligerne ere tydelige og sees nær Enden al Hovedfligerne.

Det forste Kjabepars ydre Plade har paa Enden gaffelformede Torne; den indre er forlanget smal og har tre fjordannede Borster. Palpen har ligeledes paa Enden tynde Torne eller grove Borster.

Kjabef $q$ ddernes ydre Plade er forlmenget $0 g$ er par Enden af den indre Rand væbnet med Torne, der blive længere mod Spidsen og end langere og krumme paa Enden af den ydre Rand; den indre Plade er lang, smal og naar nxsten frem til Midten af Palpens andet Led, samt har i Spidsen lange fjærdannede Borster; Palpens andet Led er meget langt og har talrige Borster; det sidste Led er smalt og har i Spidsen $2-3$ stærke, grove Tome. 
Det forste Fodpar er meget mindre end det andet; det fjerde Led er convex paa den bagre Rand og har mange Borstebundter. Haanden er lidt kortere, bliver bredere udad, med skraa afskaaren Griberand.

Det andet Fodpars fjerde Led er triangulært. Haanden er storre, næsten af den samme Form som paa det første Fodpar. Griberanden er saugtakket og har fine Torne. Kloen har Borstebundter paa den forreste, convexe Rand.

Det tredie og fjerde Fodpar ere meget tynde, det tredie Led er kun lidet udvidet, længere end det fjerde; det femte er kortere end det foregaaende Led.

De tre følgende Fodpar tiltage efter hverandre i Længde, ligesom deres forste Led i Bredde; paa det femte Par er dette næsten ikke udvidet, paa det syvende er det næsten tre Gange saa langt som bredt og grovtsaugtakket paa den bagre Rand; det tredie Led er lidet udvidet, længere end det fjerde, der atter er læugere end det femte Led.

Det forste Par Springfodder er meget længere end det andet; begge Pars Grene ere lige lange.

Det sidste Pars indre Gren er ubetydelig kortere end den ydre, begge ere smale, Hade og have fine Torne paa Randene; de ere dobbelt saa lange som Grundleddet.

Halevedhanget er spaltet næsten til Roden; Fligerne staa ud fra hinanden, ere lancetformede $\mathrm{g}$ indshaarne $\mathrm{i}$ Spidsen, hvor de have en liden Torn.

Denne Art er fundet af Smitt ved Spitsbergen, af Danielssen ved Christiansund paa 10-20 Favnes Dybde, ved Bohuslen af Lovén, Malm og Bruzelius, som anfører, at den er sjelden $0 g$ findes kun paa 40-60 Favnes Dybde. Efter Norman findes den ogsaa ved England.

Spence Bates Tegning er taget efter Bruzelius.

\section{MERA TORELLI, Goës, 1865.}

Gammarus Torelli, Goës, Crust. amphip. maris Spetsb. 1865. p. 14.

Mera Torelli, A. Boeck, Crust. amphip. bor. et arct. 1870. p. 128.

Antennæ superiores inferioribus tertia parte longiores; articulo pedunculi Ino longiore qvam capite; 2do paulo longiore sed angustiore qvam 1mo. Epimera deorsum angulata. Segmenta postabdominis tria anteriora angulo inferiore postico spinulam formanti. Pedes 2di paris manu permagna, elongata, ovata, multo longiore qvam carpo. Pedes trium parium ultimorum brevissimi; ultimi paris articulo, 1 mo ferme duplo longiore qvam lato et in angulo inferiore postico paulum producto. Pedes saltatorii $1 \mathrm{mi}$ paris in medio margine inferiore pedunculi spina valida armati; ultimi paris ramis prelongatis, latis, lanceolalis, longitudinem segmentorum postabdominis trium posteriorum junctorum apvantibus. Appendix caudalis 
non usque ad basin fissa, in margine exteriore spinis nonnullis et in extrema utraqve lacinia spinis singulis validis armata.

Lxngden er $5^{\mathrm{mm}}$.

Legemet er meget forlænget, ikke synderlig sammentrykt; de tre forste Haleleds nedre, bagre Vinkel danner en spids Hage. Sidepladerne ere smaa; de tvende forste ere omtrent saa høie som brede; den tredie og fjerde ere bredere end høie, den femte er storre end den foregaaende, med en stor forreste Lap; de tvende sidste ere smaa. Hovedet er noget længere end det forste Legemsled; den forreste Rand danner kun en svag Vinkel mellem de ovre Folere; Sidevinklerne ere kun lidet udvidede, afrundede.

De ovre Folere naa, naar de bøies bagud, ikke fuldstændig til Halens forste Led. Skaftet er meget forlænget; dets første Led er en Trediedel længere end Hovedet; det andet er noget længere end det første, og det tredie er knapt en Trediedel af det foregaaende Leds Længde. Svoben, der ikke er fuldt saa lang som Skaftets tvende sidste Led, dannes af 35 korte Led. Bisvoben, der er meget tynd og har 5 Led, naiar til Enden af Svobens femte.Led.

De nedre Folere naa ikke frem til Enden af de ovres Skaft. Det forste Led er meget stort, opsvulmet $0 \mathrm{~g}$ er ikke skjult indenfor Hovedets Bedækning; det andet er lidet og udsender fra sin nedre Ende en tilspidset Lugteknude, der er næsten saa lang som det tredie Led, der el dobbelt saa langt som tylit; det fjerde naar frem nasten til Enden af de ovre Foleres første Skaftled; det femte Led er kortere og smalere. Svøben, der har omtrent den samme Længde, som det sidste Led, dannes af 16 Led.

Overlæben er meget stor og dannes som særlvanlig af en forreste mindre og en bagre større Del.

Kindbakkerne ere særdeles kraftige; Tyggeknuden ex meget fremstaaende. Palpens tredie Led er meget kortere end det andet.

Det første Kjæbepars ydre Plade er paa Enden forsynet med gaffeldannete Torne; den indre Plade er forlænget, med fjærdannede Borster paa den indre Rand. Palpens andet Led er bredere mod Enden og er der besat med Borster.

Det andet Kjæbepars ydre Plade er lidt længere end den indre og besat paa Enden med Borster, der tildels ere fjærdannede.

Kjabefoddernes ydre Plarle har paa den indre Rand og paa Enden tynde Torne, der ved den ydre Rands Ende gaa over til krumme Børster; den indre Plade naar frem foran Palpens forste Led.

Det fol'ste Fodpars fjerde Led er triangulært; Haanden er lidt større, og begge have talrige Borster paa den bagre Rand.

Det andet Fodpar er meget storre end det første. Det fjerde Led el kort, medens Haanden er overmaade stor, bredere mod Enden, og med skraa afskaaren Griberand. Begge Led lave talrige Borstebundter paa den bagre Rand. Kloen er saugtakket paa den bagre Rand. 
Det tredie og fjerde Fodpar ere korte; de tvende sidste Led ere næsten lige lange, tilsammen langere end det tredie Led.

Det femte Fodpar er særdeles kort; det første Led er kun noget kortere end de folgende Led tilsammen og saugtakket paa den bagre Rand; det tredie er kortere end det fjerde Led.

De tvende følgende Fodpar tiltage efter hinanden meget i Længde, saaledes at det sidste er omtrent dobbelt saa langt som det femte Par; det forste Led er ikke meget bredt, den bagre Rand er saugtakket, og den nedre, bagre Vinkel er lidt udstaaende; det tredie Led er paa det sjette Par længere, paa det syrende kortere end det fjerde Led.

Det forste Par Springfodders Grene ere nasten lige lange; Grundleddet er indskaaret paa den undre Rand, og i denne Indskjæring sees en kraftig Torn.

Det sidste Pars Grene ere flade, lancetformede, meget forlængede, mere end dobbelt saa lange som Grundleddet, og forsynede med Torne i begge Rande; den ydre Gren er lidt kortere end den indre.

Haleved hanget er ikke meget langt, spaltet til over Midten; Fligerne, der staa ud fra himanden, ere paa den ydre Rand vabnede med Torne og have en lignende stærkere paa den noget indskaarne Spids.

Af Torell er denne Art fundet i Maven paa en Torsk ved Islands Kyst i faa Exemplarer. Et Exemplar fra den samme Kyst har jeg seet i Kjgbenhavns Museum.

MERA LONGIMANA, (Leach), Thompson, 1847.

Gammarus longimanus, Thompson, Ann. Nat. Hist. 1847. 1. ser. XX. p. 242; Nat. Hist. of Ireland. IV. p. 396.

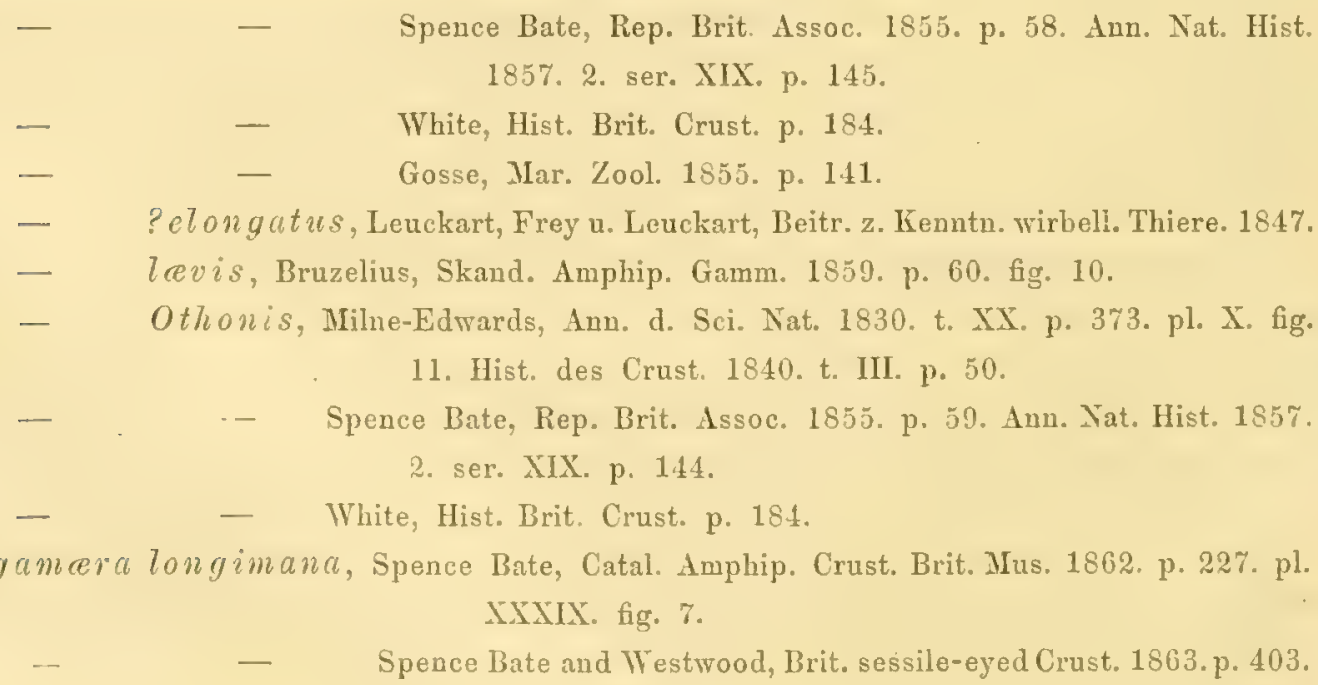


Megamera Othonis, Spence Bate, Catal. Amphip. Crust. Brit. Mus. 1862. p. 227. pl. XXXIX. fig. 8.

- $\quad$ - Spence Bate and Westwood, Brit. sessile-eyed Crust. 1863. p. 405. Mrera longimana, Norman, Rep. on the Shetland Crust. 1868. p. 284.
A. Boeck, Crust. amphip. bor. et arct. 1870. p. 129 .

Epimera in margine inferiore rotundata: cpimerum 1 mum in angulo interiore inferiore acutum et in margine inferiore dentibus armatum; epimera tria seqventia etiam dentibus sed minoribus armala. Segmentum postabdominis 2 dum et 3 tium angulo inferiore posteriore in dentem desinenti et margine inferiore spinoso. Oculi magnitudinis mediocris, ovales. Antennæ superiores inferioribus fere duplo longiores; articulo pedunculi 2lo longitudinem arliculi 1 mi æqvanti. Antenne inferiores pedunculo superiorum longiores. Pedes 1 mi paris manu ovata, paulo breviore qvam carpo. Pedes 2 di paris manu majore qvam 1 mi paris, apud feminam elongata, ovata, longiore qvam carpo, apud marem permagna, majore qvam arliculis 3 præcedentibus junctis, elongata et ovata; ungve valde curvato: angulo inferiore posteriore articuli 3 tii et 4 li dente armato. Pedes $5 t, 6$ ti et $7 \mathrm{mi}$ paris articulo $1 \mathrm{mo}$ dilatato, in margine posteriore serrato. Pedes saltatorii ultimi paris ramis angustis, lanceolatis, longioribus quam pedunculo. Appendix caudalis usqve ad basin fissa; laciniis oblongis, in apice spinis singulis instructis.

Læ ngden er $12-35^{\mathrm{mm}}$.

L e gemet er forlænget smalt; Ryggen er afrundet, uden Kjøl eller Torne; det andet og tredie Haleleds nedre, bagre Vinkel er udtrukket i en skarp Spids, og disse Leds nedre Rand er vabnet med flere Torne. Sidepladerne ere smaa; de fire forste ere kun lidt større end de folgende og saugtakkede paa den nedre Rand; den førstes nedre, forreste Vinkel er udtrukket, tilspidset. Øinene ere ovale.

De ovre Folere ere meget forlængede; Skaftets forste Led er omtrent af Hovedets Lxngde og saa langt som det andet, men tykkere end dette, samt har nogle Torne par Enden af den nedre Rand; det tredie Led er kort. Svoben er meget langere end Skaftet og dannes af omtrent 50 med Borster besatte Led. Bisvoben har 7 Led.

De nedre Folere ere meget kortere end de øvre; Skaftets 3die Led er omtrent dobbelt saa langt som tykt; de tvende sidste ere omtrent lige lange. Svoben er lidt længere end Skaftets sidste Led og dannes af omtrent 25 Led.

Det forste Fodpars fjerde Led er mere buet paa den bagre end forreste Rand og forsynet ligesom paa det første Led med stærke og lange Borster paa begge Rande; Haanden er kortere end det foregaaende Led og af en forlanget oval Form, samt har, ligeledes Borster paa begge Rande. 
Det andet Fodpar er storre end det forste og meget stærkere hos Hannen end hos Huninen; det tredie og fjerde Leds nedre, bagre Vinkel er udtrukket og tilspidset; det fjerde Led er hos Hunnen triangulært, kortere end den forlængede ægdannede Haand, der er 3-4 Gange længere end bred. Den bagre Rand er paa alle Led besat med lange Børster. Hos Hannen er det fjerde Led meget kort; Haanden er særdeles stor, større end de tre foregaaende Led tilsammen og af en forlænget, oval, lidt boiet Form. Kloen er meget krummet.

Det tredie og fjerde Fodpar tiltage efter hinanden i Længde; det forste Led er bredt, tandet, den bagre Rand med afrundet øverste og næsten ret nederste Vinkel.

De tre følgende Fodpars forste Led er buet paa begge Rande, især den bagre, der er forsynet med Saugtakker.

Det sidste Par Springfodder naar langst bagud; Grenene ere lige lange, meget længere end Grundleddet, af en smal, lancetdannet Form og besatte i Randene med spredte Torne.

Halevedhanget er kløvet næsten til Roden; Fligerne ere tilspidsede, indskaarne paa Enden og der forsynede med en Torn.

Farven er efter Bruzelius lysrød, Øinene ere sorte. Jeg har taget nogle enkelte Exemplarer af denne Art udenfor Moss. Ved Koster er den fundet af Malm og forekommer efter Bruzelius paa flere Steder ved Bohuslen. Den er ogsaa fundet paa Here Steder ved England og Skotland, ved Shetland er den taget af Norman.

Gen. IV. MELITA, Leach, 1813.

Deriv.: Melita, et mythologisk Navn.

Syn.: 1813. Melita, Leach, Edinb. Encyc. art. Crust. p. 403. App. p. 432. Linn. Trans. Soc. 1815 . XI. p. 3558.

1825. - Desmarest, Consid. sur les Crust. p. 265.

1849. Mera, Dana, U. S. explor. exped. p. 965. On the Classif. of the Crust. Chorist. or Tetradec. The Am. Journ. of Sc. et Arts. 1852. 2. ser. XIV. p. 308.

1857. Melita, Costa, R. sui Crost. amfip. del regno di Napoli. p. 224.

1862. - Spence Bate, Catal. Amphip. Crust. Brit. Mus. p. 181.

1863. - Spence Bate and Westwood, Brit. sessile-eyed Crust. p. 335.

1870. - A. Boeck, Crust. amphip. bor. et arct. p. 129.

Typo: Cancer (Gammarus) palmatus, Montagu.

Handibulæ articulo palpi 3 tio elongato, angusto.

Ilaxille $1 \mathrm{mi}$ paris lamina interiore angusta, setis nonnullis, plumosis instructa. 
Dorsum non carinatum. Segmenta posteriora trunci et omnia postabdominis dentibus transversim positis plus minusve armata.

Oculi parvi, rotundati.

Antennæ superiores inferioribus longiores.

Pedes 2di paris iisdem 1 mi paris majores; manu permagna, apud marem majore.

Pedes saltatorii ultimi paris reliqvos multo eminentes, ramo interiore minimo; exteriore prælongato.

Appendix candalis usque ad basin fissa.

Denne Slægt blev opstillet af Leach paa Montagus Cancer (Gammanus) palmatus og optaget i 1825 af Desmarest. Den er af Nilne-Edwards stillet under Slægten Gammarus, medens Dana atter har optaget Slægtsnavnet med følgende Diagnose: „Epimeræ 5 tre 4 tis multo breviores. Styli caudales uno ramo longo, sive subeylindrico sive foliaceo, altero brevi vel obsoleto. (Digitus in manu latus sæpe claudens). Antennæ $1 \mathrm{~m}$ sæpius longiores." Hertil kommer: „Antennæ Imæ non appendiculatæ," medens hos Slægten Mlera ere "Antennæ primæ appendiculatæ." Spence Bate viser imidlertid, at dette netop er Tilfieldet med Slægten Mclita, hvorfor Dana's Arter af Slægten Mrara maa henfores hertil. Costa's Slægt Ceradocus er ogsaa stillet herhen af Spence Bate, men det er uvist, om dette bor ske, da Costa ogsaa optager Slægten Melita, og da det sidste Par Springfodder hos hans Slægt Ceradocus er anderledes formet end hos Deelita. Som hos de tvende foregaaende Slægter ere her Kindbakkernes Palper tynde; det første Kjæbepars indre Plade er storre end hos Mlera, men mindre end hos Gammans, og besat paa den indre Rand med en Række fjærdannede Børster. Iøvrigt stemmer den i Munddelene overeens med Slægten Gammarus. I det Ydre skiller den sig let fra denne sidstnævnte Slægt ved sine sma runde Øine og ved Halens Led, der paa den bagre Rand ere væbnede med stærke Tænder og ikke med Grupper af Torne som hos hin Slægt. I den sidste Henseende skiller den sig ogsaa fra Slægten Mrera, hos hvilken ogsaa Sidepladerne ere smaa, medens de ere temmelig store hos MIelita. Denne adskiller sig ogsaa fra den foregaaende Slægt, ved at det sidste Par Springfødders ydre Gren er meget forlænget, merlens den indre er meget liden. Til denue Slægt hører ikke faa Arter baade fra ten nordlige og sydlige Del af vor Halvkugle, hos os er der dog hidtil kun fundet tre Arter.

MELiTa OBTUSATA, Montagu, 1815.

Cancer (Gammarus) obtusatus, Montagu, Trans. Linn. Soc. 1815. XI. p. 5.t. 2. fig. \%. Amplithoë obtusata, Milne-Edwards Ann. d. sci. nat. 1830. XX. p. 377. Hist. d. Crust. 1840. III. p. 83.

- - Gosse, Mar. Zool. 1855. I. p. 141. 
Aimplitţoё obtusata, White, Hist. Brit. Crust. 1857. p. 201.

Gammarus maculatus, Lilljeborg, Öfr. af Kgl. Vet.-Akad. Förhandl. 1852. p. 10. 1853. r.. 138 .

- obtusatus, Lilljeborg, Öfv. af Kgl. Vet.-Akad. Förhandl. 1854. p. 4 2.

- $\quad$ - Bruzelius, Skand. Amphip. Gamm. 1859. p. 55.

Melita proxima, Spence Bate, Catal. Amphip. Crust. Brit. Mus. 1862. p. 184.

- obtusata, Spence Bate, Catal. Amphip. Crust. Brit. Mus. 1862. p. 183.

- $\quad$ - Spence Bate and Westrood, Brit. sessile-eyed Crust. 1863. p. 341.

- - Norman, Rep. on the Shetland Crust. 1868. p. 284.

- $\quad$ A. Boeck, Crust. amplip. bor. et arct. 1870. p. 130.

Antenna superiores arliculo pedunculi 1 mo eadem longitudine ac articulo 2do. Segmenta postabdominis dno anteriora in angulo inferiore postico acuta; segmentum 3tium acutum et sursum productum; segmentum postabdominis 2dum et 3tium in medio margine posteriore dentibus singulis armata: segmentum 4tum et 5 tum dentibus binis aut ternis instructa. Pedes 1 mi paris manu ovata, in margine posteriore, setis longis instructa. Pedes 2di paris manu apud marem permagna, triangulari, in acie dentibus $2-3$ ohtusis armata et in dentem latum, acuminatum desinenti; ungve magno, obtuso, compresso; manu apud feminam multo minore et fere ovata. Pedes saltatorii ultimi paris ramo interiore ovata.

Langden er $9-10^{\mathrm{mm}}$.

Legemet er sammentrykt, hoit, dog temmelig forlænget. Ryggen er rund, uden Kjol. Det andet og tredie Haleled ere væbnede med en liden Tand paa Midten af den bagre Rand; det fjerde har tre og det femte Led 2-3 Tæunder. De tre forste Haleleds nedre, bagre Vinkel er udtrukket, tilspidset, især paa det tredie Led. Hovedets Sidevinkler ere afrundede. Oinene ere runde.

De ovre Folere naa, naar de boies bagud, omtrent til det forste Haleled. Skaftets forste Led er kortere end Hovedet; det andet er næsten af den samme Længde, men smalere, og det tredie er noget kortere end det foregaaende Led. Svøben dannes hos Hannen af 25, hos Hunnen af 20 Led.

De nedre Foleres tredie Lerl el omtrent dobbelt saa langt som tylit; det fjerde og femte Led ere næsten lige lange. Svoben dannes af 6-8 Led.

Kindbakkerne ere kraftige. Palpens forste Led er temmelig forlænget.

Det forste Kjabepars indre Plade er temmelig stor og har mange fjordannede Børster.

Kjab efoddernes ydre Plade er stor, med grove Tander langs den indre Rand.

Det forste Fodpars femte Led er forlenget ovalt, med Børsteknipper paa den bagre Rand.

Det andet Fodpar er: meget storre end det forste og meget storre hos Han- 
nen end hos Hunnen. Hos den forste er det fjerde Led overmaade kort; Haanden er næsten triangulær, med en mere buet forreste end bagre Rand 0 g med en skraa afskaaret Griberand. Denne har 3-4 brede Tiender og paa Enden en stor, bred Tand, paa hvis indre Side der findes en dyb Grube, der optager Kloens Spids. Kloen er bred og sammentrykt, især mod Spidsen, der er afrundet.

Det tredie og fjerde Fodpar ere forlængede, smale.

De tre folgende Fodpars forste Led er bredt, saugtakket paa den bagre Rand; det tredie er ikke meget udvidet, længere end det fjerde, men kortere end det femte Led. Kloen er stærk og krummet.

Det første Par Springfødders Grene ere næsten lige lange, med Torne i Spidsen og paa den ovre Rand, samt naa næsten til Enden af det sidste Pars Grundled.

Det andet Par er noget kortere.

Det sidste Pars ydre Gren er meget forlænget og langere end Grundleddet, der ligeledes har Torne i Spidsen og paa den ovre Rand; den indre Gren er kort, rudimentær.

Halevedhanget er dobbelt; Fligerne ere tilspidsede mod Enden og have et Par Torne nar Spidsen paa den ydre Rand.

Farven er hvid, med svage zinnoberrodle bolgende Baand over den bagre Del af hv er ${ }_{t}$ Led og over Fodparrene. Efter Bruzelius er den hvid med røde Flekker.

Ifolge Norman er II lita proxima, Spence Bate and Westwood, Brit. sessile-eyed Crust. p. 344, den almindeligste Form for Hannen af denne her omhandlede Art, og IIegamara Alderi, sammesteds p. 407, Hunnen, hvorimod den typiske Form er meget minare almindelig ved Shetland.

Den forekommer ved Bergenskysten, hvorfra der findes Exemplarer i Bergens Museum. Ved Haugesund fandt jeg den temmelig hyppig paa flere Steder, ligesom ved Mandal, Farsund og i Christianiafjorden. Efter Bruzelius forekommer den ved Bohuslen. Af Norman er den taget ved Shetland og forekommer ogsaa paa flere Steder ved England. Ifolge Metzger findes dens Varietet $\boldsymbol{M}$. proxima hyppig paa $\mathbf{S}-10$ Favnes Dybde ved den ostfrisiske Kyst.

IIELITA PALMATA, Montagu, 1806.

(PI. XXIV. fig. 4.)

Cancer (Gammarus) palmatus, Montagu, Trans. Linn. Soc. 1806. VII. p. 69. t. VI. fig. 4. Gammarus Dugèsii, Milne-Edwards, Ann. d. sci. nat. XX. p. 368. Hist. d. Crust. 1840. III. p. 54.

- - Zaddach, Synops. Crust. Pruss. 1844. p. 6.

- palmatus, Milne-Edwards, Hist. d. Crust. 1840. III. p. 55. Régne animal. 3. edit. Crust. pl. 60. fig. 3.

- - Frey u. Leuckart, Beitr. z. Kenntn. wirbell. Thiere. 184\%.p. 162. 
Gammarus palmatus, Lilljeborg. Öfv. af Kgl. Vet.Akad. Förhandl. 1854.p. 453.

- Spence Bate, Brit. Assoc. Rep. 1855. p. 58. Synopsis etc. Ann. Nat. Hist. 2. ser. XIX. p. 144.

- - White, Ilist. Brit. Crust. p. 184.

- $\quad$ - Bruzelius, Skand. Amphip. Gamm. 1859 p. 56.

- incequimanus, Spence Bate, Synopsis etc. Aun. Nat. Hist. 2. ser. XIX.p. 145. - $\quad$ - White, Hist. Brit. Crust. p. 403.

Melita palmata, Leach, Edirb. Encye. art. Crust. 1813. VII. p. 403. Trans. Linn. Soc. 1815. XI. p. 358. Suppl. Enc. Brit. I. p. 425. pl. XXI.

\begin{tabular}{|c|c|c|}
\hline - & - & Desmarest, Consid. sur les Crust. 1825. p. 264. pl. 45. fig. 7 . \\
\hline - & - & Costa, R. sui Crost. amfip. del regno di Napoli. 1856. p. 192. t. II. fig. 4. \\
\hline . & - & $\begin{array}{l}\text { Spence Bate, Catal. Amphip. Crust. Brit. Mus. 1862. p. 182. pl. } \\
\text { XXXIII. fig. } 2 .\end{array}$ \\
\hline & - & Spence Bate and Westwood, Brit. sessile-eyed Crust. 1863. p. $33 \%$ \\
\hline & & r. et arct. 1870. p. 129. \\
\hline
\end{tabular}

Antennæ superiores articulo pedunculi 1 mo parum breviore qvam 2do. Segmentum postabdominis $2 \mathrm{dum}$ et 3 tium in angulo inferiore postico acuminata; segmentum 4tum in medio margine posteriore dente acuto armatum, 5 tum in eadem margine bidentatum et parum setosum. Epimerum 6tum apud marem in processum longum, deorsum curvatum et in apice rotundalum, productum. Pedes Imi paris manu ovata. Pedes 2di paris angulo inferiore postico articuli 3tii apud marem in aculeum producto; manu apud marem permagna. triangulari, in margine inferiore. levi; ungve angusto, longo, acuto et versus latus internum manus inflexo; manu apud feminam ovata et multo minore.

Længden er omtrent $10^{\mathrm{mm}}$.

Legemets Form er meget lig den hos den foregaaende Art, men den er lidt mere forlænget. Ligesom hos den foregaaende er det fjerde Haleled paa Midten af den bagre Rand vabnet med en stærk Tand; det følgende Led har tvende lignende, og mellem dem sees en liden Borste; det andet og tredie Haleleds nedre, bagre Vinkel er udtrukket, tilspidset. Hos Hannen er den forreste Lap paa den sjette Sideplade nedad udtrukket til en lang, bøiet, i Spidsen afrundet Fremragning. Hovedet og Øinene ere som hos den foregaaende Art.

De ovre Følere naa, naar de bøies bagud, til det fjerde Haleled. Skaftets andet Led er længere og tyndere end det forste, og ilke fuldt dobbelt saa langt som det tredie Led. Svaben dannes af omtrent 25 Led hos Hannen, og af omtrent 18 hos Hunnen. Bisvøben har 2 Led.

De nedre Folere ere meget kortere end de ovre; Skaftets fjerde Led er lidt 
længere end det femte. Svøben dannes af 7 Led. Hos Hunnen ere Følerne kortere end hos Hannen.

Mund delene ere som hos den foregaaende Art.

Det andet Fodpar er hos Hannen meget kraftigt; det tredie Leds nedre, bagre Vinkel er udtrukket til en skarp Spids hos Hannen; Haanden er stor, næsten triangulær; paa dens indre Flade sees en dyb Fure, hrori optages den lange, tynde Klo. Hos Hunnen er dette Fodpar meget mindre, og Haanden er oval.

De fem folgende Fodpar ligne de samme hos $\boldsymbol{M}$. obtusata.

Det sidste Par Springfodders ydre Gren er meget længere end Grundleddet; den indre Gren er rudimentæer.

Halevedhænget er som hos den foregaaende Art.

F arven er bleg, brunlig gul. Øinene ere sorte.

Den er endnu ikke fundet ved den norske Kyst, men ifølge Bruzelius er den fundet ved Bohuslen, og i Kjobenhavns Museum sa jeg talrige Exemplarer, der vare tagne i Sundet. Den findes ligeledes ved de engelshe Kyster, efter Milne-Edwards ved Bretagne og efter Heller i Adriaterhavet.

MELITA DENTATA, Kroyer, 1842.

(Pl. XXIII, fig. 10.)

Gammarus dentatus, Krøyer, 1842. Nat. Tidsskr. 1. R. IV. B. p. 159.

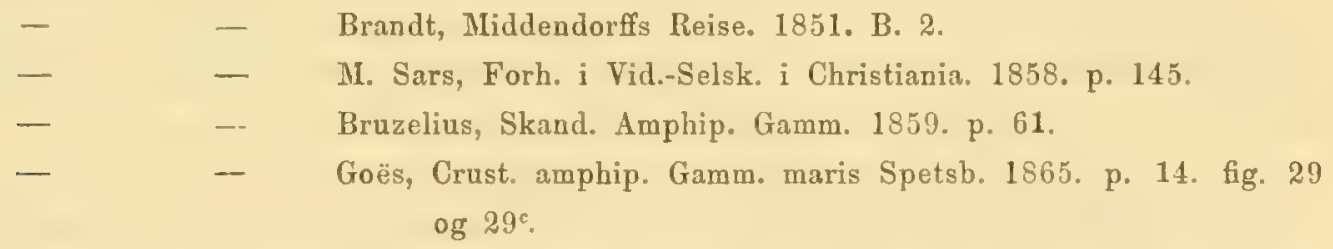

- purpuratus, Stimpson, Mar. Invert. of Grand Manan. 1854. p. 55.

- Kroyeri, Bell, App. to Belchers the last of the arct. voy. 1855. p. 405. t. 34. fig. 4 .

Megamara dentata, Spenoe Bate, Catal. Amphip. Crust. Brit. Mus. 1862. p. 225. pl. XXXIX. fig. 4.

- Kroyeri, Spence Bate, Catal. Amphip. Crust. Brit. Mus. 1862. p. 229. t. XL. fig. 4.

Melita dentata, A. Boeck, Crust. amphip. bor. et arct. 1870. p. 131.

Oculi-parvi, ovales. Antenna superiores ad segmentum postabdominis 4tum porrecte: articulo pedunculi 1 mo paulo brevioré qvam 2do. Segmentum postabdominis 3tium angulo inferiore postico acuto et sursum producto; segmentum Imum in medio margine posteriore spinis plurimis, spina media maxima, instructum; segmentum 2dum et 3tium spinis qvinis-septenis, Itum qvinqve armata; spina media 
semper maxima, præcipue segmenti ti; segmentum 5tum dentibus qvatuor, 6tum dentibus 6 armata. Pedes 1 mi paris manu ovala, breviore qvam carpo; ungve dentato ciliatoqve. Pedes 2 di paris arliculo 3 tio in angulo inferiore postico in dentem producto; manı multo majore qvam 1 mi paris elongata, ovata aut subqvadrata, in acie obliqve truncata et in apice dente magno, obluso armata, ungre sutis pradito.

\section{I. $æ n g d e n$ er $17 \mathrm{~mm}$.}

Legemet er ikke meget sammentrykt, Ryggen er rund, uden Kjøl. Paa den ovre, bagre Rand af Halens Led findes Trender, hvis Antal vexler paa de forskjellige Led. Paa store Exemplarer, saaledes som paa det her beskrevne, findes en Bevabning af talrige (9), men smaa Tæuder paa den ovre, bagre Rand af det andet og tredie Haleled, og tildels af det forste Led. Det sjette har tvende Sidekjøle, der undertiden ende $\mathrm{i}$ en Tand. Den nedre, bagre Vinkel paa Halens tre forste Led, især det tredie, danner en liden, skarp Hage. Sidepladerne ere ikke meget store, dog hoiere end brede, med afrundede, nedre Rande; den fjerde er kun lidet indskaaret for den femte. Hovedet er ikke fuldt saa langt som de tvende forste Legemsled tilsammen og danner kun en stump Vinkel mellem de ovre Folere, men intet egentligt Pandehorn; dets Sidevinkler ere meget store, afrundede; den nedre, forreste Vinkel danner en fremadrettet skarp Torn under Udspringet for de nedre Folere, Øinene ere ovale.

De øvre Folere ere næsten saa lange, som Legemet. Skaftets første Led er noget langere end Hovedet; det andet er ubetydelig længere og smalere, det tredie er kun en Fjerdedel af det andet Leds Liengde. Svoben er noget lrengere end Skaftet og dannes af 50-60 Led. Bisvøben er meget smalere og har 5-6 Led.

De nedre Folere have kun noget mere end Halvdelen af de ovre Foleres Længde. Skaftets første Led er ikke meget tykt; det andet gaar ud i en meget lang, smal, spids Lugtelnude, der er noget kortere end det tredie Led; dette er nasten tre Gange saa langt som tykt og har nogle Torne i den forreste Rand; det fjerde naar ikke fuldt frem til den halve Længde af de ovre Foleres andet Led; det femte Led er kortere end det fjerde. Svoben er ikke længere end Skaftets sidste Led og dannes af 15 Led.

Overlæben er ikke meget forlænget.

Kindbakkerne ere meget kraftige; den ydre Gren er meget bred, og den indre Bigren har fire stærke Tænder; Tornerækken dannes af lange, krumme, ikke fjærdannede Børster; Tyggeknuden er meget fremstaaende. Palpens tredie Led er kortere, end det andet, meget tynd og har paa Randen ikke mange, tynde, men lange Børster.

Underlæben er temmelig bred, med stærke Bifliger.

Det første Kjæbepar har en meget bred Palpe; dens forste Led er forsynet med flere Børster paa den ydre Rand; det andet Led er paa Enden vabnet med Torne, der gradvis blive langere udad, foruden med mange Børster. Den indre Plade er tem- 
melig stor, tilspidset paa Enden, og paa den indre Rand besat med talrige, ikke fjærdannede Borstel:

Det andet $\mathrm{K}$ j bepars Hovedplade er paa Randen ikke besat med fjurdannede Borster.

K jæb fof d derne ere forlængede; den ydre Plade har paa den indre land en Række smale, men meget tætstaaende Tænder, der mod Pladens Ende blive længere og gaa mod den ydre Rand over i længere, krumme Torne og Borster; den indre Plade er væbnet med tre Tænder, hvoraf de tvende indre staa hinanden meget nær; desuden sees her Borster og tvende Torne paa Enden af den indre Rand. Palpens andet Led er meget forlænget; det tredie er kort. Kloen er tydelig afdelt.

Det forste Fodpar er meget mindre end det andet. Det fjerde Led er længere end Haanden, der er oval eller agdannet, med en meget skraa afskaaret Griberand; begge Led har tatte Børsteknipper paa den bagre Rand, og det sidste tillige paa den forreste Rand. Kloen er fint saugtakket paa den bagre Rand.

Det andet Fodpars nedre, bagre Vinkel paa det tredie Led er urltrukket i en Torn; det fjerde er meget kort, triangulært; Haanden er meget stor, forlænget oval, med skraa afskaaret, tandet Griberand; den bagre Rand, der er temmelig tret besat med Borstelinipper, hvilke ogsaa sees paa den forreste Rand, springer frem i en Torn, hvor Kkloens Spids lægger sig til. Kloen er stærk, krum, med Borster paa den convexe Rand.

Det tredie og fjerde Fodpar ere smale; det tredie Led er kun lidet udvidet nedad, og langere end det fjerde, der el saa langt som det femte Led, eller noget længere end dette.

De tre folgende Fodpar ere af cens Bygning, men tiltage efter hverandre i Længde; det for'ste Led, der el saugtakket paa den bagre Rand, er bredest paa det sidste Par; det tredie er ubetydelig langere end det fjerde, der har omtrent den samme Længde som det femte Led. Kloen er liden og af den almindelige Form.

Det forste Par Springfødders Grene ere omtrent lige lange og kun lidt kortere end Grundleddet, der bagtil paa den ydre Rand gaar ud i en Torn.

Det andet Pars ydre Gren er kun lidt kortere end den indre.

Halevedh nget dannes af trende lancetlignende Plader, der i Spidsen have flere Torne.

Farven er lysrod, blegere paa Folerne og Fodparrene. Et Exemplar fra Tromsø var mere brunrodt, med lysere Pletter paa Hovedet og lignende Baand tværs over Leddene. Øinene ere sorte. Efter Torell ere nogle Exemplarer blege, gulhvide, med gule eller brune 'Tværbaand.

Ved Gronland er den taget af Holboll og Torell; ved Spitsbergen er den fundet paa 20-40 Favnes Dybde; ved Island er den taget af Torell, ved Grand Manan af Stimpson. Ved Tromsø og Vadsø forekommer den hyppig; efter M. Sars forekomme: den i Laminariabeltet. Af R. Collett er den ligeledes fundet ved Tromsø og af S. Lovén 
ved Finmarken. Jeg har fundet den ved Haugesund paa 60 Farnes Dybde, og den er ligeledes tagen paa forskjellige Steder langs Kysten og lige til Bohuslen, hvor den af Bruzelius er funden paa 40-60 Favne. Efter Packard forekommer den ved Labrador.

Herhen hører vistnok ogsaa Megamcera longicauda, Brandt, Middendorffs sibirische Reise, p. 141, pl. 6, fig. 32; Spence Bate, Catal. Amphip. Crust. Brit. Mus. 1862, p. $229, \mathrm{pl} . \mathrm{XL}$, fig. 3.

\section{Gen. V. ELASMOPUS, Costa, 1856.}

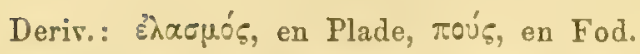

Syn.: 1853. Elasmopus, Costa, Rend. della Reale Ac. d. Sci. di Napoli. p. 170. R. sui Crost. amfip. del regno di Napoli. 1856. p. 212.

1870. - A. Boeck, Crust. amphip. bor. et arct. p. 130.

Type: Elasmopus rapax, Costa.

Mandibulæ articulo palpi 3tio multo majore qram 2do, curvato, persetoso. Maxillæ 2di paris lamina interiore ovata, in apice setis nonnullis instructa. Antennæ superiores inferioribus longiores; pedunculo elongato.

Pedes 2di paris iisdem $1 \mathrm{mi}$ paris majores.

Pedes trium parium ultimorum perlati.

Pedes saltatorii ultimi paris ramis invicem eadem longitudine brevibus et latis. Appendix caudalis pernagna, profundissime fissa.

Costa opstillede denne Slægt i 1853 med følgende Diagnose: „Antennæ superiores bisetæ, inferiores articulo primo inermi. Pedes qvatuor anteriores prehensiles, 2 di primis majores; sex postici elati, laminares, articulo ultimo tantum tereti." Ved denne sidste Karakter skal denne Slægt endvidere skille sig fra Gammarus. Spence Bate henforrer Elasmopus som synonym med Podocerus, hvor den aldeles ikke kan have sin Plads, da Halevedhænget er pladeformet, klovet, det sidste Par Springfodders Grene pladeformede, og da Sidepladerne ere store. Derimod tror jeg, at Spence Bate's Art Megancera brevicaudata maaske kan stilles herhen, da den stemmer overeens med den typiske Art E. rapax i flere Henseender. Om man end ikke af Costa's Diagnose har faaet Noget, der kan karakterisere den som Slægt, frembyder hans Tegning af den typiske Art flere Holdepunkter til at skille den fra nærstaaende Slægter. Jeg har henfort til denne en Art fra Norge, efter hvilken jeg har udkastet en ny Slægtsdiagnose. Den skiller sig fra de foregaaende Slægter, ved at Kindbakkernes Palper ere meget stærke, brede, medens de ere meget tynde hos de foregaaende. Heri ligner den noget Slægten Gammanus, men Palpen er her stærkere, og dens tredie Led er her længere end det andet, medens det hos hin Slægt er kortere. Det andet Kjæbe- 
pars indre Plade er her ogsaa meget svagere end hos hin og er kun forsynet med nogle Borster i Spidsen, medens hos hin den hele indre liand el besat med saadanne. I det Ydre ligner den ogsaa Slægten Gammarus, men Yinene ere runde, og der mangler de Tornebuniter paa de tre sidste Haleled, hvilke findes hos hin Slægt; der findes heller ikke Tænder paa det fjerde og femte Haleleds bagre Rand, hvilket er Tilfoldet hos Slagten Melita. I det Hele er den særdeles karakteristisk ved de brede tre sidste Fodpar og ved det sidste Par Springfødders Grene, der ikke ere saa forlængede som brede. Arter af denne Slægt har jeg foruden fra Norge ogsaa faaet fra. den vestlige Del af Amerika og fra Afrikas Sydkyst; da den tillige findes i Middelhavet og i de nordlige Have, synes den saaledes at være meget udbredt.

\section{ELASMOPUS LATIPES, A. Boeck, 1870.}

(P1. XXIV. fig. 1.)

Elasmopus latipes, A. Boeck, Crust. amphip. bor. et arct. 1870. p. 132.

Oculi rotundati. Antennæ superiores articulo pedunculi 2do longitudinem $1 \mathrm{mi}$ xqvanti; 3tio longiore qvam dimidio 2do; flagello accessorio parvulo, 2articulato. Pedes 2di paris manu permagna, elongata, ovata; ungve parvo. Pedes 5ti paris articulo 1 mo parum modo longiore qvam lato; articulo 3tio apicem versus perlato, in angulo producto; articulo 4 to ferme eadem longitudine ac latitudine. Pedes $7 \mathrm{mi}$ paris iisdem 5 ti paris longiores et latiores. Pedes saltatorii ultimi paris ramo exteriore ovali, in margine exteriore dentibus duobus armato; ramo interiore in apice spinam gerenti. Appendix caudalis longiore qvam lata, ovata.

Længden er 8 mm.

Le gemet er temmelig langstrakt, uden Kjol eller Torne. Den bagre Rand paa Halens Led er ikke tandet eller bar noget Fremspring, men den nedre Rand har enkelte Borster. Sidepladerne ere middelmaadig store $0 \mathrm{~g}$ afrundede paa den undre Rand. Hovedet er længere end det forste Legemsled og danner en kort Vinkel mellem de øvre og nedre Følere. Øinene ere runde.

De øvre Følere naa, naar de bøies bagud, omtrent til det forste Haleled. Shaftet er forlænget; det forste Led er omtrent saa langt som Hovedet; ret andet er omtrent af den samme Lxngde, lidt kortere og smalere; det tredie er noget langere end Halvdelen af det andet Leds Længde. Svoben er kortere end Skaftet og dannes af mange, meget korte Led. Bisvøben er meget liden og har 2 tynde Led.

De nedre Folere ere meget kortere end de ovre; det tredie Led er omtrent saa langt som bredt; det fjerde er omtrent saa langt som de gvre Foleres forste Led, men er meget tyndere end dette; det femte er kortere end det foregaaende Led. Svoben, der er længere end Skaftets sidste Led, dannes af 12 korte Led. 
Kindbakkernes Palper ere meget stærke; det tredie Led er krummet, bredest ved Roden og smalere opad, og er paa den indre Rand væbnet med en Rakke Torne.

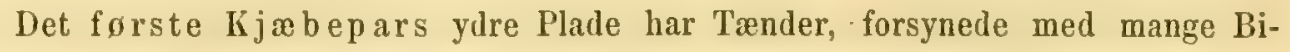
tsender; den indre Plade er liden, bred, med nogle fjærdannede Børster paa Enden.

Kjæbefoddernes ydre Plade har paa den indre Rand en Rækie Tænder, der mod Pladens Ende blive længere og mere krumme; den indre Plade er forlænget.

Det første Fodpar er kort; det fjerde Led er paa den bagre, noget udvidede Rand forsynet med mange Børsteknipper; det femte Led er forlænget, med en skraa afskaaret Griberand. Kloen er kort.

Det andet Fodpar er meget større end det første; det fjerde Led er meget kort, med en noget forlænget nedre, bagre Vinkel; Haanden er forlænget ægdannet, med Knipper af Børster paa den bagre Rand. Kloen er omtrent saa lang som Halvdelen af det sidste Led og noget krummet.

Det tredie og fjerde Fodpar ere forlængede; det tredie Led er noget udvidet nedad; det fjerde er lidt kortere end det femte Led, og begge ere paa den bagre Rand besatte med korte Torne. Kloen er kort.

De tre følgende Fodpar ere meget brede; det forste Led er længere end bredt, af en nxsten firkantet Form, med afrundede Vinkler; det tredie er paa det femte Fodpar noget længere end bredt, men paa det syvende ligesaa bredt som langt, baade den forreste og bagre nedre Vinkel er udvidet, og Randene ere forsynede med Torneknipper; det fjerde Led er meget kortere, medens det femte er forlænget, smalt. Det syvende Fodpar er længere og bredere end det femte Par. Kloen er kort og stærk.

De tvende første Par Springfødder naa næsten lige langt bagud; Grenene ere lige lange, samt væbnede med Torne paa Randen og i Spidsen.

Det sids te Par naar laengst bagud; Grenene ere omtrent af den samme Længde som Grundleddet og ere meget brede; den ydre har tvende Torne paa den ydre Rand; den indre har en lignende i Spidsen.

Halevedhæuget er kløvet til Roden; Fligerne ere afrundede og paa den ydre Rand nær Enden væbnede med en Torn.

Denne Art staar nær den af Spence Bate opstillede Megamera brevicaudata, men adskiller sig let fra denne, foruden ved Folernes forskjellige Form, tillige ved de tre bagre Fodpars forskjellige Udseende og ved at Halens Led mangle de Fremspring, der ere saa tydelige hos $\boldsymbol{M}$. brevicaudata.

Et eneste Exemplar af denne Art fandtes i vort Museum, kun med Angivelse, at det var fra Christianiafjorden. 
Gen. VI. CHEIROCRATUS, Norman, 1865.

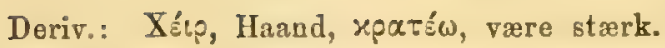

Syn.: 1865. ? Cheirocratus, Norman, Trans. Nat. Hist. Soc. Northumberland and Durham. Vol. I. p. 12.

1868. - Spence Bate and Westwood, Brit. sessile-eyed Crust. II. App. p. 513.

1870. - A. Boeck, Crust. amphip. bor. et arct. p. 133.

Type: Gammarus assimilis, Lilljeborg.

Mandibulæe articulo palpi 3tio longo, attamen breviore qvam 2do.

Maxillæ $1 \mathrm{mi}$ paris lamina interiore lata, sed non perlonga, in margine setis compluribus plumosis instructa.

Corpus elongatum; epimeris parvis.

Oculi parvi, rotundati.

Segmenta postabdominis posteriora dentibus armata.

Antennæ superiores inferioribus multo breviores; pedunculo longitudinis mediocris.

Pedes 1 mi paris manu debili, vix subcheliformi.

Pedes 2di paris manu majore qram 1mi paris, subcheliformi; manu apud marem permagno et multo majore qvam apud feminam.

Pedes saltatorii ultimi paris prælongati; ramis lanceolatis, invicem longitudine fere æqualibus.

Appendix caudalis profunde fissa.

Den af Lilljeborg i 1851 opstillede Gammarus assimilis blev af Norman i 1864 opført under Navnet Cheirocratus Mantis. Gammarus Sundevalli, som staar den nærmest, blev af Spence Bate og Westwood i 1863 henfort til Slægten Lilljeborgia under Artsnavnet $L$. Shictlandica. Begge Arter maa dog henføres til den samme Slægt, hvorhen ogsaa G. Pugetensis, Dana, maa høre hjemme. Fra Slægterne Melita og Mfera samt Elasmopus skiller den sig let ved de korte øvre Følere, der ere kortere end de nedre Foleres skaft, medens den ligner MLera ved springfoddernes forlangede Grene, og $\mathbf{M r}$ lita ved at de tvende sidste Haleled have Tænder paa den bagre Rand. Sidepladerne ere større end hos Mlara, men mindre end hos Melita. Det er ogsaa eiendommeligt ved denne Slægt, at det forste Fodpars Haand er saa svagt bygget og neppe indrettet som Griberedskab. I Munddelenes Bygning stemmer den i de fleste Henseender overeens med Slægten Gammarus. 


\section{CHEIROCRATUS SUNDEVALLI, Rathke, 1843.}

(PI. XXIV. fig. 2.)

Gammarus Sundevalli, Rathke, Acta Acad. Leop. 1843. T. XX. p. 65. t. III. fig. 2.

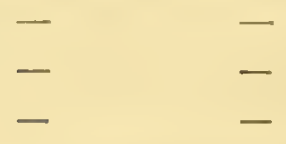

Lilljeborg, Kgl. Vet.-Akad. Handl. 1853. p. 454.

Bruzelius, Skand. Amphip. Gamm. 1859. p. 57.

Spence Bate, Catal. Amphip. Crust. Brit. Mus. 1862. p. 213. pl. XXXVIII. fig. 1 .

Lilljeborgia Shetlandica, Spence Bate and Westwood, Brit. sessile-ejed Crust. 1863. p. 206.

Norman, Rep. on the Shetland Crust. 1868. p. 279.

Cheirocratus Sundevalli, A. Boeck, Crust. amphip. bor. tt aret. 1870. p. 133.

Segmentum postabdominis $4 \mathrm{tum}$ et $5 \mathrm{tum}$ in medio margine posteriore dentibus aculis binis aut ternis armata; segmentum 6tum spinis nonnullis instructum; segmentum 3tium angulo inferiore posteriore acuminato. Antenne superiores pedunculo inferiorum breviores aut parum modo longiores. Pedes $1 \mathrm{mi}$ paris manu oblonga, ovali, angusla, longitudinem carpi aqvanti. Pedes 2 di paris manu apud marem permagna, oblonga, ovata, pilosa, in margine inferiore posteriore dentibus ferme destituta, apud feminam multo minore.

Længden er $S-10^{\mathrm{mm}}$.

Legemet er sammentrylit fra Siderne; Ryggen er rund, uden Kjøl; det tredie Haleleds nedre, bagre Vinkel gaar ud i en Spids; det fjerde og femte Haleled have paa Midten af den bagre Rand 2-3 spidse Tænder; det sjette er forsynet med nogle Torne; Sidepladerne ere af middelmaadig Storrelse. Hovedet er kortere end de tvende forste Legemsled tilsammen.

De ovre Folere ere meget korte, omtrent saa lange som de nedres Skaft, og naa, naar de bøies bagud, til det femte Legemsled. Skaftets andet Led er af den samme Langde som det første, men meget smalere; det tredie er meget kort. Svøben er kortere ved Skaftet og dannes af 18 Led. Bisvoben er meget kort og har 3 Led.

De nedre Følere ere nasten dobbelt saa lange som de ovre. Skaftets andet Led, der er meget liort, udsender en stor Lugteknude; det tredie er længere og har en kort Torn paa Enden af den nedre Rand; det femte er af den samme Længde som det fjerde Led, men er smalere end dette.

Kindbakkerne ere kraftige, kløvede og tandede i Spidsen; Tornerækken er stark; Palpens andet Led er liun lidt længere end det tredie, der er besat med mange Borster.

Det første Kjabepars ydre Plade har paa Enden lange, gaffeldannede Torne; den indre Plade er særdeles bred og besat med lange, fjærdannede Børster paa Randen. Palpens andet Led er forlænget, smalt ved Roden og med Torne paa den brede, ydre Ende. 
Det andet $\mathrm{Kj}$ æbepar er kraftigt og forlænget; den indre Plade har, foruden den sædvanlige Besætning paa Enden og den indre Rand, tillige en skraa Række Børster paa den indre Flade.

Kjæbeføddernes ydre Plade er lang, krummet og har mange Tænder paa den indre Raid; den indre Plade er særdeles stærk. Palpen er meget forlænget, smal.

Det første Fodpar er forlænget, smalt, og Haanden er ikke indrettet til Griberedskab. Det første Led er det langste; det fjerde er længere end det femte, og begge ere paa Randene forsynede med mange Bursteknipper. Kloen er kort, ubetydelig krummet.

Det andet Fodpar er særdeles stort; det første Led er meget stærkt og bredt; det fjerde er triangulært; Haanden er meget lang, ægdannet og har Torne paa den bagre Rand. Kloen har kun Halvdelen af Haandens Længde og lægger sig mod Griberandens indre Side. Hos Hunnen er dette Fodpar mindre.

Det tredie og fjerde Fodpar ere forlangede, smale; det femte Led er længere end det fjerde, men kortere end det tredie Led.

De tre følgende Fodpar ere forlingede, smale; det forste Led ere omtrent tre Gange saa langt som bredt, saugtakket paa den bagre Rand; det tredie er kortere end dette $\mathrm{og}$ kun ubetydelig udvidet; det fjerde er omtrent af den samme Lxngde, eller noget langere; det femte Led er noget kortere $\mathrm{og}$ smalere, forsynet med en ret, kort Klo.

Det første Par Springfødders Grene ere cylindriske, lige lange og forsynede med mange Torne.

Det andet $\mathrm{Pars}$ ydre Gren er kun lidt kortere end den indre, og det naar ikke saa langt bagud som det forste Par.

Det sidste Par er særdeles langt; Grenene, der ere langere end Skaftet, ere lancetdannede og have stærke Torne.

Halevedhrenget er delt til Roden; Fligerne ere korte og i Spidsen forsynede med en Tand og en Torn.

Farven er gulagtig, spættet med Rødbrunt; en større rødbrun Flek sees paa hvert af Legemsleddene. De øvre Føleres Skaft er rødbrunt. Paa de nedre Følere og Fodparrene sees brede, rodbrune Ringe. Øinene ere smukt violette.

Herhen horer vistnok ogsaa Protomedeia Whitei, Spence Bate, hvilken Norman anser for at være Hunnen af $L$. Shetlandica.

Denne Art forekommer efter Rathke ved Molde og er af Danielssen taget ved Christiansund og Molde paa 5-10 Favne. Ved Haugesund har jeg fundet den paa 60 Favnes Dybde, og G. 0. Sars ved Hvidingsøerne paa $80 \mathrm{og}$ ved Skraaven paa 10 -20 Favne. Efter Bruzelius findes den ved Bohuslen. 


\section{CHEIROCRATUS ASSIMILIS, Lilljeborg, 1851.}

(Pl. XXIV. fig. 3.)

Gammarus assimilis, Lilljeborg, Öfv. af Kgl. Vet.-Akad. Förh. 1851. p. 23. Kgl. Vet.Akad. Handl. 1853. p. 445.

$\begin{array}{lll}- & - & \text { Bruzelius, Skand. Amphip. Gamm. 1859. p. } 58 . \\ - & - & \text { Spence Bate, Catal. Amphip. Crust. Brit. Mus. 1862. p. 214. }\end{array}$

Cheirocratus Mantis, Norman, Trans. Nat. Hist. Soc. Northumberland and Durham. 1865. Vol. I. p. 12.

- $\quad$ - Spence.Bate and Westwood, Brit. sessile-eyed Crust. 1868. II. App. p. 513.

Cheirocratus assimilis, A. Boeck, Crust. amphip. bor. et arct. 1870. p. 134.

- Pedes 2di paris manu apud marem elongata, fere rectangulari, in acie obliqve truncata et dentibus obtusis 3 armata. Cæteroqvin ferme ut apud speciem præcedentem.

Længden er $9-10^{\mathrm{mm}}$.

Denne Art ligner meget den foregaaende i Le gemets Form.

De $ø v r e$ Følere ere lidt længere end de nedres Skaft. Svøben dannes af 22, Bisvoben af 2 Led.

De nedre Føleres Svøbe dannes af 30-35 Led.

Det første Fodpars Haand er lidt kortere end det foregaaende Led, forlanget oval, lidt bøiet og paa begge Rande, isier paa den bagre, forsynet med lange Børster.

Det andet Fodpars første Led er langt og bliver bredere nedad og bagtil; det fjerde Led er kort, triangulært; Haanden er mere end tre Gange saa lang, forlænget smal, med en meget skraa afskaaret Griberand, der er væbnet med 3-4 kraftige, stumpe Tænder; af disse er den nærmest Griberandens Ende kløvet, og i denne Fordybning optages Kloen; mellem denne Tand og Kloens Rod sees en tredie; mere afrundet Tand. Kloen er stærk og krum.

Det tredie og fjerde Fodpars forste Led er omtrent saa langt som det tredie og fjerde Led tilsammen. Kloen er kun svagt krummet.

Denne.Art er taget af v. Düben ved Christiansund og af mig ved Mandal, af Bruzelius ved Bohuslen. Ved Englands Kyster forekommer den ifølge Norman.

Gen. VII. GAMMARACANTHUS, Spence Bate, 1862.

Syn.: 1862. Gammaracanthus, Spence Bate, Catal. Amphip. Crust. Brit. Mus. p. 201. 1868. - G. O. Sars, Hist. nat. d. Crust. d'eau douce de Norvège. p. 73 .

1870. - A. Boeck, Crust. amphip. bor. et arct. p. 134. 
IIandibulæ articulo palpi 3tio longiore qvam 2do. mosis instructa.

Ilaxillæ 1 mi paris lamina interiore parva, in apice setis compluribus plu-

Maxillæ 2di paris laminis perbrevibus et perlatis.

Pedes maxillares lamina exteriore brevi, vix ad dimidium articuli palpi 2 dum elongatum porrecla.

Corpus elongatum, angustum; epimeris parvis, rigidis; dorso carinato; carina in extremo margine posteriore segmentorum trunci ultimorum et postabdominis qvinqve anteriorum in dintes retroversos desinenti.

Antenne superiores inferioribus longiores; pedunculo mediocriter elongato.

Pedes 1 mi et 2 di paris invicem eadem forma, sed pedes 1 mi paris paulo majores qvam 2di paris.

Pedes parium reliqvorum sat elongati; pedes $7 \mathrm{mi}$ paris iisdem 6ti paris breviores.

Pedes saltatorii ultimi paris elongati; ramis foliaceis invicem fere eadem longitudine, in margine setosis.

Appendix caudalis sat brevis, usque ad basin fissa.

Denne af Spence Bate i 1862 opstillede Slægt paa Gammarus loricatus, Sabine, er atter optaget af G. O. Sars i 1867 og af mig i $18 \% 0$. Spence Bate nævner i sin Karakter af Slægten, at Kjæbefødderne ere subpediforme, og at den indre sqvamiforme Plade kun er lidet udviklet. Det er ikke den indre, men den ydre Plade, der er saa lidet udviklet, hvilket Sars allerede har fremhævet. Palpen derimod er meget forlænget. Det tredie Led paa Kindbakkernes Palpe er ikke meget bredt, men derimod længere end det andet. Det forste Kjæbepars indre Plade er liden og oval, med ikke mange fjærdannede Børster paa Enden. Det andet Kjæbepars Plader ere temmelig smaa og se derfor meget brede ud. I det Ydre er Formen meget karakteristisk ved den KjøI, der strækker sig langs det hele Legeme, og som paa Enden af de fleste Led gaar ud i stærke Tænder. Sidepladerne ere ikke store, men stive. Det forste Fodpars Haand er storre end den samme paa det andet Par, og medens det i Regelen er Tilficldet, at de tre bagre Fodpar tiltage efter hverandre i Længde, er her det syvende meget mindre end de tvende foregaaende Par. Det andet Par Springfødder er meget forkortet, hvilket ogsaa er Tilfældet hos Slægten Pallasea. Det sidste Par Springfødders Grene ere store, lige lange, Halevedhænget er lidet, kløvet til Roden. 


\section{GAMMARACANTHUS LORICATUS, Sabine, 1824.}

Gammarus loricatus, Sabine, Suppl. to the App. of Parrys first voy. 1824. p. 231. pl. 1. fig. 7 .

\begin{tabular}{|c|c|c|}
\hline 一 & - & Ross, App. to Parrys third voy. p. 118. Polar voy. p. 2 \\
\hline - & - & $\begin{array}{r}\text { Krøyer, Grønlands Amphip. Danske Vid. Selsk. Afh. } 1 \\
\text { 250. t. 1. fig. 4. Nat. Tidsskr. 1. R. II. p. } 258 .\end{array}$ \\
\hline & - & Milne-Edwards, Hist. d. Crust. 1840. III. p. 52. \\
\hline & - & Bell, Belchers last of the arct. voy. App. 1855. p. 4 \\
\hline & - & Lovén, Öfv. af Kgl. Vet.-Akad. Förh. 1861. p. 287. \\
\hline & - & aris Spetsb. p. 15. \\
\hline
\end{tabular}

Gammaracanthus loricatus, Spence Bate, Catal. Amphip. Crust. Brit. Mus. 1862. p. 202. pl. XXXVI. fig. 2.

A. Boeck, Crust. amphip. bor. et arct. 1870. p. 135.

Dorsum carinatum. Segmenta trunci quinqve posteriora et segmenta postabdominis qvinqve anteriora carina in margine posteriore in dentes acutos desinenti. Caput rostro frontali longo, acuminato, instructum. Pedes 1 mi paris manu ovala, permagna, in acie spinis tenuibus instructa; carpo in angulo inferiore posteriore in processum parvum producto. Pedes 2 di paris manu ferme ut apud pedes $1 \mathrm{mi}$ paris. Pedes 5 ti et 6 ti paris articulo 1 mo sat angusto; articulo 3 tio breviore qvam 5 to et multo breviore qvam 4 to. Pedes 7 mi paris articulo 1 mo longiore el latiore; arliculis cateris brevioribus qvam apud pedes 5ti et 6ti paris. Pedes saltatorii ultimi paris ramis invicem ferme eadem longitudine et in margine interiore setis plumosis instructis. Appendix caudalis laciniis fere eadem latitudine ac longitudine.

Længden er omtrent $40 \mathrm{~mm}$.

Legemet er ikke meget stærlit sammentrylit; Ryggens Midtlinie indtages af en Kjol, der strækker sig lige fra Hovedet til Enden af det femte Haleled; den bliver efterhaanden høiere og er høiest paa det sidste Legemsled og de tvende første Haleled. Paa de fem sidste Legemsled og de fem forste Haleled danner denne Kjol bagudrettede Tænder. Legemsleddenes nedre Rand er fortykket og noget udadbøiet, hvorved der fremkommer en tværsgaaende Kjol; det syvende Led har tvende saadanne Kjole, den ene ovenfor den anden. De fire forste Haleled have ligeledes tværsgaaende Kjole paa Siden af hvert Led. De tre første Haleleds nedre, bagre Vinkel er tilspidset, og herfra strækker sig skraat opad en Kjol. De fire første Sideplader ere smaa, neppe dobbelt saa hoie som brede, og afrundede paa den nedre Rand; paa den ydre Flade sees en svag Kjøl nærmere den bagre end den forreste Rand. Den femte Sideplades forreste, nedre Vinkel er noget udtrukket; den sjettes bagre, nedre Vinkel er noget forlænget, 
ligesom ogsaa den forreste nedre, men i mindre Grad. Hovedet, der er lidt længere end det forste Legemsled, har ogsaa en langsgaaende skarp Kjol og gaar fortil, mellem de ovre Følere, ud i et langt, krummet, tilspidset Pandehorn; dets Sidevinkler ere afrundede, og dets nedre, forreste Vinkel gaar frem i en lang, noget udadboiet Spids. Øinene ere store, fremstäaende, halvmaaneformede.

De øvre Følere naa, naar de bøies bagud, omtrent til det første. Haleled. Skaftets forste Leil er lidt langere end Hovedet, og de tvende folgende aftage saavel i Langde som i Tykkelse, saa at det sidste er omtrent tre Gange saa langt som tykt, Svoben er lidt langere end Skaftet og dannes af omtrent 25 Led. Bisvøben har 3 Led.

De nedre Følere ere kortere end de øvre. Skaftet er longere end paa de øre; det forste Led er meget stærkt opsvulmet; det andet udsender en stærk Lugteknude; det tredie er omtrent saa langt som tykt; det fjerde er omtrent saa langt som de øvre Foleres andet Skaftled, men er meget tyndere; det femte er af den samme Længde som det foregaaende Led. Svaben er længere end Skaftets sidste Led og dannes af 16 Led.

Overlæben er meget stor, bred, afrundet paa den nedre Ende.

Kindbakkerne ere meget kraftige; Gribedelen er indskaaret i fem dybe Trender og den indre Bigren i fire lignende; Tornerækken dannes af mange fjærdannede Torne og kortere fjærdannede-Børster; Tyggeknuden er fremstaaende og er omgivet af et ikke afbrudt Gjærde af Tænder. Palpens tredie Led er smalt, længere end det andet og med fjærdannede Borster paa den øvre Rand og med nogle længere paa Enden.

Det første Kjæb epars ydre Plade har fem stærke Tænder, der paa den concave Rand har tvende Bitænder, samt fem længere lignende, men smalere; den indre Plade er liden og er besat med sex fjærdannede Borster. Palpen er ikke meget lang, væbnet paa begge Sider med forlængede tynde Torne.

Det andet Kjæbepars Plader ere særdeles smaa; den ydre er længere end den indre.

Kjæbefoddernes ydre Plade er liden og naar ikke længere frem end til den nedre Trediedel af Palpens andet Led samt har i Randen otte Tander; den indre Plade er ligeledes liden og har tre Tander paa Enden. Palpen er særdeles forlanget og sinal; det sidste Led er kloformet, med nogle Torne paa Enden.

Det forste Fodpar er meget stærkt, lidt større end det andet Par; det første Led er af en langagtig trekantet Form; det fjerde er meget kort, tyndt, og dets nedre, bagre Vinkel danner en meget kort, med Børster besat tynd Fremragning. Haanden er meget stor, xgdannet og omtrent saa lang som det første Led; Griberanden er skraa, noget bueformet indskaaret og har en Torn, hvor Kloens Spids legger sig til, samt forøvrigt fine Torne. Kloen er lang, meget krummet.

Det andet Fodpar er af den samme Form. Haanden er mere xgdannet, idet den bagre Rand staar pukkelformet frem. 
Det tredie og fjerde Fodpar ere meget tynde; det tredie Led er længere. end det fjerde, der er omtrent saa langt som det femte Led. Kloen er liden.

De tre følgende Fodpars første Led tiltage efter hverandre i Længde, ere smale, bredere ved Roden end ved den ydre Ende og med en skarp Kjøl langs Midten. Det syvende Par er kortere end de foregaaende; paa disse er det tredie Led betydelig kortere end det fjerde, der er længere end det femte Led. Det syvende Pars første Led er mere udvidet ved Roden og smalere ved Enden end paa det femte Par; det tredie Led er kun lidt kortere end det fjerde, der er omtrent saa langt som det femte Led.

$\mathrm{S} v ø \mathrm{mmef} ø$ d d erne ere strerke, lange, Grundleddet er cylindrisk.

Det forste Par Springfodders Grene ere omtrent lige lange, med smaa Torne, is æer paa den indre Rand.

Det andet $\mathrm{P}$ ar er kortere, men af den samme Form.

Det sidste Pars Grene ere flade, forlangede, lige lange, eller den ydre ubetydelig kortere end den indre, forsynede paa begge Rande med talrige Borster. Grundlesldet er kortere end Grenene.

Halevedhrnget dannes af tvende Flige, der begge ere omtrent saa lange som brede ved Roden, afrundede paa Enden og der besatte med nogle Børster.

Farven er graagul hvid, Fodparrene ere svagt lysgule.

Den er fundet ved Gronland og Spitsbergen af Krøyer og Malmgren samt i det hvide Hav.

Denne Art er tillige fundet af Malmgren i Finlands Indsøer, af Lovén i Wettern, af Widegren i Stora Le og af G. O. Sars i Mjosen.

Sars har beskrevet (1. c. p. 73) denne som en Varietet, G. Toricatus var. lacustris, og den skal efter ham ikke i Ferskvand opnaa den Størrelse som i dens Opholdssted i de arctiske Have

Gen. VIII. NIPHARGUS, Schiørlte, 1851.

Syn.: 1851. Niphargus, Schiødte, Acta Soc. Reg. Dan. p. 26. Trans. Ent. Soc. Lond. 2. ser. V. I. p. 149. Nat. Hist. Rev。 1857. I. p. 43.

1857. - While, Hist. Brit. Crust. p. 186.

1859. Eriopis, Bruzelius, Skand. Amphip. Gamm. p. 64.

1862. Niphargus, Spence Bate, Catal. Amphip. Crust. Brit. Mus. p. 174.

- Eriopis, Spence Bate, Catal. Amphip. Crust. BAt. Mus. p. 178.

1863. Niphargus, Spence Bate and Westwood, Brit. sessile-eyed Crust. p. 311.

1868. Eriopis, Norman, Ann. and Mag. of Nat. Hist. p. 414.

1870. Niphargus, A. Boeck, Crust. amphip. bor. et arct. p. 135.

Handibula articulo palpi 3tio longiore qvam 2do, angusto.

Maxille 1 mi paris lanina interiore ovata, magnitudinis mediocris, in margine interiore perselosa. 
Corpus prælongatum, angustum; epimeris sat parvis.

Antennæ superiores inferioribus multo longiores.

Pedes 2di paris manu majore qvam eadem 1 mi paris.

Pedes trium parium ultimorum longitudine gradatim crescentes.

Pedes saltatorii ultimi paris ramo interiore parvulo; ramo exteriore prælongato, 2articulato.

Appendix caudalis profunde fissa.

Bruzelius opstillede i 1859 Slægten Eriopis med en Art E. elongata, som adskiller sig fra de øvrige af Familien Gammaride, ved at Legemet kun er lidet sammentrykt, ved at Sidepladerne ere meget smaa, samt væsentlig ved at det sidste Par Springfordder har en eiendommelig Form, idet den indre Gren er rudimentær, medens den ydre er usædvanlig stor, næsten saa lang som alle Halens Led tilsammen og dannes af tvende tynde, ikke særdeles brede Led. Forøvrigt afviger den ikke meget fra Slægten Gammarus i Munddelenes Bygning. Jeg kan ikke finde, at denne Slægt i nogen væsentlig Henseende afviger fra slægten Niplargus, der er opstillet af Schiödte, og hvis Arter ere Ferskvandsdyr, om jeg end ikke har havt nogen af disse til Undersøgelse. Schiødtes Tegning af $N$. stygicus synes mig dog at være tilstrækkélig afgjørende til at forene disse heromhandlede Slægter. Hvorvidt Niphargus kunde falde sammen med Slægten Triura, kan jeg ikke afgjøre, da Tellkampfs Tegning er mindre heldig udført. I Munddelenes Form stemmer denne Slægt meget overeens med Slægten Gammarus, men i det Ydre skiller den sig let ved de mindre Sideplader og ved den overordentlig store Forlængelse af det sidste. Par Springfødders ydre Gren. Herved viser det sig iøinefaldende, at denne Gren oprindelig bestaar af tvende Led, hvilket allerede er antydet hos mange andre Slægter, ved at der paa Enden af denne Gren findes en stærk Torn.

\section{NIPHARGUS ELONGATUS, Bruzelius, 1859.}

(Pl. XX1r, fig. 5).

Eriopis elongatus, Bruzelius, Skand. Amphip. Gamm. 1859. p. 65.

Spence Bate, Catal. Amphip. Crust. Brit. Mus. 1862. p. 178. pl. XXXII. fig. 5.

- - Norman. Ann. and Mag. of Nat. Hist. 1868.p. 415.pl. XXI. fig. 7-10. Niphargus elongatus, A. Boeck, Crust. amphip. bor. et arct. 1870. p. 136.

Antennæ superiores longitudinem animalis æqvantes; articulo pedunculi 1 mo paulo breviore et crassiore qvam 2do; flagello accessorio minimo, 2articulato. Antennæ inferiores articulo pedunculi 4 to et 5 to invicem eadem longitudine. Caput rostro frontali destitutum, sed in angulo inferiore anteriore profunde incisum. Epi- 
mera multo latiora qvam alta. Pedes 1mi paris carpo longiore et angustiore qvam manu; hac apicem versus latiore et in acie obliqve truncata. Pedes 2 di paris manu elongata, ovata, in acie spinis et setis nonnullis instructa. Pedes trium parium ultimorum articulo 1 mo et longitudine et latitudine paulatim crescenti. Pedes saltatorii ultimi paris ramo interiore sat parvo, ovali; ramo exteriore longitudinem segmentorum postabdominis omnium junctorum fere æqvanti; segmento ultimo paulo breviore qvam segmento 1 mo. Appendix caudalis multo longior qvam lata, fere usque ad basin fissa; laciniis in apice setis nonnullis instructis.

Længden er omtrent $10^{\mathrm{mm}}$.

Legemet er forlænget, smalt; Ryggen er rund og glat. Sidepladerne ere meget smaa, bredere end høie. Hovedet er næsten saa langt som de tvende første Legemsled tilsammen; det danner intet egentligt Pandehorn mellem de ovre Folere, men har der kun en stump Knude.

De ørre Folere naa, naar de bøies bagud, hos Hunnen omtrent til Halens første Led, men ere hos Hannen lærigere end Legemet. Skaftets første Led er omtrent saa langt som Hovedet, noget bredere ved Roden end ved Enden, paa hvis undre Side er fæstet et Fremspring; det andet er omtrent af den samme Længde, men meget tyndere; det tredie Led er særdeles kort og kun lidt længere end Svgbens Led. Svgben er lidt længere end Skaftet $0 \mathrm{~g}$ dannes hos Hunnen af 25, hos Hannen af 36 Led, der ere meget længere end brede. Paa et Exemplar var den venstre Foler meget kortere end den høire. Bisvøben er rudimentær, 2leddet.

De nedre Folere ere meget kortere end de øvre. Skaftets forste Led er meget tykt; det andet udsender paa den undre Rand en lang Lugteknude; det tredie er mere end dobbelt saa langt som bredt; det fjerde og femte Led ere omtrent lige lange og af samme Længde som det forste Lerl paa de ørre Føleres Skaft, eller noget kortere end dette. Svøben er meget kortere end det sidste Led og synes at dannes af 3-4 Led.

Overlaben er oval.

Kindbakkerne ere delte i Spidsen, og Grenene ere tandede; Tyggeknuden er meget stor, rund. Palpen er tynd; dens andet og tredie Led ere omtrent lige lange.

Det forste Kjabepars ydre Plade er paa Enden væbnet med tandede Torne; den indre Plade er særdeles stor og bred samt forsynet med fjærdannede Børster. Palpen er toleddet; det første Led er meget kort.

Det andet Kjæbepars Plader ere besatte med lange Torne.

Kjæbeføddernes Palpe er forlænget, og begge Plader have lange, krumme, men tynde Torne, der paa Pladernes Ende gaa over til krumme, fjærdannede Børster.

Det forste Fodpar er mindre end det andet og forlænget; det fjerde Led er omtrent dobbelt saa langt som bredt, med mange Børster paa den bagre Rand; det 
femte Led eller Haanden er meget kortere, retvinklet trekantet, med den rette Vinkel paa den bagre Rand.

Det andet Fodpars Haand er forlanget oval, meget længere end det foregarende Led. Kloen er lang og krum.

Det tredie og fjerde Fodpar ere af eens Bygning; det tredie Led er meget kortere end det første, der er det længste, det fjerde er kortere end det foregaaende, og det femte er længere end det fjerde Led.

De tre $f \propto l g e n d e$ Fodpar tiltage efter hverandre i Langde og i Bredde af det første Led; dette er forlænget ovalt og Iængere end noget af de følgende; nærmest dette. i Langde er det tredie, hvorpaa de tvende sidste efter hinanden ere kortere.

Halens Svømmefødder ere forlwngede.

Det forste Par Springfødders ydre Gren er kun ubetydelig kortere end den indre og besat med nogle Torne paa Enden og paa den øvre Rand.

Uet andet Par har den samme Form, men er kortere.

Det sidste Pars Grundled er kort; den ydre Gren er overordentlig forlænget og toleddet, det ydre Led er noget kortere end det indre og forsynet med nogle Børster paa Enden, begge have. Torne paa begge Rande. Den indre Gren er liden, oval.

Halevedhænget er dobbelt og meget længere end bredt; Fligerne ere tilspidsede paa Enden og have nær Spidsen paa den ydre Rand en bevægelig Torn.

Denne Art er fundet af Bruzelius ved Bohuslen, af mig i Christianiafjorden, af Koren nær Bergen, overalt paa 40-80 Favnes Dybde. Ved Skraaven er den taget af G. O. Sars paa 2-300 Favne. Efter Norman findes den ved den engelske Kyst. Herhen hører vistnok ogsaa $G$. longicaudatıs, Costa, hvorpaa ogsaa Bruzelius har gjort opmærks om.

Gen. IX. AMATHILLA, Spence Bate and Westwood, 1863.

Syn.: 1837. Amathia, Rathke, Fauna d. Krym. Mém. Acad. St. Petersbourg IlI. p. 291. 1855. - Spence Bate, Brit. Ass. Rep. p. 58. Ann. Nat. Hist. 2. ser, XIX. 1857. p. 143.

185\% - - White, Pop. Hist. Brit. Crust. p. 182.

1860. - A. Boeck, Forh. ved de Skand. Naturf. 8 de Møde. p. 660.

1862. - Spence Bate, Catal. Amphip. Crust. Brit. Mus. p. 197.

1863. Amathilla, Spence Bate and Westwood, Brit. sessile-eyed Crust. p. 359. 1866. - Heller, Beitr. z. näh. Kenntn. d. Amphip. d. Adriat. Meeres. p. 35. 1870. - A. Boeck, Crust. amphip. bor. et arct. p. 136.

Mandibula palpo brevi, robusto; articulo palpi 3 tio curvato, eadem longiludine ac "2do. 
Naxillæ $1 \mathrm{mi}$ paris palpo in apice spinis longis armato; lamina interna elongata, ovata, in margine interiore setis plumosis instructa.

Pedes maxillares brevissimi et crassi; lamina exteriore perbrevi et lata, spinis gracilibus armata.

Corpus crassum; dorso lato, sæpe carinato; carina segmentorum posteriorum in spinas retroversas exeunti; epimeris parvis.

Antennæ invicem eadem longitudine; superiores pedunculo brevi, crasso.

Pedes $1 \mathrm{mi}$ et 2 di paris invicern ferme eadem forma, non pervalidi.

Pedes reliqui breves latique.

Pedes saltatorii ultimi paris neqve prælongati neqve ultra extremos pedes saltatorios $1 \mathrm{mi}$ et 2 di paris porrecti; ramis laminiformibus, in margine spinis armatis.

Appendix caudalis non fissa, in margine posteriore insinuata.

Rathke havde ved Krim fundet en Amphipode, som han kaldte Amathia carinata, og senere, i 1844, anførte han, at denne Art sant Gammarus Sabini og G. angulosus staa hverandre meget nær, ved at de gvre Følere ere korte, at Ryggen har en Kjøl, samt ved at Halevedhænget er heli. Han optog dog dengang ikke Slægtsnavnet, fordi dette allerede forhen var benyttet til en Decapode. Dette blev dog optaget af Spence Bate, men senere af ham og Westwood forandret til Amathilla. Dana forener denne Slægt med Gammarus. I Munddelenes Form stemmer denne Slægt i flere Henseender overeens med Slægten Gammarus, men Kindbakkernes Palpe er her meget stærkere og kortere, og Kjæbefoddernes ydre, ikke meget store Plader ere besatte med Torne, og ikke med Tænder.

AMATHILLA SABINI, Leach, 1819.

Gammarus Sabini, Edv. Sabine, App. to Parrys first voy. 1819-20.p. 238. t. 1. fig. 8-11.

- $\quad$ - Leach, App. to Ross's first voy. 1819. Octbr. edit. II. p. 178.

- $\quad$ - Ross, App. to Parrys third voy. p. 118. Polar voy. p. 204.

- - Owen, App. to Ross's sec. voy. 1835. p. 89.

- - White, Cat. Crust. Brit. Mus. 1847.

- Krøyer, Grønlands Amphip. D. Vid. Selsk. Afh. 1838. p. 16. t. 1. fig. 8-11. Nat. Tidsskr. 1. R. II. p. 257.

- - Milne-Edwards, Ann. d. sci. Nat. 1830. XX p. 368. Hist. d. Crust. 1840. III. p. 50 .

-. - Rathke, Acta Acad. Leop. 1843. XX. p. 71.

- - Frey u. Leuckart, Beitr. z. Kenntn. d. wirbeli. Thiere. 1847. p. 261.

- - Lilljeborg, Öfv. af Kgl. Vet-Akad. Förhandl. 1853. p. 447. 
Gammarus Sabini, Stimpson, Mar. Inv. Grand Manan. 1854. p. 54.

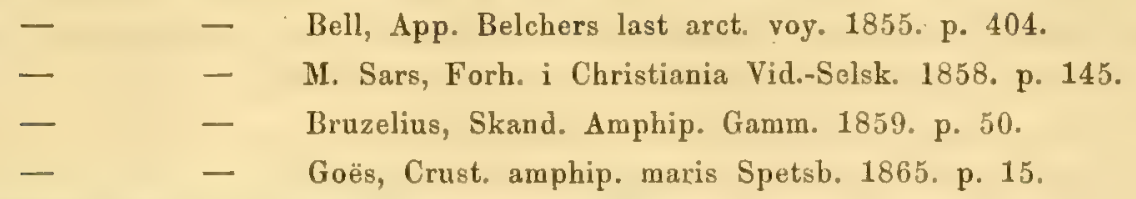

Amathia Sabini, Spence Bate, Catal. Amphip. Crust. Brit. Mus. 1862. p. 197.

- carinata, White, Hist. Brit. Crust. 1857. p. 182.

- - Spence Bate, Brit. Assoc. Rep. 1855. p. 58. Ann. Nat. Hist. 2. ser. XIX. 185\%. p. 143.

- carino-spinosa, White, Cat. Crust. Brit. Mus, 1847. Cat. Crust. Brit. Mus. 1850. p. 178.

Spence Bate, Catal. Amphip. Crust. Brit. Mus. 1862. p. 199. pl. XXXV. fig. 11.

Amathilla Sabini, Spence Bate and Westwood, Brit. sessile-eyed Crust. 1863. p. 361.

- - Norman, Rep. on the Shetland Crust. 1868. p. 284.

- $\quad$ - $\quad$ B. Boeck, Crust. amphip. bor. et arct. 1870. p. 136.

Amphithoü Moggridgei, Spence Bate, Ann. Nat. Hist. 1855. 2. ser. VII. p. 318. pl. $\mathrm{X}$. fig. 10 .

- - Gosse, Mar. Zool. 1855. p. 141.

- carino-spinosa, Gosse, Mar. Zool. 1855. p. 141.

Dexamine carino-spinosa, White, Cat. Crust. Brit. Mus. 1847. Cat. Brit. Mus. 1850. Hist. Brit. Crust. 1857. p. 178.

Cancer carino-spinosa, Turton, Linn. Syst. Nat. III. p. 760. (ifølge Spence Bate).

Oculi magni, fere reniformes. Dorsum carinatum. Segmenta trunci tria posteriora et segmentum postabdominis 1 mum et 2 dum carina postice dentes magnos formanti. Segmentum postabdominis 4 tum carina e transverso valde depressa. Segmentum postabdominis 3tium angulo inferiore posteriore perrotundato. Antenna invicem fere eadem longitudine; superiores articulo pedunculi 1 mo et 2 do longitudine requalibus, 1 mo vero crassiore; flagello accessorio ex articulis 7 composito. Pedes $1 \mathrm{mi}$ paris manu ferme eadem magnitudine ac eadem 2di paris; manu utriusqve paris ovata. Appendix caudalis in margine posteriore subtruncata, parum fissa.

Længden er $28^{\mathrm{mm}}$.

Legemet er ikke meget sammentrykt. Paa Ryggen strækker sig en Kjol langs alle Legemsleddene og Halens fire forste Led; paa det femte Legemsled danner den en bagudrettet Tand, der voxer efterhaunden paa de folgende Led og er størst paa det andet Haleled; paa det tredie er den mindre, og paa det fjerde findes ingen Tand, men kun en sadelformet Indsynkning tværs over den nævnte Kjøl. Paa det 
sidstnævnte Led sees ogsaa en Kjol paa liver Side af den midtre. Det tredie Haleleds nedre, bagre Vinkel er afrundet. Sidepladerne ere smaa; de fire forste ere dog noget høiere end brede og tiltage efter hverandre i Størrelse; den fjerde er bagtil kun lidt indskaaret for den femte, hvis nedre Rand danner tvende Lapper. Hovedet er lidt længere end det første Legemsled og danner fortil et lidet, ovalt, med Kjol forsynet Pandehorn mellem de ovre Folere; Sidevinklerne ere afskaarne. Øinene ere temmelig store, nyreformede.

De øvre Følere naa, naar de bøies bagud, til det femte eller sjette Legemsled. Skaftets forste Led er omtrent saa langt som Hovedet; de tvende folgende aftage i Længde og Tykkelse. Svøben, der er længere end Skaftet, dannes af 40-55 Led, hvoraf de første ere meget kortere, end brede, og besatte med fine, tæette Børster rundt Randen og med nogle længere langs den indre Side. Bisvøben har 6 forlængede, smale Led og er omtrent saa lang som Svobens forste 8-10 Led.

De nedre Følere ere omtrent af den samme Længde som de øvre. Skaftets første Led er tykt og udsender en kort Tand; det andet er kort; det tredie er knapt saa langt som tykt $\mathrm{og}$ har tvende Børstebundter paa Enden af den indre Side; det fjerde er meget længere og smalere; det femte er noget kortere og smalere end det foregaaende Led og naar frem til Enden af de øvre Føleres tredie Led. Svøben er ubetydelig længere end Skaftet og dannes af omtrent 40 Led, hvoraf de frrste ere meget korte og paa Enden omgivne af Krandse af fine Torne; medens de sidste ere mere langstrakte og smalere.

Overlæbens,ovre Del er af middelmaadig Storrelse, den nedre er temmelig høi, afrundet paa Enden.

Kindbakkerne ere kraftige, delte i Spidsen og meget tandede; Tyggehnuden er fremstaaende. Palpens tredie Led er meget langt, smalore mod Enden og er paa den concave Rand besat med talrige Borster.

Underlæben er temmelig bred, og dens indre Plader ere store.

Det forste Kjæbepars ydre Plade er stærk og bred, paa Enden skraa afskaaret og væbnet med fem kamdannede og ligesaa mange saugtakkede Tærnder; den indre Plade er forlænget smal, med 9-10 fjærdannede Børster paa den indre Rand. Palpen er i Spidsen paa den ene Side besat med fire Torne og paa den anden med ligesaa mange Tæunder.

Det andet Kjabepars Plader ere korte og smale, med talrige forlængede Borster paa Enden; den indre Plade har paa den ydre Side en sliraa Rakke langere; fjærdannede Borster.

Kjæbefødderne ere korte, brede; den ydre Plade naar kun frem til lidt over Midten af Palpens andet Led og har Torne paa den indre rette Rand, livilke morl Pladens Ende blive længere og gaa paa den ydre Rand over til krumme Børster; den indre Plade nar ikke frem til Enden af Palpens første Led. Palpens andet Led er særdeles bredt, det fjerde er stærkt kloformet. 
De tvende forste Fodpar ere omtrent af eens Bygning og Størrelse; Haanden er agdannet $\mathrm{g}$ har paa den bagre Rand mange Torne, hvoriblandt tvende meget stærke, hvor Kloens Spids lægger sig til. Kloen er kraftig og har nogle Børster paa den bagre Rand.

Det tredie og fjerde Fodpars tredie Led er ikke meget udvidet nedad og er længere end det fjerde, men kortere end det femte Led; de tre sidste Led ere paa den bagre Rand besatte med stærke Torne. Kloen er kort, men kraftig.

De tre følgende Fodpar tiltage efter hverandre lidt i Langde; deres første Led bliver efter hverandre langere; de øvrige Led ligne de tilsvarende hos de tvende foregaaende Fodpar.

Springfodderne naa omtrent lige langt bagud.

Det forste Pars ydre Gren er noget kortere end den indre, der er omtrent saa lang som Grundleddet, hvilket ligesom Grenene have stærke Torne paa begge Rande samt paa Enden.

Det andet Pars ydre Gren er lidt kortere end den indre.

Det sidste Pars ydre Gren er af den samme Langde som den indre, eller endog lidt længere; begge eré lancetdannede samt paa den ydre og tildels paa den indre Rand væbnede med Torne, hvorhos den indre ogsaa har Børster.

Halevedhænget er længere end bredt ved Roden, tvært afskaaret paa Enden, der er indbugtet og forsynet med nogle Torne.

Farven er livid med carmoisinrøde og gulbrune Aarer og Flekker.

Strøm gav først (Act. Hafn. X. 5, t. 2, fig. 1-8) en Beskrivelse af denne Art under Navnet Cancer macrourus articularis: „dorso carinato serrato, spinis caudx bifidis." Den blev i 1776 optaget af 0 . F. Müller, der gav den det grønlandske Navn Arksegiansoak.

Den forekommer almindelig ved Grønland og Spitsbergen ifølge Goës. Af M. Sars og Danielssen er den fundet ved Vadsø. Langs Kysten er den hyppig paa forskjellige Steder; den er saaledes taget af Danielssen ved Christiansund paa sandet Bund paa 10-20 Favne. Den er ligeledes fundet i Christianiafjorden og gaar efter Bruzelius ned til Bohuslen. Af Lilljeborg er den fundet ved Kullen paa 14-15 Favneśs Dybde. Den er ligeledes taget ved Nordamerikas Østkyst efter Stimpson, ved Baffinsbugten efter Leach, ved de engelske Kyster og efter Norman ved Shetland.

AMATHILLA ANGULOSA, Rathke, 1843.

Gammarus angulosus, Rathke, Acta Acad. Leop. XX. p. 72. t. III. fig. 3.

$\begin{array}{lll}- & - & \text { Frey u. Leuckart, Beitr. z. Kenntn. d. wirbell. Thiere. 1847. p. } 162 . \\ - & - & \text { Lilljeborg, Kgl. Vet.-Akad. Handl. 1853. p. 447. } \\ - & - & \text { Bruzelius, Skand. Amphip. Gamm. 1859. p. 51. }\end{array}$

Amathilla angulosa, A. Boeck, Crust. amphip. bor. et arct. 1870. p. 137. 
Oculi magni, fere ovales. Segmenta trunci anteriora angulata, posteriora. carinata; carina edentata, humili. Autemne superiores inferioribus paulo breviores; articulo pedunculi 1 mo longiore et crassiore qram 2do; articulis flagelli apicem versus latiorihus; flagello accessoria 5articulato. Appendix caudalis in margine posteriore sinuata et spinis duabus armata. Cateroqvin ferme ut apud speciem Sabini.

Liengden er $10-12^{\mathrm{mm}}$.

Legemet er af en robust, tyk, ikke meget sammentrykt, men dog høi Form Langs Ryggens Midte lober en stump Kjøl, der er svag paa det første Legemsled, men tiltager efterhanden i Størrelse, saa at den er tydelig fremtrædende paa de tre forste Haleled; den er ikke par noget Led forsynet med Tænder. Det tredie Haleleds nedre, bagre Vinkel er meget strerkt afrundet; over Midten paa det fjerde Led gaar en svag, sadelformet Indsynkning. Sidepladerne ere smaa. Hovedet er lidt langere end det første Legemsled. Panden danner fortil et kort, bredt Pandehorn. Øinene ere meget store, svagt nyreformede.

De ovre Folere ere korte og naa, naar de bojes bagud, omtrent til det femte Legernslerl. Skaftets første Led er omtrent dobbelt saa langt som tykit; de tvende følgende aftage meget i Lxngde. Svoben dannes af 13-15, mod Enden meget fortykkede, korte Led, der ere besatte med Lrrandse af korte Børster. Bisvoben har 5 Led.

De nedre Folere ere længere end de ovre. Skaftets tredie Led er meget kortere end tykt; de trende sidste ere omtrent lige lange. Svoben er læugere end Skaftet og dannes af $15-17$ Led, der ligne Leddene paa de ovre Følere.

Overlæben er i Spidsen afrundet og forsynet med fine Borster.

K ind bakkerne ere stærke, næsten triangulære; Gribedelen er bred, delt i 6-7 Tæuder; Ilen indre Bigren er ligeledes bred, væbnet med 4-5 Tænder; Tyggeknuden er fremstaaende, stork; Tornerækken dannes af fem, paa den concave Rand saugtakkede Torne og nogle korte, men stærkere fjærdannede Børster. Palpen er kort; temmelig bred; det tredie Led er omtrent saa langt som det andet og har paa den øvre Rand en Række fjærdannede Børster.

Underlæbens Flige ere meget brede, paa Enden afrundede og forsynede med Børster.

Det første $\mathrm{Kj}$ æbepar er meget stærkt; den ydre Plade er paa Enden skraa afskaaret og har tvende Rader stærke, krumme Torne, hvoraf den ene er saugtakket, den anden kamformet paa den indre Rand; den indre Plade er forlænget, xgdannet og tilspidset paa Enden, samt forsynet med mange fjærdannede Borster paa den indre Rand. Palpen er paa Enden afrundet; den høire har fem stærke Tænder, den venstre ligesaa mange forlængede Torne.

Det andet $\mathrm{Kj}$ æbepars Plader ere korte, ikke meget brede, med trende Rader Børster paa Enden; den indre har desuden nogle lange fjærdannede Børster paa den indre Rand. 
Kjæbefødderne ere korte og meget brede; den ydre Plade er næsten oval, den indre ret afskaarne Rand er besat med lange, tynde Torne, der paa Pladens Ende forlange sig til krumme Børster; den indre Plade har paa Enden korte Børster og Torne. Palpens andet Led er særieles bredt; det fjerde er kort, næsten kloformet.

De tvende forste Fodpar ere næesten af eens frorm og Storrelse; det fjerde Led er meget kort, lidt ulvidet, afrundet paa den nedre, bagre Vinkel og forsynet med lange, fjærdannede Børster. Haanden er forlænget ægdannet; Griberanden har korte, stærke Torne.

Det tredie og fjerde Fodpar have stærke Torne paa den bagre Rand; det tredie Led er kun lidet udvidet og langere end det fjerde, men kortere end det femte Led.

De tre folgende Fodpar tiltage efter hverandre i Læengde; det forste Led er meget bredt, saugtakket paa den bagre Rand.

De tvende forste Par Springfodders ydre Gren er lidt kortere end den indre; begge Grene samt Grundleddet ere paa begge Rande samt paa Enden væbnede med stærke Torne.

Det sidste Pars ydre Gren er lidt længere end den indre og ikke fuldt dobbelt saa lang som Grundleddet; begge have Torne paa Randene.

Halevedhænget er lidt længere end bredt ved Roden, indbugtet paa den ydre Ende, hvor der sees tvende Torne.

Farven er olivenbrun eller gronlig.

Den er fundet af Rathke ved Christiansund, af Danielssen sammesteds og ved Molde paa 10-20 Favnes Dybde, af G. O. Sars ved Hvidingsøerne paa 150 Favne, og findes efter Bruzelius ved Bohuslen, i hvis tijardand den undertiden sees i tallose Stimer.

AMATHILLA PINGVIS, Krøyer, 1838.

Gammarus pingvis, Krøyer, Gronlands Amphip. D. Vid. Selsk. Afh. 1838. p. 252. pl.

1. fig. 5. Nat. Tidssk. 1. R. II. p. 258.

- - Milne-Edwards, Hist. des Crust. 1840. III. p. 50.

Goës, Crust. amphip. maris Spctsb. 1865. p. 15.

Amathia pingvis, Spence Bate, Catal. Amphip. Crust. Brit. Mus. 1862. p. 200. Amathilla pingvis, A. Boeck, Crust. amphip. bor. et arct. 1870. p. 138.

Oculi reniformes. Dorsum non carinatum. Segmentum postabdominis 3tum angulo inferiore posteriore acuto et sursum produclo. Antennæ superiores inferioribus octava parte breviores; articulo pedunculi 1 mo longiore et crassiore qvam 2do. Pedes 1 mi et 2 di paris invicem ferme eadem forma et magnitudine, elongati et angusti; manu breviore qvam carpo, ter-quater longiore quam lata, in acic $52 *$ 
obliqve truncata, ungve parvo. Appendix caudalis duplo longior qvam ad basin lata, parva, in apice 3lobata et inter lobas spinula instructa.

Langden er $15^{\mathrm{mm}}$.

Legemet er forlænget, temmelig tykt, med en meget bred, afrundet Ryg; det andet Haleleds nedre, bagre Vinkel er tilspidset, og paa det tredie dannes her en opadbøiet Hage. Sidepladerne ere af en middelmaadig Størrelse, meget høiere end brede; den fjerde er den bredeste og er paa den bagre Rand dybt indskaret for den femte Sideplade, der er meget hredere end høi. Hovedet er tykt og saa langt som de tvende forste Legemsled tilsammen; dets forreste Rand danner et kort Pandehorn mellem de ovre Følere. Øinene ere nyredannede.

De øvre Føle're naa, naar de bøies bagud, omtrent til det femte Legemsled. Skaftet, der er kortere end Svøben, er ubetydelig langere end Hovedet; det forste Led er det længste og tykkeste; de tvende følgende aftage efter hinanden i Løngde og Tykkelse. Svøben dannes af omtrent 20 forlængede Led. Bisvøben, der naar til Enden af Svobens tredie Led, har 5-7 Led.

De nedre Følere ere længere end de øvre. Skaftets tvende første Led ere smaa, men vel adskilte; det tredie er knapt saa langt som bredt; det fjerde og femte Led ere lige lange, men det sidste er smalere. Svøben er meget længere end Skaftet.

Overlaben er meget stor, ikle delt paa Enden, og forsynet med Børster.

Kindbakkerne ere kraftige, med faa Tæender i Spidsen; den indre Bigren er forlænget $0 \mathrm{~g}$ har tre Tænder i Spidsen; Tornerækken dannes af mange, i Spidsen gaffelformede Torne; Tyggeknuden er ikke meget fremstaaende. Palpens andet Led er det langste.

Det $\mathrm{f} ø \mathrm{rste}$ Kjæbepars ydre Plade er ikke meget bred, med tornede Tænder paa Enden; den indre Plade er meget lang og har paa Enden tre Tænder og talrige fjordannede Børster. Palpen har i Spidsen smale Torne og nogle Børster.

Kjæbeføddernes ydre Plade har paa den indre Rand tætstaaende Tænder, der mod Pladens Ende forlænge sig og gaa paa den convexe Side over til lange, fjærdannede Børster. Palpens andet Led er kun lidt løngere og tykkere end det første, der er omtrent af den samme Længde, som det tredie Led. Kloen er kort og tyk.

De tvende forste Fodpar ere omtrent af eens Bygning og Storrelse, forlængede og smale; det fjerde Led er langt; Haanden er kortere, samt 3-4 Gange saa lang som bred, paa Enden skraa afskaaren. Kloen er liden.

Det tredie og fjercle Fodpar ere kraftige; det tredie Led er kun lidet udvidet; det fjerde er kortere; det femte er af den samme Længde som det tredie Led og har, strerke Torne paa den bagre Rand.

De tre følgende Fodpar tiltage efter hverandre kun ubetydelig i Længde; den forreste Rand er besat med Torne. Det forste Led er ovalt, forlænget i sin nedre, 
bagre Vinkel, der er afrundet; det tredie Led er omtrent saa langt som det femte, men dette er smalere; det fjerde Led er kortere.

Alle Springfodder naa omtrent lige langt bagud.

De tvende forste Pars ydre Gren er ubetydelig kortere end den indre, og begge have Torne paa Randene og i Spidsen.

Det sidste Pars Grene ere lige lange og neppe længere end Grundleddet, af en forlænget lancetformet Bygning, og ere paa den indre Rand besatte med Torne.

Halevedhxnget er omtrent dobbelt saa langt som bredt ved Roden, udelt, svagt trelappet paa den ydre Ende og med en liden Torn mellem Lapperne.

Denne Art er taget ved Julianehaab ved Grønland $\mathrm{g} g$ er ifølge Goës hyppig ved Spitsbergen paa 2-12 Favnes Dybde.

\section{Gen. X. MELPHIDIPP $\Lambda$, A. Boeck, 1870.}

Derivo: Melphidippa, Tjenestepige hos Plautus.

Syn.: 1870. Melphidippa, A. Boeck, Crust. amphip. bor. et arct. p. 138.

Mandibula palpo brevi atyve perangusto; articulo palpi 3 tio breviore gram 2 do.

Maxilla $1 \mathrm{mi}$ paris lamina interiore sat lata, non vero longa, in margine interiore selis compluribus plumosis instructa.

Pedes maxillares palpis angustis, elongatis; lamina exteriore brevi, lata, in margine interiore dentibus paucis, parvis armata.

Corpus elongatum, maxime postabdomen. Segmenta postabdominis in margine posteriore dentibus majoribus aut minoribus armata. Epimera sat parvula.

Intenar elongate, graciles; superiores et inferiores longitudine fere aqvales.

Pedes angusti, elongati; pedes $1 \mathrm{mi}$ et 2 di paris manu subcheliformi, parva; pedes trium parium ultimorum articulo 1 mo parum modo dilatato.

Pedes saltatorii ultimi paris ultra finem eorundem $1 \mathrm{mi}$ et 2 di paris longe producti.

Appendix caudalis elongata, plus minusve fissa.

Goës beskrev i 1865 en Gammanus spinosus fra Spitsbergen, som afviger meget fra de øvrige Gammarus-Arter i sin hele Legemsform og ved sine smaa Sideplader. Senere har jeg fundet tvende nye Arter, som staa Goës's Form meget nær, hvorfor jeg i 1870 ansaa det rigtigst at opstille disse tre Arter sammen under en ny Slægt, Melphidippa, der foruden ved den anforte Karakter ogsaa i Munddelenes Bygning adskiller sig fra de øvrige her omhandlede Slægter. Hos en af dem, $\boldsymbol{M}$. longipes, er Bisvoben paa de ovre Følere rudimentær, medens den er lang hos $\boldsymbol{M}$. borealis. Kindbakkernes Palpe er meget tynd hos denne Slogt, der dog i Sardeleshed afviger fra de fleste andre ved 
Kjæbefuldernes meget smaa Plader, medens Palpen er særdeles forlænget. Heri ligner den noget Slægten Gammaracanthus, hvorfra den dog adskiller sig ved, at det syvende Fodpar ikke er kortere, men ligesaa langt som det foregaaende. Det sidste Par Springfødder er meget forlænget, og Halevedhænget er mere eller mindre spaltet.

\section{MELPHIDIPPA LONGIPES, A. Boeck, 1870.}

(P1. XXIV. fig. 5.)

Me lphidippa longipes, A. Boeck, Crust. amphip. bor. et arct. 1870. p. 139.

Segmentum trunci ultimum et segmenta postabdominis qvinqve anteriora postice in medio in spinam producta; segmenta postabdominis qvatuor anteriora in margine posteriore serrata; flagello accessorio brevissimo, fere obsoleto. Pedes 2di paris articulo 3tio in angulo inferiore posteriore non producto; manu longissima el angusta. Pedes trium parium ultimorum angulo inferiore posteriore articuli $1 \mathrm{mi}$ non producto. Appendix caudalis ultra medium fissa: laciniis in apice rotundatis.

Længden er omtrent $4^{\mathrm{mm}}$ fra Pandehornet til Halevedhænget.

Legemets Form er meget forlænget, smal. Ryggen er uden Kjøl, men de sidste Legemsled og de fem forste Haleled gaa paa Midten af den bagre Rand ud i en Tand, og paa hver Side af denne er de fire forste Haleleds bagre Rand vabnet med mange smaa Torne; det fjerde Haleleds Tand er den største og har tvende mindre Tænder paa hver Side; det tredie Haleleds nedre, bagre Vinkel gaar ud i en Spids, og ovenfor denne sees fine Saugtakker paa-den bagre Rand. Sidepladerne ere ikike boiere end brede. Hovedet danner fortil, mellem de avre Folere, en stump Vinkel, men intet egentligt Pandehorn. Øinene ere store, ovale.

De øvre Følere ere meget forlængede, næsten saa lange som det hele Legeme; Skaftets forste Led er ubetydelig kortere end Hovedet og temmelig tykt; det andet er kortere og smalere; det tredie Led er meget kort. Svoben dannes af mere end 20 lange og smale Led. Bisvoben er rudimentær.

De nedre Folere ere kortere end de ovre. Skaftets tvende forste Led ere sammensmeltede; det tredie er kun noget langere end bredt; det fjerde er meget forlinget, smalt; det femte er kortere end, det foregaaende Led. Svoben, der er længere end Skaftets sidste Led, dannes af omtrent 10 forlængede, med Borstebundter forsynede Led.

Kindbakkerie ere meget stærke, klovede i Spidsen, og begge Grene ere tandede; Tornerækken dannes af mange, i Spidsen noget gaffelformede Torne; Tyggeknuden er meget fremstaaende. Palpens tredie Led er meget kortere end det andet og har tre fjærdannede Børster i Spidsen.

Det forste Kjæbepars ydre Plade er paa Enden væbnet med i Spidsen saugtakkede Torne; den indre Plade er bred, men kort og har fire fjærdannede Børster. 
Det andet $\mathrm{Kj} \rightsquigarrow b$ epar er af den sædvanlige Form.

Kjæbeføddernes ydre Plade er bred, men kort og har fem Tænder paa den indre Rand, hvilke mod Pladens Ende forlænge sig og blive mere krumme, samt desuden en krum, fjerdannet Borste. Palpen er forlanget, og dens sidste Led danner en Klo.

Det forste Fodpar er forlænget; det fjerde Led er bredt, men forlænget, smalere mod den ydre Ende, samt er paa den bagre Rand besat med mange fjærdannede Borster; det femte Led er forlænget ovalt og danner ingen egertlig Haand, skjønt den lange, noget krumme og i Spidsen med nogle Børster forsynede Klo er bevagelig.

Det andet Fodpar er længere, men smalere; det tredie Leds nedre, bagre Vinkel er afrundet; det femte er forlanget, kun lidt kortere end det fjerde Led, og begge have paa den bagre Rand Bundter af fjærdannede Børster. Kloen er kort og har nogle Børster i Spidsen.

Det tredie og fjerde Fodpar ere meget forlængede, smale; det tredie Led er omtrent saa langt som det forste, men smalere end dette; de tvende sidste Led aftage efter hinanden noget i Længde. Kloen er kort.

De tre følgende Fodpar ere meget forlængede; det forste Led er forlænget ovalt; det tredie er ikke udvidet i den nedre, bagre Vinkel, men længere end det forste Led.

De trende forste Par Springfodder naa omtrent lige langt bagud; den indre Gren er kortere og spadere end den ydre.

Det sidste Par er særdeles forlænget; Grenene ere lange og smale, omtrent af den samme Længde som Grundleddet.

Halevedhænget el ovalt, kløvet i de ydre Totrediedele.

Farven er gul, med gulrode store Flekker og lignende Baand paa den bagre Del af Legemet. Øinene ere hvide, med rode Lindser.

Den er fundet af G. O. Sars i Hardangerfjorden og ved Aalesund paa 80-100 Favne, af mig ved Haugesund og i Christianiafjorden paa omtrent den samme Dybde.

MELPHIDIPPA BOREALIS, A. Boeck, 1870.

(PI. XXIII. fig. 3.)

Ilelphidippa borealis, A. Boeck, Crust. amphip. bor. et arct. 1870. p. 139.

Segmentum postabdominis 3tium et 4 tum in medio dentibus ternis armata; segmenta duo anteriora in margine posteriore parum serrata. Antenna superiores arliculo pedunculi 2 do longiore qvam 1mo; flagello accessorio elongato, 3articulato. Pedes 2di paris articuli 3tio in spinam non prodnclo; manu elongata, ovali, fere eadem longitudine ac carpo. Pedes trium parium ultimorum angulo inferiore 
posteriore articuli 1 mi non producto. Appendix caudalis prælongala, usqve ad basin fissa.

Længden er $5 \mathrm{~mm}$.

Le gemet er forlænget, smalt; Legemsleddene ere meget smale og alle næsten af den samme Bredde. De tre forste-Haleled ere meget bredere, og deres nedre, bagre Vinkel er neppe udtrukket; de tvende forste Haleled ere ubetydelig saugtakkede paa Midten af den bagre Rand; det tredie og fjerde have her 2-3 Tænder. Sidepladerne ere smaa, ikke høiere end brede, og de fire forste neppe større end de følgende. $\mathrm{H}_{0}$ vedet er omtrent saa langt som de tvende forste Legemsled tilsammen og gaar fortil, mellem de øvre Følere, ud i et lidet Pandehorn; Sidevinklerne ere ikke udtrukne. Øine sees ikke.

De øvre Følere ere omtrent saa lange som Legemet. Skaftets første Led er kun lidt kortere end Hovedet; det andet er næsten dobbelt saa langt som det foregaaende; det tredie er af den samme Længde som det første Led, men smalere end dette. Svoben er meget længere end Skaftet og dannes af 16 forlængede Led. Bisvøben har 3 forlængede Led.

De nedre Fgleres tredie Slaftled er omtrent dobbelt saa langt som tykt; det fjerde er meget langt, og det femte længere end dette, men tyndere. Svoben er meget kort og dannes af omtrent 6 Led.

Kindbakkerne ere meget stærke, tandede i Spidsen og med en ligeledes stærk, med Tænder forsynet indre Bigren; Tornerækken dannes af otte Torne; Tyggeknuden er meget fremstaaende. Palpen er kort, smal; dens andet Led er lidt længere end det tredie.

Det andet $\mathrm{Kj}$ abepars indre Plade er meget bredere end den ydre.

Kijæbefoddernes ydre Plade nar frem kun til lidt over Midten af Palpens andet Led og er paa Enden væbnet med sex krumme Børster, der blive længere mod Pladens ydre Rand; den indre Plade er meget bred og har paa Enden tre Tæuder og nogle Børster. Palpen er smal og forlænget; det forste Led er kort; det tredie er meget kortere end det andet, og det fjerde Led er kloformet.

Det forste Fodpar er ikke meget stærkt; det tredie Led er kort; det fjerde er paa den bagre Rand nær Roden bredere end ved den ydre Ende og forsynet med Børsteknipper; det femte Led er forlænget, dobbelt saa langt som bredt, med en mere convex bagre end forreste Rand; begge ere besatte med mange Børsteknipper.

Det andet Fodpar er af den samme Bygning som det forste; det tredie Led danner intet Fremspring paa den nedre, bagre Vinkel; det fjerde Led er lidet udvidet paa den bagre Rand; Haanden er næsten af den samme Længde som det foregaaende Led.

Det tredie og fjerde Fodpar ere meget smale; det tredie Led er næsten 
ikke udvidet, langt og smalt; det fjerde er noget langere, men smalere; det femte Led er noget kortere. Kloen er kortere end det sidste Led, kun svagt boiet.

De tre folgende Fodpar tiltage efter hverandre kun lidt i Længde og ere af eens Bygning; det forste Led er kun lidet udvidet, spindelformet; det tredie er omtrent saa langt som det forste, men er meget smalere end dette samt længere end det fjerde Led; det femte er kortere end det foregaaende Led.

Springfødderne ere meget forlængede.

Det første Pars ydre Gren, der er omtrent saa lang som Grundleddet, er kortere end den indre.

Det andet Par er kortere; den ydre Gren er længere end den indre.

Det sidste Par naar langst bagud; Grenene ere næsten lige lange og omtrent saa lange som Grundleddet.

Halevedhænget er omtrent tre Gange saa langt som bredt ved Roden og spaltet næsten til denne. Fligerne ere indskaarne paa Enden 0 g have her en liden Torn.

Denne Art er taget af G. O. Sars ved Skraaven paa 200 Favnes Dybde og i Hardangerfjorden, ved Lyngholmen af mig paa 100 Favne og $\mathrm{i}$ Christianiafjorden paa samme Dybde.

MELPHIDIPPA SPINOSA, Goës, 1865.

(Pl. XXIII. fig. 4.)

Gammarus spinosus, Goës, Crust. amplip. maris Spetsb. 1865. p. 14. fig. 30. Melphidipp a spinosa, A. Boeck, Crust. amphip. bor. et aret. 1870. p. 139.

0culi rotundati. Segmenta postabdominis quinqve anteriora carinata et in medio dentibus singulis vel ternis armata; segmenta tria anteriora etiam in margine posteriore serrata. Antenna superiores articulo pedunculi 1 mo parum longiore qvam 2do; flagello accessorio brevissimo, 2-3articulato. Pedes 2di paris articulo 3tio in angulo inferiore posteriore in spinam producto; manu elongata, ovali. Pedes trium parium ultimorum angulo inferiore posteriore articuli $1 \mathrm{mi}$ producto. Appendix caudalis in exteriore terlia parte fissa; laciniis in apice bidentatis.

Længden er $4^{5} / 10^{\mathrm{mm}}$ til Roden af Halevedhænget.

Legemet er ikke meget sammentrykt, og Ryggen er rund, men Halens Led ere dog noget mere sammentrykte. De fem forste Haleled, der ere forsynede med en Kjol, have paa Midten af den bagre Rand Torne, der ere meget store, samt nogle mindre paa Siderne af disse; paa den nedre Del af den bagre Rand sees smaa Saugtakker og fine Børster; det tredie Haleleds nedre, bagre Vinkel er tilspidset. Sidepladerne ere smaa. Hovedet gaar fortil ud i et stumpt Pandehorn; dets nedre, forreste 
Vinkel er meget bred og gaar ud i et Fremspring, ved hvilket de store, ovale Øine have sin Plads.

De ovre Følere ere meget forlængede, smale og naa, naar de bøies bagud, til Halens andet eller tredie Led. Skaftet er temmelig kort; det første Led er omtrent saa langt som Hovedet; det andet er smalere og kortere; det tredie er meget lidet. Svgben er flere Gange saa lang som Skáftet og dannes af omtrent 20 meget lange og smale Led. Bisvoben er meget kort, 2-3leddet.

De nedre Følere ere omtrent af den samme Længde som de øvre. Skaftets tredie Led er meget kort; det fjerde er meget langt og smalt; det femte er meget kortere end det foregaaende Led. Svøben har omtrent 15 Led.

Kindbakkerne ere i Spidsen delte og tandede; Tornerækken og Tyggeknuden ere meget udviklede. Palpens tredie Led er lidt kortere end det andet.

Det forste $\mathrm{K} j \mathfrak{j}$ bepars indre Plade er særdeles bred og besat med mange fjærdannede Børster.

Kjabefoddernes Plader ere temmelig brede; den ydre har Trender paa den indre Rand.

Det forste Fodpars tredie Led er ikke meget udvidet, mere end dobbeit saa langt som bredt. Haanden er forlænget oval.

Det andet Fodpar er meget smalt; det tredie Leds nedre, bagre Vinkel er udtrukket $i$ et Fremspring. Haanden er længere end det fjerde Led.

Det tredie og fjerde Fodpar ere traadformede; det tredie og fjerde Led ere omtrent lige lange, medens det femte er kortere.

De tre folgende Fodpars forste Led er meget smalt, med en udtrukket nedre, bagre Vinkel.

De trende forste Par Springfødder naa omtrent lige langt bagud; den indre Gren er noget længere end den ydre.

Det sidste Par er særdeles forlinget; Grenene ere indbyrdes lige lange, cylindriske, længere end Grundleddet og besatte med Torne.

Halevedh a get er klovet i den ydre Trediedel; Fligerne, der ere indskaarne paa Enden, have nogle Torne langs den ydre Rand.

Den er efter Goës (paa hvis Tegning de ovre Foleres andet Led er læugere end det forste) fundet af Torell og Malmgren ved Spitsbergen paa 5 -30 Favnes Dybde. Af G. 0. Sars er den taget ved Brettesnæs paa 40 Favne og i Hardangerfjorden i eet Exemplar paa 80 Favne.

\section{Familia IU.}

LEUCOTHOID E, A. Boeck, 1871.

Labium superius in apice incisum.

Mandibula in apice plerumqve dilatatæe et dissimiles, plus minusve aut non dentali, tuberculo molari prominente aut nullo, palpo 3articulato, raro absenti. 
Maxillæ $1 \mathrm{mi}$ paris palpo 1- aut 2articulato.

Pedes maxillares laminis externis plus minusve latis, magnis aut parvis, interdum fere obsoletis; laminis internis sæpe elongatis, interdum latis, aut minimis, fere obsoletis; palpo sxpissime elongato, raro brevi, lato; articulo palpi ultimo raro non ungviformi, articulis duobus ultimis palpi interdum absentibus.

Corpus plerumgve crassum; epimera plus minusve magna, raro parva; epimera anteriora interdum crescentia.

Antennæ superiores flagello append ${ }_{\mathfrak{i}}$ culari instructæ aut destitutæ.

Pedes saltatorii sxepissime 2ramosi, raro ultimi paris ramo uno instructi.

Appendix caudalis integra vel divisa.

Til denne Familie har jeg henfort Underfamilierne Stegocephatince, Amphilochine, Stenothoina, Syrrhoince; Pardaliscine, Lencothoince og Iphimedince. Som det sees, har min i 1870 givne Opstilling lidt en viesentlig Forandring derved, at jeg har spaltet Familien Gammaridce og af denne dannet en ny Familie Lercothoide, væsentlig paa Grund af det Hensyn, jeg har taget til Munddelenes Bygning og Form.

\section{Subfamilia I.}

STEGOCEPHALINÆ, Dana, 1852.

Syn.: 1852. Stegocephalince, Dana, U. S. explor. exped. Crust. p. 907.

1862. Stegocephalides, Spence Bate, Catal. Amphip. Crust. Brit. Mus. p. 54.

1870. Stegocephalinæ, A. Boeck, Crust. amphip. bor. et arct. p. 47.

Hypostomum productum.

Labium superius latum, in apice fissum; laciniis longitudine dissimilibus.

Mandibula prælongatæ, tuberculo molari et palpis destitute, in apice latissimæ, valde aut parum dentata, utrobiqve dissimiles; mandibula sinistra processu accessorio instructa.

Labium inferius angustum, elongalum, laminis internis destitulum, sed in apice articulo appendiculari dentato instructum.

Maxillæ 1mi paris perlatæ; lamina exteriore in apice ungvibus validis sed simplicibus instructa; palpo 1 - aut 2articulato; lamina interiore perlata, valde setosa.

Maxillæ 2di paris lamina interiore latissima, exteriore angusta aut minima.

Pedes maxillares laminis perlatis; lamina exteriore dentibus invalidis instructa aut modo serrata; palpis gracilibus, angustis; articulo palpi ultimo ungviformi. 
Corpus peraltum, crassum vero. Epimera qvatuor anteriora magnitudine valde crescentia; epimerum $\mathbf{1 t u m}$ permagnum. Caput perbreve, altum vero.

Antennæ breves, sed robuste; superiores flagello appendiculari parvo instructa; articulo flagelli 1 mo elongato et crasso.

Pedes $1 \mathrm{mi}$ et $2 \mathrm{di}$ paris eadem ferme forma et magnitudine, vix subcheliformes.

Pedes 5ti et 6ti paris articulo 1 mo parum aui non dilatato.

Pedes $7 \mathrm{mi}$ paris pedibus præcedentibus breviores; articulo $1 \mathrm{mo}$ valde dilatato et elongato.

Pedes saltatorii omnes ramis duobus cylindricis instructi.

Appendix caudalis parvula, interdum paululum fissa.

Denne Underfamilie blev opstillet af Dana som den første Underfamilie under Gammarice og karakteriseres af ham paa folgende Maade: "Antennæ breves, superiores basi crassæ. Mandibulæ acie denticulata instructæ, palpo brevi, uniarticulato, intus dentato. Epimeræ permagnæ." Han henforer hertil kun een Slægt, Stegocephalus. Spence Bate optager den, men han finder, at Here Slægter bør tilføies, og karakteriserer den vasentlig ved Storrelsen af de tvende forste Sideplader, som kan indeslutte alle Dyrets Lemmer, naar det boier sig sammen. Til Stegocephalides henforer han saaledes, foruden den typiske Slægt, ogsaa Slægterne Montagua (Stenothoë), Danaia, Stenothoë, Pleustes. Disse Slagter deler han i tre Afdelinge̊r, eftersom de ovre Folere ere uden Bisvabe, Kindbakkerne uden Palpe og det sidste Par Springfødder eengrenet, (Montagua, Danaia og Stenothoë), eller de øve Folere ere uden Bisvobe, Kindbakkerne med Palpe og det sidste Par Springfodder togrenet (Pleustes), eller endelig de øvre Folere med en rudimentær Bisvøbe, Kindbakkerne uden Palpe og det sidste Par Springfødder togrenet (Stegocephalus). Jeg gaar tilbage til Dana's Inddeling og udelader de af Spence Bate tilforte-Sliegter, men tilføier derimod foruden den typiske Slægt en ny, Andania.

Hos denne Underfamilie ere Kindbakkerne ulige paa begge Sider, idet den ene har og den anden mangler den indre Bigren; hermed er ogsaa forbundet, at Overlæben i Spidsen ikke er afrundet, men spaltet. Dana anfører efter Krøyer, at Kindbakkerne ere forsynede med Palpe, hvilken den dog ikke har, og denne Karakter maa saaledes udlelades.

Gen. I. STEGOCEPHALUS, Kroyer, 1842.

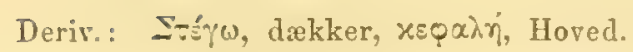

Syn.: 1842. Stegocephalus, Kroyer, Nat. Tidsskr. 1. R. IV. p. 150.

1852. - Dana, U. S. explor. exped. Crust. p. 908. 
Syn.: 1859. Stegocephalus, Bruzelius, Skand. Amphip. Gamm. p. 38.

1862. - Spenee Bate, Catal. Amphip. Crust. Brit. Mus. p. 63.

1865. - Lilljeborg, On the Lysianassa magellanica. p. 18.

- - Goës, Crust. amphip. maris Spetsb. p. 5.

1870. - A. Boeck, Crust. amphip. bor. et arct. p. 47.

Type: Cancer ampulla, Phipps.

Mandibula in apice dentibus multis, magnis armatæ; mala interiore mandibulte sinistræe item armata.

Maxilla $1 \mathrm{mi}$ paris palpo brevi, angusto, 1arliculato, ad finem laminæ exterioris porrecto.

Maxillæ 2di paris lamina exteriore angustissima, eadem longitudine aut longiore qvanı interiore.

Appendix caudalis mediocris longitudinis, in apice incisa.

I Krøyers Diagnose for denne Slægt anfores: „Mandibulæ palpo instructæ brevissimo, crasso, uniarticulato." Dette, der ogsaa anfores af Bruzelius, beror paa en Feiltagelse, hvilket allerede Spence Bate i 1862 har oplyst. Heller ikke er det fuldkommen rigtigt, naar han siger: "Pedes quinti paris pedibus tertii qvartiqve paris structura, et directione similes." Dana anfører i sin Slægtskarakter: "Epimeræ 4tæ maximæ, 5tis parvis. Antennæ superiores appendiculatæ. Peles $1 \mathrm{mi} 2$ di manibus carentes. Pedes 5ti 3tii 4tiqve directione similes."

\section{STEGOCEPHALUS AMPULLA, Phipps, 1774.}

Cancer ampulla, Phipps, Voy. toward the North Pole 1774. p. 191. tab. 12. fig. 2.

- Gammarellus ampulla, Herbst, Krabben u. Krebse. 1804. II. p. 156. pl. 35. fig. 1.

Gammarus ampulla, Fabricius, Entom. syst. 1794. II. p. 515.

-- $\quad$ - Latreille, Hist. Nat. d. Crust. VI. p. 318.

- $\quad$ - Sabine, Parrys first voy. (Suppl.) 1824. p. 229.

- $\quad$ - Ross, App. to Parrys Polar voy. 1828. p. 20.

- - Owen, App. to J. Ross's sec. voy. 1834. XXVIII.

Lysianas a ampulla, Milne-Edwards, Hist. d. Crust. 1840. III. p. 22

Stegocephalus influtus, Kroyer, Nat. Tidsskr. 1k42. 1. R. IV. p. 150. 1845. 2. R.

I. p. 522. Voy. en Scand. 1840. pl. 20. fig. ?.

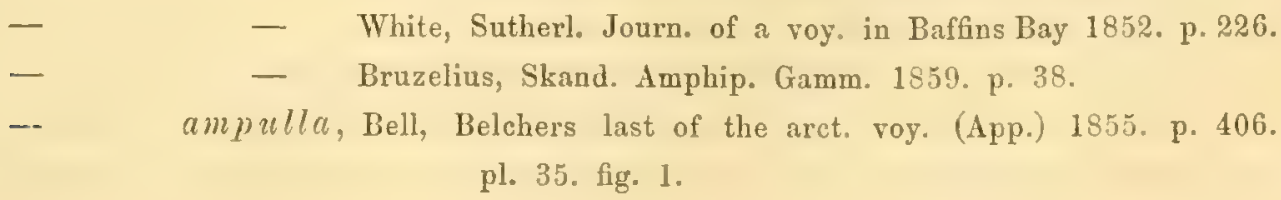


Stegocephalus ampulla, Spence Bate, Catal. Amphip. Crust. Brit. Mus. 1862. p. 63. pl. X. fig. 2 .

- $\quad$ Goës, Crust. amphip. maris Spetsb. 1865. p. 5. fig. S.9.
- $\quad$ Norman, Rep. on the Shetland Crust. 1868. p. 276.
- $\quad$ A. Boeck, Crust. amphip. bor. et arct. 1870. p. 48.

Antennæ superiores articulo flagelli 1 mo eadem longitudine ac crassitudine. Antennæ inferiores articulo pedunculi 5to longiore quam 4to. Pedes $1 \mathrm{mi}$ paris manu parum breviori qvam carpo. Pedes 6ti paris articulo 1mo dilatato; articulis duobus ultimis longitudine æqvalibus. Pedes $7 \mathrm{mi}$ paris angulo inferiore postico articuli $1 \mathrm{mi}$ fere recto, non producto. Appendix caudalis ad medium fissa.

\section{Læn gden er $19-222^{m m}$.}

Legemet er særdeles høit, sammentrykt; Ryggen er krummet, tyk og uden Kjøl og Tænder. De tre første Haleleds nedre, bagre Vinkel er uddragen til en kort Spids. Sidepladerne ere særdeles store; nedad danne de fem forste tilsammen en Bue, idet de fire første efter hverandre tiltage i Længde; den første er. næsten triangulær, nedad tilspidset; de tvende folgende ere langagtig firkantede, noget bøiede; den fjerde er meget stor, dens forreste, længere Rand er noget indbøiet, den nedre danner en stor Bue, der forlænger sig bagtil og opad, den bagre, kortere Rand er bueformet indskaaret for den femte Sideplade, hvorved der fremkommer Lighed med Formen af en Øxe. Hovedet er temmelig stort, dog skjult under den første Sideplade, og udsender fra sin forreste Rand mellem de gvre Folere et lidet Pandehorn.

De øvre Følere ere korte og tykke. Skaftets første Led er tykkere end det andet $0 \mathrm{~g}$ dobbelt saa langt som dette, hvilket sidste ogsaa har den dobbelte Lingde af det tredie Led. Svøben dannes af 10-12 Led. Bisvaben er meget kort, enlẹddet og paa Enden forsynet med Børster.

De nedre Følere ere lidt længere end de øvre, men meget tyndere. Skaftets tredie Led er meget kort; det fjerde er dobbelt saa langt; det femte er saa langt som de tvende foregaaende tilsammen, men meget tyndere end disse Led. Svoben er af den samme Længde som Skaftets tvende sidste Led og dannes af 16 Led.

Overlæben er spaltet paa Enden, og Fligerne ere ulige store.

Kindbakkerne ere forlængede; Gribedelen er bred, paa den ene Side er den indskaaret i færre (5) grove Tænder, og den indre Bigren mangler, paa den anden Side er den delt i talrige finere Tæender og har en meget bred indre Bigren, der ligeledes er delt $\mathrm{i}$ talrige Tænder. Palpen mangler.

Underlæbens Flige ere meget smale, paa Enden afrundede.

Det forste Kjæbepar er særdeles bredt; den ydre Plade er i Spidsen væbnet med stærke, krogdannede Torne; den indre Plade er meget bred og har paa den øvre 
skraa afskaarne Rand talrige fjærdannede Børster. Palpen er meget tynd, naar ikke længere frem end til den ydre Plades Ende og har i Spidsen fire krumme, tynde Torne.

Det andet $\mathrm{Kj}$ æb e pars ydre Plade er meget tynd, cylindrisk og er paa Enden besat med otte, i Spidșen krumme, tynde Torne; den indre Plade er særdeles bred $0 \mathrm{~g}$ har paa den indre Rand talrige fjærdannede Børster.

Kjabefødderne ere meget brede; den ydre Plade er meget stor, paa Enden og den indre Rand saugtakket og forsynet med fine Torne; den indre Plade er oval, halvt saa lang og med fjordannede Borster paa den indre Rand og paa Enden. Palpen er meget tynd; dens første Led er næsten saa langt som det andet; Kloen er meget kort.

Det forste Fodpar er temmelig stærkt, men kort; det fjerde Led er bredere mod den ydre Ende og lidt liengere end det femte, som er smalere mod Enden uden at danne nogen Griberand. Kloen er stærk, spids, fint saugtakket paa den bagre Rand.

Det andet Fodpar er længere og smalere, men af den samme Form som det første; det femte Led er lidt længere end det fjerde.

Det tredie og fjerde fodpars tredie Led er saa langt som det fjerde og lidt længere end det femte Led.

Det femte Fodpars forste Led er ikke udvidet, men smalt; det tredie er saa langt som det fjerde og lidt længere end det femte Led.

Paa de treude folgende Fodpar er det sjette Fodpars første Led bredere; paa det syvende Par er dette Leds nedre, bagre Vinkel nasten ret, og den bagre Rand er saugtakket, det fjerde og femte Led have den samme Længde.

Springføddernes Grene naa alle lige langt bagud og ere paa hvert Par lige lange, tlade og uden Torne.

Halevedhanget er ikke fuldt dobbelt saa langt sóm bredt ved Roden, tilspidset mod Enden og kløvet til lidt over Midten.

Goës anforer 1. c. p. 5: "Formæ duæ occurrunt. Altera epimero qvarto æqve fere alto ac lato, articulo pedum sexti et septimi paris primo dilatato, angulo infero postico subrecto aut acuto."

"Altera epimero qvarto latiore qvam altiore, articulo pedis sexti primo angusto, angulo infero postico lobulo rotundato determinato, pedis septimi articulo eodem dilatato margine infero postico rotundato nec angulato."

Jeg har havt Anledning til at undersøge den forste af disse og fundet, at den stemmer overeens med Krøyers Exemplarer fra Grønland.

Den findes ved Gronland og det arctiske Amerika, ved Spitsbergen ifølge Goës paa 20-60 Favne. Fra Finmarken er den medbragt af Lovén og Esmark; G. O. Sars har fundet den ved Hvidingsøerne; af Norman er den taget i St. Magnus Bay paa 80 Favne, og af Belcher i Northumberland Sund. 
STEGOCEPHALUS CHRISTIANIENSIS, A. Boeck, 1870.

(Pl. VIII. fig. 4 ; pl. IX, fig. 1.)

Stegocephalus Christianiensis, A. Boeck, Crust. amphip. bor. et arct. 1870. p. 48.

Antemm superiores articulo flagelli 1 mo elongato, extrorsum angustiore et plus qvam duplo longiore ac ad basin crasso. Antennæe inferiores articulo pedunculi 4 to et 5to eadem fere longitudine. Pedes $1 \mathrm{mi}$ paris manu multo longiore qvam carpo. Pedes 6ti paris articulo 1 mo non dilatato, articulo 5to longiore qram 4to. Pedes $7 \mathrm{mi}$ paris articulo $1 \mathrm{mo}$ deorsum et postice in angulum subrotundatum. ad finem articuli 3 tii porrectum, producto. Appendix caudalis parum ultra medium fissa.

L $æ n g d e n$ er omtrent $6 \mathrm{~mm}$.

Le gemet er meget høit. Ryggen er bred, og naar Halen er indbøiet under Bugen, har Dyrets Omkreds en bred, oval Form. Det første Legemsled er noget bredere end det andet. Den første Sideplade er triangulær, med den spidse Vinkel nedad, og dens forreste Rand er noget buet; den anden er noget smalere end den tredie; den fjerde er særdeles stor, dybt indskaaret paa den øvre Del af den bagre Rand for den lille femte Sideplade, og den nedre Rand danner med den bagre en stump afrundet Vinkel. Hovedet er kortere end det forste Legemsled og dækkes paa Siderne af den forste Sideplade; dets Sidevinkler ere noget udtrukne og afrundede.

De ovre Følere ere omtrent dobbelt saa lange som Hovedet. Skaftets forste Led er ubetydelig længere end tykt; de folgende Led aftage efter hinanden noget i Tykkelse og end mere i Længde. Svøbens første Led er kortere end Skaftet, meget smalere mod Enden, og har paa den indre Side talrige Tværrader af Borstebundter; de tvende følgende ere tilsammen meget kortere end det forste; det fjerde Led er børstedannet. Bisvoben dannes af eet smalt Led, der har flere Borster i Spidsen.

De nedre folere ere omtrent af den samme Langde som de ovre, men meget tyndere; Skaftets tredie Led er bredere end langt; de tvende sidste ere af cens Længde. Svoben er meget smalere end Skaftet, kun lidt længere end dettes sidste Led, og dannes af $6-8$ Ised.

Overlæben er temmelig høi, indskaaret paa Enden, og Fligerne ere ulige lange.

Kindbakkerne ere forlangede, afplattede paa Enden og skraa afskaarne. Den ene af disse er delt i tolv Tænder, der efterhaanden tiltage i Storrelse mod den bagre Rand, og er forsynet med en bred, kamdannet indre Bigren, hvis Trender ere særdelés talrige, men korte; den anden er paa Enden kun delt i 8-10 Tæuder og mangler den indre Bigren.

Underlæben er særdeles forlænget; Fligerne ere smale og have i Spidsen en tandet Klo. 


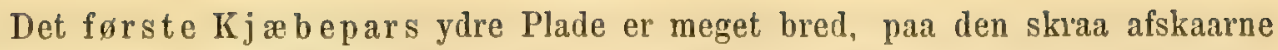
Ende væbnet med talrige stærke Torne, der langs den ovre Del af den indre Rand har mange smaa Tænder; den indre Plade er meget stor og bred og har 12-14 Torne paa Enden. Palpen naar kun frem til Enden af den ydre Plade, er meget tynd, eenleddet samt har i Spidsen tre meget stærke, i Randen saugtakkede Børster.

Det andet $\mathrm{Kj}$ sebepars ydre Plade er af en smal, cylindrisk Form og har paa Enden ti, i Spidsen hagedannede Børster; den indre Plade er meget bred og har omtrent fjorten meget stærke fjærdannede Borster.

Kjæbefødderne ere særdeles brede; den ydre Plade er meget stor, oval, med en ret indre Rand, der paa den ydre Del er forsynet med Saugtakker; den indre Plade er meget bred mod Enden, hvis Rand er indbugtet, og hver af Fligerne har fire fjærdannede Børster. Palpen er kun lidt længere end den ydre Plade, meget smal og aftager i Tykkelse mod Enden; dens første Led er kun lidt kortere, men bredere end det andet; det tredie er end kortere og bærer i Spidsen en kraftig Torn og nogle Borster.

Det forste Fodpars forste Led er saa langt som de følgende tilsammen; det fjerde er meget kort; det femte Led er noget længere, men smalere og spidsere mod Enden. Den bagre Rand af de tre sidste Led er forsynet med mange Børster. Kloen er kort, kun lidt krummet.

Det andet Fodpar er af den samme Form, men langere, hvilket især er Tilfældet med det sidste Led.

Det tredie og fjerde Fodpars tredie Led er længere.end paa det foregaaende Par, noget udvidet ved den ydre Ende og med en udtrukket nedre, bagre Vinkel; det fjerde er noget kortere end det foregaaende; det femte Led er langere og smalere. Kloen er kort, kun ubetydelig krummet.

De trende følgende Fodpar ere af eens Bygning, men det femte Led er længst paa det sjette Fodpar, saa at det er kun lidt kortere end de tvende foregaaende Led tilsammen.

Det syvende Fodpar er kortere end de tvende foregaaende; det første Led er meget stort, ovalt, med en udtrukken nedre, bagre Vinkel, der er noget tilspidset og naar frem til Enden af det tredie Led; den bagre Rand er fint saugtakket; det tredie er meget kort, bredt, med en udtrukken nedre, bagre Vinkel; det fjerde er noget længere end det foregaaende; det femte Led er meget længere og har stive Børster paa den forreste Rand. Kloen er ret.

Springføddernes Grene ere næsten lige lange.

Halevedhænget er meget længere end bredt, spaltet omtrent til Midten.

Farven er gul, vatret med brunt; efter Malm er den mørkegrøn.

Den er taget ved Langenæs af mig paa 70 Favnes Dybde; ved Skraaven af G. O. Sars paa 100-300. Favne, ved Risvær paa 300-400 Favne, ved Christiansund 
og ved Aalesund paa 50-100 Favne samt i Christianiafjorden udenfor Holmestrand paa omtrent 100 Favnes Dybde. Ved Bohuslen er den fundet af Malm.

Gen. II. ANDANIA, A. Boeck, 1870.

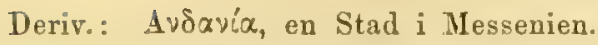

Syn.: 1870. Andania, A. Boeck, Crust. amphip. bor. et arct. p. 48 .

Type: Andania abyssi, A. Boeck.

Mandibulx in apice non aut minime modo dentatæ; mala interiore mandibula sinistræ item minima.

Maxilla $1 \mathrm{mi}$ paris palpo elongato, lato, 2articulato.

Maxilla 2di paris lamina exteriore multo breviore qvam interiore et parum modo angustiore qvam longa.

Appendix caudalis integra, minima.

Denne Slægt blev i 1870 opstillet af mig paa tvende nye Arter, der i det Ydre kun skille sig fra Slægten Stegocephalus ved at Halevedhænget er meget lidet, udelt, medens det hos den sidstnæunte Slægt er meget større og indskaaret paa Enden. Derimod vise Munddelene en stor Uoverensstemmelse mellem begge Slægter. Dens tvende Arter afvige med Hensyn til Munddelene fra hinanden væsentlig ved Formen af det forste Kjæbepars Palpe.

ANDANIA ABYSSI, A. Boeck, $18 \% 0$.

(Pl. IX. fig. 2.)

Andania abyssi, A. Boeck, Crust. amphip. bor. et arct. 1870. p. 49.

Articulus trunci 1 mus longitudine duos seqventes junctos rqvans. Epimerum 4 tum multo altius qvam latum. Pedes $1 \mathrm{mi}$ paris articulo 5 to elongato, ovato, eadem ferme longitudine ac articulo 4to. Pedes 6 ti paris articulo 1 mo postice dilatato. Pedes $7 \mathrm{mi}$ paris articulo $1 \mathrm{mo}$ in margine antico longitudine fere articulis qvatuor sequentibus junctis aqvali, et in margine inferiore parum modo producto et deorsum ad medium articuli brevissimi 3tii porrecto; articulo 3tio breviore qvam 4to ef in angulo inferiore postico in dentem brevem producto.

L $æ \mathrm{ngden}$ er $5-6^{\mathrm{mm}}$.

Legemet er kort, høit og tykt, Ryggen er rund. Det første Legemsled er saa bredt som de tvende folgende tilsammen; de ovrige ere smale. De tre forste Hale- 
led ere brede, og deres nedre, bagre Vinkel er afrundet. Den første Sideplade er trekantet, meget høiere end bred ved Roden, den forreste, øverste Vinkel er ret, den nedre tilspidset; de folgende ere smale, tilspidsede nedad; den fjerde er meget storre og bredere, af en næsten rhomboidalsk Form, med afrundede Vinkler og et dybt Indsnit i den ovre Del af den bagre Rand for den lille femte Sideplade. Hovedet er meget kort; dets nedre forreste Vinkel er forlænget $\mathrm{og}$ afrundet.

De øvre Følere ere meget korte. Skaftets andet og tredie Led ere tilsammen meget kortere end det forste. Svoben bliver meget tyndere mod Enden; dens første Led er langt, dog kortere end de følgende fem Led tilsammen. Bisvoben er eenleddet, kortere end Svøbens første Led.

De nedre Folere ere ubetydelig liengere end de ovre. Skaftets forste og andet Led ere korte og i den ydre Ende udtrukne i et kort Fremspring; det tredie er neppe saa langt som tykt; det fjerde er omtrent dobbelt saa langt, og det femte Led er længere og smalere end dette. Svøben er omtrent saa lang som Skaftet og dannes af 11 korte Led.

Kindbakkerne ere næsten eens paa begge Sider og ikke tandede, der sees kun et lidet opadboiet Fremspring paa den ydre Rand; Tyggeknuden og Tornerækken mangler; den venstre Kindbakke har et lidet Spor af en indre Bigren.

Det første Kjæbepar er særdeles bredt; den ydre Plade er væbnet med en dobbelt Rad af Tænder, hvoraf den indre er mindre end den ydre; den indre Plade er bred og har 10-12 lange fjærdannede Borster. Palpen er toleddet; det andet Led har i Spidsen nogle Torne.

Det andet Kjæbepars ydre Plade er kort og smal, samt i den skraa afskaarne Rand forsynet med 7-8 lange fjardamnede Borster; den indre P'ade er sardeles bred, paa Enden væbnet med en Rad lange, fjærdannede Børster og en Rad stærke Børster, der ikke ere fjærdannede $\mathrm{g}$ voxe efterhanden i Længde fra den indre til den ydre Vinkel.

Kjæb f f $ø$ ddernes ydre Plade er lang, bred og naar næsten til den ydre Ende af Palpens tredie Led; den har paa sin indre Rand 12-14 smaa, ikke tæt sammenstillede Torne; den indre Plade er temmelig bred og har i Spidsen nogle længere, smale Torne og en liden Tand. Palpens forste Led er meget langt, men dog tillige saa bredt, at det kun er lidt længere end bredt; det andet er omtrent lige saa langt, men smalere; det tredie er længere end det foregaaende; det fjerde er tydelig delt i tvende næsten lige lange Dele, hvoraf den indre er tykkere og den ydre er smalere, kloformet.

Det forste Fodpar er ikke kraftigt; det forste Led er omtrent saa langt som de folgende tilsammen og forsynet med nogle Borster paa begge Raude; det andet er længere end bredt; det tredie er særdeles kort; det fjerde Led er lidt længere end det andet og tykkere paa den bagre Ende; det femte Led er forlanget rgdannnet og har paa den bagre, mindre convexe Rand flere Bundter af tildels saugtakkede Torne. Kloen er kort, ubetydelig bøiet,

Det andet Fodpar er meget langere og smalere; det forste Led er noget $54^{*}$ 
kortere end de folgende tilsammen; det andet er næsten tre Gange saa langt som bredt; det tredie er kort; det fjerde er lidt længere end det andet $0 \mathrm{~g}$ har flere Børstebundter paa den bagre Rand; det femte Led er længere, smalere mod Enden og har paa den bagre Rand talrige Bundter af tildels med fine Saugtakker besatte Børster. Kloen er kort, smal, lidt krummet.

Det tredie og fjerde Fodpars tredie Led er ikke meget udvidet og har kun en lidet udtrukket nedre, bagre Vinkel; det fjerde er kortere; det femte har omtrent den samme Længde som det tredie Led, men er smalere end dette.

Det femte F odpar ligner det foregaaende; det forste Led er ikke udvidet.

Det sjette Fodpars forste Led er noget udvidet, omtrent tre Gange saa langt som bredt ved den ydre Ende, og ubetydelig længere end Halvdelen af de følgende Led tilsammen; ret femte er meget længere og smalere end det tredie Led.

Det syvende Fodpar er kortere end de tvende foregaaende; det forste Led er meget længere og bredere end det tilsvarende hos det foregaaende Par og er meget længere end de folgende Led tilsammen; dets bagre Rand er fint saugtakket, dets nedre, bagre Vinkel er ikke meget forlænget $0 \mathrm{~g}$ er bred, afrundet; det tredie Led er kun lidt længere end bredt, med forlænget nedre, bagre Vinkel; det fjerde er ubetydeligt, medens det femte er meget langere, men smalere, end det tredie Led. Kloen er kort, ret.

Springfoddernes Grene ere meget kortere end Grundleddet.

Det første $\mathrm{Par}$ naar længst bagud; den indre Gren er ubetydelig kortere end den ydre.

Det sidste Pars Grene ere næsten af eens Lrengde.

Halevedhænget er udelt, omtrent saa langt, som bredt ved Roden, tilspidset i Enden.

Farven er gulbrun med mørkere brune Spætter.

Den er fundet af G. O. Sars i Christianiafjorden paa 200 Favne, ved Skraaven paa 100-300 Favne, ved Lyngholmen af mig paa 100 Favne.

ANDANIA NORDLANDICA, A. Boeck, 1870.

(P1. IX. fig. 3.)

Andania nordlandica, A. Boeck, Crust. amphip. bor. et arct. 1870. p. 49.

Articulus trunci 1 mus articulis duobus seqventibus junctis multo brevior. Epimerum 4tum paululum altius qvam latum. Pedes 1 mi paris carpo breviore quam articulo 5to angusto, elongato. Pedes 6 ti paris articulo 1 mo non dilatato. Pedes $7 \mathrm{mi}$ paris articulo 1 mo in margine antico multo breviore qvam articulis sequentibus, in margine inferiore longe producto et rotundato: articulo 3 tio multo longiore qvam the et in angulo inferiore postico ad finem articuli 4 ti producto. 
Længden er $5-6^{\mathrm{mm}}$.

Legemets Form er meget lig den hos $A$. abyssi, men adskiller sig i det Ydre fra denne vasentlig ved at den fjerde Sideplade er bredere i Forhold til Høiden.

De avre Føleres forste Skaftled er langere end de tvende folgende tilsammen; det andet $0 g$ tredie aftager efter hinanden i Længde og Tykkelse. Svøben er længere end Skaftet og er meget smalere mod Enden; dens første-Led er saa langt som de tre følgende Led tilsammen. Bisvoben er meget smalere end Hovedsvoben og kun saa lang som Halvdelen af dennes første Led.

De nedre Foleres tredie Skaftled er ikke saa langt som tykt, skraat afskaaret paa Enden; det fjerde er omtrent 2-3 Gange saa langt som tykt; det femte er af den samme Længde som det foregaaende, men lidt tyndere. Svoben dannes af 7 forlængede Led.

K indbakkerne ere kun i Spidsen svagt tandede, den venstre har en indre, lidet tandet, bevægelig Bigren.

Det forste Kjæbepars ydre Plade er paa Enden vabnet med sex, med Bitænder besatte stærke, lidt krumme Torne; den indre Plade er kort, bred, med sex fjærdannede Børster. Palpen er liden, uden Borster.

Det andet $\mathrm{Kj}$ œbepars ydre Plade er meget kort, smal, medens den indre er meget længere, bred, og har paa Enden fjorten, tildels fjærdannede Borster.

Kjæbefoddernes ydre Plade er bred og naar ikke ganske frem til Enden af Palpens andet Led; den indre Plade har paa Enden en Tand og tre krumme Torne. Palpens første Led er kun lidt kortere, men tykkere end det andet, som er længere og bredere end det tredie Led.

Det forste Fodpars første Led er noget kortere end de følgende Led tilsammen og har paa den forreste Rand kortere, paa den bagre længere Børster; det andet $\mathrm{og}$ tredie Led ere meget korte; det fjerde er omtrent dobbelt saa langt som bredt ved den ydre Ende og har paa den bagre Rand korte, men stærke Børster; det femte Led er meget langere end det foregaaende, smalere mod Enden, og har paa den bagre Rand korte, stærke Børster. Kloen er kort, lidet krum.

Det andet Fodpar er ubetydelig længere og smalere end det foregaaende og ligner dette i sin Bygning, men det femte Led har meget stærke Børster, der tildels langs Randen have smaa Bitorne.

Det tredie og fjerde Fodpars tredie Led er lidet udvidet, men den nedre, bagre Vinkel er noget udtrukket; det fjerde er meget kortere og smalere; det femte Led er næsten af den samme Langde som det tredie, men er smalere end dette.

Det femte og sjette Fodpar ere af eens Bygning, men det forste at disse er noget tyndere; det første Led er ikke udvidet, smalt; det tredie er ubetydelig udvidet $\mathrm{og}$ noget udtrukket $\mathrm{i}$ den nedre, bagre Vinkel; det fjerde er meget kort; det femte Led er saa langt som det tredie, men er meget smalere.

Det syvende Fodpars forste Led er meget udvidet og udtrukket nedad, den 
bagre, nedre Vinkel er afrundet, og den strækker sig nedad til kun lidt over det tredie Leds halve Langde; dette sidste er udvidet, udtrukket i den nedre, bagre Vinkel og besat med Torne paa begge Rande; det fjerde er lidet, smalt, saa at det ikke rager udenfor det foregaaende Leds nedre, bagre Vinkel; det femte Led er næsten dobbelt saa langt, smalt. Kloen er liden, næsten ret.

Springfødderne naa alle næsten lige langt bagud, og Grenene ere alle næsten lige lange.

Det sidste Pars Grene ere meget kortere end Grundleddet.

Halevedhænget er bredere end langt, ikke spaltet, spidst i Enden.

Farven er hvid med brune Spætter.

Den er fundet i eet Exemplar i Nordland af G. O. Sars, ved Christiansund og Aalesund af Koren paa 50-100 Favne, ved Lyngholmen af mig paa 100 Favne.

Subfamilia II.

AMPHILOCHINÆ, A. Boeck, 1870.

Syn.: 1870. Amphilochince, A. Boeck, Crust. amphip. bor. et arct. p. 49.

Labium superius in apice valde incisum.

Mandibulx validre, dissimiles, in apice dilatate; mandibula altera ramo interno prædita, altera eodem carens; tuberculo molari magis minusve prominente; palpo 3articulato, elongato.

llaxilla $1 \mathrm{mi}$ paris lamina interiore parva; palpo plerumqve 2articulato, in apice spinis armato.

llaxillæ 2di paris lamina exteriore sat angustiore quam interiore.

Pedes maxillares laminis interioribus prælongatis, angustis; exterioribus mediocribus aut parvis; palpo plus minusve elongato: articulo ultimo ejusdem ungviformi.

Corpus sat altum, crassum; epimeris magnis.

Antennæ superiores breves et flagello appendiculari aut carentes aut parvo instructæ.

Pedes $1 \mathrm{mi}$ et 2 di paris ferme endem forma aut subcheliformes, nunc validi nunc invalidi, aut vix subcheliformes.

Pedes 3tii et 4 ti paris tenues filiformes.

Pedes trium parium ultimorum longitudinem paulatim crescentes. 
Pedes saltatorii 2ramosi; zdi paris brevissimi, ramo exteriore breviore qvam interiore.

Appendix caudalis integra aut in apice incisa.

Denne Underfamilie indbefatter tre Slægter, Amphilochus, Gitana og Astyra, hvoraf den forste er bekjendt f; Spence Bate, 1862, hrorimod de ovrige ere opstillede af mig i $18 \% 0$. Ligesom hos den foregaaende Underfamilie, Stegocephatine, ere Kindbakkerne ulige par begge Sider, idet den ene har, medens den anden mangler den indre Bigren. Overlæben er ligeledes kløvet, men forovrigt afviger den fra hin Underfamilie i Munddelenes Form. Skjønt Legemet er høit og tykt og Sidepladerne ere store, staa de dog langt tilbage for dem hos hin Underfamilie, og den skiller sig saaledes ogsaa i det Ydre let fra denne.

Gen. I. AMPHILOCHUS, Spence Bate, 1862.

Deriv.: 'Appinoxos, Navnet paa en Græker.

Syn.: 1862. Amphilochus, Spence Bate, Catal. Amphip. Crust. Brit. Mus. p. $10 \%$.

1863. - Spence Bate and Westwood, Brit. sessile-eyed Crust. p. 179.

1870. - A. Boeck, Crust. amphip. bor. et arct. p. 50.

Type. Amplilochus manudens, Spence Bate.

Mandibule articulo palpi 3tio eadem longitudine aut longiore qvam 2 do.

Iaxillæ $1 \mathrm{mi}$ paris palpo 2articulato; articulo 2 do in apice lato.

Pedes $1 \mathrm{mi}$ et 2 di paris manibus magnis, subcheliformibus instructi.

Spence Bate opstillede denne Slægt i 1862 paa Arten A. manudens fra den engelske Kyst. og henforer den under Grammaride til den fjerde Underfamilie Phoxides. Han adskiller den fra Slagten Monoculodes ved at Ginene sidde paa hver Side af Hovedet, og fra Kröyera ved at det andet Fodpars Haand ikke er saxdannet, samt fra begge disse Slægter ved at det sidste Fodpar er kortere. Han er uvis, om det sidste Par Springfødder er togrenet eller engrenet. Da han intet nævner om Munddelene, var jeg længe i I'vivi, om den Form, som af mig er beskrevet under Navnet A. manudens, hører herhen, især da Sidepladerne paa hans Tegning ere saa smaa, medens de paa min Form ere særdeles store. Navnet Amphilochus er forøvrigt i 1834 givet til en Coleopter og burde derfor ombyttes med et andet. 
AMPHILOCHUS IIANUDENS, Spence Bate, 1862.

(P1. XI. fig. 1.)

Amphilochus manudens, Spence Bate, Catal. Amphip. Crust. Brit. Mus. 1862. p. 107. pl. XVII. fig. 6.

Spence Bate and. Westwood, Brit. sessile-eyed Crust. 1863. p. 180 .

A. Boeck, Crust. amphip. bor, et arct. 1870, p. 50.

Pedes maxillares lamina externa fere ad finem articuli palpi 2di parvi, lamina interna ad medium articulum palpi 1 mum porrectis. Corpus leve; articulis non spinosis. Caput angulo laterali non producto. Pedes $1 \mathrm{mi}$ et 2di paris manu extrorsum latiore triangulari, in acie obliqve truncata et in angulo anteriore inferiore in spinam producta; ungve gracili, subcurvato, levi, dentibus et spinis destituto. Pedes 2di paris manu paulo longiore qvam 1mi paris; calce carpi ad aciem manus porrecta; articulo 3 tio in angulo inferiore posteriore in spinam producto.

Længden er omtrent $3^{\mathrm{mm}}$.

Legemet er meget høit, dog ikke meget sammentrykt. Ryggen er rund, uden Kjøl eller Torne. De tre første Haleleds nedre, bagre Vinkel gaar ud i en Spids, hvilket især er Tilfœldet paa det tredie Led. Sidepladerne ere meget høiere end brede, saugtakkede paa den nedre Rand; den anden Sideplade dækker næsten fuldstændig den første, saaledes at der sees kun en Del af dennes øvre Ende; den fjerde har paa den øre Del af den bagre Rand et Indsnit for den meget mindre, bredere end høie og ovale femte Sideplade; de følgende ere smaa. Hovedets Sidevinkler ere ikke udtrukne, afrundede.

De øvre Følere ere korte. Skaftet er særdeles tykt og stort; det forste Led er det langste og tykkeste; de tvende følgende aftage efter hinanden saavel i Længde som Tykkelse. Svøben dannes af 3-4 Led; det første er længere, men smalere end Skaftets tredie Led; det sidste har paa Enden flere Borster.

De nedre Folere ere omtrent af den samme Længde som de øvre, men meget tyndere end disse. Skaftets tvende første Led ere korte; det fjerde er længere og tykkere end det femte Led. Svøben er længere end Skaftets sidste Led og dannes af 5 Led.

Overlæben er kløvet $i$ Spidsen.

Kindbakkerne have i Spidsen et bredt, med mange Tænler forsynet Parti, som en Eg; Tornerækken dannes af en Række stærke Børster; Tyggeknuden er rudimentær. Palpens første Led er kort; det andet og tredie ere omtrent lige lange, men det sidste af disse er det tyndeste.

Det første Kjæbepars ydre Plade har i Spidsen flere krumme Tænder; den 
indre Plade er liden, af en oval Form. Palpen er toleddet, med nogle faa Torne paa Enden.

Kjæbeføddernes ydre Plade er stor og naar frem næsten til Enden af Palpens andet Led; den er bred oval, noget skraa afskaaret paa Enden, med en Rad fine Torne langs den indre Rand og en større Tand i Spidsen; den indre Plade naar frem til Midten af Palpens forste Led og er meget forlauget smal, med tvende smaa Tander paa Enden. Palpen er stærk, treleddet; det forste Led er det længste; det andet er kortere end det tredie. Kloen er liden, men stærk.

Det forste Fodpars forste Led er længere end de folgende tilsammen; det fjerde Leds nedre, bagre Vinkel er udtrukket og har nogle Borster paa Enden. Haanden er forlænget, uregelmæssig triangulær; Griberanden er forsynet med smaa Tæuder og nogle lange Børster, ved Kloens Udspring sees en Torn. Kloen er lang og tynd, og paa dens Ende sees ligesom en tyndere Klo.

Det andet Fodpar er meget støre, men har omtrent den samme Form; det tredie Leds nedre, bagre Vinkel danner en Torn; det fjerdes nedre, bagre Vinkel danner en Forlængelse, der naar frem til Enden af Haandens bagre Rand og er forsynet med Børster paa den bagre Rand. Haanden er triangular; den nedre, forreste Vinkel forlænger sig i en Spids udover Kloens Udspring. Kloen er noget længere end den med smaa Tænder og nogle Borster besatte Griberand.

Det tredie og fjerde Fodpar ere meget forlæugede og smale.

De tre følgende Fodpar ere af eens Bygning og tiltage høist ubetydelig i Lingde; det forste Led er udvidet, ovalt, saugtakket paa den bagre Rand; det tredie er temmelig langt, noget udvidet nedad; det fjerde er kortere og smalere; det femte er længere end det foregaaende Led. Kloen er omtrent saa lang som Halvdelen af det sidste Leds Langde.

Springfoddernes Grene ere alle cylindriske, uden Torne.

Det forste Pars ydre Gren er noget kortere end den indre.

Det andet Par naar kun lidt frem for Enden af det forste Pars Grundled; den ydre Gren er kortere end den indre.

Det sidste Par er det længste; Grenene ere omtrent lige lange, men meget kortere end det forlængede Grundled.

Ha levedh $x$ get er forlænget, cylindrisk, tilspidset, ontrent tre Gauge saa langt som bredt ved Roden.

F arven er brungul, Folerne ere straagule. Paa enkelte Dele af Legemet, saaledes paa den anden og tredie Sideplade og paa den ovre Del af de tre forste Haleled sees store, hvide Pletter. Langs Enderanden af hvert af Legemsleddene og af Sidepladerne er der stroet morkebrune, forgrenede Pigmentceller. Svommefoddernes Grundled ere noddebrune. Øinene ere rode.

Den er fundet af G. O. Sars ved Brettesnæs paa 40 Favne, og af mig i eet Exemplar i Christianiafjorden og ved Karmøen. 
Denne her beskrevre Form afviger meget fra Spence Bates og Westwoods Tegning af $A$. manudens. Formen af Hovedet, Legemsleddene og Sidepladerne ere afvigende; det forste Fodpars Haand er paa deres Tegning mere forlænget, medens den hos min Form er triangulær; desuden findes flere mindre Afvigelser. Senere Undersøgelser ville derfor maaske bevirke en Adskillelse af disse som tvende forskjellige Arter.

\section{AMPHILOCHUS ODONTONYX, A. Boeck, 1870.}

(PJ. XI. fig. 3.)

Amphilochus odlontonyx, A. Boeck, Crust, amphip. bor. et arct. 1870. p. 51.

Pedes maxillares lamina externa minima, ad medium modo articulum palpi 1mum, lamina interna non ad articulum eundem, porrectis. Antennæ superiores articulo pedunculi $2 d_{0}$ in extremo margine superiore ad spinam longam producto. Corpus segmentis non spinosis. Caput angulo laterali producto, aculo. Pedes $1 \mathrm{mi}$ paris manu extrorsum latiore, triangulari, in acie obliqve truncata; carpo calcem brevem emittenti. Pedes 2di paris manu multo majore qvam $1 \mathrm{mi}$ paris, elongata, ovata; ungve perlongo, prope ad basin percurvato, in margine interiore spina valida armato; articulo tertio in angulo posteriore inferiore acuto.

Længden er i Dyrets udstrakte Tilstand $4^{\mathrm{mm}}$.

Legemet er tykt, temmelig opsvulmet. Ryggen er rund og Halen forlænget. Sidepladerne ere høie, saugtakkede paa den nedre Rand. Hovedet, der er noget længere end det forste Legemsled, gaar fortil ud i et langt, mellem de øvre Følere bøiet Pandehorn, der er bredt ved Roden, men sammentrykt fra Siderne; dets Sidevinkler ere udtrukne, tilspidsede. Øinene ere smaa, runde og sidde paa Silerne af Hovedet.

De øvre Følere ere neppe længere end Hovedet og de tvende forste Legemsled tilsammen. Skaftets forste Led er kortere end Hovedet, det andet er noget kortere og smalere, begge gaa paa den gvre og nedre Rands Ende ud i en Torn; det tredie er lidet, smalt, dobbelt saa langt, som bredt. Svoben er kortere end Skaftet og dannes af 6 meget tynde Led.

De nedre Folere ere omtrent af den samme Langde som de øvre. Skaftets tredie Led er meget kort, det fjerde er forlænget, og det femte er noget længere end Halvdelen af det fjerde Led. Svoben er meget kort og dannes af 4 Led.

Kindbakkernes Palpes andet og tredie Led ere lige lange og tynde.

Det forste $\mathbf{K j}$ æbe pars Palpe er meget bred

Kjæbeføddernes ydre Plade er meget liden, i Spidsen væbnet med en tynd Torn; den indre Plade er dobbelt saa lang som bred, med en Torn paa Enden. Palpen er tynd; det forste Led naar længere frem end til Enden af den ydre Plade; det 
andet er noget kortere, og det tredie er af den samme Længde som det første Led. Kloen er liden.

Det første Fodpars fjerde Led forlænger sig i den nedre, bagre Vinkel til et kort, buet, med Børster besat Fremspring; Haanden er bredere udad, Griberanden er skraa afskaaret $0 \mathrm{~g}$ forsynet med fine Tænder.

Det andet Fodpar er meget storre; det tredie Leds nedre, bagre Vinkel er væbnet med en skarp Torn; det fjerde Leds forlængede Fremspring af Ien nedre, bagre Vinkel er smalt, med nogle Borster i Spidsen, og naar næsten til det Sted af Haanden, hvor Kloens Spids lægger sig til. Haanden er forlænget, omtrent dobbelt saa lang som bred, og Griberanden er forsynet med fine Tæuder. Kloen er lang, meget bøiet ved Roden og har her en stærk Tand paa den bagre Rand.

Det tredie og fjerde Fodpar ere linieformede og meget forlangede; det femte Led er meget længere end det fjerde, der knap er saa langt som det tredie Led. Kloen er middelmaadig lang, krummet.

De tre følgende Fodpars første Led er skjoldformet udvidet, noget længere end bredt. saugtakket paa den bagre Rand; det tredie er kortere end det første, og dets nedre, bagre Vinkel er forlænget; det fjerde er kortere, men det femte Led er længere end dette. Kloen er lidt længere end Halvdelen af det femte Led.

Det sidste Par Springfødder naar langst tilbage; Grenene, hvoraf den indre er ubetydelig længere end den ydre, ere meget kortere end Grundleddet.

Haleved hæ nget er særdeles forlænget, lancetdannet og naar længere tilbage end til Enden af det sidste Par Springfødders Grundled.

Den er fundet ved Aalesund af G. O. Sars paa 60-100 Favne og af mig i Christianiafjorden og ved Haugesund.

\section{AMPHILOCHUS BISPINOSUS, A. Boeck, 1870.}

(Pl X. fig. 1.)

Amphilochus bispinosus, A. Boeck, Crust. amphip. bor. et arct. 18r0. p. 51.

Pedes maxillares Inmina externa elongata ultra medium articulum palpi 2dum, lamina interna ad finem articuli palpi 1 mi parvi, porrectis. Segmentum postabdominis $1 \mathrm{mum}$ et $2 \mathrm{dum}$ in medio margine posteriore in spinam producta. Pedes 1 mi paris manu ovali, spinis transversis armata; ungve lato, in margine selis gracilibus instructo; calce perbrevi. Pedes 2di paris manu magis elongata, angusta, in acie obliqve truncata; calce carpi ad aciem porrecta. Pedes qvinqve parium posteriorum sat elongati, articulo tertio breviore qvam qvarto et qvinto. Pedes saltatorii ultimi paris ramis tam longis vel parum brevioribus qvam pedunculo. 
Lingden er omtrent $5^{\mathrm{mm}}$.

Legemet er tykt, næsten opsvulmet, uden Kjøl, men Halens tvende første Led gaa paa Midten af den bagre Rand ud i en spids Torn; det tredie Haleleds nedre, bagre Vinkel danner ingen egentlig Spids De fire første Sideplader ere høie, saugtakkede paa den nedre Rand og tiltage efter hverandre i Størrelse, saaledes at den fjerde er den høieste og bredeste; denne er ikke meget indskaaret for den mindre femte Sideplade, der er tolappet paa den nedre Rand. Hovedet er omtrent saa langt som det forste Legemsled, eller noget kortere end dette, og danner mellem de øvre Folere et kort, bredt Pandehorn.

De $\emptyset$ vre Folere ere korte. Skaftets andet Led er næsten saa langt som det forste, men er smalere; det tredie Led er kort. Svoben dannes af 12-15 Led.

De nedre Følere ere langere og tyndere end de ovre. Skaftets tredie Led er lidt længere end tykt; de tvende sidste ere lige lange.

Overlæben er bred i det fastsiddende Parti, men bliver smalere mod den fri Del og er indskaaret paa Enden.

Kindbakkerne ere af den samme Bygning paa begge Sider, men den høire mangler den indre Bigren, hvilken paa den venstre er bred mod Enden og indskaaret i talrige Trender; Gribedelen er bred og har mange smaa Tæuder; Tornerækken dannes af 10-12 stærke, men forlængede, brede, simple Torne; Tyggeknuden er fremstaaende, oval. Palpen er forlænget; det tredie Led, der er forsynet med enkelte, fjærdannede Torne, er længere end det andet, men smalere.

Det første Kjæbepars ydre Plade er paa Enden skraa afskaaret og der besat med otte strerke, men simple Torne i tvende Rader. Palpen er tydelig toleddet; det andet Led har paa Enden af den ydre Rand tre knivformede Torne samt paa den indre en Rxkke fine Torne.

Det andet $\mathrm{Kj}$ bepars ydre Plade er meget smalere, men længere end den indre, og har fem krumme 'Torne paa Enden; den indre Plade er meget bred, paa Enden besat med en Række tykkere Torne og en lignende tyndere.

Kjæbef $ø$ d d ernes ydre Plade er ikke meget stor, oval, naar noget længere frem end til Midten af Palpens andet Led $\mathrm{og}$ har fem smaa Tænder langs den indre Rand og nogle smaa Torne paa Enden; den indre Plade naar frem til Enden af Palpens forste Led, er næsten fire Gange saa lang som bred og forsynet paa Enden med nogle krumme Torne og Børster. Palpen el kort, men tyk; det andet Led er omtrent saa langt som det første korte Led; det tredie er smalere, lidt krummet. Kloen er omtrent saa lang som det foregaaende Led.

Det første Fodpar er kort og stærkt; det forste Led har paa den forreste Rand en Rakke fine Torne; det fjerde er udtrukket i den nedre, bagre Vinkel til et bredt, afrundet Fremspring, der har tvende Rader tynde Torne; Haanden ex ikke dobbelt saa lang som bred, ned en kort, skraa afskaaret Griberand, samt er vabnet med 
tre Rader twærsgaaende Torne. Kloen er kort og stærk, besat paa Randene med talrige, smaa Torne.

Det andet Fodpar har den samme Form, men er mere forlænget og smalere end det forste Par; det fjerde Leds nedre, bagre Vinkel danner en storre Forlængelse, der naar frem til Enden af Haandens Griberand.

Det tredie og fjerde Fodpar ere meget lange og smale; det tredie Led er ikke meget udvidet; det fjerde er kortere, og det femte omtrent af den samme Længde som det tredie Led, men er smalere end dette. Kloen er lang, lidt krummet.

De tre følgende Fodpar ere af eens Bygning; det furste Led er meget bredt, fint saugtakket paa den bagre Rand og paa den forreste besat med en Rxkke fine, smaa Torne; det tredie Led er kortere end det fjerde og femte Led.

Det andet Par Springfødder er det korteste; den ydre Gren er kortere end den indre, der er omtrent saa lang som Gmundleddet, eller noget kortere end dette.

Det sidste Par naar ubetydelig længere tilbage end det første; den ydre Gren er lidt kortere end den indre, hvis Langde er ubetydelig mindre end Grundleddets.

Halevedhanget er lancetdannet, tilspidset paa Enden.

Farven er lysegul, vatret med Rosenrødt.

Den er fundet af G. O. Sars ved Christiansund paa 50-100 Favne og i Hardangerfjorden, og af mig i Christianiafjorden og ved Haugesund paa 50 Favne.

\section{AMPHILOCHUS TENUIMANUS, A. Boeck, 1870.}

(P1. IX. fig. 7.)

Amphitockus tenuimanus, A. Boeck, Crust. amphip. bor. et arct. 1870. p. 51.

Pedes maxillares lamina externa extra finem articuli palpi 1 mi elongati, lamina interna extra articulum eundem, porrectis. Corpus segmentis non spinosis. Caput antice fere in extremum articulum pedunculi 1 mum antennarum superiorum productum; angulis lateralibus productis, peraculis. Pedes $1 \mathrm{mi}$ paris manu extrorsum latiore, triangulari, in acie obliqve truncata et dentibus armata; ungve gracili, levi, in margine setis destituto. Pedes 2 di paris manu magis elongata, in acie truncata carpo breviore qvam manu; calce carpi elongata, ad aciem porrecta.

Langden er omtrent 5 mm.

Leg emet er temmelig opsvulmet og er høit, med særdeles store Sideplader. Disse ere fint saugtakkede paa den nedre Rand; den første er meget liden og er skjult af den smale anden; den fjerde er den største og noget indskaaret i den øvre Del af den bagre Rand for den meget mindre femte Sideplade; denne er dobbelt saa lang som høi og er indskaaret i den nedre Rand. Hovedet er meget kort; dets Side- 
vinkler ere fremstaaende, tilspidsede, og det gaar frem i et særdeles stærkt, bredt, paa Fnden afrundet Pandehorn, der er længere end det første Led paa de wre Føleres Skaft.

De øvre Følere ere meget korte og naa, naar de bøies bagud, neppe til det fjerde Legemsled. Skaftets andet Led er længere, men smalere end det første; det tredie Led el kort. Svøben er meget kortere end Skaftet og dannes af 5 forlængede Led.

De nedre Folere ere noget længere end de øvre. Skaftets tredie Led er meget kort; det fjerde, der er omtrent saa langt som det femte Led, er meget længere end det andet Led paa de øvre Føleres Skaft. Svøben er kortere end Skaftets sidste Led $0 \mathrm{~g}$ dannes af 4 Led.

Overl $\rightsquigarrow$ ben er indskaaret paa Enden.

Kindbakkerne ere særleles forlængede $\mathrm{og}$ fint tandede $\mathrm{i}$ den brede Ende; der sees neppe en Tyggeknude. Palpens andet og tredie Led ere næsten lige lange.

Det forste Kjæbepars ydre Plade har paa Enden temmelig korte, krumme Tænder. Palpens andet Led er meget bredt.

Det andet $\mathbf{K} \mathbf{j}$ be $\mathbf{p}$ ars Plader ere smale.

Underlæben er forlænget, med vidt adskilte Flige; den indre er rulimentær.

Kjæbefødderne ere ligeledes forlængede, især de indre Plader. Den ydre Plade naar langere frem end til Enden af Palpens forste Led, er bred oval paa Enden, hvis indre Rand er fint saugtakket, $0 \mathrm{~g}$ i Spidsen sees en fin Tand; den indre Plade naar frem foran Begyndelsen af Palpens første Led og har en Torn paa Enden af den indre Rand. Palpens første Led er læengere end det andet, det tredie er det længste. Kloen er meget smal.

Det forste Fodpars fjerde Leds nedre, bagre Vinkel er udtrukket næsten til Midten af Haandens bagre Rand og er besat med enkelte Torne. Haanden er meget bred udad, trekantet; den skraa afskaarne Griberand er indskaret i mange Tænder; paa Enden af den forreste Rand sees nogle længere Børster. Kloen er temmelig lang $0 \mathrm{~g}$ tynd.

Det andet Fodpars fjerde Leds nedre, bagre Vinkel er udtrukket til Haandens Griberand og har langs den bagre Rand spredte, stærke Børster. Haanden er forlænget firkantet, længere end det foregaaende Led, bredere ved den ydre Ende; Griberanden er næsten ret afskaaret, saugtakket. Kloen er lidt længere end denne, med fine Torne paa den bagre Rand.

Det tredie og fjerde Fodpar ere særdeles lange, linieformede; det tredie Led er ikke synderlig udvidet; de tvende sidste Led ere indbyrdes lige lange, kortere end det tredie Led.

De tre følgende Fodpars første Led er meget ovalt, og dets bagre Rand er neppe tandet; det tredie er kortere, omtrent saa langt som det femte Led, der er længere end det fjerde. 
Springfødderne ere meget lange. Det forste og det sidste Par naa næsten lige langt bagud, det sidste Pars Grene ere meget kortere end Grundleddet.

Denne Art er fundet af G. O. Sars ved Christiansund paa $50-100$ Favne, ved Hvidingsøerne og i Hardangerfjorden, af mig ved Mosterhavn paa 150 Favne.

Gen. II. GITANA, A. Boeck, 1870.

Syn.: 1870. Gitana, A. Boeck, Crust. amphip. bor. et arct. p. 52.

Type: Gitana Sarsi, A. Boeck, 1870.

Mandibula articulo palpi 3 tio breviore qvam 2 do.

Haxillæ $1 \mathrm{mi}$ paris palpo uniarticulato, in apice angusto.

Pedes maxillares palpis perangustis, elongatis: articulo 3tio in extremo margine interiore producto.

Pedes $1 \mathrm{mi}$ et 2 di paris manibus angustis, vix subcheliformibus.

Jeg opstillede denne Slagt i 1870 og adskiller den fra den foregaaende ved at det første Kjæbepars Palpe er eenleddet, medens den er toleddet hos Amphilochus. Desuden ere Fijobefoddemes Palper meget forlæugede, og de tvende forste Fodpars femte Led er smalt, neppe gribende, medens det er meget stærkt hos den foregaaende Slægt.

GITANA SARSI, A. Boeck, 1870.

(PI. XI. fig. 2.)

Gitana Sarsi, A. Boeck, Crust. amphip. bor. et arct. 1870. p. 52.

Corpus segmentis non spinosis. Epimera margine inferiore subserrato. Caput rostro lato: hoc in extremum articulum pedunculi 1 mum antennarum superiorum perbrevem, parum modo longiorem qvam crissum, porrecto. Angulus lateralis capitis non productus. Pedes $1 \mathrm{mi}$ 2diqve paris manu angusta; ungve angustiore et in margine interiore modo setoso. Pedes qvinqve parium posteriorum multo breviores qvam apud speciem seqventem.

Længden er $3^{\mathrm{mm}}$.

Legemet er høit og tykt. Sidepladerne ere svagt tandede paa den nedre Rand. Hovedet er længere end det første Legemsled og gaar fortil, mellem de ovre Følere, ud i et stærkt, fra Siderne sammentrykt, dog bredt Pandehorn, der naar frem 
til Enden af de øvre Føleres første Skaftled; Sidevinklerne ere brede, ikke udtrukne, og afrundede. Øinene ere smaa, runde.

De $\emptyset$ vre Følere ere kun lidt længere end Hovedet. Skaftets forste Led er det længste og tykkeste; de tvende følgende aftage efter hinanden meget baade i Længde og Tykkelse. Svøben, der er længere, men noget smalere end Skaftet og tilspidser sig meget mod Enden, dannes af 7 Led, hvoraf det forste er det længste.

De nedre Folere ere meget længere end de ovre. Skaftets tvende forste Led ere korte; det tredie er ogsaa kort, men dog 1ængere end de foregaaende; det femte er noget længere, men smalere end det fjerde Led. Svoben er tynd og synes at være dannet af kun 4 forlængede, smale Led, hvoraf det første er sąa langt som de følgende tilsammen.

Overlæben er dybt indskaret paa Enden.

Kind bakkernes Tyggeknude er fremstaaende. PaIpens tredie Led er kortere end det andet.

Det forste Kjæbepars ydre Plade har paa Enden nogle Torne. Palpen er eenleddet og har et Par grove Torne i Spidsen.

Kjabef $\emptyset d d e r n e s$ ydre Plade er forlanget smal, naar frem omtrent til Midten af Palpens andet Led og har en Torn paa Enden af den ydre Rand; den indre Plade er ogsaa meget smal og naar frem til lidt over Midten af Palpens forste Led. Palpens andet Led er det korteste; det tredie er længere end det andet og er udtrukket paa Enden af den indre Rand.

Det forste Fodpar er lidet; det første Led er næsten saa langt som de følgende tilsammen; det fjerde Leds nedre, bagre Vinkel er noget udtrukket, og den bagre Rand er ligesom paa det tredie Led besat med Torne; det femte er smalt, kortere, eller omtrent saa langt som det foregaaende Led, og har ligeledes Torne paa den bagre Rand. Kloen er smal og har Børster paa den bagre Rand.

Det andet Fodpar er længere og smalere; især det fjerde Led, hvis nedre, bagre Vinkel ogsaa er noget forlanget; det femte er smalt, kortere end det fjerde Led, begge ere besatte med Torne paa den bagre Rand. Kloen har fine Borster paa den bagre Rand.

Det tredie og fjerde Fodpar ere meget lange og smale; det tredie Led er meget smalere end det første og har kun dettes halve Længde; det fjerde er omtrent af den samme Lxngde, medens det femte er meget længere. Kloen er smal, mere end halvt saa lang som det sidste Led.

De tre følgende Fodpars forste Led er ovalt og besat med nogle Torne paa den forreste Rand.

Det første og sidste Par Springfødder naa næsten lige langt bagud; den ydre Gren er kun ubetydelig kortere end den indre. Grenene paa det sidste Par ere meget kortere end Grundleddet. 
Det andet Par er det korteste; Grenene ere kortere end Grundleddet, og den indre er meget kortere end den ydre.

Hal evedhænget er lancetdannet, tilspidset paa Fnden og noget kortere end Halvdelen af det sidste Par Springfodders Grundled.

Den er fundet af G. O. Sars ved Christiansund paa $50-100$ Favnes Dybde.

GITANA ROSTRATA, $\Lambda$. Boeck, 1870.

(PI. XI. fig. 4.)

Gitana rostrata, A. Boeck, Crust. amphip. bor. et arct. 1870. p. 52.

Corpus segmentis non spinosis. Caput rostro longo et lato; hoc in extremum articulum pedunculi 1 mum antennarum superiorum, duplo longiorem qvam crassum, porrecto. Angulus lateralis capitis rotundatus. Pedes 1 mi 2diqve paris perangusti; manu plus ter longiore qvam lata, apicem versus angustiore, breviore qvam carpo; hoc in calcem non producto: ungve gracili, subcurvato. Pedes qvinqve parium posteriorum perlongi et graciles. Pedes trium parium ultimorum arliculo 1 mo perdilatato. Pedes saltatorii ultimi paris ramis parum longioribus qvam dimidio pedunculo.

L $x$ nglen er $4^{\mathrm{mm}}$.

Legemet er høit; Ryggen er rund, ulen Torne; det tredie Haleleds nedre, bagre Vinkel er ubetydelig fremstaaende. Sidepladerne ere meget hoiere end brede, svagt tandede paa den nedre Rand; den forste Sideplade er skjult af den anden; den fjerde er den bredeste. Hovedet er lidt længere end det første Legemsled og gaar fortil ud i et langt, bredt Pandehorn, der naar frem til Enden af de gvre Foleres forste Skaftled; Sidevinklerne ere afrundede.

De $\emptyset$ vre Følere ere kortere end de nedre. Skaftets forste Led er længere end Hovedet; det andet er længere og tyndere; det tredie er kort. Svoben dannes af 7 Led, hvoraf det forste er det lingste, og der sees nogle lange Børster paa deres ydre Ende.

De nedre Folere ere tyndere end de ovre. Skaftets fjerde og femte Led ere forlængede og lige lange. Svoben er omitrent saa lang som Skaftets sidste Iaed og synes neppe delt i tydelige Led.

0 verlæben er dybt indskaaret, og Fligene vige meget fra hinanden.

Kindbakkerne ere i Spidsen brede, delte i smaa Trender; Tyggelnuden er fremstaaende. Palpens tredie I.ed er kortere end det andet.

Det forste $K j$ jo epars ydre Plade har paa den skraa afskarne Lnde fem Torne, forsynede med fine Bitinder. Palpen er eenleddet, med fine Børster paa Enden.

Kjæbefoddernes ydre Plade naar frem til Midten af Palpens andet Led $0 \mathrm{~g}$ er forsynet med en Torn paa Enden; den smale, forlængede, indre Plade naar frem til 
Enden af Palpens forste Led. Palpen er meget smal, forlænget; det tredie Led er lidt længere end det andet og er udtrukket paa Enden af den indre Rand.

Det forste Fodpar er. smalt; det fjerde Led er fire Gange saa langt som bredt, og dets nedre, bagre Vinkel er ikke udtrukket; det femte Led er kortere samt er smalere mod den ydre Ende, begge Led have Børster paa dén bagre Rand. Kloen er tynd, noget krummet og har en liden Tand nær Enden af den bagre Rand.

Det andet Fodpar er længere og smalere end det første, men har forøvigt den samme Bygning.

Det tredie og fjerde Fodpar ere lange og smale; det tredie Led er ikke udvidet, længere end det fjerde, og af den samme Længde som det femte Led. Kloen er kort, nasten ret.

De tre folgende Fodpar ere ligesom de trende foregaaende Par lange og smale; det forste Led er stort, ovalt, med en saugtakket bagre Rand; det tredie er noget udvidet bagtil, med en udtruklet nedre, bagre Vinkel, længere end det fjerde, men kortere end det femte Led. Kloen er næsten halvt saa lang som det sidste Led.

Det forste og sidste Par Springfød der naa lige langt bagud, og Grenene have den samme Længde.

Det andet $\mathrm{Par}$ er meget kortere og naar kun til Enden af det sidste Pars Grundled.

Det sidste P'ars Grene have kun lidt mere end Grundleddets halve Længde. Den er fundet i Hardangerfjorden af G. 0. Sars.

Gen. III. ASTYRA, A. Boeck, $18 \% 0$.

Syn.: 1870. Astyra, A. Boeck, Crust. amphip. bor. et arct. p. 53.

Type: Astyra abyssi, A. Boeck.

Mandibulæ in apice dilatate et dentatæ; tuberculo molari prominenti sed tenui, apicem versus angustiore; articulo 3tio palpi breviore quam 2 do.

laxilla $1 \mathrm{mi}$ paris lamina interna latiore, setis multis instructa.

llaxillæ 2di paris lamina interna perbrevi sed lata.

Pedes maxillares lanina externa permagna, in margine interiore dentibus multis armata; palpo brevi.

Antenna breves; superiores inferioribus breviores; flagello accessorio parvo; pedunculo brevi, sed crasso.

Pedes $1 \mathrm{mi}$ et 2di paris vix subcheliformes.

Pedes trium parium ultimorum articulo $1 \mathrm{mn}$ non perdilatato. 
Pedes saltatorii ultimi paris ramo interiore breviore qram exteriore.

Appendix caudalis brevis, in apice incisa.

Denne af mig i 1870 opstillede Slægt hénførte jeg til Underfamilien Amphitochince, skjønt den i enkelte Punkter afviger fra de foregaaende Slægter og nærmer sig Pardaliscince. Kindbakkerne ere væbnede med en vistnok tynd, men tydelig Tyggeknude: Kjæbeføddernes Plader, som hos de tvende foregaaende Slægter ere smale, ere her meget brede, og de ørre Folere ere forsynede med en, rigtignok liden, Bisvøbe, der heller ikie findes hos de foregaaende Slægter. Denne Slægt bor maaske udskilles som Typus paa en Underfamilie, der maa stan mellem Amphilochince og Pardatiscince. Den indibefatter kun een Art.

ASTYRA ABYSSI, A. Boeck, 1870.

(Pl. IX. fig. 4).

Astyra alyssi, A. Boeck, Crust. amphip. bor. et arct. 1870. p. 53.

Corpus altum, crassum. Dorsum rotundatum. Epimerum 2dum et 3tium perangusta. Segmentum postabdominis 4tum e transverso profundo depressum. Antemne superiores flagello accessorio 1 articulato instructie. Pedes $1 \mathrm{mi}$ paris manu parum breviore quan carpo; hoc in calcem minimam, rolundatam, setosam producto; ungve lato, in margine interiore spinulis instructo. Pedes 2di paris rqve ut 1 mi paris sed majores. Pedes 3 tii 4 tique paris articulo 3 tio parum breviore qvam articulis duobus sequentibus junctis. Pedes trium parium ultimorum articulo 1 mo ferme duplo longiore quam lato; articulo 3 tio non dilatato, longiore qvam 4to, breviore qvam 5to. Pedes saltatorii ultimi paris ramo exteriore ferme ter longiore quam pedunculo brevissimo; ramo interiore paulo breviore. Appendix caudalis multo longior qvam ad basin lata, ultra medium fissa.

I. ængden er $6^{\mathrm{mm}}$.

Le gemet er tykt og bredt, Ryggen er rund. Det tredie Haleleds nedre, bagre Vinkel er tilspidset; det fjerde har paa Midtlinien en dyb, transversal Fordybning. Den anden og tredie Sideplade ere meget smale; den fjerde er bredere, og dens bagre, afrundede Rand danner med den forreste en næsten ret Vinkel; de tre folgende Sideplader ere smaa. Hovedet er længere end det første Legemsled; dets forreste Rand gaar frem i et bøiet Pandehorn; Sidevinklerne ere udtrukne, afrundede.

De øvre Følere ere korte. Skaftets forste Led er tykt, omtrent saa langt som Hovedet og meget længere end begge de folgende meget kortere Led tilsammen. 
Svoben dannes af 12-14 smale Led, besatte med Børster paa den undre Rand. Bisvoben er meget liden, eenleddet, forsynet med en fin Børste.

De nedre Følere ere noget langere end de øvre. Skaftets tredie Led er saa langt som bredt; det fjerde er dobbelt saa langt som bredt; det femte er kortere end dette, og begge have enkelte Borster paa den undre Rand. Svoben er længere end Skaftet $0 \mathrm{~g}$ dannes af omtrent 14 med Børster paa den undre Rand forsynede Led.

Overlæben har en bred Indskjaring paa Enden.

K indbakkerne, der ere ulige paa begge Sider, ere i Spidsen brede og stærkt tandede; Tornerækken dannes af en Række tynde Børster; Tyggeknuden er meget fremstaaende, men tynd, meget smalere mod Enden samt forsynet med nogle Børster. Palpens andet Led er langt; det tredie er meget kortere og tyndere og er besat med nogle fjærdannede Børster.

Det første Kjæbepars ydre Plade er bred, med grovere, fjærdannede Børster paa Enden; den indre Plarle er ligeledes bred, oval, med tildels fjærdannede Børster paa Enden. Palpen er toleddet og paa Enden besat med Torne.

Det andet $\mathrm{Kj}$ æbepars ydre Plade har paa Enden fjærdannede Børster; den indre Plade er ligeledes bred, men kort, og med fjordannede Børster paa Enden.

Kjæb efordernes ydre Plade er meget stor og bred og naar frem næsten til Midten af Palpens tredie Led, den indre Rand er tret besat med Trender, der blive længere mod Pladens Ende; den indre Plade er ogsaa bred, med fjærdannede Børster langs den indre Rand og nogle liorte Torne paa Enden, samt naar frem til Midten af Palpens forste Led. Palpen er kort; de tvende forste Led ere næsten af eens Læengde; det tredie er kortere. Kloen har Børster paa den bagre Rand.

Det forste Fodpar er lidet; det fjerde Led er noget udtrukket i den nedre, bagre, afrundede Vinkel, der er besat med Borster; det femte Led er lidt kortere end det foregaaende og meget smalere, ined næsten parallele Rande. Kloen er liden, men bred, med fine Torne paa den bagre Rand.

Det andet Fodpar er storre og kraftigere end det forste, men af den samme Form.

Det tredie og fjerde Fodpar ere smale; det tredie Led er ikke udvidet, ubetydelig lengere end de tvende falgende tilsammen, hvilke ere nasten lige lange; det fjerde Leds nedre, bagre Vinkel er lidt udtrukket. Alle tre Led have Borster paa den bagre Rand. Kloen er næsten saa lang som Halvdelen af det sidste Led.

De tre folgende Fodpars forste Led er noget udvidet paa den bagre Rand og dobbelt saa langt som bredt; det tredie Led er ikke udvidet og er længere end det fjerde, men kortere end det femte Led.

Det første og sidste Par Springfødder naa næsten lige langt bagud.

Det forste Pars Grene, hvoraf den indre er lidt kortere end den ydre, ere omtrent saa lange som Grundleddet. 
Det andet Par er kortere, og Grenene ere meget længere end Grundleddet; den indre Gren er lidt længere end den ydre.

Det sidste Pars Grene ere tre Gange saa lange som Grundleddet, og den indre er kortere end den ydre Gren.

H alevedhænget er. længere end bredt ved Roden, spaltet til over Midten.

Den er fundet af G. 0. Sars ved Christiansund paa 50-100 Favne og i Hardangerfjorden, samt ved Skraaven paa 2-300 Favne.

Subfamilia III.

-STLNOTHOINA, A. Boeck, 1870.

Syn.: 1870. Stenothoine, A. Boeck, Crust. amphip. bor. et aret. p. 58.

Labium superius in apice fissum.

Mandibule elongatx, in apice late, dentata, utrobiqge dissimiles; mandibula sinistra processum accessorium emittens; tuberculo molari minimo aut nullo; palpo absenti aut prælongato, 3articulato.

Labium inferius parvulum.

Maxilla $1 \mathrm{mi}$ paris palpo 1 - aut 2arliculato; lamina interiore parva aut nulla.

Pedes maxillares palpis prolongatis; lamina interiore minima, exteriore fere obsoleta.

Corpus compressum, sed tamen crassum; epimerum Imum parvulum, tectum; epimera reliquva magnitudine valde crescentia; ftum sæpissime permagnum; clipeoforme.

Antenne mediocriter elongati: superiores flagelli appendiculari destitute.

Pedes Imi paris graciles; manu sape non subcheliformi.

Pedes 2di paris manu valde subcheliformi.

Pedes 5ti, 6ti et $7 \mathrm{mi}$ paris eadem forma; articulus 1 mus 5 ti et 6 ti paris sæpissime non dilatatus.

Pedes saltatorii ultimi paris ramo uno instructi; ramo biarticulato; articulo ultimo styliformi.

Appendix caudalis parva, non fissa.

Typus paa denne Underfamilie er Dana's Slagt Stenothoë, som af ham er stillet sammen med Lencothoë til en Underfamilie Leucothoince paa Grund af de forlængede, smale Kjæbefødder, hvis indre Plader ere meget smaa, og hivis Palpers sidste Led er forlænget, kloformet. Forskjellen mellem disse Slægter finder han især at ligge i, at hos den forste mangle Kindbakkeme Palpe ligesom ogsaa Tyggeknude, og det sidste 
Par Springfødder er eengrenet, meilens hos Leucothö̈ Kindbakkerne have Palpe og det sidste Par Springfodder er togrenet. Spence Bate henfører derimod i 1862 den typiske Slagt Stenothuë, hvormed tildels Monta!nıa falder sammen, til sin Underfamilie Stegocephalides paa Grund af de meget store Sideplader. Costa stillede i 1856 Slagten Probolium, som ogsaa falder sammen med den nævnte Slægt, til Gammarina. I 1860 fulgte jeg Dana's Classification og heuforte Slrgen Stenothoë til Leucothoince, ligesom Lilljeborg i 1865. Derimod maatte jeg i 1870, da jeg fandt, at flere nye Slægter staa Stenothoë meget nær og vise en stor typisk Overensstemmelse med denne, medens de afvige fra Leucothö̈, sammenstille disse i en ny Underfamilie, Stenothoince.

Gen. I. STENOTHOE, Dana, 1852.

Syn.: 1852. Sten othoë, Dana, Am. journ. of sci. and arts. p. 59. U. S. explor. exped. Crust. p. 909.

1853. Probolium, Costa, R. sui Crost. amfip. del regno di Napoli. 185\%. p. 199. 1855. Montagua, Spence Bate, Brit. Assoc. Rep. p. 57. Ann. Nat. Hist. 1857. XIX. p. 137. Catal. Amphip. Crust. Brit. Nus. 1862. p. 54. 185\% - White, Pop. Hist. Brit. Crust. p. 166.

1860. Stenothoë, A. Boeck, Forh. ved de skand. Naturf. 8de Møde. p. 65 ว.

1862. - Spence Bate, Catal. Amphip. Crust. Brit. Mus. p. 60.

1863. Montagua, Spence Bate and Westwood, Brit. sessile-eyed Crust. p. 53.

1865. Sten othoë, Lilljeborg, On the Lysianassa magellanica.

1867. Probolium, Heller, Denkschr. d. k. k. Acad. d. Wissensch. 2. Abth. p. 13.

1868. - Norman, Rep. on the Shetland Crust. p. 273.

1870. St enothoë, A. Boeck, Crust. amphip. bor. et arct. p. 59.

Type: Stenothoüvalidus, Dana.

Mandibula sine palpo et tuberculo molari.

Maxillæ $1 \mathrm{mi}$ paris palpo 2articulato.

Pedes 5 ti paris articulo 1 mo postice non dilatato.

Epimerum 4tum postice non incisum, sed perrotundatum.

Dana opstillede denne Slægt paa en Art fra Brasilien, S. validus. Han fremhæver blandt de ovrige Karakterer, at Kindbakkerne ikke ere forsynede med Palpe, og at de mangle Tyggeknude. Spence Bate opforte Sligten Montagua i 1855, men i hans Diagnose kan jeg ikke finde, at den i nogen væsentlig Henseende kan skilles fra Stenothoë, hvilket han ogsaa selv ytrer i 1862; for begge er det karakteristisk, at Kindbakkerne mangle Palpe. Costa opstillede i 1853 Slagten Probolium, men anforer i sin Diagnose ikke noget om, hvorvidt Kindbakkerne have eller mangle Palpe. Han henførte 
hertil kun Arten polyprion. Jeg har havt Anledning til at undersøge denne Art fra Middelhavet og fundet, at Kindbakkerne mangle Palper, og den kan saaledes ikke skilles fra Slægten Stenothoe. Heller, som optager Costa's Slægtsnavn, stiller ogsaa hertil $P$. marimum, der er en karakteristisk Stenothoë. Han nævner Intet om Munddelene og karakteriserer den kun ved Sidepladernes Størrelse samt stiller den i Familien Gammarida foran Slægten Lysianassa.

STENOTHOË MARINA, Spence Bate, 1855.

(Pl. XVII. fig. 2.)

Montagua marina, Spence Bate, Brit. Assoc. Rep. 1855. p. 5\%. Ann. Nat. Hist. 1857. XIX. p. 13\%. Catal. Amphip. Crust. Brit. Mus. 1862. p. 56. pl. VIII. fig. 5.

- - White, Pop. Hist. Brit. Crust. 1857. p. 166.

- $\quad$ - Spence Bate and Westwood, Brit. sessile-eyed Crust. 1863. p. 58. Stenothoё Danai, A. Boeck, Forh. ved de skand. Naturf. 8de Møde 1860. p. 655.

Proboliam marinum, Heller, Denkschr. d. k. k. Acad. d. Wissensch. 1867. 2. Abth. p. 14. - - Norman, Rep. on the Shetland Crust. 1868. p. 273.

Stenothoë marina, A. Boeck, Crust. amphip. bor. et arct. 1870. p. 59.

Antennx elongatx; superiores articulo pedunculi 1 mo circiter ter longiore qvam crasso. Pedes $1 \mathrm{mi}$ paris articulo 3 tio in angulo inferiore postico valde producto et in apice setis instructo; manu eadem ferme longitudine ac carpo, in margine anteriore parum et in posteriore valde curvata. Pedes 2 di paris articulo 3 tio brevissimo, postice sursum producto et acuto; manu permagna, elongata, ovata, in margine posteriore nodulis vel dentibus obtusis et setis instructa. Pedes 6ti paris arliculo 1mo dilatato. Pedes trium parium ultimorum arliculo 4to breviore qvam 3tio; articulo 5to longitudinem articulorum antecedentium junctorum non reqvanti. Pedes saltatorii ultimi paris ramo eadem ferme longitudine ac pedunculo.

Længden ểr $3^{5 / 1} 0^{\mathrm{mm}}$.

Legemet er sammentrykt fra Siderne $\mathrm{og}$ temmelig høit. Det tredie Haleleds nedre, bagre Vinkel er forlænget, stump. Den første Sideplade er næsten fuldkommen skjult af den anden, der er afrundet paa den nedre Rand; den tredie er storre end den foregaaende, mere skraa afskaaren paa.den nedre Rand; den fjerde er meget stor, oval, bred paa det forreste $\mathrm{og}$ smalere paa det bagre Parti, med en afrundet nedre Rand samt ikke indskaaret paa den bagre Rand. Hovedet er langere end det forste Legemsled og gaar mellem de øvre Følere ud i et stumpt Pandehorn.

De øvre Følere naa, naar de boies bagud, til det forste eller andet Haleled. Skaftets første Led er omtrent saa langt som Hovedet; det andet er lidt kortere, men 
smalere; det tredie er meget kort. Svøben er langere end Skaftet og dannes af 16 forliengede Led.

De nedre Følere ere af den samme Længde som de øvre, eller lidt længere. Skaftets fjerde og femte Led ere omtrent lige lange. Svaben, der er noget længere end Skaftets sidste Led, dannes af 8-10 Lied.

Kindbakkernes Gribedel er meget bred, forsynet med mange 'Tænder, hvoraf de midtre ere de største; den indre Bigren er ogsaa meget bred, ubetydelig skraa afskaaret og har mange Tænder.

Det første Kjæbepar er lidet. Palpen er kort og bred; det andet Led, der er noget længere end det første, har paa Enden og paa den indre Rand inange smaa, stumpe Torne.

Kjabeføddernes Palpe er overmaade forlænget; Leddene aftage efter hverandre $\mathrm{i}$ Bredde og ere besatte med Borsteknipper paa den indre Rand. Kloen er meget stærk.

Det forste Fodpar er meget-mindre end det andet; det forste Led er omtrent saa langt som de følgende tilsammen og har Borster paa den bagre Rand og paa den indre Sfde; det tredie Leds nedre, bagre Vinkel forlanger sig i et tykt stumpt Fremspring, der naar frem til det folgende Leds ydre Eude, og hvilket, saavel som den bagre Rand, er besat med Borster; Handen er noget længere end bred, af den samme Længde som det foregaaende Led og af en noget udvidet Form, med en større Krumning af den bagre end af den forreste Rand; den bagre Rand har nogle Børster.

Det andet Fodpar er hos Hannen særdeles stort; det første Led er det længste, medens de tre folgende ere meget korte; det tredie og fjerde Leds nedre, bagre Vinkel er udtrukket 0 g tilspidset, livilket især er Tilfaldet hos det tredie Led; det femte er særdeles stort, ægformet, med stumpe Tænder og korte Børster paa den bagre Rand. Kloen er lang, noget krummet og har nogle Borster paa den bagre Rand.

Det tredie og fjerde Fodpar ere stærke og have Børster paa den bagre liand.

De tre folgende Fodpar ere næsten af eens Bygning og eens Længde; det femte Pars første Led er ikke udvidet; de tvende følgende Pars første Led er ovalt; det tredie Led er meget bredt, med en forlanget nedre, bagre Vinkel; det fjerde er kortere end det foregaaende Led, og det femte er meget længere end det fjerde; disse Led have stærke Torne paa den forreste Rand.

Det forste Par Springfødder naar langst bagud; dets Grene, der ere forlængede, cylindriske, ere indbyrdes lige lange og kortere end Grundleddet.

Det andet Pars ydre Gren er kortere end den indre, der er omtrent saa lang som Grundleddet.

Det sidste Par har kun een Gren, der er toleddet, og hvoraf det første Led er det længste; den er noget længere end Grundleddet. Alle Springfolders Grundled og Grene ere forsynede med Torne. 
Halevedhænget er forlænget ovalt, tilspidset mod Enden og besat med trende Torne.

Den er fundet ved Mosterhavn og ved Christiansund af G. O. Sars paa 50-100 Favne og af mig ved Farsund. Efter Spence Bate findes den ved den engelske Kyst og efter Norman ved Shetland; den gaar ned lige til Middelhavet. Heller tror at have fundet den i det adriatiske Hav. Af Metzger er den taget ved den ostfrisiske Kyst.

\title{
STENOTHOE MONOCULOIDES, Montagu, 1815.
}

\author{
(Pl. XVII. fig. 1.)
}

Cancer Gammarus monoculoides, Montagu, Trans. Linn. Soc. XI. p. 4. pl. 2. fig. 3. Typhis monoculoides, Milne-Edwards, Ann.'sci. Nat. XX Aug. 1830.

$$
\begin{aligned}
& \text { - White, Cat. Brit. Crust. 1850. p. } 58 \\
& \text { - - Gosse, Mar. Zool. 1855. p. 140. fig. } 252 .
\end{aligned}
$$

Montagua monoculoides, Brit. Assoc. Rep. 1855. p. 57. Ann. Nat. Hist. 185\%. XIX. p. 137. Catal. Amphip. Crust. Brit. Mus. 1862. p. 55. pl. VIII. fig. 4.

Probolium monoculoides, Norman, Rep. on the Shetland Crust. 1868. p. 273.

Stenothoë monoculoides, A. Boeck, Crust. amphip. bor. et arct. 1870. p. 60.

Antenna perbreves; superiores articulo pedunculi Imo vix duplo longiore qvam crasso. Pedes 1 mi paris articulo 3tio postice purum producto; carpo perbrevi, triangulari; manu plus qvam duplo longiore. fere ractangulari, in acie obligve truncata. Pedes 2di paris eadem forma, sed multo majores; articulo 3 tio in angulo inferiore postico ad spinam produclo; manu extrorsum paulo latiore. Pedes 6 ti paris articulo 1 mo parum modo dilatato, plus duplo longiore qvam lato. Pedes $7 \mathrm{mi}$ paris arliculo 1 mo dilatato. Pedes trium parinu ultimorum articulo 3tio non perdilatato et longitudinem 4 li angusti aeqvanti; articulo 5 to eadem ferme longitudine ac articulis duobus antecedentibus junctis. Pedes saltatorii ultimi paris rano longiore qvam pedunculo brevi.

Længden er $3^{\mathrm{mm}}$.

Legemet er langstrakt, smalt, sammentrykt fra Siderne. Det tredie Haleleds nedre, bagre Vinkel er udtrukket. De fire første Sideplader ere store, især den sidste af disse, der bedakker aldeles det forste Led paa det femte Fodpar og tildels paa det sjette. Hovedet er næsten saa langt som de tvende første Legemsled tilsammen og gaar fortil frem i et lidet Pandehorn; Sidevinklerne ere afrundede. 
De øvre Følere ere korte og naa, naar de bøies bagud, til det fjerde Legemsled. Skaftets første Led el kortere end Hovedet og omtrent dobbelt saa langt som tykt; de tvende følgende aftage efter hinanden saavel i Længde som Tykkelse. Svoben, der er længere end Skaftet, dannes af 12 Led.

De nedre Følere ere omtrent af den samme Langde som de ovre, eller noget kortere; det tredie Led er kort; det fjerde og femte, der ere næsten lige lange, ere kun lidt mere end dobbelt saa lange som brede. Svøben er omtrent saa lang som Skaftet $0 \mathrm{~g}$ dannes af 8 Led.

Kindbakkerne ere delte $\mathrm{i}$ Spidsen $\mathrm{i}$ en indre, ikke tandet Plade og en ydre, meget bredere, der er indskaaret i fire grove 'Tænder; under Spidsen sees en Række krumme Torne.

Det første Kjæbepars ydre Plade er forlænget og har paa Enden meget grove Torne. Palpen er toleddet og har paa Enden nogle smaa Torne.

Kjæb efod dernes Plader ere rudimentære. Det Led, hvortil den indre PJade er fæstet, er meget kort, hvorimod det, hvortil den ydre er fæstet, er særdeles langt, meget længere end Palpens tvende forste Led. Dennes tredie Led er forlænget. Kloen er kort, men stærk, kamdannet paa den indre Rand.

Det forste Fodpar er kort; det forste Led er langt, men de tre følgende ere meget smaa. Det tredie Leds nedre, bagre Vinkel er ubetydelig udtrukket, besat med Borster; det fjerde er meget kort, triangulært; Haanden er derimod meget lang; forlænget firkantet, med en skraa afskaaret, kort Griberand. Kloen er stærk, temmelig bgiet.

Det andet Fodpar er af den samme Form, men længere og kraftigere; det tredie Leds nedre, bagre Vinkel er udtrukket, ligesom ogsaa hos det fjerde Led; Haanden, der er lidt bredere mod den ydre Ende, er forsynet med tvende strerke Torne, hvor Kloens Spids lægger sig til.

Det tredie og fjerde Fodpar ere middelmaadig forlængede; det tredie Led er lidet udvidet, med en tilspidset nedre, forreste Vinkel, og er længere end det fjerde, men kortere end det femte Led. Kloen er kortere end det sidste Leds halve Langde, lidt krummet.

Det femte og sjette Fodpar ere lig de tvende foregaaende og af den samme Bygning, men det sjette Pars forste Led er noget udvidet.

Det syvende Fodpars forste Led er udvidet meget mere end hos det foregaaende Par; det tredie Led er noget udvidet nedad, saa langt som det fjerde, og begge tilsammen ere næsten af den samme Længde som det femte Led.

Springfodderne ere korte og Grenene lige lange.

Det første $\mathrm{P}$ ar nar længst bagud.

Det andet $\mathrm{Par}$ er meget kortere, og Grenene ere kortere end Grundleddet.

Det sidste Pars Gren er næsten dobbelt saa lang som Grundleddet og delt i trende næsten lige store Dele. 
Halevedhænget er kort, rgformet tilspidset, besat paa Randene med 3-4 korte Børster.

Farven er hvid, med enkelte røde Pletter. Oinene ere røde.

Den er ikke ualmindelig i Tangen ved vore Kyster. Jeg har fundet den ved Karmoen og Farsund, G. O. Sars i Christianiafjorden. Den er ligeledes fundet paa mange Steder ved den engelske Kyst, Shetland, og af Metzger ved den ostfrisiske Kyst.

Gen. II. METOPA, A. Boeck, 1870.

Deriv.: MÉrorx, et Egennavn.

Syn.: 1870. Metop a, A. Boeck, Crust. amphip. bor. et arct. p. 60.

Type: Leucothoü clypeata, Kroyer.

Mandibula palpo brevi, 3articulato; articulo 3tio fere obsoleto.

Maxilla $1 \mathrm{mi}$ paris palpo 1articulato.

Reliqva cum genere Stenothoë ferme conveniunt.

Krøyer henforte tvende nye Arter til Slxgten Lucothoë, nemlig L. clypeata og L. glacialis, men for at faa disse ind i Slægten maatte han forandre dennes Karakter. Spence Bate og Goës henforte disse Arter til Slagten Montagur. endskjont Kroyer baade har beskrevet og afbildet Kindbakkerne som forsynede med Palpe, hrorfor de altsaa ikke kunde komme ind under en Slægt, der netop karakteriseres ved, at Kindbakkerne mangle Palpe, saaledes som Tilfieldet er med Spence Bate's Montanun, der er synonym med Stenothoë. Disse Arter maa derfor udelukkes saavel fra denne Slægt som fra Lencothoë og danne en ny Slægt, som jeg i 1870 kaldte Metopa. Til denne henregner jeg ogsaa de allerede forhen kjendte Montagua Alderii og Montagna (Lencothoï) Norvegica, Lilljeborg, samt desuden flere nye Arter. Tenne Slægt adskiller jeg vasentlig fra Stenothoë ved, at Kindbakkerne have en kort, treleddet Palpe, hvis sidste Led dog er rudimentært, og ved at det forste Kjæbepars Palpe er cenleddet.

\section{ME'TOPA CLYPEATA, Krøyer, 1842.}

(Pl. XVIII. fig. 4, 5; Pl. XIX. fig. 3.)

Leucothoë clypeata, Kroyer, Nat. Tidsskx. 1842. 1. R. IV. p. 157; 2. R. I. p. 545. Voy. en Scand. pl. 22. fig. 2. a.

Montagua clypeata, Spence Bate, Catal. Amphip. Crust. Brit. MLus. 1862. p. 58. pl. IX. fig. 4.

- - Goës, Crust. amphip. maris Spetsb, 1865. p. 6. 
Montagua clypeata, Spence Bate and Westwood, Brit. sessile-eyed Crust. 1868. II. App. p. 499.

Metopa clypeata, A. Boeck, Crust. amphip. bor. et arct. 1870. p. 60.

Epimera non longissima. Antennæ superiores tres qvartas longitudinis corporis aqvantes; articulo 1 mo multo longiore qvan capite; flagello 25 articulato. Antenna inferiores articulo 3tio fere ter longiore quam crasso. Pedes 1 mi paris articulo 3tio ad processum magnum, apicem versus rotundatum, dilatato; 4 to ter aut qvater longiore qvam crasso; 5to ferme duas tertias longiludinis 4ti partes axvanti, lineari; ungve parvulo, nodoformi. Pedes 2 di paris manu permagna, apicem versus latiore, in acie obliqve truncata et denticulis multis, in angulo inferiore postico dente magno, armala. Pedes 3 tii et 4 ti paris articulo 3 tio multo longiore qvam 4 to; ungve in margine postico serrato. Pedes 5 ti paris articulo 1 mo non dilatato; articulo 4 to et 5to junctis paulo longioribus qvam 3tio. Pedes 6li et $7 \mathrm{mi}$ paris articulo 1 mo dilatato. Pedes saltatorii ultimi paris pedunculo apicem versus crassiore et in margine superiore postico producto; ramo et pedunculo eadem ferme longitudine: dimidio exteriore rami spinam validam efficienti.

Længden er $4^{\mathrm{mm}}$.

Legemet er temmelig sammentrykt. Det forste Legemsled er meget lidet, og de tre følgende tiltage efter hverandre saavel i Høide som i Bredde. Den første Sideplade er ogsaa meget liden og er skjult under den anden, der er forlænget nedad og afrundet; den tredie er langere og noget bredere; den fjerde er overmaade stor, skjoldformet, noget bredere end høi, høiere paa det forreste end paa det bagre Parti og dækker ikke det femte Fodpars forste Led; de følgende Sideplader ere brerlere end høie. Hovedet er ikke fuldt saa langt som de tvende første Legemsled tilsammen og danner mellem de ørre Folere en stump Vinkel; Sidevinklerre ere afrundede. Øinene ere ovale, næsten runde.

De øvre Følere ere noget kortere end Legemet. Skaftets første Led er meget længere end Hovedet; det andet er næsten af den samme Længde, men smalere; det tredie er sierdeles kort, omtrent en Fjerdedel af det sidste Leds Længde. Svøben, der er meget langere end Skaftet, dannes af 20-25 Led, hyoraf det forste er længere end Skaftets sidste Led og længere end de tvende folgende tilsammen. Hos Hunnen er dette Led kortere.

De nedre Følere ere kortere end de ovre. Skaftets tredie Led er mere end dobbelt saa langt som tykt; det fjerde og femte ere længere og omtrent lige lange. Svgben er af Skaftets halve Laogde og dannes af 10-12 Led.

Overlæben er kort og bred, indskaaret paa Enden.

Kindbakkerne ere korte og stærke; Gribedelen er bred, paa Enden indskaaret i ti Tænder, hvoraf de tre midtre ere de største; den indre Bigren er bred, 
tandet; Tornerækken dannes af mange, men korte og stærke Torne; Tyggeknuden mangler. Palpen er kort; det andet Led er forsynet med fem lange Børster; det tredie er knudeformet, med en lang Børste paa Enden.

Det forste Kjæbepars ydre Plade er paa Enden vabnet med mange simple Torne; den indre Plade er liden, oval, med en enkelt Børste paa Enden. Palpen er forlænget, eenleddet, afrundet paa Enden og besat med stærke, korte Torne.

Det andet $\mathrm{Kj}$ æbepar er lidet; den indre Plade er kortere og smalere end den ydre.

Kjæbefødderne ere forlangede; den ydre Plade er rudimentær og sees kun som en Knude paa det andet Led, som saaledes synes at tilhore Palpen; den indre Plade er firkantet, med nogle Børster paa Enden. Palpens tre første Led tiltage efter hverandre lidt i Længde; det fjerde er det længste, kloformet, med fine Torne langs den indre Rand.

Det forste Fodpars tredie Led er i den nedre, bagre Vinkel udvidet til en buet, med lange Børster forsynet Fremragning; det fjerde er meget langt, smalere mod den ydre Ende og har Børster paa den bagre Rand; det femte Led er kortere end det foregaaende, cylindrisk og roed spredte Børster paa den bagre Rand. Kloen er knudeformet.

Det andet Fodpar er meget stærkt; det fjerde Led er lort, triangulært, og dets nedre, bagre Vinkel er udtrukket til en buet, med Borster besat Fremragning. Haanden er meget stor, længere end det første Led, bliver bredere udad, med noget convexe Rande; Griberanden er skraa afskaaret, fint saugtakket, og der sees en stærk Torn paa Enden af den bagre Rand. Iỉloen er meget stærk og krum.

Det tredie og fjerde Fodpar ere af næsten eens Form og Storrelse, men det forste af disse er smalere end det andet, hvis tredie Led er ikke fuldt saa langt som de tvende sidste tilsammen og har en udtrukken nedre, forreste Vinkel; det femte I.ed er kun lidt læengere end det fjerde, og begge have Tornebundter paa den bagre Rand.

Det femte Fodpars forste Led er ikke udvidet; det tredie er forlænget og næsten saa langt som de tvende folgende Led tilsammen, hvilke indbyrdes ere omtrent lige lange.

De trende følgende Fodpars første Led er udvidet bagtil, med en afrundet, glat, bagre Rand; det tredie er noget kortere end de tvende følgende Led tilsammen.

Springfodderne ere forlængede.

Det forste Pars Grene ere lidt kortere end Grundleddet.

Det sidste Párs Grundled er meget tykt, lidt bredere mod Enden og udvidet samt udtrukket indad paa Enden af den ovre Rand. Endegrenen er omtrent saa lang som Grundleddet, og dens ydre Halvdel dannes af en Torn.

H a l eved hæn get er forlænget ægdannet.

Denne Art er fundet af Kroyer i Bell Sund paa Spitsbergen. Den er efter Krøyer ligeledes fundet ved Grønland. 
Lilljeborg har i Kgl. Vet.-Akad. Handl. 1850. p. 335 beskrevet en Form $L$. Norvegica, som jeg har anseet at være synonym med $\boldsymbol{M}$. clypeata.

Denne Form, der af Spence Bate kaldes Montagua Norvegica og af ham ligeledes antages synonym med $\boldsymbol{M}$. clypeata, og som er optaget af Spence Bate og Westwood, beskrives af Lilljeborg paa folgende Maade:

„L. clypeata sat affinis. Antennæ superiores inferioribus longiores, Hagello pedunculo longiore, articulo primo secundum superante et articulo tertio minimo; flagellum antennæ inferioris ultimo pedunculi articulo brevius vel æqvale: manus pedum secundi paris maximæ, dilatatæ, apice vero acuminat $x$ aculeoqve marginis posterioris medii validissimo et ungve æqvali. Epimera qvarti annuli thoracici maxima, latitudine vero altitudine parum majore." Bruzelius (Skand. Amphip. Gamm. p. 96) har optaget den med følgende Diagnose: "Corpus compressum, epimeris primi paris perparvis, qvarti paris maximis. Pedes secundi paris articulo qvinto magno, oblongo, postice processum longum emittente. Pedes abdominis ultimi paris singulis ramis instructi." Han anforer dog, at det er muligt, at den kun er Hannen til $L$. clypeata. Han har fundet den i et Exemplar i Gullmarsfjorden i Bohuslen, Lilljeborg ligeledes i et Exemplar ved Tromsa. Af G. O. Sars er den fundet red Christiansund paa 50-100 Favne. Af Milne-Edwards er den ifolge Spence Bate og Westrood taget ved Bannf.

\section{METOPA GLACIALIS, Kroyer, 1842.†}

Leucothoë glacialis, Kroger, Nat. Tidsskr. 1842. 1. R. IV. p. 159. 1845. 2. R. I. p. 539. Voy. en Scand. pl. 22. fig. 3.

Montagua glacialis, Spence Bate, Catal. Amphip. Crust. Brit. Mus. 1862. p. 58. pl. IX. fig. 3 .

Goës, Crust. amphip. maris Spetsb. 1865. p. 6.

Metopa glacialis, A. Boeck, Crust. amphip. bor. et arct. 1870. p. 61.

Epimera minora qvam apud speciem priorem. Antenna superiores breviores, dimidiam animalis longitudinem reqvantes; articulo pedunculi 1 mo parum longiore qvam 2do; flagello 10articulato. Antenne inferiores superioribus parum breviores; articulo pedunculi 4 to vix longiore qvam 5to; 3tio paulo plus qvam duplo longiore ac crasso. Pedes $1 \mathrm{mi}$ paris parvi; carpo inflato, lato, ovato, non duplo longiore qvam lato: manu breviore et angustiore qvam carpo, apicem versus paulo latiore, in acie truncata: ungve brevi, in apice attenuato. Pedes 2di paris manu elongata, fere ter longiore qvam lata, in medio margine posteriore dente valido armata; ungve curvato. Pedes 3 tii et 4 ti paris articulo 3 tio nou multo lon- 
giore qvam 4to; loc et 5to eadem ferme longitudine. Pedes 5 ti paris articulo 1 mo non dilatato; articulo 4to et 5to junctis longioribus qvam 3tio. Pedes 6ti et żmi paris articulo 1 mo postice dilatato. Pedes saltatorii paris ultimi pedunculo crasso, non producto.

Længden er $3^{3} / 5^{\mathrm{mm}}$.

Le gemet er forlænget, sammentrykt; Ryggen er rund. Den første Sideplade er skjult af den anden, som er temmelig bred, afrundet paa den nedre Rand; den tredie er bredere og høiere; den fjerde er den storste, skjoldformet, med en regelmæssig afrundet nedre og bagre Rand, hvorved der fremkommer en oval Form; de sidste Sideplader ere smaa og bredere end høie.

De øvre Følere ere lidt kortere end Legemets halve Længde. Skaftet er forlænget; dets første Led er lidt længere og meget tykkere end det andet; det tredie er kort. Svoben dannes af 10 Led.

De nedre Folere ere næsten af den samme Længde som de øvre. Skaftets tredie Led er lidt mere end dobbelt saa langt som bredt; det fjerde er omtrent af den samme Længde som det femte.

Det $f$ rste Kjæbepars Palpe er efter Krøyer toleddet.

Kjæbef $ø$ ddernes Palper ere meget tynde; det tredie Led er meget forlænget, næsten saa langt som de tvende foregaaende tilsammen og meget længere end Kloen.

Det første Fodpar er lidet, men kraftig udviklet; det fjerde Led er opsvulmet, bredt, ovalt, medens Haanden er meget kortere og smalere samt bliver bredere mod Enden; Griberanden er kort. Kloen er kort og stærk.

Det andet Fodpar er næsten dobbelt saa langt som det første; det fjerde Led er kort, bredt, triangulært; Haanden er meget lang, med noget bøiede Rande. Den bagre Rand har nær Midten en stærk Tand, hvor Kloens Spids lægger sig imod; mellem denne Tand og et nærmere Enden liggende Uddsnit er Randen fint crenuleret. Kloen er stærk og krum.

Det tredie og fjerde Fodpar ere næsten af eens Længde; det tredie Led er lidet, udvidet nedad og noget længere end det fjerde Led.

Det femte Fodpars forste Led er ikke udvidet; det tredie er lidt længere end det fjerde, men ikke meget udvidet i sin nedre, bagre Vinkel.

De tvende følgende Fodpars forste Led er temmelig udvidet bagtil; det tredie er, kun lidt linngere end det fjerde Led.

Det forste Par Springfødders Grene ere saa lange som Grundleddet.

Det sidste Pars Grundled er meget tykt og skal efter Krøyer besidde tvende Torne.

Halevedhænget er forlænget ægdannet.

F arven er hvidgul. 
Den er fundet af Kroyer i tvende Exemplarer ved Spitsbergen, og ifølge Goës sammesteds i Kings Bay af Smitt, i Bellsund og Hornsund af Torell, i Storfjord af Malmgren, samt ved Grønland og Island af Torell.

METOPA ALDERII, Spence Bate, 1855.

(PI. XVII. fig. 3 og 4.)

Montagua Alderii, Spence Bate, Brit. Assoc. Rep. 1855. Ann. Nat. Hist. 1857. XIX. p.

137. Catal. Amphip. Crust. Brit. MIus. 1862. p. 57. pl. VII. fig. 6. White, Pop. Hist. Brit. Crust. 185\% p. 166.

Montagua Alderi, Spence Bate and Westrood, Brit. sessile-eyed Crust. 1863. I. p. 61. - - Goës, Crust. amphip. maris Spetsb. 1865. p. 6.

Probolium Alderi, Norman, Rep. on the Shetland Crust. 1868. p. 273.

Metopa Alderii, A. Boeck, Crust. amphip. bor. et arct. 1870. p. 61.

Epimerum 4tum sat altum, non vero latum. Antenna superiores et inferiores apud feminam ferme eadem longitudine. Antemm inferiores apud marem multo magis elongati qvam apud feminam. Antenna superiores articulo pedunculi 1 mo apud feminam paulo breviore, apud marem paulo longiore quam capite; articulis duobus seqventibus magnitudine paulatim decrescentibus. Antenne inferiores articulo pedunculi 410 el 510 eadem longitudine. Pedes $1 \mathrm{mi}$ paris carpo angusto: manu eadem ferme longitudine, apicem versus apud feminam angustiore, apud marem paulo dilatata. Pedes 2di paris apud marem multo robustiores qvam apud feminam; carpo perbrevi, in angulo inferiore postico calce brevi instructo; manu apud marem permagna, subquadrata, in acie obliqve truncata et dentibus armata, in angulo inferiore postico in dentem validum producta. Pedes 3 tii et 4 ti paris articulo 3 tio non multo dilatato. Pedes 5 ti paris articulo 3 tio postice dilatato et in angulo inferiore postico producto. Pedes 6ti et $7 \mathrm{mi}$ paris articulo 1 mo perdilatato, interdum fere eadem latitudine ac altitudine; 3tio postice valde dilatato et in angulo inferiore postico ad finem articuli 4 ti producto; 4 to brevi, multo breviore qvam 5to. Pedes saltatorii ultimi paris ramo et pedunculo eadem ferme longitudine; pedunculo in margine superiore spinis $2-3$ instructo; dimidio exteriore rami spinam validam eflicienti.

Længden er 7 mm.

Den auden Sideplade dækker nsesten fuldstæendig den forste; den fjerde er bredere $\mathrm{i}$ det øvre end $\mathrm{i}$ det nedre Parti, temmelig høi og skjuler ikke de trende sidste Fodpars forste Led. Hovedet, der er nxsten saa langt som de tvende første Legemsled, 
gaar ud i et kort, stumpt Pandehorn; Sidevinklerne ere afrundede. Øinene ere smaa, runde.

De. øve Føleres første Skaftled er omtrent saa langt som Hovedet; det andet er smalere og kortere samt kun lidt mere end dobbelt saa langt som bredt; det tredie Led er end kortere. Svøben er saa lang som Skaftet og dannes af 10 korte Led.

De nedre Følere ere hos Hannen længere end de øvre. Skaftet naar omtrent til Enden af de øvre Følere; dets tredie Led er mere end dobbelt saa langt som tykt; det femte Led er saa langt som det fjerde, eller noget langere end dette Led. Svøben er kortere end Skaftets sidste Led.

Kjæbeføddernes Palpes forste Led er noget længere end bredt, og de tvende følgende tiltage efter hinanden i Langde. Kloen er besat med Børster paa den bagre Rand.

Det forste Fodpar er kort og stærkt; det tredie Leds nedre, bagre Vinkel er ikke meget udvidet; det fjerde er længere end tykt; det femte, der danner en Haand, er omtrent af den samme Længde, men smalere $\mathrm{og}$ lidt krummet paa Enden. Denne er skraa afskaaret og hos Hannen bredere end hos Hunnen. Kloen er krum og har nogle Borster paa den bagre Rand.

Det andet Fodpar er længere end det forste, men dog kort og stærkt; det fjerde Leds nedre, bagre Vinkel er ikke meget udtrukket, besat med fjordannede Børster; Haanden er hos Hannen forlænget firkantet, Griberanden er skraa afskaaret og tandet, med en dyb Indskjæring nær den bagre Rands ydre Ende, hvorved dannes en Tand, og ved denne sees en Torn. Hos Hunnen er dette Fodpar meget svagere dannet.

Det tredie og fjerde Fodpar ere af eens Bygning, men det sidste af disse er det kraftigste; det tredie Led er noget udvidet nedad, og dets nedre, bagre Vinkel er udtrukket; det fjerde er kortere; det femte er længere end dette, saa langt som det tredie Led, men meget smalere.

Det femte Fodpars forste Led er ikke udvidet.

De tvende følgende Fodpars forste Led er meget stærkt udvidet, og dets nedre, bagre Vinkel er udtrukket, afrundet, især paa det syvende Par; det tredie er ogsaa meget udvidet, og den nedre, bagre Vinkel er betydelig udtrukket; det fjerde er meget kortere end det fortil krummede femte Led.

Det forste Par Springfødder naar længst bagud; Grenene ere lige lange, kortere end Grundleddet.

Det andet Pars Grene ere af den samme Længde som Grundleddet, eller ubetydelig længere.

Det sidste Pars Gren, der er delt i tvende næsten lige lange Dele, er saa lang som Grundleddet; dette er par den ovre Rand besat med 2-3 Torne.

Halevedh $x$ get ér dobbelt saa langt som bredt ved Roden, med fine. Torne paa den øvre Rand.

Paa Spence Bate's Tegning er det første Fodpars tredie Led mere udtrukket 
nedad, end det er Tilfældet paa min Form, og er i denne forlængede Vinkel forsynet med nogle fjærdannede Børster. Haanden er desuden kortere og smalere end det foregaaende Led. Det sjette og syvende Fodpars forste Led er ogsaa mere tydelig udtalt saugtakket, end det finder Sted paa min Form.

Farven er hvid; rode Baand gaa over Ryggen paa hvert af Leddene og strække sig ned over Sidepladerne. Øinene ere røde.

Den synes at være sjelden. Jeg har kun fundet den ved Karmøen og i et Exemplar i Christianiafjorden. G. O. Sars har taget den ved Odvær, i Christianiafjorden, ved Aalesund og ved Christiansund paa 80-100 Favne. Den er taget ved Spitsbergen af Torell $0 \mathrm{~g}$ ved Bohuslen af B. Fries. Ved England synes den heller ikke at være hyppig og er der fundet af Alder og Norman.

\section{METOPA BRUZELII, Goës, 1865.}

(P1. XVIII. fig. 2.)

Leucothoë clypeata, Bruzelius, Skand. Amphip. Gamm. 1859. p. 96. Montagua Bruzelii, Goës, Crust. amphip. maris Spetsb. 1865. p. 6. fig. 10. Metopa Bruzelii, A. Boeck, Crust. amphip. bor. et aret. 1870. p. 62.

Corpus et epimera ferme ut apud speciem antecedentem. Antennæ superiores articulo pedunculi 2do longiore qvan 1mo. Pedes trium parium ultimorum articulo 3tio non tam dilatato et pedes saltatorii ultimi paris longiores qvam apud speciem Alderii.

Lrngden er $2^{\mathrm{mm}}$.

Legemet er sammentrykt; Ryggen er rund. Den første Sideplade er dækket af den anden; den fjerde er overmaade stor, bredere end hoi.

De øvre Føleres forste Skaftled er omtrent saa langt som Hovedet; det andet er hos Hunnen lidt kortere, hos Hannen lidt længere end det første Led; det tredie er kort. Svoben dannes af 16-20 Led.

Det forste Fodpars femte Led er forlænget, smalt, ubetydelig kortere end det foregarende Led.

Det andet Fodpars fjerde Led er kort, triangulært og i den nedre, bagre Vinkel udtrukket til en kort, med Borster besat Hæl. Haanden er meget længere end det foregaaende Led $\mathrm{g}$ er bredere mod den ydre Ende, med skraa afskaaret Griberand.

Det femte Fodpars forste Led er ikke udvidet, lineært.

De tvende følgende Fodpars første Led er meget udvidet, med afrundet nedre, bagre Vinkel; det tredies nedre, bagre Vinkel er udtrukket, dog ikke saa meget som hos den foregaaende Art; det femte er ikke fuldt saa langt som de tvende foregaaende Led tilsammen. 
Det første Par Springfodders Grene ere lige lange.

Det sidste Pars Grens ydre Halvdel dannes af en stærk Torn.

Hal evedhænget er smalt, forlænget ægdannet, udelt, paa hver Side væbnet med tre stærke Tænder.

Den er fundet af Torell ved Grønland og Spitsbergen, af Lovén ved Vardø, af v. Düben ved Bergen, af mig ved Haugesund, af Bruzelius ved Bohuslen.

METOPA AFFINIS, A. Boeck, 1870.

(Pl. XIX, fig. 2.)

Mletopa affinis, A. Boock, Crust. amphip. bor. et arct. 1870. p. 62.

Epimerum 4tum multo latius qvam altum, in parte posteriore perrotundatum. Antennæ superiores inferioribus apud feminam breviores, apud marem longiores. Antenna inferiores articulo pedunculi 4 to parum longiore qram 5to. Pedes 1 mi paris manu et carpo eadem fere longitudine; manu angusta, ungviculo, in margine posteriore setoso, instructa. Pedes 2 di paris carpo brevissimo: manu parum modo longiore qvam lata, apicem versus latiore, apud marem valde, apud feminam parum dentata. Pedes 3 tii et 4 ti paris longissimi et angustissimi: articulo 4 to parum breviore qvam 3tio. Pedes 5 ti paris articulo 1 mo non dilatato et sat angusto. Pedes parium duorum ultimorum articulo 1 mo dilatato, 3tio non valde dilatato et in angulo inferiore postico parum modo producto. Pedes saltatorii ultimi paris breves; ramo longitudine pedunculo ferme aqvali, non duplo longiore qvam ungve.

L æn g d e n er $3-4^{\mathrm{mm}}$.

Legemet er forlænget, smalt, uden Kjol. Sidepladerne ere ikke saa store som hos de foregaaende Arter; den fjerde, der i det ovre Parti er bredere, end den er hoi, er meget smalere paa den nedre Ende og dakker ikke det sjette og syvende Fodpars forste Led. Hovedet er ubetydelig langere end de tvende forste Legemsled tilsammen.

De øvre Følere naa, naar de bøies tilbage, næsten til det forste Haleled. Skaftets første Led er saa langt som Hovedet; de følgende aftage i Længde og Bredde. Svøben er meget længere end Skaftet og er dannet af 11 Led, hvoraf det forste er langt, medens det andet er kort, og de folgende tiltage efter hverandre i Længde.

De nedre Folere ere meget kortere end de øvre. Skaftets tredie Led er omtrent saa langt som bredt, eller noget længere; det fjerde er ubetydelig længere end de ovre Foleres første Led og næsten af den samme Langde som det femte Led. Svøben, der er lidt længere end Skaftets sidste Led, er dannet af 5 Led, hvoraf det første er det længste. 
Kj $x b$ eføddernes Palpe er forlænget; det forste Led er det korteste; de tvende følgende tiltage efter hinanden $\mathrm{i}$ Længde. Kloen, der er smal og noget krummet, er længere end det foregatende Led og har fine Torne paa den bagre Rand.

Det første Fodpars tredie Led er kort, med en meget fremragende, tyk, afrundet nedre, bagre Vinkel, der er forsynet med Børster; de tvende følgende ere af eens Længde, men det fjerde er tykkere end det femte Led, der er forlænget smalt, noget krummet og danner ingen Haand. Kloeu er tynd, kort, med Børster paa den bagre Rand.

Det andet Fodpar er større og kraftigere; det fjerde Led er meget kort, og dets nedre, bagre Vinkel er ikke meget fremragende; det femte, eller Haanden, er noget kortere end det forste Led, af en uregelmæssig firkantet Form, og bliver bredere mod Enden; den næsten tvært afskaarne Griberand er hos Hannen forsynet med mange, hos Hunnen med færre Tænder. Kloen er stærk og svagt krummet.

Det tredie og fjerde Fodpar ere af eens Bygning, men det første af disse er noget længere og tyndere; det tredie Led er kort og lidet udvidet; det fjerde er end kortere, men det femte er meget længere end det tredie Led. Kloen er lang, svagt kiummet.

Det femte Fodpars forste Ised er ikke udvidet.

De tvende følgende Fodpars første Led er udvidet, af en kort, næsten firkantet Form og med en afrundet nedre, bagre Vinkel; det tredie er kort, udvidet paa den bagre Rand og med en lidet udtrukket nedre, bagre Vinkel; det fjerde er meget kortere end dette, og det femte Led er læengere. Kloen er stærk, lang og noget krummet.

Det første Par Springfødier naar længst bagud.

Det sidste Pars Gren er ubetydelig længere end Grundleddet, der er omtrent dobbelt saa langt som bredt.

Hal evedhanget er meget bredt.

Den Varietet af $\boldsymbol{M}$. Alderii, som Norman beskriver, hører sandsynligvis herhen.

Den er fundet af mig i Christianiafjorden, af G. O. Sars ved Skraaven paa 80-100 Favne og omtrent paa den samme Dybde ved Hvidingsøerne.

METOPA LONGICORNIS, A. Boeck, 1870.

(P1. XIX. fig. 1.)

Metop a longicornis, A. Boeck, Crust. amphip. bor. et arct. 1870. p. 63.

Epimerum 4tum multo latius qvam altum, securiforme. Antennæ perlongæ; superiores inferioribus parum breviores, ferme usqve ad seginentum postabdominis 4tum porrectix. Antennæe superiores articulo pedunculi 1 mo parum longiore qvam 
capite; 2do longitudine 1 mo ferme æqvali. Pedes $1 \mathrm{mi}$ paris apud feminam angustissimi, imprimis carpo el manu; manu non subcheliformi; apud marem latiores; manu parum subcheliformi. Pedes 2di paris utriusqve sexus non pervalidi, validiores tamen apud marem qvam apud feminam; manu apicem versus latiore, in acie oblique truncata. Pedes 3 tii et 4 ti paris perangusti. Pedes 6 ti et $7 \mathrm{mi}$ paris arliculo 1 mo dilatato; articulo 3 tio longitudinen articulorum duorum seqventium junctorum fere aqvanti. Pedes saltatorii ultimi paris ramo longitudine ferme pedunculo æqvali, in apice spina brevissima instruclo.

Længden er $4 \mathrm{~mm}$.

L egemet er smalt, sammentrykt, uden Kjøl. Det tredie Haleled har en bred Indskjæring paa Siderne, hvorved den nedre, bagre Vinkel synes at være noget tilspidset. Den anden Sideplade drkker fuldstændig den første; den fjerde er meget stor, bredere end høi, den øvre Del af den bagre Rand er indskaaret, men dækker dog næsten de tre sidste Fodpars forste Led. Hovedet er saa langt som de tvende forste Legemsled tilsammen og gaar fortil, mellem de ovre Følere, ud i et lidet Pandehorn; dets Sidevinkler ere udtrukne, afrundede.

De øvre Følere ere lange og naa, naar de bøies tilbage, til det fjerde Haleled. Skaftets første Led er længere end Hovedet; det andet er saa langt som det foregaaende; det tredie Led er meget kort, kun dobbelt saa langt som bredt. Svøben, der er saa lang som Skaftet, er dannet af 16 Led.

De nedre Følere ere lidt længere end de gvre. Skaftets tredie Led er dobbelt saa langt som tykt; det fjerde er længere og smalere end det forste Led paa de øvre Folere; det femte er omtrent af den samme Lxngde som det fjerde Led og dannes af 7 Led.

Kjæbefóddernes Palpe er temmelig kort; de tvende første Led ere lige lange; det tredie er ubetydelig længere. Kloen er næsten saa lang som det foregaaende Led, med fine Borster paa den bagre Rand.

Det første Fodpar er bredere og kraftigere hos Hannen end hos Hunnen; det tredie Led er kort, og dets nedre, bagre Vinkel er forlænget til en tyk, med Børster besat Fremragning; det fjerde er næsten tre Gange saa langt som bredt, smalere paa den ydre Halvilel; det femte Led er omtrent af den samme Langde, med en mere buet bagre end forreste Rand. Hos Hunnen er dette Led meget tyndere og smalere. Kloen er tynd, noget krummet.

Det andet Fodpar er meget forlænget og hos Hannen kraftigere end hos Hunuen; det tredie og fjerde Leds nedre, bagre Vinked er kun lidet udvidet. Haanden er bredere mod den ydre Ende; Griberanden er skraa afskaaret og forsynet med en stærk, bred Torn, hvor Kloens Spids lægger sig til.

Det tredie og fjerde.Fodpar ere meget forlængede, smale, dog mest det 
første af disse; det fjerde Led er kun lidt kortere end det femte. Kloen er neppe halvt saa lang som det sidste Led.

Det femte Fodpars forste Led er ikke udvidet; det tredie er omtrent saa langt som de tvende folgende tilsammen, af hvilke det femte er længere end det foregaaende Led.

De trende følgende Fodpars første Led er meget udvidet; det tredie Led er noget udvidet, med en ubetydelig udtrukket nedre, bagre Vinkel, og er omtrent saa langt som de tvende folgende Led tilsammen.

Det første Par Springfødder naar længst bagud; Grenene ere lige lange, meget kortere end Grundleddet.

Det sidste Par er forlænget; Grenen er ubetydelig længere end Grundleddet, der er omtrent tre Gange saa langt som tykt.

Halevedhænget er tilspidset, med nogle Borster paa den ovre Rand.

Den er fundet ved Brettesnæs af G. O. Sars og af mig i Christianiafjorden.

METOPA MEGACHEIR, A. Boeck, 1870.

(Pl. XVIII. fig. 1.)

IIetopa megacheir, A. Boeck, Crust. amphip. bor. et arct. 1870. p. 63.

Epimerum 4tum non magnum, circiter eadem altitudine ac latitudine. Antennæ prælongatæ; corpore paulo breviores. Antemna superiores articulo pedunculi 1 mo longitudine ferme capiti eqvali; 2do longiore qvam 1mo. Antennæ inferiores articulo pedunculi 4to et 5 to eadem longitudine; flagello perbrevi. Pedes $1 \mathrm{mi}$ paris utriusqve sexus manu subcheliformi instructi; articulo 3tio apud marem ad processum, in apice rolundatum, calciformem producto. Pedes 2di paris apud marem articulo 3tio in angulo inferiore postico producto et acuto; manu permagna, ovata, in parte inferiore marginis posterioris arcuata, incisa, in incisura dentibus duobus validis et obtusis, ante incisuram dentibus qvatuor minutis, instructa: ungve longo et curvalo. Pedes 3 tii et 4 ti paris tenues; articulo 3 tio paulo breviore qvam duobus seqventibus junctis. Pedes 5 ti paris articulo 1 mo non dilatato, at 6 ti et 7 mi paris valde dilatato; articulo 3tio subdilatato, longitudine articulos duos seqventes junctos ferme aqvanti. Pedes saltatorii prelongati; pedunculo ultimi paris in margine superiore dentibus sex validis armato; ramo fere eadem longitudine ac pedunculo; dimidio ramo spinam validam efficienti.

Længden er 8 mm.

Legemet er ikke meget sammentrykt eller høit. Den første Sideplade er 
skjult af den anden, og de tiltage efter hinanden i Størrelse; den fjerde er dog ikke meget stor, neppe bredere end hoi, smalere nedad og drekker ikke det sjette or syvende Fodpar. Hovedet er længere end det forste Legemsled; dets Sidevinkler ere afrundede.

De $ø$ vre $F ø l$ ere ere meget lange og naa, naar de bøies tilbage, til det første Haleled. Skaftets første Led er ubetydelig længere end Hovedet; det andet er lidt længere og smalere; det tredie er kort. Svøben, der er noget længere end Skaftet, dannes af $12-14$ forlængede Led.

De nedre Følere ere ubetydelig langere end de ovre. Skaftets tredie Led er kort; det fjerde naar frem omtrent til Enden af de øvre Føleres Skaft; det femte er saa langt som det foregaaende Led eller ubetydelig længere end dette. Svoben er meget kort.

Kjæbef $ø$ ddernes Palpes tvende forste Led ere lige lange; det tredie er længere. Kloen har korte, fine Børster paa den bagre Rand.

Det forste Fodpar er lidet; det tredie Leds nedre, bagre Vinkel danner hos Hannen en Hæl; det femte Led er omtrent saa langt som det foregaaende, bredere udad, med en meget skraa afskaaret, med Børster besat Griberand.

Det andet Fodpar er hos Hannen særdeles stort; det tredie Led er kort, og dets nedre, bagre Vinkel er-tilspidset; det fjerde Led er ogsaa meget kort; Haanden er derimod meget stor, forlænget ægdannet; den meget skraa afskaarne Griberands storre, bagre Parti har en Indbugtning, hvori sees tvende stærke, par Enden afrundede Tander; det meget mindre, nur Kloens Rod liggende Parti er indskaret i Saugtakker. Kloen er lang, stærk, krummet.

Det tredie og fjerde Fodpar ere forlængede, smale; det tredie Led er noget kortere end de tvende følgende Led tilsammen.

Det femte Fodpars forste Led er ikke udvidet; det tredie er ubetydelig udvidet, omtrent saa langt som de tvende folgende tilsammen, hvilke ere besatte med stirke Torne paa den forreste Rand.

De tvende følgende Fodpar ere lig det foregaaende, men det første Leds bagre Rand er meget udvidet.

S pringfø d derne ere forlængede, med stærke Torne paa Grundleddets øvre Rand.

Det andet $\mathrm{Par}$, hvis ydre Gren er lidt kortere end den indre, naar ei saa langt bagud som de tvende øvrige Par.

Det-sidste Pars Gren, hvis Endetorn er saa lang som Roddelen, er omtrent af den samme Langde som Grundleddet; dette har sex starke Torne paa den ovre Rand.

Halevedhænget er kort, noget tilspidset, og har nogle faa Torne paa den ovre Rand.

Den er fundet i Christianiafjorden og i Hardangerfjorden af $G$. 0 . Sars $0 \mathrm{~g}$ ved Bohuslen af Malm paa 100 Favnes Dybde. 
METOPA LONGIMANA, A. Boeck, 1870.

(Pl. XVII. fig. 5. 6; Pl. XVIII. fig. 3.)

Metopa longimana, A. Boeck, Crust. amphip. bor. et arct. 1870. p. 64.

Epimerum 4tum permagnum, multo latius qvam altum, postice productum, rotundatum. Antennæ apud marem multo magis elongatæ et robustiores qram apud feminam. Antennæ superiores inferioribus paulo breviores; articulo pedunculi 1 mo longitudinem 2di ferme xqvanti, in parte anteriore marginis inferioris paulo produclo. Antennæ inferiores flagello perbrevi; articulo pedunculi 4to longiore qvam 5to. Pedes $1 \mathrm{mi}$ paris carpo et manu eadem longitudine, manu non subcheliformi. Pedes 2di paris manu maris multo majore qvam feminæ, sat elongata, extrorsum latiore, ter longiore qvam lata, in acie et in angulo inferiore postico dentilus firmis armala; manu feminæ in acie spinis parvis instructa. Pedes 5 li et $6 t^{i}$ paris articulo $1 \mathrm{mo}$ postice non, at $7 \mathrm{mi}$ paris parum dilatato, qvadrangulari, ter longiore qvam lato. Pedes 5ti paris articulo 3tio non perdilatato, longitudinem arliculi 5ti æqvanti, 7 mi paris magis dilatato, breviore qvam articulo 5to. Pedes saltatorii ultimi paris breves, ramis longitudine pedunculum æqvantibus: ungve rami dimidiam longitudinem efficienti.

Længden er $4^{\mathrm{mm}}$.

Legemet er sammentrykt og smalt. Den første Sideplade er skjult af den store, fortil convexe, bagtil lidt concave anden Sideplade; deu fjerde er bagtil særideles forlænget og jævnt afrundet, bredere end høi, og dækker aldeles det femte og sjette Fodpars første Led. Hovedet er næsten saa langt som de tvende første Legeinsled tilsammen og gaar fortil ud i et lidet Pandehorn.

Følerne ere hos Hannen længere og tykkere end hos Hunnen.

De ovre Føleres første Skaftled er lidt længere end Hovedet og har et lidet Fremspring paa den ydre Endes nedre Rand; det andet er af den samme Længde, men smalere; det tredie er meget kort. Svgben er kortere end Skaftet og dannes af 7 Led.

De nedre Følere ere lidt længere end de øvre. Skaftets tredie Led or længere end bredt; det fjerde er saa langt som de øvre Føleres forste Led, eller noget længere end dette; det femte er kortere end det foregaaende Led. Svoben, der er kortere end Skaftets sidste Led, dannes af 5 Led.

Det forste Fodpars tredie Led er kort, og dets nedre, bagre Vinkel danner et tykt, afrundet, kort Fremspring; det fjerde har en forlænget oval Form, det femte er smalere, men af den samme Læingde som det foregaaende Lied. Kloen er liden, krummet og med Børster paa den bagre Rand. 
Det andet Fodpar er kraftigere hos Haunen end hos Humnen og meget stort; det fjerde Led er længere end bredt, og dets. nedre, bagre Vinkel damner et kort, med Borster besat Fremspring; det femte Led eller Haanden er især hos Hannen meget kraftigt, særdeles forlænget, tre Gange saa langt som bredt og bredere mod den ydre Ende; Gribedelen er noget skraa afskaaret, tandet og har en storre Tand ved den ydre, bagre Vinkel samt et dybt Indsnit noget foran dette. Kloen er kort, stærk og krummet. Hos Hunnen er Griberanden besat med smaa 'Torme.

De folgende fem Fodpar ere næsten af eens Form, idet det femte og sjette Fodpars forste Led ikke er udvidet og det syvende Fodpars første Led kun er lidet udvidet. Det femte Fodpars tredie Led er ubetydelig udvidet, omtrent af den samme Lingde som det femte og meget længere end det fjerde Led. Det syvende Fodpars tredie Led er kortere end det femte.

Det forste Par Springfødder naar længst bagud, og Grenene ere meget kortere end Grundleddet.

Det sidste Par er det korteste; Grenen er lidt langere, men meget smalere end Grundleddet.

Halevedhænget er forlanget, ovalt eller lancetformet, med Torne paa begge Rande.

Denne Form staar meget nxr den af Spence Bate opstillede Montayna pollexiana, fra hvilken den vasentlig skiller sig ved de nedre Foleres Form og Lxugde samt ved Dannelsen af de tvende forste Fodpars femte I.ed. I Here Henseender er den ogsaa lig Spence Bate's $\boldsymbol{M}$. longimana.

Denne Art er af mig fundet i Christianiafjorden og ved Haugesund.

METOPA NASUTA, A. Boeck, 1870.

(PI. XVIII. fig. 6.)

Metopu nasuta, A. Boeck, Crust. amphip bor. et arct. 1870. p. 65.

Epimerum 4tum permagnum, parum altius qvam latum, postice rotundatum. Aniennæ perbreves, ferme ad segmentum trunci 5 tum porrecte; superiores inferioribus paulo longiores. Antenna superiores articulo pedunculi 1 mo longitudine articulos duos seqventes junclos fere aequanti et ex extremo margine superiore processum longum acutum emiltenti. Antennæ inferiores articulo pedunculi 4 to et 5to eadem ferme longitudine. Pedes $1 \mathrm{mi}$ paris manu angusta et non subcheliformi. Pedes 2di paris carpo brevi; manu fere qvadrangulari, duplo longiore qvam lala, in acie obliqve truncata. Pedes 3 tii et 4 ti paris longissimi et angustissini; articulo 
3 tio parum dilatato, parum modo longiore quam 4to; at 5 to tam longo ant parum breviore quam articulis duobus pracedentibus junctis; ungve recto et circiter duas terlias longiludinis arliculi ultimi partes aqvanti. Pedes trium parium ullimorum articulo 1 mo non dilatalo, 3tio parum dilatalo; $7 \mathrm{mi}$ paris articulo 5 to longitudine duos precedentes junctos xqvanti, 5ti paris parum breviore.

I. angden er omtrent $4^{\mathrm{mm}}$.

Legeinet er særdeles høit; Legemsleddene tiltage efter hverandre i Bredde, saalerles at det sidste ikke er meget smalere end det forste Haleled; det tredie Haleleds nedre, bagre Vinkel er ubetydelig udtrukket, afrundet. Den forste Sideplade er aldeles skjult af den anden, hvis forreste. Rand er meget convex; den fjerde er meget bueformet forlanget bagtil, omtrent saa bred som hoi paa det forreste Parti og lakker med sin afrundede bagre Rand fuldstandig de tre sidste Fodpar. Hovedet er saa langt som de tvende første Legemsled tilsammen; dets Sidevinkler ere afrundede

De øvre Folere ere korte og naa kun til Enden af det fjercle Legemsled. Skaftets forste Led er temmelig tykt og næsten saa langt som de tvende følgende tilsamımen samt forlænger sig paa den ovre Rands ydre Lnde til et meget starkt, spidst Næb, der naar næsten frem til Enden af det andet Led; dette er kun lidt længere og tykkere end det tredie Led. Svaben or lidt langere end Skaftet og dannes af 7 - 8 Leil.

De nedre Folere ere noget kortere og smalere end de ovre; Skaftets fjerde og femte Led ere næsten lige lange. Svoben er ubetydelig lingere end Skaftets sidste leed.

Kjæbef $ø$ ddernes andet Grundled med den rudimentære ydre Plade er saa langt som de tvende folgende Ised tilsammen; det tredie Led er kortere. Kloen er meget kortere end det foregaaende Ised, med Borster paa den bagre Rand.

Det første Fodpars femte Led er smalt, ovalt, lidt læengere end det foregaaende triangulære Led. Kloen er ret.

Det andet Fodpars fjerde Led har en med Børster besat udtrukket nedre, bagre Vinkel; det femte Led er noget forlienget firkantet, dobbelt saa langt som bredt, med en skraa afskaaret Griherand.

Det tredie og fjerde Fodpar ere sardeles forlængede, smale; det tredie Led er kun lidet udvidet, med en udtrukket nedre, forreste Vinkel, og er kun ubetydelig længere end det fjerde, men meget kortere end det femte Led. Kloen er længere end Halvdelen af det sidste Led.

De tre folgende Fodpar ere meget lig de tvende foregaaende Fodpar; det fórste Led er aldeles ikke udvidet; det femte Pars sidste Led er kortere end de tvenile foregaaende tilsammen, men paa det syvende Par er det længere. Kloen er kun ubetydelig kortere end det sidste Led. 
De tvende første Par Springfødders ydre Gren er lidt kortere end den indre. Det første Par er det længste.

Det sidste Pars Gren er omtrent dobbelt saa lang som Grundleddet.

Hal evedhænget er tilspidset, med en Torn paa Midten af den yilre Rand.

Den er fundet i Hardangerfjorlen af G. O. Sars.

Gen. III. CRESSA, A. Boeck, 1870.

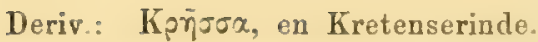

Syn.: 1870. Cressa, A. Boeck, Crust. amphip. bor, et arct. p. 65.

Type: Cressa Schiödtei, A. Boeck.

Mandibulæ palpo elongato, 3articulato.

Antennæ superiores inferioribus multo crassiores et Inngiores.

Epimera non permagna; 4 tum in supremo margine postico profunde incisum.

Pedes trium parium ultimorum articulo 1 mo postice valde dilatalo.

Reliqva cum genere Stenothoë ferme conveniunt.

Af denne Slægt har jeg fundet tvende Arter ved den norske Kyst, hvilke i det Yire stemme saa meget overeens med den af Spence Bate i 1857 opstillede Slagt $D_{a-}$ naia, at jeg havde villet henfore den hertil, hvis jeg ikke havde fundet, at begge Slagter vasentlig ere forskjellige. Denne slagt har nemlig en meget forlænget, treleddet Palpe paa Kindbakkerne, hvilken Danaia mangler. Den maa derfor opstilles som en ny Slægt.

CRESSA SCHIÖDTEI, A. Boeck, 1870.

(PI. XVIII. tig. 8.)

Cressa Schiödtci, A. Boeck, Crust. amphip. bor. et arct. 1870. p. 65.

Angulus anticus lateralis capitis valde productus, aculus, in margine inferiore dente uno instructus. Epimerum 2dum et 3tium in postremo margine inferiore dentibus qvatuor crassis, antice porrectis et curvalis, instructa. Antennæ superiores articulo pedunculi lmo longiore qvam capite; articulis duobus seqventibus et longitudine et crassitudine gradatim valde decrescentibus. Antenna inferiores articulo pedunculi 4 to longiore qvam 5to. Pedes Imi paris pertenues, manu broviore qvam carpo parum dilatato. Pedes 2 di paris manu extrorsum latiore, fere duplo longiore ac latiore, in acie obliqve Iruncata. spinis paucis validis ar- 
mata. Pedes trium parium ultimorum articulo 3tio brevi, in angulo inferiore postico parum dilatato. Pedes saltatorii ultimi paris ramo parum longiore qvam pedunculo et in exteriore parte tertia marginis superioris denlibus duobus armato.

L $x$ ngden er omtrent $6^{\mathrm{mm}}$.

Legemet er temmelig sammentrykt, Ryggen er rund. De fem forste Legemsled tiltage i Bredde og Høide, medens det sjette og syvende atter aftage, saa at det femte Led er det storste. De tre forste Haleled ere ikke meget brede; den nedre, bagre Vinkel paa det tredie Haleled er svagt afrundet. Den første Sideplade dækkes af den anden, der er bredere end den tredie; begge disse have paa den bagre Del af nedre Rand 3-4 krumme Saugtakker; den fjerde Sideplade er bredere, høiere end bred, afrundet paa den nedre Rand og i den ovre Del af den bagre Rand bueformet indskaaret for den femte Sideplade. Hovedet er saa langt som de tvende forste Legemsled tilsammen, eller noget længere; fortil gaar det ud i et bredt, men kort Pandehorn; dets Sidevinkler ere meget udtrukne, tilspidsede og vabnede med en stærk Tand. Xinene ere store, næsten runde.

De øve Følere naa, naar de bøies bagud, omtrent til Halens forste Led. Skaftets første Led er længere end Hovedet; det andet er kun lidt længere end Halvdelen af det forste Led; det tredie er kort. Svøben, hvis forste Led er let langste, er lidt lengere end Skaftet og dannes af 18 Led.

De nedre Folere ere meget tyndere end de ovre; det fjerde Led er længere og tykkere end det femte samt kortere og meget tyndere end Skaftets forste Led paa de ovre Folere. Svgben er kortere end Skaftet og dannes af 7 forlængede Led.

Kindbakkerne ere meget smaa; Gribedelen er stærkt tandet. Palpen er særdeles forlænget, men smal og dannes af $3 \mathrm{Led}$, hvoraf det andet er det længste og tykkere end det tredie Led.

Det forste Fodpars fjerde Led er kun svagt udvidet mod Enden og er lidt langere end det femte, der er mere end fire Gange saa langt som bredt, smalere mod den ydre Ende.

Det andet Fodpar er meget stærkere; det fjerde Led er kort, triangulært, og dets nedre, bagre Vinkel forlænger sig til en kort, paa Enden afrundet og med Børster forsynet Hel. Haanden er meget storre, bredere udad; Griberanden er meget skraa afskaaret $0 \mathrm{~g}$ vebnet med fem stærke Torne.

Det tredie og fjerde Fodpar ere forlengede; det fjerde Led er lidt kortere end det femte.

De tre følgende Fodpar ere omtrent af eens Bygning; det forste Led or meget hoiere end bredt, udvidet bagtil; det tredie er kort, udvidet mor Enden, og den nedre, bagre Vinkel er noget udtrukket; det fjerde er kortere end det femte Led.

Det forste Par Springfod der naar langst bagud; den indre Gren er meget længere end den ydre, der er omtrent saa lang som Grundleddet; begge Grene ere i 
den ydre Trediedel af den ovre Rand væbuede med en spids Tand samt en bevægelig 'Torn.

Det andet Par er ligt det forste.

Det sidste Pars Gren er lidt længere end Grundleddet, men forovrigt af samme Bygning som paa det foregaaende Par.

Jeg har fundet denne Art ved Haugesund.

CRESSA MINUTA, A. Boeck, 1870.

(PI. XVIII. fig. 7.)

Cressa minuta, A. Boeck, Crust. amphip. bor. et arct. 1870. p. 6่6.

Angulus anticus lateralis capitis non tam productus qvam apud speciem priorem et in margine inferiore edentatus. Epimerum 2dum el 3tium in extremo margine inferiore dentibus singulis crassis, porrectis et paulo curvatis, instructa. Antenna superiores articulo pedunculi 2 do circiter eadem longitudine ac lmo sed angustiore; utroqve in extremo margine inferiore paululum produclo. Pedes 2 di paris ferme ut apud speciem priorem sed carpo paulo breviore et manu parum majore. Pedes ultimi paris et pedes saltatorii ut apud speciem priorem.

L æ n g d en er omtrent 5 mn.

Legemets Form er omtrent som hos den foregaaende Art. Hovedets Sidevinkler ere dog ikke saa udtrukne og mangle den Taud, som sees hos hin. Den anden og tredie Sideplade have paa den bagre Del af den afrundede og korte nedre Rand en Indskjæring, hvorved fremkommer en enkelt krogformet Saugtand; den fjerde er smalere end hos den foregaaende Art 0 g har en næsten parallel forreste og bagre Rand.

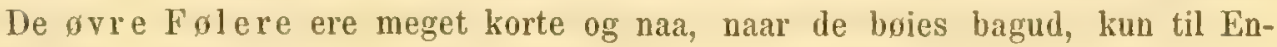
den af det femte Legemsled. Skaftets første Led er af den samme Længde som det andet, og begge ere lidt udtrukne paa den ydre Ende af den indre Rand. Svgben er omtrent saa lang som Skaftet og dannet af 9 Led.

De nedre Følere ere meget tyndere og kortere end de øvre. Skattets fjerde Led er omtrent saa langt som det andet Led paa de øvre Føleres Skaft, men er meget tyndere end dette; det femte er kortere end det fjerde Led.

Det første Fodpars fjerde Led er lidt længere end det femte, der er meget smalere mod den ydre Ende. Kloen er ret.

Det andet Fodpars Haand er lig den hos den foregaaende Art.

Springfoddernes Grene have paa Midten af den gvre Rand en Tand, ved hvilken der tillige sees en Børste. 
Det første Par Springfødder naar lidt længere tilbage end det andet; pas begge er den indre Gren længere end den ydre og Grundleddet.

Det sidste Pars Gren er længere end Grundleddet.

Den er fundet af mig ved Haugesund.

Subfamilia IV.

SYRRHOINÆ, A. Boeck, 1870.

Syn.: 1870. Syrrhoince, A. Boeck, Crust. amphip. bor. et arct. p. 66.

Labium superius latum, in apice insinuatum.

Mandibulæe pervalidie, latæ; utrobiqve dissimiles; mandibula sinistra processu accessorio interiore instructa; palpo 3 articulato; articulo ultimo perbrevi.

Labium inferius latum.

Maxilla $1 \mathrm{mi}$ paris lamina interiore lata, setosa; palpo 2articulato, angusto, in apice plerumqve setis paucis instruclo.

Maxilla 2di paris laminis lalis.

Pedes maxillares lamina exteriore permagna, in margine interiore dentibus validis arnata; lamina interiore lata, longa; palpo lato, brevi aut magis elongato.

Corpus plus minusve subdepressum; capite magno; epimeris magniludinis mediocris.

Oculi sape approximati el coaliti.

Antennæ superiores flagellum appendiculare gerentes.

Pedes $1 \mathrm{mi}$ et 2di paris eadem forma, tenues, angusti; manu subcheliformi.

Pedes trium parium ullimorum longitudine gradatim crescentes; articulo 1 mo postice plus minusve dilatato.

Pedes saltatorii 2ramosi; $1 \mathrm{mi}$ et 2di paris ramo exteriore breviore qvam interiore; ultimi paris ramo utroqve ferme eadem longitudine, laminiformi, in margine setoso.

Appendix caudalis pralongata, fissa.

Til denne Underfamilie har jeg henført Slagterne Syrrhoë, der blev opstillet af Goës 1865, og Tiron, der ligeledes i samme Aar blev opstillet af Lilljeborg, hvortil kom Bruzelia, A. Boeck i 1870. Den nærmer sig Underfamilien Pardaliscinœ, især med Hensyn til Kindbakkernes Bygning, men afviger fra denne væsentlig ved, at deres Palpers tredie Led er sardeles kort, ved at det forste Kjæbepars indre Plader ikke ere 
rudimentære, men meget store, ved at Kjæbeføddernes Palper ikke ere forlængede, samt endelig ved at deres Plader ikke ere saa smaa soı hos Pardaliscina.

Gen. I. SYRRHOË, Goës, 1865.

Syn.: 1865. Syrrhö̈, Goës, Crust. amphip. maris Spetsb. p. 12.

1868. - Norman, Rep. on the Shetland Crust. p. 249.

$1870 . \quad-\quad$ A. Boeck, Crust. amphip. bor. et arct. p. 67.

Type: Syrrhoü erenulata, Goës.

Mandibula crassissimx, robuste, in apice parum dentate; tuberculo molari prominenli, non robusto.

Oculi confluentes.

Epimera magnitudinis mediocris.

Pedes $1 \mathrm{mi}$ el 2 di paris manu parva, subcheliformi; pedes 2 di paris pedibus $1 \mathrm{mi}$ paris magis elongati.

Pedes trium parium ultimorum elongati, angusti; arliculo 1 mo postice plus minusve dilatato.

Pedes saltatorii 1 mi et 2 di paris ramo exteriore multo breviore qvam interiore.

Pedes ultimi paris ramis foliaceis; utroqve longitudine ferme aqvali.

Appendix caudalis fissa.

Denne Slægt blev i 1865 opstillet af Goës med tvende Arter, S. crenulata og S. bicuspis, og af ham givet følgende Diagnose: „Frons producta, oculi oedicerorum, antennæ supernæ flagello appendiculari instruct:, mandibulæ palpo triarticulato." Samme Aar opstillede Lilljeborg Slingten Tiron med Arten T. acanthurus, hvilken er synonym med S. bicuspis. Man kan saaledes kun beholde Slægtsnavnet for den ene, S. crenulata, som da ogsaa bliver Slægtens typiske Art. Hertil kommer en ny Art, S. levis, A. Boeck.

SYRRHOË CRFNULATA, Goës, 1865.

(Pl. IX. fig. 5 ; pl. XII. fig. 8.)

Syrrhaë crenulata, Goës, Crust. amphip. maris Spetsb. 1865. p. 11. fig. 25.

A. Boeck, Crust. amphip. bor, et arct. 1870. p. $6 \%$. 
Caput antice inflatum; fronte prominenti, curvala. Epimerum 3tium axiforme, 4 to majus. Segmentum postabdominis 1mum, 2dum et 3tium postice serrata, 1 mum in parte dimidia superiore, 2dum et 3tium toto margine posteriore. Epimerum 6 tum et 7 mum postice bidentata. Antennæ superiores articulo pedunculi $1 \mathrm{mo}$ in extrema parte inferiore ad spinam curvatam elongato: articulis duobus seqventibus longitudine parum decrescentibus. Pedes 1 mi et 2 di paris manu parva, apicem versus latiore, in acie dente uno magno, in margine anteriore serrato, armata. Pedes trium parium ultimorum articulo 1 mo dilatato, in margine posteriore valde serrato. Pedes saltatorii 3tii paris laminis duplo longioribus qvan pedunculo. Appendix candalis elongata. lanceolata. in cxterioribus duabus tertiis partibus fissa.

Længden er $\gamma^{m m}$.

Legemet er temmelig sammentrykt. liyggen er rund, men er mere sammentrykt paa Halens Led; de første Legemsled ere meget smale, men blive efter hverandre bredere; de tre første Haleled gaa paa Midten af den bagre Rand ud i Torne, der paa det forste Led fortsatte sig langs den ørre Dẹ af den bagre Rand, men paa det andet indtage næsten hele denne Rand og paa det tredie fortsætte sig til den nedre, bagre Vinkel. Sidepladerne ere smaa; de tvende første ere meget smale; den tredie er meget større, næsten triangulær, med Basis nedad; den fjerde er meget mindre og noget indskaaret $\mathrm{i}$ den bagre Rand for den femte Sideplade. Hovedet er meget stort, opsvulmet, og gaar fortil ud i et stort, bøiet Pandehorn, ved hvis Basis øinene ligge.

De øve Føleres Skaft er forlænget; det forrste Led er Here Gange saa langt som bredt og gaar paa den ydre Ende af den undre land ud i et bøiet Fremspring; de tvende følgende aftage saavel i Længde som Bredde. Svoben er noget længere end Skaftet $0 \mathrm{~g}$ dannes af 16 Led. Bisvgben har 5 Led.

De nedre Folere ere længere end de ovre; Skaftets tredie Led er saa langt som bredt; det fjerde er noget kortere end det femte, og begge ere paa Randene forsynede med Børsteknipper.

Kindbakkerne ere sxrdeles starke og tykke, delte i Spidsen, men kun forsynede med faa Tænder. Tyggeknuden er bred, men kun lidet fremstaaende. Palpen er forlænget; det andet Led er særdeles langt; det tredie er rudimentært, forsynet med en Dusk lange Børster.

Det første Kjæbepars ydre Plade har paa Enden trende Rader Torne, hvoraf de ydre ere gaffeldannede, de indre saugtakkede; den indre Plade er forlenget, smal og besat med fjærdannede Børster. Palpens andet Led er forlænget og har Børster i Spidsen og langs den indre Rand.

Det andet Kjæb epars indre Plade er den bredeste.

Kjæbefødderne ere stærke; den ydre, meget store Plade har paa den indre saugtakkede Rand lange, tynde Torne, der mod Pladens Ende blive længere og noget 
krumme; den indre Plade er bred og besat paa Enden med fjordannede Børster. Palpen er kort, men bred.

De tvende forste Fodpar ere af eens Bygning, men det andet er længere og smalere end det forste Par; det tredie. Led er kort; det fjerde er forlænget og har fjærdannede Borster paa den indre Rand; paa det første Par er det femte, meget mindre Led triangulært, paa det andet forlænget firkantet. Kloen er liden.

Det tredie og fjerde Fodpar ere af eens Bygning; det tredie Led er lidet udvidet; det fjerde og femte, ler ere indbyrdes omtrent lige lange, ere langere end det tredie Led og have fjærdannede Borster paa den bagre Rand. Kloen er meget kort.

De tre folgende Fodpar tiltage efter hverandre noget i Langde; det forste Led er paa det forste af disse af en temmelig rund Form, men er noget smalere paa de falgende Fodpar; den bagre Rand er strerkt saugtakket og den nedre, bagre Vinkel er udvidet, afrundet; det tredie Led er lidet udvidet; det femte er længere end det fjerde Led. Kloen er kort.

Det forste Par Springfodders ydre Gren er meget kortere end den indre.

Det andet Par naar lrengere bagud; den ydre Gren er kortere end den indre, der er mere end dobhelt saa lang som. Grundleddet.

Det sidste Pars Grene ere nxsten lige lange og dobbelt saa lange som Grundleddet.

Halevedhæuget er lancetdannet, forlænget, kløvet i de ydre Totrediedele.

Den er fundet i Christianiafjorden og ved Christiansund af G. O. Sars paa 100 Favne, af mig ved Skraaven paa 5-20 Favne, ved Spitsbergen af Malmgren paa 2080 Favne.

SYRRHOË LEVIS, A. Boeck, 1870.

Syrrhö̈ levis, A. Boeck, Crust. amphip. bor. et arct. 1870. p. 68.

Corpus leve. Segmenta postabdominis non serrata. Epimerum 3tium 4 to non latius sed angustius. Antennæ superiores arliculo pedunculi 1 mo dente non armato. Pedes $1 \mathrm{mi}$ paris manu elongata, ovata. Pedes 2 di paris manu perangusta, extrorsum angustiore. Pedes 5 ti paris arliculo 1 mo peranguslo, duplo longiore qvam lato. Pedes 6 ti et $7 \mathrm{mi}$ paris articulo 1 mo Jalitudine gradatim crescenti; articulo 3tio longiore qvam 4to. Pedes saltatorii $1 \mathrm{mi}$ paris pedibus saltatoriis 2 di paris multo minores; ramis 3 tii paris brevioribus qvam pedunculo.

Længden er $5^{\mathrm{mm}}$

Legemet er forlænget, smalt. Ryggen er rund; intet af Legemsleddene eller Halens Led ere vabnede med Torne eller Saugtakker paa den bagre Rand; de tre forste Haleleds nedre, bagre Vinkel er afrundet. Den tredie Sideplade er ikke udviılet nedad, 
men smal: den fjerde er nerlar tilspidset. Hoverlet er meget tykt, ligesom opsvulmet, og gaar fortil ud i et langt Pandehorn.

De øvre Følere ere korte, noget længere end Hovedet og de tvende første Legemsled tilsammen. Skaftets andet Led er noget kortere og meget smalere end de første, hvis ydre Ende ikke, som hos den foregaaende Art, er forsynet med et Fremspring; det tredie er læengere end Halvdelen af det andet Led. Svgben er hos Hunnen kortere end Skaftet og dannes af 8 Led, hvoraf det første er længere end de følgenle. Bisvoben er liden og har 1 Led, hvorhos der sees Spor af et 2det Led.

De nedre Folere ere lidt kortere end de ovre. Skaftets tredie Led er kort $\overline{o g}$ noget udvidet mod den ydre Ende; det fjerde er noget langere og tykkere end det femte Led. Svgben er meget kortere end Skaftet og dannes af 6 Led.

Mundelene ere lig dem hos den foregaaende Art.

Det første Fodpar er meget tyndt; det forste Leds Rande ere besatte med Børster; det femte Led er forlænget ægdannet, længere end Halvdelen af det foregaaende Led. Kloens bagre Rand har nær Spidsen nogle tynde Torne.

Det andet Fodpar er længere og smalere end det forste Par; det femte Led er meget smalt, tyndere mod Enden og er omtrent halvt saa langt som det fjerde Led.

Det tredie og fjerde Fodpars tredie Led er kun lidet udvidet mod den ydre Ende og ubetydelig lwngere end det fjerde, der er omtrent saa langt som det femte Led. Kloen er lidt kortere end det sidste Led og kun ubetydelig krummet.

Det femte Fodpars første Led er omtrent dobbelt saa langt som bredt, ikke udvidet, saugtakket paa den bagre Rand og er paa den forreste, nedad noget udbugtede Rand besat med Torne; det tredie er langere end det fjerde, der er onitrent af den samme Længde som det femte Led. Kloen er kortere end det sidste Led og næsten ret.

Det sjette Fodpars forste Led er meget bredere; begge Rande ere besatte med Torne, og den nedre, bagre Vinkel er forlienget, afrundet.

Det syvende Fodpars første Led er bredere end hos det foregaaende Par, saa at det kun er lidt langere end bredt; de øvrige Led ere lig dem hos det femte Fodpar.

Det første Par Springfodder er meget kortere end de følgende; den ydre Gren er meget kortere end den indre, der er omtrent af den samme Længde som Grundleddet.

Det andet $\mathrm{Par}$ er det længste; den indre Gren er af den samme Længde som Grundleddet, med Torne paa Randene; den ydre er kortere.

Det sidste Pars ydre Gren er kun lidt kortere end den indre, og begge ere kortere end Grundleddet.

Halevedhænget, som er spaltet til lidt over Midten, naar ikke saa langt tilbage som til Enden af det sidste Par Springfødder.

Jeg har fundet denne Art i tvende Exemplarer ved Mosterhavn paa 150 Farnes Dybde. 
Gen. II. TIRON, Lilljeborg, 1865 .

Deriv.: Teiper), et Egennavn.

Syn.: 1865. Tiron, Lilljeborg, On the Lysianassa magellanica. p. 19.

- Syrrhoë, Goës, Crust. amphip. maris Spetsb.p. 12.

1868. Tessarops, Norman, Ann. and Mag. of Nat. Hist. p. 412.

1870. Tiron, A. Boeck, Crust. amphip. bor. et arct. p. 68.

Mandibulæe in apice dentalæ, luberculo molari robusto instructæ. Oculi non coaliti.

Epimera magnitudinis mediocris.

Antennæ superiores inferioribus breviores; flagello appendiculari longo.

Pedes $1 \mathrm{mi}$ et 2 di paris carpo pralongato; articulo 5 to non subcheliformi, angusto; ungve crasso, brevi, in apice spinis validis armato.

Pedes trium parium ultimorum breves; articulo 1 mo postice valde dilatato. Appendix caudalis lissa.

Slregten 'Irom blev i 1865 opstillet af Lilljeborg med Arten $T$. acanthurus, hvilken Goës samme Aar havde givet Navnet Syrrhoë bicuspis. Lilljeborgs Værk er utvivlsomt ældre, da Goës citerer det, hvorfor hans Benævnelse har Prioritetsret. Han fremhæver isæ i sin Sliegtskarakter, at Tiron i Hovedets Bygning er meget overensstemmende med Slægten Oediceros, men afviger væsentlig fra denne ved, at de ovre Folere ere forsynede med Bisvabe, og ved at det syvende Fodpar ikke er forlænget som hos hin Slægt, men derimod kort og tykt. Han viser ogsaa, at de tvende forste Fodpar ere tynde og ikke forsynede med nogen boielig Klo, altsaa ikke subcheliforme. Herved skiller den sig ogsaa fra Slægten Syrrhoë. Han henfører den til sin fjerde Underfamilie Phoxinæ, sammen med Slægterne Phoxus og Urothoë, og tilfoier, at Hovedet er noget ultrukket paa sin forreste Rand. Senere har Norman opstillet denne Slægt under Navnet Tessarops, hvilket saaledes falder bort, tilmed da dette forhen er benyttet til en Arachnide. Han omtaler, at den har fire Øine, tvende storre over Udspringet af de ovre Folere, og tvende næsten simple red Basis af de nedre.

TIRON ACANTHURUS, Lilljeborg. 1865.

(PI. IX, fig, 8 ; pl. XIII. fig. 1.)

Tiron acanthurus, Lilljeborg, On the Lysianassa magellanica. 1865. p. 10.

A. Boeck, Crust amphip. bor. et aret. 1870. p. 69.

Syrrhö̈ bicuspis, Goës, Crust. amphip. maris Spetsb. 1865. p. 12. pl. 40. fig. 26.

Tessarops hastata, Norman, Ann. and Mag. Nat. Hist. 1868.p. 412. pl. XXII. fig. 4-7. 
Frons paulo producta, curvata. Segmenta poslabdominis carinata; carina postice in spinas porrecta; spina segmenti 4 ti et 5 ti maxima; segmentis Iribus anterioribus in margine posteriore serratis. Antennæe superiores longitudinem pedunculi antenn datim decrescentibus; flagello appendiculari duas tertias partes longitudinis flagelli aqvanti. l'edes $2 d_{\imath}$ paris paulo lungiores sed angustiores qvam pedes 1 mi paris; articulo 510 apud $1 \mathrm{mi}$ paris multo longiore quam dimidio carpo et mullo angustiore. Pedes trimm parium ultinorum articulo 1 mo postice parum serrato. Appendix caudalis laciniis angustissimis, lanceolatis.

Læugden er $8-10^{\mathrm{mm}}$.

Le gemet er høit, noget sammentrykt; Ryggen er rund. Halens Led ere forsynede med en Kjol, hvilken paa det fjerde og femte Led gaar ud i en lang Torn, der er storst paa det silste af disse Led; en lignende, men mindre Torn sees ogsaa paa det sjette Led; de forste Haleled danne paa den øvre Del af den bagre Rand en Rxkke Fremspring, der paa det tredie Led ogsaa sees paa den nedre Del af denne Rand, og paa dette Leds nedre, bagre Vinkel sees en meget liden Hage. Sidepladerne ere af middelmaadig Størrelse, høiere end brede, med fjærdannede Børster paa den nedre Rand; den fjerde er omtrent af den samme Storrelse som den tredie og er lidt indskaaret paa den bagre Rand. Hovedet har paa det forreste Parti en Kjøl, der gaar frem i et kort Pandehorn.

De øvre Føleres Skaft er saa langt som Hovedet eller noget længere end dette; Leddene aftage efter hverandre $i$ Langde og Tykkelse. Svøben er langere end Skaftet $0 \mathrm{~g}$ dannes af 12 forlængede Led. Bisvoben, der er tyndere og kortere, har 6 Led.

De nedre Følere ere meget længere end de øvre. Skaftets andet Led udsender et kort Fremspring fra den undre Side; det tredie er omtrent saa langt som tykt; det fjerde er noget længere og tykkere end det femte Led. Svøben er omtrent saa lang som Skaftet og dannes af 12 forlængede, med Børster besatte Led.

Kindbakkerne ere meget kraftigt udviklede, i Spidsen delte og tandede; Tornerækken, der foruden Torne også har fjærdannede Børster, er stærk ligesom Tyggeknuden, der er fremstaaende. Palpen er meget tynd; det andet Led er langt; det tredie er særdeles kort, med nogle Borster paa Enden.

Det forste Kjæbepars ydre Plade har paa Enden stærke Børster, besatte med Bitorne; den indre Plade er bred og har paa Enden en Række fjærdannede Børster.

Det andet Kjabepars ydre Plade er noget smalere end den indre og har stærke Børster; den indre Plade er besat med tildels fjæerdannede Børster.

Kjæbefødderne ere kraftige; den ydre Plade naar frem næsten til Enden af Palpens andet Led og har paa den indre Rand stærke Tænder, der forlænge sig og 
blive krumme mod Pladens Ende; den indre Plade er af middelmaadig Storrelse og har paa Enden tre Tander og Borster samt fjærdannede Borster paa den indre Rand. Palpens første Led er kort.

De tvende første Fodpar ere af eens Bygning, men det andet Par er noget mere forlanget end det forste; det forste Led er langt, stixkt, besat med lange Borster paa begge Rande; det tredie er kort; det fjerde er meget forlænget, kraftigt, smalere mod den ydre Ende og har mange Borster paa den bagre Rand og den indre Side; det femte har kun Halvdelen af det foregaaende Leds Langle og danner ingen Haand; det er paa den indre Side besat med mange fjærdannede Børster. Kloen er stærk, lidt krummet.

Det tredie og fjerde Fodpars første Led er det længste og tykkeste; de følgende aftage efter hverandre i Tykkelse; det tredie og femte ere omtrent lige lange, medens det fjerde Led er kortere.

De tre følgende Fodpar tiltage noget i Længde; det første Leds bagre Rand er meget uividet, men er neppe tandet.

Det første Par Springfødders Grene ere kortere end Grundleddet.

Det andet $\mathrm{Par}$ er kortere.

Det sidste Par er det længste. Grenene ere meget længere end Grundleddet, lige lange, lancetformede og i Randene besatte med en Rxkke Torne, ligesom den indre har fjærdannede Børster.

H al evedhænget, der er klovet til Roden, naar næsten lige saa langt bagud som det silste Par Spriogfodder. Fligene ere smale, lancetformede og ikke indskaarne paa Enden.

Farven er efter Norman rodlig. Følerne have brune Baand; Øinene ere blodrode.

Den er fundet af Malmgren i Finmarken og sammesteds i Grøtsund af Goës; ved Brettesnæs af G. O. Sars paa 20-30 Favne; af Danielssen ved Ona paa 40 Favne; af Lilljeborg ved Christiansund paa 30-40 Favne og sammesteds af G. O. Sars paa 50 - 100 Favne. Efter Goës er den fundet i Davisstrædet og ved Godthaab paa Gronland af Torell paa 30-40 Favne: efter Norman findes den ved den shotske og engelske Kyst.

Gen. III. BRUZELIA, A. Boeck, 1870.

Deriv.: Opkaldt til Ere for R. Bruzelius, Forf. til Skand. Amphipoda Gammaridea.

Syn.: 1870. Bruzelia, A. Boeck, Crust. amphip. bor. et arct. p. 69 .

Type: Bruželia typica, A. Boeck.

Mandibula crassissima, latx, pyramidales, in apice insinuatæ, non dentatæ. Maxillæ $1 \mathrm{mi}$ paris palpo angusto. 
Corpus subdepressum: epimeris perrigidis, prominentibus, magnitudinis mediocris; epimero 4to maximo.

Pedes 1 mi et 2di paris manu parva, subcheliformi.

Pedes 3lii et 4 ti paris perangusti, elongati; articulo 3 tio perbrevi.

Pedes trium parium ultimorum elongati; articulo 1 mo parum dilatalo.

Pedes saltatorii $1 \mathrm{mi}$ paris ramo exteriore breviore qvam interiore; $2 \mathrm{di}$ paris ramo interiore latissimo, exteriore parvo.

Appendix caudalis longa, non fissa.

Denne Slægt afviger fra de foregaaende meget ved Kindbakkernes Bygning, idet disse kun have en Indskjæring i Gribedelen og ikke ere forsynede med Tænder. Legemet faar ogsaa en fra de foregaaende Slægtel afvigende Form, ved at Sidepladerne ere stive og staa und til Siderne.

Denne Slægt indbefatter for Øieblikket kun en eneste Art, men jeg har dog seet et mindre godt conserveret Exemplar, der uden Tvivl maa henføres hertil og danne en ny Art, uden at jeg dog nøiere har kunnet bestemme den.

BRUZLLIA TYPICA, A. Boeck, 1870.

(P1. X. fig. 3.)

Bruzelia typica, A. Boeck, Crust. amphip. bor. et arct. 1870. p. 70.

Caput permagnum, rostro longo, lato, in apice rotundalo, instructum. Corpus depressum, latum. Segmenta postabdominis tria anteriora carinata; carina segmenli 3 tii in dentem acutum, segmenti 5 ti in dentem longum, acutum, curvatum, producta. Angulus inferior posticus lateralis segmenti postabdominis 1 mi rolundalus, segmenti 2 di et 3 tii in dentem aculum productus. Pedes $1 \mathrm{mi}$ paris articulo 2 do et 3tio perbrevibus; carpo prælongato; manu subquadrata; ungve parvo. Pedes 3tii el 4 ti paris articulo 3 tio parum longiore quam dimidio 410 ; arliculo 5 to multo breviore qvam 4to. Pedes trium parium ultimorum arliculo 1 mo parum latiore et in angulo inferiore postico paulo producto et rotundalo. Pedes saltatorii $1 \mathrm{mi}$ paris ramis cylindricis; 2di paris exteriore perangusto, interiore lato, longo, lanceolato et acuminato; ultimi paris interiore latiore qram exteriore; ramo utroqve in margine interno setoso. Appendix caudalis permagna, apicem versus acuminata.

Lingden er $8--10 \mathrm{~mm}$.

L e gemet er tykt; Ryggen er glat, hvælvet; Legemsleddene tiltage efter hverandre i Langde og Bredde. De tre forste Haleled ere meget bredere; det forste Leds 
nedre, bagre Vinkel er ret eller ubetydelig afrundet; paa ret andet er den uritrulket til et fladt Fremspring, der er end mere udtrukket paa let tredie samt vender udad og opad; paa alle tre Led gaar der langs Ryggens Midtlinie en svag Kjøl, der par det tredie gaar ud i en bred, opadbøiet Torn; paa de følgende Led er denne Kjøl end mindre og danner paa de tvende sidste Led en lang, krummet, bagudrettet. Torn. Sidepladerne staa skraa ud fra Siderne; de fire første ere høiere end brede, især den anden og tredie, samt ere stive og vende udad, den fjerde has en meget skraa opadboiet og bueformet hand og er ikke meget indskaret for den femte lille Sideplade; de tvente folgende ere ligelerles smaa. Hovedet er temmelig fladt og gaar ud i et langt, noget bredt, paa Enden afskaaret og afrumlet Pandehorn, der krummer sig nedad mellem de svre Folere; dets Sidevinkler ere ikke udtrukne, og Sidepartieme strakke sig sia langt ned som til den forste Sideplades nedre Rand.

De øvre Følere naa, naar de bøies bagud, omtrent til det femte Legemsled. Skaftets forste Led er tykt, opsvulmet, noget længere end bredt; det andet er meget kortere og smalere; det tredie er en Trediedel kortere end det foregaaende Led. Svoben er omtrent af den samme Længde som Skaftet; de forste Led ere hos Hannen sammenvoxede til et langt, mod Enden smalere Led, der paa den indre Fand har talrige Børster; de følgende Led ere derimod adskilte. Hos Hunnen ere dens 8 Led adskilte. Bisvgben dannes hos Hunnen af 2 Led, af hvilke det forste er meget langt.

De nedre Følere ere længere end de øvre. Skaftets tredie Led er kun noget langere end tykt; det fjerde og femte ere meget forlængede, smale og nxsten af eens Længde. Svøben danpes hos Hunnen af 7 Led og er noget længere end Skaftets sidste Led.

K indbakkerne ere særdeles stærke, noget pyramideformede med en firkantet Basis og en noget indadbøiet, svagt buet Spids; under denne sees i en liden Grube en kort, tyk indre Plade, der ligeledes er noget indbøiet i-Spidsen. Palpen er fæstet i det ene Hjørne, nær Roden; den er meget smal og lang, især dens andet Led; det tredie er kun en Trediedel af det foregaaende Leds Længde; begge de sidste Led ere forsynede med en Række Børster.

Underlæben er meget kort og bred, med Spor af indre Plader.

Det første Kjæbepar er ikke meget stærkt; den ydre Plade har paa Enden tildels gaffelformede Torne; den indre Plade er stor, bred, oval, paa den øvre og indre Rand besat med ti fjærdannede Børster. Palpen er særdeles smal; det andet Led tilspidser sig noget mod Enden, paa hvilken der, ligesom paa den ydre Rand, sees syv simple Børster.

Det andet $\mathbf{K} \mathfrak{j} \rightsquigarrow \mathrm{bepars}$ Plader ere temmelig brede; den ydre er kortere og smalere end den indre.

Kjabeføddernes ydre Plade naar ikke frem til Enden af Palpens andet Led og har paa den indre Rand 14-16 knivformede Tænder, der mod Pladens Ende forlange og krumme sig; den indre Plade er bred og kort og naar kun frem til Enden 
af Palpens forste Led, samt er vabnet med tre smale, krumme 'Tænder og flere fjardannede Børster. Palpen er smal og lang; det første Led er kort; det andet er meget langt; det tredie er forlænget ovalt, og det fjerde er kloformet med en stærk Torn paa Enden.

De tvende første Fodpar ere af eens Bygning, men det andet Par er noget længere $0 \mathrm{~g}$ smalere end det forste; det tredie Led er kort; det fjerde er særdeles forlænget; det femte, eller Haanden, er forlanget firkantet, med en lillen skraa afskaaret Griberand;'paa det forste Par er Haanden neppe Halvdelen og paa det andet neppe en'Trediedel af det fjerde Leds Langde. Paa den bagre Rand have begge Par lange Børster. Kloen er kort.

Det tredie og fjerde Fodpar ere meget lange og tynde; det tredie Led er meget kort og ikke udvidet; det fjerde er næsten dobbelt saa langt; det femte er næsten en Trediedel kortere end det foregaaende Led. De tvende sidste Leds bagre Rand er forsynet med Børster. Kloen er kort, lidt. krummet.

De tre folgende Fodpar ere af eens Bygning og tiltage efter hverandre ubetydelig i Langde; det første Led er paa det femte Forlpar temmelig smalt, men er bredere paa de folgende Par, saa at det paa det sidste kun er liit mere end dobbelt saa langt som bredt; den bagre Rand er lidt udtrukket og afrundet; det tredie Led er lidt kortere end det forste og er bredere paa de tveude sidste Par; det fjerde er kortere og smalere end det foregaaende; det femte er omtrent saa langt som det tredie Led paa alle disse Fodpar.

Det første Par Springfødders Grene ere meget smale, cylindriske; den ydre er kortere end den indre, der er næsten saa lang som Grundleddet og har fine Torne paa Randene.

Det andet Pars ydre Gren er smal og meget kortere end den indre, men langere end Grundleddet; den indre Gren naar lengst bagud af alle Springfoddernes Grene, den er meget bred ved Roden og tilspidset mod Enden.

Det sidste Pars Grene ere omtrent lige lange, den ydre er lidt smalere end den indre, og begge have Børster paa den indre Rand.

Halevedhanget er meget bredt og stort, dobbelt saa langt som bredt ved Roden, ubetydelig kløvet i Spidsen og er langere end Halvdelen af det sidste Par Springfødders Grene.

Den er fundet i Christianiafjorden og i Hardangerfjorden samt ved Christiansund par 50-100 Favne af G. 0. Sars, og af mig ved Skraaven paa 200 Favne.

Subfamilia V.

PARDALISCIN $\mathbb{A}, A$. Boeck, 1870.

Sym.: 1870. Pardaliscine, A. Boeck, Crust. amphip. bor. et arct. p. 70. 
Labium superius latum, infra sinuatum.

Nandibulæ tuberculo molari destituta, dissimiles, in apice dentatæ; altera ramo interiore prodita. altera eodem carens: palpo 3articulato: articulo 2 do elongato.

Maxillæ Imi paris palpo sat lato, in apice dentibus multis instructo: lamine interna nodiformi.

Maxillæ 2di paris laminis angustis.

Pedes maxillares laminis interioribus parvulis aut obsoletis: laminis exterioribus aut latis. sed sat brevibus, aut angustis: palpo elongato. angusto: articulo ultimo ungviformi.

Corpus crassum, inflatum; epimeris parvis.

Antenne superiores tennes, flagello appendiculari instructa: pedunculo perhrevi: articulis flagelli anterioribus apud marem coalitis et articulum magnum. intus fasciculis setarum instructum, junctis formantibus.

Pedes $1 \mathrm{mi}$ et 2 di paris eadem forma.

Pedes 3tii et 4 ti paris validi; articulo 3tio brevi.

Pedes trium parium ultimorum longitudine gradatim crescentes: articulo 1 mo non valde dilatato; ungvibus longis.

Pedes saltatorii 2ramosi: ramis fere eadem longitudine: ultimi paris laminiformihus.

Appendix caudalis elongata, fissa.

Den typiske Slægt for denne Underfamilie er Pardalisca, Krøyer. Ved Formen af Kindbakkerne, der ligeledes her ere ulige paa begge Sider, slutter den sig til Underfamilierne Stenothoine og Syrhoine, hvilken silste den isar staar meget nær, samt er ogsal meget nær besliegtet med Underfamilien Amphilochina. Dens tre Slagter Pardalisca, Halice og Nicippe ligne hverandre meget og skille sig fra hverandre vaesentlig kun ved Formen af Hovedet og de tvende første Fodpar.

\section{Gen. I. PAlDALISCA. Kroyer, 1842.}

Deriv: P'ardalisca, en Tjenestepige hos Plautus i Komedien Casina.

Syn.: 1842. Pardalisea, Kroyer, Nat. Tidsskr. 1. R. 4. B. p. 153.

1852. - Dana, U. S. explor. exped. p. 912.

1859. - Bruzelius, Skand. Amphip. Gamm. p. 101.

1862. - Spence Bate, Catal. Amphip. Crust. Brit. Mus. p. 158

1865. - Lilljeborg, On the Lysianassa Magellanica.

Goës, Crust. amphip. maris Spetsb. p. 13. 
Syn.: 1870. Parilalisca, A. Boeck, Crust. amphip. bor. et arct. p. 71.

Type: Parlalisca euspidata, Kroyer.

Mandibula dextra in apice dentibus qvatuor validis armata: mandibula sinistra dentibus invalidis instructa.

Pedes maxillares lamina exteriore lata sed brevi, parum prominenti; lamina interna absenti.

Antennæ superiores inferioribus longiores; pedunculo perbrevi.

Antennæ inferiores pedunculo non prælongato.

Pedes 1 mi et 2 di paris carpo plus minusve dilatato; manu angusta et non subcheliformi; ungve lato.

Pedes 3tii et 4 ti paris articulo 3 tio dilatato, sed sat brevi; articulo 4 to ovato, ungve laminiformi.

Pedes trium parium ultimorum non prælongati.

Krøyer anforer i sin Slægtskarakter: "Palpus maxillarum posterioris paris articulo terminali valde dilatato, cordiformi." Herved kan neppe menes det andet Kjæbepar, men det forste, dog passer Diagnosen heller ikke fuldstændig paa dette Pars Bygning, da Palpen ikke er cordiformis, men afrundet paa Enden. Han antager ogsaa, at de tvende forste Fodpars fjerde Ler danner den egentlige Hand, fordi det er meget stærkt, og det folgende Led tilligemed Kloen skulle efter ham danne en 2leddet Klo, hvilken Anskuelse ogsaa deles af Bruzelius og Dana: Lilljeborg stiller denne Slægt i sin Underfamilie Gammarine sammen med Slægterne Gammanus, Eriopis, Eusirus, Microplax og Nicippe. Spence Bate stiller den mellem Slægterne Leucothoë og Seba under Gammarides og oversætter Krøyers Diagnose af Slægten.

PARDALISCA CUSPIDATA, Krøyer, $18+2$.

(II. XII. fig. 5.)

Pardalisca cuspidata, Kroyer, Nat. Tidsskr. 1842. 1. R. 4. B. p. 153.

\begin{tabular}{|c|c|c|}
\hline- & - & Lilljeborg, öfv. af Kgl. Vet.-Akad. Förhandl. 1850. p. \$2. \\
\hline- & - & M. Sars, Forh. i Vid.-Selsk. i Christiania 1858. p. 130. \\
\hline- & - & Bruzelius, Skand. Amphip. Gamm. 1859. p. 101. \\
\hline & & Spence Bate, Catal. Amphip. Crust. Brit. Mus. 1862. p. \\
\hline & & ip. maris Spetsb. $1865 . \mathrm{p}$ \\
\hline & & phip. bor. et aret. 1870 \\
\hline
\end{tabular}

Segmentum postabdominis 3tium et 4 tum in margine superiore postico dentibus binis armata; segmentum 5tum unidentatum. Pedes $1 \mathrm{mi}$ paris manu longitudinem carpi dimidiam non apqanti et multo angustiore qvam carpo latissimo, fu- 
siformi: ungve ovato, lalo, in apice el in margine posteriore spinis aculis instructo, dimidio longiore quam manu. Pedes 2di paris pedibus 1 mi paris paulo longiores et angustiores: ungve duas tertias partes longitudinis manus reqvanti. Pedes trium parium ultimorum ungvibus tam longis aut parnm lougioribus qvam dimidio articulo ultimo.

L. $x \mathrm{~g} \mathrm{~g}$ en er $15^{\mathrm{mm}}$.

Legemet er forlæenget, men meget tykt, opsvulnet: liyggen er rum, uden Kijgl, undtagen paa det femte Haleled. Det tredie Haleleds nedre, bagre Vinkel er næsten ret, og dets bagre Rand gaar ud i tvende T'orne, der ere skilte fra hinanden næsten ved liele Ryggens Bredde; det fjerde Led har ligeledes tvende Tome, der dog staa hinanden nærnere; det femte har liun een Torn. Sidepladerne ere smaa, omtrent saa høie som brede, og tiltage efter hverandre noget i storrelse; den fjerde er bagtil indskaret fol den femte, der er meget bred. Hovedet er meget tykt, og dets forreste Rand gaar mellem de ovre Folere lig en Vinkel un i et kort, but Pandehorn; dets nederste, forreste Vinkel er afrundet. Øinene ere smale, nyreformede.

De ovre F nedal og kort; det forste Led er neppe dobbelt saa langt som tykt og danner en stump Knude paa Enden af den indre og ydre Rand; det andet er meget kortere og smalere; det tredie el tykkere end langt. Svoben, der or saa lang som Skaftet, dannes af $40-50$ tykkere end lange Led. Bisvøben, der naar frem til Svobens 9de Lerl, damnes af $6-7$ længere end tykke Led.

De nedre Foleres tvende forste Led ere sammenvoxede; det andet udsender en meget kort, stump Lugteknude; det tredie er linapt saa langt som tykt; det fjerde er noget længere end de øvre Foleres Skaft; det femte er kortere, end let foregaaende lued. Svoben er forlænget $0 \mathrm{~g}$ dannet af 45 meget smaa Led.

Kindbakkerne ere meget tynde, ulige paa begge sider. Yaa hoire Side er Enden indskarret i fire meget store T'ænder, der udad blive kortere, men bredere; den indre Bigren mangler; paa venstre Side sees Enden, der er meget bred og har en svagt buet Rand, at vare forsynet med fine Tonder; her sees desuden en stor; bred, indre Bigren, der ligelerles er svagt bugtet i Randen og tandet; Tyggeknuden mangler. Palpen er treleddet; det forste Led er temmelig langt, men kortere end de følgende: det andet er længere end det tredie Led, der er afrundet paa Enden, begge de sidste Led have Burster paa den indre Rand.

Det forste Kjæbepars ydre Plade er bueformet indadboiet og er paa Enden væbnet med sex Trender, som paa den concave Side, nær Roden, have en Bitand; der sees desuden paa den indre Kant en tyk Børste; den iudre Plade mangler og danner kun en tynd Knude, forsynet med en Borste paa. Enden. Palpen er toleddet, meget bred, afrundet paa Enden samt har smaa Indskjaringer, og i hver af disse sees en Tand.

Det andet $K j \mathfrak{j}$ bepars ydre Plade er temmelig lang og smal, i Spidsen for61 * 
synet med Børster; den indre Plade er ogsaa smal, med Borster paa Enden og fjærdannede Børster paa den.indre Rand.

Kjæbefødderue ere meget store; den indre Plade, hvis Led er særdeles kort, sees kun som en Knude med tornede Børster paa Enden; det andet Led er derimod meget langt og fortsætter sig i den brede, ydre Plade, der dog kun naar frem neppe til Midten af Palpens andet Led; denne Plade er paa den øvre og indre Rand besat med talrige Borster, men er uden Tænder eller Torne. Palpens andet Led er meget længere end det tredie. Kloen er kort, af konisk Form.

Det forste Fodpar er stærkt; det første Led er meget bredt; det tredie er kort, men meget udvidet paa Enden; det fjerde er meget langt, bredt ovalt, paa den hagre Rand besat med ilels tornlignende og ilels fjwrianuede Borster. Det femte Led og det sidste, eller Kloen, ere smale og tilsammen kun Totrediedele af det fjerde Leds Læengle; det femte er næsten dobbelt saa langt som det sidste, noget krummet og har Børster paa den bagre Rand; det sjette, Kloen, el ovalt, væbnet paa den bagre Rand med Torne, der blive længere og stærkere mod Spidsen.

Det andet liorlpar er af den samme Bygning som det første, men det fjerde Led er længere og smalere, og dets bagre Rand har stærkere Børstebundter. Kloen er Totrediedele af det foregaaende Leds Længde.

Det tredie og fjerde Fodpars forste Led er meget langt, udvider sig nedad, samt er paa begge Rande besat med talrige Børster; det tredie er meget kort, men langere end det andet, med en meget udvidet forreste, nedre Vinkel; det fjerde er forlænget, spolformet og har Børster paa den bagre Rand; det femte er af den samme Længde som det foregaaende Led, men smalere mod dette. Kloen er bred.

De tre følgende Fodpar ere af eens Bygning, men det sjette er det længste; det femte Pars første Led er det bredeste; det andet er smalere, mere end dobbelt saa langt som bredt; det tredie er paa alle Par neppe udvidet nedad; det fjerde er noget kortere; det femte er af den samme Længde som det foregarende Led, men smalere. De trende sidste Led have Torne paa den forreste Rand. Kloen er lidt længere end Halvdelen af det sidste Led.

De trende første Par Springfødders ydre Gren er noget kortere end den indre, begge ere $\mathrm{i}$ Randene vabnede med Torne.

Det sidste Par naar længst bagud; dets Grene ere flade, lancetformede, fire Gange saa lange som brede, næsten dobbelt saa lange som Grundleddet og væbnede med Torne $\mathrm{i}$ begge Rande og med nogle fjærdannede Børster paa den indre Rand.

Halevedhænget naar længere tilbage end til Enden af det sidste Par Springfwdders Grundled, er kløvet til Roden og har Børster paa den ydre Rand og i Fligernes Spids en Torn.

Den er fundet af M. Sars ved Odvær, af Lilljeborg ved Tromsø, af G. 0. Sars ved Christiansund; den anfores af Bruzelius at gaa ikke sydligere end til Bergen, men 
siges af Goës at vare fundet indtil Bohuslen oy af Malm ved Koster. Inen er ligeledes taget ved Gronland, i Waygatstrodet og Here Steder ved Spitsbergen af Malmgren og ved Grønland af Torell.

PARDALISCA BOECKII, Malm, $18 \%$.

(Pl. X. fig. 4.)

Pardalisca Boeckii, Malm, 1870.

- $\quad$ A. Boeck, Crust. amphip. bor. et arct. 1870. p. 72.

Dorsum leve, dentibus et spinis destitutum. Angulus inferior posticus lateralis segmenti postabdominis 3 tii rotundalus. Pedes Imi et 2di paris carpo parum modo longiore et non multo latiore qvam manu elongata, ovata, et apicen versus angustiore; ungve curvato, angusto, acuminato, in margine postico spina armato. Pedes trium parium ultimorum articulo 1 mo angustiore qvam apud speciem præcedentem.

L $æ n$ gden er $8-10^{\text {mm }}$.

L e gemet er forlanget; Ryggen er rund; intet af Halens Led er paa den bagre Rand vabnet med Tander; det treslie Haleleds nedre, bagre Vinkel er megret afrumlet. Hovedets Sidevinkler ere ligeledes meget afrundede.

De ovre Føleres første Skaftled er ikke fuldt dobbelt saa langt som tykt; det tredie er kortere og smalere end det andet Led. Svøben er længere end Skaftet og dannes af 16 Led. Bisvoben har 2 Led.

De $n$ edre Folere ere kortere end de øvie; det tredie Led er nxsten dobbelt saa langt som tykt; det fjerde er længere og smalere end dette; det femte er kortere og smalere end det foregaaende Led. Sroben er kortere end Skaftet og danues af 10 - 12 Led.

De tvende forste Fodpar ere omtrent af eens Form og Storrelse; det fjerde Led er lidt tykkere og længere end det femte, der er smalt og tilspidset mod Enden. Begge disse Led have Børstebundter paa den bagre Rand. Kloen er krum, tynd, tilspidset mod Enden og er noget kortere end det sidste Led samt vabnet med en 'Torn paa den bagre Rand.

Det.tredie og fjerde Fodpars tredie Led er meget kort, kun lidt længere. end bredt, og dets nedre, forreste Vinkel er afrundet samt besat med Borster: det fjerde er meget længere, af en forlænget oval Form og har stærke Børster paa den bagre Rand; det femte er omtrent af den samme Langde som det foregarende Led, men meget smalere end dette. Kloen er svagt krummet, meget tynd og meget kortere end det sidste Led.

De tvende følgende Fodpar ere af eens Bygning; det forste Led er kum 
lidet udvidet, ligesom ogsaa ilet tredie, der er langere og tykkere end det fjerde; det femte er kortere og smalere end det foregaaende Led, samt har paa Enden en meget lang og sinal Torn.

Det syvende Fodpar er meget forlanget, tyndt og smalt; det forste Led er 4-5 Gange saa langt som bredt: det tredie er af den samme Længde som det fjerde, men meget bredere end dette; det femte er lidt længere end det foreganende Led. Kloen er overmaade tynd, nresten ret, kun lidt kortere end det sidste Led.

De trende forste Par Springfodders Grene naa nasten lige langt bagud og have ligesom Grundleddet faa, men lange 'T'orne paa den ovre Rand.

Det sidste Par er det laengste: Grenene ere nden Torne, nasten lige lange og laengere end Grundletdet.

Ha leved $\mathrm{h}$ ænget er lancetilannet, spaltet til Roden.

Denne Art er fundet af mig i Christianiafiorden og ved Karmoen, af Malm ved Rohuslen.

PAIDALISCA ABYSSI, A. Boeck, $18 \% 0$.

l'ardalisea abyssi, A. Boeck. Crust. amphip. bor. et arct. 1870. p. 72.

Antennæ superiores articulo pedunculi 2 do longitudinem articuli Imi reqvanti. Pedes Imi paris manu circiter duas tertias partes longitudinis carpi aqvanti: ungve paulo breviore qvam manu. in apice acuminato, in margine interiore spinis minulis armalo. Pedes 2di paris pedibus $1 \mathrm{mi}$ paris paulo longiores et angustiores. Pedes trium parimm ultimorum ungvibus hrevissimis. qvartam partem longitudinis articuli 5 ti vix requantibus ant parum longioribus. Creteropvin ferme ut apud P. cuspidala.

Liengden er $15^{\mathrm{mm}}$.

Legemet er bredt; Ryggen er rund, uden Kjol, undtagen en liden saadan paa det femte Haleled. hvor den bagtil gaar ud i en krum Tand: det tredie Haleled er paa Midten af den bagre Rand svagt halvmaaneformet indskaaret, hvorved der paa Sideme dannes tvende stumpe Vinkler, der begrændse dette Indsnit: dette Leds nedre, bagre Vinkel el nasten ret: det fjerde har tvende tret ved hinanden staaende Tronder. De fire forste Sideplader ere smaa, afruntede paa den nelre Rand, knap saa høie som brede; den femte forlanger sig derimod meget bagtil, livor den er smalere: de trende sidste ere meget forlingede og smale. Hovedet er omtrent saa langt som de trende forste Legemsled tilsammen og gaar fortil, mellem de ovre Folere, ud i et kort, stumpt Pandehorn; Sidevinklerne ere afrundede, og i den nedre Rand sees intet Indsuit for de nedre Folere.

De gvre Fglere ere ubetydelig kortere end de nedre. Skaftet er kortere end Hovedet og naar kun frem til Midten af Skaftet paa de nedre Folere; det forste Led 
er af den samme Liengde som det andet eller noget langere og tykkere end dette hos Hannen; det tredie er neppe langere end bredt. Svoben damnes af 50-60 Led, hvoraf de første ere meget korte. Bisvøben har 5 smale Led.

De nedre Føleres andet Skaftled udsender fra den indre Rand en stærk Lugteknude; det tredie er meget langere end tykt; let fjerde er noget længere og tykkere end det femte Led. Svøben er længere end Skaftet og dannes af 40-50 Led, hvoraf de forste ere meget korte.

Munddelene er lig dem hos $P$. cuspidata.

Det forste Fodpar er meget strerkt; det fjerde Led er forlænget ovalt, lidt smalere mod den ydre Ende og besat med fine Børster paa den bagre Rand; det femte er smalt, omtrent Totrediedele af det fjerde Leds Længde og har paa den bagre Rand stive, korte Borster. Kloen er kortere end det silste Led, noget krummet, tilspidset og med en Rxkke korte Torne paa den bagre Rand.

Det andet Fodpar har den samme Bygning, men er noget smalere og langere.

Det tredie og fjerde Fodpars tredie Led er meget kort, meget udvidet og uitrukket i den nedre, forreste V'inkel; det fjerde er forlænget ovalt, meget lougere end det tredie Led og med en Rakke lange, fint fjacdannede Borster paa den hagre laand: det femte Led er noget kortere end det tredie. Kloen er spids.

De tre følgende Fodpar ere efter. hverandre langere, og det første af disse er meget kortere end de folgende Par. Det femte Pars første Led er lidet udvidet bagtil, og dets nedre, bagre Vinkel er lidet udtrukket samt afrundet; det tredie Led er kortere end det forste. Paa de tvende følgende Par er det tredie Led langere end det første. Det fjerde er kortere, men det femte er længere end det tredie Led; alle have paa cien bagre Rand Knipper af Torne. Kloen er paa disse Fodpar kort, neppe en Fjerdedel af det sidste Leds Langde eller noget langere.

Det forste Par Springfødders Grene ere lange og smale, meget kortere end Grundleddet.

Det andet Pars Grene ere omtrent af den samme Langde som Grundleddet

Det sidste Pars Grene ere ikke fuld dobbelt saa lange som Grundleddet. meget brede og vabnede med lange, fjærdannele Børster paa den indre Rand.

Halevedhænget er kløvet til Roden, og hver Flig hal paa den ydre Rand tvende Torne og en lignende $\mathrm{i}$ den lidt indskaarne Spids.

Et Exemplar fandtes i Mosterhavn ved Haugesund. Jeg har ligcledes fundet den ved Hvidingsoerne samt ved Skraaven paa 2-300 Favne.

Gen. II. HALICE, A. Boeck, 1870.

Syn.: 1870. Halice, A. Boeck, Crust, amphip. bor. et arct. p. 72.

Type: Halice abyssi, A. Boeck. 
Instrumenta cibaria aqve ut apud genus Pardalisca:

Caput parvum, non inflatum; rostrum frontale elongatum.

Antennæ inferiores pedunculo prælongato, angusto.

Pedes $1 \mathrm{mi}$ et 2di paris carpo angusto; manu elongata; ungve gracili.

Pedes trium parium nltimorum sat prælongati.

Denne Slægt staar meget nær Pardalisca og adskiller sig fra denne væsentlig kun deri, at den har et lidet Hoved, medens hin Slægt har et overmaade stort og opsvulmet Hoved; lesuden har den et mere forlanget Skaft paa de nedre Følere, og de tre bagre Fodpar ere meget forlængede. Jeg kunde vistnok ogsaa have henfort dens Arter til Slægten Pardalisca, hvis jeg ikke havde kjendt tre Arter af denne Slægt foruden de tvende nedenfor nævnte, hvilke indbyrdes vise en saa stor Overensstemmelse, at de paa Grund heraf bor sammenføies under denne nye Slogt.

\section{HALICE ABYSSI, A. Boeck, 1870.}

(P1. X. tig. 2.)

Halice abyssi. A. Boeck, Crnst. amphip. bor. et arct. 1870, p. 72.

Antennæ superiores articulo pedunculi 1 mo duplo longiore qvam crasso; articulo llagelli 1 mo angusto: articulo flagelli appendicularis 1 mo angusto. Pedes $1 \mathrm{mi}$ paris manu parum longiore qvam carpo. Pedes 2di paris manu longitudinem carpi reqvanti. Segmentum postabdominis 4tum in medio margine posteriore spinas duas. segmentum 5tum eoden loco dentem unum longissimum. retroversum, formantia.

Legemet er ikke meget sammentrykt; Ryggen er rund, men det fjerde og femte Haleled have en Kjol, der paa det første af disse gaar ud i en kortere og bredere dobbelt Tom og paa det andet $\mathrm{i}$ en længere og smalere Tand; det tredie Haleleds nedre, bagre Vinkel er ret og springer frem i en liden Torn. Sidepladerne ere smaa, knay saa høie som brede; den fjerde er ikke meget indskaaret for den ferrte. Hovedet er omtrent saa langt som det forste Legemsled og danner fortil, mellem de gvre Folere, et lille Pandehorn. Øine kan ikke sees at være tilstele.

De grre Folere ere forlængede, tynde og naa, naar de bøies bagud, til det sjette Legemsled. Skaftet er kort; det forste Led er kun dobbelt saa langt som tykt og meget langere end de folgende Led tilsammen. Svøben er flere Gange saa lang som Skaftet og darnet af utydelig arlskite Led. Bisvoben er meget lang og tynd samt har 3 Led, hroraf det forste er langere end de tvende folgende-tilsammen.

De nedre Følere ere lidt længere end de øvre; det tredie Led er knap saa langt som tykt; det fjerde er meget forlanget, smalt; det femte er af den samme Længde, men smalere. Svøben er kortere end Skaftet. 
Kindbakkerne ere meget brede; den venstre er kun svagt indskaaret i Tænder, med en meget stark Hjornetand og forsynet med en indre, meget bred Bigren, der er ubetydelig tandet. Palpen er tynd; det tredie Led er meget kortere end det andet og har nogle Børster i Spidsen.

Det forste Kjæbepars ydre Plade er paa Enden væbnet med tvende meget stærke og 3-4 forlængede, men tynde, kloformede Tænder, samt paa Enden af den indre Iand med en fjærdannet Børste; den indre Plade er liden og har en kort Børste paa Enden. Palpens andet Led er meget bredt, afrundet paa Enden og besat med 16 Torne.

Det andet Kjæbepars Plader ere smale; den ydre er lidt kortere og smalere end den indre og har paa Enden tre fjærdannede Børster; den indre har paa den indre Rand tolv fjærdannede Borster.

Kjabeføddernes ydre Plade, der naar kun lidt frem for Palpens forste Led, har paa den indre Rand og paa Enden en Rokke tynde, i Spidsen noget krumme Torne eller stærke Børster. Palpen er forlænget; det andet Led er meget længere end det tyndere tredie Led, Lvilket er smalere mod Enden; det fjerde Led er kloformet.

De trende første Fodpar ere af eens Bygning, men det andet er det længste og synes derfor at være smalere end det første Par; det fjerde Led er forlænget smalt, med flere Børsteknipper paa den bagre Rand; det femte er noget langere, men smalere end det foregaaende Led, bliver tyndere mod den ydre Ende og har paa den bagre Rand tætstaaende Børstelnipper. Kloen er lidt krummet.

Det tredie og fjerde Fodpar ere af eens Bygning; det tredie Led er meget kort og ikke meget udvidet; det fjerde er ubetydelig længere; det femte er saa langt som det foregaaende Led, men tyndere. De tre sidste Leds bagre Rand er besat med enkelte Borstelmipper. Kloen er liden.

De tre folgende $\mathrm{Fodpar}$ ere af eens Bygning, men tiltage efter hverandre $\mathrm{i}$ Længde, ligesom det forste Led i Bredde. Paa det femte Par er det forste Led meget forlænget, eliptisk; det tredie er neppe udvidet og er af den samme Længde som det forste; det fjerde er ubetydelig kortere; det femte er end kortere og smalere. Paa det sjette Par er det første Led noget bredere, og det femte længere, hvilket er end mere Tilfaldet paa det syvende Par, hvis forste Led or næsten ret paa den forreste og convex paa den bagre Rand.

Det første Par Springfødders Grene ere næsten lige lange og forsynede med Torne i Randene og i Spidsen.

Det and et Par naar ikke fuldt saa langt bagud.

Det sidste $\mathrm{Par}$ er længere, og dets Grene, der ere indbyrdes lige lange, ere omtrent dobbelt saa lange som Grundledlet og besatte med lange, fjardannede Borster.

Halevedhænget er forlænget smalt, spaltet næsten til Ruden.

Denine Art er af G. 0. Sars fundet i Christianiafjorden paa 200 Favne, i Hardangerfjorden og ved Risvær i Nordland paa 300-400 og 180-200 Favne samt af mig ved Skraaven paa 200 Favne. 


\section{HALICE GRANDICORNIS, A. Boeck, $18 \%$.}

Halice grandicornis, A. Boeck, Crust. amphip. bor. et arct. 1870. p. 73.

Antenna superiores articulo pedunculi 1 mo non longiore qram crasso; articulo 1 mo flagelli et flagelli appendicularis permagnis et fusiformibus. Pedes $1 \mathrm{mi}$ paris manu longitudinem carpi duplam fere æqvanti. Pedes 2di paris manu multo longiore qvam carpo. Ceteroqvin ferme ut apud H. abyssi.

Længden er $10^{\mathrm{mm}}$.

Legemet er hos Hannen forlænget smalt; Ryggen er bred, rund, uden Kjøl; Legemsleddene ere meget smale, medens Halens tre første Led ere meget brede; de tre forste Haleleds nedre; bagre Vinkel er noget tilspidset; det fjerde Leds bagre Rand gaar paa Midten ud i en liden, tyk Torn; paa det femte Led sees ligeledes en Torn, der er meget Iang og nedadboiet, men naar ikke Enden af det folgende Led. Hovedet er kort og gar mellem de ovre Folere ud i et bredt, spidst Pandehorn.

De øvre Følere ere kortere end de nedre. Skaftets første Led er saa langt som tylit og saa langt som de tvende folgende, smalere, tilsammen. Svoben er meget forlænget; det meget store forste Led, der er omtrent dobbelt saa langt som Skaftet, er af en spollignende Form og forsynet paa den indre Side med meget tatstanende Børster; den øvrige Del, der dannes af 40 Led, hvoraf de første ere meget korte og skiveformede, er omtrent dobbelt saa lang som det første Led. Bisvoben er omtrent af den samme Langde som Svobens forste Led og bar 2 Led, hvoraf det forste er særdeles forlanget oỵalt, det andet meget tyndt og ledet.

De nedre Følere ere meget tyndere end de øvre, næsten traalformede; de tvende forste Led ere smaa; det tredie er kun ubetydelig liengere end tykt; det fjerde er meget tyndt, omtrent saa langt som de ovre Foleres Skaft og deres forste Svobeled tilsammen; det femte Led er noget kortere og tyndere. Svøben, der er langere end Skaftets sidste Led, dannes af 24 Led.

Kindbakkerne ere meget brede i Griberanden, samt uden Tænder og Bigren paa den ene Sirle, hvorimod der paa den anden sees en bred Bigren. Palpen er tynd; det tredie Led er meget kort.

Det forste K j $x$ b e pars ydre Plade er væbnet med tvende Rader stærke, krumme Torne der ere uden Bitander. Palpen er afrundet paa Enden og har 5-6 Torne.

Det andet $K j a b e p a r s$ Plader ere meget smale; den ydre har paa Enden tvende fjærdannede Borster; den indre een lignende samt mange mindre paa den indre Rand.

Kj $x$ efoddernes ydre Plade er kort og smal, skraa afskaren paa Enden og er der vabnet med nogle krumme Tander, og langs den indre Rand sees Børster; den indre Plade mangler. Palpen er smal, med et kloformet fjerde Led.

Det forste Fodpars fjerde Led er kun ubetydelig bredere mod den ydre 
Ende; det femte er næsten af den dobbelte Længde og er smalere mod Enden. Kloen er noget kortere end det sidste Led, smal og lidt krummet.

Det andet Fodpar er noget længere end det forste; det fjerde Led er meget kortere end det femte, bredere mod den ydre Ende og forsynet med talrige Børstebundter paa den bagre convexe Rand; det femte er længere end det tilsvarende paa det forste Fodpar, men af den samme Bygning, og har mange Børstebundter paa den bagre Rand. Kloen er meget kortere end det sidste Led og er kun ubetydelig krummet.

Det tredie og fjerde Fodpars tredie Led er noget kortere end det fjerde, der er meget ovalt forlænget; det femte er kortere end de tvende foregaaende Led tilsammen og meget smalere end disse. De fire første Led have lange fjærlannede Borster paa den bagre Rand; det femte har smaa Tornebundter. Kloen er saa lang som Halvdelen af det sidste Led.

De tre folgende Fodpar ere meget lange og smale.

Det femte Fodpar er noget kortere end de ovrige; dets forste Led er meget smalt, næsten fire Gange saa langt som bredt, og har paa den ydre Side en Forhøining, der er afrundet mod Leddets ydre Ende; det tredie Led er længere end det forste og lidt længere end det smale fjerde Led; dette er længere og tykkere end det femte Led. Kloen er liden, ret.

Det sjette Fodpars første Led er bredere end paa det foregaaende Par og har en lignende, men mindre Forhøining; de følgende ere af den samme Form som de tilsvarende paa det femte Fodpar, men ere længere.

Det syvende Fodpar er af den samme Form som de trende foregaaende Par, men det forste Led er udvidet paa den bagre Rands overste Del, medens den neilre er smal.

De tvende forste Par Springfødder naa omtrent lige langt bagud; den ydre Gren er lidt kortere end den indre og forsynet med Torne paa Randene.

Det sidste Par er længere end de foregaaende; den ydre Gren er lidt kortere end den indre og næsten dobbelt saa lang som Grundleddet; begge Grene ere lancetformede og besatte med talrige Borster paa den inile Rand.

Halevedhænget er meget langt, spaltet til Roden.

Jeg har fundet denne Art kun i eet Exemplar i Hardangerfjorden paa 150 Favnes Dybde.

Gen. III. NICIPPE, Bruzelius, 1859.

Deriv.: Nicippe, en Datter af Pelops.

Syn.: 1859. Nicippe, Bruzelius, Skand. Amphip. Gamm. p. 99.

1862. - Spence Bate, Catal. Amphip. Crust. Brit. Mus. App. p. 374.

1865. - Lilljeborg, On the Lysianassa magellanica.

1868. - Spence Bate and Westwood, Brit. sessile-eyed Crust. App. p. 115. 
Syn.: 1868. Nicippe, Norman, Ann. and Mag. Nat. Hist. p. 413.

1870, - A. Boeck, Crust. amphip. bor. et arct. p. 73.

Type: Nicippe tumida, Bruzelius.

Dextra mandibula in apice paucis modo deǹtibus magnis instructa; sinistra ut ramus accessorius dentibus multis parvis et nonnullis magnis instructa.

Pedes maxillares lamina utraqve parva et angusta; lamina interiore in apice setam plumosam gerenti.

Antennæ superiores inferioribus multo longiores; pedunculo brevi.

Pedes $1 \mathrm{mi}$ et 2 di paris robusti; carpo brevi sed extrorsum lato; manu magna, ovata, subcheliformi; ungve longo, angusto.

Pedes 3tii et 4 ti paris articulis anguslis; 3tio longiore qvam apud genus præcedens; ungvibus gracilibus curvatisquve.

Bruzelius opstillede denne Slægt i 1859 paa den af ham fundne nye Art $N$. tumida og stiller den mellem Slægterne Laphystius, Kr., og Pardalisca, Kr., samt bemærker, at den i flere Henseender staar nær den sidstnævnte Slægt. Spence Bate optager den i $1862 \mathrm{og}$ vil stille den mellem Slægterne Oedicerus og Monoculodes til Underfamilien Phoxides. Lilljeborg henfører den i 1865 til Underfamilien Gammarina, sammen med Slægterne Gammarus, Eriopis, Eusins, Microplax og Pardalisca. Ved Munddelenes Bygning og det hele Legemes Form afviger denne Slægt dog meget fra de nævnte Underfamilier med Hensyn til de Karakterer, der tilhøre disse. Med Rette har Bruzelius og Lilljeborg stillet den sammen med Pardalisca, hvilken den staar meget nær.

NICIPPE TUMIDA, Bruzelius, 1859.

Nicippe tumida, Bruzelius, Skand. Amphip. Gamm. 1859. p. 99. pl. IV. fig. 19.

- $\quad$ - Spence Bate, Catal. Amphip. Crust. Brit. Mus. 1862. App. p. 374.

- $\quad$ - Spence Bate and Westwood, Brit. sessile-eyed Crust. 1868. App.p. 511.

- - Norman, Ann. and Mag. Nat. Hist. 1868. p. 414.

- - A. Boeck, Crust. amphip. bor. et arct. 1870. p. 73.

Segmenta dorsi et postabdominis rotundata, dentibus et spinis destituta; tamen segmentum postabdominis 4 tum in medio margine postico dentibus duobus armatum. Angulus inferior posticus segmenti postabdominis 3tii in aculeum parvum productus. Pedes $1 \mathrm{mi}$ et $2 \mathrm{di}$ paris manu ovata; ungve longo, curvato, in margine spinis gracilibus instructo. Pedes saltatorii ultimi paris ramis elongatis, lanceolatis. 
Længden er omtrent $12^{\mathrm{mm}}$.

Legemet er meget tykt, opsvulmet; Ryggen er rund, uden Kjøl eller Torne, undtagen paa det fjerde Haleled, som paa det bagre Parti har en Kjol, der bagtil gaar ud i en Torn; de tre første Haleleds nedre, bagre Vinkel er noget tilspidset. Sidepladerne ere smaa, bredere end hoie; den tredie og fjerde ere mindre end de foregaaende, men alle ere dog næsten af den samme Størrelse. Hovedet er længere end det forste Legemsled og gaar fortil, mellem de ovre Folere, ud i et lidet Pandehorn.

De øvre Følere naa, naar de bøies bagud, omtrent til det fjerde Halelea. Skaftets første Led er noget kortere end Hovedet; det andet er kortere end det foregaaende; det tredie er neppe længere end tykt. Svoben er flere Gange saa lang som Skaftet $0 \mathrm{~g}$ dannes af 48 korte Led, hvoraf de første ere utydelig adskilte. Bisvøben har 3-4 Led, af hvilke det første er meget langt og bredt, de ovrige ere meget korte.

De nedre Følere ere noget kortere end de øvre; de tvende første Led ere skjulte i Hovedet; det tredie er meget længere end bredt; det fjerde og femte ere efter hinanden længere. Svøben dannes af 18 Led.

Kindbakkerne ere ulige paa begge Sider. Den høire mangler Bigren; Spidsen er væbnet med tre store Tænder og en skarp Rand, der er fint tandet. Paa den venstre har Spidsen en stor Tand paa den ydre Side, og den skarpe Rand har paa Midten tre Tænder, der aftage efter hverandre i Størrelse, og lignende mindre paa Siderne; den indre Bigren har tre Tænder paa Midten og en paa den ydre Side samt mange smaa mellem disse. Tyggeknude mangler. Palpen er smal; det andet Led er længere end det tredie, og begge ere paa Randen forsynede med spredte Børster.

Det forste Kjæbepars ydre Plade er bred, paa Enden besat med grove Torne; den indre Plade er liden, men forlænget, og har nogle fjærdannede Børster paa Enden. Palpen er meget bred paa Enden, der har mange Torne og Børster.

Det andet $\mathrm{Kj}$ æbepars Plader ere smale; den ydre har fjærdannede Børster paa Enden, den indre har lignende Børster langs den indre Rand og i Spidsen.

Kjæbefoddernes Plader ere smaa; den ydre er vabnet med nogle Torne, forsynede med Bitæender; den indre har kun en Borste paa Spidsen. Palpen er særdeles forlænget, smal; det andet Led er længere og tykkere end det tredie; Kloen er smal, med smaa Trender paa den bagre Rand.

Det forste Fodpar er noget kortere end det andet, men omtrent af den samme Form; det fjerde Led er bagtil noget udvidet, hvorved dannes et bredt Fremspring, der er.forsynet med talrige Børster; Haanden har en noget xglignende Form og har paa den bagre Rand talrige, tildels fjerdannede Børster. Kloen er lang, smal, krum, med fine Saugtakker paa den bagre Rand.

Det andet Fodpars fjerde Leds nedre, bagre Vinkel udsender et noget lingere Fremspring end hos det foregaaende Par, og hvilket ligeledes er besit med Borster.

Det tredie og fjerde Fodpar ere smale; det forste Led er forlanget; det tredie er meget lidet udvidet paa den ydre Ende; det fjerde er omtrent af den samme 
Længde soin det foregaaende; det femte Led er længere. Den bagre Rand, især paa det tredie Led, er forsynet med talrige Børster.

De tre følgende Fodpar ere smale og tiltage efter hverandre meget i Længle; det første Led er ikke udvidet hos det femte Par, men mere paa de følgende; det fjerde Led er paa det femte Par kortere end det tredie, det forlænger sig paa det sjette Par, og paa det syvende er det længere end det tredie Led. Det femte Led er paa det femte og syvende Fodpar omtrent af den samme Læengde som det foregaaende Led, paa det sjette Par er det længere.

Det andet Par Springf $\emptyset$ dder er det korteste.

Det sidste Par naar længst bagud; Grenene ere af en meget forlænget, lancetlignende Form; den ydre er ubetydelig længere end den indre og har paa den ydre Rand tætstaaende, fjærdannede Børster; den indre har lignende Børster paa den indre Rand.

Hal evedhænget er kløvet næsten til Rorlen; Fligerne ere lange, smale, lancetdannede, og $\mathrm{i}$ den indskaarne Spids sees en liden Torn.

Denne Art, der forst blev funden af Bruzelius ved Drøbak, er taget af G. O. Sars ved Stavanger paa 40-60 Favne, ved Mosterhavn paa 100-150, ved Christiansund paa 50-100 Favne, samt ved Hvidingsøerne; af mig ved Holmestrand og ved Skraaven paa 200 Favne. Af Jeffreys er den fundet ved Shetlandsøerne.

\section{Subfamilia VI.}

\section{LEUCOTHOINE, Dana, 1852.}

Syn.: 1852. Leucothoince, Dana, On the Classif. of the Crust. Choristopoda or Tetradecapoda.

1855. Leucothoides, Spence Bate, On the Brit. Edriophtalmata.

1856. Leucothoini, Costa, R. sui Crost. amfip. del regno di Napoli.

1865. Leucothoina; Lilljeborg, On the Lysianassa magellanica.

1870. Leucothoinre, A. Boeck, Crust. amphip. bor. et arct. p. 74.

Labium superius latum, in apice insinuatum.

Mandibuls parvule; in ap. a dilatate, plus minusve dentate, dissimiles, altera ramo interiore predita, altera eodem carens; tuberculo molari robusto aut nullo; palpo elongato, 3articulato.

Labium inferius laminis interioribus angustis.

Maxilla 1 mi paris lamina interiore magnitudinis mediocris aut parva, paucis aut nullis selis instructa; palpo angusto, 2arliculato.

Maxilla 2di paris breves, lamina interiore laliore qvam exteriore.

Pedes maxillares laminis mininis, aul fere obsoletis; exteriore in margine 
interiore et in apice spinis tenuibus instructa; palpo prelongato, robusto: articulo ultimo ungvem longum et curvum efficienti.

Corpus compressum, altamen sat crassum; dorso lato; epimeris magnitudinis mediocris; 1 mo majore qvam 2do et 3 tio.

Antennæ superiores flagello appendiculari breviore aut longiore; interdum nullo.

Pedes $1 \mathrm{mi}$ et 2 di paris invicem eadem forma aut raro dissimiles; manu apud sextum utrumqve robustissima; carpo brevi, in angulo inferiore postico valde producto.

Pedes reliqvi elongati; trium parium ultimorum articulo 1 mo dilatalo.

Pedes saltatorii 2ranosi; ramo exteriore duorum anteriorum parium breviore qvam interiore; ramis ultimi paris longitudine fere æqvalibus.

Appendix caudalis elongata, non aut plus minusve fissa.

Denne Underfamilie er opstillet af Dana i 1852 under Familien Gammavidee, og han henførte hertil tvende Slægter; Stonothö̈ og Loucothoë. Som Karakter for denne anføres, at Folernes Skaft er mere eller mindre tyndt, hvilket ikke er Tilfældet hos hans foregaaende Underfamilie Lysianassinœ, at. Kjæbefodderne ere forlængede, smale, deres indre Plader meget smaa og Palpernes sidste, lange Led liloformet, at Kindbakkerne enten ere forsynede med Palpe (Leucothoë) eller udenjen saadan (Stcnothoë), men at de ('n sempor?) mangle Tyggeknude. Spence Bate stillede i 1855 til sin Underfamilie Leucothoides kun Slægten Lerucothoë, medens Slægten Montagua, som falder sammen med Stenothoë, af ham blev henfort til Underfamilen Stegocephalides. A. Costa henforte i 1856 til sin Underfamilie Leucothoini kun Slsgten Leucothoë. Jeg anførte i 1860 („Bemærkninger angaaende de ved de norske Kyster forekommende Amphipoder"), at Bruzelius's Slægt Paramphithoë, saaledes som jeg sammesteds havde begrændset den, og med hvilken Pleustes, Spence Bate, fuldkommen falder sammen, viser en lignende Bygning af Kjæbefodderne, som den, der er angivet af Dana for hans Underfamilie Lencothoinc. Ligeledes fanit jeg, at det samme er Tilfoldet med Slægten Eusirus, som baade af Bruzelius og Dana er stillet nær Slægten Gammarus, og tillige med den af mig som ny opforte Slægt Iduna (Liljeborgia, Spence Bate, Microplax, Lilljeborg). Derimod fandt jeg, at enkelte af disse Slagter besidde en Tyggeknude paa Kindbakkerne, hvoraf ogsaa Leucothoë viser et lidet Rudiment. Jeg omtalte, at Leucothoë og Stenothoë mángle Bisvobe paa de ovre Folere, at denne hos Eusinus er meget liden, hos Iduna meget lang, samt at Kindbakkerne mangle Palpe og Tyggekunde hos Stenothoë; hos Leucothoë fandt jeg en Palpe, men neppe en Tyggeknude, hvilken hos Iduna er liden, men hos Eusirus stor. Spence Bate henfører i 1862 Slægten Lencothoë, der er Typus for denne Underfamilie, til Gammarides og sloifer saaledes ganske hin Underfamilie. 
Derimod optages denne af Lilljeborg i 1865, og han henfører til denne, foruden I)ana's tvende Slægter, desuden Slægten Montamua, Spence Bate, og Plcustes. Spence Bate (Puramphithoï). Som Karakterer for denne Underfamilie nævner han kun Kjæbefiddernes ciendommelige Form, idet deres Plader ere meget lidet udviklede. Jeg formener, at som Typus for denne Underfamilie maa Slagten Lencothoë antages, og hertil maa tilfoies de Former, der næermest gruppere sig om den. I 1870 henførte jeg hertil, foruden Leucothoe, Slægterne Lilljeborgia (Iduna, Boeck), Eusirus og Tritrcpis (Amphithonotus, Costa), medens Stenothoë blev henført til en anden Underfamilie, Stenothoina. Endvidere maa hertil henføres Slægten Pleustes, Spence Bate, der ved en Feiltagelse af Forfatteren blev i 1870 stillet til Underfamilien Ocdicerinc, hvilken Feil paa Grund heraf ogsaa er gaaet over i dette Vark.

Gen. I. LILJEBORGIA, Spence Bate, 1862.

Deriv. : Opkaldt til Ëre for den svenske Zoolog Professor Liljeborg.

Syn.: 1860. Iduna, A. Boeck, Forh. ved de Skand. Naturf. 8de Møde. p. 656.

1862. Liljeborgia, Spence Bate, Catal. Amphip. Crust. Brit. Mus. p. 118.

1863. - Spence Bate and Westwood, Brit. sessile-eyed Crust. p. 202.

1865. Microplax, On the Lysianassa magellanica.

1870. Lilljcborgia, A. Boeck, Crust. amphip. bor. et arct. p. 74.

Type: Gammarus pallidus, Spence Bate,

Mandibulæ in apice valde dentatæ; tuberculo molari obsoleto.

Antennæ superiores pedunculo inferiorum breviores nut parum longiores; flagello appendiculari longissimo.

Pedes 1 mi paris manu parum minore sed eadem forma ac 2di paris; carpo sat brevi, postice et deorsum in calcem producto.

Pedes trium parium ultimorum longilud ne gradatim crescentes.

Appendix caudalis usque ad basin fissa.

Jeg opstillede i 1860 Slagten Iduna paa den af Bruzelius ny beskrevne Art Gammarus brevicornis, idet jeg fandt, at den adskilte sig fra Slægten Gammanus, med hvilken den kun havde det tilfælles, at de øvre Følere have en Bisvøbe. Derimod fandt jeg, at den stemmede i Hlere Henseender overeens med Slægten Eusims og nærmede sig desuden meget til Leurothoë. Spence Bate, der ikke kjendte min Afhandling, opforte denne Slægt i 1862 under Navnet Liljeborgia og stillede den nær Urothoë. Da imidlertid det af mig angivne Navn var benyttet til Slægtsuavn for en Annelide, maa Spence Bates Navn indtræde for det af mig givne. Synonym hermed er ogsaa Lilljeborgs Slagt Microplax. Denne Slxgt er af Spence Bate henfort til Phoxides og stillet ved Siden af Urothö̈ og af Lilljeborg til Gammarina. Jeg antager derimod, at den maa 
henføres til Lencothoinc. Hertil maa vistnok høre den af Costa i 1853 beshrevne Gammarus bispinosus, ligesom ogsaa Phadra Kinahani, Spence Bate, synes at maatte henføres til denne Slægt.

\section{LILLJEBORGIA PALLIDA, Spence Bate, 1855.}

(Pl. XVIII. fig. 9.)

Gammarus pallidus, Spence Bate, Brit. Assoc. Rep. 1855. p. ว̌. Ann. Nat. Hist. 1857. 2. ser. XIX, p. 145.

\section{- $\quad$ White, Pop. Hist. Brit. Crust. 185\%. p. 185.}

- brevicornis, Bruzelius, Skand. Amphip. Gamm. 1859. p. 62. pl. III. fig. 11. Iduna brevicornis, A. Boeck, Forh. ved de skand. Naturf. Sde Mode. 1860. p. 655. Liljeborgia pallida, Spence Bate, Catal. Amphip. Crust. Brit. IIus. 1862. p. 118. pl. Xx. fig. 5.

Spence Bate and Westwood, Brit. sessile-eyed Crust. 1863. p. 203. - $\quad$ - A. Boeck, Crust. amphip. bor. et arct. 1870. p. 75.

Seguenta qvingve anteriora postabdomins in medio margine posteriore denticulis singulis acutis instructa. Dorsum non carinatum. Angulus inferior posticus lateralis segmenti postabdominis 3tii rectus et, ut segmentum postabdominis 2dum. dente aculo armatus. Antemme inferiores articulo pedunculi 4 to et 5 to longitudine ferme rqualibus. Pedes $1 \mathrm{mi}$ paris manu oblonga, ovata, in margine postico magis curvata quam in margine antico. Pedes 2 di paris eadem forma ac $1 \mathrm{mi}$ paris. Pedes trium parium nltimorum articulo 1 mo lato. ovato. in margine postico rolundato, dentato. Pedes saltatorii ultimi paris ramis invicem eadem longitudine, lanceolatis et paulo longioribus qvam pedunculo.

Længden er $9^{\mathrm{mm}}$.

Legemet er sammentrykt fra Siderne og temmelig hoit; Ryggen er rund $0 \mathrm{~g}$ bred; de fem forste Haleled ere paa Midten af den bagre Rand væbnede med en liden Tand; det andet og tredie Haleleds nedre, bagre Vinkel er tilspidset. Den forste Sideplade er meget større end de tvende følgende, og dens nedre, forreste Rand er udtrukket $0 \mathrm{~g}$ afrundet. Hovedet er længere end det forste Legemsled og gaar fortil, mellem de øvre Folere, ud i et lidet Pandehorn; dets Sidevinkler ere ikke neget udtrukne, afrundede. Øinene ere temmelig store, lidt indbugtede i den forreste Rand.

De øvre Folere ere korte og naa, naar de boies bagud, kun til Enden af det femte Legemsled. Skaftets forste Led er af den samme Langde som Hovedet eller lidt kortere; det andet har kun den halve Liengde; det tredie Led er meget kort. Svoben er lingere end Skaftet og dannes af 16 skraa afskaarne, med Borster besatte Led. Bisvøben er meget tyndere, Totrediedel af Svøbens Langde og har omtrent 10 Led. De nedre Følere ere meget langere end de ovre. Skaftets tredie Led er 
kun lidt længere end tykt; det fjerde er ubetydelig kortere end det femte Led. Svöben er lidt længere end Skaftets sidste Led og dannes af 14 Led.

Kindbakkerne ere forlængede; Gribedelen er meget bred, tandet; den indre Bigren er ogsaa meget bred, og begge ere indskanne.i $5-7$ Tænder. Tornerækken dannes af omtrent sex, paa den concave Rand saugtakkede Børster; Tyggeknuden mangler, og paa dens Plads sees en stærk Bundt Borster. Palpen er meget tynd, forlænget; det første Led er kun lidt kortere end det andet, der er langere end det tredie Led, hvilket sidste har nogle Borster i Spidsen.

Det andet $\mathrm{Kj}$ xbepars ydre Plade er lingere og smalere end den indre, der er meget bred.

Kjæbeføddernes ydre Plade er særdeles liden, med nogle faa Torne paa den indre Rand og i Spidsen; den indre Plade er meget kort, naar neppe frem til Enden af Palpens forste Led og er paa Enden væbnet med tre Torne. Palpens andet og tredie Led ere meget forlængede; det fjerde er særdeles smalt, kloformet, saugtakket paa den bagre Rand.

Det første Fodpar er mindre end det andet; det fjerde Led er meget kort, bredt og udsender fra sin nedre, bagre Rand en smal, ikke meget lang, paa den bagre Rand med Børstebundter besat Hæl. Haanden er oval, med en mere convex bagre end forreste Rand, og er ikke fuldt dobbelt saa lang som bred; dens ydre Totrediedel indtages af Griberanden, der har langere eller kortere krumme Torne og tvende lignende, meget storke paa Enden. Ǩloen er lang, smal, krummet, saugtakket paa den indre Del af den bagre Rand.

Det andet Fodpar er af den samme Form, men Haanden er ægdannet, og Kloen er saugtakket næsten paa den hele bagre Rand.

Det tredie og fjerde Fodpar ere meget forlængede; det tredie Led er kun lidet udvidet, liengere end det fjerde, men kortere end det femte Led.

De tre følgende Fodpar ere næsten af eens Form og Størrelse; det første Led er ovalt, saugtakket paa den bagre Rand; det tredie er lidt længere end det fjerde og nasten saa langt som det femte Led. Disse tvende sidste have lange Børster paa den forreste Rand. Kloen er tynd, omtrent en Trediedel af det sidste Leds Længde.

Det første Par Springfødder naar længst bagud. Grenene ere kortere end Grundleddet; den ydre er lidt langere end den indre, der paa den ovre Rand er væbnet med Torne.

Det andet Pars Grene ere længere end Grundleddet.

Det sidste Pars Grene ere lancetformede, næsten lige lange, og lingere end Grundleddet.

Halevedhonget el klovet til Roden; Fligerne ere indskaarne i Spidsen, og her sees en Torn.

Farven er efter Spence Bate hvid, med en høirød Flek nær Ryggens Midtlinie; det sidste Led paa de tvende forste Fodpar har en rosenrød Farve, og en Nuance af denne sees paa Here af de følgende Fodpars Led. 
Den er fundet af G. 0. Sars ved Christiansund paa 50-100 Favne, ved Laurkullen paa 150 Favne, ved Utne paa 300 Favne, af mig ved Skraaven paa 300 Favne. Efter Bruzelius er den taget af Lovén ved Finmarken og gaar ned til Bohuslen.

\section{LILLJEBORGIA FISSICORNIS, M. Sars, 1858.}

(Pl. XVIII. fig. 10.)

Gammarus fissicornis, M. Sars, Overs, over norsk-aret. Krebsdyr, Forh. i Vid.-Selsk. i Christiania 1858. p. 147.

- - Spence Bate, Catal. Amphip. Crust. Brit. Mus. 1862. App. 380. Iduna fissicornis, A. Boeck, Forh. ved de skand. Naturf. 8de Mgde.1860. p. 65\%. Lilljeborgia fissicornis, A. Boeck, Crust. amphip. bor. et arct. 1870. p. 75.

Segmenta postabdominis dun anteriora in medio margine posteriore dentibus singulis sat aculis, retroversis instructa: segmentum 3tiun dente sxpe destitutum: segmentum 4tum et 5tum carinata; carina postice in dentem acutum, erectum et triangularem, segmenti 4 ti majorem, desinenti. Antennæ superiores duas tertias longitudinis inferiorum agvantes. Antenne inferiores ad segmentum trunci 5tum porrecta; articulo pedunculi 4 to parum breviore qvam 5to. Pedes 2di paris manu fere triangulari, apicem versus angustiore. Pedes 5 ti et 6 ti paris arliculo 5 to breviore qvam 4to. Pedes $7 \mathrm{mi}$ paris articulo 5 to longitudinem 4 ti reqvanti.

Længden er $11^{\mathrm{mm}}$.

Legemet er langstrakt; Ryggen er rund; de tvende forste Haleled ere paa Midten af den bagre Rand vabnede med en temmelig spids, bagudrettet Torn, som ofte mangler paa det tredie Led; det fjerde og femte Led ere meget korte og have en skarp sammentrykt Kjol, der lober ud i en stærk, opadrettet spids Torn. Den første Sideplade er bredere end den anden, og den forreste, nedre Vinkel er meget udtrukket, afrundet. Hovedet er længere end det forste Legemsled og gaar fortil ul i et kort, spidst Pandehorn; dets Sidevinkler ere udtrukne, afrundede.

De øvre Føleres Slaft er kort; det andet Led er kun halvt saa langt som det første; det tredie er kort. Svøben er længere end Skaftet og dannes af 26 skraa afskaarne Led. Bisvaben har Totrediedel af Svobens Longde og har 14 Ised.

De nedre Følere ere longere end de ovre og naa frem til det femte Legemsled. Skaftet er meget langt; det tredie Led er dobbelt saa langt som tylit; det fjerde er ubetydelig kortere end det femte Led. Svgben er kortere end Skaftets sidste Led og dannes af 19 Led.

Kindbakkerne ere meget stærke; Enden er bred og tandet; Tornerækien dannes af faa, men stærke og tandede Torne; Tyggeknuden er rudimentær. 
Det forste Kjæbepars ydre Plade har paa Enden fiere Rækker lange, stærke, kamdannede Tænder; den indre Plade er liden, oval, forsynet med en meget lang, fjærdannet Børste og en mindre, der ikke er fjærdannet. Palpen er lang; det forste Led er kort, det andet er forlanget ovalt.

Det andet Kjæbepars indre Plade er meget bred, skraa afskaaren paa Enden og besat med mange simple Børster og nogle lignende fjærdannede.

Kjæbefoddernes ydre Plade er smal, med nogle Torne i Randen; den indre Plade er meget liden, vabnet med tre lange Tænder paa Enden. Palpen er forlænget, men stærk; det andet Led er meget langt, længere end det tredie. Kloen er stærk, saugtakket paa den bagre Rand.

Det første Fodpars tredie Led er kort og gaar i den nedre, bagre Vinkel ud i en Spids; det fjerile er fæstet paa det foregaaende Leds forreste Flade og danner paa den nedre, bagre Vinkel en lang, med Borster besat Hæl, der naar frem til Haandens bagre Rand, hvor Griberanden begynder. Haanden er bred oval og meget stor, med en mere ret forreste og mere convex bagre land. Den meget skraa convexe Griberand er besat med Torne, hvor Kloens Spids lagger sig imod. Kloen er meget stor, krummet og indskaaret i fine 'T’nder nær Roden paa den bagre Rand.

Det andet Fodpar er storre end det forste, men har den samme Bygning; Haanden har en mere triangulær Form, og dens Griberand er fint saugtakket sant har et Par. Torne, hvor Kloens Spids lagger sig imod. Kloen er saugtakket paa den bagre Rands indre Halvdel.

Det tredie og fjerde Fodpar ere lange og smale og af den for disse sadvanlige Form; det fjerde Led er noget kortere end det femte.

De tre folgende Fodpar tiltage efter hverandre i Længde og Tykkelse, saaledes at det syvende er omtrent dobbelt saa langt og tykt som det femte Fodpar. De trende forste Pars tredie Led er længere end det fjerde, der atter er længere end det femte Led, medens disse tvende sidste Led paa det syvende Par ere omtrent lige lange.

De tvende forste Par Springfodders Grene cre forsynede med mange Torne paa den øvre Rand.

Det sidste Pars indre Gren er kortere, men bredere end den ydre.

Hal evedhænget er lancetformet delt til Roden; Fligerne ere indskaarne paa Enden og forsynede i deune Indskjæring med tvende smaa Torne.

Den er fundet af M. Sars i et enkelt Exemplar ved Vadsø paa 20-30 F'annes Dybde, af G. O. Sars ved Risvær og Odvær i Nordland paa 3-400 Favne, af Malm ved Koster paa 120 Favne.

Gen. II. EUSIRUS, Kroyer, 1845.

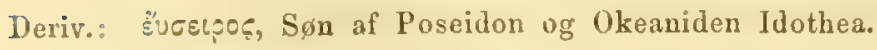


Syn.: 1845. Eusirus, Krøyer, Nat. Tidsskr. 2. R. 1. B. p. 511.

1859. - Bruzelius, Skand. Amphip. Gamm. p. 63.

1860. - A. Boeck, Forh. red de skand. Naturf. Sde Møde. p. 655.

1862. - Spence Bate, Catal. Amphip. Crust. Brit. Mus. p. 154.

1863. - Spence Bate and Westwood, Brit. sessile-eyed Crust. p. 266.

1865. - Lilljeborg, On the Lysianassa magellanica.

1870. - A. Boeck, Crust. amphip. bor. et arct. p. 76.

Type: Eusirus cuspidatus, Kroyer.

Mandibula in apice parum modo dentatx, tuberculo molari robusto.

Maxillæ primi paris palpo elongato, acuminato, setoso, cujus articulus primus dimidiam secundi articuli longitudinem superat.

Antennæ superiores inferioribus longiores, tertioqve pedunculi articulo minulissimo, fere rudimentari; flagello appendiculari minimo.

Pedes $1 \mathrm{mi}$ et 2 di paris manibus magnitudine et forma aqvalibus; carpo elongato, postice calcarato, angusto et in medio margine anteriore manus ovata et inflate affixo.

Pedes trium parium ultimorum valde elongali, graciles.

Pedes saltatorii 3 tii paris ramis longitudine requalibus, laminiformibus, in margine setosis.

Appendix caudalis prælongata, in apice parum modo fissa.

Denne Slægt blev opstillet af Krøyer i 1845. Dana mener, at den bor falde sammen med Slægten Gammarus, hvorfra den dog skiller sig saa meget, at den ikke engang kan henfores til Underfamilien Cónmmarince. Bruzelius optog den i 1 s.jp vistnok som en egen Slægt, men troede dog, at den stod Gammanus meget nær, hvorfra den hovedsagelig skulde skille sig ved de tvende forste Fodpars Form. Jeg antog i 1860, at den burde stilles nær Leucothoë, da den viser et nært Slægtskab med denne, især i Munddelenes Bygning, idet det første Kjæbepars Palpe har et meget forlanget forste Led og den indre Plade er liden, kun forsynet med en Børste, ligesom Kjæbeføddernes Palpe er forlænget, medens Pladerne ere meget smaa. Heri adskiller den sig meget fra Slagten Gammarus. Fra Leucothoë skiller den sig ved, at Kindbakkerne ere væbnede med en stærk Tyggeknude, medens denne hos hin Slægt er rudimentær eller mangler. Ogsaa i den ydre Form viser den et nart Slægtskab med Leucothoë og skiller sig fra denne væsentligt derved, at de ovre Følere ere forsynede med en liden Bisvobe. Spence Bate stiller den i 1862 ogsa nær Lcucothoë i sin fomte Lnderfamilie Grammarides, idet han forbigaar Dana's Underfamilie Leucothoinc. Lilljeborg, som i 1865 optager denne Underfamilie, stiller Eusirus dog til Gammarina sammen med den nærstaaende Slægt Lilljeborgia (Microplax, Iduna), Spence Bate. I 1870 stillede jeg 
den her omhandlede Slægt sammen med Lilljcborgia, Leucothoë samt Iritropis (Amphithonotus, Costa) til Underfamilien Leucothoince.

\section{EUSIRUS CUSPIDATUS, Krøyer, 1845.}

Eusirus cuspidatus, Kroyer, Nat. Tidsskr. 1845. 2. R. 1. B. p. 501. pl. 7. fig. 1. Voy. en Scand. pl. 19. fig. 2.

- $\quad$ Bruzelius, Skand. Amphip. Gamm. 1859. p. 63.
- $\quad$ Spence Bate, Catal. Amphip. Crust. Brit. Mus. 1862. p. 154. pl.
$\quad$ XXVIII. fig. 6 og 7.
- $\quad$ Goës, Crust. amphip. maris Spetsb. 1865. p. 13.
- $\quad$ A. Boeck, Crust. amphip. bor. et arct. 1870. p. 76.

Segmentum Irunci 6tum in medio margine postico denticulo instructum. Segmentum trunci 7 mum et segmenta postabdominis qvatuor anieriora carinata. Carina segmenti trunci $r$ mi et segmentorum postabdominis duorum anteriorum postice in dentes validos producta. Antenne superiores articulo pedunculi 1 mo et 2 do invicem eadem longitudine, in margine anteriore serratis. Pedes $1 \mathrm{mi}$ et 2 di paris manu ovata. duplo longiore qvam lata. Pedes trium parium ultimorum articulis qvinqve posterioribus junctis non ter longioribus qvam articulo Imo. Appendix caudalis fere usque ad medium fissa.

L $x$ gden er indtil $24^{\text {m }}$ fra Pandehornet til Halevedhænget.

Legemet er temmelig høit og sammentrykt fra Siderne; den forreste Del af Ryggen er rund. En Kjol begynder at hæve sig langs Midtlinien af de tvende sidste Legemsled og fortsæetter sig langs Midtlinien af de fire første Haleled; paa det sjette Legemsled gaar den ud i en flad, ikke meget bemærkbar Tand, som bliver større paa det følgende Led og de tvende forste Haleled, medens den ikke sees paa det tredie og fjerde Led; det tredie Haleleds nedre, bagre Vinkel er meget afrundet og fint saugtakket; det fjerde er sadelformet indboiet paa den bagre Rand. Sidepladerne ere ilike meget store, $\log$ høiere end brede; den første or bredere nedad og bredere end de tvende folgende; den fjerde er $\mathrm{i}$ den øvre Del af den bagre Rand ikke meget dybt indskaaret for den femte; denne sidste er bredere end høi og tvedelt ved en Indboining paa den nedre Rand. Hovedet er, noget længere end det første Legemsled og gaar fortil, mellem de $ø$ vre Folere, ud i et lidet Pandehorn; dets Sidevinkler ere lidet udtrukne og bredt afrundede. Oine sees ikke paa Spiritusexemplarer, men ere ifolge Kroyer nyreformede.

De øvre Følere naa, naar de bøies bagud, til det sidste Legemsled. Skaftets forste Led er noget længere end Hovedet og saugtakket paa Enden; det andet er omtrent af den samme Længde, men smalere, og ligeledes forsynet paa den ydre Ende 
med SSaugtakker eller Torne, hvoraf især tre paa den ovre og nedre Kant ere fremtrædende; det tredie Led er lidet og næsten skjult, men har en lang Torn paa den undre Kant. Svøben er længere end Skaftet og dannes hos Hannen af henimod 70 , med Børsteknipper besatte Led, hvoraf de forste ere meget bredere end lange, medens de sidste ere noget længere end brede; hos Hunnen er der 40 Led. Bisvgben har 1 Led.

De nedre Følere ere kortere end de ovre, men Skaftet er længere; dets første Led er temmelig stort; det andet udsender en lang, smal Lugteknude; det tredie er noget længere end bredt; det fjerde er meget forlænget, naar frem til Enden af det andet Led paa de ovre Foleres Skaft og er forsynet paa den ydre Ende med enkelte brede Tænder; det femte er noget kortere og tyndere end det foregaaende Led og, ligesom dette, besat med Børsteknipper. Svøben er længere end Skaftet og dannes af 36-42 Led.

Overlæben er tyk, afrundet i Spidsen.

Kindbakkerne have i Spidsen tvende brede Trender, og den indre Bigren er forsynet med tre saadanne; Tyggeknuden er meget stor.

Underlæben er bred, med mange Børster; de indre Plader ere meget store og have ligeledes mange Børster.

Det første Kjæbepars ydre Plade har ti Tænder i tvende Rader, og hvoraf nogle have 1-2 Bitænder; den indre Plade er temmelig stor, forlænget oval, med tvende fjærdannede Borster i Spidsen. Palpens andet Led er fire Gange saa langt som det forste, temmelig bredt, smalere mod Spidsen og har Borster paa den indre og ydre Rand.

Kjæbefødderne ere forlængede; den ydre Plade naar frem knap til Midten af Palpens andet Led og er paa den indre Rand og i Spidsen væbnet med borstelignende Torne; den indre Plade er kort, med 3-4 stærke, tætstaaende Tænder og nogle Torne i Spidsen. Palpen er meget stor og bred; det forste I ed er kort; det andet er længere, bredere mod Enden og har her paa den indre Rand fire stærke Torne ellor Tænder; det tredie Led er meget kortere, men ligeledes bredere mod Enden, der er tvært afskaaret $\mathrm{og}$ afrundet paa Kanterne $\mathrm{og}$ er her samt paa den indre Rand forsynet med mange Børster. Kloen er stærk, kortere end det foregaaende Led, med fjærdannede Børster paa 'deu bagre Rand og med en Torn i Spidsen.

De tvende forste Fodpar ere af eens Bygning og Storrelse; det forste Led har Børster paa den ydre Side; det tredie er kort, med Børster og Torne i den nedre, bagre Vinkel; det fjerde er meget forlæenget, lidt krummet og udsender fra den nedre, bagre Vinkel et noget boiet Fremspring, der paa begge Rande og paa Enden er forsynet med Børster; Haanden er meget stor, af en bred, xgformet Bygning, og er i et Indsnit paa Midten af den forreste Rand frestet til Enden af det foreganende Led; Griberanden indtager næsten den hele bagre Rand, der er væbnet med tynde Torne foruden flere stærkere paa Enden, hvor Spidsen af den lange, smale, noget krumme Klo lagger sig imod.

Det tredie og fjerde Fodpar ere lange og smale; det tredie Led er lidt ud- 
videt $0 \mathrm{~g}$ længere end det fjerde; (lette er af den sanme Længde som det fente; disse Led have paa den forreste Rand mange korte, men stærke Torne.

De tre følgende Fodpar tiltage efter hverandre kun lidt i Længde; det første Led er ikke meget stærkt udvidet paa den bagre Rand, men af en forlænget oval Form, med Saugtakker paa den bagre og Torne paa den forreste Rand; det tredie er udvidet, og dets nedre, bagre Vinkel er udtrukket og væbnet med tvende stærke Torne; det fjerde er noget kortere, det femte er noget længere, men begge ere smalere end det tredie Led. Alle Led have sterke Torne paa den forreste Rand.

Springføddernes Grene ere forlængede, lidt afplattede paa den ovre Side og have Torne paa begge Rande; den ydre Gren er meget kortere end den indre. Det sidste Pars Grene naa længst bagud; den indre Gren, der er ikke fuldt dobbelt saa langt som Grundleddet, har paa den indre Rand foruden Torne ogsaa enkelte fjordannede Børster.

Hal evedhæinget er forlænget smalt, halvmaaneformet indskaret paa den ydre Rand og spaltet næsten til Midten.

Farven er hvidgul, med Overgang til rodlig.

Den findes, on end sjelden, ved vore Kyster, og er ligeledes taget i Kiattegattet. Ved Grønland er den fundet af Holbøll paa 50-60 Favnes Dybde.

EUSIRUS LONGIPES, A. Boeck, 1860.

(Pl. XIX. tig. 4.)

Eusirus longipes, A. Boeck, Forh. ved de skand. Naturf. 8de Mode. 1860. p. 656.

A. Boeck, Crust. amphip bor. et aret. 1870. p. $15 \%$

- Helvetice, Spence Bate, Catal. Amphip. Crust. Brit. Mus. 1862. 1. 155. pl. XXIX. fig. 2.

- $\quad$ - Spence Bate and Westwood, Brit. sessile-eyed Crust. 1863. p. 207.

- - Norman, Rep. on the Shetland Crust. 1868. p. 281.

- bilens, Heller, Denkschr. d. k. k. Acad. d. Wissensch. 26. B. 2. Abth. 1866. p. 32. tab. III. fig. 19.

Dorsum non carinatum. Segmenta postabdominis duo anteriora in medio margine postico dentibus singulis armata. Segmentum postabdominis 3tium in margine postico serratum. Antenne superiores articulo pedunculi 1 mo in extremo margine inferiore serrato: articulo 2do in margine superiore denticulis instructo. $\mathrm{Pe}-$ des $1 \mathrm{mi}$ paris manu multo latiore quam apud speciem pracedentem. Pedes trium parium ultimorum articulo 1 mo angustiore; articulis reliqvis junclis plus qvam qvater longioribus qvam 1mo. Appendix caudalis solum in exteriore qvarta parte fissa. 


\section{Længden er $8-9 \mathrm{~mm}$.}

Legemet er høit, dog ikke meget sammentrykt; de tvende forste Haleled gaa paa Midten af den bagre Rand ud i en skarp, bagudrettet 'Tand; det tredie Haleleds bagre Rand er saugtakket. Den første Sideplade er større end de tvende følgende, bredere nedad, og dens forreste nedre Vinkel er udtrukket, afrundet. Hovedet er omtrent saa langt som de tvende forste Legemsled tilsammen og gaar fortil ud i et kort, bredt, paa Enden spidst Pandehorn. Oinene ere store, ovale eller svagt nyreformede.

De øvre Føleres første Skaftled er omtrent saa langt som Hovedet og forsynet med Tæunder paa den ydre Ende af den ovre og nedre Rand; det andet er omtrent af den samme Langde, men meget smalere end dette, og har Torne paa Enden af den øve Rand; det tredie Led er meget kort. Svoben, der er længere end Skaftet, dannes hos Hunnen af omtrent 20, hos Hannen af over 40, med Sugeskaale besatte I.ed. Bisvoben er særdeles liden.

De nedre Folere ere lidt kortere end de orre eller nasten af den samme Langde. Skaftets tredie Led er kort; det fjerde er langere og tykkere end det femte Led og los Hannen forsynet med talrige korte Borstebundter paa den ovre Rand. Svoben dannes hos Hannen af 42, i den orre Rand med Sugeskaaler besatte Led; Hunnen har meget frre, omtrent 34, Led.

Kjæbefoddernes Palpers andet Led er meget bredt, ikke meget forlænget og har ikke Tander paa den indre Rand, men tre længere Torue.

Det forste Fodpars Haand er meget bred oval; Griberanden er buet, besat med talrige, mod Spidsen boiede Torne, samt en stærkere, hvor Kloens Spids lægger sig imod.

Det andet Fodpar er ubetydelig storre end det forste Par.

Det tredie og fjerde Fodpar ere sardeles forlangerle; det tredie Led er nedad kun ubetydelig udvidet, længere end det fjerde, men kortere end dette og det femte Led tilsammen.

De tre folgende Fo lp a r ere ligelerles meget forlangede; det forste Led er langt, ovalt, smalere nedad og saugtakliet paa den bagre Rand; det tredie er længere end det første og fjerde, men kortere end det femte Led.

De trende første Par Springfødders ydre Gren er kortere end den indre, især paa det andet Par, hvor den har kun lidt mindre end den halve Del af den indre Grens Liengde.

Det sidste Pars Grene ere omtrent lige lange, næsten dobbelt saa lange som Grundleddet, og $\mathrm{i}$ den ydre Rand besatte med fjærdannede Børster.

Halevedhænget er langt, smalt, spaltet i den ydre Fjerdedel.

Farven er hvid, med storre og mindre gulagtige Flekker over Ryggen og mindre lignende paa Sidepladerne. Dinene ere rosenrøde, med hvide Lindser.

Den er fundet af G. 0 . Sars ved Utsire paa 40-50 Farne, ved Aalesund paa 
50-100 Favne og i Christianiafjorden, af mig ved Skraven paa 2-300 Favne, af Milne-Edwards ved Bantf, ved Shetland af Norman, ved Lessina af Heller.

Gen. III. LEUCOTHÖ̈, Leach, 1813.

Deriv.: Leucothö̈, et mythologisk Navn.

Syn.: 1813. Leucothoë, Leach, Edinb. Encyc. 1813-14. VII. p. 403. Trans. Linn. Soc. 1815. XI. p. 358. Suppl. Ent. Brit. I. p. 425.

1816. Lyeesta, Savigny, Mem. s. I. anim. sans vert. vol. I. p. 109. Egypt. Crust. pl. 1I. fig. 2.

1825. Leucothö̈, Desmarest, Consid. gén. sur les Crust. p. 263.

1840. - Milne-Edwards, Hist. d. Crust. t. III. p. 56. Ann. d. sci. nat. t. XX. p. 380 .

1847. - White, Cat. Crust. Brit. Mus. Cat. Brit. Crust. Brit. Mus. 1850. Hist. Brit. Crust. 1857. p. 188.

1857. - Costa, R: sui crost. amfip. del regno di Napoli. p. 226.

-- - Spence Bate, Ann. Nat. Hist. 2. ser. XIX. p. 146. Catal. Amphip. Crust. Brit. Mus. 1862. p. 156.

1860. - A. Boeck, Forh. ved de skand. Naturf. Sde Møde. p. 653.

1863. - Spence Bate and Westwood, Brit. sessile-eyed Crust. p. 269.

1870. - - A. Boeck, Crust. amphip. bor. et arct. p. $7 \%$

Type: Gammarus spinicarpus, Abildgaard.

Iandibula in apice valde dilatatæe et dentatæ; tuberculo molari absenti.

Jaxilla $1 \mathrm{mi}$ paris lamina interna minima.

Pedes maxillares lamina externa fere obsoleta.

Antennæ superiores flagello appendiculari destituta.

Pedes $1 \mathrm{mi}$ paris carpo ovato, in angulo inferiore postico ad processum longum tenuem, curvatum. acuminatum producto; manu elongata, lineari, in margine posteriore spinis armata.

Pedes 2di paris carpo calcen longum ernittenti; manu permagna, subcheliformi.

Pedes reliqvi graciles.

Pedes saltatorii ultimi paris pedunculo sat elongato.

Appendix caudalis non fissa.

Denne af Leach opstillede Slægt har ogsaa Milne-Edwards i 1840 beholdt. Han opforer herunder tvende Arter, $L$. furina og $L$. articulosa. Krøyer (Nat. Tidsskr. B. IV, S. 159) tror, at nogle af ham ved Spitsbergen fundne Amphipoder bor henføres til 
denne Slægt, og efter hans Mening maa de af Milne-Edwards opstillede Karakterer undergaa store Forandringer og de af disse udgaa, der ere lentede fra Sidepladerne, fra de tre sidste Fodpars første Led samt fra Følernes Svobe; derimod burde der optages som Slægtskarakter den Eiendommelighed, at de øvre Føleres tredie Skaftled er meget kort, at Munddelene have en eiendommelig Bygning, samt at Halevedhanget bestaar kun af een Plade. De af Kroyer til denne Slægt regnede Arter maa dog skilles fra denne og henfores til den af mig opstillede Slægt Metopa, men Slægtskarakteren maa dog ansees at være meget god. Dana gjorde Leucothoë til Typus par sin Underfamilie Leucothoince, hvortil han ogsaa henforte Slægten Stenothoë. Bruzelius optog Slægten efter den Udstrækning, Kroyer havde givet den, dog med en vis Tvivl, da han synes, at Arterne ere hverandre saa ulige. Han kunde dog ikke optrække Grændserne for Slægten, da lian ikke tilfulde kjendte Leachs Typus. Spence Bate havde imidlertid adskilt de af Kroyer og Bruzelius hertil henforte Arter og optaget Slagten efter det mere begrændsede Omfang, hvilket de senere Zoologer har billiget. Han fører Slægten Leucothoë til Underfamilien Gammarides, medens Costa, Lilljeborg og jeg optage Dana's Lnderfamilie Leucothoince og henfører den dertil.

\section{LEUCOTHOË SPINICAIPA, Abildgaard, 1789.}

(PI. XVI. fig. 5.)

Gammarus spinicarpus, Abildgaard, Zool. Dan. III. p. 66. pl. CXXIX. fig. 1-4. 1\%. Cancer (? Gammarus) articulosus, Montagu, Linn. Trans. Soc. vol. VII. p. 70. pl. 6. fig. 7. Leucotho ë articulosa, Leach, Edinb. Encye. 1814. VII. p. 403. Linn. Trans. vol. XI.p. 358.

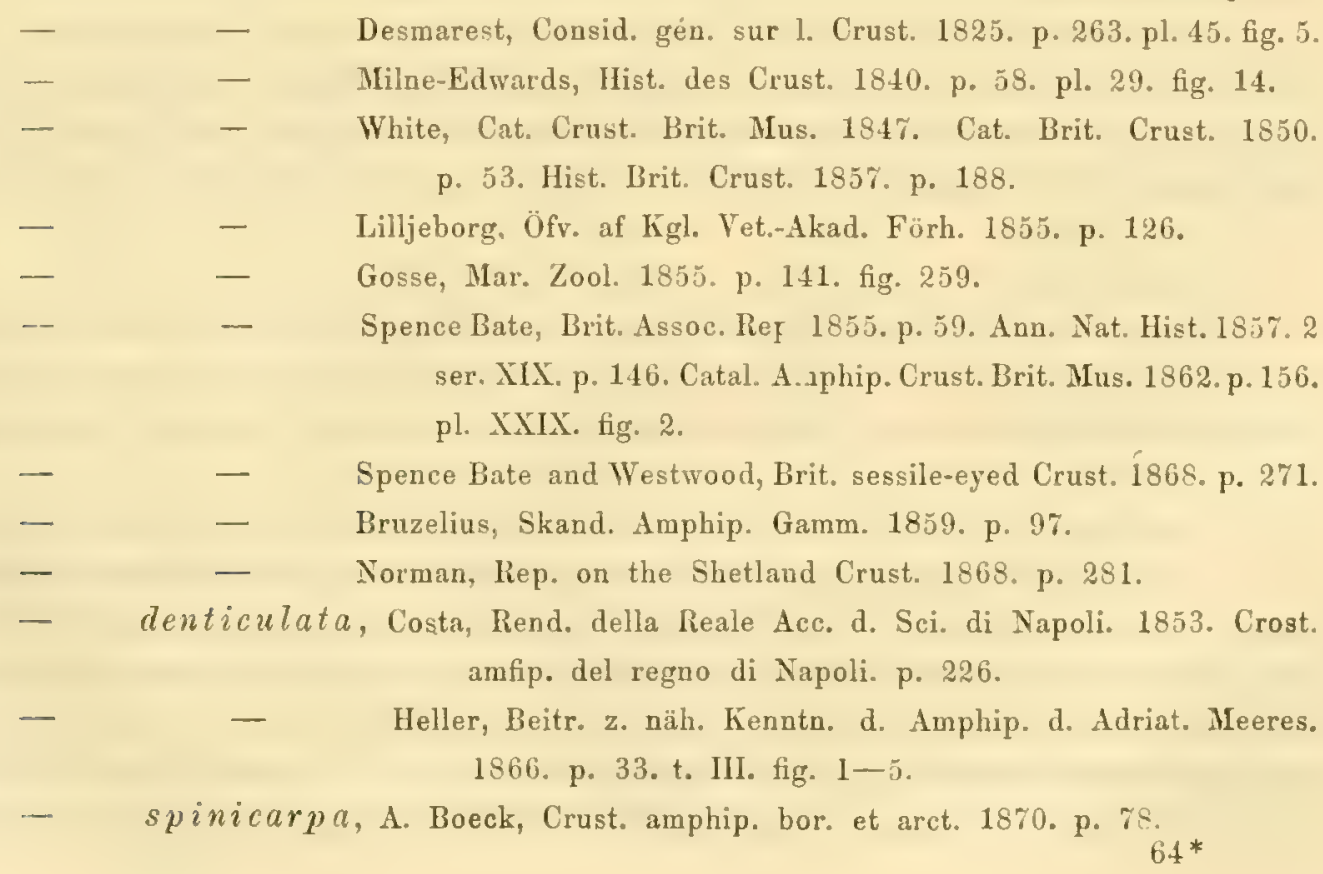




\section{Oculi ovati. Antennæ superiores articulo pedumculi 1 mo et 2 do longitudine} fere rqvalibus. Pedes $1 \mathrm{mi}$ paris processu carpi longitudinem manus ferme aqvanti. Pedes 2di paris manu ovata, in acie curvata, non incisa. Pedes saltatorii ultimi paris ramis brevioribus qvam pedunculo. Appendix caudalis lanceolata.

L æng en er $12 \mathrm{~mm}$.

Legemet er forlænget, Ryggen er bred, afrundet; det tredie Haleleds nedre, bagre Vinkel danner kun en utydelig Hage. De første Sideplader ere brede, men ikke meget høie; den forste er noget indskaaret fortil, hvorved dannes en liden Hage; den fjerile er ikke meget dybt indskaaret for den femte i den ovre, bagre Rand; den femte er lang, men ikke meget hoi. Hovedet er noget kortere end det forste Legemsled og gau fortil, mellem de ovre Folere, ud i et kort, men bredt Pandehorn; dets Sidevinkler ere afrundede. Ofinene ere store, ovale.

De øvre Følere naa, naar de bøies bagur, til det femte Legemsled. Skaftets forste Led er omtrent saa langt som Hovedet og gaar paa sin forreste Ende ud i nogle Saugtakker; det andet er af den samme Liengde, men tyndere; det tredie ei kort, mere end dobbelt saa langt som Svobens forste Led. Svoben er noget lingere end Skaftets andet Led $0 \mathrm{~g}$ dannes af $15-17$ Led.

De nedre Folere ere ubetydelig kortere end de qvre, samt tyndere. Skaftets tredie Led er omtrent dobbelt saa langt som tykt; det fjerde er længere og tykkere end det femte Ler. Svgben ex kortere end Skaftets sidste Led og dannes af 7 Led.

Overlæben er indskaret paa Enden; den ene af Lapperne er mere forlænget end den anden.

Kindbakkerne ere stærke, Gribedelen er bred og tandet; den ene har ligeledes en bred, tandet, indre Bigren, hvilken den anden mangler; Tornerakken dannes af talrige, tretstaaende, noget krumme, men simple Torne; Tyggeknuden mangler. Palpens tredie Led er meget tyndt, tilspidset, meget kortere end det andet, og har kun far Børster i Spidsen.

Underlæbens ydre Plade er bred; den indre synes at mangle.

Det første Kjæbepars ydre Plade er paa Enden væbnet med stærke Torne, der tildels ere forsynede med en liden Bitorn; den indre Plade er meget liden, med et Par smaa Børster paa Enden. Palpens forste Led er forlænget; det andet bærer Here Torne i Spidsen.

Det andet Kjæbepar er meget lidet, med grove Borster paa Pladernes Ende.

Kjæbef $ø$ d dernes ydre Plade er næsten rudimentær, med en stærk Torn paa Enden; den indre Plade er af middelmaadig Størrelse, væbnet paa Enden med tre Tænder. Palpen er stærk; det tredie Led er omtrent saa langt som det andet, bredere paa den ydre, skraa afskaarne Ende, hvor der sees flere Børster. Kloen er lang, lidt krummet, med mange fine Torne paa den bagre Rand.

Det forste Fodpar er stærkt; det tredie Led er meget kort og har en torn- 
lignende, noget krummet Forlængelse, der lægger sig til den indre Side af det store, brede, ovale fjerde Led; dette sidstes nedre, bagre Vinkel forlænger sig til en mod Spidsen noget krummet Torn, der er af den samme Langde som det følgende Led; det femte Led er omtrent fire Gange saa langt som bredt og har paa den bagre Rand fine Saugtakker og en Række Torne. Kloen er ikke meget lang, tynd og krum.

Det and et Fodpar er storre og kraftigere; det fjerde Led forlænger sig til et bredt, men ikke meget langt Fremspring, hvilket er saugtakket paa den ydre Rand og har paa den bagre Rand talrige Børsteknipper, samt lægger sig til det femte Leds bagre Rand; det femte Led er meget stort, forlanget ovalt, med en tilspidset forreste, ydre Vinkel, der springer frem foran. K̉loens Rod og er forsynet med lange Børster; Griberanden, der indtager Totrediedel af den bagre Rand, har mange, men smaa, knudelignende Forhøininger. Kloen er stor, noget krummet.

Det tredie og fjerde Fodpar ere lange, smale; det tredie Led er lidet udvidet, meget længere end det fjerde, der er kortere end det femte Led.

De tre folgende Fodpar ere af eens Bygning, men tiltage efter. hverandre lidt i L'ængde; det første Led er meget stort, ovalt, saugtakket paa den bagre Rand; det tredie er lidet udvidet, meget længere end det fjerde, men omtrent af den samme Lrongde som det femte Led. Disse Led lave en Række Torne paa den forreste Rand.

Det forste Par Springfodders Grene ere ontrent lige lange, af den samme Længde som Grundleddet, og have smaa Torne paa begge Rande.

Det andet Par er meget kortere; den ydre Gren er ubetydelig kortere end den indre, der er kortere end Grundleddet.

Det sidste Par naar længst bagud, og dets Grene ere kortere end Grundleddet. Halevedhænget er forlænget, smalere mod Enden og tilspidset.

F arven er hvid; den bagre Del af hvert Led er svag rosenrod; Øinene ere rode. Par et $15^{\mathrm{mm}}$ stort Exemplar, som jeg fandt ved Skraaven paa $80-100$ Favnes Dybde, havde Farven et græsgront Anstrøg. Efter Spence Bate er Farven fin rosenrød eller kjodlignende.

Den er fundet af M. Sars ved Manger, af G. O. Sars ved Hvidingsøeme, ved Stavanger paa 40-60 Favne, ved Aalesund paa 100 Favne, af mig ved Skraaven paa indtil 300 Favne, ved Farsund i Gjallehulen hos Ascidier, under hvilket Forhold den ogsaa blev fundet af $\mathrm{M}$. Sars, af Lilljeborg ved Kullaberg paa den svenske Kyst; den er ligeledes fundet paa Østsiden af Sjælland, samt paa flere Steder paa den engelske Kyst, af Norman ved Shetland, ligeledes i Ascidier (A. mentula og A. venosa). Den af Lilljeborg i 1855 beskrevne $L$ 。 articulosa, hvilken han, ligesom Bruzelius i 1859, anser at være Montagu's Cancer articulosus, afviger i flere Henseender fra den her beskrevne og blev i 1860 (A. Boeck, Forh. ved de skand. Naturf. Sde Møde) af Forfatteren foreslaaet at erholde Navnet $L$. Lilljeborgii. Den her beskrevne Art er vistnok mere overensstemmende med Ilontagu's Form, da den baade er større og hyppigere end hin. Paa den af Lilljeborg beskrevne Form, $4^{\mathrm{mm}}$ lang, og som af Bruzelius anføres 
kun at være fundet $i$ eet Exemplar ved Kullen af Prof. Lilljeborg, er Fremspringet paa det første Fodpars fjerde Led tandet i Randen; den fjerde Sideplade er væbnet med en Tand i den forreste Kant; alle tre Par Springfødders Grene ere lige lange; Halevedhænget er meget lidet, afrundet paa den ydre Ende. Forøvigt ere begge Former hinanden meget lige, men bør maaske opføres som tvende særegne Arter.

Gen. IV. TRITROPIS, A. Boeck, 1870.

Deriv.: трótıย, en Kjøl.

Syn.: 1851. Amphithonotus, Costa, in Cat. Crost. Ital. per Fr. Gugl. Hope, Napoli.

1862. - $\quad$ Spence Bate, Catal. Amphip. Crust. Brit. Mus. p. 150, pars.

1865. - Goës, Crust. amphip. maris Spetsb. p. 150.

1870. Tritropis, A. Boeck, Crust. amphip. bor. et arct. p. 78.

Oculi prominentes.

Antennæ superiores inferioribus breviores.

Epimera parva; 1 mum in angulo inferiore antico productum.

Pedes 1mi et 2di paris manu sat magna, ovata; ungve longo; carpo brevi, in angulo inferiore postico producto.

Pedes 3tii et 4 ti paris perlongi, graciles; articulo 3 tio brevi.

Pedes trium parium ultimorum gracillimi et longissimi; articulo 1 mo dilatato.

Appendix caudalis prælongata, in apice fissa.

Costa opstillede i 1851 de Arter, som af Milne-Edwards vare henforte til Slægten Amphithoë, og hvis Ryg eller hele Legeme har en Kjol og er besat med Torne, nemlig $A$. marionis, M.-Edwards, $A$. panoplus, Kr., $A$. carinata, $\mathrm{Kr}$., og andre til een Slægt, Amphithonotus. Da A. marionis matte være Typus for denne Slægt, og den er synonym med Dexamine spinosa, skulde altsaa Amphithonotus blive synonym med Dexamine, Leach, og saaledes falde bort. Imidlertid har Stimpson (Marin. Invert. of Grand Manan, 1855, p. 52) henført til Slægten Amphithonotus $A$. serratus, O. Fabr., og $A$. cataphractus, Stimps. Den første af disse var allerede forhen henført til Slægten Acanthonotus, Owen; den anden Art maatte beholde Stimpsons Slægtsnavn Amphithonotus, der saaledes har en anden Betylning end efter Costa's Opfattelse af samme. Spence Bate stiller i 1862 Slægten Amphithonotus til sin Underfamilie Gammarides og henfører hertil Costa's Arter A. spiniventris og A. acanthophthalmus, hvilke vistnok begge høre til Slægten Dexamine, og A. Edwardsii, Ross, der falder sammen med Oniscus aculeatus, Lepechin, samt A. cataphractus, Stimps. Jeg har i 1870 indskrænket denne Slægts Omfang til de Arter, der staa nær A. cataphractus, Stimps., og ormbyttet Slægtsnavnet, da det allerede forben, i 1843 , er af Fitz benyttet til et Reptil. 
TRITROPIS ACULEATA, Lepechin, 1778.

Oniscus aculeatus, Lepechin, Acta Petropolit. 1778. t. 247. t. 8. fig. 1.

Talitrus Edwardsii, Sabine, Suppl. to the App. of Parrys first voy. 1824. p. 223. t. 2. fig. $1-4$.

Amphithoë Edwardsii, Owen, App. to Ross's sec. voy. 1834. p. 90.

- $\quad$ - Ross, App. to Parrys third voy. p. 119. Polar voy. p. 205.

Krøyer, Nat. Tidssk. 1846. II. p. 76. Voy. en Scand. t. 10. fig. 1.

Amphithonotus Edwardsii, Spence Bate, Catal. Amphip. Crust. Brit. Mus. 1862. p. 151. pl. XXVIII. fig. 5.

aculeatus, Goës, Crust. amphip. maris Spetsb. 1865. p. 10.

Tritropis aculeata, A. Boeck, Crust. amphip. bor. et arct. 1870. p. 78.

Rostrum frontale perlongum, inter antennas superiores situm. Carina a capite ad segmentum 4 tum postabdominis porrecta et in segmentis trunci duobus ultimis in spinas singulas retroversas et in segmentis postabdominis qvatuor anterioribus in spinas binas, in margine posteriore segmenti majorem et in medio segmento minorem, producta. Carina in utroqve latere carina accessoria instructa; hac in margine posteriore segmenti trunci ultimi et segmentorum postabdominis trium anteriorum in spinas singulas validas producta. Antenna superiores articulo 3 tio perbrevi. Pedes 1 mi paris manu magna, ovata, in acie spinis tenuibus instrucla; ungve sat elongato, curvalo. Pedes 3 tii et 4 ti paris articulo 4 to parum modo longiore qvam 3tio. Pedes 5 ti et 6 ti paris articulo 1 mo in medio margine posteriore in processum obtusum producto. Pedes $7 \mathrm{mi}$ paris articulo $1 \mathrm{mo}$ in angulo inferiore posteriore paulum producto et accuminato. Appendix caudalis ter - qvater longior qvam lata, in exteriore quarta parte fissa.

$\mathrm{L} \rightsquigarrow \mathrm{ngde}$ er $27_{\mathrm{mm}}$ fra Roden af Pandehornet til Halevedhænget.

L e gemet er meget bredt, noget nedtrykt; paa Ryggens Midtlinie sees en Kjøl, der strækker sig til det fjerde Haleled; de fem forste Legemsleds bagre Rand hæver sig paa Ryggens Midtlinie til en liden Knude; paa det sjette er der en bagudrettet Tand, hvilken er storre paa det syvende Led og. paa de tre første Haleled, men er atter mindre paa det fjerde; foran denne Tand sees en mindre paa disse Halens Led. Paa hver Side af den nrvnte Kjøl sees en anden Fremstaaenhed, der begynder paa den nedre Del af det sjette Legemsleds bagre Rand og ender paa det tredie Haleled, idet den gradvis nærmer sig mere Midtlinien; den gaar ligeledes ud i et tornlignende Fremspring eller en Tand, hvorved man paa den bagre Rand ser tre Tæender; de forste Halelerls nedre, bagre Vinkel er afrundet, paa de tvende sidste er den bagre Rand noget saugtakket. Sidepladerne ere smaa, stive; den første er langt bredere end høi, udtrukket i den forreste, nedre Vinkel; de tre folgende tiltage efter lwerandre noget i 
Høide og Bredde. Hovedet er bredt og danner fortil, mellem de ovre Folere, et langt, smalt, triangulært Pandehorn, der danner en stump Fremstaaenhed mellem de fremspringende, skraa liggende, bagtil noget bredere Øine.

De ovre Følere naa, naar de bøies bagud, til det forste Haleled. Skaftets forste Led naar frem til Pandehornets Spids eller er lidt længere, samt er noget fladtrykt, paa Enden af den indre Side sees tvende skarpe Torne; det andet er noget kortere og smalere og er ligeledes fladtrykt, med en ydre og indre skarp Kant, hvoraf den sidste er fint saugtakket; det tredie Led er meget kort. Svoben er omtrent af den samme Langde som Skaftet, eller noget kortere; de forste Led ere kortere end tykke.

De nedre Folere ere meget langere end de ovre. Skaftets forste Led er méget stort; det andet udsender en kort Lugteknude; det tredie er lidt længere end breit; det fjerde er meget langt, breit, fladtrykt, naar frem næsten til Enden af de øvre Foleres andet Led og er forsynet med Saugtakker paa den indre Rand; det femte Led er omtrent af den samire Læengde som det foregaaende, men smalere, og er bevæbnet paa den samme Maade. Svoben er omtrent saa lang som Skaftet.

Overlæben er meget stor; tyk, afrundet og besat med Børster, hvor den dækker Munden.

Kindbakkerne ere meget stærke; den ydre Gren synes ikke at vare indskaaret i Tænder paa Enden; den indre Bigren har syv Tæender; Tornerækken dannes af syv Torne; Tyggeknuden er meget fremstaaende. Palpens andet Led er kortere end let tredie, som paa sin concave Rand har talrige Borster.

Underlæben er meget bred; Fligerne ere vidt adskilte.

Det forste Kjæbepars ydre Plade er paa Enden væbnet med 10-12 Tænder $\mathrm{i}$ tvende Rader, hvoraf de $\mathrm{i}$ den ene af disse have $2-3$ lange Bitænder; den indre Plade er stor, oval. Palpen er stærk; det andet Led er smalere mod Enden og er i begge Rande forsynet med Børster.

Kjæbefoddernes ydre Plade er liden, naar neppe frem til Midten af Palpens andet Led og har paa den indre Side borstelignende Torne, der blive langere mod Pladens Ende; den indre Plade er liden, bied, paa Enden vabnet med 8-10 Tænder. Palpen er forlænget; det andet Led or det lingste og har tilligemed det tredie Led talrige Borster paa den indre Rand. Kloen er stærk.

De tvende forste Fodpar ere af eens Bygning, men det andet Par er det storste; det forste Led el paa den forreste Rand besat med mange Børster; det tredie er kort; det fjerde er kort og udsender fra den nedre, bagre Vinkel et Fremspring, der har Børster i Spidsen; Haanden er meget stor, forlænget oval, og næsten den hele bagre Rand indtages af Griberanden, som er forsynet med Børster el er smaa Torne af forskjellig Længde, samt med nogle meget stærkere, hvor Kloens Spids lægger sig imod. Kloen er ling, krummet.

Det tredie og fjerde Fodpar ere meget smale; det tredie Lerl er lidet ud- 
videt; det fjerde er noget langere end det foregaaende, og det femte Led er meget længere; alle disse tre Led have Torne paa den bagre Rand.

De tre følgende Fodpar tiltage efter hverandre i Længde; de tvende første Pars forste Led er ikke meget stærkt udvidet, undtagen paa den bagre Rands øverste Del, der gaar sporeformet ud bagtil; det syvende Pars forste Led er derimod meget bredt, især i den ovre Del, og dets nedre, bagre Vinkel forlænger sig i en Torn; det tredie Led er ikke meget udvidet, men dets nedre, bagre Vinkel er udtrukket, spids; det fjerde er noget kortere; det femte er længere end det tredie Led.

De tvende første Par Springfødders ydre Gren er kortere end den indre, især paa det andet Par.

Det sidste Par naar længst bagud; Grenene ere mere flade, end paa de foregaaende Par, og forsynede med Torne foruden nogle fjærdannede Borster.

Halevedhænget er meget forlænget smalt, med en midtre Indbøining og spaltet i den ydre Trediedel.

Farven er efter Kroyer hvid og blegrod spraglet eller marmoreret. Øinene ere sorte.

Den er fundet ved Finmarken og efter Goës paa forskjellige Steder ved Spitsbergen, ved Julianehaab paa Gronland af Amondsen, ved det arctiske Amerika efter Lepechin, ved Labrador af Packard, ved Davisstrædet efter Sabine.

TRITROPIS HELLERI, A. Boeck, 1870.

(Pl. XX. fig. 6.)

Tritropis Helleri, A. Boeck, Crust. amphip. bor. et arct. 1870. p. 79.

Rostrum frontale parvum, inter anlennas superiores situm. Carina in medio trunco oriunda, in margine posteriore in spinas, in segmentis ultimis trunci tenues, in segmentis postabdominis quatuor anterioribus longiores. producta. Segmenta postabdominis in medio dentibus destituta. Carina accessoria propius carinam primariam sita et similiter armala. Segmentum postabdominis 3tium in margine posteriore serratum. Antennæ superiores articulo pedunculi 3tio elongato. Pedes $1 \mathrm{mi}$ et $2 \mathrm{di}$ paris ferme ut apud speciem pracedentem. Pedes parium quingve posteriorum prælongati. Pedes 5ti, 6ti et $7 \mathrm{mi}$ paris articulo 1 mo non multo dilatato et in margine posteriore non producto.

Længden er indtil $15^{\mathrm{mm}}$ fra Hovedets forreste Rand til Halevedhænget.

Le gemet er meget tylit, opsvulmet, noget sammentrykt ovenfra nedad; Legemsledlene ere meget smale, hos de storste Exemplarer sees langs Ryggens Midtlinie en svag Kjøl, der ved den bagre Rand liæver sig noget mere op og danner et stumpt. Fremspring; hos smaa Exemplarer er Ryggen rund. Paa de fire første Haleled er denne Kjøl 
mere udtalt og gaar paa Midten af den bagre Rand frem i en bagudrettet Tand; paa hver Side og parallel med denne Kjøl sees paa de fire første Haleled en lignende Kjol, der ligeledes paa Leddenes bagre Rand danner et skarpt Fremspring. Det tredie Haleleds nedre, bagre Rand er fint tandet. Sidepladerne ere meget smaa; den første er fortil forlenget i en smal, paa Enden tilspidset Fremstaaenhed, der lægger sig til den bagre Del af Hovedets nedre Rand. Hovedet gaar fortil, mellem de øvre Folere; ud i et kort, men bredt Pandehorn; dets Sidevinkler danne mellem de øvre og nedre Følere en stor, i Spidsen noget afrundet Lap. Øinene ere store, ovale, fremstaaende.

De ovre Følexe naa, naar de boies bagud, omtrent til det forste Haleled. Skaftets forste Led er omtrent saa langt som Hovedet og har paa den ydre Ende et kort Fremspring og nogle lange, fjærdannede Børster; det andet er lidt længere og smalere; det tredie Led er det korteste. Svoben, aer er næsten saa lang som Skaftet, dannes af 9 forliengede Led.

De nedre Fol lere ere længere end de ovre. Skaftets forste Led har et kort Fremspring paa Enden af den øvre Side; det andet er særdeles kort og danner kun et svagt Fremspring paa Enden; det tredie er længere og har et kort Fremspring; det fjerde er meget langt og har Sugeskaale paa den ovre Side; det femte er længere og smalere end det fjerde Led, og er ligeledes forsynet med Sugeskaale paa den øvre Side. Svoben er omtrent saa lang som Skaftets sidste Led og dannes af 9 forlængerle Led.

Kindbakkerne ere meget stærke, delte i Spidsen, og Grenene ere tandęde; Tornerækken dannes af fire stærke Torne; Tyggeknuden er meget fremstaaende og paa dens skraa afskarme Ende vabnet med Krandse af smaa Tænder. Palpen er forlænget; det tredie Led er længere end det andet.

Det forste Kjabepar er stærkt; den ydre Plade har paa Enden kamformede Tænder; den indre Plade er stor, forlænget oval, med nogle fjærdannede Børster paa Enden.

Det andet Kjabepars indre Plade er storre end den ydre.

Kjæbef $ø$ ddernes Plader ere smaa, men brede; den ydre, der naar frem til Midten af Palpens andet Led, er paa den indre Rand vabnet med tynde Torne, der blive længere mod Pladens Ende; den indre er liden, med nogle Børster paa Enden. Palpen er særdeles stor, forlænget; det tredie Led er kun lidt kortere og smalere end det andet. Kloen er lang og stærk.

De trende forste Fodpar ere af eens Bygning, men det andet er det længste; det fjerde Led er kort og udsender fra den nedre Del af den bagre Rand et noget bøiet, med Borsteknipper besat Fremspring; Haanden er forlænget oval, Griberanden indtager næsten den hele bagre Rand $0 \mathrm{~g}$ er væbnet med smaa Torne og et Par større, hvor Spidsen af den lange, krumme Klo lægger sig imod.

Det tredie og fjerde Éodpar ere meget tynde; det tredie Led er meget 
kort $0 \mathrm{~g}$ smalt; det fjerde er meget længere; det femte er af den samme Længde som det foregaaende Led. Kloen er ikke fuldt saa lang som det sidste Led.

De tre følgende Fodpar ere sicrdeles lange og smale, det syvende er det længste; det forste Led er noget udvidet, størst paa det sidste Par, og dets bagre Rand er afrundet; det tredie er temmelig langt og har et Fremspring paa den ydre Ende af den forreste Rand; det fjerde er kortere end det foregaaende Led, men det femte er omtrent af den samme Længde, dog meget tyndere. Kloen er lang, ret.

Det første og sidste Par Springfødder naa omtrent lige langt bagud; det andet er kortere; den ydre Gren er ubetydelig kortere end den indre.

Halevedhænget er meget stort, naar næsten lige saa langt bagud som det sidste Par Springfødder og er kløvet til henimod Midten; Fligerne ere afrundede i Spidsen.

Den er fundet af Danielssen i Hardangerfjorden paa 300 Favne, af G. O. Sars ved Risvær i Nordland paa 3-400 Favne, ved Christiansund paa 50-100 Favne og ved Aalesund paa 60-100 Favne, af mig ved Skraaven paa 200 Favne og i Christianiafjorden.

\section{TRITROPIS FRAGILIS, Goës, 1865. †}

Paramphithoë fragilis, Goës, Crust. amphip. maris Spetsb. 1865. p. 8. fig. 16. Tritropis fragilis, A. Boeck, Crust. amphip. bor, et aret. 1870. p. 80.

Caput sine rostro frontali, sed frons prominula. Oculi subreniformes. Segmenta postabdominis tria anteriora obtusa, tricarinata, edentata. Segmentum postabdominis $2 \mathrm{dum}$ in angulo inferiore postico acutum. 3tium in angulo rolundatum. Antennx multo magis elongata qvam apud species duas pracedentes. Pedes lmi et 2 di paris elongati, manu parva, subcheliformi, breviore qvam carpo. Pedes parium seqventium elongati. Pedes trium parium ultimorum arliculo 1 mo non valde dilitato; pedes $7 \mathrm{mi}$ paris articulo $1 \mathrm{mo}$ in angulo inferiore postico producto. Appendix caudalis circiter duplo longior qvam lata, in exteriore tertia parte tissa et in margine exteriore serrata.

Læn gden er $15^{\mathrm{mm}}$.

Legemet er temmelig tykt, bredt; dets forreste Del er mere halvcylindrisk, den bagre mere sammentrykt fra Siderne. Paa Ryggen af de tre forste Haleled sees tre Kjøle, der ere af en stump Form og gaa ikke ud i Tæuder paa den bagre Rand; det andet Haleleds nedre, bagre Vinkel er tilspidset, paa det tredie er den afrundet. Sidepladerne ere smaa; den første danner paa den nedre, forreste Vinkel en Fremstaaenbed, der lægger sig til Hovedets temmelig fremspringende nedre Rand. Hovedet er omtrent saa langt som de tvende forste Legemsled tilsammen. Panden er 
fremragende, men danner intet egentligt Pandehorn. Øinene ere fremstaaende, svagt nyreformede.

De øvre Følere ere meget forlængede, næsten saa lange som det hele Legeme. Skaftet er kort, og dets Led aftage efter hverandre meget i Længde.

De nedre Følere ere meget langere end de øvre. Skaftets fjerde og femte Led ere omtrent lige lange.

De tvende første Fodpar ere forlængede, smale; det andet Par er lidt længere end det forste. Haanden er noget kortere end det fjerde Led, med skraa afskaaret Griberand.

Det tredie og fjerde Fodpar ere meget forlængede; det tredie Led er kun svagt udvidet mod Enden og kortere end det fjerde; det femte Led er det længste.

De tre følgende Fodpar tiltage efter hverandre lidt i Langde; det forste Led er ikke meget bredt, smalere mod den ydre Ende og saugtakket paa den bagre Rand; det syvende Pars forste Leds nedre, bagre Vinkel er lidt udtrukket, afrundet; de ovrige Led have Torne paa begge Rande.

Det sidste Par Springfod ders Grene ere meget længere end Grundleddet.

Halevedhænget er næsten dobbelt saa langt som bredt ved Roden, kløvet i den ydre Trediedel; den nedre Del af dets ydre Rande er saugtakket.

Den er|fundet af Malmgren ved Spitsbergen paa 5-10 Favnes Dybde, af Torell ved Grønland.

\section{Familia $v$.}

AMPELISCAID E, A. Boeck, 1872.

Syn.: 1855. Tetromatides, Spence Bate, Brit. Assoc. Rep. p. 21. Synopsis, Ann. Nat. Hist. Febr. 1857.

185\%. Ampeliscades, Spence Bate, Ann. Nat. Hist. vol. XX. p. 525. Catal. Amphip. Crust. Brit. Mus. 1862. p. 90.

- Ampeliscini, Costa, Mem. d. Accad. d. Sci. di Napoli. p. 173.

1863. Ampeliscides, Spence Bate and Westwood, Brit. sessile-eyed Crust. p.124.

1865. Ampeliscina, Lilljeborg, On the Lysianassa magellanica.

1870. Ampeliscina, A. Boeck, Crust. amphip. bor. et arct. p. 140.

Labium superius latum, in apice parum arcuatum.

Mandibulæ utrobiqve similes, in apice latæ, dentatæ; processu accessorio item perdentato; tuberculo molari valde prominenti; serie spinarum ex spinis multis, longis, validis et in apice plus minusve furcatis et partim serratis composita; palpo plus minusve prælongato, 3articulato. 
Labium inferius perlatum; lamina interiore lata.

Ilaxillæ $1 \mathrm{mi}$ paris lamina interiore longa, non vero lata, in apice setis plumosis paucis instructa; palpo 2articulato, in apice spinis et dentibus paucis, validis armato.

Haxillæ 2di paris lamina exteriore longiore et partim latiore qvam interiore.

Pedes maxillares robusti; lamina interiore elongata; exteriore magna, in margine interiore dentibus latis, in apice spinis curvatis armata.

Corpus elongatum, altum, compressum; epimeris sat magnis aut magnitudinis mediocris, in margine inferiore setis instructis; capite in apice producto; oculis duobus (?) aut qvatuor, simplicibus.

Segmenta postabdominis duo posteriora coalita.

Antennæ superiores flagello longo præditæ, flagello accessorio destitutæ, ad apicem capitis affixæ.

Antennæ inferiores item flagello longissimo instructæ, sub capite affixæ.

Pedes $1 \mathrm{mi}$ et 2 di paris graciles, manibus parvis, subcheliformibus instructi.

Pedes 3tii et 4ti paris angusti; articulo 3tio lato.

Pedes 5ti et 6 ti retroversi; ungvibus parvis.

Pedes $7 \mathrm{mi}$ paris iisdem 5 ti et 6 ti paris multo breviores; articulo 1 mo infra et postice valde dilatato.

Pedes saltatorii biramei; ultimi paris ramis laminiformibus et setosis.

Appendix caudalis plus minusve profunde fissa.

Spence Bate kaldte sin herhen horende Underfamilie i 1855 Tetromatides efter Slægten Tetromatus, men da han fandt, at denne var synonym med Ampelisca, forandrede han i 1857 Navnet til Ampeliscades, og han henførte herunder kun een Slægt, Ampelisca. Costa opstillede denne Familie som en Underfamilie Ampeliscini og anfører som Karakter for den, at Hovedet har ocelli og ikke sammensatte Øine, som hos de gvrige Underfamilier af Familien Gammuridei. Spence Bate fremhxver ogsaa Hovedets eiendommelige Form og finder, at den bør staa nær Lysianassides og Phoxides. Lilljeborg benæunte sin Underfamilie i 1865 Ampeliscinn og adstiller den fra de øvrige under Gammaridee hørende 3 Underfamilier, hvis ørre Følere mangle Bisvøbe, ved at Øinene ere simple. Han henforer hertil Slægterne Haploops og Ampelisca. Krøyer har allerede i 1842 vist, at Hannerne skille sig fra Hunneme ved, at deres Folere, især de nedre, ere meget forlængede og forsynede med Sugeskaale, formodentlig for derved at holde Hunnerne fast under Parringen. Alle Slægter af denne Familie bebo Rør, som de danne sig af Dynd, hvilket er allerede anført af Lilljeborg og Danielssen, men desuagtet stiller Spence Bate denne sin Underfamilie under Subdivisionen Vagantia og ikke under Domicola. 
Gen. I. AMPELISCA, Krøyer, 1842.

Deriv.: Ampelisca, en Kivindes Navn hos Plautus.

Syn.: 1842. Ampelisca, Kroyer, Nat. Tidsskr. 1. R. IV. p. 154.

1851. - Lilljeborg, Öfv. af Kgl. Vet.-Akad. Förhandl. 185̌1. p. 22. 1855. p. $13 \%$.

1852. - Dana, U. S. explor. exped. p. 912.

1853. Araneops, Costa, R. d. Accad. d. Sci. di Napoli. p. 169. Mem. d. Reale Accad. d. Sci. 1856 p. 177.

1854. Pseudophthalmus, Stimpson, Mar. Inv. Grand-Manan. p. 47.

1855. Tetromatus, Spence Bate, Brit. Assoc. Rep. p. 58. Synopsis, Ann. Nat. Hist. Febr. 185\% p. 139.

185\% - White, Hist. Brit. Crust. p. 171.

- Ampelisca, Spence Bate, Ann. Nat. Hist. ser. 2. vol. XX. p. 255. Catal. Amphip. Crust. Brit. Mus. 1862. p. 90.

1859. - Bruzelius, Skand. Amphip. Gamm. p. 82.

1860. - A. Boeck, Forh. ved de Skand. Naturf. 8de Møde. p. 652.

1863. - Spence Bate and Westwood, Brit. sessile-ejed Crust. p. 125.

1865. - Goës, Crust. amphip. maris Spetsb. p. 13.

1870. - A. Boeck, Crust. amphip. bor. et arct. p. 141.

Mandibulae articulo palpi 2 do lato; articulo 3 tio multo angustiore, sed ferme eadem longitudine ac 2 do.

Pedes maxillares articulo palpo 3 tio apicem versus valde dilatato.

Oculi qvaluor, in margine capitis anteriore positi.

Antennæ inferiores articulo pedunculi 1 mo et 2 do non extus visibilibus.

Pedes $7 \mathrm{mi}$ - paris articulo $1 \mathrm{mo}$ triangulari, postice et infra elongato; articulo 5 to pralongato, ovali, longiore quam 4to; ungve lanceolato.

Pedes saltatorii ultimi paris ultra extremos pedes saltatorios $1 \mathrm{mi}$ et $2 \mathrm{di}$ paris porrecti; ramis elongatis, laminiformibus, setis longis, plumnsis instructis.

Appendix caudalis elongata, plus duplo longior qvam lata, usqve ad ba$\sin$ fissa.

Denne Slægt er, efter at den i 1842 blev opstillet af Krøyer, i 1853 af Costa kaldt Araneops, af Stimpson Pseudophthatmus, af Spence Bate Tetromatus. Ved Folmen af det syvende Fodpar og af Halevedhænget skiller den sig i det Ydre fra de tvende folgende Slægter, men ogsaa i Bygningen af Kindbakkernes Palper og af det tredie Led paa Kjæbefoddernes Palper er der en Eiendommelighed for denne Slægt. Spence Bate henforte hertil 10 Arter, hvoraf han dog selv kun kjendte 5; jeg har her beskrevet 10 Arter. 
ANIPELISCA TENUICORNIS, Lilljeborg, 1855.

(Pl. XXXI. fig. 1.)

Ampelisca tenuicornis, Lilljeborg, Öfv. af Kgl. Vet.Akad. Förh. 1855. p. 123.

- $\quad$ - $\quad$ Bruzelius, Skand. Amphip. Gamm. 1859. p.84.

- $\quad$ Spence Bate, Catal. Amphip. Crust. Brit. Mus. 1862. p. 96.

- - Norman, Ann. and Mag. Nat. Hist. 1868.

- - A. Boeck, Crust. amphip. bor. et arct. 1870. p. 141.

Ampelisca lavigata, Spence Bate and Westwood, Brit. sessile-eyed Crust. 1868. II. App. p. 504 .

Arancops diadema, Costa, Mem. d. R. Accad. d. Sci. di Napoli. 1856. p. 178. t. 1. fig. 1.

Caput productum, in apice obliqve truncatum. Postabdomen carinatum; segmento 4 to maxime carinato; segmento 3 tio in angulo inferiore posteriore non acuto. Antennæ superiores fere longitudinem dimidiam inferiorum æe(yantes; articulo pedunculi Imo paulo breviore qvam 2do. Antenna inferiores longitudinem animalis xqvantes aut parum superantes: articulo pedunculi 3 tio circiter ad funem capitis porrecto; articulo 4 to et 5 to longitudine fere reqvalibus. Pedes 3 tii et 4 ti paris ungve longiore qvam articulis duobus pracedentibus junctis. Pedes 5ti et 6ti paris articulo 4 to non longo, longitudine articulo 2 lo el 3 tio junctis ferme aqvali. Pedes $7 \mathrm{mi}$ paris arliculo $1 \mathrm{mo}$ in margine inferiore rolundato et ad finem articuli 2di producto; articulo 5to ovali, longitudinem articuli 3 tii et 4 ti junctorum æovanti. Pedes saltatorii ultimi paris ramis prælongatis.

Lingden er $7^{m m}$.

Legemet er sammentrykt fra Siderne; Ryggen er rund paa den forreste Del af Legemet, medens der paa Halens Led viser sig en meget smal Kjøl, især paa det fjerde Led, hvor Midtlinien tillige ved en Indsynkning faar et pukkellignende Udseende; det tredie Haleleds nedre, bagre Vinkel er ikke udtrukket. Sidepladerne ere høie, med fjærdannede Borster paa den nedre Rand og af den sædvanlige Form. Hovedet er længere end de tvende forste Legemsled tilsammen og er smalere mod den ydre Ende, der er skraa afrundet.

De ovre Folere udspringe fra Hovedets Ende, vende nedad og naa lidt lingere frem end Skaftet paa de nedre Folere. Skaftets første Led er ikke dobbelt saa langt som tykt og er smalest ved Roden; det andet er noget længere, men meget smalere; det tredie er omtrent af det foregaiende Leds halve Lrengde. Svoben er omtrent dobbelt saa lang som Skaftet og dannes hos Hannen af 20 , hos Hunnen af 7 Led.

De nedre Folere ere saa lange som Legemet eller lidt længere, hos Hannen længere end hos Hunnen; det tredie Led naar frem knap til Hovedets Ende; det meget forlængede fjerde og femte Led ere omtrent lige lange. Svoben, der er mere 
end dobbelt saa lang som Skaftet, dannes hos Hannen af omtrent 35 ilkie meget tydelig adskilte Led.

Kindbakkerne ere kraftig udviklede; Gribedelen er bred, delt i 5-6 Tæn-

der; den indre Bigren er ligeledes stirk; Tornerækken dannes af tolv, i Spidsen gaffelformede Torne; Tyggeknuden er fremstaaende. Palpens tredie Led er meget tyndt og noget bøiet, kortere og meget smalere end det andet, samt paa den concave Rand besat med mange stive Børster.

Det forste $\mathrm{Kj}$ bepars ydre Plade er væbnet med mange tynde, lange Torne; den indre er smalere mod Enden og har tvende Børster. Palpen har fiere Torne paa Enden.

Det andet $\mathrm{Kj}$ æbepars ydre Plade er længere og bredere end den indre og er, ligesom Palpen, paa Enden besat med fjærdannede Børster.

Kj $æ b$ efodderne ere stærke; den ydre Plade er stor, naar frem til Enden af Palpens andet Led og er paa den indre Rand vabnet med knivformede Tænder, der mod Pladens Ende blive længere og ga paa dennes ydre Rand over til forlængede Børster; den indre Plade naar frem for Enden af Palpens forste Led og har paa Enden tre Torne og nogle fjærdannede Børster, der ogsaa findes paa den indre Rand. Palpens tredie Led er kort, bredere mod Enden; det fjerde er kort, smalt, med tvende Torne i Spidsen.

Det forste Fodpars første Led er paa den bagre Rand besat med fjærdannede Børster; det fjerde har en oval Form og er lidet udvidet paa den bagre Rand; det femte er mere convex paa den bagre end forreste Rand og er kortere end det foregaaende Led. Begge de sidste Led have Børstebundter paa begge Rande.

Det andet Fodpar er meget mere forlænget og smalt; det femte Led er omtrent Totrediedel af det foregaaende Leds Længde, og begge have talrige Børstebundter paa den bagre Rand.

Det tredie Fodpar er tyndere og mindre forsynet med Børstebundter end det fjerde; dette sidstes forste Led er paa den forreste Rand besat med smaa, paa den bagre med længere fjærdannede Børster; det tredie er bredest paa Midten eller lidt foran denne og har lange fjærdannede Børster paa begge Rande; det fjerde er kort; det femte er længere end det foregaaende Led og noget krummet. Ḱloen er næsten ret, noget længere end de tvende sidste. Led tilsammen.

Det femte Fodpars forste Led er meget convex paa den forreste Rand og besat med mange Børster; det fjerde er næsten saa langt som de tvende foregaaende Led tilsammen og kun lidt længere end det femte, der er krummet og har nogle forlængede Torne paa' den forreste Rand. Kloen er kort og har tvende Torne paa den bagre Rand.

Det sjette Fodpar ligner det foregaaende, men er lidt støre. Kloen er som hos det foregaaende Par.

Det syvende Fodpars første Leds forreste Rand er næsten ret, den bagre, 
nedre Vinkel er udtrukket næsten til Enden af det andet Led, afrundet, forsynet med lange fjærdannede Børster; det fjerde er længere end det tredie; det femte er ovalt, saa langt som de tvende foregaaende Led tilsammen. Kloen er bred, neppe halvt saa lang som det sidste Led.

Det sidste Par Springfodder naar længst bagud; Grenene ere meget længere end Grundleddet, og den ydre noget længere end den indre, denne er i den ydre og den ydre er i den indre Rands bagre Del besat med fjærdannede Børster.

Haleved $\mathbf{h} \rightsquigarrow \mathbf{n g e t}$ er omtrent tre Gange saa langt som bredt ved Roden, smalere mod den ydre Ende og kløvet næsten til Roden; Fligerne have i Spidsen en liden Torn.

Pseudophthalmus limicola, Stimps. (Mar. Invert. of Grand Manan p. 57), er vistnok synonym med denne Art. Den af Spence Bate og Westwood beskrevne og afbildede Art A. levigata maa ogsaa være den ovenfor beskrevne Form, da Hovedet er skraa afskaaret og de nedre Føleres tvende sidste Skaftled ere lige lange.

Den er temmelig almindelig ved Molde, sjeldnere ved Christiansund paa $30-60$ Favne ifølge Danielssen; ved Hvidingsøerne er den taget af G. 0. Sars; efter Bruzelius er den fundet ved Kullen og Bohuslen, hvor den er sjelden. Costa har fundet den almindelig i Bugten ved Neapel.

AMPELISCA ASSIMLIS, A. Boeck, 1870.

(P1. XXXI. fig. 2.)

Ampelisca assimilis, A. Boeck, Crust. amphip. bor. et arct. 1870. p. 14\%.

Segmentum postabdominis 4 tum carina alta, gibberiformi instructum. Pedes 3 tii et 4 ti paris ungve breviore qvam articulo 4 to et 5 to junctis. Pedes $7 \mathrm{mi}$ paris articulo 1 mo postice valde arcuato. Cateroqvin ferme ut apud speciem pracedentem.

Lx ngden er $10^{\mathrm{mm}}$.

Legemet er sammentrykt fra Siderne; Ryggen er rund, uden Kjøl; en saadan viser sig dog paa det tredie Haleled og fortsætter sig paa de tvende følgende Led; paa det fjerde danner Ryggen en bueformet Ophøining; de tre første Haleleds nedre, bagre Vinkel er næsten ret, afrundet; de trende sidste Led synes at være sammensmeltede, men man kan dog se mellem dem en Grændse, der skiller det meget korte femte fra det meget længere sjette Led. Sidepladerne ere store; den første er større end den anden. Hovedet er læugere end de tre forste Legemsled tilsammen, noget skraa afskaaret paa den forreste Ende.

De øyre Følere ere noget længere eud Skaftet paa de nedre. Skaftets forste Led er dobbelt saa laugt som bredt; det andet er meget længere, men smalere; det tredie er kort. Svøben dannes af 14 forlængede Led. 
De nedre Følere ere meget lange. Skaftets tredie Led naar omtrent saa langt frem som til Hovedets forreste Ende; det fjerde, der er meget langt, e r noget længere end det femte Led. Svøbens Led ere meget lange og smale.

Mund delenes Bygning er lig den hos $A$. spinipes.

Det første Fodpars første Led er kortere end de følgende tilsammen; det femte er temmelig kort, meget udvidet paa den bagre Rand, der, ligesom paa det foregaaende Led, er besat med lange Borstebundter.

Det andet Fodpars femte Led er meget længere end det foregaaende Leds halve Længde.

Det tredie og fjerde Fodpars første Led er læugere end det tredie, der er temmelig udvidet, bredest nær den ydre Ende og besat med fjærdannede Børster paa begge Rande; det fjerde og femte Led ere tilsammen saa lánge som Halvdelen af det tredie Led. Kloen er kun ubetydelig krummet, kortere end de tvende sidste Led tilsammen.

Det femte Fodpars første Led er meget udvidet, bredere end langt.

Det syvende Fodpars forste Led er meget bueformet udvidet paa den bagre Rand og har sin storste Bredde paa Midten; den bagre Rands nedre Del er besat med fjærdannede Borster; den nedre, bagre Vinkel er udtrukket til Midten af det andet Led; det tredie Led er kun halvt saa langt som det andet; det fjerde er af den samme * Længde; det femte er noget længere og smalere end det foregaaende Led. Kloen er forlænget, tyk.

Det forste Par Springfødders Grene ere lige lange, cylindriske.

Det andet Par naar lidt længere bagud og er ubetydelig længere end det sidste Pars Grundled.

Det sidste Pars Grene ere bredere, lancetformede.

Halevedhænget er forlænget smalt, kløvet i den ydre Totrediedel; Fligerne ere forsynede med Torne i den ydre Rand og med en stærkere Torn i Spidsen.

Jeg har fundet denne Form ved Haugesund.

AMPELISCA TYPICA, Spence Bate, 1855.

(Pl. XXXI. fig. 4.)

Tetromatus typicus, Spence Bate, Brit. Assoc. Rep. 1855. Synopsis, Ann. Nat. Hist. 185\%. 2. ser. XIX. p. 139.

- - White, Hist. Brit. Crust. 1857. p. 171. pl. 10. fig. 4.

Ampelisca carinata, Bruzelius, Skand. Amphip. Gamm. 1859. p. 8\%. fig. 16.

- $\quad$ - Spence Bate; Catal. Amphip. Crust. Brit. Mus. 1862. p. 371.

- $\quad$ - Norman, Rep. on the Shetland Crust. 1868. p. 277.

- Gaimardii, Spence Bate, Catal. Amphip. Crust. Brit. Mus. 1862. p. 91. pl. XV. fig. 1 . 
Ampelisca Gaimardii, Spence Bate and Westwood, Brit. sessile-eyed Crust. 1863.p. 127.

typica, A. Boeck, Crust. amphip. bor. et arct. 1870. p. 142.

Caput.parum productum, in apice recte truncatum. Dorsum antice rotundatum, postice carinatum; carina segmenti postabdominis $4 \mathrm{ti}$ altissima et in medio e transverso depressa. Segmentum postabdominis 3tium in angulo inferiore postico non sursum productum et acutum, in margine inferiore arcuatum. Antenna superiores pedunculo inferiorum longiores et apud marem longissimæ. Antenna inferiores articulo pedunculi 3 tio ultra fuem capitis porrecto. Antenne superiores pedunculo in margine inferiore et inferiores pedunculo in margine superiore scopis setarum multis, brevibus, rigidis instructis. Pedes 3tii et 1ti paris ungve longiore qvam articulo 4 to et 5 to junclis. Pedes 5 ti paris articulo 1 mo in margine posteriore lobo lato instructo. Pedes $7 \mathrm{mi}$ paris articulo $1 \mathrm{mo}$ deorsum fere ad finem articuli 2 di producto; articulo 5 to ovali, duplo longiore qvam litto. Appendix candalis brevis, ovata.

Læng d en er $10-12 \mathrm{~mm}$.

Legemet er af den sædvanlige Form; Ryggen er rund paa den forreste Del af Legemet, men har en Kjol paa den bagre, der især er fremtrædende paa det fjerde Haleled; dette har tillige en tværsgaaende Fordybning paa sin forreste Trediedel; det tredie Haleleds nedre Rand er buet, og den nedre, bagre Vinkel er noget tilspidset. Hovedet er ikke meget udtrukket, paa Enden tvært afskaaret.

De øvre Følere ere langst hos Hannen. Skaftets første Led er omtrent dobbelt saa langt som bredt og har paa den nedre Side Bundter af korte Borster, staaende i Tværrader; det andet er noget lingere, men smalere, og er, ligesom det tredie, der er meget kortere, besat med lignende Børstebundter. Svøben, der naar langere frem end til Enden af de nedre Føleres Skaft, dannes af 12-20 Led; det første af disse er meget længere end de folgende og kun ubetydelig kortere enil Skaftets sidste Led.

De nedre Foleres tredie Skaftled naar frem foran Hovedets Ende og er, ligesom de tvende følgende, rigelig forsynet med Børstebundter, der her indtage den ovre Side; det femte er noget længere, men noget smalere end det foregaaende Led. Svøben er meget lang og dannes af $60-80$ Led.

De trende første Fodpar ere af den samme Bygning som hos den foregaaende Art.

Det fjerde Fodpar er stærkere end det tredie og i Randene tæettere besat med lange Børster. Kloen er paa disse Fodpar længere end de tvende sidste Led tilsammen. 
Det femte Fodpars første Led er paa den bagre Rand mere end sædvanligt hos disse herhen hørende Arter ultrukket til en bagtil forlænget Lap, medens den forreste, weget convexe Rand er forsynet med lange fjærdannede Børster.

Det syvende Fodpars forste Led er ikke udtrukket i den nedre, bagre Vinkel til det andet Leds Ende; det femte er forlænget ovalt, dobbelt saa langt som bredt, og lingere sad de tvende foregaaende Led tilsammen.

De tvende første Par Springfødders Grene ere længere end Grundleddet, især paa det forste Par, og naa lige langt bagud.

Det sidste Pars Grene naa længst bagud og ere lancetformet tilspidsede; den indre er ubetydelig længere end den ydre og er paa den ydre Rand forsynet med fjærdannede Børster; den ydre Gren har lignende Børster paa den indre Rand.

Halevedhænget er ægdannet, omtrent dobbelt saa langt som dets største Bredde, kløvet i den ydre Totrediedel.

Farven er efter Spence Bate hyalin hvid, med rosenrøde Pletter paa flere Steder af Legemet, især paa Fodparrene og Følernes Skaft.

Den er fundet af Bruzelius i 2 Exemplarer ved Drøbak paa 50-60 Favnes Dybde, og ved Bohuslen; efter Spence Bate er den taget paa flere Steder ved de engelske og irske Kyster; efter Norman, der antager, at den muligens er Hannen til $A$. aqvicarnis, er den fundet ved Shetland, Orkney, Aberdeenshire.

AMPELISCA EQVICORNIS, Bruzelius, 1859.

(PI. XXXI. fig. 3.)

Ampelisca aqvicornis, Bruzelius, Skand. Amphip. Gamm. 1859. p. 82. pl. 4. fig. 15. Norman, Rep. on the Shetland Crust. 1868. p. 276.

A. Boeck, Crust. amphip. bor. et arct. 1870. p. 143.

Caput parum productum. Dorsum non carinatum. Segmentum postabdominis 3 tium angulo inferiore postico recto. Antennæ superiores et inferiores longitudine fere xqvales. Antennæ inferiores articulo pedunculi 3tio ultra tinem capitis porrecto; articulo 410 et 5 to longitudine fere æeqvalibus. Pedes 3 tii et 4 ti paris ungve parum modo longiore qvam articulo 4 to et 5 to junclis. Pedes $7 \mathrm{mi}$ paris arliculo 1 mo infra dilatato et ad extremum articulum 2dum, vix longiorem qvam latum, producto; articnlo 5to elongalo, ovato, vix longitudinem articuli 3 tii et 4 ti junctorum æqvanli. Pedes saltatorii ultimi paris ramis parum modo setosis, Appendix caudalis duplo longior quam ad basin lata.

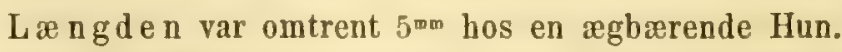

Legemet er sammentrykt; Ryggen er rund, uden Kjol; det tredie Haleleds nedre, bagre Vinkel er ret, afrundet; det fjerde har en liden Indsynkning tvars over Ryggen, og den bagre Rand danner en svag Ophøining. Sidepladerne ere høie, med 
fjærdannede Børster paa den nedre Rand; den forste er meget bred paa den nedre Rand. 'Hovedet er ikke meget udtrukket og kortere end de tre første Legemsled tilsammen.

De øvre Følere ere forlængeđ̄e og naa, naar de bøies bagud, omtrent til det fjerde Haleled. Skaftets forste Led er omtrent halvt saa langt som det andet og megei tykkere end dette; det tredie er kort og kun noget tykkere end Svøbens Led. Svøben er meget længere end Skaftet og dannes af $20-24$ forlængede, med Børster besatte Led.

De nedre Følere ere af den samme Længde som de øvre, eller kun lidt langere. Skaftets tredie Led rager $\mathrm{i}$ sin hele Længde foran Hovedets Ende og til Midten af det første Led paa de ovre Føleres Skaft; det fjerde naar ikke fuldt frem til den ydre Ende paa de øvre Føleres andet Led; det femte er af den samme Længde som det foregaaende eller noget længere. Svøben er meget længere end Skaftet og dannes af 18-24 lange, med Borster besatte Led.

De tvende forste Fodpars første Led er forsynet med llange Børster, og lignende, mere tretstaaende, men kortere sees paa de tre sidste Leds bagre Rand; paa det første Fodpar er det femte Led forlænget xgdannet, noget kortere end det fjerde Led; paa det andet Par er det meget kortere og smalere end det fjerde Led.

Det tredie og fjerde Fodpars Klo er længere end de trende sidste Led tilsammen.

Det femte og sjette Fodpars femte Led er smalt, lidet krummet, forsynet med Torne paa den forreste Rand og er længere end de tvende foregaaende Led tilsammen.

Det syvende Fodpars første Led er af en triangulær Form, den nedre Rand er afrundet $\mathrm{og}$ besat med fjærdannede Børster, den nedre, bagre Vinkel er ikke udtrukket længere end til det andet Leds Ende; det andet Led er længere og bredere end det tredie og det fjerde; det femte er neppe saa langt som de tvende foregaaende Led tilsammen. Kloen er lancetformet.

Det sidste Par Springfodder naar længst bagud, Grenene ere forlænget lancetformede, den indre er paa den ydre og den ydre paa den indre Rand forsynet med faa Børster.

Halevedhanget er omtrent dobbelt saa langt som bredt ved Roden, spaltet meget dybt.

Den er fundet af G. O. Sars ved Risvær paa 180-200 Favne, ved Christiansund paa 50-100 Favne og ved Hvidingsøerne; af mig ved Skraaven paa 2-300 Favne. Ved Shetland er den efter Norman almindelig og er taget paa tlere Steder ved den engelske Kyst. 


\section{AMPELISCA SPINIPES, A. Boeck, 1860.}

(P1. XXXI. fig. 5.)

Ampelisca spinipes, A. Boeck, Forh. i de skand. Naturf. 8de Mode. 1860. p. 653.

A. Boeck, Crust. amphip. bor. et arct. 1870. p. 143.

Postabdomen segmentis qvatuor anterioribus carinatis; segmento flo maxime: segmento 3 tio in angulo inferiore posteriore non acuto. Antenns superiores et inferiores longitudine fere æqvales, prælongatæ. Antennæ inferiores articulo pectunculi 3tio non ad finem capitis porrecto. Pedes 3tii et 4 ti paris ungve longitudinem articuli 4 li et 5 ti junctorum xqvanti. Pedes 5 ti et 6 ti paris articulo 410 et 5 to per totam longitudinem spinis multis et validis instructis. Pedes $7 \mathrm{mi}$ paris arliculo $1 \mathrm{mo}$ in margine inferiore ad extremum articulum 2dum producto; articulo 2do multo longiore qvam lato; articulo 5to Iongitudinem articuli 3tii et 4 ti junclorum multo superanti. Pedes saltatorii ultimi paris ramis in margine valde setosis. Appendix caudalis ter longior qvam ad basin lata.

L $æ n$ gden er $30^{\mathrm{mm}}$.

Legemet er forlænget, sammentrykt; den forreste Del af Ryggen er rund; de tre forste Legemsled ere korte, omtrent af den samme Størrelse, det fjerde er bredere end det foregaaende; de tvende sidste og de fire første Haleled have paa Ryggens Midtlinie en Kjol; det tredie Haleleds nedre, bagre Tinkel er næsten ret, ikke tilspidset. Sidepladerne ere høie; de tre forste have paa sin nedre Rand smaa Børster; den fjerde er meget bredere, indskaret næsten til Midten af den bagre Rand for den femte Sideplade. Hovedet er saa langt som de tre forste Legemsled tilsammen, smalere fortil, med en tvært afskaren Ende.

De øvre Følere ere forlængede, og Skaftets andet Led er lidt kortere end Hovedet. Svøben dannes af 30 forlængede Led, besatte med Børster paa den indre Rand.

De nedre Følere ere af den samme Længde som de øvre, eller lidt længere end disse; det tredie Led naar lidt frem foran den første Sideplade, men ikke til Hovedets Ende; det fjerde er længere end det andet Led paa de ovre Foleres Skaft; det femte er længere end det foregaaende Led. Svoben er meget lang og dannes af omtrent 50 forlængede Led, med Borstebundter paa den undre Rand.

Kindbakkernes Tyggeknude er besat med mere end 20 Rader Tænder, der ere længere paa dens Omkreds, kortere i Midten. Palpens andet Led er usædvanlig tykt, ovalt; det tredie er af den samme Længde, men meget tyndere.

Det første Fodpar har den sædvanlige Form og har Børstebundter paa Leddenes bagre Rand. Kloen er ikke indskaaret i Tænder paa den bagre Rand.

Det andet Fodpar er meget længere og smalere; det fjerde Led er langt; det femte er kun halvt saa langt som dette. 
Det tredie og fjerde Fodpars første Led har fjærdannede Børster paa begge Rande; det tredie er af den samme Længde som det forste, kun lidt fortykket noget foran Midten, med en tvært afskaaren ydre Ende, og har ligeledes fjærdannede Borster paa begge Rande; det femte er ikke fuldt dobbelt sai langt som det fjerde Led og er meget tyndere mod Enden. Kloen er tynd og spids, lidt longere end de tvende sidste Led.

Det femte Fodpar er meget kort og bagoverbøiet; det forste Led har sin største Vidde forfra bagtil, og dets forreste Rand har mange fjærdannede Borster; det fjerde er langt, med en Række Tænder paa den ydre Side og paa den forreste Rand, samt med stærke Børster paa den skraa afskaarne Ende; det femte er kortere end det foregaaende Led og meget smalere, med stærke Børster paa begge Rande og paa den ydre Ende, og har ligeledes en Række langsgaaende Tænder paa den ydre Side.

Det sjette Fodpars første Led er af en mere rundagtig Form; det tredie er noget længere end det andet, og det fjerde har omtrent den dobbelte Læagde; dette sidste har en Række Tænder paa den ydre Side og den forreste Rand, af hvilke de nærmest Leddets ydre Ende ere de største; den ydre skraa afskaarne Ende har mange lange Torne; det femte Led er lidt kortere end det foregaaende, meget smalere og noget krummet, dets forreste Rand har en Række lange, nedad boiede Tænder.

Det syvende Fodpars første Led er nasten rhomboidalsk, og den nedre, bagre Vinkel er udtrukket til Enden af det andet Led; den nedre Del af den bagre Rand er forsynet med lange, fjerdannede Borster; den forreste Rands nedre Del er dybt indskaaret for det andet Led, saa at det ligger i denne Indskjæring; det andet Led er meget længere end bredt; det fjerde er længere end det tredie, men kortere end det andet Led; det femte er langere end de tvende foregaaende Led tilsammen, men ilke saa langt som de tre foregaaende. Kloen er halv saa lang som de sidste Led, flad lancetformet.

De tvende første Par Springfødders Grene ere nasten af den samme Længde, forlængede, smale.

Det sidste Par naar længst bagud; Grenene ere tlade, den ydre Gren er neppe kortere end den indre og har Borster paa den indre, medens den indre Gren har Børster paa den ydre Rand.

Halevedhænget er næsten tre Gange saa langt som bredt ved Roden, kløvet til over Midten; Fligerne have et Par Torne ved Spidsen.

Denne Art, der foruden ved de ovenfor omtalte Tænder paa det femte og sjette Fodpars tvende sidste Led, tillige udmærker sig ved sin Størrelse, er af G. O. Sars fundet ved Bergen og af mig ved Farsund.

AMPEIISCA DUBIA, A. Boeck, 1870.

Ampelisca dubia, A. Boeck, Crust. amphip. bor. et arct. 1870. p. 144. 
Caput non multo productum, in apice truncatum. Dorsum non carinatum. Segmentum postabdominis 3tium angulo inferiore posteriore producto et acuto. Antennæ superiores longitudinem pedunculi inferiorum æqvantes. Antennæ inferiores articulo pedunculi 3 tio ad finem capitis circiter porrecto; articulo 4 to et 5 to invicem ferme eadem longitudine. Pedes 3 tii et 4 ti paris ungve longiore qvam articulo 4 to et 5 to junctis.

Forfatterens Beskrivelse af denne Art var ei faldstændig, og Udgiveren har ei havt Anledning til at foretage en nuiagtigere Undersøgelse, der kan tilstrækkelig fuldstændiggjøre Beskrivelsen.

AMPELISCA. ESCHRICHTI, Krøyer, 1842.

(Pl. XXXI. fig. 7.)

Ampelisca Eschrichti, Krøyer, Nat. Tidsskr. 1842. 1. R. 4. B. p. 155.

$-\quad$ A. Boeck, Crust. amphip. bor. et arct. 1870. p. 144.
-- ingens, (Stimpson), Spence Bate, Catal. Amphip. Crust. Brit. Mus. 1862. p.
92. pl. XV. fig. 2.

Caput productum, in apice truncatum. Segmentum postabdominis 3tium angulo inferiore posteriore acuto et sursum producto; margine posteriore arcuato. Antennæ superiores inferioribus multo breviores sed pedunculo inferiorum longiores; articulo pedunculi 1 mo dimidiam 2di longitudinem fere æqvanti. Antennæ inferiores articulo pedunculi 3tio ad finem capitis porrecto; articulo pedunculi 4 to multo longiore qvam 5to. Pedes $1 \mathrm{mi}$ paris manu dimidiam carpi longitudinem xqvanti; carpo duplo longiore quam lato. Pedes 2 di paris carpo duplo longiore qvam manu. Pedes 3tii et 4li paris ungve multo longiore qvam articulo tho et 5 to junclis. Pedes 5 ti et 6 ti paris articulo 5 to parum modo breviore qvam 4 to. Pedes $7 \mathrm{mi}$ paris articulo 1 mo in margine posteriore non arcuato, in margine inferiore obliqve truncato, in angulo rotundato et ad medium marginem posteriorem articuli 3 tii porrecto; arliculo 4 to longiore qvam 3tio, lato; articulo 5 to perangusto, ter longiore qvam lato. Pedes saltatorii ultimi paris sat elongati; ramo exteriore paulo longiore et latiore qvam interiore et in margine interno setis plumosis instructo; ramo interiore in margine interno et externo similiter armato. Appendix caudalis angusta, ter longior qram lata.

Længden er indtil $25^{\mathrm{mm}}$ fra Pandehornets Ende til Halevedhænget.

Legemet er noget sammentrykt; paa Legemsleddene sees en svag Kjol, hvilken fremtrieder tydeligere paa de tre forste Haleled og er paa det fjerde afbrudt ved en sadelformet Indsynkning; det tredie Haleleds nedre, bagre Vinkel er udtrukket i en 
liden Hage; de tvende sidste Led, paa hvilke der ikke sees nogen Kjøl, ere sammensmeltede, men deres Grændse betegnes ved en Fure; det sidste Led har en Indskjæring for Halevedhænget, hvilken begræendses af tvende kjolformede Forhoininger. Sidepladerne ere høie, smale; den fjerde er næsten dobbelt sa høi som den største Bredde og ubetydelig indskaaret i den øvre Del af den bagre Rand for den femte Sideplade. Hovedet er omtrent saa langt som de tvende for'ste Legemsled tilsammen og er paa den ydre Ende ret afskaaret.

De øvre Følere, der ere fastede til Spidsen af Hovedet, naa, naar de boies bagud, til Midten af det fjerde Legemsled og ere noget længere end Skaftet paa de nedre Følere. Skaftets andet Led er næsten dobbelt saa langt som det første, men meget smalere end dette; det tredie er kort. Svoben er længere end Skaftet og dannes af 26, med lange Børster forsynede Led.

De nedre Foleres tredie Led naar lidt frem foran Hovedets ydre Ende; det femte er en Trediedel kortere end det foregaaende Led. Svøben er noget længere end Skaftet og dannes af 45 Led.

Overl 1 ben er stor, temmelig tyk, afrundet paa Enden.

Kindbakkerne ere stærke, dybt indskaarne i Spidsen med syv Tæuder; den indre Bigren har fem Tænder; Tornerækken dannes af tolv flade Torne, der i Spidsen ere indskaarne i 2-3 Tænder, hvoraf len ydre er større end den indre; Tyggeknuden er meget stærkt fremstaaende. Palpen er kort, smal; det andet Led er noget smalere mod Enden, med fjærdannede Borster paa begge Rande; det tredie er kun halvt saa langt som det andet Led og meget smalere, med Borster paa den øvre Kant.

Det forste Kjæbepars ydre Plade er kort, vabnet paa Enden med tolv Tænder i tvende Rader, og hvoraf ingen har Bitænder; den indre Plade er forlænget smal, med tvende fjærdannede Børster paa Enden. Palpens andet Led er bredere mod Enden og der afrundet, med fire Indskjæringer, hvori der sidder korte Torne; tvende længere sees paa den gvre Del af den ydre Rand samt flere paa den bagre Flade.

Det andet Kjæbepars Plader ere forlængede; den ydre er længere end den indre, og begge ere besatte med talrige fjærlannede Børster.

Kjæbefoddernes ydre Plade er stor, naar til Enden af Palpens andet Led og er væbnet paa den indre Rand med ti knivdannede Tænder, der forlænge sig mod Pladens Ende til krumme Torne og danne tilsidst Borster; den indre Plade er af middelmaadig Længde, paa Enden og den indre Rand besat med stive, korte, tildels fjærdannede Børster. Palpens andet Led er forlanget smalt, besat med Børster paa den indre Rand; det tredie er triangulært, med afrundede Vinkler; det fjerde er fæstet midt imellem den spidsere øvre ydre og den mere stumpe nedre Vinkel og har Børster paa den indre Rand samt i Spidsen en stærk Kilo.

Det forste Fodpar er forlænget smalt; det forste Led har en Række Torne paa den forreste Rand og Børster paa den bagre; det fjerde har en oval Form, er 
dobbelt saa langt som bredt og er forsynet med talrige Børster paa den bagre Rand; det femte Led er en Trediedel kortere, temmelig smalt.

Det andet Fodpar er langt og smalt, men af den samme Bygning som det foregaaende Fodpar; det fjerde Led er neppe saa bredt ved Roden som ved den ydre Ende og er meget langere end det smalere femte Led; begge disse sidste Led have Borstebundter paa begge Rande.

Det tredie og fjerde Fodpar ere af eens Bygning, men det sidste af disse er det stærkeste og tættest besat med fjærdannede Børster; det første Led har paa den forreste Rand en Række Torne og paa den bagre fjærdannede Børster; det tredie er meget bredt forlænget, med fjærdannede Børster paa begge Rande. Kloen er længere end de tvende sidste Led tilsammen.

Det femte Fodpars forste Led er meget udtrukket bagtil og danner der en stump Vinkel, der ligesom den bagre, nedre Vinkel er forsynet med fjærdannede Børster; let tredie er kort, dobbelt saa langt som bredt; det fjerde er en Trediedel lingere end dette; det femte er lidt kortere end det foregaaende Led og meget smalere.

Det sjette Fodpars første Led danner fortil en stump, afrundet Vinkel; den forreste nedre Rand er besat med fjærdannede Børster, den bagre Raud er kun lidet udvidet, næsten ret; det fjerde Leds nedre, bagre Vinkel er noget udvidet og forsynet med Torne; det femte er omtrent af den samme Længde som det foregaaende Led, men meget smalere, og cr, ligesom dette, paa den forreste Rand væbnet med Torne. Kloen er meget kort, fæstet i deu bagre Kant nær Spidsen af det sidste Led.

Det syvende Fodpars forste Led er skjævt triangulært, med en nedre, bagre stump Vinkel; den nedre, forreste Vinkel er dybt indskaaret for det andet Led, saa at dette $\mathrm{og}$ mere end Halvdelen af det tredie Led ligger indenfor denne Indskjæring; det fjerde er noget længere end det tredie, og det femte er længere end det foregaaende Led, men meget smalere. Kloen er forlænget lancetformet.

Det første Par Springfødiers Grene ere næsten lige lange, og ubetydelig langere end Grunlleddet.

Det andet Pars ydre Gren er noget kortere end den indre, der er kortere end Grundleddet.

Det sidste Pars ydre Gren er lancetformet, grovt saugtakiket paa den ene og med fjærdannede Børster paa den andeu Rand; den indre Gren er kortere og forsynet med fjærdannede Børster paa begge Rande.

Halevedhænget er omtrent tre Gange saa langt som bredt, kløvet næsten til Roden.

Denne Art er efter Danielssen ikke sjelden ved Tromsø og Varsø paa 40-60 Favne; af mig er den fundet ved Skraaven og flere Steder i Nordland paa 10-20 Favne; af Holböll og Torell er den fundet ved Grønland og Island; ifølge Lilljeborg gaar den lige til Kullen. Stimpson har fundet den ved Grand Manan. Efter Packard findes den ved Labrador. 
AMPELISCA MACROCEPHALA, Lilljeborg 1852.

(Pl. XXX. fig. 8.)

Ampelisea macrocephala, Lilljeborg, Öfv. af Kgl. Vet.Akad. Förhand. 1852. p. 7. 1855. p. 137.

\begin{tabular}{|c|c|}
\hline 一 & Bruzelius, Skand. Am \\
\hline - & Spence Bate, Catal. Amphip. Crust. Brit. Mus. 1862. $r$ \\
\hline- & Norman, Rep. on the Shetland Crust. 1868. p. 278. \\
\hline & A. Boeck, Crust. amphip. bor. et arct. 1870. p. 145 . \\
\hline & Lilljeborg, Öfv. af Kgl. Vet.-Akad. Förh. 1 \\
\hline
\end{tabular}

Araneops brevicornis, Costa, R. sui crost. amfip. del regno di Napoli. Mem. d. reale Accad. d. Sci. Napoli. 1851. p. 180. Tab. 1. fig. 2.

Caput in apice obliqve truncatum. Segmenta postabdominis qvatuor anteriora carina parvula instructa. Antenne superjores pedunculi inferiorum longitudinem xquales, vel parum modo longiores. Antennx inferiores articulo pedunculi 3tio non ad finem capitis porrecto. Pedes 1 mi paris manu parum modo breviore qvam carpo; hoc duplo longiore quam lato. Pedes tmi paris articulo 1 mo in margine inferiore perrolundato: articulo 4 to fere tam longo qvam lato; 5 to ovali, duplo longiore qvam lato et longitudinem articulorum 3tii ef 4 ti junctorum fere aquali. Appendix caudalis paulo brevior qvam apud speciem pracedentem. Cæteroqvin ferme ut apud speciem Eschrichti.

Længden er $16^{\mathrm{mm}}$.

Legemet er meget sammentrykt; Ryggen er rund undtagen paa de fire forste Haleled, paa hvilken der sees en Antydning til en Kjol; det tredie Haleleds nedre, bagre Vinkel er udtrukket til en opadboiet, spids Hage, og den bagre Rand er meget convex, hvorved der fremkommer en afrundet Fremstaaenhed. Hovedet er meget udtrukket, omtrent saa langt som de tre forste Legemsled tilsammen, skraa afskaaret paa den ydre Ende, hvorved de ovre Folere vende nedad.

De ovre Folere ere noget længere end de nedre Foleres Skaft, hos Hannen længere end hos Hunnen. Skaftets forste Led er omtrent dobbelt saa langt som bredt, det andet er en Trediedel længere, men meget tyndere; det tredie er lidt kortere end det første Led. Svoben dannes af $20-25$ Led hos Hannen, af $10-12$ hos Hunnen.

De nedre Følere ere hos Hannen saa lange som Legemet, hos Hunnen kortere. Skaftets tredie Led naar neppe frem til Hovedets Ende; det fjerde er meget længere end det femte Led. Svgben dannes hos Hannen af omtrent 50, hos Hunnen af omtrent 25 Led.

Overlæben er afrundet, paa Enden forsynet med faa Børster. 
Kindbakkerne ere meget stærke; Gribedelen er bred, forsynet med syv Tænder, den indre stærke Bigren med sex Tæender; Tornerækken dannes af ni tlade, lange, saugtakliede Torne; Tyggelinulen er meget fremstanende. Palpens tredie Led er kortere og meget smalere end det andet, med kun faa Børster i Spidsen.

Det forste Kjabepars ydre Plade naar frem til Midten af Palpens andet Led og har paa Enden flere Torne, besatte med Bitænder; den indre Plade er forlænget, med tvende Børster paa Enden. Palpens andet Led er krummet, bredest i den ydre Ende, og er der væbnet med 3-4 smaa Trender, mellem hvilke sidde 4 korte, strerke Torne.

Det andet $\mathrm{Kj}$ œbepars ydre Plade er længere og stærkere end den indre; begge ere paa Enden besatte med lange, fjærdannede Borster.

Kjæbefoddernes ydre Plade naar lidt længere frem end til Enden af Palpens andet Led og har paa den indre Rand $6-7$ stærke, brede Tænder, der mod Pladens Ende blive langere og smalere samt gaa i den ydre Rand over til krumme Torne. Palpens tredie Led er neppe længere end bredt vea den ydre Ende og er her forsynet med Børster; det fjerde, der er fæstet paa det foregaaende Leds skraa afskaarne Ende, har tvende Kløer paa Spidsen.

Det forste Fodpars fjerde Led er ovalt, dobbelt saa langt som bredt, det femte er forlænget ovalt, lidt kortere end det foregaaende Led; begge have paa den bagre Rand mange, tildels fjærdannede Børster.

Det andet Fodpar er meget længere end det forste; det femte Led er meget smalere end det foregaaende og har neppe Halvdelen af dettes Længde.

Det tredie og fjerde Fodpar ere næsten af eens Bygning, men det forste af disse er tyndere og smalere end det andet; det tredie Led er paa det tredie Fodpar meget tyndere end paa det fjerde. De tre sidste Leds Rande have talrige fjærdannede Borster. Kloen er Iængere end de tvende sidste Led tilsammen.

Det femte og sjette Fodpars fjerde Led er længere end de trende foregaaende tilsammen, samt væbnet med faa, men lange Torne paa den forreste Rand; det femte er kortere end det foregaaende Led.

Det syvende Fodpars forste Led er afrundet paa den nedre, bagre Rand, der er besat med fjærdannede Børster og kun forlenget til det tredie Leds halve Længde; det tredies bagre Rand er ret, og det er lidt udtrukket, tilspidset i den nedre, bagre Vinkel; det fjerde er næsten saa langt som bredt; det femte er ovalt, næsten saa langt, som de tvende foregaaende Led tilsammen og omtrent dobbelt saa langt som bredt ved Midten.

Det sidste Par Springfødders Grene ere lancetdannede; den ydre er længere end den indre og forsynet med fjardannede Børster $\mathrm{i}$ den ydre Del af begge Rande; den indre har Børster kun paa den indre Rand.

H alevedhænget er omtrent dobbelt saa langt som bredt ved Roden, spaltet nasten i sin hele Langde; hver af Fligerne har en Indskjæring, hvori der sidder en Torn. 
Saavel Spence Bate som Norman antager, at denne Art er synonym med A. Belliana, Spence Bate.

Den er fundet af Danielssen ikke ganske sjelden paa sandet Lerbund ved Christiansund paa 40-60 Favne; af G. O. Sars ved Stavanger, af mig paa Here Steder i Nordland; efter Lilljeborg og Bruzelius gaar den ned til Kullen; efter Goës er den taget paa flere Steder ved Spitsbergen, Grønland, Island (Torell). Efter Metzger findes den ved den ostfrisiske Kyst, og den er ligeledes fundet ved de engelske Kyster.

AMPELISCA PROPINQVA, A. Boeck, 1870.

(Pl. XXXI. fig. 8.)

Ampelisca propinqva, A. Boeck, Crust. amphip. bor. et arct. 1870. p. 145.

Caput in apice truncatum. Antennæ superiores pedunculo inferiorum parum longiores. Pedes $7 \mathrm{mi}$ paris articulo $1 \mathrm{mo}$ latiore qvam apud speciem pracedentem, in margine posteriore valde rotundato, in margine inferiore ad cxtremum articulum 3tium fere producto; articulo 4to permagno, in margine anteriore longiore qvam in posteriore, profunde inciso et spina valida armato; articulo 5 to vix longiore quam 4to, perangusto. Appendix caudalis duplo longior qvam ad basin lata. Cæteroqvin ferme ut apud speciem præcedentem.

L. 1 gden er $8 \mathrm{~mm}$.

Legemet er temmelig høit, tykt; Ryggens forreste Del er rund, men ile bagre Legemsled har en Kjøl, der bliver større paa de tre første Haleled, men er mindre udtalt paa det fjerde; det tredie Haleleds nedre, bagre Vinkel er udtrukket, tilspidset. Hovedet er ikke meget forlænget, omtrent saa langt som de tre første Legemsled tilsammen, paa Enden ret afskaret. Det ovre Øie sees bag og noget over Befæstelsespunktet for de øvre Følere; det nedre sees i Randen nedenfor disse.

De $ø$ vre $F$ olere ere meget kortere end de nedre og naa kun lidt længere frem end Skaftet paa disse. Skaftets første Led er knapt dobbelt saa langt som tykt; det andet er læugere og smalere; det tredie ligner Svobens Led. Svoben er kun ubetydelig læugere end Skaftet $0 \mathrm{~g}$ dannes af 7 forlængede Led.

De nedre Føleres tredie Skaftled naar frem foran Hovedets Ende; det fjerde er omtrent saa langt som de øvre Føleres Skaft; det femte er meget kortere end det foregaaende Led. Svoben er langere end Skaftet og dannes af 11 forlængede, med Børster besatte Led.

I Munddelenes Bygning og i Formen af de sex forste Fodpar er denne Art lig A. macrocephala.

Det syvende Fodpars forste Led er meget stort, dets bagre Rand danner en stor Boining, og den nedre, bagre Vinkel er afrundet, besat med enkelte fjærdan- 
nele Borster, samt strækker sig næsten til Enden af det tredie Led; det andet er kortere, og det tredie er længere end hos den foregaaende Art; det fjerde er bredt ovalt. ved sin ydre, bredere Ende omtrent saa bredt som høit, med en noget skraa, indadboiet ydre Rand; den forreste, længere Rand har paa sin nedre Trediedel et Indsnit, hvori der sees en stærk Tand; det femte Led er ovalt, smalt, lidt længere end det foregaaende Led. Kloen er lancetdannet.

Springfødderne ere meget korte.

Halevedhænget er kortere end hos den foreganende Art og mindre bredt. Den er fundet af mig i Christianiafjorden.

AMPELISCA LEVIGATA, Lilljeborg, 1855.

(P1. XXXI. fig. 6.)

Ampelisca lavigata, Lilljeborg, Öfv. af Kgl. Vet.-Akad. Förh. 1855. p. 123.

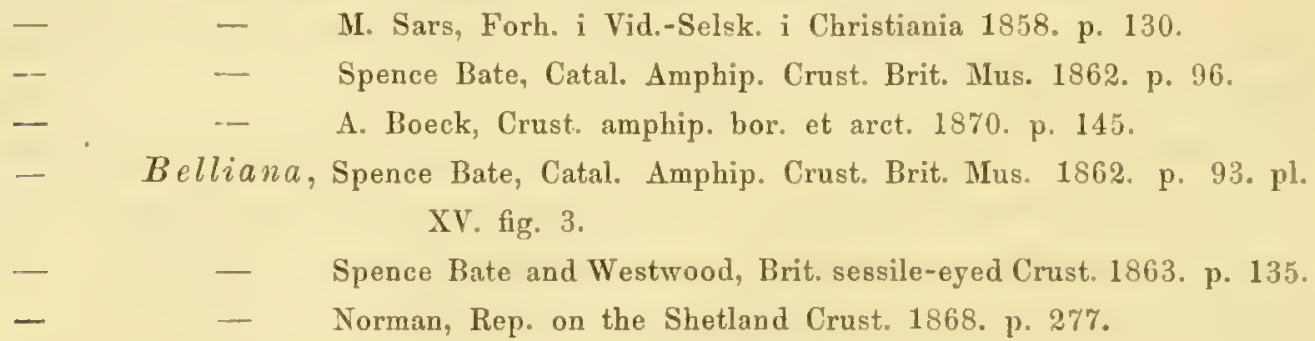

Tetromatus Bellianus, Spence Bate, Brit. Assoc. Rep. 1855. p. 58. Synopsis, Ann. Nat. Hist. XIX. p. 139.

White, Hist. Brit. Crust. 1857. p. 171.

Caput prælongatum, in apice truncatum. Segmentum postabdominis 3tium angulo inferiore posteriore acuto et sursum producto; segmentum 4tum per totam dorsi longitudinem carinatum. Antennæ superiores pedunculo inferiorum apud feminam breviores, apud marem longiores. Antennæ inferiores articulo pedunculi 3tio ad finem capitis circiter porrecto; articulo 4 to multo longiore qvam 5to. Pcdes 3tii et 4 ti paris ungve longiore qvam articuli 4 to et 5̆to junctis. Pedes 5 ti et 6ti paris prælongati: articulo 4to longitudinem articulorum duorum pracedentium junctorum multo superanti et longiore qvam articulo 5to. Pedes $7 \mathrm{mi}$ paris articulo $1 \mathrm{mo}$ in margine inferiore arcuato et ad medium articulum 3tium producto; articulo 3tio in angulo inferiore posteriore in processum magnum, latum, in apice rotundatum, setosum, eadem longitudine ac articulum 4tum triangularem, producto: articulo 5 to Iongitudinem 3 tii et 4 ti junctorum reqvanti, elongato et ovato.

Længden er $12 \mathrm{~mm}$.

Le gemet er meget. sammentrykt; Ryggen er rund, uden Kjøl, undtagen paa 
det fjerde Haleled, der har en saadan paa Ryggens Midtlinie; det tredie Haleleds nedre, bagre Vinkel er ultrukket, tilspidset, og dets bagre Rand har en halvmaaneformet Indskjæring. Hovedet er omtrent saa langt som de tre første Legemsled tilsammen og smalere mod den ydre Ende, der er tvært afskaaret. Øinene sidde nær Randen.

De øvre Følere, der ere fæstede paa Hovedets Ende, ere meget korte. Skaftets første Led er knapt dobbelt saa langt som bredt, det andet er mere end dobbelt saa langt som det første, men smalere; det tredie er kort og ligt Svobens Led. Svøben dannes hos Hannen af $20 \mathrm{Led} 0 \mathrm{~g}$ naar frem foran de nedre Foleres Skaft, hos Hunnen af 8 Led.

De nedre Folere ere hos Hannen saa lange som Legemet, hos Hunnen kortere. Skaftets tredie Led naar neppe frem til Hovedets Ende; det fjerde er meget længere end det femte Led. Svoben dannes hos Hannen af 50 Led, hos Hunnen af 15 Led.

Munddelene ere meget lig dem hos de foregaaende Arter.

Kindbakkernes Palpes andet Led er temmelig kort, ovalt, længere og bredere end det tredie Led.

Kjæbeføddernes ydre Plade har kun sex knivdannede Tænder, af hvilke de yderste ere meget tynde.

Det første Fodpars femte Led er ovalt, noget kortere end det fjerde Led.

Det andet Fodpar er meget langere og smalere; det fjerde Led er neppe dobbelt saa langt som det femte.

Det tredie Fodpar er tyndere og kortere end det fjerde, især dets tredie Led, bvilket er bredest ved den ydre Ende, samt er besat med fjærdannede Børster paa begge Rande; det fjerde er kort; det femte er dobbelt saa langt som det foregaaende Led. Kloen er meget længere end de tvende sidste Led tilsammen.

Det femte og sjette Fodpar ere meget mere forlængede end hos de foregaaende Arter; det tredie Led er længere end bredt; det fjerde er længere end de tvende foregaaende Led tilsammen; det femte, noget krumme Led er kortere end det foregaaende.

Det syvende.Fodpars forste Leds nedre, bagre Vinkel er meget forlænget, næsten ret, afrundet, den naar til Midten af det tredie Led, og den nedre Rand er besat med Borster; det tredie Leds bagre Rand er udvidet nedad, den nedre, bagre Vinkel er udtrukket og danner en bred, afrundet Lap, der èr besat med Børster og naar til Enden af det korte fjerde Leds bagre Rand; det fjerde har en triangulær Form, med Basis nedad; det femte er forlænget ægdannet, saa langt som de trende foregaaende Led tilsammen eller noget længere end disse.

Det sidste Par Springfødder naar længst bagud; Grenene ere brede, lancetformede; den ydre er kortere end den indre; begge have fjærdannede Borster paa den indre Rand $0 g$ i spidsen; den indre Gren har lignende Borster paa den ydre Rand. Halevedhænget er aflangt, dybt kløvet. Fligerne have en Torn i Spidsen. 
Den af Spence Bate og Westwood i Brit. sessile-eyed Crust. II. App. 504 under dette Navn tegnede og afbildede Form er synonym med A. temicornis, Lilljeborg, da Hovedets forreste Ende er skraa afskaret $0 \mathrm{~g}$ de nedre Føleres tvende sidste Led ere lige lange.

Den er fundet ved Grotg og Slotholmen af Danielssen paa sandet Lerbund paa 40-60 Fanne, af G. 0. Sars ved Christiansund ligeledes paa sandet Lerbund og paa $40-50$ Favne, ved Aalesund paa 50-100 Favne og ved Stavanger. Den findes forøvigt efter Bruzelius lige ned til Kullen. Af Norm an er den taget ved Shetland.

Gen. II. HAPLOOPS, Lilljeborg, 1855.

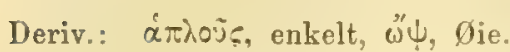

Syn.: 1855. Haploops, Lilljeborg, Öfv. af Kgl. Vet.-Akad. Förhandl. p. 13ら̌

1859. - Bruzelius, Skand. Amphip. Gamm. p. 58.

1862. - Spence Bate, Catal. Amphip. Crust. Brit. Mus. App. p. 371.

1865. - Goës, Crust. amphip. maris Spetsb. p. 12.

1868. - Spence Bate and Westwood, Brit. sessile-eyed Crust. II. App. p. 505 .

1868. - Norman, Ann. and Mag. of Nat. Hist. p. 411.

1870. - A. Boeck, Crust. amphip. bor. et.arct. p. 146.

Type: Haploops tubicola, Lilljeborg, 1855.

Oculi duo (qvatuor?)

Mandibulæ articulo palpi terlio longitudinem arliculi 2di perangusti fere æeqvanti.

Pedes maxillares articulo palpi 3 tio apicem versus dilatato.

Antennæ inferiores articulo pedunculi 1 mo et 2 do extus non visibilibus.

Pedes $7 \mathrm{mi}$ paris articulo 1 mo postice parum dilatato, fere rhomboidali; articulo 3tio et 4 to elongatis, latis; 5 to perangusto, lineari: ungve parvulo, tenui.

Appendix caudalis perbrevis fere usque ad basin fissa.

Lilljeborg opstillede i 1855 denne Slægt paa Arten $H$. tubicola, som han forhen havde antaget at være Ampelisca Eschrichti. Han skilte den væsentlig fra Slægten Ampelisca ved, at den kun shulde have tvende Øine, medens den nævnte Slægt har fire. Goës har imidlertid fundet, at $H$. tubicola fra Grønland, fundet af Torell, ogsaa har fire Øine, hvorved denne Karakter bortfalder.

Jeg har ikke seet de tvende af Goës angivne Øine, men finder desuagtet, at denne Slægt bør adskilles fra Ampelisea ved andre Karakterer, ¿ Særdeleshed ved den eiendommelige. Form af det sidste Fodpar. Foruden de tvende forhen bekjendte Arter tilføiede jeg en tredie i 1870. Hos denne Slægt fandt jeg forst og noiagtig undersøgte den eiendommelige Halsring, eller rettere øsophagusring, som ligger indenfor Læberne og er saaledes den inderste og en constant Del af Tyggeapparatet. 
HAPLOOPS TUBICOLA, Lilljeborg, 1855.

(PI. XXX. fig. 5.)

Haploops tubicola, Lilljeborg, Öfv. af Kgl. Vet.Akad. Förh. 1855. p. 135.

$\begin{array}{lll}- & - & \text { Bruzelius, Skand. Amphip. Gamm. 1859. p. } 88 . \\ \text { - } & \text { - } & \text { Spence Bate, Catal. Amphip. Crust. Brit. Mus. 1862. App. p. } 371 . \\ \text { - } & \text { - } & \text { Goës, Crust. amphip. maris Spetsb. 1865. p. 12. } \\ \text { - } & \text { - } & \text { Spence Bate and Westwood, Brit. sessile-eyed Crust. II. 1868. p. } 505 . \\ \text { - } & \text { Norman, Trans. Tyn. Nat. Field Club. 1863. V. pag. 279. Ann. } \\ & \text { Mag. Nat. Hist. 1868. p. 411. pl. XXXI. fig. 1-3. }\end{array}$

Ampelisca Eschrichti? Lilljeborg, Öfv, af Kgl. Vet.-Akad. Förhandl: 1852. p. 6.

Dorsum non carinatum. Segmentum postabdominis 4tum in medio margine posteriore tuberculo parvulo instruclum. Antenna superiores et inferiores longitudine fere aqvales. Antennæ inferiores articulo pedunculi 4 to paulo breviore qvam 5to. Pedes 5 ti et 6 ti paris articulo 4 to perangusto. Pedes $7 \mathrm{mi}$ paris articulo $1 \mathrm{mo}$ ferme duplo longiore qvam lato, in margine posteriore spinis multis, tenuibus instructo, in angulo inferiore posteriore producto et rotundato; articulo 3tio non duplo longiore qvam lato; articulo 4 to multo breviore qvam 3tio, ovali, in margine anteriore spinis validis armato, in margine inferiore pro articulo 5to perbrevi et tenui inciso. Pedes saltatorii ullimi paris ramis lanceolatis; ramo interiore parum longiore qvam exteriore, in margine spinoso et setoso: ramo exteriore solum setoso. Appendix caudalis ultra medium fissa.

Længden er $12-14^{\mathrm{mm}}$.

Legemet er sammentrykt fra Siderne, temmelig høit; Ryggen er rund, og kun paa det fjerde Haleled sees en liden Fremstaaenhed; det tredie Haleleds nedre, bagre Vinkel er næsten ret. Den forste Sideplade er bredest nedad og er bredere end de tvende følgende; den fjerde er større end de foregaaende, er bredest opad, og den bagre Rand, der nedad danner med den forreste en afrundet Vinkel, er dybt indskaaret for den lille femte Sideplade; deres nedre Rand har fjærdannede Børster. Hovedet er kort, dog længere end de tvende første Legemsled, og danner intet Pandehorn; Øinene sidde ovenfor de øvre Følere paa dets forreste, ovre Kant.

De øvre Følere ere forlængede og naa, naar de boies bagud, til det tredie eller fjerde Haleled. Skaftets forste Led er knapt dobbelt saa langt som bredt; det andet er meget længere og smalere, med Rader af lange Børster paa den undre Rand; det tredie er kortere end det første Led. Svøben dannes af 30 Led, der ere brerlest i den ydre Ende og have, ligesom Skaftet, Børster paa den undre Rand.

De nedre Følere ere næsten af den samme Længde som de ovre. Skaftets 
tredie Led er kort; det fjerde er kortere og bredere end det femte Led, og begge have Borster paa den undre Rand. Swoben dames af 46-50 Led hos Hannen, af 30 hos Hunnen og have den samme Form som de ovre Foleres Led.

Kindbakkerne ere stærke, korte, brede; Gribedelen er bred, med 5-6 Tænder; den indre Bigren har 4-5; Tornerækken dannes af talrige mod Spidsen bredere og der gaffelformede Torne; Tyggeknuden er fremstaaende. Palpen er meget stærkt forlanget $\mathrm{og}$ tynd; det tredie Led er omtrent saa langt som det andet, men tyndere end dette, og begge have lange, spredte, fjærdannede Borster.

Det forste $\mathrm{Kj}$ æbepars ydre Plade er stærk, vabnet med otte dobbelte, meget saugtakkede Torne; den indre Plade er næsten æglannet, med en Børste i Spidsen. Palpen har paa Enden fem Tænder og mellem hver af disse en Torn.

Kjæbeføddernes ydre Plade er smal, naar frem næsten til Enden af Palpens andet Led og har paa den indre Rand stærke, knivdannede Tænder, der mod Pladens Ende blive længere og gaa paa dens ydre Rand over til krumme Borster; den indre Plade er forlanget smal, naar frem langt foran Enden af Palpens forste Led, og har i Spidsen fjærdannede Borster. Palpens tredie Led har en skraa afskaaret, bredere øvre Ende, besat med lange Borster; det fjerde er kloformet, med en kort Grunddel og en langere Spids, besat med fine borster.

Det første Fodpars fjerde Led er forlænget, ikke meget udvidet; det femte er xgdannet, kortere end det foregaaende, med lange Borster paa begge Rande.

Det andet Fodpar er længere og smalere end det første Par.

Det tredie og fjerde Fodpar ere forlangede, smale; det tredie Led er meget langt og bredt, lrengere end de tvende folgende tilsammen; det femte er længere end det fjerde Led.

Det femte Fodpars forste Led er bredt, meget convex paa den bagre Rand; de tvende folgende ere meget korte; det fjerde er forlænget, smalt, lidt udtrukket i den nedre, bagre Vinkel, der har nogle Torne og en lang Borste, og paa den ydre Flade sees 3-4 Rxkker Torne; det femte er smalere og kortere end det foreganende Led, med en Rakke Torne paa den ydre Flade. Kloen er kort, noget krummet.

Det sjette Fodpar er omtrent af deu samme Bygning, men dets forste Led danner bagtil en storre Bue.

Det syvende Fodpars forste Led har en rhomboidalsk Form, med en udtrukket og afrundet ovre, forreste Vinkel, den nedre, bagre Vinkel er ogsaa udtrukket, afrundet $\mathrm{g}$ naar til Enden af det andet Led; den bagre Rand er næsten ret og, ligesom den ydre Flade, besat med lange, tynde Torne; det andet er kort, med nogle Torne paa den ydre Ende; det tredie er længere end det fjerde, hvilket har en meget indadbøiet smalere, ydre Ende, og begge Leds Rande ere forsynede med Torne; det femte Led er meget kort og smalt, neppe tykkere end Roden af Kloen; denne har i Spidsen nogle fine Børster. 
De tvende forste $\mathrm{Par}$ Springfodder naa næsten lige langt bagud; Grenene ere lige lange, væbnede i Randen med Børster og Torne.

Det sidste Par naar længst bagud; Grenene ere næsten lige lange, forlænget lancetdannede; den ydre har paa begge Rande lange fjærdannede Borster; den indre er vabnet med Torne og fjærdannede Borster.

Halevedhænget er kort, langere end bredt ved Roden, kløvet til henimod Midten; Fligerne ere afrundede, med en fin Børste paa Enden.

Farven er hvid, med rode Pletter paa Ryggen; Følernes Skaft og de første Eodpar have vage, rode Streger. Øinene ere røde, Eggene mørkeblaa.

Den af Spence Bate og Westwood tegnede Form er forskjellig fra den her beskrevne derved, at det syvende Fodpars forste Led paa Hovedfiguren ikke er saa forlænget rhomboidalsk, ligesom paa den specielle Figur dette Fodpars tredie og fjerde Led ere næsten lige lange, medens paa Hovedfiguren det fjerle er kortere end det tredie; begge maa dog antages at reprasentere den samme Art.

Denne Art er ikke ualmindelig ved vore Kyster. Danielssen har fundet den ved Christiansund, Molde og ved Vadsø paa sandet Lerbund, paa 40-60 Favnes Dybde; efter Bruzelius gar den ned til Bohuslen og Kullen. Ved Spitsbergen er den fundet af Smitt og Torell, ved Island og Gronland af O. Torell. Den findes ligeledes ved de engelske Kyster. Packard har taget den ved Labrador.

Prof. Lovén (Öfv, af Kgl. Vet-Akad. Förhandl. 1852, p. 42) har beskrevet Bygningen af de Lerrør, hvori den lever.

\section{HAPLOOPS CARINATA, Lilljeborg, 1855.}

(PI. XxX. fig. 6.) Ampelisca Eschvichti?, Mas., Lilljeborg, Öfv. af Kgl. Vet.Akad. Förh. 1852. p. 6. Haploops carinata, Lilljeborg, Öfv. af Ḱgl. Vet.-Akad. Förh. 1855. p. 89.

Bruzelius, Skand. Amphip. Gamm. 1859. p. 89.

- - Spence Bate, Catal. Amphip. Crust. Brit. Mus. 1862. App. p. 372.

Corpus angustius et longius qvam apud specien pracedentem. Segmentum postabdominis 4tum valde carinatum et in medio margine posteriore gibbere alto ot setoso instructum; segmentum 5tum et 6tum parum carinata, utrobiqve tuberculis binis minoribus instructa. Antennx superiores inferioribus breviores. Anteunx inferiores corpore longiores. Pedes $1 \mathrm{mi}$ et 2di paris manibus angustioribus qvam apud speciem præcedentem. Pedes 3 tii et 4 ti paris articulo 3 tio magis dilatato qvam apud speciem precelentem. Pedes $7 \mathrm{mi}$ paris articulo $1 \mathrm{mo}$ in margine posteriore sinuato, in angulo inferiore posteriore producto el rotundato: articulo 3tio duplo longiore qvam lato, angusto; articulo 1 to elongato. ovali, multo bre- 
viore qvam 3tio. Pedes saltatorii ultimi paris fere subulati, ranis angustis, acuminatis, extus et intus setis longis plumosis instructis. Appendix caudalis angustior qvam apud speciem præcedentem, profunde fissa.

L $æ \mathrm{ngden} \mathrm{el} 12-15^{\mathrm{mm}}$.

Legemet er mere forlænget, end hos den foregaaende Art, og ikke saa høit; Ryggen er rund; det tredie Haleleds nedre, bagre Vinkel er næsten ret; det fjerde har en Kjøl og er paa Midten af den bagre Rand forsynet med en høi Fremstaaenhed, der er besat med Børster; de tvende sidste have paa liver Side tvende mindre fremtrædende, langsgarende Kjole, og den bagre Ende er forsynet med Borster. Følerne ere længere og smalere end hos den foregaaende Art.

De øvre Foleres forste Skaftled er kun lidt langere end Halvdelen af det andet, men meget bredere, begge have talrige Borstebundter paa den nedre Rand. Svoben dannes af 50 Led.

De nedre Følere ere meget længere end de øvre og længere end det hele Legeme. Skaftets tredie Led er kortere end det fjerde, og begge have Børster paa den ovre Side, det femte er langere og smalere end det foregaaende Led. Svøben dannes af 80 meget smale Led.

De tvende forste Fodpars Haand er meget forlænget smal, meget kortere end det fjerde Led.

Det tredie og fjerde Fodpars tredie Led er bredere ved den ydre Ende end hos den foregaaende Art.

Det syvende Fodpars første Led er. ikke udvidet paa den bagre, noget indadbøiede Rand; den nedre, bagre Vinkel er afrundet samt udtrukket meget længere end til det andet Leds ydre Ende; det tredie er noget bredere nedad; det fjerde er en Trediedel kortere end det foregaaende Led, forlænget ovalt; det femte er kort og megét smalt.

Det første Par Springfødders Grene ere lange, smale, længere end Grundleddet.

Det andet Par naar ei saa langt bagud som det første; Grenene ere saa lange som Grundleddet.

Det sidste Par er af den samme Længde som det første; Grenene ere længere end Grundledilet, lancetdamet tilspidsede, forsynede med lange fjærdannede Borster.

Halevedhænget er smalere og længere end hos den foregaaende Art, kløvet i den ydre Totrediedel.

Denne Art er af mig fundet i Christianiafjorden; efter Lilljeborg findes den ved Bohuslen; Bruzelius har taget den paa de samme Steder som den foregaaende Art, men meget sjelden; han anforer kun at have seet Hanner. 
HAPLOOPS SETOSA, $\Lambda$. Boeck, $18 \%$.

(P1. XXX. fig. 7.)

Haploops setosa, A. Boeck, Crust. amphip bor. et arct. 1870. p. 148.

Corpus perlongum et angustum. Dorsum rotundatum. Segmentum postabdominis 4tum in medium dorsi gibbere instructum. Dorsum inter segmenta tria posteriora et postabdominis tria anteriora scopis setarum instructum. Antennæ superiores et inferiores longitudine fere æqvales. Antennæ inferiores articulo pedunculi 4to longiore qvam 5to. Pedes 5 ti et 6ti paris articulo 4to postice valde dilatato, in angulo inferiore posteriore producto et spinis armato. Pedes $7 \mathrm{mi}$ paris articulo 1 mo multo latiore qram apnd species duas præcedentes, parum modo longiore qvam lato; articulo 3tio ferme eadem longitudine ac latitudine; articulo 4to parum longiore, in margine utroqve spinoso. Pedes saltatorii ultimi paris ramis setis plumosis instructis; ramo interiore insuper in margine interno dentibus duobus armato. Appendix caudalis parum longior quam ad basin lata, ultra medium fissa.

Længden er $12^{\mathrm{mm}}$.

Le gemet er sammentrykt; Ryggen er rund, uden Kjgl, men en stor Knude sees paa Midten af det fjerde Haleled; fra Mellemrummet mellem det fjerde og femte Legemsled indtil det samme mellem det fjerde og femte Haleled sees en opstaaende Børstebundt; det tredie Haleleds nedre, bagre Vinkel er ret. De tre første Sideplader ere middelmadig lange, men smale, med smaa Børster paa den nedre Rand; den fjerde er kortere end den foregaaende, omtrent saa hoi som bred, med en næsten ret forreste nedre og afrundet bagre, nedre Vinkel; den bagre Rand er dybt indskaaret for den femte Sideplade. Hoverlet er noget længere end de trende forste Legemsled tilsammen.

De øvre Følere naa, naar de bøies bagud, til det første eller andet Haleled. Skaftets forste Led er næsten saa langt som Hovedet, tykt, bredere ved Roden end ved den ydre Ende; det andet er meget længere, men smalere, med Børster paa den undre Rand; det tredie Led er meget kort, bredere ved den ydre Ende end ved Roden. Svoben er længere end Skaftet og dannes af 21 Led, af hvilke hvert er forsynet paa Enden med Bundter af lange Borster.

De nedre Følere ere noget længere end de øvre. Skaftets tredie Led rager frem foran Hovedets Ende; det fjerde er saa langt som de ovre Føleres andet Led; det femte er kortere end det foregaaende Led, og alle have Børster paa den undre Rand. Svøben er længere end Skaftet og dannes af $1 \%$ lange, smale, med Børsteknipper paa den undre Rand besatte Led.

Kindbakkerne ere meget stærke, væbnede i Spidsen med fem Tænder; den indre Bigren har noget færre Tænder; Tornerækken dannes af otte forlængede 'Torne, 
forsynede i Spidsen med en Bitand. Palpens tredie Led er længere og smalere end det andet.

Det første Kjæbepar's ydre Plade naar frem til Midten af Palpens andet Led og har paa Enden fire brede, med Bitænder forsynede Tænder og sex grove Torne af den samme Længde; den indre Plade har paa Enden flere fjærdannede Børster. Palpens andet Led er bredere mod Enden, der er besat med fem stumpe, korte Tænder, og mellem disse fire korte, men stærke Torne, samt med flere lange, grove Børster paa den indre Side.

Kjæbefoddernes ydre Plade, der er oval og naar næsten frem til Enden af Palpens andet Led, har paa den indre Rand elleve Tænder, af hvilke de forste ere tykke og korte, men forlænge sig mod Pladens Ende og gaa der over til lange, noget krumme Torne; den indre Plade har nogle korte Tænder og Borster. Palpens tredie Led er bredere mod den ydre Ende, der er skiaa afskaaren og har lange Børster. Kloen er lang.

Det forste Fodpars femte Led er forlænget ovalt, kortere end det foregaaende Led.

Det andet Fodpars femte Led er meget kortere end det foregaaende Led.

Det tredie og fjerde Fodpar ere næsten lige lange; det tredie Led er neppe tykkere end de foregaaende og temmelig sparsomt besat med lange Børster paa den bagre Rand og med tvende længere fjærdannede Børster paa Enden af den forreste Rand; det fjerde er kun noget længere end bredt; det femte er længere end det foregaaende Led. Kloen er omtrent saa lang som de tvende sidste Led tilsammen.

De trende folgende Fodpar ere af næsten eens Bygning; det forste Led er ovalt, dets forreste Rand er ikke meget udvidet samt besat med nogle fjærdannede Børster, den bagre Rand er stærkt udvidet, og den nedre, bagre Vinkel er udtrukket og besat med Torne; det tredie er kort; det fjerde er kun ubetydelig lingere, men dets nedre, bagre Vinkel er meget forlænget og har smaa Torne; det femte er noget længere end det foregaaende Led, men meget smalere og krummet. Kloen er liden, krum.

Det syvende Fodpars forste Led er meget kortere og bredere end hos de tvende foregaaende Arter, noget forlænget firkantet, med en skraa afskaaret bagre Rand $\mathrm{og}$ en afrundet, lidet udtrukket nedre, bagre Vinkel, forsynet med tykke, fjærdannede Børster; det andet er bredere end langt; det tredie er kun noget længere end bredt; det fjerde er ovalt, længere end det foregaaende Led, besat med Torne paa begge Rande og noget indskaret i den nedre Ende, hvor det korte, smale femte Led er frestet.

De trende forste Par Springfodders Grene have Tome paa Randene.

Det sidste Par. Springfodder naar længst bagud, og Grenene ere meget længere end Grundleddet; den ydre Gren, der er ubetydelig længere end den indre, har fjærdannede Børster $\mathrm{i}$ den nederste Del af begge Rande og $\mathrm{i}$ Spidsen; den indre 
er væbnet med twende Tænder paa den indre Rand og nogle fjærdannede Børster paa den ydre Rand og i Spidsen.

Halevedhænget er kun noget længere end bredt, afrundet paa Enden og spaltet næsten til Roden; Fligerne have en Torn i Spidsen.

Denne Art er fundet i eet Exemplar af Danielssen ved Christiansund paa 40-60 Favne, og sammesteds af G. O. Sars paa 50-100 Favne, og af mig ved Karmøen i eet Exemplar.

Gen. III. BYBLIS, A. Boeck, 1870.

Deriv.: Bußjis en Datter af Eidothea.

Syn.: Byblis, A. Boeck, Crust. amphip. bor. et arct. 1870. p. 148.

Oculi qvatuor.

Mandibulæ articulo palpo 3 tio multo breviore qvam articulo 2 do angusto.

Pedes maxillares articulo palpo 3 tio vix dilatato.

Epimera minora qvam apud genera prxcedentia.

Antenne inferiores articulo pedunculi 1 mo el 2 do extus visibilibus, in incisura capitis sitis.

Pedes $7 \mathrm{mi}$ paris articulo $1 \mathrm{mo}$ deorsum et postice perdilatato; articulo 3tio brevi; articulo 4 to et 5 to elongatis.

Pedes saltatorii ultimi paris perbreves.

Appendix caudalis brevis, lata, parum fissa.

Ampetisca Gaimaidi har af flere Forskere været anerkjendt at have en fra de ovrige Arter af Slægten Ampetisca eiendommelig Form og at skille sig fra disse væsentlig ved Dannelsen af Kindbakkernes Palpe. Desuden er der en Uoverensstemmelse ogsaa $\mathrm{i}$ det Ydre mellem denne og de ovrige, idet Sidepladerne ere mindre og de nedre Føleres tvende forste Led ikke ere skjulte som hos Arterne af Slægterne Ampelisca og Haploops, men vise sig udenfor den første sideplades Rand. Ogsaa ved Udseendet af det syvende Fodpar og af Halevedhænget fjerner den sig fra de øvrige Arter. Jeg opstillede derfor i 1870 denne Art under en ny Slægt, Byblis.

\section{BYBLIS GAIMARDI, Kroyer, 1840?}

Ampelisca Gaimardi, Króger, Voy. en Scand pl. 23. fig. 1.

$$
\begin{aligned}
& \text { - - M. Sars, Forh. i Vid.-Selsk. i Christiania 1858. p. } 130 . \\
& \text { - - Bruzelius, Skand. Amphip. Gamm. 1859. p. } 86 . \\
& \text { - - Packard, Nem. of the Boston Soc. of Nat. Hist. 1867. p. } 229 . \\
& \text { pl. VIII. fig. 1, } 1 \text { a. }
\end{aligned}
$$

Byblis Gaimardi, A. Boeck, Crust. amphip. bor. et arct. 1870. p. 148. 
Dorsum rotundatum sed in posteriore parte segmenti postabdominis 5ti paulum carinatum. Segmentum postabdominis 3tium in angulo inferiore posteriore valde rotundatum. Caput parum productum, in margine anteriore truncatum. Antennæ superiores pedunculn inferiorum parum longiores. Antennæ inferiores articulo pedunculi 4 to multo longiore qram 5to. Pedes $1 \mathrm{mi}$ et 2 di paris manu multo breviore qvam carpo. Pedes 3 tii et 4 ti paris ungve tam longo ant paulo breviore qvam articulo 5to. Pedes 5ti et 6ti paris articulo 1 mo altiore qvam lato: articulo 4to fere duplo longiore qvam 3tio. Pedes $7 \mathrm{mi}$ paris articulo $1 \mathrm{mo}$ ad medium marginem posteriorem articuli 4 ti deorsum et postice producto: articulo 5to lanceolato, paulo breviore qvam 4to. Pedes saltatorii ultimi paris ramis invicem fere eadem longitudine, in margine interiore spinis armatis. Appendix caudalis parum longior qvam lata, in margine posteriore Iruncata, parum fissa.

Lring en er omtrent $15^{\mathrm{mm}}$.

Le gemet er meget forlænget, sammentrykt, Ryggen er dog bred og rund paa Legemets forreste Del, paa den bagre sees en Kjøl; den nedre, bagre Vinkel paa det tredie Haleled er afrundet; det femte danner en liden spids pukkelformet Forhøining paa Ryggens Midtlinie. Sidepladerne ere ikke meget høie, men temmelig brede, idet de tre forste ere neppe dobbelt saa høie som brede; den første er bredere nedad, den fjerde er meget bred, med en oval, opadbøiet nedre Rand og i den bagre Rand dybt indskaaret for den femte Sideplade. Hovedet er noget længere end de tvende forste Legemsled tilsammen, fortil tvært afskaaret og temmelig bredt; dets nedre Rand er meget halvmaaneformet udskaaret for at optage Grundleddet for de nedre Folere, hvilket ikke er dækket af den forste Sideplade. Øinene ere store.

De ovre Følere ere kortere end de nedre, men liengere end Skaftet paa. disse. Skaftets forste Led er meget kort, kun lidt længere end bredt; det andet er 3-4 Gange længere, men meget tyndere; det tredie er meget kort. Svoben dannes hos Hannen af 30 Led, hos Hunnen af 18-20.

De nedre Føleres tvende forste Skaftled ere ikke bedækkede af den forste Sideplade; det tredie naar længere frem end til Hovedets Ende; det fjerde er meget længere og tykkere end det andet Led paa de ovre Foleres Skaft; det femte er en Trediedel kortere end det foregaaende Led. Svoben er lang og dannes hos Hannen af 50 Led, hos Hunnen af 40.

Overlæben er meget bred, kun lidt indbøiet i den ovre Rand, som er forsynet med Børster.

Kindbakkerne ere meget stærke; Spidsen er indskaaret i talrige Tænder, og den indre Bigren er ligeledes indskaret i lignende Tænder, men i et mindre Antal; Tornerskken dannes af tolv krumme Torne, der paa den undre Rand ere forsynede 
med mange smaa Bitorne og ere kløvede i Spidsen; Tyggeknuden er meget stærk og fremstaaende. Palpen er smal, forlanget; det tredie Led er meget kortere end det andet. Underlæbens ydre Plade er afrundet, og den indre er meget bred.

Det første $\mathrm{Kj}$ æbepars ydre Plade er paa Enden væbnet med fem simple Torne $\mathrm{i}$ en dobbelt Række; den indre Plade er forlænget, smalere mod Enden, hvor der sees en fjærdannet Børste. Palpens andet Led er i den brede Ende indskaaret i fire Tænder, med en smal Torn i hvert Indsnit, samt med flere paa den indre Rand.

Det andet $\mathrm{Kj}$ æbepars ydre Plade er længere og bredere end den indre, med talrige, krumme Borster i en dobbelt Række paa dens Ende.

Kjabef $ø$ ddernes ydre Plade naar længere frem end til Enden af Palpens andet Led og er paa den indre Rand vabnet med 10-12 knivdamede Tænder, der blive længere mod Pladens afrundede Ende, hvor de gaa over til krumme Torne og Børster; den indre Plade er lang og meget smal, paa Enden besat med en Tand og flere krumme Børster, foruden med nogle fjardannede Børster paa den indre Rand. Palpens andet Led er meget langt; det tredie er meget kort, kun lidt bredere mod den ydre Ende. Kloen er lang, spids.

Det forste Fodpars fjerde Led er forlænget, med en ret forreste og en convex bagre Rand, der er forsynet med talrige Børsteknipper; det femte Led er meget kortere end det foregaaende, ovalt, med mange Borsteknipper paa begge Rande.

Det andet Fodpar har den samme Bygning som det forste, men er længere og smalere, især dets fjerde og femte Led.

Det tredie og fjerde Fodpar ere lige, men det tredie Pars tredie Led er kortere end paa det fjerde Par. Kloen er omtrent saa lang som det femte Led.

De tvende følgende Fodpars tredie Led er kort; det fjerde er meget længere, end de tvende foregaaende tilsammen og har mange Tvarrader af smaa Torne; det femte er meget kortere end det foregaaende Led.

Det syvende Fodpars første Leds nedre, bagre Vinkel er forlænget næsten til Midten af det fjerde Led og har her talrige fjærdannede Børster; det tredie er kort, kun lidt længere end Halvdelen af det fjerde Led; det femte er forlænget ovalt, kortere end det foregaaende Led og forsynet med stærke Torne paa den bagre Rand.

Springfødderne ere korte, og alle naa næsten lige langt bagud.

Det sidste Pars Grene ere brede ved Roden; den ydre har Tænder paa den indre Rand $0 \mathrm{~g}$ Torne paa den ydre; den indre Gren er fint tandet langs den ydre Rand og har Torne paa den indre.

Halevedh nget er meget kort, bredt, kløvet i den ydre Del.

Farven er hvid, med et svagt rodligt Anstrog og med en sort Ring om Øinene.

Den er efter Danielssen temmelig almindelig ved Molde, sjeldnere ved Christiansund paa sandet Lerbund, paa 30-60 Favne, og er af ham taget paa lignende Lokaliteter ved Tromsø paa 40-80 Favne; af M. Sars er den fundet ved Vadso; af mig ved Stegen paa 20 Favnes Dybde. Efter Bruzelius er den almindelig ved Bohuslen i 
Gullmarsfjorden paa Lerbund paa 40-60 Favne. Den er ligeledes fundet ved Spitsbergen, og ved Gronland og Island af Torell. Efter Packard findes den ved Labrador, efter Heller i Adriaterhavet, og er ifolge Costa ikke sjelden ved Neapel.

\section{Familia VI.}

PHO'TIDE.

Labium superius latum, in apice rotundatum.

Mandibulæ validie, in apice dentatæ; ramo accessorio eliam dentato; tuberculo molari prominenti; palpo 3articulato.

Maxilla $1 \mathrm{mi}$ paris lamina interiore plerumqve parva aut magnitudine mediocri.

Haxillæ 2di paris laminis latis.

Pedes maxillares in margine interiore plerumqve dentibus paucis, sed validis, apicem versus longioribus et curvatis, interdum spinis tenuis instructe; articulo palpi ultimo raro non ungviforme.

Corpus plus minusve compressum, dorso rotundato.

Antennæ superiores flagello accessorio parvo præditæ aut eodem destitutæ.

Pedes $1 \mathrm{mi}$ paris manu subcheliformi instructi.

Pedes 2di paris manu subcheliformi, raro vix subcheliformi.

Pedes trium parium ultimorum plerumqve longitudinem gradatim valde crescentes.

Pedes saltatorii ultimi paris 2ramosi, raro 1ramosi.

Appendix candalis crassa.

Til denne Familie har jeg henført Underfamilierne Leptocheirince, Photince og Microdectopince.

Subfamilia I.

LEPTOCHEIRINA, A. Boeck, 1870.

Syn.: 1870. Leptocheirince, A. Boeck, Crust. amphip. bor. et arct. p. 149.

Labium superius latum, in apice rotundatum.

Mandibulæ validx, in apice dentata; ramo accessorio item dentato; tuberculo molari magno, prominenti: palpo tenui, 3articulato; articulo palpi 1 mo elongato.

Maxilla $1 \mathrm{mi}$ paris lamina interiore magnitudine mediocri.

Maxillie 2di paris laminis latis; lamina exteriore multo latiore et longiore qvam interiore. 
Pedes maxillares lamina exteriore spinis tenuibus, non dentibus, instructa.

Corpus plus minusve compressum; dorso rotundato.

Epimera magnitudine mediocri aut magna, in margine inferiore setis instructa: epimerum 5tum magnum sed non tam altum qvam 4tum.

Antennæ superiores flagello elongato; flagello accessorio parvo.

Antennæ inferiores superioribus breviores; flagello non multiarticulato.

Pedes 1 mi paris manu subcheliformi instructi.

Pedes 2di paris setis permultis et longis, in margine interiore maxime, instructi; manu parva, partim subcheliformi, partim vix subcheliformi.

Pedes trium parium ultimorum longitudine gradatim valde crescentes; pedes 5 ti paris retroversi.

Pedes saltatorii biramei.

Appendix caudalis crassa.

Denne Underfamilie indbefatter kun tvende Slægter, som ved Formen af Sidepladerne, der paa den nedre Rand have talrige Børster, $0 \mathrm{~g}$ ved at de tvende forste Fodpar ligeledes ere forsynede, i Sxrdeleshed paa det første Led, ined en hel Rxkke overmaade lange fjærdannede Børster, have et ved det første Blik ganske egent Udseende. Ogsaa red enkelte Eiendommeligheder med Hensyn til Munddelene adskiller den sig fra dé fọlgende herhen hørende Underfamilier.

Gen. I. LEPTOCHEIRUS, Zaddach, 1844.

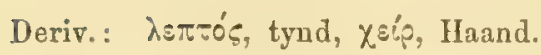

Syn.: 1844. Leptocheirus, Zaddach, Synops. Crust. Pruss. p. \%.

1852. - Dana, U. S. explor. exped. p. 910.

1854. Ptilocheirus, Stimpson, Synops. Mar. Invert. Grand Manan. p. 55.

1862. Protomedeia, Spence Bate, Catal. Amphip. Crust. Brit. Mus. p. 167.

1863. - - Spence Bate and Westwood, Brit. sessile-eyed Crust. p. 297.

1870. Leptocheirus, A. Boeck, Crust. amphip. bor. et arct. p. 150.

Type: Leptocheirus pilosus, Zaddach.

Corpus compressum sed tamen crassum; dorso rotundato; epimeris sat magnis; epimero 2do maximo, 410 angustiore qvam 3tio.

Pedes 1 mi paris manu parva, subcheliformi.

Pedes 2di paris sat elongati, graciles, in margine anteriore setis perlongis, plumosis instructi; articulo tho sat elongato: articulo 5 to parvo. manum subcheliformem non formanti. 
Pedes $7 \mathrm{mi}$ paris iisdem 6ti paris multo longiores.

Pedes saltatorii ultimi paris ramis brevissimis.

Zaddach opstillede denne Slagt i 1844 paa Arten L. pilosus fra Ostersoen og gav en udforlig Beskrivelse af den. Müller viste i 1848 (Arch. f. Naturgesch. XIV. p. 62), at Zaddach havde overseet, at Kindbakkerne ere forsynede med en Palpe, ligesom han ikke havde bemærket, at de ovre Følere have en Bisvobe. Stimpson fandt i 1854 ved Grand Manan en Amphipode, paa hvilken han opstillede en ny Slægt Ptilocheirus, hvilken han troede mantte henføres til Zaddachs Slægt, men han ansaa sig berettiget til at give den dette nye Slagtsnavn, da Leptocheirus allerede forhen var benyttet til et Insekt. Spence Bate mener, at disse Navne bør anføres som Synonymer til Krøyers Slagt Protomedeia, og $\mathrm{i}$ de senere Arbeider har man fulgt denne Anskuelse, hvilken dog er urigtig. Allerede tidligere havde jeg Tvivl om, at hans Nening var rigtig, og efter at jeg i Kjobenhavn i 1866 havde undersogt Kroyers typiske Art Protomedeia fasciata, fandt jeg, at denne er den samme som Gammaropsis macromyx, Lilljeborg, og saaledes en fra Leptocheirus meget forskjellig Slægt og Art.

\section{LEPTOCHEIRUS PILOSUS, Zaddach, 1844.}

Leptocheirus pilosus, Zaddach, Synops. Crust. Pruss. Prodr. 1844. p. S.

- - A. Boeck, Crust. amphip. bor. et arct. 1870. p. 150.

Protomedeia pilosa, Spence Bate, Catal. Amphip. Crust. Brit. Mus. 1862. p. 168.

Oculi parvi, ovales. Segmentum postabdominis 3tium angulo inferiore posteriore perrolundato. Epimerum $1 \mathrm{mum}$ ab epimero 2do fere tectum. Antennæ superiores articulo pedunculi 1 mo longitudinem capitis non aqvanti; articulo 2do fere eadem longitudine sed angustiore qvam Imo. Antenne inferiores articulo pedunculi 4 to et 5to longitudine fere æqvalibus. Pedes $1 \mathrm{mi}$ paris manu longiore qvam dimidio carpo, in acie obliqve truncata, in margine anteriore et posteriore setis longis instructa; articulo 2do, 3tio et carpo in margine posteriore setis longis plumosis instructis. Pedes 2 di paris articulo 1 mo in margine anteriore arcuato; setis ejusdem longitudinem articulorum seqventium junctorum circiter aeqvantibus; manu ovata; carpo ter longiore qvam lato. Pedes 5 li paris articulo 3tio breviore quam 4 to.

L $æ n g d e n$ er $8^{\text {m }}$ fra Pandehornet til Halevedhænget.

Legemet er hoit, dog tillige tykt; Ryggen er land og bred; det tredie Haleleds nedre, bagre Vinkel er meget afrundet. Den forste Sideplade er næsten bedækket af den store anden, som udvider sig meget nedad og har Borster par den nedre Rand, ligesom le tvende folgende; den tredie Sideplade er meget smalere end den anden og lige saa bred paa den ørre som paa den nedre Rand; den fjerde er smalere, og den 
femte er kun lidet kortere, mere udvidet i den ovre Del af den bagre Rand; de tvende følgende Sideplader ere smaa. Hovedet danner intet Pandehorn mellem de øvre Følere; dets Sidevinkler ere meget afrundede, og lige bag disse have de skraa ovale Øine sin Plads.

De ørre Følere ere korte og naa, naar de boies bagud, til det sjette Legemsled. Skaftets forste Led er kortere end Hovedet; det andet er af samme Længde, men meget smalere; let tredie er ikke ganske halvt saa langt som det foregaaende Led. Svøben er noget længere end Skaftet $0 \mathrm{~g}$ dannes af 17 Led. Bisvøben er smal og har 6 Led.

De nedre Følere ere kortere end de øvre. Skaftets tredie Led er længere end bredt; det fjerde er lidt læengere og tykkere end det andet Skaftled paa de wrre Folere; det femte er noget langere, men smalere end det foregaaende Led. Svøben dannes af 9 Jed $0 \mathrm{~g}$ er længere end Skaftets sidste Led.

Overlæben er bred, i Spidsen afrundet, svagt indskaaret og her forsynet merl Børster.

Kin dbakkerne ere meget stærke, brede, med Tænder i Spidsen; den indre Bigren er ogsaa stark og vabnet med Tænder; Tornerækken dannes af 16 krumme, tildels saugtakkede Torne; Tyggeknuden er meget stor. Palpen er smal; dets første Led er forlænget, noget kortere end det andet, der er omtrent af den samme Længde som det tredie Led.

Underla bens Flige ere brede.

Det forste Kjob epars ydre Plade har paa Enden ikke meget stærke, paa den indre Rand svagt saugtakkede Tænder; den indre Plade er ikke meget stor. Palpens andet Led er smalt og paa begge Randes Ende besat med forlængede Torne.

Det andet Kjabepars Plader ere meget brede, med talrige Borster paa den indre Rand.

Kjabefodderne ere forlængede, smale; den ydre Plade er meget smal, naar ikke frem til Enden af Palpens andet Led, og den indre Rand ex væbnet med forlængede Torne; den indre Plade er meget bred, smalere mod Spidsen og med talrige Børster paa begge Rande. Palpen er forlanget smal; det forste Led er meget kort; det andet er særdeles forlænget; det tredie er omtrent halvt saa langt som det andet; det fjerde er ikke klodannet, men lidet, smalt, med tvende lange Torne par Enden.

Det forste Fodpar er meget stærkt, det forste Led er bredere mod den ydre Ende og har tretstaaende, lange Borster paa den forreste Rand; det andet er bagtil noget udvidet 0 , ligesom de tvende følgende, forsynet med lange Borster paa den bagre Rand; det fjerde er forlænget smalt, ikke dobbelt saa langt som det femte Led, der er bredere udad og har lange Børsteknipper paa begge Rande; Griberanden er kort. Kloen er liden.

Det andet Fodpar er forlinget og kraftig bygget; det første Led er meget bredt paa den forreste Rand og her besat med i en tæt Række staaende Børster, der ere 
saa lange som de øvrige Led tilsammen; det fjerde Led er 3-4 Gange saa langt som bredt og henved tre Gange saa langt som det femte Led, der er smalere mod Enden og har lange Børster paa begge Rande.

Det tredie og fjerde Fod pars tredie Led er meget udvidet mod den ydre Ende og neppe længere end det fjerde; dette er meget kortere og bredere end det femte Led. Kloen er tynd, kun lidet boiet.

Det femte Fodpar er rettet mere bagud end nedad; det tredie Led er kortere end det fjerde.

Det sjette og syvende Fodpar tiltage efter hinanden meget i Længde.

Det sidste Par Springfodders Grene ere lige lange, meget korte og brede.

Denne Art er af mig fundet i Christianiafjorden og er ligeledes taget ved Bohuslen.

Gen. II. GOËSIA, A. Boeck, $18 \%$.

Deriv.: Opkaldt til Ære for Goës, Forf. af "Crust. amphip. maris Spetsbergiam alluentis" etc. Syn.: 1870. Goësia, A. Boeck, Crust. amphip. bor. et arct. p. 151.

Corpus subdepressum; epimeris non altis; epimero 2 do minore qvam apud genus Leptocheirus.

Antenna superiores llagello accessorio fere obsoleto.

Pedes 2di paris iisdem $1 \mathrm{mi}$ paris validiores, sed non multo longiores, in margine anteriore setis longis plumosis instructi; manu magna, subcheliformi; carpo non prælongato.

Creteroqvin ferme ut apud genus Leptocheirus.

Goës beskrev i 1865 en Art Autonoë depressa fra Spitsbergen. Denne Form afviger dog meget fra dẹ øvrige Autonoëarter og staar Slægten Leptocheirus meget nær; den skiller sig fra denne i Særdeleshed ved de tvende forste Fodpars Form, ved at Sidepladerne ikke ere saa hoie, samt ved at Legemet er mere nedtrykt end hos hin Slægt. Denne Art maatte saaledes blive Typus for en ny Slægt, som jeg til Ere for den nevnte Forfatter kaldte Goësia.

\section{GOËSIA DEPRESSA, Goës, $1865 \dagger$.}

Autonö̈ depressa, Goës, Crust. amphip. maris Spetsb. 1865. p. 16. fig. 35.

Goësia depressa, A. Boeck, Crust. amphip. bor, et arct. 18ro. p. 151.

Oculi parvi, ovales. Segmentum postahdominis 3tium angulo inferiore posteriore acuto. Antennæ superiores articulo pedunculi 2 do longiore qvam articulo Imo. Pedes Imi paris in margine posteriore setis longis instructi: manu longitudinem carpi fere aqvanti. subcurvala. in acie truncata: ungve in margine posteriore 
pectinato, longiore quam acie parva manus. Pedes 2di paris iisdem Imi paris non multo majores; manu et carpo longitudine ferme rqvalibus; manu apicen versus angustiore, in extrema acie spina longa acuta armata; articulo 1 mo et 5 to in margine anteriore et partim posteriore setis multis, longis et plumosis instructis. Pedes trium parium ultimorum longitudine gradatim valde crescentes. Pedes saltatorii ullimi paris ramis parvis, ovalibus, longitudine invicem reqvalibus. Appendix caudalis duplo latior qvam longa. in apice parum sinuata.

L $₫ \mathrm{ngden}$ er $12 \mathrm{~mm}$.

Le g emet er forlænget, bredt, temmelig nedtrykt; det tredie Haleleds nedre, bagre Vinkel er udtrukket $\mathrm{og}$ tilspidset. De fire forste Sideplader ere løiere end de brede, paa den frie, nedre Rand besatte med Børster; den første, livis forreste, nedre Rand er noget forlænget, dxkkes kun ubetydelig af den anden; den fjerde er omtrent af den samme Storrelse som de tvende foregaaende. Hovedet er omtrent saa langt som de tvende forste Legemsled tilsammen, fortil ret afskaaret; den nedre Rand har en Indskjæring, hvorved de nedre Føleres forste Led viser sig; dets Sidevinkler ere noget tilspidsede.

De øvre Følere er forlængede, noget kortere end Legemet. Skaftets første Led er saa langt som Hovedet; det andet er noget længere og tyndere; det tredie Led er kort. Svøben er længere end Skaftet og dannes af 20-25 Led, besatte med Børster. Bisvoben er rudimenter.

De nedre Følere ere meget kortere end de øvre. Skaftets tredie Led er omtrent saa langt som bredt; det fjerde og femte ere lige lange. Svøben er længere end Skaftets tvende sidste Led og dannes af 10-15 med Børster besatte Led.

Kindbakkerne ere stærke. Palpens andet Led er saa langt som det tredie, der paa den ovre Rand og i Spidsen er besat med Børster, af hvilke de paa det sidste Sted ere fjærdannede.

Det andet $\mathbf{K j} æ b e p a r s$ ydre Plade er bredere og længere end den indre og har paa Enden mange fjardannede Børster.

Kjæbeføddernes ydre Plade er lang, men naar ikke frem til Enden af Palpens andet Led, og har lange, tynde Torne paa den indre Rand; den indre Plade naar meget længere frem end til Enden af Palpens første Led.og har Børster paa begge Rande. Palpens andet Led er særdeles langt; det tredie er omtrent halvt saa langt; det fjerde Led synes at mangle.

Det forste Fodpar er smalt; de fire sidste Led have paa den bagre Rand trtte-Rækker af lange Borster; det fjerde Led er ikke udvidet, kortere og lidt smalere end det femte; dette er mere end dobbelt saa langt som bredt, lidt krummet, med en ret afsharet Griberand; ogsaa paa den ydre Side sees Børstebundter. Kloen er kort, med en Rad Torne paa den bagre Rand. 
Det andet Fodpar er noget længere og stærkere end det forste; det forste Led er meget langt, med en cunvex forreste Rand, der er forsynet med særdeles lange, fjœrdannede Børster; det andet og tredie Led ere korte, og det sidste af disse har paa den ydre, skraa afskaarne Rand meget lange, fjærdannede Børster; det fjerde er bredere udad; det femte er omtrent af den samme Lingde som det foregaaende Led samt smalere mod den ydre Ende, dets Griberand er skraa afskaaret, med en stærk Torn i en Indsynkning i dens bagre Del. Den bagre Rand paa disse tvende sidste Led er besat med lange Børster, og det sidste Leds forreste Rand har mange fjardannede Børster.

Det tredie og fjerde Fodpar ere forlængede. Kloen er kortere end det femte Led.

De tre folgende Fodpar tiltage efter hverandre meget i Længde; det forste Led er forlænget ægdannet; det fjerde tiltager i Forhold til det foregaaende betydelig i Længde, saa at det paa det sy vende Fodpar er næsten saa langt som det tredie Led.

Springfodderne ere korte.

Det sidste Pars Grundled er meget kort og bredt; Grenene ere omtrent lige lange, eliptiske, forsynede med lange Børster.

Halevedhænget er dobbelt saa bredt ved Roden som langt, svagt indbugtet paa Enden og har tvende tynde Borster paa hver Side.

Den er fundet i 1864 af Malmgren i Storfjord ved Spitsbergen paa 5 Favnes Dybde.

\section{Subfamilia II.}

PHOTINAE.

Syn.: 18\%0. Photince, A. Boeck, Crust. amphip. bor. et arct. p. 151.

Labium superius latum, breve, in apice rotundatum.

Mandibulæ validx, in apice dentatx; ramo accessorio item dentalo; tuberculo molari in margine inferiore serie dentum instructo et in fine seriei setam longam plumosam gerenti; serie spinarum ex spinis paucis (4), in margine convexo serratis, composita: palpo elongato. 3articulito; articulo palpi 3tio breviore qvam 2 do.

Labium inferius latum; lamina interna magna.

Maxillæ $1 \mathrm{mi}$ paris lamina interiore parva; palpo in apice spinis paucis sed validis armata.

Maxillæ 2di paris latæ.

Pedes maxillares laminis validis: lamina interiore dentibus tribus armata: lamina exteriore in margine interiore dentibus paucis sed validis, apicem versus longioribus et angustioribus, in setas curvatas desinentibus, armata; palpo valido, longo; articulo palpi ultimo non ungviformi sed in apice spinis validis armato. 
Corpus altum, compressum; dorso rotundato; capite producto; oculis parvis, ovalibus.

Epimera qvatuor anteriora magna, in margine inferiore plumosa; epimerum 5 tum 4 to majus, in margine posteriore pro pedibus 5 ti paris retroversis incisum.

Antennæ superiores in apice capitis sitæ; flagello accessorio parvo præditæ aut codem destitutæ.

Pedes 1 mi et 2di paris manu subcheliformi; pedes 2di paris iisdem $1 \mathrm{mi}$ paris robustiores.

Pedes 3tii et 4 ti paris breves et validi.

Pedes $6 \mathrm{ti}$ paris iisdem 5 ti paris longiores.

Pedes $7 \mathrm{mi}$ paris breviores qvam 6ti paris; articnlo 1 mo perdilatato.

Pedes saltatorii $1 \mathrm{mi}$ et 2 di paris biramei; ramis dentalis.

Pedes saltatorii ultimi paris 1- aut 2-ramosi; ramo interiore breviore qvam exteriore.

Appendix caudalis brevis, crassa, interdum in apice incisa.

Underfamilien Photince slutter sig i flere Henseender til den foreganende, hvorfra den kun skiller sig noget i Munddelenes, væsentlig i Kjæbeføddernes Bygning. Men hos denne er den femte Sideplade, som allerede hos den foregaaende Underfamilie var temmelig stor, end mere udviklet, saa at den er større end den fjerde, og er indskaaret i den bagre Rand for det femte Fodpar. Dette vender ikke, som sædvanligt er 'Tilfældet, nedad, men bagud og er af en meget kort, stærk Bygning samt tjener isæer til at skyde Dyret ud af det Rør, hvori det bor, af hvilken Grund det har den nærnte eiendommelige Stilling. Den femte Sideplade har den nærnte betydelige Storrelse, da der paa den fastes de stærke Muskler, der skulle bevæge dette Fodpar. Den samme Bygning ville vi ogsaa gjenfinde hos Slægten Amphithoë.

Gen. I. PHO'TIS, Kroyer, 1842.

Deriv.: Photis, Navnet par en Tjenestepige hos Apuleius i det gyldne Esel.

Syn.: 1842. Photis, Krøyer, Nat. Tidsskr. 1. R. 4. B. p. 1 5̌

1852. - Dana, U. S. explor. exped. p. 911.

1863. Eiscladus, Spence Bate and Westwood, Brit. sessile-eyed Crust. p. 411.

1870. Plotis, A. Boeck, Crust. amphip. bor. et arct. p. 152.

Type: Photis Reinhardi, Kroyer.

Antennæ superiores articulo pedunculi 3tio elongato: flagello accessorio absenti.

Pedes 1 mi paris carpo brevi.

Pedes 3tii et 4 ti paris articulo 1 mo non crasso. 
Pedes saltatorii ultimi paris ramo interiore minimo.

Appendix caudalis in apice rotundato.

Krøyer opstillede denne Slægt i 1842, og deu blev optaget af Dana, som stillede den nær Slægterne Gammarus og Melita; han skilte den væsentlig fra disse ved den femte Sideplades Størrelse og ved at det sidste Par Springfødders indre Gren er meget liden. Den kan dog ikke staa nær disse Slægter, da det tykke Halevedhæng henviser den til en ganske auden Afdeling af Amphipoderne. Lilljeborg og Bruzelius henforte en Art, som de havile fundet i Øresund, til Slægten Amphithoë under Navnet A. mymaea, uden at de vidste, at denne var den samme som Krøyers typiske Art Photis Reinhardi. Spence Bate synes ogsaa at have overseet denne Slagt, der ikke er optaget i hans Catal. Amphip. Brit. Mus. 1862.

\section{PHOTIS REINHARDI, Kroyer, 1842}

(Pl. XXVI. fig. 1.)

Phot is Reinhardi, Kroyer, Nat. Tidsskr. 1842. 1. R. IV. B. p. 155.

- -. A. Boeck, Crust. amphip. bor. et arct. 1870. p. 153.

Amp hithoë pygmcea, Lilljeborg, Öfv. af Kgl. Vet.-Akad. Förh. 1852. p. 9.

- $\quad$ - Bruzelius, Skand. Amphip. Gamm. 1859. p. 32.

- Reinhardi, Goës, Crust. amplip. maris Spetsb. 1868. p. 16.

Eiscladus longicaudatus, Spence Bate and Westwood, Brit. sessile-eyed Crust. 1863. p. 412 .

Angulus capitis lateralis anticus parum productus, rotundatus. Antennæ inferiores articulo pedunculi :3tio duplo longiore quam crasso. Pedes 1 mi paris robusti: carpo ferme eadem longiludine ac latiludine, in margine interiore truncato et setoso; manu majore qvam carpo, fere triangulari, postice valde rotundata. Pedes 2 di paris carpo brevissimo; angulo carpi inferiore posteriore producto et in apice rotundato et setoso; manu fere qvadrangulari. in acie apud marem profunde, apud feminam parum sinnata, in angulo inferiore maris acuta, femine rotundata. Pedes 3 tii et 4 ti paris articulo 4 to duas tertias partes longitudinis articuli 5 ti requanti. Pedes saltatorii 1 mi et 2 di paris ramis in margine superiore dentatis; pedes saltatorii ultimi paris ramo exteriore paulo breviore qvam pedunculo, in apice setis nonnullis instructo.

Længden er omtrent $6^{\mathrm{mm}}$.

L e gemets gvre Side er rund og bred; det tredie Haleleds nedre, bagre Vinkel er afrundet. De fem første Sideplader ere temmelig høie, tiltage efter hverandre i Størrelse og have Børster paa den nedre afrundede Rand; den femte er bred paa det 
øvre Parti og er paa dettes bagre Rand indskaaret for Befastelsen af det femte Fodpar. Hovedet er næsten saa langt som de tvende forste Legemsled tilsammen; dets forreste Rand danner intet Pandehorn; dets Sidevinkler ere ikke meget udtrukne, noget afrundede. Øinene ere smaa, runde.

De ovre Følere naa, naar de bøies bagud, ikke ganske til det forste Haleled. Skaftets forste Lerl er tykt, meget kortere end Hovedet; det andet er en Trediedel langere, men meget smalere; det tredie er lidt kortere samt smalere end det foregaaende Led, og begge ere forsynede med flere lange Børsteknipper paa den undre Rand. Svsben, der er omtrent saa lang som Skaftets tvende sidste Led, dannes af 8 forlængede Led, der efter hverandre ere smalere og længere, og hvert af Leddene har et Børsteknippe paa den undre Rand.

De nedre Følere ere længere end de øvre og paa den samme Maade besatte med lange Borsteknipper. Skaftets tredie Led er omtrent dobbelt saa langt som bredt og træder med sin ydre Halvdel frem foran Hovedets Sidevinkler; det fjerde er mere end dobbelt saa langt og naar.ikke frem til Enden af de øvre Foleres andet Skaftled; det femte er næsten af den samme Længde, men er noget smalere og naar frem til Enden af de ovre Foleres tredie Skaftled. Svoben, der er saa lang som de ovre Foleres Svobe, men smalere end denne, dannes af 7 Led.

Det første Fodpar er stærkt og kort; det forste. Leds nedre, forreste Vinkel er forlænget; det fjerde Led er næsten saa langt som bredt, den bagre Rand er kort $\mathrm{og}$ kun lidet udvidet, forsynet med mange Børster; Haanden er større end det foregaaende Led, af en triangulær, afrundet Form; dens forreste Rand er hos Hannen mindre convex end den bagre; Griberanden er skraa afskaret, med Indskjæringer og forsynet med Borster. Hos Hunnen er Haanden mere agformig tilspidset mod den ydre Ende.

Let andet Fodpar er kraftigere bygget; det fjerde Led er kortere, end hos det foregaaende Par, og dets nedre, bagre Vinkel er forlænget til en med talrige Børster besat afrundet Fremragning; Haanden er stor, af en næsten firkantet Form, bredere mod den ydre Ende, hvor den bagre Rand el halvmaaneformet indskaaret, samt ender med en tilspidset Fremstaaenhed, hvor Kloens Spids lægger sig imod; Griberanden er hos Hamen svagt skraa afskaret, med dybere Indskjæringer; den bagre concave Rand og den ylre Side ere besatte med Børster. Kloen er krummet, stærk. Hos Hunnen danner Griberanden mindre Indskjæringer, og den forreste ydre Vinkel, hvortil Kloen er fæstet, ser længere ud, end den afrundede bagre, ydre Vinkel.

Det tredie og fjerde Fodpars forste Led er temmelig langt og, ligesom de folgende, besat med lange Børster paa begge Rande; det tredie er noget udvidet nedad; det fjerde er meget kortere end dette; let femte er en Trediedel længere end det foregaaende, men noget kortere end det tredie Led.

Det femte Fodpars forste Led er meget convex paa den forreste Rand og udvidet paa den bagre, noget hoiere end bredt; det tredie er kun en Trediedel langere 
end bredt, og det fjerde er omtrent af den samme Længde og Bredde; det femte er længere end det foregaaende Led, men meget smalere, lidt krummet $0 \mathrm{~g}$ har tvende Torne paa Enden af den bagre Rand. Kloen er kort, meget krummet.

De tvende følgende Fodpar tiitage efter hinanden i Længde; det første Led er smalere og længere end paa det foregaaende Fodpar; det tredie er lidt længere end det fjerde; det femte er en Trediedel længere end det foregaaende Led og meget smalere.

Springfod derne naa næsten lige langt bagud.

Det første Pars ydre Gren er ubetydelig kortere end den indre og har korte stærke Torne paa den ydre Rand, medens den sidste har lignende paa den indre Rand.

Det andet Pars Grene ere lige lange.

Det sidste Pars ydre Gren er en Trediedel kortere end Grundleddet og meget smalere eni dette, noget bøiet mod Enden; paa denne og den øvre Rand sees nogle Torne; den indre Gren er næsten rudimentær, med et Par Torne paa Enden.

Haleved hænget er neppe længere end bredt ved Roden, afrundet paa Enden.

Den er fundet ved Aalesund af $G$. O. Sars, paa 50-100 Favne; ved Kullen af Lilljeborg, ved Grønland og Island af Torell.

PHOTIS LÜTKENI, A. Boeck, 1870.

(Pl. XXVI. fig. 2.)

Photis Lïtleni, A. Boeck, Crust. amphip. bor. et arct. 1870. p. 153.

Angulus capitis lateralis productus et rolundatus. Antennæ inferiores articulo pedunculi 3tio ter longiore qvam crasso. Pedes 1 mi paris carpo angustiore qvam apud speciem Reinhardi; manu elongata, ovata. Pedes 2di paris carpo in angulo inferiore posteriore parum modo producto; manu minore, in margine inferiore neqve profunde sinuata neqve dentala. Pedes 3 tii et 4 ti paris articulo 4 to parvo, ovali, vix longitudinem dimidiam articuli 5 li angusti et elongati æqvanti. Pedes saltatorii 1 mi et 2 di paris ramis non spinosis, in extremo margine superiore serratis. Pedes saltatorii ultimi paris ramo exteriore longiore qvam pedunculo.

L æ $n$ g d en er omtrent $5 \mathrm{~mm}$.

Legemet er sammentrykt, Ryggen er glat, uden Kjøl eller Torne. De fem forste Sideplader ere høie, høiere end brede, og paa den nedre, afrundede Rand besatte med Børster; den femte er ligesaa høi som den fjerde, men bredere, indskaaret dybt paa den bagre Rand, hworved den gverste Del danner en fremstaaende, liden Lap. Hovedet er omtrent saa langt som de tvende første Legemsled tilsammen; dets Side- 
vinkler ere udtrukne til en meget forlenget, i Spidsen afrundet Fremstaaenhed mellem de ovre og nedre Fglere, og ved hvis Basis de skraa ovale Øine have sin Plads.

De ovre Folere naa, naar de bøies bagud, omtrent til det sjette Legemsled og ere besatte med Børstebundter paa den undre Rand. Skaftets forste Led er kortere end Hovedet; det andet er meget længere, men smalere, længere hos Hunnen end hos Hannen; det tredie er kortere end det foregaaeede, men noget længere end det første Led. Svgben, der er omtrent saa lang som Skaftets tvende sidste Led, dannes hos Hannen af 10 , hos Hunnen af 7 Led, hvoraf det første er det langste.

De nedre Folere, der ere frestede paa Hoverlets undre Flade, langt bag de øv'e, ere noget lingere end disse og have ligeledes Børsteknipper paa den undre Rand. Skaftets tvende forste Led ere korte; det tredie er næsten tre Gange saa langt som bredt, længere end de tvende foregaaende tilsammen, og naar frem til Enden af Hoverlets Sidevinkler; det fjerde og femte Led ere næsten lige lange eller det sidste er lidt kortere. Svoben, der er længere end Skaftets tvende sidste Led, dannes af 8 meget forlængede Led.

M und delene ere meget lig dem hos den foregaaende Art.

Overlæben er særdeles stor, oval, noget indskaaret i den nedre Ende og forsynet med fine Børster; $i$ den øvre Ende er den meget forlænget $i$ en triangulær Spids.

Kindbakkerne ere meget stærke, væbnede i Spidsen med mange Tænder; den indre Bigren har ogsaa lignende Tænder; Tornerækken dannes af grove Borster, besatte med Bitænder; Tyggeknuden er meget fremstaaende og besat med mange fine Tænder paa den tvært afskaarne Tyggeflade. Palpen er lang, det tredie Led er kun noget kortere end det andet, afrundet paa Enden og forsynet med mange, med fine Bitorne besatte Børster.

Det forste $\mathrm{Kj}$ abepars ydre Plade nar frem til den ovre Trediedel af Palpens andet Led og har paa den tvært afskaarne Ende mange, med Bitænder forsynede Torne; den indre- Plade er liden, oval. Palpens andet Led lar nogle korte, stærke Torne i Spidsen.

Kjæbeføddernes ydre Plade er stol, oval og naar frem til over Midten af Palpens andet Led, samt er paa den indre Rand væbnet med 5-6 stærke Tænder, der mod Pladens Ende forlænge sig til krumme, indadbøiede, med Bitænder forsynede Torne; den indre Plade naar frem til Enden af Palpens første Led og har paa den indre Rand fjærdannede Borster og tre Tænder paa Enden. Palpen er forlænget; det andet Led er besat med Tværrader af Børster; det tredie har kun det foregaaende Leds halve Længde, med nogle Børster paa Enden; det fjerde Led er i Spidsen forsynet med et Par stærke Torne.

Det forste Fodpar er noget mindre end det andet; det fjerde Led er længere end bredt, med en kun ubetydelig skraa afskaaren ydre Ende; Haanden er næsten ægformet og forsynet med mange Børster paa den bagre Rand.

Det andet Fodpars fjerde Led er kortere, end paa det første Par, triangu- 
lært, med en med Borster forsynet udtrukket og afrundet nedre, bagre Vinkel; Haanden er stor, bredere udad; den bagre Rands ydre Ende er bueformet indskaaret. Kloen er stærk og har mange, fine Torne paa den bagre Rand.

Det tredie og fjerde Fodpars tredie Led er par sin ydre Ende temmelig udvidet; det fjerde er lidet, ovalt; det femte er mere end dobbelt saa langt som det foregaaende Led, meget smalere og synes næsten umiddelbart at fortsætte sig over i Kloen.

De tre folgende Fodpar ere hos denne Art meget længere og smalere end hos den foregaaende Art. Det femte Pars første Led er længere end bredt; det fjerde er kun noget kortere end det tredie Led, medens det femte er længere end dette Led. Det syvende Pars femte Led er meget længere end det tredie Led.

Springfødderne naa alle næsten lige langt bagud.

De tvende forste Pars ydre Gren er kun lidt kortere end den indre, og begge have tre Tæander i Spidsen.

Det sidste Pars ydre Gren er noget længere end Grundleddet, smal, tilspidset mod Enden og besat med nogle Børster; den indre Gren er rudimentær og danner kun en Knude.

Halevedhænget er bredere end langt, tilspidset paa Enden.

Findestedet ved Norges vestlige Kyst er ikke angivet.

Gen. II. MICROPROTOPUS, Norman, 1866.

Syn.: 1866. Microprotopus, Norman, Brit. Assoc. Rep. p. 202. Ann. and Mag. Nat. Hist. 1868. p. 419. pl. XXIII. fig. 7-11.

1870. - A. Boeck, Crust. amphip. bor et arct. p. 154.

Type: Microprotopus maculatus, Norman.

Antenna superiores articulo pedunculi 3tio non prilongalo; flagello accessorio parvo.

Pedes $1 \mathrm{mi}$ paris carpo elongato.

Pedes 3 tii et 4 ti paris articulo 1 mo non crassissimo.

Pedes saltatorii ultimi paris 1-ramosi.

Appendix caudalis in apice insinuata.

Allerede for 10 Aar siden fandt jeg en Form, som jeg maatte antage at tilhøre en ny Slægt, men som jeg senere gjenkjendte som den af Norman beskrevne Microprotopus maculatus. 


\section{MICROPROTOPUS MACULATUS, Norman, 1866.}

(11. XXVI, fig. 3.)

Microprotopus maculatus, Norman, Brit. Assoc. Rep. 1866. p. 203. Ann. Mag. Nat.

Hist. 1868. p. 419. pl. XXIII. fig. $7-11$.

A. Boeck, Crust. amphip. bor. et arct. 1870. p. 154.

Antennæ superiores articulo pedunculi 1 mo longitudinem articuli 2 di ferme rquanti; articulo 3tio apud marem longiore qvam apud feminan. Antennæ inferiores articulo pedunculi 4to el 5to longitudine aqvalibus. Pedes $1 \mathrm{mi}$ paris manu breviore quam carpo ovali. Pedes 2di paris carpo apud marem multo breviore qvam apud feminam, in angulo inferiore posteriore producto el selis plumosis instructo, manu femine qvadrangulari, in acie obliqve truncata et parum sinuata; manu maris jermagna, oblonga, ovata, in exteriore tertia parte acici dente magno, obtuso instructa. Pedes saltatorii ultimi paris ramo paulo longiore qvam pedunculo, in margine interiore spinis tribus et in apice selis nonnullis instructo. Appendix caudalis paulo latior yvam longa, in margine posteriore triangulariter sinuata.

Længden er omtrent $10 \mathrm{~mm}$.

Legemet er ikke meget sammentrykt, meget høit; Ryggen er rund. Sidepladerne ere noget hoiere end brede, afrundede paa den nedre Ende og der besatte med Børstex; den femte er ligesaa høi som den fjerde og paa den øvre Del af den bagre Rand udvidet til en afrundet Lap, hvorved det femte Fodpar vender bagud. Hovedet er længere end de tvende forste Legemsled tilsammen; dets Sidevinkler ere noget udtrukne, tilspidsede, Oinene er smaa, ovale.

De øvre Følere naa, naar de bøies bagud, omtrent til det sjette Legemsled. Skaftets forste Led er kortere end Hovedet; det andet er af den samme Længde, eller lidt længere $0 \mathrm{~g}$ smalere; det tredie er saa langt som Halvdelen af det foregaaende, eller lidt længere, sarnt kortere hos Hunnen end hos Hannen. Alle have Borstebundter paa den ydre Ende. Svoben er omtrent saa lang som Skaftet og dannes af 8-10 Led, $\mathrm{i}$ hvis Mellemrum der paa den ovre og undre Rand sees fine Børstebundter. Bisvøben dannes af trende korte Led, og paa dens Ende sees nogle fine Børster.

De nedre Folere ere kortere end de avre. Skaftets tredie Led er ikke dobbelt saa langt som bredt; det fjerde og feinte Led ere næsten af den samme Længde 0 g Bredde. Svoben, der er lidt længere end Skaftet, dannes af 5-6 Led, af hvilke det forste er dobbelt saa langt som de tvende folgende tilsammen. I Leddenes Mellemrum sees Borstebundter.

Overlaben er afrundet paa Enden.

Kindbakkerne ere meget stærke; Gribedelen og den indre Bigren ere begge indskaarne i 4-6 Tænder; Tornerækken dannes af nogle faa Torne, der ere saugtak- 
kede paa den convexe Rand; Tyggeknuden er meget fremstarende, og dens indre Tandrad afbrydes af en lang fjærdannet Borste. Palpens andet Led har en lang Børste nær Enden af den indre Rand; det tredie er kortere og har 6-7 Borster i Spidsen samt en lang Børste paa Midten af den ydre Rand.

Det første Kjæbepars ydre Plade naar næsten frem til Palpens Ende og er besat med 5-6 Torne, af hvilke hver har en Bitand; den indre Plade er meget liden, bred, afrundet, med en liden Borste paa Enden. Palpen er i Spidsen væbnet med fire stærke Torne og med en lignende lang, bevægelig paa den ydre Ende.

Det andet Kjæbepars Plader ere ikke meget lange eller brede; den ydre har Børster paa Enden; den indre, noget kortere, har lignende Børster ogsaa langs den indre Rand.

Kjæbefoddernes ydre Plade er forlænget, naar frem til Enden af Palpens andet Led $o g$ har paa den indre Rand talrige, lange Trender, der forlange sig mod Pladens Ende; den indre Plade naar frem til Begyndelsen af Palpens andet Led og har paa Enden tre forlængede Tænder og nogle Børster. Palpens fjerde Led er kort, i Spidsen væbnet med $3-4$ Torne.

Det første Fodpar er forlænget; det fjerde Led er smalt; Haanden er bortere end det foregaaende Led, oval; dens Griberand er skraa afsliaaret, forsynet med smaa Torne, samt har en liden Fremstaaenhel, hror Kloens Spids lagger sig imod.

Det andet Fodpar er meget stærkere; hos Hannen er i Særdeleshed Haanden doblyelt saa stor som hos Humen; hos denne sidste er det fjerde Led triangulært, med en Indad buet ydre Rand, og den nedre, bagre Vinkel er udtrukket til en i Spidsen afrundet, med lange, fjærdannede Børster besat Lap; Haanden er næsten firkantet, med en skraa afskaaret, noget indbugtet, fint saugtakket Griberand. Hos Hannen er det fjerde Led særdeles kort; Haanden er saa stor som de foregaaende Led tilsammen, forlænget ægdannet, med nogle fjærdannede Børster paa den forreste Rand, og bevæebnet med en stærk, fremstaaende, paa Enden afrundet Tand ved Begyndelsen af den bagre Rands ydre Trediedel; bag denne sees Borstebundter og en spids Fremstaaenhed, hvor Spidsen af den lange, stærke, noget krumme Klo lægger sig imod.

Det tredie og fjerde Fodpar ere korte og stærke.

De tre folgende Fodpar tiltage efter hverandre meget i Langde. Det femte Pars forste Led er næsten saa bredt som langt, crenuleret paa den bagre Rand og merl fine Torne mellem Takkerne; det sjette og syvende Pars forste Led er derimod længere end bredt; det tredie Led er kun lidt længere end det fjerde og ubetydelig kortere end det fernte Led.

De tvende første Par Springfødder naa omtrent lige langt bagud; Grenene ere kortere end Grundleddet, næsten lige lange, vabnede med Torne paa den gvre Rand og i Spidsen.

Det sidste Pars Gren er lidt langere end Grundleddet, med Here Torne i den indre Rand og nogle Borster i Spidsen. 
Halevedhænget er tykt, bredere ved Roden end langt, bredt indskaaret paa den ydre Ende, der er besat med Torne.

Farven er gul, mer eller mindre bedækket med brunlige dentristiske Pletter. Øinene ere rode.

Den er fundet af mig ved Farsund og Haugesund.

Gen. III. XENOCLEA, A. Boeck, 1870 .

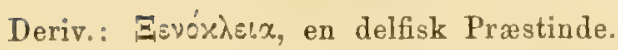

Syn.: 1870. Xenoclea, A. Boeck, Crust. amphip..bor. et arct. p. 154.

Antenne superiores articulo pedunculi 3tio elongato; flagello accessorio absenti.

Pedes $1 \mathrm{mi}$ paris carpo elongato.

Pedes 3tii et 4 ti paris articulo 1 mo latissimo.

Pedes saltatorii ultimi paris biramei: ramis invicem longitudine fere xqvalibus. Appendix caudalis in apice sinuata.

Denne Slægt afviger fra Photis ved, at det sidste Par Springfødlers Grene ere omtrent lige lange, og ved at det forste Fodpars fjerde Led er meget forlænget, medens det hos Slægten Photis er kort. Derimod ligne begge Slægter hinanden i, at de øvre Føleres tredie Skaftled er forlænget, og $\mathrm{i}$ at begge mangle Bisvøbe, hvilken derimod findes hos den tredie herhen horende Slægt Microprotopus. Med Hensyn til Munddelene hos denne Slægt ligne de meget dem hos Slægten Photis.

XENOCLEA BATEI, A. Boeck, 1870.

(Pl. XXV, fig. 8.)

Xenoclea Batei, A. Boeck, Crust. amphip. bor. et arct. 1870. p. 155.

Segmentum postabdominis 3tum in parte inferiore marginis posterioris crenulatum. Antennæ superiores articulo pedunculi $1 \mathrm{mo}$ parum breviore qvam 2do, longitudinem articuli 3tii fere reqvanti. Pedes $1 \mathrm{mi}$ paris manu ovali, parum breviore qvam carpo. Pedes 2 di paris carpo brevissimo: manu permagna, apicem versus latiore, in acie obliqve truncata; minu maris multo majore qvam feminæ, in acie dentibus duobus, anteriore perlato et in apice sinuato, posteriore acuto, utroqve crenulato, armata; manu femina in acie sinuata et dente obtuso instructa. Pedes saltatorii ultimi paris ramis in apice spinis nonnullis instructis.

Længden er $6^{\text {mm }}$.

Legemet er sammentrykt; Ryggen er glat, uden Kjøl eller Torne; det tredie Haleleds nedre, bagre Rand er crenuleret. Sidepladerne ere store, brede, besatte med 
Borster paa den nedre, fri Rand; den femte er særdeles stor og danner ved en Indbugtning tvende Lapper, af hvilke den overste er meget liden. Hovedet er meget læn. gere end det forste Legemsled og gaar fortil, mellem de ovre Følere, ud i en liden stump Spids; dets Sidevinkler danne et stumpt Fremspring, hvorpaa de skraa, ovale Øine have sin Plads.

De øvre Eølere udspringe fra Spidsen af Hovedet og naa, naar de bøies bagud, omtrent til det forste Haleled. Skaftets første Led er kortere end Hovedet; det andet er længere, men tyndere; det tredie er mere end Halvdelen af det foregaaende Leds Langde. Svoben, der er kortere end Skaftet, dannes af omtrent 12 Led, hvoraf det første er meget længere end de folgende. Skaftets tvende sidste Led og Svøben have Børsteknipper paa den undre Rand. Bisvøben mangler.

De nedre Folere ere af den samme Længde som de øvre, eller lidt længere, og ere fæstede paa Hovedets nedre Side, meget bag de gvre. Skaftets tvende første Led ere meget korte, og Lugteknuden er ogsaa liden; det tredie er længere end de tvende foregaaende. Led tilsammen; det femte er noget kortere og smalere end det fjerde Led. Svoben er omtrent saa lang som Skaftets tvende sidste Led tilsammen og dannes af 12 forlængede Led, af hvilke det forste er det længste. Saavel denne som Skaftets tvende sidste Led have Børsteknipper paa den undre Rand.

Det forste Fodpar er forlænget; det fjerde Led er længere end den forlængede ovale Haand, der har en skraa afskaaret Griberand. Kloen er lang, men kortere end det sidste Led.

Det andet Fodpar er større end det forste og meget stærkere hos Hannen end hos Hunnen; det forste Led er temmelig bredt; de tre folgende ere meget korte; Haanden er stor, noget længere end bred, oval, med en skraa afskaaret Griberand. Hos Hannen el denne forsynet med tvende skarpe Fremspring, adskilte ved et dybt Indsnit, og af hvilke det, der er nærmest Kloen, er firkantet, delt ved en Indsynkning i tvende Lapper og har nogle Børster; det andet er trekantet, forsynet med Saugtakker. Den stærke, noget krumme, paa Enden stumpe Klo har en Fremstaaenhed paa Midten af den bagre Rand. Hos Hunnen sees paa Griberanden kun tvende knudeformede, med Børster besatte Fremragninger.

Det tredie og fjerde Fodpar ere stærke; det forste Led er meget bredt; det tredie er stærkt udvidet mod Enden; det fjerde er kort, kun lidt længere end bredt; det femte Led er meget længere, men smalere. Kloen er stærk.

Det femte Fodpar er bøiet bagover; det forste Led er meget udvidet. Kloen er meget liden, tyk.

De tvende folgende Fodpar tiltage efter hinanden i Langde og have mange rette Torne paa den bagre Rand.

De trende forste Par Springfodders ydre Gren er kortere end den indre, og begge ere væbnede med stærke Torne, af hvilke fire kortere og tvende længere ere fæstede til Grenenes Spids. 
Det sidste Pars Grene ere forlænget cylindriske, kun lidt kortere end Grundleddet $0 \mathrm{~g}$ væbnede med rette Torne langs den øvre Rand og i Spidsen.

Halevedhænget er tykt, klovet i den ydre Ende, besat med Børster og hos Hannen med tvende smaa Torne.

Jeg har fundet denne Art i Christianiafjorden og ved Haugesund.

Subfamilia III.

MICRODEUTOPINÆ, A. Boeck, 1870.

Syn.: 1870. Microdeutopine, A. Boeck, Crust. amphip. bor. et arct. p. 155.

Labium superius latum, in apice rotundatum.

Mandibulæ pervalide, in apice dentatæ; ramo accessorio etiam dentato; tuberculo molari prominenti: serie spinarum ex spinis paucis sed validis, in margine convexo serratis, et ex setis paucis plumosis composita: palpo elongato, 3articulato; articulo 3 tio in apice obtuso, rotundato.

Maxilla $1 \mathrm{mi}$ paris lamina interiore parva.

Maxillæ 2di paris laminis perlatis.

Pedes maxillares lamina exteriore magna, in margine interiore dentibus paucis sed validis, apicem versus longioribus et curvatis, instructa; articulo palpi ultimo in apice spinis duabus validis et curvis armato.

Corpus parum modo compressum; epimeris parvis.

Antennæ elongata; flagello longo; flagello accessorio parvo aut raro absenti; flagello antennarum inferiorum non prælongato.

Pedes $1 \mathrm{mi}$ et 2 di paris manu subcheliformi.

Pedes trium parium ultimorum longitudine gradatim valde crescentes.

Pedes saltalorii biramei.

Appendix caudalis crassa.

Den typiske Slægt Microdeutomus blev af Costa stillet sammen med Slægten Unciola, Say, i en Underfamilie Unciolini. Da Unciola var mig ubekjendt, fordi den ikke staar i Forbindelse med Kroyers Slægt Glauconome, med hvilken den af Dana, Spence Bate og Andre er slaaet sammen, vovede jeg ikke at opfore Underfamilien under dette Navn, men kalite den i 1870 Microdeutopine. I Munddelenes Bygning ligner den, ligesom de tvende foregaaende Underfamilier, Gammarine, men det første Kjæbepars indre Plade er altid liden, og det andet Kjæbepars Plader ere brede, smaa. I det Ydre udmærker den sig ved sit næsten nedtrykte Legeme, sine smaa Sideplader og 
sit tykke Halevedhæng. De tvende første Fodpars Form er i Almindelighed meget forskjellig hos Hanner og Hunner. Normans Slagt Megamphopus hører vistnok herhen.

Gen. I. MICRODEUTOPUS, Costa, 1853.

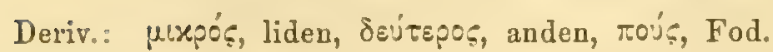

Syu.: 1853. MI icrodeutopus, Costa, Rend. d. Reale Accad. d. Sci. d. Napoli. T. 3. p. 171. R. sui Crost. Amfip. del regno di Napoli. p. 230.

1854. Gammaropsis, Lilljeborg, Öfv. af Kgl. Vet.-Akad. Förh. p. 455.

1855. Lémbos, Spence Bate, Brit. Assoc. Rep. p. 58. Ann. Nat. Hist. 2. ser. XIX. p. 142 .

1857. - White, Pop. Hist. Brit. Crust. p. 180.

1859. Autonoë, Bruzelius, Skand. Amphip. Gamm. p. 23.

1862. Microdeutopus, Spence Bate, Catal. Amphip. Crust. Brit. Mus. p. 163.

1863. - - Spence Bate and Westwood, Brit, sessile-eyed Crust. p. 287.

1870. - A. Boeck, Crust. amphip. bor. et arct. p. 156.

Type: Microdeutopus gryllotalpa, Costa.

Antennæ superiores inferioribus longiores; articulo pedunculi 3 tio brevi.

Pedes $1 \mathrm{mi}$ paris iisdem 2di paris majores; carpo maris perdilatato, in angulo inferiore posteriore producto; articulo 5to vel manu angustiore qvam carpo et una cum ungve pollicem 2articulatum formanti; articulo 5to femina maxime dilatato et manum formanti.

Pedes 3tii et 4ti paris ungve breviore qvam articulo 510.

Pedes saltatorii ultimi paris ramo interiore et exteriore longitudine fere aqvalibus.

Costa opstillede denne Slægt i 1853, og i 1856 henførte han den til sin Underfamilie Unciolini. I Slægtsdiagnosen anforer han: „Pedes $1 \mathrm{mi}$ paris majores, in sexuibus difformes, (mas.) carpo maximo, manu parva, ungviculum gerenti; (fem.) manu majore fere ut in g. Amphithoë, secundi minuti filiformis." En Art, som maatte henføres til denne Slregt, og som er den typiske Art Mr. gryllotalpa, stillede Lilljeborg i det folgende Aar til sin Slægt Gammaropsis, medens Spence Bate satte den under Slægtsnavnet Lembos og Bruzelius i 1859 til sin Slægt Autonoë, under Navnet $A$. grandimana. Jeg troede i 1860 , at den omhandlede Slregt maatte ind under Slægten Leptocheirus, Zaddach. I 1862 optoges den af Spence Bate, der stillerle den til sin Underfamilie Gammarides. Hos denne Slægt ere de ovre Følere længere end de nedre, men hos Arten $\boldsymbol{M}$. Titii, Heller, fra det adriatiske Hav, sees det Omvendte at finde Sterl. 
MICRODEUTOPUS GRYLLOTALPA, Costa, 1853.

(PI. XXIX. fig. 6.)

Microdeutopus gryllotalpa, Costa, Rend d. Reale Accad. d. Sci. di Napoli. 1853. p. 178. Mem. d. Reale Accad. d. Sci. di Napoli. 1857. p. 231. t. IV. fig. 10 .

- $\quad$ Spence Bate, Catal. Amphip. Crust. Brit. Mus. 1862. p. 163. pl. XXX. fig. 1 .

Spence Bate and Westwood, Brit. sessile-eyed Crust. 1863. p. 289.

A. Boeck, Crust. amphip. bor. et arct. 1870, p. 156.

Lembos Danmoniensis, Spence Bate, Brit. Assoc. Rep. 1855. p. 58. Ann. Nat. Hist. 1857. 2. ser. XIX. p. 142 .

White, Pop. Hist. Brit. Crust. 1857. p. 180.

Autonö̈ grandimana, Bruzelius, Skand. Amphip. Gamm 1859. p. 26. fig. 5.

Microdeutopus grandimanus, Spence Bate, Catal. Amphip. Crust. Brit. Mus. 1862. - App. p. 378

Epimerum 1 mum epimeris cæeteris paulo majus, in angulo inferiore anteriore aculum. Segmentum postabdominis 3tium angulo inferiore posteriore rolundato. Pedes 1 mi paris apud marem permagni; articulo 3 tio angusto et parvo; carpo permagno, inflato, paulo longiore qvam lato, in margine posteriore in processum magnum, compressum, postice dentibus validis 3-4 armatum, producto; articulo 5to compresso, in margine posteriore nodulis duobus latis instructo; pedes $1 \mathrm{mi}$ paris apud feminam manu multo minore, rectangulari, in acie obliqve truncata; carpo et manu longitudine fere æqualibus. Pedes 2di paris articulo $1 \mathrm{mo}$ maris valde dilatato, laminari; manu rectangulari; articulo Imo feminæ non dilatato. Pedes saltatorii ultimi paris ramo exteriore parum longiore qvam interiore, endem longitudine ac pedunculo.

Is $æ$ ngden er $\delta^{m m}$.

Legemet er nedtrykt, Ryggen er rund og bred; det tredie Haleleds nedre, bagre Vinkel er afrundet. Sidepladerne ere smaa, bredere end høie; den nedre, forreste Vinkel paa den forste af disse er noget udtrukket. Hovedet er lidt længere end det forste Legemsled; dets Sidevinkler ere afrundede. Øinene ere skraa ovale.

De øvre Følere naa, naar de bøies bagud, omtrent til det fjerde Haleled. Skaftets forste Led er meget kortere og tykkere end det andet; det tredie Led er meget kort. Svøben er længere end Skaftet og dannes af 16-24 Led. Bisvøben har 1 Led, der er længere og meget smalere end Svøbens forste Led. 
De nedre Følere ere kortere end de ovre. Skaftets tredie Led er meget længere end bredt; det fjerde og femte Led ere omtrent lige lange. Svøben er kortere end Skaftets sidste Led og dannes af $7-9$ Led.

Overlæben er afrundet i Spidsen.

Kindbakkerne ere meget stærke; Gribedelen er indskaaret i 7 og den indre Bigren i fem Tænder; Tornerækken dannes af tre, paa den convexe Rand saugtakkede Torne, samt har tre andre, korte, tykke, fjærdannede ved Siden af disse; Tyggeknuden er meget fremstaaende, forsynet med en Krands af Torne, der i den nedre, ydre Vinkel afbrydes af en lang, fjærdannet Borste. Palpen er forlænget, stærk; det tredie Led er kortere end det andet, bredt afrundet paa Enden og besat med mange Tværrader af Børster.

Underlæbens ydre Plader ere bredt afrundede paa Enden; de indre Plader ere meget store, med fjærdannede Børster i Spidsen.

Det forste Kjæbepar er stærkt; den ydre Plade har paa den brede Ende kraftige Torne, der ere forsynede med en Bitand; den indre Plade er liden, med en Børste paa Enden. Palpens sidste Led er bredere mod Enden, væbnet par den ene Side med fem Tænder, paa den anden med fem Torne.

Kjæbefodderne ere meget stærke; den ydre Plade er meget stor, bred oval, og har paa den indre Rand en Række Tænder; den indre Plade naar frem til Enden af Palpens første Led, er forlænget smal, med tre Tænder og flere fjærdanuede Børster paa Enden. Palpens fjerde Led har tvende stærke Torne paa Spidsen.

Det første Fodpar er storre end det andet, og hos Hannen meget storre, end hos Hunnen; hos hin er det forste Led meget tykt og bredt ved den ydre Ende; det fjerde er særdeles stort, ovalt, kun lidt længere end bredt, dets bagre Rand er indskaaret i tre stærke Saugtakker, og den nedre, bagre Vinkel gaar frem i en stærk, spids Tand; det femte Led er smalt, noget langere end bredt, bølgeformet indskaaret i den bagre Rand. Kloen er saa lang som det sidste Led, eller noget kortere end dette. Hos Hunnen er det sidste Led af en rectangulær Form, næsten af den samme Liengde som det fjerde Led, med en skraa afskaaret Griberand.

Det andet Fodpar er meget smalere; det forste Led er hos Hannen dog overmaade bredt og fladt, med en meget convex forreste Rand; det fjerde er ikke meget udvidet, af en forlænget ægrund Form, forsynet paa begge Rande, især paa den bagre, med tætte Børster; det femte er smalere end det foregaaende Led, rectangulært, med en kun svagt afskaaret Griberand. Hos Hunnen er det forste Led smait; det fjerde er a gdannet; det femte er langere end det foregarende Led, med en meget skraa afskaret Griberand. Kloen er saugtakket paa den bagre Rand.

Det tredie og fjerde Fodpars tredie Led er kort, neppe længere end det ovale fjerde; det femte er smalere end det fjerde Led. Kloen er kortere end det sidste Led.

De tre følgende Fodpar tiltage efter hverandre ineget i Langde; det før- 
ste Led er smalere mod Enden; det tredie er kun lidt eller neppe længere end det fjerde, men meget kortere end det forlængede, smale femte Led.

Springfødderne ere korte og naa omtrent lige langt bagud.

Det forste Pars Grene have Torne paa den øvre Side og i Spidsen.

Det sidste Pars indre Gren er noget kortere end den ydre, der er saa lang som Grundleddet; begge have Børster paa den ovre Side og i Spidsen.

Halevedhænget er stærkt og har tvende Forhøininger; der sees nogle Børster paa den ovre Side, og det er lidt indskaaret paa den bagre Rand.

Den af Spence Bate og Westwood beskrevne og afbildede Form er meget forskjellig fra vor Form. Det forste Fodpars Carpus er smalere og paa den bagre Rands Ende kun forsynet med en stærk, tandlignende Fremstaaenhed; de øvre Følere ere ogsaa kortere og have kun omtrent Halvdelen af Legemets Langle; Halevedhanget er nær Spidsen forsynet med en eller tvende lange, noget eiendommelig dannede Børster og med en eller flere korte, fjærdannede Børster. Norman antager, at den repræsenterer en ung Han af $M$. anomalus. Jeg har dog indtil Videre troet at burde beholde de under disse Arter anførte Synonymer.

Den er fundet i Christianiafjorden, ved Haugesund og Farsund. Ved Bohuslen er den sjelden. Den er ligeledes taget ved den engelske Kyst, af Heller i Adriaterhavet, og er efter Costa hyppig i Mirdelhavet.

\section{MICRODEUTOPUS ANOMALUS, Rathke, 1843.}

(Pl. XXV. fig. 5.)

Gammarus anomalus, Rathke, Acta Acad. Leop. 1843. XX. p. 63. t. IV. fig. \%.

- (Gammaropsis) anomalus, Lilljeborg, Öfv. af Kgl. Vet.-Akad. Förh. 1854. p. $45 \%$.

Lembos Cambriensis, Spence Bate, Brit. Assoc. Rep. 1855. p. 58. Ann. Nat. Hist. 1857. 2. ser. XIX. p. 142.

White, Pop. Hist. Brit. Crust. 1857. p. 180.

Auton ö̈ anomala, Bruzelius, Skand. Amphip. Gamm. 1859. p. 25. pl. 1. fig. 4.

Microdeutopus anomalus, Spence Bate, Catal. Amphip. Crust. Brit. Mus. 1862. p. 154. pl. XXX. fig. 3.

- $\quad$ Spence Bate and Westwood, Brit. sessile-eyed Crust. 1868. p. 293.

Epimerum 1 mum angulo inferiore anteriore in aculeum producto. Segmenta postabdominis tria anteriora angulo inferiore posteriore rotundato. Antennx superiores articulo pedunculi 1 mo spina una instructo. Pedes 1 ni paris apud ma- 
rem carpo dilatato, duplo longiore qvam lato, in angulo inferiore posteriore in processum longum, dentiformem, extus dente accessorio armatum, producto; articulo 5 to angusto, cylindrico; pedes $1 \mathrm{mi}$ paris apud feminam articulo 5 to vel manu rectangulari, in acie obliqve truncata. Pedes 2di paris articulo 1 mo maris non dilatato; manu angustiore. Pedes saltatorii ultimi paris ramis longitudine invicem æqvalibus et paulo longioribus qvam pedunculo.

Længden er $9^{\mathrm{mm}}$.

Legemet er ikke meget nedtrykt; Ryggen er rund og bred; det tredie Haleleds nedre, bagre Vinkel er ret, afrundet. De fire første Sideplader ere bredere end høie; den førstes nedre, forreste Vinkel er udtrukket, tilspidset. Hovedet er lidt læn. gere end det første Legemsled og danner mellem de ovre Følere et lidet Pandehorn. Øinene ere skraa ovale.

De øvre Følere naa, naar de boies bagud, til det fjerde Haleled. Skaftets forste Led er lidt kortere end Hovedet og har en liden Torn paa den ydre Endes undre Side; det andet er lidt læugere og smalere; det tredie er kort. Sroben dannes af 20-30 Led. Bisvoben har 4-5 meget smale Led.

De nedre Folere ere kortere end de øvre. Skaftets tredie Led er mere end dobbelt saa langt som bredt; det fjerde og femte ere lige lange, men det forste af disse er lidt tykkere. Svøben er af den samme Længde som Skaftets sidste Led og dannes. af 8 Led.

Det forste Fodpar er større end det andet, og hus Hannen meget større end hos Hunnen. Hos hin er det forste Led langt, lidt krummet; det andet og tredie Led ere korte; det fjerde er overordentlig stort, bredere udad, omtrent dobbelt saa langt som tykt, hvorved det faar en forlænget, triangulær Form; dets nedre, bagre Vinkel forlænger sig til et langt, tyndt, tandlignende Fremspring, hvilket ikke er fuldt saa langt som det femte Led, samt har en liden Bitand og 2-3 smaa Tænder ved Roden af den ydre Rand; det femte Led er meget smalt, meget kortere end det fore. gaaende Led, noget krummet, bredere paa Enderne end paa Midten, noget nærmere den ydre Ende sees paa den bagre Rand en Forhoining. Kloen er noget kortere end det sidste Led, krummet i den ydre Del og tilspidset. Hos Hunnen er det fjerde Led kort, lidet udvidet mod den ydre Ende; det femte er langere end det foregaaende Led, af en qvadrangulær Form, med skraa Griberand. Kloen er lidt krummet.

Det andet Fodpar er af den samme Bygning hos begge Kjon; det forste Led er temmelig stærkt, bredt; det fjerde er forlænget, omtrent saa langt som det følgende Led, meget bredere mod den ydre Ende; det femte Led er af en rectangulær Form, med en skraa afskaaren Griberand, der er forsynet med Saugtakiker. Begge de sidste Led have talrige Børsteknipper paa den bagre Rand.

Det tredie og fjerde Fodpar ere lange og smale; det tredie Led er mod den ydre Ende kun lidet udvidet og kun noget længere. end det fjerde; dette er kor- 
tere og bredere end det femte Led. Ḱloen er lang, smal, lidt kortere end det sidste Led, ubetydelig krummet.

Det femte Fodpars forste Led el forlanget smalt, af en oval Form; det tredie er kun lidt længere og bredere end det fjerde; det femte er noget boiet og længere end det foregaaende Led. Kloen er ikke meget lang, nwsten ret.

De trende folgende Fodpar tiltage efter hinanden betydelig i Langde; det forste Leds bagre Rand har Torne; det syvende Pars tredie Led er meget langere end det fjerde og kun lidt liortere end det femte Led.

Det forste Par Springfodders Grene ere næsten af den samme Længde, ikke fuldt saa lange som Grundleddet, samt vabnede med Torne pan den gvre Rand og i Spidsen.

Det andet Par er kortere, og Grenene ere langere end Grundleddet; der sees Torne paa den ovre Rand og i Spidsen.

Det sidste Pars Grene er ubetydelig langere end Grundleddet og ere bevæbnede par den samme Maade, som paa de foregaaende Par.

Halevedhæn get er temmelig stort, noget indskaaret paa Enden, hvor der sees trende Knuder, besatte med Borster.

Farven er stragul, med tvarsgaaende grabrune Band paa liyggen og Sidepladerne.

Den findes langs Kysten fra Christiansund, og er efter Bruzelius almindelig ved Bohuslen. Den er ligeledes fundet pan Here Steder ved de engelske og irske Kyster.

Gen. II. AORA, Kroyer, 1845.

Deriv: Aora, en Nymfes Navn.

Syn.: 1845. Aora, Kroyer, Nat. Tidsskr. 2. R. 1. B. p. 335.

1849. Lalaria, Nicolet, Gay's Hist. de Chile. Vol. III.

1855. Lonchomerus, Spence Bate, Brit. Assoc. Rep. p. 58. Anu. Nat. Hist. $185 \%$. 2. ser. XIX, p. 143.

1857. - White, Hist. Brit. Crust. p. 180.

1858. Lalaria, Spence Bate, Ann. Nat. Hist. XX. p. 525.

1859. A utonö̈, Bruzelius, Skand. Amphip. Gamm. p. 23.

1862. Aora, Spence Bate, Catal. Amphip. Crust. Brit. Mus. p. 160.

1863. - Spence Bate and Westwood, Brit. sessile-eyed Crust. 1. 279.

1870. - A. Boeck, Crust. amphip. bor. et arct. p. $15 \%$.

Type: Aaratypica, hroyer.

Pedes $1 \mathrm{mi}$ paris iisdem 2 di paris majores; apud marem articulo 3tio postice in processum longum, styliformem producto; carpo elongato, angusto; manu item 
elongato, ovali; apud feminam articulo 3tio in angula inferiore posteriore non producto; carpo brevi; manu lata.

Cateroqvin ferme ut apud genus Microdeutopus.

Kroyer opstillede i 1845 denne Slægt paa Arten A. typica fra Valparaiso, og han anforer om denne Art, at det tredie og fjerde Fodpars fjerde Led er ovalt og danner en Haand, hvis Finger udgiores af det femte og sjette Led eller Kloen. Dette kan jeg dog ikke anse at være rigtigt, ligesaa lidt som hans Formening, at Halevedhænget dannes af twende tilspidsede Plader. Det stemmer nemlig hos denne Art fuldkommen overeens med det hos A. gracilis, og det er kun tilsyneladende, at det er spaltet, naar man ser det noget paaskraa. Nicolet kalder Slægten i 1849 Lalaria, og Spence Bate i 1855 Lonchomerus. I Diagnosen af denne Slægt nævner han ikke Hunnen, hvis forste Fodpar, ligesom hos Slægten Microdeutopus, er meget forskjellig fra Hannens. Den indbefatter kun tvende. Arter fra Sydamerikas Kyster og fra det nordlige Europa.

AORA GRACILIS, Spence Bate, 1855.

(Pl. XXV. fig. 9.)

Lonchomerus gracilis, Spence Bate, Brit. Assoc. Rep. 1855. p. 58. Ann. Nat. Hist. 1857. 2. ser. XIX.p. 143.

Lalaria gracilis, Spence Bate, Ann. Nat. Hist. 1858. 2. ser. Xx. p. 525.

Aut on ö̈ punctata, Bruzelius, Skand. Amphip. Gamm. 1859. p. 24. pl. 1: fig. 3.

Aora gracilis, Spence Bate. Catal. Amphip. Crust. Brit. Mus. 1862. p. 160. pl. XXIX. fig. 7.

- - Spence Bate and Westwood, Brit. sessile-eyed Crust. 1863. p. 281.

- - Norman, Rep. on the Shetland Crust. 1868. p. 281.

- - A. Boeck, Crust. amphip. bor. et arct. 1870. p. 158.

Pedes $1 \mathrm{mi}$ paris apud marem articulo 3 tio in angulo inferiore posteriore styliformi, elongato et ultra finem carpi prodncto: articulo sto vel mann apicem versus angustiore; manu femine sat lata, ovali, parum longiore qvam carpo. Pedes 3 tii et 4 li paris ungve breviore qvam arliculo 5to. Pedes saltatorii ultimi paris ramo interiore parum breviore qvam exteriore; hoc duplo longiore qvam pedunculo.

La ngilen er $8^{\mathrm{mm}}$.

Legemet er langt, tyndt, noget nedtrykt; Ryggen er rund. Den forste Sideplade er storre end de folgende, der efter hverandie aftage i Langde, den er storst hos Hannen, og dens nedre, forreste Vinkel gaar hos denne ud i en Spids, medens den er afrundet hos Hunnen. Hoverlet er ikke fuldt saa langt som de tvende forste Legemsled tilsammen og danner mellem de ovre Folere et lidet Pandehorn. Øinene ere ovale. 
De øve Følere naa, naar de bøies bagud, til det fjerde Haleled. Skaftets første Led er lidt kortere end Hovedet; det andet er længere og noget tyndere; det tredie Led er kort. Svoben, der er meget længere end Skaftet, dannes af $20-25$ forlængede Led, i hvis Mellemrum der paa den ovre og undre Side sees Borsteknipper. Bisvobell er tynd og har 4 Led.

De nedre Følere ere meget kortere, end de grre. Skaftets andet Led udsender en lang Lusteknude; det tredie er længere end bredt; det fjerde er længere end det femte Led. Svaben, der er kortere end Skaftets sidste Led, dannes af 5 Led.

Kindbakkerne ere meget stærke; Gribedelen har fem Tæender, og den indre Bigren, der staar langt fra den anden, er indskaret i $4-5$ Tander.

Det første Kjæbepars indre Plade er rudimentær, med en fjærdannet Børste paa Enden. Palpen er forlrenget.

Det andet $\mathrm{Kj}$ æbe pars Plader ere brede, korte.

Kjæbefødderne ere meget starke; den ydre Plade er paa den indre Rand væbnet med grove Tænder, der blive smalere og krumme paa Pladens Ende; den indre Plade er lang, bred og har tre Tænder foruden nogle Borster paa Enden. Palpen er kort, bred.

Det forste Fodpar er hos begge Kjon storre end det andet. Hos Hannen er det meget forlænget, stærkt; det tredie Leds nedre, bagre Vinkel er forlænget til et spidst Fremspring, der er saa langt som det folgende Led; Haanden, der er kortere end det fjerde Led, er forlænget oval, smalere mod den ydre Ende, med nogle Borsteknipper paa den bagre land. Kloen er kortere end det sidste Led, svagt krummet og væbnet paa den bagre Rand med fine Truder. Hos Hunnen er dette Fodpar af den samme Form som det andet.

Det andet Fodpar er af den sædvanlige Bygning og paa de tvende sidste Leds bagre Rand besat med stærke Borsteknipper; det femte Led er forlæuget firkantet, noget langere end det foregaaende Led.

Det tredie og fjerde Fodpars tredie Led er kort; det fjerde er meget kortere end dette; det femte er omtrent saa langt som det foregaaende Led, men meget smalere. Kloen er meget kortere end det sídste Lerd.

De tre folgende Fodpar tiltage efter hverandre meget i Længde.

Springfodderne naa omtrent lige langt bagud; Grenene ere næsten lige lange, forsynede med Torne paa flen grre Rand og i Spidsen. Det sidste l'ars Grene ere omtrent dobbelt saa lange som Grunilleddet; den yilre er lidt længere end den indre.

Ha levedhænget er tykt, ret afskaaret paa Enden og er der, paa hver Side, forsynet med en stump Tand samt har et Børsteknippe paa den øvre Kant.

F arven er efter Bruzelius bleggul, bestrwet med runde, sortagtige smaa Punkter, soin ikke sammenflyde til storre Pletter. Eggene ere blaagrome. Efter Spence 
Bate er den vinrod, med sorte Pletter, isser paa Fodparrene og hvert af Legemsleddenes Rygtlade.

Norman anser Microdentomus anomalus, beslirevet af Spence Bate og Westwood, p. 293, at vare Hunnen af denne Art, ilet han dog anforer, at Hunnen af disse tvende Artel ere sa lige, at de næsten ikle kunne adskilles fra hinanden.

Denne Art, der findes langs den norske Vestkyst nedover fra Christiansund, gaar efter Bruzelius ned til Bohuslen, hvor den er almindelig. Den findes ogsaa ved de engelske Kyster; efter Norman ved Shetland.

Gen. III. AUTONOË, Bruzelius, 1849.

Deriv: 'Autonoë, en Datter af Nereis og Doris.

Syn.: 1S59. Autonoë, Bruzelius, Skand. Amphip. Grumm. p. 23.

1870. - A. Boeck, Crust. amphip. bor, et arct. p. 158.

Type: Gammanus longipes, Lilljeborg.

Pedes 1 mi paris iisdem 2 di paris majores; articulo 5to ulriusqve sexus manum formanti; hac validiore apud marem qvam apud feminam.

Pedes saltatorii ultimi paris ramo exteriore longiore quam interiore.

Creteroqvin ferme ut apud genus Microdeutopus.

Under dette Navn sammenfattede Bruzelius i 1859 forskjellige Amphipodearter, livoraf flere allerede vare optagne under særskilte Slagter, saterles A. grandimana, der er den samme som Microlcutopus gryllotalpa, Costa, A. punctata, der henhorer til Kiroyers Slagt Aora, A. macromy, der hører til Kroyers Slægt Protomedeia, A, erythrophthatma, som allerede Lilljeborg havde stillet sammen med nogle andre Arter under Navnet Gammaropsis. Ved at stille Arterne under forskjellige Slægter var A. longipes tilbage, som ikke kunde henfores til nogen af de allerede anforte Slægter, og for denne Art, hvortil kommer en ny, har jeg benyttet Bruzelius's Slagtsnavn Autonoë.

\section{AUTONOE LONGIPES, Lilljeborg, 1552.}

(I’. XXV. fig. ?.)

Gammarus longipes, Lilljeborg, Öfv. af Kgl. Vet.-Akad. Förhand. 1S5̆2. p. 10. 1858. p. 135. Kigl. Vet.-Akad. Hand1. 1853. p. 457.

Autanö̈ longipes, Bruzelius, Skand. Amphip. Gamm. 1859. p. 28.
-
A. Boeck, Crust. amphip. bor. et arct. 1S70. p. 158.

Lembos Websterii, Spence Bate, Ann. Nat. Hist. 1857. 2. ser. XIX. p. 142.

White, Pop. Hist. Brit. Crust. 185\%. p. 150.

Microdeutopus Websterii, Spence Bate, Catal. Amphip. Crust. Brit. Mus. 1862. p. 164. pl. XXX. fig. 2. 
Microdeutopus Websterii, Spence Bate and Westwood, Brit. sessile-eyed Crust. 1863. p. 291.

Microdeuteropus Websteri, Norman, Rep. on the Shetland Crust. 1868. p. 282.

Microdeutopus longipes, Spence Bate, Catal. Amphip. Crust. Brit. Mus. 1862. r. 166.

Pedes Imi paris apud marem articulo 1 mo postice perdilatato et seloso; carpo permagno sed breviore qvam manu; hac ovata, in margine inferiore dentibus validis duobus armata; apud feminam articulo lmo non dilatato; manu oblonga, ovata, edentata, spinis modo instructa. Pedes 2 di paris apud marem carpo paulo majore qvam manu clongata, ovata et in margine anteriore persetosa; apud feminam carpo parum breviore. Pedes 3 tii et 4 ti paris ungve longitudinem articuli 5li rervanti. Pedes saltatorii ultimi paris ramo exteriore multo longiore qvam pedunculo.

L snglen er $8^{\mathrm{mm}}$.

Legemet er forlænget, temmelig meget nedtrykt. Sidepladerne ere smaa. Hoverlet danner fortil intet egentligt Pandehorn, men der sees her en liden Knude; dets Sidevinkler ere afrundede. Øinene ere smaa, runde.

De ovre Foleres forste Skaftled er kortere end Hovedet; det andet er liongere og smalere; det tredie er temmelig kort. Svoben dannes af 12-16 forlængerle, med korte Børster besatte Led. Bisvoben har 3 I.ed.

De nedre Følere ere meget kortere end de øvre. Skaftets tredie Led er kun lirlt lingere end breit; det fjerde og femte ere omtrent lige lange. Svoben, der er kortere end Skaftets sidste Led, dannes af 5 Led, hvoraf det sidste bærer trende Kloer pai Spidsen.

Kindbakkerne ere meget strerke; Gribedelen er bred, indskaret i 5-6, len indre Bigren i 4-5 Tander. Palpens tredie Led er kortere end det andet $0 \mathrm{~g}$ forsynet med talrige Børster paa den ovre Rand og i Spidsen.

Det forste Kjæbepars indre Plade er meget liden, med en fjærdamnet Bølste paa Enden. Palpens sidste Led har paa Enden 5-6 Truder.

Det andet $\mathrm{K} \mathrm{j} x \mathrm{bepars}$ Plader ere brede; den ydre naar lidt liengere frem end den indre, som har, foruden en tæt Række Borster i Randen, tillige en skraa Rxkke lignende Borster paa den indre Flade.

Kijobefoddernes ydre Plade er temmelig stor og er paa den indre, rette Rand vabnet med otte Trender, der mod Pladens Ende blive meget langere og gaa paa den ydre Rand over til krumme Børster; den indre Plade, der naar frem til Enden af Palpens forste Led, har tre Tanler og nogle Borster paa Enden. Palpens fjerde Led er kloformet med en stark, kort Torn.

Det forste Fodpar er storre end det andet, hos Hannen meget storre end los Hunnen. Hos hin er det forste Lell meget bredt, starkt bueformet paa den bagre Rand, hvor der sees talrige, lange Borster; det fjerde Led er stort, triangulært, med 
stærke Borster paa den bagre Rand, ligesom paa det foregaaende Led. Haanden er oval, lidt storre end det foregaaende Led, og især paa den forreste Rand væbnet med lange Borstebundter; Griberanden har tvende stærke Tænder, af hvillie den ydre er smalere end den indre. Kloen er stærk, me? smaa Tænder paa den bagre Raud. Hos Hunnen er det forste Led meget smalt og har kun smaa Borster; de tvende sidste Led ere smale, og det sidste har en skraa afskaret, med smaa Torne besat Griberand.

Det andet Fodpar er kraftigere hos Hannen end hos Hunuen; hos hin er det fjerde Led forlænget, paa den bagre Rand forsynet med Børster, og lidt længere end den forlængede, ovale Haand, der har Børstebundter paa begge Rande. Hos Hunnen er Haanden lidt længere end det foregaaende Led, næsten firkantet, med skraa afskaaret Griberand.

Det tredie og fjerde Fodpars tredie Led er kun lidt udvidet samt noget længere end det fjerde, men neppe længere end det femte Led, hvilket sidste er meget smalere. Kloen er omtrent saa lang som det sidste Led, svagt krummet.

De tre folgende Fodpar tiltage efter hverandre sardeles meget i Langde, det forste Led er $2-3$ Gange saa langt som bredt $o g$ er af en forlænget æodannet Form; det tredie er kun lidet udvidet og meget langere end det fjerde, men ubetydelig kortere end det femte Led. Kloen er liden.

Spring fod der ne naa næsten lige langt bagud.

Det forste Pars ydre Gren er lidt kortere end den indre og omtrent saa lang som Grundleddet; begge Grene have Torne paa den ovre Rand 0 g i Spidsen.

Det andet Par er lidt kortere, men omtrent af den samme Form.

Det sidste Pars Grundled er meget kort; den ydre Gren er dobbelt saa lang som dette, eller lidt kortere; den indre er ubetydelig kortere end den jdre Gren.

Halevedhæuget er liort, paa den ydre Ende forsynet med tvende Knuder, paa hvilke der sees Børster.

Herhen horer maaske $\boldsymbol{M}$. versiculatus, Spence Bate, hvis Han er bestemt af Norman.

Den er fundet af Danielssen i 1859 ved Christiansund, men sjelden, paa 20-30 Farne, paa sandet Bund; af mig ved Aalesund paa 50-100 Favne, af G. O. Sars ved Risvar paa 180-200 Favne; den er efter Bruzelius taget ved Bohuslen og Kullen. Den findes ligeledes ved den engelske Kyst.

AUTONOE PLUMOSA, A. Boeck, 1570.

(Pl. XXV. fig. 3.)

A utonö̈ plumosa, A. Boeck, Crust. amphip. bor. et arct. 1870. p. 159.

Antennæ superiores arliculo pedunculi 2 do multo longiore qvam apud speciem præcedentem. Pedes 1 mi 2dique paris validiores et scopis multis selarum 
instructi. Pedes saltatorii ultimi paris ramis duplo longioribus qvam pedunculo. Cæteroqvin ferme ut apud speciem præcedentem.

Langilen er $6^{\mathrm{mm}}$.

L e gemet er i det Hele meget ligt det hos A. longipes. Hovedet er omtrent saa langt som det forste Legemsled; dets Sidevinkler ere ikke meget udtrukne. Øinene ere ovale.

De øvre Foleres forste Skaftled er saa langt som Hovedet. med nogle Børster paa Enden af den ovre Rand; det andet er meget langere og smalere samt forsynet paa den ovre Rand med enkelte Borsteknipper; det tredie er meget kort. Svoben, der er noget liengere end Skaftet, dannes hos Hannen af omtrent 15 forlængede Led. Bisvoben, der er meget tynd, har 2 Led.

De nedre F qlere ere meget kortere end de ovre. Skaftets fjerde Led er dobbelt saa langt som det tredie og omtrent af samme Langde som det femte Led. Svgben, der er meget kortere, end Skaftets sidste Led, dannes af 6 Led, af hvilke det første er det langste.

I Munddelene stemmer den overeens med den foregaaende Art.

Det forste Fodpar er hos Hannen meget stort, stærkere bygget end det andet Par, men det forste Led er meget kort, bredt, noget krummet; det fjerde er noget kortere end dette, men meget bredt, næsten triangulært; det femte er saa langt, som det foregaaende Led, af en oval Form, med en mere bøiet forreste end bagre Rand; Griberanden er forsynet med tvende Tænder. Kloen er meget krum med fine Saugtakker paa den bagre Rand. Dette Fodpar er paa begge Rande besatte med lange Borster.

Det andet Fodpar er langere, men smalere end det forste Par, især det forste Led; det fjerde er særleles langt, meget længere end det tilsvarende paa det forste Par, og er bredere udad; det femte er meget kortere end det foregaaende Led, af en oval Form, og begge disse Led ere paa begge Rande besatte med txtte Tværrader af lange, krumme Børster.

De tre sidste Fodpar tiltage efter hverandre i Langde, men ere i Forhold meget kortere, end hos den foregaaende Art.

Springfollernes Bygning sternmer overeens med den hos den foregaaende Art. Jeg har fundet denre Art i Christianiafjorden.

Gen. IV. PROTONEDEIA, Krøyer, 1842.

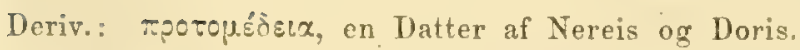

Syn.: 1842. Protomedeia, Kroyer, Nat. Tidsskr. 1. R. 4. B. p. 154.

1870. - $\quad$ A. Boeck, Crust. amphip. bor. et arct. p. 159

Type: Protomedeia fasciata, Kroyer. 
Pedes 2 di paris iisden $1 \mathrm{mi}$ paris validiores el apud marem robustiores qvam apud feminam.

Pedes saltatorii ultimi paris ramo interiore breviore qram exteriore.

Pedes 3tii et 4ti paris ungve sat elongato.

Cæteroqvin ferme ut apud genus Microdeutopus.

Slægten Protomedeia, som var opført af Kroyer i 1842, har længe været forvexlet med andre Slægter. Jeg antog først den af Spence Bate fremsatte Mening rimelig, at den var synonym med den af Zaddach opforte Slægt Leptocheirus, ligesom ogsaa flere andre Zoologer have fulgt ham i denne Anskuelse. Ved at gjennemgaa Krøyers originale Samling i Kjøbenhavn fandt jeg imidlertid, at Protomedeia er en ganske anden Slægt. Det var mig allerede paafaldende ved denne Undersøgelse, at der i de ovrige fra Gronland bragte Samlinger af Amphipoder ikle fandtes nogen Form, der kunde passe til Kroyers Beskrivelse af denne Slægt, og at hieller ikke Goës i sit Arbeide over Spitsbergens Amphipoder, hvori han tillige optager dem fra Gronland, nevner, at den findes ved disse Kyster. Jeg fandt, at Protomedeia fasciata, Kroyer, var den samme som den af Lilljeborg i 1853 beskrevne Gammanus macronyx, og denne er saaledes Typus paa Slægten. Det, som har forvildet de fleste Forskere i denne Retning, er, at Krøyer i Slægtsdiagnosen anfører: „Pedes secundi paris parvi, manu non instructi subcheliformi." Dette er en Skrivfeil for: "Pedes primi paris." Hos Hunnerne er ogsaa det andet Fodpars Haand svagt udviklet, saa at han maaske med Rette kunde sige, at den ikke er subcheliform. Han anforer endvidere: "Pedes tertii qvartiqve paris sat magni, articulus eorum qvintus sextusqve quasi ungvem longissimum sunt coaliti, qvi cum articulo tertio qvartoqve manum qvodammodo efficere videtur prehensilem." Omtrent det samme siger Lilljeborg i 1853: "det tredie Led er meget stort, det femte og Kloen ere forenede," et Forhold, der kun er tilsyneladende. Dana stiller denne Slægt tilligemed Aora til sin femte Underfamilie Pontoporcince.

PROTOMEDEIA FASCIATA, Kroyer, 1842.

(Pl. XXV. fig. 1.)

Protomedeia fasciata, Frøyer, Nat. Tidsskr. 1842. 1. R. IV. p. 154.

- - Spence Bate, Catal. Amphip. Crust. Brit. Mus. 1862. p. 172.

- - A. Boeck, Crust. amphip. bor. et arct. 1870. p. 159.

Gammarus macronyx, Lilljeborg, Kgl. Vet.-Akad. Handl. 1853. p. 458. Öfv. af K̈gl. Vet.-Akad. Förh. 1855. p. 125.

Autonoë macronyx, Bruzelius, Skand. Amphip. Gamm. 1859. p. 29.

- $\quad$ - Goës, Crust. amphip. maris Spetsb. 1865. p. 15.

Microdeutopus macronyx, Spence Bate, Catal. Amphip. Crust. Brit. MIus. 1862. p. 167. 
Antennæ superiores articulo pedunculi 1 mo parum modo breviore qvam 2do. Antennæ inferiores articulo pedunculi 3tio vix duplo longiore qvam crasso. Oculi parvi, ovales. Pedes 1 mi paris manu ovala, parum minore qvam carpo. Pedes 2di paris apud marem carpo dilatato, perlato et longiore qranı manu ovata: ungve perbrevi, curvato; manu feminæ majore qvam carpo, elongata, ovata. Pedes 3tii et $4 \mathrm{ti}$ paris arliculo 3 tio permagno, tto parvo et ovali. 5to perangusto; ungve parum breviore qvam articulo 5 to.

Længden er 8-10ma.

Legemet er temmelig nedtrykt, forlænget; det tredie Haleleds nedre, bagre Vinkel er afrundet. Hovedet er omtrent saa langt, som de tvende første Legemsled tilsammen. Øinene ere smaa, ovale.

De øvre Følere naa, naar de bøies bagud, ikke ganske til det forste Haleled. Skaftets forste Led er omtrent saa langt som Hovedet; det andet er længere og smalere; det tredie er noget længere end Halvdelen af det foregaaende Led og meget smalt. Sroben dannes hos Hannen af omtrent 20 Led; hos Hunnen er den omtrent saa lang som Skaftet og dannes af 15-16 Led. Bisvøben er meget tynd og har 3-5 forlængede Led.

De nedre Folere ere meget kortere end de ørre. Skaftets tredie Led er ikke dobbelt saa langt som bredt; det fjerde og femte ere lige lange. Svøben, der er kortere end Skaftets sidste Led, dannes af 7 Led.

Overlæben er afrundet i Spidsen og besat med fine Borster.

Kindbakkerne ere stæerke; Gribedelen er bred, bøiet, indskaaret i 5-6, og den indre Bigren i 4-5 Tæender; Tyggeknuden er høi, og dens Tandrad er afbrudt ved en lang, fjærdannet Børste i den indre Vinkel. Palpens andet Led er lidt længere end det tredie, der er besat med talrige Børster.

Det forste Kjæbepars ydre Plade er noget krummet, væbnet paa Enden med gaffeldannede Torne; den indre Plade er meget liden, spids paa Enden og forsynet med en Borste. Palpen har i Spidsen stærke, paa den ydre land noget saugtakkede Torne.

Det andet Kjæbepars Plader ere smaa; den ydre er lidt længere end den indre.

Kjæbeføddernes ydre Plade naar frem til Palpens tredie Led og har paa den indre, rette land stærke Tænder, hvilke mod Pladens Ende ere længere og gaa paa dennes ydre Rand over til krumme Børster; den indre Plade er temmelig stor, naar frem omtrent til Palpens andet Led og er paa Enden væbnet med tre stærke Tænder og nogle fjærdannede Børster. Palpens fjerde Led har i Spidsen en stærk Torn og har derfor et kloformet Udseende. 
Det forste Fodpars fjerde Led er ikke meget bredt, med lange Børster paa begge Rande; Haanden er noget kortere, hos Hunnen mere oval, hos Hannen mere ægdannet, med en Knude i den bagre, ydre Vinkel.

Det andet Fodpar er storre end det forste. Hos Hunnen er det omtrent af den samme Bygning; Haanden er af en forlænget oval Form, længere end det foregaaende Led. Hos Hannen er dette Fodpar overmaade stærkt udviklet, hvilket især er Tilfældet med Carpus, som nær Roden er næsten bredere end ved den ydre Ende, længere end Haanden, samt har paa begge Rande, især den bagre, talrige Børstebundter; Haanden er oval, ægdannet, med færre Borstebundter paa den forreste samt korte og stærke lignende paa den bagre Rand, dens Griberand er saugtakket, samt har enkelte Børster og en ștærkere Torn paa Enden af den bagre Rand. Kloen er kort og krum.

Det tredie og fjerde Fodpars tredie Led er forlænget, temmelig bredt, nresten saa langt som de tvende følgende Led tilsammen, og paa den forreste Rand besat med mange Børstebundter; det fjerde er ikke dobbelt saa langt som bredt og har starke Børstebundter paa den bagre Rand; det femte Led er meget længere og smalere, især mod den ydre Ende. Kloen er næsten saa lang som det sidste Led, kun svagt krummet.

De tre folgende Fodpar tiltage efter hverandre i Langde. Det femte Pars første Led er nedad liat smalere.

De tvende forste Par Springfodders ydre Gren er lidt kortere end den indre, især paa det andet $\mathrm{Par}$ og væbnet med stærke Torne paa den gvre Rand og i Spidsen.

Det sidste Pars ydre Gren er omtrent saa lang som Grundleddet og længere end den indre; begge Grene have stærke Torne paa den ovre Rand og i Spidsen.

Halevedhænget er kort, tykt, lidt indskaaret $\mathrm{i}$ den bagre Rand og forsynet med tvende smaa, med Børster besatte Knuder, samit nærmere mod Enden med tvende Kløer.

Den er fundet (alene Hunner) ved Skraven, paa 10-20 Favne, og ved Aalesund af G. 0. Sars. Efter Lilljeborg og Bruzelius findes den fra Finmarken til Kullen, efter Goës ved Spitsbergen og Grønland. Torell har taget den ved Island.

\section{PROTOMEDEIA LONGIMANA, A. Boeck, 1870.}

(Pl. XXV. fig. 4; Pl. XXIX. fig. 5.)

Protomedeia longimana, A. Boeck, Crust. amphip. bor. et arct. 1870. p. 160.

Antennæe superiores articulo pedunculi 1 mo tertiam longitudinis articuli 2 di fere rqvanti aut parum breviori. Antennæ inferiores articulo pedunculi 3tio plus duplo longiore qvam crasso; flagello appendiculari parvulo. Oculi sat magni, ovati, sursum angustiores. Pedes $1 \mathrm{mi}$ paris elongati et angusti; carpo longiore qvam 
manu orali; manu maris in margine posteriore spinis pancis validis armata: manu femina setis modo instrucla. Pedes 2 di paris validiores; carpo longiludinem manus elongatæ et angustæ fere xqvanti; manu maris, non feminæ, in margine posteriore tuberculis duobus armata. Pedes 3 tii et 4 ti paris ungve multo breviore qvam articulo 5to. Pedes trium parium ultimorum longitudine gradatim parum modo crescentes. Pedes saltatorii ultimi paris ramo exteriore paulo longiore qvam pedunculo.

Længden er $6-8^{\mathrm{mm}}$.

Legemet er forlænget smalt; det tredie Haleleds nedre, bagre Vinkel er afrundet. Den anden Sideplade er storre end den forste; de følgende ere næsten rhomboidalske, med afrundede Vinkler. Hovedet er næsten saa langt som de tvende forste Legemsled tilsammen; dets Sidevinkler ere udtrukne, afrundede. Øinene ere store, smalere opad.

De øvre Følere ere korte og naa, naar de boies bagud, til det femte Legemsled. Skaftets forste Led har neppe mere end Hovedets halve Længde; det andet er meget langere og tyndere, det tredie er liortere end det foregaaende Led. Svøben, der er saa lang som Skaftet, dannes af 10 forlængede Led. Bisvøben har 2 Led, hvoraf det yderste er meget lidet.

De nedre Folere ere noget længere end de ovre. Skaftets tredie Led er nasten tre Gange saa langt som bredt og naar frem foran Hovedet; det fjerde og femte ere lige lange. Svøben er kortere end Skaftets sidste Led og dannes af 9 Led.

Det første Fodpars fjerde Led er forlænget, med talrige Børsteknipper paa den bagre Rand; Haanden er oval, kortere end det foregaaende Led, vabnet paa den bagre Rand med fire lorte, men stærke Torne og med en stump Knude nær Kloens Udspring. Hos Hunnen er den bagre Rand besat med Borster.

Det andet Fodpar er hos Hannen meget længere og stærkere end det forste; Haanden er forlænget og saa lang som det foregaaende Led, eller noget læugere end dette, ikke fuldt fire Gange saa lang som bred, samt har hos denne paa Enden af den bagre Rand tvende stumpe Tænder. Kloen er krum og har næsten Halvdelen af det sidste Leds Længde. Hos Hunnen er dette Fodpar neppe stærkere end det første Par.

Det tredie og fjerde Fodpar ere tynde. Kloen er kortere end det sidste Led.

De tre folgende Fodpar ere af den samme Form og Storrelse; det forste Led er forlænget ovalt, mere end dobbelt saa langt som bredt, med fine Saugtakker paa den bagre Rand. Kloen er meget kortere end det sidste Led.

De trende første Par Springfødders ydre Gren er lidt kortere end den indre, begge ere vabnede mnd Torne paa den ovre Rand og i Spidsen. 
Det sidste Pars Grene ere langere end Grundleddet og have nogle tynde Torne i Spidsen.

Farven var paa Spirituspræparater gulbrun, og hele Legemet var spættet med rodbrune, stjerneformede Pletter. Øinene ere sorte.

Den er fundet $\left(q 5^{\mathrm{mm}}\right)$ af G. 0. Sars ved Skraaven paa 10-12 Favne og ved Aalesund paa 50--100 Favne, samt af mig ved Haugesund.

\section{Gen. V. GAMMAROPSIS, Lilljeborg, 1854.}

Deriv.: Gammarus, ö $\psi \iota \varsigma$, Udseende.

Syn.: 1854. Gammaropsis, Lilljeborg, Öfv. af Kgl. Vet.-Akad. Förh. p. 455.

1855. Eurystheus, Spence Bate, Brit. Assoc. Rep. p. 58. Ann. Nat. Hist. 1857.

$$
\text { 2. ser. XIX. p. } 148 .
$$

185\% - White, Pop. Hist. Brit. Crust. p. 181.

1860. Gammaropsis, A. Boeck, Forh. ved de Skand. Naturf. 8de Møde. p. 659.

1862. Eurystheus, Spence Bate, Catal. Amphip. Crust. Brit. Mus. p. 196.

1863. - Spence Bate and Westwood, Brit. sessile-eyed Crust. p. 353.

1870. Gammaropsis, A. Boeck, Crust. amphip. bor. et arct. p. 160.

Type: Gammarus (Gammaropsis) erythrophthalmus, Lilljeborg.

Antennæ superiores articulo pedunculi 3tio perlongo.

Hypostomum antice productum et acuminatum.

Epimerum 4tum maximum.

Pedes $1 \mathrm{mi}$ et 2 di paris utriusqve sexus invicem eadem forma, sed pedes 2 di paris validiores; articulo 5 to manum subcheliformen formanti.

Pedes 3 tii et 4 li paris ungve magnitudinis mediocris.

Pedes saltatorii ultimi paris ramo exteriore paulo breviore qvam interiore.

I 1854 opførte Lilljeborg denne Slægt, idet han fra Slægten Gammarus udskilte de Former, hvis sidste Par Springfødders Grene ere cylindriske og ikke pladeformede, som hos Gammarus locusta, samt hvis Halevedhang er tykt, og hvis Øine ere runde. Hertil regnede han som den forste Art $G$. èrythrophthalmus, som saaledes maa blive Typus paa denne Slægt. De senere Forskere have ikke bemærket denne Lilljeborgs Udsondring af Gammarusarterne under et eget Navn, skjønt hans Arbeide citeres af Flere. Saaledes har Spence Bate opstillet den typiske Art under Navnet Eurystheus tridtentatus nær Slægten Nara og Bruzelius under Navnet Autonoë erythrophthalma. I 1860 optog jeg Lilljeborgs Slægt ligesom i 1870. Heller angiver, at Halevedhanget hos den af ham beskrevne Mcera erythrophthalma, der forøvigt skulde henføres hertil, er dobbelt, og den kan saaledes ikke have sin Plads paa dette Sted. 
GAMMAROPSIS ERYTHROPHTHALMUS, Lilljeborg, 1855.

(Pl. XXV. fig. 6.)

Gammarus (Gammaropsis) erythrophthalmus, Lilljeborg, Kigl. Vet-Akad. Handl. 1853. p. 455. Öfv. af Kgl.Vet.Akad. Förhandl. 1855.p. 124.

Eurystheus tridentatus, Spence Bate, Brit. Assoc. Rep. 1855. p. 58. Ann. Nat. Hist. 1857. 2. ser. XIX. p. 143.

- $\quad$ White, Pop. Hist. Brit. Crust. 185\% p. 181.

Autonoë erythrophthalma, Bruzelius, Skand. Amphip. Gamm. 1859. p. 27.

Eurystheus erythrophthalmus, Spence Bate, Catal. Amphip. Crust. Brit. Mus. 1862.

p. 196. pl. XXXV. fig. 7 .

Spence Bate and Westwood, Brit. sessile-eyed Crust. 1863. p. 354 .

Norman, Rep. on the Shetland Crust. 1868. p. 284.

Gammaropsis erythrophthalmus, A. Boeck, Crust. amphip. bor. et arct.1870. p. 161.

Oculi magni, ovales aut parum reniformes. Angulus lateralis capitis antice acutus. Hypostomum antice longe productum et acuminatum. Epimerum 4tum tam altum sed multo latius qvan epimerum 3tium. Segmentum postabdominis 3tium angulo inferiore posteriore sursum produclo et acuto; segmentum 4tum postice in medio dentibus duobus minutis armatum. Antenna superiores articulo pedunculi 2 do et 3tio longitudine fere rqvalibus; articulo 1 mo multo breviore et crassiore. Flagellum pedunculi paulo brevius, articulis circiter qvindecim, flagellum appendiculare longum, articulis qvatuor. Pedes 2di paris manu maris multo longiore qvam carpo, apicem versus dilatata, in acie obliqve truncata et tuberculis tribus instructa. manu femina multo minore, ovali, in acie tuberculis duobus pradita. Pedes 3 tii et 4 ti paris ungve multo minore qvam articulo 5to. Pedes saltatorii ultimi paris ramo interiore longitudinem pedunculi fere axvanti. Appendix caudalis postice truncata, in fine marginis posterioris spinis duabus armata.

Liengden er $7^{m m}$.

Legemet er meget nedtrykt; Ryggen er glat; de tre første Haleleds nedre, bagre Vinkel er noget udtrukket, med en spids Fremstaaenhed; det fjerde har paa Midten af den bagre Rand tvende smaa Tander. Den fjerde Sideplade er meget bredere end den tredie og af den samme Høide. Hovedet er langere end det første Legemsled; dets Sidevinkler gaa ud i en oval, tilspidset Forlængelse mellem de ovre og nedre Folere, og paa hvilken de $\mathrm{i}$ den forreste Kant noget indbøiede Øine have sin Plads.

De øvre Følere, der ere forsynede med Børsteknipper paa den undre Rand, 
naa, naar de bøies bagud, omtrent til det første Haleled og ere meget tynde. Skaftets første Led er omtrent saa langt som Hovedet og har en liden Tand paa Enden af den undre Rand; det andet er noget længere og smalere; det tredie er saa langt som det foregaaende Led, eller lidt kortere end dette, og begge have Børstebundter paa den undre Rand. Svøben, der er omtrent saa lang som Skaftets tvende sidste Led, dannes af omtrent 15 Led, hvoraf det første er meget længere end hver af de følgende. Bisvøben, der er længere end Svøbens forste Led, har 4 forlængede, smale Led.

De nedre Folere, der ere frestede paa Hovedets undre Side, bag de ovre, ere næsten af den samme Længde, som disse, Skaftets tvende første Led ere korte og sammensmeltede, samt springe frem paa den undre Rand i en lang Lugteknude; det tredie er meget kort; de tvende sidste ere lige lange og besatte med Borster paa den undre Rand. Svoben, der er liengere end Skaftets sidste Led, dannes af 10 Led, med Børster paa den undre Rand; dens forste Led er længere end de tvende folgende tilsammen.

Overlæben har en eiendommelig Form, idet den bestaar af en rund, noget udhulet Plade, med en lang, tornlignende. Forlængelse.

Kindbakkerne ere meget stærke, delte i Spidsen; Gribedelen har fem, den indre Bigren fire Tonder; Tornerækken dannes af meget brede Borster; Tyggeknuden er meget fremstaaende. Palpens tredie Led er kortere, end det andet, forlæuget ovalt; paa begge Rande sees mange Børster, af hvilke nogle ere fjærdannede.

Det første Kjæbepars ydre Plade har paa Enden mange, i Spidsen delte, eller med Bitrender forsynede stierke Torne; den indre Plade er ikke meget stor, med en liden Torn i Spidsen. Palpens andet Led har paa Enden stærke Torne.

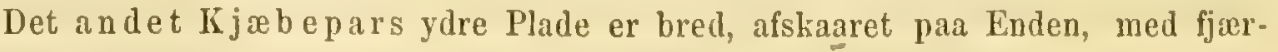
dannede Børster; den indre Plade er oval, bred, med tætte Rækker af Børster paa Enden og den ydre Flade.

Kjæbefødderne ere stærke; den ydre Plade er bred, naar næsten til Enden af Palpens andet Led og har paa den indre Rand og ved Enden af denne Tværrader af smaa Tænder, der ere bredere og længere mod Pladens Ende og gaa tilsidst over til krumme Børster; den indre Plade er forlænget, Enden er bred og forsynet med tvende Tæuder og flere Borster, den indre Rand har fjærdannede Borster. Palpens tredie Led er kun halvt saa langt som det andet, afrundet paa Enden, paa hvilken der sees mange fine Børster.

Det forste Fodpar er forlænget smait; det andet og tredie Led ere meget korte; det fjerde er langt, bredere mod den ydre Ende og besat paa den bagre Rand med Borster; Haanden er kortere end det foregaaende Led, af en oval Form, med mange Tværrader af Børster og med skraa afskaaren Griberand. Kloen er kort, med Tænder paa den bagre Rand.

Det andet Fodpar er noget længere og starkere end det foregaaende; det fjerde Led er noget kortere og bredere; Haanden er forlænget oval, længere end det 
foregaaende Led, og begge Rande, især den bagre, ere forsynede med Borsteknipper; Griberanden, der er skraa afskaaret, er hos Hannen bueformet indskaaret og har tre Fremstaaenheder samt en starkere Torn foruden mange Børsteknipper; hos Hunnen, hvis Haand er mindre og svagere udviklet, sees et Par smaa Fremspring paa den mindre udtalte Griberand. Kloen har Saugtakker paa den bagre Rand.

Det tredie og fjerde Fodpar ere meget smale; det tredie Led er kun lidet udvidet mod Enden; det fjerde er kortere, det femte længere og smalere. Kloen er svagt krummet, halv saa lang som det sidste Led.

De tre folgende Fodpar tiltage efter hverandre i Langde; det forste Led er forlænget ægdannet, smalere mod den ydre Ende; det fjerde er kortere, det femte meget længere end det tredie Led. Ieddenes forreste Rand have Torneknipper. Kloen er kort.

Springfodderne naa næsten lige Iangt bagud; den ydre Gren er lidt kortere end den indre, og begge ere stærkt væbnede med Torne. Det sidste Pars Grene have den samme Længde som Grundleddet.

Halevedhænget er bredt ovalt, med tvende Torne nær den ydre Ende.

Farven er efter Bruzelius gulagtig hvid.

Den findes fra Nordkap, hvor den er taget af R. Collett, til Bohuslen og Kullen, efter Lilljeborg og Bruzelius, ligeledes ved de engelske Kyster efter Spence Bate, og ved Shetland efter Norman.

Gen. VI. PODOCEROPSIS, A. Boeck, 1870.

Deriv.: Podóceros, öụı, Udseende.

Syn.: 1860. Podoceropsis, A. Boeck, Forh. ved de skand. Naturf. 8de Møde. p. 666.

1862. Nenia, Spence Bate, Catal. Amphip. Crust. Brit. Mus. p. 271.

1863. - Spence Bate and Westwood, Brit. sessile-eyed Crust. p. 471.

1870. Podoceropsis, A. Boeck, Crust. amphip. bor. et arct. p. 162.

Type: Podoceropsis Sophice, A. Boeck.

Antenne superiores articulo pedunculi 3tio pralongato; flagello accessorio absenti.

Pedes 2 di paris iisdem $1 \mathrm{mi}$ paris majores et apud marem multo validiores qvam apud feminam.

Pedes 3 tii et 4 li paris ungve parvo.

Pedes saltatorii ultimi paris ramis invicem aqvalibus.

Paa en ny Art Podoceropsis Sophice fra Farsund opstillede jeg denne Slagt i 1860. Den samme blev af Spence Bate i 1862 kallt Nrenia tubcrulosa, og han skiller Slægten fra Eurystheus, væsentlig ved, at de øvre Følere mangle Bisvøbe, og ved at det 
andet Fodpars Haand er storre. Han nevner ikke i Slagtskarakteren, men tegner dog de ovre Foleres meget forlængede tredie Skaftled. Han stiller den nær Siphonoecetus og Cerapus til Underfamilien Podlocerides og til Familien Corophide, medens Slagten Eurystheus henføres til Gammaride.

\section{PODOCEROPSIS SOPHIA, A. Boeck, 1860.}

(Pl. XXV, fig. 7.)

Podoceropsis Sophic, A. Boeck, Forh. ved de skand. Naturf. 8de Møde. 1860. p. 666.

- - A. Boeck, Crust. amphip. bor. et arct. 1870. p. 162.

Nania tuberculosa, Spence Bate, Catal. Amphip. Crust. Brit. Mus. 1862. p. 271. pl. XLVI. fig. 2.

Spence Bate and Westwood, Brit. sessile-eyed Crust. 1863.p. 472.

Antenne superiores articulo pedunculi 3́tio breviore qvam articulo 2do, longitudinem articuli 1 mi fere reqvanti sed tamen multo graciliore. Oculi magni, reniformes, ovales. Pedes 1 mi paris manu ovata, breviore qvam carpo. Pedes 2di paris manu maris multo majores qvam carpo, oblonga el ovata, bis aut ter longiore qvam lata, in media acie tuberculis duobus armata; manu feminx multo minore, attamen lata, in acie obliqve truncata et serrata; ungve etiam serrato. Pedes 3tii et 4 ti paris articulo 4 to multo breviore qvam 5to. Pedes trium párium nltimorum articulo 1 mo non perlato, in angulo inferiore posteriore paulo producto et rotundato. Pedes saltatorii ultimi paris ramis longitudinem pedunculi fere aqvantibus.

I. $x$ ngden er $5-7 \mathrm{~mm}$.

L egemet er noget sammentrykt; Ryggen er glat. De fire første Legemsled afvige ikke meget med Hensyn til Størrelse. Hovedet er ikke saa langt som de tvende forste Legemsled tilsammen, meget smalere i den ydre Ende; dets Sidevinkler ere afrundede. Øinene ere store, næsten ovale, med meget store Facetter.

De øvre Følere naa, naar de boies bagud, til det forste eller andet Haleled. Skaftets første Led er noget kortere end Hovedet; det andet er næsten dobbelt saa langt; det tredie er noget længere end det første Led. De tvende sidste Led have Børsteknipper paa den undre Rand. Svoben er meget kortere end Skaftet og dannes af 8-12 forlængede, med Børster paa den undre Rand forsynede Led.

De nedre Følere, der udspringe langt bag de øvre, paa Hovedets undre Side, ere lidt kortere end de øvre. Skaftets andet Led er lidt længere end bredt og udsender en liden Lugteknude; det tredie er omtrent dobbelt saa langt som bredt og naar noget længere frem end til Hovedets Ende; det fjerde og femte ere omtrent lige lange, af den samme Langde som de ovre Foleres andet Led, og begge have lange 
Børsteknipper paa den undre Rand. Svøben, der er længere end Skaftets sidste Led, dannes af 7 forlængede Led.

Kindbakkerne ere store, delte og tandede i Spidsen. Palpen er lang, trelediet.

Det forste Kjæbepars ydre Plade har paa Enden stærke Børster og lignende paa den indre Rand; den indre Plade er liden, oval. Palpens sidste Led har paa Enden nogle stumpe Tæ̉nder og en langere Torn paa den ydre Rand.

Det andet $\mathrm{Kj}$ æb epars Plader ere omtrent lige lange; den indre har foruden Børster en stærkere Torn.

Kjæbef $ø$ ddernes ydre Plade er smal, naar næsten frem til Enden af Pal- . pens andet Led og har paa den indre, rette Rand fem stumpe Trender, mellem hvilke sees Borster; den indre Plade naar neppe frem til Enden af Palpens første Led og har paa den ret afskaarne Ende tre Tander og nogle Børster. Palpens fjerde Led bliver kloformet, ved at det har en stærk Torn paa Enden.

Det forste Fodpars fjerde Led er kortere, men bredere end det forste og, ligesom det tredie Led, besat paa den bagre Rand med lange Børster; det femte er ubetydelig kortere end det foregaaende Led, ovalt forlænget, med en mere convex, fint saugtakket, bagre Rand. Kloen er lang, noget krummet, med Torne paa den bagre Rand.

Det andet Fodpar er stærkere end det forste, hos Hunnen meget mindre, end hos Hannen; hos denne sidste er det femte Led omtrent saa langt som det første, forlænget ovalt, med en Indboining paa Midten af den bagre Rand, foran hvilken sees tvende store stumpe Tænder; Kloen er lang, krum, ned Saugtakker paa den bagre Rand. Hos Hunnen er Haanden meget mindre, noget længere end bred ved den ydre Ende, med en skraa afskaaret Griberand, der kun er forsynet med et Fremspring og fine Saugtakker; Kloen er mindre stærk end hos Hannen, saugtakket paa den bagre Rand.

Det tredie og fjerde Fodpars tredie Led er hortere end det forste, med en noget udtrukket forreste, nedre Vinkel; det fjerde er neppe længere end bredt; det femte er kortere og smalere end det tredie Led. Kloen er meget kortere end det sidste Led.

De tre folgende Fodpar tiltage efter hverandre i Længde; det forste Led er ikke meget bredt, ovalt, med en lidt udtrukket, næsten ret afskaaret nedre, bagre Vinkel; det tredie er meget kortere end det forste; det femte er kun noget længere end det foregaaende Led.

Springfødderne naa alle lige langt bagud; Grenene ere coniske, uden Torne, lige lange, eller den ydre er ubetydelig kortere end den. indre. Det sidste Pars Grene ere lidt læengere end Grundleddet.

Halevedhænget er kort.

Farven var hos en agbærende Hun graasort, med en brun, bred Rand langs Ryggen. 
Den er fundet af mig ved Farsund paa 15 Favnes Dybde og af G. 0. Sars ved Hvidingsøerne. Efter Spence Bate og Westwood er den taget paa flere Steder ved de engelske og irske Kyster.

\section{Familia}

PODOCERID Æ, A. Boeck, 1872.

Mandibulæ validæ, in apice perdentatæ; ramo accessorio etiam dentato; tuberculo molari prominenti; serie spinarum ex spinis multis, sæpe validis, in mar- gine convexo serratis, composita; palpo elongato, 3articulato, sxpe pervalido.

Labium inferius lamina interna magna.

Maxillæ $1 \mathrm{mi}$ paris lamina interiore parvula.

Maxillæ 2di paris laminis latis.

Pedes maxillares laminis exterioribus in margine interiore dentibus validis armalis; articulo palpi 4 to non ungviforme, sed in apice spinis duabus curvatis armato.

Corpus compressum seu subdepressum, dorso rotundato.

Antennæ superiores flagello accessorio brevi aut absenti.

Pedes 1 mi paris iisdem 2di paris minores, manu subcheliforme instructi.

Pedes 2di paris manu subcheliformi, interdum cheliformi.

Pedes trium parium ultimorum longitudine gradatim crescentes.

Pedes saltatorii ultimi paris 1 - aut 2-ramosi.

Appendix caudalis crassa.

Denne Familie indbefatter tvende Underfamilier Amphithoince og Podocerince.

Subfamilia $I$.

AMPHITHOINA, A. Boeck, 1870.

Syn.: 1870. Amphithoine, A. Boeck, Crust. amphip. bor. et arct. p. 162.

Mandibulæ in apice perdentatæ, robustæ; ramo accessorio etiam dentato; tuberculo molari prominenli; serie spinarum ex spinis multis, validis, in margine convexo serratis, composita; palpo elongato, 3articulato.

Labium inferius laciniis exterioribus in apice profunde incisis; laciniis interioribus magnis.

Maxilla $1 \mathrm{mi}$ paris lamina interiore parvula.

Maxilla 2di paris laminis latis. 
Pedes maxillares laninis exterioribus in margine interiore dentibus validis armatis; palpo robusto sed non longo; articulo palpi 4 to non ungviformi sed in apice spinis duabus curvatis armato.

Corpus compressum; epimeris mediocribus, in margine interiore non plumosis; epimero 5 to tam alto sed latiore qvam 4 to, in margine posteriore pro pedibus 5to paris retroversis inciso.

Antennæ superiores tenues; articulo pedunculi 3tio perbrevi; flagello longo: flagello accessorio absenti.

Antennæ inferiores flagello brevissimo.

Pedes $1 \mathrm{mi}$ et 2 di paris manu subcheliformi instructi; manu $1 \mathrm{mi}$ paris endem forma ac 2 di paris: pedes $2 d i$ paris validiores apul marem qram apud feminam.

Pedes 5ti paris retroversi.

Pedes trium parium ultimorum longiludine gradatim crescentes.

Pedes saltatorii biramei; pedes ultimi paris ramis parvulis; ramo exteriore ungvibus duobus instructo.

Appendix caudalis crassa.

Denne Underfamilie, der indbefatter tvende Slægter, Amphithoë og Sunamphithoë, foruden Here fremmede, skiller sig i det Ydre fra den folgende Podocerince, ved at den femte Sideplade er større end den fjerde, samt ved at det femte Fodpar ikke, som sædvanligt er Tilfældet, vender nedad, men bagud, i hvilken Henseende den ligner Underfamilien Photince. Denne Stilling af det femte Fodpar tjener til, at Dyret derved med Kraft kan skyde sig ud af sit Hus, naar det vil fange sit Bytte. Fra Photince skiller den sig ved det sidste Par Springfødders korte Grene, af hvilke den ydre har tvende stærke Kløer. I Munddelenes Bygning afviger den fra den nærmest staaende Underfamilie Podocerince i Særdeleshed ved Underlæbens karakteristiske Form, idet dens ydre Flige ere dybt indskaarne i Spidsen, lvvilket ikke er Tilfældet hos andre Amphipoder.

Gen. I. AMPHITHÖ̈, Leach, 1813.

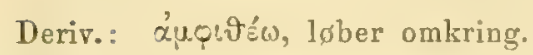

Syn.: 1813. Amphithoë, Leach, Edinb. Encyc. VII. p. 402. Linn. Trans. XI. p. 361.

- Cymadusa, Savigny, Egypte. Crust. pl. 26.

183\%. Amphithoë, Rathke, z. Fauna d. Krym. p. 241.

1852. - Dana, U. S. explor。 exped. p. 935.

185\% - White, Hist. Brit. Crust. p. 200.

- $\quad-\quad$ Spence Bate, Ann. Nat. Hist. 2. ser. XIX. p. $14 \%$.

- Pleonexes, Spence Bate, Aun. Nat. Hist. 2. ser. XIX. p. 147. 
Syı.: 1859. Amp hithoë, Bruzelius, Skand. Amphip. Gamm. p. 30.

\begin{tabular}{|c|c|c|}
\hline 1860. & 一 & A. Boeck, Forh. ved de skand. Naturf. 8de Møde. p. 668. \\
\hline 15 & & Spence Bate, Catal. Amphip. Crust. Brit. Mus. p. 233. \\
\hline 186 & & nd Westwood, Brit. sessile \\
\hline
\end{tabular}

Type: Cancer (Gammarus) rubricatus, Montagu.

Mandibula articulo palpo 3 tio non perdilatato, longitudinem articulo 2 di ferme aqvanti.

Pedes $1 \mathrm{mi}$ et 2di paris ungve dentato; pedes 2di paris iisdem $1 \mathrm{mi}$ paris validiores.

Leach opforte i 1813 denue Slægt, hvis typiske Art er Cancer (Gammanis) nbricatus, Montagu. Hertil er af Milne-Edwards henfort alle de Amphipodearter, som ligne Slægten Gammarus, men som mangle den lille Bisvobe paa de øvre Følere, hvis tvende forste Fodpar ere forsynede med en mer eller mindre fuldkommen Griberand, hvis fem folgende Fodpar ikke ere gribende, og endelig hvis ovre Folere ere længere, end de nedre Foleres Skaft. Derved inddrog han herunder Leachs Slægter Pherusa og Dexamine. Han henforte hertil ikke mindre end 26 bestemte Arter, foruden nogle, som han kun med 'Tvivl kunde stille herhen, og han inddelte dem, eftersom Ryggen er afrundet, uden Tænder paa dens Midtlinie, eller forsynet med en Kjøl og med Tænder. Dernæst tog han Hensyn til Formen af Folerne og Fodparrene. Dana udsondrede fra Slægten Amplithoë de Arter, som ikke have et nært Slægtskab med den typiske Art A. mbricata, og i 1852 gav han folgende Diagnose: „Epimeræ maguæ, 5tæ 4tis non breviores, bilobatx, lobo posteriore minimo vel fere obsoleto. Styli caudales postici biramei, ramis perbrevibus, uno (externo) sæpe subconico, apice bi-ungviculato, ungvibus recurvatis, altero lamellato, apice sæpius paulo ciliato et non spinuloso." Han henforte den til sin Underfamilie Gammarince under Familien Gammaridea. Spence Bate stiller den derimod til sin Underfamilie Podocorides og Familien Corophide, hvor den vel nærmere har sin Plads, end den, der er givet den af Dana. Han udsondrede Slægten Sumamphithoë, der alene skiller sig fra Amp̈rithö̈ ved, at Halevedhænget ender i en stærk Hage. Bruzelius udvidede noget hans Slægtskarahterer for at optage A. pygmcea Lilljeb., (P. Reirhardi, Kroy.) Jeg satte disse Slægter i 1870 med en forandret Slixgtskarakter i en Lnderfamilie Amphithoine, der i Mlunddelenes Bygning adskiller sig fra den nærstaaende Podocerince.

AMPHITHOE PODOCEROIDES, Rathke, 1843.

(Pl. XXVI. fig. 5. og Pl. XXVIL. fig. 3.)

Amphithö̈ podoceroides, Rathke, Acta Leop. 1843. XX. p. 79. t. IV. fig. 4.

Lilljeborg, Öfv. af Kgl. Vet.-Akad. Förh. 1852. p. S. 
Anphithoë podoceroides, Bruzelius, Skand. Amphip. Gamm. 1859. p. 31.

Sunamphithoё podoceroides, Spence Bate, Catal. Amphip. Crust. Brit. Mus. 1862. p. 251. pl. XIIII. fig. 7.

Oculi parvi, obliqvi, ovales. Antennæ superiores dimidiam corporis longitudinem parum superantes. Pedes 1 mi paris manu paulo breviore qvam eadem 2 di paris, qvadrangulari, vix duplo longiore qvam lata. Pedes 2 di paris manu maris majore qvam eadem feminx, in acie obliqve truncata; acie manus antice tuberculo, postice spinis duabus validis instructa; margine manus posteriore seriebus multis setarum instructo. Pedes 3 tii et 4 ti paris arliculo 1 mo plus duplo longiore qvam lato. Pedes 5 ti paris articulo 1 mo elongato; articulo 4 to breviore qvam 3tio et longiore qvam lato; articulo 5to angusto, longitudinem articuli 3 tii et 4 ti junctorum ferme reqvanti.

Langden er indtil $20 \mathrm{~mm}$.

L e gemet er ikke meget hoit, dog sammentrykt, Ryggen er rund; de tre første Haleleds nedre, bagre Vinkel er afrundet. Sidepladerne ere af middelmaadig Størrelse; den første er lidt udtrukket i den nedre, forreste Vinkel; de følgende tiltage i Størrelse $0 \mathrm{~g}$ ere afrundede paa den nedre Ende; den fjerde er ikke indskaaret for den femte i den bagre Rand; den femte er noget storre end den foregaaende Sideplade, med en bred Flig paa den øvre Del af den bagre Rand for Befæstelsen af det femte Fodpar. Alle Sideplaāer have Børster paa den nedre, frie Rand. Hovedet er kortere end de trende forste Legemsled tilsammen og danner intet Pandehorn; dets Sidevinkler ere afrundede. Øinene ere skraa ovale.

De øvre Følere ere noget langere end Halvdelen af Legemet og stærke. Skaftets forste Led er omtrent saa langt som Hovedet; det andet er liortere og sma- 
lere; det tredie er meget kort. Svøben, der er længere end Skaftet, dlannes af $30--35$ forlængede Led.

De nedre Folere ere kortere end de øvre, men i det Hele stærkere udviklede. Skaftets fjerde Led er ubetydelig længere end det femte. Svøben, der er længere end Skaftets sidste Led, dannes af $9-15$ Led.

0 verl rben er kort, afrundet i Spidsen.

Kindbakkerne ere meget kraftige, brede, Gribedelen er delt i 6-7 Tæuder, hvoraf de yderste ere de største, og den indre Bigren har 4-5 Trender; Tornerækken dannes af 8-9 stærke, krumme, med fine Bitorne paa den undre Rand forsynede Torne; Tyggeknuden er meget fremstaaende. Palpen er kort og stærk; det tredie Led er længere end det andet, i Spidsen afrundet 0 g der besat merl Børster.

Underlæbens ydre Plader ere meget brede, paa Enden delte i tvende Flige, hvoraf det ene Par sees paa den indre Rand af det andet; de indre Plader ere ovale, tykke.

Det forste $K \mathbf{j} æ b \mathrm{~b}$ ar er kraftigt; den ydre Plade er paa Enden vabnet med Tæender, der ere saugtakkede paa den concave Rand; den indre Plade er meget liden. Palpens andet Led er bredere udad og har paa Enden 5-6 stærke, korte Torne, som paa den ene Side ere liengere end paa den anden.

Det andet $\mathrm{Kj}$ æbe pars Plarler ere iklie meget stærke.

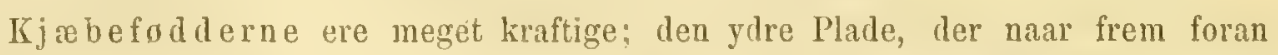
Enden af Palpens andet Led, er fint saugtakket paa den indre Rand og med mange stærke Tænder, der blive længere mod Pladens Ende; den indre Plade naar frem lidt foran Palpens forste Led og har paa Enden en Tand og nogle Borster. Palpen er forlænget; det fjerde Led er kloformet, ved at en stærk Torn danner dets Spids.

Det forste Fodpar er kort, stærkt; det forste Led er kort, krummet, bredere mod den ydre Ende, og dets forreste, nèdre Vinkel er udtrukket, afrundet; det fjerde Led er bredere, mod Enden; Haanden er noget længere end det foregaaende Led, forlænget firkantet, næsten dobbelt saa lang som bred, med en noget sliraa afskaaret Griberand, der har en stærk Torn paa Enden. Kloens bagre Rand er fint saugtakket.

Det andet Fodpar er kraftigere og storre hos Hannen end hos Hunnen; hos hin er det fjerde Led meget kort og Haanden længere end paa det forste Fodpar: Griberanden er forsynet med en stump ophoining samt med tvende, stærkere Torne; den bagre Rand er besat med mange Børster.

Det tredie og fjerde Fodpar ere korte; det forste Led er bredt, dog mere end dobbelt saa langt som bredt, med en mere convex forreste end bagre Rand; det tredie Led, hivis nedre, forreste Vinkel er udtrukket, er kun lidt længere end det fjerde, men næsten af den samme Læengde, som det meget smalere femte Led. Kloen er lidt krummet.

Det femte Fodpar vender bagud og er meget kortere end det folgende Par, som atter er kortere end det syvende Par; det forste Led er saa bredt som langt; 
det tredie, som er lidt udvidet nedad, er langere end det fjerde, men kortere end det smalere femte Led; dette sidste er næsten saa langt som de tvende foregaaende Led tilsammen og er forsynet med en liække Torne langs den bagre Rand.

De tvende folgende Fodpars forste. Led er forlænget, meget smalere og længere end paa det femte Par; de ovrige Led ere ligeledes længere og smalere.

Det første Par Springfødders Grene ere kortere end Grundleddet; den ydre Gren er noget kortere end den indre, og begge have stierke Torne paa den gvre Rand.

Det andet $\mathrm{Par}$ er kortere end det foregaaende.

Det sidste Par er særdeles kort og tykt; Grundleddet har 2-4 Torne paa Enden af den ovre Rand; den ydre Gren er vrbnet med tvende stærke, krumme Torne paa Enden, (paa et af Sars i Nordland fundet $15^{\mathrm{mm}}$ langt Exemplar saaes tre Torne); den indre Gren har tvende meget smaa Torne og mange Borster.

Halevedhænget er næsten saa bredt ved Roden som langt, smalere mod Enden, der er ret afskaaret; de ydre bagre Vinkler ere vabnede med en bøiet Torn og nærmere Midtranden med tvende Børsteknipper.

Spence Bate har henfort denne Art til Slægten Sunamplithoë, fordi Bruzelius, hvis Beskrivelse han har fulgt, omtaler, at Halevedhrenget paa den ydre Ende har tvende korte, boiede Torne.

Farven el gronagtig brun paa Ryggen, lysere paa Siderne, med hvide Punliter eller Pletter nær Bugen, Fodderne ere hvidgule.

Den findes langs Norges Vestkyst fra Vadsø, hvor Danielssen har taget den i Tangen, og gaar lige til Bohuslen; ifolge M. Sars er den hyppig i Stranden mellem Tang ved Nordlands og Finmarkens Kyster. Efter Kroyer er den taget ved Forøerne og Island, og ifolge engelske Forskere paa flere Steler ved Englands liyster, ved Shetland efier Norman.

\section{AMPHITHOË GRANDIMANA, A. Boeck, 1860.}

(Pl. XXVI, fig. 4.)

Amphithoë grandimana, A. Boeck, Forh. ved de skand. Naturf. Sde Møde. 1860.p. 668.

A. Boeck, Crust. amphip. bor. et arct. 1870, p. 164.

Antennæ superiores dimidiam longitudinem animalis æqvantes. Pedes 2di paris manu marıs pergrandi, tam longa qvam articulis omnibus praecedentibus junctis, oblonga et ovata, in acie crenulata; manu feminre multo minore, in acie obliqve truncata. Pedes 3 tii et 4 ti paris articulo 1 mo multo latiore qran apud speciem pracedentem; articulo 3 tio antice perdilatato. Pedes 5 ti paris articulo 1 mo fere rotundo; articulo tho non longiore qvam lato; articulo 5 to ovali, breviore qvam articulo 3 tio et 4 to junctis. 


\section{Længden er $8 \mathrm{~mm}$.}

Le gemet er i det Hele meget ligt det hos den foregaaende Form. Sidepladerne have fjærdannede Borster paa den nedre, frie Rand. Hovedet er saa langt som de trende første Legemsled tilsammen; dets Sidevinkler ere brede, korte, afrundede. Øinene ere store, noget ovale.

De øvre Folere ere lidt lingere end Dyrets halve Længde. Skaftet er meget kort og er omtrent en Fjerdedel af Folernes Længde; det forste Led er kortere end Hovedet; det andet er kortere og smalere, men meget lingere end det lille tredie Led. Svoben dannes af 26-30 forlængede, paa Enden noget tykkere Led, forsynede med Børsteknipper.

De nedre Folere ere meget kortere, men kraftigere end de ovre. Skaftets tredie Led er meget bredere end langt; det fjerde er længere og smalere end det forste Led paa de ovre Folere; det femte er kortere og smalere end det foregaaende Led. Svøben, der er ikke fuldt saa lang som Skaftets tvende sidste Led tilsammen, dannes af 12 med Børsteknipper forsynede Led.

Overlæben er svagt indboiet paa den nedre, frie Ende.

Kindbakkerne ere meget stærke; Gribedelen er delt i otte, den indre Bigren i sex Tænder; Tornerækken dannes af otte, med fine Bitorne besatte Borster; Tyggeknuden er meget fremstaaende.

Det forste Kjæbepar er kraftigt udviklet; den ydre Plade har paa Enden stærke, med Bitorne besatte Tænder; den indre Plade er liden, med en kort Borste par Enden. Palpen er forlænget smal, med 3-4 Torne paa Enden af det sidste Led.

Det andet $\mathrm{Kj}$ xbepars ydre Plade er noget bredere end den indre.

Underlæbens ydre Pladers dybt indskaarne Sideforlængelser ere seglformede, de indre Plader ere vel udviklede, ovale.

Kjæbefødderne ere stærke; den ydre Plade har langs den indre Rand tolv Tænder, af hvilke hver har tvende smaa Bitænder nær Spidsen, mod Pladens Ende forlange de sig til krumme Torne og ga paa Enden af den ydre Rand over til krumme Børster; den indre Plade har tynde Torne i Spidsen og fjærdannede Børster langs den indre Rand. Palpen er kort.

Det forste Fodpar er forlænget; det forste Leds bagre Rand er udvidet, og dets nedre, forreste Vinkel er afrundet; det fjerde er længere end bredt, lidet udvidet bagtil og der besat med Børster; Haanden er forlænget firkantet, med noget bøiede Rande og med Tværrader af Børster paa den forreste Rand. Kloen er længere end Griberanden.

Det andet Fodpar er hos Hannen meget stort; det fjerde Led er kort, og dets nedre, bagre Vinkel er udtrukket til et lidet Fremspring, besat med Borster; Haanden er omtrent af den samme Længde, som de ovrige Led tilsammen, oval, med en svagt indadbøiet, bagre Rand, ved Lvis Ende sees en T'orn; Griberanden er skraa afskaaret, 
noget uregelmæssig bugtet, forsynet med Børsteknipper. Hos Hunnen er dette Fodpar meget mindre og det sidste Led meget ligt det tilsvarende paa det andet Fodpar.

Det tredie og fjerde Fodpars forste Led er meget bredt, men dog forlænget, med en Indbugtning paa den forreste og bagre Rand, af livilke den forste er mere udvidet; det tredie er mere kort og uividet paa den forreste Rand; det fjerde er længere, men meget smalere; det femte er langere end det foregaaende Led, med Børster paa den bagre Rand.

Det femte Fodpar er meget starkt; det første Led er bredere end hoit, meget udvidet bagtil; det tredie er noget længere end bredt ved den ydre Ende; det fjerde er af den samme Form, men liortere; det fernte er længere, kortere end de tvende foregaaende Led tilsammen, af en forlænget, oval Bygning, med nogle Torne paa den bagre Rands ydre Ende. Kloen er stærk, krumiaet.

Det syvende Fodpar er forlnnget; det første Led er dobbelt saa langt som bredt, med ovale Rande; det tredie er noget kortere end dette, bredere nedad; det fjerde er kortere end det foregaaende Led; det femte er saa langt som det forste Led, med Børsteknipper paa begge Rande.

Springfødderne ere starkt forsynede med Torne.

Det sidste Pars ydre Gren er bred, besat med tvende krumme, stærke Torne; den indre har mange fine Torme og nogle Børster.

Halevedhænget er tykt, med et Børsteknippe paa hver Side.

Denne Form er fundet af mig ved Farsund paa ringe Dybde.

\section{Gen. II SUNAMPHITHOË, Spence Bate, 1855.}

Derivo: o's, med, Amploithoë.

Syn.: 1836? Anisopus, Templeton, the Mag. of Nat. Hist. and Journ. of Zool.

1840. - Milne-Edwards, Hist. des Crust. p. 27.

1855. Sunamphithö̈, Spence Bate, Brit. Assoc. Rep. p. 59. Ann. Nat. Hist. 2. ser. XIX.p. 148. Catal. Amphip. Crust. Brit. Mus. 1862.p. 250.

1857. Synamphithö̈, White, Hist. Brit. Crust. p. 201.

1863. Sunamphithoë, Spence Bate and Westwood, Brit. sessile-eyed Crust.p. 429. 1870. - A. Boeck, Crust. Amphip. bor. et arct. p. 164.

Type: Sunamphithoё hamulus, Spence Bate.

Pedes trium parium posteriorum articulo ultimo deorsum dilatato et manum subcheliformem formanti.

Reliqva cum genere Amphithoë fere conveniunt.

Denne Slægt skal efter Spence Bate, der opstillede den i 1855, men gav den sin Diagnose først i $\mathbf{1 8 5 7}$, skille sig fra Amphithoê alene ved, at Halevedhrnget er udviklet til Formen af en Hage. Den typiske Art maa være S. hamulus, som ogsaa fin- 
des ved Norges Kyster, men hertil kommer efter min Formening S. longicornis, der aldeles mangler saadanne Hager. Jeg tror saaledes, at denne Karakter Intet har at betyde, da det samme tillige er Tilfældet hos Slægter, horende til Underfamilien MFicrodertopine, hos hvilken nogle Former have saadanne Hager, medens de mangle hos andre. Spence Bate henforer til denne Slrgt den typiske Art S. hamulus, foruden tvende æeldre Arter og Amphithoë podoceroides, Rathke. Som forhen omtalt, henhører denne sidste Art til Slægten Amphithoü, hos hvilken næsten alle Arter have de nævnte Hager paa Halevedhænget, som skulde være eiendommelige for Sunamphithoë. Disse tvende Slægter vilde saaledes falde sammen, hvis der ikke gaves en anden Karakter, der generisk kunde adskille den typiske Art fra Slægten Amphithoë. Det er nemlig karakteristisk for Slægten Sunamphithoë, at de tre sidste Fodpars femte Led er udvidet mod den ydre Ende, hvortil desuden kommer en tilskjærpet, med fine Torne besat Griberand, mod hvilken Kloen lægger sig, og som ender $\mathrm{i}$ en eller tvende stærke Torne; den er saaledes subchelat. Denne eiendommelige Karakter er ikke anfort af Spence Bate i hans Beskrivelse af $S$. hamulus, men jeg kan dog ikke tvivle om, at den af mig undersøgte Art er den samme som hans Form, hvorfor jeg har optaget denne Karakter som Slægtsmærke. Jeg skulde tro, at denne Slægt falder sammen med Templetons Slægt Anisopus, men jeg kan intet bestemt afgjore herom, da jeg ikke har havt Anledning til at se hans originale Afhandling. Denne Mening er grundet paa, at Dana anforer i sin Diagnose af denne Slægt: „Pedes 4 postici ac in Icea, (articulo 5to apice dilatato et truncato, ungve in articuli 5 ti extremitatem latiusculam claudente) validiores, articulo 5to apice inferiore dentato." Han henregner den paa Grund af dette Forhold til sin Underfamilie Iccince.

SUNAMPHTHOË HAMULU's, Spence Bate, 1855.

(11. XxVII, fig. 1.)

Sunamplithoё hamulus, Spence Bate, Brit. Assoc. Rep. 1855. p. 59. Ann. Nat. Hist. 1857. 2. ser. XIX. p. 148. Catal. Amphip. Crust. Brit. Mus. 1862. p. 250. pl. XLIII. fig. 5 .

$\begin{array}{lll}\text { - } & \text { - } & \text { White, Hist. Brit. Crust. 1857. p. 202. } \\ \text { - } & \text { - } & \text { Spence Bate and Westwood, Brit. sessile-eyed Crust. 1863.p. } 430 . \\ \text { - } & \text { - } & \text { Norman, Rep. on the Shetland Crust. 1868. p. } 285 . \\ \text { - } & \text { A. Boeck, Crust. amphip. bor. et arct. 1870. p. 165. }\end{array}$

Oculi parvi, rotundi. Antennæ superiores dimidia animalis longitudine breviores; articulo pedunculi 1 mo duplo longiore qram crasso, longitudinem capitis æqvanti. Pedes 2di paris manu maris paulo majore qvam eadem feminæ, elongata, qvadrangulari, in acie obliqve truncata. Pedes 3tii et 4 ti paris arliculo 1 mo elongato; articulis cæeteris brevioribus; articulo 3 tio parum modo dilatatn, 4 to breviore 
qvam lato. Pedes 5ti paris articulo 1 mo in margine posteriore perdilatato, tam lato qvam alto; articulo 4 to breviore qvam lato; manu in acie prope ad basin ungvis dente serrato instructa. Pedes 7 mi paris articulo 1 mo postice non perdilatato; articulo 4 to parum breviore qvam 5to. Appendix caudalis in apice ungvibus duobus instructa.

Længden er $8^{\mathrm{mm}}$.

Legemet er forlænget, temmelig tykt; Ryggen er rund. Sideplarlerne ere af middelmaadig Høide, dog meget høiere end brede, neppe forsynede med Børster paa den nedre Rand. Hovedet er noget kortere end de trende forste Legemsled tilsammen; dets Sidevinkler ere lidt fremstaaende og ligesom trært afskaarne. Dinene ere næsten runde, smaa.

De øvre Følere ere knapt saa lange som Legemets halve Længde. Skaftets forste Led er lidt kortere end Hovedet og har tvende Torne paa Enden af den nedre Rand; de folgende Led aftage i Længde og Tykkelse, saa at det tredie kun er dobbelt saa langt som tykt. Svoben, der er noget længere end Skaftet, dannes af 12 forlængede, mod Enden fortykkede Led, der ere forsynede med en Krands af Borster.

De nedre Folere ere kortere end de ovre. Skaftets tredie Led er saa langt som bredt; det fjerde er dobbelt saa langt, men tyndere, og naar frem omtrent til Enden af de ovre Foleres Skaft; det femte er længere og tyndere end det foregaaende Led, og begge have Borster paa Randene. Svoben er noget kortere end Skaftets tvende sidste Led tilsammen og dannes af 8 Led, med Borsteknipper, især paa den undre Rand.

Det forste Fodpars fjerde Led er næsten ligesidig trekantet; Haanden er forlænget firkantet, lidt bøiet, med en skraa afskaret Griberand. Kloen er noget længere end Griberanden.

Det andet Fodpar er storre end det forste og stærkere hos Hannen end hos Hunnen; de tvende forste Leds nedre, forreste Vinkel danner en udvidet, afrundet Lap; det fjerde er meget kortere end det tilsvarende paa det forste Par, med en forlanget nedre, bagre Vinkel, der er besat med Borster; Haanden er forlanget firkantet, og dens Griberand er skraa afskaaret. Kloen er kortere end denne.

Det tredie og fjerde Fodpars forste Led er stort, forlænget ovalt, med skraa afskaaren øvre og nedre Rand og er noget kortere end de tvende folgende Led tilsammen; det tredie er lidt udvidet nedad, kun lidt længere end bredt, medens det Omvendte er Tilfældet med det fjerde Led; det femte er smalere mod Enden og har sinaa Borster paa den bagre Rand. Kloen er kort.

Det femte Fodp'ars første Led er noget bredere end hoit; det tredie er dobbelt saa langt som bredt, udvidet nedad; det fjerde er kortere ena bredt; det femte er lingere end det tredie Led, bredere nedad og damer en Haand, paa hvis ovale Griberand 
sees tre Torne og nogle Borster samt en i Saugtakker indskaaret Tand nær Roden af den stærke, lirumme Klo.

De tvende folgende Fodpar ere længere, men have et paa den samme Maade udviklet femte Led, der er saa langt som det tredie og langere end det fjerie Led.

Det sidste Par Springfolders ydre Gren er væbnet med tvende strerke, krumme Torne, hvoraf den ene er storre end den anden; den indre Gren er oval, med nogle Torne paa Enden.

Halevedhænget har en krum Torn paa hver Side.

Farven er brungul, Oinene ere rode.

Den er fundet af mig ved Haugesund og Farsund. Den er efter Spence Bate taget paa flere Steder ved de engelske Kyster, ved Shetland af Norman.

SUNAMPHITHOË LONGICORNIS, A. Boeck, $18 \% 0$.

(P1. XxVII. figg. 2.)

Sunamphithö̈ longicornis, A. Boeck, Crust. amphip. bor. et arct. 1870. p. 165.

Antenna prælongatr; superiores inferioribus longitudine circiter æcqvales, longitudinem animalis eqvantes; articulo pedunculi Imo longitudini capitis et articuli 2 di rergali. Antennæ inferiores articulo pedunculi 4 to breviore qvam 5to. Pedes $1 \mathrm{mi}$ paris manu fere qvadrangulari. Pedes 2di paris manu maris permagna, apicem versus latiore, in margine anteriore sinuata, in acie obliqve truncata; manu femina multo minore, paulo longiore qvam eadem $1 \mathrm{mi}$ paris. Pedes 3tii et 4ti paris longiores et angustiores qvam apud speciem pracendentem; articulo 4 to longiore qvam lato. Pedes $7 \mathrm{mi}$ paris articulo ultimo longiore qvam articulo 3tio, apicem versus dilatato. Appendix caudalis ungvibus destituta, in margine posteriore paulum incisa.

L ængden er $7,5^{\mathrm{mm}}$.

Legemet er noget sammentrykt; Ryggen er bred, rund; de tre forste Haleleds nedre, bagre Vinkel er afrundet. Sidepladerne ere af middelmaadig Størrelse; den femte er af den samme Længde som den fjerde, ubetydelig indskaaret bagtil, hvorved dannes en ganske liden Lap. Hovedet er længere end det forste Legemsled og danner intet Pandehorn; dets Sidevinkler ere korte, afrundede

De ovre Folere ere lange og naa, naar de boies bagud, omtrent til det fjerde Haleled. Skaftets forste Led er noget længere end Hovedet; det andet er omtrent af den samme Langde, men smalere; det tredie Led er kort. Svøben, der er noget længere end Skaftet, dannes af 18 Led, forsynede med korte, fine Børster paa den øvre og undre Rand. 
De nedre Følere ere af den samme L.xngde som de ovre, eller noget langere. Skaftets tvende forste Led ere sammensmeltede; det tredie er længere end det foregaaende; det fjerde er mere end dobbelt saa langt som det tredie, men meget smalere; det femte er længere end det foregaaende Led, besat med fine, smaa Børster paa den ovre og undre Rand. Svoben, der er omtrent saa lang som Skaftets sidste Led, dannes af 12 grove Led, med smaa Borster paa den ovre og undre Rand.

0 verlaben er meget forlænget, svagt indskaret i den frie Rand.

Kindbakkerne have en meget forlænget Spids, indskaaret i mange Tænder. Palpen er kort, med nogle, tildels fjærdannede Borster paa det silste Led.

Det forste Kjæbepars ydre Plade er bred, med stærke Torne paa Enden; den indre Plade er liden. Palpen er forlanget smal, krum og har nogle Tæender paa Fuden.

Underlæben dannes af fire Plader, hvoraf de ydre ere trelappede.

Kjæbefoddernes ydre Plade naar lidt længere frem end til Fnden af Palpens andet Led, er bred, med smaa Tænder langs den indre Rand, hvilke mod Pladens Ende blive længere og gaa over til krumme Torne; den indre Plade er kort, med fjordannede Borster paa den indre Rand og i Spidsen. Palpen er kort og stærk.

Det forste Fodpars fjerde Led er uregelmæssig firkantet, med en stump, med Børster besat Fremstaaenhed paa Midten af den bagre Rand; Haanden er forlænget firkantet, ikke fuldt dobbelt saa lang som bred, med en skraa afskaaret Griberand, besat mell fine Borster.

Det andet Fodpar er hos Hannen meget storre og stærkere; det forste Leds nedre, forreste Vinkel udvider og forlænger sig paa den ydre Side; de tre folgende Led ere meget korte; det femte, eller Haanden, er særdeles stor, bredere udad, med en Indbugtning paa Midten af den forreste Rand, og med en skraa afskaaren Griberand. Ḱloen er meget stærk, noget krummet, med en Ophoining paa den bagre Rand. Hos Hunnen er Haanden meget mindre, noget længere end paa det forste Fodpar.

Det tredie og fjerde Fodpar ere ikke meget store; det forste Led er forlænget, udvidet nedad; det fjerde Led er længere end bredt.

De tre folgende Fodpar tiltage efter hverandre noget i Langde, og det sidste danner med den krumme Klo en subchelat Haand. Det femte Fodpars forste Led er ovalt, med en lidet udvidet bagre Rani; det fjerde er længere end bredt; det femte er omtrent saa langt som det tredie Led, meget bredere mod den ydre Ende, $0 \mathrm{~g}$ dets Griberand er forsynet med fine Torne. De tvende folgende Fodpar have en lignende Form; det syvende Pars femte Led er længere end det tredic og det fjerde Led.

De trende forste Par Springfodders Grene ere lige lange og have en Torn paa Enden.

Det sidste Pars Grene ere meget korte; den ydre er bevæbnet med tvende opadbøiede Kløer; den indre har fine Børster. 
Halevedhænget er tykt, længere end bredt ved lioden, ubetydelig klovet i Enden.

Jeg har fundet denne Art ved Haugesund.

Subfamilia II.

PODOCERINE, A. Boeck, $18 \%$.

Syn.: 1856. Podocerini, Costa, R. sui Crost. amfip. del regno di Napoli.

1870. Podlocerince, A. Boeck, Crust. amphip. bor. et arct. p. 165.

Labium superius in apice parum sinuatum.

Iypostomum sæpe valde prominens.

Mandibula pervalida, in apice perdentatr; processu accessorio magno, item perdentato; serie spinarum ex setis multis, latis, in margine convexo serratis, constanti; tuberculo molari permagno et serie dentium inferiore in setas plumosas desinenti; palpo elongato, 3articulato, sæpe pervalido.

Labium inferius latum; lamina interna magna.

Naxilla 1 mi paris palpo spinis paucis elongatis armato; lamina interiore parvula, ovali, setis destituta.

Maxillæ 2di paris late; lamina externa latissima et longiore qvam interiore.

Pedes maxillares laminis mediocribus; lamina interiore dentibus tribus, exteriore permultis validis et apicem versus longiorihus, postice in setas curvatas desinentibus, armatis; palpo permagno; articulo 2 do elongato; articulo 4 to non ungviformi sed in apice spinis duabus curvatis, validis armato.

Corpus subdepressum; dorso rotundato; epimeris parvis.

Oculi in lobis capilis lateralibus siti.

Antennæ superiores pedunculo prælongato; articulo ejusdem 3tio longitudinem 2di fere aqvanti: flagello brevi aut perbrevi: flagello accessorio brevi aut absenti.

Antenne inferiores flagello ex articulis paucis aut multis, nunqvam permultis, composito.

Pedes $1 \mathrm{mi}$ paris subcheliformes, iisdem 2di paris minores.

Pedes 2di paris apud marem majores, subcheliformes, interdum cheliformes, articulo 4to manum efficienti: articulo 5to et ungve policem 2articulatum una formantibus; pedes 2di paris apud feminam semper subcheliformes.

Pedes trium parium ultimorum longitudine gradatim crescentes.

Pedes saltatorii ultimi paris 1- aut 2-ramosi; ramis perbrevibus et dentibus curvatis armatis; pedunculo elongato.

Appendix caudalis crassa, spinis aut dentibus instructa. 
Costa opforte i 1857 en Underfamilie Podocerini, i hvilken han indesluttede Slægterne Erichthonius, Podocerus, Cerapodina og Cerapus. Denne Underfamilie optog jeg i 1870 under Navnet Podocerince og stillede herhen Slægterne Podocenus, Janassa og Cerapus. Fra den foregaaende Underfamilie skiller den sig let i det Ydre ved Sidepladernes Form, idet de her ere meget mindre, og ved Bygningen af det femte Fodpar, ligesom Munddelenes, især Underlæbens, Form tildels er forskjellig.

Gen. I. PODOCERUS, Leach, 1815.

Deriv.: Tóvৎ, Fod; xśpxৎ, Horn.

Syn.: 1815. Podocerus, Leach, Linn. Trans. XI. p. 360.

- Jassa, Leach, Linn. Trans. XI. p. 361.

1825. Podocerus, Desmarest, Consid. s. des Crust.p. 269.

- Jassa, Desmarest, Consid. s. des Crust. p. 269.

1838. Ischyrocerus, Krøyer, Grønl. Amphip. Danske Vid.-Selsk. Skrift. p. 59.

1840. Podocerus, Milne-Edwards, Hist. d. Crust. III. p. 63.

1842. - Kroyer, Nat. Tidsskr. 1. R. IV. p. 162.

1852. - Dana, U. S. explor. exped. p. 832.

- Cratophium, Dana, U. S. explor. exped. p. 841. $\sigma^{7}$.

- Dercothoë, Dana, U. S. oxplor. exped. p. 968. ㅇ.

1855. Podocerus, Gosse, Mar. Zool. p. 141.

185\% - Spence Bate, Ann. Nat. Hist. 2. ser. XIX. p. 148. Catal. Amphip. Crust. Brit. Mus. 1862. \%. 252.

- - White, Hist. Brit. Crust. 1857. p. 197.

- Jassa, White, Hist. Brit. Crust. p. 198.

1859. Podocerus, Bruzelius, Skand. Amphip. Gamm. p. 20.

1863. - Spence, Bate and Westwood, Brit. sessile-eyed Crust. p. 434.

1865. Polloceros, Goës, Crust. amphip. maris Spetsb. p. 16.

1870. Podocerus, A. Boeck, Crust. amphip. bor. et arct.p. 166.

Mandibulæ palpo elongato, non lato; articulo palpi ultimo in apice rotundato et setis plumosis permultis instructo.

Epimera anteriora parva.

Antenna superiores articulo pedunculi 3tio sat elongato; flagello brevi sed multiarticulato; flagello appendiculari parvo.

Pedes 2di paris maximi, apud marem validiores qvam apud feminam; articulo 5to manum subcheliformem formanti.

Pedes 3 tii et 4 ti paris articulo 1 mo parum modo dilatato.

Pedes saltatorii ultimi paris biramei; ramis brevibus sed crassis.

Appendix caudalis crassa. 
Leach opstillede dette Slogtsnavn i 1815, og hans typiske Art er vistnok $P$. variegatus; desuden opførte han Slægterne Jassa, med Arterne J.pulchella og J.pelagica. Disse tvende Slægter, der senere af Flere ere slaaede sammen, bleve begge i 1825 optagne af Desmarest, der aldeles følger Leach. Milne-Edwards, der fandt, at der var en stor Ulighed mellem de tvende under Slægtsnavnet Jassa opforte Arter, henforte den ene, J. pelagica, til Slægten Cerapus, Say, og den anden, J.pulchella, til Slægten Podocerus, hvorved han altsaa inddrog Yavnet Jissu. Dana og Spence Bate forenede disse trende Slægter, men White og Bruzelius optog dem begge. Under Navnet Podocerus har de nævnte tvende Arter af Jassa vret opforte, og Navnet har senere faet Hævd, saaledes at det neppe bor ombyttes, i Særdeleshed da Navnet Jassa allerede forhen har været benyttet. Grunden til, at Bruzelius fandt det rigtigt at optage begge Slægtsnavne, var dell, at han fandt, at Jassa indeholder tvende forskjellige Typer af Arter, idet Folerne hos J. pelagica ere meget grovere, og at de ovre Folere mangle den mangeleddede, smale Bisvobe, som findes hos J. pulchella ifolge Milne-Edwards Tegning efter Leachs originale Exenplar. Han opstiller derfor J.pelagica som Type for Slægten Jassa og henforer J. pulchella til Podocerus. Lilljeborg har allerede vist, at Kroyers Slægt Ischyrocemes maa falde sammen med Podocerus, hvori Bruzelius ogsaa er enig. Derimod hører den af Kroyer beskrevne Art P. Leachii til Slægten Cerapus. Rathke vil ogsaa i 1843 udskille under Nannet Podocerus de af Milne-Edwards under folgende Karakterer sammenstillede Gammarusarter: "Yeux circulaires fausses pattes abdominales de la sixième paire ne portant pas 2 grands articles ciliés," og hvortil han regner sin Gammarus Zebra. Til denne Slægt maa henføres den af Dana opstillede Slægt Cratophium, hvis Arter ere Hanner til de under Navnet Dercothoe opforte Hunner, hvilket jeg har anfort i 1870 .

PODOCERUS LATIPES, Kroyer, 1842.

(Pl. XXIX. fig. 1.)

Ischyrocerus latipes, Kroyer, Nat. Tidsskr. 1842. 1. R. IV. p. 162. Podocerus latipes, Spence Bate, Catal. Amphip. Crust. Brit. Mus. 1862. p. $25 \%$.

A. Boeck, Crust. amphip. bor, et arct. 1870 . p. 167.

Angulus lateralis capitis rotundatus. Pedes 1 mi paris manu perlata, dilatata, triangulari, in angulo rotundata. Pedes 2di paris manu eadem forma sed majore ac 1 mi paris; carpo perbrevi; ungve parum modo breviore qvam manu. Pedes saltatorii ultimi paris ramo exteriore dentibus duobus parvis instructo; ramo interiore edentato.

Længden er $14-15^{\mathrm{mm}}$.

Legemet er forlænget, nedtrylit; Ryggen er rund, bred; det tredie Haleleds nedre, bagre Vinkel er ret. De første Sideplader ere næsten saa brede som hoie; den 
fjerde er kun ubetydelig indskaaret bagtil for den femte, der er meget mindre høi. Hovedet, der er meget fladt, er længere end det første Legemsled og danner fortil, mellem de øvre Folere, en liden fremstaaende Vinkel; dets Sidevinkler ere kun lidet fremstaaende, afrundede. Øinene ere skraa ovale.

De øvre Følere naa, naar de bøies bagud, ikke ganske til det første Haleled. Skaftets første Led er omtrent saa langt som Hovedet; det andet er meget langere; det tredie er saa langt, som det foregaaende, men noget smalere, og alle have talrige Børsteknipper paa den undre Side. Svoben, der er kun lidt længere end Skaftets sidste Led, dannes af 9, med Børsteknipper paa den undre Side besatte korte Led. Bisvoben dannes af 1 lidet Led, der har omtrent den halve Længde af Svobens forste Led.

De nedre Folere ere længere end de øvre. Skaftets første Led er kort; det andet udsender fra den nedre Rand en kort Lugteknude; det tredie er ikke fuldt dobbelt saa langt som bredt; det fjerde er længere og tykkere end de ovre Foleres andet Led; det femte er ubetydelig læengere end det foregaaende Led. Svoben, der er omtrent' saa lang, som Skaftets sidste Led, dannes af 7 Led, af hvilke det første er omtrent saa langt, som de tre folgende tilsammen; de gvrige ere korte.

Kindbakkerne ere stærke; Gribedelen er delt i Tænder, den indre Bigren er stor og tandet; Tornerækken dannes af stærke, brede Børster, der ere saugtakkede paa den convexe Rand; Tyggeknuden er fremstaaende og har, foruden en Række Tænder, nogle fjærdannede Børster. Palpen er forlænget; det tredie Led er kortere end det andet, bredere mod den afrundede Ende og besat paa denne samt paa Randen med lange, tildels fjærdannede Borster.

Det forste Kjæbepars ydre Plade har paa Enden sex stærke Torne, af hvilke de tre ydre ere gaffeldannede; den indre Plade er liden, oval, med Borster paa Enden. Palpen er noget bredere mod den afrundede Ende og har her fire Torne samt lange Borster.

Det andet $\mathrm{Kj} \mathfrak{\mathrm { j }} \mathrm{bepars}$ ydre Plade er noget bredere mod Enden, der er besat med stærke Børster; den indre Plade er smalere og kortere, med en noget skraa afskaaret Ende, der har finere Børster.

Kjæb efødderne ere kraftige; den ydre Plade naar frem næsten til Enden af Palpens andet Led og er paa den indre Rand tæt besat med Tænder, der blive længere mod Pladens Ende, hvor de gaa over til stærkere Borster; den indre Plade naar frem foran Palpens første Led og har tre Tænder paa Enden samt Børster paa den indre Rand. Palpens tredie Led er ontrent halvt saa langt som det andet og er meget tyndere end dette, med ovale Rande; det fjerde har paa Spidsen tvende stærke, lange Torne.

Det forste Fodpars fjerde Led er udvidet paa den bagre Rand og der besat med Børster; Haanden el agdannet, næsten triangulær, en Trediedel længere end bred, med en noget bølgeformet Griberand, der er tæt besat med Børster. Kloen er lang, noget krummet, med Torne paa den bagre Rand. 
Det andet Fodpar er meget storre; det fjerde Led er meget kort, med en udtrukket og med Børster besat nedre, bagre Vinkel; Haanden er meget større end paa det første Fodpar, men af den samme Form, ikke fuldt dobbelt saa lang, som bred, med en noget skraa afskaaret og med tætte Børster besat Griberand. Kloen er ubetydelig kortere end Griberanden.

Det tredie og fjerde Fodpars første Led er ikke meget udvidet; det fjerde er noget kortere end det foregaaende og saa langt som det femte Led. Kloen er kort.

Det femte Fodpars første Led er længere end bredt; det fjerde er meget kortere, og det femte er længere end det tredie Led.

Springfod derne naa næsten lige langt bagud.

Det forste Pars 'ydre Gren er ubetydelig kortere end den indre, og begge ere paa Randene besatte med Torne.

Det sidste Pars Grundled er meget langt; Grenene ere meget korte, den ydre er kortere end den indre og besat med tvende stumpe Tænder paa Enden; den indre Gren har ingen Tænder.

Halevedhxnget er længere end tykt ved Roden, xgdannet, tilspidset, med en Torn paa hver Side af Spidsen.

Denne Art er ifølge lírøyer fundet af Holböll ved Grønland.

PODOCERUS MEGACHEIR, A. Boeck, 1870.

(PI. XXIX. fig. 4.)

Podocerus megacheir, A. Boeck, Crust. amphip. bor. et arct. 1870. p. 167.

Angulus capilis lateralis acutus. Pedes $1 \mathrm{mi}$ paris manu elongata, ovata, multo longiore quam carpo. Pedes 2di paris apud feminam eadem forma ac pedes $1 \mathrm{mi}$ paris, sed carpo breviore et manu majore; manu maris vero prælongata, magna, ovali, circiter ter longiore qvam lata; acie manus prope ad basin ungvis tuberculo instructa. Pedes saltatorii ultimi paris ramo exteriore in apice dente uno armato; ramo interiore inermi.

L $æ \mathrm{ngden}$ er $6^{\mathrm{mm}}$.

Legemet er forlænget; Ryggen er rund. Hovedets Sidevinkler ere tilspidsede.

De øvre Følere naa, naar de bøies bagud, til det tredie Haleled. Skaftets første Led er noget kortere end Hovedet; det andet er længere og smalere; det tredie er af den samme Længde som det foregaaende Led. Svøben, der er længere end Skaftets sidste Led, dannes hos Hannen af 9 forlængede Led, af hvilke det forste er det længste, hos Hunnen af 4 Led. Bisvoben er meget tynd, eenleddet, saa lang som Svobens første Led. Følernes Led have Børstebundter paa den undre Side.

De nedre Følere ere længere end de øvre. Skaftets tredie Led er mere end dobbelt saa langt som bredt; det fjerde er noget længere end de ovre Føleres andet 
Led; det femte er længere end det foregaaende Led. Svøben, der er længere end Skaftets sidste Led, dannes af 11 Led hos Hannen, af 9 hos Hunnen; det første er meget længere end det følgende Led. Følernes undre Side er besat med lange Borstebundter.

Det første Fodpars Haand er hos Hannen større end hos Hunnen, forlænget xgdannet, meget længere end det foregaaende Led.

Det andet Fodpars Haand er hos Hannen af den samme Form som paa det første Fodpar, større end hos Hunnen, noget bøiet mod den ydre Ende, tre Gange saa lang som bred; den ydre Halvdel af den bagre Rand er noget indskaaret. Hos Hunnen er det fjerde Led meget kortere end paa det foregaaende Fodpar; Haanden er stærkere og større.

Det tredie og fjerde Fodpar ere smale; det tredie Led er kun lidet udvidet mod den ydre Ende, meget længere end det fjerde, og saa langt som det femte Led eller lidt kortere end dette. Kloen er halv saa lang som det sidste Led.

De tre følgende Fodpar tiltage efter hverandre meget i Længde; det første Led er i Forhold til Høiden bredest paa det femte Fodpar, og den nedre, bagre Vinkel er lidt udtrukket samt besat med en eller flere Torne; det tredie er smalt, kun lidt udvidet mod den ydre Ende; det fjerde er kortere, det femte længere end det tredie Led.

De tvende forste Par Springfødders ydre Gren er noget kortere end den indre, med Torne paa den øvre Rand, samt med tvende eller flere paa Enden.

Det sidste Pars Grundled er forlænget, smalere ved den ydre Ende og er væbnet paa den ovre Rand med faa, korte Torne; den ydre Gren er kortere end den indre $\mathrm{og}$ har en Torn paa den ydre Ende; den indre Gren er ubevæebnet.

Halevedhænget er forsynet med tvende lange Børster.

Denne Art er fundet af mig ved Haugesund og ved Skraaven paa 300 Favnes Dybde.

\section{PODOCERUS ANGVIPES, Krøyer 1838.}

(Pl. XXVII. fig. 5. 6.)

? Podlocerus cylindricus, Say, Journ. Acad. Philad. 1817. I. pl. 2.

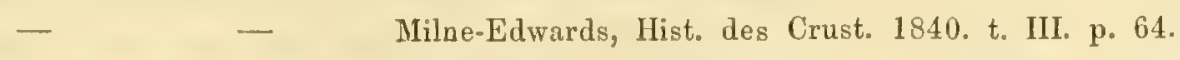

- $\quad$ Spence Bate, Catal. Amphip. Crust. Brit. Mus. 1862. p. 256.

pl. XLIV. fig. 4.

Ischyrocerus angvipes, Kroyer, Gronlands Amphip. Danske Vid.-Selsk. Afh. 1838.

VII. p. 283. t. III. fig. 14. హ. Nat. Tidsskr. 1842. 1. R. IV. p. 162.

Milne-Edwards, Hist. des Crust. 1840. t. III. p. 56.

Gammarus Z Zebra, Rathke, Fauna Norwegens. Acta. Acad. Leop. 1843. t. XX. p. 74. t. III. fig. 4. . 
Ischyrocerus minutus, Lilljeborg, Kgl. Vet.-Akad. Handl. 1850. p. 335. \&.- Öfv. af Kgl. Vet.-Akad. Förhandl. 1855. p. 128.

II. Sars, Forh. i Vid.-Selsk. i Christiania 1858, p. 148.

?Cerapus fucicola, Stimpson, Mar. Invert. Grand Manan. 1854. p. 48. fig. 34.

Podocerus punctatus, Spence Bate, Ann. Nat. Hist. 1857. 2. ser. XIX. p. 148. \&.

Dercothoü (Cerapus) punctatus, Spence Bate, Catal. Amphip. Crust. Brit. Mus. 1862. p. 260. pl. XLIV. fig. 10. ‥

Podocerus largimanus, Heller, Beiträge etc. Denkschr. d. k. k. Acad. d. Wissensch. 1867. 26. B. 2. Abth. p. 46.

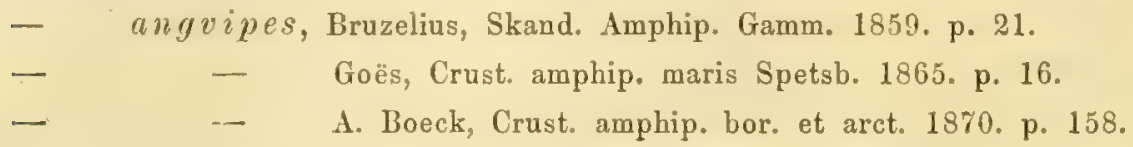

Angulus capilis lateralis nec productus nec acutus. Pedes $1 \mathrm{mi}$ paris manu lata, ovali. Pedes 2di paris apud marem manu ter longiore qvam lata, curvata, infra truncata, in extremo margine posteriore prope ad basin ungvis tuberculo instructa; apud feminam sat breviore, ovali. Pedes saltatorii ultimi paris ramo exteriore in extremo margine superiore dentibus qvatuor instructo; ramo interiore acuminato, edentato.

Læugden er $10^{\mathrm{mm}}$.

Legemet er nedtrykt, ikke meget høit; Ryggen er meget rund, glat; det tredie Haleleds nedre, bagre Vinkel er afrundet. Sidepladerne ere bredere hos Hunnen end hos Hannen. Hovedets Sidevinkler ere afskaarne, eller mere afrundede. Øinene ere smaa, ovale.

De øvre Følere ere noget kortere og smalere end de nedre og have, ligesom disse, Børstebundter paa den undre Side. Skaftets første Led er kortere end Hovedet; det andet er længere; det tredie er lidt kortere end det foregaaende I,ed, eller af den samme Længde som dette. Svøben dannes af 6-8 Led, af hvilke det første er det længste. Bisvoben har 1 Led.

De nedre Folere udspringe bag de øvre paa Hovedets undre Side. Skaftets tredie Led er længere end bredt; det fjerde er næsten tre Gange saa langt som det foregaaende; det femte er lingere end det fjerde Led. Svoben dannes af 7 Led, af hvilke det forste er det længste.

I Mund delenes Bygning er denne Form lig P. latipes.

Det første Fodpar er mindre end det andet, større hos Hannen end hos Hunnen; Haanden er bred oval, med Torne paa den bagre Rand. Kloen er lang, med Torne paa den concave Rand.

Det andet Fodpars Haand er hos Hannen meget storre end hos Hunnen. Hos hin er det fjerde Led kort; Haanden er 3-4 Gange saa lang som bred, svagt 
krummet; den bagre Rand er lidt convex, har talrige Borstebundter og nær Kloens Udspring en stump Tand, hvorpaa sees en Bundt Børster. Hos Hunnen er Haanden næsten ægdannet, lidt indbugtet paa den bagre Rand, samt har tvende stærke Torne, hvor Kloens Spids lagger sig imod, og en ubetydelig, men bred Fremstarenhed nær Randens ydre Ende. Hos den unge Han er Haanden næsten af den samme Form som hos Hunnen, men meget større og uden nogen Indbugtning paa den bagre Rand.

Det tredie og fjerde Fodpar ere længere end de foregaaende, hos Hannen smalere end hos Hunnen; det tredie Led er udvidet nedad; det femte er længere end rlet fjerde, men kortere end det tredie Led.

Det femte Fodpars første Led er bredt ovalt; det tredie er udvidet nedad; det fjerde er meget kortere, det femte længere, men smalere end det tredie Led.

De tvende folgende Fodpar have den samme Bygning, men ere længere.

Springfodderne naa næsten lige langt bagud.

De trende første Pars ydre Gren er kortere end den indre, med Torne paa den øvre Rand og i Spidsen.

Det sidste Pars Grene ere meget korte; den ydre er opadboiet og har paa Enden af den øvre Rand 3-4 Saugtakker eller smaa Tænder, foruden en større, but Endetand; den indre Gren mangler Tænder.

Halevedhænget er tykt, af en afrundet triangulær Form.

F arven er svag straagul, med brede, kirsebærrøde Baand paa Legemsleddene.

Den er fundet af Lilljeborg ved Tromsø, af $[G$. O. Sars og mig ved Skraaven paa 10-20 Favne; ifølge Lilljeborg og Bruzelius gaar den ned til Kullen. Den findes ved Spitsbergen efter Goës, der anfører, at den varierer meget i Legemets Udseende og Formen af Følerne. Ved Grønland og Island er den taget af Torell.

PODOCERUS FALCATUS, Nontagu, 1808.

(PI. XXVII. fig. 4. 7 ; PI. XXVIII. fig. 2.)

Cancer (Gammarus) falcatus, Montagu, Linn. Trans. 1808. IX. p. 100. pl. 5. fig. 1-2. $\sigma^{7}$ jun.

Jass a falcata, Leach, Edinb. Encyc. 1813-1814. VII. p. 433. ơ jun. Linn. Trans.

XI. p. 361 .

- - White, Hist. Brit. Crust. 1857. p. 198.

- pulchella, Leach, Edinb. Encyc. VII. p. 433. o7. Linn. Trans. XI. p. 361.

- - Desmarest, Consid. des Crust. 1825. p. 269.

- - Milne-Edwards, Règne Animal. pI. LXI. fig. 3.

- pelagica, Leach, Edinb. Encyc. VII. p. 433. \&. Linn. Trans. XI. p. 361.

- - Desmarest, Consid. des Crust. 1825. p. 270.

- - White, Cat. Brit. Crust. 1847. p. 54. Hist. Brit. Crust. 185\%. p. 198.

Cerapus pelagicus, Milne-Edwards, Hist. d. Crust. 1840. III. p. $361 . \sigma^{7}$ jun. 
Cerapus falcatus, Thompson, Ann, and Mag. of Nat. Hist. 1847. XX. p. 244.

Podocerus pulchellus, Milne-Edwards, Ann. d. Sei. Nat. Hist. 1830. t. XX. p. 384. o’.

Hist. d. Crust. 1840. p. 64.

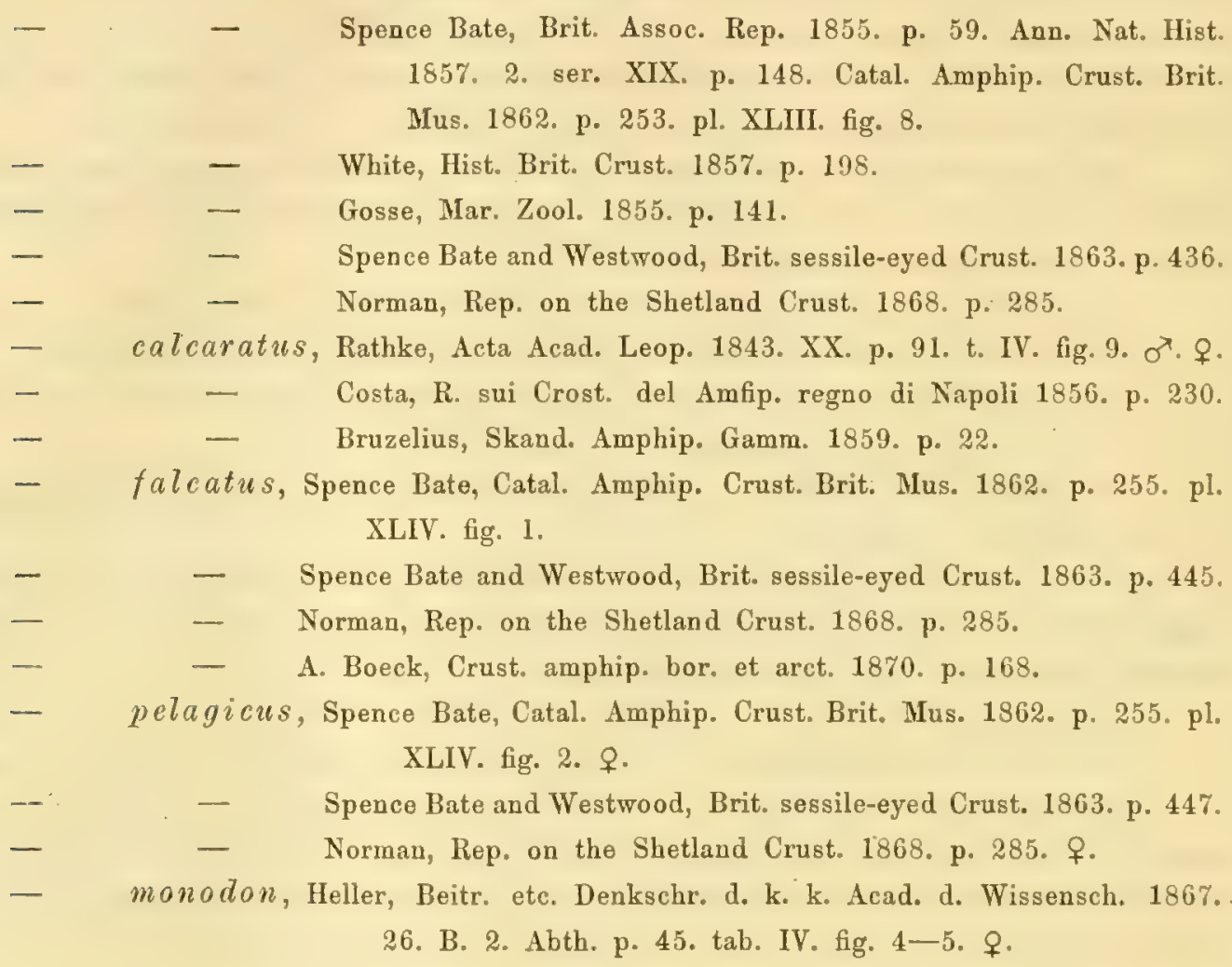

Angulus capitis lateralis rotundatus. Pedes 2 di paris apud marem manu prælongata, curvata, longiore quam articulis præcedentibus junctis, ex summo margine posteriore calcem longam emittenti, in fine marginis ejusdem tuberculo instructa; apud feminam manu ovata, in margine posteriore tuberculis duobus vel tribus instructa. Pedes 3 tii et 4 ti paris articulis brevissimis; articulo 3 tio in angulo inferiore posteriore ad finem articuli 4 ti producto; articuli 5to ovato. Pedes saltatorii ultimi paris ramo exteriore in extremo margine superiore spinis duabus vel tribus armato; ramo interiore in apice dente uno obtuso instructo.

Længden er $9^{\text {mm }}$.

Legemets Form er lig den hos $P$. angvipes.

De øvre Følere naa frem omtrent til Enden af Skaftet paa de nedre Følere $0 \mathrm{~g}$ ere smalere end disse. Skaftets første Led er kortere end Hovedet; det andet er en Trediedel længere; det tredie er noget kortere end det foregaaende, men længere end det første Led. Alle Led have Børsteknipper paa den undre Side. Srøben 
er længere end Skaftets sidste Led og dannes af 7 med Børster paa den undre Rand forsynede Led, af hvilke det forste er det længste. Bisvøben dannes af 1 lidet Led.

De nedre Følere have talrige Børsteknipper paa den undre Side. Skaftets tredie Led er lidt længere end bredt, det femte. Led er omtrent saa langt som det fjerde, men er tyndere end dette. Svoben, der er omtrent saa lang som Skaftets sidste Led, dannes af 5 Led, af hvilke det forste er det længste.

Overlaben er meget bredere end høi, afrundet samt forsynet med smaa Borster.

Kindbakkerne ere meget stærke; Gribedelen er bred, delt i 5-6 Tænder, og den indre Bigren har 4-5 Tænder; Tornerækken dannes af faa, brede, paa den concave Rand tandede eller saugtakkede Torne; Tyggeknuden er meget hoi, og den nedre Tandrad afbrydes $\mathrm{i}$ den indre Kant af en Børste. Palpen er lang; det tredie Led er meget kortere end det andet, afrundet paa Enden og forsynet med mange, tildels fjærdannede Borster.

Det forste $\mathrm{Kj} \rightsquigarrow b$ epars ydre Plade har paa Enden sex stærke Tænder, af hvilke hver paa den concave Rand, nær Spidsen, er væbnet med en liden Bitand; den indre Plade er meget liden. Palpen har paa Enden en Række forlængede Tænder.

Det andet $\mathrm{Kj} \rightsquigarrow \mathrm{b}$ e pars ydre Plade er meget bredere og længere end den indre.

Kjæbeføddernes :ydre' Plade er stor og vabnet paa den indre Rand med talrige, stærke Tænder; den indre Plade er ikke meget stor og naar kun frem til Enden af Palpens første Led. Palpens andet Led er meget langt; det fjerde har i Spidsen $2-3$ stærke Torne.

Det første Fodpar er forlænget; Haanden er ægdannet, med mange Børster * paa den bagre Rand og med en Torn, hvor Kloens Spids lægger sig imod. Kloen er lang, tandet paa den bagre Rand.

Det andet Fodpar er hos Hannen meget større end hos Hunnen; Haanden. er større end de foregaaende Led tilsammen, noget bøiet, og fra den ovre Del af den bagre Rand udgaar der et Fremspring, der er saa langt som Halvdelen af Leddet; nær Kloens Spids sees en tuberkelformet Fremstaaenhed. Hos Hunnen er Haanden noget mere end dobbelt saa lang som bred samt noget krummet; den bagre Rand er indskaaret, hrorved dannes tvende stumpe 'Tænder, den ene nær Enden, og den anden midt paa den bagre Rand. I Fordybningen mellem disse sees flere fjardannede Børster.

Det tredie og fjerde Fodpar ere temmelig stærke; det første Led gaar paa Enden af den forreste Rand ud i en stump Fremragning; det tredie er fortil meget udvidet, og dets nedre, forreste Vinkel er udtrukket næsten til Enden af det fjerde Led, hvilket er neppe saa langt som bredt; det femte Led er kortere end det tredie.

De tre følgende Fodpars første Led er bredere, ovalt, med en udtrukket nedre, bagre Vinkel.

De tvende første Par Springfødders ydre Gren er noget kortere end den indre, med Torne paa den øvre Rand og i Spidsen. 
Det sidste Pars Grundled er tykt, med Torne paa den øvre Rand og nogle Børster paa Enden. Grenene ere meget korte; den ydre er opadboiet, vabnet med trende smaa Kløer; den indre er smalere, med een Klo i Spidsen.

Halevedhinget er paa Enden bredt, kort tilspidset.

F arven er gulhvid, spraglet med brunrøde Pletter, der løbe sammen til større Flekker paa Hovedet, Ryggen, Sidepladerne og paa det andet Fodpar, samt danne Ringe paa Følerne. Paa Halen sees spredte større, stjerneformede Pletter. Øinene see røde ud ved de talrige Lindser i hvidt Felt.

Den er fundet af Danielssen ved Tromsø og ligeledes ved Christiansund og Molde, af mig ved Haugesund paa 20 Favnes Dybde. Den er ligeledes taget paa flere Steder af Kysten samt gaar ned til Bohuslen. Den findes ogsaa ved de engelske Kyster, samt ved Shetland, og er efter Costa fundet ved Neapel, efter Heller i Adriaterhavet.

Gen. II. JANASSA, A. Boeck, 1870.

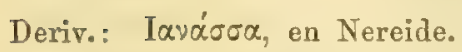

Syn.: 1859. Jassa, Bruzelius, Skand. Amphip. Gamm. p. 18.

1870. Janassa, A. Boeck, Crust. amphip. bor. et arct. p. 169.

Type: Podocerus variegatus, Leach.

Mandibulæ palpo perlato, non vero longo; articulo palpi 3 tio obovato.

Antennæ robustæ, setis densis instructæ; superiores flagello perbrevi, ex articulis paucis (3) constanti; articulo ejusdem 1 mo perlongo; flagello accessorio fere obsoleto.

Antennx inferiores superioribus multo longiores et classiores; flagello ex articulis paucis constanti; articulo ejusdem 1 mo permagno, prælongato.

Corpus subdepressum; epimeris parvis.

Reliqva cum genere Podocerus forme conveniunt.

Bruzelius har adskilt Podocerus capillatus, Rathke, fra Slægten Podocerus og kaldt den Jassa capillata; denne er dog synonym med Podocerus variegatus, Leach, hvilken var Typus for hans Slægt Podocerus. Jassa er saaledes synonym med denne Slægt. Jassa, Leach, er synonym med Podocenus auctorum. Da Navnet Jassa allerede forhen, i 1839, er af Münster benyttet til en Fisk, har jeg kaldt denne Bruzelius's Sligt Janassa.

JANASSA VARIEGATA, Leach, $1813-14$.

(Pl. XXVIII. fig. 1。og Pl. XXIX. fig. 2.)

Podocerus variegatus, Leach, Edinb. Encyc. 1813-14. VII. p. 433. ㅇ. Linn. Trans. XI. p. 361. Suppl. Enc. Brit. I. p. 426. 
Podocerus variegatus, Desmarest, Consid. s. les Crust. 1825. p. 269.

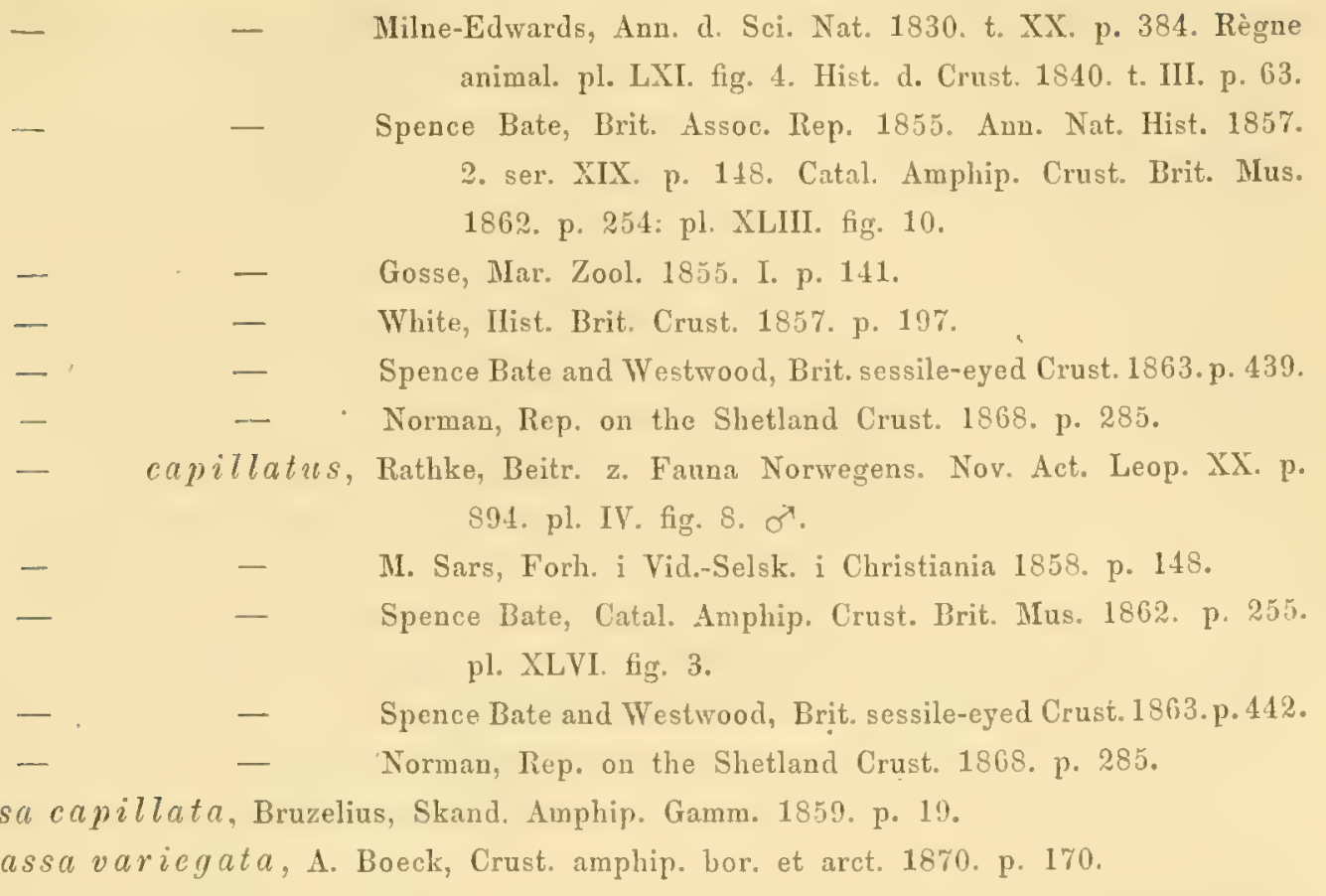

Angulus lateralis capitis productus, subrotundatus. Oculi minimi. Antennæ superiores articulo pedunculi 2 do at 3tio longitudine fere aeqvalibus, longioribus sed angustioribus qvam articulo 1mo: flagello 3articulato; articulo ejusdem 2do et 3tio junctis dimidiam longitudinem articuli $1 \mathrm{mi}$ non apvantibus. Antenne inferiores articulo pedunculi 5to longiore sed angustiore qvam 4to. Pedes 1 mi paris manu ovali, longiore qvam carpo. Pedes 2di paris manu maris multo majore qvam feminx, ovata, in acie profunde incisa et dentibus duobus armata; manu feminæ in acie incisa, tuberculo valido, non dentibus, instructa. Pedes 3 tii et 4 ti paris perbreves et lati. Pedes saltatorii ultimi paris ramo interiore in apice spina una armato; ramo exteriore edentato.

Længd en er 8-9 $9^{\mathrm{min}}$.

Legemet er brealt; Ryggen er glat. Sidepladerne ere smaa; de fire forste tiltage efter hverandre i Storrelse. Hovedet er kort; dets forreste Rand gaar fortil, mellem de øvre Følere ud i et kort, spidst Pandehorn; dets Sidevinkler ere meget udtrukne, lidt afrundede. Øinene, der sidde ved Roden af disse Vinkler, ere meget smaa, ovale.

De øvre Følere ere meget stærke og have paa den øvre Side spredte Bølsteknipper, paa den' undre meget lange, svagt fjærdannede Børster. Skaftets forste Led er kortere end Hovedet; det andet er noget længere og smalere; det tredie er næsten af den samme Længde og Bredde som det foregaaende Led. Svoben dannes af 
et langt første Led, der er noget kortere, end Skaftets sidste Led, og tvende meget smaa Led. Bisvoben er næsten rudimentær.

De nedre Følere ere længere og af en grovere Bygning end de ovre. Skaftets tvende første Led ere sammenvoxne og udsende fra den undre Side en stærk Lugteknude; det tredie er neppe saa langt som tykt; det fjerde er noget kortere og tykkere end det femte Led. Alle Led have paa den øvre og undre Side Børstebundter, hvilke ere talrige paa det sidste Led og ere tildels fjærdannede mod den øvre Sides ydre Ende. Svøben dannes af et langt forste Led, der er smalere, men næsten saa langt, som Skaftets sidste Led, samt af tvende korte Led; ogsaa denne har en txt Rakke borster paa den ovre og undre Side, hvilke paa den forste tildels ere fjærdannede.

Overlæben er meget bred; i Spiasen forsynet med meget smaa Børster.

Kindbakkerne ere meget stærke; Gribedelen er væbnet med sex og den indre Bigren med ligesaa mange stærke Tænder; Tornerækken dannes af tre brede, paa den convexe Side saugtakkede Børster; Tyggeknuden er meget stærk og fremstaaende. Palpen er bred; det andet Led er neppe mere end dobbelt saa langt som bredt; det tredie er bredere udad og er paa den afrundede Ende besat med talrige lange Børster.

Underlæbens Flige ere brede.

Det forste Kjæbepars ydre Plade er bred; den indre er meget liden, noget tilspidset. Palpen dannes af tvende Led.

Det andet $\mathrm{KJ} \mathfrak{\mathrm { J }} \mathrm{bepars}$ Plader ere korte og brede, især den ydre.

Kjæbefoddernes ydre Plade er forlænget, men ikke meget bred, væbnet paa den indre Rand med tætstaaende Tænder, der mod Pladens Ende blive længere og gaa over til krumme Børster; den indre Plade er bred, naar frem til Enden af Palpens forste Led og har paa Enden tre smaa Tænder og langs den indre Rand og paa Enden tildels fjærdannede Børster. Palpen er meget stærk; det tredie Led er bredere mod Enden, der er forsynet med Børster; det fjerde er ikke kloformet, men afrundet paa Enden, hvor der sees tvende meget stærke, forlængede Klør.

Det forste Fodpar er meget mindre og smalere end det andet; Haanden er næsten ægdannet, meget længere end den triangulære Carpus. Kloen er stærk, noget krummet, fint tandet paa den bagre Rand.

Det andet Fodpar er hos Hanuen stærkere end hos Hunnen. Haanden er hos hin bueformet indskaaret paa den bagre Rands ydre Trediedel, hvorved dannes en fortil rettet, stor Tand, der er forsynet med Borster paa den stumpe Ende og den indre Rand; mellem denne store Indskjæring og Kloens Rod sees tvende smaa Indskjæringer, hvorved dannes en mindre Tand. Kloen er stor, krummet, noget tandet paa den bagre Rand. Hos Hunnen er Haanlen meget mindre, med tvende smaa, afrundede Indskjæringer, hvorved dannes et noget større og et mindre afrundet Fremspring.

Det tredie og fjerde Fodpar ere brede; det fjerde Led er kortere og smalere end det tredie; det femte, der er langere end det foregaaende Led, har en æglignende Form. Kloen er kort, stærk. 
Det femte Fodpars forste Led er af en bred, rectangulær Form, og dets nedre, bagre Vinkel er afrundet.

De tvende folgende Fodpar ere af den samme Form som det femte, men det første Leds nedre, bagre Vinkel er tilspidset.

De tvende forste Par Springfodders ydre Gren er kortere end den indre; begge have Torne paa den ovre Rand og i Spidsen.

Det sidste Par naar længst bagud; Grundleddet er langt, conisk; den ydre Gren er glat; den indre har en Torn i Spidsen.

Hal evedhanget er kort, tilspidset, med en Torn paa hver Side.

Farven er efter Bruzelius - der anfører, at det sidste Par Springfødders Grene ere korte, koniske, noget opadbøiede og vabnede i Spislsen med en kort, kroget og grov Torn - brun, mørkere paa Ryggen, lysere paa Siderne.

Den lever i cylindriske Ror, som den danner sig af Sovæxter, og hvis indre Side er overtruklet af en seig Masse.

Den er efter M. Sars hyppig fra Nordkap til Bergen; af Danielssen er den fundet ved Grøtø i Nordland i Tang, samt ved Christiansund og Molde; efter Bruzelius er den ligeledes almindelig ved Bohuslen. Efter Spence Bate og Norman er den taget paa flere Steder ved de engelske Kyster og Shetland; af Heller ved Lessina.

Gen. II. CERAPUS, Say, $181 \%$.

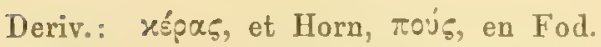

Syn.: 1817. Cerapus, Say, Journ. Acad. Philad. I. p. 49.

1825. - Desmarest, Consid. s. les Crust. p. 271.

1830. -- Milne-Edwards, Ann. d. Sci. Nat. XX. p. 382.

- Erichthonius, Milne-Edwards, Ann. d. Sci. Nat. XX. p. 383. Hist. d. Crust. 1840, t. III. p. 59.

1836. Cerapus, Templeton, Trans. Ent. Soc. I. p. 188.

1840. Cerapodina, Milne-Edwards, Hist. d. Crust. t. III. p. 62.

1842. Podocerus, Krøyer, Nat. Tidsskr. I. R. IV. p. 153.

1852. Pyctilus, Dana, U. S. explor. exped. p. 973.

- Dercothoë, Dana, U. S. explor. exped. p. 968.

1855. Cerapus, Gosse, Mar. Zool. I. p. 140.

- Erichthonius, Spence Bate, Brit. Assoc. Rep. p. 55. Ann. Nat. Hist. 1857.

2. ser. XIX. p. 149.

- $\quad$ - Lilljeborg, Öfr. af Kgl. Vet.-Akad. Förh. p. 131.

1857. Cerapus, White, Hist. Brit. Crust. p. 189.

- Erichthonius, White, Hist. Brit. Crust. p. 196.

- C Costa, R. sui Crost. amfip. del regao di Napoli. p. 227.

1859. - Bruzelius, Skand. Amphip. Gamm. p. 17. 
Syn.: 1862. Cerapus, Spence Bate, Catal. Amphip. Crust. Brit. Mus. p. 262.

1863. - Spence Bate and Westwood, Brit. sessile-eyed Crúst. p. 452.

1865. Erichthonius, Goës, Crust. amphip. maris Spetsb. p. 10.

1870. Cerapus, A. Boeck, Crust. amphip. bor. et arct. p. 170.

Type: Cerapus tubularis, Say.

Hypostomum productum et acuminatum.

Mandibula articulo palpi 3 tio breviore quam 2do, in apice rotundalo.

Antemus superiores flagello elongato; flagello accessorio absenti; articulo pedunculi 3 tio elongato.

Antenne inferiores flagello multiarticulato.

Corpus depressum; dorso lalo; epimero 2do magno; epimeris creteris minimis.

Pedes 1 mi paris utriusqve sexus æqvales; articulo 5to manum subcheliformem formanti.

Pedes 2di paris carpo maris permagno et pervalido, in angulo inferiore posteriore plus minusve producto; articulo 5 to multo angustiore; articulo 5 to et ungve longo una pollicem 2articulatum efficientibus; pedes 2di paris feminæ iisdem maris multo minores; carpo brevi, ex angulo inferiore posteriore calcem emittenti; articulo 5to manum subcheliformem formanti.

Pedes 3tii et 4 ti paris articulo 1 mo perlato.

Pedes saltatorii ultimi paris 1-ramosi; ramo sat brevi.

Appendix caudalis in apice tuberculis spinosis duobus instructa.

Denne Slægt blev i 1817 opstillet af Say paa Arten C. tubularis, og han fremhaver især, at Tommelen paa det andet Forlpars Haand er toleddet, $0 \mathrm{~g}$ at de indre Folere ere firleddede, de ydre femleddede. Milne-Edwards opforte i 1830 Slagten Erichthonius, idet Lan adskilte den fra Cerapus, hvis Svobe kun stiulde bestaa af 1 Led; han grundede desuden Sliegten Cerapodina paa Karakterer, der vare hentede fra Templetons mindre gode Tegning af hans Cerapus abditus. Disse tre Slægter maa falde sammen, ligesom ogsaa Dana's Slægt Pyctilus maa regnes herhen. Krøyer vil i 1842, at Cerapits (Erichthonius) skal gaa ind, da Hunnen aldeles ligner Slægten Podocerus og kun Hannen adskiller sig derfra, hvilket han har seet paa sin Art P. Leachii. „Feminæ hujus speciei (P. Leachii) forma pedum secundi paris Podocerus est, mas vero Erichthonius. Cienus Erichthonius igitur delendum videtur." Lilljeborg optager i 1855 paany Slægten Erichthonius, idet han viser, at den væsentlig skiller sig fra den Art, der var opstillet som Typus for Slrgten Podocerus, ved at det sidste Par Springfødder kun er eengrenet, medens det hos denne er togrenet, og Bruzelius folger ham i denne Anskuelse. Spence Bate henfører kun Hannerne til Slægten Cerapus, medens Hunnerne komme ind under Slægten Siphonoecetus, ligesom han anser de Former, der hen- 
føres under Dana's Slægt Dercothoë, for at være Hunner af Slægten Cerame; han bibeholder dog Slægtsnavnet Derotheё for flere Former, hos hvilke Hannerne ei ere kjendte.

CERAPUS ABDITUS, 'Templeton, 1836.

(Pl. XXVIII. fig. 4.)

Cerapus abditus, Templeton, Trans. Ent. Soc. 1836. I. p. 188. pl. XX. fig. 5.

- - Spence Bate, Catal. Amphip. Crust. Brit. Mrus. 1862. p. 263. pl. XLV. fig. 2.

- $\quad$ - Spence Bate and Westwood, Brit. sessile-eyed Crust. 1863. p. 455.

- - A. Boeck, Crust. amphip. bor. et arct. 1870. p. 171.

Cerapodina abditus, Milne-Edwards, Hist. d. Crust. 1840. t. III. p. 62.

? Cerapus Whitei, Gosse, Nat. Rambles Devonshire coast. 1853. p. 383. pl. XXII. fig. 12. Erichthonius difformis, Spence Bate, Ann. Nat. Hist. 1857. 2. ser. XIX. p. 149.

- $\quad$ - White, Hist. Brit. Crust. 1857. p. 196.

- bidens, Costa, R. sui Crost. amfip. del regno di Napoli. 1853. p. 229. t. IV. fig. 9 .

Sipteonoecetus Kroyeranus, Spence Bate, Brit. Assoc. Rep. 1855. p. 58. ‥

Whitei, Spence Bate, Catal. Amphip. Crust. Brit. Mus. 1862. p. 270. pl. XLV. fig. 10. + .

Siphonoecetes - Spence Bate and Westwood, Brit. sessile-eyed Crust. 1863.p.467. Podacerus punctatus , Spence Bate, Ann. Nat. Hist. 1857. 2. ser. XIX. p. 148.

Dercothoü (Cerapus Q) punctatus, Spence Bate, Catal. Amphip. Crust. Brit. Mus. 1862. p. 260 .

Spence Bate and Westwood, Brit. sessile-eyed Crust. 1863. p. 461.

Antenne superiores dimidia longitudine animalis parum longiores, inferioribus æqvales. Pedes $1 \mathrm{mi}$ paris maris et feminæ ferc æqvales, manu triangulari. Pedes 2di paris apud marem carpo permagno, paulo longiose qvam lato, in angulo inferiore posteriore in dentem longum, vix ad finem articuli 5ti porrectum, producto et dente magno accessorio interiore instructo; articulo 5to sat lato, in margine interiore nodulis latis armato; apud feminam carpo calcem validam, longam, in apice rotundatam, emittenti; articulo 5to manum latam, triangularem, in margine interiore paulum sinuatam, formanti.

$\mathrm{I}_{4}$ ængden er $6-8_{\mathrm{mm}}$.

Legemet er nedtrykt; det forste Legemsled er mindre end de følgende. Sidepladerne ere smaa. Hovedet er omtrent saa langt som de tvende første Legemsled tilsammen; dets Sidevinkler ere udtrukne, afrundede og danne en Lap, paa hvilken de ovale Øine have sin Plads. 
Følerne ere tyndere hos Humnen end hos Hannen.

De øvre Følere naa, naar de bøies bagud, omtrent til det første Haleled og ere besatte med Børstebundter paa den undre Side. Skaftets første Led er meget kortere end Hovedet; det andet er meget længere; det tredie er noget længere end det forste, men kortere end det andet Led. Svøben er omtrent saa lang som Skaftet og dannes af 14 forlængede Led.

De nedre Følere ere frestede langt baig de øvre, paa Hovedets undre Side; de ere af den samme Læugde som hine og ligeledes besatte med Børsteknipper paa den undre Side. Skaftets andet Led bærer en lang Lugtelnude; det tredie, der er mere end dobbelt saa langt, som bredt, rager længere frem end til Hovedets Sidevinkler; det fjerde er omtrent saa langt som det andet Led paa de ovre Føleres Skaft, men tykkere end dette; det femte er længere end det foregaaende Led. Svøben, der er noget længere end Skaftets sidste Led, dannes af 10 forlængede Led.

$\mathrm{K}$ indbakkerne ere delte i Spidsen og tandede; Tornerrkken og Tyggeknuden ere vel udviklede og forsynede med Trnder. Palpens tredie Led er temmelig bredt, kortere, end det andet, noget afrundet paa Spidsen.

Det forste Kjæbepars indre Plade er liden, spids paa Enden.

Det andet $\mathrm{Kj} \mathfrak{\mathrm { j }} \mathrm{b}$ epars Plader ere brede.

Kjæbeføddernes ydre Plade er stor, oval, væbnet med stærke Tæuder paa den indre Rand. Palpen er forlænget; Kloen er i Spidsen forsynet med et Knippe stive Børster.

Det forste Fodpar er mindre end det andet; det fjerde Led er lidt hortere end det første, men meget bredere, samt er bredere udad, hvorved det faar en triangulær Form; dets nedre, bagre Vinkel udvider sig hos Hannen til en oval Fremstaaenhed; det femte, der frester sig nær det foregaaende Leds nedre, forreste Vinkel, er af den samme Bygning hos begge Kjøn, triangulært, næsten saa langt som bredt, med Børster paa den forreste Rand og med fine Tænder paa Griberanden. Kloen er lidt krummet, med Børster paa den bagre Rand.

Det andet Fodpars fjerde Led er hos Hannen omtrent saa langt som det forste, eller noget længere end dette; det er noget smalere end langt, og dets nedre, bagre Vinkel forlænger sig til en stor, bred Tand, der er noget kortere end det femte Led og er forsynet med en stærk Bitand; det femte Led er krummet, længere end bredt, paa sin bagre Rand væbnet med stærke, stumpe Tænder. Kloen er kraftig, noget krummet, med Torne paa den bagre Rand. Hos Hunnen er dette Fodpar meget svagere udviklet; det fjerde Leds nedre, bagre Vinkel forlænger sig til en meget stærk, paa Enden afrundet Fremstaaenhed, der paa den bagre Rand er besat med Torne; Haanden er meget større end det foregaaende Led, af en ægdannet Form, med en lidt uregelmæssig dannet Griberand, der er besat med enkelte Torne.

Det tredie og fjerde Fodpar ere korte; det første Led er ovalt, næsten saa langt som bredt. 
De tre følgende Fodpar tiltage efter hverandre noget i Længde og blive smalere, især deres forste Led.

Det første Par Springfødders Grundled er paa den ydre Kant forsynet med grovere Torne, paa den indre med enkelte lignende Torne og med fine Saugtakker; Grenene ere lige lange, med tvende smaa Torne paa Enden, mellem hvilke sees en lang, bevægelig Torn; den ydre har T'orne kun paa den indre Rand; den indre har saadanne paa begge Rande.

Det andet $\mathrm{P}$ ar ligner det foregaaende, men er kortere.

Det sidste Par har kun een Gren, der danner en kort, lidt udadboiet Klo paa et meget længere, stærkt Grundled.

Halevedhænget, der er sammenvoxet med det sidste Haleled, er tykt og danner paa Enden tvende Knuder, besatte paa hver Side med Torne.

Paa Spence Bate og Westwoods Tegning af $C$. abditus har de nedre Foleres Svobe talrige Led; det tredie Haleleds nedre, bagre Vinkel er afrundet, og den nedre Del af dets bagre Rand er saugtakket; det andet Fodpars Haand er ogsaa forskjellig fra den her beskrevne.

Denne Art lever selskabelig, idet flere fæste sine Rør nær hverandre, hyppig paa en Koralstok.

F arven er gulhvid, med brun-violette Tegninger paa Ryggen og Sidepladerne.

Den er fundet paa flere Steder ved Norges Vestkyst og ned til Bohuslen, ligeledes ved Spitsbergen, ved de engelske Kyster, og findes efter Heller i Adriaterhavet, og efter Costa ved Neapel.

CERAPUS DIFFORMIS, Nilne-Edwards, 1830.

Erichthonius difformis, Milne-Edwards, Ann. d. Sci. Nat. 1830. t. XX. p. 382. Hist. d. Crust. 1840, t. III. p. 60. pl. 29. fig. 12.

$\begin{array}{lll}- & - & \text { Lilljeborg, Öfv. af Kgl. Vet.-Akad. Förh. 1855. p. } 129 . \\ \text { - } & - & \text { Costa, R. sui Crost. amfip. d. regno di Napoli. 1857. p. } 228 . \\ \text { - } & - & \text { Bruzelius, Skand. Amphip. Gamm. 1859. p. 17. } \\ \text { - } & - & \text { Goës, Crust. amphip. maris Spetsb. 1865. p. 16. }\end{array}$

Podocerus Leachii, Krøyer, Nat. Tidsskr. 1842. 1. R. IV. p. 163.

Cerapus Leachii, Spence Bate, Catal. Amphip. Crust. Brit. Mus. 1862. p. 268.

- difformis, Costa, R. sui Crost. amfip. del regno di Napoli. p. 228.

- - Spence Bate, Catal. Amphip. Crust. Brit. Mus.1862.p. 265. pl. XLV. fig.5.

- - Spence Bate and Westwood, Brit. sessile-eyed Crust. 1863. p. 457.

- $\quad$ - Norman, Rep. on the Shetland Crust. 1868. p. 285.

- - A. Boeck, Crust. amphip. bor. et arct. 1870. p. 172.

Pedes 2di paris carpo apud marem duplo longiore qvam lato, in angulo inferiore posteriore dentem longum formanti; articulo 5to angusto, subcurvato. Cæteroqvin ferme ut apud speciem præcedentem. 
L $\rightsquigarrow$ ngden er $6-8^{\mathrm{mm}}$.

Leg e met ligner meget det hos den foregaaende Art, fra bvilken det vasentlig adskiller sig kun ved Formen af det andet Fodpar hos Hannen; det fjerde Led er nemlig forlænget smalt, omtrent dobbelt saa langt som bredt, og gaar i den nedre, bagre Vinkel ud $\mathrm{i}$ et stærkt Fremspring, der naar frem til Enden af det smale, lidt krumme femte Led.

Norman antager, at Dercothoe punctatus, Milne-Edwards, er Hunnen af denne Form og ikke af $C$ abditus, og at den Form, som Spence Bate og Westwood beskrive som Hunnen af $C$. difformis, sandsynligvis er en Varietet af Hannen.

Farven var efter Bruzelius hos en ægbærende Hun graagul, med graa, paa Ryggen parvis stillede Pletter. Oinene ere morkerode, Foleme hvidagtige, med hrune Baand.

Den er taget af mig i Christianiafjorden; efter Bruzelius og Lilljeborg findes den ved den svenske Kyst fra Kullen til Bohuslen. Af Malmgren og Smitt er den taget ved Spitsbergen, hvor den ifølge Goës er meget større end vor Form. Efter Spence Bate findes den ved de engelske Kyster, efter Norman ved Shetland; Milne-Edwards har taget den ved Bretagne, og ifolge Costa er den ikke meget sjelden ved Fusaro.

\section{CERAPUS LONGIMANUS, A. Boeck, 1870.}

(Pl. XXVIII. fig. 3.)

Cerapus longimanus, A. Boeck, Crust. amphip. bor. et arct. 1870. p. 172.

Pedes 2di paris apud marem longitudinem animalis fere reqvantes; carpo ter longiore qvam lato, ex angulo inferiore posteriore dentem emiltenti; dente dimidiam longitudinem carpi a eqvanti. ultra medium articulum 51 mo porrecto, gracili, prope ad finem marginis interioris denticulo accessorio instructo; articulo 5to elongato, angusto, prope ad basin marginis posterioris luberculo armato: ungve angustiore qvam apud species præcedentes.

L æing den er $5^{\mathrm{mm}}$.

Le gemet ex nedtrykt; Ryggen er bred, afrundet; det første Legemsled er kort; det andet er det lxngste; det femte er høiere end det fjerde, med en forlænget, afrundet nedre Rand. Sidepladerne ere smaa; den anden er den storste, længere end bred, firkantet, med afrundede Rande. Hovedet er noget langere end det første Legemsled; dets Sidevinkler ere mindre end paa de foregaaende Arter.

De øvre Følere naa, naar de bojes bagud, til det sjette Haleled. Skaftets forste Led er kortere end Hovedet; det andet er længere; det tredie Led er saa langt som det foregaaende, eller noget læugere. Alle Led have Borsteknipper paa den undre Side. Svoben, der er saa lang som det sidste Led, dannes af 8 tynde Led.

De nedre F glere ere af den samme Længde som de ovre. Skaftets tredie 
Led er omtrent dobbelt saa langt som bredt; det fjerde naar frem til Enden af de øve Føleres andet Led; det femte er meget længere end det foregaaende Led og har Børster paa den undre Side. Svøben er længere end Skaftets sidste Led og dannes af 10 Led, livoraf det første er det længste, livilke have Borstebundter paa den undre Side.

Kindbakkerne ere i Spidsen delte i Tænder; den indre Bigren er ogsaa forsynet med Tænder; Tornerækken dannes af stærke, med Bitorne besatte Torne; Tyggeknuden er fremstaaende, besat med T'xnder. Palpens tredie Led er meget kortere, end det andet, af en oval Form, med afrundet Ende, der er besat med Borster.

Det første Kjæbepars ydre Plade er paa Enden besat med fjordannede Borster; den indre Plade er liden, spids paa Enden.

Det andet Kjæbepars Plader ere brede; den ydre er bredere og meget længere end den indre.

Kj $æ$ bef $ø$ ddernes ydre Plade er bred, oval, naar frem til den overste Trediedel af Palpens andet Led og har paa den indre Rand fire stumpe Tænder, der blive længere mod Pladens Ende og gaa her over til 3-4 stierke Borster; den indre Plade naar frem til Enden af Palpens forste Led og har paa den afskaarne Eude tre stumpe T'ænder og nogle stærke Børster. Palpens andet Led har Børster paa den ovre Del af den indre Rand; det tredie er meget kortere, noget bredere mod den afrundede Ende, der er forsynet med Børster; det fjerde Led er kloformet, med tvende Børster i Spidsen.

Det første Fodpars forste Led er kort, men meget bredt; det fjerde er af den samme Længde som det forste, og dets nedre, bagre Vinkel danner et kort, men bredt, afrundet Fremspring; det femte Led er triangulært, ligt det samme hos de foregaaende Arter.

Det andet Fodpar er særdeles stort hos Hannen, næsten saa langt som det hele Legeme, i det Hele af en mere cylindrisk Form end hos de foregaaende Arter; det fjerde Led er kortere end det forste, omtrent tre Gange saa langt som bredt, dets nedre, bagre Vinkel danner et smalt, tilspidset Fremspring med en liden Fremstaaenhed nær Spidsen paa den indre Rand, hvilket er næsten Totrediedel af Leddets Længde, samt lidt kortere end det følgende Led; det femte er forlænget cylindrisk, smalere mod den ydre Ende, lidt bøiet, og har paa sin bagre Rand, nær Basis, en stump Fremragenhed; den stærke, krumme Klo er i Spidsen besat med et Knippe Borster.

Det tredie og fjerde Fodpar ere korte; det forste Led er noget længere end bredt, af en næsten omvendt xgdannet Bygning, med en mere buet forreste end bagre Rand.

De tre folgende Fodpar tiltage efter hverandre i Længde; det tredie Led er længere end det forste, bredere udad; det fjerde er kortere, det femte er længere end det tredie Led.

Det første Par Springfødders Grundled er langt, noget smalere paa Mid- 
ten, med fine Tander paa Randene; Grenene ere lige lange, kortere end Grundleddet, merl tvende Torne i Spidsen, og mellem disse en længere og bevægelig Torn.

Det andet Par er kortere end det forste.

Det sidste Pars Grundled er tykt, cylindrisk, smalere udad, med Torne paa den ydre Rand; Grenen danner en kort, mod Spidsen krummet Klo, samt har en mindre Tand nær Spidsen.

Denne Art er fundet af mig ved Haugesund.

\section{CERAPUS HUNTERI, Spence Bate, 1862.}

(PI. IXVIII. fig. 5.)

Cerapus Hunteri, Spence Bate, Catal. Amphip. Crust. Brit. Mus. 1862. p. 264. pl. XLV. fig. 3. $\sigma^{7} \mathrm{og}$ 오.

Pedes 2di paris carpo maris ferme duplo longiore qvam lato, ex angulo inferiore posteriore dentem perbrevem, acutum, circiter ad medium marginem posteriorem articuli 5 ti porrectum, emiltenti; articulo 5 to in margine posteriore serrato el tuberculis duobus vel tribus litis instructo.

L $æ$ ngden er $10^{\mathrm{mm}}$.

Legemet er nedtrykt; Ryggen er rund, glat; det forste Legemsled er det korteste; det tredie Haleleds bagre Rand danner en dyb, halvmaaneformet Indskjæring, og dets nedre, bagre Vinkel er tilspidset. Hovedet er saa langt som de tvende første Legemsled tilsammen; dets Sidevinkler ere fremstaaende. Øinene ere smaa, ovale.

De ovre Folere naa, naar de bøies bagud, til det sjette Haleled og ere paa den undre Side besatte med Borster. Skaftets forste Led er kortere end Hovedet; det andet er længere og smalere; det tredie Led er omtrent saa langt som det foregaaende, men tyndere end dette. Svoben er meget liengere end Skaftets sidste Led og dannes af omtrent 12 forlæugede Led.

De nedre Folere ere noget langere end de ovre og udspringe langt bag disse, paa Hovedets undre Side, samt have ligeledes Børster paa den undre Side. Skaftets andet Led udsender en lang Lugteknude; det tredie er dobbelt saa langt som bredt; det fjerde er af den samme Længde som de øvre Føleres sidste Led, men er tykkere end dette; det femte er meget længere end det foregaaende Led. Svoben, der er længere end Skaftets sidste Led, dannes af 10 Led, af hvilke det første er meget liengere end de folgende.

I Munddelene stemmer den overeens med den foregaaende Art.

Det første Fodpars fjerde Led er omtrent af den samme Længde som det første og er i Forhold smalere end hos den foregaaende Art, med Børster paa den bagre Rand; dets nedre, bagre Vinkel danner intet Fremspring. Kloen er kortere, tykkere, med Saugtakker paa den bagre Rand. 
Det andet Fodpai er hos denne Art mindre sammentrykt fra Siderne end hos den foregaaende, men af en mere cylindrisk Form; det fjerde Led er hos Hannen af den samme Lxugde som det forste, omtrent dobbelt saa langt som tykt, samt udsender fra den nedre, bagre Vinkel en tilspidset Fremstaaenhed; denne er dog kort og naar kun frem omtrent til Halvdelen af Haandens Længde, samt er paa den bagre Rand besat med enkelte Børsteknipper;; det femte Led er cylindrisk, noget bøiet, og har paa den bagre, saugtakkede Rand tvende forlængede Fremstaiaenheder, af hvilke den, der er narmest Kloens Udspring, har en afrundet Form. Kloen el kortere end det sidste Led, stærk, noget krummet.

Det tredie og fjerde Fodpars forste Led er ægdannet.

Det første Par Springfødders ydre Gren er længere og tykkere end den indre og har paa den ydre Rand nogle stærke Torne, paa den indre meget smaa og talrige Torne, samt tvende i Spidsen; den indre Gren har en Torn i Spidsen.

Det andet Par er meget kortere; Grenene ere lige lange, med Torne paa Randene og i Spidsen.

Det sidste Par naar længere bagud end det foregaaende; Grenen danner en kort, stærk, noget boiet Klo, hvis Spids ender med en Torn, og bag denne har Grenen en lignende.

Halevedhanget er ubetydelig lingere end bredt, med en knudeformet Fremstaaenhed paa hver Side, hvilken er besat med 5-6 smaa Torne.

Jeg har fundet denne Art ved Haugesund. Spence Bate har først beskrevet den efter Exemplarer, opbevarede i en Samling tilhørende Royal College of Surgeons, og har opkaldt den efter Stifteren af denne Samling.

\section{Tamilia VIIT.}

COROPHID A, Dana, 1849.

Syn.: 1849. Coroplide, Dana, Amer. Journ. of Sci. 2. ser. vol. VIII. U. S, explor. exped. 1852. p. 829.

$\begin{array}{lll}1859 . & - & \text { Bruzelius, Skand. Amphip. Gamm. p. } 12 . \\ 1862 . & - & \text { Spence Bate, Catal. Amphip. Crust. Brit. Mus. p. } 233 . \\ 1863 . & - & \text { Spence Bate and Westwood, Brit. sessile-eyed Crust. p. } 414 . \\ 1865 . & - & \text { Goës, Crust. amphip. maris Spetsb. p. 16. } \\ \text { - } & \text { - } & \text { Lilljeborg, On the Lysianassa magellanica. }\end{array}$

Mandibulæ palpo sæpissime 3 articulato.

Maxillre primi paris lamina interiore parva aut obsoleta: palpo 2articulato, in apice dentibus, raro setis armato.

Maxillæ 2di paris plus minusve latæ. 
Pedes maxillares lamina exteriore in margine interiore dentibus aut spinis brevis armata; articulo palpi ultimo in apice spinis instructo aut ungviforme.

Corpus depressum; epimeris minimis.

Pedes saltatorii ultimi paris 1ramosi.

Dana opstillede Corophicte som den tredie Familie under hans anden Subtribus Gammarilca; den svarer omtrent til Milne-Edwards's 'Tribus des Crevettines marcheuses. Han delte den i tre Underfamilier, Clydonince, Corophince og Icilince. Til den forste af disse henforer han Slægten Clydonia, Dana, til den anden Slægterne Corophium, Latr., Siphonoccetes, Kroy., Platophium, Dana, Cyrthophium, Dana, Unciola, Say, Podoccrus, Leach, Crathoplizm, Dana, Cerapus, Say, Cerapodina, M.-Edw., Erichthomius, H.-Edw., og til den tredie Slægterne Icilius, Dana, og Pterygocera, Latr. Spence Bate, der sloifer Dana's Underfamilier Clydonince og Icilince, opstiller Familien Corophida under sin Subdivision Domicola, tilligemed Cheturida, og deler den i tvende Underfamilier, Podocerides, hvortil han regner Slægterne Amphithoë, Leach, Sunamphithoe", Sp. Bate, Poclocerus, Leach, Dcreothoè, Dana, Corapus, Say, Siphonoccetes, Kroy., og Ncenia; Sp. Bate, (Podoceropsis, A. Boeck), samt Corophides, hrortil han regner Slægterne Cyrthophium, Dana, Cratippus, Sp. Bate, Dryope, Sp. Bate, Unciola, Say, Corophizm, Latr., Clyrlonia, Dana, og Icilins, Dana. Bruzelius, der kun tager Hensyn til de Former, der forekomme ved Skandinaviens Kyster, deler i 1859 Familien Corophidce i tvende Hovedafdelinger, eftersom det sidste Par Springfødder er forsynet kun med een Gren, hvortil horer Sliegterne Corophium, Latr., og Erichthonius, M.-Edw., eller den er togrenet, hvortil henregnes Sliegterne Jassa, Leach, Podocerus, Leach, Autonoë, Bruz., og Amphithoë, Leach. Disse Slegter, idetmindste de skandinaviske, stemme deri overeens, hvad Halen angaar, at Halevedhænget har en eiendommelig Form, er tylst og knudeformet, ikke tyndt og pladeformet. Det sidste Par Springfødder er kort, for det meste tykt og cylindrisk. Af denne Grund har han henfort Slægten Amphithoë til denne Familie, endskjønt den ved sine Sidepladers Størrelse mere nærmer sig Familien Ġammarider. Lilljeborg, der i sin Opstilling af Amphipoderne narmer sig Spence Bate, stiller Corophide efter Familiene Gammaride og Orchestidce, sammen med disse, og henforer den under Gammarine, idet han tager Hensyn til Halens sidste Led, der hos disse ere adskilte, medens de ere sammenvoxne hos Familien Chelurida. De tvende Familier Orchestidce og Corophide adskille sig fra Gammaride derved, at Halevedhænget er tykt og knudeformet, medens det hos den sidstnævnte er pladeformet, helt eller spaltet, og indbyrdes adskille de sig, eftersom Sidepladerne ere store og Kindbakkerne fordetmeste mangle Palpe (Orchestidee), eller Sidepladerne ere smaa eller af middelmaadig storrelse og Kindbaklierne forsynede med Palpe (Coroplidec). Af arctiske Amphipodeslægter nævner Goës i 1865 under Familien Corophida: Podocerus, Erichthonius, Siphonoecetes, Glauconome. Som forhen omtalt i Indledningen til dette Værk, henforte jeg Corophince som en Underfamilie under Gammaride; i dette Arbeide 
optager jeg lerimod Corophirlu: som en Familie med tvende Underfamilier, Corophine og IIclaine, hville vasentlig have det tilfalles, at det sidste Par Springfodder kun har cen Gren.

\section{Subfamilia I.}

COROPHIN E, Dana, 1849.

Syn.: 1849.' Coropline, Dana, Amer. Journ. of Sci. 2. ser. vol. VIII. U. S. explor. exped. 1852. p. 836.

1856. Corofini, Costa, R. sui Crost. amfip. del regno di Napoli.

1859. Corophince, Bruzelius, Skand. Amphip. Gamm. p. 13.

1862. Corophides, Spence Bate, Catal. Amphip. Crust. Brit. Mus. p. 273.

1863. - Spence Bate and Westwood, Brit. sessile-eyed Crust. p. 478.

1870. Coroplince, $\Lambda$. Boeck, Crust. amphip. bor. et arct. p. 174.

Labium superius latum, in apice rotundatum et setosum.

Mandibula validx, in apice dentatæ; processu accessorio eliam dentato et serie dentium inferiore in selam longam, plumosam desinenti; serie spinarum ex spinis paucis sed latis, in apice dentatis, composita; palpo 3articulato aut 2articulato.

Labium inferius latum; laminis internis validis.

Maxillæ $1 \mathrm{mi}$ paris palpo in apice dentibus validis armato; lamina interiore parva aut obsoleta.

Maxilla 2di paris plus minusve latæ.

Pedes maxillares lati, validi; lamina exteriore in margine interiore dentibus aut spinis armata; articulo palpi tho in apice spinis duabus validis instructo aut ungviformi.

Corpus depressum, lalum, robustum; epimeris minimis, rigidis.

Caput dilatatum.

Antennx inferiores superioribus vulgo validiores, pediformes, in apice ungvibus instructe, apud marem robustissima.

Pedes 2di paris iisdem $1 \mathrm{mi}$ paris sæpissime validiores.

Pedes natatorii breves, validi; pedunculo interdum introrsum valde dilatato.

Pedes saltatorii $1 \mathrm{mi}$ et 2 di paris 2 ramosi; ramis parum elongatis.

Pedes ultimi paris parvi, breves, lati, 1ramosi.

Appendix caudalis laminaformis.

Denne Underfamilie dannede Dana i. 1849 og stillede den under Familien Corowhide mellem Underfamilierne Clydonine og Icilince, samt henførte herunder de ovenfor 
nxvnte Slxgter. Costa stillede til sin Underfamilie Curofmi af italienske Amphipoder kun Slagten Corophium. Spence Bate optog blandt Corophicles, som forlen anfort, y Slægter. I 1870 henf srte jeg af nordiske Amphipoder til Lnderfamilien Corophine Slirgterne Corophium, Siphonoccetes, Glauconome (Unciola) og Hela, hvilken sidste jeg nu har stillèt $\mathrm{i}$ en egen Underfamilie. I Munddelenes Form ligner den væentlig Underfamilien Podocerine, men Kjæbefødderne ere meget bredere og stærkere. I det Ydre adskiller den sig fra hin ved de meget korte Springfodder, hvis sidste Pars Grundled er meget kort, med en pladeformet Gren, ligesom Halevedhænget er pladeformet.

Gen. I. COROP HIUM, Latreille, 1807.

Syn.: 1807. Coroptium, Latreille, Gen. Crust. et Insect. I. p. 58.

\begin{tabular}{|c|c|c|}
\hline 1814. & - & Leach, Edinb. Encyc. VII. p. 403. Linn. Trans. XI. p. 362. \\
\hline 1825. & - & Desmarest, Consid. sur 1. Crust. p. 270. \\
\hline 1852. & - & Dana, U. S. explor. exped. p. 831. \\
\hline 355. & - & Gosse, Mar. Zool. p. 141. \\
\hline 1856. & - & Costa, R. sui Crost. amfip. del regno di Napoli. p. 332. \\
\hline $185 \%$. & - & Spence Bate, Ann. Nat. Hist. 2. ser. XIX. p. 149. \\
\hline - & 一 & White, Hist. Brit. Crust. p. 193. \\
\hline 59. & 一 & Bruzelius, Skand. Amphip. Gamm. p. 13. \\
\hline & - & Spence Bate, Catal. Amphip. Crust. Brit. Mus. p. 279. \\
\hline & - & Spence Bate and Westwood, Brit. sessile-eyed Crust. p. 492. \\
\hline & - & A. Boeck, Crust. Amphip. bor. et a \\
\hline
\end{tabular}

Type: Cancergrossipes, Linné.

Mandibulæ serie setarum ex setis tribus validis, in apice latis et dentatis, constanti; palpo 2articulato.

Maxillæ $1 \mathrm{mi}$ paris palpo elongato; lamina interiore absenti.

Pedes maxillares validi; articulo palpi 4 to in apice obtuso, spinis duabus crassis armato; lamina exteriore in margine interiore spinis tenuibus instructa: lamina interiore angusta.

Antennæ superiores utriusqve sexus inferioribus graciliores; articulo pedunculi 3 tio brevi; flagello brevi, pluriarticulato; flagello accessorio absenti.

Antennæ inferiores pervalidæ; pediformes.

Pedes 1 mi paris graciles, manu subcheliformi instructi.

Pedes 2di paris articulo 3tio elongato, setis multis plumosis instructo, in margine anteriore cum margine posteriore articuli 4 ti coalito: articulo 5to elongato, manum subcheliformem non formanti.

Pedes 3 tii et 4 ti paris non sat elongati. 
Pedes 5ti et 6ti paris breves, invicem eadem forma; articulo 1 mo parum dilatato.

Pedes $7 \mathrm{mi}$ paris magis elongati, angusti; articulo 1 mo paulo dilatato.

Pedes saltatorii ultimi paris ramo minimo; pedunculo in margine interiore non dilatato.

Typus paa denne Slægt er Cancer grossipes, Linné, hvilken falder sammen med Gammanus longicornis, Fabricius. Hos den typiske Art ere de nedre Følere meget længere og tykkere end de øvre, medens Forskjellen hos andre Arter af denne Slægt er meget mindre. Skaftets fjerde og femte Led kunne boies mod hinanden og benyttes saaledes som et Gribeorgan, der er mindre stærkt udviklet hos Hunnen end hos $\mathrm{Han}$ nen. D’Orbigny beskriver og afbilder (Notice sur les Coroph. 1\$21, p. 149) Miunddelene meget godt, men han har dog overseet Underlæben. Han giver ogsaa meget nøiagtig Underretning om dens Levemaade og viser, at den om Vinteren forlader Strandbredden og gaar ud paa Dybet, medens den om Vaaren i talrige Masser atter søger ind og indretter sig Huler i Havbunden, i hvilke den opholder sig Sommeren over. Hele dens Legemsform henviser den ogsaa til et saadant Liv i Huler, idet det femte og sjette Fodpar ikke ere rettede nedad, men bagtil, og benyttes sammen med Halen til at skyde Dyret hurtig ud af Hulen. Det syvende Fodpar er derimod af den sædvanlige Form. Med de nedre Folere, der rage langt ud af Hulen, griber den sit Bytte og holder det fast, medens den fortærer det.

Af denne Slægt har Spence Bate i 1862 opført otte Arter, af hvilke han selv har undersøgt tvende Arter. Af disse har han senere henført sin nye Art $C$. spinicome til C. Bonellii, M.-Edw., saa at der altsaa bliver syv Arter tilbage, og af disse er det ogsaa tvivlsomt, om C. quadriceps, Dana, hører til denne Slægt. Jeg kan ikke afgjøre bestemt, om $C$. spinicome og C. Bonellii falde sammen, men det er uden Tvivl, at den forste af disse er synonym med $C$. crassicome, Bruzelius. Der bliver altsaa kun fem sikre Arter tilbage.

\section{COROPHIUM GROSSIPES, Linné, $176 \%$.}

\section{(Pl. XXVIII. fig. 6.)}

Cancer grossipes, Linné, Syst. Nat. 1767. Ed. 12. n. 80. p. 1055.

Oniscus volutator, 0. F. Müller, Zool. Dan. Prodr. 1776.

Pallas, Spic. Zool. 1777. IX. p. 59. tab. IV. fig. 9.

Gammarus grossipes, Fabricius, Genera insectorum. 1776. p. 248.

Astacus linearis, Pennant, Brit. Zool. 177\%. IV. p. 1\% pl. 16. fig. 31.

Gammarus longicornis, Fabricius, Syst. Ent. 1775. II. p. 515. Reise nach Norwegen. 1779. p. 258.

Roemer, Gen. insect. etc. 1789. p. 63. pl. XXXIII. fig. 6. 
? Gammarus parvus, Fabricius, Reise nach Norwegen. 1779. p. 258.

Corophium longicorne, Latreille, Gen. Crust. et Ins. 1807. I. p. 59.

- - Leach, Edinb. Encyc. 1814. VII. p. 403. Linn. Trans. XI. p. 362. Suppl. Encyc. Brit. I. p. 426.

- - Brébisson, Cat. d. Crust. terr. fluv. et mar. etc. 1825. p. 252.

- $\quad$ - Samouelle, Ent. Comp. 1819. p. 105.

- - d'Orbigny, Journ. d. Phys. et Chem. d'hist. nat. et d. arts. 1821. t. 93. p. 194.

- - Desmarest, Consid. sur les Crust. 1825. p. 270. pl. 46. fig. 1.

- - Guerin, Icon. des. Crust. 1829. t. 27. fig. 1. $0^{7}$. ‥

- - Milne-Edwards, Règne anim. ed. 3. Crust. pl. 61. fig. 1. Hist. d. Crust. 1840. III. p. 66. pl. 29. fig. 16. Aun. d. Sci. nat. 1848. t. XX. p. 385.

- Zaddach, Syn. Crust. pruss. prodr. 1844.

- - White, Cat. Brit. Crust. 1850. p. 55. Hist. Brit. Crust. p. 1857. p. 193. pl. XI. fig. 1.

- $\quad$ - Spence Bate, Ann. Nat. Hist. 185\% 2. ser. XIX. p. 149. Catal. Amphip. Crust. Brit. Mus. 1862. p. 280. pl. XLVII. fig. 4.

- $\quad$ - Bruzelius, Skand. Amphip. Gamm. 1859. p. 14.

- $\quad$ - Spence Bate and Westwood, Brit. sessile-eyed Crust. 1863.p. 493.

- - Norman, Rep. on the Shetland Crust. 1868. p. 286.

Corophium grossipes, Templeton, Mag. of Nat. Hist. and Journ. 1836. IX. p. 12.

A. Boeck, Crust. amphip. bor. et arct. 1870. p. 175.

Rostrum frontale parvum. Angulus lateralis capitis rotundatus. Anienna inferiores apud marem longitudinem animalis superantes, apud feminam non xqrantes; articulo pedunculi 5to edentato. Pedes $1 \mathrm{mi}$ paris ungve longitudinem aciei manus rqvanti; carpo paulo longiore qvam ma.uu. Pedes 2di paris ungve levi. Pedes 3tii et 4 ti paris ungve breviore qvam articulo 4 to et 5 to junctis. Pedes 5 ti et 6ti paris angulo inferiore anteriore articuli 3 tii valde producto: articulo 4 to Iato, brevi, spinoso. Pedes $7 \mathrm{mi}$ paris articulo 4 to breviore qvam 3tio. Pedes saltatorii ultimi paris ramo brevi, ovali. Segmentum postabdominis 4 tum. 5 tum et 6tum non coalita.

L $æ n g d$ en er omtrent $10^{\mathrm{mm}}$.

Legemet er meget bredt, nedtrykt; de tre sidste Haleled ere adskilte. Sidepladerne ere smaa, meget lave. Hovedet er bredt og udsender mellem de ovre Folere et kort, spidst Pandehorn; dets Sidevinkler ere afrundede, og de smaa, runde Øine sidde nær Enden af disse. 
De grre Folere ere tynde og korte og naa hos Hannen frem til de nedres fjerde Skaftled, hos Hunnen ere de noget lingere. Skaftets forste Led er næsteu saa langt som Hovedet, og dets indre Kant er hos Hannen væbnet med en Kakke Kinuder; det andet er noget mere end halvt saa langt og meget tyndere; det tredie Led er det tyndeste og korteste. Hos Hunnen sees paa Skaftets forste Led, istedetfor de nævnte Knuder, tvende stærke Torne. Svøben, der er lidt kortere end Skaftet, dannes af omtient 15 Led hos Hannen, af $10-12$ hos Hunnen.

De nedre Følere ere særdeles stærke og fæstede $\mathrm{i}$ en dyb Indskjæring paa Hovedets undre Side. Hos Hannen ere de længere end det hele Legeme, hos Hunnen kortere. De tvende første Led ere meget nøie forbundne og have paa den undre Side tvende stærke Tænder; det tredie er omtrent saa langt som tykt; det fjerde er mere end dobbelt saa langt som det foregaaende og har tvende Trender paa den ydre Ende af den undre Side; det femte Led er kortere og smalere. Svøben dannes af et langt første Led, der dog er meget kortere og smalere end Skaftets sidste Led, samt tvende meget smaa Led, af hvilke det sidste har nogle smaa, men stærke Kløer.

Overlæben er bred, afrundet paa Enden.

Kindbakkerne ere meget kraftige; Gribedelen er paa Enden vabnet med fem, den indre Bigren med fire Tænder; Tornerækken dannes af tre Torne, der mod Enden ere bredere og ere der indskaarne i talrige tynde Torne; Tyggeknuden er meget stærk, høi, og dens nedre Kant er forsynet med en Række stærke Torne og en lang, fjærdannet Børste. Palpen er 2leddet, det forste Led er noget bredere mod Enden; det andet er meget tyndt, tilspidset mod Enden, ved hvilken der er fæstet en lang Børste.

Underlæben er meget bred, dybt klovet; de indre Plader ere meget store.

Det forste $\mathrm{Kj} æ b \mathrm{~b}$ ars ydre Plade er paa Enden væbnet med stærke, gaffeldannede 'Torne. Palpen har otte forlængede Tænder.

Det andet $\mathrm{Kj}$ æbepars Plader ere brede; den ydre er noget længere end den indre, og begge have paa den indre Rand lange, tildels fjærdannede Børster.

Kjæbef $ø$ d derne ere forlængede, men stærlie; den ydre Plade er forlænget, naar frem næsten til Enden af Palpens andet Led og har paa den indre Rand talrige tynde Torne, samt tre længere, meget stærkere i Spidsen; den indre Plade er smal, med tvende Tænder paa Enden og nogle lange, fjærdannede Borster. Palpen er særdeles stærk; det andet Led er det længste; det tredie er kort og bredere mod Enden; det fjerde er ligeledes kort og har paa den noget stumpe Ende en stærk, krummet Klo.

Det forste Fodpar er tyndt; det fjerde Led er forsynet paa den bagre Rand med talrige Borster; det femte er lidt kortere end det foregaaende Led og har talrige Tværrader af Børster, der tildels ere fjærdannede, Griberanden er ret afskaaret, kort og har enkelte Børster. Kloen er saa lang som Griberanden og har fine Torne paa den bagre Rand.

Det andet F odpar er læugere og stærkere; det tredie Led lægger sig med 
den forreste Rand op til og er forenet med wæsten den hele bagre Rand af det trianguliere fjerde Led; dea bagre Rand er forsynet med lange, fjærdannede Borster i flere Rækker; det.femte Led er langt, smalt, noget bøiet og er paa den ydre Side besat med en Rad lange, fjærdannede Børster. Kloen, der er fæstet paa Enden af dette Led, er temmelig lang, krummet, spids.

Det tredie og fjerde Fodpars forste Led er langt, med en paa den nedre Del boiet, bagre Rand, der har nogle fjærdannede Borster; det tredie er temmelig kort og kun noget udvidet mod Enden; det fjerde er ubetydelig længere end bredt; det femte Led er forlænget, noget bøiet, smalere mod Enden. Kloen er længere end det sidste Led, kun lidt krummet.

Det femte Fodpars forste Led er omtrent dobbelt saa langt som bredt; det tredie er bredere mod Enden, med en udtrukket $0 \mathrm{~g}$ afrundet forreste, nedre Vinkel, samt er paa begge Rande besat med lange, fjærdannede Borster; det fjerde er meget kort, bredt, med skraa afskaaret nedre Rand, og paa den ydre Flade besat med tvende Rækker krumme Torne; det femte er smalt, bøiet, noget kortere end det tredie Led. Kloen er kort, krummet.

Det sjette Fodpar er af den samme Bygning som det foregaaende, men det forste Led er noget bredere.

Det syvende Fodpar er meget længere og smalere end de tvende foregaaende Par; det første Led er ovalt, forsynet paa den forreste og bagre Rand med lange Børster; det tredie er nedad ikke udvidet og er længere end det fjerde, men kortere end det smalere femte Led. Kloen er ikke lang, lidt krummet.

Svømmefød derne ere korte; Grundleddet er meget bredt, rhomboidalsk, med afrundede Hjørner; Grenene ere korte.

Det første Par Springfodders Grundled er bredt, væbnet paa den ydre Rand med en Række stærke Torne; Grenene ere lige lange, brede, paa den ydre Rand og paa Enden besatte med Torne.

Det andet Par er meget kortere og har færre Torne.

Det sidste Pars Grundled er kort og bredt; Grenen er længere end Grundleddet, bred oval, med mange Borster paa Randene.

Halevedhænget er meget bredt og har paa hver Side, nær Enden, korte Kløer.

Foruden langs Skandinaviens Kyster findes denne Art langs de engelske, franske og belgiske Kyster; den findes efter Metzger ogsaa i Brakvand ved den ostfrisiske Kyst, og efter Heller i Adriaterhavet.

COROPHIUM CRASSICORNE, Bruzelius, 1859.

(PI. XXVIII. fig. 8.)

Corophium crassicorne, Bruzelius, Skand. Amphip. Gamm. 1859. p. 15. pl. 1. fig. 2. Spence Bate, Catal. Amphip. Crust. Brit. Mus. 1862. p. 282. pl. XLVII. fig. 6. 
?Corophium crassicorne, (Bruzelius) Spence Bate and Westwood, Brit. sessile-eyed Crust. 1863. p. 499.

Norman, Rep. on the Shetland Crust. 1868. p. 286.

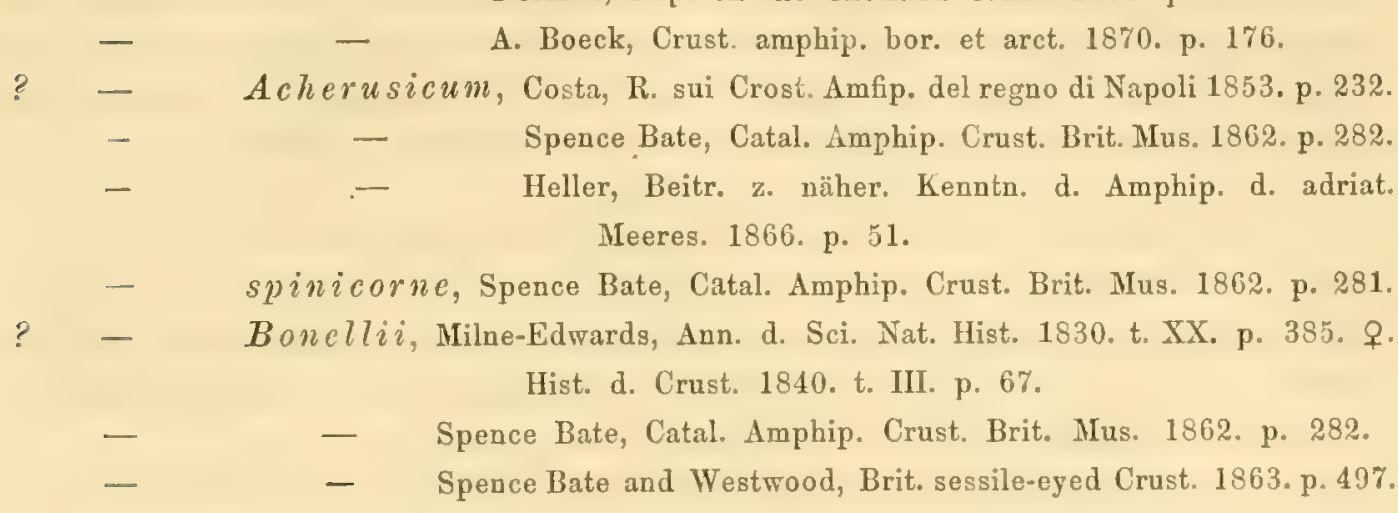

Rostrum frontale parvum. Angulus capitis lateralis valde productus et acuminatus. Antennæ inferiores corpore breviores: articulo pedunculi 5to dente brevi armato. Pedes 1 mi paris ungve longitudinem aciei manus superanti; carpo paulo longiore qvam manu. Pedes 2 di paris ungve prope ad finem marginis posteriores spina una valida armato. Pedes 3 tii et 4 ti paris ungve longitudinem articuli 4 ti et 5 ti junctorum xavanti. Pedes 5 ti et 6 ti paris angulo inferiore anteriore articuli 3tii non valde producto; articulo 4 to nec dilatato nec spinoso. Pedes $7 \mathrm{mi}$ paris articulo 3 tio et 4to longitudine ferme aeqvalibus. Pedes saltatorii ultimi paris ramo ovali. Segmentum postabdominis 4tum, 5 tum et 6tum coalita.

L $æ n g d e n$ er $4^{\mathrm{mm}}$.

L egemet er nedtrylit, bredt; Ryggen er glat; de tre sidste Haleled ere sammensmeltede. Den forste Sideplade er fortil udtrukket og paa Fnden besat med nogle Borster; Hovedet gaar fortil, mellem de øvre Folere, ud i et kort, spidst Pandehorn; dets Sidevinkler ere udtrukne, noget tilspidsede. De smaa, runde Øine sidde ved Roden af denne Forlængelse.

De $\emptyset \mathrm{vre}$ Folere ere meget tyndere end de nedre og naa frem til disses fjerde Skaftled. Skaftets første Led er tykkere og længere end det andet, samt forsynet med stærke Torne paa den indre og undre Rand; det tredie er smalere og kortere end det foregaaende Led. Svoben, der er meget kortere end Skaftet, dannes hos Hanuen af 6 Led.

De nedre Følere ere meget stærke, noget kortere end Legemet. Skaftets forste Led er væbnet paa den indre og undre Rand med tvende stærke Torne, af hvilke den ene er mindre end den anden; det tredie er kort; det fjerde er meget langt, spoldannet, og har paa Enden af den indre og undre Rand tvende stærke Tænder, af hvilke den yderste er den længste; det femte Led er smalere og kortere, ved Roden væbnet med en bred, stump Tand, der, naar Leddet boies mod det foregaaende, passer ind 
mellem de paa dette værende tvende Tænder; paa den ydre Endes indre Side sees ligeledes en bred Tand, der lægger sig op til den indre Side af Svøbens første Led; paa den undre Side sees nogle Børster. Svøben er kortere end Skaftets sidste Led og dannes af 3 Led; det forste er. halvt saa langt som Skaftets sidste Led og har nogle meget lange Børster paa den ydre Ende af den indre Rand; de følgende ere meget korte, og det sidste af disse er forsynet med nogle grove Torne.

Overlse en er bred, afrundet paa Enden.

Kindbakkerne ere stærke; Gribedelen og den indre Bigren have hver $3-4$ Tænder; Tornerækken dannes af tre Torne, der paa Enden synes at være gaffeldannede. Palpens første Led er særdeles bredt og udsender et tykt Fremspring, der paa Spidsen bærer en fjærdannet Borste; det andet er smalt og langt, samt har ligeledes paa Enden en fjærdannet Børste.

Det forste Kjæbepar er temmelig smalt, men af den samme Form som hos den foregaaende Art.

Det andet $\mathrm{Kj}$ jepar ligner ligeledes det samme hos den foregaaende Art.

Kjabefoddernes ydre Plade er smal og naar ikke frem til Enden af Palpens andet Led, den er paa den indre Rand forsynet med ikke tætstaaende, smale Torne; den indre Plade er liden, tilspidset, med tre Børster paa Enden, men uden nogen Tand. Palpens andet Led er smalt.

Det første Fodpars tredie og fjerde Led ere paa den bagre Rand besatte med tætte Børster; det femte er forlænget, med en smal Griberand. Kloen er længere, end Griberanden, fint tandet paa den bagre Rand, og nær Spidsen sees en længere Tand.

Det andet Fodpar er længere og stærkere end det første Par; det tredie $0 \mathrm{~g}$ fjerde Led danne tilsammen et triangulært Led, der har talrige fjærdannede Børster paa den bagre Rand; det femte er omtrent af den samme Længde som det foregaaende Led, men meget smalere end dette. Kloen har paa den bagre Rand, nær Spidsen, en Tand.

Det tredie og fjerde Fodpars første Led er meget forlænget ovalt; det tredie er meget udvidet, samt er forsynet paa den nedre, forreste Vinkel med lange, tildels knxboiede Borster; det fjerde er kort; det femte er lingere end det foregaaende Led, krummet, smalere mod den ydre Ende. Kloen er lidt længere end de tvende sidste Led tilsammen, noget krummet.

Det femte og sjette Fodpars tredie Leds forreste, nedre Vinkel er ikke saa meget udtrukket, som hos den foregaaende Art; det fjerde er smalere, uden Torne; det femte Led er længere end hos den foreganende Art.

Det syvende Fodpars første Led er ægdannet, paa begge Rande forsynet med lange, tildels fjærdannede Borster; det tredie og fjerde ere lige lange; det femte er længere end det foregaaende Led. Alle ere forsynede med lange Børsteknipper paa begge Rande. 
Springfodderne ere af den samme Bygning som hos $C$. grossipes, men Grenene ere noget smalere.

Halevedhænget er ligt det hos den foregaaende Art.

Jeg har fundet den ved Skraaven paa 6-20 Favne; den findes forøvrigt langs Kysten og ned til Bohuslen. Af Norman er den taget ved Shetland; efter Heller findes den i Adriaterhavet og er ifølge Costa hyppig ved Fussaro.

COROPHIUM AFFINE, Bruzelius, 1859.

(PI. XXVIII, fig. 7.)

Corophium affine, Bruzelius, Skand. Amphip. Gamm. 1859. p. 16.

- $\quad$ - Spence Bate, Catal. Amphip. Crust. Brit. Mus. 1862. p. 283.

- - A. Boeck, Crust. amphip. bor. et arct. 1870. p. 176.

Caput rostrum frontali destitutum. Angulus lateralis capitis parum modo produclus et acuminalus. Antenne breviores et angustiores qvam apud species pracedentes. Antennæ inferiores articulo pedunculi 5to spina destitulo. Pedes $1 \mathrm{mi}$ paris ungve longiludinem aciei manus superanti; carpo multo longiore qvam manu. Pedes 2di paris ungve prope apicem marginis posterioris dente uno armato. Pedes 3tii et 4 ti paris ungve multo longiore qvam articulis duobus posterioribus junctis. Pedes 5ti et 6 ti paris angulo inferiore anteriore articuli 3 tii parum modo producto; articulo 4 to non spinoso. Pedes $7 \mathrm{mi}$ paris articulo 3tio et 4 to longitudine ferme reqvalibus. Pedes saltatorii ultimi paris ramo elongato, cylindrico. Segmentum postabdominis 4tum, 5tum et 6tum non coalita.

Længden er omtrent $4^{\mathrm{mm}}$.

Legemets Bygning er meget lig den hos den foregaaende Art; de tre sidste Haleled ere dog ikke sammensmeltede. Hovedets forreste Rand er kun boiet og danner ikke noget Pandehorn; dets Sidevinkler ere udtrukne og tilspidsede.

De øvre Føleres første Skaftled er tykkere ved Roden og bliver meget smalere mod Enden, samt er paa den indre Side væbnet med flere Torne; det andet er lidt kortere, men meget smalere; det tredie er ubetydelig længere end Svøbens første Led. Svoben dannes hos Hunnen af 8 Led

De nedre Folere naa til det forste Haleled; de ere ikke betydelig tykkere og stærkere end de ovre, men stærkere og længere hos Hannen end hos Hunnen. Hos hin er det fjerde Led det længste og har paa den ydre Ende af den undre Side tvende Tænder; det femte har paa den indre Side en stærkere Tand. Svøbens første Led har en Knude paa den ydre Ende af den undre Side.

Iunddelene ligne dem hos den foregaaende Art, men Kjæbeføddernes ydre 
Plader ere smalere og have kun mere spredte Torne paa den indre Rand. Palpen er ogsaa tyndere.

Det første Fodpar er temmelig tyndt; det fjerde Led er smalere mod Enden, med mange Børster paa den bagre land; det femte er smalt, noget læengere end Halvdelen af det foregaaende Led. Kloen er længere end den korte Griberand, fint tancet paa den bagre Rand og forsynet nær Spidsen med en grovere Torn.

Det andet Fodpar har den samme Bygning som hos den foregaaende Art.

Det tredie og fjerde Fodpars tredie Led er meget kort; det femte er næsten saa langt som dette. Kloen er meget. længere end de tvende sidste Led tilsammen, kun lidet krummet.

Det femte Fodpar er temmelig smalt, især det forste Led; det tredie er kun lidet udvidet og udtrukket $\mathrm{i}$ den forreste, nedre Vinkel, og dets Rande ere kun sparsomt forsynede med Børster; det fjerde er uden Torne; det femte er længere og smalere end det foregaaende Led.

Det sjette Fodpar er noget længere, og dets første og tredie Led ere mere udvidede.

Det syvende Fodpars første Led er meget smalere mod Enden og har fjærdannede Borster paa begge Rande; det tredie er omtrent saa langt som det fjerde, men bredere cnd dette; det fente er noget kortere end de tvende foregaaende Led tilsammen.

Det $f ø r s t e$ Par Springfødder er smalt; Grenene ere lige lange, med meget faa og tynde Torne paa den ydre Rand samt i Spidsen.

Det andet Pars Grene have kun tre Torne i Spidsen, af hvilke den midtre er den længste.

Det sidste Pars Grundled er omtrent saa langt som Endegrenen, men tykkere end denne, der er cylindrisk og har nogle Børster paa den ydre Rand og den afrundede Ende.

Halevedhænget er som hos de foregaaende Arter.

Den er fundet af $G$. O. Sars i Nordland paa 80-100 Favne, af mig i Christianiafjorden, af Bruzelius i Gullmarsfjorden i Bohuslen. Af Metzger er den taget i eet Exemplar ved den ostfrisiske Kyst.

Gen. II. SIPHONOECETES, Krøyer, 1845.

Deriv.: Yipov, et Rør, o'xetทs, Indbygger.

Sya.: 1845. Siphonoecetes, Krøyer, Nat. Tidsskr. 2. R. 1. B. p. 491. pl. VII. fig. 4.

Voy. en Scand. pl. XX. fig. 1.

18ว2. - Dana, U. S. explor. exped. p. 831.

1855. Siphonoecetus, Spence Bate, Brit. Assoc. Rep. 1855. p. 59. Ann. Nat.

Hist. 155\%. 2. ser. XIX. p. 149. Catal. Arphip.

Crust. Brit. Mus. 1862. p. 268. 
Syn.: 185\% Siphonocetus, White, Hist. Brit. Crust p. 196.

1863. Siphonoecetes, Spence Bate and Westwood, Brit. sessile-eyed Crust. p. 463.

1865. - Goës, Crust. amphip. maris Spetsb. p. 17.

1870. Siphonoecetus, A. Boeck, Crust. amphip. bor. et arct. p. 177.

Type: Siphonoecetes typicus, Kroyer.

Mandibulæ palpo 3articulato; articulo 3tio nodiformi, fere obsoleto.

Maxillæ $1 \mathrm{mi}$ paris lamina interna destitutæ.

Pedes maxillares validi; laninis exterioribus magnitudinis mediocris, in margine interiore dentibus paucis, robustis, apicem versus in spinas validas el curvatas desinentibus, armatis; articulo palpi 4to ungviformi.

Antennæ superiores inferioribus breviores; pedunculo elongato; flagello brevi, pauciarticulato; flagello accessorio absenti.

Antennæ inferiores pediformes, apud marem majores qvam apud feminam.

Pedes $1 \mathrm{mi}$ et 2 di paris validi; pedes 2 di paris manu subcheliformi, parum robustiore qvam apud pedes $1 \mathrm{mi}$ paris.

Pedes 3 tii et 4 ti paris perlati; articulo primo latissimo, laminari; articulo 3 tio deorsum cordiformiter dilatato; articulo 4 to ef 5 to multo angustioribus et perbrevibus.

Pedes natatorii pedunculo introrsum perdilatato.

Pedes saltatorii ultimi paris 1 ramosi; pedunculo introrsum valde dilatato.

Appendix caudalis lamelliformis.

Denne Slægt blev opstillet af Kroyer i 1845 paa Arten S. typicus, og i sin Slægtskarakter anforer han: „Labium superius profunde bifidum vel duabus compositum laminis ovalibus." Dette er dog ikke Tilfældet med Overlæben, og han har sandsynligvis forvexlet den med Underlieben. Dana stiller Slægten nar Corophium, Latr. Spence Bate heufører den ikke til sin Underfamilie Corophides, men til Podoccrides, og stiller den mellem Cerapus, Say, og Nania, Sp. Bate, (Podoceropsis, A. Boeck).

Til den typiske Art er af Spence Bate tilføiet en ny Art fra den engelske Kyst, S. crassicornis, og af Gosse en anden, $S$. (Cerapus) Whitei. Af disse hører den sidste neppe herhen, men til Slægten Corophium. Spence Bate opfører blandt Karaktereme for Slægten, at det sidste Par Springfødder er meget kort og ender i en enkelt Gren, der er dannet som en Dobbelthage. Disse Hager ere efter ham ikke, som hos Slægten Amphithoë og Cerapus, paa Enden af Greuen, men denne dannes af dem, idet de ere forenede ved Basis. Dette er dog ikke Tilfældet. Heller ikke er Krøyers Afbildning af dette Par korrekt, idet han tegner det forsynet med tvende smaa Grene; der findes kun een, og den tilsyneladende indre Gren tilhører Grundleddet, der er stærkt udvidet paa den indre Side. 
SIPHONOECETES TYPICUS, Kroyer, 1845.

Siphonoccetes typicus, Kroyer, Nat. Tidsskr. 1845. 2. R. 1. B. p. 481. pl. VII. fig. 4. Voy. en Scand. pl. 20. fig. 1.

- $\quad$ - Spence Bate and Westwood, Brit. sessile-eyed Crust.1863.p.465.

- - Goës, Crust. amphip. maris Spetsb. 1865. p. 1\%

- - Norman, Rep. on the Shetland Crust. 1868. p. 285.

Siphonoecetus typicus, Spence Bate, Catal. Amphip. Crust. Brit. Mus. 1862. p. 270.

- - A. Boeck, Crust. amphip. bor. et arct. 1870. p. 177.

Angulus capitis lateralis non valde productus. Antennæ inferiores longitudinem animalis superantes. Pedes 3 tii et 4 ti paris articulo 1 mo longiore qvam lato: articulo 3tio vix duplo longiore qvam lato; ungve breviore qvam articulo 5 to angusto. Pedes saltatorii 1 mi et 2 di paris ramo exteriore elongato, angusto. curvato, apicem versus acuminato, in margine exteriore convexo dentibus permultis instructo; ramo interiore spinis destituto. Pedes saltatorii ultimi paris ramo in apice attenuato. Appendix candalis latior quam longa.

Længden er $6^{\mathrm{mm}}$.

Legemet er meget nedtrykt; Ryggen er rund, uden Tænder; Bugen er flad. Sidepladerne ere smaa. Hovedet er stort og danner mellem de øvre Følere en fremstaaende Vinkel.

De ovre Folere ere af Legemets halve Længde og meget stærke. Skaftets første Led er meget længere end Hovedet; de tvende følgende aftage efter hinanden kun lidt i Længde, men mere i Tykkelse. Svøben er saa lang som Skaftets sidste Led og dannes af 4 forlængede Led, der efter hverandre aftage i Længde og Tykkelse.

De nedre Folere ere dobbelt saa lange som de gvre og omtrent af Legemets hele Længde. Skaftets tvende første Led synes at være sammensmeltede; det tredie er meget forlænget, omtrent tre Gange saa langt som bredt; det fjerde er længere, men smalere end dette; det femte Led er længere end Svøben, der dannes af 3 Led, af hvilke de tvende sidste ere meget smaa.

Kindbakkerne ere korte, stærke; Gribedelen er delt i tvende kraftige Tænder; Tyggeknuden er fremstaaende.

Det forste $\mathrm{Kj}$ bepar er smalt; den indre Plade er obsolet.

Det andet $\mathrm{Kj} \mathfrak{\mathrm { b }} \mathrm{b}$ pars Plader ere ligeledes temmelig smale.

Kjæbefødderne ere brede; den ydre Plade naar næsten til Enden af Palpens andet Led og har paa den indre Rand mange, starke Torne, der mod Pladens Ende forlænge og krumme sig; den anden Plade er paa Enden besat med stærke Børster. Palpen er kort, i Spidsen væbnet med en stærk Klo.

Det forste Fodpar er meget stærkt, men kort; det fjerde Led er noget læn- 
gere og tykkere end det ovale, forlangede fente Led, som paa den bagre Rand er besat med nogle Torne. Kloen er saugtakket paa den bagre Rand.

Det andet Fodpar er stærkere; det tredie Leds nedre, bagre Vinkel er forlænget og lægger sig til det folgende triangulare Led; Haanden er oval, meget længere end det fjerde Led, besat paa den bagre Rand med mange Torne og Børster. Kloen er stærk, saugiakket paa den bagre Rand.

Det tredie og fjerde Fodpar have Børster paa begge Rande; det første Led er meget udvidet; det tredie er hjerteformet udvidet nedad, saa at det næsten skjuler det korte fjerde Led i sin dybt indskaarne ydre Ende; det femte Led er kort, smalt. Kloen er ret, næsten af den samme Længde som det sidste Led.

De tvende folgende Fodpar lave en fra de foregaaende afvigende Bygning og ere rettede bagud og til Siden; det forste Led er ikke meget udvidet, næsten ægdannet, med lange fjærdannede Borster paa begge Rande; det tredie er noget udvidet mod Enden; det fjerde er omtrent saa langt som bredt; det femte Led er smalere, buet; Kloen er liden, kløftet i Spidsen.

Det syvende Fodpar er langere end de tvende foregaaende Par; det forste Led er næsten agdannet, med lange, fjærdannede Borster paa begge Rande; det tredie ikke udvidet, lidt længere end det fjerde, men lidt kortere end det femte Led. Kloen er kløftet i Spidsen.

Det første Par Springfødders ydre Gren er længere end den indre, samt. meget kortere end Grundleddet og forsynet med stærke Torne paa den øvre Rand.

Det andet Par er kortere.

Det sidste Par er overmaade kort; det indad udvidede Grundled er besat med nogle Børster paa Enden; den xgdaunede Gren har en Rikke Børster paa den indre Rand.

Halevedhanget er meget længere end bredt ved Roden, pladeformet, afrundet paa Enden.

F arven er hvidgul, hist og her marmoreret med brunt paa Rygfladen og Hovedet.

Den lever i Ror, der ere sammensatte af Stene og Konkyliefragmenter, og som ere fladtrykte, af mindre Høide end Bredde. Dyret sidder skjult deri, saa at kun Følerne rage frem, og kryber om ved Hjælp af disse, slæbende Røret med sig.

Den findes efter Krøyer ved Grønland, paa Sandbund, paa 16-20 Favnes Dybde (Holböll). Norman har taget den paa 40-50 og 70-90 Favne øst for Balta og Shetland.

SIPHONOECETES COLLETTI, A. Boeck, 1870.

(Pl. XXVIII. fig. 9.)

Siphonoecetus Colletti, A. Boeck, Crust. amphip. bor. et arct. 1870. p. 178. 
Angulus capitis lateralis in lobum, antice rotundatum, productus. Oculus in extremo lobo positus. Antennæ inferiores sat graciles, longitudine animalis breviores. Pedes 3 tii et 4 ti paris articulo 1 mo fere latiore qvam alto; articulo 3tio paulo longiore qvam lato; articulo 5to parum longiore qvam lato; ungve longitudinem articuli 4 ti et 5 ti junclorum superanti. Pedes saltatorii $1 \mathrm{mi}$ et 2 di paris ramis in apice rotundatis, in margine exteriore dentibus paucis, crassis, et in apice spinis nonnullis tenuibus instruclis. Pedes saltatorii ultimi paris pedunculo in margine posteriore setis longis instructo; ramo parvo, rotundato aut ovali, in apice seloso. Appendix caudalis vix longior quam lata.

Længden er $4^{\mathrm{mm}}$.

Legemet er lineært forlænget, nedtrykt. Sidepladerne ere smaa, med Børster paa den frie Rand. Hovedet gaar mellem de øvre Følere ud i et spidst Pandehorn; dets Sidevinkler ere forlængede, afskaarne, og paa deres ydre Del sidde de smaa, ovale Øine.

De øvre Følere ere korte og naa, naar de bøies bagud, omtrent til det fjerde Legemsled. Skaftet er forlænget; det forste Led er omtrent saa langt som Hovedet; de tvende følgende aftage efter hinanden noget i Længde og Tykkelse; det tredie er dog længere end Halvdelen af det forste Led. Svoben, der er noget længere end Skaftets sidste Led, dannes af 3 forlængede Led.

De nedre Følere ere meget stærkere og længere end de øvre, samt naa, naar de bøies bagud, omtrent til det forste Haleled. Skaftets tvende forste Led ere sammensmeltede; det tredie er forlæenget, længere og tykkere end det første Led paa de øvre Foleres Skaft; det fjerde er meget længere og noget smalere end det tredie; det femte er næsten saa langt som det foregaaende Led, men smalere end dette. Svøben er meget kortere og smalere end Skaftets sidste Led og dannes af 2 Led, af hvilke det forste er omtrent Totrediedel af det sidste Skaftleds Længde og det sidste er kort.

Kindbakkerne ere stærke, kløvede i Spidsen; Tornerækken dannes af Torne og fjærdannede Børster; Tyggeknuden er meget fremstaaende, tæat besat med smaa Torne. Palpens andet Led er stærkt, med Børsteknipper paa Enden; det tredie er rudimentært.

Det første Kjæbepars ydre Plade har paa Enden forlængede, i Spidsen gaffeldannede Torne; den indre Plade synes at mangle. Palpen er smal; det andet Led er noget bredere mod den skraa, afskaarne Ende, hvor der sees fem Tænder og en Rakke Børster.

Underlæben er stærk, dybt kløvet, med meget udviklede indre Plader.

Kjæb efødderne ere kraftige; den ydre Plade naar frem næsten til Enden af Palpens andet Led og har paa den indre Rand fem stumpe Tænder, der blive liengere 
mod Pladens Ende og gaa over til krumme Torne: Palpens tredie Led har mange Børster paa Enden. Kloen er stærk, krum.

Det første Fodpar er forlænget, men dog stærkt; det fjerde Led er forlænget; det femte er saa langt som dette, forlænget xgdannet, og har nogle Torne paa den bagre Rand. Kloen er lidt bøiet, med nogle fine Torne paa den bagre Rand.

Det andet Fodpar er meget stærkere og bredere; det tredie Led, som paa sin bagre Rand er besat med enkelte Borsteknipper, lagger sig langs den bagre Rand af det triangulære fjerde Led, hvilket sidstes nedre, bagre Vinkel er forlænget, tilspidset, med en Torn paa Enden; det femte Led er ægdannet, smalere mod den ydre Ende, med nogle Torne paa den bagre Rand. Kloen er stærk, krum, med fine Saugtakker paa den bagre Rand. Dette saavel som det forste Fodpar ere paa begge Rande forsynede med Børsteknipper.

Det tredie og fjerde Fodpar ere brede; det forste Led er af en næsten uregelmassig cirkelformet, flad Bygning; det tredie or næsten hjerteformet, bredere nedad og omslutter det lille fjerde Led; det femte er noget longere end bredt, smalere nedal, med mange txtstaaende Borsteknipper paa den bagre Rand. Kloen er ret, langere end de tvende sidste Led tilsammen.

De tvende folgende Fodpar ere af eens Bygning; det første Led er forlænget firkantet, besat med Børstebundter paa begge Rande; det tredie er bredere nedad; det fjerde er omtrent saa langt som bredt; det femte er liengere end det foregaaende Led, samt boiet. Kloen er kort, med en Biklo ner Spidsen paa den convexe Rand.

Det syvende Fodpar er forlænget; det forste Led er ovalt, med fjærdannede Børster paa begge Rande; det fjerde er kortere end det tredie Led, det femte er noget længere $\mathrm{og}$ meget smalere end det fjerde og af den samme Længde som det tredie Led. Kloen er liden.

Svommef $\varnothing$ dderne ere korte, brede; Grundleddet forlænger sig indad.

Det første Par Springfødder er det længste; Grundleddet har Torne paa den indre og ydre Rand, især paa den sidste. Grenene ere forlænget ovale; den ydre er længere end den indre, og begge have paa den ydre Rand enkelte tykke Torne; den afrundede Ende er besat med nogle fine Torne.

Det andet Par er af den samme Form, men kortere.

Det sidste Pars Grundled er meget bredere mod den ydre Ende og indad og er paa Enden besat med nogle lange Børster samt paa den indre Kant med nogle Torne. Grenen er kort, oval, med lange Børster paa den afrundede Ende.

Halevedhænget er stort, ovalt, omitrent saa langt som bredt ved Roden.

Jeg har fundet denne Art ved Haugesund, i Christianiafjorden og ved Christiansund paa 50-100 Favnes Dybde; G. O. Sars har taget den ved Aalesund paa den samme Dybde og red Skraaven paa 2-300 Favne. 
Gen. III. GLAUCONOME, Krøyer, 1845.

Deriv.: Glauconome, en Nereide.

Syn.: 1845. Glauconome, Kroyer, Nat. Tidsskr. 2. R. 1. B. p. 494.

1865. - Goës, Crust. amphip. maris Spetsb. p. 17.

1870. - A. Boeck, Crust. amphip. bor. et arct. p. 178.

Mandibulæ palpo 3articulato; articulo 3 tio elongato, angusto sed breviore qvam 2 do.

Maxilla $1 \mathrm{mi}$ paris lamina interiore parva.

Pedes maxillares lamina exteriore parva, in margine interiore dentibus paucis sed validis instructa; lamina interiore lata; articulo palpi ultimo fere ungviformi.

Antenna superiores inferioribus parum modo longiores; flagello multiarticulato; flagello accessorio parvo.

Antenna inferiores apud maren multo validiores qvam apud feminam, fere pediformes; flagello ex articulis pluribus composito; articulo flagelli ultimo spinis duabus curvatis instruclo.

Pedes 1 mi paris validi; manu subcheliformi.

Pedes 2di paris iisdem $1 \mathrm{mi}$ paris multo graciliores et angustiores; manu parum subcheliformi.

Pedes 3 tii et 4 ti paris graciles.

Pedes trium parium ultimorum longitudine gradatim crescentes; articulo 1 mo parum dilatato.

Pedes saltatorii ultimi paris 1ramosi; pedunculo introrsum dilatato.

Appendix caudalis laminaformis.

Denne Slægt blev opstillet af Kroyer i 1845. Dana troede i 1852, at den var synonym med Unciola, Say, og Spence Bate folger ham i denne Anskuelse. Say's Beskrivelse af Unciola irrorata (Journ. Acad. Nat. Sci. Philad. I. p. 388) passer ikke herhen, og Krøyers Slægtsnavn maa saaledes igjen optages.

Krøyer tegner (Voy. en Scand.) det sidste Par Springfødder feilagtigt, idet han giver det trende Grene, istedetfor een; den indre af ham tegnede Gren hører nemlig til Grundleddet, som er meget udvidet indad. Spence Bate har selv ikke havt Anledning til at undersøge nogen Art af denne Slægt. Ved Norges Kyster er der fundet tre Arter, af hvilke den ene maaske falder sammen med den af Norman beskrevne Art Unciola planipes.

GLAUCONOME LEUCOPIS, Krøyer, 1845.

Glauconome leucopis, Krøyer, Nat. Tidskr. 1845.2. R. 1. B. p. 491. pl. 7. fig. 2. Voy. en Scand. pl. 19. fig. 1 a. 
Glauconome leucopis, M. Sars, Forh. i Vid.-Selsk. i Christiania 1858. p. 150.

- $\quad$ - Goës; Crust. Amphip. maris Spetsb. 1865. p. 17.

- - A. Boeck, Crust. amphip. bor. et arct. 1870. p. 179.

Unciola leucopes, Spence Bate, Catal. Amphip. Crust. Brit. Mus. 1862. p. 279. pl. XLVII. fig. 3 .

- $\quad$ - Spence Bate and Westwood, Brit. sessile-eyed Crust. 1868. App. p. 518. Cyrthophium Darvini, Danielssen, Beretning om en zoologisk Reise. p. 8.

Segmenta postabdominis tria anteriora in utroqve latere dorsi tuberculo parvo, sat lato, conico, rotundato instructa. Antennæ superiores articulo pedunculi 3tio elongato, duas tertias partes longitudinis 2di reqvanti. Pedes 1 mi paris carpo multo breviore qvam lato, in angulo inferiore posteriore producto. Pedes 2di paris manu longitudinem carpi fere æqvanti, in acie truncata. Pedes 3tii et 4 ti paris articulo 4 to multo breviore qvam 5to. Pedes trium parium ultimorum articulo 1 mo in utroqve margine setis longis, plumosis instructo. Pedes $7 \mathrm{mi}$ paris articulo 4 to multo breviore qvam 5to. Appendix caudalis brevior qvam lata.

Længden er $12^{\mathrm{mm}}$.

Legemet er bredt, nedtrykt; de tre første Haleled have paa hver Side af Ryggen en liden, men bred Fremstaaenhed af conisk Form; det tredie Leds nedre, bagre Vinkel danner en liden Hage. Sidepladerne ere smaa, meget længere end hoie, med en ultrukket forreste, nedre Vinkel. Hovedet er længere end det første Legemsled og gaar fortil ud $\mathrm{i}$ et lidet Pandehorn; dets Sidevinkler ere stumpe. Øinene ere ovale.

De øvre Følere ere lidt længere end Legemets halve Længde, besatte med Burster paa den undre Side. Skaftet er forlænget; det første Led or lidt kortere, men tykkere end det andet, vabnet med en Torn paa Enden af den nedre Rand; det tredie er omtrent saa langt som det andet Leds halve Længde. Svøben, der er noget kortere end Skaftet, dannes af 18-20 Led. Bisvgben er smal, kort 0 g har 4 Led.

De nedre Følere ere meget kortere end de ørre, med Børster paa den undre Side. Skaftets tredie Led er meget tykt, lidt længere end bredt, og den ydre Ende af den indre Rand gaar frem $\mathrm{i}$ en stump Tand; det fjerde er lidt længere og tykkere end det femte Led. Svøben er. længere end Skaftets sidste Led og dannes af 10-14 Led.

Overlæben er afrundet paa Enden.

Kindbakkerne ere meget kraftige; Gribedelen er indskaaret i $5-6$, den indre stærke Bigren i 4-5 Tænder; Tornerækken dannes af $2-3$ tynde Torne; Tyggeknuden er meget fremstaaende, paa Ender omgivet af en Krands af fine Tænder. Palpens tredie Led er kortere end det andet, temmelig smalt, med enkelte Børster paa Enden. 
Underl $x$ bens Hovedplader ere meget brede; de indre Plader ere store, besatte med Børster.

Det forste Kjæbepar er stærkt; den ydre Plade har paa Enden mange, tildels gaffeldannede Tænder; den indre Plade er oval, med tvende fjardannede Borster paa Enden. Palpen er paa Enden væbnet med fem korte Torne.

Det andet Kjæbepars Plader ere smale; den ydre er lidt længere og bredere end den indre; begge ere forsynede med Borster paa Enden.

Kjæb ef $ø$ d derne ere brede og stærke; den ydre Plade, der er bred oval og naar frem til den ydre Trediedel af Palpens andet Led, har strerke, men ikke talrige $(7-8)$ Tænder paa den indre Rand, hvilke mod Pladens Ende blive længere, smale, krumme og gaa tilsidst over i tynde Torne og fjærdannede Børster; den indre Plade har paa Enden tre Tiender og nogle Borster. Palpen er meget strerk og forlienget; det fjerde Led er meget smalt ved Enden og besat med tvende stærke Torne.

Det første Fodpar er kort, men kraftigt; det forste Led er nedad meget bredt; de tre følgende ere korte, og det fjerde Leds nedre, bagre Vinkel er udtrukket til en stærk Knude, besat med Børster; det femte er længere end det forste Led, meget bredt ved Roden, men smalere mod Enden, den bagre Rand er forsynet med nogle Børster og med flere stærke Tæuder, især der, hvor Kloens Spids lægger sig imod. Kloen er stærk, saugtakket paa den bagre Rand.

Det andet Fodpar er meget svagere og. tyndere; det fjerde Led er meget længere end bredt; det femte er af den samme Længde som det foregaaende Led, af en langstrakt firkantet Form, og danner ikke nogen egentlig Griberand.

Det tredie og fjerde Fodpar ere forlwngede, smale, paa begge Rande besatte med talrige fjærdannede Børster; det tredie Led, hvis bagre Rand er lidet udvidet, er længere end det fjerde, men af den samme Langde som det femte Led.

De tre følgende Fodpar ere af eens Bygning, men tiltage efter hverandre meget i Længde og ere, især paa det første Led, forsynede med lange, fjærdannede Borster; det forste Led er kun lidet udvidet bagtil og af en forlænget oval Form; det tredie er næsten dobbelt saa langt som det fjerde, og lidt længere end det femte Led. Kloen er lidt mere end halvt saa lang som det-sidste Led.

Det første Par Springfodders Grene ere meget tynde og have en Torn i Spidsen.

Det andet Par er kortere; Grenene ere ligeledes i Spidsen væbnede med en Torn, der næsten er saa lang som disse, samt med en tyndere og kortere paa hver Side af den større.

Det tredie Pars Grundleds indre, nedre Vinkel er meget udtrukket. Grenen er oval, med 5-6 lange Borster paa Enden.

Halevedhænget er meget stort, pladeformet, lidt kortere end bredt ved Roden, svagt tilspidset paa Enden. 
F arven er gulrød, eller graagul, med gulrødt Trærbaand over Rygsiden paa hvert Legemsled; alle Vedhæng ere hvidagtige. Øinene ere hvide.

Den er efter Danielssen hyppig ved Vadsø paa 60-100 Favne, paa blød Lerbund; af Malmgren er den ogsaa fundet ved Finmarken, af Torell og Malmgren paa Spitsbergen, i Bellsund, Storfjord og flere Steder; af 'Torell ved Grønland.

GLAUCONOME KRØYERI, A. Boeck, 1870.

(Pl. XXX. fig. 1.)

Glauconome Kroyeri, A. Boeck, Crust. amphip. bor. et arct. 1870. p. 179.

? Unciola planipes, Norman, Trans. Nat. Hist. Soc. of Northumberland and Durham 1865.

Vol. I. pl. VII. fig. 9-13. Rep. on the Shetland Crust. 1868. p. 286.

Corpus leve. Antenna superiores articulo pedunculi 3tio perbrevi et tertiam partem longitudinis articuli 2di aqvanti. Pedes $1 \mathrm{mi}$ paris carpo Iongiore qvam apud speciem prrecedentem, in angulo inferiore posteriore non producto; manu maris lata, in acie undata et spinis paucis sed validis armata; manu feminæ ovata, in acie spinis parvis instructa. Pedes 2di paris manu multo breviore qvam carpo, apicem versus angustiore. Pedes 3 tii et 4 ti paris articulo 4 to longitudinem articuli 5 ti fere æqvanti et parum longiore qvam 3tio. Pedes trium parium ultimorum articulo 1 mo setis longis, plumosis destituto; pedes 7 mi paris articulo 4 to et 5 to longitudine fere xqvalibus. Appendix caudalis paulo brevior qvam lata.

L ængden er omtrent $6^{\text {mm }}$.

L e gemet er glat og Ryggen uden Fremstaaenheder. Sidepladernes nedre, forreste Vinkel er hos Hannen udtrukket, hos Hunnen mere afrundet. Hovedet gaar fortil, mellem de øvre Følere, ud i et spidst Pandehorn.

De øvre Følere ere hos Hannen noget kortere end Legemet og middelmaadig tykke. Skaftets første Led er længere end Hovedet og er paa Enden af den ydre Side forsynet med en stump Torn; det andet er omtrent af den samme Længde, men meget smalere; det tredie Led er meget kort. Svoben er kortere end Skaftet $0 \mathrm{~g}$ dannes af $12-13$, med Børsteknipper besatte Led. Bisvoben er liden og har 1 Led.

De nedre Følere ere omtrent af den samme Længde som de øre, men meget stærkere, og ligne deri Arterne af Slægten Corophium. De tvende første Led ere sammenvoxede og paa den indre Rand forsynde med tvende korte, men stærke Torne; det tredie er længere end bredt og paa Enden af den indre Side besat med en stærk stump Torn; det fjerde er længere end det foregaaende Led; det femte Led er omtrent af den samme Længde som det fjerde, men meget smalere, og har paa Enden af den undre Side en stærk, stump Torn og Borsteknipper langs den undre Side. Svoben er kort og dannes af 7 Led, af hvilke de forste ere meget brede. Hos Hunnen ere disse Fø- 
lere meget tynde, kortere end de gvre; Svoben dannes af 6 tynde Led, med Børster paa den undre Side.

Munddelene ligne meget de samme hos den foregaaende Art.

Det forste Fodpar, der paa den bagre Rand er besat med Børster, er hos Hannen meget mere forlænget og ikke saa stærkt som hos den foregaaende Art; det fjerde Led er noget hjerteformet, og dets nedre, bagre Vinkel er ikke forlanget; det femte er ovalt, med en meget skraa afskaret Griberand, der er udbugtet, hvorved dannes tvende Fremragninger, besatte med fine Tænder og Børsteknipper samt med en større Torn. Kloen er stærk, lirum, paa den bagre Rand forsynet med fine Torne. Hos Hunnen er dette Fodpar noget mere forlænget; det femte Leds bagre Rand er mere skraa afskaaret og glat, uden Indbugtninger, og paa Enden af den forreste Rand sees et langt Børsteknippe.

Det andet Fodpar, der er af den samme Bygning hos begge Kjøn, er meget forlænget og smalt, især det fjerde Led, der er flere Gange saa langt som bredt, med Børsteknipper paa begge Rande; det femte er kun halvt saa langt som det foregaaende Led, smalere mod Enden, og har paa begge Rande Borsteknipper, der ere talrigst paa den forreste Rands ydre Halvdel. Kloen er kort, næsten ret, skjult af Børster.

Det tredie og fjerde Fodpar ere lange, smale; det første Led er pladeformet udvidet; de tre sidste ere smale og afvige kun ubetydelig fra hverandre i Laengde. Kloen er stærk, noget krummet, med fine Torne paa den bagre Rand.

De tre følgende Fodpar tiltage efter bverandre i Længde, men ere af eens Bygning; det første Led er pladeformet udvidet, uden fjærdannede Borster; de følgende Led ere lineære. Det femte og sjette Fodpars tredie Led er kortere end det første, og dets nedre, bagre Vinkel er forsynet med tvende rette Torne; det fjerde el dobbelt saa langt som bredt; det femte er omtrent saa langt som det første Led. Det syvende Fodpars fjerde Led er kortere end det tredie og saa langt som det femte, men bredere end dette.

Srommeføddernes Grundled er forlænget.

De tvende forste Par Springfødder naa omtrent lige langt bagud; Grenene ere cylindriske, nasten lige lange, kortere end Grundleddet, i begge Rande besatte med enkelte spredte Torne og i Spidsen med tre stærkere Torne, af hvilke den midtre er den længste.

Det sidste Pars Grundleds nedre, indre Vinkel er forlænget og har en Torn paa Enden; Grenen er langere end bred, oval, med nogle lange Borster paa den afrundede Ende.

Halevedhrnget er saa langt som bredt ved Roden, afrundet paa Enden.

Den er fundet af mig red Haugesund, i Christianiafjorden, samt ved Brettesnæs paa 40 Favnes Dybde. 
GLAUCONOME STEENSTRUPI, A. Boeck, 1870.

Glauconome Steenstrupi, A. Boeck, Crust. amphip. bor. et aret. 1870. p. 180.

Femina. Dorsum leve, tuberculis destitutum. Caput inter antennas superiores rostrum pervalidum, curvum emittens. Antennæ multo magis elongalæ qvam apud species præcedentes. Antennæ superiores articulo pedunculi 3tio dimidium longitudinis articuli 2di xqvanti; flagello longiore qvam pedunculo. Pedes $1 \mathrm{mi}$ paris manu ovali, fere endem longitudine ac carpo; hoc non perdilatato. Pedes 2 di paris manu multo breviore qvam carpo, in acie truncata. Pedes qvinque parium posteriorum setis plumosis destituli. Pedes 3 tii et 4 ti paris articulo 4 to longiludinem 3tii et 5ti xqvanti. Pedes trium parium posteriorum articulo 1 mo lineari. non dilatato, tam longo vel paulo longiore qvam 3tio; ungve dimidium longitudinis articuli 5ti superanti. Appendix caudalis ovalis.

Længden er $5^{\mathrm{mm}}$.

Legemet er forlænget, smalt, nedtrykt; liyggen er rund, bred. Hovedet er meget længere end det første Legemsled og gaar fortil, mellem de øvre Folere, ud i et lidet spidst Pandehorn.

De øvre Følere ere hos Hunnen meget forlængede og smale. Skaftets første Led er omtrent saa langt som Hovedet; det andet er. længere og smalere; det tredie har kun Halvdelen af det foregaaende Leds Længde. Svøben er længere end Skaftet og damet af 15 forlængede Led. Bisvoben er smal og har 1 Led.

De nedre Følere ere kortere end de gvre. Skaftets tredie Led er nasten tre Gange saa langt som bredt; det fjerde og femte ere omtrent lige lange. Svoben, der er omtrent saa lang som Skaftets sidste Led, dannes af 6 Led, af hvilke let sidste er viebnet med tvende Kløer.

Munddelene ligne dem hos de foregaaende Arter.

Det forste Fodpar er meget stærkt; det fjerde Led er ubetydelig bredere mod den ydre Ende; det femte er noget kortere, men meget bredere end det foregaaende Led, af en ægdannet Form. Kloen er forlænget, med Torne paa den bagre liand.

Det andet Fodpar er meget tyndere end det forste; det femte Led er forlænget ovalt, noget mere end halvt saa langt som det foregaaende Led og er ikke smalere mod den ydre Ende.

Det tredie og fjerde Fodpar ere meget smale; de tre sidste Led ere næsten lige lange.

De tre folgende Fodpar ere af en lineær Form og tiltage efter herandre i Længde; det første og tredie Led ere ikke udvidede nedad, omtrent af den samme Længde som det femte, og meget længere end det fjerde Led. Ḱloen er bred, længere end det sidste Leds halve Laengde og har nogle korte Børster paa den bagre Rand. 
Det forste.Par Springfødders ydre Gren er noget længere end den indre; begge have i Spidsen tre Torne, af hvilke den midtre er den langste.

Det andet Par er af den samme Form, men meget kortere.

Det sidste Par er meget kort. Grundleddet er udvidet paa den indre Rand og besat med nogle Torne; Grenen er forlænget oval, med nogle Børster paa Enden.

Halevedhænget er meget bredt, afrundet paa Enden.

Den er maaske kun Hunnen til G. Kroyeri, men maa indtil fornyede Undersøgelser fremdeles opfores som en særegen Art.

Den er fundet af G. O. Sars ved Aalesund paa 50-100 Favne og af mig ved Haugesund.

\section{Subfamilia 11.}

HELAIN代, A. Boeck, 1872.

Ilandibulæ articulo palpi 3tio breviore quam 2 do.

Pedes maxillares lanina exteriore in margine interiore dentibus paucis sed validis armata.

Corpus gracile, depressum; epimeris sat parvis.

Antennæ?

Pedes sat elongati; pedes $1 \mathrm{mi}$ paris iisdem 2 di paris majores.

Pedes trium parium ultimorum longitudine gradatim crescentes; articulo Imo non dilatato, lineari; articulo 4 to minimo.

Pedes saltatorii 1mi et 2di paris biramei, ultimi paris 1ramosi.

Forfatteren opstillede i 1860 Slægten Hela, der udmærkede sig saameget fra de ovrige til Underfamilien Corophince henforte Slægter, at han var i Tvivl, om den ikke hurde opfores som en egen Underfamilie; en fuldstændig Afgjorelse ansaa han dog ikke for berettiget, da det eneste Exemplar, han havde fundet af Hela monstrosa, manglede en Del af Folerne. Ved Formen af de fem sidste, lange, smale Fodpar, som ere væbnede med særdeles lange, næsten rette Kløer, og hvis første Led ikke er udvidet, men lineært, samt ved Bygningen af det sidste Par Springfodder, der vel er engrenet, men meget forlænget, afviger denne Slægt meget fra de øvrige hertil regnede Slægter. Munddelene frembyde derimod ikke noget særdeles eiendommeligt, men have den samme Typus som de foregaaende Slægter, horende til Underfamilien Corophine. Han har dog senere anseet det nødvendigt at udsondre denne Slægt paa Grund af de anførte Forskjelligheder og at opfore den som en egen Underfamilie under Familien Corophida.

Af denne Underfamilie er hidtil kun fundet een Slægt og Art. 
HELA, A. Boeck, 1860.

Deriv.: Hela, et nordisk, mythologisk Navn.

Syn.: 1860. Hela, A. Boeck, Forh. ved de skand. Naturf. Sde Mode, p. 668.

1870. - A. Boeck, Crust. amphip. bor. et arct. p. 180.

Type: Hela monstrosa, A. Boeck.

HELA MONSTROSA, A. Boeck, 1860.

(PI. XXXII. tig, 1.)

Hela monstrosa, A. Boeck, Forh. ved de skand. Naturf. 8de Møde. 1860. p. 669. Crust. amphip. bor. et arct. 1870 . p. 181 .

Caput latius qvam longum, in rostrum frontale productum, ad radicem antennarum inferiorum utrobiqve spinis singulis instructum. Antennæ inferiores articulo pedunculi 3 tio ad finem articuli pedunculi $1 \mathrm{mi}$ antennarum superiorum porrecto. Pedes $1 \mathrm{mi}$ paris manu breviore sed latiore qvam carpo, triangulari, in acie dentibus tribus validis armata; ungve longo, curvo, in margine convexo setoso. Pedes 2di paris manu angustiore qvam eadem $1 \mathrm{mi}$ paris, breviore qvam carpo, ovata, edentata. Pedes 3tii et 4 ti paris articulo 3tio longitudinem articuli $1 \mathrm{mi}$ fere arvanti; articulo 4 to et 5 to longitudine requalibus, brevioribus qvam 3tio. Pedes trium parium ultimorum articulo 4to tertiam vel frvartam longitudinis articuli 3tii aqvanti, in margine anteriore scopis setarum instructo; ungve fere reclo. parum breviore qvam articulo 5to. Pedes saltatorii $1 \mathrm{mi}$ paris ramo exteriore latiore qvam interiore. Pedes saltatorii ultimi paris ramo longiore qvam pedunculo.

Længden er omtrent $30^{\mathrm{mm}}$.

Legemet er nedtrykt. Sidepladerne ere meget smaa, knudeformede; den tredie og fjerdes forreste og bagre, ovre Vinkel udsender en stump Fremstaaenhed; de tvende følgende have kun en saadan bagtil; den sidste Sideplarle mangler disse Fremstaaenheder. Hovedet er bredt og fladt, bredere end langt, paa den forreste Rand forsynet med tre Fremspring, et mellem de øvre Folere, og et paa hver Side af disse; paa den forreste, nedre Vinkel sees et spidst Fremspring, der rager frem over Uispringet af de nedre Følere. Øine sees ikke.

De øvre Føleres første Skaftled er noget længere end Hovedet. Den ovrige Del manglede paa det undersøgte Exemplar.

De nedre Føleres første Skaftled er kort, kugleformet og udsender et Fremspring fra den nedre Sides ydre Kant; det andet er kortere end det første; det tredie er længere end de twende foregaaende Led tilsammen, men kortere end det forste Led paa de ovre Foleres Skaft. De ovrige Dele manglele. 
K indbakkernes Flige ere indskaarne i Tænder; Tornerækken dannes af tvende Torne, med smaa Bitorne; Tyggeknuden er stærk, fremstaaende. Palpen er kort; det andet Led er længere end det tredie.

Det forste Kjæbepars ydre Plade har paa Enden 6-8 stærke Torne; den indre Plade el liden med nogle Borster paa Enden. Palpen er lang og temmelig tynd; let andet Led har Torne paa Enden.

Det a ndet $\mathrm{Kj}$ a be pars Plader ere brede, den ydre er længere end den indre.

Kjæbefødderne ere stærke; den ydre Plade, der naar frem til den ydre Trediedel af Palpens andet Led, har paa den indre Rand stumpe Tænder, der blive længere mod Pladens Ende; den indre Plade, der naar frem til Begyndelsen af Palpens andet Led, er paa Enden indskaaret i tre Tænder, samt har her og langs den ydre Del af den indre Rand fine Børster. Palpens andet Led er meget længere end det tredie; let fjerde har nogle Torne paa Enden.

Det første Fodpar er kortere, men stærkere end det andet; det første Led er langt, noget fortilbøiet, breilere nedad, med en lidet udvidet bagre Rand, og begge Rande, især den forreste, er besat med Børstebundter; det andet er meget kort; det tredie er lidt længere end det foregaaende; let fjerde er kortere, men meget bredere end det første Led, ovalt, med en mere bøiet bagre end forreste Rand, og paa begge Rande besat med Borstebundter, hvilke ere længere og mere tætstaaende paa den bagre Rand; det femte Led eller Haanden er kortere og bredere end det foregaaende Led, af en trekantet Form; dens forreste, meget bøiede Rand er besat med kortere, i Tværraler staaende Børsteknipper, den bagre har længere, mere tætstaaende Børster; den skraa afskaarne Griberand har tvende mindre Tænder samt nogle Børster og en stærkere, større Tand paa den ydre Ende. Kloen er længere end det sidste Led, stærk, krummet, med Børster paa den forreste Rand.

Det andet Fodpar er langere, men tyndere, og er ligeledes besat med Børster; Haanden er mere langstrakt oval, Griberanden er mere skraa afskaaren, svagt indbugtet.

Det tredie og fjerde Fodpar ere af eens Bygning og Størrelse; det første Led er saa langt som det tilsvarende paa de tvende forste Fodpar, men er meget smalere; det andet er kun noget længere end bredt; det tredie er ubetydelig længere end det forste; det fjerde er noget længere end Halvdelen af det foregaaende; det femte er omtrent saa langt som det fjerde. Kloen har Halvdelen af det sidste Leds Længde.

De tre følgende Fodpar ere af eens Bygning, men tiltage efter hverandre i Langde; det første Led er langt og smalt; det tredie er omtrent af den samme Længde; det fjerde er kun lidt længere end det korte andet Led; det femte er noget mere end Halvdelen af det tredie Leds Lrengde, men er meget smalere. Kloen er næsten ret, lidt kortere end det sidste Led. Alle Led, især det fjerle, have spredte Borsteknipper. 
Svgmmefold erne ere meget lange, smale.

Det første Par Springfødder naar længst bagud; Grundleddet er langt, uden Torne; Grenene ere lige lange, tlade, den ydre er forlænget trekantet, den indre er smal, lancetformet, og begge ere forsynede med Torne paa den ydre Rand.

Det andet Par er meget kortere og tyndere; Grenene ere lige lange, smale, med fine, tynde Torne.

Det sidste Par er meget lidet, eengrenet; Grenen er meget lixngere end Grundleddet, konisk, med spredte Torne.

H a levedhrnget er lidet, ovalt, helt.

Aandes akke findes ved Befrestelsen fira det andet til det sjette Fodpar.

Denne Art blev fundet i eet Exemplar i Christianiafjorden paa 20-30 Favnes Dybde.

\section{Frmilia IX.}

CHELURID A, Allman, 1847.

$$
\begin{aligned}
& \text { Syn.: 1847. Uheluride, Allman, Ann. Nat. Hist. XIX. p. } 361 . \\
& \text { 1819. - Dana, Amer. Journ. of Sci. 2. ser. Vol. VIII. U. S. explor. } \\
& \text { exped. 1852. p. } 829 \text {. } \\
& \text { 1862. - Spence Bate, Catal. Amphip. Crust. Brit. Mus. 1862. p. } 285 . \\
& \text { 1863. - Spence Bate and Westwood, Brit. sessile-eyed Crust. p. 501. } \\
& \text { 1865. - Lilljeborg, On the Lysianassa magellanica. } \\
& \text { 1870. Chelurince, A. Boeck, Crust. amphip. bor. et arct. p. 172. }
\end{aligned}
$$

Labium superius elongatum, in apice rotundatum.

Mandibulx in apice productæ, acuminatæ, parum dentatæ; ramo accessorio parvo, bidentato; serie spinarum ex spinis paucis validis et setis plumosis constanti: tuberculo molari valde prominenti; palpo brevi, 3articulato.

Maxilla $1 \mathrm{mi}$ paris dentibus validis armate; palpo 2articulato, in apice dentibus paucis validis vel spinis armato; lamina interiore elongata, angusta.

Iaxillæ 2di paris laminis brevibus, non vero perlatis.

Pedes maxillares laminis magnitudinis mediocris, spinis aracilibus modo instructis; palpo elongato, robusto; articulo palpi 4 to non ungviformi, in apice spinis duabus curvatis instructo.

Corpus subdepressum; epimeris parvis.

Segmenta tria posteriora postabdominis coalita.

Antennæ superiores breves, flagello accessorio instructæ.

Antennæ inferiores superioribus multo longiores, late; segmentis flagelli coalitis. 
Pedes natatorii pedunculo introrsum valde dilatato.

Pedes saltatorii 1mi et 2di paris parvi.

Pedes saltatorii ultimi paris pedunculo perbrevi. uniramosi: ramo magno lamelliformi.

Appendix caudalis parva.

Allman opstillede denne Familie i $184 \%$ paa den af Philippi beskrevne Slægt Chelura. Han adskilte den fra Familien Corophidee ved, at flere af Halens Led ere sammensmeltede, og ved Springføddernes eiendommelige Form. Dana optog den ogsaa som en Familie i 1852, hvilket man senere har fulgt. Jeg antog dog i 1870 , at Slægten Chelura burde henføres til en Underfamilie. Chelurina. der blev stillet mellem Underfamilierne Podocerince og Corophince.

I Munddelenes Form viser denne Familie flere Eiendommeligheder, der bør benyttes som Karakterer. De ere nemlig indrettede til at søndergnave det haarde Træ, som Dyret trænger gjennem. Desuden bør som Karakter, hvilket jeg har anført i 1870. optages de nedre Folere: disse have et skuffeformet Udseende, idet Svobens Led ere sammenvoxede og uddannede til et Redskab, hvormed de udgravede Spaaner hortskaftes.

\section{CHELURA, Philippi, 1839.}

Syn.: 1839. Chelura, Philippi, Archiv f. Naturgesch. V. p. 120. Aun. Nat. Hist. IV. pl. III. fig. 5 .

- - Allman, Ann. Nat. Hist. XIX. p. 361.

1847. Nemertes, White, Cat. Crust. Brit. Mus. p. 90.

- Chelura, White, Cat. Crust. Brit. Mus. p. 56. Hist. Brit. Crust. 1857. p. 202.

1855. - Gosse, Mar. Zool. I. p. 138.

185\% - Spence Bate, Ann. Nat. Hist. 2. ser. XIX. p. 149. Catal. Amphip. Crust. Brit. Mus. 1862. p. 285.

1863. - Spence Bate and Westwood, Brit. sessile-eyed Crust. p. 502.

1870. - A. Boeck, Crust. amphip. bor. et arct. p. 173.

Type: Chelura terebrans, Philippi.

Segmentum postabdominis 3tium in medio spina longa, crassa, curvata. apud marem majore qqam apud feminam, armatum.

Pedes $1 \mathrm{mi}$ et 2di paris parvi, invicem fere eadem forma; manu angusta. cheliformi; pedes 2di paris graciliores.

Pedes trium parium ultimorum articulo 1 mo parum dilatato.

Appendix caudalis lamelliformis, in apice rotundata.

Slægten er opstillet af Philippi i 1839. White har i 1847 kaldt den Nemertes; begge Navne ere dog allerede forhen benyttede. 
CHELURA TEREBRANS, Philippi, 1839.

Cheluraterebrans, Philippi, Arch. f. Naturgesch. 1839. V. p. 120. pl. III. fig. う.

\begin{tabular}{|c|c|c|}
\hline - & 一 & Allman, Ann. Nat. Hist. 1839. XIX. p. 361. pl. XIII. \\
\hline - & - & $\begin{array}{l}\text { White, Cat. Brit. Crust. 1850. p. 56. Hist. Brit. Crust. 1857. p. } 202 . \\
\text { pl. XI. fig. 2. }\end{array}$ \\
\hline 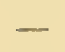 & 一 & Gosse, Mar. Zool. 1855. I. p. 138. fig. 250. \\
\hline & - & $\begin{array}{l}\text { Spence Bate, Brit. Assoc. Rep. 1855. p. 59. Ann. Nat. Hist. } 1857 . \\
\text { 2. ser. XIX. p. 149. Catal. Amphip. Crust. Brit. Mlus. } 1862 . \\
\text { p. 285. pl. XLVIII. fig. 1. }\end{array}$ \\
\hline & - & Spence Bate and Westwood, Brit. sessile-eyed Crust. 1863. p. 503. \\
\hline & -- & Heller, Beitr. z. näh. Kenntn. d. Amphip. d. adriat. Meeres 1866. p. 52. \\
\hline & - & A. Boeck, Crust. amphip. bor. et arct. 1870. p. 173. \\
\hline
\end{tabular}

Antennæ inferiores flagello ovali, eliptico; segmentis flagelli coalitis. Pedes $1 \mathrm{mi}$ paris manu longiore, 2di paris breviore qvam carpo. Pedes saltatorii $1 \mathrm{mi}$ paris pedunculo perdilatato et crenulato. Pedes saltatorii ultimi paris ramo apud marem majore qvam apud feminam, elongato, ovato. Appendix caudalis in apice paulo producta.

Langden er $4,5^{\mathrm{mm}}$.

Legemet er meget nedtrykt; Ryggen er bred, rund; de bagre Legemsled og (le tvende første Haleled ere paa sin bagre Rand forsynede med en Rrkke fine Tome; det tredie Haleled er af en eiendommelig Form, det er meget bredere end de foregaaende og bøiet paa den bagre Rand; fra Rygsidens Midte udgaar der bagtil en stork og bøiet Torn, som er større hos Hannen end hos Hunnen, og til Siderne af denne danner Leddet tvende bredere, men kortere Fremragninger; de tre sidste Haleled ere sammensmeltede til en bred Plade, der barer de tre bagre Halefodder. Sirlepladerne ere smaa, kantede. Hovedet er meget bredt, afrundet og nedbøiet fortil. Øinene ere runde.

De øvre Følere ere kortere end Skaftet paa de nedre. Skaftets Led aftage efter hverandre i Længde og Tykkelse, saa at det tredie kun er lidt længere end tykt. Svøben, der er kortere end Skaftet, dannes af 6 Led. Bisvøben er'meget liden, tynd.

De nedre Foleres forste Skaftled er tykt; det andet udsender en kort Lugteknude; det tredie er noget længere end bredt; det fjerde og femte ere omtrent lige lange $0 \mathrm{~g}$, især det sidste, paa begge Rande besatte med lange, stærke Børster. Alle Svobens Led ere sammenvoxede til en stor, bred, concav Plade, der paa begge Rande har tætte Borsteknipper.

Overlæben er afrundet paa Spidsen og besat med Børster.

Kindbakkerne ere stærke, i Spidsen indskaarne $\mathrm{i}$ faa Tæender; den indre Bigren er liden; Tornerækken dannes af' fire krumme, stærke Torne og af $5-6$ fjærdan- 
nede Borster; Tyggeknuden er meget stor, fremragende. Palpen er tyk og kort; det tredie Led er næsten saa langt som det andet og har paa Enden talrige Børster samt tvende langere i Spidsen.

Underlæben er meget bred og lidet hoi; de ydre Plader have paa Enden en Bundt Børster; de indre sees ikke.

Det forste Kjæbepars ydré Plade er paa Lnden vabnet med mange, med Bitænder forsynede Tænder; den indre Plade er smal, med fjærdannede Børster i Spidsen. Palpens Ende har paa den ene Side fire grove, paa den anden mange tyndere Tænder.

Det andet Kjæbepars ydre Plade er noget bredere end den indre.

Kjæbefodderne ere stærke; den ydre Plade er væbnet paa den indre Rand med tynde Torne, der blive langere mod Pladens Ende; len indre Plade, der naar frem til Enden af Palpens forste Led, er lang, smal og har paa Enden lange, tynde Torne. Palpen er meget stærk; det fjerde Led har tvende stærke Torne i Spidsen.

Det forste Fodpar er lidet; det fjerde Led er kort, lidt bredere mod Enden; Haanden er langere, lidt bøiet, og dens nedre, bagre Vinkel er udtrukket, hvorved der fremkommer en chelat Form; den forreste og bagre Rand, ligesom de tvende foregaaende Leds bagre Rand, ere forsynede med fjærdannede Børster.

Det andet Fodpar er længere og smalere; det fjerde Led er kum ubetydelig smalere mod Enden og er lidt længere end den smale chelate Haand. Alle Led have, saavel paa den forreste Rand som ogsaa, især det sidste, paa den bagre lange fjærdannede Borster.

Det tredie og fjerde Fodpars forste Led er forlanget ovalt; det tredie er kort, dog langere end det fjerde, der ogsaa er kortere end det femte Led. Kloen er liden, krum.

De tre følgende Fodpars første Led er kun lidet udvidet, med fjærdannede Borster paa den bagre Rand; det tredie Leds nedre, bagre Vinkel er udtrukiet, besat med fiærdannede Børster; det fjerde er kort; det femte er kun ubetydelig kortere end de tvende foregaaende Led tilsammen. Kloen er krummet, væbnet med en Bitand paa den convexe Rand.

Svommefoddernes Grunlled er indad meget udvidet, afrundet 0 g væbnet med tvende saugtakkede Kløer. Grenene ere ikke meget lange; den ydre er længere end den indre, og begge have kortere Borster.

Det forste Par Springfødders Grundled er indad meget udvidet og besat med Tagger paa den convexe Rand; Grenene ere særleles korte, pladeformede, kun lidt langere end brede, og rundtakkede paa Enden.

Det andet Pars Grundled er smalt; Grenene ere smaa, med Torne paa Enden.

Det sidste Pars Grundled er kort, meget bredere end langt; Grenen er pladeformet, forlænget, ægdannet, væbnet med smaa Torne paa Randene.

Halevedhanget er meget bredere end langt, lidt tilspidset paa Enden.

Jeg har fundet den i talrig Mængde i en Stok i Christianiafjorden. Efter All- 
man er den fundet ved Dublin og ligeledes paa flere Steder ved de engelske Kyster, efter Philippi ved Triest og er efter Heller i det Hele hyppig ved Adriaterhavet. Efter Spence Bate forekommer den i Tommer, der er under Vandets Overflade, sammen med Limnoria lignorum, rimeligvis langs alle Europas Kyster.

\section{Familia $\mathbf{X}$.}

DULICHID E, Dana, 1849.

Syn.: 1849. Dulichiide, Dana, Amer. Journ, of Sci. 2. ser, vol, VIII.

1852. Dulichida, Dana, U. S. explor. exped. p. $82 \%$

1857. Dyopedidee, Spence Bate, Synopsis etc. Ann. Nat. Hist. 2. ser. XIX.

1859. Dulichidre, Bruzelius, Skand. Amphip. Gamm. p. 10.

1862. - Spence Bate, Catal. Amphip. Crust. Brit. Mus. p. 347.

1865. - Goës, Crust. amphip. maris Spetsb. p. 18.

- - L Lilljeborg, On the Lysianassa magellanica.

1868. Dulichiide, Spence Bate and Westwood, Brit. sessile-eyed Crust. II. p. 28.

1870. Dulichida, A. Boeck, Crust. amphip. bor. et arct. p. 181.

Labium superius perlatum, in apice subsinuatum.

Mandibula validæ, in apice dentatæ, ramo accessorio magno et dentato instrucle; luberculo molari robusto; serie spinarum ex spinis paucis, validis vero, in extremo margine convexo serralis, constanti; palpo longo, gracillimo; articulo palpi 3tio breviore qvam 2 do.

Labium inferius validum; laminis interioribus pervalidis.

Maxillæ $1 \mathrm{mi}$ paris lamina interiore majore vel minore; articulo palpi 2 do elongato, in apice spinoso.

Pedes maxillares lamina exteriore in margine interiore spinis crassis armata; articulo palpi 4 to crasso, in apice spina una valida, ungviforme instructo.

Corpus elongatum, lineare, depressum; epimeris minimis; postabdomine ex qvinqve modo articulis constanti et qvinqve pedum paribus instructo; sextus thoracis annulus cum septimo plerumqve coalitus.

Antennæ superiores et inferiores subpediformes, prælongatæ, superiores flagello appendiculari plerumqve instructæ.

Dana opstillede denne Familie i 1849 under Amphipoda Grammaridea, og den indbefattede da kun Slægten Dulichia, Kr. Han fremhæver væsentlig, at den i Udseende ligner Caprellida, da Legemet er lineært og Sidepladerne ere næsten rudimentære; desuden siger han, at de bagre Fodpar ere lange, næsten uddannede til Gribefodder, hvilket dog neppe forlrolder sig saaledes. Den vigtigste Karakter, hvorved 
den skiller sig fra de foregaaende Familier, er, at Halen dannes af kun fem Led, og at den har kun fem Fodpar. Krøyer har allerede i 1845 panvist, at hans Slægt Dulichia danner Overgang mellem Gammaride og Caprellide. Spence Bate har opstillet Familien sammen med Caprellidee til en egen Gruppe, Aberrantia, for hvilken han anfører som Karakter, at de tre bagre Fodpars forste Led ikke er udvidet, og at Halen mangler et eller flere Led. Jeg indser imidlertid ingen Grund til, at disse tvende Familier mere bør stilles sammen i en egen Gruppe end mange af de foregaaende. Spence Bate kaldte denne Familie i 1857 Dyopedide efter Slrgten Dyopedos, som han senere fandt at være synonym med Dutichia.

Til denne Familie føiede Bruzelius i 1859 en ny Slægt Latmatophilus, og jeg i 1870 Slægterne Paradulichia og Xenodice.

Gen. I. DULICHIA, Krøyer, 1845.

Deriv.: Soגıxós, lang.

Syn.: 1845. Dulichia, Krøyer, Nat. Tidsskr. 2. R. 1. R. p. 521. Voy. en Scand. pl. XXIII. fig. 1 .

1857. Dyopedos, Spence Bate, Ann. Nat. Hist. 2. ser. XX. p. 150.

- Dulichia, Spence Bate, Ann. Nat. Hist. 2. ser. XIX. p. 526. Catal. Amphip. Crust. Brit. Mus. 1862. p. 347.

1859. - Bruzelius, Skand. Amphip. Gamm. p. 10.

1865. - Goës, Crust. amphip. maris Spetsb. p. 18.

1868. - Spence Bate and Westwood, Brit. sessile-eyed Crust. II. p. 30.

1870. - - A. Boeck, Crust. amphip. bor, et arct. p. 182.

Type: Dulichia spinosissima, Krøyer.

Segmentum trunci 6 tum et $7 \mathrm{mum}$ coalita.

Antennæ superiores flagello accessorio parvo.

Antennæe inferiores superioribus graciliores et breviores.

Pedes 1 mi paris tenues; manu parva, subcheliformi.

Pedes 2di paris apud feminam iisdem $1 \mathrm{mi}$ paris similes, sed carpo breviore et latiore quam eodem $1 \mathrm{mi}$ paris; pedes 2 di paris apud marem multo majores; manu permagna.

Pedes 3tii et 4 ti paris invicem ejusdem longitudinis et formæ, sed pedes 3 tii paris articulo 3 tio breviore et articulo 4 to longiore qvam 4 ti paris.

Pedes 5 ti et 6ti paris invicem similes.

Pedes $7 \mathrm{mi}$ paris pralongati.

Pedes saltatorii $1 \mathrm{mi}$ et 2di paris 2ramosi; ramo exteriore breviore quam interiore. 
Krayer opstillede denne Slægt i 1845 paa Arten $D$. spinosissima fra Gronland. I sin Slægtsdiagnose anfører han, at det første Fodpars fjerde Led er den egentlige Haand, og at det femte med Kloen danner en toleddet Finger. Denne Anskuelse synes mig tvungen, og jeg kan ikke finde andet, end at det femte Led danner den egentlige, om end lille Haand. Krøyer har ogsaa angivet, hvilken stor Forskjel der paa det andet Fodpar er mellem Hannen og Hunnen, hvilket Spence Bate mindre synes at have bemærket. Han har ligeledes fremhævet, at det tredie og fjerde Fodpars Bygning ikke er fuldkommen eens.

I 1855 kaldte Spence Bate Slægten Dyopedos, forinden han kjendte Krøyers Arbeide, hvorpaa han senere optog Slægtsnavnet Dulichia.

DULICHIA SPINOSISSIMA, Krøyer, 1845.

Dulichia spinosissima, Krøyer, Nat. Tidsskr. 1845. 2. R. 1. B. p. 512. Voy. en Scand. pl. XXII. fig. 1 ,

- $\begin{aligned} & \text { Spence Bate, Catal. Amphip. Crust. Brit. Mus. 1862. p. } 347 . \\ & \text { pl. LIV. fig. 8. }\end{aligned}$
- $\quad$ Goës, Crust. amphip. maris Spetsb. 1865. p. 18.
- $\quad$ A. Boeck, Crust. amphip. bor. et arct. 1870. p. 182.

Caput in rostrum frontale longum, rectum et acuminatum productum. Segmenta trunci in margine inferiore spinis validis instructa. Segmentum trunci 7 mum et segmenta postabdominis duo anteriora in margine posteriore dentibus binis armata; segmentum postabdominis 3tium in eodem loco dente uno longissimo armatum. Pedes 2 di paris apud marem articulo 1 mo valde dilatato, in angulo inferiore anteriore producto; manu elongato, subcurvata, ex superiore tertia parte marginis posterioris calcem suhcurvatam emittenti et in extremo margine prope radicem ungvis spina valida instructa. Pedes trium parium ultimorum prælongati; articulo 3tio longitudinem articuli 4 ti et 5 ti junctorum superanti. Pedes saltatorii 1 mi paris ramo exteriore longitudinem pedunculi xqvanti; ramo interiore longiore.

Le gemet er forlænget smalt; det første Legemsled, der er lidt kortere end det andet, er paa hver Side væbnet med tvende udad og nedad rettede Torne; det andet har fem; det tredie og fjerde have hver fire: det femte Led 3-4, af hvilke dog de bagre i Regelen ere utydelige; det sjette og syvende, som ere sammensmeltede, ere væbnede paa den samme Maade og udsende fra Midten af den bagre Rand tvende stærke Torne ved Siden af hinanden. Halens tvende forste, korte Led have lignende Torne; det længere tredie udsender derimod en stor, bagudrettet Torn; det fjerde er meget langt og tyndt; det femte Led er meget kort. Sidepladerne ere særdeles smaa. Horedet er meget forlænget, idet Panden gaar fortil ud i et meget sammentrykt, knivdan- 
net, mod Enden tilspidset Horn; en stor, fladtrykt, ud-og nerlad rettet Torn udgaar fra den nedre, bagre Del af Hovedets Sider. Øinene ere runde.

De øvre Følere ere en halv Gang længere end Legemet. Skaftets første Led er tykt, noget kortere end Hovedet; det andet er fem Gange saa langt som det første og er paá Enden af den øvre Rand forsynet med en Knude eller et stumpt. Horn; det tredie er tyndere og længere, samt har ligeledes en Knude paa Enden af den øvre Rand. Svøben dannes af 5 Led, der aftage efter hverandre i Længde. Bisvøben er liden og har 3 Led.

De nedre Folere ere omtrent halvt saa lange som de ovre. Skaftets tredie Led er kort; det femte er længere, men tyndere end det fjerde, og paa Enden af den øvre Rand ere begge udtrukne til et stumpt Horn. Svøben dannes af 3 Led, af hvilke det første er tre Gange saa langt som de tvende følgende tilsammen.

Det første Fodpar er meget mindre end det andet; det første Led er pladeformet; det fjerde er længere end dette og er nedad meget smalere; det femte er bredere nedad $0 \mathrm{~g}$ kortere end det foregaaende Led.

Det andet Fodpar er hos Hannen meget stort; det første Led er fortil udvidet, især mod den ydre Ende, og er her udtrukket til en tilspidset Flig; det fjerde er meget kort; det femte Led eller Haanden er.særdeles stort, længere end det forste, trindt, noget boiet, og fra den bagre Rand udgaar der en stor, paa Enden sammentrykt, fingerdannet Forlangelse, ligesom der fra Enden af denne Rand udspringer en stærk Torn. Kloen er stor, stærk, krummet, med Børster paa den bagre Rand. Hos Hunnen er dette Fodpar meget mindre.

Det tredie Fodpar er lidet og tyndt; det tredie Led er ubetydelig udvidet og saa langt som det femte.

Det fjerde Fodpar er lidt langere'og smalere.

De tre følgende Fodpars første Led er ikke udvidet, men lineært; det tredie er paa det femte Fodpar længere end det forste Led, ligesom det paa alle Fodpar er længere end det fjerde og femte Fodpar tilsammen. Disse tvende sidste Led ere lige lange paa det femte og sjette Fodpar; paa det syvende Fodpar er det fjerde Led længere end det femte.

Det første Par Springfødders ydre Gren er noget længere end Grund-. leddet, men kortere end den indre.

Halevedhænget er lancetformet.

Denne Art er ikke sjelden ved det sydlige Grønland ifølge Holböll og Torell. Ved Spitsbergen er den ifølge Goës fundet i Storfjord af Malmgren.

DULICHIA FALCATA, Spence Bate, 1857.

(Pl. XXIX. fig. 10.)

Dyopedos falcatus, Spence Bate, Ann. Nat. Hist. 185\%. 2. ser. XIX. p. 151. 
Dulichia falcata, Spence Bate, Ann. Nat. Hist. 1857. 2. ser. XX. p. 526. Catal. Amphip. Crust. Brit. Mus. 1862. p. 348. pl. LIV. fig. 10.

$-\quad$ White, Hist. Brit. Crust. 185\%. p. 209.
- $\quad$ - $\quad$ Spence Bate and Westwood, Brit. sessile-eyed Crust. 1863. p. 33.
- $\quad$ A. Boeck, Crust. amphip. bor. et arct. 1870. p. 183.

Corpus non spinosum, leve. Caput antice rotundatum. Pedes 2 di paris apud marem manu prælongata, angusta, ex superiore tertia parte marginis posterioris calcem tortam, ex extremo margine prope radicem ungvis spinam acutam, validam emittenti. Pedes trium parium ultimorum prælongati, graciles. Pedes 5 ti et 6 ti paris articulo 3tio longiore quam 1 mo et longitudinem articuli 4 ti et 5 ti junctorum superanti; articulo 4 to et 5 to angustis, longitudine invicem æqvalibus. Pedes $7 \mathrm{mi}$ paris articuli 3 tio vix longiore qvam articulo 4 to et 5to junctis. Pedes saltatorii 2di paris pedunculo pralongato, longitudine ramum interiorem fere reqvanti, exteriorem superanti.

Længden er $5-6^{\mathrm{mm}}$.

Legemet er uden Torne, Hovedet er uden Pandehorn.

De ørre.Følere ere omtrent saa lange som Legemet. Skaftets første Led er ikke fuldt tre Gange saa langt som tykt; det andet er kortere, men tykkere end det tredie Led. Svoben er omtrent saa lang som Skaftets sidste Led.

De tvende første Fodpar ere hos Hunnen lige de tilsvarende hos D. porrecta; hos Hannen derimod er det andet Fodpars Haand forlænget, lidt bøiet; fra den indre Ende af den bagre Rand udgaar der en S-formet Fremstaaenhed, og fra denne Rands ydre'Ende udgaar der en stærk Tand, ligesom Randen forøvrigt er besat med stærke Børster.

De tre bagre Fodpar ere meget forlængede, smale. Det femte Fodpars første Led er lineært, kortere end det tredie Led, men bredere end dette; det tredie er ikke dobbelt saa langt som de tvende sidste Led tilsammen.

Det sjette og syvende Fodpars forste Led er kortere, men det tredie er længere end paa det femte Par. Det syvende Fodpars tredie Led er omtrent saa langt som de tvende følgende Led tilsammen; det fjerde Led er dobbelt saa langt som rlet femte.

Det andet Par Springfødders Grundled er kun lidt kortere end den indre Gren; den ydre Gren er kortere end den indre.

Jeg har fundet denne Art i Christianiafjorden og ved Haugesund; G. O. Sars har fundet den i Hardangerfjorden. Ifolge Spence Bate er den af Mc'Gregor taget ved Macduff.

DULICHIA NORDLANDICA, A. Boeck, 1870.

(Pl. XXIX, fig. 11.)

Dulichia Nordlandica, A. Boeck, Crust. amphip. bor. et arct. 1870. p. 183. 
Corpus leve. Frons brevior qvam apud speciem præcedentem, rotundata. Pedes 2di paris apud marem manu magna et lata, calce destituta. in fine marginis posterioris dentibus duobus instructa; dente postico validiore et acuto. dente antico breviore et magis obtuso; ungve in summo margine interiore tuberculo robusto instructo. Pedes trium parium ultimorum prælongati, angusti. Pedes 5ti et 6ti paris articulo 3tio longiore qvam articulis duobus seqventibus junclis; articulo 410 longiore qvam 5to. Pedes saltatorii ultimi paris pedunculo paulo breviore qvam ramo exteriore et multo breviore qvam interiore.

\section{Længden er $4^{m m}(?)$.}

Legeme $t$ er meget langstrakt, tyndt; det første Legemsled er kortere end det andet; de følgende tiltage i Længde, saaledes at det fjerde er det længste af alle; de tvende sidste ere sammensmeltede; de tre forste Haleled ere meget korte, men tiltage efter hverandre i Længde; det fjerde er smalt $\mathrm{og}$ saa langt som de tvende foregaaende tilsammen; det sidste Led er overordentlig kort. Hovedet danner fortil intet Pandehorn.

De øvre Følere have spredte Børsteknipper paa den undre Rand. Skaftets forste Led er omtrent saa langt som Hovedet; det andet er mere end dobbelt saa langt; det tredie er længere end det foregaaende Led, men smalere. Svoben dannes af 4 forlængede Led, af hvilke det forste er saa langt som de sidste tilsammen. Bisvoben har 2 Led.

De nedre Følere ere kortere end de ovre og ligesom disse med enkelte Børsteknipper paa den undre Rand. Skaftets tredie Led er kun lidt længere end tykt; det femte er omtrent saa langt som det andet Led paa de øvre Folere og lidt 'længere end det foregaaende Led.

Det første Fodpar er langt og smalt; det tredie Led er længere end tykt, forsynet med flere lange Børster paa den bagre, meget convexe Rand; det fjerde er mere end dobbelt saa langt, smalere mod Enden og har tre lange, tildels fjærdannede Borster paa den bagre Rand; det femte er kortere end det foregaaende Led, af en forlænget oval Form og har paa den bagre Rand lange fjærdannede Børster. Kloen er krummet, lidt kortere end det sidste Led.

Det andet Fodpar er meget stærkere og større hos Hannen end hos Hunnen; det fjerde Led er kort, meget bredt, den bagre, nedre Vinkel er meget afrundet, med mange Børster; Haanden er forlænget, noget oval, med en stærkere krummet forreste end bagre Rand, hvilken sidste paa sin ydre Ende har en lang, stærk Tand. Griberanden er næsten ret afskaaret, kort og forsynet med en stump Fremstaaenhed. Kloen er meget lang, dog kortere end det sidste Led, og væbnet nær sin Rod med en stærk Tand paa den bagre Kand, hvilken, naar Kloen lægger sig mod Griberanden. passer ind mellem de-næunte Tænder.

Det tredie og fjerde Fodpar ere af eens Bygning; det tredie Led er meget 
kort, lidet udvidet nedad; det fjerde er længere og smalere, omtrent saa langt som det første Led; det femte er kortere end det foregaaende Led. Kloen er liden.

De tre følgende Fodpar ere meget lange og smale; det første Led er lineært.

Det femte Fodpars tredie Led er noget længere end det første og længere end de tvende følgende tilsammen; det femte er kortere end det foregaaende Led.

Det sjette Fodpars forste Led er noget kortere end paa det foregaaende Fodpar.

Det syvende Fodpars første Led er end kortere; det tredie er i Forhold meget længere end det første Led, og det fjerde meget længere end det femte, forlænget agdannede Led, der har nogle Torne paa den forreste, mere convexe Rand. Kloen er kortere end det sidste Led, med tre Torne paa den bagre Rand.

Det første Par Springfødder naar længst bagud; den ydre Gren er kortere end den indre, der er noget længere end Grundleddet.

Det andet Par er kortere og den indre Gren meget længere end Grundleddet. Paa begge Par sees spredte Torne.

Denne Art har jeg fundet $\mathrm{i}$ Christianiafjorden og ved Skraaven paa 2-300 Favnes Dybde.

\section{DULICHIA TUBERCULATA, A. Boeck, 1870.}

(Pl. XXX. fig. 4.)

Dulichia tuberculata, A. Boeck, Crust. amphip. bor. et arct. 1870. p. 183.

Caput magis productum et rotundatum qvam apud speciem præcedentem. Pedes 2di paris breves, lati, in summo margine posteriore calce perbrevi, acuminata, in infimo margine posteriore dente valido instructi; ungve in summo margine posteriore tuberculis duobus instructis. Cæteroqvin ferme ut apud speciem præcedentem.

$L \rightsquigarrow n g d e n$ er $4^{\mathrm{mm}}$.

L e gemet er lineært forlænget, noget nedtrykt; det første Legemsled er noget kortere end det andet, der er omtrent saa langt som hvert af de følgende; de tvende sidste Led ere sammensmeltede, men der sees en skraa Fure, der betegner Grændsen mellem dem. De tre første Haleled ere korte; det fjerde er meget forlænget; det sidste er meget kort. Sidepladerne ere-næsten rudimentære. Hovedet er næsten saa langt som de tvende første Legemsled tilsammen og gaar fortil ud i et bredt, men stumpt Pandehorn, der bøier sig over Udspringet for de øvre Følere; den forreste Rand er skraa afskaaret. Øinene ere temmelig store, runde.

De grre Følere ere omtrent af den samme Længde, som det hele Legeme. Skaftets første Led er noget kortere end Hovedet; det andet er omtrent tre Gange saa langt, men meget smalere; det tredie Led er kun ubetydelig kortere end det fore. 
gaaende Led. Svoben, der er en Trediedel længere end Skaftets sidste Led, dannes af 4 særdeles forlængede Led, der efter hverandre aftage i Læugde, saa at det forste Led er omtrent saa langt som de følgende tilsammen. Bisvøben er meget tynd og har 2 Led, af hvilke det sidste er næsten rudimentært.

De nedre Følere ere meget kortere end de ovre. Skaftets trende forste Led ere sammensmeltede; det tredie er noget længere end tykt; det fjerde og femté, der ere næsten lige lange, ere hvert omtrent saa lange som de øvre Foleres andet Led. Svøben, der er kortere eud Skaftets sidste Led, dannes af 3 Led, af hvilke det forste er længere end de tvende følgende Led til sammen.

Kindbakkerne ere kløvede i Spidsen, og Grenene ere brede, tandede; Tyggeknuden er stærk. Palpen er forlænget og har tre Led.

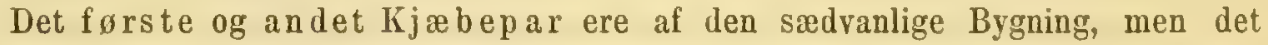
første Pars indre Flade er næsten rudimentær.

$\mathrm{Kj}$ j b efødderne ere brede, især Palpens andet Led; det sidste, der ikke er sammensmeltet med det foregaaende, bærer i Spidsen en Bundt Børster.

Det første Fodpar er forlænget; det forste Led er temmelig kort; det fjerde er længere end dette, men meget bredt ved Roden, samt smalere paa Enden, med Børster paa den bagre Rand; det femte Led, eller Haanden, er liortere, forlænget oral, med Børster paa den bagre Rand. Kloen er tynd, noget krummet.

Det andet F odpar er forskjelligt hos Hannen og Hunnen. Hos hiin el det første Led kort, noget krummet; det fjerde er kort, triangulært; Haanden er særdeles stor, oval, med en noget boiet forreste og en uregelmæssig dannet bagre Rand, idet der sees en stærkt fremspringende Tand $\mathrm{i}$ den bagre Kant og en lignende noget kortere nærmere Kloens Udspring; Griberanden er kort, noget indbugtet. Iíloen er stærk, meget krummet, indskaaret nær Rodeu, og danner der en halvkugleformet Fremstaaenhed. Hos Hunnen er dette Fodpar omtrent af den samme Størrelse og Form som det første Par; àet fjerde Led er kort; Haanden er af den samme Længde som dette. Det tredie Fodpars første Led er langt, smalt, ovalt; det tredie er meget kort, lidet udvidet; det fjerde og femte ere omtrent lige lange.

Det fjerde Fodpar er noget længere; det forste Led er kortere, det tredie er længere end paa det tredie Fodpar.

De tre følgende Fodpar tiltage efter hverandre $i$ Længde og ere af en lineær Form.

Det femte Fodpars tredie Led er saa langt som det forste og længere end det fjerde og femte Led tilsammen; det femte er af den samme Længde som det foregaaende Led, og begge have Børster paa den forreste Rand. Ǩloen er kortere end det sidste Led.

Det sjette Fodpars tredie Led er meget længere end det forste.

Det syvende Fodpars tredie Led er ligeledes meget langere end det første; det fjerde er meget længere end det femte Led. 
Svømmef $ø$ d derne ere meget forlængede.

Det første Par Springfødder naar 'længst bagud; Grenene ere betydelig længere end Grundleddet, cylindriske, forsynede med mange Torne paa Randene, samt med tvende smaa og en længere $\mathrm{i}$ Spidsen; den ydre er kortere end den indre Gren.

Det andet Par er meget kortere; Grenene ere næsten dobbelt saa lange som Grundleddet; den ydre er en Trediedel kortere end den indre Gren, der har enkelte Torne paa den indre Rand.

Haleved hænget er pladeformet, afrundet paa Enden.

Denne Art er af G. O. Sars fundet i Hardangerfjorden, af mig i Christianiafjorden.

\section{DULICHIA CURTICAUDA, A. Boeck, 1870.}

(Pl. XXIX. fig. 9.)

Dulichia curticauda, A. Boeck, Crust. amphip. bor. et arct. 1870. p. 184.

Caput antice paulum productum et rotundatum. Pedes trium parium ultimorum multo breviores et validiores gram apud species prrecedentes. Pedes 5 ti et 6 ti paris articulo 3tio tam longo qvam 1 mo et longitudine articulos duos seqventes junctos fere aqvanti; articulo 4 to et 5 to longitudine invicem xqvalibus. Pedes $7 \mathrm{mi}$ paris articulo $1 \mathrm{mi}$ perbrevi; articulo 4 to paulo breviore qvam 3 tio et multo longiore qvam 5to. Pedes saltatorii ultimi paris pedunculo brevissimo, parum modo longiore quam crasso, quartam partem longitudinis ramo interioris vix aqvanti.

Længden er $5-6$ mm.

Legemets Form er meget lig den hos den foregaaende Art. Det forste Legemsled er kort; det andet er bredere og længere; de tvende følgende ere de største; det sjette og syvende, der tilsammen danne eet Led, ere ikke saa høie som det femte Led og kun ubetydelig bredere end dette. Hovedets forreste Rand er kun lidet fremstaaende, afrundet.

De øvre Følere ere af den samme Længde som det hele Legeme, eller noget længere. Skaftets forste Led er ikke dobbelt saa langt som tykt; det andet er kortere end det tredie Led.

Det tredie F odpars tredie Ised er kortere end det fjerde; det femte er omtrent saa langt som det foregaaende Led.

Det fjerde Fodpars tredie Led er længere end det fjerde, der er omtrent saa langt som det femte Led.

Det femte Fodpars første Led er smalt, linexrt; det tredie er ubetydelig kortere end det første og omtrent saa langt som det fjerde og femte tilsammen; disse tvende sidste Led ere lige lange.

Det sjette Fodpars første Led er kortere end paa det femte Par; de tre sidste Led ere derimod længere. 
Det syvende Fodpars forste Led er kortere end paa de tvende foregaaende Fodpar; det tredie er ogsaa længere; det fjerde er noget kortere end det foregaaende og meget længere end det femte Led.

Det sidste Par Springfodders Grundled er neppe længere end tykt; den ydre Gren er kortere end den indre, hvilken er 4-5 Gange saa lang som Grundleddet.

Jeg har fundet denne Art i Christianiafjorden.

DULICHIA PORRECTA, Spence Bate, $185 \%$.

(PI. XXX. tig. 2, 3.)

Dyopedos porrectus, Spence Bate, Ann. Nat. Hist. 185\% 2. ser. XIX. p. 151.

Dulichia porrecta, Spence Bate, Ann. Nat. Hist. 185\%. 2. ser. XX. p. 526. Catal.

Amphip. Crust. Brit. Mis. 1862. p. 348. pl. LIV. fig. 9.

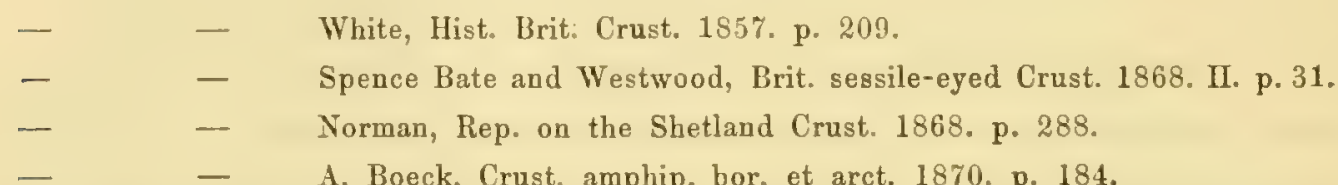

Caput paulum productum, rotundatum. Epimerum 2dum antice productum et acuminatum. Pedes 2di paris apud marem prælongati; manu elongata, angusta, in fine marginis posterioris processu dentiformi valido instructa; calce manus recta, in apice acuminata; ungve non perlongo, in margine posteriore tuberculis duobus parvis et setis coimpluribus instructo. Pedes trium parium ultimorum breviores et latiores quam apud species præcedentes. Pedes 5 ti paris articulo 1 mo paulo longiore, 6ti paris breviore, $7 \mathrm{mi}$ paris multo breviore quam articulo 3 tio. Pedes 5 ii et 6 ti paris articnlo 4 to spinoso, multo breviore qvam 5to; pedes $7 \mathrm{mi}$ paris articulo 4 to ferme eadem longitudine ac 5́to. Pedes saltatorii ultimi paris pedunculo circiter dimidiam longitudinem rami interioris æqvantes.

Lingden er $7 m$ m.

Legemet er forlænget, smalt, uden Torne. Den anden Sideplade er den største; dens forreste, nedre Vinkel er tilspidset. Hovedet gaar fortil ud i en forlænget, stump Fremstaaenhed.

De øvre Følere ere næsten saa lange som Legemet. Slaftets første Led er kortere end Hovedet; det andet er 3-4 Gange saa langt; det tredie er omtrent af den samme Længde som det foregaaende Led. Svoben er kortere end Shaftets sidste Led. Bisvøben har 2 smaa Led.

De nedre Følere ere kortere end de øvre; det femte Led er meget kortere end det fjerde. Svoben er kortere end Skaftets sidste Led.

Det første Fodpar er kort; det første Led er lidet, bredere nedad; det 
fjerde er kortere end de tre foregaaende Led tilsammen, er smalere mod Enden og har paa den bagre, convexe Rand talrige Borstebundter; Haanden er forlænget oval, med Børster paa den bagre Rand.

Det andet Fodpar er meget storre end det første og hos Hannen meget større end hos Hunnen; det første Leds nedre, forreste Vinkel er forlænget afrundet. Haanden er længere end det første Led og lidt bredere mod den ydre Ende; fra den bagre Rand udgaar en forlænget, noget krum, paa Enden spids tandformet Fremstaaenhed, der naar frem ikke fuldt til Leddets Ende; en lignende, meget mindre Tand sees paa Randens Ende. Kloen er krum, med tvende Knuder og nogle Borster paa den bagre Rand.

Det tredie og fjerde Fodpar ere af eens Bygning, men det fjerde Pars tredie Led er længere end det tilsvarende paa det tredie Par.

Det femte Fodpars første Led er saa langt som det tredie eller ubetydelig længere end dette Led; det tredie er forsynet med Torne paa den ydre Del af den forreste Rand; det fjerle er meget kort og har tvende Længderader af Torne, som nedad blive længere; det femte er meget liengere end det foregaaende led, lidt krummet

Det sjette Fodpar er af den samme Form, men det forste Led er meget kortere; det tredie er liengere end det forste; det fjerde er meget kortere end det femte Led og forsynet med Torne.

Det syvende Fodpars forste Led er lidt længere end det samme paa det foregaaende Par; det tredie forlængede Led er meget længere end det første og næsten saa langt som de tvende folgende Led tilsammen; det fjerde er noget kortere end det femte Led og forsynet med Torne.

Det sidste Par Springfodders ydre Gren er kortere end den indre, som er mere end dobbelt saa lang som Grundleddet.

Halevedhæuget er lancetformet.

Spence Bate og Westwood angive, at de øvre Folere ere omtrent af Dyrets halve Liengde. De omtale ogsaa en Varietet, paa hvilken det andet Fodpars Haand er kortere og tykkere end paa de typiske Exemplarer, ligesom den nederste Tand er rettet ikke saa meget fremad. Dette finder Sted hos yngre Individer og sees oftere hos de ved vore Kyster fundne Exemplarer:

Farven er hvid, med Rxkker af brune Pletter langs hvert Legemsled og paa Sidepladerne, Halen og tildels Fodparrene. Øinene ere hvide.

Den er fundet af G. 0. Sars i Hardangerfjorden, af mig ved Haugesund og i Christianiafjorden. Efter Spence Bate er den fundet ved Banff, af Norman i St. Magnus Bugt paa 40-60 Favne; efter Packard er den ikke sjelden ved Labrador.

(I et af Forfatterens Manuskripter findes en Afbildning af en Form, benæunet D. armata. Den nedre Rand af det første Legemsled løber ud i et langt, nedad og fremad rettet Fremspring, der naar frem til Hovedets forreste Rand. Det andet F odpars Haand er saa langt som det fjerde Led; fra Midten af den bagre Rand og fra 
dens ydre Ende udgaar en Tand; Griberanden er kort, næsten tvært afskaaret og har en større Tand og nærmere Kloens Udspring en liden Fremstaaenhed. Kloen er længere end Griberanden og har paa den bagre Rand et afruncet Fremspring, der møder, naar den bøies mod Griberanden, den paa denne værende Knude. Forøvrigt er den meget lig $D$. porrecta.

Den er noteret at vare fundet af G. O. Sars ved Aalesund paa 40-50 Favnes Dybde.)

Gen. II. PARADULICHIA, A. Boeck, 1870.

Deriv: $\pi \alpha \alpha^{\prime}$, hen til, Dulichia.

Syn.: 1870. Paradulichia, A. Boeck, Crust. amphip. bor. et arct. p. 185.

Type: Paradulichia typica, A. Boeck.

Antenna multo breviores qvam apud genus Dulichia.

Pedes saltatorii ultimi paris 1ramosi; ramo minimo.

Reliquva cum genere præcedenli conveniunt.

Jeg adskiller denne Slægt fra den foregaaende, som den i det Hele staar meget nær, ved at Folerne ere meget kortere, og ved at det sidste Par Springfødder er eengrenet og Grenen er meget liden. Jeg troede forst, at denne Karakter kun betegnede en Abnormitet, idet dette Par muligens var afbrukket og ikke paany fuldstandig udvoxet. Efter at have havt Anledning til at undersøge flere herhen hørende Exemplarer fandt jeg dog, at denne Dannelse var normal hoṣ den Art af Slægten Dulichia, der tillige besad kortere Folere end de øvrige Arter.

\section{PARADULICHIA TYPICA, A. Boeck, 1870.}

(PI. XXIX. fig. 8.)

Paradulichia typica, A. Boeck, Crust. amphip. bor. et arct. 1870. p. 185.

Femina. Caput parum modo productum. Pedes trium parium ultimorum non prælongati. Pedes 5 ti paris articulo $1 \mathrm{mo}$ paulo longiore, 6 ti et $7 \mathrm{mi}$ paris breviore qvam articulo 3 tio; hoc longitudine articulum 4 tum et 5 tum junctos, invicem longitudine aqvales, fere requanti. Pedes $7 \mathrm{mi}$ paris articulo 4 to parum modo longiore qram 5to. Pedes saltatorii $1 \mathrm{mi}$ paris pedunculo breviore qram ramo exteriore. Pedes saltatorii 2di paris articulum cylindricum parvum formantes.

Længden er $5-6^{\mathrm{mm}}$.

Legemet er uden Kjøl eller Torne. Hovedets forreste Rand er kun lidet udtrukket.

De ørle Følere ere kortere end Legemet, besatte med Børsteknipper paa 
den undre Rand. Skaftets første Led er mere end dobbelt saa langt som tykt; det andet er næsten tre Gange saa langt, men tyndere; det tredie er længere end det foregaaende Led. Svøben dannes af 2 meget forlængede Led, af hvilke det forste er det længste; det andet har tvende lange Børster paa Enden. Bisvøben er meget liden.

De nedre Fglere naa ikke frem til Enden af de ovre Føleres Skaft og har ligeledes Børstebundter paa den undre Rand. Skaftets fjerde og femte Led ere næsten lige lange. Svøben dannes af 3 forlængede Led, af hvilke det forste er saa langt som de tvende følgeride tilsammen.

Kindbakkerne ere meget kraftige; Gribedelen er tandet; den indre Bigren er stxrk; Tornerakken dannes af tvende Torne; Tyggeknuden er fremstaaende. Palpen er særdeles tynd; det tredie Led er neppe halvt saa langt som det andet, med trende Borster paa Enden.

Underlæbens indre Plader ere ovale, omtrent af den samme Størrelse som de ydre.

Det $\mathrm{f}$ rs te $\mathrm{Kj}$ wb e pars ydre Plade er vabnet med fem almindelige og ligesaa mange gaffeldannede Torne; den indre Plade er liden, næsten triangular. Palpen har paa Enden fire stærke Torne.

Kjæbefoddernes ydre Plade er stor, og dens indre Rand er væbnet med en Række stærke Torne; den indre Plade er meget bred, naar frem til Enden af Palpens forste Led og er paa den indre Rand besat med nogle fjærdannede Borster og paa Enden med tre Tiender og nogle krumme Børster. Palpens andet Led er forlænget; det tredie er bredere mod den ydre Ende, der er besat med Børster; det fjerde er meget kort, med trende lange Torne i Spidsen.

Det forste Fodpars fjerde Led er forlænget, smalere mod Enden, med Børster paa den bagre Rand; det femte er forlænget ovalt, kortere end det foregaaende Led $0 \mathrm{~g}$ er besat med talrige Børster paa den bagre Rand og den indre Side. Kloen er svagt krummet og har fine Torne paa den bagre Rand.

Det andet Fodpars fjerde Led er kortere og bredere end det første, med en stærkt buet bagre Rand, hvis ydre Del er længere end den indre; Haanden er lidt kortere, ægdannet, med tvende Torne, hvor Kloens Spids lægger sig imod. Kloen er forsynet med Torne paa den bagre Rand.

Det tredie Fodpars første Led er noget udvidet bagtil; det tredie Led er kort.

Det fjerde Fodpars tredie Led er længere end paa det foregaaende Fodpar.

Det femte Fodpars forste Led er lineært; det tredie er kortere end dette og neppe saa langt som de tvende følgende Led tilsammen.

Det sjette Fodpars forste Led er kortere, det tredie er længere end paa det foregaaende Fodpar og omtrent saa langt som det fjerde og femte Led tilsammen; det fjerde Led har Torne paa den forreste Rand.

Det syvende Fodpars tre sidste Ised tiltage meget i Liengde i Forhold til de tvende foregaaende 'Fodpar. 
Det første Par.Springfødders ydre Gren er kortere end den indre, der er noget længere end Grundleddet og har Torne paa den øvre Rand.

Det andet Par er overmaade kort, rudimentært, smalt, eenleddet.

Den er fundet af mig i Hardangerfjorden, og ved Aalesund af G. O. Sars paa 50-100 Favnes Dybde.

Gen. III. LATMATOPHILUS, Bruzelius, 1859.

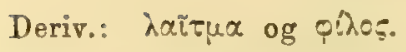

Syn.: 1859. Latmatophilus, Bruzelius, Skand. Amphip. Gamm. p. 10.

1870. - A. Boeck, Crust. Amphip. bor. et arct. p. 185.

Type: Lutmatophilus tuberculatus, Bruzelius.

Segmentum trunci 6tum et $7 \mathrm{mum}$ coalita.

Antennæ superiores processui frontali magno affixæ; flagello pauci-articulato; flagello accessorio absenti.

Antennæ inferiores crassitudine et longitudine superioribus æqvales.

Pedes $1 \mathrm{mi}$ et 2 di paris manibus subcheliformibus instructi; pedes 2di paris majores.

Pedes 3 tii et 4 ti paris invicem ejusdem formæ, pervalidi; articulo 3 tio perbrevi, articulo 4 to et 5 to elongatis.

Pedes trium parium ultimorum invicem ejusdem forma, longitudine gradatim crescentes.

Pedes saltatorii $1 \mathrm{mi}$ paris 2ramosi; ramo exteriore breviore qvam interiore.

Pedes saltatorii ultimi paris tuberculiformis.

Bruzelius, som har opstillet denne Slægt i 1859, har tillige vist, at den maa stilles nær Slagten Dulichia, hvorfra den dog skiller sig i flere Henseender. Folerne ere frstede paa Spidsen af en fra Hovedet udgaaende større Forlængelse; de tvende forste Fodpars femte Led danner en temmelig stor, stærk Gribehaand; det tredie og fjerde Fodpar, som hos Slægten Dulichia ere korte, ere her forlængede, kun lidt kortere end de følgende Fodpar, som ere lange, og hvis samtlige Led ere smale. Deres Kløer ere lange, stærke, krumme. De tre første Haleled ere korte, hrorimod det fjerde er meget længere, smalt, med lange 2-grenede Springfodder; derimod er det femte Led meget lidet og har kun et kort, tykt, rudimentært Fodpar, som ei viser Spor af Led. Halevedhænget er lidet.

Denne saaledes beskrevne karakteristiske Slægt blev imidlertid af Spence Bate, der dog ikke havde seet noget Exemplar af $L$. tuberculatus, i 1862 henfort til Slægten Cyrthophium, Dana, idet han antog, at Halen var afbrukket og ikke atter udvoxet. 
Dens Form er dog normal for denne Slægt, der saaledes maa stilles paa den af Bruzelius angivne Plads. I 1870 forggede jeg denne Slægt med en ny Art, L. spinosissimus. Herhen hører maaske ogsaa Cyrthophium armatum, Norman.

\section{LÆTMATOPHILUS TUBERCULATUS, Bruzelius, 1859.}

(PI. XXIX, fig, 7.)

Lætmatophilus tuberculatus, Bruzelius, Skand. Amphip. Gamm.1859. p.11.pl.1. fig.1. A. Boeck, Crust. amphip. bor. et arct. 1870. p. 185.
Cyrthophium tuberculatum, Spence Bate, Catal. Amphip. Crust. Brit. Mus. 1862. p. 275.

Caput supra tuberculis duobus parvis instructum. Segmenta trunci qvinqve anteriora supra e transverso depressa et nodulis ternis instructa. Segmenta trunci duo posteriora et duo anteriora postabdominis supra tuberculis binis armata. Antennæ superiores, longitudine inferioribus æqvales, ad segmentum postabdominis 3tium circiter porrectæ; articulo flagelli 1 mo minimo; 2do prælongato. Pedes $1 \mathrm{mi}$ paris manu ovata, breviore qvam carpo. Pedes 2 di paris articulo 3tio brevi, in angulo inferiore posteriore acuminato; manu maris elongata, ovali, in margine anteriore arcuata, in posteriore recta; manu femina ovata. Pedes quinqve parium posteriorum articulo 3 tio breviore qvam 4to; hoc breviore qvam 5to; ungve perlongo, valido et curvo.

Længden er $5--6^{\mathrm{mm}}$.

Legemet er meget nedtrykt; Ryggen er bred; paa det forste Legemsled sees tvars over Ryggen en Indsynkning og tvende smaa Fremstaaenheder; paa de folgende fire Led er en lignende Indsynkning, samt tre Fremstaaenheder nor den bagre Rand, den ene foran de tvende andre; det sammenvoxede sjette og syvende Led har tvende Par Fremstaaenheder, ligesom de tvende forste Haleled. Det fjerde Haleled er af den samme Lxngde, som de tvende foregaaende tilsammen, det femte er kort og lidet. Hovedet, der er lidt længere end det forste Legemsled, er bredt, afplattet og har paa den ovre Side tvende smaa Fremstaaenheder; dets forreste Rand forlænger sig til et bredt, fremragende Fremspring, hvortil de ovre Følere ere fæstede; dets Sidevinkler ere skarpt tilspidsede; paa den nedre Kant af Hovedet sees en dyb Indskjaring for de nedre Følere.

De øvre Følere naa, naar de bøies bagud, omtrent til det tredie Haleled og ere besatte med Børster paa den undre Rand. Skaftets forste Led er kort; det andet er dobbelt saa langt, men smalere; det tredie er omtrent af den samme Længde. Svoben dannes af 3 Led, af hvilke det forste er saa langt som Skaftets sidste Led; de øvrige ere meget korte.

De nedre Følere ere omtrent af den samme Længde og have ligeledes Bør- 
ster langs den undre Rand. Skaftets tredie Led er kort; det fjerde og femte ere nasten lige lange. Svøben dannes af 3 Led, af hvilke det første er saa langt som Skaftets sidste Led; de følgende ere meget korite.

Overlæben er bred, paa Enden afrundet og forsynet med fine Børster.

Kindbakkerne ere stærke, triangulære; Gribedelen er bøiet, bred, indskaaret i 5-6 Tænder, den indre Bigren er ligeledes bred og forsynet med 4-5 Tænder; Tornerækken dannes af grove Børster; Tyggeknuden er meget fremstaaende, med et Gjærde af fine Tænder. Palpen er meget lang og tynd; det tredie Led er kortere end det andet og har talrige Børster i Spidsen.

Underlæbens Plader ere meget brede.

Det første Kjæbepars ydre Plade er bred, væbnet paa Enden med stærke Tænder, som paa Enden af den concave Rand have et Par Bitænder; den indre Plade er rudimentær, knudedannet. Palpen har nogle Torne i Spidsen.

Det andet Kjæbepars Plader ere korte; den ydre er længere og bredere end den indre.

Kjæbeføddernes ydre Plade naar frem til Midten af Palpens andet Led, er oval, og dens indre, næsten rette Rand er væbnet med korte, grove Torne; den indre Plade naar frem til Enden af Palpens forste Led og har i Spidsen fjærdannede Børster. Palpens fjerde Led er ikke klodannet, men er smalere mod Enden, der er besat med tvende stærke, grove Torne.

Det forste Fodpars fjerde Led er forlænget bredt, med en forreste ret og bagre buet Rand; begge ere besatte med talrige Børster; Haanden er kortere end det foregaaende Led, med Børster paa begge Rande.

Det andet Fodpar er meget større. Hos Hannen er det første Led nedad meget bredere, og den forreste, nedre Vinkel er udtrukket, tilspidset; det fjerde Led er meget kort; Haanden er af den samme Længde som alle de foregaaende Led tilsammen, med bueformet forreste og ret bagre Rand, der har lange Børster og paa Enden gaar ud i en stærk, i Kanterne saugtakket Tand. Kloen er lang og stærk. Hos Hunnen er dette Fodpar forholdsvis meget mindre, især Haanden, der her er oval og midt paa den bagre Rand er væbnet med en Torn.

Det tredie og fjerde Fodpar ere af eens Bygning; det tredie Led er meget kort; det fjerde er længere; det femte er længere end det foregaaende Led.

De tre følgende Fodpar tiltage efter hverandre noget i Længde; det første Led er ikke udvidet, lineært; det tredie er kort, lidt udvidet; det fjerde og femte Led tiltage efter hinanden i Langde.

Det første Par Springfødders ydre Gren er kortere end den indre og saa lang som Grundleddet.

Det andet Par er cylindrisk, uleddet.

Halevedhæuget er kort, paa Enden afrundet, helt.

Denne Art er fundet af G. 0. Sars ved Kysten af Nordland paa 60-100 Favne, 
af mig $\mathrm{i}$ Christianiafjorden; af Bruzelius i Gullmarsfjorden i Bohuslen og ved Kosterøerne paa.120-130 Favne.

\section{LETMATOPHILUS SPINOSISSIMUS, A. Boeck, 1870.}

Latmatophilus spinosissimus, A. Boeck, Crust. amphip. bor. et arct. 1870. p. 186.

Caput spina longa armatum. Segmentum trunci 1 mum in medio dentibus duobus latis, ad basin pedum $1 \mathrm{mi}$ paris tuberculo instructum; segmenlum 2lum spinis tribus longis, antice in medio spina una, postice spinis duabus, instructum. Segmenta qvinqve seqventia trunci et duo anteriora postabdominis in utroqve latere dorsi spinas singulas gerentia. Segmentum trunci 4 tum et 5 tum ad basin pedum spinis singulis validis armata. Capteroqvin ferme ut apud speciem pracedentem.

Det andet Fodpars tredie Leds nedre, bagre Vinkel er ikke tilspidset; hos Hannen er Haanden længere end de foregaaende Led tilsammen; den forreste Rand er boiet, den bagre er næsten ret, besat med Borster, samt har henimod Enden en stump Tand, foran hvilken der er en dybere Indskjæring, og mellem denne og Kloens Rod sees brede Saugtakker. Kloen er krum, længere end det sidste Leds halve Lıængde. Hos Hunnen er det fjerde Led forlænget, af en trekantet Form, med Børster paa den bagre, rette Rand; Haanden er meget mindre, oval. Kloen er omtrent saa lang som det sidste Led. Forøvrigt er denne Art meget lig den foregaaende.

Den er fundet af G. O. Sars ved Christiansund og Aalesund paa 50-100 Favne, samt i Hardangerfjorden; af mig ved Skraaven paa 300 Favne.

Gen. IV. XENODICE, A. Boeck, 1870.

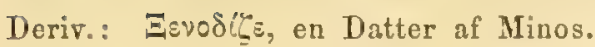

Syn.: 1870. Xenodice, A. Boeck, Crust. amphip. bor. et arct. p. 186.

Type: Xenodice Frauenfeldti, A. Boeck.

Pedes maxillares 2 di paris lamina interiore magnitudinis mediocris, in margine interiore setis pluribus (7) instructa.

Antennx superiores et inferiores longitudine fere aqvales; flagellis multiarticulatis sed multo brevioribus qvam pedunculo.

Antennæ superiores flagello accessorio instructæ.

Segmentum trunci 5tum et 6tum non coalita.

Pedes $1 \mathrm{mi} 2$ diqve paris magnitudine et forma fere æqvales; manu parva, subcheliformi. 
Pedes 3tii et 4 li paris ejusdem magnitudinis, elongati.

Pedes trium parium posteriorum longitudine gradatim crescentes, filiformes. Pedes saltatorii $1 \mathrm{mi}$ 2diqve paris elongati, biramei.

Denne Slægt afviger mere fra Slægten Dutichia end den foregaaende, især ved at Folernes Svober ere mangeleddede. Forøvrigt viser den Overensstemmelse med den nævite Slagt, med Undtagelse af, at de tvende sidste Legemsled ikke ere sammensmeltede, som hos de tre foregaaende Slægter.

XENODICE FRAUENFELDTI, A. Boeck, 1870.

Xenodice Franenfeldti, A. Boeck, Crust. amphip. bor. et arct. 1870. p. 18\%

Corpus leve. Antennæ superiores longitudine animalis paulo breviores; articulo pedunculi 2do et 3tio longitudine fere æqvalibus; flagello accessorio 3articulato, fere duplo longiore, qvam articulo flagelli 1mo. Antennæe inferiores articulo pedunculi 4 to et 5 to longitudine fere reqvalibus. Pedes $1 \mathrm{mi}$ paris manu triangulari, breviore qvam carpo. Pedes 2di paris paulo angustiores; pedes utriusque paris in margine anteriore et posteriore scopis setarum instructi. Pedes 3 tii et 4 ti paris articulo 3tio paulo breviore qvam articulis duobus seqventibus conjunctis. Pedes 5ti paris articulo 3 tio multo breviore qvam 4to et paulo longiore qvam 5to. Pedes 6ti paris articulo 3tio vix longiore qvam articulis duobus seqventibus conjunctis; his longitudine reqvalibus. Pedes 7 mi paris articulo 3tio breviore qvam articulo 4 to et 5 to; 5 to longiore.

$\mathrm{L} æ \mathrm{ngden}$ er indtil $14^{\mathrm{mm}}$.

Legemet er forlænget smalt; Ryggen er bred og rund. Sidepladerne ere smaa. Hovedet er længere end det første Legemsled og gaar fortil ud i en Fremragning for Befiestelsen af de øvre Folere; mellem begge disse sees en Indskjæring i denne Fremragning.

De ørre Følere ere ikke fuldt saa lange som Legemet. Skaftets første Led er omtrent saa langt som Hovedet; det andet er meget tyndere og mere end dobbelt saa langt; det tredie er næsten af den samme Længde; begge disse have spredte, lange Borstebundter paa den undre Rand. Svøben, der er noget længere end Skaftets sidste Led, dannes af 10 forlængede, med Børstebundter besatte Led. Bisvøben har 3 Led og er næsten dobbelt saa lang som Svøbens første Led.

De nedre Følere, der ligeledes have spredte Børstebundter paa den undre Rand, ere noget kortere og smalere end de øvre, samt ere fæstede $i$ en Indskjæring paa Hovedets Siderande. Skaftets andet Led udsender en lang, spids Lugteknude; det tredie naar ikke frem til de ovre Foleres forste Skaftled og er omtrent tre Gange saa 
langt som tykt; det fjerde har liat mere end den dobbelte Længde af det tredie Led, det femte er ubetydelig længere end det foregaaende Led.

0 verlæben er meget bred.

Kindbakkerne ere kraftige, i Spidsen stærkt tandede ligesom den indre Bigren; Tyggeknuden er stor, fremstaaende. Palpen er tynd, forlænget; dens sidste Led er afrundet paa Enden og besat med lange Borster.

Det forste Kjæbepars indre Plade er bred med mange Borster paa den indre Rand. Palpen har faa, men stærke Torne paa Enden.

Det andet $\mathrm{Kj}$ jepers Plader ere særdeles brede, især den ydre.

Kjæbeføddernes ydre Plade naar ikke frem til Enden af Palpens andet Led og har Tænder paa den indre Rand; paa dens Ende sees ligeledes Trender og krumme Torne. Palpen er tynd.

Det første Fodpars begge Rande ere besatte med Børster; det første Led er noget bøiet og udvidet nedad, og den nedre, bagre Vinkel er lidt udtrukken; de tvende folgende Led ere meget korte; det fjerde er forlænget, næsten ligesaa langt som det forste, men bredere end dette, og har paa begge Rande, især den bagre, lange, noget krumme Børstebundter; Haanden er kort, triangulær. Kloen er næsten saa lang som det sidste Led, svagt krummet.

Det and et Fodpar er af den samme Bygning, men meget langere, og Haanden er mere langstrakt.

Det tredie og fjerde Fodpar ere af eens Form og meget langstrakte; det tredie Led er noget kortere end det første og de tvende folgende tilsammen; det fjerde Led er noget længere end Halvdelen af det tredie Leds Længde; det femte er ubetydelig længere, men smalere end det foregaaende Led.

Det femte Fodpars forste Led er noget længere og tykkere end det tilsvarende paa de tvende foregaaende Fodpar; det tredie er kun ubetydelig længere end det første Leds halve Længde og kortere end det fjerde, men længere end det femte Led. Kloen er liden.

Det sjette og syvende Fodpar tiltage efter hinanden lidt i Længde og Tykkelse; det tredie Led er meget lingere end paa det femte Par, og kun lidt kortere end det forste Led. Paa det sjette Fodpar er det tredie Led neppe længere end de tvende følgende tilsammen; det femte er af den samme Længde som det fjerde Led. Paa det syvende Fodpar er det tredie Led kortere end de tvende folgende tilsammen; det femte er længere end det fjerde Led.

De fem sidste Fodpar ere kun svagt besatte med Borster.

Springfodderne ere af eens Form, med lange, tynde Torne, især paa Enden af Grenene; den ydre Gren er lidt kortere end den indre; begge ere meget lortere end Grundleddet.

Hal evedhænget er. meget kort, bredt, noget tilspidset paa Enden, og er paa hver Side forsynet med tvende tynde Børster. 
Denne Art er fundet af G. O. Sars i Hardangerfjorden og af mig ved Skraaven paa 120—200 og paa 2-300 Favne.

III. Divisio.

\section{Caprellina.}

Syn.: 1842. Amphipoda Lamodipoda, Krøyer, Nat. Tidsskr. 1. R. 4. B. p. 495. 1852. Caprellidea, Dana, U. S. explor. exped. p. 807.

1870. Caprellidæ, A. Boeck, Crust. amphip. bor. et arct. p. $18 \%$

Mandibula plerumqve palpo destitulæ.

Maxillæ $1 \mathrm{mi}$ paris lamina interiore carentes.

Pedes maxillares palpo elongato; articulo ultimo ungviformi.

Corpus partim elongatum, gracile, partim latum et depressum; epimeris nullis; segnento trunci Imo cum capite coalito et pedibus 1 mi paris pone pedes maxillares aut sub iisdem affixis; segmento trunci 3 tio et 4 to pedibus vulgo destitulis; postabdomine plus minusve rudimentari.

Pedes omnium parium manibus subcheliformibus plerumqve instructi.

Latreille har opført denne tredie Division af Amphipoderne som en egen Orden under Navnet Lcemodipoda i den anden Udgave af Cuviers "Règne animal". MilneEdwards, ligesom Desmarest, folger ham i hans Fremstilling, men Krøyer viser i 1842 , Nat. Tidsskr. 1. R. 4. B., at mange af de Forskjelligheder, der ere angivne at finde Sted mellem Amphipoder og Læmodipoder, maa falde bort. De sidste have nemlig ikke, som forhen var angivet, 6, men 7 Legemsled; skjønt det første er forbundet med Hovedet, kan det dog tydelig adskilles. Kindbakkerne mangle heller ikke altid Palpe, thi flere Slagter ere forsynede med en saadan, og Iunddelene stemme meget overeens med dem hos Gammaride. Heller ikke have de herhen hørende Former, hvilket er angivet af Burmeister, enkelte, men sammensatte Øine. At Sidepladerne mangle, har ingen Betydning, da de ere saa meget reducerede hos flere Amphipoder. Kun den rudimentære Bagkrop er mere karakteristisk; hos Slægten Cercops er den dog længere og flerleddet. Læmodipoderne kunne saaledes ikke skilles mere fra Amphipoderne end de langhalede Decapoder fra de korthalede. Kroyer opstillede dem derfor som en Familie under Amphipoderne og delte denne i tvende Underfamilier, Caprellina og Cyamea. Dana satte dem ogsaa under Amphipoderne som en Subtribus, Caprellidea, og delte denne, som Kroyer, i 2de Underafdelinger, Caprellide og Cyamide. Spence Bate forte Familien Dulichidce herhen og opstillede dem som en Gruppe Aberrantia, ligesom senere Lilljeborg. I 1870 satte jeg Lemodipoderne som en Familie, Caprellide, og delte den i 
tvende Underfamilier, Caprellince og Cyamince. Jeg var nemlig, som anfort i Indledningen til dette Arbeide, af den Formening, at Dana's Subtribus Caprellidea ved Munddelenes Bygning stod nær hans anden Subtribus, Gammaritea, hvorimod den adskiller sig meget fra den tredie, Hypcridea; de tvende forste burde saaledes ikke adskilles, men Caprellide opstilles kun som den femte Familie under den anden Division, Gammaride. I dette nye Arbeide opstiller jeg derimod Caprellina som en egen Division, med tvende Familier, Caprellide og Cyamidee, og følger saaledes Dana's Inddeling.

\section{Familia I.}

CAPRELLID $Æ$, Dana, 1852.

Syn.: 1842. Caprellina, Kroyer, Nat. Tidsskr. 1. R. 4. B. p. 495.

1852. Caprellide, Dana, U. S. explor. exped. p. 806.

1862. - Spence Bate, Catal. Amphip. Crust. Brit. Mus. p. 349.

1865. - Lilljeborg, On the Lysianassa magellanica.

1868. $\quad-\quad$ Goës, Crust. amphip. maris Spetsb. p. 18.

1870. Caprelline, A. Boeck, Crust. amphip. bor. et arct. p. 187.

Mandibulæe palpo partim preditre, partim eodem destilutx.

Corpus elongatum, gracile.

Antennæ inferioris magnitudinis mediocris.

Pedes vulgo elongati.

Vesiculæ branchiales lamelliformes vel sacciformes.

Til de forhen kjendte Slægter Proto, Leach, og Caprclla, Lamarck, tilføiede Kroyer i 1843 tvende nye Slægter Cercops og Egina, af hvilke den første ikke har nogen Repræsentant ved vore Kyster. Senere tilføiede han Slægten Podalirius og Dana Protella, der dog er synonym med Egina, og jeg optog i 1860 Slægten Eginella. Den af Latreille opførte Slægt Naupredia er, hvad Krøyer har paavist, synonym med Proto. Studiet af denne Familie er, som anfort af Dana, forbundet med enkelte Vanskeligheder paa Grund af den store Forskjel, som Kjøn og Alder frembyder, men Krøyer har paa en saa fortrinlig. Maade bearbeidet de af ham kjendte Arter, at det nu er forholdsvis lettere at bestemme de herhen horende Former. Han lægger hovedsagelig Vægt paa den relative Langde af Hovedet og det forste Legemsled samt af det andet Led og Formen af det femte Led paa det andet Fodpar og dettes Befæstelsespunkt.

Han adskilte denne Familie i 1843 fra Cyamida ved, at Formen i Almindelighed er langstrakt, tynd, cylindrisk, Gjællepladerne blæredannede, de nedre Folere af middelmaadig Størrelse, Fodparrene af middelmaadig Styrke, og ved at der ofte findes en 
Palpe pai Kindbakkerne. Spence Bate vil med Hensyn til Munddelene skille denne Familie fra Cyamide, ved at de her ere normalt udviklede, medens de hos den sidste Familie ere smaa, hvilket vistnok ikke er rigtigt. Denne Karakter optages heller ikke i Diagnosen hos Spence Bate og Westwood. De ovrige af ham ere omtrent de samme. I 1870 optog jeg de samme Karakterer som de af Kroyer angivne, hvilke her ogsaa gjentages.

Gen. I. PROTO, Leach, 1814.

Deriv.: трот

Syn.: 1814. Proto, Leach, Edinb. Encyc. t. VI. Linn. Trans. XI. 1815. p. 362.

1817. Leptomera, Latreille, Règne animal. 1. ed. III. p. 51.

- Naupredia, Latreille, Règne animal. 2. ed. IV. p. 128. Cours d'Ent. p. 393.

1818. Leptomera, Lamarck, Hist. nat. d. Anim. sans vertebr. t. F.

1825. Proto, Desmarest, Consid. sur les Crust. p. 276.

- Leptomera, Desmarest, Consid. sur les Crust. p. 275.

1829. - Guerin, Icon. Crust. pl. 28. fig. 3.

1840. - Milne-Edwards, Hist. d. Crust. p. 109.

- Naupredia, Milne-Edwards, Hist. d. Crust.

1842. Leptomera, Krøyer, Nat. Tidsskr. 1. R. 4. B. p. 496.

1852. Proto, Dana, The Amer. Journ. of sc. and arts. U. S. explor. exped. p. 807.

1855. - Gosse, Mar. Zool. I. p. 313.

1861. Naupredia, v. Beneden, Fauna litt. d. Belg. Crust. p. 97.

1862. Proto, Spence Bate, Catal. Amphip. Crust. Brit. Mus. p. 349.

1868. - Spence Bate and Westwood, Brit. sessile-eyed Crust. II. p. 36.

1870. - A. Boeck, Crust. amphip. bor. et arct. p. 188.

Mandibulæ palpo elongato, 3articulato.

Antennæ inferiores flagello 5articulato.

Septem pedum paria; pedes 5 ti paris manu subcheliformi destituti; pedes 2 di-4ti paris ad basin vesiculis branchialibus instructi.

Postabdomen rudimentare, 1articulatum: pedibus qvatuor rudimentaribus. 2articulatis.

Denne Slægt blev i 1814 opstillet af Leach, men Navnet blev senere af Latreille forandret til Leptomer $a$. Denne Forfatter opforte senere Slagten Nanpreclia, som han grundede paa den af Desmarest beskrevne Proto pedatum, der skulde have fem Fodpar i fortløbende Række. Lamarck diagnosticerer Slagten saaledes: „articulo primo a capite non distincto, pedes decem aut qratuordecim in serie continua dispositi“. Under denne Slægt forener han Leptomera, Latr., og Proto, Leach. Milne-Edwards optager efter Latreille Slægten Nanpredia; den er dog kun en Leptomera, hvis bagre 
Fodpar ere afrevne, hvilket Kroyer paaviste allerede i 1843. Krøyer vil ogsaa, at Navnet Leptomera skal erstattes af Proto, som det aldre Navn, hvilket de senere Forskere har benyttet, undtagen van Beneden, som i 1861 troede ogsaa at have gjenfundet Slægten Naupredia i en Form, som han fandt paa Chelonia midas; F. R. Müller har dog vist, at denne kun er en Proto, som har mistet de bagre Fodpar.

\section{PROTO GOODSIRII, Spence Bate, $185 \%$.}

(PI. XxxII. fig. 2.)

Proto Goodsirii, Spence Bate, Ann. Nat. Hist. 185\% 2. ser. XIX. p. 151. Catal. Amphip. Crust. Brit. Mus. 1862. p. 350, pl. LV. fig. 2.

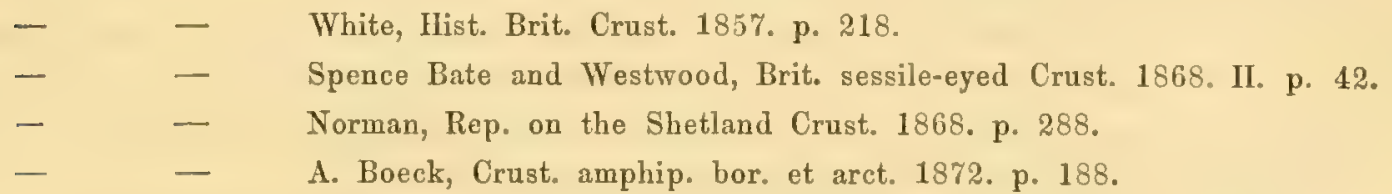

Antennæ superiores duas tertias animalis longitudinis aqvantes; flagello longiore qvam articulo pedunculi ultimo. Pedes 2di paris manu elongata, ovata. Pedes 3tii et 4 ti paris articulo 4 to brevissimo, tertiam articuli 3tii longitudinis partem vix reqvanti; articulo 5̆to elongato, ovato, in margine spinis tribus instructo. Pedes duorum parium posteriorum articulo 3tio articulum 5tum longitudine xqvanti.

Længden er $18^{\mathrm{mm}}$.

Legemet er meget tyndt, traadformet; det første Legemsled er noget længere end Hovedet; det andet er meget længere end Hovedet og det første Led tilsammen; det tredie og fjerde ere omtrent lige lange og meget liengere end det andet Led; hos Hunnen ere de til hinanden stødende Dele af disse Led udvidede; det femte er meget længere end det foregaaende, men ikke saa langt som dette og det tredie Led tilsammen; det sjette er omtrent af den samme Længde; det syvende Led er meget kort. Halen dannes af tre, utydelig adskilte Led, af hvilke de tvende første bære rudimentære Tilhæng. Hovedet er kort, fortil afrundet, Øinene ere store, runde.

De øvre Følere naa, naar de bøies bagud, til noget over det tredie Legemsled. Skaftets første Led er omtrent saa langt som Hovedet; det andet er ikke iuldt dobbelt saa langt som dette; det tredie er noget kortere end det andet Led. Svoben, der er kortere end Skaftet, dannes af 12 Led.

De nedre Følere naa ikke frem til Enden af de øvre Føleres Skaft og ere meget tyndere end disse. Skaftets tvende forste Led ere sammensmeltede; det tredie er tre Gange saa langt som tykt; det fjerde er omtrent saa langt som det første Led paa de øvre Føleres Skaft; det femte er længere end det foregaaende Led. Svøben er af den samme Længde som Skaftets sidste Led, eller noget kortere end dette, og dannes af 5 forlængede Led. 
Kindbakkerne ere meget stærke, delte i Spidsen; Gribedelen og den indre Bigren ere meget brede, tandede. Palpen er forlænget, treleddet; det andet Led er meget langere end det tredie.

Det forste Kjæbepars ydre Plade er kort, men bred, paa Enden væbnet med krumme Torne. Palpen er bred, paa den indre Rand besat med Saugtakker, i hvilke der sees en liden Bitand, og i Spidsen sees fire lignende, men stærkere Saugtakker.

Det andet $\mathrm{Kj}$ æbepars Plader ere smaa, smale, med korte Børster paa Enden.

Kj $æ b$ ef $ø$ ddernes ydre Plade er liden og naar kun frem til Enden af Palpens forste Led, samt har nogle Torne paa den indre Rand; den indre Plade er stor og bærer paa Enden nogle Tænder. Palpen er forlænget; det tredie Led er næsten saa langt som det andet. Kloen er stark.

Det fors te Fodpar er forlænget; Haanden er agformet, paa den bagre Rand væbnet med smaa Torne og med en strerk, dobbelt Fremragning, hvorpaa der er fæstet tvende Torne paa det Sted, hvor Kloens Spids lægger sig imod. Kloen er næsten af den samme Lingde som det sidste Led og meget stærk.

Det an'det Fodpar udspringer hos Hunnen fra den forreste Trediedel af den undre Side, hos Hannen noget bag Midtlinien paa det andet Legemsled, samt er meget længere og stærkere end det første Fodpar; Haanden er omtrent saa lang som det forste Led, forlænget oval, noget indkneben, hvor Kloens Spids lægger sig imod, og har her tvende Torne, af hvilke den bagre er den største. Kloen er særdeles bred og stærk.

Det tredie og fjerde Fodpar ere traadformede; det tredie Led har omtrent Totrediedelen af det forste Leds Liengde, det fjerde er meget kort, længere paa det tredie end paa det fjerde Fodpar; det femte er meget langere end det foregaaende Led, men kortere end det tredie og forsynet paa den bagre Rand med tre Torne. Kloen er ikke fuldt saa lang som det sidste Led.

Det femte Fodpar er meget kortere end det foregaaende; det andet Led kan ikke sees.

Det sjette og syvende Fodpar ere af eens Bygning, men det sidste er det længste; det femte Led er forlænget, kun lidt længere end det fjerde og saa langt som det tredie Led, eller lidt kortere end dette.

Denne Art er fundet ved Utue af G. O. Sars paa 80 Favne, samt er taget ved Bohuslen. Ifølge Spence Bate findes den ved de engelske Kyster; af Norman er den taget ved Shetland.

PROTO VENTRICOSA, Müller, 1776.

(Pl. XXXII, fig. 3.)

Squilla ventricosa, Müller, Prodr. 1776. p. 360. \&. Zool. Dan. Fasc. II. p. 20. pl. LVI. fig. $1-3$.

? - ecaudata, Gronovius, Act. Helv. 1781. p. 439. pl. IV. fig. 8-10. 
Gammarus pedatus, Abildgaard, Zool. Dan. 1789. Fasc. III. p. 33. tab. LVI. fig. 1-3. ㅇ. tab. CI. fig. 1. 2. $0^{7}$.

Cancer (Gammarus) pedatus, Montagu, Linn. Trans. 1815. XI. p. 6. pl. 2. fig. 6. Proto pedata, Leach. Linn. Trans. 1815. XI. p. 362. Edinb. Encyc. VII. p. 433.

- - Fleming, Edinb. Phil. Journ. 1823. VIII. p. 296.

- - Johnston, Mag. Nat. Hist. 1825. VIII. p. 673. fig. 72. 73.

- - White, Cat. Brit. Crust. 1850. p. 61. Hist. Brit. Crust. 185\%. p. 218.

- - Spence Bate, Brit. Assoc. Rep. 1855. Ann. Nat. Hist. 1857. 2. ser. XIX. p. 151. Catal. Amphip. Crust. Brit. Mus, 1862. p. 349.

- - A. Boeck, Forh. ved de skand. Naturf. 8de Móde. 1860. p. 670.

- - Spence Bate and Westwood, Brit. sessile-eyed Crust. 1868. II. p. 38. ○. ㅇ.

- - Norman, Rep. on the Shetland Crust. 1868. p. 288.

- pedatum, Desmarest, Consid. s. les Crust. 1825. p. 276. pl. 28. o7. ㅇ․

Lep tomera rubra, Lamarck, Hist. nat. d. anim. sans vertebr. 1818.

- pedata, Latreille, Règne anim. 1817. III. p. 51.

- - Desmarest, Consid. s. les Crust. 1825. p. 276. pl. 46. fig. 3.

- $\quad$ Rathke, Beitr. z. Fauna Norwegens. 1843. p. 97.

- - Guerin, Icon. Crust. 1829. pl. XXVIII. fig. 3.

- - Milne-Edwards, Hist. d. Crust. 1840. III. p. 109.

- _ Lilljeborg, Öfv. af Kgl. Vet.-Akad. Förh. 1855.

- - Kroyer, Nat. Tidsskr. 1842. 1. R. 4. B. p. 607. t. VII. fig. 13-23.

- - M. Sars, Forh. i Vid.-Selsk. i Christiania 1858. p. 150.

- ventricosa, Desmarest, Consid. s. les Crust. 1825. p. 276. \&.

Proto ventricosa, A. Boeck, Crust. amphip. bor. et aret. 1870. p. 188.

Antennæ superiores duas tertias animalis longitudinis reqvantes: flagello et articulo pedunculi 3tio longitudine aqvalibus. Antemn inferiores articulo pedunculi 4to et 5to longitudine etiam æqvalibus. Pedes 2di paris manu ovali, elongata. Pedes 3 tii et 4 ti paris articulo 4 to prælongato, articulum 5tum angustum et gram cilem longitudine fere æqvanti; articulo 3 tio breviore qvam 4 to et 5 to junctis; articulo 5to multo longiore qvam ungve. Pedes duorum parium ultimorum articulo 4 to ejusdem longitudinis ac articnlo 5 to et paulo breviore qvam 3 tio.

Længden er $14^{\mathrm{mm}}$.

Le gemet er forlænget, tyndt; Ryggen er uden Torne og Fremstaaenheder; det femte Legemsled er det længste. Hovedet er længere end det forste Led.

De øvre Folere ere meget tynde og hos Hannen noget længere end Legemets halve Længde. Skaftets andet Led er det længste; det tredie er længere end det første, men kortere end det andet Led. Svoben, der er saa lang som Skaftets sidste Led, dannes af 14 Led, af hvilke det første hos Hannen er saa langt som 
de tre følgende tilsammen, og hos Hunnen som de trende fø̈lgende tilsammen; de følgende Led aftage efter hverandre lidt i Længde.

De nedre Følere naa ikke frem til Enden af de ovre Føleres Skaft og ere meget tyndere end disse. Skaftets fjerde og femte Led ere lige lange. Svøben, der er halv saa lang som Skaftets sidste Led, dannes af 5 Led.

$\mathrm{Overlæben} \mathrm{er} \mathrm{meget} \mathrm{bred,} \mathrm{indbugtet} \mathrm{i} \mathrm{Spidsen.}$

Kind bakkerne ere kraftige. Palpen er tynd, forlænget, treleddet.

Det forste Fodpar er lidet; Haanden er af den samme Længde som det forste Led, smalere udad, bredere ved Roden, hvor der paa den bagre Rand sees en stærk Knude, der er væbnet med 3-4 stærke Tænder; paa Griberanden sees fine Torne.

Det andet Fodpars Haand er længere end det forste Led, stor, oval. Hos Hannen er den forreste land noget vinkelformet udbugtet; den bagre er nær Roden væbnet med tvende nær hinanden siddende Tænder, der have 1-2 Torne og ere adskilte ved et dybt, halvmaaneformet Indsnit; forøvrigt har denne Rand smaa Knuder. Hos Hunnen og den unge Han er Haanden oval og har kun smaa Tænder i Randen, foruden tvende større nærmere Leddets Rod.

Det tredie Fodpars tredie Led er omtrent lialvt saa langt som det første, men. ikke dobbelt saa langt som det fjerde Led; det femte er kortere end det tredie, men længere end det fjerle Led, og den bagre Rand er væbnet med fire Tænder, af hvilke enhver er forsynet med en lang Torn. Kloen er kun lidet krum, kortere end det sidste Led.

Det fjerde Fodpar er lidt smalere, men omtrent af den samme Bygning som det foregaaende Par; det femte Led har fem Tænder paa den bagre Rand.

Det femte Fodpar er neppe halvt saa langt som det foregaaende; det første Led er saa langt som de tre folgende tilsammen; det sidste er tykkere mod Enden, uden Tænder eller Torne. Kloen er halv saa lang som det sidste Led.

Det sjette og syvende Fodpar ere omtrent af eens Bygning, men det sidste er det længste. Det sjette Fodpars tredie Led er kortere end det første, men paa det syvende Fodpar er det længere; det fjerde er noget kortere end det tredie og det femte Led, hvilket sidste er smalt, og har paa den bagre Rand 3-4 Tænder.

Halen er meget liden, knudeformet $0 \mathrm{~g}$ bærer tvende rudimentære Fodpar, af hvilke det første er det længste.

Gjælleblarerne ere liniedannede og findes ved Roden af det andet, tredie og fjerde Fodpar.

Farven er bleg, purpurrod.

Den er fundet af G. O. Sars ved Christiansund paa 50-100 Favne; af mig i Christianiafjorden paa 40 Favne; efter M. Sars er den ikke sjelden ved.Hammerfest mellem Hydroider i Laminariernes og Corallinernes Belte; den gaar ligeledes ned til Øresund. Den er ogsaa tagen paa flere Steder ved de engelske Kyster og ved Shetland af Montagu, Norman og tlere. 
Gen. III. CERCOPS, Iŕrøyer, 1843.

Deriv.: Kepsw $\psi$, forsynet med Hale.

Syn.: 1842. Cercops, Kroyer, Nat. Tidsskr. 1. R. 4. B. p, 496.

1852. - Dana, U. S. explor. exped. p. $80 \%$.

1862. - Spence Bate, Catal. Amphip. Crust. Brit. Mus. p. 352.

1870. - A. Boeck, Crust. amphip. bor. et arct. p. 189.

Type: Cercops Holbölli, Kroyer.

Mandibulæ palpo 3articulato.

Antennæ inferiores flagello 2articulato.

Qvinqve pedum paria; pedes 3 tii et 4 ti paris absentes; pedes omnes manibus subcheliformibus instructi.

Segmentum trunci 2dum, 3tium et 4 tum vesiculis branchialibus instructa.

Postabdomen 5articulatum; pedibus qvatuor rudimentaribus, 2articulatis.

Denne Slægt afviger fra den folgende, Egina, væsentlig ved den meget forlængede Hale, som er femleddet, forsynet med tvende 2-leddede Fodpar; denne Slægt af Caprelliderne har saaledes den mest udviklede Hale. Der er desuden tilstede en Gjalleblare paa det andet Fodpar.

\section{CERCOPS HOLBÖLLI, Krøyer, 1842.}

Cercops Holbölli, Krøyer, Nat. Tidsskr. 1842. 1. R. 4. B. p. 504. t. VI. fig. 1-12. Spence Bate, Catal. Amphip. Crust. Brit. Mus. 1862. p. 352. pl. LV. fig. 6.

A. Boeck, Crust. amphip. bor. et arct. 1870. p. 189.

Caput rostro frontali acuminato et curvato, in margine anteriore aculeis duobus instructum. Segmentum trunci 2dum prope medium marginem posteriorem tuberculis duobus obtusis et in utrogve latere spinis binis instructum; segmentum 3tium et 4tum in margine posteriore tuberculis singulis obtusis et in angulo anteriore spinis binis instructa. Antenne superiores tertiam partem animalis longitudinis eqvanles, inferioribus duplo longiores; articulo pedunculi 3tio paulo longiore qvam 1mo. Antennæe inferiores articulo pedunculi 5 to breviore qvam 4lo. Pedes 2 di paris manu ovata, longiore qvam articulo 1ıno, in margine posteriore apud marem dentibus duobus validis, apud feminam nodulis nommullis instructa. Pedes trium parium ultimorum articulo 3tio longitudinem articuli tti fere regvanti, panlo breviore qvam manu. 
La ng glen er omtrent $8^{\mathrm{mm}}$.

Det første Legernsled er kun halvt saa langt som Hovedet og har paa Rygfladen et knudelignende Fremspring; det andet er tre Gange saa langt og har tvende stumpe Knuler paa den bagre Del af Ryggens Midtlinie, samt fire spidse Torne, af hvilke det ene Par udgaar fra den øvre, forreste Rand, det andet fra Siderne, Leddet er nedad opsvulmet; det tredie og fjerde Led, som ere de længste og omtrent lige lange, have hver et Par Torne, som udgaar fra den ovre, forreste Rand, og en stump Ḱnude paa Rygfladen nær den bagre Rand; det femte Led er ubetydelig kortere end det fjerde og har paa den forreste Ende, paa hver Side, en stump Torn; det sjette er ikke halvt saa langt som det foregaaende; det syvende har ligeledes kun den halve Længde af det sjette Led, og begge have enkelte Torne. Hovedet er væbnet med et særdeles spidst, fortil krummet Horn, der udgaar fra Rygfladen; fra den forreste Kant udgaar tvencie smaa, fremad rettede Torne.

De øvre Følere ere temmelig stærke og have lidt mere end en Trediedel af Legemets Længde. Skaftets forste Led er halvt saa langt som det andet; det tredie er ubetydelig kortere end det forste Led. Svoben er saa lang som Skaftet og dannes af 10 Led.

De nedre Folere ere halvt saa lange som de ovre og tyndere end disse. Skaftets femte Led er ubetydelig kortere end det fjerde. Svøben dannes af 2 Led, af hvilke det forste er lidt længere end det andet.

Kindbakkerne have en lang, treleddet Palpe.

Det første Fodpar er lidet.

Det andet Fodpar er tre Gange saa langt; det fjerde Led er kort; Haanden er længere end det første Led, af en oval, ægdannet Form, med en stærk Torn paa den bagre Rand.

De tre sidste Fodpar ere omtrent af eens Bygning, men tiltage efter hverandre lidt $i$ Længde. Pa det første af disse Fodpar er det femte Led længere end det fjerde og saa langt som det tredie. Paa det femte Fodpar er derimod det femte Led længere end de tvende foregaaende tilsammen og længere end det første Led.

Halen dannes af fem Led; fra Bagfladen af de tvende sidste udgaar der et tyndt, toleddet Fodpar, hvis ydre Led er fint saugtakket; det sidste af disse Fodpar er let korteste.

A andeblærerne ere af en langstrakt, oval Form og findes ved Roden af det andet Fodpar samt paa det tredie og fjerde fodløse Led.

Farven er skiddengul, lysere end hos de øvrige Caprellider.

Den er fundet af Holböll i faa Exemplarer ved det sydlige Grønland, paa Sertularier, paa 45-60 Favnes Dybde.

Gen. III. EGINA, Krøyer, 1842.

Deriv.: Egina, en Havnymphe. 
Syn.: 1842. Eg gina, Kroyer, Nat. Tidsskr. 1. R. 4. B. p. 509.

1852. - Dana, U. S. explor. exped. p. 807.

- Protella, Dana, Amer. Journ. of Sci. and arts. 2. ser. t. XIV. p. 307.

1860. Egina, A. Boeck, Forh. ved de skand. Naturf. 8de Møde. p. 670. Crust. amphip. bor, et arct. 1870. p. 190.

1862. Protella, Spence Bate, Catal. Amphip. Crust. Brit. Mus. p. 351.

1868. - Spence Bate and Westwood, Brit. sessile-eyed Crust. II. p. 44. Type: Egina longicornis, Krøyer.

Nandibulæ palpo longo, 3articulato.

Antenne inferiores flagello 2articulato.

Qvinqve pedum paria; pedes 3 tii et 4 ti paris absentes; pedes omnes manibus subcheliformibus instructi.

Postabdomen 2articulatum; pedibus qvatuor elongatis, duobus anterioribus 2articulatis, duobus posterioribus 1articulatis.

Krøyer opstillede denne Slægt i 1842. Han skilte den fra Slægten Caprella ved, at Kindbakkerne ere forsynede med en Palpe, og ved at Halen er meget mere udviklet end hos deme og forsynet med et 2-leddet og et 1-leddet lidet Fodpar. Dana optager ogsaa denne Slægt og fremhæver væsentlig, at den skiller sig fra Slægten Caprella ved, at Kindbakkerne have Palpe; derimod lægger han ikke Vægt paa Halens Dannelse. Spence Bate derimod, som overhovedet ikke tillægger Munddelene nogen Betydning, sloifer derfor ogsaa Slægten aldeles og henforer Arterne til Slægten Caprella. I 1860 optog jeg atter Slægten paa Grund af Munddelenes og Halens Dannelse og tilføiede nogle nye Arter. En af de Arter, som Krøyer henførte herhen, $\mathbb{E}$. longispina, som falder sammen med Montagu's Cancer phasma, er af Spence Bate henfort til Dana's Slægt Protella, hvilket jeg ogsaa i 1860 antog at være rigtigt. Denne udmærker sig ifølge Dana's Diagnose ved, at Kindbakkerne have Palpe, at Gjællesækkene ere fæstede til det tredie og fjerde Legemsled, og ved at der paa disse Led ogsaa er fæstet rudimentære, styliforme Fodpar, men dette finder ikke Sted hos Egina (Protella) phasma, og jeg skulde tro, at han har havt for sig en Hun, hvorfra, Tegningen er hentet, og ikke en Han, samt at hvad han antager for rudimentære Fodpar er Gjæller og ved disse en Udvikling af Eggesækkene. Spence Bate og Westwood have i 1868 ogsaa optaget Slægten Protella.

\section{EGINA LONGICORNIS, Krøyer, 1842.}

Egina longicornis, Kroger, Nat. Tidsskr. 1842. 1. R. 4. B. p. 509. t. VII. fig. 1-12.

A. Boeck, Crust. amphip. bor. et arct. 1870. p. 190.

Corpus pralongatum, angustius, gracilis, spinis et tuberculis destitutum. An- 
tennæ superiores longitudinem animalis fere æquantes; articulo pedunculi 2do fere duplo, 3 tio paulo longiore qvam 1 mo. Antennæ inferiores dimidiam longitudinem superiorum non aqvantes; articulo pedunculi 5to longiore qvanı 4to. Pedes 2di paris manu maris paulo longiore qqam articulo 1 mo; manu femine paulo breviore, elongata, ovali, in margine posteriore dentibus duobus validis et prope ungvem tuberculo obtuso, lato armata. Pedes trium parium ultimorum gracilimi; manu fere ter longiore qvam lata, paulo longiore qvam articulo fto. longitudinem articuli 3tii fere æqvanti. Vesiculæ branchiales elongatæ, perangustæ.

Legemet er meget fórlnget, tyndt, uden Fremstaaenheder eller Torne. Hovedet er kortere end det første Legemsled, kortere hos Hamnen end hos Hunnen.

De øvre Følere ere næsten saa lange som Legemet. Skaftets andet Led er dobbelt saa langt som det første; det tredie er lidt læugere end det første Led. Svoben, der har Halvdelen af Skaftets Længde hos Hannen og er noget kortere hos Hunnen, dannes af 26 Led; det første er hos Hannen saa langt som de fire følgende Led tilsammen, hos Hunneu har det kun den dobbelte Længde af det folgende Led.

De nedre Følere ere en Trelliedel kortere end de øvre. Skaftets femte Led er længere end det fjerde. Svøben dannes af 2 Led, af hvilke det første er fem Gange saa langt som det andet Led.

Kindbakkernes Palpe er treleddet; det tredie Led er det længste.

Det første Fodpar er lidet, af den sædvanlige Form; Haanden er forlienget ægdannet.

Det andet Fodpar er forlænget; det forste Led er omtrent af den samme Længde som det Legemsled, hvortil det er fæstet; Haanden er hos Hannen meget længere end hos Hunnen og noget kortere end det første Led, af en forlænget ægdannet Form; den bagre Rand er væbnet med tvende meget store Tænder, den forreste er forlænget $i$ en spids Torn.

De tre sidste Fodpar ere forlængede, meget smale. Det første Led er pan det første af disse Fodpar lidt længere end det tredie; Haanden er meget kortere end det første og saa lang som det fjerde Led, samt særdeles smal. Paa det andet, længere Par er Haanden længere end det forste, men kortere end det tredie Led. Paa det tredie Par, der er ikke ubetydelig længere end det foregaaende, er hos Hannen Haanden ligeledes længere end det første, men kortere end det tredie Led; hos Hunnen er Haanden og det tredie Led af eens Længde.

Halen er tydelig og dannes af tvende tykke Led, der begge ere forsynede med et Fodpar, af hvilke det forste er strerkt, toleddet, det andet er mindre, smalere, eenleddet, paa den indre Rand væbnet med smaa Torne.

A andeblærerne ere smale, næsten liniedannede.

Farven er ikke ganske ren kastaniebrun. 
Den er fundet af Holböll ved det sydlige Gronland i stor Mængde paa Lerbund paa 12-16 Favnes Dybde og blandt Sertularier paa 45-60 Favne.

EGINA PHASMA, Montagu, 1806.

Cancer phasma, Montagu, Linn. Trans. 1806. VII. p. 66. pl. VI. fig. 3. Astacus phasma, Pennant, Brit. Zool. 1812. IV. p. 27.

Caprella phasma, Leach, Edinb. Encyc. 1814. VII. p. 404. Encyc. Brit. Suppl. I. p. 426.

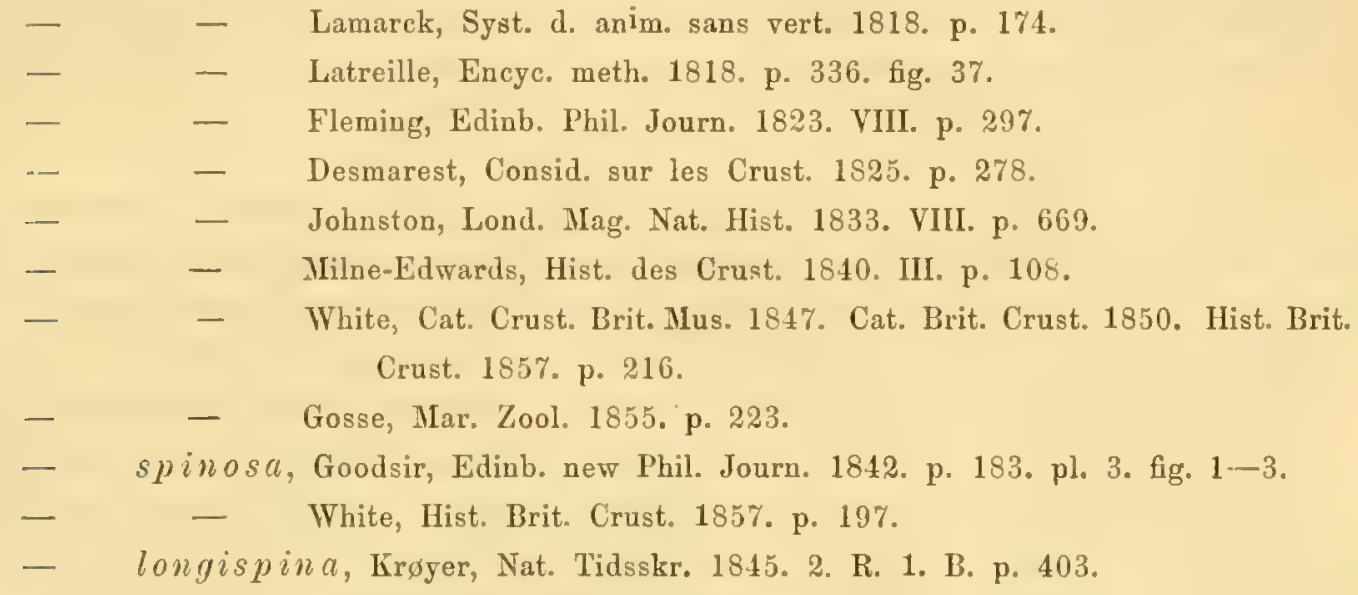
ZE'gina lon̈gispina, Kroyer, Nat. Tidsskr. 1845. 2. R. 1. B. p. 476.

Protella longispina, Spence Bate, Ann. Nat. Hist. 1857. 2. ser. XIX. p. 151.

- - A. Boeck, Forh. ved de skand. Naturf. Sde Møde. 1860. p. 670. - plasma, Spence Bate, Catal. Amphip. Crust. Brit. MIus. 1802. ץ. 351. pl. LV. fig. 4.

- $\quad$ - Spence Bate and Westwood, Brit. sessile-eyed Crust. 1868. II. p. 45. Agina phasma, A. Boeck, Crust. amphip. bor. et aret. 1870. p. 191.

Caput rostro frontali longo, antice curvato, acuminato. Segmentum trunci 1 mum in medio margine posteriore aculeo valido, 2 dum in medio dorsi aculeis duobus et in margine posteriore aculeo uno instructa; segmenta duo seqventia similiter armata sed aculeis minoribus. Antennx superiores longitudinem animalis vix aequantes; articulo pedunculi 2 do paulo modo longiore qvam 1 mo et 3tio; articulo 3 tio parum longiore qvam 1mo. Pedes 2di paris ferme ut apud speciem pracedentem. Pedes ultimi paris manu articulum 3tium et 4 tum junctos longitudine vix xqvanti. Vesiculæ branchiales breves, apicem versus dilatatæ.

Læn g d e n er omtrent $14^{\mathrm{mm}}$.

Det forste Legemsled har paa Rygsidens bagre Rand en stor, spids Torn; det andet, der er mere end dobbelt saa langt, har tvende, ved Siden af hinanden staaende, 
spidse Torne nær Midtlinien og en nær den bagre Rand; de tvende følgende, der ere noget kortere end det foregaaende Led, have tvende smaa Torne bag hinanden; de øvrige Led ere glatte. Hovedet er kort og gaar fortil ud i et stort, spidst, fremadbøiet Pandehorn. Øinene ere usædvanlig store, runde.

De øvre Følere ere tynde, næsten saa lange som Legemet. Skiftets første og tredie Led ere omtrent lige lange; det andet er noget længere. Svøben, der er saa lang som Skaftet, dannes af 24 Led.

De nedre Følere ere meget kortere og naa kun frem til Enden af Skaftet paa de ovre Folere. Skaftets andet Led har en Torn paa Enden af den undre Rand; det femte er longere end det fjerde Led.

Det forste Fodpar er lidet, men stærkt; Haanden er bred, oval. Kloen er stor.

Det andet Fodpar er tre Gange saa langt som det forste; det første Led har paa den ydre Side en Torn; Haanden er stor, smal, længere end det første Led og har paa den bagre Rand dybe Indskjæringer, hvorved dannes tvende Tænder, den forreste Rand har en Tand paa den ydre Ende. Kloen er stærk, spids, krum.

De tre sidste Fodpar ere forlangede, smale, næsten af eens Bygning; det sidste er det lrengste. Paa det forste af disse Fodpar er det femte Led smalt, kortere end det fjerde; paa det andet er det længere; paa det sidste har det næsten den samme Lingde som de tvende foregaaende tilsammen.

Halen er længere end det sidste Legemsled, toleddet.

Gjællebladene ere af en oval, langstrakt Form.

Denne Art er fundet af Ørsted red Drobak paa 20 Favne, af mig i Christianiafjorden og ved Karmøen; af M. Sars ved Manger; af G. O. Sars ved Risør. Efter Spence Bate er den fundet paa flere Steder ved de engelske Kyster.

ÆGINA ECHINATA, A. Boeck, 1860.

(PI. XXXII. fig. 6.)

? Egina spinosissima, Stimpson, Mar. Invert. of Grand Manan. 1854. p. 45.

? Cap rella spinifera, Bell, App. to Belchers last of arct. voy. 1855. p. 407.t. 35. fig. 2. Goës, Crust. amphip. maris Spetsb. 1868. p. 19.

Caprella spinosissima, Spence Bate, Catal. Amphip. Crust. Brit. Mlus. 1862. p. 364. pl. LVII. fig. 3.

Eg ina echinata, A. Boeck, Forh. red de Skand. Naturf. 8de Møde. 1860. p. 670. Crust. amphip. bor. et arct. 1870 . p. 192.

Corpus tuberculis et spinis multis, plus minusve acutis, instructum, maximis in capite spinis duabus, in medio margine utroqve segmenti trunci 2di binis. in medio dorso tribus, (media maxima) prope radicem pedum $2 d i$ paris et vesicularum bran- 
chialium spinis singulis. Antennæ superiores dimidiam longitudinem animalis paulo superantes; pedunculo a tuberculis obtecto; articulo 1 mo parum longiore qvam articulo dimidio 2do, multo breviore qvam 3tio. Antennæ inferiores dimidiam longitudinem superiorem vix æqvantes; articulo pedunculi 4 to et 5to longitudine invicem fere æqvalibus. Pedes 2di paris articulo 1 mo in margine anteriore serrato; manu longiore qvam articulo $1 \mathrm{mo}$, tuberculis dense obtecta, in angulo inferiore anteriore producta et in margine posteriore dentibus duobus minoribus et tuberculo uno instructa. Pedes trium parium ultimorum fere ut apud speciem præcedentem. Vesiculæe branchiales breves, apicem versus clavatæ.

Lrengden er $35-40^{\mathrm{mm}}$.

Legemet udmærker sig ved sin Størrelse og den paa dette værende store Mrngde Pigger. Det første Legemsled er meget bredere ved dets forreste Parti; den forreste Rand er næsten dobbelt saa lang som den bagre; det er stærkt besat med Pigger, og paa Ryggen sees tvende større ved Siden af hinanden paa den forreste Rand, en stærk, i Spidsen kløvet, sees paa Midten, og en dobbelt Torn nær den bagre Rand. Det andet Led er dobbelt saa langt som det forste og har lignende Ophøininger paa Ryggens Midtlinie; de forreste af disse staa paa en liden Ophøining nær den forreste Kant, og desuden sees flere smaa Fremstaaenheder, foruden mange lignende paa Siderne. Der findes ogsaa et fortil rettet langt, stærkt Fremspring, som dæekker Udspringet for det andet Fodpar. Det tredie og fjerde Led ere indbyrdes omtrent lige store og tilsammen saa lange som de tvende foregaaende Led; deres største Gjennemsnit er, hvor de støde til hinanden; de ere ligeledes stærkt forsynede med Pigger, af hvilke dog ingen paa Rygsiden udmærker sig særdeles fra de ovrige paa Grund af sin Størrelse; over Befæstelsespunktet for Aandeblærerne sees et stærkt Fremspring paa hvert af disse Led. Det femte Led er længere og smalere, samt har ligeledes mange uregelmæssig stillede, mindre Pigger foruden et bagtil rettet' stærkt Fremspring over Fodparrets Befæstelsespunkt. De følgende Led ere tilsammen kortere end det femte og have lignende Fremstaaenheder. Disse meget stærke Fremspring, der constant sees over Befæstelsespunktet for de respektive Fodpar sanit Aandeblærerne, synes at minde om de fastvoxede Sideplader. Hovedet or kort og har kun den halve Længde af det forste Legemsled; det er afrundet fortil og kun utydelig adskilt fra det første Legemsled ved en skraa Fure; det er besat med mange smaa Fremstaaenheder, af hvilke tvende, ved Siden af hinanden staaende og noget fortil rettede paa dets øvre Side ere de største.

De øvre Følere ere meget lange og naa til Enden af det femte Legemsled. Skaftets første Led er omtrent af den samme Længde som det forste Legemsled; det andet er omtrent dobbelt saa langt, men smalere; det tredie er kortere end det foregaaende, men længere end det forste Led. Alle Led ere besatte med smaa Ophoinin- 
ger. Svoben, der er noget længere end Skaftets andet Led, dannes af 18 Led, der efter hverandre ere længere og tyndere.

De nedre Følere ere korte og naa ikke frem til Enden af det andet Led paa de ovre Folere, samt ere meget tyndere end disse. Skaftets tvende første Led ere saa nøie forenede, at de se ud som eet Led, og ere tilsammen kortere end det tredie Led, samt have, ligesom dette, nogle knudeformede Fremstaaenheder; det tredie er meget kortere og tykkere end det fjerde; det femte er lidt længere end det foregaaende Led, og begge have korte Borster paa den undre Rand. Svoben, der er noget længere end Skaftets tvende første Led tilsammen, dannes af 2 Led.

Munddelene ere noget længere og tyndere i Forhold til den foregaaende Art.

Kindbakkernes Palpe er noget kortere end hos $F$. longicornis.

Det forste Kjæbepar er stærkt; den indre Plade mangler.

Kjæbeføddernes ydre Plade naar frem til Midten af Palpens andet Led, samt har langs den indre Rand nogle korte Torne, der mod Pladens Ende blive længere og krumme; den indre Plade naar neppe frem til Enden af Palpens forste Led og har nogle Børster paa den afskaarne Ende. Palpen er lang; det tredie Led er ikke meget kortere end det andet; det fjerde, kloformede Led er meget langt og stærkere bygget end hos $\mathbb{E}$. longicornis.

Det forste Fodpar er lidet, og dets bagre Rand er forsynet med smaa Torne; det første Led er udvidet bagtil og er meget bredere nedad; det fjerde gaar paa den bagre Rand ud i et stumpt Fremspring, der er besat med Børster; det femte Led er forlænget ægdannet. Kloen er saa lang som det sidste Led, noget krummet.

Det andet Fodpar er meget større; det forste Led har langs den forreste Rand en med Saugtakker besat Indskjæring, hvori Haandens forreste Rand kan lægge sig ind; Haanden er stor, oval, langere end det første Led, overalt besat med knudeformede Fremstaaenheder; den forreste Rand er mod den ydre Ende indskaaret i Saugtakker og gaar ud i en Spids; paa den bagre Rand sees tre stærke Tænder, af hvilke den ene er paa det Sted, hvor Kloens Spids lægger sig imod, de trende andre, mere stumpe, findes nær Kloens Rod, og mellem disse sees fine Torne. Kloen en lang og har nogle Torne paa den forreste Rand.

De tre sidste Fodpar tiltage efter hverandre i Længde og have den samme Form som hos den foregaaende Art.

Denne Art er fundet af C. Boeck og Rasch ved Beian og Søndmøre.

EGINA LEVIS, A. Boeck, 1860.

(PI. XXXII. fig. 9.)

Egina lavis, A. Boeck, Forh. yed de skand. Naturf. 8de Møde. 1860. p. 672. Crust. amphip. bor. et arct. 1870. p. 192. 
Corpus leve, spinis et tuberculis destitutum, brevius et crassius qram apud species præcedentes. Antennæ superiores longitudinem animalis fere æqvantes; articulo pedunculi 1 mo multo longiore qvam dimidio articulo 2do parum modo breviore qvam 3tio. Antennæ inferiores dimidiam longitudinem superiorum superantes; articulo pedunculi 4 to breviore qvam 5to. Pedes 2di paris manu in margine posteriore dentibus duobus, non pervalides, et tuberculo uno obtuso armata. Pedes ultimi paris manu longiore qvam articulo 3tio; hoc parum modo longiore qvam articulo 4 to.

Legemets Form er som hos den foregaaende Art; det er overalt glat, uden Torne eller Knuder; Leddene ere kortere end hos $\not E$. longicornis, Halen er som hos denne Art.

- De øvre Følere naa, naar de bøies bagud, til det sjette Legemsled. Skaftets forste Led er længere end Hovedet; det andet er længere og smalere end dette; det tredie er længere end det forste, men kortere end det andet Led. Svoben, der er kortere end Skaftet, dannes af 18 Led.

De nedre Fglere ere korte og naa ikke frem til Enden af Skaftet paa de øvre, samt have Børster paa den undre Rand. Skaftets tredie Led er omtrent dobbelt saa langt som tykt; det fjerde er kortere end det femte Led. Svøben dannes af 2 Led, af hvilke det forste er tre Gange saa langt som det følgende Led.

Munddelene ligne meget dem hos de foregaaende Arter.

Kjæbeføddernes ydre Plade naar længere frem end til Enden af Palpens andet Led og har smaa Tænder langs den indre Rand, hvilke tiltage i Længde mod Pladens Ende og gaa der over til krumme Børster; den indre Plade naar længere frem end til Enden af Palpens første Led og har paa Enden fire korte, stærke Torne, mellem hvilke sees fjærdannede Børster. Palpens tredie Led er kortere end det andet, bredere udad, og har stærke Borster paa Enden; det fjerde Led, eller Kloen, er stærk.

Det $f ø r s t e$ Fodpar er kort; det fjerde Leds bagre Rand gaar ud i et kort, med Børster besat Fremspring; Haanden har den samme Længde som det forste Led, er oval, ægdannet, samt har paa den bagre Rand mange smaa Tænder, hror Kloens Spids lægger sig imod.

Det andet Fodpar er saa langt som de tre første Legemsled tilsammen; det forste Led er langt og har paa sin forreste Rand en langsgaaende Fordybning, i hvilken Haandens forreste Rand kan lægge sig ind, og paa hver Side af demne gaar dens Rande nedad ud $\mathrm{i}$ en Spids. Haanden er omtrent af den samme Længde som det forste Led, langagtig oval; den bagre Rand har, foruden nogle fine Borster, tre Trnder, af hvilke den ene, der er meget stærk, sees, hvor Kloens Spids lægger sig imod, den anden mindre og noget mere nedadrettede er nærmere Kloens Rod, og mellem 
disse sees en bredere, mindre tydelig Fremstaaenhed. Kloen er knæformet bøiet, en Trediedel kortere end det sidste Led.

De tre sidste Fodpar ere temmelig lange; det tredie Led er længere end det fjerde; det femte er det længste, og dets bagre Rand har en med Torne besat Fremstaaenhed.

A andeblirerne ere ovale.

Denne Art er fundet ved Bergen.

Gen. IV. EGINELLA, A. Boeck, 1860.

Deriv.: AEgina, Deminutiv af.

Syn.: 1852. Eg ina, Dana, U. S. explor. exped. p. 826.

1860. Eiginella, A. Boeck, Forh. ved de skand. Naturf. 8de Móde. p. 670.

1870. - A. Boeck, Crust. amphip. bor. et arct. p. 192.

Type: AEginella spinosa, A. Boeck.

Postabdomen 2articulatum; pedibus qvatuor, non articulatis.

Cateroqvin ferme ut apud genus Egina.

Denne: Slægt opstillede jeg i 1860 paa en Art, der ligner Slægten Finina, ved at Kindbakkerne have Palpe, men afviger fra den ved Halens Form, idet den, som hos Slægten Caprella, har uleddede Fodpar. Dana beskriver i 1853 tvende nye Arter, E. tenclla og E. aculeata fra Sooloosøen, som han med Tvivl henfører til Slægten Egina, da de afvige fra denne med Hensyn til Halens Form, og for at faa disse Arter ind under Slagten sloifer han Kroyers Diagnose, Halens Bygning. Disse tvende Arter maa henfores til den her omhandlede Slægt, og maaske ogsaa $C$. acanthifera, Leach, og C. armata, Heller.

EGINELLA SPINOSA, A. Boeck, 1860.

(PI. XXXII. fig. 4.)

Eginella spinosa, A. Boeck, Forh. ved de skand. Naturf. 8de Møde. 1860. p. 673. Crust. amphip. bor. et arct. 1870. p. 192.

Caprella calva, Spence Bate, Catal. Amphip. Crust. Brit. Mus. 1862. p. 359. pl. LVII. fig. 1.

Frons in dentem obtusum producta. Segmentum trunci 1 mum in medio margine anteriore spina longissima instructum; segmentum 2dum in media tertia parte anteriore dentibus duobus, in medio margine posteriore dente uno armatum; segmentum 3tium-5tum in margine anteriore tuberculis binis validis in medio spinis binis, in margine posteriore spinis singulis armata; segmentum 3tium et 4 tum ad 
basin vesicularum branchialium tuberculis singulis validis instrucla; segmentum 6tum et 7 mum in medio et prope ad basin pedum luberculis armata.

Længden er $14^{\mathrm{mm}}$.

Det forste Legemsled, der er meget smalere ved den bagre end forreste Ende, har paa Rygsidens forreste Kant et langt, fortil rettet, noget krummet Fremspring. Det andet er meget længere, med noget ovale Rande, og er bredere fortil; paa Rygsidens forreste Trediedel sees tvende ved Siden af hinanden staaende mindre Torne og en lignende næer den bagre Kant; paa Siderne sees over Befæstelsespunktet for det andet Fodpar tvende store Knuder. Det tredie og det fjerde Led ere langere end det andet og indbyrdes lige lange; par Rygsidens forreste Ende sees tvende, ved Siden af hinanden staaende Knuder; tvende lignende findes paa Siderne, nær Midten af den crre Rand, og en enkelt nær Ryggens bagre Kant; Siderne begrændses mod Bugen af en skarp Linie, som er forsynet med strrke Torne ved disse Leds forreste Ende, samt noget længere bagtil, og over Aandeblærerne. Det femte Led er noget længere end det foregaaende og er besat paa samme Maade med lignende Knuder. Det sjette Led er kort, længere end det syvende, og begge have starke Kinuder paa Ryggens Midte og over Fodparrenes Befæstelsespunkt. Halen er 2-leddet. Hovedet er kortere end det første Legemsled og gaar fortil ud i et kort og opadstaaende Pandehorn.

De øvre Følere naa, naar de bøies bagud, til det fjerde Legemsled. Skaftets forste Led er længere end Hovedet $0 \mathrm{~g}$ af den samme Længde som det tredie Led; det andet er længere end dette Led. Svoben, der er længere end Skaftet, dannes af 20 Led.

De nedre Folere ere af den samme Længde som Skaftet paa de øvre. Skaftets andet Led udsender en lang Lugteknude; det tredie er omtrent saa langt som tylit; det fjerde og femte Led ere næsten lige lange og have korte Børster paa den undre Rand. Svøben dannes af 2 Led, af hvilke det andet er meget kort.

Kindbakkernes Spids er forsynet med 'Tænder; Tornerækken dannes af tire stærke Torne, forsynede med Bitænder; Tyggeknuden er fremstaaende. Palpens tredie Led er kortere end det anclet.

Det første Kjæbepars ydre Plade lar Torne paa Enden. Palpen er bredere mod Enden og er der besat med korte Torne.

Det forste.Fodpar er lidet; det forste Led er noget udvidet bagtil; det fjerde danner paa den bagre Rand tvende smaa Fremstaaenheder, besatte med Børster; Haandens forreste Rand er bøiet, den bagre er næsten ret, og paa den nedre, bagre Vinkel sees en Torn. Kloen er næsten saa lang som det sidste Led.

Det andet Fodpar er meget storre; det forste Led har langs den forreste Rand en Indskjæring for Haandens forreste Rand. Haanden er langagtig, oval; paa den bagre Rand dannes ved en Indskjæring en Tand, hvor Kloens Spids lægger sig imod, en lignende sees nærmere den ydre Ende, og mellem fine Børster; en mindre, 
stump Tand findes ved Kloens Rod. Kloen er stærk, krum og er Totrediedel af det sidste Leds Længde.

Halens Fodpar ere uleddede.

Aandeblærerne er ovale.

Jeg har fundet denne Art ved Haugesund.

Gen. V. CAPRELLA, Lamarck, 1801.

Deriv.: Capra, Deminutiv af.

Sya.: 1815. Caprella, Leach, Linn. Trans. XI. p. 363.

1818. - Lamarck, Syst. d. anim. sans vertebr. p. 165.

$\begin{array}{lll}\text { 1825. } & \text { L } & \text { Latreille, Hist. d. Crust. } \\ \text { Desmarest, Consid. s. les Crust. p. } 277 .\end{array}$

1840. - Milne-Edwards, Hist. d. Crust. p. 105.

1842. - Krøyer, Nat. Tidsskr. IV. p. 497.

1852. - Dana, U. S. explor. exped. p. $80 \%$.

1860. - $\quad$ A. Boeck, Forh. ved de skand. Naturf. 8de Møde. p. 674. Crust. amphip. bor. et arct. 1870. p. 193.

1862. - Spence Bate, Catal. Amphip. Crust. Brit. Mus. p. 353.

1865. - Goës, Crust. amphip. maris Spetsb. p. 18.

1868. - Spence Bate and Westwood, Brit. sessile-eyed Crust. II. p. 49.

Type: Cancer linearis, Linué.

Mandibulæ palpo destitutæ.

Segmentum trunci $1 \mathrm{mum}$ et 2 dum maris prælongata, feminæ multo breviora.

Postabdomen pedibus qvatuor uniarticulatis.

Antennæ inferiores flagello 2-articulato.

Friederich Martens afbildede forst en Caprella fra Spitsbergen i 1771, hvorefter senere Slægten Caprella blev opstillet i 1801 af Lamarck. Fra denne ere flere andre Slægter udsondrede, og Krøyer har i 1842 fastslaaet meget nøiagtigt Slægtens Karakteristik. Ved Mangel af Palpe paa Kindbakkerne skiller den sig fra AEgina; den afviger fra denne Slægt ogsaa ved Halens Bygning, i hvilken Henseende den ligner Slagten EEginella, der dog har Palpe paa Kindbakkerne. Denne Slægt har kun tvende Gjællesække, paa det tredie og fjerde Fodpar, medens Cercops har tre saadanne. Kroyer har ogsaa paavist, at Hunnen skiller sig meget fra Hannen, ved at hos hiin ere de tvende første Legemsled korte og det andet Fodpar er fæstet ved Begyndelsen af Leddet, inedens hos Hannen disse Led ere forlængede og det andet Fodpar er fæstet nær Leddets Ende. Han har af de forskjellige Arter udredet Kjønnene, hvilket ikke nok har været iagttaget $\mathrm{i}$ den senere Tid. Han har saaledes paavist, at Han og Hun 
af $C$. Jamuarii, Kr., ere saa forskjellige, at de kunne opstilles som forshjellige Arter, og at den yngre Han ligner mest Hunnen. Hos en Art, C. dilatata, Kr., bliver, som han paaviser, Legemet saa plumpt og bredt, at det synes at vise en Overgang til Cyamiderne. Dana, der ogsaa har paavist den store Kjønsforskjel mellem Arterne, tror, at Halens Bygning ikke er af nogen særdeles generisk Værd, men benytter den dog ved sin Diagnose af Slægten Caprella. Spence Bate, som heller ikke tager Hensyn til Munddelenes Bygning, forener endog Kroyers Slægter FEina og Podalirius med Slægten Caprella, hvori han folges af Spence Bate og Westwood; han har ikke observeret, at Slægten Podalirius kun har et rudimentært Fodpar paa det femte Legemsled, og at Slægten Egina er forsynet med Palpe paa Kindbakkerne. Han tror ogsaa, at Halens forste Fodpar er constant tilstede hos Hannen af enhver Art og sandsynligvis saavel analog som homolog med "the intromittent" Organ hos Decapoderne, hvilket ikke er Tilfældet, da der heri er en constant Forskjel hos de forskjellige Slægter.

\section{CAPRELLA LINEARIS, Linné, 1767.}

Cancer linearis, Linné, Syst. Nat. 1767. ed. XII. p. 1056.

- - Herbst, Vers, einer Naturgesch. d. Krabben u. Krebse. 1782-1804. t. 2. pl. 36. fig. 9. 10 .

Squilla lobata, Müller, Zool. Dan. Prodr. 1776. p. 197. No. 2359.

- quadrilobata, Müller, Zool. Dan. fasc. II. p. 21. t. LVI. fig. 4. 5. ऊ. Gammarus quadrilobatus, Müller, Zool. Dan. 1789. fasc. III. p. 58. t. CXIV. fig. 11. $12 . \%$.

Gammarus linearis, Fabricius, Ent. Syst. t. 2. p. 519. Oniscus scolopendroides, Pallas, Spic. Zool. 1774. IX. p. 78. pl. IV. fig. 15.

Caprella scolopendroides, Lamarck, Hist. nat. d. anim. sans vertebr. 1818. p. 174. - $\quad$ Rathke, Beitr. z. Fauna Norwegens. 1843. B. XX. p. 97.

- linearis, Leach, Edinb. Encyc. 1813-14. p. 404.

- - Risso, Crust. d. Nice. 1816. p. 130.

- Latreille, Hist. aat. d. Crust. et Ins. 1818. IV. p. 324. pl. LVII. fig. $2-5$.

- $\quad$ - Desmarest, Consid. s. les Crust. 1825. p. 278.

- - Johnston, Mag. Nat. Hist. and Journ. 1833. VII. p. 672. fig. 71.

- - Milne-Edwards, Hist. d. Crust. 1840. III. p. 106.

- - Goodsir, Edinb. new Phil. Journ. 1842. XXXIII. p. 190. pl. III. fig.8.

- - White, Hist. Brit. Crust. 185\%. p. 214.

- - Spence Bate, Ann. Nat. Hist. 1857. 2. ser. XIX. p. 161. Catal. Amphip. Crust. Brit. Mus. 1862. p. 353. pl. LV. fig. 7.

- $\quad$ - Spence Bate and Westwood, Brit. sessile-eyed Crust. 1868. II. p. 52. 
Caprella linearis, Norman, Rep. on the Shetland Crust. 1868. p. 288.

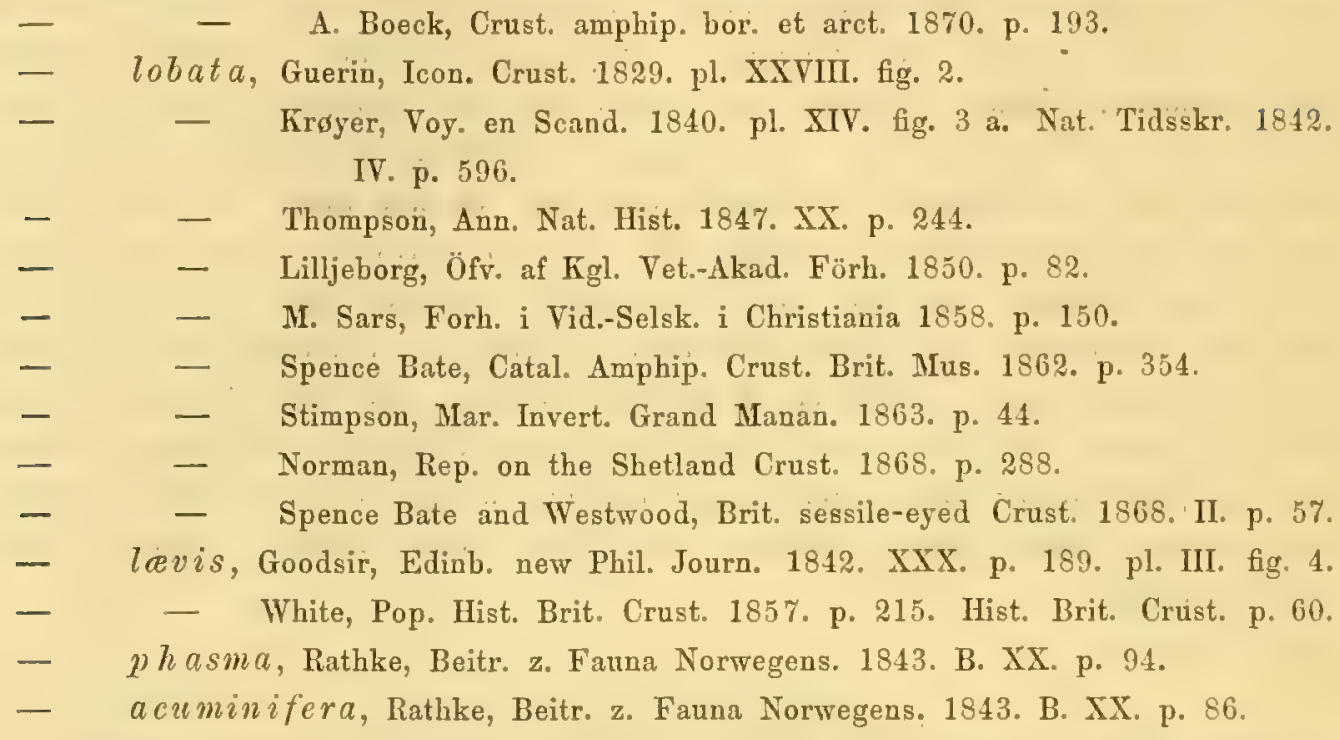

Segmenta trunci anteriora tuberculis nonnullis obsoletis vel nullis, segmentum 5tum tuberculis sexternis, 6tum et 7 mum binis instructa. Segmentum trunci 1mum et 2dum apud marem longitudine invicem fere rqvalia et segmento 3tio multo longiora; segmentum 1 mum apud feminam multo brevius qvam 2do; hoc longitudinem segmenti 3 tii fere aqvanti. Antennæ superiores dimidiam longitudinem anlmalis aqvantes; articulo pedunculi 1 mo parum Iongiore qvam dimidio articulo $2 \mathrm{do}$, et eadem longitudine vel paulo breviore ac articulo 3 tio. Pedes 2 di paris apud marem pone medium segmentum trunci 2dum siti; articulo 1 mo longitudinem segmenti trunci 2di fere acqvanti; manu in margine posteriore dentibus tribus validis armata et articulum 1mum longitudine reqvanti; pedes 2di paris apud feminam prope ad medium segmentum trunci 2dum siti; manu minore qvam apud marem, elongata, ovata, denticulis tribus instructa. Pedes 7 mi paris eosdem 5 ti et 6 ti paris longitudine valde superantes; manu eadem longitudine ac articulis duobus præcedentibus angustissimis junctis.

L $\rightsquigarrow$ gden er $18^{\mathrm{mm}}$.

Legemet er forlænget smalt; Følerne og Fodparrene ere forlængede, tynde. Hannen og Hunnen ere meget forskjellige i Udseende.

Hos Hannen er det første Legemsled særdeles forlænget, smalere mod den bagre Ende; det andet er lidt længere, samt tykkere paa det bagre Parti, hvor det andet Fodpar er fæstet; det tredie er meget kortere, omtrent saa langt som det fjerde, og begge tilsammen ere længere end det andet Led; det femte er omtrent af den samme Længde som det foregaaende, eller lidt lingere end dette, og har paa Ryggen 2-3 Par 
Knuder, af hvilke det forste er nær den forreste, de tvende andre nær den bagre Kant, det sjette og syvende Led ere meget korte, tilsammen neppe langere end det femte Led, eller ubetydelig længere end dette, og begge have 1-2 Par Knuder nær den bagre Rand. Hovedet er kort.

De øvre Følere ere meget forlængede, af Legemets halve Længde. Skaftets forste Led er kortere, men tykkere end det tredie, der er omtrent Totrediedel af det andet Leds Længde. Svøben, der er kortere end Skaftet, dannes af 17 Led.

De nedre Følere naa ikke frem til Enden af det andet Led paa de ovre Føleres Skaft og ere særdeles tynde; det fjerde og femte Led ere lige lange.

Det andet Fodpars forste Led ere meget tyndt, lidt kortere end det andet Legemsled; Haanden er omtrent af den samme Lingde, forlænget smal, og er paa den bagre Rand væbnet med tre stærke Tænder, af hvilke den midtre er tynd og lang, de tvende øvrige brede, triangulære.

De tre sidste Fodpar ere tynde, men tiltage efter hverandre meget i Læangde; det forste Led er omtrent saa langt som det tredie, og begge ere kun lidet udvidede nedad; det fjerde er meget kortere end det foregaaende Led, næsten ikke udvidet nedad; det femte er meget smalt, næsten saa langt som de tvende foregaaende tilsammen, væbnet med en stærk Tand ved Enden af den bagre Rands indre Trediedel.

Hos Hunnen er det forste Legemsled meget kort; det andet er meget langere end dette og Hovedet tilsammen, samt er tykkest foran Midtlinien, hvor Fodparret er fæstet; det tredie er omtrent af den samme Længde som det andet Led.

De øvre Følere ere meget kortere end hos Hannen; Skaftets andet Led er kortere end det forste.

De nedre Følere ere lrongere end Skaftet paa de ovre.

Det andet Fodpar er mindre end hos Hannen; Haanden er oval og forsynet paa den bagre Rand med tre Tænder, der dog ere meget mindre end hos Hannen.

Den er fundet af Lilljeborg i Finmarken, af $R$. Collett ved Nordkap, af Danielssen ved Tromsø, og er forøvrigt fundet fiere Steder langs den norske Kyst og ligeledes ved Bohuslen. Den er ogsaa fundet paa forskjellige Steder af de nordeuropæiske Kyster ifølge Spence Bate, Norman, Metzger og Flere.

\section{CAPRELLA LATICORNIS, A. Boeck, 1860.}

(Pl. XXXII. fig. 10.)

Caprella laticornis, A. Boeck, Forh. ved de skand. Naturf. 8de Møde. 1860. p. 675. Crust. amphip. bor. et arct. 1870. p. 194.

Mas. Corpus leve. Segmentum trunci 5tum-7mum nodulis $(2-4)$ et prope ad basin pedum trium parium ultimorum spinis singulis armata. Segmentum trunci $1 \mathrm{mum}$ et 2 dum prxlongata, longitudine invicem circiter xqvalia et fere duplo 
longiora qvam segmentum 3tium. Antennæ superiores dimidiam longitudinem animalis fere xquantes, perlatæ et setis gracilibus instructæ; articulo pedunculi $1 \mathrm{mo}$ parum modo breviore qram $2 \mathrm{do}$; hoc longiore qvam articulo 3 tio; flagello longitudinem articuli 3tii æqvanit. Antennæ inferiores ad extremum articulum pedunculi 2dum antennarum superiorum porrectx. Pedes 2di paris articulo 1mo fere eadem longitudine ac segmento trunci 2do; manu ovali, subcurvata, in margine posteriore dentibus tribus armata; dente manus medio minimo, infimo pervalido. Vesiculæ branchiales elongatæ, obovatæ. Pedes trium parium ultimorum breves; pedes ultimi paris manu longiore qvam articulo 3 tio et 4 to angustissimis junctis.

L ængden er $15^{\mathrm{mm}}$.

Le gemet er uden Knuder eller Torne, undtagen paa de tre sidste Legemsled, paa hvilke der paa hvert Led sees 2-4 Knuder; det første Legemsled, der er sammenvoxet med Hovedet, er noget kortere end det andet; dette er lidt kortere end en Trediedel af det hele Legeme, er bredest nær den bagre Ende og har her en Fremstaaenhed over Udspringet for det andet Fodpar. De folgende Led ere meget kortere, tilsammen omtrent af Legemets halve Længde; det tredie og fjerde Led ere næsten lige lange og bære Aandeblærerne; det femte er omtrent af den samme Længde, meget bredere bagtil, og har en stærk Torn over Udspringet for det femte Fodpar; det sjette og syvende Led ere næsten af eens Længde og have ligeledes foruden de nævnte Knuder en Torn over Udspringet for de tilsvarende Fodpar. Hovedet er lidet, uden Pandehorn eller Fremspring. Øinene ere smaa, runde.

De øvre Følere ere særdeles brede og naa, naar de bøies bagud, omtrent til Enden af det andet Legemsled. Skaftets første Led er meget tykt og noget længere end Halvdelen af det forste Legemsled; det andet er længere end det første, meget bredt, noget smalere mod Enderne, især mod den bagre, og overalt besat med korte, fine Borster; det tredie er kortere end det andet Led og meget smalere, samt er ligeledes besat med fine Borster. Svøben, der er omtrent saa lang som Skaftets sidste Led, dannes af 10-12 Led, af hvilke det første er af den samme Længde som de trende følgende tilsammen; de efterfølgende aftage efter hverandre i Længde og Tykkelse.

De nedre Følere ere meget tyndere og naa ikke frem til Enden af Skaftets andet Led paa de øvre Følere, samt ere besatte med Børster paa den undre Rand. Skaftets første Led er kort; det andet og tredie have den samme Længde; det fjerảe og femte ere meget længere og ligeledes indbyrdes lige lange, eller det femte er lidt kortere end det foregaaende Led og er meget smalere end dette. Svøben, der er omtrent saa lang som Skaftets sidste Led, dannes af $\approx$ Led, af hvilke det sidste er meget kort.

Det forste Fodpar er meget mindre end det andet; det første Led er temmelig langt; de tre folgende ere korte, især det andet; det fjerde er udvidet bagtil; 
Haanden er forlænget ægdannet, tvært afskaaret paa den indre Ende. Kloen er bred og stærk, saa lang som det sidste Led, saugtakket paa den bagre Rand.

Det andet Fodpar er fæstet paa den bagre Trediedel af det andet Legemsled $0 \mathrm{~g}$ er langt $\mathrm{og}$ tyndt. Paa den forreste Rand af det første Led, der er noget liortere end det Led, paa hvilket det er fæstet, sees en langsgaaende Indsynkning, begrændset af tvende Fremspring, og hvori Haandens forreste Rand kan lægge sig ind; af disse Fremspring er det yderste det stærkeste og ender $\mathrm{i}$ en kraftig Torn. Det andet Led er meget kort, og gaar fortil og nedad ud i en stærk Torn. Det fjerde Leds bagre Rand er forsynet med nogle Borster. Haanden er meget stor, af den samme Længde som det første Led, og af en forlænget oval Form, den forreste Rand er oval med en svag Indsynkning nær den ydre Ende; den bagre Rand er forsynet med en stærk Tand, hvor Kloens Spids lægger sig imod, og. har mod den ydre Ende tvende Tænder, en mindre og en større triangulær, nærmere Kloens Rod; der sees ligeledes paa denne Rand mange korte Børster. Kloen er stærk, krum, med en stump Fremstaaenhed nær Roden og med Børster paa den bagre Rand.

De tre sidste Fodpar ere temmelig korte og brede samt af eens Bygning og tiltage efter hverandre i Længde; det femte Led er længere end de tvende foregaaende tilsammen, eller omtrent af den samme Længde, tre Gange saa langt som bredt, noget bøiet, med en Torn og nogle Børster paa den bagre Rand.

A a ndeblarerne ere forlænget ovale.

Farven er hvid eller hvidgul, med spredte rødbrune Punkter paa Leddene samt paa det andet Fodpar.

Denne Art er beskrevet efter faa Exemplarer, Hanner, der i 1843 bleve fundne af C. Boeck og Rasch ved Beian paa Søndmøre, og som opbevares i Universitetets Samlinger.

CAPRELLA LONGICORNIS, A. Boeck, 1870.

\section{(PI. XXXII. fig. 7.)}

Caprella longicornis, A. Boeck, Crust. amphip. bor. et arct. 1870, p. 194.

Mas. Frons tuberculo in apice fisso, parvo instructa. Segmentum trunci 5tum-7mum tuberculis $(4-6)$ armata. Segmentum trunci 1 mum multo brevius qvam 2dum. Antennæ superiores dimidiam Iongitudinem animalis paulo superantes, latx, attamen multo angustiores qvam apud speciem præcedentem; articulo pedunculi 1 mo longiore qvam articulo 3tio et dimidio 2do; articulo 3tio multo breviore qvam flagello elongato. Antenne inferiores ultra finem articuli pedunculi 2 di antennarum superiorum longe porrecta. Pedes 2di paris articulo 1 mo dimidiam longitudinem segmenti trunci 2 di fere aqvanti; manu curvata, ovali, magna, longiore 
qvam articulis qvatuor anterioribus junctis, in acie dentibus tribus, dente medio minimo, armata; ungve valido, curvato. Vesicula branchiales lamelliformes et rotundatx. Pedes trium parium ultimorum perbreves et validi; manu longiore qvam articulo 3tio, fere ter longiore qvam carpo.

Længden er $22^{\mathrm{mm}}$.

Legemet er glat, uden Torne eller Knuder, undtagen paa de tre sidste Legemsled, paa hvis Rygside der sees $4-6$ smaa Fremstaaenheder. Det forste Legemsled er meget længere end Hovedet og forenet med dette i en skraa, bagfra fortil gaaende Linie; ved den nedre, forreste Vinkel er det første F'odpar fæstet; det andet er længere end Hovedet og det første Legemsled tilsammen, samt er tykkest noget bag Midtlinien, hvor der sees en Fremstaaenhed over Udspringet for det andet Fodpar; det tredie er omtrent saa langt som det foregaaende Led; det fjerde er ubetydelig kortere; det femte er saa langt som dette; de tvende sidste Led ere korte. Hovedet har en liden, dobbelt Knude bag Panden. Øinene ere smaa.

De øvre Folere naa, naar de bøies bagud, noget længere end til det tredie Legemsled $0 \mathrm{~g}$ ere meget mindre brede end hos den foregaaende Art. Skaftets forste Led er længere end Hovedet, omtrent fire Gange saa langt som tykt; det andet er længere og tyndere; det tredie er kortere og tyndere end det første Led. De tvende sidste Led have fine Borster paa begge Rande. Svøben, der er næsten af den samme Længde som Skaftets tvende sidste Led, dannes af omtrent 20 Led, hvis nedre Rands forreste Ende er fremspringende og giver dem et saugtakket Udseende.

De nedre Folere ere omtrent saa lange som Skaftet paa de gvre, meget smale og tynde, samt paa den undre Rand besatte med lange Børster. Skaftets tredie Led er lidt længere end bredt; det fjerde og femte ere omtrent af eens Længde og Tykkelse. Svøben, der er omtrent saa lang som Skaftets sidste Led, dannes af ¿ Led, af hvilke det sidste er meget kort.

Det forste Fodpar er lidet og kort; Haanden er bred ved Roden og bliver smalere udad, dens forreste Rand er convex, den bagre næsten ret og forsynet med fem tynde Torne samt med tvende stærkere ved don bagre Kant. Kloen er stærk.

Det andet Forlpars første Led er neppe halvt saa langt som det Legemslerl, hvortil det er fæstet; Haanden er længere end de foregaaende Led tilsammen, meget convex paa den forreste Rand og concav paa den ydre Del af den bagre; her sees, foruden mange fine Borster, en dobbelt Tand paa den bagre Trediedel, en mindre omtrent i Midten af en dyb Indskjæring, samt en større, af en triangulær Form, nær Kloens Rod. Kloen er stærk, meget krum og har nær Roden en stump Fremstaaenhed paa den bagre Rand.

De tre sidste Fodpar ere meget korte og stærke; det femte Led er meget ængere end det fjerde og noget længere end det tredie Led. 
A andeblærerne ere runde, skiveformede hos ældre Individer, ovale, blæreformede hos yngre, og fæstede bag Midten af det tredie og fjerde Fodpar.

De Fremstaaenheder, der sees hos xldre Exemplarer paa det andet Legemsled over det tilsvarende Fodpar, samt paa det tredie og fjerde over Aandeblærerne, findes ikke, eller ere mindre udtalte hos yngre, der i det Hele ogsaa have en finere Bygning. Paa enkelte mindre Exemplarer give Hunnerne sig strax tilkjende ved de kortere Legemsled, de kortere Folere og det mindre udviklede femte Led paa det andet Fodpar.

Denne Art er fundet ved Norges Vestkyst, uden at Stedet er nøiagtigere angivet.

CAPRELLA ESMARKII, A. Boeck, 1860.

(Pl. XXXII. fig. 5.)

Caprella Esmarlii, A. Boeck, Forh. ved de skand. Naturf. 8de Møde. 1860. p. 674. Crust. amphip. bor. et arct. 1870. p. 194.

- monocantha, Heller, Beitr. z. näh. Kennt. d. Amphip. Denkschr. d. K. K. Akad. d. Wiss. Wien. 1867, p. 54. t. IV. fig. 17--19.

? - avilibra, Spence Bate, Catal. Amphip. Crust. Brit. Mus. 1862. p. 362. pl. LVII. fig. 6.

II as. Frons antice in tuberculum desinens. Segmentum trunci $1 \mathrm{mum}$ tam longum qvam 2dum; hoc longitudine segmento 3tio et 4 to junctis aqvale et prope ad basin pedum 2di paris spina valida armatum. Antenna superiores dimidiam longitudinem animalis fere aqvantes; articulo pedunculi $2 d_{0}$ vix duplo longiore qvam 1mo; articulo 3 tio paulo breviore qvam 2do et longiore qvam 1mo. Antemnie inferiores ad extremum articulum pedunculi 2dum antennarum superiorum non porrectx. Pedes 2 di paris brevissimi. extremo segmento trunci 2 do affixi; articulo 1 mo dimidium segmentum trunci 2 dum longitudine vix æqvanti, in margine anteriore serrato; manu fere duplo longiore qvam articulo lmo, elongata, ovata, in acie dentibus tribus parvis, medio minimo, armata. Vesicula branchiales claviformes. Pedes trium parium ultimorum perbreves, lati; manu articulum 3tium et $4 \mathrm{tum}$ junclos longiludine fere reqvanti, plus duplo longiore qvam carpo.

Læn gden er indtil $18^{\mathrm{mm}}$.

Legemet er glat; det første Legemsled er forlænget smalt, bredere fortil og smalere bagtil, og ved dets nedre, forreste Vinkel er det forste Fodpar fxstet; det andet, der er næsten saa langt som Hovedet $0 \mathrm{~g}$ det første Legemsled tilsammen, er tykkere end dette samt bredest nær den bagre Rand, og her sees en spids, stærk Torn ved Befæstelsespunktet for det andet Fodpar; disse Led danne tilligemed Hovedet omtrent den halve Del af Legemets Langde; det tredie og fjerde Led ere indbyrdes omtrent lige lange og tilsammen næsten af den samme Længde som det andet Led; det femte er 
noget kortere; de sidste aftage efter hinanden i Længde. Den gvre Rand af Hovedet, der er kort afskaaret, danner intet Pandehorn, men gaar frem i en liden Knude.

De øvre Følere naa, naar de bøies bagud, næsten til det tredie Legemsled. Skaftets forste Led er noget længere end Hovedet; det andet er næsten af den dobbelte Længde, samt smalere ved den bagre Ende; det tredie er meget længere end det forste, samt en Trediedel kortere end det andet Led, meget tyndere end dette, og noget tykkere fortil end bagtil. Svoben, der er noget kortere end Skaftets sidste Led, dannes af 9 Led, der tilsammen have et saugtakket Udseende.

De nedre Følere naa ikke frem til Enden af det andet Led paa de ovre Føleres Skaft og ere forsynede med Børster paa den undre Rand. Skaftets tredie Led er ikke længere end tykt; det fjerde og femte ere omtrent lige lange. Svoben, der er af den samme Længde som Skaftets sidste Led, dannes af 2 Led, af hvilke det sidste er kun en Trediedel af det foregaaende Leds Længde.

Det forste Fodpar er kort og smalt, af den sædvanlige Form; det fjerde Led gaar bagtil ud i en Fremstaaenhed; Haandens bagre Rand er besat med fine Børster. Kloen er neppe saugtakket paa den bagre Rand.

Det andet Fodpars første Led er kort, kun omtrent dobbelt saa langt som bredt ved den nedre Ende, saugtakket paa den forreste Rand; de tre folgende Led ere korte; Haanden er forlænget oval, kortere end det andet Legemsled, omtrent dobbelt saa lang som det forste Led, bredere ved den bagre Ende; den forreste Rand er mest bøiet paa den bagre Trediedel; den bagre Rand, der har faa Børster, er svagt krummet, væbnet med en stark Tand, hvor Kloens Spids lægger sig imod, en meget mindre paa Midten, og mellem denne og Kloens Rod sees en triangulær, med Børster besat Fremstaaenhed. Kloen har et Par smaa Ophøininger nær Roden paa den bagre Rand, der er uden Børster.

De tre sidste Fodpar ere korte, brede og tiltage efter hverandre lun lidt i Længde; det syvende Pars fjerde Led er omtrent dobbelt saa langt som bredt; det femte har den dobbelte Længde af det foregaaende og er næsten saa langt som de trende foregaaende Led tilsammen, samt omtrent dobbelt saa lang som bred.

A andeblærerne ere forlænget ovale.

Hos en yngre Han vare Folerne forholdsvis meget kortere, og de ovres tredie Skaftled var kun ubetydelig længere end det forste Led.

Denne Art er fundet red Beian af C. Boeck og Rasch. Af Heller er den fundet ved Pirano, Lessina, Curzola.

CAPRELla LOVÉNI, A. Boeck, 1870.

(PI. XXXII. fig. 8.)

Caprella Lovéni, A. Boeck, Crust. amphip. bor。 et arct.1870. p. 196.

IIas. Frons in tuberculum obtusum producta. Segmenta trunci tuberculis obtusis instructa; tuberculo segmenti 2di maximo. Antennæ superiores dimidiam 
longitudinem animalis non æquantes; articulo pedunculi 1 mo parum breviore qvam 2do et longiore qvam 3tio; flagello fere duplo longiore qvam arliculo pedunculi ultimo. Antennæ inferiores ad extremum pedunculum antennarum superiorum porrectr. Pedes 2di paris articulo 1 mo medio segmento trunci 2 do aflixo et tertiam ejusdem longitudinis partem xqvanti; manu plus duplo longiore qvam articulo $1 \mathrm{mo}$, longa, ovata, in acie denticulis tribus instructa. Pedes trium pariun ultimorum breves et perlati; manu elongata, ovata, longiore qvam articulo 3 tio.

L $æ n g d e n$ er $25^{\mathrm{mm}}$.

Legemet er af en særdeles tyk og kraftig Bygning; Ryggen er besat med mange smaa Knuder, af hvilke dog kun enkelte udmarke sig fremfor de ovrige; det forste Legemsled er mere end dobbelt saa langt som Hovedet, sammenvoxet med dette, $0 \mathrm{~g}$ Grændsen betegnes med en skraa, fortil og nedad gaaende Linie, ved hvis Ende er frstet det forste Fodpar; det andet er af den dobbelte Længde, bredere noget bag Midten, og her sees en stor Knude over Befæstelsespunktet for det andet Fodpar; det tredie er af den samme Længde som det foregaaende Led; det fjerde er noget kortere, og noget bag Midten af disse Leds undre Side ere Aandeblærerne fistede, over hvilke sees en enkelt eller dobbelt knudeformet Fremstaaenhed; det femte Led er kortere end det foregaaende; de tvende sidste aftage efter hinanden meget i Længde. Paa Rygsiden af hvert af disse Led sees fire Knuder, af hvilke de bagre ere de største. Hovedet er meget lidet; paa Midten af dets gvre Side sees en meget stor Knude, der er spaltet i Spidsen, og paa Siderne af denne sees nogle lignende mindre Knuder; dets forreste Rand er bøiet.

De øvre Følere naa, naar de bøies bagud, neppe til Enden af det andet Legemsled. Skaftets forste Led er længere end Hovedet, omtrent tre Gange saa langt som tykt; det andet er noget længere, men smalere, tyndest ved den bagre Ende; det tredie er meget kortere end det forste $0 \mathrm{~g}$ kun ubetydelig længere end Halvdelen af det andet Led. Svøben, der er meget kortere end Skaftet, dannes af 12 korte Led, af hvilke hvert er bredest ved den ydre Ende.

De nedre Folere ere lidt længere end Skaftet paa de øvre. Skaftets tredie Led er noget længere end tykt; det fjerde og femte, der indbyrdes ere næsten lige lange, ere lidt kortere end de ovre Foleres første Led og besatte med lange fine Børsteknipper paa den undre Rand. Svoben, der er saa lang som Skaftets sidste Led, dannes af 2 Led, af hvilke det sidste er meget kort.

Det forste Fodpar er meget kort, af den sædvanlige Form.

Det andet Fodpars forste Led er meget kortere end det tilsvarende Legemsleds halve Længde; de tre følgende ere meget korte; Haanden er særdeles tyk og stor, noget kortere end det andet Legemsled, af en oval Form; den bagre Rand har en spids, stærk Tand, hvor Kloens Spids lægger sig imod, og nærmere den ydre Ende sees paa hver Side af en dyb Indskjaring tvende lignende Tænder; Randen er besat med mange 
fine Børster. Kloen har nær sin Rod tre mindre, stumpe Fremstaaenheder paa den bagre Rand.

De tre sidste Fodpar ere lorte og tiltage efter liverandre noget i Længde; det tredie Led er længere end det fjerde og kortere end det femte Led, der er omtrent dobbelt saa langt som bredt; det syvende Pars tredie og fjerde Leds nedre, bagre Vinkel danner ved en liden Indskjæring tvende fine Tænder.

A a ndeblærerne ere store, ovale.

Denne Art er fundet paa Norges Vestkyst; Findestedet er ikke angivet.

\section{CAPRELLA SEPTENTRIONALIS, Krøyer, 1842.}

Sqvilla lobata, Fabricius, Fanna Groenl. 1780. p. 248.

Caprella septentrionalis, Kroyer; Nat. Tidsskr. 1842. 1. R. 4. B. p. 596. pl. 8.

fig. 10-19. Voy, en Scand. t. 25. fig. 2.

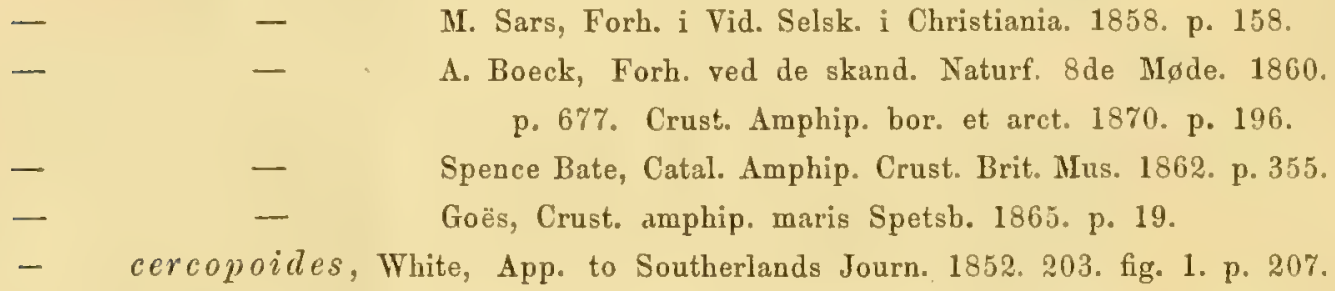

Corpus crassum et robustum, nunc tuberculatum, nunc fere leve. Frons in tuberculum producta. Segmenta trunci qvatuor anteriora tuberculis singulis vel binis obsoletis, segmentum 5 tum paribus tribus, 6tum et 7 mum paribus duobus tuberculorum instructa. Segmentum trunci 1 mum multo brevius qvam 2dum; hoc longitudinem segmenti 3tii fere aqvans. Antenna superiores dimidiam longitudinem animalis fere reqvantes; articulo pedunculi 1 mo parum breviore qvam 2do, longiore vero qvam 3tio; flagello ejusdem longitudinis ac articulis pedunculi duobus ultimis junctis. Antenna inferiores ultra pedunculum antennarum superiorum longe porrectæ. Pedes 2 di paris articulo 1 mo segmento trunci 2 do affixo et dimidiam longitudinem segmenti ejusdem reqvanti; manu articulum 1 mum longitudine parum superanti, ovata, in acie denticulis tribus instructa. Vesicule branchiales obovatæ. Pedes trium parium ultimorum manu pervalida, longitudinem articulorum duorum præcedentium junctorum fere æqvanti.

$I_{i} æ n g d e n$ er $16^{\mathrm{mm}}$.

Legemet er temmelig tykt og kraftigt, næsten glat, med 1-2 smaa Ophøininger paa Rygsiden af Legemsleddene. Hos Hunnen er det første Legemsled meget kort; det andet er lidt længere end Hovedet og det forste Legemsled tilsammen, og det derpaa fæstede andet Fodpar udspringer fra dette Leds forreste Trediedel. Hos 
Hanner er det andet Led mere forlænget, og Fodparret har sit Befæstelsespunkt længere tilbage. Det tredie Led er omtrent saa langt som det fjerde, eller ubetydelig længere end dette; begge erè, ligesom de foregaaende Led, enten glatte eller forsynede med en dobbelt Knude paa Ryggen; de tre sidste Led, af hvilke det forste er det længste, ere ligeledes paa Ryggen vabnede med stumpe Knuder; paa det femte Led sees tre Par, paa det sjette og syvende tvende Par, af hvilke det forste er meget lidet. Hovedet er kort, med 1-2 Knuder paa Panden.

De øvre Følere ere korte, af Legemets halve Lingile. Skaftets første Led er kortere end det andet, men længere end det tredie Led. Svaben er saa lang som Skaftets tvende sidste Led tilsammen.

De nedre Folere naa hos Hunnen langt foran de ovre Foleres Skaft; det fjerde og femte Led ere lige lange. Svøbens forste Led er kortere end det sidste Led paa Skaftet. Hos Hannen ere disse Følere kortere i Forholn til de ovre.

Det forste Fodpar er af den sædvanlige Form; Haanden er trekantet.

Det andet Fodpars første Led er hos Hunnen meget kort og omtrent halvt saa langt som det tilsvarende Legemsled; over dets Udspring sees en knudeformet Fremstaaenhed; den xgdannede Haand er meget langere en d det forste Led. og dens bagre Rand er vabnet med en Tand og nogle Torne, hvor Kloens Spids lægger sig imod, samit med tvende mindre Trender nærmere den ydre Ende. Hos Hannen er det første Led lidt længere end hos Hunnen.

De tre sidste Fodpar tiltage efter hverandre i Længrle; det forste Led er meget kort, og paa det forste af disse Folpar er llet kortere end det tredie Led, paa det sidste er det lidt længere end dette; det tredie er neppe mere end dobbelt saa langt som bredt; det fjerle er kortere end dette; det femte er omtrent af den samme Længde som de tvende forégaaende Led tilsammen, med en stærk Tand, hvor Kloens Spids lagger sig imod, samt nogle Torne, og med tine. Torne paa den forreste Rand.

Aandeblærerne ere xgdannede, og over deres Udspring sees en stump Fremstaaenhed.

Hos en Hun, der utvivlsomt maatte henfores til denne Art, var det tredie Lell paa de ovre Foleres Skaft omtrent af den samme Lxengle som ret forste Led; det tredie og fjerde Legemsled vare besatte med talrige Knuler, merlens Hoverlet mangleile saadanne; det andet Folpars forste Led var længere end saedvanligt. Farven var hvil, spættet med Rodt, hvilket var mest fremtræende paa Ryggen. Hos et andet Exemplar. en Hun, taget af R. Collett, fandtes ingen knulleformet Fremstaaenhed pila Hoveret; en liden Knude saaes paa det andet Legemsled, hvorimod ingen paa de folgende; Legemet havde overalt fine Punkter.

Farven var paa enkelte Exemplarer olivenbrun.

C. obtusa, Heller, synes at være identisk med denne Art.

Herhen bør vistnok ogsaa henføres $C$. tuberculata, Goodsir, (the Edinb. New 
Phil. Journ. 1842), og C. Tystrix, Spence Bate and Westwood, (Brit. sessile-eyed Crust. 1868. II. p. 63).

Efter M. Sars er den hyppig i Finmarken; ved Nordkap er den fundet af R. Collett, og findes forovrigt langs den norske Vestkyst og ned til Bohuslen. Efter Goës er den almindelig ved Spitsbergen, og ligeledes ved Grønland. Efter White er den taget i Baffinsbugten.

CAPRELLA PUNCTATA, A. Boeck, 1870.

(P1. XXXII. fig. 11.)

Caprella punctata, A. Boeck, Forh. ved de skand. Naturf. 8de Iøde. 1860. p. 676. Crust. amphip. bor, et arct. 1870. p. 197.

Corpus tuberculis et spinis permultis instructum maximis: in capite spina gemina, in medio segmento trunci 2 do luberculis duobus pervalidis, in margine anteriore et posteriore ejusdem segmenti binis minoribus. Antennæ superiores maris dimidiam longiludinem animalis fere æqvantes; arliculo pedunculi 1 mo paulo breviore qvam 2do, multo longiore qvam 3tio; flagello articulos pedunculi duos ultimos junctos longitudine reqvanti. Antennæ inferiores ultra finem pedunculi antennarum superiorum longe porrectæ. Pedes 2di paris segmento trunci 2do, apud marem postice, apud feminam antice, affixi; articulo 1 mo dimidian longitudinem segmenti trunci 2di fere reqvanti; manu ovata, tuberculis permultis majoribus vel minoribus instructa. Vesiculie branchiales obovatæ. Pedes trium parium ultimorum manu articulos duos precedentes junclos longitudine fere aqvanti.

Længden er $18^{\mathrm{mm}}$.

Legemets Form er kun lidet afvigende hos begge Kjøn og overalt bedxkket med tildels høie Knuder, hvorved der fremkommer et eiendommeligt Udseende. Det forste Legemsled er kort og har tvende Knuder langs Rygsiden og Tværrader af saadanne langs Enderanden; det andet er omtrent tre Gange saa langt, tykkest paa,Midten, livor det andet Fodpar er frstet hos Hannen, og paa Ryggens Midtlinie sees en længere, tyk, afstumpet, i Spidsen spaltet Knude, samt tvende mindre foran $0 \mathrm{~g}$ bag denne, foruden en ved den forreste og bagre Rand; paa Siderne findes flere storre og mindre Knuder i uregelmæssige Rækker; det tredie har; foruden flere smaa Knuder, en større nær den forreste Rand, samt tvende mindre paa Siderne, endnu nærmere denne Rand, og tillige en stor, spaltet Knude paa Midten af Rygsiden; det fjerde er næsten af den samme Længde som det foregaaende Led og har en stor dobbelt Knude paa den forreste Del af Ryggens Midtlinie, tvende storre ved Siden af hinanden paa Midten og en dobbelt Iinude nær den bagre Rand, ligesom der ogsaa paa Siderne sees flere smaa Knuder; det femte Led er noget kortere og er bredere paa det bagre Parti, 
hvor ogsaa Knudernes Antal roxer, og fremviser tvende store bag hinanden paa Ryggen, en paa hver Side af disse, foruden en storre ved Befastelsespunktet for det tilsvarende Fodpar, og forøvrigt mange smaa Knuder; det sjette og syvende Led ere korte, og af de her værende Knuder udmarke sig tvende paa Ryggen og en længere, bagud rettet paa hver Side over Udspringet for Fodparrene. Hos Hunnen er det andet Led noget længere, og det tilsvarende Fodpar er fæstet til Leddets forreste Trediedel; det tredie og fjerde ere længere og tykkere, hvor de støde til hinanden. Hovedet er kort og bærer paa Enden, bag Panden, en lang, i Spidsen tvedelt Knude, forurlen flere smaa.

De ovre Folere ere hos Hanmen langere end hos Hunnen og ere hos hiin noget længere end Hovedet og de trencie forste Legemsled tilsammen. Skaftets forste Led er omtrent tre Gange saa langt som tykt, og tykkere ved den ydre Ende; det andet er omtrent af Hovedets og det forste Legemsleds Længde tilsammen, længere enil det forste 0 g næsten dobbelt saa langt som det tyndere tredie Led. Svoben er kortere end Skaftet og dannes af 10-12 Led, der tilsammen have et saugtakket Udseende.

De nedre Folere ere lingere end Skaftet paa de ovre og ere nasten saa tylke som disse. Skaftets tredie Led er længere end tykt og smalere ved Roden; det fjerde og femte ere næsten lige lange og omtrent af den samme Længde som det første Led paa de øvre Føleres Skaft, men meget tyndere end dette, samt have tætte, fine Børstebundter paa den undre Rand. Svoben er kortere end Skaftets sidste Led og har ligeledes Borster paa den undre Rand. Hos Hunnen ere alle Led tyndere og faa derved et længere Udseende.

Det forste Fodpar er liort og bredt, men forovrigt af den sædvanlige Form.

Det andet Fodpar er kort, fæstet hos Hannen lidt bag Midten af Leddet, hos Humnen lidt foran denne; det forste Led har omtrent den halve Længde af det andet Legemsled $\mathrm{og}$ er noget bredere samt fortil boiet ved den nedre Ende; Haanden er længere end det forste Led, bred oval, agdannet, med mange smaa Knuder; den forreste Rand, der er besat med mange Knuder, er mere boiet end den bagre, paa hvilken sees, foruden mange fine Børster, en stærk Tand, forsynet med tvende Torne, hvor Kloens Spids lægger sig imod; nærmere den ydre Ende sees tvende mindre, af hvilke den yderste er bredest. Kloen er stærk og bred ved Roden. Hos Hunmen er dette Fodpar af den samme Form, men spædere.

De tre sidste Fodpar tiltage efter hverandre i Langde og ere korte, men brede; det femte Led er stærkt, mere end dobbelt saa langt som bredt, og af den samme Lærngde som de tvende foregaaende Led tilsammen.

A a ndeblærerne ere forlænget ægdannede.

Farven er lys, med morke Pletter.

Den er fundet i Throndhjemsfjorden og ved Sondmore af C. Boeck og Rasch, ved Manger af M. Sars. 
CAPRELLA HYSTRIX, Kroyer, 1842.†

Caprella hystrix, Kiroyer, Nat. Tidsskr. 1842. 1. R. 4. B. p. 603. pl. VIII. fig. 20-26. Voy en Scand. pl. 24. fig. 1.

- Norman, Rep. on the Shetland Crust. 1868. p. 288.
- $\quad$ A. Boeck, Crust. amphip. bor. et àret. 1870. p. 197.

Caput et segmentum trunci 1 mum aculeis dorsalibus destituta. Segmentum Irunci 2dum-4tum aculeis validis, qvorum bini posteriores juxta positi. armata; segmentum 5luin - 7mum aculeis binis, juxta positis, armata. Segmentum trunci 1 mum brevissimum; segnentum ¿2dum 3tio paulo brevius. Antenne superiores inferioribus plus duplo longiores, duas tertias longitudinis animalis fere aqvantes. Pedes 2 di paris manu dilatata, ovata, in acie dente magno armata. Pedes trium parium ultimorum manu lineari, in acie aculeis instructa, longitudinem articuli 3tii et 4 ii junctorum xqvinti.

Længden er $3^{\mathrm{mm}}$.

Det forste Legemsled er meget lidet, uden Knuder; det andet har tvende, stærkt fremragende Torne paa Rygsiden, den ene foran Midten, den anden, der er tvedelt, nær den bagre Rand; det tredie, der er længere end det foregaaende Led, har ligeledes tvende 'Torne eller Knuder, af hvilke den forreste her staar meget nærmere den bagre, der ligeledes er delt; det fjerde Leds Knuder sidde tæt sammen, nær den bagre Rand; de tre sidste Led have hver en dobbelt Knude paa Ryggens Midte. Halen er meget fremtrædende, tilsyneladende uden Spor af Lemmer. Hovedet er usædvanlig stort og er især fremtrædende paa Grund af Munddelenes betydelige Udvikling; det er uden Knuder og Horn

De øvre Følere have næsten Totrediedel af det hele Legemes Længde. Skaftets tredie Led er lidt længere end det forste, men lidt kortere end det andet Led. Svaben, der er lidt kortere end skaftet, dannes af 11-14 Led, der ere forsynede med lange, tynde Børster.

De nedre Folere ere ikke saa lange som Halvdelen af de grre. Skaftets fjerde og femte Led ere lige lange. Svobens andet Led er meget kort.

Det forste Fodpar er noget storre end sælvanligt hos disse Former; Haanden er smal. Kloen er saugtakket paa den bagre Rand og har en Torn nær Spidsen.

Det andet Fodpar er ikke dobbelt saa langt som det første; Haanden er lidt længere end det forste Led, bred oval, med en Tand midt paa den bagre Rand.

De tre sidste Fodpar ere stærke, af eens Bygning, og tiltage efter hverandre lidt i Længde; det femte Led er saa langt som de tvende foregaaende tilsammen og mere end dobbelt saa langt som det første Led, meget smalt og uden nogen Tand paa den bagre Rand.

Krøyer anfører, at han fandt. kun Exemplarer af ringe Størrelse, hvilke neppe 
kunde ansees voxne, trods Folernes Længde; paa Grund af den stærke Udvikling af Rygsidens Torne kunde de dog ikke henfores til noget Udviklingstrin af nogen anden bekjendt Art. Det er tvivlsomt, om Spence Bate og Westwoods Art hører herhen.

Farven er lys purpurrød.

Den er fundet af Kroyer ved Christiansund i faa Exemplarer, paa 3-4 Favnes Dybde.

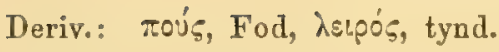

Syn.: 1845. Podalivius, Kroyer, Nat. Tidsskr. 2. R. 1. B. p. 283.

1852. - Daua, U. S. explor. exped. p. 807.

1862. Caprella, Spence Bate, Catal. Amphip. Crust. Brit. Mns. p. 353. (pars).

1868. - - Spence Bate and Westwood, Brit. sessile-eyed Crust. II. p. 79. (pars).

1870. Podalirius, A. Boeck, Crust. amphip. bor. et arct. p. 197.

Type: Podalirius typicus, Kroyer.

Mandibulæ palpo destitutæ.

Antennæ inferiores flagello 2articulato; articulo 2do elongato.

Segmentum trunci 1 mum et 2 dum, 6tum et 7 mum pedibus perfectis, 5tum rudimentaribus, 2articulatis instructa; segmentum 3tium et 4tum pedibus destituta sed vesiculis branchialibus prædita.

Postabdomen 2articulatum, pedibus destitutum.

Krøyer opstillede denne Slægt i 1845, idet han skilte den fra Slægten Caprella, væsentlig ved at Fodparret paa det femte Legemsled er rudimentært, men dog 2-leddet, og ved at Halen mangler Lemmer. Spence Bate, som har havt Exemplarer fra den engelske Kyst til Undersøgelse, har overseet dette rudimentare Forpar og antager, at et vel udviklet Fodpar paa det femte Led har været afrevet. Han og Westwood angive derfor paa en Tegning dette Fodpar med Punkter og have feilagtig henfort Arten $P$. typicus til Slægten Caprella. Heller ikke have de bemærket, at Halen mangler Fodpar, medens Rudimenter af saadanne findes paa Caprella.

PODALIRIUS TYPICUS, Krøyer, 1845.

(Pl. XXXII. 6ig. 12.)

Podalirius typicus, Krgyer, Nat. Tidsskr. 1845. 2. R. 1. B. p. 283. Voy. en Scand. pl. 25.

Frey u. Leuckart, Beitr. z. Kenntn. d. wirbell Thiere. 1847. p. 163.

- - A. Boeck, Crust. amphip. bor. et arct. p. 198.

Caprella typica, Spence Bate, Catal. Amphip. Crust. Brit. Mus. 1862. p. 354. pl. LVI. fig. 2.

- - Spence Bate and Westwood, Brit. sessile-eyed Crust. 1868. II. p. 75. 
Corpus leve, tuberculis destitutum, apud utrumqve sexum fere simile. Antennæ superiores apud marem dimidiam longitudinem animalis superantes, apud feminam breviores: articulo pedunculi 1 mo paulo breviore gram 2 do et 3tium longitudine fere æqvanti. Antennæ inferiores articulo pedunculi 4 to parum longiore qvam 5to. Pedes 2di paris manu maris in acie incisa el supra dentibus duobus latis armata; manu feminæ ovata. Pedes duorum parium ultimorum manu angusta, lineari, articulos duos præcedentes junctos longitudine fere æquvanti.

L $æ \mathrm{ngden}$ er $4^{\text {mm }}$.

L egemet er forlænget, glat, uden Knuder eller Torne, og næsten af den samme Form hos begge Kjon; det andet Legemsled er noget længere hos Hannen end hos Hunnen; det tredie og fjerde, der ere indbyrdes lige lange, ere noget kortere og bredere hos Hunnen; det femte er hos Hannen af den samme Langde som det foregaaende, men hos Hunnen er det noget kortere; det sjette er næsten saa langt som det femte; det syvende Led er meget kortere. Halen er 2-leddet. Hovedet er ikke stort. Øinene ere smaa, runde.

De øvre Følere ere hos Hannen længere, hos Hunnen kortere end Legemets halve Længde. Skaftets Led ere hos Hunnen kortere end hos Hannen; det forste er lidt kortere end det andet, men lidt længere end det tredie Led. Svoben dannes hos Hannen af 6 , hos Hunnen af 5 Led, af hvilke det første er længere end de folgende.

De nedre Følere ere meget kortere end de øvre, hos Hannen meget korte i Forhold til de ovre, hos Hunnen længere. Skaftets fjerde og femte Led ere omtrent lige lange. Svoben dannes af 2 Led; det sidste er forlænget.

Kindbakkerne ere meget stærke og mangle Palpe.

Det andet $\mathrm{Kj}$ æbepars ydre Plade er meget smalere end den indre.

Det forste Fodpar er lidet, Haanden er noget kortere end det forste Led, forlænget ægdannet.

Det andet Fodpars forste Led er boiet fortil; Haanden er hos begge IKjon længere end det forste Led; hos Hunnen er den af en forlænget oval Form, med en stærk Torn ved Griberandens bagre Ende, hvor Kloeus Spids lægger sig imod; hos Hannen er Haanden meget stærkere bygget, større og noget krummet, og her findes paa den bagre Rand et meget strerkt, tandlignende Fremspring, der ofte har en mindre opadrettet Bitand.

Et lidet Spor af et femte 2-Ieddet Fodpar sees paa det tilsvarende Legemsled.

Det sjette Fodpar er forlænget smalt; det forste Led er meget kort og ubetydelig længere end det tredie; dette er noget kortere end det fjerde og kun ubetydelig udvidet; det femte er meget længere end det tredie Led, særdeles smalt og tyndt.

Det syvende Fodpar er noget længere end det foregaaende. 
Halen er 2-leddet og mangler Lemmer.

Aandeblarerne ere ovale.

Farven er mork, graalig brun.

Den er fundet paa forskjellige Steder langs Norges Vestkyst og gaar ned til Bohuslen. Krøyer og Metzger anføre, at den hyppig findes fæstet til Søstjerner.

\section{Familia II.}

\section{CYAMID年.}

Syn.: 1843. Cyamea, Kroyer, Nat. Tidsskr. 1. R. 4 B. p. 496.

1852. Cyamide, Dana, U. S. explor. exped. p. 807.

1862. - Spence Bate, Catal. Amphip. Crust. Brit. Mus. p. 366.

1865. - Lilljeborg, On the Lysianassa magell.

1868. - Spence Bate and Westwood, Brit. sessile-eyed Crust. II. p. 7\%.

1870. Cyamince, A. Boeck, Crust. amphip. bor. et arct. p. 198.

Corpus breve, latum, depressum.

Vesiculæ branchiales magna, ensiformes, interdum fissa, raro parva; vesiculæ maris ad basin sapissime appendicibus propriis instructæ.

Antennæ inferiores minimæ.

Pedes sal validi.

Mandibulæ palpo destitute.

Da Dr. Lütken, Docent ved Universitetet i Kjobenhavn, monographisk har behandlet denne Afdeling, har jeg ikke troet at burde beskrive den i nærværende Værk og forbigaar den saaledes her, ligesom tidligere i min Prodromus. 



\section{Index.}

\begin{tabular}{|c|c|}
\hline $\begin{array}{r}\text { Pag. } \\
\text { otozoma . . } 237\end{array}$ & $\begin{array}{ll} & \text { Pag. } \\
& 405\end{array}$ \\
\hline $\begin{array}{l}\text { otozoma. . . 237 } \\
\text { tum } \ldots \ldots .238\end{array}$ & 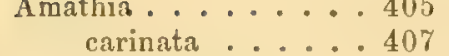 \\
\hline inflatum .... 242 & carino-spinosa . . 4 407 \\
\hline atum. . . . . 2 240 & pingris . . . . . \\
\hline canthonotus . . . 2.237 & Sabinii .... 407 \\
\hline Cranchii ....2233 & Amathilla ......... \\
\hline $15 \ldots 2$ & ulosa ..... \\
\hline$s \ldots . . .2$ & vis ...... \\
\hline nii . . . . . . & Sabinii . . . . 406 \\
\hline$\ldots \ldots 2$ & Ambasia...... 120 \\
\hline tus ..... & Danielssenii . . . 1 121 \\
\hline us ...... & Ampelisca ......518 \\
\hline$\ldots \ldots .2$ & ceqvicornis . . . . . 524 \\
\hline is ...... & ilitis . . . . . . 521 \\
\hline a...... & Belliana ..... 534 \\
\hline & carinata ..... \\
\hline pheia .... & dubia ........5527 \\
\hline treni..... & Eschrichtï 528, 531, \\
\hline ne ..... & 537,539 \\
\hline cuspindata ..... & Gaimardii . . 522, 543 \\
\hline$\ldots \ldots \ldots$ & ingens . . . . 5 528 \\
\hline$\ldots \ldots$ & lovigata. . . 519,534 \\
\hline$x \ldots$ & macrocephala ... 531 \\
\hline Acidostoma & propinqua..... 533 \\
\hline obesum...... & spinipes . . . . 526 \\
\hline Ėgina & tenuicornis..... 519 \\
\hline ata & $\ldots \ldots$ \\
\hline 10 & AMPELISCADES . . . 516 \\
\hline longicornis . . . 6 & AMPELISCAIDAE $\ldots \ldots 516$ \\
\hline longispina $\ldots 6$ & AMPELISCIDES $\ldots \ldots 516$ \\
\hline $\operatorname{ma} \ldots \ldots$ & AMPELISCINA. . . . 5 516 \\
\hline ssima.. & AMPELISCINæ $\ldots \ldots 516$ \\
\hline Fginella. & AMPELISCINI ..... 516 \\
\hline spinosa . . . . . 6 6s4 & AMPHILOCHINA $\ldots . .430$ \\
\hline brotus $\ldots . . .$. & Amphilochus .... 431 \\
\hline . & bispinosus. . \\
\hline Allorchestes. . & manudens..... \\
\hline Danai........ & odontony. .....434 \\
\hline Nilsoni ...... & tenuimanus ....447 \\
\hline
\end{tabular}

Amphithoë...... 587

albomaculata... 589

bicuspis .... 308

carinata ... 321

carino-spinosa . . 407

compressa .... 328

crenulata.... 335

cristata.....2 238

Edwardsii ....5 511

fulvocincta . . . 342

grandimana .... 591

hystrix ....2 230

inermis..... 335

leviuscula . . . 345

latipes ..... 355

littorina ....5589

macrocephala. .. 33s

Marionis ... . 312

Moggridgei . . . 4 407

Nilssonii . . . . 109

Norvegica ... 348

obtusata .... 385

panopla..... 303

parasitica ...2 233

podoceroides.... 588

Prevostii ..... 109

pulchella.... 306

punctata .... 589

pygmæa ..... 554

Rathkei..... 345

Reinhardi..... 554

serra...... 240

serraticornis ... 345

spinosa.... 312

Swammerdamii. . 328

tenuicornis . . . 3 312

Aмrнiтhorñ . . . . 586

Amphithonotus . 312, 510

acanthophthalmus . 312 
Pag.

Amphitonotus aculeatus 511

Edwardsii ....5 511

Malmgreni ....263

Marionis .... 312

Amphithopsis . .... 349

bicuspis .....308

elegans.... 338

glaber ..... 300

læviuscula ... 345

latipes..... 355

longicaudata ....351

longimana .... 353

Malmireni. .... 350

tridentata .... 341

Andania ......426

abyssi......4426

Nordlandica . . . 4 428

Anisopus ..... 593

Anonjx ...... 150 ampulla. . 152, 184 brachycercus... 169

Bruzelii ..... 157

denticulatus ... 137

Edwardsii . . 167, 172

gulosus ...... 157

Holbölli. . . 136, 157

Krgyeri..... 134

lagena...... 152

Lilljeborgi..... 154

litoralis .... 162

longipes ..... 184

Martensi ..... 156

minutus .... 174

nanoides .... 186

nanus.... 181, 186

Norvegicus . . . 157

obesus ..... 193

obtusifrons... 169

pingris ...... 176

plautus...... 164

pumilus ...... 159

serratus ..... 172

tumidus ..... 148

Vahli ..... 129

Aora ....... 569

gracilis ..... 570

Araneops ...... 518

brevicornis ... 531

diadema .... 519

Argissa ...... 205

typica......206

Aristias ...... 146

tumidus ...... 148

Astacus linearis ... 623

locusta..... 105
Pag.

Astacus phasma ... 679

Astyra . . .....4442

abyssi..... 443

ATYLIN ...... 320

Atylus ......... 322

bispinosus ... 338

carinatus .... 324

compressus. ... 329

crenulatus .... 335

gibbosus .... 318

inermis ..... 335

Nordlandicus ... 332

Smitti..... 326

Swammerdamii. . . 328

Vedlomensis....330

Autonoë ...564, 569, 572

anomala .... 567

depressa .... 550

erythrophthalma . 581

grandimaúa ... 565

longipes :.... 57\%

macronyx.... 576

plumosa..... 574

punctata .... 570

Bathyporeia ....2208

pelagica. ..... 209

pilosa ...... 209

Bellia.....222

arenaria ....223

Bruzelia ...... 477

typica......448

Byblis ....... 543

Gaimardi .... 543

Calliope...... 344

Fingalli..... 355

grandoculis ... 345

læviuscula .... 345

Leachii ..... 345

Norvegica ... 348

Ossiani ..... 355

Calliopius ..... 344

Fingalli..... 355

Iæviusculus....345

Norvegicus. ... 348

Ossiani .... 355

Callisoma ..... 131

crenata ..... 132

Krøyeri.....134

Cancer ampulla....421

carino-spinosa...407

corniger .....233

gammarellus ... 102

ampulla 421
Cancer (?gammarus) articulosus.... 507

(gammarus) falcatus . . 605

- $\quad$ galba.. 79

- locusta . 366 monocu-

loides. 449

obtusa-

tus . . 385

palmatus 387

pedatus. 673

saltator. 105

spinosus 312

grossipes ....6 623

linearis..... 673

locusta .... 366

macrourus ... 366

medusarum ... 79

phasma: :...6 679

pulex... 366, 373

Caprella ... 686, 701

æqvilibra.... 693

acuminifera . . 688

calva..... 684

cercopoides . . 696

Esmarkii .... 393

hystrix : . 698, 700

læris .....688

laticornis ...6689

linearis:.... 687

lobata..... 688

longicornis . . . 691

longispina ... 679

Lovéni. . . . . 694

monocantha ... 693

obtusa ..... 697

phasma...679, 688

punctata..... 698

scolopendroides . 687

septentrionalis . . 696

spinifera .... 680

spinosa..... 679

spinosissima ...68 680

tuberculata . .. 697

typica ..... 701

Caprelitidae. . 6 668, 669

Caprelimea . . . 668

Caprellina . . 668, 669

Caprelitin . . . 669

Ceradocus..... 385

Cerapodina ..... 611

abditus .....6 613

Cerapus......6 611 

difformis ....6 615 falcatus .... 606 fucicola..... 604 Hunteri .....6.618 Leachii .....615 longimanus ... 616 pelagicus..... 605 Whitei .... 613

Cercops ......675 Holbölli .... 675

Cheirocratus. .... 395 assimilis ..... 398 mantis .... 398 Sundevalli.... 396

Chelura ...... 646 terebrans.... 047

Chimlridda . . . . 645

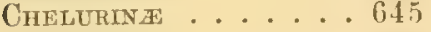

Cleippides ..... 357 tricuspis .... 358

Coroftnt......6 621

Corophtidat ..... 619

Corophines .... 621

Corophinde . . . 621

Corophium...... 022 Acherusicum ...6627 affine ..... 62? Bonellii . . . . 6027 crassicome. . . 626 grossipes. . . . 6 623 longicorne ... 624 spinicorne ... 627

Cratophium ..... 599

Cressa ...... 46r minuta. .... 469 Schiodtei. .... 467

Cramea ....... 703

Cramidan ..... 703

Cyamina...... 703

Cymadusa ...... 587

Cyphocaris ..... 140 anonyx ..... 141

Cyrtophium Darwini . . 637 tuberculatum... 063

Darwinia......2 250 compressa ... 252

Dercothoë ......66 611 (Cerapus) punctatus.....6613

Dexaminæ..... 310

Dexamine ...... 311 bispinosa.... 338 carino-spinosa .. 407

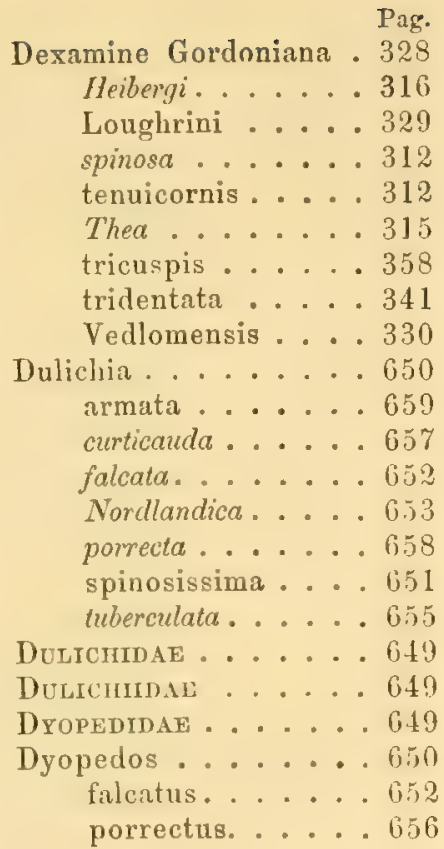

Egrdia . . . . . . 22t

Eiscladus ..... 553 longicaudatus . . 554

Elasmopus..... 392 lutives..... 393

Ephippiphora .... 129

Epidesura . ..... 322 compressa ... 328

Epimeria ..... 232 cornigera .... 233 tricristata ... 233

Eptumertat. .... 227

Erichthonius. .... 611 bidens.....613 difformis .. 613, 615

Eriopis . . . . . 402 elongata .... 403

Eurystheus ..... 580 erythrophthalmus . 581 tridentatus ....581

Eurytenes ...... 143 gryllus ..... 144 magellanicus ... 144

Eusirus . . . . . 500 bidens.... 504 cuspidatus .... 502 Helvetice ....504 longipes ..... 504

Galanthis ...... 107 Lubbockiana. . 109
Pag.

Gammaracanthus . . 398 loricatus .... 400 var. lacustris ...402

Gammaridar ..... 111

Gammarides. . . . 362

Gammarina ...994, 362

Gammarin Ae .... 362

GamimarinI. .... 362

Gammaropsis . . 564, 580 erythrophthalmus . . . 581

Gammarus ...... 364 ampulla. .... 421 angulosus. .... 409 anomalus.... 567 arcticus. ... 367 assimilis .... 398 boreus ..... 367 brevicornis .... 497 cancelloides...375 carinatus .... 324 corniger ..... 233 dentatus .... 389 Duebenii .... 367 Dugèsii...... 387 elongatus..... 382 fissicornis ... 499 fluviatilis..... 373 (Gammaropsis) anomalus ..... 567

(Gammaropsis) erythrophtbalmus. . 581 glaber ..... 118 gracilis ..... 369 grossipes.....623 gryllus ..... 144 inæqimanus . . . 388 Krøyeri . . . 369, 389 lacustris .... 370 lævis ..... 382 libellula .... 88 linearis .... 687 locusta.... 366 longicornis . . . 623 longimanus.... 382 longipes .... 572 loricatus .... 400 Lovéni ..... 378 macronyx.... 576 maculatus ... 386 marinus. .... 369 medusarum.... 79 mutatus. .... 367 neglectus .... 370 nugax...... 129 obtusatus. ... 386 $89 *$ 


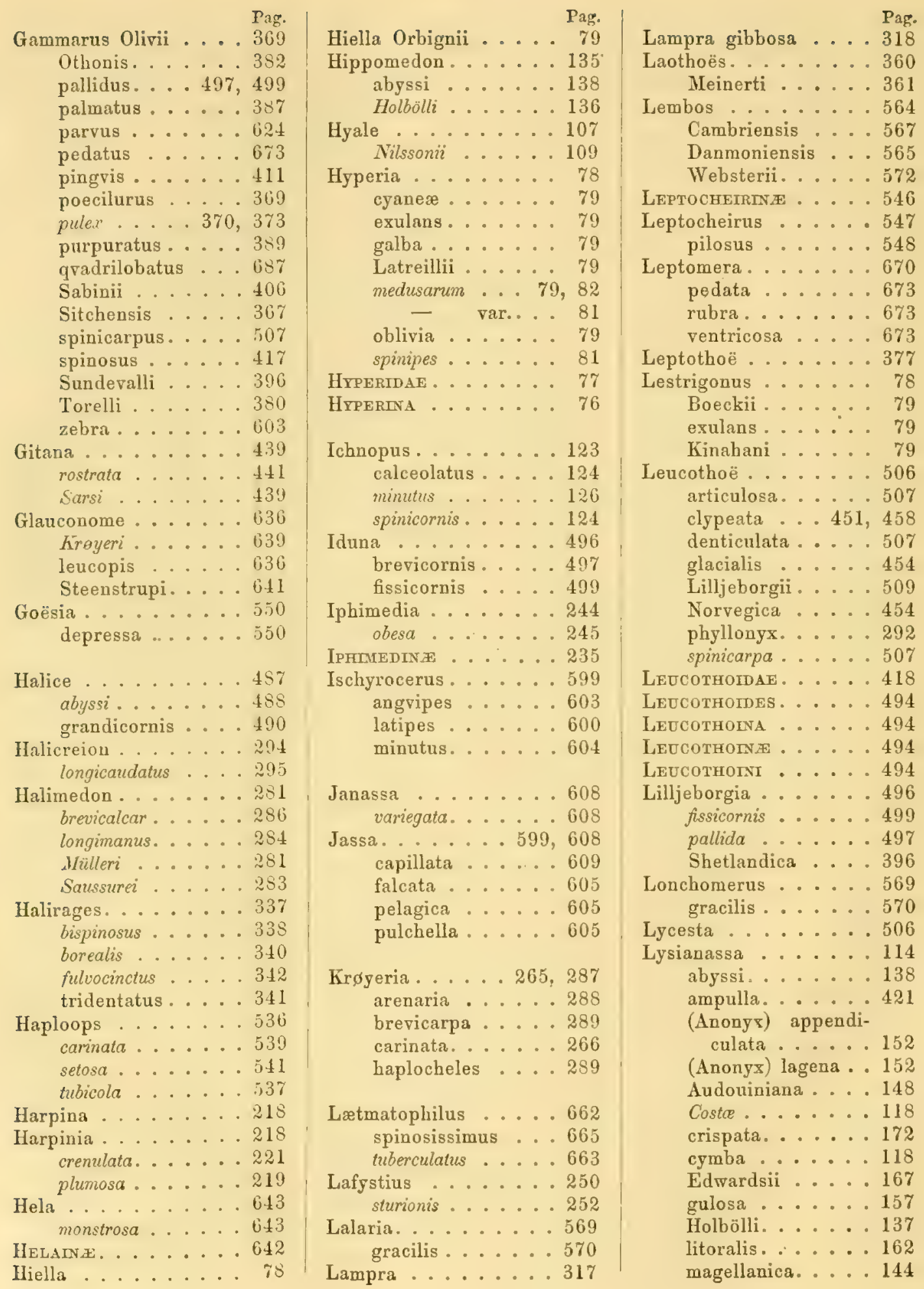


Lysianassa Martensi . 156

plauta ..... 164

plumosa ...... 116

producta ..... 159

spinicornis .... 124

tumida ..... 148

umbo ....... 178

Vahli ......129

LISIANASSINI . . . 112

LYYSIANASSIDES …112

LYSIANASSINA . . . . 112

LrsianAsSIN西 . . . 112

Mæra . . . 3 377, 384

longimana ... 382

Lovéni ..... 378

Torelli ..... 380

Megamæra...... 377

Alderi ..... 387

dentata..... 389

Kroyeri. . . . . . 389

longimana ... 382

Othonis. . . . . 383

Melita . . . . . . 384

dentata ..... 389

obtusata .... 385

palmata...... 387

proxima .. 386, 387

Mrelphidippa......4413

borealis .....4415

longipes ......4414

spinosa . . . . 4 417

Menigrates . . . . 169 obtusifrons..... 169

Metoecus ...... 82 abyssorum .... 83 cyaneæ ...... 79 medusarum.... 82

Metopa........4451 affinis ...... 459 Alderii. . . . . 4 456

Bruzelii . . . . . 458

clypeata.....4451

glacialis. . . . . 454

longicomis . . . . 460

longimana. . . . 44 464

megacheir .... 462

nasuta...... 465

Microcheles . . . . 244

armata ..... 245

Microdeuteropus anomalus ...... 567

Microdeuteropus Websterii......5 573
Mrcronettopin a . . . 563

Microdeutopus . . . 5 564 anomalus .....5567

grandimanus ...5565

gryllotalpa.... 565

longipes .... . 573

macronyx....5 576

versiculatus ...5574

Websterii. ....572

Microplax ....... 496

Microprotopus. . . . 558 maculatus ..... 559

Monoculodes .....265

affinis ..... 265

borealis .....2.278

carinatus ....2 266

Grubei ....2269

Kroyeri . . . . . 272

latimanus ....2 279

longicornis. . . . 273

longirostris. . . 270

Norvegicus. . : . . 267

Packardi .....2 274

tenuirostratus ...2276

tuberculatus ....277

Montagua . . . . . 446

Alderi .....4456

Bruzelii. . . . . 458

clypeata .... 451

glacialis .....4454

marina ..... 447

monoculoides....449 44

Norvegica . . . 4454

phyllonyx ....2 292

Nænia . . . . . . 583 tuberculosa ...584

NaUpREDIA. ... 670

Naupridia . . . . 670

Nemertes ..... 646 nesæoides ... 6 647

Nicea ....... 107 Lubbockiana . . . 109 Nilsoni ...... 109

Nicippe ...... 491 tumida ..... 492

Niphargus. . . . 402 elongatus ....4403

Normania ...... 187 quadrimana ... 188

Notrotopis..... 322

Odius .......2.247 carinatus. ....2248
OEDICERTNA. . . . 254

Oediceropsis.....2296 brevicornis . . . . 297

Oediceros ...... 255 affinis . 265, 267, 278 arcticus..... 259 borealis .....2261 brevicalcar ....286 latimanus. . . . 279 longirostris. . . 2 270 lynceus. . . . . 2 259 Norvegicus . . . 2 288 obtusus. . . . . 202 propinquus....2 259 saginatus. . . . . 257

Onesimus ...... 161 Edwardsii . . . . 167 litoralis . . . . 162 plautus....... 164

Oniscus aculeatus....511 arenatius ... . 223 cicadre.... 335 cuspidatus . . . 229 gammarellus . . . 102 locusta ..... 105 medusarum..... 82 pulex ...... 367 scolopendroides . . 687 serratus ....2 240 volutator . . . 623

Opis .......187, 190 Eschrichti . . . 190 qvadrimana. ... 188 typica ...... 190

Opisa ....... 190

Eschrichti . . . 190

Orchestia ..... 100

Euchore .... 102

gammarellus ... 102

littorea..... 102

Nidrosiensis . . . 109

Orchestidae … 99

Orchomene ..... 171

Goësii....... 177

minutus . . . . 174

pingris. . . . 176

serratus ..... 172

umbo ....... 178

Otus ........2247

carinatus . . . 2 248

Pallasea ...... 374

cancelloides . . . 375

qvadrispinosa ... 375 
Pag

Paradulichia.....660 660 typica ..... 660

Paramphithoë . . 229, 299 bicuspis .... 308 carinata .... 324 compressa ... 328 elegans..... 338 exigua..... 300 fragilis ..... 515 fulvocincta ... 342 glabra ..... 300 hystrix ..... 230 inermis..... 335 laviuscula ... 345 media..... 302 Norvegica ... 348 panopla .... 303 parva..... 305 pulchella .... 306 Smitti .... 326 tricuspis ..... $35 \mathrm{~S}$ tridenta..... 341

Parathemisto ..... 81 abyssomum .... 85 compressa ... 86

Pardalisca. . . . . 481 abyssi...... 486 Boeckii ..... 48 cuspidata ....4 482

Pardatitscinæ.... 450

Pherusa bicuspis . . . 308 cirrus ...... 308 elegans.... 338 pulchella .... 306 tricuspis .... 342

Photidae ..... 546

Photine...... 552

Photis ....... 553 Litheni . . . . 556

Reinhardi ..... 554

Phoxides ..... 212

Phoxina...... 212

PHoxine...... 212

Phoxus.......2 213

llolbolli..... 214

Krøyeri......217

plumosus.... 219

simplex ..... 217

Pleonexes ...... 587

Pleustes .... 299, 496 bicuspis .... 308 glaber...... 300 medius .... 302 panoplus..... 302 parvus...... $30 j$
Pleustes pulchellus. . . 306 tuberculatus ... 303

Podalirius ..... 701 typicus .....7701

Podocerinae . . . 586

Podochrtam. . . 598

Ponocfrtnt .... 598

Podoceropsis .... 583 Sophice ..... 584

Podocerus .... 599, 611 angvipes..... 603 calcaratus ... 606 capillatus ... 609 cylindricus . . . 603 falcatus .....6 605 largimanus . . . 604 latipes......600 600 Leachii .....6 615 megacheir ....6602 monodon ....666 606 pelagicus .... 606 pulchellus .... 606 punctatus.....613 variegatus .... 608

Pontocrates .....2 287 haplocheles.... 289

Norvegicus.....2 288

Pontogeneia ..... 334 inermis ..... 335

Pontoporeia .... 196 affinis.....2201 armata ..... 203 femorata.... 197 furcigera ....200

Pontoporentz: . . 194

Pontoporin

Priscilla ..... 202 armata. ....2 203

Probolium ......446 Alderi. .... 456 marinum ....447 monoculoides ..4449

Prostomatae ..... 95

Prostomatidae.... 95

Protella ..... 677 longispina ... 679 phasma.....679

Proto.......6 670 Goodsimii...6.671 pedata .....673 pedatum ....6 673 ventricosa ....672

Protomedeia... 547, 577 fasciata ..... 576 longimana ....5 578
Pag

Protomedeia pilosa. . 548

Whitei..... 397

Pseudophthalmus ... 15

limicola..... 521

Ptilocheirus .... 547

Pyctilus...... 611

Scopelocheirus .... 131 crenatus .... 132

Siphonoecetes.... 630 Colletti.....6.633 typicus .... 632

Siphonoecetus....630 Kroyeranus ...613 Whitei ....6 613

Socarnes..... 128 Vahli..... 129

Sqvilla ecaudata ...672 lobata ...687, 696 qvadrilobata ...687 ventricosa ... 672

Sqville puce .... 373

Stegocephalmes . . 419

Stegocerhatin . . 419

Stegocephalus .....42n ampulla.....4421 Christianiensis...4 424 inflatus..... 421

Stenothoë ...... 416 Danaï..... 447 marina .....44 44 monoculoides... 449

Stenothotnæ.... 445

Sulcator .....222 arenarius.... 223 arenatius .... 223

Sunamphithoё..... 593 hamulus..... 594 longicornis.... 596 podoceroides... 589

Synamphithoë .... 593

Syrrhoë ....4471, 475 bicuspis .... 475 crenulata.....471 levis ........ 473

Syrrholy ..... 470

Talitrint. ..... 99

Talitrus ...... 104 cyanes..... 79

Edwardsii .... 511 locusta.... 105 saltator..... 105 tripudians .... 102

Tauria....... 82 
Tauria abyssomem ... 83 medusarum.... 82

Tessarops ...... 475 hastata.....475

Temronatmes.... 516

Tetromatus ..... 518 Bellianus .... 534 typicus ..... 522

Themisto ..... 86 arctica ..... 88 bispinosa .... 87 compressa .... 86 crassicornis ... 88 libellula ..... 88

Thersites. . . . . 208 Guilliamsoniana . 209 pelagica .... 209

Tiron....... 475 acanthumes....475
Trischizostoma .... Pag. 96 Raschii ..... 97

TrischizostomatiNa . 95

Tritaeta ...... 317 gibbosa...... 318

Tritropis...... 510 aculeata .....511 fragilis ..... 515 Helleri...... 513

Tryphana ...... 91 Malmii ..... 92

TrYPHanIDAE .... 90

Tryphosa ..... 180 Höringii ...... 182 longipes ..... 184 nanoides .... 186 nants..... 181 Typhis monoculoides. . 449
Pag.

Unciola leucopes ... 637 planipes .... 639

Urothoë ....213, 224 Bairdii .....226 Norvegica . . . 2 226

Vertumuus ......237 Cranchii ...2 233 cristatus ....2 238 inflatus.....242 serratus .... 240

Westwoodia carinata. . 265

Xenoclea .....561

Batei..... 561

Xenodice......665

Frauenfeldti ... 666 


\section{Rettelser og Tillæg.}

Pag. 72. Istedetfor Divisio Hyperida læs: Hypcrida.

" " - Divisio Gammaridre læs: Gammarida.

" 79. Udtages Hyperia Medusarum, Spence Bate, etc.

" $"$ Istedetfor cyanea læs: cyanea.

$95 . \quad$ - Prostomate læs: Prostomatide.

" " - Trischizostomatinae læs: Trischizostomatina.

" 109. - Hyale Nitsoni 1æs: Nilssonii.

" " - Prevosti læs: Prevostii.

"144. - Lysianassa gryllus læs: Gammarus gryllus.

" 152. - Lysianassa (Anonyx) appendiculosa læs: appendiculata.

" 15\%. Ved Pl. 5. fig. 4 tilføies: var.

" "Tilføies Anonyx Brnzelii, A. Boeck, Forh. ved de skand. Naturf. 8de Møde. 1860. p. 643 .

"159. - - - - Lilljeborg, On the Lysianassa magell. 1865. p. 28.

》 174. - Lysianassa minuta, Goës, Crust. amphip. maris Spetsb. 1865. p. 4.

"229. Istedetfor Acanthozoma læs: Acanthosoma.

"250. - Laphystius læs: Lafystius.

" 270. - fig. 21. læs: fig. 21'.

" 311. Tilføies Amphithonotus, Costa, in Hope Cat. 1851. p. 46.

"312. - Amphithonotus acanthophthalmus, Costa, 1. c.

" " - Acanthonotus(?) spinosus, Milne-Edwards, Hist. d. Crust. 1840. III. p. 25.

"328. Istedetfor Schwammerdamii læs: Swammerdamii.

"403. - Eriopis elongatus læs: elongata.

"406. - Sabini læs: Sabinii.

» 471. - pl. XII. fig. 8. læs: fig. 4.

" 496. - Liljeborgia læs: Lilljeborgia.

" 516. Indskydes Subfamilia VII. Iphimedince.

" 528. Istedetfor Eschrichti les: Eschrichtii.

599. Udtages Dercothoë.

" " - Podocerus, Kroyer, etc.

" 604. - Dercothoë (Cerapus) punctatus.

" $\quad-$ Podocerus punctatus.

"611. 11 L. f. n. staar: 153, læs: 163.

612. Tilføies 1862. Dercothoë (Cerapus \%), Spence Bate, Catal. Amphip. Crust. Brit. Mus. p. 259.

1863. - $\quad$ Spence Bate and Westwood, Brit. sessileeyed Crust. p. 459.

"6r0. Istedetfor Naupredia, Milne-Edwards, læs: Naupridia. 






\section{Date Due}


